University of Michigan Law School

University of Michigan Law School Scholarship Repository

\title{
A Digest of Important Cases on the Law of Crimes
}

John R. Rood

University of Michigan Law School

Available at: https://repository.law.umich.edu/books/89

Follow this and additional works at: https://repository.law.umich.edu/books

Part of the Common Law Commons, Criminal Law Commons, Criminal Procedure Commons, Jurisdiction Commons, and the Legal Education Commons

\section{Recommended Citation}

Rood, John R. A Digest of Important Cases on the Law of Crimes. Ann Arbor: George Wahr, 1906.

This Book is brought to you for free and open access by the Faculty Scholarship at University of Michigan Law School Scholarship Repository. It has been accepted for inclusion in Books by an authorized administrator of University of Michigan Law School Scholarship Repository. For more information, please contact mlaw.repository@umich.edu. 
$v^{60}$
A DIGEST
$c \div$

OF

\section{IMPORTANT CASES}

ON THE

\section{LAW OF CRIMES}

COMPILED EDITED AND ARRANGED

FOR THE USE OF LAW STUDENTS

JOHN R. ROOD

s.

GEORGE WAHR, ANN ARBOR, MICH. 1906 


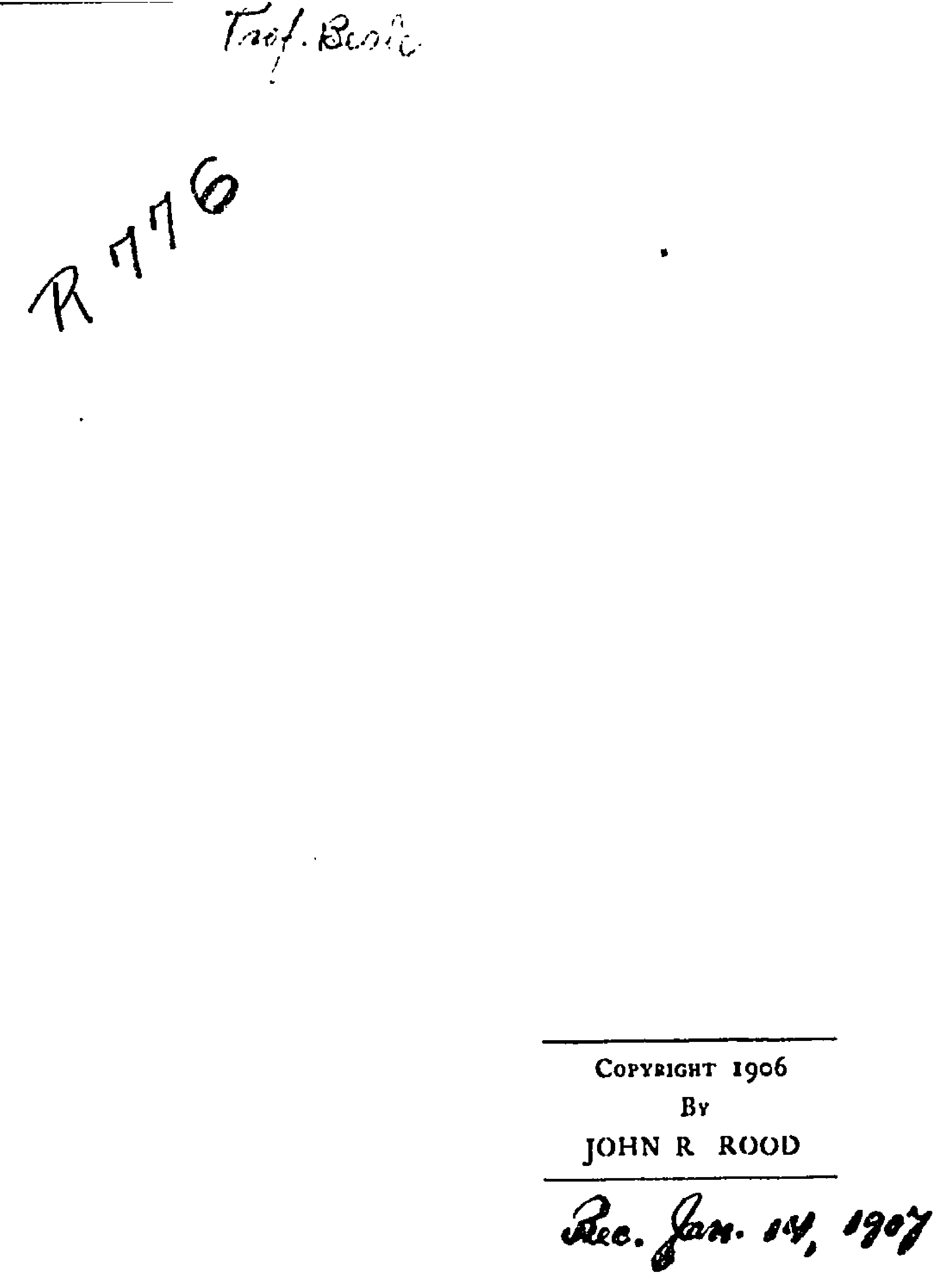




\section{PREFACE.}

Some four hundred years ago, one of the greatest advocates of the eas. system of studying law-indeed, the only one, so far as I am aware, who ever wrote a series of law reports for students' usesaid: "The reporting of particular cases or examples is the most perspieuous course of teaching the right rule and reason of the law ; for so did Almighty God himself, when he delivered by Moses his judicial laws." 5 Reports. Preface, p. ix. And apparently those who agree with this eminent professor of law have been increasing in mumber's for some time. I do not wish to challenge the statement, but to eall attention to the maturer experience and after conduct of the great judge who made it.

There are various methods of reporting decided cases, and there are various methods of studying law by the ease sy'stem. The most elaborate method of case reporting is first to give the entire record in the case, then a briefer statement of the facts, then the arguments on both sides at large and all the authorities eited on either side stated at length as to each point in the case separately, together with any other arguments and anthorities that the industry of the reporter can discover. and finally the conclusion of the court as to ench, with the reasons assigned therefor. By this method of reporting hord Coke made many of his cases such storehouses of learning that they have been the delight and admiration of every seeker for the law on these questions ever since; for nowhere could such elaborate statements of the matter be found, nor even anything to add to what he had said. For example, there are Shelley's Case and Chudleigh's Case, in the first volume of Lord Coke's reports. What more could be said than is there reported? Indeed. these are the fountains from which all we have has been drawn. Yet what teacher of law has seen fit since to incorporate either of these cases in the assignment of matter for his students to prepare for recitation and discussion in class? Indeed. it is evident to all that the law : too large a subject for such a method, and life is too short to study !aw in that way. In the prefince to his first volume, Lord Coke said: "In these reports I have (of purjose) not observed one method, to the end that, in some other edition (if God so please). I may follow the form that the learned shall allow of. and will sequester my own opinion; for it may be I should prefer those reports which ale less painful, and yet (perhaps) no less profitable." It would seem that his conclusion from his experiment was that the more compendions report is the more profitable. for we notice a very decided tendener to brevity in his later reports. and finally he abandoned the ease system entirely and revoted himself to the writing of his eolobinter commentariess or institutes. 
One objection often heard to abridging the reports of. cases students are asked to study is that it does not give the student a colrect view, which ean be had only by seeing the case entire. A moment's thought would prevent anyone making such a statement. No one ever saw a case reported entire; the official reports are themselves only abridgments. The law library of the University of Michigan contains a printed report of the case of Perrin v. Lepper boiled down to sixteen volumes of about 1000 pages each; but in the official reports most cases are even further abridged, the extent of the abridgment depending on the purpose and discretion of the reporter. Others say that the upinion of the court at least should be given entire; yet most of those who say this profess a fondness and preference for the English decisions because of the suceinct and logical statements of arguments and conclusions found in the English reports; which, as we all know, is due largely to the fact that the reporter does not grive the opinions of the judges in full, but revises the language, and prints only what he deems of general interest. Their preference for the old cases, in which this policy was practised even more extensively than in these days of cheap pinting, is also noticeable. 'There are many reasons why cases for students should not be given even as fully as in the official reports, for example: the official reporter addresses himself to readers for all purposes, the teacher is instructing on one subject; the judges do not speak to give instruction on law, but because the parties are entitled to know how their case is decided and why; judges do not always stop. here, the teacher's report of a case certainly should.

Another reason often given for asking the student to read grait masses of undigested material is that he will find it so in practice and should learm in school how to use it. Thus many are persuaded; but the statement is not true. No one but the under-graduate liw student ever uses such material. The reporter has the record and briefs of counsel, which time and space forbid to the student. The lawyer has abridgments of these generally, and always the reporter's syllabi; which would be depended on by the indolent student. and would be a stumblingrblock to all students. The lawyer with a question to examine does not have a book of selected cases on it put into his hand to read, nor does he take down and ransack the reports of decided cases to find the auswer to his question. Gen. erally he has a glimmering notion as to what the law is; what he wants is authority for it, and a precise statement of the doctrine. For both of these he Jooks first to his texts, digests, etc., and then to the reports of decisions there eited. Then he reads-not like the student, one case on each of many points taken up in successionbut many cases all centering about one point.

Further, the purpose of the student and the purpose of the lawyer are wholly different, in fact the reverse. The lawyer starts with the facts and seeks the decision of the law upon them; the student starts with the decision of the law and seeks to learn its application 
to facts-if by studying cases, it is to appreciate its application to other facts, if by studying a text it is to appreciate its application to any facts. 'The decision is put into the hands of the student; the lawyer must find it. Whatever merits there may be in the so-called case system of studying law now in rogue, it is evident that there is no foundation for the claim that it is the natural or practical method. A more practical case method would be to put into the hands of the student a book of undecided cases involving close questions: but with 110 indication of what the question is or where to find the answer; both of which the student is asked to give. Or better yet, let him 'lear'n the facts from the student who witnessed them; and then let him discover his rights and remedies, and pursue them to judgment and execution, as our students do in our practice court. While such a case system of studring law would be severely practical, it probably would not be practicable as a sole or general method of study.

This book is not offered as a solution of the difficulties of the law student and teacher, nor is anything claimed for it. Frankly, it is an experiment, made with the hope of presenting a more connected and general view of the subject than can be acquired by reading cases umabridged, of which the student can read but few on a topic, nor even one on each topic, without infringing on the time due to other courses. It is hoped and believed, also, that a more definite, concrete, and precise knowledge of the law will be obtained from reading such a book than could be acquired by studining a text of the same size. As it is a departure from accustomed lines, opposition and criticism are expected. If this experiment is not successful, perhaps another may get from it a hint that will suggest a better plan.

In selecting the cases to be abridged, an effort has been made to choose those that have drawn the most attention, comment, and citation. The reputation of each case is shown to the reader in part by reference to the various collections of important cases on crimes in which it has been included. Probably many cases have been included which more mature deliberation would have excluded, and as many omitted which should have been included. For thes and other errors the charity of the reader is requested. Especial acknoweldgment is due to Miss G. E. Woodard, assistant law librarian, for making the table of cases, for adding the parallel citations. and for much other assistance in getting the matter into type. JOHN R. ROOD.

University of Michigan, Nov. 26, 1906. 


\section{TABLE OF CONTENTS.}

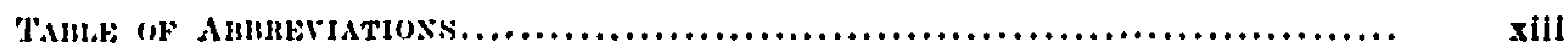

SOURCES OF OUR CRIMINAL LAW (Chapter I) ..... 1-20

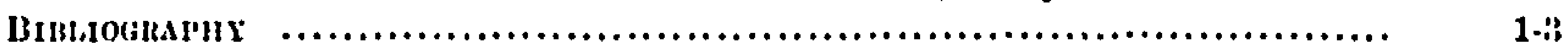

\$1. Constitutions, Statutes, IRepolts, und 'Treatises, 1.

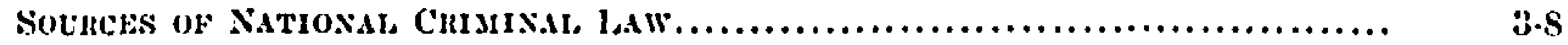

\$2. Constitution, Statutes, and Decisions, :

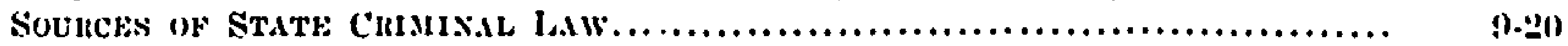

\$3. Gencral Statement, ).

\&. "Common Iaw of England and English Statutes Luncted before tha Settle. ment," 9.

§5. "As is Sultable and Adapted to our Condition and Instltutions," 11.

§6. "Supplemented and Amended by the Common Iaw and Customs that have Grown up in thls Country," 14.

87. "And by the Constlution and statutes of the State," 17.

§ 8. "Iixcept as liestrained by the United States Constltution," 19.

DEFINITION AND NATURE OF CRIME (Chipter II) ... 21-83

DeFintTios of a Crint.........................................................

$\$ 9$. Inefinition, 21.

\$10. "A Crime is Any Act," 21.

\$11. "Of Commission ol Omission," 25.

"In Violation of I, Rw."

\$12. Interpretation, 33.

\$13. Repeals and Amendments, 3i.

§ 14. "Causing Injurg," 37 .

"To the Publle at Lar,;e,"

\$ 15. Mrilicious Infuries, 47.

\$16. Tivate Chents, 40.

\$17. Nuisances, 50 .

\$18. Disturbing I'ublic Peace. Safety, or Comfort, j1.

§ 19. Corrupting Public Morals, 54.

\$20. Touching the Government, 57.

$\$, 21$. "For Which the W'ongdoer may be I'rosectited and l'unished," $\therefore$.

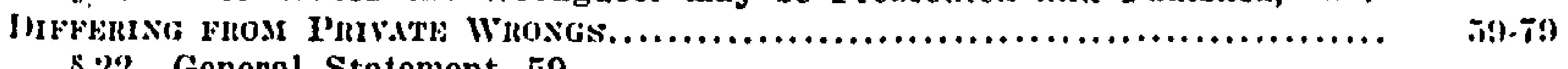

$\$ 22$. General Statement, 50 .

\$23. "Mllght IIave Escaped but for His Own Negligence," a9.

\$24. "Was Bqually Gullty," 61.

$\$ 25$. "Has Been Relmbursed," 64.

$\$ 26$. "Has Forglyen the Wrong," $6 \overline{5}$.

\$27. "Entrapped the Offender," 6 i.

\$28. "Consented to the Act," 66 .

\$29. "Want of Consent an Essential Blenent of I'articular Crime," 68.

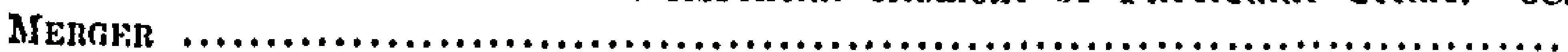

$\$ 30$. Of Private in Public Wrong, 79 .

\$31. Of Misdemennors in Felonies, 81.

\$32. General Stntement, 81.

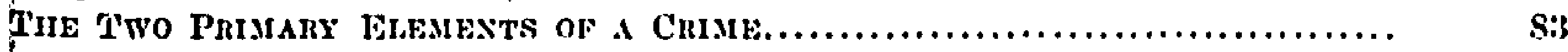

§33. General Statement. \$3. 
THP CRIMINAL INTENT (Chapter III) .......... 84-177

NATUIRE ANO KINUS OF INTHNT............................................. 84.109

$\$ 34$. General statement, 84 .

\$35. "Crimianl Intent is the Stite of Mind of the Criminal," sio.

\$36. "At the 'ilme of committing the crime," ss.

$\S 37$. "Distinguished flom the Motive," 90 .

\$3S. "Intent to do Some Other Illegul Act," 94.

§39. "Natural Consequence," 98.

\$.40. "Criminal Neglect of Duty" and "Natural Consenuence," 101.

$\$ 41$. "States of Mind Must be .Found to Convict," 101.

842. "That the Breach of Iegal Duty Shall be Cirminal Regardless of any Intent," 103.

\$43. "Specific Intent Which Must Generally be Direct," 105.

\$44. "To a certuin lixtent May be Supplled by construction from a Similar I'us. pose," 106.

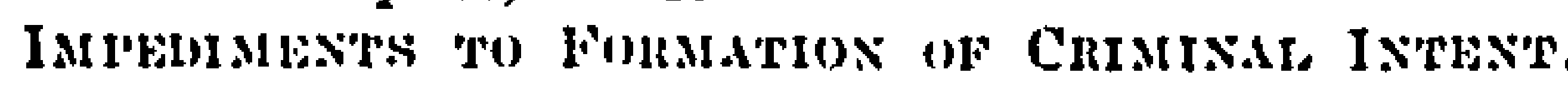

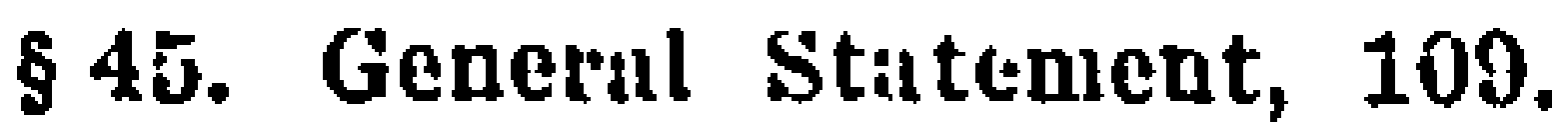

\$46. "That the Defendant is a Corporation," 110.

847. "Ihat the Act was Compelled," 111.

§48. "Of the Command of a Husband to His Wife," 111.

$\$ 49$. "Of the Command of any Other to His Subordinates," 114.

§50. "Of Actual Duress by l'ersons without Authority," 117.

\$51. "Of Necessity of Self-P'eservation in Other Cases," 120.

852. "Of Inability of Defendant to I'erform IIis Legal Duty," 12.5.

\$53. "That the Defendant was Mistaken as to the Facts," 120.

854. "That the Defendant was Mistaken us to the Law," 134.

\$55. "That the Defendant was an Infant," 138.

\$50. "That the Defendant was Idiotic or Demented," $1+1$.

\$57. "That the Defendant was Intoxicated," 14 .

\$58. "That the Defendant was Insane," 150 .

THE CRIMINAL ACT (Chapter IV) .............178-248

INCIPIENT ACTS ....................................................... 17\$.

\$59. Classiffed, 178.

\$60. "Soliciration to Crime," 178.

\$ 61. "Consulracy," 184.

\$62. "Attempt," 206.

Ulthimate Acts.

Chiminal Acts.

863. Classified, 214.

JUSTIFIABLE ANI) BXelsalHL: ACTS.

864. Classifled, 218.

\$65. "In Obedience to the Orders of a Supertor Onicial," 218.

866. "In Reasonable Exerclse of Parental or Oficlal Authorits," 219.

\$67. "In Preserving or liestoring Public Peace," 224.

\$68. "In Preventing Commission of Crime and Appreheniling or l'reventing d:: Escape of Criminals," 224.

\$69. "In Self-Defense," 228.

80. "In Defense of Castle," 238.

71. "In Defense of Property," 243.

\$72. "In Defense of Friend or Stranger," 248.

THE PÁRTIES TO CRIME (Chapter Y)...........249-268

\$73. Classlfted, 240.

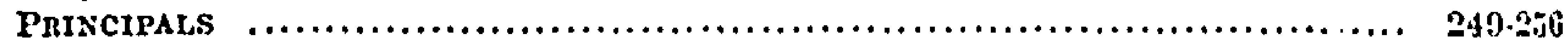

874. "In the First Degree," 249.

75. "In the Second Deglee," 252.

ACcessomes

\$ 76. "Before the Fact." 256.

87. "After the Fact," 256. 
DEFr:PSES

§ 78. Genernlly, 259.

\$ 79. "Jbe I'rinclpal Must be Convieted Befrle the Accessory can be Tried," 259.

$\$$ 80. "There IInst be I'roof of Compllelty Jietween the Intries," 201.

881. "Within the Scope of the Original Uesign," 261.

\$ 82. "A Natural Consequence of its Execution," 263.

§ S3. "Abandonment," 266.

JURISDICTION AND PUNISHIVIENT (Chapter VI)......269-322

§84. Outline, 269.

Locality of the Crime.............................................. 269-299

8 85. Classification, 260.

\$ 86. "What Courts Have Jurisiliction to I'unish Crimes Committed at the Par. ticular Place," 269.

\$ S7. "If the Wrong-doer Wis in One Place and IIls Act Took Enect in Another," 270.

\$88. "If Goods Stolen In One Place are Taken to Another," 286.

8 89. "If a Fatal Injury is Inflicted in One Place and the Victim Goes to Another Place nud Dlew," 204.

ExtRADITION AND RENm;iON

\$ 90. In General, ?:).

$209-306$

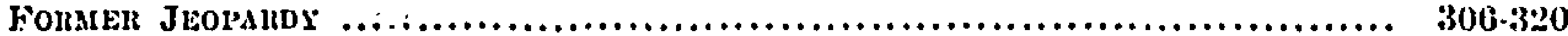

\$ 91. Old Maxim and Constitutional Provision, 306.

\$ 92. "I'wlee P:it in Jeopardy," 307.

8 93. "For Ont: and the Snme Offense," 315.

OFFENSES AGAINST TIIE PERSON (Chapter VII) ....323-368

\$ 05. Classified, 323.

Srartu: ASSAl:L,T

\$90. De Uned, etc., \$ 323.

Agghavathi asgault

\$97. Generally, 328.

BaTTEIX.

\$ 93. Defined, etc., 328.

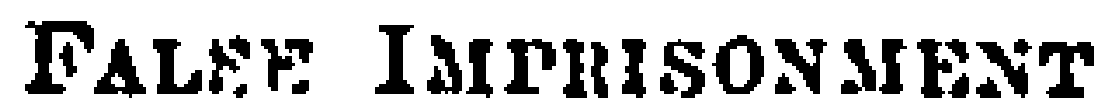

323.329

\$ 99. Defined, etc., 330.

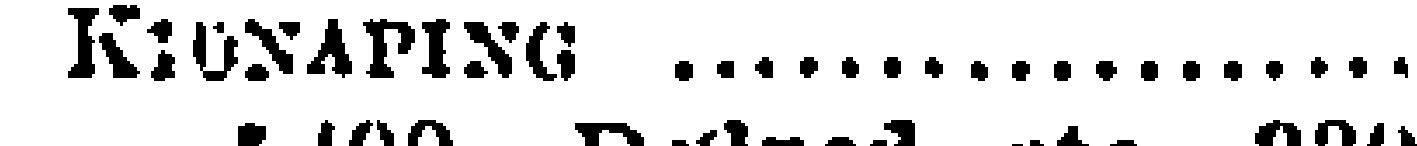

$\$ 100$. Drilned, etc., 330 .

MAIIM

\$ 101, Defined, etc., 331.

RAp: $\ldots \ldots \ldots \ldots \ldots \ldots \ldots \ldots \ldots$.................

FHOJICIDE

\$103. Definition and Classification, 341 .

8104. Murder, 341.

105. Mansluughter Defined, 350 .

$\$ 100$. Voluntary Manslaughter, 350 .

\$107. Involuntary Manslaughter, 357.

\$108. Proof of Corpus Delleti, 362.

OFFENSES AGAINST THE HABITATION (Chapter VIII) 369-393

Burglary

$\$ 109$. Defned, 369.

8110. "Breaking," 300.

8111. "Entering," 374.

\$112. "Dwelling House," 378.

§113. "Of Another," 384.

\$114. "In the Night-Time," 385.

8115. "With Intent to Commlt a Felony-Thereln," 356. 
Ansox

8116. Defined, 38 i.

\$117. "Maliclously and Voluntarily," 3Si.

8 118. "Burning," 388.

\$119. "The House," 388.

3120. "Of Another," 300.

OFFENSES AGAINST PROPERTY (Chapter IX) $394-550$

8 121. Classification, 30J.

IARCEYY

$\$ 122$. Defined, $39 \overrightarrow{\mathrm{J}}$.

\$123. "Larceuy at Common Iaw," 395.

8 124. "Taklng," 396.

\$ 125. "By Trespass," 399.

$\$ 126$. Classification, 400 .

\$ 127. "As Servant," 400.

\$128. "In Maklng an Exchnnge," 404.

129. "In Some Other Cananity." 408.

\$120. "Where the Accused Received the Iroperty from Anotber," 411 .

$\$ 131$. "Delivered by Mistake," 415.

\$ 132. "Iinding Lost l'roperty," 418 .

\$ 133. "Fraud," 424.

$\S 134$. "Without Consent," 438.

813i. "Carrying Away," 444 .

\$136. "Another's," 447 .

§137. "Valuable," 451 .

§ 138. "I'ersonal," 45".

8139. "Property," 4is.

\$140. "Clain of IRght," 460.

"With Intent."

\$14. General lkule, 46s.

8 142. Cases of Ballee's Breaking Bulk, 470 .

8 143. "To Deprlve the Ownel of Ills l'roperty." 476 .

$\$ 144$. "Permanently." 4 S1.

\$145. "Convert It to the 'raker's Own Lse." 4 s::.

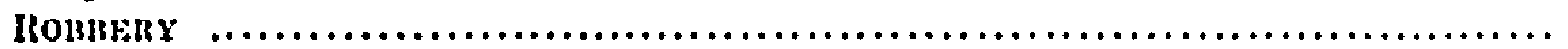

§ 146. Defined, 485.

8147. "Felonlous Taking," 4 S.T.

8148. "In IIIs Presence," 486 .

\$149. "Hy Vlolence or I'utiline in lienr." tss.

LaIrCeNY Fon THE PersoN

$\$ 150$. In General, 400.

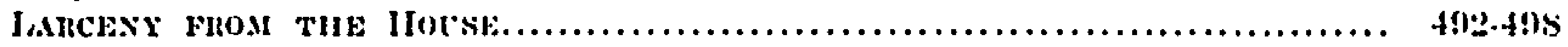

§151. In General, 402.

EMREZZLLMENT

\$152. In General, 498.

IRECHuing STOLEN GoOts.......

153. The Statutes, j06.

$\$ 154$. "Recelve," 506.

\$15i). "That Shall be Feloniously Taken or Stolen," it1.

$\$ 156$. "Inowing the Same to be Stolen," $\mathbf{5 1 4}$.

\$15T. "Shall he Taken and Deemed an Accessory." 515.

Chliatixi at Condon law.

\$1;s. Defincl, $\mathbf{5} 1 \mathrm{i}$.

lontiknY

1.19. Definition, 518 .

$\$ 160$. "It Includes as Well the Tinsuccessful Attempt," 18 .

161. "It Is the False Making." $\$ 18$.

\$162. "MInterially Altering." 氵23.

\$163. "With Intent to lefinul," 5.4.

164. "Of Any Writing." 524.

\$165. "Mlight Appinently le of some Legal Eflicacy." \$20. 


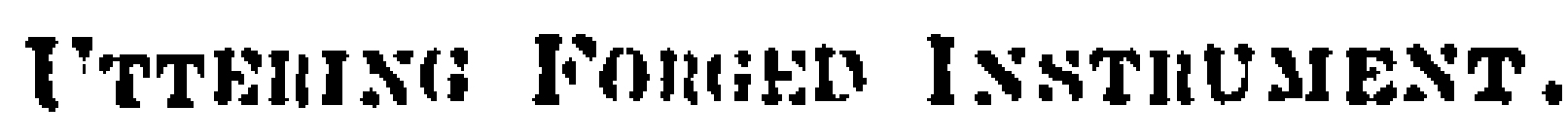

8106. In General, 52t.

ORtativisg MY Faise Tokess..

: 167. In Generat. 629.

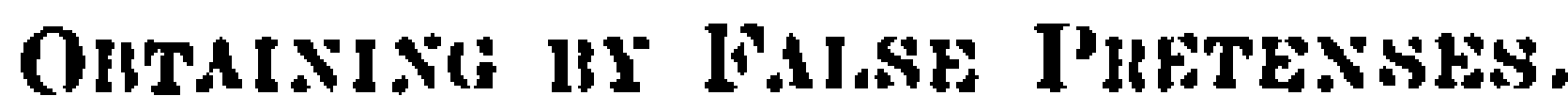

\$168. Statute 30 Geo. 2 , c. 24,531 .

$\$ 169$. "By," 532.

\$170. "False," 534.

\$171. "I'retenses," 535.

8170. "Shall Obtain." 543.

\$173. "From Any Person," 546.

\$174. "Inney, Goods, Wares, or IIfrchandise." 546.

\$ 175. "With Intent to Cheat or Defraud," 549.

Maliciols MISCHIEF

s17iia. In General.

OFFENSES AGAINST PUBLIC PEACE (Chapter $\mathrm{X}$ )

$551-557$

\$17\%. General statement, 551.

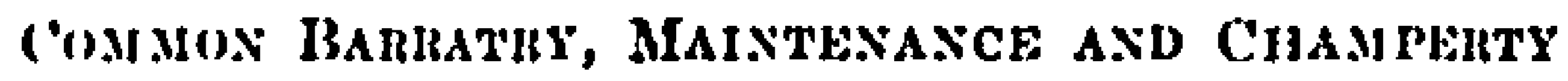

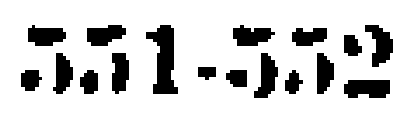

\$177. Common Barrati'y, 551.

$\$ 178$. Maintenance, 551 .

\$17). Champerty, 552.

SIMPLE BReaches of thi Peace.

$.5 .5-5.53$

$\$ 180$. Nolses, etc., 552.

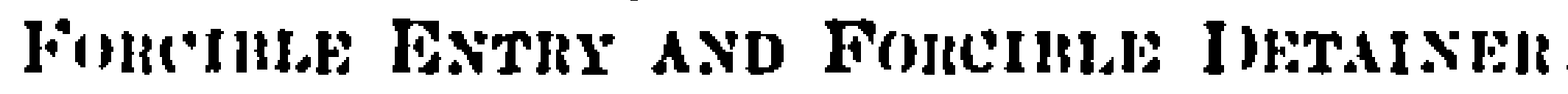

\$181. Defined, etc., 555 .

AFFIIY

\$182. Defined, etc., 554.

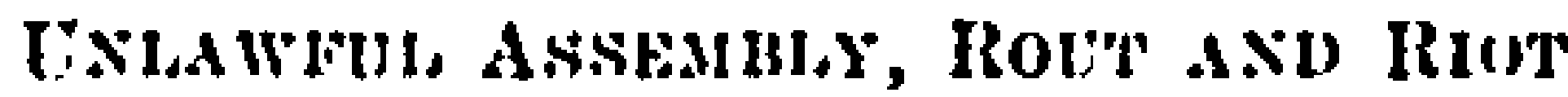

\$ 183. Defined and Distinguished. 55J.

l.1 Hi:I,

$\S 184$. Defined, etc., 556 .

.5.3.5.5.

i.5. ה.5.

$5.55 \cdot 5.54$

$556-5 \pi 7$

OFFENSES AGAINST GENERAI WELFARE-PUBLIC MORALS, SAFETY, HEALTH AND COMFORT (Chapter $\mathrm{XI}$ ).

558.581

§ 185. Geneinl Stntement, 558.

AnonTION

$\$ 186$. In General, 558 .

BItiaMY ole Iotsifasir

\$ 187. Defined, etc., 559.

ADLITHUY

$5.59 \cdot 5(30)$

$\$ 188$. In General, 560 .

Mischassatiox

5130

501

\$189. Defined, 501.

I.NChst

$\$ 100$. Defined, etr.., 561 .

Sonoms on Bugianx. 8 191. Defined, ธ82.

Alinucrion \$ 102. In General, 562.

S:DUctoxiox \$193. General Statement, etc., 565.

Foinication \$194. Deflned, 568 .

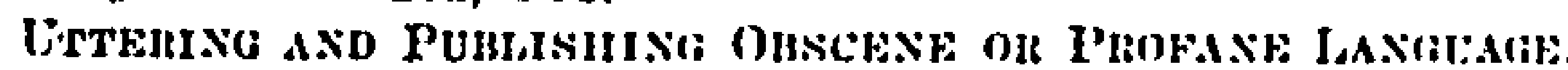
\$19:. In General, 568 .

Nuisaxce \$196. Definition, 5io.

\$107. "By Act or Neglect Creates a Condition of Things Prejudiclal," 570. $\$ 108$. "Safety," 572.

$.111 \cdot 36 ! 3$ 
Nuisanch--Continued.

\$ 199. "IBusIness," 572.

\$. 200. "Ilenlth," 574.

s:211. "Comfort," 5705.

\$ 202. "Moruls or Outraglng the Sense of Decency," 579.

$\$ 203$. "Or the Citizens at Large." 581.

OFFENSES AGAINST PUBLIC JUSTICE AND AUTHOR-

ITX (Chapter XII) .....................582-597

\$204. General Stratemeni. 582.

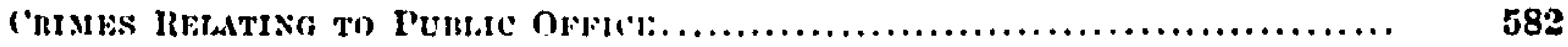

$\$:(0 . \overline{0}$. Feneral Statument, Es:.

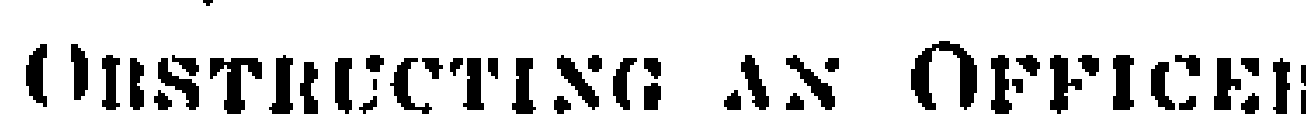

.82.583

\$:Mi. General statement, 5i:-

I3แก):H

$\$ 207$. Deflned, etc., 583.

('i)

$\$ 20$ S. Defined, etc.. 584.

MIsImison of libioxy. \$ 200. Defined, 585 .

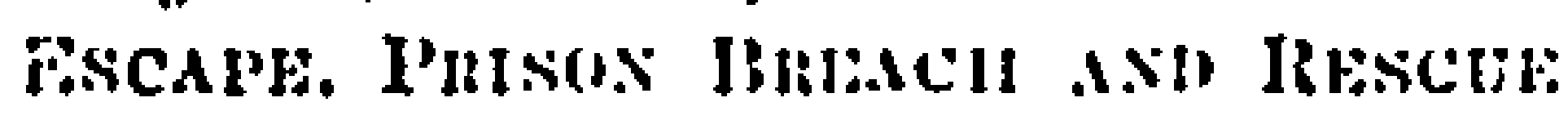
\$210. Coneral Statement, etc., 5si.

lismickils $\$ 211$. betined, etc., $5 \$ \beta$.

l'kilkrtilix $8: 212$. Deflned, etc., 587 .

Con:riat I'r

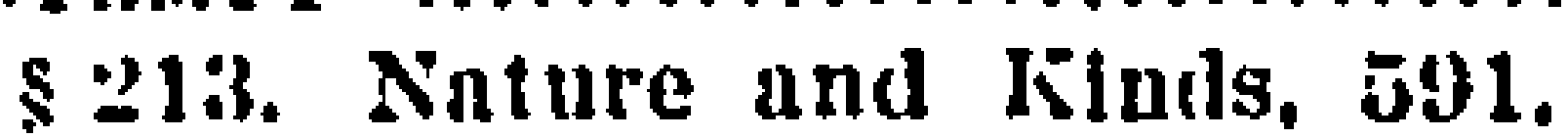

TREASON AND PIRACY. (Chapter XIII)............ 598

'Trmasox

liakison.

S 214. lleftned. הns.

I'ImACY 


\section{SOME ABBREVIATIONS USED IN THIS BOOK.}

Acc. Accord, or in harmony with the case preceding. This is stated only when the similarity is very close.

B. Beale's Cases on Criminal Laww.

B. \& H. Bennett \& Heard's Cases on Criminal Law.

C. When pireceded or followed by $v$. as the title to a case this is an abbreviation for Commonwealth; e. g., C. v. Way. Otherwise it means Chaplin's Cases on Criminal Law, second edition. 1896.

Eng. C. C. R. English Crown Case Reserved. It has been a castom among the English trial judges from time immemorial to reserve questions arising on criminal trials to take the advice of the other judges and dispose of the case accordingly. This custom was sanctioned by statute in 1848, legalizing this as a method of review in criminal cases.

F. Fisher's Cases on Criminal Law, being identical with Clark's Cases on Criminal Law except in the paging and notes.

Ke. Kenney's Cases on Criminal Law.

Kn. Knowiton's Cases on Criminal Law.

L. Inawson's Crimes and Defenses.

Mi. Mikell's Cases on Criminal Law.

n. This leter following the page number shows that the case is reported in a foot-note in the book referred to.

-n. This indicates that there is a monographic note on the point

P. People. appended to the ease in the book referred to.

R. Rex or Regina.

S. State. 


\section{CHAP'IER I.}

\section{SOURCES OF OUR CRIMINAL LAIV.}

Brimiograrily.

§. 1. Constitutions, Statutes, Reports, and 'lrentises, 1. Souhces of National Corminal Iaw.

\$2. Constitution, Statutes, and Decisions, 3.

Sounces of State Chimisit Iaw.

\$3. General statement, 9.

\$4. "Common Law of England and Engllsh Statutes Enacted before the Settlement," 9.

\$5. "As is Suitable and Adapted to our Condition and Institutions," 11.

\$6. "Supplemented and Amended by the common Law and customs that have Grown up in this Country," 14.

$\S 7$. "And by the Constitution and Statutes of the State," 17.

§ 8. "Except as Restrained by the United States Constitution," 19.

\section{BIBLIOGRAPHY.}

\$1. The law of crimes is found in the constitutions and statutes of the state and nation, in the decisions of the courts on particular cases, and in the works of writers on the law.

The Constitution of the United States is the fundamental law of the land, par'amount to all other statutes so far as it extends. All others must yield to it so far as they conflict. 'The acts of congress are likewise paramount so far as they are constitutional. Next in order, the state constitutions are paramount within the state, so far as they do not conllict with valid laws of the United States. Next in order of command, the state statutes control so far as not in conflict with any of the foregoing, and with these exceptions control and slipplant all prior statutes and decisions in conflict with them.

The Decisions of the Courts are supposed to indicate the law existing then and before, and to depend on the law then found to exist. But in fact the decisions mark the growth of the Jaw, by applying it to new cases, thus forming precedents for :" similar cases in the future. Within the same jurisdiction, the decisions of the courts of last resort are held to create a fixed rule for all similar cases, until overruled by a court of equal or greater authority (which rule is called the doctrine of stare decisis), or abrogated by legislative enactment. Outside of the same jurisdiction these decisions have a persiasive influence, depending on the good sense indicated by the decision, the force of the reasoning given to support it, the respect entertained for the court by the persons sought to be influenced by it, and by numerous other consilerations.

These Decisions are Reported or Published in various forms. The earlier English decisions are found in the Year Books, mixed with civil cases, covering the period from $20 \mathrm{Fd} .1$ (1222) to near the 
close of the reign of Hen. 8, and a few older records have been published recently from manuscripts in the British MIuseum. Likewise, cases on crown law after the peried of the Year Books till now have generally been published with reports of eivil eases, both in England and America. Howell's State 'Trials is a set of thirtyfour books, in which eriminal cises exclusively are reported with great detail, arranged in chronological order and extending from the time of the conquest to 1820 . Reports of criminal cases confined to brief statements of the ficts, arguments, and law points decided, may be mentioned as follows: A thin quarto by John Kelyng, ehief justice of the king's beneh, first published in 1708, after the death of the writer; leach's Crown Cases in two volumes, including decisions from 1730 to 1813; Russell and Ryan's Crown Cases in one volume. 1799 to 1824; Moody's Crown Cases in two volumes, 1824 to 18t4; Denison's Crown Cases in two volumes, 1844 to 1852; Dearsly's Crown Cases, one volume, 1852-6; Dearsly \& Bell's Crown Cases, one volume, 18:26-8; Bell's Crown Cases, one volume, 18i3-60; Leigh \& Cave's Crown Cases, one volume; Law Reports Crown Cases Reserved, two volumes, 1865 to 1875 ; and Cox's Criminal Cases, beginning in 1843 and continuing to the present time. All of the above are English publications of English decisions. In Ameriea there are several eollections of criminal cases published for use of the lawyer. Among these might be mentioned the American Criminal Cases (1Sis current), Bennett \& IIurd's Leadling Criminal Cases (2 Vols., 1856), Green's Criminal Cases (2 Vols., 1875), and Latwson's Crimas and Defenses (1885, a collection of linglish and American decisions and annotations, arranged by topies, is Vols.). Among the cases selected for use of students in law schools may be mentioned: One volume of 983 pages by Prof. Joseph H. Beale. 1894; one volume of 461 pages by W. I. Clark (author of Clark's Criminal Law) 1895; republished without the notes as "Fisher"s Cases" in 344 pages in 1895; one volume of 583 pages by MIr. W. II. Chaplin. in 1891, second ed. in 1896; one volume of 396 pages by Prof. J. C. Knowlton in 1902; and one volume of 9S3 pages by Prof. Wm. E. Mikell in 1903.

Works of Writers on the Law of crimes are numerous. Those of highest repute are Coke's Institute Concerning High Treason and other Pleas of the Crown, by Sir Fdward Coke, 16+4; Hale's History of the Pleas of the Crown, by Sir Matthew IIale, two volumes, 1680; Hawkins's Pleas of the Crown. two volumes, 1716; Foster's Crown Law, a collection of cases and commenturies by Justice Fester, one small volume. 1762; Fast's Pleas of the Crown, two volumes, 1803. All these have weight as anthorities irrespective of the cases they cite to support their statements, and all of them contain brief reports of eases not otherwise published. Perhaps mention should be made, also, in the same connection, of Russell on Crimes. two volumes, and Archbold's Criminal Procedure, two volumes. The books on this subject most used by lawyers in practice, 
aside from the encyclopedias and local books, are the writings of Mr. Joel Bishop, one on Criminal law in two volnmes, first published in one volume in 1556 ; one on Criminal Procedure in two volumes, first published in i366; and one on Statutory Crimes in one volume, fir'st published in 1873; and N[cClain's Criminal Law in two volumes, 1897 , by $\mathrm{Mr}$. Justice MeClain of the lowa supreme court, formerly dean of the law departmont of the Iowa state university. Of the briefer hand books on the subject, mention may be made of those by Claris, Clark \& Mrarshall, IIawley \& MIeGregor, sind May.

We have two systems of criminal law in this country, one national, the other state.

\section{SOURCES OF NATIONAL CRIMINAL LAW.}

\$2. There are no common law crimes against the nation.

The United States courts have implied jurisdiction to try and punish all offenses that would interfere with their appointed business, such as disturbance of order in court or contempt of its proceedings.

They have jurisdiction of offenses made criminal by tire constitution of the United States or acts of congress in pursuance of its express or implied powers under the constitution.

U. S. Const., Art. 1, §8. Congress shall have power: * * * 3. To regulate commerce with foreign nations, and among the several states, and with the Indian tribes. ***6. To provide for the punishment of counterfeiting the securities and current coin of the United States. 7. 'To establish postoffices and post roads. * * 9. T'o define and pumish piracies and felonies committed on the high seas, and offenses agianst the law of mations. * * 17. To make all laws which shall be necessary and proper for carrying into execution the foregoing powers. and all other powers vested by this constitution in the government of t?: United - States. or in any department or officer thereof.

U. S. Const., Amend. 10. The powers not delegated to the United States by the ennstitution, nor prohibited by it to the states, are reserved to the states respectively, or to the people.

(U. S. Sup. Ct.. 1812.) Implied Jurisdiction of Courts and Power of Congress. Indietment for libel, in publishing that the president and congress of the United States had secretly roted tribute to Napoleon. Defendant demurred, and the case was eertified here, the judges of the circuit being divided in opinion. JOHNSON. J. The only question which this sase presents is, whether the circuit courts of the United States can exercise a common law jurisdiction 
in criminal cases. *** The powers of the general government are made up of concessions from the several states. *** The only ground on which it has ever been contended that tiris jurisdiction could be maintained is that, upon the formation of any political body, an implied power to preserve its own existence and promote the object of its creation, necessarily results to it.

But if admitted as applicable to the state of things in this country, the consequence would not result from it which is here contended cor. * * * The legislative authority of the union must first make an act a crime, affix a punishment to it, and declare the court that shall have jurisdiction of the offense. Certain implied power's must necessarily result to our courts of justice from the nature of their institution. But jurisdiction of crimes against the state is not among these powers. To fine for contempt, imprison for contumacy, enforce the observance of order, etc., are powers which cannot be dispensed with in a court, because they are necessary to the exercise of all others. *** Demurrer sustained. U. S. v. Hudson, 7 Cranch (11 U. S.) 32, C. 14, F. 42.

(U. S. Sup. Ct., 1820.) Jurisdiction of U. S. Courts.-What is Piracy? On indictment for piracy the jury found that Smith and others of the crew of a private armed vessel commissioned by Buenos Ayres (a colony at war with Spain) mutinied at Margaritta, seized another privateer commissioned by Artigas (another government at war with Spain), put to sen on a cruise, without ary documents or commission whatever, and while so at sea committed the offense charged in the indictment, by plunder and robbery of the Spanish vessel therein named. The circuit court being divided on the question whether this be punishable under act of congress March 3, 1819, as piracy, certified the question to this court for decision. STORY, J. The act of congress upon which this indictment is founded provides, "that if any person or persons whatsoever, shall, upon the high seas. commit the crime of piracy, as defined by the law of nations, and such offender or offenders shall be brought into, or found in the United States, every such offender or offenders shall, upon conviction thereof, etc., be punished with death." The first point made at the bar is whether this enactment be a constitutional exercise of the authority delegated to congress upon the subject of piracies. The constitution declares that congress shall have power "to define and punish piracies and felonies committed on the high seas, and offenses against the law of nations." The argument which has been urged in behalf of the prisoner is, that congress is bound to define in terms the offense of piracy, and is not at liberty to leave it to be ascertained by judicial interpretation. If the argument be well founded, it seems admitted by counsel that it equally applies to act of congress, 1790, c. $9, \S 8$, which declares that robbery and murder committed on the high seas shall be deemed piracy. *** When the act of 
1790 declares that any person who shall commit the crime of robbery or murder on the high seas shall be deemed a pirate, the crime is not less clearly ascertained than it would be by using the definitions of these terms as they are found in our treatises of the common law. In fact, by such a reference, the definitions are necessarily included, as much as if they stood in the text of the act. In respect to murder, where "malice aforethought" is of the essence of the offense, even if the common-law definition were quoted in express terms, we should still be driven to deny that the definition was perfect, since the meaning of "malice aforethought" would remain to be gathered from the common law. 'There would then be no end to our difficulties or our definitions, for each would involve some terms which might still require some new explanntion. Such a construction of the constitution is therefore wholly inadmissible. To define piracies, in the sense of the constitution, is merely to enumerate the crimes which shall constitute piracy; and this may be done either by a reference to crimes having a technical name and determinate extent, or by enumerating the acts in detail upon which the punishment is inflicted. It is next to be considered whether the crime of piracy is defined by the law of nations with reasonable certainty. What the law of nations on this subject is, may be ascertained by consulting the works of jurists, writing professedly on public law; or by the general usage and practice of nations; or by judicial decisions recognizing and enforcing that law. There is scarcely a writer on the law of nations who does not allude to piracy as a crime of a settled and determinate nature. * * So that, whether we advert to writers on the common law, or the maritime law, or the law of nations, we shall find that they universally treat of piracy as an offense against the law of nations, and that its true definition by that law is robbery upon the sea. And the general practice of all nations in punishing all persons, whether natives or foreigners, who have committed this offense against any persons whatsoever, with whom they are in amity, is a conclusive proof that the offense is supposed to depend not upon the particular provisions of any municipal code, but upon the law of nations, both for its definition and punishment. We have therefore no hesitation in declaring that piracy, by the law of uations, is robbery upon the sea, and that it is sufficiently and constitutionally defined by the 5th section of the act of 1819 . Another point has been made in this ease, which is that the special verdict does not contain sufficient facts unon which the court can pronounce that the prisoner is guilty of piracy. We are of a different opinion. The special verdict finds that the prisoner is guilty of the plunder and robbery charged in the indictment; and finds certain. additional facts from which it is most manifest that he and his associates were, at the time of committing the offense. freebonters unon the sea, not under the acknowledged authority or deriving protection from the flag or commission of any government. If under such 
circumstances the offense be not piracy, it is difficult to conceive any whish would more eompletely fit the definition. It is to be certified to the cireuit court that ipon the firets stated the case is piracy, as defined by the law of nations, so as to be punishable under the act of congress of the $3 \mathrm{~d}$ of $\mathrm{M}$ ilrch, 1819. Livingston, J., delivered a dissenting opinion. U. S. v. Smith, 5 Wheaton (18 U. S.) 153, C. 28 .

\section{Technlcal terms in statutes, how construed. Pitcher v. P., 87.}

(U. S. Sup. Ct., 1869.) Matter of Local Police. Indictment for selling and keeping for sale illuminating oils mixed with naphtha contrary to act of congress March $2,1867, \S 29$. Defendant demurred, and the circuit court being divided in opinion as to whether an offense against the United States under any constitutional statute was charged, certified the case for the opinion of this court. CHASE, C. J. The questions certified resolve themselves into this: Has congress power under the constitution to prohibit trade within the limits of a state? 'That congress has power to regulate commerce with foreign nations and among the several states and with the Indian tribes, the constitution expressly declares, But this express grant of power to regulate commerce among the states has always been understood as limited by its terms, and as a virtual denial of any power to interfere with the internal trade and business of the separate states, except, indeed, as a necessary and proper means ior carrying into execution some other power expressly granted or vested. It has been urged in argument that the provision under which this indictment was framed is within this exception; that the prohibition of the sale of the illuminating oil described in the indietment was in aid and support of the internal revenue tax imposed on other illumingting oils. * * This consequence is too remote and too uncertain to warrant us in stying that the prohibition is an appropriate and plainly adapted means for carrving into execution the power of laying and collecting taxes. There is, incleed, no reason for slying that it was regarded by congress as such a means. except that it is found in an act imposing internal duties. Standing by itself it is plainly a regulation of police. ** * As a police regulation relating exclusively to the internal trade of the states. it can only have effect where the legislative anthority of congress excludes territorially all state legislation. as for example, in the District of Columbia. Within state limits it can have no constitutional operation. This has heen so frequently declared by this court, results so obviously from the terms of the constitution, and has been so fully explained and supported on former necasions, that we think it unnecessarv to enter again unon the discussion. *** U. S. v. DeWitt, 9 Wall. (76 U. S.) 41, C. 60.

(U. S. Sup. Ct., 1877.) Power of Congress on Crimes in General. Defendant was convicted under U. S. R. S. (1871) $\$ 5132$, in the 
U. S. C. C. for southern New York; and on motion in arrest of judgment, the circuit judges were opposed in opinion, and certified the case for the opinion of this court: "If a person shall engage in a transaction which, at the time of its occurrence, is not in violation of any law of the United States. to-wit, the obtaining of goods upon credit by false pretenses, and if, subsequently thereto. proceedings in bankruptcy shall be commenced respecting him, is it within the constitutional limits of congressional legislation to subject him to punishment for such transaction considered in connection with the proceedings in bankruptcy?" FIELD, J. The question presented by the certificate of division does not appear to is difficult of solution. Upon principle,

An Act which is not an Offense at the Time it is Committed cannot become such by any subsequent independent act of the party with which it has no connection. $B y$ the clause in question, the obtaining of goods on credit upon false pretenses is made an offense against the United States, upon the happening of a subsequent event, not perhaps in the contemplation of the party, and which may be brought about, against his will, by the agency of another.

The Criminal Intent Essential to the Commission of a Public Offense must exist when the act complained of is done; it cannot be imputed to a party from a subsequent independent transaction. There are cases. it is true, where a series of acts are necessary to constitute an offense, one act being auxiliary to another in carrying out the criminal design. But the present is not a case of that liind. Here an act which may have no relation to proceedings in bankruptcy becomes criminal, according as such proceedings may or may not be subsequently taken, either by the party or by another. There is no doubt of

The Competency of Congress to Provide, bv suitable penalties. for the enforcement of all legislation necessary or proper to the execution of powers with which it is intrusted. And as it is anthorized "to establish iniform laws on the subject of bankruptcies throughout the United States." it may embrace within its legislation whatever may be deemed important to a complete and effective bankrupt system. 'The object of such a system is to secure a ratable distribution of the bankrupt's estate among his creditor's "hen he is unable to discharge his obligations in full, and at the same time to relieve the honest debtor from legal proceedings for his debts. upon a surrender of his property. The distribution of the property is the principal object to he attained. The discharge of the debtor is merely incidental. and is granted onlv where his conduct has been free from fraud in the creation of his indebtedness or the disposition of his propertv. To legislate for the prevention of frands in either of these narticulars. when committed in contemnlation of bankruptcy. would seem to be within the competencv of congress. Anv act committed with a view of evading the legislation of congress passed in the execution of any of its powers. or of fraudu- 
lently securing the benefit of such legislation, may properly be made an offense against the United States. But an act committed within a state, whether for a good or a bad purpose, or whether with an honest or a criminal intent, cannot be made an offense against the United States, unless it have some relation to the execution of a power of congress, or to some matter within the jurisdiction of the United States. An act not having any such relation is one in respect to which the state can alone legislate. The act described in the ninth subd. of $\S 5132, R$. S., is one which concerns only the state in which it is committed; it does not concern the United States. It is quite possible that the framers of the statute intended it to apply only to acts committed in contemplation of bankruptcy; but it does not say so, and we cannot supply qualifications which the legislature has failed to express. Our answer to the question certified must be in the negative. U. S. v. Fox, 95 U. S. 670 , B. 227 , C. 58. $\S 13$.

Intent must exist at the tlme of the act. $\$ 30$. Act must be criminal at the time.

(U. S. C. C. for Dist. of E. Mich., 1887.) Court Civil or Martial. BROWN, J. In view of the fact that this was a homicide committed by one soldier, in the performance of his alleged duty, upon another soldier, within a military reservation of the United States, I had at first some doubt whether a civil court could take cognizance of the case at all; but, as crimes of this nature have repeatedly been made the subject of inquiry by civil tribunals, I have come to the conclusion that I ought not to decline to hear this complaint. Indeed, it is difficult to see how I could refuse to do so without abdicating that supremacy of the civil power which is a fundamental principle of the Anglo-Saxon polity. While there is no statute expressly conferring such jurisdiction, there is a clear recognition of it in the fifty-ninth article of war, which provides that "when any officer or soldier is accused of a capital crime, or of any offense against the person or property of any citizen of any of the United States, which is punishable by the laws of the land. the commanding officer, and the officers of the regiment, troop. battery, company, or detachment to which the person so accused belongs, are required (except in time of war), upon application duly made by or in behalf of the party injured, to use their utmost endeavors to deliver him over to the civil magistrate, and to aid the officers of justice in apprehending him and securing him, in order to bring him to trial." This article makes no exception of crimes committed by one soldier upon another, nor of cases where there is concurrent jurisdiction in the military courts. Tytler, in his work upon Military Law, says: "The martial or military law, as contained in the mutiny ac' and articles of war, does in no respect supersede or interfere with the civil or municipal laws of the realm." *** U. S. v. Clark, 31 Fed. 710, B. 319.

More of this case in $\$ 49$. 


\section{SOURCES OF STATE CRIMINAI LAW.}

§3. The criminal law of the states consists of so much of the common law of Fingland and English statutes enacted before the settlement of the American colonies as is suitable and adapted to our condition and institutions, supplemented and amended by the common law and customs that have grown up in this country, and by the constitution and statutes of the state where the crime is committed, except as restrained by the United States constitution.

\section{\$4. "Common Law of England and English Statutes Enacted before the Settlement."}

(MIass. Sup. Judicial Ct., 1809.) Getting Credit by Lies. Indictment against Warren for deceit, cheating, and fraud, in that he obtained fifty pairs of shoes on credit by falsely pretending that he had good credit, kept a grocery at Salem, and that his name was Waterman. Being convicted, defendant moved in arrest of. judgment, on the ground that the indictment charged no offense. The motion was granted, because: 1, defendant being alone, no conspiracy was charged; 2 , there is no pretense that false weights or measures were used, which alone would make cheating at the common law; 3 , no false token was used to obtain the credit, which is punishable by the statute of 33 Hen. 3 , c. 1 , which is a part of our common law, having been enacted before the settlement of this colony ; and $\dot{4}$, the statute 30 Geo. 2 , c. $2 t$, which makes obtaining by false pretenses indictable, is not in force here. Defendant gave a note for the price at the time of obtaining the shoes, and signed it "William Waterman." C. v. Warren, 6 Mass. 72, C. 11, F. 3, Kn. 3.

St. 33 H. 8, c. 1 ; and St. 30 G. 2, c. 24 , wlll be found under "False Tokens and Iretenses" post. See these sections and $\$ 16$ for further discussion of filse toliens nnd pretenses.

(Mass. Sup. Judicial Ct., 1804.) Jurisdiction-Common Law Crime. Defendants were convicted, on a common law indictment, in the court of general sessions, of poisoning a cow, property of A. Bliss moved in arrest of judgment that justices of the pi. ae had no jurisdiction to try this common law offense, having no such power given them by statute; citing Com. Dig. t. Justices of Peace, B. 1; 1 Salk. 406. SEDGWICK, J. Justices of the peace, whether acting individually or in sessions, are creatures of stitute, and their powers are given them by the statutes. 2 Hawk. 61, 8. It appears to me, generally speaking, that the English statutes which were in force at the time of the emigration of our ancestors from that country are common law here. The statutes of Ed. 3 [1 Fdw. 3, c. 16; 34 Edw. 3, c. 1] have been adopted and practiced upon here, and are therefore to be considered as part of our common law. This is decisive of the question before the court, as the offense charged in 
the indictment is, by those statutes, within the jurisdiction of the sessions. [Dana, C. J., Thatcher, and Strong, JJ., expressed similar views.] Motion overruled. C. v. Leach, 1 Mlass. 59, C. 9.

(Mass. Sup. Judicial Ct., 180T.) Same-Statutory Crime. Indictment for damming up Sandy river, without leaving a passage for fish, contrary to the statute. Upon plea of not guilty the jury found guilty, and defendant moved in arrest of judgment that the common pleas court which tried the case had no jurisdiction. PER CURIAN. The court of sessions, to whose jurisdiction in eriminal causes the court of common pleas has succeeded, by statute of March, 1804, was erected by the statute of July 3, 1782, and it is empowered to hear and determine all matters relating to the conservation of the peace, and such offenses as are cognizable by them at common law, or by the acts of the legisiature. If by common law, mentioned in this statute, be understood strictly the common law of England, those words cannot have any effect; for the sessions being created by statute cannot have any jurisdiction but what is given it by some statute. But, if these words import the common law of the commonwealth, they have an extensive operation and are easily understood. Our ancestors, when they came into this new world, claimed the common law as their birthright, and brought it with them, except such parts as were judged inapplicable to their new state and condition. The common law, thus claimed, was the common law of their native country, as it was amended or altered by English statutes in force at the time of their. emigration. Those statutes were never re-enacted in this country, but were considered as incorporated into the common law. Some few other English statutes, passed since the emigration, were adopted by our courts, and now have the authority of law derived from long practice. To these may be added some ancient usages, originating probably from laws passed by the legislature of the colony of the Massachusetts Bay, which were annulled by the repeal of the first charter, and from the former practice of the colonial courts accommodated to the habits and manners of the people. * * The offense, of which the defendant is indicted, is clearly not an offense at common law, but it is a new offense created by the statute, on which this indictment is drawn, as it is not supposed that, there is any otner statute by which the sessions can have jurisdiction; the validity of the objection to judgment on this conviction must depend on the construction of the statute on which it was obtained. In the twelfth section it is enacted, that all the fines imposed shall be recovered by presentment of the grand jury, or by action of debt. This section does not expressly, or by necessary implication, include the sessions. for the words may be perfectly satisfied by a presentment of the grand jury to this court. And the sessions before the statute of March, 1804, or the common pleas since, not having jurisdiction at common law, nor by the 
express provisions of any statute, the judgment must be arrested. C. v. Knowlton, 2 Mass. 530, B. 1, C. 1.

\section{§5. "As is Suitable and Adapted to Our Condition and Insti- tutions."}

('Tenn. Sup. Ct., 1808.) Indictment in the County Court for Eavesdropping: Appeal to this court, and the only question was whether such a prosecution can be maintained. It was insisted for the defendant: 1st, that there was no statute of the state upon the subject; 2d, that the act which adopted the laws of Fingland confined such adoption to such as are consistent with our mode of living. 1715 , c. 31 . s. 5. No precedent can be found of such an indictment, which furnishes a strong inference that such a prosecution was not conformable to the principles of our government, or modes of living. CAMIBELL, J. Agreeably to the common law, such an indictment well lies, and nothing can be seen in this part of it, which is inconsistent with our situation, or in fact the situation of any society whatever. S. v. Williams, 2 Overton (2 Tenn.) 108, Mi. 63.

'The common law rules for interpretation of statutes are sultable to our condition and adopted. C. v. Churchill, \&13.

(Pa. Sup. Ct., 1825.) Barbarous Punishments-Ducking-Stool. Nancy James was convicted of being a common scold, and sentenced to be placed on a ducking-stool and plunged three times into the river. She brings error, claiming the judgment to be illegal. DUNCAN, J. * * * This sentence, we are informed, has created much ferment and excitement in the public mind. It is considered as a cruel, unusual, unnatural, and ludicrous judgment. But whatever prejudices may exist against it, still, if it be the law of the land, the court must pronounce judgment for it. But, as it is revolting to hununity, and is of that description that only could have been invonted in an age of barbarism, we ought to be well persuaded, either that it is the appropriate judgment of the common law, or is inflicted by some positive law; and that that common law or statutory provision has been adopted here. and is now in force. The late Judge Ingersoll, a name respected and honored, when attorney general, in his report to the legislature in 1813, stated, that by several acts of assembly "cruel and unnatural punishments, which tended only to harden and confirm the criminal, had been abolished for all inferior offenses." The sanguinary code of England could be no favorite with William Penn and his followers, who fled from persecution. Cruel punishments were not likely to be introduced by a society who denied the right to touch the life of man, even for the most atrocious crime. For had they bronglut with them the whole body of the British criminal law, then we should have had the appeal of death. and the impious spectacle of trial by battle in a Quaker colony. ** * The common 
law punishment of ducking was not received nor embodied by usage, so as to become a part of the common law of Pennsylvania. It was rejected, as not accommodated to the circumstanees of the country, and against all the notions of punishment entertained by this primitive and humane community; and though they adopted the common law doctrines as to interior oftenses, yet they did not follow their punishments. One remarkable instanee I will notice. A gross libel in Eingland was sometimes punished by the pillory; I believe Mr. Pryme lost both his ears. Though the oftense is the same here, yet the sentence is very different. It is not true that our ancestors brought with them all the common law offenses; for instance, that of champerty and maintenance, this court decided in Stoever v. Whitman's lessee, 6 Binn. 4.16, did not exist here. * * This is a very difterent question from the common law rules of real and personal property, -the modes of acquisition and alienation of estates. For although the reasons of many of those rules have ceased, yet it might be dangerous, on that account, to abolish them; as it would lessen the security of property of titles to land, which should always be firm and stable; and by the charter they were to remain the same as in England, except when altered by the representatives of the people. But $I$ am far from professing the same reverence for all the degrading and ludicrous punishments of the early days of the common law. I am far from thinking that this is an unbroken pillar of the common law, or that to remove this rubbish would impair a structure which no man can admire more than I do. But I must confess. I am not so idolatrous a worshipper as to tie myself to the tail of this dung-cart of the common law. * * Reversed. James v. C., 12 S. \& R. 220, Mi. 7.

(Mass. Sup. Judicial Ct., 1847.) Libel a Crime. SHAW, C. J. This was an indictment against the defendants for a false and malicious libel, tried before the court of common pleas, and, upon a. conviction there, the case is brought before this court, upon an exception, * * that there is no law of this commonwealth by which the iviting and publishing of a malicious libel can be prosecutec by indictment, and punished as an offense. The proposition struck us with great surprise, as a most startling one.

[Sources and Scope of Unwritten Law.] It is true that there is no statute of the commonwealth declaring the writing or publishing of a written libel, or a malicious libel by signs and pictures, a punishable offense. But this goes little way towards settling the question. A great part of the municipal law of Massachusetts, both civil and criminal, is an unwritten and traditionary law. It has been common to denominate this "the common law of England," because it is no doubt true that a large portion of it has been derived from the laws of England, either the common law of England, or those English statutes passed before the emigration of our ancestors, and constituting a part of that law by which, as English 
subjects, they were governed when they emigrated; or statutes mude afterwards, of a general nature, in amendment or modification of the common law, which were adopted in the colony or province by general consent. In addition to these sources of unwritten law, some usages, growing out of the peculiar situation and exigencies of the earlier settlers of Massachusetts, not traceable to any written statute or ordinance, but adopted by general consent, have long had the force of law. *** To a very great extent the unwritten law constitutes the basis of our jurisprudence, and furnishes the rules by which public and private rights arc established and secured, the social relations of all persons regulated, their rights; duties, and obligations determined, and all violations of duty redressed and punished. Without its aid. the written law, embracing the constitution and statute laws, would constitute but a lame, partial, and impracticable system. Even in many cases where statutes have been made in respect to parlicular subjects, they could not be carried into effect, and must remain a dead letter, without the aid of the common law. In cases of murder and manslaughter, the statute declares the punishment; but what acts shall constitute murder, what manslaughter, or what justifiable or excusable homicide, are left to be decided by the rules and principles of the common law. So, if an act is made criminal, hut no mode of prosecution is directed, or no punishment provided, the common law furnishes its ready aid, prescribing the mode of prosecution by indictment, the common-law punishment of fine and imprisomment. Indeed, it seems to be too obvious to require argument that without the common law our legislation and jurisprudene? would be impotent, and wholly deficient in completeness and symmetry as a system of municipal law. *** [Here the judge states the point made by counsel, that no common law of England exists here beyond what has been recognized, because the Massachusetts constitution declares that the common law as practiced continues. After declaring the point not well taken, he proceeds.]

[Effect of Migration and Revolution.] We take it to be a wellsettled principle, acknowledged by all civilized states governed by law, that by means of a political revolntion, by which the nolitical organization is changed, the municipal laws regulating thusi social relations, duties, and rights are not necessarily abrogated. They remain in force, except so far as they are repealed or modified by the new sovereign authority. *** [Here it is shown that what has been practiced cannot be known exactly.] When our ancestors first settled this country, they came here as English subjects; they settled on the land as English territory, constituting part of the realm of England, and of course governed by its laws; they accepted charters from the English government, conferring both political powers and civil privileges; and they never ceased to acknowledge themselves English subjects, and never ceased to claim the rights and privileges of English subjects, till the revolu- 
tion. It is not, therefore, perhaps, so accurate to say that they established the laws of Eugland here as to say that they were subject to the laws of England. When they left one portion of its territory, they were alike subject, on their transit and when they arrived at another portion of the English territory; and therefore always, till the declaration of independence, they were governed and protected by the laws of England, so far as those laws were applicable to their state and condition. Under this category must come all municipal laws regulating and securing the rights of real and personal property, of person and personal liberty, of habitation, of reputation and character, and of peace. *** That the law of libel existed at the first migration of our ancestors, and during the whole period of the colonial and provincial governments, is proved by a series of unquestionable authorities. ***** [The rest of the opinion is devoted to instances in which the Massachusetts courts had punished libel without question as to its criminality or in which the legislature had prescribed regulations for conducting the prosecution.J Exceptions overruled. C. v. Chapman, 13 Metc. 68, F. 28, Kn. 219.

\section{6. "Supplemented and Amended by the Common Law and Customs that have Grown up in this Country."}

(Pa. Sup. Ct., 1791.) Criminal Conversation with Married Woman. Question on special verdict. PER CURIANI. The single question is, whether an ummaried man may be guilty of adultery, under the act of assembly. Originally the offense was of temporal juriscliction, but after the statute of circumspecte agatis, it was remitted to the bishop of Norwich, and through him to the spiritual courts. Had the case been res integra, the decision of the court might be different from what it now is. It is true that practice sub silentio will not make the law, but it is strong evidence of what the law is. It having been the constant practice to proceed against unmarried persons for fornication, though they have been guilty of eriminal conversation with married persons, we will not exaggerate the offense, nor carry it further than our predecessor's have donc; and, therefore, the court pronounce him guilty of fornication. and fine him $\mathfrak{1 0}$, and the costs, and commit him to the sheriff of Philadelphia county. who always exceutes the process of the court in banc. *** Respublica v. Roberts, 1 Yeates, 6, Mi. 13.

(Va. Gen. Ct., 1826.) Matters Settled by Ancient Usage-Illicit Intercourse. Appellant was convicted on an indictment charging, that he, beirg a married man, entieed a maiden of 16 years away from her mother and earnally knew her. DADF. J. **** it, is admitted. that before the statute of circumspecte agatis, 13 Fdward 1, the court of king's bench did on this principle punish 
the offense of ineontineney, and that by that statute the jurisdiction was transferred to the ecclesiastical courts. *** After the statute of circumspecte agatis, the court of king's bench did not exercise jurisdiction in punishing the mere act of incontinence. It, however, letained its general power of punishing offenses contra bonos mores, and it is pigesumed might have punished an offense of incontinence combined with eircumstances, which, beyond the mere criminality of the simple fact, were calculated to make it injurious to society ; as, in case of incontinence in a strect or highway. But, in such cases the jurisdiction would not spring from the criminal character of the simple fact, but from its publicity; as, there are many cases where an act, which is not criminal in private, becomes penal by the publicity which attends its perpetration. The act of Sir Charles Sedler, in ruming naked through the streets, derived its whole criminality from its publicity. *** * * It is too late now to assume jurisdiction over a new class of cases, under the idea of their being contra bonos mores. We must eonsider the prictice of the English courts, from which we derive the principle, as having settled in the course of many centuries. the true limits and proper subjects of this principle. If we are to disregard these landmarks, and take up any case which mily arise under this principle, as res integra, then might it be extended to cases which none has yet thought of as penal. A case of slamder may display as much baseness and malignity of purpose, as much falsehood in its perpetration, as ruinous effects in its consequenees. and as pernicious an example in its dissemination, as this case of seduction. And yet none would think of prosecuting it criminally. It is true, that if something peculiar in our situation had given rise to a class of cases contric bonos mores, as in regall to our slaves, which could not have existed in England, we might be justified in applying the rule in the absence of all precedent. Bint. in relation to seduction, no such supposition can be made, as we know from the books of reports that many such cases have occurred there. And we even see that in two cases. it was in fact the prominent feature, and yet the jurisdiction in one of them [R. v. Delaval, § 19$]$ was made to hang on another hinge: and in the other. which was never decided, was certainly fortified by the allegation allat pron: of a common law mistemeanor. From these premises. it would seem to be proper to infer that since the statute of cireumspecte agatis, in England, the enmmon law courts have never tiken jurisdietion of the mere offense of incontinence. nor of any offense of incontinence combined with other reprehensible cirerumstances. not in themselves importing a common law misdemeanor: that in this . country the legislature has taken up the subject of simple fornication and adultery, and has defined a precise mode of pronf. and a fixed and certain punishment; that there is no reason to believe. that these statutes are cumulative; but. that ther necupy the whole ground; and that, as in England, the offense bring merely spiritual. 
is not, under any circumstances, allowed to be the foundation of a criminal prosecution in the courts of common law; so here, by parity of reasoning, the offense being entirely statutory, it shall not be converted into the foundation of a common law misdemeanor. * * Reversed. Anderson v. C., 5 Randolph 627, 16 Am. Dec. 776, Mi. 64 .

(Tenn. Sup. Ct., 1851.) Case of First Impression. Appellant was convicted of using obscene language in public. McKINNEY, J. * * Upon the first point, the argument for the plaintiff in error rests upon the narrow and unsubstantial ground, that no precedent, or adjudication, has been found in support of such an indictment. Admitting this to be true, for the present, what does it establish? If the case stated in the indictment falls within the operation of elear, well defined, and well established principles of law, is it to be urged against the maintenance of this prosecution, that no similar case has heretofore occurred calling for the like application of such principles? Surcly not, at this day. Are not innumerable instances to be found in the modern reports, both of England and America, in which the liberal, enlighteued, and expansive principles of the common law have been adapted and applied to new cases, for which no precedents were to be found, so as to meet the ever varying condition and cmergencies of society? And this must continue to be so, unless a stop be put to all further progress of society ; and unless a stop be also put to the further workings of depraved human nature, in seeking out new inventions to evade the law. ** * Affirmed. Bell v. S., 1 Swan (31 Tenn.) 42, Mi. 59.

(Pa. Sup. Ct., 1892.) Test of Criminality-Indictment for Solicitation to Murder. Defendant moved to quash, and the motion being refused, appealed. PER CURIAII : * * \# It mav be conceded that there is no statute which meets this case, and if the crime charged is not an offense at common law, the judgment must be reversed. What is a common law offense? We endeavored to answer this question in C. v. AIcHale, 97 Pa.. 397, 410, 39 Am. Rep. 808, Mi. 2T, in which we held that offenses against the purity and fairness of elections were crimes at common law, and indictable as such. We there said: "We are of opinion that all such crimes as especially affect public society are indictable at comımon law. The test is, not whether precedents can be found in the books, but whether they injuriously affect the public policy and economy." Tested by this rule, we have no doubt that the solicitation to commit murder, accompanied by the offer of money for that purpose, is an offense at common law. * * Affirmed. C. v. Randolph,

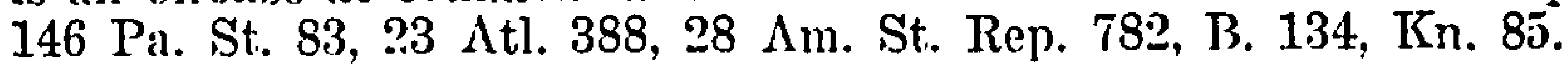




\section{\$7. "And by the Constitution and Statutes of the State."}

(IIl. Sup. Ct., 1860.) Seduction-Implied Abrogation. Defendants bring error on convietion of eonspiracy to seduce Mr., assigning that no offense wals charged in the indictment. CAITON, C. J. $* *$ * The objection that this being but a common law offense, is not punishable in this state, where we have a criminal eode defining most criminal offenses and preseribing their punishment, is answered by the ease of .Johnson v. P.. 2.2 Ill. 314. It is there shown. that our eriminal cole preseribes pumishment for ofienses not enumerated, which can mean nothing but common law offonses, showing conelusive? that it was not the intention of the legislature to repeal that portion of the eommon liaw by implication. ** * Smith v. P., 25 1ll. 17, 76 Am. Der. 780, B. 811.

(Iowil Sup. Ct., 1s60.) Slander, Sodomy-Implied Change by Statnte. JoWv. C. J. This was an action of slander, lor charging the plaintift with having committed the erime of sodomy. No special damages being laid in the petition for nttering and miblishing the slanderons words. a demurere was filed to the effect that the words complaned of imputed no erime which was indietable under the criminal laws of the st.1:", and were therefore not actionable per se. The demurrer was overruled, and the question bronglit up to this cot.:t for revision. * * * Article 5, \$6, of the constitution, declares that the district conrts of this state shall have jurisdiction in eivil and criminal matters arising in their respective districts in such mannel as shall be prescribed by law. The mode thus prescribed is contained in our Code Crim. Proc., and is limited. we think. to the prosecution and punishment of othenses therein enumeraterl. This is inferable from the powers and duties of the grind jury and the conrt therein expressed. Besides, the statutory oftenses so nearly cover all the common law oflenses that it is reasonable to infer that those which are omitted were intended to be excluded. *** In this state the mode of punishing the erime of sodomy is not prescribed by law, and in the absence of such statutory anthority, the comt can exereise no such power'. 'The demurrer in this ease should have bentl s'. : aned and the caluse dismissed. Estes v. Carter, 10 Iowa 400, F. 40.

(Minn. Sup. Ct.. 1866.) Implied Abrogation-Conspiracy. Indicted for conspiracy to assault. Demurrer. that no statute created such a crime. Overruled. and defendant appeals. "That our statutes expressly abolish common-law offenses is not pretended. A statute which is elearly repugnant to the common law must be held as repealing it. for the last expression of the legislative will must prevail. Or we may admit. for the purposes of this ease. that witun a now statute covers the whole ground necupied by a previous one, or by the common law, it repeals by implication the prior law, 
though there is no repugnancy. Beyond this the authorities do not go in sustaining a repeal of the common law by implication. On the contrary, it is well settled that where a statute does not espe. cially repeal or cover the whole ground occupied by the common law, it repeals it only when and so far as directly and irreconcilably opposed in terms. See 1 Bish. Cr. Litw (3d ed.) $\$ \S 195-200$, and cases cited in notes to said sections. Our statutes fall far short of covering the whole field of common-law erimes. It is not pretended that conspiracy is by them made a crime, and we think it very clear that libel is not, and many other instances might be added. We think, therefore, that they do not by implication abolish these crimes. *** [Here the judge refers to instances in which the statutes regulate prosecutions for libel and other offenses not made criminal by statute. or mention common-law crimes.] These sections are an admission or recognition by the legislature of the fact that common-law offenses may be pumished in this state. This conclusion is in accordance with the views entertained by the courts generally throughout the United States. See anthorities cited in note to $\$ 36,1$ Bish. Cr. Latw (3d ed.)" Per WILSON. C. J. Berry, J., dissented. Exceptions overruled. S. v. Pulle, 12 Minn. $16 t$ (Gil. 99), F. 41. Ni. 16.

Common law crimes are held to be abolished in Ohlo. Sce Smlth v. S., \$12. Crime of libel not abolished by implication. C. v. Chapman, $\$ 5$. Further as to con. splracy, \$ 61 .

(Mich. Sup. Ct., 1867.) Technical Terms in Statute-Burglary in "Dwelling House." Pitcher was convicted on an information for feloniously receiving wool burcrlariously taken by Reed from Moore's dwelling house. It was proved that the wool was taken by Reed at night from a barn back of Moore's house and connected with it by fences so as to inclose the back yard, into which the barn opened. Ile brings error, claiming that Reed's act was not burglary because the stitute confines that crime to felonious breaking and entering of the "dwelling house," and therefore defendint could not be sentenced to confinement in the state prison. "The statutory definition of burglary in a dwelling house is the same as that of the common law, and we must infer that the statute designs simply to provide for the punishment of the common-law offense, unless we discover some reason for believing that the legislature employed the definitio: in some new and restricted sense.

It is a cardinal rule in the interpretation of statutes that words which have acquired a well defined technical meaning are to he understood in their technical sense, especially when employed by way of definition. *** There can be no doult that the barn in question would have been regarded as within the curtilage. and embraced by the term 'dwelling house' as a part of the congregited buildings occupied and used by the family for domostic nurnos's, and that consequently the act of Reed would have been a burgalon at the common law. 4 Bl. Com. 225; P. v. Tavlor. 2 Mich. 250 . 
And see 1 Bish. Cr. Law, $\$ 171$. It was therefore, I think, a burglary under the statute, and correctly described in the information." Per COOLEY, J. Affirmed. Pitcher v. P., 16 Mich. 142, F. 35.

'Ihat technical words are to he understood in the common law technlenl sinse.

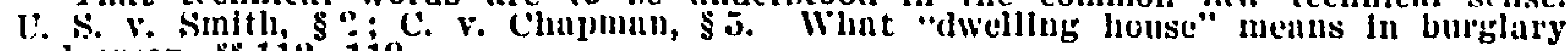
and arson, $\$ \$ 112$, 119 .

(Mass. Sup. Judicial Ct., 1865.) Watered Milk. Indictment for selling adulterated milk contrary to St. 1864, c. 122. Defendant moved to quash on the ground that the statute was unconstitutional. "The argument is this: It is innocent and lawful to sell pure milk, and it is innocent and lawful to sell pure water; therefore, the legislature has no power to make the sale of milk and water, when mixed, a penal offense, unless it is done with fraudulent intent. But it is notorious that the sale of milk adulterated with water is extensively practiced with fraudulent intent. it is for the legislature to judge what reasonable laws ought to be enacted to protect the people against this fraud, and to adapt the protection to the nature of the case. 'They have seen fit to require that every man who sells milk shall take the risk of selling a pure arti. cle. No man is obliged to go into the business." Per CHAPMLN, J. Judgment affirmed. C. v. Waite, 11 Allen (MIass.) $264,87 \mathrm{Am}$. Dec. 711, F. 33.

See sereral similar cases. \$\$3. As to acts male criminal peratrdless of intent, see $\$ 42$.

\section{\$ 8. "Except as Restrained by United States Constitution."}

U. S. Const., Art. 1, §10. No state shall *** pass any bill of attainder, ex post facto law, or ****.

U. S. Const., Amend. XIV, $\S 1$. No state shall make or enforce any law which shall abridge the pirivileges or immunities of citizens of the United States; nor shall any state deprive any person of life, liberty, or property, without due process of law ; nor deny to any person within its jurisdiction the equal protection of the laws.

(U. S. Sup. Ct., 1887.) Prohibition. Act Kan. F(l). 1:, 1881, prohibits the manufacture and sale of intoxicating liquors within that state, except for medical, scientific, and mechanical purposes, and punishes the manufacture and sale thereof, except for those purposes, as a misdemeanor, and declares all places where such liquors are manufactured, sold, bartered, or given away in violation of this law to be common nuisances, and provides for their abatement. Defendant, who had been engaged in the business of brewing beer prior to the passage of this act. and had made extensive improvements peculiarly adapted to such business, was arrested for selling beer manufactured prior to the enactment of the act. Feld, that the act did not deprive defendant of any right. privilege, or 
immunity as a citizen of the United States, or deprive him of life, liberty, or property without due process of law, within the mean. ing of Const. U. S. 14th amend. Mugler v. Kansas, 1:3 U. S. 6:3, 8 S. C't. 2Ti?.

(L. S. Sup. Ct., 1sss.) Oleomargarine Law. Appellant was convieted of violating act Pa., Nay 21,1855 , which provides "that no person, firm, or corporate body shall manulacture out of any oleaginous substance, or any eompound of the same, other than thit produced from unadulterited milk, or of eream from the sime, any article designed to take the place of butter or chese produced from pure, unadulterated milk, or eream firom the same. * * nor shall sell, or offer for sale, or have in his, her, or their possession. with intent to sell, the same as an anticle of food;" and dechares void all contracts made in violation of it, and suljects the offender' to a penalty recoverable in an action of debt. and also to a criminal prosecution. The supreme court of the state aflirmed the judgment (Powell v. C., 114 Pa. St. 265, T Atl. 913); and Powell brought the case here as violating L. S. Const. Amed. $14 . \$ 1$. In this case HARLAN, J., in giving the court's opinion, said: "It is scarcely necessary to say that if this statute is a legitimate exercise of the police puwer of the state for the protection of the health of the people, and for the prevention of frand. it is not inconsistent with - that amendment f for it is the settled doctrine of this court that, as government is organized for the purpose, among others. of preserving the public health and the public morals. it cannot divest itself of the power to provide for these objects, and that the fourteenth amendment was not designed to interfere with the exercise of that power by the states." Judgment alfirmed. FIELD, J., dis-

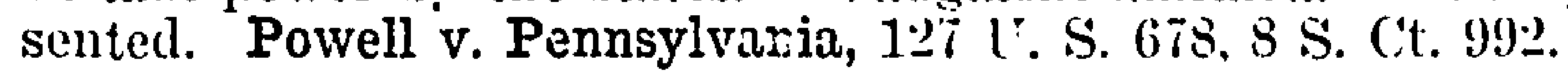

(Mich. Silp. Ct., 1885.) Physician's License. Act Mich., 18\$3, No. 167, enacting that no person shall practice medicine or surgery who is not a graduate of a medical college, unless he has practiced in Michigan for five years when the act takes effect. is not a discriminating liw, repugnant to Const. U. S., Art. 4. $\$ 2$, providing that citizens of ench state shall be entitled to all the privilerges of citizens in the several states; nor is it repugnant to amendments to Const. U. S.. Art. 14. \$1. Judgment affirmed. Camphell and Mor'se, J.T.. dissenting. P. v. Phippin, 70 Mich. 6, 37 N. TV. S8S. $14 \mathrm{Am}$. St. Rep. 470. 


\section{CIIAPTER II.}

\section{DEFINITION AND NATURE OF CRIALE.}

DHFINITS OF A Cl:IME.

s. Definition, 21.

$\$ 11$. "A Crime is Any Act," 21.

\$11. "Or Commission or Omission," 25.

"In Violntion of Law."

\$12. Interpretation, 33.

\$13. IRepeals and dmendments, 3..

\$14. "o'musing Injury." "3i.

"lo the Public at Linge."

\$1.T. Malfeious Injuries, $4 T$.

\$16. Irivate Cheats, 4!).

\$17. Nuistunces, 50.

\$1s. Instumbing I'ublic l'afles. Sufety, or Comfort, z1.

\$19. Corrupting lublic Morals, 5t.

$\$ 20$. 'Touching the Government, 57 .

$\$ 21$. "For" Which the Wronglued mily be l'rosectited and Punished," ss.

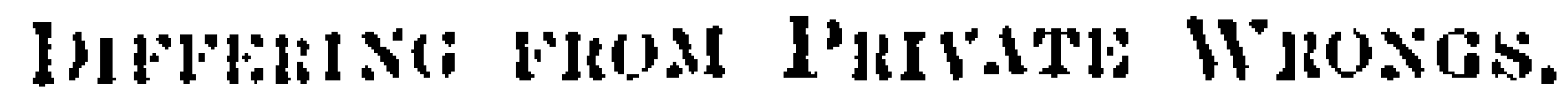

$\$$ :.:. General statement, is.

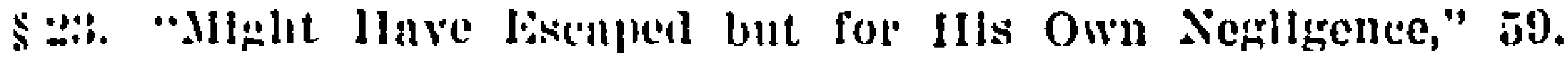

\$24. "Was Equally Guilty." (11.

\$.7. "Uns licen liambursed," (it.

$\$ 2$ (i. "Ifas Furgiven the Wrong," 65.

$\$ 2$. "Intrapped the ofrenter," 65 .

$\$$ s.s. "Consented to the Act," 66 .

s.29. "Want of consent an Essential Element of I'articular Crime," 68.

Menibin.

sill. of Irivale in "ublic Wrong, 7 .

\$31. Of Mistemeanol's in Felonies, 81.

\$3:- General statement. 81 .

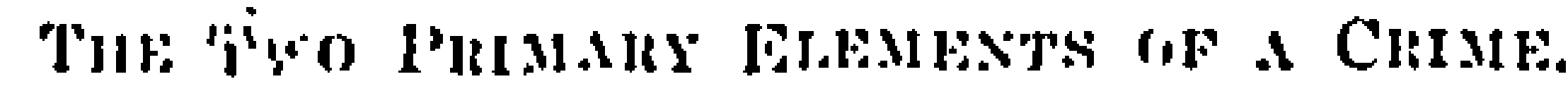

$\$ 3:$ Cenoral stutement, S3.

\section{DEFINITION ON A CRIME.}

\$9. A crime is any nct of commission or omission, in violation of law, causing injury, to the public at large, and which mij be prosecuted and punished in a proceeding in the name of the state.

\section{\$10. "A Crime is Any Act."}

(English King's Bench, 1736.) Having Dies to Stamp Coins. Defendant was convicted on indictment for possessing two stamps to impress scepter's on sixpences, color them like gold, and pass them for half guineas. On certiorari to this comrt it was argued for defendant that the common law takes no notice of a bare intention, as a crime, inless coupled with some overt act; and therefore, though in the time of Edw. III an intention to rob was a felony, 
yet even then, as appears by 3 Inst. fo. 5, there must have been some overt act to show that intention. So in Bacon's Case, 1 Sid. 230, 1 Lev. 146, though an intention to kill the master of the rolls was adjudged a misdemeanor, yet there was an overt act, viz., a s'eward offered by the defendant for doing it; so in Holmes's Case, Cro. Car. 376 [\$119], where burning his house with an intention to burn his neighbor's was held a misdemeanor; yet there was an act joined to the evil intention, viz., the burning his own house. So in the case of R. v. Cooper, 5 Mod. 206, Skinner, 637, where an intention to assist the king's enemies was held a misdemeanor; yet there was an overt act laid, viz., hiring a boat for that purpose. But this indictment is really nothing more than for an intention to make an impression with such stamps as he had in his custody; and a man may be possessed of a thing without having done any. thing to acquire the possession; and the bare having a thing is not unlawful. LEE, J. It is certain that a bare intention is not punishable; and yet when joined with acts whose circumstances may be tried, it is so; so an action innocent in itself may be made punishable by an intention joined to it; as loading wool with intention to transport it, as Lord Hale says in his Hist. Plac. Coron. vol. i., p. 229. In this case the indictment is for unlawfully having in his custody stamps capable of making impression of scepters, with intent to make such impression; now the statute of $8 \& 9$ Will. III. [c. 26] has considered the having as an act; for, by the statute, it is high treason to have [lnowingly any] instrument, etc., in his possession; and though the word knowingly is adder, yet that is an act of the mind only; and the only act capable of trial in the offense against the statite is the having in possession. All that is necessary in this case is an act charged, and a criminal intention joined to the act. Judgment by the whole court (Hardwick, C. J., Lee, Page, and Probyn. J.J.) that defendant stand in the pillory at Charing-cross, pay 6s. 8d. (being very poor and long imprisoned), and be imprisoned six months. R. v. Sutton, Cases t. Hardwicke 370, 2 Śtrange 1074, 13. 125.

(Pa., Oyer and Terminer for Philadelphia, 1778.) Intended Treason. Indictment for treason. Defendant mistook American for British troops and went to join them. Evidence of his words was offered to show his mistake and real intention. The court held that no evidence of words relative to joining the American troops conld be admitted; for any adherance to them, though contrary to the design of the party, cannot possibly come within the idea of treason. Respublica v. Malin, 1 Dallas 33, B. 127.

(Mass. Sup. Judicial Ct., 1806.) Intending to Issue Forged Notes. The defendant was charged with having in his possession certain forged notes on a bank which he knew had no existence, "with intent falsely, fraudulently, and deceitfully to utter and pass the 
same for and as true and genuine notes" of a genuine bank. To this indictment he demurred, and the court said: "'l'he allegations amount only to an intention to cheat, which at common law is not indictable." Defendant discharged. C. v. Morse, 2 Mass. 138.

(Eng. C. C. R., 1810.) Mere Intent to Pass Counterfeit Coins. Defendant was indicted on three counts, (1) for uttering, (2) for possessing with intent to circulate, and (3) for guilty possession of counterfeit money. 'The only act of uttering was a delivery of a box containing 2,800 bad shillings and 1,000 bad sixpences to a coach office for carriage to a man at (ylasgow. The box was stopped where received. The judges were at first inclined to think that an offense was stated in the second count; but the majority finally concluded that "having in his possession," with the term "knowingly" annexed to it, could not be considered an act, and that an intent without an act was not a misdemeanor; and they considered $R$. v. Sutton [above] untenable. R. v. Heath, Russ. \& R. 184, F. 140.

(English Qucen's Bench, 1853.) Having Obscene Prints. A was indicted for unlawfully and knowingly preserving and keeping in his possession indecent and obscene prints and libels, with intent and purpose to priblish and disseminate them. This was held not to be a crime, since the prints might have been innocently procured, and the intent to publish them may not have been entertained until afterwards; and entertaining the intent was not an act, and therefore but the commencement of a misdemeanor. Dugdale v. R., 1 Ellis \& B. 435, 1 Pierce C. C. 61, 16 Eng. L. \& Eq. 380, Dears 64, 17 Jur. 546, B. 221.

$\Lambda$ s to criminality of publishing nbicene books and pictures see $R$. V. Read, $\$ 10$ R. v. Curl, $\$ 19$ : C. v. Shistpless, \$19: U. S. v. Hirmon, $\$ 3 \pi$,

(Ark. Sup. Ct., 1848.) Coming to Assault. Yoes was convicted of assault and battery. JOHNSON, C. J. The circuit court manifestly erred in giving the first instruction asked by the state. The instruction is, that if the jury believe from the evidence that the defendant went to the meeting-house yard and called Hughes out for the purpose of having a difficulty with him, they shoul? find him guilty. A crime or misdemeanor consists in a violation of public law, in the commission of which there must be a union or joint operation of act and intention or criminal negligence. See R. S. c. $44, \S 1$. The mere fact of going to a place with the intention of doing an unlawful act, will not of itself subject the party to the punishment denounced against such act, unless he also carries his intention into effect. *** Reversed. Yoes v. S., 9 Ark. 42, Mi. 20.

(Conn. Sup. Ct. of Errors, 1862.) Picking Empty Pocket. Appellant was convicted of attempt to steal from the person, on allegation and proof that he put his hand into the pocket of an unknown 
woman, without allegation or proof that anything of value was in the pocket. He excepted. BU'l'LER, J. We alre all satisfied, upon a careful consideration of the case, that this verdict and judgment should stand. It may well be doubted whether the first count of the information is sufficient. A mere intent to commit a crime, which exists in the mind only, and has not induced and character"ized an aet, is not a punishable offense; and therefore an "attempt" necessarily includes the intent, and also "an act of endeavor" adapted and intended to enlectuate the purpose; and both must be specifically alleged and proved. *** Nor is the averment of the overt act sulficient. It is essential that the act of endeavor should be intrinsically adapted to eftectuate the purpose; and in order that the court and the accused miny see that the act is so adapted, it should be specifieally stated. Here the averment of the act, "by picking her pocket," is uncertain and equivocal. * * * The second count is not open to these objections. In that the act of endeavor-" by thrusting the hand into the pocket"-and the intent, are specifically charged; and that count in those particulars is clearly sufficient. *** Affirmed. S. v. Wilson, 30 Comn. 500, Kn. 80.

ree simllar canses of attempt, $\$ 6 .$.

(Ark. Sup. Ct., 188T.) Statement Delieved to be False. Indictment for obtaining money by fialse j)retenses. Demurrer by defendant was sustained, and the siate appealed. COCKRILL, C. J. *** By the terms of the statute the pretense must be false. And the doctrine undoubtedly is, that if it is not false, though believed to be so by the person employing it, it is insufficient. 2 Bish. Cr. Law, s. 41 . The false pretense charged in this case is Asher's representation that the mortgage. npon the security of which he got the mules from Moore, was the first lien on the land. If the representation is true, there is no foundation for this prosecution, however reprehensible Asher's motive may have been, because the false pretense would not be established. Now, construing all the allegations of the indictment together, is it shown that the representation was false? It is charged that Asher had previously executed a mortgage to his co-defendant, Fitzpatriek, for the full value of the land and that it was the prior lien; but it is also charged that Fitzpatrick counselled $\Lambda$ sher to malie the representation that the lind was free from incumbrance and aided him in obtaining the mules from Moore on the faith of it. 'The demurrer admits that these allegations are true. Being true, the legall conclusion is that Fit\%patrick waived the priority of his lien and is estopped from asserting it against Moore. Scott v. Orbison, 21 Ark. 202; Gill v. Hardin. 48 Ark. 412 ; Shields v. Smith, 37 Id. 47. Asher's representation that Moore's mortgage was the prior lien was therefore true. Moore got just what he bargained for, according to the allegations of the indictment, and he has not, therefore, 
been injured in any way. The statutory oflense has not been committed. $* *$ Affirmed. S. v. Asher, 50 Ark. $4 \cdot 2 \bar{\imath}, \mathrm{S}$ S. W. $17 \tau$, B. 229.

\section{§11. "Of Commission or Omission."}

(Eng. Queen's Bench, 1705.) Neglecting Apprentione. Indictment for that a poor child, being an apprentice to the defendant pursllaut to the statute, he vi et armis refinsed to provide for him. IE'T P'BR CUR. Since we allow the justices powel to put out apprentices, we must allow an indictment for disobedience, either in case of not receiving, turning off:, or not providing for such apprentice, as the law recuires; and the vi et armis is surplusage. R. v. Gould, 1 salk. 381 .

\section{(ling. C. C. R., 1802.) Failure to Provide for an Apprentice} of tencler year's suitable food, apparel, bedding, and sustenance, defendint being able and the apprentice unable to provide, whereby she was nearly starved and greatly injured in health, wats held to be an indictable misdemeanor. In this case the indictment was defective in not stating the age and ability of the child. but the objection was rather to the evidence. There being some difterence of opinion, all the judges (says the report) thought it right that the fintal decision should be adjourned, and that the prisoner should sutier the whole term of his imprisomment. Chambre. J., thought it no way indictable, being founded wholly on contract. $R$. v. Friend, Russel \& R. 20, 13. 190.

(Eng. Assize, 18t7.) An Explosion of Gas in a mine calused the death of the under-foreman and eighteen other men in the mine, and on trial of the minager or groumd bailift for manslaughter of the under-foreman, on the ground that the explosion wiss due to failure to provide proper ventilation, the jury were instructed by MAULE, J. * * * The questions for you to consider ire whether it was the duty of the prisoner to have directinl : airheading to be made in this mine; and whether, by his omitting to do so, he was guilty of a want of reasonable and ordinary precalution. If you are satisfied that it was the ordinary and plain duty of the prisoner to have caused an air-heading to be malde in this mine, and that a man using reasonable diligence vould have had it done, and that. by the omission, the death of the deceased occurred, you ought to find the prisoner guilty of manslanghter. It has been contended that some other persons were. on this necasion. also guilty of neglect. Still, assuming that to be so. their neglect will not excuse the prisoner; for. if a person's death be occasioned by the neglect of several, they are all guilty of manslanghter; and it is no defense for one who was negligent to say 
that another was nergligent also, and thus, as it were, try to divide the negrignenee among them. Verdict, not grilty. $R$. v. Haines, 2 Car. \& Kir. 368, 13. 17).

(Eng. Assize, 1850.) A Mine Engineer whose duty it was to laise the men from the mine in a skip. was convicted of manslaughter before Camplell, C. J., beciase he loft the engine in charge of a boy who declared he could not manage it. and under threat from defendant. raised the skip. but was unable to stop it at the top. whereby the skip was drawn over the pulley, and deceased fell back into the mine and was instantly killed. In this ease CAMPPBELI, C. J.. said: I am clearly of opinion that an act of omission as well as of commission, may he so eriminal as to be the subject of an indietment for manslaughter, and that there is evidence to go to the jury of such a criminal omission in this case. Guilty. R. v. Iowe, :3 Cur. \& Kir. 123, 4 Cox. C. C. 449. 1 B. \& H. 49-n, B. 192.

(Eng. Queen's Bench, 1851.) Death from Defect in Highway. This was a rule to quash a coroner's inquisition which had been removed into this court by certiorari. 'The inquisition alleged that the defendants were the trustees of a public road under an act of parliament; that it was their duty to contract for the due reparation of the said road; that ther feloniously did neglect and omit to contract for the repar of the same, wherehy it became very niry, ruin. ous, deep, broken, and in great decay: and that a cart. which the deceased was driving along the road. fell into a hole in the road. and by reason thereof the deceased was thrown ont. and sustained the injuries of which he afterwards died. IAORD CAMIPBELI. C. J. The eases cited show a personal dutr, the negrect of which has directly caused death; and. no doubt. where that is the case, a conviction of manslaughter is right. But how do those apply to trustees of a highway? IIow can it be said that their omission to raise a rate, or to contract for the reparation of the road. directly causes the death? If so, the surveyors or the inhabitants of the parish would be equally guilty of manslaughter; for the law casts upon them the duty of keeping the roads in repair. To uphold this inquisition would be to extend the criminal law in a most alarming manner, for which there is 110 principle or precedent. * * The other judges concurred. Inquisition quashed. R. v. Pocock, 5 Cox C. C. 172,17 Q. B. 34, B. 423, Mi. 233.

Compare R. v Richards, \$17.

(Eng. C. C. R., 1857.) Open Mine Shaft. Indictment and con. viction of manslaughter. It was defendant's duty in sinking a shaft in a colliery to guard the letting down of buckets and material. The buckets were run on trucks on a tramway to the mouth of the shaft, then onto the shaft on a moveable stage. which was removed after the bucket had been lifted. On one oceasion he left the stage 
off the mouth of the shaft, and a truck and bucket of bricks ran off the track into the shaft, and killed decensed. LORD CAMPBSELL, C. J. We are of the opinion that this conviction ought to be affirmed. It was the duty of the prisoner to place the stare on the mouth of the shaft; the death of the decensed was the direct consequence of the omission of the prisoner to perform this duty. If the prisoner, of malice aforethought and with the premeditated design of causing the death of the deceased, had omitted to place the stage on the mouth of the shaft. and the death of the deceased had thereby been eaused, the prisoner would have been gruilty of murder. * * If the omission was not malicious and irose from negligence only. it is a case of manslaughter. * * * There is no authority for the position that without an act of commission there can be no manslaughter; and on the contrary, the general doctrine seems well established that what constitutes murder being by design and of malice prepense, constitutes manshanghter when arising from culpable negligence. Conviction affirmed. R. v. Hughes, 7 Cox C. (.. 301. ')ears. \& B. 248, 26 L. J. m. c. 202. 3 Jur. n s. 696,5 W. R. 732, c. 11 t.

(New Jersey Sup. Ct., 1867.) Felonious Omission of DutySwitchman. Defendant heing a switchman in the eity of Newark, whose duty it was to shift the switches for approaching trains, forgot his duty for a little while. and as a result a train was wrecked and one Gardner killed. For this he was tried and eonvicted of manslaughter. He complains of the instruction of the court that he could be convicted on proof of mere culpable omission resulting in death. DAIRYMPLE. .T. * * * The very definition of "crime" is an act omitted or committed in violation of public law. The defendant in this ease omitted his duty under such circumstances as amounted to gross or culpable or criminal negligence. The comrt churged the jury that if the defendant. at the time of the aceident. was intending to do his duty. but, in a moment of forgetfulness. omitted something which any one of reasonable care would be likely to omit. he was not guilty. The verdict of guilty finds the question of fact involved in this i...oposition against the defendant, and convicts him of gross negligence. He owed a personal duty, not only to his employers. but to the public. He was found to have been grossly negligent in the performance of that duty, wherehy human life was sacrificed. His conviction was right. and the court below should be so advised. S. v. O'Brien, 32 N. J. L. 169, F. 212. Kn. 1, Mi. 218.

(Eng. Assize. 1869.) The Watchman at the Crossing of a private tramway and highway, left his post in violation of strict orders; and while away, one crossing the track was killed by passing trucks. For this the watchman was indicted for manslaughter; but the duty being merely private to his employer, who was not bound to 
keep a watchman there, it was held that there was no such breach of duty as to make him liable for manslaughter. R. v. Smith, 11 Cox C. C. $7 \tilde{5}$, B. 192, C. 116.

(Eng. Assize, 1875.) Neglect of Grandchild. Indictment for manslanghter of defendant's grandson. IBRE'I'I', J., to the jury. * * Here was an old woman left in a difficult position. The child was probably illegitimate. Its mother, who was the prisoner's daughter, had died, and would not probably have suckled it for some days before her death. This child was small and weakly. It might, perhaps, have lived. What, however, was the prisoner to do? It is said that she had, through her own misconduct, fallen into bad circumstances; that she was addieted to drink, and that her furniture had been seized. She was out all day eollecting ratuss and bones. What ought she to have done with respect to the child? The prosecution say that she ought to have sent it to the parish anthorities. Perhaps she ought. But she, like others, might be full of prejudice, and dislike to send it there. So her omission to send it is not sufficient; for, as I have pointed out, there must be wicked negligence on her part. 'l'hen she must go out to work. She could not find any one else, for she had no means, so she get a son of nine rear's old to look to the infant. She may have been very careless, but the question is. was she wickedly careless? *** Verdict, not guilty. R. v. Nicholls, 13 Cox C. C. T5, 13 M[oak 42:3, B. 193.

(Eng. Assi\%c, 1S68.) Medical Treatment_-"Peculiar People." Defendants were indicted for manslanghter of their child, by nerrlecting medical attendance. Deceased was very roung, delicate, especially in the lungs, and in the last illness defendants amnointed it with oil two or three times and prayed to the Lord. but called no doctor. 'They were of the sect, callerl "Peculiar People," one of whose tenits is not to call a doctor in cases of illness. 'Their faith is based on the General Fpistle of St. James, c. 5, vv. 1t-15. as follows: "Is any sick among you? let him call for the elders of the church; and let them pray over him, annointing him with oil in the name of the Lord; and the prayer of faith shall save the sick. and the Isord shall raise him up; and if he have eommitted sins, they shall be forgiven him." WILJWS, J., in summing up to the jury, said that in order to malke out the offense of manslaughter in a case of this description, the proposition to be established was that the prisoners had the charge of the child in question, who would from its tender age not be able to care for itself; that they hald the means of providing things reasonably fit for it, and that they were guilty of gress and culpable negligenee in not resorting to those means for its benefit. by lack of which its death was occasioned. The question was whether the jury were satisfied on the evidence that the child came by its death by the gross and culpable negligence of its parents; and that was a very wide question. If a 
parent hat the means of supplying his child with food and were to keep it starving, even under a notion that he had some religious duty imposed noon him to starve it, and it: it condel be miacle ont that that was an insane and morbid beliel", everybory would come to the conchusion that there must be a conviction, lor all the reasoning in the world would not justify a m:m in starving a ehild to death. But when a jury had to consider what was the precise medical treatment to be applied to a particular case, they grot into a much higher latitude indecel. At difterent times people hald come to different conclusions as to what might be done with a sick person. 'Two humberel yoan's ano, if a child was aftlieted with the king's cvil, the populatr feeling was, regardless of medieal science, to have it tonehed with the royal hand, becanse that might result in offeeting a cure. Again. in some Catholic eomontries, a custom obtained of taking a child haboring under a disease to a particular shrine, under a belief that that was the best eomese to adopt with a view to affect a cure. In such calses a miln might be convicted of minshalughter becanse he lived in a place where all the community was of a contrary opinion. and in another he might be acquitted because they were all of his opinion. Verdict, not gruilty. R. v. Wagstaffe, 10 Cox C. C. 8330, C. 100 .

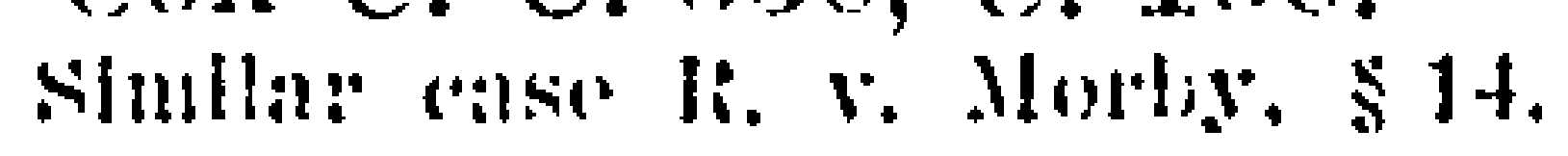

(Wing. C. C. R., 1875.) Same-Statute on Medical Attendance. Defendant was indicted for and convicted of manslanghter of his son of two years, who hald been ill and wasting for eight or nine months belore death, and during the whole period had no skilled treatment; but, by reason of the religious faith of defendant, of the sect of "Peculiar People," having peligions seruples against ealling physicians, was left in eharge of a womm of their sect. prayed over, and amointed with oil. COLSRIDGE, C. J. I think that this eonviction should be affirmod. For mo own part, but for the statute $31 \& 32$ Viet. c. 122 . \$37, I should have much doubt about this case, and should have desired it to be further argued and considered. Perhaps it is enongh to say that the opinions of Willes, J., and Pigott, B., are deserving of grave consideration. 'The statnte 31 \& 32 Viet. c. 12:2, $\$ 37$, however, is a strong illolit...nt in favor of the conviction. By that enactment it is made an offense punishable summarily if any parent wilfully neglects to provide (inter alia) medieal aid for his child being in his eustody under the age of fourteen years, whereby the health of such child shall have been or shall be likely to be seriously injured. That enactment I understand to mean that if any parent intentionally, i. e., with the knowledge that medical aid is to be obtained, and with a deliberate intention abstains from providing it. he is guilty of an offense. Under that enactment upon these facts the prisoner would elearly have been guilti of the offense created br it. If the denth of a person results from the culpable omission or a breach of duty 
created by the law, the death so caused is the subject of manslaughter. In this case there was a duty imposed by the statute on the prisoner to provide medical aid for his infant child, and there was the deliberate intention not to obey the law,-whether proceeding from a good or bad motive is not material. The necessary ingredient to constitute the crime of manslaughter existed, therefore, in this ease, and for that reason this conviction ought to be affirmed. * * * The other judges concurred. Conviction affirmed. R. v. Downes, 13 Cox C. C. 111 , 45 L. J. m. c. 8,1 Q. B. D). 8, 33 L. 'T. 675,25 W. R. 278, 15 Moik. 161, 13. 195, C. 102.

(Me. Sup. Judicial Ct., 1Si6.) Death of Wife from Exposure. Defendant, convicted of manslaughter, moved in arrest of judgment, and excepted to the ruling on this motion and to certain charges to the jury and refusals to charge. It was shown that deceased was the wife of defendant, was insane, a cripple, unable to move herself except by her hands, and would tear all the elothing from her body; that defendant kept her confined in a very open cold room in the house, day and night, with nothing to sleep on but husks and rages in filthy condition, with no covering but a piece of canvas from Jan. 18 to Feb. 9, 1875, with no fire or other artificial heat to warm the room. and with one light out of the window; that in this eondition she was found by the neighbors, badly frosted, discolored, and aftected with gangrene, of which she soon after died. BARROWS, J. **** The defendant objects to the first count, because he says it contains no allegation that the condition of his wife, her necessities, and the facts alleged in that count as constituting the crime of manslaughter were known to him. The count alleges the relation which he sustained to the deceased, his duty to provide for her necessities, her own incapacity and his ability to do it, and that he did "feloniously and wilfully neglect and refuse to provide necessary clothing, shelter, and protection from the cold and inclemency of the weather" for her from the 19th day of January to the 9th day of February, the consequent sickness and death of the wife, and manslaughter by the defendant "in the manner and by the means aforesaid." The objection is not sustained. The allegation of a wilful and felonious neglect and resusal to perform the duties devolved upon him by law in the premises of itself imports an allegation that he knew the necessities of his wife and the essential facts alleged in the count. *** It was not necessary to allege nor to prove that the defendant knew from day to day the effect which his brutal neglect was producing. If such knowledge could have been brought home to him, he should have been charged, not with manslaughter, but with murder. *** For further illustration of the doctrine that manslaughter may be committed by a negligent omission of duty, see R. v. Marriott, 8 Car. \& P. 425; R. v. Edwards. Id. 611; R. v. Lowe, 4 Cox C. C. 449 [§11] ; R. v. Plummer, 1 Car. \& K. 
600 ; Nixon v. P., 2 Scam. 269. * * * Affirmed. S. v. Smith, 65 Me. 257, F. 213.

(Eng. C. C. R., 1893.) Neglecting Helpless Aunt. Defendant, in unmarried woman of 30 or 40 years, without occupation or means of her own, was convicted of manslanghter for the death of her aunt, who had a small income, with which she provided for herself and defendant, who alone lived with her. Decensed was found half dressed, reclining partly on her bed and partly on the ground; and the post mortum disclosed that she had been dead several days when discovered, and probably died of gantrone in the leg, from which she must have been umable to attend her wants for several days before death. Defendant lived in the house all this time, and took and lived on the provisions furnished by the tratlesmen on the means of her aunt, yet gave no notice to the neighbors of her aunt's condition or needs, nor attended her; and exhaustion from want of food and drink apparently hastened if it did not cause the death. In the court below and here it was contended for the prisoner, that no legal duty required her to provide food or attendance for her aunt, and such duty can arise only from contract, common law, or statute. LORD COLERIDGli, C. J. We are all of opinion that this conviction must be atfirmed. It would not be correct to say that every moral obligation involves a legal duty; but every legal duty is founded on a moral oblination. A legal common law duty is nothing else than the enforcing by law of that which is a moral obligation without legal enforcement. 'liere can be no question in this case that it was the elear duty of the prisoner to impart to the deceased so much as was necessary to sustain life of the food which she from time to time took in, and which was paid for by the deceased's own money for the purpose of the maintenanee of herself and the prisoner; it was only through the instrumentality of the prisoner that the deceased conld get the food. There was, therefore, a common law duty imposed upon the prisoner which she did not discharge. Nor can there be any question that the failure of the prisoner to discharcre her legal duty at least accelerated the death of the decensed, if it did not intually cause it. There is no case directly in point; but it would be a slur upon and a discredit to the administration of justice in this country if there were any doubt as to the legal principle, or as to the present case being within it. The prisoner was under a moral obligation to the deceased from which arose a legal duty towards her; that legal duty the prisoner has wilfully and deliberately left imperformed, with the consequence that there has been an acceleration of the death of the deceased owing to the non-performance of that legal duty. It is unnecessary to say more than that unon the evidence this conviction was most properly arrived at. Hawlins, Cave, Day, and Collins, J.J., concurred. Conviction affirmed. R. v. 
Instan, $\mid 189: 3\rfloor 1$ Q. 13. 450, 17 Cox C. C. 602,62 I. J. m. c. 86,68 L. 'T. 420 i), 41 W. R. 368, 57 J. R. 28:2, B. 198.

('Tex. ('t. of App., 1889.) Failure to Volunteer Help Beyond Line of Duty-Liability of Brakemen for Homicide by Engine. The engineer, fireman. and brakemen, enganged in operating an engine on the Honston, E. \& W. 'I. RY., Were jointly indieted for negligent homicide, in ruming the engine and tender backwards over and killing a child on the track, withont ringing the bell, blowing the whistle, giving any warning, or looking to see il any person was in danger. The lirakemen only were tried, were convicted. and appeal. WihlsSOX.J. $* *$ As we view the eridence and the law applicable thereto, this ennvietion is not warranted. These appellants were brakenen. They had no emtrol whatever of said engine and tender. Ther vere riding upon the same lor the prupose merely of performing their specific duties as brakomen, which duties had no eommetion with, or relation to the lomicide. It was the exchusive duty of the engineer and fireman to operate the. engine callefully; to jook out for obstructions on the track; to give signals of dinger when necessaly. With these duties appellants were in no way concerned. They had no right to start the engine in motion, to blow the whistle, to ding the hell, to stop the engine, or otherwise to eontrol its movements. 'They performed no act which eommected them with the death of the child. It is only for a supposed omission of duty on their part that they have heen eonvieted of negligent homicile. They omitted to look out for obstructions on the track. 'Whey might have seen the elild in time to sive its life, hat they omitted to sie him; or. if they did soe him. they omitted to stop the tring or to signal the engineer to stop it. Were these omissions criminal, within the meaning of the statute defining negligent homicide? We think not; beciluse to constitute criminal negligence or carelessnoss there must be a violation of some duty imposed by law, directly or impliedly, and with which duty the defendant is especially charged. Mr. Wharton says: "Omissions are not the basis of penal aetion. unless ther constitute a defeet in the discharge of a responsibility with which the defendant is especially invested." Whatt. IIom. $\$$ i: Aguin, this anthor says, in treating of omissions by those charged with machinery, ete. "'l'he responsilility of: the defendant which he thus fatils to discharge. must he exchusive and peremptory. A stranger who sees that unless a railway switeh is turned, or the call stopped. an aecident mily ensue. is not indietalble for not turning the switch or stopping the carr. The reason for this is obvious. 'T' coerce hy criminal prosecution every person to supervise all of hep persons and things. would destroy that division of libor and respon. sibility by which alone business ean be safely ennducted. and would establish an inclustrial commumism by which private enterprise and private caution would be extinguished. Nothing can be effectually guarded when everything is to be guarded by everybody. No mi- 
chinery could be properly worked if every passer-by were compelled by the terror of a criminal prosecution to rush in and adjust everything that might appear to him to be wrong, or which was wrong, no matter how it might happen to appear. By this wild and irresponsible interference even the simplest forms of machinery would be speedily destroyed." Id. § 80. * * * Reversed. Anderson v. S., 27 Tex. App. 117, 11 S. W. 33, 11 Am. St. Rep. 189, 3 L. R. A. 644.

\section{"In Violation of Law."}

\$12. Interpretation.

(Eng. Queen's Bench, 1598.) If a Statute Prohibits Anything Without Naming a Penalty, a violation of the stitute is indictable, unless the statute indicates otherwise. This was stated by the court in a case in which a constable was indicted for refusing to raise a hue and cry after a burglar at night, and denira that he was bound to do so, because not bound to be in attendince at that time; but the indictment was held good. Crouther's Case, Cro. Eliz. 65t, B. 95.

(N. Car. Sup. Ct., 1884.) Same. Parker was indicted for selling liquor within two and one-half miles of Zion church, contrary to act of 1883 , c. $166, \S 7$, providing that it shall be unlawful for any person to sell liquor within that distance, but providing no penalty for violation. In $\$ 8$ it is provided that "any per'son violating sections four, five, and six of this act, shall be deemed guilty of a misdemeanor." Defendant contended that no prosecution could be maintained for violation of $\S 7$ because of the ficts above stated. He was convicted and assigns error. ASHE, J. **** If a statute prohibit a matter of public grievance, or command a matter of public convenience, all acts or omissions contrary to the prohibition or command of the statute. being misdemeanors at common law, are punishable by indictment, if the statute specify no other mode of proceeding. Arch. Cr. Law 2; 2 Hawk.. ch. .5. \$ 4. There is no other mode of proceeding specified in the act; ergo, the defendant is indictable at common law. Affirmed. S. v. Parker, 91 N. Car. 650, Mi. 15.

Ace. C. v. Chitpmin. 5. A busing any statutory privilege (right to vote), is a misdemeanur at common law. C. v. Silsber, $\$ 20 ; C$. v. Ualiarhan, $\$ 20$.

(Ohio Sup. Ct., 1861.) Attempt to Rape Child Conșenting. Defendant bringing error from conviction on indictment for assault with intent to commit statutory rape on a consenting child under ten, the court discharged him; because the statutes have abolished all common law crimes, assault on a consenting party is an absurdity, and the statute on this matter (probably by inadvertent omission) covers only the completed act. Brinkerhoff. J., dissenting, 
on the ground that the assent of the child was void, as held in Hays v. P., 1 Hill (N. Y.) 351. Smith v. S., 12 Ohio St. 466, 80 Am. Dec. 355, F. 37 .

As to implied ubrogution of common law offenses see $\$ 7$; and Baker v. S. (Ohio), $\$ 7.5$ As to child's cousent see $R$ v. Alurtin, $\$ 29 ; R$. v. Woudhurst, $\$ 28$,

(N. Car. Sup. Ct., 1875.) Selling Iiquor Without License. Judgment for defendant on special verdict. The state excepts. SII'ILE, J. *** The letter of the law has been broken, but has the spirit of the law been violated? * * We shall remember that the reason of the law is the life of the law, and when one stops the other should also stop. What was the evil sought to be remedied by our statute? Evidently the abusive use of spirituous liquors, keeping in view at the same time the revenues of the state. The special verdict is very minute in its details. and makes as strong a case for the defendants as perhaps will ever find its waly into court again. A physician prescribes the brandy as a medicine for a sick lady, and directs her husband to get it from the defend. ants, who are druggists. It may be that a pure article of brandy, such as the physician was willing to administer as a medicine, was not to be obtained elsewhere than at the defendants' drug store. The doctor himself goes to the defendants and directs them to let the witness have the brandy as a medicine for his wife. And the further fact is found, which perhaps might have been assumed without the finding, that French brandy is an essential medicine, frequently preseribed by physicians and often used; and the farther and very important fact is established, that in this case it was bought in good faith as a medicine, and was used as such. After this verdict we cannot doubt that the defendants acted in good faith and with due eaution, in the sale which is alleged to be a violation of law. In favor of defendants, criminal statutes are both contracted and expanded. 1 Bishop, $\S 261$. Now unless this sale comes within the mischief which the statute was intended to suppress, the defendants are not guilty. * * Judgment affirmed. S. v. Wray, 72 N. Car. 253, B. 366, Mi. 209.

(Ohio Sup. Ct., 1902.) Bicycle Racing. Defendant rode a racing bicycle at a speed of twenty miles per hour down the main street of a village, at dusk, without bell or other alarm, leaning forward as is usual in bicycle racing. Many people were about the streets; and while so riding he collided with a pedestrian, who died of the injuries thus received. For this homicide defendant was indicted and convicted of manslaughter, and brings error. PRICE, J. * * To convict of manslaughter it is incumbent upon the state to establish that the killing was done "either upon a sudden quarrel, or unintentionally while the slayer was in the commission of some unlawful act." It is clear that from the facts and the instructions given the jury that Barrows was not killed by John- 
son in a quarrel, nor was the killing intentional. Ilence, the latter clause of the definition of the crime is the one to which our investigation should be confined. The state was required to show that while the killing was unintentional, it was done by Johnson while he was in the commission of some unlawful act; and the question arises whether the negligent act or acts of the slayer, though no breach of any law, may be sufficient to constitute the unlawful act designated in the statute? $O r$, is the state required to show that he was in the commission of an act prohibited by law? At the time of this homicide there was even no ordinance of the village of Sciota regulating the speed or manner of riding bicycles upon its streets. * * * In our judgment the unlawful act, the commission of which gives color and character to the unintentional killing, is an act prohibited by law, and that such is the natural meaning of the term or clause when used in the parlance of criminal jurisprudence. **** If the contention of the state in this case is tenable, it is not difficult to see how the criminal dockets of our courts will soon be flooded. The gross negligence of one may cinuse the death of many. *** The position is untenable. * * * Plaintiff in error is discharged. Johnson v. S., 66 Ohio St. 59, 63 N. E. 607.90 Am. St. Rep. 564 .

Compare cases under 11,23 , and 40.

8 13. Repenls tind Amendments.

(Mass. Sup. Judicial Ct., 1831.) Amendment Between Act and Trial. Indictment fo: disinterring a dead body Feb. 20, 1831, contrary to the act of Mar. $2,1.81$, repealed by act of Feb. 1831 (St. 1830, c. 57). Plea, nolo contendere. Notion in arrest of judgment. SHAW, C. J. * * * It is clear, that there car be no legal conviction for an offense, unless the act be contrary to law at the time it is committed; nor can there be a judgment; unless the law is in force at the time of the indictment and judgment. If the law ceases to operate by its own limitation or by a repeal, at any time before judgment, no judgment can be given'. Hence, it is usual in everv repealing law, to make it "f rate prospectively only, and to insert a saving clause, preventing the operation of the repeal, and continuing the repealed law in force, as to all pending prosecutions, and often as to all violations of the existing law already committed. These principles settle the -present case. By the statute 1830, c. $57, \S 6$, that of 1814 was repealed without any saving clause. The act charged upon the defendants as an offense, was done, after the passing of the statute of 1814, and before that of 1830 . The act cannot be punished as an offense at common law, for that was not in force during the existence of the statute; nor by the statute of 1814 , because it has been repealed without any saving clause; nor by the statute of 1830, for the act was done before that statute was passed. No 
judgment therefore can be rendered against the defendants, on this indictment. Judgment arrested. C. v. Marshall, 11 Pick. 350, 22 Am. Dec. 377, B. 5, Kn. 24.

Congress cannot make innocent acts criminal by virtue of subsequent ncts of others. U. S. v. Fox, \&2.

(NIass. Sup. Judicial Ct., 1840.) Repeal of Repealing Law. Indictment of five counts for seiling different liquors without a license. Verdict, guilty. Defendant excepted that the statute under which he was convicted had been repealed, whereas the court instructed the jury that it was still in force. SHAW, C. J. * * It is conceded to be a maxim of the common law, appli. cable to the construction of statutes, that the simple repeal of a repealing law, not substituting other provisions in place of those repealed, revives the pre-existing law. As a maxim of the com. mon law, it was in force here when the constitution of the common. wealth was adopted. *** Taling it, then, as well established that the rules and maxims of the common law referred to in the constitution were those which our ancestor's brought with them, and which had been, to some extent, modified and adapted to our condition by the legislative jurisprudence of the colonial and pro. vincial governments, it follows that these rules and principles were regarded as binding both upon legislators and judges in their respective departments. A part of this system are the well known rules of construction for the expounding of statutes, which are as much a part of every statute as its text. These are presumed to be known and kept in view by the legislature in framing the statute; and they must be alike regarded by judges in expounding it. It was further insisted in the argument that the legislature could not have intended, when they repealed one license law, in effect to re-establish another. But their intentions must be ascertained by their acts alone, and not by evidence aliunde. We cannot possibly know the intentions of members of the legislature. It is the will of the aggregate body as expressed in the statutes which they pass. which can be regarded as having the force of law; any different construction would lead to the greatest confusion and uncertainty. The legislature are presumed to understand and intend all conse. quences of their own measures; and the only safe course is for courts of justice to expound the intentions of the legislature by their acts, and those acts construed by known and established rules of construction. *** On the whole, the court are of opinion that the simple repeal of St. 1838 , c. 157 , by that of 1840 , c. 1 , did revive the second and third sections of the R. S. c. 47 , and that the provisions of those sections were in force at the time of the offenses charged in the indictment, and that the conviction was right. Exceptions overruled. C. v. Churchill, 2 Met. 118, B. 6, C. 3.

(Miss. Sup. Ct., 1887.) Iocal Option Election Before Trial. ARNOID, J. The sale of liquors in Copiah county was regulated 
by a local act passed in 1884, and appellant was indicted and convicted of a violation of this statute. After the indictment was found, but before appellant was tried, an election was held in Copiah county under the local-option act of 1886, which resulted against a sale of liquors in the county. *** The scheme proposed by the local-option act is that, *** the local-option act shall supersede all other laws on the subject in the county. *** The proposition is too plain to admit of diseussion, that, after the repeal of a law, no penilty can be enforced or punishment inflicted for a violation of its provisions, committed while it was in operation, unless provision be made for that purpose. 'T'eague v. S., 39 Miss. 516; Cooley Const. Lim. 471, note; Bishop St. Cr. $\$ 177$. Prisoner discharged. Wheeler v. S., 64 Miss. 62, 1 So. 63:.

Ace. S. v. Mansel, 52 S. Car. 458,30 S E. 481 .

(N. Car. Sup. Ct., 188T.) Repeal After Sentence. Defendant was convicted and fined $\$ 5$, at the fall term, 1886, for selling liquor within five miles of Bethel church, contrary to acts of 1881, c. 234 , $\$ 5$, repealed by act of Narch 7,1887 ; by which the like selling within two miles was made indictable. IIe appeals. "The act punished must be criminal when judgment is demanded, and authority to render it must still reside in the court. 'The recent statute has no saving clause continuing it in force until pending prosecutions are ended; and, in withdrawing the power, the act arrests all further action in the matter." Per SNIITH, C. J. Prior decisions reviewed. Judgment arrested. S. v. Williams, $9 T$ N. Car. 455,2 S. E. 55, F. 34.

\section{$\S 14 . \quad$ "Causing Injury."}

(Eng. Assize, 1826.) Debilitated by Drink. The deceased died from a blow received in a fight with the prisoner; a surgeon expressed an opinion that "a blow on the stomach [in the state in which the deceased was] arising from passion and intoxication, was cilculated to occasion death, but not so if the party had been sober." HALLOCK, B., directed an acquittal, obser'vin: "that where the death was occasioned partly by a blow and partly by a predisposing circumstance, it was impossible so to apportion the operations of the several causes as to be able to say with certainty that the death was immediately occasioned by any one of them in particular." R. v. Johnson, 1 Lewin C. C. 164 .

Of thio case Roscoe remarks that it may be doubted how far this ruling of the learned judge was correct. Roseoe's Crim. Ev., Tth ed., Tl8

(Fing. C. C. R., 1858.) Negligence of Servants and Illegal Act of Accused. Bennett was convicted of manslaughter caused by the explosion of material collected at his place to manufacture fireworks, contrary to 9 and 10 W. 3, c. 7 . COCKBURN. C. J. The 
keeping of the fireworks in the house by the defendant caused the death unly by the superaddition of the negligence of some one else. By the negligence of the defendant's servants the fireworks ignited, and the house in which the deceased was was set on fire and death ensued. 'The kecping of the fireworks may be a nuisance, and if, from the unlawful act of the defendant, death had ensued as a necessary and immediate consequence, the conviction might be upheld. 'The keeping of the fireworks, however, did not alone cause the death; plus that act of the defendant, there was the megligence of the defendant's servants. [Wightman, Williams, Willes, JJ., and Channell, B., expressed similar views.] Conviction quashed. $R$. v. Bennett, Bell 1, 8 Cox C. C. 74,28 L. J. m. c. 27,4 Jur. n. s. 1088,7 W. R. 40, Ke. 98, Mi. 567.

(Eng. C. C. R., 1882.) Proof Required-Medical Aid. Conviction of manslaughter under $31 \& 32$ Vic. c. $122, \$ 37$, requiring parents to supply skilled medical attendance for their children when in need of it, was held erroneous on proof that the deceased child died of smallpox, was furnished no medical attendance (his father, the defendant being of the faith of "Peculiar People"), and on testimony of a physician, who did not see the child in life, that his life probably would have been prolonged by medical attendance, but who would not say that the death would probably have been averted by medical attendance. There was no satisfactory evidence to sustain the conviction. R. v. Morby, L. R. 8 Q. B. Div. ji1, $\bar{j} 1$ L. J. m. c. 85,46 L. 'T. 288,30 W. R. 613,15 Cox C. C. 35,46 J. P. 422,36 Moak 358, F. 63.

Compare other cases on fallure to furnish medical trentment. 1. v. Whastafie, 811: 1R. v. llownes. \$11.

(Nass. Sup. Judicial Ct., 1861.) Other Contributing CausesBad Treatment. Defendant was indicted for murder. The evidence tended to show that the wound given by the defendant became infected with gangrene by reason of maltreatment, on which death ensued. He was convicted of manslanghter, and excepted to the instruction given to the jury, in substance, that the burden of proof was upon the government to prove beyond a reasonable doubt that the deceased died of the wounds inflicted by the defendant, but that this general rule required explanation in its application to certain aspects of the present case; that a person who has inflicted a dangerous wound with a deadly weapon upon the person of another cannot escape punishment by proving that the wound was aggravated by improper applications or unskilful treatment by surgeons; that if, in the present case, they were satisfied that the wounds inflicted by the defendant were improperly and unskilfully treated by the surgeons in attendance, and that such treatment hastened or contributed to the death of the deceased, the defendant was not for this reason entitled to an acquittal; and that if these wounds were unskilfully treated, so that gangrene and 
fever ensued, and the deceased died from the wounds combined with the maltreatment, the defendant was guilty of murder or manslaughter, according as the evidence proved the one or the other.

BlGELOW, C. J. * * * We have looked with eare into the authorities which bear on the correctness of the instructions given to the jury, relating to the unskilful or improper treatment of the wounds alleged to have been intlicted by the prisoner upon the body of the deceased. We find them to be clear and uniform, from the earliest to the latest decisions. *** * 'The well established rule of the common law would seem to be, that if the wound was a dangerous wound, that is, calculated to endanger or destroy life, and death ensued therefrom, it is sufficient proof of the offense of murder or manslaughter; and that the person who inflicted it is responsible, though it may appear that the deceased might have recovered if he had taken proper care of himself, or submitted to a surgical operation, or that unskilful or improper treatment aggravated the wound and contributed to the death, or that death was immediately caused by a surgical operation rendered necessary by the condition of the wound. 1 Russ. Crimes (7th Am. Ed.) 505; Roscoe, Cr. îv. (3d Ed.) 703, 706; 3 Greenl. Ev. \$139; C. v. Green, 1 Ashm. (Pa.) 289 ; R. v. Iraines, 2 Car. \&. K. $368\lfloor \$ 11]$; S. v. Baker, 1 Jones ( 46 N. C.) 267 ; C. v. MI'Pike, 3 Cush. 184.

The Principle on Which This Rule is Founded is one of universal application, and lies at the foundation of all our criminal jurisprudence. It is, that every person is to be held to contemplate and to be responsible for the natural consequenees of his own acts. If a person inflicts a wound with a deadly weapon in such manner as to put life in jeopardy, and death follows as a consequence of this felonious and wicked act, it does not alter its nature or diminish its criminality to prove that other causes co-operated in producing the fatal result. Indeed, it may be said that neglect of the wound or its unskilful and improper treatment, which were of themselves consequences of the criminal act, which might naturally follow in any case, must in law be deemed to have been among those which were in contemplation of the guilty party, and for which he is to be held responsible. But however this may be, it is certain that $i$, rule of law, as stated in the authorities above cited, has its foundation in a wise and sound policy. A different doctrine would tend to give immunity to crime, and to take away from human life a salutary and essential safeguard. Amid the conflicting theories of medical men, and the uncertainties attendant on the treatment of bodily ailments and injuries, it would be easy in many cases of homicide to raise a doubt as to the immediate cause of death, and thereby to open a wide door by which persons guilty of the highest erime might escape conviction and punishment. * * * Excentions overruled. C. v. Hackett, 2 Allen 136, C. 168, F. 170.

See also cases of unexpected constquences, $\$ \$ 38 \cdot 4(), 81$, \&2. 
(Conn. Sup. Ct. of Errors, 187i.) Lockjaw from Mistreatment. PARDEE, $J$. On the night of June 11th, 1876, the accused inflicted a severe gun-shot wound upon the arm of one Mrareh, between the elbow and shoulder. March died eleven days thereafter of lockjaw. 'The prosecution claimed that death resulted from the wound; the accused claimed that it resulted from the treatment of the calse by the attending physicians. The wound was dressed in the first instance by one surgeon, afterwards to the time of death by another; these differed radically as to the manner in which the case should have been treated. The comsel for the aceused claimed. and asked the court to charge the jury. that if they should find that the death of Mareh was the result or consequence of wilful mismanagement or gross earelessness on the part of the attending surgeons, they could not find the accused guilty of manslaughter, ats charged in the information. The court charged the jury, that unless they should find that March died from a wound inflicted on him by the accused, as charged in the information, they conld not convict him of manslaughter; but that if they should find that the acensed wilfully, and without justifiable cause, inflicted on March a dangerous wound, fiom which death would be likely to ensue, and if they should find also that his death did in fact ensue from and was calused by the wound, and not from any other cause, carelessness and mismanagement of whatever character on the part of the attending surgeons would be immaterial, and the treatment of the case by them, whatever it may have been, could not avail the accused as a defense. The jury having returned a verdict of guilty. the accused moved for a new trial for error in the charge.

[Here his honor reviewed the authorities.] Upon these anthorities we may stite the rule as follows: If one person infliets upon another a dangrerous wound, one that is calculated to endanger and destroy life. and death ensues therefrom within a year and a day, it is sufficient proof of the offense either of manslaughter or murder as the case may be; and he is none the less responsible for the result although it may appear that the deceased might have recovered if he had taken proper calre of himself. *** Affirmed. S. v. Bantley, $4+$ Conn. 53T, 26 Am. Rep. $486, \mathrm{Kn} .121$.

(Mich. Sup. Ct.. 1878. Death from Morphine Given by Physician After Mortal Wound. Fxceptions before judgment. Cook was charged with murder and convicted of manslanghter. ITe had inflicted a dangerous wound, but it was contended by the defense that death was caused by an overdose of morphine. Defendant asked an instruetion as follows: "If the jury helieve that the injury inflieted by the prisoner would have heen fatal, but if death was actually produced by morphine poisoning. they must acquit." The instruction was refused. but the jury were told that if the wound was not in itself mortal, and death was caused solely by the morphine, they must aequit. The action of the trial court was 
sustained, on the ground that a mortal wound had been given which neeessitated medical treatment; that the physicians were competent and acted in good faith; and that it was not made clearly to appear that the morphine solcly produced death, and that the wound did not at all contribute to the death at that time. Order to proceed to julgment. P. v. Cook, 39 Mich. 236.

Compure cases post $\$ 23$.

(Kiy. Ct. of App., 1880.) Fatal Disease Taken from Physician. Appellant was indieted and convicted of murder, and sentenced to be hung. 'The deceased received a wound not necessitrily mortal, and, in consequence, was taken to a hospital where she took scillet fever, negligently communicated to her by her attendingr physician, and died of the fever. HIINES, J. *** When the discase is a consequence of the wound, although the proximate cause of the death, the person inflicting the wound is guilty, because the death can be traced as a result naturally flowing from the wound and coming in the natural order of thing; ; but when there is a superrening caluse, not naturally intervenng by reason of the wound, and not produced by any necessity ereated by the wound, the death is by visitation of providence, and not from the act of the party inflicting the wound. In the case under consideration the fiever Wils not the natural consequence of the wound, nor was it produced by any necessity ereated by the infliction of the wound. It did not render it necessary to have the wound treated by a physician just recovering from the scarlet fever, even if it be conceled that medical treatment was necessary at all. If the death was not comnected with the wound in the regular chain of canses and consequences, there ought not to be any responsibility. If a new and wholly independent instrumentality interposed and produced the death, it cannot be said that the wound was the natural or proximate caluse of the death. (14 Gratt. 601, Livingston v. C.) This view was not so presented to the jury as to give the appellant its full benefit. * * Reversed. Bush v. C., is Ky. 268.

(Iowa Sup. Ct., 1890.) Death from Heart Disease and Assault.

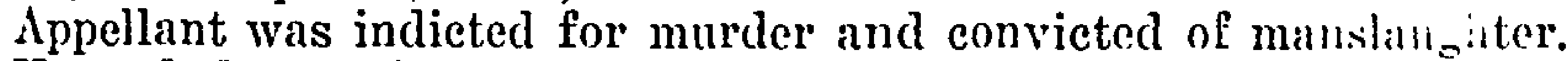
He and deceased were 17 years old; and he and two other boys caught deceased on the street, and appellant knocked him down, kicked him, holding and choking him after he was down. and causing one of the other boys to kick him. When deceased got away they chased him for some distance. IIe applied at a house in the vicinity for shelter, said he was afraid to go home, was pale, bruised, muddy, and very much scared. IIe had not been well for some time before the aftair, and had heen taking treatment for heart disease. Appellant claimed that the death was duc to causes for which he was not responsible. and that there was no evidence to support the verdict. ROBINSON. J. *** The medical 
testimony shows that his conclition and failing health after the assault, and his death, were natural and probable results of his physical condition on the night of July 15 , and of great excitement and physical exertion. It was the province of the jury to determine whether the wrong of defendant caused or contributed to dece. dent's death. The fact that he was aftlicted with a disease which might have proved fatal would not justify the wrongful acts of defendint, nor constitute a defense in law. S. v. Smith, 73 Iowa 32. Nor would ignorance on the part of defendant of the diseased physical condition of Stocum excuse his acts. S. v. Castello, 62 Jowa 404 . We think the evidence sufficient to sustain the verdict, and find no error prejudicial to defendant of which he can com. plain. The judgment of the district court is affirmed. S. v. O'Brien, 81 Iowa 88, 46 N. W. 752, B. 433.

(Cal. Sup. Ct., 1899.) Mortal Wound Causing Suicide. TEMIPLE, J. 'The defendant was convicted of manslaughter and appeals from the judgment and from an order refusing a new trial. * * * Defendint and deceased were brothers-in-law, and not altogether friendly, although they were on speaking and visiting terms. On the morning of the homicide the decensed visited the residence of the defendant, was received in a friendly manner, but after a while an altercation arose, as a result of which defendant shot deceased in the abdomen, inflicting a wound that was necessarily mortal. Farrell fell to the ground, stunned for an instant, but soon got up and went into the house, saying: "Shoot me again; I shall die. anyway." His strength soon failed him and he was put to bed. Soon afterward, about how long does not appear, but within a very few minutes, when no other person was present except a lad of about nine years of age, nephew of the deceased and son of the defendant, the deceased procured a knife and cut his throat, inflict. ing a ghastly wound, from the effect of which, according to the medical evidence, he must necessarily have died in five minutes. The wound inflicted by the defendant severed the mesenteric artery, and medical witnesses testified that under the circumstanees it was necessarily mortal, and denth would ensue within one hour from the effects of the wound alone. Indeed, the evidence was that usually the effect of such a wound would be to cause death in less time than that, but possibly the omentum may have filled the wound. and thus, by preventing the flow of the blood from the body, have stayed its certain effect for a short period. Internal hemorrhage was still occurring, and, with other effects of the gunshot wound, produced intense pain. The medical witnesses thought that death was accelerated by the knife wound. Perhaps some of them con. sidered it the immediate cause of death. Now, it is contended that this is a case where one languishing from a mortal wound is killed by an intervening cause, and. therefore, deceased was not killed by Lewis. To constitute manslaughter, the defendant must have killed 
some one, and if, though mortally wounded by the defendant, Farrell actually died from an independent intervening caluse, Lewis, at the most, could only be guilty of a felonious attempt. lle was as effectually prevented from killing as he would have been if some obstacle had turned aside the bullet from its course and left Farrell unwounded. And they contend that the intervening act was the cause of death, if it shortened the life of Farrell for any period whatever. The attorney greneral does not controvert the greneral proposition here contended for, but argues that the wound inflicted by the defendant was the direct eause of the throat-cutting, and, therefore, defendant is criminally responsible for the death. He iliustrates his position by supposing a case of one dangerously wounded and whose wounds had been bandaged by a surgeon. IIe says, suppose through the fever and pain consequent upon the wound the patient becomes frenzied and tears away the banclage and thus accelerates his own death. Would not the defendant be responsible for a homicide? Undoubtedly he would be, for in the case supposed the deceased died from the wound, agrgravated, it is true, by the restlessness of the deceased, but still the wound inflicted by the defendant produced death. Whether such is the case here is the question. The attorney general seems to admit a fact which I do not concede, that the gunshot wound was not, when Farrell died, then itself directly contributory to the death. I think the jury were warranted in finding that it was. But if the deceased did die from the effect of the linife wound alone, no doubt the defendant would be responsible, if it was made to appear, and the jury could have found from the evidence, that the knife wound was caused by the wound inflicted by the defendant in the natural course of events. If the relation was causal, and the wounded condition of the deceased was not merely the occasion upon which another cause intervened, not produced by the first wound or related to it in other than a casual way, then defendant is guilty of a homicide. But, if the wounded condition only afforded an opportunity for another unconnected person to kill, defendant would not be guilty of a homicide, even though he had inflicted a mortal wound. In such case, I think, it would be true that the defendant was thus prevented from killing. *** But why is it thi: one who inflicts a wound not mortal is guilty of a homicide, if through misconduct of the patient or unskilful treatment gangrene or fever sets in, producing a fatal termination-when, if it can be clearly made to appear that the medicine and not the wound was the cause of the death, he is not guilty of a homicide? In each case if the wound had not been, the treatment would not have been, and the man would not then have died. In each case the wound occasioned the treatment which caused or contributed to the death. The reason. I think, is found in the words advisedly used in the last sentence. In the one case the treatment caused the death, and in the other it merely contributed to it. In one case the treatment 
aggravated the wound, but the wound thus aggravated produced death. In the other the wound, though the occusion of the treatment, did not contribute to the death, which occurred without any present contribution to the natural effect of the medicine from the wound. 'lake, for instance, the giving of a dose of morphine, by mistake, sufficient to end life at once. In such case it is as obvious that the treatment produced death as it would have been had the physician cut oft' his patient's head. *** 'The intervening cause, which it is alleged hastened death, was not medical treatment, designed to be helpful, and which the deceased was compelled to procure because of the wound, but was an act intended to pro. duce death, and did not result from the first wound in the natural course of events. But we have reached the conclusion by a course of argument unnecessirily prolix, except from a desire to fully consider the earnest and able argument of the defendant, that the test is-or at least one test-whether, when the death occurred, the wound inflicted by the defendant did contribute to the event. If it did, although other independent causes also contributed, the causal relation between the unlawful acts of the defendant and the death has been made out. Here, when the throat was cut, Farrell was not merely languishing from a mortal wound. IIe was actually dying-and after the throat was cut he continued to languish from both wounds. Drop by drop the life current went out from both wounds, and at the very instant of death the gunshot wound wis eontributing to the event. If the throat cutting had been by a third person, unconnected with the defendant, he might be guilty; for; although a man cannot be killed twice, two persons, acting independently, may contribute to his death and each be guilty of a homicide. A person dying is still in life, and may be killed, but if he is dying from a wound given by another both may properly be said to have contributed to his death. **** P. v. Lewis, 124 Cal. 551, 57 Pac. 470, 45 L. R. A. 783, MTi. 569.

(Mass. Sup. Judicial Ct., 1863.) Riot-Proof of Cause. Defendant was indicted for murder. 'The homicide was committed near the armory at $T \mathrm{p}$. $\mathrm{m}$. in a riot caused by attempt to inforce the draft of recruits for the army. The soldiers were defending the armory, and the rioters attacking. Whether the shot that killed the deceased was fired by one of the soldiers or one of the rioters was not proved. The defendant was one of the rioters. The attorney general requested the court to instruct the jury: "I'hat whether Currier was killed by a shot from within or without the armory, all the parties unlawfully engaged in the transactions which resulted in the homicide were at common law guilty, at least of manslaughter." *** BIGELOW, C. J. The rule of criminal responsibility for the acts of others is subject to the reasonable limitation that the particular act of one of a party for which his assuciates and confederates are to be held liable must 
be shown to have been done for the furtherance or in prosecution of the common object and design for which they combined togrether. Without such limitation a person might be held respousible for acts which were not the natural or necessary consequences of the enterprise or undertaking in which he was engaged, and which he could not either in fact or in law be deemed to have contemplated or intended. No person can be held guilty of homicide unless the act is either actually or constructively his, and it cannot be his act in either sense unless committed by his own hand, or by some one acting in concert with him or in furtherance of a common object or purpose. Certainly that cannot be said to be an act of a party, in any just sense, or on any sound legal principle, which is not only not done by him, or by any one with whom he is associated or connected in a common enterprise, or in attempting to accomplish the same end, but is committed by a per'son who is his direct and immediate adversaly, and who is, at the moment when the alleged criminal act is done, actually engaged in opposing and resisting him and his confederates and abettors in the accomplishment of the unlawful object for which they are united. * * * The doctrine contended for, if followed to its legitimate and logical conclusion, would lead to extraordinary consequences. It would render everybody who participated in a transaction, whether acting in concert or in opposition. whether united in a common design or arrayed on opposite sides in a contrast or aftray in which each contending party was striving to defeat the purposes of the other, if all acted without legal justification, responsible for every criminal act which was done by any person during the progress of the affair in which they were all engaged. **** If it was his act at all, then it was committed by him or his confederates while engaged in an unlawful enterprise, and, according to well-settled principles, it would be murder, and not manslaughter. * * The jury will accordingly be instructed that, unless they are satisfied beyond a reasonable doubt that the deceased was killed by means of a gim or other deadly weapon in the hands of the prisoner, or of one of the rioters with whom he was associated and acting, he is entitled to an acquittal. C. v. Campbell, $T$ Al,$\overline{5}+1$, 83 Am. Dec. 705, F. 167.

(Tex. Ct. of Crim. App., 1900.) Robbers' Prisoner and Buffer Killed. Appeal from conviction of murder in first degree. IIENDERSON, J. * * * Appellant objected to that portion of the charge of the court which instructed the jury, in effect, that if defendant and those with him took deceased, Johnson, in custody, and compelled him to go against his will from the engine to the express car, and that same was a place of danger, where deceased's life was exposed. and that while said Johnson was in such place of danger, and they were attempting to rob the train, and using him for that purpose, if Buchanan, in resistance to the perpetration of 
said attempted robbery, in shooting at the robbers, innocently shot and killed Lee Johmson, not intending to kill him, but intending to kill the parties attempting to perpetrate the robbery, defendant and those with him would be as gruilty as if they themselves had shot and killed said Lee Johnson. Appellant objected to this charge of the court on the grounds: (1) That the evidence did not show that defendant and those acting with him placed Johnson in front of the express car to get him shot, but to prevent a shooting; (2) because in front of the express car was not more dangerous than at any other place along the line; (3) because said charge forced the jury to convict, even if they believed that Bucinman killed Johnson, and did not allow them to pass upon that question; (4) it destroyed appellant's innocence, and forced a conviction even if Johnson came to his death by any outside, independent, and unexpected force, by a mere passenger, when he was under no obligation to shoot; $(\bar{b})$ it does not give defendant the benefit of a reasonable doubt as to the existence of facts that would not render him guilty if Buchanan killed Johnson; (6) it does not submit the law of murder in the second degree. 'This presents a novel question and has never, so far as we are advised, been passed upon in this state; nor do we find an analogous case reported elsewhere. Appellant cites us to two cases in support of his contention. C. v. Camploll, 7 Allen 541 [above] ; Butler v. P., 125 Ill. 641,18 N. F. 338,1 L. R. A. 211 . 13oth of these were cases of rint, where *** the prosecution attempted to hold the rioters responsible for the killing by the officers who were opposed to them. * * If the rioters in said cases had taken the man who was killed, and made a breastwork of him, it would be a different case. We do not understand the doctrine enunciated to apply to a case where the rioters might forcibly make use of another in their design, and cause him to be lilled by putting him in a place of danger. *** Appellant was indicted as a principal; and the allegation made that he shot and killed decensed; and whether he or one of his companions fired the fatal shot, or the shot which killed him was fired by Buchanan in resistance to their attempt, they using appellant as a means to consummate the robbery, the allegation that appellant, as a principal. fired the shot which killed deceased, is equally correct. * * * [Reversed on another ground. Davidson, P. J.. filed a concurring opinion.] Tay. lor v. S., 41 Tex. Cr. App. 564, 5j S. W. 961, Mi. 575.

(Fng. Queen's Bench, 1882.) Causing Disturbance by OthersSalvation Army March. Question certified on conviction of memhers of the Salvation Army for unlawful assembly. FIELD. J. * * The offense charged against them is "unlawfully and tumultuously assembling with others to the disturbance of the public peace. and against the peace of the queen:" and of course, hefore they can be convicted unon the charge, clenr proof must be addueed 
that the specific ofitense charge has been committed. Now, was that charge sustained? There is no doubt that the appellants did assemble together with other persons in great number's, but that alone is insulticient. 'The assembly must be a "tumultuous assembly" and "against the peace," in order to render it an unlawiful one. but there was notning, so tare as the appenants were concerned, to show that their conduet was in the least degree "tumultuous" or "against the peace." All that they did was to assemble torgether to walk through the town; and it is admitted by the learned counsel for the respondent, that as regards the appellants themselves, there was no disturbance of the peace, and that their conduct was quict and peaceable. But then it is argued that, in fact their line of conduct wals the same as had on previous similar occasions led to tumultuous and riotons proceedings with stone-throwing and tighting. [Nec.] * * But the evidence as set forth in the case shows thait, so far from that being the case, the acts and conduct of the appellants caused nothing of the lind, but on the contrary, that the disturbance that did take place was caused entirely by the malawful and unjustifiable interference of the Slieleton Army, a body of persons opposed to the religious views of the appellants and the Salvation Army, and that but for the opposition and molestation offered to the salvationists by these other persons, no disturbance of any kind would have taken place. ** * The present decision of the justices. however, amounts to this, that a man may be pmmished for acting lawfully if he knows that his so doing may induce another man to act unlawfully-a proposition without any anthority whatever to support it. Under these cireumstances. the questions put to us by the justices must be negatively answered, and the order appealed against be discharged. Beatty v. Gillbanks, 15 Cox C. C. 138 , L. R. 9 Q. B. D. 308,51 L. J. m. c. 117.47 L. T. 194 , 31 W. R. 275,46 J. P. 789, 36 Moak 386, B. 105, Ke. 39:.

\section{"To the Public at Large."}

\$ 15. Malicious Injuries.

(Pa. Sup. Ct., 1788.) Maliciously Killing a Horse. After conviction on indictment for maliciously killing a horse, defendant moved in arrest of judgment. MICKEAN, C. J. *** It is true that on the examination of the cases we have not found the line accurately drawn; but it seems to be agreed that whatever amounts to a public wrong may be made the subject of an indictment. The poisoning of chickens, cheating with false dice, fraudulently tearing a promissory note. and many other offenses of a similar description. have heretofore been indicted in Pennsvivania: and 12 Mod. 33T. furnishes the case of an indictment for killing a dog,-an animal of 
far less value than a horse. Breaking windows by throwing stones at them, though a sufficient number of persons were not engarged to render it a riot, and the embezzlement of public moneys, have, likewise, in this state been deemed public wrongs, for which the private sufferer was not alone entitled to redress; and unless, indeed, an indictment would lie, there are some very heinous offenses which might be perpetrated with absolute impunity; since the rules of cvidence, in a civil suit, exclude the testimony of the party injured, though the nature of the transaction generally makes it impossible to produce any other proof. Motion denied. Respublica v. Teischer, 1 Dallas 335, B. 108.

(New York Sup. Ct., 1825.) Maliciously Killing a Cow. The defendant was indicted and convicted of "maliciously, wickedls: and wilfully killing a cow," the property of another. Whether this was an indictable ofiense at common law? WOODWOR'II, $J$. There is no precise line by which indictments for malicious mis. chief are separated from actions of trespalss. Blackstone $( \pm$ Com. 243 ), speaks of the former as done, not animo furandi, or with an intent of gaining by another's loss; but either out of a spirit of wanton cruelty, or black and diabolical revenge. It cannot be expected, that the mere liability to damages, will operate on a mind so depraved. The injury may be committed when none but the person injured is a witness. The perpetrator may be insolvent; and thus gratify his malice with impunity, if there is no redress other. wise than by civil action. This would he contrary to the policy of every well regulated government; which is to protect the citi\%en in his right, by restraining and punishing the wrongdoer. 'The oftense is distinguishable from an ordinary trespass, in this-that it is not only a violation of private right, without color or pretense, hut without the hope or expectation of gain. Such an act discovers a degree of moral turpitude dangerous to society, and, for their security, ought to be punished criminally. It is an evil example of the most pernicious tendency, inasmuch as the act is an ontrige upon the principles and feelings of humanity. The direct tendency is a breach of the peace. What more likely to produce it, than wantonly killing, out of mere malice, a useful domestic animal? * * * Affirmed. P. v. Smith, 5 Cowen 258.

(New York Sup. Ct., 1848.) Breaking Windows. Error from conviction on plea of not guilty to an indictment charging that defendant below "with force and arms, * * * unlawfully, wilfully, and maliciously, did break in pieces and destroy two windows in the dwelling house of Moses Cory." The court held that, as no statute touched the case, it depended on the common law; that the words "force and arms" did not import a criminal offense, being mere form used in charges of either civil or criminal wrongs; that malice alone did not make a wrong indictable; that if a tres- 
pass committed secretly, in the night time, or aceompanied with cruelty to a domestic animal, be indictable at common law, as has been held in several cases cited, this indictment charges nothing of the kind. Judgment reversed. Kilpatrick v. P., 5 Denio 277, F. 4.

\section{\$16. Private Chents.}

(Engr. King's Bench, 1720.) Short Delivery. "Wilders, a brewer, was indieted for a cheat in sending in to MIr. Ilicks, an ale-house keeper, so many vessels of ale marked as containing such a measure, and writing a letter to Mr. IIicks, assuring him that they did contain that measure, when in fact they did not contain such measure, but so much less, etc. 'This indictment was quashed on argument, upon motion." R. v. Wilders, stated by Lord MIansfield in R. v. Wheatly, below.

(Eng. King's Bench, 1761.) Selling 16 Gallons for 18. Defendant was indicted for that, being a common brewer, and intending to defraud Webb, he sold and delivered him sixteen gallons of amber beer for eighteen gallons. and received pay for the sime. After conviction defendant moved in arrest of judgment. LORD MANSFIELD. *** * The offense that is indictable must be such a one as affects the public. As if a man uses false weights and measures, and sells by them to all or to many of his customers, or uses them in the general course of his dealing; so, if a man defiands another, under false tokens. For these are deceptions that common care and prudence are not sufficient to guard against. So, if there be a conspiracy to cheat; for ordinary care and caution is no guard against this. Those cases are much more than mere private injuries; they are public offenses. But here, it is a mere private imposition or deception. No false weights or measures are used, no false tokens given, no conspiracy; only an imposition upon the person he was dealing with, in delivering him a less quantity instead of a greater, which the other carelessly accepted. "Tis only a non-performance of his contract, for which non-performanno he may bring his actior. The selling an unsound horse, as and for a sound one, is not indictable; the buyer should be more upon his guard. *** DENISON, J. This is nothing more than an action upon the case turned into an indictment. "Tis a private breach of contract. * ** FOSTER, J. We are obliged to follow settled and established rules already fixed by former determinations in cases of the same lind. The case of Rex v. Wilders was a strong case; (too strong, perhaps, for there were false tokens; the vessels were marked as containing a greater quantity than they really did.) * * WILNIOT, J. This matter has been fully settled and established, and upon a reasonable foot. The true distinction that ought to be attended to in all cases of this kind, and 
which will solve them all, is this-that in such impositions or deceits, where common prudence may guard persons argainst the suffering from them, the oftense is not indictable, but the party is left to his civil remedy for the redress of the injury that has been done him; but where false weights and measures are used, or false tokens produced, or such methods taken to cheat and deceive, as people cannot, by any ordinary care or prudence be guarded against, there it is an offense indictable. $R$. v. Wheatly, 2 Burr, 1125, 1 Wm. Bl. 273, 1 B. \& 11. 1-n, B. 9i, j L. 100.

Acc. Outaining credil by lies. c. v. Wurren, $\$ 4$.

(Eng. King's Bench, 1775.) Selling Inferior for Standard. The defendant was found guilty of "knowingly exposing for sale and selling a gold chain, under the sterling alloy, as and for gold of the true standard weight." On motion in arrest of judgment, LORD MANSFLLLD, C. J., said: "The question is, whether the expos. ing wrought gold to sale under the standard, is indictable at com. mon law! * * It is certainly an imposition, but I incline to think it is one of those frauds only which a man's own common prudence ought to be sufficient to grlard him against, and which therefore is not indictable, but the party injured is left to his civil remedy." R. v. Bower, 1 Cowper 323.

\section{§17. Nuisance.}

(Va. General Ct., 1828.) Stagnant Pond Defiling the Air. Indictment for nuisance in erecting a mill-dam on Little creek, whereby the waters were rendered stagnant and the air impure, "to the great damage, and common nuisance of all the good citizens of this commonwealth, not only there residing and inhabiting, but also going, returning, passing, and repassing by the neighborhood of the said pond." Defendant demurred, and the case was adjourned to this court for difficulty and novelty. "To constitute a public nuisance, the act done. or duty omitted, must aflect injuriously some thing or right in which the community, as a body politic. have a common interest; and the facts producing this injury, and connecting it with such special public right or interest, must be both alleged and proved. 'I'o carry this matter further would oblit. erate every line that now marks the difference between public and private wrongs. *** It ought to be alleged and proved, that the obstructions placed in Little creek, in the comity of Nottowily: produced a stagnation of the waters thereof. in or near a public highway, or some other place in which the public have such special interest. The general conclusion, that the stagnation of the said waters does injure all the citizens of the commonwealth will not cure the want of such special averment, becanse the facts stited do not warrant that conclusion." Per DANIEL, J. Demurrer sus. tained. C. v. Webb, 6 Rand. 726, F. 7.

For other cases of private nulsance see "Nuisance." 
(Eng. King's Bench, 1802.) Tin-shop Near Inn. The defendant, a tinman, was indicted for a nuisance, from the noise made in carry. ing on his trade. The prosecutors were attorneys in Clifford's Inn. From the evidence, it appeared that the noise affected only three numbers, 14, 15, and 16, of that inn. LORD ELLENBOROUGH said. that, upon this evidence, the indictment could not be sustained; and that it was, if anything, a private nuisance. It was confined to the inhabitants of three numbers of Clifiord's Inn only; it did not even extend to the rest of the society, and could be aroided hy shutting the windows; it was therefore not of sufficiently general extent to support an indictment. Defendant was acquitted. R. v. Lloyd, 4 Espinasse 200.

(Engr. King's Bench, 1801.) Failure to Repair Road. The defendants were indicted for the non-repair of: a road. 'The jury found specially, that the road had been laid out under an act of parliament (31 G. 3), for the use of nine parishes, and that it was made the duty of the defendants, as inhabitants of six of the parishes, to keep the road in repair, which duty they had neglected. Whether this was an indictable offense, 'THE COUR'I said, that however convenient it might be that the defendants should be indieted, there was no legal ground on which this indictment could be supported. That the known rule was, that those matters only that concerned the public, were the subject of an indictment. That the road in question being described to be a private road, did not coneern the public, nor was of a public nature, but merely concerned the individuals who had a right to use it. 'That the question was not varied by the circumstance that many individuals were liable to repair, or that many others were entitled to the benefit of it. And they also held, that the fact that the road was set out under a public act, did not make the non-repair of it indictable. Judgment for defendants. R. v. Richards, 8 'Term 634, Ke. 2.

Compare R. V. Pocock, $\$ 11$.

\section{§ 18. Disturbing Public Pence, Snfety, or Comfort.}

(Eng. King's Bench, 1765.) Entry without Breach of Peace. Rule to show calse why an indictment for breaking and entering premises not a dwelling house and unlawfully keeping the owner out should not be quashed. WILMIO'T, J. No doubt, an indictment will lie at common law for a forcible entry, though they are generally brought on the acts of parliament. On the acts of parliament, it is necessary to state the nature of the estate, because there must be restitution; but they may be brought at common law. IIere the words "force and arms" are not applied to the whole; but if they were applied to the whole. yet it ought to be such an actual force as implies a breach of the peace. and makes an indictable offense. And this I take to be the rule, "that it ought to appear 
upon the face of the indictment to be an indictable offense." IIere indeed are sixteen defendants. But the number of the defendants makes no difference, in itself; no riot, or unlawful assembly, or any. thing of that kind is charged. It ought to amount to an actual breach of the peace indictable, iu order to support an indictment. For, otherwise, it is only a matter of civil complaint. And this ought to appear upon the face of the indictment. Per CURIAI, unanimously, rule made absolute. R. v. Bake, 3 Burr. 1731, B. 103.

(Eng. King's Bench, 1815.) Exposing to Smallpox. After con. viction on indictment for inoculating two children with smallpor and sending them along the highway to the common injury, ete., defendant moved in arrest of judgment that this was no offense. LORD ELLENBOROUGH, C. J. 'The indictment lays it to be unlawfully and injuriously, and to make that out it must be shown that what was done was in the manner of doing it incautious, and likely to affect the health of others. The words "unlawfully" and "injur. iously" preclude all legal cause of excuse. And though inoculation for the smallpox may be practiced lawfully and innocently, yet it must be under such guards as not to endanger the public health by communicating this infectious disease. DAMPIER, J. The charge amounts to this, that the defendant, after inoculating the children, unlawfully exposed them, while infected with the disease, in the public street to the danger of the public health. LFBLANC, J., in passing sentence observed that the introduction of vaccination did not render the practice of inoculation for the smallpox unlawful, but that in all times it was unlawful, and an indictable offense, to expose persons infected with contagious disorders, and therefore liable to communicate them to the public, in a public place of resort. The defendant was sentenced to six months' imprisomment. R. v. Burnett, 4 Maule \& Sel. 272, B. 104.

(Mass. Sup. Judicial Ct., 1829.) Causing a Woman to Have a Fit, by standing in the highway near the house defendant lineir she was in, and shooting a wild goose, well knowing her nervous disorder and that the noise would give her a fit, was held to be an indictable offense. Defendant contended that, as the disease was incurable and inveterate, and he was doing a lawful act, no ofiense was charged. PARKER, C. J. **** If the indictment were for a nuisance, the authorities cited by the defendant's counsel would clearly show that it could not be sustained; for the most that could be made of it would be a private nuisance, for which an action on the case only would lie. But we think the offense described is a misdemeanor, and not a nuisance. It was a wanton act of mischief, necessarily injurious to the person aggrieved, after full notice of the consequences, and a request to desist. The jury have found that the act was maliciously done. * * * Judgment on the verdict. C. v. Wing, 9 Pick. 1,19 Am. Dec. 347, B. 119. 
(New York Sup. Ct., 18t6.) Selling Lottery Tickets. Indictment for unlawfulty maintaning a room where lottery tickets are sold. 'the people brought error on the judgment for defendant on demurrel. BRUNSON', C. J. We hatve not enacted the statute $33 \mathrm{H} .8$, c. 9, §11, agrainst gaming-houses. (See 1 llawk. 1'. C. T21, Curwood's Ld.) Still, 1 have no cloubt that the keeping of a common gaming-house is indictable at the common law. (King v. Rogrier, 1 B. C. 272 ; People v. Sergeant, 8 (lowen 139.) It is illegal, because it draws together evil-disposed persons, encourages excessive gaming, idleness, cheating, and other corrupt practices, and tends to public disorder. Nothing is more likely to happen at such places than breaches of the public peace. (1 Hawk. P. C. 693, $\$ 6$; Roscoe, (r. Lv. 663, ed. of '36; 1 Russ. on Cr. 299, ed. of '36; 3 Chit. Cr. L. 6i3, note, ed. of '19; Arch. (r. Pl. 600, ed. of ' 40. ) But it is not so of a house or room for the illegal sale of lottery tickets. MIen do not congregate at such places. Un the contrary, they go in one at a time, and the business is transacted behind screens and in corners, where there is no witness. 'lhere is enough of evil in it, but no tendency to bieaches of the public peace. It is true that an unauthorized lottery is a public nuisance. (1 R. S. 665, § 26.) But a place for the sale of tickets is not a lottery. Keeping an office or other place for registering tickets in an unauthorized lottery is expressly forbidden ( $\$ 34$ ); but there is no prohibition against keeping an office or place for the sale of tickets. I see no principle on which the first count can be supported. * * * Judgment affirmed. P. v. Jackson, 3 Denio 101, 45 Am. Dec. 449 , B. 121.

(Va. Gen. Ct., 1852.) Shooting Dog on Porch. Defendant was convicted of wickedly, mischievously, and maliciously entering the close of one Pugh, and while standing on the porch of Pugh's house, shooting and killing his dog, against the protest and to the terror and dismay of Nancy Pugh, against the peace and dignity of the commonwealth, whereby she and her daughters, being alone, became alarmed, and in consequence sick. He moved in arrest of judgment, on the ground that no offense was charged at common law or $11, \cdot$ ?er the statutes. 'The court said, mere brealing the close, though in contemplation of law with force and arms, was no crime; but affirmed the judgment, because entering the dwelling house in a violent manner, and there killing the domestic animals of the householder, with dangerous wcapons, to the terror of the members of the family in the house, was such an aggravated trespass as to be a misdemeanor at common law. "No trespass could be aggravated beyond the wrongs of a private injury, and swell into the magnitude of a crime against the public peace, if the facts stated in the record do not amount to a misdemeanor." Per LOMAX, J., citing R. v. Storrs, 3 Burrows 1698, and R. v. Bathurst. Henderson v. C., 8 Grat. 708, 56 Am. Dec. 160, F. 6, Kn. 5. 
(Me. Sup. Judicial Ct., 1821.) Throwing the Body of a Child into the River was held an indictable offense on motion in arrest of judgment. The court said: "We have no doubt upon this sub. ject, and do not hesitate a moment to pronounce the indictment to be good and sufficient, and that there must be sentence against the prisoner. From our childhood we all have been accustomed to pay a reverential respect to the sepulchres of our fathers, and to attach a character of sacredness to the grounds dedicated and enclosed as the cemeteries of the dead. Hence, before the late statute of Miassa. chusetts was enacted, it was an offense at common law to dig up the bodies of those who had been buried, for the purpose of dissection. It is an outrage upon the public feelings, and torturing to the afflicted relatives of the deceased. If it be a crime thus to dis. turb the ashes of the dead, it must also be a crime to deprive them of a decent burial, by a disgraceful exposure, or disposal of the body contrary to usages so long sanctioned, and which are so grate. ful to the wounded hearts of friends and mourners. If a dead body may be thrown into a river, it may be cast into a street; if the body of a child, so the body of an adult, male or female. Good morals, decency, our best feelings, the law of the land,-all forbid such proceedings." Kanavan's Case, 1 Gr. (1 Me.) 226, B. 115.

§19. Corrupting Public Morals.

(Eng. Queen's Bench, 1708.) Publishing an Obscene Book called The Fifteen Plagues of a Maidenhead was the basis of an informa. tion for libel, and on motion in arrest of judgment, that it was not punishable in the temporal courts, HOL'T, C. J., was so strong with the objection that the prosecutor never stirred it again. R. v. Read, stated in argument, 2 Strange 789.

(Eng. King's Bench, 1714.) Indictment for Publishing "Venus in the Cloister," an obscene book intended to corrupt the public morals. After conviction defendant moved in arrest of judgment, relying on $R$. v. Read. The attorney general argued that destroying the public morals is destroying the public peace and order, which the government is ordained to keep. "Chief Justice Irale used to say, Christianity is part of the law, and why not morality too? I do not insist that every immoral act is indictable, such as telling a lie, or the like; but if it is destructive of morality in gen. eral, if. it does, or may, affect all the king's subjects, it then is an offense of a public nature. And upon this distinction if is, that particular acts of fornication are not punishable in the temporal courts, and bawdy-houses are. In Sir Charles Sedley's case it was said, that this court is the custom morum of the ling's subjects. 1 Sid. 168." FORTESCUE, J. I own this is a great offense, but I know of no law by which we can punish it. Common law is com. 
mon usage, and where there is no law there can be no transgression. At common law drunkemness, or cursing and swearing, were not punishable; and yet I do not find the spiritual court took notice of them. This is but a generil solicitation of chastity, and not indictable. Lady Purbeck's case was for procuring men and women to meet at her house, and held not indictable, unless there had been particular facts to make it a bawdy-house. To make it indictable there should be a breach of the peace, or something tending to it, of which there is nothing in this case. A libel is a technical word at common law, and I must own the case of the IR. v. Read sticks with me, for there was a rule to arrest the judgment nisi. And in Sir Charles Sedley's case there was a force in throwing out bottles upon the people's heads. REYNOLDS, J. It is much to be lamented if this is not punishable. I agree there may be many instances, where acts of immorality. are of spilitual cognizance only; but then those are particular acts, where the prosecution is pro salute animae of the offender, and not where they are of a general immoral tendency; which I take to be a reasonable distinction. Read's case is indeed a case in point. But I confess I should not have been of that opinion. Libellus does not ex vi termini import defamation, but is to be governed by the epithet which is added to it. 'This is surely worse than Sir Charles Sedley's case, who only exposed himself to the people then present, who might choose whether they would look upon him or not; wherens this book goes all over the kingdom. Drunkenness and swearing were punishable in the spiritual court before the acts which made them temporal offenses, and in which the jurisdiction of the spiritual court is saved. (Being a case of great consequence, it was ordered to stand over to the next term, at which time the judges gave their unanimous opinion that this was a temporal offense, and defendant was set in the pillory.) R. v. Curl, 2 Strange 788.

(Eng. King's Bench, 1763.) Against Public Decency and Manners. LORD MANSFIELD, C. J. This is a motion for an information against the defendants for a conspiracy to put this young girl (an apprentice to one of them) into. the hands of a giville: ialn of rank and fortune, for the purpose of prostitution; contrary to decency and morality, and without the knowledge or approbation of her father, who prosecutes them for it, and has now cleared himself of all imputation, and appears to be an innocent and an injured man. A female infant, then about fifteen, was bound apprentice by her father to the defendant Bates, a music master; the girl appearing to have natural talents for music. The father became bound to the master in the penalty of $£ 200$ for his daughter's performance of the covenants contained in the indenture. She became eminent for vocal music; and thereby gained a great profit to Bates, her master. * And then she is indentured to Sir Francis Delaval to learn music of him; and she covenants with him, both 
in the usual covenants of indentures of apprenticeship, and likewise in several others (as "not to quit even his apartments"), ete. These articles between the parties are signed by all but the father, and $a$ bond is drawn from him, in the penalty of $£ 200$ for his daughter's performance of these covenants (which he never executed). And the girl goes and lives and still does live with Sir Francis, notoriously, as a kept mistress. Thus she has been played over, by Bates, into his hands, for this purpose. No man can avoid seeing all this; let him wink ever so much. I remember a cause in the court of chancery, wherein it appeared that a man had formally assigned his wife over to another man, and Lord Hardwicke directed a prosecution for that transaction, as being notoriously and grossly agairst public decency and good manners. And so is the present cise. ** * Besides this there is, in the present case, a conspiracy and confederacy amongst the defendants, which was clearly and indisputably within the proper jurisdiction of this court. * * Rule absolute. R. v. Delaval, 3 Burr. 1+34, 1 Wm. Bl. 410 . 439,1 B. \& H. 457 , B. 101.

Acc. on similar fucts: Smlth v. P., 81.

(Pa. Sup. Ct., 1815.) Indictment for Exhibiting Indecent Pictures. Motion in arrest of judyment, that no oflense was charged. IILGHIIAN, C. J. *** There is no act punishing the offense charged against the defendants, and therefore the case must be decided upon the principles of the common law. That actions of public indecency were always indictable, as tending to corrupt the public morals, I can have no doubt; because, even in the protligate reign of Charles II, Sir Clistrles Sedley was punished by imprisonment and a heavy fine for standing naked in a balcony in a public part of the city of Isondon. It is true that, besides this shamefinl exhibition, it is mentioned in some of the reports of that ease that he threw down bottles containing offensive liquor among the people; but we have the highest authority for saying that the most criminal part of his conduct, and that which principally drew upon him the vengeance of the law, was the exposure of his person. For this I refer to the opinion of the judges in Queen v. Curl, 2 Strange 792 [above]; Lord Mansfield in R. v. Delaval, 3 Burr. $143 \pm$ [above]; and of Blackstone in 4. Bl. Com. 64. *** The law in Curl's case was established upon true principles. What tended to corrupt society was held to be a breach of the peace and punishable by indictment. The courts are guardians of the public morals, and therefore have jurisdiction in such eases. Hence it follows that an offense may be punishable if in its nature and by its example it tends to the corruption of morals, although it be not committed in public. *** Now, to apply these principles to the present case. The defendants are charged with exhibiting and showing to sundry persons, for money, a lewd, scandalous, and obscene painting. A picture tends to excite lust as strongly as a writing; and the 
showing of a picture is as much a publication as the selling of a book. Curl was convicted of selling a book. It is true, the indictment charged the act to have been in a public shop, but that can make no difterence. The mischief was no greater than if he had taken the purchaser into a private room and sold him the book there. The law is not to be evaded by an artifice. * * * AIotion overruled. C. v. Sharpless, 2 Serg. \& R. 91, 7 Am. Dec. 632, B. 113.

\& 20. Touching the Government.

(Milss. Sup. Judicial Ct., 1812.) For Voting More than Once on in election of selectmen at a town meeting, a legal voter was indicted, and after conviction moved in arrest of judgment, that no statute made the act an offense, nor was such office known to the law. On the other side it was argued that such frauds were becoming so common that they must be stopped to save the purity of elections. CURIA. 'There cannot be a doubt that the offense described in the indictment is a misdemeanor at common law. It is a general principle that where a statute gives a privilege, and one wilfully violates such privilege, the common law will punish such violation. In town meetings every qualified voter has equal rights, and is entitled to give one vote for every officer to be elected. 'The person who gives more infringes and violates the rights of the other voters, and for this offense the common law grives the indictment. * * * Fine, $\$ 10$ and costs. C. v. Silsbee, 9 Mass. 417, B. 111.

Acc. C. v. Randolph, $\$ 6$.

(Va. General Ct., 1825.) Misdemeanors in General-Trading Votes. Case adjourned by the superior court for the opinion of this court. The indictment states that defendants, being magistrates, attended a meeting of the county court held to elect a clerk of the court and a revenue commissioner, and corruptly agreed the one to vote for one Holloway for commissioner in consideration that the other would vote for one Callaghan for clerk. 'The cour't iumd the case did not fall within the statute against buying and selling public offices, because neither would profit personally by the transaction. Further, BARBOUR. J., said: "The court being thus of opinion that this case was not cmbraced by the statute. but at the same time considering that that system of criminal jurispradence nust be essentially defective which had provided no pumishment for acts such as are charged in the information, and which merit the reprehension of all good mev, were led to inquire whether the acts charged in the information did not constitute an offense at common law; and they are of opinion that they do. In relation to those offenses which rise to the grade of felony there is usually. particularly in the designation of them by name. an accuracy in the defini- 
tion; as, for example, murder, burglary, arson, etc., in each of which the term ex vi termini imports the constituent of the offense; but in the general classitication of erimes whatever is not felony is misclemeanor. In relation to these, then, they are not only numerous but indefinitely diversified, comprehending every act which, whilst it falls below the grade of felony, is either the omission of something commanded or the commission of something prohibited by law. As to these the law can do no more than lay down general principles, and it belongs to the courts of the country to apply those principles to the particular cases as they occur, and to decide whether they al'e or are not embraced by them. 'l'hus the law, as a general proposition, prohibits the doing of any act which is contra bonos mores. The particular acts which come up to this description it is impossible to include in any precise enumeration; they must be decided as they occur, by applying this principle to them as a standard. 'Thus, again, it is now established that the incitement to commit a crime is itself eriminal under some circumstances. 6 Last, $46 \pm ; 2$ Last, $\bar{\jmath}$. ** Let us apply these principles to the present case. 'The defendants were justices of the peace, and as such held an office of high trust and confidence. In that character they were called upon to vote for others, for offices also implying trust and confidence. 'Their duty required them to vote in reference only to the merit and qualifications of the officers, and yet upon the pleadings in this case it appears that they wicliedly and corruptly violated their duty and betrayed the confidence reposed in them, by voting under the intluence of a corrupt bargain or reciprocal promise, by which they had come under a reciprocal obligation to vote respectively for a particular person, no matter how inferior the qualifieations to their competitors." C. v. Callaghan, 2 Va. Cas. 460, B. 116, C. 6.

\section{\$21.; "For Which the Wrongdoer May be Prosecuted and Pun. ished."}

(U. S. C. C., East Dist. La., 1892.) Excluding Chinese. Motion to quash an indictment for coming into the United States contrary to act of congress of May 5, 1892, $\$ 4$, which provides: "I'hat any such Chinese person, or person of Chinese descent, convicted and adjudged to be not lawfully entitled to be or remain in the United States, shall be imprisoned at hard labor for a period not exceed. ing one year, and thereafter removed from the United States. as hereinbefore provided." BILLINGS, D. J. * * * The whole proceeding of keeping out of the country a class of persons deemed by the sovereign to be injurious to the state, to be effective of its object, must be summary in its methods and political in its character. It could have no place in the criminal law, with its forms and rights and delays. After the unlawful presence of the alien 
is determined, he must be sent back to his country by the treasury department at Washingtou. To prevent an unreasonable and possibly oppressive detention it must be within one year. NIeanwhile he must lieep from entering the community of the people of the United States, and therefore he is to be imprisoned. 'To prevent expense to the government, and as a sanitary matter, he is to be made to work. 'This, it seems to me, is the meaning of the clause relied upon to authorize trial and punishment for a crime. There is nothing in the statute declaring that it shall be a crime or a misdemeanor for a Chinese to come into the country. The unlawfulness is not made the basis of criminal procedure or detention, but rather is made the warrant to send him back. The imprisonment spoken of in the statute is that which is necessary to effectuate his return. It seems to me that $\S 4$ deals with proceedmgs before the commissioner conducting an examination which is political and not criminal, and amounts to a direction to him and to the authoritics who conduct the transportation or removal back to China, and is two-fold: 1, that a Chinese adjudged to be here unlawfully shall be removed within a year; 2 , that till removal he shall be kept in prison and made to work. In accordance with these views, I must direct that this indictment be quashed, and that the defendant be remanded to the custody of the commissioner, to be dealt with according to law. U. S. v. Hing Quong Chow, 53 Fed. 233, B. 123.

\section{DIFFERING FROM PRIVATE WRONGS.}

\$22. Since the criminal prosecution is by the state because of the injury to the public, it is no defense that the person especially injured (1) might have escaped but for his own negligence, (2) was equally guilty, (3) has been reimbursed, (4) has forgiven the wrong, (5) entrapped the offender, or even (6) consented to the act (7) unless want of consent is an essential element of the particular crime.

\section{§23. "Might Have Escaped but for his Own Negligence."}

(Eng. Sessions at Newgate, 1662.) Neglecting Wound. Edward Rew was indicted for killing Nathaniel Rew, his brother, and upon the evidence it was resolved that if one gives wounds to another, who neglects the cure of them. or is disorderly, and doth not keep that rule which a person wounded should do; yet if he die it is murder or manslaughter, according as the case is in the person who gave the wounds; because if the wounds had not been the man had not died; and therefore the neglect or disorder in the 
person who received the wounds shall not excuse the person who gave them. K. v. Kew, Kelyng 26, B. 163, Mli. jjy.

set vibur chses lo sume ellect. Ante $\$ 15$.

(Eng. Assize at Liverpool, 18t1.) Refusing Amputation. Deceased had been severely eat with an iron instrument across one of his finger's, and had refused to have it amputated. At the end of two weeks lock-jaw came on and the finger was then amputated, but too late; and the lock-jaw ultimately caused death. 'L he surgreon expressed the opinion that early amputation would probably have saved his life. Mable, J., held that a party infleting a wound which ultimately became the eause of death is guilty of murder, though life might have been saved if the deceased had not refiused to submit to a surgical operation, $R$. v. Holland, 2 Houd. diub. 351, B. 16t, Ke. 93.

(Eugr. Assize, 1s \pm 6. ) Same. Manslaughter. Defendants, inciting each other while somewhat intoxicated, and one following the other closely, drove their horses and carts of pottery at a furrous rate along a public road, and one or both ran over an old man, thus killing him. POLLOCh, C. B. (to the jury'): 'I'le prisoner's are charged with contributing to the death of the deceased, by their negligence and improper conduct, and if they did so, it matters not whether he was deaf, or drunk, or negrigent, or in part contributed to his own death; for in this consists a great distinction between eivil and eriminal proceedings. If two coaches run against each other, and the driver's of both are to blame, neither of them has any remedy against the other for dimages. ** Generally; it may be laid down, that, where one by his negligenee has contributed to the death of another, he is responsible; therefore, you are to say, by your verdict, whether you are of opinion that the deceased eame to his death in consequence of the negligence of one or both of the prisoners. * * Where two coaches, totally independent of each other, are proceeding in the ordinary way along a road, one after the other, and the ciriver of the first is guilty of negligence, the driver of the second, who had not the same means of pulling up, may not be responsible. But when two persons are driving together, encouraging each other to drive at a dangerous pace, then whether the injury is done by the one driving the first or the second earriage. 1 am of opinion that in point of law the other shares the guilt. K. v. Swindall et al. 2 Carr. \& K. 230, 2 Cox C. C. 141, 13. 167, F. 26, Ke. 74, Kn. 12.

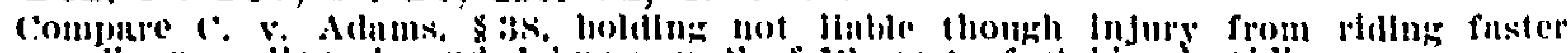

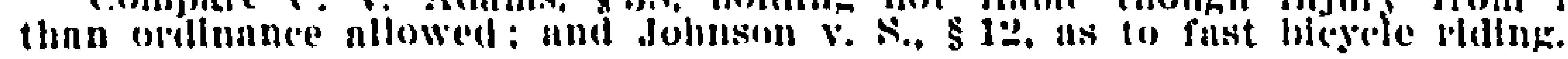

(Eng. Assize, 1849.) Deaf Man in Highway. 'Two indicted for mans!aughter. 'The evidence proved that defendants, while partly' intoxicated, drove in a girs, after dark, mapidly down a hill in a road thickly shaded by trees; and that three men shortly following 
found a man insensible and dying in the middle of the road, apparently having been just run over by a vehicle. Deceased had been dealf flom childhood, but had a habit of walking at all hours in the middle of the road. At the close of the calse for the prosecution, defendants asked to be aequitted because of the contributory negligence of deceased. "I do not at all recogni\%e the analogy which has been put with regard to an action under Lord Campbell's aet, and a charge of felony. *** * There is no balance of blame in charges of felony, but, wherever it appears that death has been occisioned by the illegal act of another, that other is guilty of manslaughter in point of law, though it may be that he ought not to be severely punished. If the jury should be of opinion that the prisoners were driving along the road at too rapid a pace. considering the time and place, and were conducting themselves in a careless and negligent way, in the management of the horse intrusted to their care, I am of opinion that such conduct amounts to illegalitr, and that the prisoners must be found guilty on this indictment. whatever may have heen the negligence of the deceased himself." Por ROLFE, 13. Regina v. Longbottom, 3 Cox Cr. Cas. 439, 1 B. \& II. $34-n$. F. 25. Mi. 94 .

A(c.. 12. v. Dalloway (Assize, 1847), 2 Cox C. C. 273, B. 185: R. v. liew (Assize, 1872), 12 Cox C. $1: 35 \%$. 13. 165. ¿. 150 .

\section{§24. "Was Equally Guilty."}

(Eng. Central Crim. Ct., 1845.) Counterfeit for Intercourse. The defendint was indicted for uttering counterteit coin. Evidence was adduced to show that he had given a counterfeit sovereign to a girl with whom he had had intercourse. DENMIAN, C. J. (in summing up) : As to the law of this case. my learned brother (Coltman, J.) and myself are clearly of opinion that if the defendant gave the coin to the womm under the circumstances stated, linowing it to be counterfeit, he is guilty of the offense charged. **** $\mathbf{R}$. v. $\longrightarrow, 1$ Cox Cr. Cas. 250, B. 158, C. 145.

(Mass. Sup. Judicial Ct., 1851.) Trading "Gold" Watch. Defendants were convicted on an indictment eharging them with cheating one Lynch of his goods by falsely pretending that a watch they offered to trade was gold, 18 carats fine, and worth $\$ 80$. Lynch also overstated the value of his watches. The judge instructed the jury that if they supposed that each of the parties was endeavoring to defraud the other, and Lyneh knew that his watches were of little value, the jury should not convict the defendants merely because they had the best of the bargain: but that if the defendants made the false representations charged in the indictment, with the intent to defraud, knowing them to be false. and they were such as would mislead and deceive a man of ordinary pru- 
dence, and Lynch, by reason of the representations, and trusting in them, parted with his property and was defrauded, it was not necessary to show that he was defrauded to the extent charged in the indictment. Defendants excepted. DEWFY, J. The exceptions taken to the instructions of the presiding judge cannot be sustained. If it were true that the party from whom the defendants obtained goods by false pretenses also made false pretenses as to his goods which he exchanged with the defendants, that would be no justification for the defendants, when put on trial upon an indictment charging them with obtaining goods by false pretenses, knowingly and designedly in violation of a statute of this commonwealth. Whether the alleged misrepresentation of Lynch, being a mere representation as to the value or worth of a certilin watch and an opinion rather than a statement of a fact, would be s: sh false pretense as would render him amenable to punishment I nder this statute, might be questionable; but supposing that to be itherwise, and it should appear that Lynch had also violated the statute, that would not justify the defendants. If the other party has also subjected himself to a prosecution for a like offense, he also may be punished. This would be much better than that both should escape punishment because each deserved it equally.

C. v. Morrill, 8 Cush. 571, B. 160, C. 146.

(Eng. C. C. R., 18600.) Cheating a Cheat. Crown case reserved on conviction on indictment for conspiracy to cheat. The prosecuter and defendants were in a public house when defendant Dewhirst put a pen case on the table where they were and left to get some paper, whereupon defendant Hudson took a pen out of the case, put it under prosecutor's drinking glass. and with defendant Smith induced prosecutor to bet $£ 2,10$ s with Dewhirst on his return that there was no pen in the case. When the case was turned over another pen fell out, and the prisoners took the money. BLACK. BURN, J. Here the prisoners cheated the prosecutor into the belief that he was going to cheat, when in fact he was to be cheated. POLLOCK, C. B. We are all of opinion that the conviction on the third count is good and ought to be supported. *** There is abundant evidence of a conspiracy by the prisoners to cheat the prosecutor, and though one of the ingredients in the case is that the prosecutor himself intended to cheat one of the prisoners, that does not prevent the prisoners from liability to be prosecuted upon this indictment. Conviction affirmed. R. v. Hudson, 8 Cox C. C. 305 , Bell C. C. 263,29 L. J. m. c. 145,6 Jur. n. s. 566,2 L. T. 263 , 8 W. R. 421 , B. 158 , C. 142.

(New York Ct. of App., 1871.) Blackmail by Pretended Officer. Defendant was convicted of obtaining a gold watch and diamond ring of prosecutor by pretending to be an officer with a warrant to arrest him. Per CURIAM. If the prosecutor parted with his property 
upon the representations set forth in the indictment, it must have been for some unlawful purpose, a purpose not warranted by law. 'There was no legitimate purpose to be attained by delivering the goods to the accused upon the statements made and alleged as an inducement to the act. What action by the plaintiff in error was promised or expected in return for the property. given is not disclosed. But whatever it was, it was necessarily inconsistent with his duties as an officer having a criminal warrant for the arrest of the prosecutor, which was the character he assumed. 'The false representation of the accused was that he was an officer and had a criminal warrant for the prosecutor. There was no pretense of any agency for or connection with any person or of any authority to do any act save such as his duty as such pretended officer demanded. The prosecutor parted with his property as an inducement to a supposed officer to violate the law and his duties; and if in attempting to do this he has been defrauded, the law will not punish his confederate, although such confederate may have been instrumental in inducing the commission of the offense. Neither the law or public policy designs the protection of rogues in their dealings with each other, or to insure fair dealing and truthfulness as between each other in their dishonest practices. The design of the law is to protect those who, for some honest purpose, are induced upon false and fraudulent representations to give credit or part with their property to another, and not to protect those who for unworthy or illegal purposes part with their goods. * * * Judgment rerersed. [Peckham, J., filed an exhanstive dissenting opinion.] McCord v. P., 46 N. Y. 470, B. 162, C. 148.

Arc. Stute v. Crowley, 41 Wis. 271.

(Mich. Sup. Ct.. 1882.) Furnishing Money to be Used Illegally. MARSTON, J. The respondent was charged with obtaining the indorsement of Martin Kline to a promissory note by false pretenses, and upon trial had was convicted. The case comes here on exceptions before judgment. * * * This objection, as we understand it, under the facts in this eãse, means that if the money to be obtained from a negotiation of the note after its indorscment. was to be used by the respondent for an unlawful or immoral purpose, and such fact was known to the person before endorsing, there could be no conviction. This position is based upon the theory that the statute upon which this prosecution was founded was in some way intended to protect the party deceived or defrauded but not to punish the party guilty thereof. When a crime has been committed the law seeks to punish the party guilty thereof. The injured individual has been wronged, and his object. motive, or complicity therein, may affect any remedy that he might have against the perpetrator thereof. In every crime there is in addition to this wrong done to the individual, also a public wrong. This the state punishes; and, except in certain trivial cases, the person injured has 
no control over, and cannot prevent or interfere with the public prosecution by the state authorities. The penalty attached to the commission of the offense charged in the information is imposed upon public grounds, and the fact that the party deceived or detrauded may have supposed or known the money obtained on his endorsement would be used for immoral or unlawful purposes, would not purge the gruilt of the accused. **** Proceed to judgment. P. v. Henssler, 48 Mich. 50,11 N. W. 804.

(Colo. Sup. Ct., 1891.) Public Land Fraud. Petition for writ of habeas corpus. A justice of the peace committed petitioncr to the county jail to await action by the grand jury on four charges of obtaining money by false pretenses. It appeared by the com. plaint as well as the testimony before the justice that in each instance the pretenses induced the prosecuting witnesses to pay the money in furtherance of an illegal purpose to obtain valuable coal lands of the United States by fraud. "The primary object of punishment is the suppression of crime; and, where both the prosecutor and the defendant have violated the law, it is better that both be punished than that the crime of one should be used to shicld the other. When the plaintiff in a civil action is shown to have been guilty of a wrong in the particular matter about which he complains, he cannot ordinarily recover. But there is little chance to apply this rule to criminal prosecutions conducted by the state; the person defrauded being at most a prosecuting witness in the case, and not a party to the proceeding. The language of our statute is plain. The false pretenses charged in this case are embraced within its express terms, and we are not in favor of sanctioning a rule that will permit offenders to escape by showing that another should also be punished." Petition denied. In re Cummins, 16 Colo. 451, $2 i$ Pac. 887, 25 Am. St. Rep. 291, 13 L. R. A. 752, F. 23, Kn. 15.

Acc. Com. v. O'Brien, 172 Mass. 248, 52 N. E. 77; Com. v. Henry, 22 Pa St. 253

-To adopt this position would give free license to villains and sharpers to prey upon those who have bec me credulous through the infirmities of the. or $u$ ho are unwary from the ines perience of youth. as well as a larxe class who are weakminded by nature. the very class of the community whom it is the policy of the law to protect." CHAMPLiN, J., in giving the opinion on P. v. W atson, 75 Mich. 582,42 N. W. 1005.

\section{§ 25. "Has Been Reimbursed."}

(Ark. Sup. Ct., 1893.) Reimbursement by Guaranty Co. Appeal to this court from denial of motions in arrest of judgment and for new trial, after conviction on indictment for embezzlement. "De. fendant contends that having hired the guarantee company to make his bond for faithful performance of duty to the Pacific Express Company, and that company having paid the express company for all losses claimed by it to have been suffered by reason of defendant's alleged embez:lement, therefore, there was no crime com. mitted; that the express company had no longer any interest at 
stake, and even that the state has no interest in the matter. In this the defendant is mistaken. This is no longer a controversy between himself and the two companies or either of them. * * * It is now a controversy between the state of Arkansas and himself, which the state will not permit either one of said companies to determine, at present or in the future, nor will the state acknowledge the validity of any settlement of it, by anything they, both or either of them, have done in the past." Per BUNN, C. J. Reversed on other grounds. Fleener v. S., 58 Ark. 98, 23 S. W. 1, F. 9, Kn. T.

\section{§26. "Has Forgiven the Wrong."}

(Mass. Sup. Judicial Ct., 1888.) Rape Forgiven. Exceptions were alleged on conviction of rape to the refusal of the trial court to instruct the jury "that if said Donovan [prosecutrix], at any time after the act, excused or forgave the defendant, then she ratjfied the act, and he cannot be convicted in the case." W. ALLEN, $J$. The court rightfully refused to give the instructions requested. The injured party could not condone the crime by excusing or forgiving the criminal. ${ }^{*} * *$ Exceptions overuled. C. v. Slattery, 147 Miass. 423,18 N. E. 399, B. 151.

(MIo. Sup. Ct., 1894.) Mother Forgives Forgery. There was no error in refusing defendant's request to instruct the jury, that the fact that the mother, whose name had been forged by defendant, was willing to condone the offense and pay the obligation, would lessen the crime. Affirmed. S. v. Tull, 110 Mo. 421, 24 S. W. 1010, F. 10.

\section{§27. "Entrapped the Offender."}

(Mich. Sup. Ct., 1892.) Liquor Bought to Convict. Respondent brings error after conviction of selling liquor in violation nf law. MONTGOMERY, J. ** * Respondent's counsel requested the court to charge the jury that if the prosecution was brought about by Dolbie being hired to procure the liquor for the purpose of prosecuting the respondent and convicting him, the prosecution could not be sustained. It does not appear that any public officers were concerned in sending to the respondent for the liquor in question, and the request was properly refused. *** [Reversed on another ground.] ' P. v. Murphy, 93 Mich. 41, 52 N. W. 1042.

Followed in P. v. Curts, 95 Mioh. 212,54 N. W. 767 , in which the conviction was affrmed.

(New York Ct. of App., 1894.) Decoying Extortioner. Defendant was indicted and convicted of attempt to extort by threatening to accuse the principal witness of keeping a house of prostitution, 
and promising her that if she would pay him $\$ 150$ he would not accuse her. Defendant was a private detective employed by a society for prevention of crime; and the principal witness testified that she kept a house of prostitution, and by agreement with the police had been acting as a decoy, trying to induce defendant to receive money under circumstances that would enable the police to arrest for and convict him of extortion. The judgment was reversed on appeal to the general term (73 Hun. 66, 25 N. Y. Supp. 1072, F. 14), and the state appeals. The Penal Code provides: \$552. "Extortion is the obtaining of property from another, with his consent, induced by a wrongful use of force or fear, or under color of official right." $\$ 553$. "Fear, such as will constitute extor. tion may be induced by a threat ** * to accuse a person of a crime." \$34. "An act done with intent to commit a crime, and tending, but failing to effect its commission, is an attempt to com. mit that crime." $\$ 685$. "A person may be convicted of an attempt to commit a crime, although it appears on the trial that the crime was consummated." Speaking for the court, EARL, J., said: "The evidence tended to show * * ${ }^{*}$ every element con. stituting the crime of extortion, except that Mrs. Amos, in paying the money exacted by the defendant, was not actuated by fear. It is urged on behalf of the defendant, that the fact that his threats did not inspire fear, inducing any action on the part of Mrs. Amos, an element essential to constitute the completed crime of extortion, renders it impossible to sustain an indictment and conviction for the lesser crime of an attempt at extortion, and so a majority of the judges constituting the general term held. We are of opinion that those learned judges fell into error. The threat of the defendant was plainly an act done with intent to commit the crime of extortion, and it tended, but failed, to effect its commission; and therefore the act was plainly within the statute. *** The general term, in reversing the judgment, should not, therefore, have refused to grant a new trial, and have discharged the defendant." Modified accordingly. P. v. Gardner, 144 N. Y. 119, 38 N. E. 1003. 43 Am. St. Rep. 741, 28 L. R. A. 699.

\section{§ 28. "Consented to the Act."}

(Eng. Assize at Liecester, 1604.) Self-Maiming to Beg. One Wright, a young, strong, and lusty rogue, to make himself impotent, thereby to have the more color to beg or to be relieved without putting himself to any labor, caused his companion to strike off his left hand, and both of them were indicted, fined, and ransomed therefor, and that by the opinion of the rest of the justices for the cause aforesaid. Wright's Case, Co. Lit. 127a, B. 145.

(S. Car. Ct. of App., 1833.) Whipping Requested to Avoid Prose- 
cution. Anderson having stolen some leather, and being found with it, was immediately arrested, apparently without process; whereupon someone, not Beck, asked him if he would not rather be whipped than go to jail. He said he would, and putting his arms around a tree, requested Beck to whip him. Beck hesitated, but finally, saying, "If it will oblige you, I will do it," consented; and gave him a few stripes with a switch. Anderson was then released, but later prosecuted, convicted, and punished. Beck, being prosecuted for this alleged assault and battery, was convicted, and now moves for a new trial. Granted. "Where one gave another license to beat him, there is a case in which it is said the license was held to be void. This may well be. The person receiving the license entertained hostile dispositions towards the other, and, upon being thus licensed, proceeded to carry his revengful purpose into effect. But in the case before us the defendant had no evil disposition towards Anderson, but the contrary." Per HARPER, J. S. v. Beck, 1 Hill 363, 26 Am. Dec. 190, F. 11, Mi. 68.

(Ohio Sup. Ct., 1863.) Boxing. By the COUR'L. Held, an indictment against $A$ for an assault and battery upon $B$, is not sustained by evidence that $A$ assaulted and beat $B$ in a fight at fisticuffs, by agreement between them. An assault and battery and an affray are distinct offenses under the statute, punishable by different penalties. Judgment reversed and cause reminded. Champer v. S., 14 Ohio St. 437, Mi. 69.

(Mass. Sup. Judicial Ct., 1875.) Boxing Match. Collberg and Phenix were each indicted and convicted of assault and battery on the other. The evidence showed that defendants had often engaged in wrestling matches, and that on the evening of the day on which the offenses charged were committed, they met at the railway depot, and Collberg bantered Phenix to fight, which he declined to do unless Collberg would wait till he could go home and change his clothes; that this being agreed to, he went and changed, and they together went to a retired place and fought in the presence of 50 or 75 persons till Collberg said he had enough, when both went home; but the next day both looked bruised as if they had been fighting. The court refused to instruct the jury that if what they did was by mutual consent and without anger or malice they must be acquitted, but did instruct them: "That if the defendants were simply engaged in a-wrestling match, that being a lawful sport, they could not be convicted of an ass?ult and battery; but if by mutual agreement between themselves, previously made, they went to a retired spot for the purpose of fighting with each other and for the purpose of doing each other physical injury by fighting, with a view to ascertain by a trial of their skill in fighting which was the best man, and there engaged in a fic $'$, each endeavoring to do and actually doing all the physical in. ar." in his power. to the 
other, and if, in such contest, each did strike the other with his fist for the purpose of injuring him, each may properly be convicted of assault and battery upon the other, although the whole was done by mutual arrangement, agreement, and consent, and without anger on the part of either against the other." To this instruction, and to the refusal of the judge to give the instruction prayed for, the defendants alleged exceptions. ENDICOT'T, J. It appears by the bill of exceptions that the parties by mutual agreement went out to fight one another in a retired place, and did fight in the presence of from 50 to 100 persons. Both were bruised in the encounter, and the fight continued until one said that he was satisfied. There was also evidence that the parties went out to engage in and did engage in a "run and catch" wrestling match. We are of opinion that the instructions given by the presiding judge contained a full and accurate statement of the law. *** [Expressly disapproving of s. v. Beck.] Exceptions overruled. C. v. Collberg, 119 Mass. 350, $20 \mathrm{Am}$. Rep. 328, B. 148, C. 160.

(Vt. Sup. Ct., 1884.) Same. Defendant was convicted on indict. ment for breach of the peace and proof that he engaged with one Bloxham in a boxing match of 4 to 6 rounds, under the Queensbury rules, on the village fair-grounds, before 25 to 100 people, assembled as the result of notice given three or four days in advance, that during the engagement each of the contestants assaulted and beat the other, so that blood flowed from a wound on the head of one and bruises remained visible on the face of one the second day after. Defendant was knocked down, but testified that he went down to avoid the blows of his adversary. "The court did not withdraw from the jury the determination of whether what the evidence tended to show, would enstitute a hreach of the peace. It left that whole subject to the determination of the jury, with proper instructions on the subject of what would constitute a breach of the peace. The only question reserved was whether the consent of the combat. ants would prevent their acts from being a breach of the peace. Clearly, such consent would not necessarily give character to their acts and prevent their becoming a breach of the peace. 'The conduct, -quarreling, challenging, assaulting. tumultuous and offensive carriage, etc., which the statute declares to be a breach of the peace-is capable of being consented to by all the parties guilty of it. Con. sent, therefore. was not at all determinative of whether the respond. ent and Bloxham were guilty of a breach of the peace by their sts and conduct." * * * Per ROSS, .J. Judgment affirmed. \&. Burnham, 56 Vt. 445, 48 Am. Rep. 801, F. 12, Kn. 8.

\section{§29. "Want of Consent an Essential Element of Particular Crime." .}

(Eng. C. C. R.. 1840.) Child's Consent. Indictment of three 
counts; 1 , for carnally knowing and abusing a girl above 10 and under 12 years old; 2 , for assault with such intent; and, 3 , for assault. Godson, for the prisoner, contended that, supposing the fact to have been done by the consent of the prosecutrix, no conviction could take place on the second and third counts. 'The learned judge left the question to the jury, who found the fact that the prosecutrix had consented; and he then directed a verdict of guilty on the ground that the prosecutrix was by law incapable of giving her consent to what would be a misdemeanor by statute. But as Godson stated that the point was doubtful and had been otherwise decided before, the learned judge respited the judgment. It appeared to the learned judge clear that if the indictment had charged an attempt to commit the statutable misdemeanor, the prisoner would clearly have been liable to conviction; but the learned judge was not free from doubt as to the present case, in which an assault was charged. This case was considered at a meeting of the judges in Hilary term, 18t0, and they all thought that the proper charge was of a misdemeanor in attempting to commit a statutable offense, and that the conviction was wrong. R. v. Martin, 2 Moody 123, 9 Car. \& P. 213, B. 146 , C. 152.

(Eng. Cent. Crim. Ct., 1870.) Child's Consent to Father. On indictment for having carnal knowledge of a dau, ... under twelve, with her consent, and on another ... ...t for indecent assault, LUSH, J., instructed the jury, that completed act was essential to convict on the first count, and on the second there could be no conviction if there was consent, as assault excludes consent. "But consent means consent of will, and, if the child submitted under the influence of terror, or because she felt herself in the power of a man, her father, there was no real consent."

* Verdict, guilty. R. v. Woodhurst, 12 Cox Cr. Cas. 443, F. 22.

(Eng. C. C. R., 1850.) Fraudulently Defiled by Physician. Indictment for assault. The defendant was a medical practitioner. Mary Impitt, who was fourteen years old, was placed under his professional care by her parents, in consequence of illness, arisin: from suppressed menstruation; and on the occasion of her going to his house, and informing him she was no better, he observed, "Then I must try further means with you." He then took hold of her, and litir her down in his surgery, lifted up her clothes, and had carnal w: unection with her, she making no resistance, believing (as she t.tied) that she wảs submitting to medical treatment for the ailment under which she labored. The defendant's connsel, in his address to the jury, contended that the girl was a consenting party; therefore, that the charge of assault could not be sustained. WILDE, C. J. I have no doubt in this case that the direction of the learned recorder was perfectly correct. ** * IIe treats her as competent to consent, and her consent as ground of aequittal; but 
then that direction is qualified by what he adds afterwards-that if they were satisfied that she was ignorant of the nature of the act, and made no resistance solely from a bona fide belief that the de. fendant was, as he represented, treating her medically with a view to her cure, his conduct amounted to an assault. T'hat is the part which is objected to. The jury found the prisoner guilty. *** ALDERSON, B. *** When a man gains possession of the person of a woman by fraud, it is against her will; and if the question were res nova, 1 should be disposed to say that this was a rape, but that is not necessary in this casc. 'This is an indictment for an assault, and the prisoner obtains the consent of the child by repre. senting the act as something different from what it was. PA'l'J' SON, J. Mr. Horn confounds active consent and passive non-resist. ance, which, I think, the learned recorder has very accurately dis. tinguished. Here the girl did not resist, but still there was no con. sent. COLERIDGE, J. The girl was under medical treatment, and she makes no resistance only in consequence of the confidence which she reposed in the defendant as her medical adviser. If there had been no consent the defendant's act would have been indisputably an assault; and under the circumstances, therefore, his conduct amounted to an assault according to cases which I should be sorry to see infringed. PLA'Tl, B. * * * The girl consents to one thing, and the defendant does another; that other involving an assault. Conviction affirmed. R. v. Case, 4 Cox C. C. 220,1 Den. C. C. 580 , 'T. \& NI. 318,14 Jur. 489,19 L. J. m. c. 174 , B. 435 .

Simllar cuse Inon irornn v. P., \$102.

(Mass. Sup. Judicial Ct., 1873.) Drugging with "Love Powders." Defendant was convicted of assault on a young woman on proof that he gave her figs to eat, into which he had introduced a drug purchased by him as harmless, and under the name of "love powders," but which in fact contained cantharides, which made the woman very sick, and gave her great pain for hours. The trial judge instructed the jury to convict if they found these facts, though they should believe the defenclant thought the drug harmless. WELLS, J. All the judges concur that the evidence introduced at the trial would warrant a conviction of assault and battery or for a simple assault, which it includes. And in the opinion of a majority of the court, the instructions given required the jury to find all that was essential to constitute the offense of assault and battery. 'The jury must have found a physical injury inflicted upon another person by a voluntary act of the defendant directed toward her, which was without justification and unlawful. Although the defendant was ignorant of the qualities of the drug he administered and of the effects to be expected from it, and had been assured and believed that it was not deleterious to health, yet he knew it was not ordinary food, that the girl was deceived into taking it, and he intended that she should be indued to take it without her conscions 
consent, by the deceit which he practised upon her. It is to be inferred from the statement of the case that he expected that it would produce some effect. In the most finvorable aspect of the facts for the defendant he administered to the girl, without her consent and by deceit, a drug or "foreign substance," of the probable effect of which he was ignorant, with the express intent and pulpose "to try the effect of it upon" her. 'This in itself was unlawful, and he musi be held responsible for whatever effect it produeed. Being an unlawful interference with the personal rights of another, calculated to result and in fact resulting in physical injury, the criminol intent is to be inferred from the nature of the act and its actual results. 3 131. Com. 120; R. v. Long, \pm C. \& P. 398, 407, note. The deceit, by meaus of which the girl was induced to take the drug, was a fraud upon her will, equivalent to force in overpowering it: C. v. Burke, 105 Mlass. 376 [\$102]; R. v. Lock, 12 Cox 244; R. v. Sinclair, 13 Cox. C. C. 28. Although force and violence are included in all definitions of assault, or assault and battery, yet where there is physical injury to another person it is sulficient that the cause is set in motion by the defendant, or that the person is subjected to its operation by means of any act or control which the defendant exerts. * Exceptions overulued. C. v. Stratton, 114 Mass. 303, 19 Am. Rep. 350, B. 451, C. 155.

(Eng. C. C. R., 1888.) Husband Giving Wife Gonorrhoea. WILLIS, J. 'The prisoner in this case has been convicted (1) of "an assault", upon his wife, "occasioning actual bodily harm," under St. 2t \& 25 Vict. c. $100, \$ 47$; and (2) of "unlawfiully and maliciously inflictingr" upon her "grievous bodily harm" under $\$ 20$ of the same statute. The facts are that he was, to his knowledge, suffering from gonorrhoea; that he had marital intercourse with his wife without informing her of the fact; that he infected her, and that from such infection she suffered grievous bodily harm. The question is, whether he was rightly convicted upon either count. I'irst, was he guilty of an assault? In support of a conviction it is urged that even a married woman is under no obligation to consent to intercourse with a diseased husband; that had the wife known that her hush nd wass -diseased she would not have consented; that the husband was guilty of a fraud in concealing the fact of his illness; that her consent was therefore obtained by flaud, and was therefore no consent at all, and, as the act of coition would imply an assanlt if done without consent, he can be convicted. This reasoning secms to me eminently unsatisfactory. 'That consent obtained by fraud is no consent at all is not true as a general proposition either in fact or in law. If a man meets a woman in the street and knowingly gives her bad money in order to procure her consent to intercourse with him, he obtains her consent by fraud, but it would be childish to say that she did not consent. In respect of a contract, fraud does not destroy the consent; it only makes it revocable. Money or goods obtained 
by false pretenses still become the property of the fraudulent obtainer unless and until the contract is revolsed by the person defrauded, and it has never been held that, as far as regards the application of the criminal law, the repudiation of the contract had a retrospective effect, or there would have been no distinction between obtaining money under false pretenses and theft. A second and far more effective way of stating the argument, however, is that connection with a diseased man and connection with a sound man are things so essentially different that the wife's submission without knowledge of the facts is no consent at all. It is said that such a case rests upon the same footing with the consent to a supposed surgical operation or to connection with a man erroneously sup. posed to be the woman's husband. In the latter case there has been great difference of judicial opinion as to whether it did or did not amount to the crime of rape. *** A third way of putting the case is, that inasmuch as the act done amounts to legal cruelty according to the doctrines formerly of the ecclesiastical courts, and now of the divorce court, it cannot be said to be within the consent implied by the marital relation. 'These different ways of putting the argument in favor of a conviction have some important differences. According to each the consent of the marital relation does not apply to the thing done-a fact as to which there does not seem to be room for doubt, and according to each the want of it makes the transaction an assault. * * *. If the first view be correct, every man, as has been pointed out, who knowingly gives a piece of bad money to a prostitute to procure her consent to intercourse, or who seduces a woman by representing himself to be what he is not, is guilty of assault, and, as it seems to me, therefore of rape. If the second view be correct, it applies in similar events just as much to unmarried as to married people, unless the circumstances should establish that the parties were content to take their chances as to their respective states of health; and the allegation that a man had given an assurance to a prostitute before having intercourse with her that he was sound when he was not so in fact, might be a ground for putting him upon a trial for rape. If the third view be correct, it places the married man, in the eye of the criminal law, in a much worse position than the unmarried, and makes him guilty of an assault and possibly of rape, when an unmarried man would not be liable to the same consequences. It may be said that, from the moral point of view, his case is the worse; but there are two sides to this, as to most other questions. *** The question raised is of very wide application. It does not end with the particular contagion under consideration, but embraces contagion communicated by persons having smallpox or scarlet fever, or other like diseases quite free from the sexual element, and whilst so afflicted coming into a personal contact with others which would certainly have been against the will of those touched had they known the truth.

- Yet no one has ever been prosecuted for an assault so constituted. 
* * [Similar views were expressed by Smith, Stephen, Manisty, Mathew, and Grantham, JJ., Pollock, B., and Coleridge, C. J.]. HAWKINS, J. I am of opinion that the prisoner was rightly convicted upon both counts of the indictment. *** About the unlawfulness and maliciousness of the prisoner's conduct it seems to me impossible to raise a doubt. It has long been established by authority that, if a husband knowingly communicates to his wife a venereal disease, such misconduct amounts to legal cruelty, and is ground for judicial separation; and, in the absence of evidence to the contrary, it may be presumed that a man suffering under venereal disease knows it, and knows also that, if he has communion with his wife, he will in all human probability communicate his malady to her (see Brown v. Brown, L. Rep. 1 P. \& D. 46). It is equally clear that wilfully to do an unlawful act to the prejudice of another is to do it maliciously. We have, then, these elements established, grievous bodily harm unlawfully and maliciously caused. * * I proceed now to consider the question whether there vas in fact an assault by the prisoner on his wife occasioning her either grievous or actual bodily harm. 1 answer this question also in the affirmative. By the marriage contract a wife no doubt confers upon her husband an irrevocable privilege to have sexual intercourse with her during such time as the ordinary relations created by such contract subsist between them. For this reason it is that a husband cannot be convicted of a rape committed by him upon the person of his wife. ** * It may be said that, assuming a man to be diseased, still, as he cannot have communion with his wife without contact, the communication of the disease is the result of a lawful act, and therefore cannot be criminal. My reply to this argument is that if a person, having a privilege of which he may avail himself or not at his will and pleasure, cannot exercise it without at the same time doing something not included in this privilege, and which is unlawful and dangerous to another, he must either forego his privilege or take the consequences of his unlawful conduct. * * * I ought perhaps to state that, even if to hold a husband liable for an assault under such circumstances would be to subject him also to a charge of rape, the opinion I have above expressed would " it be changed. No jury would be found to convict a husband of rape on his wife except under very exceptional circumstances, any more than they would convict of larceny a servant who stealthily appropriated to her own use a pin from her mistress's pincushion. ${ }^{*}{ }^{*}{ }^{*}$ The cases put of a person suffering from smallpox, diphtheria or any other infectious disorder, thoughtlessly giving a wife or child a mere affectionate kiss or shake of the hand from which serious consequences never contemplated ensued, seem to me cases in which it is impossible to suppose any criminal prosecution would be tolerated, or conld, if tolerated, result in a conviction; but I can picture to myself a state of things in which a kiss or shake of the hand given by a diseased person. maliciously, with a view to communicate his 
disorder, might well form the subject of criminal proceedings. I will not, however, stop to discuss such imaginary cases further. The case of R. v. Bennett, 4 F. \& F. 1105, decided in 1866, is an authority directly in support of the view I have taken. 'The indictment was for an indecent assault on a girl who had consented to sleep with the prisoner, who had connection with her, and communicated to her a foul disease. Willes, J., before whom the case was tried, in summing up, told the jury that, though it would have been impos. sible to have established rape, yet if the girl did not consent to the aggravated circumstances-i. c., to connection with a diseased man -his act would be an assault. * * * The intercourse which takes place between husband and wife after marriage is not by virtue of any special consent on her part, but in mere submission to an obligation imposed upon her by law. Consent is immaterial. In the case of unmarried persons, however, consent is necessary previ. ous to every act of communion, and if a common prostitute were to charge with a criminal oflense a man who, in having had connection with her had infected her with disease, few juries would, nnder ordinary circunstances, hesitate to find that each party entered into the immoral communion tacitly consenting to take all risks. In the case of women other than prostitutes, the circumstances of each particular case would have to be considered, and the question how far fraud vitiates consent to such communion would also have to be dealt with. In such cases, too, shame would deter most decent women from appealing to the law; and, if a man were the sufferer, seldom would he incur the ridicule and exposure which would be brought upon him. Considering how few prosecutions have been instituted for such causes since the decision in R. v. Bennett, if Cox 124: s. c. C. A. Ib. $14 \overline{5}$, and entertaining moreover, as I do, a doubt whether any person, man or woman, could, as against the public interests, consent to the infliction of grievous bodily harm, so as to give a legal defense to a criminal prosecution, although such consent might affora a good defense to a civil action, I do not see any reason for such fear's on the subject as have been entertained. Anyhow they cannot affect the law. *** [Similar views were expressed by Day, Charles, and Field, JJ.]. R. v. Clarence, $16 \mathrm{Cox}$, C. C. 511,22 Q. B. D. 23,59 L. T. 780,37 W. R. 166, 53 J. P. 149 , L. J. m. c. 10 , B. 438 , Mi. 514.

(Eng. C. C. R., 1755.) Conspiring for Informer's Reward. Judg. ment was pronounced against the defendants on an indictment for comforting, aiding, and assisting Kelly and Ellis in a highway rob. bery of which the latter had been convicted. The jury found by special verdict that by agreement between the defendants, one of them (Blee) induced Kelly and Ellis to rob another of defendants (Salmon) in the highway in order to get the reward offered by act of parliament for apprehending robbers in the highway. This special verdict was argued before all the judges of England. and 
their judgment was pronounced by FOSTER, J. *** * 'This being the state of the case with regard to Salmon, the judges are of opinion that in consideration of law no robbery was committed on him. His property was not taken from him against his will. I come now to the case which I promised at the beginning to consider and to distinguish firom the present case. One Norden, having been informed that one of the early stage coaches had been frequently robbed near the town by a single highwayman, resolved to use his cndeavors to apprehend the robber. For this purnose he put a little money and a pistol into his pocket, and attended thic coach in a postchaise, till the highwayman came up to the company in the coach and to him, and presenting a weapon demanded their money. Norden gave him the little money he had about him, and then jumped out of the chaise with his pistol in his hand; and with the assistance of some others took the highwayman. The robber was indicted ibout a year ago in this court for a robbery on Norden, and convicted. Aud very properly, in my opinion, was he convicted. But thit case differs widely from the present. In that case Norden set out with a laudable intention to use his endeavors for apprehending the highwayman, in case he should that morning come to rob the coach, which at that time was totally uncertain; and it was equally uncertain whether he would come alone or not. In the case now under consideration there was a most detestable conspiracy between Salmon and the rest of the prisoners, that his property should be taken from him under the pretense and show of a robbery; and time, place, and every other circumstance were known to Salmon beforehand, and agreed to by him. *** Defendants discharged. McDaniel's Case, Foster C. L. 121, B. 152, Ke. 259.

(Eng. C. C. R., 1801.) Servant Aiding Burglars. 'The prisoners intending to rob the factory of Mr. Boulton, asked his watchman to assist them; he agreed, but immediately informed Mr. Boulton, who assented that he should open the front gate for the burglars and continue with them. The servant let them into the yard; they went in the outside door, which was not fastened, went upstairs, bolted a door behind them there, broke open the counting house an' desks, which were locked, took 150 guineas and some silver ingots, which Mr. Boulton had marked and left for evidence, came down, and were arrested in the yard as they were going out. On this case it was urged that no felony was proved, as the whole was done with Mrr. Boulton's knowledge and consent, and the servant's acts were his. After conviction the case was argued before all the judges in the exchequer chamber, and the majority of them were of opinion that there was no assent by Boulton; that his object being to detect the prisoners he only gave them a greater facility to commit the larceny than they otherwise might have had; and that this could no more be considered as an assent, than if a man, knowing of the intent of thieves to break into his house, were not to secure it with the usual 
number of bolts. That there was no distinguishing between the degrees of facility a thief might have given to him. That it could only be considered as an apparent assent. 'That Boulton never meant that the prisoners should take away his property. And the circum. stance of the design originating with the prisoners, and Boulton's taking no step to facilitate or induce the offense until after it had been thought of and resolved on by them, formed with some of the judges a very considerable ingredient in the case. * * * Law. rence, J., doubted whether there was not assent by Mr. Boulton. Eggington's Case, 2 East P. C. 494, 666, 2 B. \& P. 508, 5 R. R. 689, B. 154 , C. $326, \mathrm{Ke} .260$.

(Eng. C. C. R., 1811.) Decoy Escape. Defendant was tried belore Wood, B., for aiding Antoine Mallet, a French prisoner of war, to escape, by arranging with him to pass him in a hired post-chaise near the prison limits, and take him in and drive on, which she did. It appeared in evidence that there was no real escape on the part of Mallet, but that he was employed by the agent for French prisoners, under the direction of the transport board, to detect the defendant, who was supposed to have been instrumental in the escape of many French prisoners from Northampton, and that all the acts done by Mallet, the contract for the money to be paid to the defendant, and the place to which they were to go before they would be stopped, were previously concerted between the agent for the prisoners and Mallet, and Mallet had no intention to go away or escape. It was objected by the counsel for the defendant that the commissary, having given license to Mallet to go to the place he did go to. had enlarged the limits of his parole to that place, and therefore Mallet could not be said to have escuped, nor could the defendant be said to have assisted him in escaping out of the limits of his parole. The learned judge proceeded in the trial, and the defendant was convicted, but he respited the judgment and reserved the point for the consideration of the judges. In Trinity term. June 15, 1811, all the judges met (except Lawrence), when they held the conviction wrong, inasmuch as the prisoner never escaped nor intended to escape. R. v. Martin, Russell \& R. 196, B. 156.

(Ga. Sup. Ct., 1875.) Invited by Owner's Orders. On indictment and trial for stealing 30 pounds of seed cotton it appeared that the owner was informed by his tenant that defendant wanted to get some cotton; that he ordered the tenant to have defendant come and get it; that the tenant went as ordered; that the owner and others armed and concealed themselves near the cotton house; that defendant came and stopped near the house; that the tenant went in, brought out a basket of cotton and gave it to defendant; and that he started off with it. The owner and his party then called "halt," and fired their guns into the air. Defendant dropped the cotton and escaped. He was convicted, and appealed. BLECKLEY, J. 
* It seems to be settled law that traps may be set to catch the guilty, and the business of trapping has, with the sanction of courts, been carried pretty far. Opportunity to conmit crime may, by design, be rendered the most complete; and, if the accused embrace it, he will still be criminal. Property may be left exposed for the express purpose that a suspected thief may commit himself by stealing it. The owner is not bound to take any measures for security. He may repose upon the law alone, and the law will not inquire into his motive for trusting it. But can the owner directly, through his agent, solicit the suspected party to come forward and commit the criminal act, and then complain of it as a crime, especially where the agent to whom he has intrusted the conduct of the transaction puts his own hand into the corpus delicti, and assists the accused to perform one or more of the acts necessary to constitute the offense? Should not the owner and his agent, after making everything ready and easy, wait passively, and let the would-be criminal perpetrate the offense for himself in each and every essential part of it? It would seem to us that this is the safer law, as well as the sounder morality, and we think it accords with the authorities: 2 Leach, 913 ; 2 East P. C. c. $16, \S 101$, p. 666 ; R. v. Johnson, 1 Car. \& M. (41 E. C. L.) 218; Dodge v. Brittain, Meigs (19 'J'enn.) 84 : Kem! v. S., 11 Hump. (30 Tenn.) 320 ; S. v. Covington, 2 Bail. L. (S. Car.) 569. It is difficult to see how a man may solicit another to commit a crime upon his property and, when the act to which he was invited has been done, be heard to say that he did not consent to it. *** Reversed. Williams v. S., 55 Ga. 391, 3 L. 359.

(Colo. Sup. Ct., 1893.) Conspiracy Suggested by Detective. Defendants Connor and Marshall were indieted and convicted of conspiracy, were denied motions for new trial and in arrest of judgment; and now they appeal. It was proved that the chiefs of police of Denver were suspected of enmplicity in a bank robbery, and Marshall was thought to be in league with them. Therefore. IInlliday was sent by Thiel's Detective Agency to see Marshall, get his confidence, and learn what he knew of the Denver police. Finding from Marshall that Connor, chief of police, would unite with hmn, Ilolliday (with the consent of the officers of the D. \& R. G. Ry. Co.) suggested that they form a scheme to steal from that company, obtained a letter of introduction from Marshall to Connor, and agreed to notify Marshall, so he could come on and take part. "To constitute the crime there must be not only an agreement to co-operate to do a certain act, but that act must be unlawful. The unlawful act to be done in pursuance of the conspiracy as charged in the indictment was the commigsion of larceny in taking the property of the D. \& R. G. Ry. Co. * * * To constitute thie crime of larceny at the common law there must be a trespass-that is, a taking of property without the consent of the owner-coupled with an intent to steal the property so taken. It is therefore evident that the crime is 
not committed when, with the consent of the owner, his property is taken, however guilty may be the taker's purpose and intent. * * * Counsel for the people concede the soundness of the doctrine as above announced, but seek to escape its application upon the ground that the plaintilfs in error were not prosecuted for stealing from the railway company, and therefore the attitude of the company made no difference. In other words, it is contended that the conspiracy to do an act constitutes a crime, although the act to accomplish which the conspiracy was iormed would not be unlawful if committed. 'To state the proposition is to refute it. * * * Accept. ing the version of the witness IIolliday as true, it shows a state of facts that can have no place in the decent administration of justice." Per GODDARD, J., giving the opinion. Connor v. P., 18 Colo. 373, 33 Pac. 159, 36 Am. St. Rep. 29j, 25 L. R. A. 341, F. 19.

(III. Sup. C'., 1896.) Detective Suggests and Plans Burglary. There having been numerous burglaries committed in the town, the authorities employed a detective to discover the criminals. Ile sought the acquaintance of the defendants, treated them liberally, insinuated that he got his money by burglary, suggested that they join him, planned the burglary, arranged to have marked money in a safe, opened it himself, and divided it among defendants. 'The ecurt held that no crime was shown, and said: "The owner and his agent may wait passively for the would-be criminal to perpetrate the offense, and eagh and every part of it, for himself, but îney must not aid, encousage, or solicit him that they may seek to punish." Love v. P., 160 Ill. 501,43 N. E. 710.

(Ore. Sup. Ct., 1898.) Detentive Plans Round Up. Having noticed that cattle were being taken from the range, the owners employed a detective to discover the thieves, and gave him full authority to do anything necessiry with the cattle to accomplish that object. He sought the acquaintance and confidence of defendants, suggested that they steal eattle, went with them, notified the owner of the plan, and the owner consented and was at the appointed place with the sherifi to arrest the thieves. The detective and defendants gathered a considerable herd on the range und were driving them into another county when they met the sheriff. The court held thet the case was the same in principle as if the owner himself had arranged with detenlunts to help him drive away the cattle. S. v. Hull, 33 Ore. 56, 5t Pac. 159, 72 Am. St. Rep. 694, Kn. 10.

Further cases on consont to larceny, 8134 .

(Iowa Sup. Ct., 1899.) Same-Burglary. Defendant was convicted of burglarizing a store, and appealed. It appeared that the town marshal was so zealous that he borrowed a key of the defendant and with it opened one store and took goods without the consent of the owner, to impress defendant with his oriminal intentions; bor- 
rowed a key of the clerk of another store and furnished it' to defendant, to enable him to make a skeleton key; agreed with him on a night to commit the burglary in that store; notified the owner to be on hand at the stated hour that night, as his store would then be opened; and went in with the defendant to take the goods. As they were coming out defendant was arrested. Such zeal was severely condemned by the court, and because of the temptation given to defendant the sentence was reduced from three years to six months; but as the owner gave no consent to the breaking and eniry, and simply prepured to defend his property, the judgment was affirmed. S. v. Abley, 109 Iown 61, 80 N. W. 225,77 Am. St. Rep. 520, 46 I. R. A. $862, \mathrm{Mi} .83$.

\section{MERGER.}

$\S 30$. By the old common law if the same act constituted a civil wrong and a criminal offense, the civil injury was deemed inerged in the higher offense, or at least redress for it was suspended till conviction of and satisfaction for the crime.

(Mass. Sup. Judicial Ct., 1854.) Civil Action Without Indictment-Embezzlement. 13IGELOW, J. *** The plaintitis seek to recover in an action of assumpsit a large sum of money alleged by tilem to have been fraudulently abstracted from their ticket office by the defendant, while he was in their employment as depot-master, having charge of their principal railway station in Boston. In regard to this item of the plaintifi's' claim, the defendant contended at the trial, and requested the judge who presided to instruct the jury, that the plaintifi's were not entitled to recover in this action the money thus taken by the defendant, because their cause of action, if any they had, was suspended, until an indictment had been found, or complaint made, against the defendant for larceny. 'This request was refused, and the jury were instructed, that if the defendant had fraudulently taken and appropriated the plaintifl's' money $i$. the manuer alleged, and was thereby guilty of larceny, he would be liable in the present action, although no criminal prosecution had first been instituted therefor. It is upon the correctness of this instruction that the first and main question in the case arises.

The Doctrine, that all civil remedies in favor of a party injured by a felony are, as it is said in the earlier authorities, merged in the higher offense against society and public justice, or, according to more recent cases, suspended until after the termination of a criminal prosecution against the offender, is the well settled rule of law in ingland at this day, and seems to have had its origin there at a period long anterior to the settlement of this country by our English ancestors. Markham v. Cob, Latch 144, and Noy 82 ; Dawkes v. 
Coveneigh, Style $3 \pm 6$; Cooper v. Witham, 1 Sid. 375, and 1 Lev. 247; Crosby $\because$ Leng, 1 Last 409 ; White v. Spettigue, $13 \mathrm{M}$. \& W. 603 . 1 Chit. Crim. Law, j.

The Source, Whence the Doctrine Took Its Rise in England, is well known. By the ancient common law, felony was punished by the death of the eriminal, and the forfeiture of all his lands and groods to the crown. Inasmuch as an action at law against a person, whose body could not be taken in execution and whose property and efiects belonged to the king, would be a useless and fruitless remedy, it was held to be merged in the public oltense. Besides, no sugh remedy in favor of the eition could be allowed without a direct interference with the royal presogative. Therefore a party injured by a felony could originally obtain no recompense out of the estate of a folon, nor exon the restitution of his own property, except aiter in conviction of the offender. * * But these incidents of fel. ony, if they ever existed in this stale, were discontinued at a very early period in our colonial history. Forfeiture of lands or goods, on conviction of crine, was rarely, if ever, exacted here; and in many cases, deomed in singland to be felonies and punishabla with death, a much milder penalty was inflieted by our laws. Consequently the remedies, to which a party injured was entitled in cases of felony, were never introduced into our jurisprudence. ** Without regard, however, to the causes which originated the doc. trine, it has been urged with great force and by high anthority,

That the Rule Now Rests on Public Policy; 12 Last 413, 414; that the interests of society require, in order to secure the effectual pres. ecutions of offenders by persons injured, that they should not be permitted to redress their private wrongs, until public justice has been first satisfied by the conviction of felons; that in this way a strong incentive is fiumished to the individual to discharge a public duty, by bringing his private interest in aid of its performance. which would be wholly lost, if he were allowed to pursue his remedy before the prosecution and termination of a criminal proceeding. * The whole system of the administration of criminal justice in Fngland is thus made to depend very much upon the vigilance and efforts of private individuals. There is no public officer, ap. pointed by law in each county, as in this commonwealth, to act in behalf of the government in such cases, and take charge of the pros. ecution, trial and conviction of offenders against the laws. It is quite obvious unat, to render such a system efficacious, it is essential to use means to secure the aid and co-operation of those injured by the commission of crimes, which are not requisite with us.

On the Other Fand, in the absence of any reasons, founded on public policy, requiring the recognition of the rule, the expediency of its adoption may well be doubted. If a party is compelied to await the determination of a criminal prosecution before he is per. mitted to seek his private redress, he certainly has a strong motive to stifle the prosecution and compound with the felon. Nor can it 
contribute to the purity of the adnainistration of justice, or tend to promote private morality, to suffer a party to set up and maintain in a court of law a defense founded solely upon his own criminal act. 'lhe right of every citizen, under our constitution, to obtuin justice promptly and without delay, requires that no one should be delayed in obtainiag a remedy for a private injury, except in a cuse of the plainest public necessity. 'There being no such necessity calling for the adoption of the rule under consideration, we are of opinion that it ought not to be engrafted into our jurisprudence. We are strengthened in this conclusion by the weight of American authority, and by the fact that in some of the states, where the rule had been established by decisions of the courts, it has been abrogated by legislative enactmonts. Pettingill v. Rideout, 6 N. II. 454; Cross v. Guthery, 2 Root (Conn.) 90; Piscataqua Bank v. 'Turnley, 1 Miles (Pa.) 312 ; Foster v. C., 8 W. \& S. (Pa.) 77 ; Patton v. Freeman, Coxe (1 N. J. L.) 113; IIepburn's case, 3 Bland (Mld.) 114; Allison v. Farmers' Bank of Virginia, 6 Rand. (Va.) 204, 223; White v. Fort, 3 Ilawks (10 N. Car.) 251; Robinson v. Culp, 1 Treadw. L. (S. C.) 231 ; Story v. Hammond, 4 Ohio 376 ; Ballew v. Nlexander, 6 Humph. (25 Tenn.) 433; Blassingame v. Glaves, 6 B. MLonr. (Ky.) 38 . Rev. Sts. of N. Y. Part. 3, c. $4, \S 2$. St. of Mine of 1844 , c. $102 . * * *$ Judirment on verdict. Boston \& W. Ry. Co. v. Dana, 1 Gray 83, $\mathrm{Kn}, 20$.

(Fla. Sup. Ct., 1891.) Plea of Prosecution Pending. In an action for $\$ 10,000$ alamages for causing the burning of a cotton gin house and machinery, defendant pleaded that the cause of action for which recovery was sought was a felony, that defendant had been indieted therefor, and that the indietment was still pending, wherefore plaintiff's suit should be abated. A demurrer to this plea was held prop. erly sustained, because the government needs no aid from the citizen in criminal prosecutions, and there is no folfeiture of goods for f'olony, which were the reasons for the rule in lingland, that civil actions could not be maintained against the felon, for injuries arising out of the felony. Williams v. Dickenson, $28 \mathrm{Fla}$. 90, 9 So. 847. Kı. 18.

$\S 31$. There are three grades of crime as to enormity-treasons, felonies, and misdemeanors.

§32. By the common law, if the same act or series of acts constituted a misdemeanor and a felony, the smaller offense was merged in the greater.

(Conn. Sup. Ct. of Tirrors, 1889.) Conspiracy to Steal-What is Felony. Information for conspiracy with another to steal. Defend- 
ant was convicted and sentenced, and appealei. She excepted to the refusal of the court to instruct the jury that the conspiracy was merged in the thelt committed; and the theft being proved, no conviction could be had for the conspiracy. ANDREWS, C. J. * * * 'The broad claim of the appellant is, that if the crime to commit which the conspiracy is formed is actually committed, then the con. spiracy is merged in the committed erime and ceases itself to be a crime at all. It is admitted, however, that if the contemplated crime be of that class of crimes called misdemeanors, the conspirace is not merged; and that in a case where there is a conspiracy to commit a misdemeanor and the misdemeanor is actually committed. the oftender may be punished for the conspiracy and for the mis. demeanos also. But it is insisted that if the contemplated crime is of that class called felonies, then if the felony is actually committed the conspiracy is merged and no longer exists as a separate and distinct offense. * * The force of the argument comes largely from the use of the word "felony," and in giving to it the same meaning it had in the common law. Originally the term imported all those offenses of which the feudal consequence was the forfeiture of all the offender's land and goods; to which, in later times, capital or other punshment wiss sometimes added. In American law the word has no clearly defined meaning except as it is given a mean. ing by some statute. ** Mr. Bishop in his treatise on Criminal Law (7 Wd.), \$ 814, after diseussing the rule that a conspiracy merges in a felony, remarks: "The doctrine, the reader perceives. is contrary to just prineiple; it has been rejected in England, and though there may be states in which it is binding on the courts, it is not to be deemed the general American law." * * " In the abscince of statutory graduation there is no test by which to determine the grade of erimes other than the punishment which may be inflicted. Conspiracy may be punished by imprisomment in the state prison for a term not exceeding five years and by a fine not exceeding five hundred dollars. Inareeny to any value less than fifteen dollars can be punished by no more than thirty days in the county jail and a fine of not more than seven dollars. By this test conspiracy is much the greater crime. Nor are tise ingredients of conspiracy the same as of theft. Theft may be committed by one person as well as by two or more; it requires some physical act in the nature of a trespass by which the possession of the thing stolen is taken from the owner, and the act must be accompanied by the intent of the thief to deprive the owner of his property. On the other hand conspiracy cannot be committed except by two or more persons. * * Upon the whole examination we are of opinion. upon principle as well as upon authority, that this conviction for a conspiracy to commit theft ought to be sustained, although the evidence by which it was proved, proved also that the theft had been actially committed. Affirmed. S. v. Setter, 57 Conn. 461, 18 Atl. 782, 14 Am. St. Rep. 121, Kn. 109. 
(Mrich. Sup. Ct., 1893.) Conviction of Lesser Crime Contained in Charge of Greater. Abbott appeals from conviction of rape on a girl of 10 ycars with her consent. LONG, J. *** 'The court also erred in instructing the jury that they must convict the respondent of rape if at all. 'The information for rape also contained a charge of the offense of assiult with intent to commit the crime of rar', and an assault and battery; and the jury should have been instrlacted that they might convict him of either of the lesser offenses. How. St. \$9428, provides: "Upon an indictment for any offense consisting of different degrees, as prescribed in this title, the jury may find the accused not guilty of the offense? in the degree charged in the indictment, and may find such accused person gruilty of any degree of such offense inferior to that charged in the indictment, or of any attempt to commit such offense." In P. v. MICDonald, 9 Mich. 149, it is said: "It is a general rule of criminal law that a jury may acquit of the principal charge, and find the prisoner guilty of an offense of a lesser grade, if contained within it." The provision of the statute above quoted was cited in that case. It was settled in Hanna v. P., 19 MIich. 316, that under an information charging rape it is competent to find the respondent guilty of an assault with intont to ravish. **** New trial granted. P. v. Abbott, 97 Mich. 484. 56 N. W. 862, 37 Am. St. Rep. 360.

\section{THE TWO PRIMARY ELEMENTS OF A CRIME.}

$\S 33$. Ordinarily there can be no crime without a union of these two elements: 1 , the mens rea or criminal intent; and, 2, the corpus delicti or criminal act. This principle is expressed in the maxim: Actus non facit reum, nisi mens sit rea. 


\section{CHAP'IER III.}

\section{THE CRIMINAI, INTINT.}

Natuil: AND KI:Nos of INTENT.

\$34. General sintement, 84.

83. "Criminal Intent is the State of Ifind of the Criminal," s.s.

\$36. "At the Time of committing the crime," 89.

837. "Distingutshed from the Motive." no.

8:8. "Intent to do Some Other Illegal sist." N.4.

\$38. "Naturnl consequence." on.

\$40. "Criminal Neglect of Duty" and "Natural Consequence," 101.

\$41. "States of Mind IIust he Found to Convict." 101.

\$42. "That the IBreach of Iegal Duty shall be CrimInal Regardless of auj Intent," 10 s.

\$4:3. "Specific Intent Which Mlust Generally be Direct," 105.

84. "To a ('ertuin listent May be supplied by Construction from a similar f'or. pose." 1106.

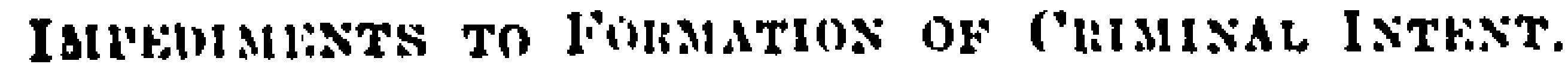

\$4. Generinl Stutement, 108 .

\$46. "That the nefondint is a corporntion." 1111.

84. "That the det wis compelled." 111.

\$48. "Of the Command of al IItshand to Ilis Wife." 111.

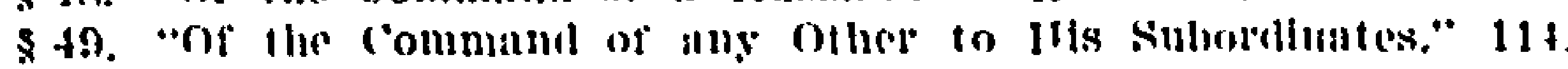

\$50. "Ot Actual Duress ly Persons without Authority." 11 i.

8.31. "of Necessity of Self-P'resirvition in Other ('ases," 1:20.

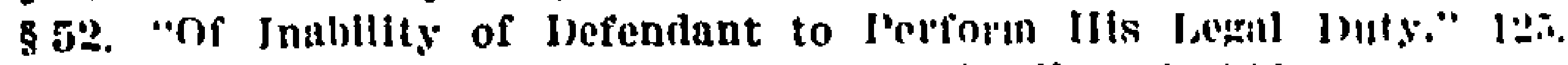

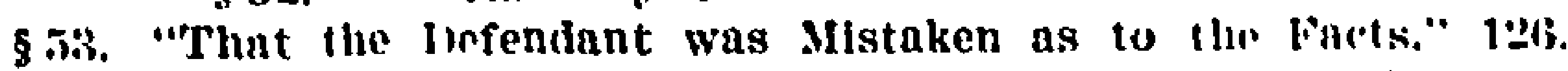

854. "That the Defondunt was Mistaken ns to the Law:" $1: 4$.

$85 \%$. "That the Defendant was an Infant," 138.

85i. "That the Defendant was Idlotic or Demented," $1+1$.

5i. "That the Defendant was Intoxicated." 14i:.

\$5s. "That the Defendant was Insaue," 10in.

\section{NATURE AND KINDS OF INTENT.}

§34. General Statement. Criminal intent is the state of mind of the criminal at the time of committing the crime, essential to criminality in the particular case, to be carefully distinguisled from the motive which induces him to do the act, and is of two principal kinds: general and specific. The general intent may be any one of the following: 1 , a direct intent to do the criminal act; 2 , an intent to do some other illegal act, from the doing of which the criminal act results as an unforeseen but natural consequence; or, 3 , a criminal negiect of a legal duty, irrespective of any actual intent, from which neglect the criminal act results as a natural consequence, which is also known as constructive intent, but which we will call negative intent. One or another of these states of mind must be found to convict of any crime, unless the legislature has expressly or by plain implication declared that 
breach of the legal duty shall be criminal regardless of any intent. In crimes which consist of doing an act with a particular purpose, this purpose is called the specific intent; which must generally be direct, but to a certain extent may be supplied by construction from a similar purpose.

\section{$\$ 35$. "Criminal Intent is the State of Mind of the Criminal."}

(Euy. C. C. R., 1889.) Meaning of Criminal Intent-Statutory Crimes-Bigamy. In this case the prisoner was convicted of bigam!. She was married on Sept. 11, 1880, and was deserted by her husbind on Dec. 13, 1881. From inquiries which she and her father made about him from his brother, she was led to believe that he hald been lost in a vessel bound for America, which went down with all hands. In January, 1887, she married again, supposing herself to be a widow. Her first husband returned from America in December, 1887. The jury found that the prisoner, in good faith, and on reasonable grounds, believed her husband to be dead at the time of her second marriage. 'The statute upon which the indictment was framed is $24 \$ 2$ Vict. e. 100 , $\$ 57$, which is in these words: "Whoever, being married. shall marry any other person during the life of the former hushand or wife shall be guilty of felony, punishable with penal servitude for not more than seven rears, or imprisonment with or without hard labor for not more than two years;" with " proviso thit "nothing in this act shall extend to any person marrving a second time whose husband or wife shall have been continually alssent from such person for the space of seven years last past. and shall not have been known by such person to be living within that time."

[Several of the judges gave separate opinions in this case, which have been much eited and quoted from since; but the opinion of Stephen, J., is most referred to, because of the excellent statement of the meaning of criminal intent given by him. Cave, Charles, Day, Grantham, Ilawkins, and Willis, J.J., and Coleridge, (. . . ., เ:oncurred with Stephen, .J., in the result. Dissenting opinions were given by Manisty and Denman, .JJ.. concurred in by Field. Fudilleston, and Pollock.]

After stating that he hat tried the case on the circuit, instructed the jury that belief on reasonable grounds that the husband was lead was no defense, and, on conviction, passed a nominal sentence. S'I'LPHEN, J., said he did so to settle a question that had been much debated, and not as an expression of his own views. The following is from his opinion: "My view of the subject is based upon a particular application of the doctrine usually, though I think not happily, described by the phrase 'non est reus, nisi mens sit rea.' Though this phrase is in common use. I think it most 
unfortunate, and not only likely to mislead, but actually mislead. ing, on the following grounds: It naturally suggests that, apart from all particular definitions of crimes, such a thing exists as a 'mens rea,' or 'guilty mind,' which is always expressly or by impli. cation involved in every definition. 'This is obviously not the case, for the mental elements of different crimes differ widely. "Nens rea' means, in the case of murder, malice aforethought; in the case of theft, an intention to steal; in the case of rape, an intention to have forcible connection with a woman without her consent; and in the case of receiving stolen goods, knowledge that the goods were stolen. In some cases it denotes mere inattention. For instance, in the case of manslaughter by negligence it may mean forgetting to notice a signal. It appears confusing to call so may dissimilar states of mind by one nitme. It seems contradictory, indeed, to describe a mere absence of mind as a 'mens ren,' or guilty' mind. The expleession again is likely to, and often does, mislead. 'To an unlegil mind it suggests that by the law of England no act is a erime which is clone from laudable motives; in other words, that immorality is essential to crime. It will, 1 think, be found that much of the discussion of the law of libel in Shipley's Case, 4 Doug. 73, 21 st. 'Trials, $84 \bar{\tau}$, proceeds upon a more or less distinct relief to this effect. It is a topic frequently insisted upon in ref. erence to political offenses, and it was urged in a recent notorious case of abduction. in which it wis contended that motives said to be laudable were an excuse for the abduction of a child from its parents. Like most legal Latin maxims, the maxim of 'mons rea' ippears to me to be too short and antithetical to be of much practical value. It is, indeed, more like the title of a treatise than a prace. tical rule. * * The principle involved appears to me. when fully considered, to amount to no more than this: The full definition of every crime contains expressly or by implication a propo. sition as to a state of mind. 'Therefore, if the mental element of any conduct alleged to be a erime is proved to have been absent in any given ease, the crime so defined is not committed; or, again, if a crime is fully defined, nothing amounts to that crime which does not satisfy that definition. Crimes are in the present dar much more accurately defined by statute or otherwise than they formerly were. 'The mental element of most erimes is marked by one of the words 'maliciously, 'fraudulently,' 'negligently, or 'knowingly,' but it is the general-I might, I thing, say, the invariable-practice of the legislature to leave unexpressed some of the mental elements of crime. In all cases whatever, competent age. sanity, and some degree of freedom from some kinds of cocreion are assumed to he essential to criminality, but I do not believe they are ever introduced into any statute by which any particular crime is defined. The meaning of the words 'malice,' 'negligence.' and 'fraud' in relation to particular crimes has been ascertained br numerous cases. Malice means one thing in relation to murder. 
another in relation to the malicious mischief act, and a third in relation to libel, and so of fraud and negligence. With regard to knowledge of fact, the law, perhaps, is not quite so clear, but it may, I think, be maintained that in every case knowledge of fact is to some extent an element of criminality as much as competent age and sanity. 'To take an extreme illustration, can any one doubt that a man who, though he might be perfectly sane, committed what would otherwise be a crime in a state of somnambulism, would be entitled to be acquitted? And why is this? Simply because he would not know what he was doing. A multitude of illustrations of the same sort might be griven. I will mention one or two glaring ones. Levet's Case, 1 Hale, P. C. 474 [§ 53], decides that a man who, making a thrust with a sword at a place where, upon reasonable grounds, he supposed a burglar to be, killed a person who was not a burglar, was held not to be a felon, though he might be (it was not decided that he was) guilty of killing per infortunium, or, possibly, se defendendo, which then involved certain forfeitures. In other words, he was in the same situation, as far as regarded the homicide, as if he had killed a burglar. In the decision of the judges in M'Naghten's Case, 10 Clark \& $W^{\prime} .200$ [\$ 58], it is stated that if, under an insane delusion, one man killed another, and if the delusion was such, that it would, if true, justify or excuse the killing, the homicide would be justified or excused. This could hardly be if the same were not law as to a sane mistalie. A bona fide claim of right excuses larceny, and many of the offenses against the malicious mischief act. Apart, indeed, from the present case, I think it may be laid down as a general rule that an alleged oftender is deemed to have acted under that state of facts which he in good faith and on reasonable grounds believed to exist when he did the act alleged to be an offense. I am unable to suggest any real exception to this rule, nor has one ever been suggested to me. A very learned person suggested to me the following case: $\Delta$ constable, reasonably believing a man to have committed murder, is justified in killing him to prevent his escape; but, if he had not been a constable, he would not have been so justified, but would have been guilty of manslaughter. This is quite true, but $1 \mathrm{l}$ : mistake in the second case would be not only a mistake of fact, but a mistake of law on the part of the homicide in supposing that he, a private person, was justified in using as much violence as a public officer whose duty is to arrest, if possible, a person reasonably suspected of murder. The supposed homicide would be in the same position as if his mistake of fact had been true; that is, he would be guilty, not of murder, but of manslaughter. I think, therefore, that the cases reserved fall under the general rule as to mistakes of fact, and that the convictions ought to be quashed. I will now proceed to deal with the arguments which are supposed to lead to the opposite result. * * * In the first place, I will observe upon the absolute character of the section. It appears to me to resemble 
most of the enactments contained in the consolidation acts of 1861, in passing nver the general mental elements of crime which are presupposed in every case. Age, sanity, and more or less freedom from compulsion, are always presumed, and I think it would be impossible to quote any statute which in any case specifies these elements of criminality in the definition of any crime. It will be found that either by using the words 'wilfully and maliciousiy,' or by specifying some special intent as an element of particular crimes, knowledge of fact is implicitly made part of the statutory definition of most modern definitions of crimes; but there are some cases in which this cannot be said. Such are $\$ 55$, on which $R$. v. Prince, L. R. 2 C. C. 154 , was decided; $\S 56$, which punishes the stealing of 'any child under the age of fourteen years;' $\$ 49$, as to procuring the defilement of any woman or girl under the age of twenty-one,'in each of which the same question might arise as in $R$. v. Prince, L. R. 2 C. C. $154 . * *$ * It was the case of a man who abducted a girl under 16, believing, on good grounds, that she was above that age. Lord Esher, then Brett, J., was against the conviction. His judgment establishes at much length, and, as it appears to me, unanswerably, the principle above explained, which he states as follows: 'That a mistake of facts on reasonable grounds, to the extent that, if the facts were as believed, the acts of the prisoner would make him guilty of no offense at all, is an excuse, and that such an excuse is implied in every criminal charge and every crimi. nal enactment in England.' Lord Blackburn, with whom nine other judges agreed, and Isord Bramwell, with whom seven others agreed, do not appear to me to have dissented from this principle, speaking generally; but they held that it did not apply fully to each part of every section to which I have referred. Some of the prohibited acts, they thonght, the legislature intended to be done at the peril of the person who did them, but not all. The judgment delivered by Lord Blackburn proceeds upon the principle that the intention of the legislature in section 55 was 'to punish the abduction unless the girl was of such an age as to make her consent an excuse.' Lord Bramwell's jndgment proceeds upon this principle: 'The legislature has enacted that if any one does this wrong act he does it at the risk of her turning out to be under sixteen. This opinion gives full scope to the doctrine of the mens rea.' *** 'The application of this to the present case appears to me to be as follows: The general principle is clearly in favor of the prisoners, but how does the intention of the legislature appear to have been against theni? It could not be the object of parliament to treat the marriage of widows as an act to be, if possible, prevented, as pre. sumably immoral. The conduct of the women convicted was nn: in the smallest degree immoral ; it was perfectly natural and legitimate. Assuming the facts to be as they supposed, the infliction of more than a nominal punishment on them would have been a scandal. Why, then, should the legislature be held to have wished to 
subject them to punishment at all. * * * it is argued that the proviso that a yemarriage after seven yeare' separation shall not be punishable, operates as tacit exclusion of all other exceptions to the penal part of the section. It appears to me that it only supplies a rule of evidence which is useful in many cases, in the absence of explicit proof of death." *** Conviction quashed. R. v. Tolson, L. R. 23, Q. B. Div. 168, B. 286, F. 45, Ke. 15, Mi. 178.

Simllar cases: C. v. Mnsh, \$53, supposed uusband dead: Squire v. \$., \$ 53. sup-

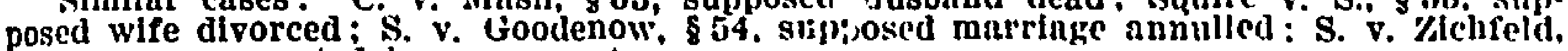
\$54, same, separated ly agrewent.

\section{§36. "At the Time of Committing the Crime."}

(Conn. Sup. Ct. of Errors, 1825.) Information for Giving Credit to a Minor and Student in Yale college, not for washing or medical aid, without the consent of parent, guardian, or officer of the college in violation of an det passed Maty, 18\%2. Defendant was convicted and brings error. HOSHER, C. J. *** From the motion it is fairly to be inferred that no credit was given to $V$ an Zandt by the defendant; but hy Northam, his bar-keeper, only, without the knowledge or conselst of Morse, and against his express directions. In the performaner: of this act, Northam was not the defendant's agent. He was not, authorized :" give the credit, either expressly or in the usual conrse of his business; but was prohibited from doing it. Notwithstanding this, which the court below impliedly admitted. the jury were charged thit if the defendant subsequently assented to the acts of Northam he ratified them and made them his own. This was an unquestionable error. In the law of contracts, a posterion recognition, in many cases, is equivalent to a precedent command; but it is not so in respect of crimes. *** Judgment reverset. Morse v. S., 6 Comn. 9, 13. 2.23.

(New Han). Sup. Judicial Ct.. 18+1.) Guest Stealing from Barroore at Night-Burglary. Indictment for breaking and entering a pinblic iouse at night to steal. It was proved that defendant otme at night, asked and was given lodging, and during thr. right fook money from a desk in the barroom. On that proof the jury found him guilty. GlLCHRIST: $J$. It is said that, as the prisoner was lawfully in the house, he cannot be convicted of the otfense of entering in the night time with intent to steal. It is clear that the prisoner had a legal authority to enter the house. without any special permission for that purpose from the owner or landlord. * * * The barroom of an inn is, from universal custom, the most public room in the house; and whether a traveler may, without permission, enter any of the private rooms or not. he has clearly a right to enter the barroom. If. after having made an entry into the house by authority of law, he commit a trespass, he may be held civilly responsible as a trespasser ab initio. This 
principle has always been recognized since the decision of the Six Carpenters' Case, 8 Coke 146. 'The prisoner, therefore, had a right to enter the inn, and the barroom; and the question arises, whether the larceny committed in the barroom can relate back, and give a character to the entry into the house, so as to make it criminal, and the prisoner punishable for it, upon rcasoning similar to that which, in a civil action, would render him liable as a trespasser ab initio. Except the inference that may lawfully be made from the act of larceny, there is no evidence that he entered with any illegal purpose, or a felonious intent. Where the law invests a person with authority to do an act, the consequences of an abuse of that authority by the party should be severe enough to deter all persons from such an abuse. But has this "policy of the law" ever been extended to criminal cases? We are not aware that it has. It is true that, in order to ascertain the intent of the accused, the law often regards the nature of the act committed. But this is generally such an act as could not have been committed with any other than a criminal purpose. Thus, the act of secretly taking the property of another, necessarily raises the presumption that the party intended to steal. * * * But where one lawfully eiters a house, it by no means follows that because he steals while there, he entered with that purpose. *** New trial granted. S. v. Moore, 12 N. H. 42, B. 224, F. 267, 4 L. 846, Mi. 918.

Intent must exist at the time of the act. $U$. $S$. v. Fox, $\$ 2$. See severul aises of larceny turning on this polnt: $\$ \$ 125,141$.

\section{\$37. "Distinguished From the Motive."}

(Eng. Cent. Crim. Ct., 1834.) Removing the Public Stamp from one piece of gold plate to another, contrary to statute, was held none the less criminal, though the smith had no fraudulent design, but in repairing a ring accidently obliterated the stamp, and to make good the injury cut one from another piece of plate and welded it in; but the jury recommended mercy, and the prisoner was pardoned. R. v. Ogden, 6 C. \& P. 631, C. 93.

(Eng. C. C. R., 1857.) Digging up Mother's Corpse. Defendant was indicted and convicted of indecently and unlawfully digging up a corpse from a burying ground. The facts were not denied. Defendant obtained the keys to the yard on pretext thai he desired to bury his father, but all the while intended to and afterwards did dig up the body of his mother and take it some miles to another burying place. He was actuated only by motives of religious duty and affection for his mother. He argued in person that the conviction was wrong, and that there was no indecorum or impropriety in his acts. No counsel appeared foi the crown. EARL, J. We are of opinion that the conviction ought to be affirmed. The defend. 
aut was wrougfully in the burial ground, and wrongtully opened the grave, and took out several corpses and carrind away one. We saly he did this wrongtully, that is to say, by trespass; for the license which he obtained to enter and open from the person who had the care of the place was not given nor intended for the purpose to which he applied it, and was, as to that purpose, no license at ail. The evidence for the prosecution proved the misdemeanor, unless there was a defense. We have considered the grounds relied on in that behalf, and although we all feel sensible of the estimable motives on which the defendant aeted, namely, filial affection and religious duty, still, neither authority nor principle would justify the position that the wrongful removal of a corpse was no misdemeanor if the motive for the act deserved approbation. $A$ purpose of anatomical science would fiall within that category. ${ }_{*}^{*} *$ We have been unwilling to alfirm the conviction on account of our respect for the motives of the defendant; but we have felt it our duty to do so rather than lay down a rule which might lessen the only protection the law affords in respect of the burial of dissenters. * * $*$ Conviction aftirmed. R. v. Sharpe, 7 Cox C. C. 214 , Deirs. \& B. 160, 26 L. J. m. c. 47,3 Jur. n. s. 192,5 W. R. 318, B. 175.

(U. S. Sup. Ct., 1878.) Bigamy as a Religious Duty. Indictment for bigamy under U. S. R. S. (1871) \$5352, providing that: "Every person having a husband or wife living, who marries another, whether married or single, * * * is guilty of bigamy," etc. In defense defendant proved that at the time of the marriage complained of he was a member of the Mormon church and believer in its doctrines; and that one of the doctrines of the church was that it was the duty of every male member of the church, circumstances permitting, to practice polygamy; that this duty was enjoined by the prophets of his church and by the Holy Bible; and that what he did was with permission of the church authorities. Upon this proof he asked the court to instruct the jury that if they found from the evidence that he "was married as charged, if he was married in pursuance of and in conformity with what he believed at the time to be a religious duty, the verdict must be "not "g. ilt.y." 'This request was refused, and the court did charge "that there must have been a criminal intent, but that if the defendant, under the influence of a religious belief that it was right, under an inspirntion, if you please, that it was right, deliberately married a second time, having a tirst wife living, the want of consciousness of evil intent, the want of understanding on his part that he was committing a crime did not excuse him; but the law inexorably in such case implies the criminal intent." WAITE, C. J. *** Upon this charge and refusal to charge the question is raised whether religious belief can be accepted as a justification of an overt act made criminal by the law of the land. The inquiry is not as to the power of congress to prescribe criminal laws for the ter- 
ritories, but as to the guilt of one who knowingly violates a law which has been properly enacted, if he eutertains a religious belief that the law is wrong. Congress caunot yass a law for the government of the territories which whall prohibit the free exercise of religion. The first amendment to the constitution expressly forbids such legislation. Religious freedom is guaranteed everywhere throughout the Linited States, so far as congressional interference is concerned. 'The question to be determined is, whether the law now under consideration comes within this prohibition. ** * At the first session of the first congless the amendment now under consideration was proposed with other's by Mr. Madison. It met the views of the adrocates of religious freedom and was adopted. Mr. Jefferson afterwards, in reply to an address to him by a committee of the Danbury Baptist Association (8 id. 113), took occasion to say: "Believing with you that relirgion is a matter which lies solely between man and his liod; that he owes account to none other for his faith or his "rorship; that the legislative powers of the government reach actions only and not opinions, $-i$ coutem. plate with sovereign reverence that act of the whole American people which declared that their legislature should make no law respecting an establishment of religion or prohibiting the free exereise thereof,' thus building a wall of separation between church and state. Adhering to this expression of the supreme will of the nation in behalf of the rights of conscience, I shall see with sincere sutisfaction the progress of those sentiments which tend to restore man to all his natural rights, convinced he has no natural right in opposition to his social cluties." Coming as this dows from an icknowledged leader of the advocates of the measure, it may be accepted almost as an allthoritative declaration of the soupe and effect of the amendment thus secured. Congress was deprived of all legislative power over more opinion, but was left free to reach actions which were in violation of social duties or subversive of good order. * * In our opinion. the statute immediately under consideration is within the legislative power of congress. it is constitutional and valid as preseribing a rule of action for all those residing in the territories, and in places over which the United States have exclusive control. 'This being so, the only yuestion which remains is, whether those who make polygamy a part of their religion are excepted from the operation of the statute. If they are, then those who do not make polygamy a part of their religious belief may be found guilty and punished, while those who do, mast be acquitted and go free. 'This would be introducing a new element into criminal law. Laws are made for the government of actions, and while they cannot interfere with mere relig. ious belief and opinions, they may with practices. Suppose one believed that human sacrifices were a necessary part of religious worship, would it be seriously contended that the civil government under which he lived could not interfere to prevent a sacrifice? 
Or if a wife religiously believed it was her duty to burn herself upon the funeral pile of her dead husband, would it be beyond the power of the eivil government to prevent her carrying her belief into practice? So here, as a law of the organization of society under the exclusive dominion of the Linited States, it is provided that plural marriagres should not be allowed. Can a man excuse his practices to the contrary because of his religious belief? 'To permit this would be to make the professed doctrines of religions belief superior to the law of the land, and in effect to permit every eitizen to become a law unto himself. Government could exist only in name under such eireumstances. A criminal intent is generally an element of crime, but every man is presumed to intend the necessary and legitimate conserfuences of what he knowingly does. Here the accused knew he had been once married and that his first wife was living. He also knew that his second marriage was forbidden by law. When therefore he married the second time, he is presumed to have intended to break the law. And the breaking of the law is the crime. Every act necessary to constitute the erime was knowingly done, and the crime was therefore knowingly committed. Ignorance of a fact may sometimes be taken as evidence of a want of criminal intent. but not ignorance of the law. The only defense of the accused in this case is his belief that the law ought not to have been enacted. It matters not that his belief was a pirt of his professed religion; it was still belief, and belief only. *** Atfirmed. Reynolds v. U. S., 98 U. S. 145, B. 179. C. 9.), Ki:. :31.

(L. S. D. C. for Kansals, 1891.) Obscene Matter Sent Through the Mails, in violation of $T$. S. R. S. (1811) \$389:3. Was charged in an indietment against defendant, who claimed his sole motive was to improve the sexual habits of the people. PIIILLIPS, J. **** Redueed to its actual essence, the ultimate position of defendint is this: 'l'hat although the language employed in the given article may be obsecene. as heretofore defined, yet as it was a necessary vehicle to convey to the popular mind the aggravation of the abruses in sexual commerce inveighed against, and the object of the publisher veing to correct the evil and thereby alleviate human condition, the author should be cleened a public benefactor, rather than a malefactor. In short. the proposition is that a man can do no public wrong who believes that what he does is for the nitimate public good. The underlying vie!e of all this ehoracter of argument is that it leaves out of view the existence of the social compact, and the idea of government by law. If the end sought justifies the means. and there were no arbiter but the individual conscience of the actor to determine the fact whether the means are justifiable. homicide, infanticide, pillage. and ineontinence mig!ht run riot: and it is not extravagant to predict that the success of such philosophy would remit us to that barbaric eondition where 
"No common iveal the human tribe allied. Bound by no law, by no fixed morals tied, Each snatehed the booty which his fortune brought, And wise in instinct each his welfare sought."

Guiteau stoutly maintained to the end his sanity, and that he felt he had a patriotic mission to fulfill in taking off President Garfield. to the salvation of a political party. The Hindu mother cast her babe to the clevoming Ganges to appease the gods. But civilized scciety says both are murderers. The Mormon contends that his religion teaches polygamy; and there is a school of so-called "modern thinkers" who would abolish monogamy, and erect on the ruins the flagrant doctrine of promiscuity, under the disguise of the affinities. All these claim liberty of conscience and thought as the basis of their dogmas, and the pro bono publico as the strength of their elaim to indulgence. The law against adultey itself would lie dormant if the libertine could get the courts to declare and the jury in obedience thereto to say that if he invaded the sanctuary of conjugal life under the belief that the improvement of the human race demanded it he was not amenable to the statute. Society is organized on the theory, horn of the necessities of human well-being, that each member yields up something of his natural privileges, predilections, and indulgenees for the good of the composite community; and he consents to all the motto implies. salus populi suprema est lex; and, as no government can exist without law, the lawmaking power, within the limits of constitutional anthority, must be recognized as the body to prescribe what is right and prohibit what is wrong. It is the very incarnation of the spirit of anarchy for a citizen to proclaim that like the heathen he is a law unto himself. *** The responsibility for this statute rests upon congress. The duty of the courts is imperative to enforce it while it stands. $*{ }^{*} *$ U. S. v. Harmon, 45 Ferl. 414. B. 180.

\section{§38. "Intent to do Some Other Illegal Act."}

(Eng. C. C. R., 1575.) Intent to Poison Another-AccessoryAccidental Result. On indictment of John Saunders and Alex. Archer for murder of Eleanor Saunders, it appeared that Saunders desired to kill his wife who was ill. that he might marry another. and to this end took counsel of Archer, who bought and gave him arsenic to give his wife; and Saunders put the arsenic in a baked apple and gave it to his wife; who ate a little of it and gave it to Saunder's daughter Eleanor; and he protested as much as he dared for fear of suspicion, that apples were not good for the child: but his wife was determined. and said it was better for the child than for her; and the child ate it and died.

"Whether or no this was Murder in John Sannders. the father. 
was somewbat doubted, for he had no intent to poison his daughter, nor had he any malice against her, but on the contrary he had a great affection for her, and he did not give her the poison, but his wife ignorantly gave it her, and although he might have taken it from the daughter, and so have preserved her life, yet the not taking it from her did not make it felony, for it was all one whether he had been present or absent, as to this point. inasmuch as he had no malice against the daughter, nor any inclination to do her any harm. But at last the said justices, upon consideration of the matters, and with the assent of Saunders, Chief Baron. who had the examination of the said John Saunders before, and who had signified his opinion to the said justices (as he afterwards said to me) were of opinion that the said offense was murder in the said John Saunders. And the reason thereof (as the said justices and the chief karon told me) was because the said John Saunders gave the poison with an intent to kill a person, and in the giving of it he intended that death should follow. And when death followed from his act, although it happened in another person than her whose death he directly meditated, yet it shall be murder in him, for he was the original cause of the death, and if such death should not be punished in him, it would go unpunished. *** And therefore it is every man's business to foresee what wrong or mischief may happen from that which he does with an ill intention, and it shall be no excuse for him to say that he intended to kill another, and not the person killed. For if a man of malice prepense shoots an arrow at another with an intent to kill him, and a person to whom he bore no malice is killed by it, this shall be murder in him, for when he shot the arrow he intended to kill. * * But the most difficult point in this sase, and upon which the justices conceived greater doubt than upon the offense of the principal, was.

"Whether or no Archer Should be Adjudged Accessory to the mulder. For the offense which Archer committed was the aid and advice which he gave to Saunders, and that was only to kill his wife, and no other, for there was no parol communication between them concerning the daughter, and although is the consequences whicil followed from the giving of the poison by Saunders, the principal, it so happened that the daughter was killed, yet Archer did not precisely procure her death, nor advise him to kill her, and therefore whether or no he should be accessory to this murder which happened by a thing consequential to the first act, seemed to them to be doubtful. *** Upon conference before had with the justices of both benches, thev were agreed that they ought not to give judgment against the said Alexander Archer, because they took the law to be that he could not be adjudged accessory to the said offense of murder, for that he did not assent that the daughter should be poisoned, but only that the wife should be poisoned, which assent cannot be drawn further than he gave it. for the 
poisoning of the daughter is a distinct thing from that to which he was privy, and therefore he shall not be adjudged accessory to it; and so they were resolved before this time. And although they were so agreed, yet, rather than make a precedent of it, they reprieved him from one session to another for divers sessions, to the intent that he might purchase his pardon.

"Note, it seems to me reasonable that he who advises or commands an unlawful thing to be done shall be adjudged accessory to all that follows from that same thing, but not from any other dis. tinct thing. As if I command a man to rob such a one, and he attempts to rob him, and the other defends himself, and a combat ensues between them, and the person attempted to be robbed is killed, I shall be accessory to this murder, because when he attempted to rob him, he pursued my command, and then when he pursued my command, and in the execution thereof another thing happened, I ought in reason to be deemed a party therein. because my com. mand was the cause of it." Saunders's Case, 2 Plowd. Com. 473, C. $176, \mathrm{Mi} .490$.

(Eng. C. C. R., 1612.) Same-Poisoned Electuary. Roper's daughter, Agnes, inarried Gore; Gore became sick; Roper went to Dr. Gray for advice; who gave him a prescription to apothecary Martin; who prepared it as ordeied, with one change, for want oi that ingredient; Agnes secretly added ratsbane to it to kill her husband, and gave him part of it, on which he became very sick; Roper took some, and also became sick immediately; next day C took some and likewise became sick; but they all recovered. Observing these results, Roper took it to Dr. Gray complaining; who sent for Martin to explain; who said it was as ordered with one change; which Dr. Gray approved; then Martin said, "To the end you may know that I have not put anything in it which I myself will not eat. I will before you eat part of it;" and thereupon he took the box. stirred it with his knife, ate some of it, and died next day. The question was on all this matter if Agnes had committed murder. And this case was delivered in writing to ill the judges of England, for their opinion. The doubt was becinse Martin himself, of his own motion, not only ate of it, but stirred it and so incorporated the poison that it was more forcible than as Agnes made it; for those who ate before lived, but Martin's mising it made it fatal. If this fact would distinguish the case firom Saunders's Case, Plow. Com. 473, was the question. And it was resolved by all the judges that Agnes was guilty of the murder of Martin; for the law ennjoins the murderous intent of $A$ gnes in putting the poison into the electuary to kill her hushind with the event which thence ensued, viz., the death of Martin: for the putting of the poison into the electuary was the occasion and cause, and the poisoning and death of Martin the event; and with. out the poison put in iy Agnes, death would not have been culused 
by 'Martin stirring it. Gore's Case, 9 Coke 81a, B. 209, C. 182, Mi. 557.

(S. Car. Ct. of App. and Errors, 1847.) Accidental ShotImplied irialice. Appeal from conviction of murder, on evidence that defendant fired toward Carter in a crowd, intending to make his horse throw him, but killed a negro boy. The court charged the jury that if defendant shot to throw Carter from his horse, the killing of ine boy was murder. "If the act which produced the death be attended with such circumstances as are the ordinary symptoms of a wicked, depraved, and malignant spirit, the law, from these circumstances, will imply malice, without reference to what was passing in the prisoner's mind at the time he committed the act. If one were to fire a loaded gun into a crowd, or throw a piece of heavy timber from the top of a house into a street filled with people, the law would infer malice from the wickedness of the act: so also, the law will imply that the prisoner intended the natural and probable consequence of his own act; as, in the case of shooting a gun into a crowd, the law will imply, from the wantonness of the act, that he intended to kill some one, although it might have been done in sport. If the prisoner's object had been nothing more than to make Carter's horse throw him, and he har used such means only as were appropriate to that end, then there would be some reason for applying to his case the distinction that, where the intention was to commit only a trespass or a misdemeanor, an accidental killing would be only manslaughter. But in this case the act done indicated an intention to kill; it was calculated to produce that effect, and no other; death was the probable consequence, and did result from it; and I am of opinion there was no error in the charge of the circuit judge that, if the prisoner shot at Carter, the crime was murder, although the prisoner may have designed only to do Carter 'some serious injury, as the falling from his horse.' The motion is therefore dismissed." Per EVANS, J. S. v. Smith, 2 Strobh. 77, 47 Am. Dec. 589, B. 468, F. 59.

(Mass. Sup. Judicial Ct., 1877.) Same-Attempting Surcide. On trial of defendant under indictment for murder of Charles Ricker, the defense was that when Ricker told defendant he would not keep his promise to marry her she became despondent, took a pistol from her trunk to kill herself, and in his struggles to get possession of it, he was accidentally shot; and the court instructed the jury that if they believed the defendant's story they should find her guilty of manslaughter, though she had no intention to kill deceased. The jury found her guilty of manslaughter, and she excepted to the instruction. GRAY, C. J. *** By the common law of England, suicide was considered a crime against the laws of God and man, the goods and chattels of the criminal were forfeited to the king, his body had an ignominious burial in 
the highway, and he was deemed a murderer. *** Since it has been provided by statute that "any crime punishable by death or imprisonment in the state prison is a felony, and no other crime shall be so considered," it may well be that suicide is not technically a felony in this commonwealth. Gen. Sts. c. $168, \S 1$; St. 1852, c. 37, $\S 1$. But being unlawful and criminal as malum in se, any attempt to commit it is likewise unlawful and criminal. Every one has the same right and duty to interpose to save a life from being so unlawfully and criminally taken, that he would have to defeat an attempt unlaw. fully to take the life of a third person. Fairfax, is., in 22 E. IV. 45, pl. 10; Marler v. Ayliffe, Cro. Jac. 134; 2 Rol. Ab. 559; 1 Hawk. c. $60, \S 23$. And it is not disputed that any person who, in doing or attempting to do an act which is unlawful and criminal, kills am. other, though not intending his death, is guilty of criminal homicide, and, at the least, of manslaughter. The only doubt that we have entertained in this case is, whether the act of the defendant, in attempting to kill herself, was not so malicious, in the legal sense, as to make the killing of another person, in the atternt to carry out her purpose, murder, and whether the instructions given to the jury were not therefore too favorable to the defendant. Exceptions overruled. C. v. Mink, 123 Mass. 422. 25 Am. Rep. 109, B. 206, C. 104, Ke. 110, Kn. 170.

(Mass. Sup. Judicial Ct., 1873.) Constructive Intent from Statutory Offense. Assault and battery. Defenaint had pleaded guilty of driving faster than the Boston ardinance allowed, and the court instructed the jury on this trial for knocking down a boy in the street while so driving, that intent to violate the ordinance sup. plied the intent necessary to sustain assault and battery. ENDICOTT, J. We are of opinion that the ruling in this case cannot be sustained. It is true that one in the pursuit of an unlawful act may sometimes be punished for another act done without design and by mistake, if the act done was one for which he could have been punished if done wilfully. But the act, to be ranlawful in this sense, must be an act bad in itself, and done with an evil intent; and the law has always made this distinction, that if the act the party was doing was merely malum prohibitum, he shall not he punishable for the act arising from misfortune or mistake; but if malum in se, it is otherwise. 1. Hale P. C. 39; Foster C. I. 259. * * It was held in C. v. Worcester. 3 Pick. 462, that nroof only of the fact that the party was driving faster than the ordinance allowed was sufficient for conviction. See C. v. Farren. 9 Ailen 489 [\$53]; C. v. Waite, 11 Allen 264 [\$7]. It is therefore immaterial whether a party violates the ordinance wilfully or not. The offense consists, not in the intent with which the act is done. but in doing the act prohibited, but not otherwise wrong. It is obvious, therefore, that the violation of the ordinance does not in itself supply the intent to do another act which requires a crimi- 
nal intent to be proved. The learned judge erred in ruling that the intent to violate the ordinance in itself supplied the intent to sustain the charge of assault and battery. The verdict must therefore be set aside, and a new trial granted. C. v. Adams, 114 Mass. 323, 19 Am. Rep. 362, B. 204, Kn. 28, Mi. 160.

(N. J. Sup. Ct., 1889.) Malum Prohibitum-Running by TollGate. Defendant attempted to drive by a toll-gate without paying. 'The keeper caught the team by the harness and was thrown down, run over, and killed, and defendant was convicted of manslaughter. The court instructed the jury that, if defendant knew he was at the gate and intended to go through without paying toll; and that the keeper caught hold of the team, which then being urged by defendant, or through fright, went so fast that the keeper was thrown down, run over, and killed, defendant was guilty. "The act of the defendant in making this attempt, in the exercise of due care, was, at its worst, merely malum prohibitum, and was in itself devoid of a dangerous tendency, and therefore was not criminal. The mere unlawfulness of the act does not, in this class of cases, per se, render the doer of it liable in criminal law, for all the undesigned and improbable consequences of it. ${ }^{*}{ }^{*}{ }^{*}$ Bishop Cr. L. §258. In this case the jury should have been told that the defendant was guilty as charged if he did the unlawful act in question under conditions that were dangerous to the toll-gate keeper; as if he drove through the gate at a rapid pace, or urged his team of mules on after they had been seized by the deceased." Per BEASLEY, C. J. Reversed. Estell v. S., 51 N. J. L. 182. 17 Atl. 118.

(Eng. Assize at Sussex, 1883.) A Mere Civil Wrong intended to a refreshment stall keeper, by wantonly taking a large box from the stall on the pier and throwing it into the sea, was held insufficient constructive intent to sustain an indictment for manslaughter resulting from the box falling on a bather in the sea and killing him; but the defenclant was convicted by the jury on the ground of negligence. I3efore FIELD, J. Nathew, J., concurring. R. v. Franklin, 15 Cox C. C. 163, B. 203, C. 105, Ke. 118, Mi. $15 S$.

\section{\$39. "Natural Consequence."}

(Eng. C. C. R., 1877.) Constructive Intent-Burning Ship. Robert Faulkner was indicted for setting fire to the ship Zeminder on the high seas, contrary to $24 \& 25$ Vic. c. $97, \$ 42$. While the ship was in mid ocean bound for England, laden with sugar, cotton, and rum, worth $t^{5} 0,000$, defendant went into the forecastle hold, opened the sliding door of the bulkhead. and so got at the rum there stored, to which he had no right; and intending to steal some of it, he bored a hole in a cask with a gimlet, and when some had run out, lighted a match in an effort to find the hole to stop 
it; and in putting the spile into the hole a jet of the rum sprayed the match he heid, set fire to the rum, seriously burned him about the neck and arms, timally exploded, and thus the whole ship was set on fire and completely destroyed. 'I he jury found him guilty; and the question is whether the court erred in instructing the jury that although the prisoner had no actual intention of burning the vessel, still, if they found he was engaged in stealing the rum, and that the fire took place in the manner above stated, they ought to find him guilty. BARIRY, J. A very broad proposition has been contended for by the crown, namely, that if, while a person is engaged in committing a felony, or, having committed it, is endeav. oring to conceal his act, or prevent or spoil waste consequent on that act, he accidentally does some collateral act, which if done wilfully would be another felony, either at common law or by statute, he is guilty of the latter felony. I am by no means anxious to throw any doubt upon, or limit in any way, the legal responsibility of those who engage in the commission of felony, or acts mala in se; but I am not prepared without more consideration to give my assent to so wide a proposition. No express authority, either by way of decision or dictum, from judge or text writer, has been cited in support of it. 'The authorities mainly relied upon are chose which lay down that if homicide or the burning of a house be the direst. though unintended, result of an act felonious or malum in se, the perpetrator will be guilty of murder or man. slaughter or arson, as the case may be. As regards the case of homicide, they may be referred to principles applicable to that class of offenses. The authorities as to arsons are more in point, but they all put the case of an act felonious or malum in se, wil. fully done and directly causing the ultimate injury. *** * To constitute the crime of arson at common law, the setting fire to the house must be unlawful and malicious, yet it is not disputed that a person firing a shot with a felonious intent, and thereby unin. tentionally burning a house, is guilty of feloniously burning it; and certainly it seems difficult to see why the words "unlawful and malicious," when used to describe the essential attributes of the burning of a house as an offense at common law, are to receive a different interpretation for the same words when used in the statute, the object of which is simply to place the burning of a house and the burning of a ship in the same legal category. * * $*$ I am of opinion that, according to R. $v$. Pembliton [\$ 44], that direction was erroneous, and that the con. viction should be quashed. Fitzgerald, J., concurred and wrote a separate opinion. PALLES, C. B. ** I am of opinion that that inference [malice] was one of fact for the jury, and not a conclusion of law at which we can arrive upon the case before us. There is one fact from which, if found, that inference would, in my opinion, have arisen as matter of law, as that the setting fire to the ship was the probable result of the prisoner's act in having a 
lighted match in the place in question; and if that had been found I should have concurred in the conclusion at which Mr. Justice Keogh has arrived. In my judgment the law imputes to a person who wilfully commits a criminal act an intention to do everything which is the probable consequence of the act constituting the corpus delicti which actually ensues. In my opinion this inference arises irrespective of the particular consequence which ensued being or not being foreseen by the criminal, and whether his conduct is reckless or the reverse. *** [Fitzgerald, Deasy, and Dowse, BB., and O'Brien and Lawson, JJ., gave concurring opinions. Keogh, J., wrote an opinion favoring affirming the judgment.] R. v. Faulkner, 13 Cox C. C. 550, Ir. R. 11 C L. 8, B. 213, C. 106, F. 251, Ke. 152.

See scher cases of result not intended, but clnimed to be natural result of intended act, $8 \$ 14,81,82$.

\section{$\S 40$. "Criminal Neglect of Duty" and "Natural Consequence."}

(Eng. Cent. Crim. Ct., 1847.) A Woman was Knocked Down as she was passing a shop, by colliding with a boy employed in the shop, who staggered or reeled into the road just then, by reason of defendant taking hold of the boy in the shop in sport, and spinning and shoving him around. The court held that the death of the woman from such injuries was mere accident, and there was no proof for the jury to convict defendant of manslaughter; because he was doing no unlawful act. The boy consented, so that there was no assault on him. R. v. Bruce, 2 Cox C. C. 262, B. 202, Ke. 136.

(Eng. C. C. R., 1880.) Homicide. Rifle Practice by three with a gun deadly at a mile, within which distance the bullet passed over three roads and several gardens, resulted in killing a boy at 393 yards in a tree in his father's garden; but which of the three fired the fatal shot was not shown. It was held that all were liable for the acts of each, being engaged in a common enterprise; and that the doing of an act so dangerous to life, without taking iroper precautions was criminal negligence, which warranted the conviction of all of manslaughter. Conviction affirmed. R. v. Salmon, 14 Cox C. C. 494,50 L. J. m. c. 25,6 Q. B. D. 79,43 L. T. 573,29 W. R. 246, 45 J. P. 270, B. 189.

\section{$\S 41$. "States of Mind Must be Found to Convict."}

(Mass. Sup. Judicial Ct., 1861.) Allegation and Proof of Intent. BIGELOW, C. J. The motion in arrest of judgment in the present case is founded on the omission to aver that the defendant, in administering poison to the deceased, did it with an intent to kill and murder. * * The law infers the intent from proof that 
the acts were committed, and that death ensued. The averment, therefore, of the criminal act comprehends the evil or wicked intention with which it was committed. 'The true distinction seems to be this: When by the common law or by the provision of a statute a particular intention is essential to an offense, or a criminal act is attempted but not accomplished, and the evil intent only can be punished, it is necessary to allege the intent with distinctuess and precision, and to support the allegation by proof. On the other hand, if the offense does not rest merely in tendency, or in an attempt to do a certain act with a wicked purpose, but consists in doing an unlawful or criminal act, the evil intention will be presumed and need not be alleged, or, if alleged, it is a mere formal averment, which need not be proved. In such ease the intent is nothing more than the result which the law draws from the act, and requires no proof beyond that which the act itself supplies. 1 Stark. Crim. Pl. 165; 1 Chit. Crim. Law 233 ; R. v. Philipps, 6 East 474; 1 Hale P. C. 455 ; C. v. Merrill, 14 Gray 415. * * * Motion $^{*}$ overruled. C. v. Hersey, 2 Allen 173, B. 183.

(Ark. Sup. Ct., 1887.) Burglary-Intent Presumed from Acts. Appeal from conviction of burglary, by entering a barber shop at night and carrying off $\$ 5$ or $\$ 6$ in cash and a few cigars, in all less than $\$ 10$, which would be petit larceny and a misdemeanor under the statute. "As the crime of burglary is complete only when the breaking is done or the entry made with the intent to commit a felony, the offense is not committed by one who breaks into and enters a house with intent to commit petit larceny only. As every larceny was a felony at common law, it was enough then to show an intent to commit larceny; but when petit larceny is reduced to a misdemeanor, the breaking or entry with intent to commit that crime will not constitute burglary. T'he precise question was ruled in P. v. Murray, 8 Cal. 520. *** It is argued that the prisoner could not have intended to steal more than he could find, and that, as all the money in the safe did not amount to $\$ 10$, he could not have intended to commit a felony. But the jury have not specially found that he intended to steal money alone. He entered, according to their verdict, with the intent to steal generally; he was interrupted in the act when there was more than $\$ 10$ worth of personal property, such as cigars, razors, etc., in his reach. It was not necessary in order to complete the crime of burglary that his anterior intent should have been consummated. Dodd. S., 33 Ark. 517. Who can say that it was his intent to confine his operations to the money in the safe? In point of fact, he did not. He took cigars as well as money. We may gather the intent from the act done. A man is presumed to intend what he does, and the jury could have inferred that, but for the interrup. tion, the prisoner would have appropriated other property as well. But if there had been no other property except that taken. the 
case would not be altered. The prisoner intended to take all the money there was in the safe. He testified to that fact upon the stand. He did not know that it contained less than $\$ 10$. His intent was to take more than that sum, if he could find it; hence the intent to commit a felony. Where an assauit upon a person with intent to steal from his pocket is a criminal offense, it is no answer to the indictment, as has been frequently held, that the pocket was empty. 1 Bish. Cr. Law, $\S 743$ et seq. The same rule was applied in a recent Ohio case, where one was indicted for breaking into a building with intent to steal money, which he supposed was in a safe; though in fact the safe contained no money, a conviction of burglary was sustained. S. v. Beal, 37 Ohio St. 108." Per COCKRELL, C. J. Affirmed. Harvick v. S., 49 Ark. 514, 6 S. W. 19 , F. 60 , Kn. 45 .

Compare S. v. Moore, ante $\$ 36$.

\section{§42. "That Breach of Legal Duty Shall be Criminal Regurdless of any Intent."}

(N. Car. Sup. Ct., 1851.) Supposed Authority of Slave. On trial for selling liquor to a slave contrary to law, defendant moved the court to instruct the jury that if defendant believed and had reason to believe the liquor was being bought for the master, he was not guilty; but the court instructed them that he acted at his peril. He appealed. RUFFIN, C. J. The court is of opinion that there was no error in the instruction given. The sale of spirituous liquor to a slave is apparently illegal, and it is incumbent upon one who does the act to justify it by showing that it was done under such circumstances as render it lawful. He must show, not merely that he thought that such circumstances existed, but that they actually existed. * * * The act, being against the policy and the letter of the law, can only be made innocent by showing facts which in law justify it, and not by showing merely the probability or the party's mistaken belief of the existence of those facts. Those circumstances might well affect the degree of punishment, an: seem to have had their effect in reducing the fine here to almost a nominal one. But could not prevent the act from being a violation of the law, for which the party was liable to conviction. Affirmed. S. v. Presnell, 34 N. Car. (12 Ired.) 103, B. 177.

See several cases to like effect, post \& jo.

(Mich. Sup. Ct., 1884.) Failing to Keep Saloon Closed. Defendant was prosecuted for not keeping the bar in his hotel closed on Sunday. The evidence was that the hotel elerk and a servant were scrubbing out the barroom Sunday morning, when a man came in and said he wanted some whiskey, that the clerk told him he should get it Saturday, but after some talk told him if he must have it to 
get it quick and get out; that he got the whiskey, handed the pay to the servant, and went; and that defendant was not present at the time, but was shortly afterwards, and probably was then about the house somewhere, perhaps not yet up; but there was no proof that he assented to opening the bar that day, nor that he did not. On error, the only question was whether there was any evidence to support a verdict of guilty. COOLEY, J. * * * The statute under which the conviction was had provides that "all saloons, restaurants, bars, in taverns or elsewhere, and all other places where any of the liquors," etc. "may be sold, or kept for sale, either at wholesale or retail, shall be closed on the first day of the week, commonly called Sunday," etc. How. St. § 2274; Public Acts, 1881, p. 350 . It will be observed that the requirement that the saloons and other places mentioned shall be closed is positive. The next section of the statute provides that any person who shall violate this, among other provisions, shall be deemed guilty of a misdemeanor, and shall be punished as therein prescribed. In terms, then, the penalties of the statute are denounced against the person whose saloon or other place for the sale of intoxicating drinks is not kept closed, and no other fact is necessary to complete the offense. It is contended, nevertheless, that to constitute an offense under the section referred to, there must be some evidence tending to show an intent on the part of the respondent to violate it. ${ }^{*}{ }^{*} *$ I agree that as a rule there can be no crime without a criminal intent; but this is not by any means a universal rule. One may be guilty of the high crime of manslaughter when his only fault is gross negligence; and there are many other cases where mere neglect may be highly criminal. Many statutes which are in the nature of police regulations, as this is, impose criminal penalties irrespective of any intent to violate them; the purpose being to require a degree of diligence for the protection of the public which shall render violation impossible. [Here his honor reviewed numerous decisions under such statute.] If intent were necessary to be found I should be of opinion there was enough in the case to warrant its submission to the jury. The bar was opened on Sunday by respondent's servants and on his business while he was about the premises. The purpose for which it was opened was immaterial: the offense was committed by opening it for cleaning as much as it would have been by opening it for the sale of liquors. P. v. Waldvogel, 49 Mich. 337. But the statute requires the proprietor at his peril to keep the bar closed. The purpose in doing so is that persons shall not be there within the reach of temptation. This respondent did not keep his bar closed and he has therefore disobeyed the law. And he has not only disobeyed the law, but the evil which the law intends to guard against has resulted; that is to say, there has been, either with or without his assent-it is immaterial which-a sale of intoxicating liquors to a person who took advantage of the bar being open to 
enter it. I think the circuit court should proceed to judgment. $\mathbf{P}$. จ. Roby, 52 . Mich. 577, 18 N. W. 365, 50 Am. Rep. 270, Kn. 51.

The consticutionality of such statutes is undoubted; it is merely a question as to the policy and intent of the statute. C. v. Waite, \& 7 .

(Ore. Sup. Ct., 1890.) Intent-Agent-Mistake-Bartender Without License. Defendant and Scott were jointly indicted for selling liquor without a license, defendant only was arrested and convicted. LORD, J. * * On behalf of the defendant, it is contended, that he was simply a servant or employe of Scott's, and had no inter. est in the business, or the result of the sales of liquor, and honestly believed his employer had procured a license, and was misled by him, he could have no notice or intention to violate the law, without which his act could not constitute a criminal offense. The contention, therefore, is that to make the transaction criminal, there must be both the will and act entering into the transaction.

The language of the statute is absolute and unconditional. Its purpose is to compel every person who engages in the sale of intoxicating drinks first to obtain a license, as required by the statute; otherwise he acts at his peril. Statutes of this character are in the nature of fiscal and police regulations, and impose criminal penalties irrespective of any intent to violate them; the purpose being to require a degree of diligence for the protection of the public which will render violation impossible. P. v. Roby, 52 Mich. 579 [above].

* Judgment affirmed. S. v. Chastian, 19 Ore. 176, 23 Pac. 863.

\section{§43. "Specific Intent, Which Must Generally be Direct."}

(Eng. C. C. R., 1824.) A Night Watchman Attempting to Arrest a Burglar discovered in the shop at night, the latter struck the watchman twice with a crowbar and then ran away, telling him to sit still or it would be worse for him. On indictment for assault with intent to murder, maim and disable, the jury found that defendant intended only to disable temporarily till he could escape; and on this finding, all the judges except Graham and Garrow, BB.. held the conviction wrong. R. v. Boyce, 1 Moody 29, B. 182.

(Ir. Assize, 1832.) Indictment for Maliciously Killing a Horse. The evidence showed that defendant shot at prosecutor. BUSCHE, C. J. Under the act [9 Geo. IV. c. $56, \S 17]$ the offense must be proved to have been done maliciously, and malice implies intention. Here the proof negatives the intention of killing the horse. The prisoner must therefore be acquitted. R. v. Kelly, 1 Crawford \& Dix 186, B. 182.

Drunkenness may prevent formation of this gpecific intent. P. r. Walker, \$57: Reagan v. S., 857 . In burglary specifle Intent is essentlal, see Harvick $v$. S., \$41, and several cases, \& 115 . In larceng it is the same, $\$ \$ 140,143,144$.

(Mass. Sup. Judicial Ct., 1849.) Wilful and Malicious Distin- 
guished. WILDE, J. 'This is an indictment for malicious mischief wherein the defendant is charged with the wilful and malicious shooting and severely injuring the mare of one Robert Noble con. trary to the R. S., c. 126, $\$ 39$. 'The evidence is not reported; but whatever it was the court, in the instruction to the jury, defined the word "maliciously" in said section to mean "the wilfully doing of any act prohibited by law, and for which the defendant had no law. ful excuse; and that moral turpitude of mind was not necessary to be shown." If this definition of the crime charged was correct it would follow that the words "wilfully and maliciously" were in. tended by the legislature to be understood as synonymous, and that the statute is to be construed in the sume manner as it would be if the word "maliciously" had been omitted. Such a construction we are of opinion cannot be sustained, for if it could be it would follow that a person would be liable to be punished criminally and with great severity for every wilful trespass, however trifling the injury might be to the personal property of another, which could not be justified or excused in a civil action against him for the recovery of damages by the owner. * * The learned judge was probably of opinion that if the mare was injured, as alleged, by the discharge of a gun ivaded with powder and shot, that, ipso facto would be conclusive proof of malice. But that question we think should have been submitted to the jury. * * New trial granted. C. v. Walden, 3 Cush. 558, C. 118.

(Tex. Civ. App., 1890.) Convicted of Assault Intending to Murder. "IIurder may be committed although a specific intent to kill the deceased does not exist in the mind of the slaver. If the intent be to inflict upon the person killed serious bodily injury, which may cause his death. the homicide may be murder, although a specific intent to kill may not be shown. Willson. Cr. St. $\$ \$ 1039.1041$. But to constitute the offense of an assault with intent to murder there must be a specific intent to kill. An intent to do serious bodily harm is not sufficient, and. if the jury believed, in this case. that the evidence did not show a specific intent to kill, whatever else they might believe. they could not convict the defendant of that offense, but might have convicted him of a lower grade of assault, and should have been. by the charge. given the discretion of doing so. Id. \$ 857." Per WILSON. I. Reversed for this error in the instruction to the jury. Carter v. S., 28 Tex. App. 355. 13 S. W. 147, F. 62.

\section{§44. "To a Certain Extent may be Supplied by Construction from a Similar Purpose."}

(Eng. C. C. R., 1787.) Blackham Assaulted a Woman with intent to commit rape; and she, without any demand from him. offered him money. which he took and put into his pocket, but continued to 
treat her with violence to effect his original purpose till he was interrupted by the approach of a third person. 'This was held by a cousiderable majority of the judges to be robbery; for the woman, from violence and terror occasioned by the prisoner's behavior, and to redeem her chastity, offered the money, which it was clear she would not have given voluntarily; and the prisoner, by taking it, derived that advantage to himself from his felonious conduct; though his original intent was to commit rape. R. v. Blackham, 2 East P. C. $711,13.202$.

(Eng. C. C. R., 1810.) Forgery to Defraud A Affects B. Indictment of four counts: 1, for forging a fictitious name (W. S. West) as signature to a receipt for $\mathbf{\$ 1 9}, 16 \mathrm{~s}$. $6 \mathrm{~d}$. purporting to be a receipt for stock therein mentioned, with intent to defraud the Bank of England; '2, for uttering it knowing it to be forged, with like intent; 3 and 4 , for forging and uttering it to defraud $R$. Mordey. 'The writing was not in its nature calculated to defraud the bank, and it was found that defendant had no intention to defraud Mordey. 'The court told the jury to acquit on the first and second counts; but that if they believed that defendant did not intend to defraud Mordey, yet as that was a necessary consequence of the forgery, that was sufficient evidence of intent to convict. 'The jury found guilty on the third and fourth counts; and the question being reserved, all the judges met in Laster term, 1810, and were of opinion that the conviction was right, as the immediate effect of the act was to defraud Mordey. R. v. Sheppard, Russell \& R. 169, 2 East P. C. 967, B. 174 , Ke. 463 , Mi. 945 .

(Eng. Assize, 1858.) Wounding with Intent. The prisoner was indicted for wounding with intent to do grievous bodily harm to the prosecutor. It appeared that the prisoner, with a knife, struck at one Withy. 'The prosecutor interfered and caught, on his arm, the blow intended for Withy. CROWDER, J. This will not sustain the charge of wounding with intent to do grievous bodily harm to the prosecutor, but he may be convicted of unlawfully wounding. R. $v$. Hewlett, 1 F. \& F. 91, B. 3ะ9, Ke. 150.

(Eng. C. C. Res., 1874.) Malicious Injury to Window, LORD COLERIDGF, C. J. I am of opinion that this conviction must be quashed. The facts of the case are these. The prisoner and some other persons who had been drinking in a public house were turned out of it at about eleven P. M. for being disorderly, and they then began to fight in the street near the prosecutor's window. The prisoner separated himself from the others, and went to the other side of the street, and picked up a stone, and threw it at the persons he had been fighting with. The stone passed over their heads, and broke a large plate-glass window in the prosecutor's house, doing damage to an amount exceeding $\mathfrak{f 5}$. The jury found that the pris- 
oner threw the stone at the people he had been fighting with, intend. ing to strike one or more of them with it, but not intending to break the window. The question is whether, under an indictment for unlawfully and maliciously committing an injury to the window in the house of the prosecutor, the proof of these facts alone, coupled with the finding of the jury, will do? Now I think that is not enough. The indictment is framed under the $24 \& 25$ Vict. c. $97, \S 51$. The act is an act relating to malicious injuries to property, and $\$ 51$ enacts that whosoever shall unlawfully and maliciously commit any damage, etc., to or upon any real or personal property whatsoever of a public or a private nature, for which no punishment is herein. before provided, to an amount exceeding $£ 5$, shall be guilty of a misdemeanor. * * I do not intend to throw any doubt on the cases which have been cited, and which show what is sufficient to constitute malice in the case of murder. 'l'hey rest upon the prin. ciples of the common law, and have no application to a statutory offense created by an act in which the words are carefully studied. * * * The other judges concurred. Conviction quashed. R. v. Pembliton, 12 Cox C. C. 607 , L. R. 2 C. C. R. 119 , B. 210 , C. 120 , Ke. 157, Mi. 171.

(Eng. C. C. R., 1886.) Blow at One Strikes Another. Defendant was indicted and convicted under statute $24 \& 25$ Vict. c. $100, \S 20$, providing, "Whosoever shall unlawfully and maliciously wound or inflict grevious bodily harm upon any other person, either with or without any weapon or instrument, shall be guilty of a misdemeanor." The proof was that defendant had a quarrel with one Chapple, and later, while passing through the room where Chapple was talking with a woman, he struck Chapple with a belt, which bounded off, and the buckle hit the woman in the face, injuring her severely. The jury found defendant had no intention of hitting her. BOWEN, L. J. *** The only difficulty that arises is from $R$. v. Pembliton [above], which was a case under an act of parliament which does not deal with all malice in general, but with malice towards property; and all that case holds is, that though the prisoner would have been guilty of acting maliciously within the common law meaning of the term, still he was not guilty of acting maliciously within the meaning of a statute which requires a malicious intent to injure property. Had the prisoner meant to strike a pane of glass, and without any reasonable expectation of doing so, injured a person, it might be said that the malicious intent to injure property was not enough to sustain a prosecution under this statute. But, as the jury found that the prisoner interided to wound Chapple, $I$ am of opinion that he acted maliciously within the meaning of this statute. The other justices concurred. Conviction affirmed. R. v. Latimer, 16 Cox C. C. 70,17 Q. B. D. 359,55 L. J. m. c. 135,54 L. T. 768, 51 J. P. 184, B. 217, C. 122, Ke. 144, Mi. 163. 
(Miss. Sup. Ct., 1885.) Mistaken Identity-Specific Intent. Appellant was convicted of assault with intent to kill and murder Levi Thompson. Appellant's brother, having been injured by one Morris at a public meeting at midnight, appellant started in pursuit of Morris to avenge the injury. The night was dark; and seeing a person in the road, whom he supposed to be Morris, he struck him in the back with a knife, giving him a severe wound. Then discovering that he had struck his best friend, he desisted. It is urged that the intent charged was not proved. ARNOLD, J. * * * He may not have inteinded to kill 'Thompson, but he was properly convicted if he intended to kill the man at whom the knife was directed. 'The evil and specific intent to strike the form before him at the time is manifest, and that form proved to be Thompson. That there was a mistake as to the identity of the person intended to be injured constitutes no defense. *** And this is not in conflict with the settled doctrine in this state that on a charge under the statute, of assault with a deadly weapon, with intent to kill and murder a particular person, it is necessary to prove the specific intent as laid in the indictment. 'There is no error in the record. McGehee v. S., 62 Miss. 772, 52 Am. Rep. 209, F. 105, Kn. 50.

\section{IMPEDIMENTS TO FORIIATION OF CRIMINAL INTENT.}

$\S 45$. Forecast. Having considered the nature of criminal intent in general, it is necessary before passing the subject to examine and understand the nature and effect of certain impediments to it; which cause action without intent, or against intent, otherwise produce action regardless of intent, or prevent formation of any rational intent. Principal among these are: 1 . That the defendant is a corporation, deriving all its powers from the law, and therefore powerless to do any wrong. 2. That the act was compelled by duress of overwhelming force or imminent peril. 3. That the defendant was mistaken as to the facts, and if they had been as he supposed they were the act would have been less criminal or entirely innocent. 4. That defendant was mistaken as to the law, and supposed that he had a right to do as he did. 5. That the defendant was an infant, who by reason of his immature age had not discretion to discern good from evil. 6. That the defendant was idiotic or demented, and therefore, regardless of his age, was too simple-minded to know right from wrong. 7. That the defendant was intoxicated at the time of the act, and therefore temporarily incompetent to form any criminal intent. 8. That the defendant was insane, and that his mental disease so affected his discernment and reasoning powers that he could form no criminal intent. We will consider these points in the order named. 


\section{§46. "That the Defendant is a Corporation."}

(Mass. Sup. Judicial Ct., 1854.) Nuisance. BIGELOW, J. The indictment in the present case is for a nuisance. 'The defendants contend that it cannot be maintained against them, on the ground that a corporation, although liable to indictment for non-feasance, or an omission to perform a legal duty or obligation, are not amen. able in this form of prosecution for a misfeasance, or the doing of any act unlawful in itself and injurious to the rights of others. There are dicta in some of the eurly cases which sanction this broad doctrine, and it has been thence copied into text writers, and adopted to its full extent in a few modern decisions. But if it ever had any foundation, it had its origin at a time when corporations were few in number, and limited in their powers, and in the purposes for which they were created. Experience has shown the necessity of essentially modifying it; and the tendency of the more recent cases in courts of the highest authority has been to extend the application of all legal remedies to corporations, and assimilate them, as far as possible, in their legal duties and responsibilitiss, to individuals. 'I'o a certain extent. the rule contended for is founded in good sense and sound principle. Corporations cannot be indicted for offenses which derive their criminality from evil intention, or which consist in a violation of those social duties which appertain to men and subjects. 'I'hey cannot be guilty of treason or felony, of perjury or offenses against the person. But beyond this, there is no good reason for their exemption from the consequences of. unlawtil and wrongful acts committed by their agents in pursuance of authority derived from them. Such a rule would, in many cases, preclude all adequate rem. edy, and render reparation for an injury, committed by a corpora. tion, impossible. * * * Judgment against defendant affirmed. C. v. Proprietors of New Bedford Bridge, 2 Gray 339, B. 277.

(Ky. Ct. of App., 1891.) Ultra Vires-Gaming. Indictment of the Pulaski County Agricultural \& M Nec. Asso. for permitting gaming on its fair grounds. A demurrer to the indictment was sustained, and the state appeals. HOLT, C. J. * * * It is contended that a corporation cannot commit this offense. It was in the early history of the law held that, as a corporation was soulless, it could do no wrongful or immoral aci, and could not, therefore, be liable in tort. This doctrine has long since become obsolete; ${ }^{*} *{ }^{*}$ but it was claimed that its nature did not admit of its doing positive wrong, and that, therefore, it was not liable criminally for a misfeasance, whereby a wrong was done by a violation of its duty. * * * If the argument be sound that a corporation is not liable to indictment for any offense, because the criminal act was not warranted by its corporate powers, then the same reasoning would result in its non. liability for all wrongs, civil as well as criminal. Such a rule would lead to its absolute impunity for all wrongs, which the experience of 
this day shows would produce great injustice both to individuals and the public. If it be said that the individuals who might do the act would be liable, it may be said that this is true as to every servant or agent who does a wrong, but because this is so the principal is not exempt. * * The object should be to reach and punish the real power in the matter, and thus prevent a repetition of the offense. It is true there are crimes of which, from their very nature, as perjury, for example, they cannot be guilty. There are crimes to the punishment for which, for a like reason, they cannot be subjected, as in the case of a felony. But wherever the offense consists in either a misfeasance or a non-feasance of duty to the public, and the corporation can be reached for punishment as by a fine and the seizure of its property, precedent authorizes, and public policy requires, that it should be liable to indictment. Any other rule would in many cases preclude adequate remedy, and leave irresponsible servants to answer for the offense, rather than those who are really most at fault. C. v. Proprietors, 2 Gray 339 [above]; S. v. Morris \& E. Ry. Co., 23 N. J. Law 360 ; Louisville \& N. Ry. Co. v. S., 3 Head (40 Tenn.) 523; Nat. Bank v. Graham, 100 U. S. 699 . If it be said that such a rule may subject the property of innocent stockholders for the acts of the directors to which they are not actual parties, and of which they have no knowledge. the answer is that they select the directors. and it is their business to have those who will see that the corporate business is so conducted as not to injure others. **** Reversed. C. v. Pulaski C. A. M. Assn., $92 \mathrm{Ky} .197,17$ S. W. 442, F. 119.

(i؟ J. Sup. Ct., 1892.) Same. Defendant corporation excepted to conviction of keeping a disorderly house, because a corporation could not commit the offense ; but the court, intimating that malice may be imputed to corporations, held that the habitual indulgence in the vicious practices on the premises of defendant warranted the conviction regardless of the intent which prompted the disorder. Affirmed. S. v. Passaic County Agr. Soc., 54 N. J. T. 260, 23 Atl. 680. Kn. 105.

§ 47. "That the Act was Compelled." This compulsion maj consist: 1 , of the command of a husband to his wife; 2 , of the command of any other to his subordinate; 3 , of actual duress by persons without semblance of authority; 4, of necessity of self-preservation in other cases; and, 5, of inability of defendant to perform his legal duty.

\$ 48. "Of the Communa of 1 Humbanel to his Wife."

(Eng. C. C. R., 1664.) Burglary with Husband. It was propounded to all the judges: If a man and his wife go both together to commit a burglary, and both of them break a house in the night. and 
enter and steal goods, what offense this was in the wife; and agreed by all, that it was no felony in the wife, for the wife being together with the husband in the act, the law supposeth the wife doth it by coercion of the husband. And so it is in all larcenies; but as to murder, if husband and wife both join in it, they are both equally guilty. Vid. 2 E. III., Fitz. Abr. Corone 160, 27 Ass. Pl. 40, Fitz. Abr. Corone 199, Poulton de Pace 126, and the case of the Earl of Somerset and his lady, both equally found guilty of the murder of Sir Thomas Overbury, by poisoning him in the Tower of London, 2 How. St. 'T'r. 951, 3 Co. Inst. 49. Anon., Kelyng 31, 1 B. \& H. 81, B. 273.

Crimes Peculiar to Women. "A wife may be indicted together with her husband, and condemned to the pillory with him for keep. ing a bawdy house; for this is an offense as to the government of the house, in which the wife has a principal share; and also such an offense as may generally be presumed to be managed by the intrigues of her sex." 1 Hawk. P. C. ch. 1, \$1:.

(Miss. Sup. Judicial Ct., 1813.) Assault Commanded by Husband. II usband and wife were indicted for assault and battery, and the jury found him guilty and that she acted in his presence and at his command. The attorney general argued that his command was no excuse to her for what she well knew was wrong. CURIA. The general doctrine is that a feme covert incurs no legal guilt by the commission of civil offenses by the coercion of her husband, or even when in his presence. To this general rule there are certain excep. tions-as of crimes forbidden by the law of nature, which are mala in se, and some where the wife may be presumed the principal agent. The case at bar is not within the exceptions, and Elizabeth Neal is not guilty, and must therefore be discharged. C. v. Neal, 10 Mass. 152, 6 Am. Dec. 105, 1 B. \& H. 76-n, F. 118, 3 L. 70.

(Eng. Assize, 1829.) Uttering Counterfeit. The prisoner was indicted for uttering base coin. The evidence was, that she had gone from house to house uttering base coin, and that her husband accom. panied her to the door, but did not go in. BAYLEY, J., directed the jury to infer that she was acting under the coercion of her husband, and to find her not guilty. Sarah Connolly's Case, 2 Lewin C. C. 229, 1 B. \& H. 81, Mi. 110 .

(Mich. Sup. Ct., 1878.) Robbery with Husband. Husband, wife, and another were convicted of robbery; and on error by the wife the court held, that, proof that the wife held the victim by the throat, and told him to keep still, while the husband and the other put their hands in his pockets and took what money he had, justified the trial court in leaving to the jury the question, and justified the jury in finding, that she was an active participant in the crime, and 
did not act under coercion of her husband. P. v. Wright, 38 Mich. 744, 31 Am. Rep. 331.

(Mass. Sup. Judicial Ct., 1888.) What is Presence-Jury's Province. Defendant was convicted of illegal sale of intoxicating liquor's, and excepted. C. ALLEN, J. *** It is apparent that the second instruction requested could not properly be given, because it could not be said as a matter of law, that, "if he was on the premises and in the house, it would be sufficient;" that is, sufficient presence to raise the presumption of coercion. 'That would be for the jury to determine. * * $*$ The instruction that, if the husband was near enough to see, hear, or know that she was making such sales, she was not liable and must be acquitted, was too favorable for the defendant, as the presumption of coercion was merely a disputable one, and might not prevail in the minds of the jury, in view of the testimony and the circumstances of the case. Exceptions overruled. C. v. Daley, 148 Mass. 11,18 N. E. 579, B. 275. Similar case: C. v. Munsey, 112 Mass, 287 , Kn. 37 .

(S. Car. Sup. Ct., 1888.) Wife's Activity. A conviction of the wife with her husband of receiving stolen goods was reversed, because the court below instructed the jury that, though the wife was drawn into the crime by her husband, she was equally guilty if she was the more active of the two. Her guilt depends on whether she acted freely or under coercion of her husband, not on her activity. S. v. Houston, 29 S. C. 108,6 S. E. 943 , Mi. 111 n.

(Mo. Sup. Ct., 1892.) When Evidently Wilful. On trial of a married woman for maining a boy by throwing concentrated lye (washwater, she called it) into his face and putting out his eyes in the presence of her husband, where by her own testimony she exhonerated him from all complicity in the felony, the court properly refused to instruct the jury, either that if the husband was present they must acquit, or that if there was no evidence that defendant's husband disapproved of the acts of defendant, and unless that fact is established, they must acquit. The presence of the husband only riases a presumption of coercion, which may always be rebutted. S. v. Ma Foo, 110 Mo. 7, 19 S. W. 222 (sub nom. S. v. Baker), 33 Am. St. Rep. 414, Mi. 113.

(Ala. Sup. Ct., 1892.) In Homicide. Defendant and her husband murdered Stark, defendant holding him from behind, and holding his arms down, whilc her husband eut him in the head with an ax. He was heard to say: "Hold him up, God damn it; hold him up." CLOP'TON, J. On trial of defendant for murder, the court instructed the jury: "In the trial of this case on the issue of guilty or nonguilty, the jury should not consider the defendant as otherwise than a feme sole." There is no error in this charge. The presumption of 
the common law, that when the wife acts with hor husband in the commission of a crime she acts under his coercion, and consequently without guilty intent, is not allowed in all offenses, in the adminis. tration of the criminal law. "It may not be positively settled," as has been well observed, "where the line of separation is, but for certain crimes the wife is responsible, although committed under the compulsior of her husband." 1 B. \& H. 85. The exceptions in. grafted on the general rule are based on the nature, grade, and heinousness of the felony, and among these is murder. ** [Citing 1 Hale P. C. 45, 1 Hawk. P. C. 4, 1 Cooley Bl. Com. 44t, 1 Bishop Crim. Law, § 361; 14 Am. \& Eng. Ency. Law 649.]. Affirmed. Bibb v. S., 94 Aia. 31,10 So. 506, 33 Am. St. Rep. 88.

\section{\$49. "Of the Commanil of Any Other to his Suborilinaten."}

(Mass. Sup. Judicial Ct., 18t6.) Bartender Without License. De. feudant convicted of selling liquor without a license, excepts to the ruling of the court below that he could be charged though he was a mere servant of another in making the sale. SHAW, C. J. * * The construction contended for by the defendant, by which the actual seller should exempt himself from the penalty of the law, by showing that he sold for the use and benefit, and by the authority, of another person, would let in all the mischief intended to be prevented by the statute. A person residing out of the state, and beyond the jurisdiction of its laws, by taking the lease of shops, and employing selling agents and barkeepers, might wholly defent the salutary objects of the law. It is then urged, secondly, as an excuse for the defendant, that he ofiered to show that he was a hired agent, having no interest in the profits, and acting in the presence of and under the control of his employer. As to his being an agent, the considerations already stated apply to it. As to his acting in the presence of his employer, we think that circumstance would make no difference if the defendant was the ostensible actor in the sale; because one who sells for another, although in his presence, does yet sell, and the law fixes the penalty upon him who does the act. We are to understand in the present case that the sale was actually made by the defendant, otherwise he would not have been convicted by the jury. If the employer should expressly or tacitly command, direct, or instigate him to do it, both might be liable; for it is a general rule of law, in cases of tort, that when two or more are guilty, as actors or participators, of one and the same offense. each is severally liable to the penalty, and either may be severally prose. cuted for it. But the command of the master will afford no justifica. tion or excuse to the servant making the sale, because it is an unlars. ful command, which he is not bound to obey. C. v. Fadley, 11 llete. 66, B. 372.

Acc, Abel v. S, 90 Aln 631, 8 So. 700: Baird v. S., 52 Ark, 320, 12 S. W. 500: Menkepr. A tlanta, 78 Ga.688, 2 S. E. 559; S. v. Chastain, 842. 
(Cal. Sup. Ct., 1866.) Mother's Command. On trial for larceny it was contended that defendant was under the age of 21 , living with his mother, and subject to her orders, and that the property was taken at her instance. Conviction was affirmed. The court said such orders were no defense and there was no proof that defendant was under the age of 14 years. P. v. Richmond, 29 Cal. 415.

(Me. Sup. Ct., 1876.) When Master is Owner. Haynes appeals from conviction of arson of Mrs. I's house to defraud the insurance companies. APPLETON, C. J. * * The house burned by defendant was the house of another. If Mrs. Ingraham nad burned her own dwelling she would not have been amenable to the penalties prescribed by R. S. c. $119, \S 1$. The fire was set at her instance, and for her supposed benefit. The servant obeving cannot be more guilty than the master comminding. * * * Exceptions sustained. $\mathbf{S}$. v. Haynes, $66 \mathrm{Me}$. 307, $22 \mathrm{Am}$. Rep. 569, 3 L. 249.

(Eng. Assize, 1660.) Command of Rebel Officer. Upon the trial of one Axtell, a soldier who commanded the guards at the ling's trial, and at his murder; he justified that all he did was as a soldier, by the command of his superior officer, whom he must obey or die. It was resolved that was no excuse, for his superior was a traitor, and all that joined him in that act were traitors, and did by that approve the treason; and where the command is traitorous, then the obedience to that command is also traitorous. Memo., Kelyng 13, Mi. 114.

(U. S. C. C. for Pa., 1813.) Command of the Saptain of the privateer snhooner, on which defendant was iilst lieutenant, was set up as 0 . 2.tense to an indictment for felonious and piratical entry on a Pertuguase brig, and assaulting the siptain of it. WASHINGTON, J., charged the jury : No military o: civil officer can command an inferior to violate the laws of his country; nor will such a command excuse, much less justify, the act. Can it be for a moment pretended that the general of an army, or the commander of a ship of war, can order one of his men to commit murder or felony" Certainly not. * * Disobedience of an unlawful order must not, of course, be punishable; and a court-martial would, in such a case, be bound to acquit the person tried upon a charge of disobedience. We do not mean to go further than to say, that the participation of the inferior officer in an act which he knows, or ought to know, to be illegal, will not be excused by the order of his superior. U. S. v. Jones, 3 Wash. C. C. 209, 26 Fed. Cas. 653, B. 368.

(Tenn. Sup. Ct. 1866.) Same. Riggs was a private soldier who had heen convicted of murder in killing a man while acting under the orders of his superior officer. The court held that an order illegal in itself, and not justifiable by the rules and usages of war, 
so that a man of ordinary sense and understanding would know, when he heard it read or given, that the order was illegal, would afford the private no protection for a crime under such order; but that an order given by an officer to his private which does not ex. pressly and clearly show on its face, or the body thereof, its own illegality, the soldier would be bound to obey, and such order would be a protection to him. Reversed. Riggs v. S., 3 Cold. (44 Tenn.) 85, 91 Am. Dec. 272, 3 L. 257, Mi. 114.

A(c.. S. v. Sparks, 27 'Tex. 627, 3 L. 251: C. v. Holland, 1 vuv. (Ky.) 182, 3 L. 260.

(U. S. C. C. for Dist. of E. Mich., 1887.) By Soldier to Prevent Escape of Convict. Defendant was indicted for shooting and killing one Stone who was endeavoring to escape from Ft. Monroe prison in Detroit. Stone, a soldier, had been court-marshaled for telling a lie to a superior officer, and senteneed to hard labor for two years. When shot he was gaining on his nearest pursuer; had been hailed by the sergeant that there was "a loarl after him," and to halt; in another half-minute would have scaled the two fences between him and the highway, and probably been lost among the houses; and defendant fired in performance of a supposed obligation to prevent the escape by any meaus in his power. BROWN, J. **** Stone had been court-martialed for a military offense, in which there is no distinction between felonies and misdemeanors. His crime was one wholly unknown to the common law, and the technical definitions of that law are manifestly inappropriate to cases which are not contemplated in the discussion of common law writers upon the subject. We are bound to take a broader view, and to measure the rights and liabilities of the prisoner by the exigencies of the military service, and the circumstances of the particular case. It would be extremely unwise for the civil courts to lay down general principles of law which would tend to impair the efficiency of the military arm. or which would seem to justify or condone conduct prejudicial to good order and military discipline. ** * It is urged by the defense that the finding of the court of inquiry acquitting the prisoner of all blame is a complete bar to this prosecution. I do not so regard it. If the civil courts have jurisdiction of murder, notwithstanding the concurrent jurisdiction by court-martial of military offenses, it follows logically that the proceedings in one cannot be pleaded as a bar to proceedings in the other; and if the finding of such court should conflict with the well recognized principles of the civil law. I should be compelled to disregard it. S. v. Rankin, 4 Cold. (tt Tenn.) 145. At the same time I think that weight should be given, and in a case of this kind great weight, to the finding, as an expression of the opinion of the military court of the magnitude of Stone's offense. and of the necessity of nsing a musket to prevent his escane. I am the more impressed with this view from the difficulty of applying common law principles to a case of this description. There is a singular and almost total absence of authority upon the subject of 
the power of a military guard in time of peace. But considering the nature of military govermment, and the necessity of maintaining good order and discipline in a camp, I should be loth to say that life might not be taken in suppressing conduct prejudicial to such discipline. * * * In the ease of MIcCall v. MicDowell, 1 Abb. (U. S.) 212,218 , it is said that "except in a plain case of excess of authority, where at first blush it is apparent and palpable to the commonest understanding that the order is illegal, $I$ cannot but think that the law should excuse the military subordinate when acting in obedience to the order of his commander." * * " I have no doubt the same principle would apply to the acts of a subordinate officer, performed in compliance with his supposed duty as a soldier ; and unless the act were manifestly beyond the scope of his authority, or, in the words used in the above case, were such that a man of ordinary sense and understanding would know that it was illegal, that it would be a protection to him, if he acted in good faith and without malice. As there is no reason in this case to suppose that Clark was not doing what he conceived to be his duty, and the act was not so elearly illegal that a reasonable man might not suppose it to be legal -indeed, I incline to the opinion that it was legal-and as there was an entire absence of malice. I think he ought to be discharged. But, even if this case were decicied upon common law principles, the result would not be different. By the statutes of the state in which the homicide was committed, a felony is defined to be any crime punishable by imprisonment in the state's prison. Stone had been convicted of a military offense, and sentenced to hard labor in the military prison for two years, and, so far as the analogies of the enmmon law are applicable at all, he must be considered, in a case of this kind, as having been convicted of a felony. **** $*^{*}$ U. S. v. Clark, 31 Fed. 710, B. 319.

\section{0. "Of Actual Iouress by Perwous Without Authority."}

(Fng. Assize at Surrer, 1746.) Imprisonment and Forfeiture. Indictment for being a lieutenant in Duke of Perth's rebel army. Defense, coercion. It was proved that the duke's men sent summonses to his tenants, of whom defendant was one. to meet him in arms; that on the third summons, the prisoner and 12 others appeared, but when ordered to follow in arms refused to go, whereon cords were brought to bind them, and they were told they would be forced to go, and their horses and eattle driven off if they refused. LEE, C. J., told the jury that fear of having houses burnt and gonds spoiled is no excuse in law for joining rebels; and that the only force that excuses is on the person with present fear of death; and that it is incumbent on every man who makes force his excluse to show actual force, and that he quitted the service as soon as he conld. Willes, C. J., Foster and Wright, J.J., and Reynolds and Clive, BB., 
being present, concurred. Verdict, guilty. He was not executed. M'Growther's Case, 18 How. St. 'Tr. 391, Foster's C. L. 13, 1 East P. C. 71, B. 273 , Ke. 56.

(Pa. Sup. Ct., 1781.) Same. McKEAN, C. J. (to the jury) : The crime imputed to the defendant by the indictment is that of levying war by joining the armies of the king of Great Britain. Enlisting, or procuring any person to be enlisted, in the service of the enemy, is clearly an act of treason. By the defendant's own confession it appears that he actually enlisted in a corps belonging to the enemy; but it also appears that he had previously been taken prisoner by them, and confined at Wilmington. He remained, however, with the British troops for ten or eleven months, during which he might easily have accomplished his escape, and it must be remembered that in the eye of the law nothing will excuse the act of joining an enemy but the fear of immediate death, not the fear of any inferior personal injury, nor the apprehension of any outrage upon property. But had the defendant enlisted merely from the fear of famishing, and with a sincere intention to make his escape, the fear could not surely always continue, nor could his intention remain unexecuted for so long a period. * * Verdict. not guilty. Respublica v. McCarty, 2 Dallas (2 U. S.) 86, 1 L. Ed. 300, B. 364.

(Engy. Assize, 1831.) On Indictment for Destroying Threshing Machines, it appeared that ?efendant was compelled to join the mob, and gave the machine a blow with a sledge, as did the others, but ran away at the first opportunity, in about 25 minutes. He was acquitted. R. v. Crutchley, 5 C. \& P. (24 E. C. L.) 133, 13. 367, 3 L. 63 .

(Mich. Sup. Ct., 1895.) Or be Killed Sometime-Murder. Appel. lant was convicted of murder in the first degree and excepted to the instruction of the trial court to the jury, that the duress testified to by him was no defense. His testimony was that Banks, one of the conspirators, told him of the contemplated murder, and said he must go along. He replied: "I can't go along with you to shoot a man. Mine heart can't do that to shoot a dog. I got a bad dog; I got to ask mine neighbor to come and shoot him." Banks said they had others to shoot. "I got no gun." Banks said: "I furnish you somethings for that time, and you got to go ; I told you about that now. You got to go if you like to live; if you back out, if you don't come, maybe we shoot you on the same night, and you been shot the first night if we can get you." The instruction was approved and the judgment affirmed by the supreme court, saying: "It would be a strange rule that would permit one to escape punishment for the crime of murder upon the plea that three days before the crime was to be committed, he had been told that he would himself be killed if he did not go and assist; especially under the circumstances de- 
tailed by respondent himself." P. v. Repke, 103 Mich. 459, $61 \mathrm{~N}$. W. 861 .

(Miss. Sup. Ct., 1890.) Same-Perjury. COOPER, J. The appellant has been indicted and convicted of the offense of perjury. The sole defense attempted to be proved was that appellant's life had been threatened by one Veto Dodd, unless he should go into court and testify so as to criminate himself and certain other persons who were suspected of having murdered a negro man and his wife, tenants upon the farm of Dodd. The court below excluded the evidence tendered to show the threats upon the ground that it was not proposed to be shown that the threats were made at the instant of delivery of the testimony nor in the presence of the court in which the appellant was testifyirig. This ruling of the court is the foundation of the error's assigned, the assignments of error other than the first presenting the same question in different forms. Counsel for appellant press upon our attention with apparent confidence that numerous class of eases in which the credibility of confessions or of testimony has been assailed and impeached by the circumstances under which the confessing person or witness spoke. We fail to perceive their application to the case at bar, in which the single question is, whether a man may justify or excuse deliberate perjury against the life and liberty of others on the ground that he was coerced to the perjury by fear engendered by the threats of others. We are not aware that a similar question has ever been presented for decision. We can conceive of cases in which an act, criminal in its nature, may be committed by one under such circumstinnces of coercion as to free him from criminality. The impelling danger, however, should be present, imminent and impending, and not to be avoided. Such was not the character of the duress here, and the appellant was not only possessed of the power and right of protecting himself, but he also could have appealed to the law to shield him from the threatened danger. * * * The social system would be subverted and there would be no protection for persons or property if the fear of man, needlessly and cravenly entertained, should be held to justify or excuse breaches of the criminal laws of the state, and to excuse or justify the crine of perjury. The judgment is affirmed. Bain v. S., 67 Miss. 557, 7 So. 408, Mi. 118.

(Ala. Sup. Ct., 1893.) Same-Murder Under Duress of Life. Arp, convicted of murder in the first degree and sentenced to be hanged, appeals, and assigns error in the refusal of the court to instruct the jury not to convict if they found that Arp killed Payne under duress, compulsion, fear, and peril of his own life. COLEMAN, J. * * * The testimony of the defendant and the evidence admitted as confessions showed that he took the life of the deceased without provocation on the part of the deceased, and when there was no real or apparent necessity for the act, so far as such necessity proceeded 
from the deceased. According to his own statement, the object to be accomplished by taking the life of the deceased was to prevent deceased appearing as a witness against him, Buckhalter, and Leith, charged with retailing whisky without a license. The defendant's excuse for the homicide was that Buckhalter and Ieith throatened to take his life unless he killed deceased; that they were present, armed with double-barreled shotguns, and threatened to lill him unless he killed deeeased; and that it was through fear, and to save his own life he struck deceased with an ax. He admits that after having struck deceased down, he ritled the pockets, and took what money was found in the pockets of the deceased. ** * [ITere his honor quotes the request to charge, reviews the anthorities at some length, and eoncludes as follows:] 'l'he authorities seem to be conclusive that at common law no man eould excuse himself, under the plea of necessity or compulsion, for taking the life of an imnocent person. Our statute has divided murder into two degreess. and affixed the punishment for each degree, but in no respect has added to or taken away any of the ingredients of murder as linown to the common law. * * * That the fear of punishment by imprisonment or death at some future day by due process of law can operate with greater force to restrain or deter from its violation than the fear of immediate death, molaw fully inflicted, is hardly reconcilible with our knowledge and experience with that class of mankind who are controlled by no other or higher principle than fear of the law. be this as it may. there are other principles of law moloultedly applicable to the facts of this case. and which we think cammot be ignored. 'The evidence of the defendant himself shows that he went to Buckhalter's house about 9 o'elock of the night of the killing. and there met Buckhalter and Leith. and that it was there and at that time that they told him he must kill Payne. * * * Linder every principle of law it was the duty of the defendant to have aseaned from Bucklalter and Leith, after being informed of their intention. * * If it was practicable and *** he failed to do so. hut remained with them until the time of the killing. the immediate necessity or compulsion under which he acted at that time wonld be no excuse to him. * * Arp v. S., 97 Ali. 5, 12 So. 301. 33 .lm. St. Rep. 137. 19 1. R. A. 33T, Kn. 37. Mi. 121.

\section{\$51. "Of Necendity of Sielf-preservation in Other Casene"}

U. s.. C. C. for B. P'i.. 1St2.) Overcrowded Life.boat-Order to Cast Over. Indiefment inainst Alex. W. IInlmes for manslanghter at sea, in violation of an alet of congress, of $A$ pril 30. 1790. Ile wass a Finn by birth. a sailor from childhood, and one of the erew of the William Brown; which left Liverpool for Philadelphia, with fis Trish and Seoteh immigrants. and a crew of: 17 on board. and struck an ieeherg 250 miles east of Cape Race. Newfoundiland, at night. 
Nonday, April 19, 1S41, and sunk in half an hour. 'The first mate, $3: 2$ passengers, and 8 seamen, inehuling llolmes, escaped in the longboat; the eaptain, a few others in the small boat. The long-boat was $22 \mathrm{ft}$. long, $6 \mathrm{ft}$. abeam, $3 \mathrm{ft}$. deep, londed to within five inches of the water's cugge, ummanageable, and so leaky that bailing had to begin the moment it struck the water. Ilolmes distinguished himself in the collision and afterwards, hy his self-possession. unseltish sacrifice for the comfort of others. giving up his coat to the shivering women, climbing the ship's side just as it wats sinking to reseme a sick child of a distracted woman in his boat, and by being so superior to all the other's in sea-graft, that the mate took his advice in steering south to seek rescue rather than for shore. The night was calm; the next day it rained; many icebergs were seen; as night githered a wind arose; the sea grew heavy; passengers and erew were exhausted in rowing and bailing; the sea frequently came over the gunwales; patssenger's exclaimed: "The boat is sinking! The plun is out! God have merey on our souls!" 'The mate, who had heen bailing, eried out: "This work won't do! Ilelp hae, God! MIen, go to work!" The sailors knew this meant to cast passenger's over. Sothing was done, $\Lambda$ few minutes hater he said: "Nlen, you must go to work, or we shall all perish." Al this command, Holmes assisted in throwing over 14 men, including Askin, of whose death he is ehanged. When seized he offered llolmes five sovereigns to save him till morning. "If God don't send us help by morning. we'll draw lots. and if the lot falls on me, I'll go over like a man." Ilolmes said: "I don't want your money, Frank," and east him into the seil. Wednesday morning the weather cleared. and Ilolmes's trained reye descried a sail, invisible to any other ; he put ahout, raised a signal of distress, and they were sinved.

On the Trial, Brown, for the Prisoner, ardured that the eiste comld not properly be tried with rule and comprass in the guidet dediberations of the court room, but only in a friricl se:as. 2010 miles from shore, in a long-boat. loaded to the colge. leaking from brown, taking sea from above. hidden in datrkness. surrounded hy icedrelers. and

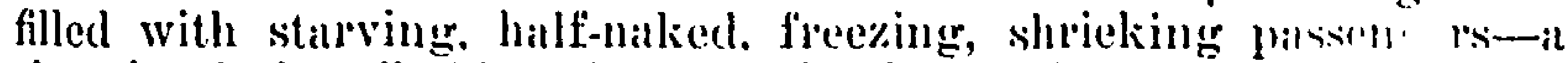
situation indescribable, where the instincts of nature displaced reit-

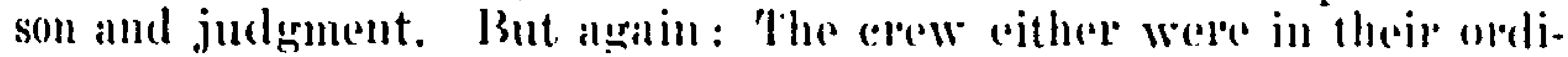
nary and original state of subordination to their officers. of they were in a state of nature. If in the former state. they are axisalile in law, for having obeyed the order of the mate-an order twien imperatively given. Independent of the mate's aroneral authority in the eaptain's absence, the captain had pointedly directed the crew to obey all the matr's orders as they would his. the capplain s: and the erew had promised to do so. It imports not to dredare that a erew is not bound to ohey an mulawful order'. for to sily that this order was malaw ful is to postulate what remains to be proved. Who is to judge of the unlawfulness" 'The cireumstances were peculiar. The occasion was emergent, without precedent. or parallel. 'The law- 
fulness of the order is the very question which we are disputing; a question about which this whole community has been agitated, and is still divided; the discussion of which crowds this room with audi. tors past former example; a question which this court, with all its resources, is now engaged in considering, as such a question demands to be considered, most deliberately, most auxiously, most cautiously. It is no part of a sailor's duty to moralize and to speculate, in such a moment as this was, upon the orders of his superior officers. 'The commander of a ship, like the commander of an army, "gives desperate commands. He requires instantaneous obedience." The sailor, like the soldier, obeys by instinct. That question is a different one from the guilt or innocence of the prisoner, and one more difficult. But if the whole company were reduced to a state of nature, then the sailors were bound to no duty, not mutual, to the passengers. The contract of the shipping articles had become dissolved by an unforeseen and overwhelming necessity. The sailor was no longer a sailor, but a drowning man. Having fairly done his duty to the last extremity, he was not to lose the rights of a human being, because he wore a roundabout instead of a frock coat. We do not seek authorities for such doctrine. 'The instinct of these men's hearts is our authority-the best authority. Whoever opposes it must be wrong, for he opposes human nature. All the contemplated conditions, all the contemplated possibilities of the voyage, were ended. The parties, suilor and passenger, were in a new state. All persons on board the vessel became equal.

BALDWIN, J., to the jury: * * * Where, indeed, a case does arise, embraced by this "law of necessity," the penal laws pass over such case in silence; for law is made to meet but the ordinary exigencies of life. But the case does not become "a case of necessity," unless all ordinary means of self-preservation have been exhausted. The peril must be instant, overwhelming, leaving no alternative but to lose our own life, or to take the life of another person. *** For example: suppose that two persons who owe no duty to one another that is not mutual should, by accident not attributable to either, be placed in a situation where both cannot survive. Neither is bound to save the other's life by sacrificing his own; nor would either commit a crime in saving his own life in a struggle for the only means of safety. But in applying this law, we must look not only to the jeopardy in which the parties are, but also to the relations in which they stand. The slayer must be under no obligation to make his own safety secondary to the safety of others. * * The passenger stands in a position different from that of the officers and seamen; it is the sailor who must encounter the hardships and perils of the voyage. *** The captain, indeed, and a sufficient number of seamen to navigate the boat, must be preserved. ** * This rule may be deemed a harsh one towards the sailor, who may thus far have done his duty; but when the danger is so extreme that the only hope is in sacrificing either a 
sailor or a passenger, any alternative is hard; and would it not be the hardest of any, to sacrifice a passenger in order to save a supernumerary sailor? *** When the ship is in no dauger of sinking, but all sustenance is exhausted, and a sacrifice of one person is necessiry to appease the hunger of others, the selection is by lot. 'This mode is resorted to as the fairest mode; and, in some sort, as an appeal to God for the selection of the victim.

The court said, briefly, that the principles which had been laid down by them, as applicable to the crew, applied to the mate likewise, and that his order (on which much stress had been laid), if an unlawful order, would be no justification to the seamen, for that even seamen are not justified, in law, by obedience to commands which are unlawful.

After deliberating sixteen hours, and once returning to the bar unable to agree, the jury returned a verdict of guilty; and the court, in view of the circumstances, gave lenient punishment of six months' solitary confinement at hard labor and $\$ 20$ fine. President Tyler refused petitions of several for pardon, because the court did not unite in the application. The penalty was subsequently remitted. U. S. v. Holmes, 1 Wall. Jr. 1, 26 Fed. Cas. 360, 1 Am. Law. School Rev. 43, B. 360n, 1 L. 757, Mi. 132n.

of this case Lord Colerilge, C. I.. snil, in 1R. v. Dudley (below): "Ihe American case cited by $\mathrm{my}$ brother Stephen in his Digest [Cr. L. alt. 32] from Wharton on

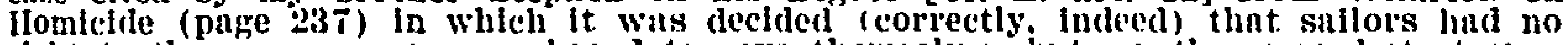
right to throw passenger's overbonrd to save themselves. but, on the somewhint strunge ground, thit the proper mode of determining who was to be sacificed was to vote npon the suljject by ballot, can hardly, as my biother Stephen says, be an authority satis. factory to a court in this countiy."

(Eng. Queen's Bench Div., 1884.) Starving Castaways. Dudley and Stephens were indicted and convicted of murdering a boy on the high seas. The jury found by special verdict that the prisoners and the deceased were escaped from a ship-wreck and adrift on the sea on a raft, with nothing to eat; and that, when near to starvation, they killed the boy to feed on his flesh. The main defense was necessity. LORD COLERIDGE, C. J. * * * From these facts, stated with the cold precision of a special verdict, it appears sufficiently that the prisoners were subject to terrible temptation and to sufferings which might break down the bodil :
of the strongest man, and try the conscience of the best.

This is clear: that the prisoners put to death a weak and unoffending boy, upon the chance of preserving their own lives by feeding upon his flesh and blood after he was killed, and with a certainty of depriving him of any possible chance of survival. The verdict finds in terms that, "if the men had not fed upon the body of the boy, they would probably not have survived;" and that "the boy, being in a much weaker condition, was likely to have died before them." They might possibly have been picked up next day by a passing ship; they might possibly not have been picked up at all. In either case it is obvious that the killing of the boy would have been an unnecessary and profitess act. It is found by the verdict 
that the boy was incapable of resistance, and, in fact, made none; and it is not even sugrgested that his death was due to any violence on his part attempted against, or even so much as feared by, them who killed him. Under these circumstances the jury say they are ignorant whether those who killed him were guilty of murder, and have referred it to this court. *** [Here his lordshi] disposed of the objection that the court was without jurisdiction to try a charge of murder so committed at sea.] 'There remains to be considered the real question in the ease, whether killing, under the circumstances set forth in the verdict, be or be not murder. 'I'he contention that it could be anything else was to the minds of us all both new and strange; and we stopped the attorney-greneral in his negative argument, that we might hear what could be said in support of a proposition which appeared to us to be at once dangerous, immoral, and opposed to all legal principle and anilogy. All, no doubt, that can be said has been urged before us, and we are now to consider and determine what it amounts to. First. it is said that it follows from various definitions of murder in books of authority-which definitions imply, if they do not state, the doctrine-that, in order to save your own life, you may lawfully talie away the life of another, when that other is neither attemptingr nor threatening yours, nor is guilty of any illegal act whatever towards you or any one else. But, if these definitions be looked at. they will not be found to sustain the contention. *** * [Ilere his honor reviewed authorities relied on, Bracton, Hale, and other's.] The one real authority of former times is Lord Bacon, who, in his commentary on the maxim "Necessitas inducit privilegium runad jura privata," lays down the law as follows: "Necessity carrieth a privilege in itself. Necessity is of three sorts: Necessity of conservation of life, necessity of obedience, and necessity of the act of God or of a stranger. First. of conservation of life. If a man steals viands to sutisfy his present hunger, this is no felon! nor lareeny. So if divers be in danger of drowning by the casting away of some hoat or barge, and one of them get to some plank, or on the boat's side, to keep himself above water, and another, to sive his life, thrust him from it, whereby he is drowned, this is neither se defendo nor by misadventure, but justifiable." *** $*$ If Lord Bacon meant to lay down the broad proposition that a man may save his life by killing, if necessary, an innocent and unofiending neighbor, it certainly is not law at the present day. $* * *$ Sow. it is admitted that the deliberate lilling of this unoftending and unresisting boy was clearly murder, unless the killing can be justified by some well-recornized excuse admitted by the law. It is further admitted that there was in this case no such excuse. muless the killing was justified by what has been called necessity. But the temptation to the act which existed here was not what the law has ever called "necessity." Nor is this to be regretted. 'Though law and morality are not the same, and though many things may 
be immoral which are not necessarily illegal, yet the absolute divorce of law from morality would be of fatal consequence, and such divorce would follow if the temptation to murder in this case were to be held by law an absolute defense of it. It is not so. To preserve one's life is, generally speaking, a duty, but it may be the plainest and the highest duty to sacrifice it. *** * It is enough in a Christian country to remind ourselves of the Great Example which we profess to follow. It is not needful to point out the awful danger of admitting the principle which has been contended for. Who is to be the judge of this sort of necessity? By what measure is the comparative value of lives to be measured? Is it to be strength or intellect or what? It is plain that the principle leaves to him who is to profit by it to determine the necessity which will justify him in deliberately taking another's life to save his own. * * There is no path safe for judges to tread but to ascertain the law to the best of their ability, and to declare it according to their judgment, and if, in any case, the law appears to be too severe on individuals, to leave it to the sovereign to exercise that prerogative of mercy which the constitution has intrusted to the hands fittest to dispense it. It must not be supposed that, in refusing to admit temptation to be an excuse for crime, it is forgotten how terrible the temptation was, how awful the suffering, how hard in such trials to keep the judgment straight and the conduct pure. We are often compelled to set up standards we cannot reach ourselves, and to lay down rules which we could not ourselves satisfy. But a man has no right to declare temptation to be an excuse, though he might himself have yielded to it, nor allow compassion for the criminai to change or weaken in any manner the legal definition of the crime. It is therefore our duty to declare that the prisoner's' act in this case was wilful murder; that the facts as stated in the verdict are no legal justification of the homicide; and to say that, in our unanimous opinion. they are, upon this special verdiet. guilty of murder. R. v. Dudley, 15 Cox C. C. 625. 14 Q. B. D. 273, 560.54 L. J. m. c. 32,52 L. T. 107. 333 W. R. 347,49 J. P. 69, B. 357 , C. 195 , F. 111, Ke. 61 , Mi. 131 .

\section{\$ 52. "Of Inability of:Defendant to Perform His Legal Duty."}

(Eng. Queen's Bench, 1843.) Sea Encroachment. Error on conviction of failure to repair highway. LORD DENMTAN, C. J. I think the defendant below is entitled to judgment. Both the road which the defendant is charged with liability to repair and the land over which it passes are washed away by the sea. To restore the road, as he is required to do, he must ereate a part of the earth anew. I do not rely much upon the argument that the ancient line of highway has been removed. But here all the materials of which a road could be made have been swept away by the act of God. Ender those circumstances can the defendant be liable for not repair- 
ing the road? We want an authority for such a proposition, and none has been found. Williams, Coleridge, and Wightman, JJ., concurred. Reversed. R. v. Bamber, 5 Q. B. (48 E. C. L.) 279, B. 336.

(Mass. Sup. Judicial Ct., 1868.) ' Complaint for Standing a Vehicle in the Street more than twenty minutes, in violation of the Boston ordinance. Defendant was convicted, and excepted. GRAY, $\mathrm{J}$. It is very clear that defendant was not proved to have violated the city ordinance on which he was prosecuted. No person transgresses the ordinance who does not voluntarily suffer his vehicle to stop on the street more than twenty minutes. The defendant, indeed, drove into S. Market St. more than twenty minutes before 4 o'clock, and intended to remain in that street until 4 o'clock. But he had the right to travel in the street, if he did not voluntarily suffer his vehicle to stop in it for the prohibited period. If he had arrived on his stand more than twenty minutes before 4 o'clock and voluntarily remained there with his wagon until that hour, or if he had voluntarily stopped his wagon for more than twenty minutes at any other place in the street, it would have been a violation of the ordinance. * * * It appears that the defendant, while driving his wagon through the street towards his stand, was delayed by the crowding of other vehicles which he could not control for five or six minutes, and then drove on and occupied his stand. He did not voluntarily stop at all before arriving at his stand; he did not stop on his stand but fifteen minutes before 40 'clock; and after 40 'clock, being a marketman, engaged in bringing vegetables into the city and selling them from his wagon at a stand occupied by him within the established limits of the market, though in a public strect. he is admitted to have had a right, by virtue of the exception in the ordinance, and of the St. of 1859 , c. 211 , to be and remain upon his stand with his wagon. New trial ordered. C. v. Brooks, 99 Miss. 434, B. 364.

\section{§53. "That the Defendant was Mistaken as to the Facts."}

(Eng. Assize at Newgate, 1638.) Servant Taken for Burglar. In the case of Levet, indicted for the death of Frances Freeman, the case was, that William Levet being in bed and asleep in the night, his servant hired Frances Freeman to help her to do her work, and about twelve of the clock in the night, the servant going to let ont Frances thought she heard thieves breaking open the door; she therefore ran up speedily to her master and informed him that she thought thieves were breaking open the door. The master rising suddenly and taking a rapier ran down suddenly; Frances hid her. self in the buttery lest she should be discovered. Levet's wife spying Frances in the buttery cried out to her husband, "Here they be that would undo us." Levet runs into the buttery in the dark. 
not knowing Frances but thinking her to be a thief, and thrusting with his rapier before him hit Frances in the breast mortally, whereof she instantly died. 'This was resolved to be neither murder nor manslaughter nor felony. Levet's Case, Cro. Car. 538, 1 Hale P. C. 42, Foster C. L. 299, 1 Hawk. P. C. 8t, B. 279, C. 85, Ke. 26, 3 I. 445.

(Eng. Assize, 17-) Statutory Proof Lacking. Indictment for having his majesty's canvas in possession without certificate of right, contrary to the statute $9 \& 10 \mathrm{~W} .3$, c. 41 . FOSTER, J. was of opinion that, though the clause of the statute which directs the sale of these things hath not pointed out any other way for indemnifying the buyer than the certificate; and though the second section seems to exclude any other excuse for those in whose custody they shall be found; yet still the circumstances attending every case which may seem to fall within the act ought to be taken into consideration; otherwise a law calculated for wise purposes may, by too rigid a construction of it, be made a handmaid to oppression. There is no room to say that this canvas came into the possession of the defendant by any act of her own. It was brought into family use in the lifetime of her husband, and it continued so to the time of his death; and by act of law it came to her. Things of this kind have been frequently exposed to public sale; and though the act points out an expedient for the indemnity of the buyers, yet probably few buyers, especially where small quantities have been purchased at one sale, have used the caution suggested to them by the act. And if the defendant's husband really bought this linen at a public sale, but neglected to take a certificate, or did not preserve it, it would be contrary to natural justice. after this length of time, to punish her for his neglect. He therefore thought the evidence given by the defendant proper to be left to the jury, and directed them that if, upon the whole of the evidence, they were of opinion that the defendant came to the possession of the linen without any fraud or misbehavior on her part. they should acquit her; and she was acquitted. Anon. Foster C. L. (3 Ed.) 439, B. 284.

(Conn. Sup. Ct. of Errors, 1816.) Letting a Coach for Sunday Use unless for necessity or charity being made a misdemeanor by statute, the court held on a trial for violation of the statute that defendant must show in justification that a case of necessity or charity existed. This was held error. It was said by SWIFT, C. J. "The letting of a carriage on Sunday, on the ground of necessity or charity, is not prohibited by the statute. If then a man acts honestly on such principle, and really believes that the case of necessity or charity exists, he is not criminal. It is true, a man may be deceived and imposed upon by falsehood and misrepresentation; vet if he verily believes that the case exists. and acts on that ground, it is as much a deed of charity in him, if the fact does not exist, as if it does. 
It is a letting of the carriage as a matter of charity." Myers v. S., 1 Conn. 502, B. 302, 3 L. 550.

(Ohio Sup. Ct., 1837.) Harboring Colored Person the property of another, in violation of statute. The indictment was sustilined in the court below, and defendant appeals. WOOD, J. *** It is true that the statute upon which the indictment is founded omits the scienter, and the indictment covers all the facts enumerated in that statute. But this is not sufficient; it cannot be assumed that an act which, independent of positive enactment, involves no moral wrong, nay, an act that in many cases would be highly praiseworthy, should be made grievously criminal, when performed in total unconsciousness of the facts that infect it with crime. This court has determined differently. In the case of Anderson v. S., 7 Ohio 255, the plaintiff in error was indicted for uttering and pub. lishing forged certificate of deposit, without averring his knowledge of such forgery. 'The statute under which the indictment was found does not, in express terms, make this knowledge a constituent of the crime. Nevertheless, the court held that the criminality could not exist without the knowledge, and that an indictment that did not aver it was defective. That ease runs upon all fours with this, and the further investigation of the principles upon which it is based confirms the court in the conviction that it is correct. This judgment must be reversed for this cause. Birney v. S., 8 Ohio 230, B. 303 .

(Mass. Sup. Judicial Ct., 1864.) Milk Supposed to be Pure. Defendant was convicted and excepts. CHAPMAN, J. This indictment is upon St. 1864 , c. $122, \$ 4$, which provides, among other things, that "whoever sells or keeps or offers for sale adulterated milk or milk to which water or any foreign substance has been added," shall be punished by a fine as therein specified. The defendant contends that the commonwealth should have been held to prove on the trial that he committed the offense knowing the milk to be adulterated. But the language of the statute does not require such proof, and it is evident that the legislature did not intend that it should do so. The St. of 1863 , c. 140 , required such proof, and one of the reasons which indueer the legislature to repeal it and substitute the existing statute for it undoubtedly was that they regarded it as impracticable in most cases to prove the knowledge, and that they also regarded it as reasonable under all the circumstances that the seller of milk take unon himself the risk of knowing that the article he offers for sale is not adulterated. It is of the greatest importance that the community shall be protected against the frauds now practiced so extensively and skillfully in the adulteration of articles of diet by those who deal in them. and. if the legislature deem it important that those who sell them shall be held absolutely liable. notwithstanding their ignorance of the 
adulteration, we can see nothing unreasonable in throwing this risk upon them. It is the same risk which every man takes who sells intoxicating drinks; the law making him liable to the penalty although it is not proved that he knew that the liquors were intoxicating. C. v. Boynton, 2 Allen 160 [below]. * * * Exceptions overruled. C. v. Farren, 9 Allen 489, F. 110.

Similur case: C. $v$. Waite, $\S 7$, holding this luw valid.

(Mass. Sup. Judicial Ct., 18s.4.) Bigamy-Belief of Death. Defendant was indicted for and convicted of bigamy under R. S. c. $130, \S 2$, which, with some exceptions, imposes a penalty on any person who marries having a spouse living. Sec. 3 excepts from the operation of the statute "any person, whose husband or wife shall have been continually remaining beyond sea, or shall have voluntarily withdrawn from the other, and remained absent for the space of seven years together,-the party marrying again not knowing the other to be living within that time." Defendant married Peter Mash Dec. 7, 1834; he left her Nov. 10, 1838, saying he would return to breakfast, and was not heard from, and was not found by diligent search and inquiry by defendant, who married again April 10, 1842 . Peter Mash returned in May, 1842. On learning that he was alive, defendant immediately left the other husband. She has always been of good character and virtuous conduct. She excepts to refusal of the court to charge the jury that honest belief of the death of Peter Miash constituted a defense. SHAW, C. J. * * * Such belief might arise after a very short absence. But it appears to us that the legislature intended to prescribe a more exact rule, and to declare as law that no one should have a right, upon such ignorance that the other party is alive, or even upon such honest belief of his death, to take the risk of marrying again, unless such belief is confirmed by an absence of seven years. *** It was urged in the argument that, where there is no criminal intent, there can be no guilt; and. if the former husband was honestly believed to be dead, there could be no criminal intent. The proposition stated is undoubtedly correct in it $\mathrm{gg}^{\prime}$. ral sense; but the conclusion drawn from it in this case by no means follows. Whatever one voluntarily does, he of course intends to do. If the statute has made it criminal to do any act under particular circumstances, the party voluntarily doing that act is chargeable with the criminal intent of doing it. On this subject, the law has deemed it so important to prohibit the crime of polygamy, and found it so difficult to prescribe what shall be sufficient evidence of the death of an absent person to warrant a belief of the fact, and as the same vague evidence might create a belief in one mind and not in another, the law bas also deemed it wise to fix a definite period of seven years. *** One, therefore, who marries within that time, if the other party be actually living, whether the fact is 
believed or not, is chargeable with that criminal intent. *** Exceptions overruled. C. v. Mash, 7 Metc. 472, B. 304, C. 88, H. 10i. Compare 1R. v. Tolson, $\$ 35$.

(Ind. Sup. Ct., 1874.) Same-Diligence. Appellant was convicted of bigamy. He testified that he settled in this state two years ago, coming from Buffialo, N. Y., where he left his wife because she refused to come with him; that he had been informed by letters from his father and brothers in New York that his wife had obtained a divoree from him in New York; and that he had since married Ruth Summers under the belief that such information was true. IIe assigns error on the refusal of the court to charge the jury: "'lhat if the jury believe, from the evidence in the case, that the defendant married the second time in the honest belief that his former wife had been divoreed from him, they should find him not guilty." BUSKIRK, J. * * * We think the court should have charged the jury, if it had been so asked, that if they believed from the evidence that the defendant had been informed that his wife had been divoreed, and that he had used due care and made due inquiry to ascertain the truth, and had, considering all the circumstances, reason to believe, and did believe, at the time of his second marriage, that his former wife had been divoreed from him, they should find him not guilty. 'There was probably no error in refusing the instruction as asked, as it was based solely upon the belief of the defendant, and did not require that such belief should be the result of due care and careful inquiry, and that he should have reasonable grounds to entertain such belief. *** [Reversed on another ground.] Squire v. S., 46 Ind. 459, C. 90, F. 106, Kn. 56.

(Mass. Sup. Judicial Ct., 1869.) Adultery After 11 Years' Absence. On indictment for adultery, defendant offered evidence that he believed the woman to be a widow, that she so believed, not having heard from her husband for 11 years, and so believing they were married; and on this evidence asked the court to instruct the jury that if they believed it they should acquit. This instruetion was refused relying on C. v. Mash [above], and this was held error. C. v. Thompson, 6 Allen 591, 83 Am. Dec. 653, B. 308.

(Ala. Sup. Ct., 1875.) Infant Votes, Ignorant of Age. Indictment under act of April 22, 1873, $\S 40$, for illegal and fraudulent voting, in that defendant was under 21 years of age. Defendant's mother and another who had known him from birth and been a member of the family for some time testified that he was of age, and that they had frequently told him he would be of age in the August before the election. The court refused to charge the jury that if defendant, relying on these statements, honestly believed he was of age when he voted he should not be convicted, though the evidence convinced the jury that he was not of age. "A wrongful 
act and a wrongful intent must concur to constitute what the law deems a crime. When an act denounsed by the law is proved to have been committed, in the absence of countervailing evidence, the criminal intent is inferred from the commission of the act. The inference may be, and often is, removed by the attending circumstances, showing the absence of a criminal intent. *** the criminal intention being of the essence of crime, if the intent is dependent on a knowledge of particular facts, a want of such knowledgre, not the result if carelessness or negligenee, relieves the net of criminality. ** * lllegal voting, when it is supposed to arise from the want of legal qualifications, is dependent on the voter's knowledge of the particular facts. which make up the qualification. $* * *$ He is bound to exercise reasonable diligence to ascertain the lauts which enter into and form these qualifications. Ilaving exercised this diligrence, if he resided near the boundary line of a county, and shoulci be iniformed by those having the means of knowledge that his residence was within the county, and he, without a knowledge of the real facts, honestly acting on this information, should vote, he could not fairly be charged with illegal roting, though on a subsequent survey, or on some other evidence, it should be ascertained his residence was not within the county. The precise time when a man arrives at the age of 21 years is a fact, knowledge of which he derives necessiarily firom his parents, or other relatives or acculaintances having knowledge of the time of his birth. 1f, acting in good faith, on information fairly obtained from them under an honest belief that he had reached the age, he votes, having the other necessary qualifications, illegal voting should not be imputed to him. * * * If he votes recklessly or carelessly, when the facts are doubtful or uncertain, his ignorance should not excuse him, if the real facts show he was not qualified." Per BRICKELL, C. J. Judgment reversed. Gordon v. S., 52 Ala. 308. 23 Am. Rep. 575, l. 43, Kn. 47.

(Ga. Sup. Ct., 1874.) Minor in Billiards. Appellant was convicted of permitting a minor to play billiards, without the cuusent of his parents or guardian. The trial court acted as judge and jury; and refused to consider evidence that the accused inquired, was informed by the infant, and believed that he was of age. $\mathrm{MICAY}$, J. We agree with the counsel for the plaintiff in error that the county judge did not take a proper view of the law on the trial. To make a crime, there must be the union of act and intent, or there must be criminal negligence. It is not conclusive evidence of guilt on the part of the defendant that he permitted this young man to play at his table; that the young man was, in fact, a minor. and that the parent did not consent. These facts. it is true, make a prima facie case, and, if they stood alone, the guilt of the defendant would be manifest; but evidently there was evidence of another element in the case, which, by the return of the county judge, is 
shown not to have been considered he him in arriving at his conchusion. 'There wass avidenee groing to show that the defendant might have heen honestly mistaken as to the age of the young man. It is clear to us that if the defendant, after due diligence, thought honestly that this young man was not a minor, he is not guilty. * * Judgment reversed. Stern v. S., 533 (G., 2.29, 21

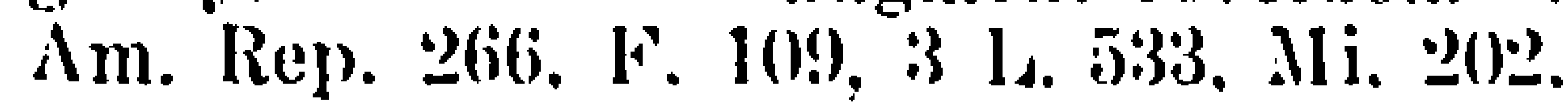

Acc. Murshall v. S. 4! Alı. 21 .

(lowa Sup. C1. 188:3.) Same. Appellant was convieted of permitting a minor. Garks. to remain in a billiard saloon. BE(K. o. * * It is ohvious that. in the alssence of watchiulness and proper effort to discharge the duty imposed by the statute, if a minol remains in the sillown withont the knowledge of the keeper or employe. aleh is liable for the penalty provided by the statute. Neither can ploal innorance of the presence of the minor. It is their duty to know of his mesence. * * * The fourth instruction holds that dofendant s gruilt does not depend upon his knowlodge of the minority of (lank. It is complained of hy defondant.

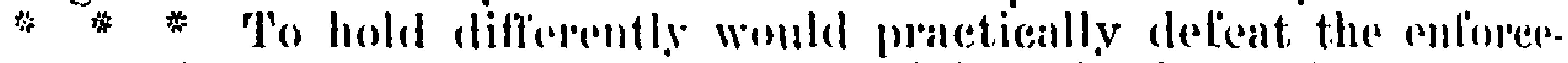
ment of the statute. Porsous anganged in it business that beromes unlawful or criminal under extain conditions. must extercise it at their peril, taking eare that their acts are not unlawful.

Afiirmed. S. v. Probasco, 62 Iowa 400. 17 N. W. 607.

(Mass. Sup. Judicial C1., 1861.) Selling Intoxicating Liquor in violation of the statute, the cont instructed the jury, would warrant conviction. though refendant did not know it was intoxicating. Defendant excepted. HOAR. J. The court are of opinion that the sale of intoxicating liquors in violation of the statute prohibition is not one of those cases in which it is necessary to allege or prove that the person charged with the offense knew the illegal reh iracter of his act; or in which a want of such knowledge would avil him in defense. If the defendant purposely sold the liquor. which was in fact intoxicating, he was bound at his peril to ascertain the nature of the article which he sold. Where the act is expressly prohibited, without reference to the intent or purpose, and the party committing it was under no obligation to act in the premises, unless he knew that he could do so lawfully. if he violates the liaw he incurs the penalty. The salutary rule that every man is conclusively presumed to know the law is sometimes productive of hardship in particular cases. And the hardship is no greater where the law imposes the duty to ascertain a fact. * * Exceptions overruled. C. v. Boynton, 2 Allen 160, B. 306.

See also: P. v. Roby. 82 , saloon opened on Sunday by clerk; $S$. v. Chastain, $\$ 42$. supposed employer had a license to sell : S. *. Smith. 11 , neglect to learn needs of insune wife: and $R$. $\nabla$. Wngstrffe. 811 , neglect of medical attendance supposing prayer to be better.

(S. Dak. Sur. Ct.. 1894.) Selling Liquor to a Minor. Appellant 
was indicted and convicted of seiling liquor to a minor, contrary to laws 1890 , c. $101, \S 5$. 'The assignments of error' relate to want of knowledge as a defense. Ife demurred to the indictment for want of averment that he knew the person was a minor, which was overruled; and on the trial he swore that he did not know the person was a minor and believed him to be of age; and produced the affidavit of the person to whom the sale was made, given as required by law at the time of the sale, averring among other things that he was over 21 years old. The court submitted the case to the jury on the theory that ignorance was no defense. FULLER, J. * * The word "knowingly" being omitted firom that part of the statute relating to minors, and no word of similar import being used, it is evident that good faith is unimportant, and the absence of criminal intent no excuse, when intoxicating liquor has in fact been soid to a boy under the age of 21 years. As a rule, ignorance of fact and absence of criminal intent is a competent defense to a criminal charge; but a distinction is made between acts or omissions containing the elements of moral turpitude and wrong in themselves, and such as are made criminal by statutory enactment designed to promote the welfare of society. *** Where a statute commands that an act be done or omitted, which, in the absence of such statute, might have been done or umitted without culpability, ignorance of the fact or state of things contemplated by the statute, it seems, will not excuse its violation. **** The law prohibiting the sale of intoxicating liquors to a minor belongs to the class above mentioned. * * * Affirmed: S. V. Sasse, 6 S. Dak. 212, 60 N. W. 853, 55 Am. St. Rep. 834.

Ace. Aruutcheon v. P. 69 Ill. 601: Ulrich v. Com. 6 Bush (Ky.) 400; In re Carlson, 127 Pa. St. 330,18 Atl. 8; S. v. Hartfiel, 24 Wis, 61. Contra: Fialks v. P. 30 Mich. 200.

(Mlass. Sup. Judicial Ct., 1896.) Rape-Mistake as to Age. Defendants were convicted under a statute (Pub. Acts, 1893, c. 466), providing that whoever carnally knows and abuses a female child under 16 years of age, with or without her consent, shall be punished with imprisonment for life. They excepted. KNOWLTON, J. * * * The legislature is ordinarily the julge .. " the expediency of creating new crimes, and of prescribing penalties, whether light or severe for prohibited acts. We cannot say that the punishment prescribed for this offense, when the girl is nearly 16 years of age, and voluntarily participates in it, is beyond the constitutional power of the legislature to inflict. The presiding justice was asked to instruct the jury that unless the defendant knew, or had good reason to believe, that the girl was under 16 years of age, he could not be convicted. How far a mistake of fact in regard to the nature of his act may be availed of by a defendant in a criminal case is sometimes a difficult question to answer. In general it may be said that there must be a malus animus, or criminal intent. But there is a large class of cases in which, on grounds of public policy, certain acts are made punish- 
able without proof that the defendant understands the facts that give character to his acts. In such cases it is decmed best to require everybody, at his peril, to ascertain whether his act comes within the legislative prohibition. * * The defendants in the present case knew that they were violating the law. Their intended crime was fornication at the least. It is a fumiliar rule that, if one intentionally commits a crime, he is responsible criminally for the consequences of his act, if the offense proves to be different from that which he intended. See R. v. Prince, I. R. 2 C. C. 15t. 175. Exceptions overruled. C. v. Murphy, 165 Mass. 66, 42 N. F. 504. 52 Am. St. Rep. 496, 30 L. R. A. 734.

Ace. 1R. v. I'rince. 1.. R. 2 c. c. 154 , revlewed in R. v. Tolson, 835 .

(N. Ham. Sup. (t., 1900.) Oleomargarine. Indictment for lurnishing oleomargarine to a guest at defiendant's hotel without notifying him that it was not butter, contrary to law of 1895 , c. 115, \$3. Verdict, guilty. Defendant excepts to the refusal to give his requested instruction to the jury, that they "must find that the defendant knew, or had reason to know, by the exercise of due diligence, that the substance so furnished on his hotel table was not butter." BLODGE'I'T, C. J. The instructions requested by the defendant were properly denied. It is true that. "in the earlier" history of the common law, only such acts were deemed criminal as had in them the vicious element of an unlawful intent, indicating a deviation from moral rectitude; but this quality has ceased to be essential, and now acts unquestionable in a moral view, except so far as being prohibited by law makes them so, constitute a considerable portion of the eriminal code. In such statutes the act is expressly prohibited without reference to the intent or purpose of the party committing it, and is usually of the class in which the person committing it is under no obligation to act unless he lnows he can do so lawfully. Under these statutes it is not a defense that the person acted honestly and in good faith, under a mistake of fact. He is bound to know the fact as well as the law, and he acts at his peril. These statutes do not make a guilty knowledge one of the ingredients of the offense." S. v. Cornish, 66 N. H. 329, 21 Atl. 180, 11 I. R. A. 191, and numerous authorities there cited. * * The statute in question clearly comes within this class. * * Fixceptions overruled. S. v. Ryan, 70 N. II. 196. 46 Atl. 49, 85 Am. St. Rep. 629.

Acc. C. Weiss, 139 Pa. 247,21 Atl. 10, 23 Am. St. Rep. 182, Mi. 205.

\section{\$ 54. "That the Defendant was Mistaken as to the Law."}

(Eng. C. C. R., 1800.) Before Law Could be Known. Conviction of malicious shooting on board his ship "Langley" oft' the coast of $\Lambda$ frica, June 27,1799 , in violation of a statute (39 Gen. 3 , c. 37) approved May 10, 1799, was held proper, notwithstanding 
defendant was at sea, and it had been impossible for him to learn that there was such a law. But the judges were of opinion that it would be proper to apply for a pardon. R. v. Bailey, Russell \& R. 1, B. 280 .

(U. S. C. C., 1873.) Woman Voting, to Test Right. Indictment against Susan 13. Anthony for a violation of the aet of congress of Nay 31,1870 (16 Stat. 144), which provides "that if, at any election for representative * * in the congress of the United States, any person shall knowingly ** vote without having a lawful right to vote, *** every such person shall be deemed guilty of a crime," etc. HUNT, J. The fourteenth amendinent gives no right to a womm to vote, and the voting by Miss Anthony was in violation of law. If she believed she had a right to vote, and voted in reliance upon that belief, does that relieve her from the penalty? It is argued that the knowledge referred to in the act relates to her knowledge of the illegality of the act, and not to the act of voting; for, it is said, that she must know that she voted. 'Iwo principles apply here: First, ignorance of the law excuses no one; second, every person is presumed to understand and to intend the necessary effects of his own acts. Miss Anthony knew that she was a woman, and that the constitution of this state prohibits her from voting. She intended to violate that provision-intended to test it, perhaps, but certainly intended to violate it. The necessary effect of her act was to violate it, and this she is presumed to have intended. There was no ignorance of any fact. but, all the facts being known, she undertook to settle a principle in her own person. She takes the risk. and she cannot eseape the eonsequences. $* * *$ To constitute a crime, it is true there must be a criminal intent. but it is equally true that knowledge of the facts of the case is always held to supply this intent. An intentional killing bear's with it evidence of malice in law. Whoever without justifiable cause, intentionally liills his neighbor, is guilty of a erime. 'The principle is the same in the case before us, and in all criminal cases. The precise question now before me has been several times decirlor. viz., that one illegally voting was bound and was assumed to know the law, and that a belief that he had a right to vote gave no defense, if there was no mistake of fact. Ilamilton v. P., 57 Barb. 625; S. v. Boyett, 10 Ired. 336 ; S. v. Hart, 6 .Jones (N. C.) 389 ; McGuire v. S., 7 Humph. (Tenn.) 54; S. v. Sheeley, 15 Iowa 404. No system of criminal jurisprudence can be sustained upon any other principle. U. S. v. Anthony, 11 Blatchf. 200. Fed. Cas. No. 14, 459. F. 104, 2 Green 208, Kn. :54.

(Me. Sup. Judicial Ct., 1876.) Supposed Marriage Avoided. PETERS, J. The respondents are jointly indicted for adultery, they having cohabited as husband and wife while the female respondent. was lawfully married to another man who is still alive. The only 
question found in the exceptions is, whether the evidence offered and rejected should have been received. This was, that the lawful husband had married again, and that the justice of the peace who united the respondents in matrimony advised them that, on that account, they had the right to intermarry, and that they believed the statement to be true, and acted upon it in good faith. It is urged for the respondents that those facts would show that they acted without any guilty intent. It is undoubtedly true that the crime of adultery camnot be committed without a criminal intent. But the intent may be inferred from the criminality of the act itself. Lord Mansfield states the rule.thus: "Where an act, in itself indif. ferent, becomes criminal if done with a particular intent, there the intent must be proved and found; but where the act is in itself unlawful, the proof of justification or excuse lies on the defendint; and in failure thereof, the law implies a criminal intent." Here the accused have intentionally committed an act which is in itself unlawful. In excuse for it, they plead their ignorance of the law. 'This cannot excuse them. Ignorance of the law excuses no one. Be sure, this maxim, like all others, has its exceptions. None of the exceptions, howevel, can apply here. ** * Exceptions overruled. S. v. Goodenow, 65 ile. 30, B. 309.

(Nev. Sup. Ct., 1896.) Bigamy-Separation Agreement. Appellant was convicted of bigamy on proof that he was married to $S$ by written contract without the services of any person authorized by law to join persons in marriage, that two years later the appellant was married before a justice of the peace to $L$, while $S$ was living. He assigns as error the rejection of his agreement in writing with $\mathrm{S}$, executed before the second marriage, whereby they severed their marital relations. It is argned that the agreement was proper evidence to go to the jury, as tending to show that there was no criminal intent on the part of the defendant in entering into the second marriage, he believing that the agreement had annulled the first marriage. BONNIFILLD, .J. ** * the rule adopted by the majority of the court in the said Gardner case (5 Nev. 377), to the effect that where a statute forbids the doing of a certain thing, and is silent concerning the intent with which it is done, a person commits no offense in law, though he does the forbidden thing, within all the words of the statute, if he had no evil or wrongful intent beyond that which is involved in the doing of the prohibited act, is disapproved, and the decision to that eftect is hereby overruled. We recognize the well settled rule that where a specific intent is required by statute to constitute a crime. such specific intent enters into the nature of the act itself, and must be alleged and proved beyond a reasonable doubt. *** There is no intent involved in this case, except the doing of the thing forbidden to be done by the statute. *** We therefore hold that the court did not err in excluding said agreement. 
* * Affirmed. S. v. Zichfeld, 23 Nev. 304, 46 Pac. 802, 62 Am. St. Rep. 800, $3 \pm$ L. R. A. 784 .

(N. IIam. Sup. Ct., 1897.) Intent to Violate the Law. Indictment for compounding a violation of the liquor law. Defendant convicted, and excepts. BIJODGEI'I, J."** "The ruling that "if the defendant knew what he was doing and did what he intended to do, it was immaterial what his opinion was as to the legal effect of what he was doing, and it would be no defense that he did not know he was violating the law," was manifestly correct. "A man's moral perceptions may be so perverted as to imagine an act to be right and legal which the law justly pronounces frandulent and corrupt; but he is not therefore to escape from the consec(uences of it." Bump Fr. Conv. (3d ed.) 25. "Ignorance of a fact mily sometimes be taken as evidence of a want of eriminal intent, but not. ignorance of the law" (Reynolds v. U. S., 98 U. S. $145)$; and "in no case can one enter a court of justice to which he has been summoned in either a civil or criminal proceeding, with the sole and naked defense that when he did the act complained of, he did not know of the existence of the law which he violated." 1 Bish. Cr. L. (7th ed.), §294. It is elementary, as well as indispensable to the orderly administration of justice, that every man is presumed to know the laws of the country in which he dwells, and also to intend the necessiry and lerritimate consequences of what he knowingly does. *** Affirmed. S. v. Carver, 69 N. H. 216, 39 Atl. 973, Kn. 308.

(Eng. Assize, 1828.) On Indictment for Robbing a Gamekeeper of a pheasant the gamekeeper had taken from wires wrongfully set by defendant, the court charged the jury to aequit if defendant acted under the impression that the pheasant was his property; because in that case there would be no animus furandi. R. v. Hall, 3 C. \& P. 409, B. 281. C. 85,3 L. 580.

(Mass. Sup. Judicial Ct., 185ion Getting Pay. Defenclint atas indicted for larceny, and on the trial it appeared that she had loaned $\$ 200$ to M. Dorsey, taking his note therefor, in the presence of prosecutor Patrick, his son; that the money was invested in a shop by Patrick; that his father soon died, leaving no will; that no administration was had, but Patrick took all the property, and went to Connecticut to live; that about four years after the loan was made, Patrick passed the night at a house where defendant then was; that, before going to bed, he counted out his money on a table near his bed; and that defendant, then being present, immediately took up the money, saying she had a right to it. that she had been looking for it a long time, now she had it, and she proposed to keep it. The court instructed the jury that if defendant took the money under an honest belief that she had a right to 
take that specific money in the way and under the circumstances she did, she would not be guilty of larceny, although in fact she may have had no such legal right. On exception by the state, the instruction was held to be correct. C. v. Stebbins, 8 Gray 492 , C. 83 .

(ling. Assiz, 1879.) Setting Fire to Furze growing on the common was held by LOPES, J., not to be within $24 \& 25$ Vict. c. 97 , $\$ 16$, "wilfully and maliciously" if defendant thought she had a right to do it. R. v. Twose, 14 Cox C. C. 327, 13. 283, C. 84,3 L. 581.

\section{\$5. "That the Defendant was an Infant."}

Age of Presumed Discretion. "It is clear that an infant above 14 and under 21 is equally subject to capital punishments, as well as others of full age; for it is presumptio juris, that after 14 years they are doli capaces, and can discern between good and evil; and if the law should not animadvert upon such offenders by reason of their nonage, the kingdom would come to confusion." 1 llale P. C. 25 .

(Eng. Assize, 1338.) Evidence of Discretion-Effect. A girl of 13 years of age was burnt because while she was servant to a wornan she killed her mistress: and it was found to be so and adjudged treason. And it was saicl that by the old law no one under age wass hung, or suffered judgment of life or limb. But SPIGURNEL found that an infant of 10 years of age killed his companion and concealed him; and he caused him to be hung, because by the concealment he showed that he knew how to distinguish between evil and good. And so malice makes up for age. Anon., Horwood's Year Book, $11 \& 12 \mathrm{Edw}$. 3, p. 626, Mi. 2j2, Lib. Ass. Ann. 12, f. 37, pl. 30, Brooke Abr. Corone 74, Fit\%. Abr. Corone 170, Ke. 41.

(Eng. C. C. R., 1486.) Same-Purpose of Punishment. An infant of the age of 9 years killed another of 9 years and confessed. And it was also found that when he had done it he hid himself and also excused the blood on his clothes by saying he had nose bleed. And they held that he should be hung. FAIRFAX, J., said that it was said by Sir John Fortesque that the reason of such hanging for murder was for an example to others that they should be treated the same. But if an infant or a man that had not discretion should kill a man they should not be hung; for no person of their discretion could set an example; and this note well. Anon. Y. B. 3 Hen. 7 , 1. pl. 4, Brooke Abr. Corone 133, Fitz. Abr. Corone 57, 1 Hale P. C. 26 . 
(Eng. C. C. R., 1748.) Same-Concealment. A boy of 10 was convicted before WILLES, C. J., at Bury assi\%, of murder of a girl of 5 years; but out of regard for the prisoner's tender years, the chicf justice respited execution to take the opinion of the judges. 'The boy and girl were parish children, left in care of a parishioner, who with his wife went to work early in the morning, leaving the children in bed together. When they returued the girl was missing; and the boy, on inquiry, said he had helped her on with her clothes but did not know where she had gone. On search, her body was found frightfully mangled and slightly buried in a dungheap near the house. At first the boy denied it; but being questioned, finally oried and said he did it and then washed the blood off his hands as well as he could, stating as his reason that she had fouled the bed (which proved false), and finally that the devil set him up to it. The judges having taken time to consider, agreed unanimously: 1, that the confessions of the boy repeated before the grand jury, before the magistrate after warning of the consequence, and again after being alone several hours, was competent to submit to the jury; and, 2 , that supposing the boy to have been guilty of the fact, there were so many circumstances which are indoubtedly tokens of what Isord Hale called mischievous discretion, that he was a proper subject for capital punishment; for it would be very dangerous consequence to have it thought that children may commit such atrocions crimes with impunity. The boy was finally pardoned, on condition of immediately entering the sea service. R. v. York, Foster C. I. 70, 1. Hale P. C. (1 $\Lambda$ m. ed.) 26 , editor's note, 1 Russell on Crimes 4, 1 13. \& II. 68-n.

(Ill. Sup. Ct., 1880.) Burden of Proof of Discretion. Appellant and his father indicted for murder. The father was found not guilty, because insane, and appellant convicted. Motion for new trial was denied. WALKER, J. * * * The statute has provided (Crim. Code, §282) that a person shall be considered of sound mind who is neither an idiot nor lunatic, nor affected with insanity, and who has arrived at the age of fourteen, or before that age if such person knows the distinction between good and evil. The $283 d$ section provides that an infant under ten years of age shall not be found guilty of any crime or misdemeanor. * * There is imeontradicted evidence in the record that plaintiff in error was little more than eleven years of age when the homicide was committed. This evidenee was not contradicted, but was virtually conceded by the eighth instruction asked and given for the people. If this was true, and the evidence tended to prove it, the rule required evidence strong and clear beyond all doubt and contradiction. that he was capable of discerning between gond and evil: and the legal presumption heing that he was incapable of committing the crime, for want of such knowledere, it devolved on the people to make the strong and clear proof of enpacity, before they could be entitled to a eonviction. 
This record may be searehed in vain to find any such proof. There was no witness examined on that question, nor did any one refer to it. There is simply evidence as to his age. For alught that ap. pear's, he may have been dull, weak, and wholly incapable of know. ing good from evil. It does not appear, from even the circum. stances in evidence, that he may not have been mentally weik for his age, or that he may not have even approached idlocy. 'The law presumes that he lacked mental capacity at his age, and that pre. sumption has not been overcome by the requisite proof, or, in fact, any proof. 'The court below should, therefore, have granted a new trial, and erred in refusing it. Reversed. Angelo v. P., 96 IIl. 209. 36 Am. Rep. 132, Kn. 34, 3 L. 123.

(Mo. Sup. Ct., 1886.) Same. Defendant, a boy under 14, was convicted of assault. Becoming involved in a school-boy scuifle, result. ing in a fight, he cut one of the boys with a pocket linife. "Under seven years of age an infant cannot be guilty of felouy. In the inter. val between that age and that of $\mathbf{1 4}$ years he is prima facie adjudged to be doli incapax. And when an infant is arraigned for a felony; this disputable presumption of the law, for the onus in such eases is on the state, is to be rebutted; and the evidence of that malice which is to supply age ought to be strong and clear, beyond all doubt and contradiction. $4 \mathrm{Bl}$. Comm. 24. In this way only cin the legal maxim be applied that malitia supplet aetatem. Ilere there was no attempt made by the state to prove that the boy in question was possessed of that 'mischievous discretion' which supplies the place of age, and rendered him amenable to legal punishment. This case, therefore, falls within the rule announced in S. v. Adams. i6 Mo. 355." Per SIIERWOOD. J. .Judgment reversed. S. v. Tice, 90 Mo. 112, 2 S. W. 269, F. 65.

(Mich. Sup. Ct., 1886.) CAMPBELL, C. J. Todd, who was a minor, was prosecuted criminally for not supporting his wife, and making her a public burden, while he was of sufficient ability.

* Upon a careful scrutiny of the testimony we discover no legal testimony tending to show that respondent was emancipated, or that he owned any property. 'This is a fatal defect, and the attention of the court below was called to it. **** Respondent discharged. P. v. Todd, 61 Mich. 234,28 N. W. 79.

(Minn. Sup. Ct., 1893.) Boys of 15 Convicted of Placing Obstruc. tions on Railway Track. GILFILLAN, C. J. * * * Their own testimony, that they did not know it was wrong to put the ties on the track, and did not know that the ties might throw the train off the track and injure the passengers, did not, in the absence of any evidence upon the question of their general mental capacity, raise any issue as to their responsibility for their acts, for the jury to pass on. It did not tend to prove either of them to have been an 
idiot, imbecile, lumatic, or insune person. ** * There was no error, therefore, in the charge of the court or in its refusals to charge. S. v. Kluseman, $533 \mathrm{Minn} .541,5 \mathrm{j}$ N. IV. 741.

(N. Car. Sup. ('t., 1895.) Simple Misdemeanor. 'I'he state appealed from judgment dismissing defendant on indictment for gambling by "shooting craps." Defendant was 13 years old. FAIRCLO'III, C. J. * * Our case presents the question of a simple misclemeanor by one who. the jury say, knew right from wrong, but did not know he was violating any law, and presumably had no intention of committing any offense. Amoug persons of full age ignorance of the law is no excuse, nor is the absence of any intent to violate it available as a defense; but it is the intent to do an act which is a violation of law that makes the actor guilty. In our examination of the early eriminal law books, such as Blackstone, Russeli, Hale, and Wharton, we have been unable to find an instance in which, for a simple misdemeanor, unattended with aggravating ircumstances, such as the above, an infant under 14 yeurs had been indieted and punished. All the cases treated hy those witers are felonies. * * No error. S. v. Yeargan, 117 N. Car. 706, 2:3 S. L. 1333,36 L. R. A. 196.

Attempted Rape' by bos under 14 year's old, see c. r. Green, $\$$ fie: lioster v. C., \$ 62 : Ir kinny s. s.. s 6:2: anil s. v. Jones, \& 02 .

\section{$\$ 56$. "That the Defendant was Idiotic or Demented."}

(Comn. Superior Ct., 1873.) Imbecility. Indictment for burning a barn, and plea of not guilty. Lack of mental capacity was the defense. SEYMOUR, J., to the jury: 'The evidence seems ample to warrant you in finding that the burning complained of was caused by the prisoner. Your attention has been turned mainly to the question whether the act was done with the felonious intent charged, ind this question depends mainly upon another, whether the accused has sufficient mental capacity to warrant us in imputing to him a felonious intent. 'That he is considerably below par in intellect is upparent to us all. This is indicated by his conntenance and gencial appearance. The same thing is indicated by his extraordinary conduct at the fire. As the flames were bursting out he was seen on all fours crawling back from under the burning barn, with no clothing upon him except his shirt and trousers. The day was excessively cold. He remained some half hour, thus scantily clothed, gazing stupidly at the blaze, until ordered into the house. All this took place in broad daylight, in plain view of MIr. Gallup's house. But it is undoubtedly true, as the attorney for the state contends, that mere inferiority of intellect is no answer to the prosecution. We are, therefore, called upon in this case to decide an interesting and difficult question, to-wit: whether the accused has sufficient mind to be held responsible as a criminal. *** He is not a 
mere idiot, nor does he appear to be a lunatic. He suffers from want of mind rather than from derangement or delusion, and the question is whether the want of mind is such as to entitle him to acquittal on the ground of what in law is termed dementia. * * It is often said in the books that a person is to be deemed responsible for crime if he understands the consequences and effects of the act laid to his charge. 'I'his is undoubtedly and obviously true if he has such understanding and appreciation of consecuences as per. tain to other men. But if he has less of it than is common to men in general, how much less must it be to escape responsibility? I think the atecused had some knowledge of the consequences of lis acts. He probably knew that by igniting a mateh and throwing it into a hay-mow a fire would be kindled and that the barn would therehy be consumed. He perhaps also had some appreciation of the loss and destruction of property which would ensue. But I am not willing to say that some knowledge of consequences, however faint and imperfect, is sufficient to warrant you in convicting the prisoner. I can give you no precise rule, but I think it clear that if the prisoner's pereeption of consequences and effects was only such as is common to children of tender years he ought to be acquitted. And this leads me to refer to the rule adopted by an eminent English judge, Lord Hale. He reasoned that, inasmuch as children under fourteen years of age are prima facie incapable of crime, imbeciles ought not to be held responsible eriminally unless of capacity equal to that of ordiuary children of that age.

I am inclined to recommend Lord Hale's rule to your adoption, not however without qualifications which I think it important to observe. And tirst, this test, like all others which I know of, is imperfect. Probably no two of us have the same idea of the capacity of children of 14 years of age; and then there is this further difficulty. that there can be no accurate comparison in detail between the healthy and properly balanced, though immature, mind of a child. and the unhealthy, abnormal, and shriveled intellect of an imbecile. The comparison, therefore, is only of the general result in their respective appreciation of right and wrong and of consequences and effects. 'This further consideration ought also to be borne in mind: that though in modern times persons under 14 are seldom subjected to the penalties of the criminal code, yet in law children between 7 and 14 may be subjects of punishment if they are shown to be of sufficient capacity to commit crimes. In applying Lord Hale's rule, therefore, the child to be taken as the standard ought not to be one who has had superior advantages of education, but should rather be one in humble life, with only ordinary training. *** Verdict, not guilty. S. v. Richards, 39 Conn. 591, B. 238. 


\section{§57. "That the Defendant was Intoxicated."}

(Eng. Assize, 1823.) Rape When Drunk. The prisoner being indicted for rape, urged that he was in liquor. HOLROYD, J., addressed the jury as follows: "It is a maxim of law that if a man gets himself intoxicated, he is answerable to the consequences, and is not excusable on account of any crime he may commit when infuriated by liquor, provided he was previously in a fit state of reason to know right from wrong. If, indeed, the infuriated state at which he arrives should continne and become a lasting malady. then he is not amenable." Burrow's Case, 1. lewin (\%. C. T).

(U. s. c. C., for Mlass., 18:8.) Homicide During Delerium Tremens. Drew was indieted for the murder of C. L. Clark on the high seas, on board the Jolnn Jay, of which Drew was cantain and Clark second mite. Drew had been in the habit of excessive indulgence in drink, and was almost continually drunk. About five days before the homicide, he ordered all liquor on board thrown over, which was done. Soon he became restless, fretful, irritable, expressed fear that the erew intended to murder him, complained of persons unseen talking to him and urging him to kill Clark, teared he would do so, could not sleep, was in motion continually day and night, and said persons threatened to kill him every time he laid down unless he killed Clark. STORY. J. We are of opinion that the indictment upon these admitted ficts caunot be maintained. 'The prisoner was unquestionably insane at the time of eommitting the offense. And the question made at the bar is, whether insanity, whose remote cause is habitual drunkenness is, or is not, an excuse in a court of law for a homicide committed by the party, while so insane, but not at the time intoxicated or under the influence of liquor. We are clearly of opinion that insanity is a competent excuse in such a cease. In general, insanity is an excuse for the commission of every crime, because the party has not the possession of that reason, which includes responsibility. $\mathrm{An}$ exception is, when the crime is committed by a party while in a fit of intoxication, the law not permitting a man to avail himself of the excuse of hi. , own gross vice and misconduct, to shelter himself from the legal consequences of such crime. But the crime must take place and be the immediate result of the fit of intoxication, and while it lasts; and not, as in this case, a remote consequence, superinduced by the antecedent exhaustion of the party, arising from gross and habitual drunkenness. However criminal in a moral point of view such an indulgence is, and however justly a party may be responsible for his acts arising from it to Almighty God, human tribunals are generally restricted from punishing them, sinee they are not the acts of a reasonable being. Had the crime been committed while Drew was in a fit of intoxication, he would have been liable to be convicted of murder. As he was not then intoxicated, but merely insane 
from an abstinence from liquor, he cannot be pronounced guilty of the offense. 'The law looks to the immediate, and not to the remote cause. Verdict, not guilty. U. S. v. Drew, 5 Mason 28 , F'ed. Cas. No. $14,993,1$ B. \& H. 113, 2 L. 601.

Ac.c. R. v. Davis, 14 Cox U. U. 563, B. 262, C. 81 .

(Gia. Sup. Ct., 1860.) Dipsomania. Defendant convicted of mur. der, excepted to the refusal of the cuurt below to instruct the jury that if they believed the prisoner had sufiered from injury or other. wise a pathological or organic change of the brain, which produced the disease of oenomania, and by this disease was irresistibly im. pelled to drink liquor, and from the liquor thus drank became insane, and while so insane killed deceased, he was not guilty of murder. In speaking for the court in holding this instruction properly re. fused, LUMIFliN, J., said: 'That this controlling thirst for liquor may be acquired by the foree of habit, until it becomes a sort of second nature, in common language, 1 entertain no doubt. Whether even a long course of indulgence will produce a pathological or organic change in the brain, I venture no opinion. Upon this prop. osition, however, 1 plant myself immovably, and rrom it nothing can dislodge me but an act of the legislature; namely, that neither moral nor legal responsibility can be avoided in this way. 'Thes is a new principle sought to be ingrafted upon criminal jurisprudence. It is neither more nor less than this-that a want of will and conscience to do right will constitute an excuse for the commission of crime; and that, too, where this deficiency in will and conscience is the result of a long and persevering course of wrong doing. If this doctrine be true-1 speak it with all seriousness-the devil is the most irresponsible being in the universe. For, from his inveterate hostility to the Author of all good, no other creature has less power than Satan to do right. 'The burglar and the pirate may induige in robbing and murder until it is as hard for an Ethiopian to cinange his skin as for them to cease to do evil, but the inabiiity of Salan to control his will, to do right, is far beyond theirs; and yet our faith assures us that the fiate of Satan is unalterably and eternally tixed in the prison house of God's enemies. The fact is, respousibility depends upon the possession of will-not the power over it. Nor does the most desperate drunkard lose the power to control his will, but he loses the desire to control it. No matter how deep his degra. dation, the drunkard uses his will when he takes his cup. It is for the pleasure of the relief of the draught, that he takes it. Ilis intellect, his appetite, and his will, all work rationally, if not wisely, in his guilty indulgence. Choice v. S., 31 Ga. 424, B. 269, 2 L. 539.

(New York Ct. of App., 1858.) To Reduce Crime. 'The supreme court reversed the judgment of the general sessions, where Rogers was convicted of murder. The state brings error. The prisoner, without any provocation on the part of the deceased, who was a 
stranger to him, came upon him and stabbed him to the heart with a kmife. He excepts to the court's charge and refusal to charge, on the efiect of drunkemness as a defense. DENIO, J. *** In the forum of conscience there is no doubt considerable difierence between a murder deliberately plamed and executed by a person of unelouded intellect, and the reckless taking of life by one infuriated by intoxication; but human laws are based upon eonsiderations of policy, and look rather to the maintenance of personal security and social order than to an accurate diserimination as to the moral qualities of individual conduct. But there is, in truth, no injustice in holding a person responsible for his acts committed in a state of voluntary intoxication. It is a duty which every one owes to his fellowmen and to society, to say nothing of more solemu obligations, to preserve, so far as it lies in his own power, the inestimable gilt of reason. * * HARRIS, J. * There was evidence to show that, when he struck the deally blow, the defendant was intoxicated; and the court was asked to charge the jury that, " if it appeared by the evidence that the condition of the prisoner from intoxieation was such as to show that there was no intention or motire, by reason of drunkeuness, to commit the crime of murder, they should convict him of manslaughter." 'The court refused so to charge, but, upou this point, instructed the jury "that intoxication never excused erime, unless it was of such a dearee as to deprive the offender of his reasoning faculties." In the proposition, as it was thus given to the jury, there was no error. * "The supreme court seem to have understood that, in all cases where, without it, the law would impute to the act a criminal intent, drunkenness may be available to disprove such intent. I am not aware that such a doctrine has before been asserted. It is certainly unsound. The adjudications upon the question, both in England and this country, are very mumerous, and are chalacterized by a singular uniformity of language and doetrine. They all agree that, where the act of killing is mequivocal and morovoked. the fact that it was committed while the perpetrator was intoxicated cannot be allowed to affect the legal character of the erime. But when the circumstanees are such as to raise the question whother the act was the result of design or the impulse of sudden patssion, the intoxication of the accused is a proper subject of consideration. * * Judgment of the supreme court reversed and the conviction affirmed. P. v. Rogers, 18 N. Y. 9, 72 Am. Dec. 484. B. 264. F. 99. 2 L. 6\%:.

(Ga. Sup. Ct.. 1893.) By Fraud of Others-Voting Twice. Appellant was convicted of voting twice at a primary election. One defense is that he was drunk. LUMPKIN, .T. *** If certain persons had given MeConk whiskey. and made him drunk, for the purpose of "voting him" unlawfully. and had carried ont this purpose, they and not he would have been guilty: and this. in eff'ect. the court charged. The court, however, qualified this charge and. 
we think, did so properly, by further instructing the jury, in sub. stance, that if other persous gave him drink in a social way, and with no view or purpose at the time to vote him unlawfully, and they after'wards did so while he was drunk, he would be guilty.

Affirmed. 'McCook v. S., 91 Ga. 740, 17 S. E. 1019. Kn. 79.

(Eng. Assize, 1835.) Wife Murder. The prisoner was indicted for the murder of his wife. It was proved that in a fit of drunken. ness he had beaten her in a cruel manner with a rake-shank, and that she died of the wounds and bruises which she received. His only defense was that he was drunk. PARK, J. Voluntary drunkenness is no excuse for crime. If a party be made drunk by strata. gem or the fraud of another he is not responsible. So drunkenness may be taken into consideration to explain the probability of a party's intention in the case of violence committed on sudden provo. cation. Pearson's Case, 2 Lewin 14t, 13. 261, C. 77.

(Eng. Assize, 1837.) Provocation. Malicious stabbing. The person stabbed had struck the prisoner twice with his fist, when the latter, being drunk, stabbed him, and the jury were charged by PARKE, B.: Drunkenness may be taken into consideration in cases where what the law deems sufficient provocation has been given, because the question is, in such cases, whether the fiatal act is to be attributed to the passion of anger, excited by the previous provocation, and that passion is more easily excitable in a person when in a state of intoxication than when he is sober. $R$. $v$. Thomas, 7 Car. \& P. (32 E. C. L.) 817.

(Mass. Sup. Judicial Ct., 1855.) Same-Melee. Indictment of Hawkins and Hicks for murder of Leet. 'The evidence was that, after insulting words had passed between Leet and Hawkins, who was somewhat under the influence of strong drink, they fought with their fists; and while they were fighting, Hicks struck Leet on the head with a pewter pitcher, and Leet knocked IIawkins down and struck him after he was down; and that a few minutes later (the evidence varying between eight minutes and a quarter of an hour), while Leet was washing the blood from the cut made by the piteher, Hawkins came behind him and stabbed him in the heart with a dirk knife, of which wound he died. The defendant's counsel did not controvert these facts; but contended that the blow with the linife was struck in the heat of blood, under the violence of passion excited by the previous combat and beating; and that the defendant was guilty of manslaughter only. SHAW, C. J. (to the jury): The rule of law is, that although the use of intoxicating liquors does to some extent blind the reason and exasperate the passions, yet, as a man voluntarily brings it upon himself, he cannot use it as an excuse or justification or extenuation of crime. A man, because he is intoxicated, is not deprived of any legal advantage or protection; but he 
cannot avail himself of his intoxication to exempt him from any legal responsibility which would attach to him, if sober. Verdict, guilty of manslaughter. C. v. Hawkins, 3 Gray 463, C. 79.

(Eng. Assize, 1836.) Presuming Malice from Acts. Indictment for stabbing with intent to murder. ALDERSON, B. (to the jury) : * * It is my duty to tell you that the prisoner's being intoxicated does not alter the nature of the oftense. If a man chooses to get drunk, it is his own voluntary act; it is very different from a maduess which is not caused by any act of the per'son. That voluntary species of madness which it is in a party's power to abstain from, he must answer for. However, with regard to the intention, drunkenness may perhaps be adverted to, according to the nature of the instrument used. If a man uses a stick, you would not infer a malicious intent so strongly against him, if drunk, when he made an intemperate use of it, as you would if he had used a different. kind of weapon; but when a dangerous instrument is used, which, if used, must produce grievous bodily harm, drunlicmness can have no eftect on the consideration of the malicions intent of the party. R. v. Meakin, 7 Car. \& P. (32 F. C. L.) 297, Ke. jt.

(S. Carr. Ct. of App. and Lirrors, 1842.) Premeditation. Defendant was convicted of murder. Deceased and two others found him lying in the road at night, and taking him for one of their company, roused him, for which he was very angry, cursed, demanded a fight, would take no appology, was given the fight and beaten till he begged, was released, drew his knife, swore he would gut deceased, who was unarmed, pursued him 225 yards, met and stabbed him to the heart. Complaint is made of the court's charge that intoxication was not a fact to consider on the question of premeditation. WARDLAW, J. * * * So far as previous habits of drunkenness may have wrought a permanent intluence upon the eonstitution, such influence will be involved in the consideration of the other circumstances, but the direct effect of existing intoxication, however maddening or stupefying, must be laid out of view. 'The question is, was there time for a reasonable man, in like circumstances, to have cooled, not a drunkard or a madman; and it is to this view that the third ground of appeal excepts, for the report shows that while the intoxication, if found to be proved, was submitted as a matter fit for consideration upon the question whether the prisoner acted from a former grudge, or in sudden heat upon new provocation, it was declared to be unfit for consideration in deciding whether there was reasonable time for cooling. Affirmed. S. v. McCants, 1 Spear 384. F. 197, 2 I. 722, Mi. 621.

(Ohio Sup. Ct., 1846.) Proof Relevant-Realization of Act-Passing Counterfeit. Appellant was convicted of passing a counterfeit bank bill, and excepted to the ruling of the court excluding evidence 
that he was drunk at the time. READ, J. Drunkenness is no excuse for crime; yet, in that class of crimes and offenses which depend upon guilty knowledge, or the coolness and deliberation with which they shall have been perpetrated, to constitute their commis. sion, or tix the degree of guilt, it should be submitted to the consid. eration of the jury. If this act is of that nature that the law requires it should be done with guilty knowledge, or the degree of guilt depends upon the calm and deliberate state of the mind at the time of the commission of the act, it is proper to show any state or concli. tion of the person that is adverse to the proper exereise of the mind, and the undisturbed possession of the faculties. person was so drunk that he actually did not know that he had passed a bill that was counterfeit, he is not guilty. It oftentimes requires much skill to detect a comnterfeit. 'The erime of passing counterfeit mones, consists of knowingly passing it. 'T'o rehut that knowledge, or to enable the jury to judge rightly of the matter, it is competent for the person eharged to show that he was drunk at the time he passed the bill. It is a circumstance, among others, entitled to its just weight. Judgment reversed. Pigman v. S., $1 t$ Ohio 555, 45 Am. Dec. 558, Kn. 77, 2 I. 720.

(Fng. Assize, 1854.) Same-Suicide. Indictment for attempted suicide. WIGH'TMAN, J., told the jury that the offense charged constituted, beyond all doubt, a misdemeanor at common law. The question for them to consider was whether the prisoner had a mind capable of contemplating the act charged, and whether he did, in fact, intend to take away his life. The prisoner alleged in lis defense that he was drunk at the time, which must be taken to mean that he had no deliberate intention to destroy his life; for the mere fact of drunkenness in this, as in other cases, is not of itself an excuse for the crime, but it is a material fact in order to arrive at the conclusion whether or no the prisoner really intended to destroy his life. Verdict, guilty. R. v. Doody, 6 Cox C. C. 463, B. 261, C. 79.

(Eng. Assize, 1858.) Appreciating Situation-Affray at a Fair. All drunk, defendant was charged with assault. CROWDER, J. Drunkenness is no excuse for crime; but in considering whether the prisoner apprehended an assault on himself, you may take into account the state in which he was. Not guilty. R. v. Gamlen, 1 F. \& F. 90, B. 262 , C. 79, Ke. 54 .

(U. S. Sup. Ct., 1881.) As to Deliberation. Defendant was convicted of murder in the first degree under the Utah territorial statute, which is defined to be any kind of wilful, deliberate, mali. cious, and premeditated killing. He complained of the court's refusal to charge that the jury should consider the intoxication of the accused as bearing on the question of deliberation, and of the charge given, that "intoxication is so casily comterfeited, and when real 
is so often resorted to as a means of nerving a person up to the commission of some desperate act, and is withal so inexeusable in itself, that the law has never recognized it as an excuse for crime." GRAY, J. ** * At common law, indeed, as a general rule, voluntary intoxication affords no excuse, justification, or extenuation of a crime committed under its influenee. U. S. v. Drew, 5 Mason 28 [\$57]; U. S. v. MeGlue, 1 Curt. 1; C. v. Hawkins, 3 Gray 463 [\$5i] ; P. v. Rogers, 18 N. Y. $9\lfloor\S 5 T$ ]. But when a statute establishing different degrees of murder requires deliberate premeditation in order to constitute murder in the first degree. the question whether the accused is in such a condition of mind, by reason of drunkenness or otherwise, as to be calpable of deliberate premeditation, necessarily beeomes a material suhject of eonsideration by the jury. 'The law has been repeatedly so ruled in the supreme judicial court of Ilassachusetts in calses tried bofore a full eourt, one of which is reported upon other points ( $\therefore$. V. Dorsey, 103 Masss. 412); and in well considered cases in courts of other states. Pirtle v. S., 9 Humpl. ('l'enn.) 663; Ilatile v. S., 11 Id. 15t; Kelly v. C., 1 Grant (Pa.) Cas. t84; Licenan v. C., 44 Pa. St. 5̄ं; Jones v. C., ij Id. 403; P. v. Belencia, 21 Cal. 5t4; P. v. Williams, $43 \mathrm{Id}$. 34t; S. v. Juhnson, 40 Comn. 136, and $41 \mathrm{Id}$. 58t; Pigmin v. S., 14 Ohio 5j5, 557 [above]. And the same rule is expressiy enacted in the Penal Code of Utah, $\$ 20$ : "No act committed by a person while in a state of voluntary intoxication is less eriminal by reason of his having been in such condition. But whenever the actual existence of any particular purpose, motive, or intent is a necessary element to constitute any particular species or clegree of crime, the jury may take into consideration the fact that the accused was intoxicated at the time, in determining the purpose. motive, or intent with which he committed the act." Com. Laws Utah (1876), pp. 568, 569. 'The instruction requested by the defendant clearly and accurately stated the law applicable to the case; and the refusal to give that instruction, taken in connection with the unqualified instruction actually given, necessarily prejudiced him with the jury. * * * New trial ordered. Hopt v. P., 104 U. S. 631, C. 78, Kn. 166, 2 L. 60 .t.

(Mich. Sup. Ct., 1878.) Specific Intent-Larceny. COOLEY, J. The defendant was convicted in the court below for the lateeny of a sum of money from one Martin. All the evidence in the calse tended to show that if the defendant took the money wrongfully, it was while he was under the influence of liquor, and some of it indicated that he was very drunk. The circuit judge was requested to charge the jury, that, "even if the jury should believe that defendant was intoxicated to such an extent as to make him unconscious of what he was doing at the time of the commission of the alleged offense, it is no excuse for him, and they should not take it into consideration. A man who voluntarily puts himself in condition to have no control of his actions must he held to intend the 
consequences." 'This eharge was given in lediance upon the general principle that clrunkemness is no exeuse for crime. While it is true that drunkenness cammot exeuse crime, it is equally true that when a certain intent is a necessiary element in a crime, the crime cinnot have been committed when the intent did not exist. In lareeny the crime does not consist in the wrongful taking of the property, for that might be a mere trespass; but it consists in the wrongful taking with felonious intent; and if the defendant, for any reason what ever, indulged no such intent, the crime cannot have been committed. 'This was fully' explained in Roberts v. P., 19 Mich. 401, and is familiar law. See also Nichols v. S., 8 Ohio St. 435 ; R. v. Moore, 3 C. \& K. 319. The circuit court should be advised to set aside the verdict and grant a new trial. P. v. Walker, 38 Mich, 156, 13. 27i.

('I'ex. Ct. of $\Lambda_{\text {ply., }}$ 1889.) Same-Intent to Rape. Pen. Code, art. 40a, provides that neither intoxication nor temporary insanity produced by the recent voluntary use of liquor shall constitute an excuse for crime, but that evidence of such temporary insanity may be shown in mitigation of the penalty, and, in cases of murder, for the purpose of determining the degree. Held, that, where a specific intent is necessialy to the commission of a crime (in this case assault with intent to rape), the statute does not eliminate that element; and, in determining the existence of such intent, the jury should be allowed to consider the mental condition of the accused, and the fact that he was intoxicated at the time of the alleged commission. Con.

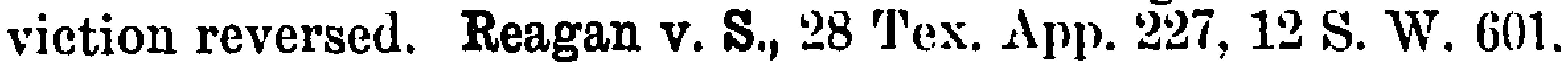

\section{- \$58. "That the Defendant was Insane."}

(Eng. House of Lords Question Judges, 1843.) Leading English Case-Right and Wrong Test. One M'Naghten was tried for killinc a Mr. Drummond, private secretary of Sir Robert Peel, mistaking him for the premier himself. He was acquitted on the ground of insinity, and his acquittal caused so much excitement that the house of lords addressed certain questions to the judges of the superior courts of England in regard to the law of insanity in certain cases. Accordingly the judges attended the house of lords; when, without any argument, the questions of law were propounded to them; and the opinion of all the judges except Maule, J., was delivered by LORD I'INDAL, C. J. *** 'The first question proposed by your lordships is this: "What is the law respecting alleged crimes committed by persons afflicted with insane delusion in respect of one or more particular subjects or persons; as, for instance, where at the time of the commission of the alleged crime the accused knew he was acting contrary to law, but did the act complained of with a view, under the influence of insane delusion, of redressing or reveng. ing some supposed grievance or injury, or of producing some sup. 
posed public benefit?" In answer to which question, assuming that your lordships' inquiries are confined to those persons who labor under such partial delusions only, and are not in other respects insane, we are of opinion that, notwithstanding the party accused did the act complained of with a view, under the influence of insane delusion, of redressing or revenging some supposed grievance or injury, or of producing some public benefit, he is nevertheless punishable according to the nature of the crime committed, if he knew at the time of committing such crime that he was acting contrary to law; by which expression we understand your lordships to mean the law of the land. Your lordships are pleased to inquire of us, secondly : "What are the proper questions to be submitted to the jury, where a person alleged to be aftlicted with insane delusion respecting one or more particular subjects or persons is charged with the commission of a crime (murder, for example), and insanity is set up as a defense?" And, thirdly: "In what terms ought the question to be left to the jury as to the prisoner's state of mind at the time when the act was committed?" And as these two quesions appear to us to be more conveniently answered together, we have to submit our opinion to be, that the jurors ought to be told in all cases that every man is to be presumed to be sane, and to possess a sufficient degree of reason to be responsible for his crimes, until the contrary be proved to their satisfaction; and that to establish a defense on the ground of insanity, it must be clearly proved that, at the time of the committing of the act, the party accused was laboring under such a defect of reason, from disease of the mind, as not to know the nature and quality of the act he was doing; or, if he did know it, that he did not know he was doing what was wrong. The mode of putting the latter part of the question to the jury on these occasions has generally been, whether the accused at the time of doing the act, knew the difference between right and wrong; which mode, though rarely, if ever, leading to any mistake with the jury, is not, as we conceive, so accurate, when put generally and in the abstract, as when put with reference to the party's knowledge of right and wrong in respect to the very act with which he is charged. If the question were to be put as to the knowledge of the accused solely and exclusively with reference to the law of the land, it might tend to confound the jury, by inducing them to believe that an actual knowledge of the law of the land was essential in order to lead to a conviction; whereas the law is administered upon the principle that every one must be taken conclusively to know it, without proof that he does know it. If the accused was conscious that the act was one which he ought not to do, and if that act was at the same time contrary to the law of the land, he is punishable; and the usual course therefore has been to leave the question to the jury, whether the party accused had a sufficient degree of reason to know that he was doing an act that was wrong; and this course we think is correct, accompanied with such observations and explanations as 
the circumstances of each particular case may require. 'The fourth question which your lordships have proposed to us is this: "If a per'son under an insane delusion as to existing facts, commits an offense in consequence thereof', is he thereby excused"' 'To which question the answer must of eourse depend on the nature of the delusion; but making the same assumption as we did before, namely, that he labors under such partial delusions only, and is not in other respects insune, we think he must be eonsidered in the same situation as to responsibility as if the facts with respect to which the delusion exists were real. For eximple, if under the influence of his delusion he supposes another man to be in the act of attempting to take away his life, and he kills that man, as he supposes, in self-defense, he would be exempt from punishment. If his delusion was that the deceased had inflicted a serious injury to his chantacter and fortume, and he killed him in revenge for such supposed injury. he would be liable to punishment. M'Naghten's Case, 10 Clark \& Win. 200.8 Sentt ( $\mathrm{N}$. R.) 595, 1 Car. \& K. 130, B. 231. Ke. 43, 2 L. 150, Mi. 256.

(Mass. Sup. Judicial (t., 184t.) Same-A Leading American Case. Defendant killed the warden of the prison in which he was eontined. 'The evidence tended to show that he was impelled to the act by a baseless notion that the warden was about to confine him in a dark room alone. 'The only defense was insanity. SIIAW, C. J., said to the jury: "In these cases, the rule of law, as we understand it, is this: I man is not to be excused from responsibility, if he has eapacity and reason sufficient to enable him to distinguish between right and wrong as to the particular act he is then doing,-al knowledge and consciousuess that the act he is doing is wrong and eriminal, and will subject him to punishment. In order to be responsible. he must have sufficient power of memory to recollect the relation in which he stands to others, and in which others stand to him; that the act he is doing is contrary to the plain dictates of justice and right. injurious to others, and a violation of the dictates of duty. On the contrary, although he may be laboring under partial insanity, if he still understands the nature and character of his act, and its consequences; if he has a knowledge that it is wrong and criminal, and a mental power sufficient to apply that knowledge to his own case, and to know that, if he does the act he will do wrong and receive pun. ishment.- such partial insanity is not sufficient to exempt him from responsibility for eriminal acts. If, then, it is proved. to the satisfaction of the jury, that the mind of the accused was in a diseased and unsound state, the question will be whether the disease existed to so high a degree that for the time being it overwhelmed the reason, conscience, and judgment. and whether the prisoner, in committing the homicide. acted from an irresistible and uncontrollable impulse. If so, then the act was not the act of a voluntary agent, but the involuntary act of the body, without the concurrence of a mind directing it. The character of the mental disease relied upon to 
excuse the accused in this case is partial insanity, consisting of melancholy, accompanied by delusion. 'The conduct may be in many respects regular, the mind acute, and the conduct apparently governed by rules of propriety, and at the same time there may be insane deiasion by which the mind is perverted. 'l'he most common of these eases is that of monomanial, when the mind broods over one idea and cannot be reasoned out of it. 'This may operate as an exense for a criminal act in one of two modes: 1 . Either the delusion is such that the person under its influence has a real and firm belief of some fiact, not true in itself, but which, if it were true, would exense his act.-as where the belief is that the party killed had an immediate design upon his life, and moler that belief the insane man lills in supposed self-defense $\quad * \quad$ *. Or this state of delusion indieates to an experienced person that the mind is in a diseased stite; that the known tendency of that diseased state of the mind is to break out into sudden paroxysms of violence, venting itself in homicide or other violent acts towards firiend or foe indiscriminately ; so that, although there were no previous indications of: violence, yet the sulsequent act, eomecting itself with the previous symptoms and indications, will enable an experienced person to say that the outbreak was of such a character that for the time being it must have overborne menory and reason; that the act was the result of the disease and not of a mind capable of choosing; in short, that it was the result of uncontrollable impulse, and not of a person acted upon by motives, and governed by the will. 'The questions, then, in the present case, will be these: 1 . Was there such a delusion and hallucination? 2 . Did the accused act under a false but sincere belief that the. warden had a design to shut him up, and, under that pretext, destroy his life; and did he take this means to prevent it?" * * Verdict, not guilty. C. v. Rogers, 7 Mete. 500. 41 Am. Dec. 458. 1 B. \& II. $87-11$. B. 235.2 L. 158.

(New York, Sup. Ct., 1848.) Manifestations and Tests of Insanity. The defendant was convicted of murder of Mrs. Russell. The following is from the charge to the jury, by BARCULO, J. The qunstion of insunity, upon which this case turns, always invokes diticutt and intricate inquiries. It is a subject upon which much has been said and written by way of theory and speculation, and it cannot be denied that the numerous adjudications are not altogether reconcilable. Without detaining you with technical terms, it will be sufficient to say that insanity assumes a variety of forms, and has many names. Among these are: (1) general insanity' ; (2) partial insanity; (3) periodical insanity ; (4) moral insanity; (5) drunken insanity. The first is insanity applied to objects generally; the second is applied to single objects; the third occurs at periods with sane intervals; the fourth is a morbid perversion of the natural feelings, affections, etc.; and the fifth is that which results directly from intoxication. Now, the rules applicable to crimes committed in any of these 
degrees of insanity are mainly those of sound reason. 'Thus it is con. eeded to be the law that insunity occasioned directly by intoxication is no excuse for a erime committed by one in that state. If it were otherwise, a man by drinking to excess could divest himself of legal responsibility, and gratify his thirst for vengeance with im. punity. In regard to the other kinds of insunity, the rule is laid down in great variety of terms. 'The English rule is thus stated in Bellingham's Case by Chief Justice Mansfield: "In order to support the defense of insunity, it ought to be proved by the most distinct and unquestionable evidence that the prisoner was incapable of judging between right and wrong; that in fact it must be proved beyond all doubt that at the time he committed ihe atrocious act with which he stood charged he did not consider that murder was " crime against the laws of God and nature." As long as they could distinguish good from evil, they would be amenable for their conduct. Lord Lyndhurst, in $R$. v. Otford, put this question: "Did the prisoner know that in doing the act, he offended against the laws of God and man?" According to the Scotch rule, the insanity must be of such a kind as entirely to deprive the prisoner of the use of reatson, as applied to the act in question, and the knowledge that he was doing wrong in committing it. If, though somewhat deranged, he is able to distinguish right from wrong in his own case, and to know that he was doing wrong in the act which he committed, he is liable to the full punishment of his criminal acts. * * The Massachusetts rule is that, if the imaginary facts would, if true, justify the act, then he is excusable-as, when the prisoner supposed that the person was about to kill him, and he slays the other in self-defense. 'There must be an immediate apprehension of danger.

Applying this principle to the present case, if the prisoner really believed that Mrs. Russell was in the act of committing a great personal injury to him, and supposed that he shot her in self-defense, he would be excusable. But it would be no defense that he supposed Russell or his wife had injured him to any extent, because, if it were true, it would be no justification of the act. If a breach of promise or anything of that kind was the origin of the act, and this was done by way of revenge, he is not excusable. A simple and sound rule may be thus expressed: A man is not responsible for an act when, by reason of involuntary insanity or delusion, he is at the time incapable of perceiving that the act is either wrong or unlawful. ** * Verdict, guilty. Executed. P. v. Pine, 2 Barb. 566, F. 69, 2 L. 234.

(Eng. Assize, 1848.) Dread of Poverty and Destitution were the reasons assigned by the prisoner for killing his wife and children with whom he had always been on most affectionate terms. He had also attempted suicide. PARKE, B., told the jury that there was but one question for their consideration now; viz., whether 
at the time the prisoner inflicted the wounds which eaused the death of his wife, he was in a state of mind to be made responsible to the law for her murder. 'That would depend upon the question whether he at the time knew the nature and character of the deed he was committing, and if so, whether he knew he was doing wrong in so acting. 'This mode of dealing with the defense of insanity had not, he was aware, the concurrence of medical men; but he must nevertheless express his decided concur'rence with $\mathrm{Mr}$. Baron Rolfe's views of such cases, that learned judge having expressed his opinion to be that the excuse of an irresistible impulse, coexisting with the full possession of reasoning powers, might be urged in justification of every crime linown to the law,for every man might be said, and truly, not to commit any erime except under the influence of some irresistible impulse. ** * * Giuily. Sentence, death. Reprieved. R. v. Barton, 3 Cox C. C. 270 , C. 73 .

(Eng. Assi\%, 1863.) Desire to be Hanged. A youth of 18 was indicted for the murder of a boy. WIGHTMAN, J., to the jury: It was urged that the prisoner did the act to be hanged, and so was under an insane delusion; but what delusion was he under"? so far from it, it showed that he was quite conscions of the nature of the act and of its consequenees. Ile wats stuposed to desire to be hanged, and in order to attain the object committed murder. 'lhat might show a morbid state of mind but not delusion. Ilomicillal mania agrin, als described by the witnesses for the defense, showed no delusion. It merely showed a morbid desire for blood. Delusion meant the belief in what did not exist. 'I'he question for the jury was whether the prisoner at the time he committed the act was laboring under such a species of insanity as to be unaware of the nature, the character, or the consequences of the act he committed-in other words, whether he was incapable of knowing that what he did was wrong. If so, they should acquit him; if otherwise, they should find a verdict of guilty. Verdict. guilty. R. v. Burton, 3 F. \& F. 772, C. 75, Ke. 50, ¿ L. 310.

(Fing. Assize, at Winchester, 1859.) No Motive-Irresistible Impulse-Three Restraints-A IMuch Quoted Case. On trial of a soldier for murder of a woman he had seduced and promised to marry and always been friendly with, BRAMIWLL, B., said to the jury: "It has been urged for the prisoner, that you should acquit him on the ground that, it being impossible to assign any motive for the perpetration of the offense, he must have been acting under what is ealled a powerful and irresistible influence or lomicidal tendency. But I must remark as to that that the circunstance of an act being apparently motiveless is not a ground from which you can safely infer the existence of such an influence. Motives exist, unknown and innumerable, which might prompt the 
act. A morbid and restless (but resistible) thirst for blood would itself be a motive urging to such a deed for its own relief; but if an influence be so powerful as to be termed irresistible, so much the more reason is there why we should not withdraw any of the safeguards tending to counteract it. 'There are three powerful restraints existing, all tending to the assistance of the person who is suftering under such an influence-the restraint of religion, the restraint of conscience, and the restraint of law. But if the influ. enee itself be held a lemal excuse, rendering the crime dispunish. able, you at once withdraw a most powerful restraint-that forbidding and punishing its perpetration. We must therefore return to the simple question you have to determine-Did the prisoner know l'o nature of the act he was doing; and did he know that he was iring what was wrong"?" Guilty. Sentence, death. Reprieved. R. v. Haynes, 1 Foster \& Fin. 666. B. 234, C. 76, Ke. 52, 2 L. 309.

(New York Ct. of $\Lambda_{p p}$., 1873.) Danger of Irresistible Impulse. Defendant, convicted, excepted to the refusal to charge and to the charge given as to what constitutes insanity to make out a defense. The charge given was in the language of 'Tindal, C. J., in the M'Naghten Case. In affirming the judgment below, the court, per $\triangle$ NDREWS, J., said: "It must be regarded as the settled law of this state, that the test of responsibility for eriminal acts, where unsoundness of mind is interposed as a defense, is the eapacity of the defendant to distinguish between right and wrong at the time of and with respect to the act which is the subject of the inquiry. We are asked in this case to introduce a new element into the rule of eriminal responsibility in cases of alleged insanity, and to hold that the power of choosing right from wrong is as essential to legal responsibility as the capacity of distinguishing between them: and that the absence of the former is consistent with the presence of the latter. The argument proceeds upon the theory that there is a form of insanity in which the faculties are so disordered and deranged that a man, though he perceives the moral quality of his acts, is unable to control them, and is urged by some mysterious pressure to the commission of acts, the consequences of which he anticipates but cannot avoid. Whatever medical or scientific authority there may be for this view, it has not been aceepted by courts of law. 'l'he vagueness and uncertainty of the inquiry which would be opened and the manifest danger of introducing the limitation claimed into the rule of responsibility in cases of erime, may well cause courts to pause before assenting to it. Indulgence in evil passions weakens the restraining power of the will and contscience; and the rule suggested would be the cover for the commis. sion of crime and its justification. The doctrine that a criminal act may be excused upon the notion of an irresistible impulse to commit it, where the offender has the ability to discover his legal 
and moral duty in respect to it, has no place in the law." Flanagan v. P., 52 N. Y. 467, 11 Am. Rep. 731, B. 241.

(Dist. of Col., Dist. Ct., 1882.) Kinds, Manifestations, and Effect of Insanity. The following is from the charge to the jury on the trial of Charles J. Guiteau for the assassination of President Garfield. COX, J. *** The defense of insanity has been so abused is to be brought into great discredit. It has been the last resort in calses of unquestionable guilt, and has been the excuse to juries for acquittal, when their own and the public sympathy have been with the accused, and especially when the provocation to homicide has 'scused it according to public sentiment, but not according to law. For these reasous, it is viewed with suspicion and disfavor, whenever public sentiment is hostile to the accused.

Nevertheless, if Insanity be Established to the degrees that has been already, in part, and will hereafter further be explained, it is a perfect defense to an indictment for murder, and must be allowed full weight. Now, it is first to be observed that we are not troubled in this ease with any question about what may be called total insanity, such as raving mania, or absolute imbecility, in which ill exercise of reason is wanting, and there is no recognition of persons or things, or their relations. But there is

A Debatable Border-line Between the Sane and the Insane, and there is often great difficulty in determining on which side of it a party is to be placed. There are eases in which a man's mental fiaculties generally seem to be in full vigor, but on some one subject he seems to be deranged. $H e$ is possessed, nerhaps, with a belief which every one recognizes as absurd, which he has not reasoned himself into, and cannot be reasoned out of, which we call an insane delusion, or he has, in addition. some morbid propensity, seemingly in harsh discord with the rest of his intellectual and moral nature. These are cases of what. for want of a better term, is called partial insanity. Sometimes its existence, and at. other times its limits, are doubtful and undefinahle. And it is in these cases that the difficulty arises of determining whethor the patient has passed the line of moral or legal accountability tor his nctions.

You Must Bear in Mind that a Man Does not Become Irresponsible by the Mere Fact of Being Partially Insane. Such a man does not take leave of his passions by becoming insine, and may retain as much control over them as in health. Te may commit offenses, too, with which his infirmity has nothing to do. He may be sane is to his crime, understand its nature, and be governed by the same motives in regard to it as other people; while on some other sulject, having no relation to it whatever, he may be sulject to some delusion. In a reported case, a defendant was convicted of. cheating by false pretenses. but was not saved from punishment by his insane delusion that he was the lawful son of a well-known 
prince. 'The first thing, therefore, to be impressed upon you is, that wherever this partial insanity is relied on as a defeuse, it must appear that the erime charged was the product of the delusion, or other morbid condition, and connected with it as effect with cause, and not the result of sane reasoning or natural motives, which the party may be capable of, notwithstanding his circumscribed dis. order. 'The importance of this will be appreciated by you further on. But, assuming that the infirmity of mind has had a direct influence in the production of crime, the difficulty is to fix the degree and character of the disorder which, in such case, will create irresponsibility in law. The ontgivings of the judicial mind on this subject have not always been entirely satisfactory or in harmony with the conclusions of medical science. Courts have, in former times, undertaken to lay down a law of insunity without reference to and in ignorance of the medical aspects of the subject, when it could only be properly dealt with through a concurrent and harmonious treatment by the two sciences of law and medi. eine. They have, therefore, adopted and again discarded one theory after another in the effort to find some common ground where a due regrard for the security of society and humanity for the afflieted may meet. It will be my effort to give you the results most commonly aceepted by the courts. It may be well to say a word as to

The Evidence by Which Courts and Juries are Guided in this difficult and delicate inquiry. That subtle essence which we call "mind" defies, of course, ocular inspection. It can only be known by its outward manifestations, and they are found in the language and conduct of the man. By these his thoughts and emotions are read, and according as they conform to the practice of people of sound mind, who form the large majority of mankind, or contrast harshly with it, we form our judgment as to his soundness of mind. For this reason evidence is admissible to show conduct and language at different times and on different occasions, which indicate to the general mind some morbid condition of the intellectual powers; and the more extended the view of the person's life the safer is the judgment formed of him. Everything relating to his physical and mental history is relevant, because any conclusion as to his sanity must often lest upon a large number of facts. As a part of the language and conduct. letters spontaneously written afford one of the best indications of mental condition. Evidence as to insanity in the parents and immediate relatives is also pertinent. It is never allowed to infer insanity in the accused from the mere fact of its existence in the ancestors. But when testimony is given directly tending to prove insane conduct on the part of the accused. this kind of proof is admissible as corroborative of the other. And therefore it is that the defense have been allowed to introduce evidence to you covering the whole life of the accused, and renching to his family antecedents. In a case so full of detail as this I 
shall deem it my duty to you to assist you in weighing the evidenoe by calling your attention to particular parts of it. But $I$ wish you distinctly to understand that it is your province, and not mine, to decide upon the facts; and if $I$, at any time, seem to express or intimate an opinion on them, which 1 do not design to do, it will not be binding on you, but you must draw your own conclusions from the evidence. The instructions that have been given you import, in substance, that

The True Test of Criminal Responsibility, where the defeuse of insanity is interposed, is whether the accused had sufficient use of his reason to understand the nature of the act with which he is charged, and to understand that it was wrong for him to commit it; that if this was the fact he is criminally responsible for it, whatever peculiarities may be shown about him in other respects; wherens, if his reason was so defective, in consequence of mental disorder, generally supposed to be caused by brain disease, that he could not understand what he was doing, or that what he was doing was wrong, he ought to be treated as an irresponsible person. Now, as the law assumes every one at the outset to be sune and responsible, the question is,

What is There in This Case to show the contraly as to this defendant? A jury is not warranted in inferring that a man is insane from the mere fact of his committing a crime, or from the enormity of the crime, or from the mere apparent absence of adequate motive for it, for the law assumes that there is a bad motivethat it is prompted by malice-if nothing else appears. Perhaps the easiest way for you to examine into this subject is, first, to satisfy yourselves about the condition of the prisoner's mind for a considerable period of time before any conception of the assissination entered it, and at the present time, and then to consider what evidence exists as to a different condition at the time of the act charged. I shall not spend any time on the first question, because to examine it at all would require a review of evidence relating to over 20 years of the defendant's life, and this has been so exhaustively discussed by counsel that anything I could say would be a wearisome repetition. Suffice it to say, that, on one side, thi evidence is supposed to show a chronic condition of insanity for many years before the assassination; and, on the other, to show an exceptionally quick intellect and decided power of discrimination. rou must draw your conclusions from the evidence. Was his ordinary. permanent, chronic condition of mind such; in consequence of disease, that he was unable to understand the nature of his actions, or to distinguish between right and wrong in his conduct? Was he subject to insane delusions that destroyed his power of so distinguishing? And did this continue down to and embrace the act for which he is tried? If so, he was simply an irresponsible lumatic. $0 r$, on the other hand, had he the ordinary intelligence of sane people, so that he could distinguish between right and wrong, as to 
his own actious? If another person had committed the assassination, would he have appreciated the wickedness of it? ** * ' the question for you to determine is what was the

Condition of the Prisoner's Mind at the Time when this tragedy was enacted? If he was sufticiently same then to be responsible, it matters not what may have been his condition before or after. Still, evidence is properly admitted as to his previous and subsequent conditions, because it throws light, prospectively and retrospectively, upon his condition at the time. Inasmuch as these disorders are of gradual growth and indefinite continuance, if he is shown insane shortly before or after the commission of the crime, it is natural to conjecture, at least, that he was so at the time. But all the evidence must center around the time when the deed was done. $*$

When Men Reason the Law Kequires them to reason correctly, as far as their practical duties are concerned. When they have the capacity to distinguish between right and wrong, they are bound to do it. Opinions, properly so called,-i.e., beliefs resultiug from reasoning, reflection, or examination of evidence,-aflord no protection against the penal consequences of crime. $A$ man may believe a course of action to be right, and the law, which lorbids it, to be wrong. Nevertheless, he must obey the law, notwithstanding his convictions. And nothing can save him from the consequences of its violation, except the fact that he is so crazed by disease as to be unable to comprehend the necessity of obedience to it. *** $\Lambda$ man may reason himself into a conviction of the expediency and patriotic character of political assassination, but to allow him to find shelter from punishment behind that belief, as an insilne delusion, would be simply monstrous. Between one and two centuries ago there arose a school of moralists who were accused of maintaining the doctrine that whenever an end to be attained is right, any means necessary to attain it would be justifiable. They were accused of practicing such a process of reasoning as would justify every $\sin$ in the decalogue when occasion required it. 'They incurred the odium of nearly all Christendom in consequence. But the mode of reasoning attributed to them would seem to be impliedly, if not expressly, reproduced in the papers written by the defendint and shown in evidence: "It would be a right and patriotic thing to unite the republican party and save the republic. Whatever means may be necessary for that object would be justifiable. The death of the president by violence is the only and therefore the necessary means of accomplishing it, and therefore it is justifiable. Being justifiable as a political necessity, it is not murder."

There is undoubtedly

A Form of Insane Delusion consisting of a belief by a person that he is inspired by the Almighty to do something - to kill another, for example-and this delusion may be so strong as to impel him to the commission of a crime. The defendant in this case claims that he labored under such a delusion and impulse, or pressure as he 
calls it. *** Let me here say a word about the characteristics of this form of delusion. It is easy to understand that the conceit of being inspired to do an act may be either a sane belief or an insine delusion. A great many Christians believe, not only that events generally are providentially ordered, but that they themselves receive special providential guidance and illumination in reference to both their inward thoughts and outward actions, and, in an undefined sense, are inspired to pursue a certain course of action; but this is a mere sane belief, whether well or ill founded. On the other hand, if you were satisfied that a man sincerely, though insanely, believed that, like Saul of Tarsus, on his way to Damascus, he had been smitten to the earth, had seen a great light shining around him, had heard a voice from heaven, warning and commanding him, and that thenceforth, in reversal of his whole previous moral bent and mental convictions, he had acted upon this supposed revelation, you would have before you a case of imaginary inspiration amounting to an insane delusion. 'The question for you to consider is, whether the case of the defendant presents anything analogrous to this.

The Theory of the Government is that the defendant committed the homicide in the full possession of his faculties, and from perfectly sane motives; that he did the act from revenge, or perhaps from a morbid desire for notoriety; that he ealculated deliberately upon being protected by those who were politically benefited by the death of the president, and upon some ulterior benefit to himself; that he made no pretense to inspiration at the time of the assassination, nor until he discovered that his expectations of help from the so-called stalwart wing of the republican party were delusive, and that these men were denouneing his deed, and that then, for the first time, when he saw the necessity of making out some defense, he broached this theory of inspiration and irresistible pressure, forcing him to the commission of the act. If this be true, you would have nothing to indieate the real motives of the act except what I have already considered. Whether it is true or not, you must determine from all the evidenee. *** Filally, on this subject, you have

The Defendant's Own Testimony. He does not profess to have had any visions or direct revelation or distorted conception of facts. But he says that while pondering over the political situation the idea suddenly occurred to him that if the president were out of the way the dissensions of his party would be healed; that he rearl the piapers with an eye on the possibility of the president's removal, and the idea kept pressing on him; that he was horrified; kept throwing it off; did not want to give it attention; tried to shake it off ; but it kept growing upon him, so that at the end of two weeks his mind was thoroughly fixed as to the necessity for the president's removal and til divinity of the inspiration. He never had the slightest doul, of the divinity of 
the inspiration from the 1st of June. He kept praying about it, and that if it was not the Lord's will that he should remove the president there would be some way by which His providence would intercept the act. He kept reading the newspapers, and his inspiral., n was being confirmed every day, and since the ist day of June i. has never had a doubt about the divinity of the act. ** * In all this matter there is one important distinction that you must not lose sight of, and you are to decide how far it is applicable to this case. It is

The Distinction Between Mental and Moral Obliquity; between a mental ineapacity to understand the distinctions between right and wrong, and a moral indifference and insensibility to those distinetions. 'The latter results from a blunted conscience, a torpid moral sense or depravity of heart; and sometimes we are not inapt to mistake it for evidence of something wrong in the mental constitution. We have probably all known men of more than the averuge of mental endowments, whose whole lives have been marked by a tind of moral obliquity and apparent absence of the moral sense. We have known others who have first yielded to temptation with pangs of remor'se, but each transgression became easier, until dis. honesty became a confirmed habit, and at length all sensitiveness of conscience disappeared. When we see men of seeming intelligence and of better antecedents reduced to this condition, we are prone to wonder whether the balance-wheels of the intellect are not thrown out of gear. But indifference to what is right is not ignorance of it, and depravity is not insanity, and we must be carcful not to mistake moral perversion for mental disease.

Two Pictures have been Drawn by Counsel. 'The one represents a youth of more than the average of mental endowments, surrounded by certain demoralizing influences at a time when his character was being developed; starting in life withont resources, but developing a vicious sharpness and cunning; conceiving "onterprises of great pith and moment," that indicated unusual forecast, though beyond his resources. ennsumed all the while by insitiate vanity and craving for notoriety; violent in temper, selfish in disposition, immoral, and dishonest in every direction; leading a life, for years, of hypocrisy, swindling. and fraud; and finally, as the culmination of a depravad career, working himself into a resolution to startle the country with a crime that would secure him a bad eminence, and, perhaps, a fu ure reward. 'The other represents a youth born, as it were, under malign influences, the child of a diseased mother, and a father subject to religious delusions: deprived of his mother at an early age; reared in retirement and under the influence of fanatical religious views: subsequently, with his mind filled with fanatical theories, launched upon the world with no guidance save his own impulses; then evincing an incapacity for any continuous occupation; changing from one pursuit to another-now a lawyer, now a religionist, now a politician-nusncessful in all; 
full of wild impracticable schemes, for which he had neither resources nor ability; subject to delusions about his abilities and prospects of success, and his relations with others; his mind incoherent and incapable of reasoning connectedly on any subject; withal, amiable, gentle, and not aggressive, but the victim of surrounding influences, with a mind so weak and a temperament so impressible that, under the excitement of political controversy, he beeame frenzied and insanely deluded, and thereby impelled to the commission of a crime, the guilt of which he could not, at the moment. understand. It is for you to determine which of these is the portrait of the accused. **** Verdict, gnilty. Guiteau's Case, 10 Fed. Rep. 161, F. 72, Ke. 48, 2 L. 163.

(Ala. Sup. Ct., 1887.) Leading Case on Uncontrollable Impulse. Defendants, convicted of murder, except, amongst other things, to the refusul of the court below to give the following instruction to the jury: "(8) If the jury believe from the evidence that the prisouer's or either of them was moved to action by an insane impulse controlling their will or their judgment, then they are, or the one so aftected is, not guilty of the crime charged." The court ex mero motu, charged the jury that, "when insanity is relied on as a defense to crime, and such insanity consists of a de'. 'in merely, and the defendant is not shown to be otherwise insi', , chen such delusion is no justification or excuse of homicide, unisss the perpetrator was insanely deluded into the belief of the existence of a fact or state of facts which, if true, would justify or excuse the homicide under the law applicable to sane persons." The defendants duly excepted to the giving of this charge.

The Evidence Tended to Show that one of the defendants, Mrs. Parsons, acted under the influence of an insame delusion that the deceased, whom she assisted in lilling. possessed supernatural power to afflict her with disease, and to take her life by some supernatural trick;" that by means of such power the deceased had caused defendant to be in bad health for a long time, and that she acted under this belief that she was in great danger of thr ."ss of her life from the conduct of deceased.

SOMERVILLE, J. In this ease the defendants have been convicter of the murder of Bennett Parsons, by shooting him with a gu.; me of the defendants being the wife and the other the diug' $:$ 's of the deceased. 'The defense set up in the trial was the pien if insanity, the evidence tending to show that the daughter "ias in idiot, and the mother and wife a lunatic, subject to insane de'us:ons, and that the killing on her part was the offspring and product of those delusions.

The Earliest English Decisions, striving to establish rules and tests on the subject, including alike the legal rules of criminal and civil responsibility, and the supposed tests of the existence of the disease of insanity itself, are now admitted to have heen deplorably 
erroneous, and, to say nothing of their vacillating character, have long since been abandoned. The views of the ablest of the old text writers and sages of the law were equally confused and uncertain in the treatment of these subjects, and they are now entirely exploded. 'I ime was in the histury of our laws that the veriest lunatic was debarred from pleading his providential affliction as a defense to his contracts. It was saicl, in justification of so alsurd a rule, that no one could be permitted to stultify himself by plead. ing his own disability. So great a jurist as Lord Coke, in his attempted classification of madmen, laid down the learal rule of criminal respousibility to be that one should "wholly have lost his menory and under'standing;" as to which Mr. Erskine, when defending lIadfeld for shooting the king, in the year 1800, justly observed: "No such madman ever existed in the world." After" this great and historical case, the existence of delusion promised for a while to beeome the sole test of insanity, and, acting under the duress of such delusion, was recognized in effect as the legal rule of responsibility. Lord henyon, after orderingr a verdict of acquittal in that ease, declared with emphasis that there wass "no doubt on earth" the haw was correctly stated in the aryument of counsel. But, as it was soon discovered that insanity often existed without delusions, as well as delusions without insanity, this view wals also abandoned. Lord Hale had before declared that the rule of responsibility was measured by the mental capacity possessed by a child 14 years of age; and $M 1 r$. Justice 'Tracy, and other judges had ventured to decide that, to be nompunishable for allenged acts of crime, "a man must be totally" deprived of his understanding and memory, so as not to know what he was doing, no more than in infint, a brute, or a wild beast." Arnold's Case. 16 How. St. Tr. Tift. All these rules have necessarily been discalrded in modern times in the light of the new scientific knowledge acfuired by a more thorough study of the disease of insanity. In Bellingham's Case, decided in 181\%, by Lord Manstield at the Old Bailey (Coll. Isun. 630), the test was held to consist in a knowledge that mulder, the erime there committed, was "agrainst the laws of God and nature," thus meaning an ability to distingruish between right and wrong in the abstratet. 'This mile was not adhered to, but seemis to have been modified so as to make the test rather a knowledge of right and wrong as applied to the particular act. Lalwsm. Insin. $231, \$ i$ et sec.

The Great Leading Case on this Subject in England is 11 ' $\mathrm{Xiahl}$ ten's Cinse, decided in 1843 before the Finglish house of lords. 10 Clark \& F. $200 ; 2$ Law won. Cr. Def. 150. It was decided hy the judges in that casse that, in order to entitle the accused to acquittal. it must be clearly proved that, at the time of committing the offense, he was laboring under such a defect of reason, from disease of the mind. is not to know the nature and quality of the act lur was doing, or, if he did. not to know that what he was doing was 
wrong. 'This rule is commonly stipposed to have heretofore been aclopted by this eourt, and has been followed by the greneral enterent of American adjudications. Boswell $v$ S., 6i3 Ala. 30T, 35 Am. Rep). 20, 2 Lawson, Cr. Det. 302; Mcallister v. S., 17 Ala. 43t; Lawson, Insan. 219-2:21, 231. In view of these contlieting decisions, and of the new light thrown on the disease of insinity by the discoveries of modern psychological medieine,

The Courts of the Country IVlay Well Hesitate before blindly following in the minsteady footsteps found upon the old sindstones of: our common-law jurisprudence a eentury ago. 'I he trial eourt, with prudent propriety, followed the previous decisions of this court, the colrectuess of which, as to this subject, we alde now repuested to peview. * * * In ancient times, lumaties were not regarded as "unfortunate sufferer's from disease, but rather as subjects of" demoniacal possession, or as self'-made victims of evil passions." 'they were not cared for humanely in asylums and hospitals, but were incareerated in jails, punished with chains and stripes, and often sentenced to death by buning or the gibbet. When put on their trial, the issue before the court then was not as now. If acquitted, they could only be turned loose on the community to repeat their crimes without molestation or restraint. They could not be committed to hospitals, as at the present day, to be liept in custody, cared for by medical attention, and often cured. It was not until the beginning of the present eentury that the progress of Christian civilization asserted itself by the exposmes of the then existing barbarities, and that the ontery of philanthropists sncceeded in eliciting an investigation of the British parliament looking to their suppression. Lip to that period the medical treatment of the insane is known to have been eonducted 11001 a basis of ignorince, inhumanity, and empiricism. 9 $\mathrm{Am}$. Cyclop. (187t) tit. "Insmanity." Being pumished for wickedness, rather than treated for disease, this is not surprising. The exposme of these evils not only led to the establishment of that most beneficent of modem civili\%ed charities, - the hospital and asylum for the insane.-but also furnished hitherto megualed opportunities to the medieal profession of investigating and treating insanity on the palandogrical basis of its being a disease of the mind. Under these new and more fitvorable conclitions,

The Medical Jurisprudence of Insanity has Assumed an Entirely New Phase. The nature and exciting enuses of the disease have been thoroughly studied and more tully comprehended. 'The result is that the "right and wrong test," as it is sometimes called, which, it must be remembered, itself originated with the medical profession, in the mere dawn of the seientitic knowledge of insanity. has been condemmed by the great current of modern medical anthorities, who believe it to be "founded on an ignorant and imperfoct view of the disease." 15 Finc. Brit. (9th ed.) tit. "Insinity.",

The Question, then, Presented seems to be whether an old rule of 
legal responsibility shall be adhered to, based on theories of phy. sicians promulgated a hundred year's ago, which refuse to recognize any evidence of insanity, except the single test of mental capacity to distinguish right and wong, or whether the courts will recognize as a possible fact, if capable of proof by clear and satisfactory testimony, the doctrine, now alleged by those of the medical profession who have made insanity a special subject of investigation, that the old test is wrong, and that there is no single test by which the existence of the disease, to that degree which exempts from punishment, can in every case be infallibly detected. The inquiry must not be unduly obstructed by the doctrine of stale decisis, for the life of the common-law system and the hope of its permanency consist largely in its power of adaptation to new scientific discoveries, and the requirements of an ever-advancing civilization. There is inherent in it the vital principle of juridical evolution, which preserves itself by a constant struggle for approximation to the highest practical wisdom. It is not like the laws of the Medes and Persians, which could not be changed. In establishing any new rule, we should strive, however, to have proper regard for two opposite aspects of the subject, lest, in the words of Lord Hale, "on one side, there be a kind of inhumanity towards the defects of human nature, or, on the other, too great indulgence to great crimes." It is everywhere admitted, and as to this there can be no doubt, that an idiot, lunatic, or other person of diseased mind, who is afflicted to such extent as not to know whether he is doing right or wrong, is not punishable for any act which he may do while in that state. Can the courts justly say, however, that the only test or rule of responsibility in criminal cases is the power to distinguish right from wrong, whether in the abstract, or as applied to the particular case? Or may there not be insane persons, of a diseased brain, who, while capable of perceiving the difference between right and wrong, are, as matter of fact, so far under the duress of such discase as to destroy the power to choose between right and wrong? Will the courts assume as a fact, not to be rebutted by any amount of evidence, or any new discoveries of medical science, thit there is and can be no such state of the mind as that described by a writer on psychological medicine as one "in which the reason has lost its empire over the passions, and the actions by which they are manifested, to such a degree that the individual can neither repress the former, nor abstain from the latter?" Dean. Med. Jur. 497.

Much Confusion Can be Avoided in the discussion of this sul,ject by separating the duty of the jury from that of the court in the trial of a case of this character. 'The province of the jury is to determine facts, that of the court to state the law. 'The rule in M'Naghten's Case arrogates to the court, in legal effect, the right to ansert. as matter of law, the following propositions: (1) That there is but a single test of the existence of that degree of insinity 
such as confers irresponsibility for crime; (2) that there does not exist any case of such insanity in which that single test-the capacity to distinguish right from wrong-does not appear; (3) that all other evidences of alleged insanity, supposed by physicians and experts to indicate a destruction of the freedom of the human will, and the irresistible duress of one's actions, do not destroy his mental capacity to entertain a criminal intent. The whole diffieulty, as justly said by the supreme judicial court of New Hampshire, is that "courts have undertaken to declare that to be law which is matter of fact." "If," observes the same court, "the tests of insanity are matters of law, the practice of allowing experts to testify what they are should be discontinued; if they are matters of fact, the judge should no longer testify withont being sworn as a witness, and showing himself to be qualified to testify as an expert." State v. Pike, 49 N. H. 399. We first consider

What is the Proper Legal Rule of Responsibility in criminal cases. No oue can deny that there must be two constituent elements if legal responsibility in the commission of every crime, and no rule can be just and reasonable which fails to recognize either of them: (1) Capacity of intellectual discrimination; and (2) freedom of will. Mir. Wharton, after recognizing this fundamental and obvious principle, observes: "If there be either incapacity to distinguish between right and wrong as to the particular act, or delusion as to the act, or inability to refrain from doing the act, there is no responsibility." 1 Whart. Cr. Law (9th ed.) §33. Says Mr. Bishop, in discussing this subject: "There cannot be, and there is not, in any locality or age, a law punishing men for what they cannot avoid." 1 Bish. Cr. Law (7th ed.) $\S 383 \mathrm{~b}$. If therefore, it be true, as matter of fact, that the disease of insanity can, in its action on the human brain through a shattered nervous organization, or in any other mode, so affect the mind as to subvert the freedom of the will, and thereby destroy the power of the victim to choose between the right and wrong, although he perceive it,-by which we mean the power of volition to adhere in action to the right and abstain from the wrong.-is such a one criminally responsible for an act done under the influence of such controlling lisei. $\because$ ? We clearly think not, and such we believe to be the just, reasonable, and humane rule, towards which all the modern anthorities in this country, lesislation in England, and the laws of other civilized countries of the world, are gradually but surely tending, as we shall further on attempt more fully to show. We next consider the question as to the probable existence of such a disease, and the test of its presence, in a given case. It will not do for the courts dogmatically to deny the possible existence of such a disease. or its pathological and psychical effects, because this is a matter of evidence. not of law, or judicial cognizance.

Its Existence, and Fffect on the Mind and Conduct of the Patient, is a Question of Fact to be Proved, just as much as the possible 
existence of eholera or yellow lever formerly: was before these diseases became the subjects of common knowledge, or the effects of delirium from fever, or intoxication from opium and alcoholic stimulants would be. 'The courts eould, with just as much propriety, years ago, have denied the existence of the Copernican sy'stem of the universe, the efficiley of steam and electricity as a motive power, or the possibility of eommunication in a few moments between the continents of Europe and America by the magnetic telergaph, or that of the instantaneous transmission of the human voiee from one distant eity to another by the use of the telephone. 'These are scientilic facts, first discovered by experts before becoming matters of common knowledge. So, in like manner, must be every other unknown scientific fact in whatever profession or departunent of knowledge. 'The existence of such a ecrebral disease as that which we have described is ealnestly allegred by the superintendents of insane hospitals, and other experts, who constantly have experimental dealings with the insane, and they are permitted every day to so testify before juries. 'The truth of their testimony-or, what is the same thing, the existence or nonexistence of such a diseise of the mind-in each particular ease is necessarily a matter for the determination of the jury from the evidence. So it is equally obrious that

The Courts Cannot, upon any Sound Principle, Undertake to Say what are the invariable or infallible tests of such discase. The attempt has been repeatedly made, and has proved a confessed failure in practice. "Such a test," say"s Mr. Bishop, "has never" been found, not because those who have searehed for" it have not been able and diligent, but because it does not exist." 1 Jish. ('r. Latw (7th ed.) \$381. In this conclusion, Dr. Ray, in his learned work on the Medical furisprudence of Insanity, fully concurs. Ray, Nied. Jur. Insan. 39. The symptoms and causes of insanity are so variable, and its pathology so complex, that no two cases may be just alike. "The fact of its existence," silys Dr. Ray. " is never established by any single diagnostic symptom, but by the whole body of symptoms, no particular one of which is present in erery case." Ray, Med. Jur. Insan. \$24. Its exciting causes being moral. psychical, and physical, are the especial subjects of specialists' study. What effect maly be exerted on the given patient by age, sex, aecupation, the seasons, personal surroundings, hereditary transmission, and other causes, is the subject of evidence based on investigation. diagnosis, observation, and experiment. L'eculiar opportunities, never before enjoyed in the history of our race, are offered in the present age for the ascertainment of these facts, by the establishlment of asylums for the custody and treatment of the insane. which Christian benevolence and statesmanship have substituted for jails and gibbets. The testimony of these experts-difter as they may in many doubtful cases-would seem to be the best which cim be obtained, however unsatisfactory it may he in some respects. 
In the Present State of our Law, under the Rule in IM'Naghten's Case, We are Confronted with This Practical Difficulty, which itself demonstrates the defects of the rule. 'The comrts, in effect. charger the juries, as matter of law, that no such mental disease exists ats that often testified to by medical writers, superintendents of insane hospitals, and other experts; that there ean he, as matter of seientific fact, no cerebral defect, congenital or ac(juired, which destroys the patient's power of self-control,-provided only he retains a mental conscionsness of right and wrong. The experts are immediately put under oath. and tell the juries just the eontrary, as matter of evidence; asserting that no one of ordinary intelligence can spend an hour in the walleds of an insane asylum without diseovering such cases, and in fact that "the whole matnagement of such asplums presupposes a knowledge of: right and wrong on the part of their immates." (ing \& F. Forensic Nled. 220. The result in practice, we repeat, is that the eourts charge one way, and the jury, following an alleged higher law of lmmanity, find another, in harmony with the evidence.

[Views of Writers on Insanity.] In Bucknill on Criminal Lumacy, 59, it is asserted, as "the result of observation and experience, that in all lumaties, and in the most degraded idiots, whenever manifestations of any mental action can be educed, the feeling of right and wrong may be proved to exist." "With regard to this test," suys Dr. Russell Reyolds, in his work on the Scientific Vahne of the Leugal 'T'ests of Insanity, 34 (London. 1872), "I may say, and most emphatically, that it is utterly untrustworthy, because untrue to the obvious facts of nature." In the learned treatise of Dr's. Bucknill and 'Tuke on P'sychological Medicine, 269 (4th ed., London, 1879), the legal tests of responsibility are discussed, and the adherence of the eourts to the right and wrong test is deplored as unfortunate; the true principle heing stated to be "whether." in consefunence of eongenital defeet or acyured disease. the power of self-control is absent altogether, or is so far wanting as to render the individual irresponsible." It is observed by the authors: "As has again and again been shown, the unconsciousuess of right and wrong is one thing, and the powerlessinesss, through cerebrial defect or discase, to do right, is another. 'To confonnd them in an asylum would have the effect of transferring a considerable mumber of the inmates thence to the treadmill or the. gallows." Dr. Peter Bryee, superintendent of the Alabama Insane llospital for more than an quarter of a century past, alluding to the moral and disciplinary treatment to which the insane inmates are subjected, ohserves: "They are dealt with in this institution, as far as it is practicable to do so, as rational beings; and it seldon happens that we meet, with an insane person who eammot be made to discern. to some feeble extent, his duties to himself and others. and his true relations to society." Sixteenth Ann. Rep. Ali. Insine IInsp.. 1876, p. 22; Biennial Rep., 1886. pp. 12-18. Other distinguished writer's on 
the medieal jurisprudence of insanity have expressed like views, with comparative unanimity. And nowhere do we find the rule more emphatically condemned than by those who have the practical care and treatment of the insane in the various lunatic asylums of every civilized country. A notable instance is found in the forlowing resolution, unanimously passed at the annual meeting of the British Association of Medical Officers of Asylums and Hos. pitals for the Insane, held in London, July 14, 1864, where there were present fifty-four medical officers: "Resolved, that so much of the legal test of the mental condition of an alleged criminal lunatic as renders him a responsible agent, because he knows the difference between right and wrong, is inconsistent with the fact. well known to every member of this meeting, that the power of distinguishing between right and wrong exists very frequently in those who are undoubtedly insane, and is often associated with dangerous and uncontrollable delusions." Judicial Aspects Insan. (Ordronaux, 1877) 423, 424. These testimonials as to a scientific fact are recognized by intelligent men in the affairs of every.day business, and are constantly acted on by juries. They cannot be silently ignored by judges. Whether established or not, there is certainly respectable evidence tending to establish it, and this is all the courts can require. Nor are the modern law writers silent in their disapproval of the alleged test under discussion. It meets with the criticism or condemnation of the most respectable and advanced in thought among them. the tendency being to incorporate in the legal rule of responsibility " not only the knowledge of good and evil, but the power to choose the one and refinin from the other." Browne, Insan. $\$ 13$ et seq.; Id. $\$ 18$; Ray, Med. Jur. $\$ \$ 16-19 ; 1$ Whart. \& S. Med. Jur. $\$ 59 ; 1$ Whart. Cr. Law (9th ed.) $\$ \$ 33,43,45 ; 1$ Bish. Cr. Law (7th ed.) $\$ 386$ et seq. ; Judicial Aspects Insan. (Ordronaux) 419; 1 Greenl. Ev. $\$ 372 ; 1$ Steph. IFist. Cr. Law, $\$ 168 ; 4$ Am. Law. Rev. (1869-70) 236 et seq.

The Following Practical Suggestion is made in the able trentise of Balfour Browne above alluded to: "In a case of alleged insallity, then," he says, "if the individual suffering from enfeeblement of intellect, delusion, or any other form of mental aberration, was looked upon as, to the extent of this delusion, under the influence of duress (the dire duress of disease), and in so far incapacitated to choose the good and eschew the evil, in so far, it seems to us," he continues, "would the requirements of the law be fulfilled; and in that way it would afford an opening, by the evidence of experts. for the proof of the amount of self-duress in each individual case, and thus alone can the criterion of law and the criterion of the inductive science of medical psychology be made to coincide." Browne, Insan. §18. This, in our judgment, is the practical solution of the difficulty before us, as it preserves to the courts and the juries, respectively, a harmonious field for the full assertion of their time-honored functions. So great, it may be added, are 
the embarrassments growing out of the old rule, as expounded by the judges in the house of linglish lords, that in MIarch, 1874, a bill was brought before the house of commons, supposed to have been draughted by the learned counsel for the queen, Mr. Fitzjames Stephen, which introduced into the old rule the new element of an alssence of the power of self-control, produced by diseases affecting the mind; and this proposed alteration of the law was cordially recommended by the late Chief Justice Cockburn, his only objection being that the principle was proposed to be limited to the case of homicide. 1 Whart. Cr. Law (9th Fd.) $\$ 45$, p. 66, note 1 ; Browne, Insull. $\$ 10$, note $1 . * * *$ LIIere the judge reviews the cases giving support to his propositions above stated, and then proceeds.] It is no satisfactory objection to say that the rule above announeed by us is of difficult application. The rule in N'Naghten's Case, supra, is equally obnoxious to a like criticism. The ditficulty does not lie in the rule, but is inherent in the subject of insanity itself. The practical trouble is for the courts to determine in what particular cases the party on trial is to be transferred from the eategory of sane to that of insane criminals; where, in other words, the border line of punishability is adjudged to be passed. But, as has been said in reference to an every-day fact of nature, no one can say where twilight ends or begins, but ther'e is ample distinction nevertheless between day and night. We think we can safely rely in this matter upon the intelligence of our juries, guided by the testimony of men who have practically made a study of the disease of insanity; and enlightened by a conscientious desire, on the one hand, to enforce the criminal laws of the land, and, on the other, not to deal harshly with any unfortunate victim of a diseased mind, acting without the light of reason or the power of volition.

A Mere Moral or Imotional Insanity, so called, unconnected with disease of the mind, or irresistible impulse resulting from mere moral obliquity, or wicked propensities and habits. is not recognized as a defense to crime in our courts. 1 Whart. Cr. Law (9th Ed.) $\$ 46$; Boswell v. State, 63 Ala. 307, 35 Am. Rep. 20; Ford v. State, 71 Ala. 385.

The Rule in IM'Naghten's Case, as decided by the English judges, and supposed to have been adopted by the court, is that the defense of insune delusion can be allowed to prevail in a criminal case only when the imaginary state of facts would, if real, justify or excuse the act; or, in the language of the English judges themselves, the defendant "must be considered in the same situation as to responsibility as if the facts with respect to which the delusion exists were real." Boswell's Case, 63 Ala. 307. It is apparent, from what we have suid, that this rule cannot be correct as applied to all cases of this nature, even limiting it as done by the Fnglish judges to cases where one "labors under partial delusion, and is not in other respects insane." MI'Naghten's Case. 10 C. \& F. 200 [above]. It 
holds a partially insme person as responsible as if he were chtipely sune. and it ignores the possibility of erime being eommitted under the duress of an insane delusion, operating upon a human mind the intergrity of which is destroyed or impatired by disease, exeept. perhaps, in cases where the imagimary state of facts, if real. would excuse or justify the act ione moler their influence. Field, Ned.

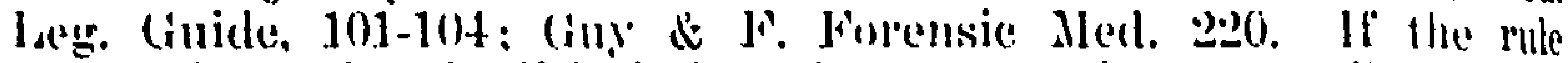
declaned by the Engrish judges be correret, it necessilrily follows that the only pussible instinne of excusible homicide, in calses of delusional insunity, would be where the delusion. if real. would have been such as to create, in the mind of a reasomable man, a just apprehension of imminent peril to life or limb. 'The personal fear or timid cowardice of the insane man, although ereated by disease acting through a prostrated nervous organization, wonld not excuste lundue precipitation of action on his part. Nothing would justify assailing his supposed anlversary excepit an overt act, or demonstration on the part of the latter, such as, if the imaginary lacts were leal. would, under like circumstances, haye justilied a man perfectly sime in shooting or lillingr. If he dare fail to reatson, on the supposed fincts embodied in the delasion, as perfectly as a sane man could do on a like state of realities, he receives no merce at the hamds of the law. It exacts of him the last poind of ftesh. It would follow also, under this rule, that the partially insmer man. afflicted with delusions. would no more be excusable than at sine man would be, if, perehance, it was by his fault the diffienlty wils provolied, whether hy word or deed; or if, in fine, he may have been so negligent as not to have declined combat when he could do so safely, without increasing his peril of life or limb. If this has been the law heretotore. it is time it shonld be so no longer. It is not only opposed to the known facts of modern medical science. but it is a hard and injust rule to be applied to the unfortunate and providential vietims of disease. It seems to be little less than inhumane, and its strict enforeement would probably transfer a large percentage of the inmates of our insime hospital from that institution to hard labor in the mines or the penitentiary.

Its Fallacy Consists in the issumption that no other phase of delusion, proceading from a diseased brain, ean so destroy the volition of an insane person as to render him powerless to do whit he knows to be right. or to avoid doing what he may know to be wrong. * * In eonclusion of this branch of the subjeet, that we may not be misunderstood. we think it follows very clearly from what we have said that the

Inquiries to be Submitted to the Jury, then, in avery criminal trial where the defense of insanity is interposed, are these: 1. Was the defendant at the time of the commission of the alleged crime. as matter of fact. afflicted with a disease of the mind. so as to bre either idintic. or otherwise insane? 2. If such be the case, did he know right from wrong, as applied to the particular act in ques- 
tion? If he did not have such knowledge, he is not legally responsible. 3. If he did have such knowledge, he may nevertheless not be legrally responsible if the two following conditions concur: (1) If, by reason of the duress of such mental disense, he had so far lost the power to choose between the right and wrong, and to avoid doing the act in question, as that his tree agency was at the time destroyed; (2) and if, at the same time, the alleged erime was so connected with such mental disease, in the relation of cause and effect, as to have been the product of it solely. **** [Strne, C. J., filed an elaborate opinion in this ease in which he dissented in part and concurred in much of the opinion of Somerville, J., with whom the l'est of the court arreed.] Judgment reversed. Parsons v. State, 81 Ala. 577, 2 So. $854,60 \mathrm{Am}$. Rep. 193, 13. 242, F. 8.. Kin. 58 .

(Me. Sup. Judicial (t., 1870.) Burden of Proof. DANFOR'IH, J. * * The question as to the burdei of proof in eriminal cases, where insanity is set up as a defense, is one of much difficulty, though until recently the anthorities seem to have been uniform in imposing it unon tile defendant. * * * It is undonbtedly true that there can be no gruilt except as the result of the action of a sound mind, there can be no crime except there be a criminal; nevertheless. there is a palpable distinction between these two; one cannot exist without the other; still they are two, and not one and the sime. 'The person doing the act is not the act itself. Ile may or may not be responsible for the act, but in no sense can he be the act. So. too, whether he committed the act is one question, and whether he is responsible for that act is another and entirely different question. Now it should not be forgotten that we start with the legal presumption that all men are sane and responsible for all their acts-in other words, that no man is insane and irresponsibleprecisely as we do with the proposition that no man has lecal anthority for doing that which otherwise would be a crime or a trespass. Ifenee the statute defines murder to he "the mlawful killing of a human being, with malice aforethought, either express or implind." Ilere are all the elements necessary to constitute the crime, assuming a responsible agent; not one word as to what is. or is not, required to make him responsible. And so of all other statute definitions, whoeve: shall do the certain aets set out, shall be guilty. \& Here, as everywhere in the law, sanity is assumed and treated as in essential attribute of humanity. The indictment follows the statute, setting ont all the acts decmed essential to the erime, but omitting all reference to the capacity of the accused. Of all that is set out in the indictment he is presimed innocent. and that must be proved and nothing else. When that is proved he is convicted. unless he interposes some defense other than a sane denial of the allegations anainst him. A simple plea of not guilty puts in issure the allegations and only the allegations in the indictment: and as to 
them the prosecution has the alfirmative. But if the aceused would put in issue any other allegation, any question as to his cilpacity or responsibility, he must do it by an affirmative statement. If he puts in the plea of insanity, he assumes the affirmative; he changes the issue. And it is immaterial whether it is in writing, or merely verbal; in either case it just as effectually raises a new issue. it is true it may be resorted to in conuection with the plea of not guilty, but it is not and cannot be a part of it. 'The plea of insanity is, and of necessity must be, a plea of confession and avoidance. It does not deny a single allegation in the indictment, but simply says, grant all these allegations to be true. that all these acts lave been done, and still guilt does not follow, because the doer of them is not responsible therefor. It does not meet any question pro. pounded by the indictment, but raises one outside of it. It is not it mere denial, but a positive allegation. It is, however, said in the argument that the plea of insinity does deny the allegation of malice, because the insane is not capable of such a state of the mind. If the term malice is used in the common meaning of that siord, it is not necessary now to discuss the question as to how far those who are insane may or may not indulge it, though it may well be doubted whether, in many instances, a person may not be so unsound in mind as to be irresponsible, and yet be actuated by malice as implying hatred. But however this may be, he may have malice in the legal and technical sense. *** But in this matter we are not left to the principles of the common law alone. Our statute law, by implication at least, leads to the same conclusion. By the R. S., 1859 , c. $137, \$ 2$. it is provided that "when the grand jury omits to find an indictment against any person arrested by legal process to answer for any offense by reason of insanity, they shall certify that fact to the court; and when a traverse jury, for the same rea. son, acquits any person indicted, they shall state that fact to the court when they return their verdict." And. in either case. l:o is to be restrained in prison or the insane hospital till restored to his right mind, or delivered according to law. It can hardly he sup. posed that the legislature expected or intended that the jury should return as a fact the insanity of the prisoner when they have only a reasonable doubt of his sinity, or that he should be detained in custody till restored to his right mind, when there is not sufficient : proof to make even a prima facie case that he is otherwise than sane. Our conclusion is, that upon this point as well as upnn the others, the ruling was sufficiently favorable to the prisoner. Exceptions overruled. S. v. Lawrence, 57 Me. 574, B. 258.

(Mich. Sup. Ct.. 1868.) Same. COOLEY, C. J. *** The defendant's counsel also requested the court to charge the jury that sanity is a necessary element in the commission of crime. and must be proved by the prosecution as a part of their case whenever the defense is insanity. Also, that where the defense makes proof of 
jusanity, partial or otherwise, whenever it shall be made to appear from the evidence that prior to or at the time of the offense charged, the prisoner was not of sound mind, but was afflicted with insanity, and such affliction was the efficient cause of the act, he ought to be acquitted by the jury. 'These requests were refused. It is not to be denied that the law applicable to cases of homicide, where insanity is set up as a defense, is left in a great deal of contusion upon the authorities; but this, we conceive, springs mainly from the fact that courts have sometimes treated the defense of insanity as if it were in the nature of a special plea, by which the defendant confessed the act charged, and undertook to avoid the consequences by showing a substantive defense, which he was bound to make ont by clear proof. The burden of proof is held by such anthorities to shift from the prosecution to the defendant when the alleged insanity comes in question; and while the defendant is to be acquitted unless the act of killing is established beyond reasonable doubt, yet when that fact is once made out, he is to be found guilty of the criminal intent, unless by his evidence he establishes with the like clearness, or at least by a preponderance of testimony, that he was incapable of criminal intent at the time the act was done. R. v. Layton, 4 Cox C. C. $149,15 j$; R. v. Stokes, 3 C. \& K. 185. 188; S. v. Brinyen, 5 Ala. 244 ; S. v. Spencer, 1 Zab. (21 N. J. L.) 196, 202; S. v. Stark, 1 Strob. (S. Car.) 479. These cases overlook or disregard an important and necessary ingredient in the crime of murder; and they strip the defendant of that presumption of innocence which the humanity of the law casts over him, and which attends him from the initiation of the proceedings until the verdict is rendered. *** The defendant was on trial for murder. MIurder is said to be committed when a person of sound mind and discretion unlawfully lilleth any reasonable creature in being, and under the ling's pence, with malice aforethought, either express or implied. 3 Coke Inst. 47, 4 Bl. Com. 195, 2 Chit. Cr. J. 724. 'These are the ingredients of the offense; the unlawful killing, by a person of sound mind, and with malice; or, to state them more concisely, the killing with criminal intentfor there can be no criminal intent when the mental condition of the party accused is such that he is incapable of forming one. 'These, then, are the facts that are to be established by the prosecution in every case where murder is alleged. The killing alone does not in any case completely. prove the offense, unless it was accompanied with such circumstances that malice in law or in fact is fairly to be implied. The prosecution takes upon itself the burden of establishing not only the killing, but also the malicious intent in every cas'. There is no such thing in the law as a separation of the ingredients of the offense, so as to leave a part to be established by the prosecution, while as to the rest the defendant takes upon himself the burden of proving a negative. The idea that the burden of proof shifts in these cases is unphilosophical, and at war with fundamental principles of criminal law. The presumption of innocence is 
a shield to the defendant throughout the proceeding's, until the verdict of the jury establishes the fact that beyond a reasonable doubt he not only committed the act, but that he did so with malicious intent. It does not follow, however, that the prosecution at the outset must grive direct proof of an actual malicious intent on the part of the defendant, or enter upon the question of sanity belore the clefendant has controverted it. The most conclusive proof of malice will usually spring from the circumstances attending the killing, and the prosecution could not well be required in such cases to go further than to put those circumstances in evidence. And on the subject of sanity, that condition being the normal state of humanity, the prosecution is at liberty to rest upon the presumption that the aceused was sime, until that presumption is overcome by the deferdant's evidence. 'The presumption establishes, prima facie, this portion of the ealse on the part of the government. It stands in the place of the testimony of witnesses, liable to be overeome in the same was. Nevertheless it is a part of the calse for the grovermment; the fact which it supports must neeessarily be established before any conviction can be had. * * Reversed. P. v. Garbutt, 17 Mich.

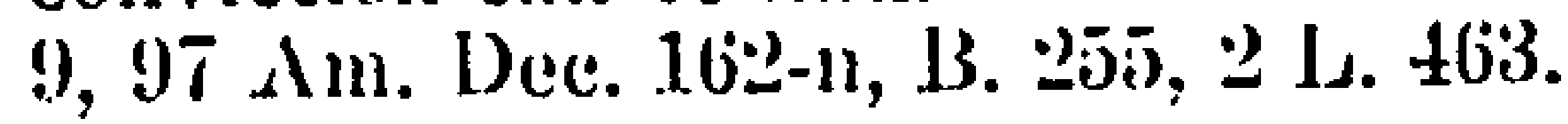

(U. S. Sup. Ct., 1595.) The same view is adopted by the United States supreme court in an exhaustive opinion written by Iarlan, $J .$, in which the cisess are reviewed at length, and the conclusion reached that the majority of the courts favor this rule. Davis v. U. S., 160 U. S. 469 , 16 S. Ct. 3ij3, 40 L. Sd. 499.

\section{(111. Sup. Ct., 1592.) Sufficient Evidence-Test of Insanty-Rea.} sonable Doubt Instruction. Defendant was convicted of assiult with intent to murder. The undisputed evidence of the people showed that he fired four shots at Clark, with a revolver, two of which in. thicted serious wounds. The only defense was insanity; and on this point the testimony was conflicting. "'The first contention now made is that in viev of the evidence as to the defendanc's insanity at the time the assanlt was committed, the verdiet of the jury finding him guilty was unwarranted and should be set aside. * * * the questions presented by the defense of insanity were for the jury, and they had the important advantage of seeing the witnesses and hearing them testify. * * * The following instructicn. asked on behalf of defendant, was modified by the court by inserting the reii the words in italies, and was given as modified: 'You are instructed that if you balieve from the evidence that the act chargod agrainst the defendant in the indictment was eommitted by him as therein charged, but that, at the time of committing the sime, the defendant. Was a lunatic or insine, to the axtent of obiiterating the scense of right and wrong as to the particular net done, you shunld so find by your verdict,' ete. 'T'wo other instructions of the same general character asked by the defendant were modified by the inser- 
tion therein of the same words. There was no error in this modification. As asked, these instructions held that lunacy or insanity, whatever its degree or character, was sufficient to take away eriminal accountability, while, as we have already seen, to have that elfect, it must be of such degree as to obliter'ate the sense of right and wrong as to trie particular act clone. The following instruction asked by the defendant was modified by the court by striking out the word in brackets, and inserting in lieu thereof the word in italies, and given to the jury so modified: "I'hat to warlant a conviction in this case, it is incumbent on the people to establish, by evidence, to the satisfaction of the jury, beyond a reasonable douht, the existence of every element necessary to constitute the crime charged; and if, after a careful and impartial examination of all the evidence in the case bearing upon the question of sinity or insanity, the jury entertair any reasonable doubt of the [sanity] guilt of the defiendant, at the time of the alieged offense, they should give the defendant the benefit of that doubt and acquit him.' Three other instructions wire asked on behalf of the defendant, by which it was sought, in various forms, to submit to the jury the issue as to the defendant's sanity; as a separate issue, and to instruct them that if, on consideration of the evidence, they had a reasonable doubt as to his sanity", they should find a verdict of acquittal. 'These instruetions were all modified in the same manner as above, and such modifications are assigned for error. We are of the opinion that this assigmment of error camnot be sustained. MIr. Bishop, in his treatise on Criminal Procedure, in discussing the defense of insanity and the mode in which it may be availed of', says: "Where the defendant sets up that he was insane when he did the act whereof he is aceused, he simply declares that he had not the criminal intent which is one of the indispensable elements in every offeuse. The defense is, in principle, precisely the same as when he declares that he had not the requisite age, or that he acted under an innocent mistake of fact, or where a wife sets up coercion from her husband. It is a bare denial of a part of the prosecuting government's case.' 2 Bish. Cr. Froc. (3d Ed.) \$669. And again: "The doctrine of principle, sustained by a large part of our courts, and rapidly becoming general. is that, as the pleadings inform us, insanity is not an issue by itself, to be passed on separately from the other issues, but, like any other matter in rebuttal, it is involved in the plea of not guilty, upon which the burden of proof is on the prosecuting power; the jury to convict or not according as, on the whole showing, they are satisfied or not, beyond a reasonable cloubt, of the defendant's guilt.' Id. \$ f72." Per BAILEY, C. J. Judgment affirmed. Hornish v. P., 142 Ill. 620.32 N. F. 677, 18 I. R. A. 237, F. 66. 


\section{CHAP'IER IV.}

\section{THE CRIMINAL AC'I.}

INCIIIST ACTs.

850. Classlfied, 178.

\$60. "Solicitation to Cirime," 178.

\$61. "Consplracy," 1 st.

\$ 62. "Attempt," 200.

ULTIMTE ACTS.

Cmiminal acts.

\$ 63. Classified, 214.

Justifiable aNd Excusiable acts.

8 64. Classilled, 218.

865 . "In Obedience to the Orders of a Superior Official," 218.

\$68. "In Reasonable Exercise of Parental or Official Authority," 219.

867. "In l'reserving or lestoring Public Peace," 224.

\$68. "In l'reventing Commission of Crime and Apprehending or l'reventing the Escape of Criminals," 224.

\$ 69. "In Self.Defense," 228.

870. "In Defense of Castle," 238.

\$ 71. "In Defense of Property," 243.

$\S 72$. "In Defense of Fliend or Stranger," 246.

\section{INCIPIENT ACIS.}

\$59. Classified. 'The criminal intent being now understood, the criminal act should be considered. It is progressive, and the scenes "between the acting of a dreadful thing and the first moment" should be separately observed: 1 . The incipient idea of committing the crime arises in the mind of the actor. 2. If the idea is not repelled, the next act is also merely mental, a decision to commit the crime; and thus far it is now agreed that there is nothing of which the criminal courts can take cognizance $[\$ 10]$. 3. The actor may proceed alone; but suppose he requires the aid or assent of an. bther; the next act is a proposal to another to join him in the crime; of this act of the proposer criminal courts sometimes take notice, and this distinctive offense is known as solicitation to crime. 4. If the person to whom the proposition is made accepts it and joins in the purpose, proposer and acceptor are then both guilty of the further distinct offense known as conspiracy. 5. Then if the single, actor or the united conspirators, with intent to commit the crime, do an act intended to accomplish the crime, they are guilty of the further indictable oflense of attempt, though the act failed of accomplishing the intended result. Observe that all these incipient crimes, apart from the one intended, are of a kindred nature. Now let us examine the last three of these more at length.

\section{$\S 60$. "Solicitation to Crime."}

(Eng. King's Bench, 1801.) Asking Servánt to Steal. The de(178) 
fendant was indicted for soliciting and enticing a servant to steal the goods of his master; and the defendant contended, that as nothing was done, no crime was committed. The judges delivered their opinions seriatim, and unanimously pronounced it an indictable oftense. LE BLANC, J. * * A solicitation or inciting of another, by whatever means it is attempted, is an act done, and that such an act done with a eriminal intent, is punishable by indictment, has been clearly established by the several cases referred to. * * * LAWRENCE, J. All such acts or attempts as tend to the prejudice of the community, are indictable. 'Then the question is, whether an attempt to incite another to steal is not prejudicial to the community; of which there can be no doubt. LORD KENYON. C. J. * * It is argued that a mere intent to commit evil is not inclictable without an act done; but is there not an act done, when it is charged that the defendant solicited another to commit a felony? The solicitation is an act; and the answer given at the bar is decisive that it would be sufficient to constitute an overt act of high treason. * * Gross, J., concurred. R. v. Higgins, 2 Eust $\overline{5}$, Ke. 83, Mi. 337.

(Comn. Sup. Ct., 1828.) Soliciting Adultery. Information for writing and sending to a married woman of good repute a letter, stating, "I think we have played peep-abo long enough. **"* * It is highly necessary that lovers meet, in order to understand each other's minds. I clo believe it was your intention to have met me a week ago last Sunday. * * * Now, if you will call at my house to-morrow, in the afternoon, at 3 o'elock." The information charged that the writer intended to insult, debauch, and seduce; accuse of libidinous actions; and solicit to commit adultery. Plea, not guilty. Verdict, guilty. He moved in arrest of judgment, and reserved the case for this court's opinion. PETERS. J. * * * * Admitting that the letter in question is not a libel, it is certainly a solicitation to commit a greater crime. It explicitly invites Mrs. White to make an assignation to meet the defendant at his house, or at some other place, to commit adultery with him. I have already shown, that adultery. is a very great crime, once capital, now punishable like most other felonies. * * And an attempt to commit, or a solicitation of another to commit such a crime, must be at least a high crime and misdemeanor. * * * Motion in arrest overruled. S. v. Avery, 7 Conn. 266, 18 Am. Dec. 105, F. 149.

(Wash. Sup. Ct., 1894.) Same. SCOT'T, J. 'The defendant was charged with attempting to commit adultery and was convicted. * * A motion in arrest of judgment, on the ground that the information did not charge any offense, was made, which the court granted, and ordered the defendant discharged. The state appeals. * * The only question presented and argued by appellant is as to whether solicitation to commit adultery is an attempt to commit 
adultery. * It being impossible for one alone to commit adultery, as that requires the co-operation of two persons, it would seem to follow logically that one acting singly could not make an attempt. One person could no more attempt to commit addultery than he could attempt to eommit a riot, which under our statues, recpuires the participation of three or more persons. * * II Smith v. C. (1867), jt Pa. St. 209, 3 L. 675, it was held that such solicitation did not amount to an attempt. A distinction his been sought to be drawn in this particular, to the effect that solicitation to commit adultery is indictable as an attempt in those states where adultery is a felony, which was the cisse in the state of Commeticnt, while in Pennsylvania adultery was but a misclemeanor. 'The distinction attempted to be drawn, it seems to us, is not somed in priticiple. It is based on the ground that in trivial misdemeanors the liw will look upon an attempt to commit them as not of sulficient gravity to justify or call for punishment. The decision of the ease last eited, however, was not founded upon this distinction, although it recognizes the fact that such a one has been sometimes made, in eiting S. v. Avery [above]. The court evidently entertained a different view. The opinion says: "An attempt to commit a misclemeanor is a misdemeanor, whether the offense is created by statute or was an offense at common law." " * In Shannon v. C., 14 Pa. St. 226, it was held that a conapiricy to commit adultery was not an offense; and in Miles v. S., is dla. 390 , a similar decision was arrived it. Adultery was but a misdemeanor, however, in that state also, though it is not apparent that any importance was attached to this fact in either of these cases. In Cox v. P., 82 Ill. 191, it was held that solicitation to commit incest was not an attempt to commit the crime of incest, which was a felony. * * * Suppose the eonsent of the other person is obtained, and, in pursunace of it, if there is no immediate opportunity to erratify the then mutual desire, a conspiracy is entered into to commit the offense between these persons, which involves the expressed consent and agreement of both of them. and some understanding between them as to when and where the offense shall be committed, and the naming of a propitious time and place to commit it. It seems that this would be much more in the way of an attempt than the ease presented here; and if that does not amount to an offense or an attempt. how can it be said that such an intention and willingness, coupled with solicitation upon the part of one person only, can amount to an attempt to commit the offense? We are of opinion that the judgment of the superior court should be affirmed. Dunbar, C. J., Hoyt, Stiles, and Anders, JJ., concur. S. v. Butler, 8 Wash. 194, 35 Pac. 1093, $40 \mathrm{Am}$. St. Rep. 900, 25 J. R. A. 434.

(Mrass. Sup. Judicinl Ct., 1839.) Purchasing Spirituous Liquor Sold in Violation of Statute was held not an indictable offense. either at common law as inducing the seller to commit a misdemeanor, or 
under the statute. The question arose on habeas corpus to release the purchaser from imprisonment for contempt in refusing to testify to the grand jury, as to the sale, claiming privilege against selfincrimination. SHAW, C. J. * * * It is difficult to draw any precise line of distinction between the eases in which the law holds it a misdemeanor to counsel, entice, or induce another to commit a crime, and where it does not. In general it has been considered as applying to cases of felony, though it has been held that it does not depend upon the mere legal and technical distinetion between felony and misdemeanor. One consideration, however, is manifest in all the eases; and that is that the offense proposed to be committed by the counsel, advice, or enticement of another, is of a high and aggravated character, tending to brenches of the peace or other great disorder and violence, being what are usually considered mala in se. * $*$ Prisoner remanded to custody. C. v. Willard, 22 Pick. 476 .

(Ill. Sup. Ct., 187\%.) An Offer to Take a Bribe, made by an alderman of the Chicago common council to influence his official action, was charged in an indictment in common law form; and it was conceded that there was no statute making such act an offense, though such action by some public officers was expressly made criminal. 'The indictment was sustained and defendant appealed. IIIORNI'ON, J. *** It is contended that the act charged does not fall within any of the common law definitions of bribery; that no precedent can be found for such an offense; and that, as propositions to receive bribes have probably often been made, and as no case can be found in which they were regarded as criminal, the conclusion must follow that the offense charged is no offense.

* The attempt to bribe a privy councillor, to procure an office, was an offense at common law. R. v. Vaughan, 4 Burr. 2494. In that case, Lord Mansfield said: "Wherever it is a crime to take, it is a crime to give. 'They are reciprocal. And in many cases, especially in bribery at elections to parliament, the attempt is a crime. It is complete on his side who offers it." Why is the mere unsuceessful attempt to bribe criminal? The officer refuses to take the offered reward, and his integrity is untouched, his conduct uninfluenced by it. The reason for the law is plain. The offer is a sore temptation to the weak or the depraved. It tends to corrupt; and as the law abhors the least tendency to corruption, it punishes the act which is calculated to debase, and which may affect prejudicially the morals of the community. The attempt to bribe is, then, at common law a misclemeanor; and the person making the offer is liable to indictment and punishment. *** The distinction between an offer to bribe and a proposal to receive one, is exceedingly nice. The difference is wholly ideal. If one man attempt to bribe an officer. and influence him, to his own degradation and to the detriment of: the public, and fail in his purpose, is he more guilty than the officer, 
who is willing to make sale of his integrity, debase himself, and who solicits to be purchissed, to induce a discharge of his duties? the prejudicial eftects upon society. are, at least, as great in the one case as in the other; the tendency to corruption is as potent; and when the officer makes the proposal, he is not only degraded, but the public service sufters thereby. According to the well-established principles of the common law, the proposal to receive the bribe was an act which tended to the prejudice of the community, greatly outraged public decency, was in the highest degree injurious to the public morals, was a gross breach of oficial duty, and must therefore be regarded as a misdemeanor, for which the party is liable to indictment. It is an offense more serious and corrupting in its tendencies than an ineffectual attempt to bribe. In the one case the officer spurus the temptation, and maintains his purity and integrity; in the other, he manifests a depravity and dishonesty existing in himself, which, when developed by the proposal to take a bribe, if done with a corrupt intent, should be punished; and it would be a slinder upon the law to surpose that such conduct cannot be checked by appropriate punishment. In holding that the act charged is indictable, we are not drifting into judicial legislation, but are merely applying old and well settled principles to a new state of facts. * * Walsh v. P., 65 11l. 58, 16 Am. Rep. 569, 13. 128.

(Pa. Sup., 189:.) Indictment for Solicitation to Murder. Defeudant moved to quash, and appealed from order denying the motion. Per CURIAMI. * * * It may be conceded that the mere intent to commit a crime, where such intent is undisclosed and nothing done in pursuance of it, is not the subject of an indictment. But there was something more than an undisclosed intent in this case. 'There was the direct solicitation to commit a murder, and an offer of money as a reward for its commission. 'This was an act done, a step in the direction of the crime; and, had the act been perpetrated, the defendant would have been liable to punishment as an accessary to the murder. It needs no argument to show that such an act affects the public policy and economy in a serious manner. ${ }^{*}{ }^{*} *$ Affirmed. C. v. Randolph, 146 Pa. St. 83, 23 Atl. 388, 28 Am. St. Rep. 78.2, B. 13.1, Kn. 85 .

(Ga. Sup. Ct., 1858.) Soliciting Arson and Making False Key. Griffin was indieted and convicted in Morgan county for an attempt to steal jewelry from the storehouse of one Richter, in said county: The proof showed that Griffin, while in Morgan county, took the impression on tin of the key to the door of the building; returneri to the city of Savannah, where he resided; made a key for the parpose of entering the storeroom; sent it in a box of fruit by express to one Jones, in MIorgan county. who feignedly agreed to become the accomplice of Griffin in the crime; and who, after plundering the store of its most valuable contents, was to fire the building, in which 
Griffin was interested, and who had previowsily effected an insurance on the premises. Jones was then to meet Griffin at the 79-mile station on the Central Railroad, and divide with him the spoils. LUMPKIN, J. * * * Was the conviction of Griffin in Morgan county, for an attempt to commit larceny from the house, legal? For myself, I entertain not a doubt r.pon the question. What is an attempt to commit a crime? It is an! endeavor to accomplish it, but falling short of execution of the uitimate design. In many cases it is difficult to determine the dif'erence between preparations and attempts to commit crime. One may intend to commit a crime, and do many things towards its commission, and yet repent of his purpose. The law gives to such an one a locus penitentiae.

Did he countermand his repeated instigations to his supposed confederate, urging him to the speedy execution of his diabolical scheme? Did he recall the key? On the contrary, had he not consummated his part of the preparations-all that he had to do except to share the spoils? hid was he not waiting in hopeful anxiety to learn the result-to ivelcome the glad tidings that a large portion of Nlalison was in irshes, that Richter perhaps was beggared, ynd to wrench from the insurance office the rewards of his iniquity? Let his letters respond. *** It matters not to me whether the proof in this case would have made Griffin a principal or an accessory provided the crime had been actually committed. He would have been one or the other. * * [McDonald, J., filed an opinion to the same effect.] BENNING, J., dissenting. * * * Procuring another to commit a crime is in fact a different thing from committing it yourself. Different words are needed to express it; different, proofs, to establish it. It is also a different thing in law. * * This is my conclusion. I know, that there stands opposed to it, a New York case, P. v. Bush, 4 Hill 133. **** Affirmed. Griffin v. S., '26 Ga. 493, F. 141.

(S. Cai. Sup. Ct., 1892.) Same-Whether an Attempt and Indictable. McIVER, C. J. The defendant was indicted for soliciting another to commit the crime of arson. ** * Bower's [1", mised to give Mayer $\$ 10$ if he would burn the house, and handed him matches, with a request that he would burn the house, which request and promise were promptly refused; and that ended it. His honor held "that a naked solicitation promptly rejected, is wanting in the essential elements of an attempt to commit a felony, and is not indictable." He therefore suggested that an order should be drawn quashing the indictment, which was accordingly done. From this ruling and order the state appeals. **** There is no doubt that there is some conflict of authority as to the question whether mere solicitation to commit a felony constitutes, of itself, an attempt to commit the felony; one of the leading text-writers on criminal law (Wharton) denying the proposition, while another standard text-writer (Bishop) supports it. But we need not go into that 
question here, for in this case the offense eharged does not consist of mere solicitation to cornmit a felony, but it is accompanied with acts-ofiering a bribe and furnishing the means with which the felony could be committed. .* * There can be no doubt that a person may commit a felony either by his own hand or by the hand of another, prompted and encouraged by him, and if he undertilkes to commit a felony by his own hand and his purpose is frustrated by the failure of the inanimate agencies which he employs to serve his felonious purpose, he would uncuestionably be guilty of an attempt to commit a felony. Upon the sume principle, if, instead of undertaking with his own hand to efteet his felonious purpose, he undertakes to employ the agency of another, furnishing him with the means requisite to effect his purpose, and offering him an induce. ment to do so, the fact that such agent fails him will not relieve him from responsibility for that which he not only intended to have done, but which he took the necessary steps to accomplish. *** The offense charged is the solicitation of another to commit a felony, which seems to be treated in some of the cases as a difterent offense from that of an attempt to commit a felony. [Citing and commenting on Stabler v. C., 95 Pa. St. 318, $40 \mathrm{Am}$. Rep. 653, sustaining conviction of solicitation to murder, and reversing convistion on a count for attempt.] * * If, therefore, the indictment in this cuse be regarded as an indictment for soliciting another to commit a felony, and not as an indictment for an attempt to commit a felony, we think it can be sustained if its allegations are established by the proof. R. v. Higgins, 2 Jast 5 [above] ; P. v. Bush, 4 Hill ( $\lambda_{\text {. Y.) }}$ 133 ; S. v. Avery, 7 Conn. 266 [above]. *** Case remanded for trial. S. v. Bowers, 35 S. Car. 262, 14 S. T. 488,28 Am. St. Rep. $84 i$, 15 L. R. A. 199.

That solicitation to murder by poisoning was not an attempt is held in Hicks $v . C_{.}, 86 \mathrm{Va}$. 223. 9 S. E 1024, 19 Am. St. Rep. 891.

\section{§ 61. "Conspiracy."}

(IId. Ct. of App., 1821.) General Nature-History of Law of Con. spiracy. James A. Buchanan, president of the Baltimore office of deposit of the Bank of the United States. James MeCulloh. cnshier of that office, and George Williams, a director of the hank. were indicted for a conspiracy to ember:le $\$ 1,500,000$ of the cur'r notes of the bank. Defendants demurred that no offenis was stated. The county court (Hauson, Ward. JJ.. and Dorsey, C. J.) sustained the demurrer, Dorsey, C. J.. dissenting. The state brings (rrror. BUCHANAN, J. *** Much reliance is placed on the statute 33 Edw. I, c. 2, de conspiratoribus, on the supposition that the offense of conspiracy was originally created by that statute; or, if it was a common law offense, that the statute either contained a definition of all the conspiracies that were before indictable at common law, or annulled the common law, and rendered dispunishable all conspirncies 
but such as it defines. * But by a course of decisions rumning through a space of more than four hundred years, from the reign of Edward III. to the 59th of George 11l., without a single conflicting adjudication,

These Points are Clearly Settled: (1) T'hat the ofiense of conspiracy is of common law origin, and not restricted or abrirlged by the statute $33 \mathrm{Edw}$. I. (2) That a conspiracy to do any act that is criminal per se, is an indictable offense at common law. for which it. can scarcely be necessary to offer any authority. (3) That in indictment will lie at common law-First, for a conspiracy to do an act not illegal, nor punishable if done by an individual, but immoral only, as in R. v. Grey [\$ 192]. * * * and R. v. Delaval [\$19]. Second, for a conspiracy to do an act neither illegal nor immoral in an individual, but to effiect a purpose, which has a tendency to prejudice the public, as in $R$. v. Journeymen 'Tailors of Cambridge, for a couspiracy to raise their wages, either of whom might legally have done so; and R. v. Widwards. 'Third. for a conspiracy to extort money from another, or to injure his reputation by means not indictable if practiced by an individual, as by verbal defamation, and that, whether it be to charge him with an indictable offense or not, as in re Timberley, Child v. North, P. v. Armstrong. R. v. Best, R. v. Kinnersly, R. v. Brian, R. v. Parsons, and R. v. Rispal. Fourth, for a conspiracy to cheat and defrand a third person, accomplished by means of an act which would not in law amount to an indictable cheat. if eftected by an individual, as in re Breerton. R. v. Skirret, R. v. Macarty, R. v. Orbell, R. v. Wheatly, and R. v. Lara. Fifth, for a malicious conspiracy to impoverish or ruin a third person in his trade or profession, as in R. v. Cope, R. v. Eceles. R. v. Leigh (Mracklin's Case), and the case of Clifford v. Brandon. Sixth, for a conspiracy to defraud a third person by means of an act not per se unlawful. and though no person be thereby injured, as in R. v. Robinson. R. v. Berenger. and R. v. Edwards. Seventh, for a bare conspiracy to cheat or defraud a third person. though the means of effecting it should not be determined on at the time. as in R. v. Gill. Eighth, that a conspirace is a substantive offense, and punishiowle at common law, though nothing be done in execution of it. as in the Book of Assizes, c. 44; Poulterer's Case. R. v. Edwards, R. v. Fecles, $R$. v. Berenger, and R. v. Gill; and all the authorities, that the conspiracy is the gist of the offonse. And. ninth, that in a prosecution for a conspiracy, it is sufficient to state in the indictment the conspiracy and the object of it; and that the means by which it was intended to be accomplished need not be set out, being only matters of evidence to prove the charge, and not the crime itself. and may be perfectly indifferent, as in R. v. Eccles, and R. v. Gill.

From All Which it Results that every conspiracy to do an unlawful act, or to do a lawful act for an illegai, fraudulent. malicious. or corrupt purpose, or for a purpose which has a tendency to prejudice the public in general, is at common law an indictable offense, 
though nothing be done in execution of it, and, no matter by what means the conspiracy was intended to be eftected, which may be perfectly indifferent, aud makes no ingredient of the crime, and therefore need not be stated in the indictment. ** * There is nothing in the objection that to punish a conspiracy where tine end is not accomplished, would be to punish a mere unexesuted inten. tion. It is not the bare intention that the law punishes, but the act of couspiring, which is made a substantive offense, by the nature of the object intended to be effected. And in that respect conspiracies ale analogous to unlawful assemblies. * * $*$ It has been con. tended that as an improper use or embezzlement of the funds of the bank, by either the president or eashier of the office, would in law be only a breach of trust, a combination to effect the same purpose cannot amount to an indietable oftense. But, however ingeniously urged, there does not appear to be anything in the argument, when stripped of the daraling attire in which it was clothed; seeing, as has been shown, that to constitute an indictable conspiracy, it is not necessary that the act conspired to be done should, if effected by an individual, be such as would per se amount to an indictable offense. It seems, therefore, to be perfectly elear, both on principle and authority, that the matter charged in each count in the indictment constitutes a punishable conspiracy at common law, and that that portion of the common law is in force in this state. * * [Chase. C. J., delivered a concurring opinion.] Judgment reversed and demurrer overruled. S. v. Buchanan, 5 Har. \& J. 317, 9 Am. Dec. j33t, F. 151, Mi. 358.

(Eng. Queen's Bench, 1705.) Without Overt Act. Indictment strated that defendants, intending to oppress and defame one $\mathrm{H}$, did falsely and malicionsly contrive, conspire, meet, and agree falsely to charge the said $\mathrm{H}$, ete. Upon demurer, it was -held by the court, that though nothing be done in prosecution of the unlawful agree. ment, yet it is a complete and consummated offense of itself; and whether the conspiracy be to charge a temporal or ecclesiastical oftense on an innocent person, it makes no difterence. $R$. v. Best, 2 Ld. Raym. 1167, 1 Salk. 174.

(Eng. King's Bench, 1811.) Conspire to Trespass. The defendants were indicted and convicted of conspiring to commit a civil trespass upon property by agreeing to go, and by going into, a preserve for hares, the property of another, for the purpose of suaring them; it was alleged to be done in the night-time; and that the defendants were armed with ofrensive weapons, for the purpose of opposing resistance to any endeavor's to apprehend or obstruct them. On motion to arrest judgment. IORD ELLENBOROUGH, C. .T.. snid he should be sorry to have it doubted whether persons agrecing to go and sport upon another's ground, in other words, to commit a civil trespass. should be thereby in peril of an indictment for an 
offense which would submit them to an infamous punishment. Motion granted. R. v. Turner, 13 East 228, B. 805.

(Eng. Nisi Prius, 1816.) Proof of Concert-False Warranty. P, one of the defendants, had advertised the sale of horses, undertaking to warrant their soundness; and upon an application by $A$ at $P$ 's stables, another of the defendants stated that he well knew the horse which he showed to $A$; and that, as $P$ 's agent, he would warrant him sound. A bought the horse, and the receipt contained a warranty, and a clause that he should be returned if disapproved of within a week. Soon after the sile, it being discovered that the horse was of no value, $A$ indicted the defendants for conspiring to defraud him by selling an unsound horse. LORD ELLENBOROUGH intimated that the case did not assume the shape of a conspiracy; the evidence would not warrant any proceeding beyond that of an action on the warranty, for the breach of a civil contract. If this (he said) were to be considered to be an indictable offense, then instead of all the actions which had been brought on warranties, the defendints ought to have been indicted as cheats. And that no indictment in a case liks this could be maintained, without evidence of concert between the parties to effectuate a fraud. 'The defendants were accordingly acquitted. R. v. Pywell et al., 1 Starlie 402, B. 807 , Ke. 409 .

(A. Ilam. Superior Ct. of Judicature, 18t4.) Lawful Act by Fraudulent Means-Election. Indictment for conspiracy. GILCHRIS'T, J. The allegations in the indictment in relation to which the questions arise, are that the respondents conspired to induce sundry persons, by issuing to them fraudulent policies of insurance, to appear at the annual meeting of the company, and vote for directors without right. * * * In the first place, we have no doubt that a conspiracy is an indictable offense in this state. It is punishable at common law, its punishment is not repugnant to our institutions, and it is an offense productive of as much injury, and as deserving reprehension under one l'vi'm of govermment as another. *** The authorities agree in stating that a conspiracy is a confederacy to do an unlawful act, or a lawful aet by unlawful means, whether to the prejudice of an individual, or of the public, and that it is not necessary that its object should be the commission of a crime. 1 Hawkins P. C. c. 72. *** Whether this indictment charges the respondents with a conspiracy to do an unlawful act, is a question which does not arise, and has not been made upon the argument. We assume, therefore, that the ultimate object which the respondents had in view was not illegal. Their purpose was to procure the election of certain persons as directors of the company. and thereby to cause themselves to be employed in the service of the company; and this end, pursued in a legitimate and open manner. and without deceiving or attempting 
to deceive and defraud those who had the power and right, to em. ploy them, or to aid them in their purposes, was as unobjectiomable as any pursuit whatever. But if, by an insatiate appetite for gain. the respondents liept exclusively in view the object to be areom. plished, lost sight of honesty and fairness in the means used to effeet it, and resorted to fraud and falseinood, in such case they have made themselves amenable to the law. Assuming, then, that the purpose of the respondents was lawful, still, if the means used to effect it be unlawful, the offense will be complete. The illegality of the means in such case must be explained by proper statements, and estab. lished by proof. 2 Russ. on Crimes $569 ;$ R. v. Seward, 1 Ad. \& E. 706 ; R. v. Eceles, 3 Dougl. 337 ; Archb. Cr. Pl. 390, 391. ** * Having a corrupt purpose in view, are they the less criminal because they prostituted the forms of law to enable them to subserve that purpose? Is the fraud on the company any less? 'The transuction, if known, certainly could have no other than an injurious effect upon the standing of the company with the public. 'The object of the company was to indemnify the public against the hazards of fire. and a large number of persons laad a deep interest in its well being. and the injurious effect of such a combination was of such a kind that common prudence would not enable one to guard himself against it. If the respondents desired to secure the election of certain persons as directors, they might well enough have induced their friends to become members of the company; they might have canvassed for votes; they might have resorted to the ordinary practices of electioneering. 'They might have used all those arts which the good sense and right feeling of every disinterested man condemn. although the moral sense of the public may not be sufficiently pure to discountenance them. But all this might have been done without an actual fraud, or even with no fraudulent intent. But here there was a gross frand. By whose voies were the directors to be elected? It was not by bona fide members of the company. It was not by those whose membership was the result of a positive contract to continue for a definite period. It was not by those who intended to take upon themselves certain responsibilities; in considerition of certain benefits to be derived from the company. But the eontrits. except for one selfish and specific purpose, were false. In their substance they were wrongful and fraudulent. They were honest only in their form and outward seeming. 'They were to exist only as blinds to those whose interests depended on their being honest. upon their being anything but what they were in fact. The choice of directors in such an association is of the last importance.

* They should, of course, be elected by those only who have a positive interest in the success of the company. But this combina. tion intended that they should be chosen by persons to whom its interests were immaterial; who took their policies under a fraudulent pretense, and who were brought forward to outvote the unsuspicious members of the association, who were ignorant of this con- 
certed action. Can we say that this was not a firad? * * * * Judgment on verdict. S. v. Burnham, 15 N. 1I. 396, Kn. 318.

lee. ats to implied abrogation by general statutes: S. v. ''ulle, $\$ \$$.

(IIl. Sup. C't, 1860.) What Unlawfulness-Certainty-Seduction. schwab, smith, and Allen were indicted for conspiring to procure, by fialse pretenses and other fraudulent means, one Lizzie bingles (age 16) to have illicit intereourse with Sehwab. Verdict, guilty. Irotion in arrest of judgment denied. Erior assigned in denying the motion and that no offense is stated in the indictment. CATON, C. J. 'I'o attempt to define the limit or' extent of the law of conspiracy, as deducible from the English decisions, would be a difficult if not an impracticable task, and we shall not attempt it at the present time. We may safely assume that it is indictable to conspire to do an unlawtiul act by any means, and also that it is indictable to conspire to do any act by unlawtul means. In the former case it is not necessary to set inut the mearis used, while in the latter it is, as they must be shown to be unlawtul. But the great uncertainty, if we may be allowed the expression, is as to what constitutes an unlawful end, to conspire to accomplish which is indictable without regard to the means to be used in its accomplishment. And again, what means are unlawfiul to accomplish a purpose not in itself unlawful. As this indictment fialls under the first class, we shall confine ourselves to that. If the term unlawful means criminal, or an offiense against the criminal law, and as such punishable, then the objection taken to this indictment is good, for seduction by our law is not indictable and punishable as a crime. But by the common law governing conspiracies the term is not so limited, and numerous cases are to be found where convictions have been sustained for conspiracy to do unlawfiul acts, although those acts are not punishable as crimes. Nor yet would it be quite safe to say that the term "unlawful" as here used includes every act which violates the legal rights of another, giving that other a right of action for a civil remedy. And we are not now prepared to say where the line ean be safely drawn. It is sufficient for the present cuse, to say that conspiracies to accomplish purposes which iale not by law punishable as crimes, but which are unlarvful as violative of the rights of individuals, and for which the civil law will aftord a remedy to the injured party, and will at the same time and by the same process punish the offender for the wrong and outrage done to society, by giving exemplary damages, beyond the damages actually proved, have in numerous instances been sustained as common law offenses. The law does not punish criminally every unlawful act, although it may be a grievous oftense to society. And in determining what sort of conspiracies may or may not be entered into without committing an offense punishable by the common law, regard must be had to the influence which the act, if done, would actually have upon society, without confining the inquiry to the question 
whether the act might itself subject the offender to eriminal punish. ment. And most prominent among the acts branded as unlawful, although not punishable as crimes, is the very act, to accomplish which this conspiracy is eharged to have been entered into. ** * We hold that it was not necessary to show that the means to be used by the conspirators were unlawful or criminal. "* * Judgment affirmed. Smith v. P., 25 Ill. 17, 76 Am. Dec. 780, B. 811.

Ace. on similar facts: R. v. Delaval, \& 10. On seduction in genernl, see \& 183.

(MIass. Sup. Judicial Ct.. 1857.) To Procure Over Insurarce. De. fendants except to conviction on the second count of an indictment for conspiracy. BIGELOW, J. The second count in the indictment, on which alone the defendants were found guilty, is fatally defective. It was not a crime in the defendants to procure an over insurance on their stock in trade. It was at most only a civil wrong. The charge of a conspiracy to do so does not therefore amount to a criminal offense. It was not a combination to eflect an unlawful purpose. and no unlawful means by which the purpose was to be effected are set out in the indictment. *** Judgment arrested. C. v. Prius, 9 Gray 127, B. 810.

(Mass. Sup. Judicial Ct., 18.2.) Agreement to Strike-Conten. tion and Ruling Below. SHAW, C. J. *** The counsel for the defendants contended, and requested the court to instruct the jury, that the indictment did not set forth any agreement to do a criminal act, or to do any lawful act by any specified criminal means, and that the agreements therein set forth did not constitute a conspiracy indictable by any law of this commonwealth. But the judge refused so to do, and instructed the jury, that the indict. ment did, in his opinion, describe a confederacy among the defend. ants to do an unlawful act, and to effect the same by unlawful means; that the society, organized and associated for the purposes deseribed in the indictment. was an unlawful conspiracy, against the laws of this commonwealth.

We are Here Carefully to Distinguish between the confederacy set forth in the indictment, and the confederacy or association contained in the constitution of the Boston Journeymen Bootmakers' Society, as stated in the little printed book, which was admitted as evidence on the trial. Because, though it was thus admitted as evidence, it would not warrant a conviction of anything not stated in the indictment. It was proof, as far as it went, to support the averments in the indictment. If it contained any criminal matter not set forth in the indictment, it is of no avail. The question then presents itself in the same form as on a motion in arrest of judgment.

The First Count Set Forth, that the defendants, with divers others unknown, on the day and at the place named, being workmen and journeymen in the art and occupation of bootmakers, unlarfully, 
perniciously and deceitfully designing and intending to continue, keep up, form and unite themselves, intc an unlawful club, socicty, and combination, and make unlawful by-laws, rules, and orders, among themselves, and thereby govern themselves and other workmen, in the said art, and unlawfully and unjustly to extort great sums of money by means thereof, did unlawfully assemble and meet together, and being so assembled, did unjustly and corruptly conspire, combine, confederate, and agree together, that none of them should thereafter, and that none of them would, work for any master or person whatsoever, in the said art, mystery, and occupation, who should employ any workman or journeyman, or other person, in the said art, who was not a member of said club, society, or combination, after notice to him to discharge such workman. from the employ of such master; to the great damage and oppression. ete. * * * Stripped then of these introductory recitals and alleged injurious consequences, and of the qualifying epithets attached to the facts, the averment is this; that the defendants and others formed themselves into a society, and agreed not to work for any person, who should employ any journeyman or other person, not a member of such society, after notice given him to discharge such workman.

[Necessary Allegation and Proof of Criminal Means.] The manifest intent of the association is, to induce all those engaged in the same occupation to become members of it. Such a purpose is not unlawful. It would give them a power which might be exerted for useful and honorable purposes, or for dangerous and pernicious ones. If the latter were the real and actual object. and susceptible of proof, it should have been specially charged. Such an association might be used to afford ench other assistance in times of poverty, sickness, and distress; or to raise their intellectual, moral, and social condition; or to make improvement in their art; or for other proper purposes. Or the association might be designed for purposes of oppression and injustice. Bit in order to charge all those, who become members of an association, with the guilt of a criminal conspiracy, it must be averred and proved that the actual. :? not the avowed object of the association, was criminal. An association may be formed, the declared objects of which are innocent and laudable, and yet they may have secret articles, or an agreement communicated only to the members, by which they are banded together for purposes injurious to the peace of society or the rights of its members. Such would undoubtedly be a criminal conspiricy. on proof of the fact, however meritorious and praiseworthy the declared objects might be. The law is not to be hoodwinked by colorable pretenses. It looks at truth and realitv, through whatever disguise it may assume. But to make such an association. ostensibly innocent, the subject of prosecution as a criminal conspiracy, the secret agreement which makes it so is to be averred and proved as the gist of the offense. But when an association is 
formed for purposes actually innocent, and afterwards its powers are abused by those who have the control and management of it, to purposes of oppression and injustice, it will be criminal in those who thus misuse it, or give consent thereto, but not in the other members of the association. In this case, no such secret algreement, vinying the objects of the association from those arowed. is set forth in this count of the indictment.

[Whether Means Alleged are Criminal.]. Nor call we perecive that the objects of this association, whatever they may have been, were to be attained by eriminal means. 'The means which they proposed to employ, as averred in this comt, and which, as we are now to presume, were established by the jroof, were, that ther would not work for a person, who, after due notice, should employ a journeyman not a member of their society. Supposing the object of the association to be landable and lawful, or at least not unlallptul, are these means criminal? The case supposes that these persons are noi bound by contract, but firee to work for whom they please, or not to work, if they so prefer. In this state of things, we camnot perceive, that it is eriminal for men to agree together to excreise their own acknowledged rights, in such a mimmer as best to subserve their own interests. One way to test this is. te consider the effect of such an agreement, where the object of the association is acknowledged on all hands to he al laudable one. Suppose a class of workmen, impressed with the manifold evils of intemperauce, should agree with each other not to work in a shop in which ardent spirit was furnished, or not to work in a shop with any one who used it, or not to work for an employer, who should, after notice, employ a journeyman who habitually used it. The consequences mighit be the sime. A workman, who should still persist in the use of ardent spirit. would find it more difficult to set employment; a master employing such an one might, at times, experience inconvenience in his work, in losing the services of a skilful but intemperate workmau. Still, it seems to us, that as the object would be lawful, and the means not unlawful, such an agreement could not be pronounced a criminal conspiracy. From this count in the indictment, we do not understand that the agrerment was, that the defendants would refuse to work for an employer, to whom they were bound by contract for a certain time,

In Violation of that Contract; nor that they would insist that an employer should discharge a workman engaged by contract for a certain time, in violation of such contract. It is perfectly consistent with everything strited in this count, that the effect of the agreement was, that when they were free to act, they would not engage with an employer or continue in his employment. if such employer when free to act should engage with a workman, or r.ontinue a workman in his employment not a member of the associa. tion. If a large number of men engaged for a certain time should combine together to violate their contract and quit their employ- 
ment together it would present a very different question. Suppose a farmer employing a large numbor of men, engaged for the year at fair monthly wayes, and suppose that just at the moment that his crops were ready to harvest, they should all combine to quit his service unless he would advance their wages at a time when other laborer's could not be obtained. It would surely be a couspiracy to do an unlawful act, though of such a character that if done by an individual it would lay the foundation for a civil action only and not of a criminal prosecution.

The Third Count, reciting a wicked and unlawful intent to impoverish one Jeremiah Horne and hinder him from following his trade as a bootmaker, charges the deifendants, with others unknown, with an unlawful conspiracy, by wrongful and indirect means, to impoverish said Horne, and to deprive and hinder him from his said art and trade and getting his support thereby, and that in pursuance of said unlawful combination, they did unlawfully and indirectly hinder and prevent, etc., and greatly impoverish him. If the fact of depriving Jeremiah IIorne of the profits of his business by whatever means it might be done would be unlawful and criminal, a combination to compass that object would be an mulawful conspiracy. and it would be unnecessary to state the means. Such seems to have been the riew of the court in R. v. Fecles, 3 Dour. $33 i$, though the case is so briefly reported that the reasons on which it rests are not very obvious. The case seems to have gone on the ground that the means were matter of evidence and not of averment. and that after verdict it was to be presumed that the means contemplated and used were such is to render the combination unlawful and constitute a conspiracy.

Suppose a Baker in a Small Village had the exclusive custom of lis neighborhood, and was making large profits by the sale of his bread. Supposing a number of those neighbors, believing the price of his bread too high, should propose to him to reduce his prices, or if he did not that they would introduce another baker, and on his refusal sueh other baker should moler their encouragement set up a rival establishment. and sell his breal at lower pricis, the effect would be to diminish the profit of the former baker and to the same extent to impoverish him. And it might be said and proved that the purpose of the associates was to diminish his profits and thus impoverish him, though the ultimate and laudable object of the combination was to reduce the cost of bread to themselves and their neighbors. The same thing may be said of all competition in every branch of trade and industry, and yet it is throngh that competition that the best interests of trade and industry are promoted. It is scarcely necessary to allude to the familiar instances of opposition lines of conveyance. rival hotels, and the thousand other instances where each strives to gain eustom to himself. by ingenious improvements, by increased industry, and by all the means by 
which he may lessen the price of commodities, and thereby dimin. ish the protits of other's.

We Think, Therefore, that associations may be entered into, the object of which is to adopt measures that may have a tendency to impoverish another, that is, to diminish his gains and profits, and yet so far from being criminal or unlawful, the object may be highly meritorious and public spirited. The legality of such an association will therefore depend upon the means to be used for its accomplishment. If it is to be carried into effect by fair or honorable and lawful means, it is, to sily the least, innocent; if by falsehood or force, it may be stamped with the character of conspiracy. It follows as a necessiary consequence that if criminal and indictable it is so by reason of the criminal means intended to be employed for its accomplishment; and as a further legal consequence, that as the criminality will depend on the means those means must be stated in the indictment. If the same rule were to prevail in criminal which holds in civil proceedings-that a case defectively stated may be aided by a verdict-then a court might presume after verdict that the indictment was supported by proof of criminal or unlawtul means to effect the object. But it is an established rule in criminal cases that the indictment must state a complete indictable offense, and cannot be aided by the proof offered at the trial. * * * Exceptions sustained and judgment arrested. C. v. Hunt, 4 Metc. 111, 38 Am. Dec. 3 36 , B. S⒈

(N. J. Sup. Ct., 1867.) Same. BEASLEY, C. J. There is, perhaps, no crime, an exact definition of which it is more difficult to give than the offense of conspiracy. 'That a combination of persons to effect an end, itself of an indictable nature, will constitute this crime, is clear; nor is there any more doubt that, though the purpose the confederacy is designed to accomplish be not eriminal, yet if the means adopted be of an indictable character, this oftense is likewise committed. 'Thus far the limits are clearly defined, and embrace, without exception, all cases which fall within them. But when we proceed one step beyond the lines thus marked out, the cases which have been adjudged to be conspiracies appear to stand apart by themselves, and are devoid of that analogy to each other which would render them susceptible of classification. It is certain, however, that there are a number of cases, in which neither the purpose intended to be accomplished nor the means designed to be used were criminal, which have been regarded to be indictable conspiracies. And yet it is obvious that, in the nature of things, it cannot be every collusion between two or more persons to do an unlawful act, or an indifferent act by unlawful means. which will constitute an offense of a public nature; for if this were so, a large portion of the transactions which, in the ordinary course of litigation between party and party, comes before the courts, would assume a criminal aspect, in which the state would have an 
interest. Indecd, I think it may be said that there are, comparatively, but few cases of combinations in which indictability does not attach, either to the end in view, or to the instrumentalities devised, which are punishable by a public prosecution. It is true, that rumning to an extreme, in the case of S. v. Rickey, 4 Halst. 293, Ford, J., insisted that, up to his day, there was but a single case extant-that of $R$. v. Cope, 1 strange 144, which held that an indictment for a conspiracy would lie for a combination of two or more to commit a private injury which was not a public wrong; and he further insisted that the case referred to was erroneously decided; but Ryerson, J., did not, as is evident from the grounds upop. which he rests his judgment, concur in that view; and the course of reasoning adopted by Ford, J., is now very generally admitted to be fallacious. In the case of S. v. Norton, $3 \mathrm{Zab}$. 33, the view of the law expressed by Ford, J., is disapproved of, and Green, C.'J., in stating his conclusion, after an examination of the subject, remarks, "The great weight of authority, the aljudged cases, no less than the most approved elementary writers, sustain the position, that

"A Conspiracy to Defraud individuals or a corporation of their property, may, in itself, constitute an indictable offense, though the act done, or proposed to be done in pursuance of the conspiracy, be not, in itself, indictable." The rule of law thus enunciated appear's to me to be the correct one. 'There are a number of cases which cannot be sustained upon any other doctrine. To this class belongs the decision that it was a conspiracy to induce a young female, by false representations, to leave the protection of the house of her parent, in order to facilitate her prostitition. R. v. Lord Grey, 3 St. Tr. 519 [\$ 192]; R. v. Delaval, 3 Burr. 1434 [\$ 19]. So a conspiracy to impoverish a tailor, and prevent him, by indirect means, from carrying on his trade, R. v. Eccles, 3 Dougl. 337. So a conspiracy to marry paupers, with a view to charge one parish and exonerate another, $R$. v. 'Tarrant, \pm Burr. 2106 ; or to charge a man with being the father of a bastard, $R$. $v$ Armstrong. 1 Vent. $304 ;$ R. v. Kimberty, 1 Lev. 62 ; R. v. Timberley, Sid. 6S; 1 ; a combination to impoverish a class of persons, $R$. v. Sterling, 1 Lev. 125 , Sid. 174. 'These are all cases, it will be noticed, in which the act which formed the foundation of the indictment would not, in law, have constituted a crime. if such act had been clone by an individual, the combination being alone the quality of the transactions which made them respectively indictable.

I Conclude, Then, that there is no uncertainty in this legal topic to this extent, in addition to the principles before adverted to, that cases may occur in which the purpose designed to be accomplished becomes punitive, as a public oftense, solely from the fact of the existence of a confederacy to effect such purpose. It is certainly not to be denied, however, that great practical difficulty is experieneed whenever any attempt is made to lay down any general rules 
by which to discriminate that class of combinations which becomes thus punishable, from those which are to be regarded in their results as mere civil injuries, remediable by private suit. It may be safely said, nevertheless, that a combination will be an indictable conspiracy, whenever the end proposed, or the means to be employed are of an highly criminal character; or where they are such as indicate great malice in the confederates; or where deceit is to be used, the object in view being unlawful; or where the confederacy, having no lawful aim, tends simply to the oppression of individuals. A careful analysis of the cases which have been heretofore adjudged, will reveal the presence of one or more of the qualities here enumerated; to this extent, therefore, they may be relied on as safe criteria whereby to test new emergencies as they may be presented for adjudication. In view, then, of these general deductions, and guided by the decisions above cited, let us turn our attention to the particular indictment now before us.

The Substantial Offense Charged is, that the defendants combined to compel their employer to discharge certain of their fellow-workmen, the means adopted to enforce this concession being an announced determination to quit their employment in a body and by a simultaneous act. On the argument before this conrt. comsel in behalf of the state endeavored to sustain

The Indictability of This Charge, on the plea that the thing thus agreed to be done was an injury to trade, and consequently came within the express language of the statute on the subject of conspiracy. Nix. Dig. 187, \$61. But I cannot concur in this view. An act, to fall within this provision, must be one which, with directness, inflicts an injury on trade, as, for example, a combination to depress any branch of trade by false rumors. But. in the case before us, the act charged, if it could be said to injure trade at all, did so not proximately, but remotely. It is true that. at a far remove, an injury to an individual manufacturer may affect trade injuriously ; but, in the same sense, so it is true, will an injury inflicted on a consumer of manufactured articles. But it is not this undesigned and incidental damage which is embraced within the statutory denunciation. On this account. I think the indictment does not present an affair which ean be comprehended by the clause of the act which, in this respect, was relied on. But as it has already been decided by this court that the statute in question has not superseded the common law, with regard to the crime of conspiracy. S. v. Norton. 3 \%ab. 33, the question still remains to be resolved. whether the facts charged on this record do not constitute such crime upon general principles. It appears to me that it is not to be denied, that the alleged aim of this combination was unlawful; the effort was to dictate to this employer whom he should discharge from his employ. This was an unwarrantable interference with the conduct of his husiness, and it seems impossible that such acts should not be, in their usual effects, highly injurious. 
Ilow far is this mode of dictation to be held lawful? If the manufincturer ean be compelled in this way to discharge two or more hands, he can, by similar means, be coereed to retain such workmen as the conspirators may choose to designate. So his eustomer's may be proseribed, and his business in other respects controlled. I eannot regard such a course of conduct as lawfinl. It is no answer to the above considerations to say, that the employer is not eompelled to submit to the demand of his employees; that the penality of refusal is simply that they will leave his service. There is this coercion: the men agree to leave simultaneously, in large numbers and by preconeerted action. We camnot close our eyes to the fact, that the threat of workmen to quit the manufacturer, under these circumstances, is equivalent to a threat, that unless he yield to their unjustifiable demand, they will derange his business, and thus cast a heavy loss upon him. 'The workmen who make this threat understind it in this sense, and so does their employer. In such a condition of affiairs, it is idle to suggest that the minufiacturer is free to rejeet the terms which the confederates offer. In the natural position of things, each man acting as an individual, there would be no coercion; if a single employee should demand the discharge of a coemployee, the employer would retain his freedom, for he could entertain or repel the requisition without embarrassment to his concerns; but in the presence of a coalition of his employees, it would be but a waste of time to pause to prove that, in most eases, he must submit, under pain of often the most ruinous losses, to the conditions imposed on his necessities. It is difficult to believe that a right exists in law, which we can searcely conceive can produce, in any posture of affairs, other than injurious results. It is simply the right of workmen, by concert of action, and by taking advantage of their position, to control the business of annother. I am unwilling to hold that a right which cannot in any event, be advantageous to the employee, and which must be always hurtfin to the employer. exists in law. In my opinion, this indictment sufficiently shows that tile force of the confederates was brought to hear upon their employer for the purpose of oppression and miscisief, and that this amounts to a conspiracy. I also think this result is sustained by all the judicial opinion which has heretofore been expressed on this point. In substance, the indictment in this cise is similar to that in R. v. Ferguson, 2 Stark. 489 . Nor were the circumstances unlike; for in the reported ease, the defendints were charged at common law with combining to quit and turn out from their employment, in order to prevent their employer from taking apprentices; and although the case, after trial and eonviction, was mooted in the king's bench on points of evidenee, no doubt was suggested as to the indictable nature of the offense, and the defendants were accordingly fined and imprisoned. So in R. v. Bykerdike, 1 M. \& Rob. 179, the same doctrine was maintained. The indictment charged, that the defendant, with others, conspired to pre- 
vent certain hands from working in the colliery; and the evidence showed that the body of the men met and agreed upon a letter addressed to their employer, to the effect that all the workmen would strike in fourteen days unless the obnoxious men were discharged from the colliery; and Patteson, J., held that these workmen had no right to meet and combine for the purpose of dictating to the master whom he should employ, and that this compulsion was clearly illegal. These two cases, it will be observed, sustain with entire aptness the opinion above expressed, and I have not found any of an opposite tendency. As to C. v. Hunt, 4 Met. 111 [above] it is clearly distinguishable, and I concur entirely, as well with the prin. ciples embodied in the opinion which was read in the case, as in the result which was attained. *** Motion to quash should not prevail. S. v. Donaldson, 32 N. J. L. 151, 90 Am. Dec. 649, B. 8:8.

(Coun. Sup. Ct. of Errors, 1887.) Agreement to Boycott Printers. Information for conspiracy. Demurrer to the information overruled. Plea, not guilty. Verdict, guilty. 'The def'endant appealed. 'The appeal raises a question as to the sufficiency of the information, and also some questions of evidence. Is an offense sufficiently charged in the information? CARPENTER, J. **** Do the acts which it is alleged the defendants conspired to do fall within the prohibition of the act of 1878 ? They propose to threaten and use means (the boycott) to intimidate the Carrington Publishing Company to compel it, against its will, to abstain from doing an act (to keep in its employ the workmen of its choice) which it had a legal right to do, and to do an act (employ the defendants and such persons as they should name) which it had a right to abstain from doing. There can be but one answer to the question. The acts proposed are clearly prohibited by the statute.

If the defendants have the right which they claim, then all business enterprises are alike subject to their dictation. No one is safe in engaging in business, for no one knows whether his business affairs are to be directed by intelligence or ignorance,whether law and justice will protect the business, or brute force, regardless of law, will control it; for it nust be remembered that the exercise of the power, if conceded, will by no means be confined to the matter of employing help. Upon the same principle, and for the same reasons, the right to determine what business others shall engage in, when and where it shall be carried on, etc., will be demanded, and must be conceded. The principle, if it once obtitins a foothold, is aggressive, and is not easily checked. It thrives on what it feeds on, and is insatiate in its demands. More requires more. If a large body of irresponsible men demand and receive power outside of law, over and above law, it is not to be expected that they will be satisfied with a moderate and reasonable use of it. All history proves that abuses and excesses are inevitable. The 
exercise of irresponsible power by men, like the taste of human blood by tigers, creates an unappeasable appetite for more. * * * Confidence is the cormer-stone of all business. But if their rights are such only as a secret, irresponsible organization is willing to concede to them and will receive only such protection as such an organization is willing to give, where is that confidence which is essential to the prosperity of the country? *** The end would be anarchy, pure and simple. *** They [defendants] had a right to request the Carrington Pub. Co. to discharge its workmen and employ themselves, and to use all proper argument in support of their request, but they had no right to say, "You shall do this, or we will ruin your business." Much less had they a right to proceed to ruin its business. ${ }^{*} * *^{*}$ The fact that it is designed as a means to an end, and that end in itself considered is a lawful one, does not divest the transaction of its criminality. *** New trial denied. S. v. Glidden, 55 Conn. 46, 8 Atl. 890.

(Va. Sup. Ct., 1888.) Agreement to Boycott Printers. Crump and others were charged with conspiracy in an indictment of two counts, demurred, and the demurrer was sustained as to the second count and overruled as to the first. $\mathrm{He}$ pleaded not guilty, was convicted, moved for a new trial, it was denied, and he brought error. FAUNTLLEROY. J. * * * The next error assigned is the action of the court in giving the instruction asked for by the commonwealth, as follows': "If the jury believe, from the evidence, that the defendant Crump entered into an agreement with one or more of the defendants. whereby they undertook to coerce the firm of Baughman Brothers to discharge from their employment, against the will of the said firm, certain persons then in their employment, and to take into their employment certain other persons that the said Baughman Brothers did not wish to take into their employment, then they are instructed that said agreement was unlawful; and if they believe further, from the evidence, that in pursuance and to carry out said agreement, he, the defendant, threatened any of the customers of the said Baughman Brothers, they (the saici persons making said agreement) would injure the business of such customers, by intimidating their customers and making them afraid to continue their patronage of the customers of the said Baughman Brothers, then they must find the defendant guilty." The instruction plainly and correctly expounds the law against unlawful combination and guilty conspiracy to interfere with, molest, break up, and ruin the legitimate, licensed business of peaceable, useful, industrious, and honest citizens, and to accomplish this end by the threat and intimidation of doing "all in the power" of the conspirators to "break up and destroy the business" of ail the existing or future customers of Banghman Brothers, who should thereafter buy "anything from the said firm of Baughman Brothers, or emploved them, the said Baughman Brothers, in their said business as print- 
ers." And the instruction, so far from being a mere declaration of abstract law, is a direct and proper application of the law to the case put in the indictment. and made by the evidence. It is next to impracticable to extend this opinion by reciting the evidence in detail, further than we shall do when we eome to consider the ceror assigned upon the admissibility and sufficiency of the evidence in the record to justify the verdict. \# * Is "boyeotting." as re. sorted to and practiced by the conspirators in this case, allowable under the laws of Virginia? * * The essential idea of bovecot. ting, whether in Ireland or the United States, is a confederation. generally secret, of many persons whose intent is to injure another by preventing any and all persons from doing business with him, through fear of incurring the displeasure, persecution, and ven. geance of the conspirators. * * A wanton, unprovoked interference by a combination of many with the business of another, for the purpose of constraining that other to discharge faithful and long. tried servants, or to employ whom he does not wish or will to employ (an interference intended to produce, and likely to produce. annoyance and loss to that business) will be restrained and punished by the criminal law as oppressive to the individual, injurious to the prosperity of the community, and subversive of the peace and grod order of society. * * * It was proved that the conspirator's de. clared their set purpose and persistent effort to "crush" Baughman Brothers; that the minions of the boyeott committee dogged the firm in all their transactions. followed their delivery wanon. secured the names of their patrons. and used every means shint of actual physical foree to compel them to cease dealing with bingh. man Brothers, thereby causing them to lose from 150 to 2011 eitstomers, and $\$ 10,000$ of net profit. *** Conviction alfirmed. Crump v. C., 84 Va. 927,6 S. E. $620,10 \mathrm{Am}$. St. Rep. 895. B. 833.

(N. Car. Sup. Ct., 190t.) Boycotting Lumber Dealer. Vin Pelt. Jenkins, Henry, and C. \& S. Shuman were indicted for eonspirner. for that being evil-disposed persons, together with others to the jury unknown. wickedly devising and intending to injure and destroy one C. A. Rice, in his trade as a lumber dealer. ther conspired together to injure and destroy him. On bili of particulars demanded, the prosecution alleged that they conspired to onpress Rice, held a meeting of the carpenters' union, and resolved not to work any material purchased from him, and published their action in a local paper together with the assertion that he was deemed unfair to union labor, and so listed. Thereupon defendants de. murred ore tenus, and moved to quash the bill. The motion wis sustained, and the bill quashed. The state excepted and appealed. CONNOR, J. * * In this country, in which judges are. in respect to their source of appointment and tenure, sensitive to changes of popular opinion and temper, amid the ever-increasing acuteness of the struggle between opposing social and industrial 
fores, the lines which separate a criminal from a noneriminal conspiracy should be clearly defined. 'To a timid, conservative, judicial mind trained to regard even the slightest disturbance of such forces as portending danger to the peace of the state, a combination of the most harmless character would assume "unlawful" form and force. 'To a different type of judicial mind, believing that the safety and highest interest of the state are p!romoted by the freest possible play of mind and action in trade competition. "however severe and egotistical, if unattended by ciremustances of" dishonesty, intimidation, molestation, or other such illegalities." the sime combination would appear not only lawful, but stimulating to trade in the community. The study of the struggle between the ruling class and the laborer's in England, culminating in the passage of the statute of 38 \& 39 Vict. is of interest to the student and value to the lawmaker and judge. It is declared hy that statute that an agreement or combination to do any act in furtherance of a trade dispute shall not render the person committing it indictable for a conspiracy if such nets committed by one person would not be punishable as a crime. "These latter words may almost be described as 'The Workmen's Charter of Liberty.' for they dispose at once and forever of the contention that a combination to do acts, not illegal in themselves, is entitled to be regarded by the law as a conspiracy." Cent. Law Reform 253. A great Engrlish statesman said that for the first time employers and employed sat under equal laws.

As Indicating the Practical Operation of the Definition of a Criminal Conspiracy Contended for by the State, We May Recall Some Incidents Coming Under Our Observation. Not long since the farmers producing cotton in this and other states belicved that their interests demanded combined action to protect themselves against what they considered an unreasonably high price charged by the manufacturers for jute cotton bagring. They openly and with the avowed purpose of compelling the manufacturers to sell hagging at a lower price, and, of eourse, reduee their profits. and to thit extent, injure them in their trade and business, formed combinatiuns and adopted measures-entirely peaceful and lawful-to accomplish their purpose. They agreed themselves. urged and by various neans indueed others, to refrain, from buying or using jute bagging. They encouraged the use of other kinds of bagging, and by and through organization maintained a peaceful but eflective contest with the manufacturers. Thejr declared purpose was to injure. cripple, and. if necessary, destroy, the manufucturer's, unless they sold their product at a lower price. Again. at a more recont date the producer's of tobaces found the price of their product. as they thought, unreasonably low. They believed that a large and wealthy corporation, being the largest purchaser in the market. was responsible for the low price of tohaces. Lalde numbers of the producers, with the avowed purpose of compelling the pur- 
chasers, and especiaily the said corporation, to pay them higher prices, combined and agreed that they would withhold tieir prod. uct from the market, urged and induced all other producers to do so. 'They declared their purpose to refuse to buy the goods of the corporation, and urged and induced merchants to refuse to buy or sell such goods. They held public meetings, made and issued addresses, and by many other lawful and peaceful means songht to injure, and, so far as possible, destroy, the offending corporition. It did not oceur to any one that these men were guilty of a criminal conspiracy, nor were they. It must be noted that in neither instance was there any legal standard as to the price of cotton bagging or tobacco. They were sold in open market, and, from a legall stand. point, with fair competition. The farmers who in one case were buyers thought bagging unreasonably high, and in the other, being sellers, thought tobacco unreasonably low. They believed that, in order to protect themselves from what they regarded unfair treat. ment, they must organize. That their purpose was to injure the manufacturer in the one instance and the purchaser in the other in their trade and business was not denied, but openly avowed; their defense being that they were seeking fair treatment at the hands of both. We must keep in mind the fact that we are discussing the question as it is affected by the common law. The prop. osition is that the defendants conspired for the purpose of injuring the prosecutor in his trade and business, and that it is unlawful for them to do so. It cannot be that every conspiracy to injure one in his trade and business, without reference to the means to be employed, is criminal. A carpenter or joiner has, by his apprenticeship, study, and experience, acquired skill and knowledge in his trade. His capital consists in his physical strength and his intel. lect trained and directed by his skill and experience. It is the use of this which, in a sense, he offers for sale. In what respeci, for the purpose of securing the best prices for his labor on the best terms, do his rights differ from the man who has cotton for sale, the product of his capital-land and labor-or the man who has money to invest in mercantile or manufacturing enterprise? Each of them enters into the field of competition. Each finds that organ. ization with others engaged in the same field of labor or investment will secure better results and fairer treatment from those with whom he deals. There is no evil or harm in organization per se. Every copartnership, corporation, joint-stock company, and other association of labor or capital is a recognition of this truth.

It is Urged by Counsel that the Guilt of Defendants does not In. volve What They Did, but What They Conspired to Do. If the defendants had pleaded to the first count in the bill without calling for a bill of particulars, they would have gone to the jury on the general issue of traverse to the bill. When, however, the state files its bill of particulars, which, for the purpose of the trial, is as if the means had been set out in the original bill of indictment, the ques. 
tion is presented whether, either in respect to the purpose of the conspiracy or the means by jwich it was to be accomplished, any crime is charged. If no crime is charged, there is nothing for the jury to pass upon. 'The court will either, upon motion, quash the indictment, or, as it did in C. v. Hunt, supra, arrest the judgment. We are of the opinion that a conspiracy to injure one's business is not per se indictable. Do the means set out make it so? 'This brings us to consider the acts done by the defendants. 'Three of them, on January 13, 1904, went together to the prosecutor's place of business, and notitied him that he could not be considered in sympathy with organized labor unless he kept constantly employed union men. Certainly, the number of the defendants was not so large as to intimidate him, and there is no suggestion that their manner was either oftensive, violent, or even discourteous. As we have scen, organized labor, or labor organizations, are not unlawful. The prosecutor had no legal right to demand that he should be considered in sympathy with organized labor; therefore he was not to be deprived of any legal right if he preferred to employ non-union men, and defendants had an equal right to consider him unsympathetic with organized labor if he exercised such right. Suppose the same number of persons, being members of the anti-saloon learue, should go to a merchant's store and notify him that he would not be considered in sympathy with the temperance caluse if he employed clerks who did not belong to the league. If he continued to employ such clerks, he was simply considered as unsympathetic with the cause. Ne fail to see any difference in principle between the act of the defendants and the case supposed. They notified him that he would not be considered in sympathy with organized labor if he kept in his employment non-union men, although he was then under contract with non-union men for a year in advance. It is intended, we assume, in this item to charge that the defendants conspired to compel the prosecutor to break his contract with nonunion men and discharge them. It will be noted that it is nowhere charged that such was the purpose of the defendants. $N^{\top} n f:$ word is said capable of that construction. Certainly nothing should be left to conjecture. To what extent a conspiracy to induce men to violate their contracts is criminal is not clear. We are not required to discuss or decide it here. There is no complaint that the conduct of the defendants was intended to injure non-union men. This case has no such element in it, and we do not wish to be understood as expressing any opinion in regard to it. The qriestion has been before other courts. There is a painful absence of harmony in the decisions. Suppose, however, that it be conceded that the defendants did notify the prosecutor that, unless he discharged non-union men with whom he had contracted, etc., what was to be the result to him if he refused? He was to be considered as unsympathetic with union labor. 'This falls far short of intimidation or coercion. It will be noted that there is no charge that these defendants were 
members of any secret or other organization, or that they had the power or threatened to control the conduct of large numbers of men. It is sald that they, "together" with other evil disposed pur. sons, conspired," ete. Who "the other evil disposed per'sous" ilre, what (if any) relation they bear to the defendants, is not stited. This alleged conspiracy is contined to the five defondants. When informed by the prosecutor that he wond not discharge any nonunion men with whom he had eontracted, and that he wonld not agree to employ only union men in his business, the defendants "went away," and "in furtheranee of the said conspiracy did ictually" publish and cause to be published the aforesaid notice, etc.: "Action of Carpenter's and Joiners. At a meeting of the carpenters held last evening for his attitude towards organi\%ed habor. Mr. C. A. Rice was declared unfair and so listed, and that no union carpenters would work any material from his shop after Februny 1;. 1904." The counsel for the prosecutor in their brief say" "It is perfectly" true that defendants had a right to refuse to work material from Rice's shop; that they had a right to put him on their unfair list." The criminality, they say, consists in the intent or purpose with which these things are done. 'This, they say, is a question for the jury. It is not easy to see how it is a question for the jury when the defendants admit the purpose, etc. If that which they did is lawful-if they had a perfect legal right to do it-we are mable to perceive how the publication renders it monlawiul. We are not aware of any principle of law which makes it criminal to publish that a person has done an act which he had a perfect legal right to do, or that a person intends to pursue a course of conduct which he has a legal right to pursue. Judge IIolmes silys: "Als a general rule, even if subject to some exceptions, what you may do in a certain event you may threaten to do-that is, giving warning of your intention to do in that event-and thus allow the other porson the chance of avoiding the consequences: so, as to 'compulsion.' it depends upon how you 'compel.', Parker, C. J.. in Nat. Protec. Ap. v. Cumming, 170 N. Y. 315, 63 N. E. 369,58 L. R. A. 133.35 Am. St. Rep. 6t8, says: "A labor organization is endowed with precisely the same legal right as an individual to threaten to do that which it may Jawfully do." "If an act be lawful-that is, one which a person has a legal right to do-the fact that he may in doing it be actuated by an improper motive does not render it minlawful." Bolm Manfg. Co. v. Hollis, $5+$ Mimn. 223. It being properly coneeded that it was not unlawful-that is. for the purpose of this discussion. criminal-for the defendants to declare Mrr. Rice "mnfair," and to refuse to work his material. we can find nothing criminal in the publication made of their opinion or purpose.

Does the Fact that the Defendants Intended to Induce Persons Who Might Otherwise Purchase Material from Mr. Rice to Refrain from Doing so Make Their Conduct Unlawful? 'This brings us lack to the original question. Persons who might wish to buy material 
from Mr. Rice had no legal claim on the services of the defendants. They were under no obligation to work the material purchased from lim. 'Therefore, in saying that they would not do so they deprived such persons of no legral pight. They could not have maintained an action for damages against the defendants for refusing to work such material or for saying so. How, then, in a legal sense, can he be said to be injured? It is said that the purpose of the defendants in maling the publication was to induce persons to refirain from purchasing material for fear of incurring the ill will of the defendants. This certainly is not unlawful. Bowen v. Matheson, 14 Allen 499. If courts were to maintain actions upon such grounds, society would soon be eonverted into an array or hostile litigants. As is well said by Judge Black in Jenkins v. Fowler, $2 \pm \mathrm{Pa}$. 308: "Mlalicious motives make a bad act worse, but they cannot make that wrong which in its own essence is lawful." * * *

We Think that it Will be Found that in Every Case Where the Act is Criminal there is a trespass on some legal right, or a legal wrong done to the complaining person. We concur with his honor that no criminal act is charged in the indietnnit. We have not overlooked the cases cited in the briet's. The courts are very far from agreement in regard to ti:e law of conspiracy. 'This fact tends to show the danger of giving to the word "unlawful" a broad and all-embracing meaning in the definition of a criminal conspiracy. We are told this is a case of great importance. It is said: "We are now at the porting of the way's. It is sate to predict that there will be no more criminal conspiracies, no more demands tor union shops, and no strikes, sympathetic or otherwise, in this state, if the court sustains the bill in this case." We are also told by counsel that "jt rests upon the members of this court to decide whesther labor and sapital * * * shall dwell together in peace and unity, controlled by the law," etc. It is desirable that this endition, which has always so happily prevailed in this state, shall be preserved. We are duly sensible of our duty, as juclges. to so declare the law as to secure, as far as the law may, this condition. As we have endeavored to show, concerted action and association to protect en!mmon interests and promote common advantage is not peculiar to those whose capital consists in their labor. 'The security of the state demands that the same principles of law must apply to all sorts and conditions of men. It is well to consider how far liberty of thought and action may be restricted by a resort to the "loose expressions" and dangerously uncertain definitions of this crime aftecting the liberty of the citizens. It is very doubtful whether industrial conditions, or relations between employer and employees. have been improved by prosecutions for eriminal eonspiracy. As we have seen. in Finglund the subject has received the most careful attention of enlightened statesmen, resulting in the passage of wise statutes. It is asked. may not a man condict his business in his own way? And undoubtedly he may. For any unlawful interference with this 
right he has a remedy, either civil or eriminal, as such interference may justify. 'I'he question is asked, may not men organize to pro. mote their common mterests, and, when such interests contlict with other interests, resort to lawful and peaceful means to secure the best results? It is clear that they may. Where, then, is the line which separates conduct which is lawful from that which is un. lawtul\% 'Ihe auswer comes from Chief Justice Shaw, one of the wisest and most learned of American jurists: "If it is to be carried into eftect by fair or honorable or lawtul means, it is, to say the least, innocent; if by falsehood or force, it may be stamped with the character of a criminal conspiracy." We would not be misunderstood. Capital, either in the form of money or other property, or in the form of skill, experience, intelligence, and strength, maly combine for lawtul purpose. When, in either form, or under whatever guise it sechs or conspires to effectuate its purpose, however lawful, by means of violence to person or property, or by firaud, or other crimi. nal means, or when, by such means, it conspires to prevent any per. son from conducting his own business in his own way, or from em. ploying such persons as he may prefer, or by preventing any person from being employed at such wages or upon such terms as he may prefer, the courts will be prompt to declare and firm to administer the law to punish the guilty and protect the injured. What acts will constitute such unlawfiul meaus it is impossible to define. As all other questions arising out of the struggle of political, social, or industrial forees, they must be decided as they are presented.

* [Clark, C. J., and Douglas, J., filed concurring opinions.] Aflirmed. S. v. Van Pelt, 136 N. Car. 633,49 S. E. 177,68 L. R. A. 760.

\section{§62. "Attempt."}

(Eng. Assize, 1837.) Attempt of Statutory Offense. Indictment in three counts for: 1 , unlawfully knowing a child under 12 years old; 2 , attempting to do so; and, 3 , a common assault. Lee objected for the prisoner that an attempt to commit a statutory misdemeanor is no offensc. PARKE, B. If this offense is made a misdemeanor by statute, it is made so for all purposes. 'There are many cases in which an attempt to commit a misdemeanor has been held to be a misdemeanor; and an attempt to commit a mis. demeanor is a misdemeanor, whether the offense is created by statute or was an offense at common law. Verdict, guilty. R. v. Roderick, 7 C. \& P. 795 , B. 127.

(Cal. Sup. Ct., 1859.) Eloping to Marry Niece. Defendant was indicted and convicted of attempting to contract an incestuous mar. riage on proof that he eloped with his niece, and requested innother to get a magistrate to perform the ceremony. He appealed. IIELD, C. J., said: "It [the evidence] shows very clearly the intention of 
the defendant; but something more than mere intention is necessury to constitute the offense charged. Between preparation for the attempt and the attempt itself, there is a wide difference. 'The preparatic $a$ consists in devising or arranging the means or measures necessuly for the commission of the offense; the attempt is the direct movement towards the commission after the preparations are made; * * but until the ofticer was engaged, and the parties stood before him, ready to take the vows appropriate to the contract of marriage, it cannot be said, in strictuess, that the attempt was made. 'T'he attempt contemplated by the statute must be manifested by acts which would end in the consummation of the particular offense, but for the intervention of circumstances independent of the will of the party." * * Judgment reversed. p. v. Murray, $1 \pm$ Cal. 160.

Solicitation is generally held not to be an attempt even when criminal: s. v. Butler, \$ 60 ; s. v. Howers, \& 60 .

(U. S. C. C. Dist. of Ore., 1882.) Ordering Whiskey for Alaska. Defendant demurred to an information charging him with being in Alaskia and sending an order by letter to a liquor dealer in San Francisco to send him 100 gallons of whiskey, thereby intending to introduce the whiskey into Alaska contrary to law. DEADY, J. * * ' 'o constitute the attempt charged in the information there must have been an intent to commit the crime of introducing spirituous liquor's into Alaska, combined with an act done in pursuance of such intention that apparently, in the usual course of events, would have resulted in such introduction, unless interrupted by extrancous circumstances, but which actually fell short of such result. But it does not appear that anything was done by the defendant towards the commission of the intended crime of introducing spirituous liquor's into Alaska, but to offer or attempt to purchase the same in San Francisco. The written order sent there by the defendant was, in effect, nothing more or less than an offer by him to purchase the one hundred gollons of whiskey; and it will simplify the ease, to regard him as being present at the house of the San Francisco firm, at the time his order reached them. seeking to purchase the liquor with the intent of committing the crime of introducing the same into Alaska. But the case made by the information stops here. It does not show that he bought any liquor. Whether he changed his mind, and countermanded the order before the delivery of the goods, or whether the firm refused to deal with him, does not appear. Now, an ofter to purchase whiskey, with the intent to ship it to Alaska, is, in any view of the matter, a mere act of preparation, of which the law takes no cognizance. As the matter then stood, it was impossible for the defendant to attempt to introduce this liquor into Alaska, because he did not own or control it. It was simply an attempt to purchase.- -an act harmless and indifferent in itself, whatever the purpose with which it was done. But suppose the defendant had gone further, and actually 
succeeded in purchasing the liquor, wherein would the case differ from that of the person who bought the gun or poison with intent to commit murder, but did no subsequent act in execution of such purpose? In all essentials they are the same. * * * Demurrer sustained as to the second count and overruled as to the first. U.S. v. Stephens, 8 Sawy. 116, 12 Fed. 52, 13. 130.

\section{(Va. Sup. Ct. of App., 1889.) Abandonment of Attempt to Rape.} Defendant appealed from a conviction of attempt to rape, on prof that he led prosecutrix (a girl of 12) to a stable promising to give her an apple; laid her down; and exposed his and her per'son; but abandoned further attempt without interference from anyoue. wherempon she ran away. JWWIS, P. *** An attempt in criminal law is an apparent unfinished crime, and hence is compounded of two elements, vi\%: (1) 'The intent to commit a crime; and, () a direct act done towards its commission, but falling short of the execution of the ultimate design. It need not, therefore, be the last proximate at to the consummation of the erime in contemplation, but is sufficient if it be an act apparently adapted to produce the result intended. It must he something more than mere preparation. Lihl v. C., 6 Gratt. 706 ; llicks v. C.. 86 Va. 2.23. 9 S. E. 1024, 19 $\mathrm{Am}$. St. Rep. 891. Hence. when the prisoner took the prosecutrix into the stable, and there dicl the acts above mentioned, the attempt to commit a rape was complete; for there was the unlawful intent acempanied by alets done towards the eommission of the intended crime, but falling short of its commission. Indeed, it is not denied that there was such attempt, but it is contendedand such was the main defense at the trial-that the subsequent voluntary abandonment of the criminal purpose cleansed the prisoner of all crime, so far as the attempt was concerned. But this is a mistaken view. For, on the contrary, it is a rule. founded in reason and supported by anthority, that if a man resolves on a criminal enterprise, and proceeds so far in it that his act amounts to an indictable attempt, it does not cease to be such, though he voluntarily abandons the evil purpose. ** * Julgment alffirmed. Glover v. C., 86 Va. 382, 10 S. E. 420, B. 133.

Abanlonment is further discussed in $\$ 83$. See also Grifin $\nabla$. S, 860 .

(Mass. Sup. Judicial Ct., 1824.) Attempt to Rape by Boy of 14. After conviction of assault with intent to rape, it was argued in arrest of judgment, that this charge could not be maintained on proof of an assault by one man on another dressed in womm's clothes; nor by a man on his wife. for she cannot retract her consent; and in like manner, it would be absurd to convict an infant of an attempt to do what the law presumes him incapable of doing. by reason of his age. Per CURIAN. The court are of opinion that the verdict must stand and judgment be rendered on it. The law which regards infants under fourteen as incapable of commit- 
ting rape was established in favorem vitae, and ought not to be applied by analogy to an inferior offense, the commission of which is not punished with death. A minor of fourteen vears of age, or just under, is capable of that kind of force which constitutes an essential ingredient in the crime of rape, and he may make an assault with an intent to commit that crime, although by an artificial rule he is not punishable for the crime itself. An intention to do an act does not necessarily imply an ability to do it; as a man who is emasculated may use force with intent to ravish, although possibly, if a certain effect should be now, as it was formerly, held essential to the crime, he could not be convicted of a rape. Females might be in as much danger from precocious boys as from men, if such boys are to escape with impunity from felonious assaults, as well as from the felony itself. Motion overiuled. Parker, C. J., dissenting. C. v. Green, 2 Pick. 380, B. 139, C. 11 \%.

(Va. Sup. Ct. of App., 1898.) Same. Appellant was convicted of attempt to rape, though under 14 years of age. The conviction was reversed on the ground that the rule of the common law that a boy under 14 is conclusively presumed to be physically incapable, had never been changed by statute in the state, and there was nothing in the elimatic influence on the people, of which the court was aware, that calls for a change, even if it were the province of the court to make it. It was also said that the questionable right of the state to compel exposure of person, the difficulty of establishing the fact, the doubtful character of the evidence in the case in hand, and the circumstar:ces under which it was obtained, were well calculated to derer any modification of the ruls. umless made necessary by the sivial condition of the people and required for the protection of? Yirtue. Foster v. C., 96 Va. 306,31 S. E. 503,70 Am. St. Rep. 846. t2 L. R. A. 589, Mi. 335n. 568.

A.c. R. v. Elde:shaw, 3 C. \& P. 386; R. v. Brimilow, 9 C. \& P. 366; S. v. Handy, 4 Harr. (Del.)

(Fla. Sun. Ct., 1892.) Same. A boy under 14 was convicted of assault with intent to commit statutory rape on a conventing girl under 10 , and the conviction was reversed because there was no proof of physical capacity nor of physical development from which such capacity could be inferred; but it was admitted that if puberty and discretion were proved in fact or found from competent evidence, the conviction would be sustained. McKinny v. S., 29 Fla. 565, 10 So. 732, 30 Am. St. Rep. 140. Rep. 207: P. v. Randolph, 2 Parker (N. Y. Crim.) 174; Williams v. S. 14 Ohio 222,45 Am. Dec. 536; Wagoner v. S.: 73 Tenn. (5 Lea) 352, 40 A m. IRep. 36.

(La. Sup. Ct., 1887.) Same. A boy under 14 was convicted of entering a dwelling house at night, without breaking, with intent to rape; and though he excepted to the court leaving his physical capacity to rape as a question of fact for the jury, without pre- 
sumption, the instruction was approved, and conviction affirmed. The climatic conditions in Louisiana so affected the people that the presumption obtaining in England was held inapplicable. S. v. Jones, 39 La. Ann. 935, 3 So. 57.

(Mass. Sup. Judicial Ct., 1850.) Picking Empty Pocket. Defendant was convicted of attempt to steal property from the pocket of a person unknown, and excepted to the refusal of the court to instruct the jury that the indictment could not be maintained without proof of property in the pocket. FLETCIIER, J. *** It was said, in argument for the defendant, that he could not be said to have attempted to steal the property of the unknown person, if there was no property to be stolen; and that therefore the indictment should have set out the property and shown the existence and nature of it by the proof. But it will appear at once, by a simple reference to the import of the term "attempt," that this proposition cannot be maintained. 'To attempt is to make an effort to effect some object, to make a trial or experiment, to endeavor, to use exertion for some purpose. A man may make an attempt, in effort, a trial, to steal, by breaking open a trunk, and be disappointed in not finding the object of pursuit, and so not steal in fact. *** So in the present case it is not probable that the defendant had in view any particular article, or had any knowledge whether or not there was anything in the pocket of the unknown person; but he attempted to pick the pocket of whaterer he might find in it, if haply he should find anything; and the attempt, with the act done of thrusting his hand into the pocket, made the offense complete. It was an experiment, and an experiment which, in the language of the statute, failed; and it is as much within the terms and meaning of the statute, if it failed by reason of there being nothing in the pocket, as if. it had failed from any other cause. The following cases fully support the view taken in this case, and I am not aware of any opposing authoritics: $R$. v. Higgins, 2 East 5; P. v. Bush, 4 Hill 133; Josslyn v. C., 6 Miet. 236 ; Rogers v. C., 5 S. \& R. 463. The indictment alleges that the defendant attempted to steal from the unknown person his personal property then in his pocket and in his possession, neither the name nor the value of the property being known to the jurors. But this allegation is wholly unnecessary and immaterial, and may be stricken out; and the indictment will still remain sufficient. *** Exceptions overruled. C. v. McDonald, 5 Cush. 365. B. 141.

(Conn. Sup. Ct. of Errors, 1862.) Same. It was chargred and evidence given to prove that while many people were assembled at the railroad station :at the funeral of Gen. Lyon, the prisoner put his hand into the pocket of an elderly lady; but no proof was offered to show that any money was in the pocket. The court 
refused to charge that no offense was proved, the jury returned a verdict of guilty, and he excepts. BU'lLER, J. *** It is further claimed that there must be present ability to perpetrate the offense; that if, in this case, the pocket was empty, there could be no stch ability; and that the second count of the information does not allege that there was in fact property in the pocket. 'There must undoubtedly be present ability to perpetrate the offense. The person must be of legal age, compos mentis, and in a situation to effect the purpose, directly or by the ageney of others. But it is not true that the thing intended to be taken must be where the attempting thief supposes it to be, or that there must be in fact property where he supposes there is. It is sufficient if he supposes there is property in the pocket, trunk, or other receptacle. and attempts, by some act adapted to the purpose, to obtain it feloniously. ** Affirmed. S. v. Wilson, 30 Conn. 500, Kn. 80.

(Eng. C. C. R., 1864.) Same. Case reserved. The prisoners were convicted of attempt to commit larceny by putting the hand of one of them into the gown pocket of a woman unknown, with intent to take and steal her property in the pocket. 'I'he witness who proved the case said he asked the woman if she lost anything, and she said, "No." Defendants being convicted, the question was whether the verdict was sustainable. Poland argued for the prisoner, that it is not indictable to put a hand into an empty pocket, and the indictment does not allege there was any property in the pocket. He relied on R. v. McPherson, 1 Dears. \& B. 197, 7 Cox C. C. 281, a case much like the present, in which Bramwell, B., said: "The argument that a man putting his hand into an empty pocket might be convicted of attempting to stenl, appeared to me at first plausible; but supposing a man, believing a block of wood to be a man who was his deadly enemy, struck it a blow intending to murder, could he be convicted of attempting to murder the man he took it to be?" So in R. v. Scudder, 3 C. \& P. 605 , it was held that there could not be a conviction for administering a drug to a woman to procure abortion, if it appeared that the woman was not with ehild at all. That case was before the Consolidation Act, $24 \& 25$ Vict., c. 96. BRAMWELL, B. You may put this case: Suppose a man takes away an unbrella from a stand with intent to steal it, believing it not to be his own, but it turns out to be his own, could he be convicted of attempting to steal? Poland: It is submitted that he could not. Metcalfe, for the prosecution. The fallacy in the argument on the other side consists in assuming that it is necessary to prove anything more than an attempt to steal. The intent to steal, it is conceded, is not sufficient; but any act done to carry out the intent, as putting a hand jnto the pocket, will do. CROMPTON, J., Suppose a man were to go down a lane armed with a pistol, with the intention to rob a particular person, whom he expected would pass that way, and the person does not happen to come, would that be an attempt to rob 
the person? COCKBURN, C. J. We are all of opinion that this conviction cannot be sustaiued, and in so holding it is necessary to observe that the judgrment proceeds on the assumption that the question, whether there was anything in the pocket of the prosecutrix which might have been the subject of lareeny, does not appear to have been left to the jury. ** R. v. Collins, 9 Cox C. C. 497 , L. \& C. 471,33 L. J. m. c. 177,10 Jur. (n. s.) 686,10 L. 'T. 581 , 12 W. R. 886 , B. 137 .

(Mich. Sup. Ct., 1881.) Same. MARS'I'ON, C. J. The respondent was charged with and convicted of an attempt to commit larceny from the person, and the proof tended to show that he had put his hand into the outside cloak pocket of Emma Bellair; that there was no property of any kind in the pocket at that time, and nothing therefore was taken therefrom. It is claimed that under such cireumstances he could not be convicted. We are of a contrilly opinion. The charge is of an attempt to commit a crime. In burg. lary and many cases of attempts the intent is gathered from the taking or other act done. But this is not the only way of proving the intent; if it were, in many cases attempts to commit crime would go mpunished. We fully concur in the views expressed by the Massachusetts court in C. v. MeDonald [above]. *** P. v. Jones, 46 Mich. $4 \pm 1$, !) N. W. 486.

(New York Ct. of App., 1890.) Same. Defendant was indicted for and convicted of attempt to commit grand larceny from the person. He obtained an order of reversal and for a new trial from the general term, on the ground that attempt cannot be perpetrated if conditions render commission impossible. The state appeals. RLiGER, C. J. *** The evidence given upon the trial showed that the defendant, accompanied by two associates, was observed passing around among the people gathered in a crowded market in New York, and was seen to thrust his hand into the pocket of a woman, and to withdraw it therefrom empty. Upon being ap. proached by an officer, the defendant's companions escaped, but the defendant was arrested. The woman became lost in the crowd, and was not discovered. Upon this evidence, the defendant's counsel asked the court to direct a verdict for the defendant upon the ground that the facts proved did not support the charge in the indictment. 'The request was denied, and the defendant excepted.

* The claim of the defendant is that the evidence did not show that the woman had any property in her pocket, which could be the subject of larcenv, and that an attempt to commit that crime could not be predicated of a condition which rendered its commission im. possible. We are of the opinion that the evidence was sufficient to authorize the jury to find the accused guilty of the offense charged. It was plainly inferable from it that an intent to commit lareeny 
from the person existed, and that the defendant did an act tending to effect its commission, though the effort failed. *** The question whether an attempt to commit a crime has been made, is determinable solely by the condition of the actor's mind, and his conduct in the attempted consummation ol his design. *** So far as the thief is concerned, the felonious design and action are then just as complete as though the crime could have been, or, in fact, had been, committed, and the punishment of such offender is just as essential to the protection of the public, as of onc whose designs have been successful. * * * It would seem to be quite absurd to hold that an attempt to steal property from a person could not be predicated of a case where that person had secretly and suddenly removed the contents of one pocket to another and thus frustrated the attempt, or had so guarded his property that it could not be detached from his person. An attempt is made when an opportunity uecurs, and the intending perpetrator has done some act tending to accomplish his purpose, although he is baffled by an unexpected obstacle or condition. Nany efforts have been made to reach the north pole, but none have thus far succeeded, and many have grappled with the theory of perpetual motion without success-possibly from the fact of its non-existence-but can it be said in either case that the attempt was not made? * * [Then his honor reviewed the decisions on like cases, and found most of them in accord with his opinion.] Order reversed and judgment affirmed. P. v. Moran, 123 N. Y. 254,25 N. E. 412, 20 Am. St. Rep. $732 n, 10$ I. R. A. 109, F. 145.

(Cal. Sup. Ct., 1892.) Shot Through Roof. Defehdant was convicted of assault with intent to murder; and appealed, insisting there was no evidence to support the verdict. GAROU'TTE, J. * * * The facts of the case are novel in the extreme, and, when applied to principles of criminal law, a question arises for determination upon which counsel have eited no precedent. A policeman secretly bored a hole in the roof of appellant's building, for the purpose of determining by a view from that point of observation. Wh. her or not he was conducting therein a gambling or lottery game. 'The fact came to the knowledge of appellant, and upon a certain night, believing that the policeman was upon the roof at the point of observation, he fired his pistol at the spot. He shot in no fright, and his aim was good, for the bullet passed through the roof at the point intended; but very fortunately for the officer of the law, at the moment of attack he was upon the roof at a different spot, viewing the scene of action, and thus no substantial results followed from appellant's fire. The intent to kill is quite apparent from the evidence, and the single question is presented. Do the facts stated constitnte an assault? Our criminal code defines an assault to be "an unlawful attempt, coupled with a present ability, to commit a violent injury upon the person of another." It will thus be seen 
that to constitute an assiult two elements are necessury, and the absenee of either is fatal to the charge. 'Ihere must be an mawful attempt, and there must be a present ability, to inflict the injury. In this case it is plain that the appellant made an attempt to kill the officer. It is equally plain that this attempt was an unlawful one. For the intent to hill was present in his mind at the time he fired the shot, and if death had been the result, under the facts as disclosed, there was no legal justification to avail him. The fact that the officer was not at the spot where the attacking party imagined he was, and where the bullet pierced the roof, renders it no less an attempt to kill. It is a well settled principle of criminal law in this country, that where the criminal result of an attempt is not accomplished simply because of an obstruction in the way of the thing to be operated upon, and these facts are unknown to the aggressor at the time, the criminal attempt is committed. * Ile knew the oflicer was upon the rool, and knowing that fact he fired through the rool: with the full determination of killing him. The fiact that he was mistaken in judgment as to the exact spot where his intended vietim was located is immaterial. 'That the shot did not fulfil the mission intended was not attributable to forbearance or kindness of heart upon defendant's part; meither did the officer escape by reason of the fact of his being so far distant that the deadly missile could do him no harm. He was sulliciently near to be killed from a bullet from the pistol, and his antagonist firel with the intent of killing him. Appellant's mistake as to the policeman's exact loeation upon the roof affords no exense for his act. and causes the act to be no less an assault. *** Affirmed. P. v. Lee Kong, 95 ('al. 666, 30 I'ac. 800. 29 Am. St. Rep. 165.17 L. R. A. 6⒍ B. 142 .

\section{ULTIMATE ACTS.}

Classified. Ultimate acts are either criminal or justifiable and excusable acts.

GRIMINAI. ACTS.

\$63. Classified. Crimes may be committed by doing a positive wrongful act, or by neglect of duty (in misfeasance or nonfeasance); and the force employed in doing the wrong may be direct or indirect, physical or mental.

(Eng. Cent. Cr. Ct., 186i.) Starving Child. .Tohn and Mary Comle were indicted for murder of their son, Wm. Conde. Evidence was given tending to prove that deceased died of starvation. nn doubt accelerated by beating. CINANNEIL, B., to the jury: If 
the prisoners or either of them wilfully withheld necessary food from the deceased, with a wilful determination, by withholding sustenauce which was req!aisite, to cause his death, then the party so withholding stleh food is guilty of murder. If, however, the prisoners had the means to supply necessaries, the want of which had led to the death of the deceased, and having the means to supply such necessaries. negligently though not wilfully withheld food which, if administered, would have sustained life, and so caused the death of the deceased, then that would amount to the crime of manslaughter in the person so withholding the food. Verdict. Mary guilty; John not gnilty. R. v. Conde, 10 Cox C. C. 547, B. 424, C. 165.

As to crime from mere neplect of duty, see severnl cases under \$11.

(Eng., Guildhall, 1730.) Exposing to Smallpox. On appeal of murcier for the death of plaintiff's husband of smallpox in the Fleet prison, of which defendant 3ambridge was warden, RAY. MOND, C. J., after a long examination, instructed the jury, that if they believed that deceased was carried to defendant Corbet's victualling house in the Fleet, against his consent, and was there detained; that Bambridge and Corbet knew the smallpox wats there: that deceased had not had it, but feared it, and desired to be removed, or not to be carried there at all; that he calught the smallpox of White there, and died therenf-then the appellees would be guilty of murder; but if any one of these facts were not proved to thr sitisfaction of the jury, they onght to be acquitted. Not guilty Castell, widow, v. Bambridge and Corbet, 2 Strange 8i) 4, B. 420.

\section{(Eng. C. C. R., 1756.) Convicting of Robbery by Conspiracy.} Kidden was convicted at Old Bailey before Foster, J., of robbing Mary Jones in the highway. on the testimony of prosecutrix and John Berry; and was executed. 'The reward for conviction, given by $4 \& 5 \mathrm{Wm}$. \& $\mathrm{MI}$. c. c. 8. to those who convict of highway robbery, was divided between said fones and Berry, and Stephen MracDaniel and Thomas Cooper. On a later prosecution of the same kind against one IBlee [See ante. MIcDaniel's Case. \$29, un cui..sent] it was discovered that both prosecutions had been contrived to get the reward. Whercon said Jones, Berry, and MacDaniel were indicted and convicted on the clearest sort of evidence of the wilful murder of Kidden, by maliciously eausing him to be accused, apprehended, tried, convicted, and executed. knowing him to be immocent of the charge, with intent to share the reward, ete. Judgment was respited on doubt whether indictment for murder would lie in this case. and that the point might be fully considered on motion in arrest of judgment. 'Th' attorney general declined to argue it, and the prisoners were discharged. But Lord Mansfield, C. .J., said afterwards that he and several other judges were of opinion at the time to support the indietment; and Sir Wm. Blackstone silil there 
were grounds to believe the case was given up from prudential rea. sons and not from any doubt on the law. R. v. MacDaniel, 1 Leach C. C. (Ed. 3) No. 21, 1 East P. C. 333, B. 421, Ke. 97.

This case is the sequel to McDaniel's case, 820 . Compare convictlons of burglary by betting constable to break in ou hue und cry, or by knocking at door, $\$ 110$.

(Ling. Assize, 1857.) Giving Disease by Rape. On indictment for murder and rape on a child under ten, it appeared that the prisoner had comnection with the child, and it was afterward discovered that she had the venereal disease. WIGITMIAN, J., told the jury that malice to constitute murder might be either express or implicl, and there being no pretense of express malice here, there was such malice implied in law as would justify them in finding him guilty of murder, if they were satisfied that he had connection with her and her death resulted therefrom. 'I'he jury returned that ther were satisfied that he had connection and that her death resulted therefrom, but were not agreed as to finding him guilty of murder. Wightman, J., told them that it was open to them to ignore the doctrine of constructive malice, and find guilty of manslanghter' which they did. Penal servitude for life. R. v. Greenwood, 7 Cox C. C. 404, B. 424, Mli. 566.

(Eng. Assize, 1874.) Scared to Death-Pulling Hair. The prisoner, somewhat intoxicated. met a nurse in a public house carrying an infant of four months; and having a grievance agrainst her for hitting one of his children, he seized her by the hair of the head and hit her; on which she screamed so that the infant turned black in the face, never recovered from the nervous shock, and died a few months later. Till so frightened, the child had been healthy. For this the prisoner was indicted for manslaughter. It was contended that there was no case for the jury ; but DENMAN. J., left it to them to say whether the unlawful act of the prisoner caused the denth of the child, or the result was so indirect as to be in the nature of an accident. He said it was a great advantage that it was to be settled by a jury and not by a judge. If he were to say, as a conchsion of law, that murder could not have been caused by such an act as this, he might have been laying down a dangerous precedent for the future; for to commit a murder a man might do the very same thing this man had done. Theyy could not commit murder upon a grown-up person by using language so strong or so vinlent as to cause that person to die. Therefore mere intimidation, cansing a person to die from fright by working upon his fancy. was not murder. But there were cases in which intimidations had been held to be murder. If for instance four or five persons were to stand round a man and so threaten him and frighten him as to make him believe that his life was in danger, and he were to back away from them and tumble over a precipice to avoid them, then murder would have been committed. Then did or did not this principle of law 
apply to the case of a child of such tender years as the ehild in question? *** After referring to the supposition that the convulsions of which the child died were brought on by teething, he said that if the man's act brought on the convulsions, or made them more dangerous, so that death could not otherwise have ensued, it would be manslaughter. Verdict, not guilty. R. v. Towers, 12 Cox C. C. 530 , B. 425 , C. 163 , Ke. 95 .

(Ky. Ct. of App., 1887.) Scared from House and Died of Exposure. Appellant was indicted for murder of his wife, and convicted of manslaughter. He was a cripple able to use only one arm. She was eight months pregnint, high-tempered and hard to get along with, and had told of whipping him in their occasional fights. I sow rooted open the cabin door at night, and a row arose over putting it out. He choked, beat, and scratched her. She knocked him down with a shovel, sat on him, choked him, and asked how he felt. He got away, started for his breeches, and said he would cut her throat. She ran out of the door, and he shut it after her, propped it with a stick of wood, and went to bed. "I'here was no evidence that she could not have opened the door if she had tried. She did not return. The night was very cold, and there was snow on the ground 18 inches deep. In the morning her daughter, the only witness of the aftray, except the parties, started in search of her, and defendant told her to take her mother's shoes and stoekings. The barefoot trail was followed about a mile and a half. throngh briars that had drawn blood and torn off bits of her nightgown, passing within 20 feet of the gate of one residence, and about 100 yards from another, where she was found lying on her face dead and badly frozen. There was no wound, bruise, or other mark of violence, that could have caused her death. The trial court instructed the jury to convict, if they found that in heat of passion, and not in reasonably necessary self-defense, defendant used such violence towards his wife as to cause her to leave his house from fear of death or great bodily harm at his hands, and that she died from exposure so caused. This instruction was held elroulu, because it did not permit the jury to inquire whether the fear of death or great bodily harm, which they must have found under this instruetion, was reasonable, in view of her disposition and relative phrsical power, without which he could not be said to have driven her from the house; and because the court should have asked the jury to find whether the death was a reasonable and natural consequence of her leaving the house under the: circumstances. New trial given. Hendrickson v. C., $85 \mathrm{Ky} .281,3 \mathrm{~S}$. W. 166, 7 Am. St. Rep. 5\%:, B. 430.

(Eng. C. C. R., 1889.) Jumping Out of Window. Case reserved on conviction of assault with intent to inflict grievous bodily harm. It appears that defendant came home drunk and threatened his wife, 
from which she became so scared that she tried to get out of the window. She was caught by her daughter; but she being also threatened, let go; and the woman fell to the sidewalk one story be. low and broke her leg; on which defendant jeered at her from the window above; said it served her right, and made no attempt to assist her. The conviction was sustained; and the court said that if one ereates in another's mind such a sense of danger that he injures himself in attempting to escape the person scaring is responsible for the result. R. v. Halliday, 61 L. 'T. R. 701,38 W. R. 256, כ4 J. P. 312, B. 427 .

\section{JUSTIFIABE ANI IEXUSA IBI. ACTS.}

§64. Classified. An act otherwise criminal may be excused or justified because it is done: 1 , in obedience to the orders of a supe. rior official; 2 , in reasonable exercise of parental or official author. ity; 3 , by anyone in preserving or restoring public peace; 4 , in preventing commission of crime and apprehending or preventing the escape of criminals; 5 , in self-defense; 6 , defense of castle; 7 , defense of property; or, 8 , defense of friend or stranger.

\section{\$65. "In Obedience to the Orders of a Superior Official."}

"Obedience to the Laws in being is undoubtedly a sufficient extenuation of eivil guilt before a municipal tribunal. 'The sherift who burnt Latimer and Ridley, in the bigoted days of Queen Mary, was not liable to punishment from Elizabeth, for executing so horrid an office; being justified by the commands of that magistracy which "ndeavored to restore superstition under the holy auspices of its merciless sister, persecution." 4 Bl. Com. 28.

To the same effect see also ante $\$ 49$.

(Eng. C. C. R., 1860.) Transported Prisoners. ERLE, C. J. In this case the question is whether a conviction for false imprisonment can be sustained. *** The defendant, being master of an English merchant vessel lying in the territorial waters of Chili, near Valparaiso, contracted with that government to take the prosecutor and his companions from Valparaiso to Liverpool, and they were accordingly brought on board the defendant's vessei by the officers of the government and carried to Liverpool by the defendant under his contract. Then, can the conviction be sustained for that which was done within the Chilian waters? We answer no. ${ }^{*} * *$ Te assume that the government could justify all that it did within its own territory, and we think it follows that the defendant can justify all that he did there as agent for the government and under its 
authority. * * * The further question remains, Can the conviction be sustained for that which was done out of the Chilian territory? We think that it can. It is clear that an English ship on the high sea, out of any foreign territory, is subject to the laws of England; and persons, whether foreign or English, on board such ship, are as much amenible to English law as they would be on English soil. * * It may be that transportation to England is lawful by the law of Chili, and that a Chilian ship might so lawfully transport Chilian subjects; but for an English ship the laws of Chili, ont of the state, are powerless, and the lawfulness of the acts must be tried by English law. For these reasons, to the extent above mentioned, the conviction is affirmed. R. v. Lesley, Bell 220, 8 Cox C. C. 269 , 29 L. J. m. c. 97,6 Jur. (n. s.) 202,1 L. T. 452, 8 W. R. 220 , B. 311, C. 151, Mi. 86.

\section{$\S 66$. "In Reasonable Exercise of Parental or Official Authority."}

(Eng. Assi\%c, 1869.) A Father Became Angry with his child of 2 years and 6 months for some fault, and struck her several blows with a strap an inch wide and 18 inches long; and two days later she died, as the doctors said, from nervous shock and congestion caused by the beating; for this the father was indicted for manslinghter. After consulting with Willes. .J., who agreed with him. MLAR'IIN, ]3., instructed the jury: The law as to correction has reference only to a child capable of appreciating correction, and not to an infant two year's and a half old. Although a slight slap may be lawfully given to an infant by her mother. more violent treatment of an infant so young by her father would not be justifiable; and the only question for the jury to decide is. whether the child's death was accelerited or caused by the blows inflicted by the prisoner. Guilty. R. v. Griffin, 11 Cox C. C. 402. B. 315.

(Ind. Sup. Ct., 1891.) A Father Chained His Daughter of 12 to a Sewing Machine, and left her ulone in the house all in! " th her infant brother; using this as a punishment for incorrigibility and a method of reformation, having tried other means without effeci. For this act he was convicted of assault and battery, and the supreme court refused to disturb the verdict that the punishment was unrensomable and unlawful. Hinkle v. S., 127 Ind. 490, 26 N. E. 777.

(N. Car. Sup. Ct.. 1874.) Wife Beating. Defendant was convicted of assault and battery. SF'l'ILE. J. We may assume that the old doctrine. that a husband had a right to whip his wife. provided he used a switch no larger than his thumb, is not law in North Carnolina. Indeed, the courts have alvanced from that barbarism until they have reached the position, that the husband has no right to chastise his wife. under any circumstances. But from motives of public 
policy-in order to preserve the sanctity of the domestic circle, the courts will not listen to trivial complaints. If no permanent injury has been inflicted, nor malice, cruelty nor dangerous violence shown by the husband, it is better to draw the curtain, shut out the public gaze, and leave the parties to forget and forgive. No general rule can be applied, but each case must depend upon the circumstances surrounding it. Without alverting in detail to the facts established by the special verdict in this case, we think that they show both malice and cruelty. In fact. it is difficult to conceive how a mam, who has promised upon the altar to love, comfort, honor, and keep a woman, ean lay rude and violent hands upon her, without having malice and cruelty in his heart. Affirmed. S. v. Oliver, 70 N. C. 60 , Mi. 399.

('l'ex. Ct. of App., 188T.) Teacher Switches. 'This conviction is for an aggravated assinlt and battery. Defendant was a school. teacher; the party alleged to have been assaulted, a boy of nine, who had been fighting with other pupils away from the school. house, contrary to the rules of the school. Defendant punished all by whipping them. He struck this pupil nine licks on the lews, with a switch of reasonable size, inflicting no severe bruises, abrasions, or other serious injuries. WILLSON, J. * * * Our law wisely provides that the exorcise of moderate restraint or correction by a teacher over a scholar is legal-does not constitute an assault ind battery. Pen. Cod., Art. 490, sub. 1. It is not shown by the evidence that the correction administered by the teacher to the pupil in this instance was immoderate. *** That the punishment was inflicted for an infraction of a rule of the school, which infraction was committed away from the schoolhouse, and not during school hours. did not deprive the teacher of the legal right to punish the pupil for infraction. * * * Reversed. Hutton v. S.,. 23 Tex. App. 386, 5 S. W. 122, 59 Am. Rep. 776.

(N. IIam. Sup. Ct.. 1887.) Same. Trespass against a schoolteacher for assault and battery. The court refused a rerjuest to charge the jury that if they believed the plaintiff could not help coughing, by reason of chin-cough, defendant was not justified in punishing plaintiff, though he believed plaintift coughed to defy his anthority. Verdict for defendant. Case reserved. SIII'II. J. The instructions requested made the defendant liable. without regard to the fact whether he exercised reasonable judgment and discretion in determining whether the plaintiff was guilty of intentional misconduct as a scholar. 'The law clothes the teacher, as it does the parent, in whose place he stands, with power to enforce discipline, by the imposition of reasonable corporal punishment. $1 \mathrm{~TB}$. Com. 4533. 2 Kent Com. 205, Reeve Dom. Rep. 288. He is not required to be infallible in his judgment. *** Fxceptions overruled. Heritage v. Dodge, 64 N. H. 297, 9 Atl. 722. 
(Ala. Siup. Ct., 1890.) Same. A school-master was convicted of assault and battery on a pupil in his school, 18 years old. The pupil used objectionable language, for which he was made to apologize, after which, defendant gave him a severe whipping. struck him several ents over the head with the butt of the switeh, hit him in the face three times with the fist, followed him from the house into the yard, struck him on the head with a club, drew a linife and stid. in the presence of the school, he would conquer or kill him, and that he could whip any man in China Grove beat. On error, the conviction was affirmed. The court said a teacher or other person in place of a parent could administer corporal punishment in moderation and the exercise of sound discretion; but that the conviction here was manifestly correct. "From this unsecmly conduct on the part of one whose duty it was to set a good example of self-restraint and gentlemanly deportment to his pupils, there was ample room for the inference of learal malice, in connection with unreasonable and immoderilte correction." Boyd v. S., 88 Ala. 169. 7 So. 268, $16 \mathrm{Am}$. St. Rep. 31.

(Mich. Sup. Ct., 1881.) Published and Reasonable Regulation-By Station Agent. CANIPBELL. J. McKay was convicted of assmult and battery on Thomas Cooley, at the Grand Trunk station at Edwardsburg, in Cass county. IIcKay was station keeper. *** The court charged the jury very distinetly that if Cooley violated any rule made either by the company or the agent which had been brought home to his knowledge, the respondent had a right to require him to leave the waiting room. and to remove him hy such force as was necessary. We think this charge was quite strong enough in favor of respondent. It is absurd to claim that the traveling community are hound to govern their behavior by the whims of an obstinate station-house keeper. or to leave the room whenever he thinks proper to drive them ont. * * * Affirmed P. v. McKay, 46 Mich. 439, 9 N. W. 486, 41 Am. Rep. 169.

(N. Car. Sup. Ct.. 1888.) Police Preserving Peace. Appellant. a policeman of Delaware city, was convicted of assault and battery. While on duty he found prosecutor and another fighting; touched prosecutor on the shoulder, and bade him to consider himself under arrest. Prosecutor looked at him. but did not stop fighting, and was in the act of striking at his retreating adversary when prosecutor struck him with the club usually carried by him as policeman. IIERRIILAN, .T. * * * It was the duty of the defendant to interfere and suppress the fight; and, if need be, he might, in good faith, strike a reasonable blow for the purpose. While he had no anthority to strike an unnecessary blow. or one greatly in excess of what was necessary for the purpose, and wanton. he was the judge of the force to be applied under the circumstances. and he would 
not be guilty of an assault and battery unless he arbitrarily and grossly abused the powers confided to him; and whether he did or not was an inquiry to be submitted to the jury, under proper instruetions from the court. A grossly unuecessary, excessive, or wanton exercise of force would be evidence-strong evidence-ol a wilful and malicious purpose; but the jury ought not to weigh the eonduct of the ofticer, as against him, in "gold scales;" the presumption is he acted in good faith. *** The court instructed the jury "that, if they believed the evidence of the witnesses, even upon the testimony of the defendant himself, the defendant was guilty, because the prosecutor offered no resistance to the officer, and there was no necessity for the blow." **** There is error. S. v. Pugh, 101 N. Car. 737, 7 S. E. 757,9 Am. St. Rep. 44.

(Ga. Sup. Ct., 1888.) Insolence by a Colored Prisoner to at white oflicer having him in arrest was held to be no excuse for the ofticer beating the prisoner with his club; and the conviction of assault and battery based on that act was affirmed. Burns v. S., 80 Ga. jtt, T S. E. 88.

(N. Car. Sup. Ct., 1891.) A Jailor Whipped a Female Prisoner severely, because she would not stop singing and making much disagreeable noise, though knowing it to be a great annoyance of the jailor's wife, who lay in an adjoining room very ill. For this the jailor was convicted of assault and battery, and fined $\$ 100$, and on appeal the judyment was affirmed. "He had not the shadow of right to gratify his feelings of revenge, or to inflict upon her such a cruel and terrible beating with a horsewhip. We cannot hesitate to say that the injury inflicted was serious, and that the fine imposed was clearly within the discretion of the court." $\mathbf{S}_{\text {. }} \mathrm{v}$. Roseman, $108 \mathrm{~N}$. Car. 765,12 S. E. 1039.

(Eng. C. C. R., 1850.) To Arrest Thief. The prisoner was convicted of shooting at Waters, with intent to do grievous bodily harm. It appeared that defendant was guard of a copse from which wood had been stolen, and seeing Waters come from the copse carrying wood, called him to stop; but he ran away, and the prisoner shot, having no other means of bringing him to justice, and wounded him in the leg. The court charged the jury that this was no justification, and he was convicted. POLLOCK, C. B. We are all of opinion that the conviction was right. The prosecutor not having committed a felony known to the prisoner at the time when he fired, the latter was not justified in firing at the prosecutor; and having no justifiable cause, he was guilty of shooting at the prosecutor with intent to do him grievous bodily harm, and the conviction is right. Conviction affirmed. R. v. Dadson, 4 Cox C. C. 358,2 Den. C. C. 35 ; 3 Car. \& K. 148, 'T. \& 11. 385, 20 J. J. m. c. 57, 14 Jur. 1051, 33. 31i. 
('T'enn. Sup. Ct., 1879.) Preventing Escape. Defendant was a constable taking deceased to jail on commitment by a justice of the peace for assault and battery, and while on the way deceased broke away, and ignored three calls to halt, whercupon defendant fired two shots, from which deceased died almost instantly. He had a bad character for violence, and had said he would not submit to arrest. The prisoner was a man of good character, regretted the result, and said he did not intend to kill. McFARLAND, J. ** * - The law on this subject, as laid down by Mr. Bishop, is, in substance, that an officer having a prisoner in custody for felony, who attempts escape, will be excused for killing him if he cannot be otherwise retaken, but if he can be otherwise retaken in any case without resort to such harsh measures, it will be at least manslaughter to kill him. But in cases where the person slain is arrested or held in custody for a misdemennor, and he fly or attempt to escape, it will be murder in the officer to kill him. although he cannot be otherwise overtaken; yet, under some circumstances, it may be only manslaughter, as if it appeal that death was not intended. 2 Bish. Cr. Law, $\S \S 648,649$. It is considered better to allow one guilty only of a misdemeanor to escape altogether than to take his life. And we may add that it may be a question worthy of consideration whether the law ought not to be modified in respect to the lower grade of felonies, especially in view of the large number of crimes of this character created by comparatively recent legislation, whether as to these even escape would not be better than to take life. The charge of the judge in this case was in accord with the law as above stated. and the jury have given the prisoner the benefit of all doubts, and convicted him of the lower grade of homicide. * * While the prisoner in this case scems to have honestly entertained the opinion that his duty required him to do what he did, and to have acted entirely without malice, and while he is entitled to strong sympathy, still we are constrained to affirm the judgment. Reneau v. S., 2 Lea 720, 31 Am. Rep, 626, F. 218.

(Ky. Ct. of App., 1887.) Same. Action for damages for p...'sonal injury. Plea that it was done by defendant as sheriff to prevent escape; plaintiff demurred. FOLT, J. The single question presented is, whether a peace officer may, in order to arrest one upon a warrant for bastardy, or to prevent his escape after arrest. kill him when fleeing. If he has the right under such circumstances to shoot and wound him, as was done in this instance. then it necessarily follows that he can not be held responsible if it results in death.

* Our statute is silent, unless it may be regarded as speaking by implication, as to the force an officer may use in effecting an arrest, or in recapturing a prisoner. It merely provides, that "no unnecessary force or violence shall be used in making the arrest." We, therefore, turn to the common law for guidance. By it an officer in a case of felony may use such force as is necessary to 
capture the felon, even to killing him when in flight. In the case of a misdemeanor, however, the rule is different. It is his duty to make the arrest; he may summon a posse, and may defend himself, if resisted, even to the taking of life; . but when the offender is not resisting, but fleeing, he has no right to kill. Ifuman life is too sacred to admit of a more severe rule. *** The reason for this distinction is obvious. The security of person and property is not endangered by a petty offender being at large, as in the case of a felon. The very being of society and government requires the speedy arrest and punishment of the latter. **** The demurrer was. therefore, properly sustained, and the judgment must be affirmed. Head v. Martin, 85 Ky. 480, 3 S. W. 62:, Kn. 188.

\section{\$67. "In Preserving or Restoring Public Peace."}

"Affrays may be Suppressed by any private person present, who is justifiable in endeavoring to part the combatants, whatever consequences may ensue." 4 Bl. Com. 145, citing 1 Hawk. P. C. 136.

\section{§ 68. "In Preventing Commission of Crime and Apprehending or Preventing the Escape of Criminals."}

(Eng. King's Bench, 1349.) To Arrest a Felon. H. De Compton was indicted, etc., that he feloniously killed H. Vesey at C. Defend. ant said, that said $\mathrm{H}$. V. and another were indicted before the sherift of Everwike of divers felonies, when said sheriff commissioned defendant to arrest said $\mathrm{H}$ and the other thieves; and when defendant and others found that said II and the other thieves, and showed them their warrant, and ordered them to surrender, they would not, but defended themselves, and killed and wounded divers persons; and in this fight II was killed; and we do not think that our lord, the king, ought to impeach us of his death. And the court asked the jury to find the fact, and whether he might have taken him without killing him, so that he killed him of his orm malice; and the jury found as defendant said, and that he could not have taken him in another way. THORP, C. J. They have acquitted you of this deed, and we acquit you. And I say well to you that when a man kills another by his warrant he may well avow the fact, and we will freely aequit him without waiting for the king's pardon by his chancellor in this case. And in many other cases a man may kill another without impeachment, as if thieves come to rob a man, or to burglarize his house, he may safely kill them, if he cannot take them. And not, how fared a jailer who came to the jail with a hatchet in his hand, when the prisoners had broken their irons, and were all ready to kill him, and they wounded him sorely, but with the hatchet in his hand he killed two, and then escaped, 
etc. And it was adjudged in this case by all the counsel, that he would not have done well otherwise, etc. Likewise he said that anyone might take thieves in the act of larceny, and felons in the act of felony, and if they would not surrender peaceably, but stood on their defense, or fled, in such case he might kill them without blame, etc. ** * R. v. Compton, Liber Assisarum 97, pl. 55, B. 316.

(Mich. Sup. Ct., 1878.) Homicide to Prevent Seduction of Sister. On the morning of the homicide, respondent's sister, left the breakfast table, bade the family good-by, said she was going off with deceased and they might never see her again, took her olothing, and went over to the house of deceased, with whom she was out till late the night before, and who had told respondent he would seduce her. MARS'ION, J. The respondent was tried upon an information charging him with having committed the crime of murder, and was convicted of manslaughter. The case comes here upon exceptions before sentence. 'The shooting of the deceased, by the respondent, was not denied on the trial. The defense relied on was * * * 2 , justifiable homicide committed in order to prevent the abduction and seduction of respondent's sister by the deceased. *** Blackstone says the English law justifies a woman killing one who attempts to ravish her, and so, too, the husband or father may justify lilling a man who attempts a rape upon his wife or daughter; but not if he takes them in adultery by consent, for the one is forcible and felonious but not the other. The principle, he says, which runs through all laws seems to be this: that where a crime in itself capital is endeatvored to be committed by force, it is lawful to repel that force by the death of the party attempting. It is not claimed that any direct force was attempted in this case, but that the felony intended was to be accomplished by the assistance of drugs administered or to be administered, and that where the power of resistance is thus overcome, and advantage thereof taken to violate her person, the act would be rape, and for such purpose the law would conclusively presume that sufficient force was us.. $d$, at the time intercourse took place, to so characterize the act. The present case, however, falls short of coming within the principles which would justify the taking of life. The utmost that can here be said is that the deceased had used and was likely to use fraudulent means, by administering drugs, to excite the passions, or overcome the resistance he otherwise would have been sure to encounter, in order to accomplish his purpose. So far as he had then gone, even conceding all that is claimed, fraudulent and not forcible means had been resorted to, which would not create that necessity for immediate action on the part of the accused, by the taking of life, to prevent an attempted forcible felony. Ample time and opportunity existed to enable the accused to resort to other available and adequate means to prevent the anticipated injury. The evil threatened 
could have been prevented by othe! means within the reach and power of the accused. There was no such immediate danger, nor would the facts warrant the apprehension of such immediate danger, as would justify a resort to the means adopted. ${ }^{*} *{ }^{*}$ Order, proceed to judgment and sentence. P. v. Cook, 39 Mich. 236, 33 Am. Rep. 380, B. 345.

(Ala. Sup. Ct., 1882.) Extent of Citizens' Rights to Kill to Prevent Crime. SOMIERVILLE, J. * * * The record contains evidence remotely tending to show that the prisoner was in pursuit of the de. censed for the purpose of recapturing a horse, which the decensed had either stolen, acquired by fraud, or else unlawfully converted to his own use. *** The fifth charge requested by the defenclunt is an assertion of the proposition, that if the horse was feloniously taken and carried away by the deceased, and there was an apparent necessity for killing deceased in order to recover the property and prevent the consummation of the felony, the homicide would be justitiable. The question is thus presented, as to the circumstances under which one can kill in order to prevent the perpetration of a larceny which is made a felony by statute-a subject full of difficulties and conflicting expressions of opinion from the very earliest history of our common law jurisprudence. The broad doctrine intimated by Lord Colke was, that a felon may be killed to prevent the com. mission of a felony without any inevitable cause, or as a matter of mere choice with the slayer. 3 Inst. 56 . If such a rule ever prevailed, it was at a very early day, before the dawn of a milder civilization, with its wiser system of more benignant laws; for Blackstone states the principle to be, that "where a crime, in itself capital, is endeavored to be committed by force, it is lawfiul to repel that force by the death of the party attempting." 4 Com. 181. 'The reason he assigns is, that the law is too tender of the public pence and ton careful of the lives of the subjects to "suffer, with impunity, any crime to be prevented by death, unless the same. if committed, would also be punished by death." .It must be admitted that there was far more reason in this rule than the one intimated by Lord Coke, although all felonies at common law were punishable by death, and the person killing, in such cases, would seem to be but the executioner of the law. Both of these views, however, have been rojuldiated by the later authorities, each being to some extent materially modified. All admit that the killing cannot be done from mere choice; and it is none the less certain that the felony need not be a capital one to come within the scope of the rule. Gray v. Combs, 7 J. J. Marsh. 478; Cases on Self-Defense (Horr. \& Thomp.). 725. 867; Oliver v. S., 17 Ala. 587 ; Carroll v. S., 23 Ala. 28. We find it often stated, in general terms, both by text writers and in many well considered cases, that one may, as Mr. Bishop expresses it, "oppose another who is attempting to perpetrate any felony. to the extinguishment, if need be, of the felon's existence." 1 Bish. Cr. 
Law, $\S \S 849-50$; S. v. Rutherford, 1 Hawks, 457. It is observed by NIr. Bishop, who is an advocate of this theory, that "the practical carrying out of the right thus conceded is, in some circumstances, dangerous, and wherever admitted, it should be carefully guarded." 1 Bish. Cr. Law, § 855. After a careful consideration of the subject we are fully persuaded that the rule, as thus stated, is neither sound in principle, nor is it supported by the weight of modern authority. 'The safer view is that taken by $\mathrm{MLr}$. Wharton, that the rule does not authorize the killing of persons attempting secret felonies, not accompanied by force. Wharton on IIom. $\$ 539$. $\mathrm{MIr}$. Greenleaf confines it to "the prevention of any atrocious crime attempted to be committed by force, such as murder, robbery, housebreaking in the night-time, rape, mayhem, or any other act of felony "gainst the person" ( 3 Greenl. Ev. 115); and such seems to be the general expression of the common law it text writers. 1 Russ. Cr. 665-70; 4 131. Com. 178-80; Whart. Amer. Cr. Law, 298-403; 1 liast P. C. 271; 1 Hale P. C. 488; Foster, 27.t. It is said by the anthors of Cases on Self-Defense, that a killing which "appears to be reasonably necessary to prevent a forcible and atrocious felony against property is justifiable homicide." "This rule," it is added, "the common law writer's do not extend to secret felonies, or felonies not accompanied with force," although no modern case can be found expressly so adjudging. They further add: "It is pretty clear that the right to kill in defense of property does not extend to cases of larceny, which is a crime of a secret character, although the cases which illustrate this excention are generally cases of theft of articles of small value." Cases on Self-Defense (Horr. \& Th.) 901-2.

* A strong case might be presented of one's shooting a felon to prevent the asportations of a stolen horse in the night time, where no opportunity is aftorded to recognize the thief, or obtain speedy redress at law. Both the Roman and Atlienian laws made this distinction in favor of preventing the perpetration of theft by night, allowing, in each instance, the thief to be killed when necessary, if taken in the act. $4 \mathrm{Bl}$. Com. 180, 181. The alleged larceny, in the present case, if it occurred at all, was in the open daylierlit. and the defendant is not shown to have been unable to obtain his redress at law. Where opportunity is afforded to secure the punishment of the offender by due course of law, the case must be an urgent one which excuses a killing to pl'event any felony, much less one not of a forcible or atrocious nature. Whart. Hom. $\$ \S 536-8$. "No man, under the protection of the law," savs Sir Michael Foster. "is to be the avenger of his own wrongs. If they are of such a nature for which the law of society will give him an adequate remedy, thither he ought to resort." "Foster 296. It is everywhere settled that the law will not justify a homicide which is perpetrated in resisting a mere civil trespass upon one's premises or property. unaccompanied by force or felonious intent. Carroll's case, 23 Ala. 28; Clark, Ma. Cr. Law, \$§ 355-7; Whart. on Hom., §540. The reason 
is that the preservation of human life is of more importance than the protection of property. The law may aftord ample indemnity for the loss of the one, while it utterly fails to do so for the other. The rule we have above declared is the safer one, because it better comports with the public tranguillity and the peace of society. The establishment of any' other would lead to disorderly breaches of the peace of an aggravated nature, and therefore tend greatly to cheapen human life. * * INew 'Trial sranted for error on another point.| Storey v. S., 71 Ala. 329, Mi. 406.

Extent of right of owner to defend or recnpture bls property when stolen: $c$. $v$ lonaliue. \$ 71 : Cruwford $v$. s.. $\$$ t1.

\section{$\S 69$. "In Self-Defense."}

(Eng. Northampton Eyre, 1330.) When Forced to the Wall. s being indicted for the death of $N$, and pleading not guilty, the jury found that $s$ and $N$ quarreled on their way to the public house, and in the eourse of the quarrel $\mathbf{N}$ struck $\mathrm{S}$ with an ash stick on the head so that he fell, and $S$ got up and ran away as far as he could and $\mathrm{N}$ followed $\mathrm{S}$ with the stick in his hand to kill him, if he could. and drove him to a wall, sitnated between two houses which he conld in no wise pass; and when $S$ saw that $N$ wanted to kill him with the stick, and that he could not avoid death unless be de. fended himself, he took a certain poleaxe and struck $N$ with it on the head, of which $\mathbf{N}$ immediately died, and the said $S$ immedi. ately after fled as far as he could. Wherefore the jurors said that s killed $\mathrm{N}$ in self-defense, and not by felony or of malice aforethought. and that he could not otherwise escape from death. Therefore $S$ is remitted to prison to wait for the merer of the king in the eustod! of the sheriff. Ilis ehattels $20 \mathrm{~s}$., whereof the sheriff is to answer. and then $\mathrm{S}$ is to purchase a pardon, etc. Fit\% Abr. t. corone, pl. 284. 3 Stephen's Hist. Cr. L. 38, Mi. 411.

( . Y. Ct. of App.. 1849.) Supposed Danger. Shorter, a negro. was indicted for murder, and when the evidence was closed, asked the court to charge the jury that the homicide was justifiable if the prisoner believed on reasonible grounds that decensed designed to do him great personal injury and there was imminent dangrer of the design being accomplished, though defendant struck the first blow. The court charged that there must have been imminent danger in fact to justify the prisoner. Verdict, guilty. Defendant took the case to the supreme court on certiorari, where a new trial was denied, and he brought error. BRONSON, J. When one who is without fault himself is attacked by another in such a manner or under such circumstances as to furnish reasonable ground for apprehending a design to take away his life, or do him some great bodily harm, and there is reasonable ground for believing the danger im. 
minent that such design will be aceomplished, I think he may sulely nct upov appearanees, and kill the assailant, if that be necessury to avoid the apprehended danger; and the killing will be justitiable, although it may afterwards turn out that the appearances were false, and there was in fact neither design to do him serious injury, nor danger that it would be done. He must decide at his peril upon the force of the circumstances in which he is placed, for that is a matter which will be subject to judicial review. But he will not act at the peril of making that guilt, if appearances prove false, which would be innocence had they proved true. I camnot better illustrate my meaning than by taking the case put by Judge, afterwards Chief Justice Parker, of Massachusetts, on the trial of 'Thomas 0 . Selfridge. "A in the peaceable pursuit of his affairs sees $B$ walking rapidly towards him with an outstretched arm and a pistol in his hand and using violent menaces aguinst his life as he advances. llaving approached near enough in the same attitude, $A$, who has $n$ club in his hand, strikes $B$ over the head before, or at the instant the pistol is discharged; and of the wound 13 dies. It turns out that the pistol was loaded with powder only, and that the real design of $B$ was only to terrify $A$." Upon this case the judge inquires, "Will any reasonable man say that $A$ is more criminal than he would have been if there had been a bullet in the pistol? Those who hold such doctrine must require that a man so attncked must, before he strikes the assailant, stop and ascertain how the pistol was loaded-a doctrine which would entirely take away the right of selfdefense. And when it is considered that the jury who try the cause. and not the party killing, are to judge of the reasonable grounds of his apprehension, no danger can be supposed to flow from this principle." The judge had befọre instructed the jury that, "when from the nature of the attack there is reasonable ground to believe that there is a design to destroy his life, or commit any felony upon his person, the killing of the assailant will be excusable homicide, although it should afterwards appear that no felony was intended." Selfrilge's Trial, p. 160; 1 Russ. on Crime 699, ed. of '2t, p. 485, note, ed. of '36. To this doctrine I fully subscribe. A different rule would lay too heavy a burden upon poor humanity. $*^{*} *^{*}$ I have met with no authority for saying that a homicide, which would he justifiable had appearances proved true. will be criminal when they prove false. * * * As there was no question of justifiable homicide in the case the prisoner had no right to call on the court to instruct the jury on that subject, and although the instruction given was wrong in point of law, I do not see how it can possibly have operated to the prejudice of the prisoner. *** Judgment affirmed. Shorter v. P., 2 N. Y. (2 Comst.) 193. 51 Am. Dec. 286, B. 330,1 I. 256.

(Ill. Sup. Ct., 1854.) Same. Appellant was indicted for murder. Deceased and others came to his house at night; deceased rapped, 
and when the door was open called to his companions that defendant was there; deceased and defendant wero seen engaged near the house; and soon after deceased was stabbed and died. When he went to the house he had a hatchet in his hand, which was found neal' where he was killed. Defendant had a cut on his head, apparently from this hatchet. 'There is no pretense of any provocation for the assault on defendant. He excepts to the charge of the court that the jury were bound to find him guilty of manslaughter if he turned on and slew his pursuer when it was not necessary for selfpreservation, or to prevent great bodily harm, though he had no previous malice toward deceased. CA'TON, J. **** 'This instruction, if not absolutely wrong, was at least liable to misconstruction, and to be understood by the jury as depriving the defend. ant of the right of self-defense, unless his danger was not only ap. parently imminent, but was real and positive. If so understood, the instruction was wrong. If the defendant was pursued or assaulted by the deceased in such a way as to induce in him a reasonable and well-grounded belief that he was actually in danger of losing his life, or suffering great bodily harm, when acting under the influence of such reasonable apprehension, he was justified in defending him. self, whether the danger was real or only apparent. Actual and positive danger is not indispensable to justify self-defense. If one is assaulted with a sword in such a way as to indicate an intent to take his life, and with an apparent ability to accomplish such intent, he is not bound to stop and inquire whether the sword is but a lath, or whether the assault is but a jest, before he repels it with the necessary force to protect himself against the threatened harm. Or if one is assaulted with a pistol in such a way as to manifestly show a design to slay him, he may be justified in killing his assuilant, although it should turn out the pistol was not loaded, and the only design was to frighten him. Men, when threatened with dinger, are obliged to judge from appearances, and determine by the actual state of things, from the circumstances surrounding them, at least as much as if placed in other and less exciting positions; and it would be monstrous to say that, if they act from real and honest conviction, induced by reasonable evidence, they shall be held responsible criminally for a mistake in the extent of the actual danger, where other reasonable and judicious men would have been alike mistaken. A contrary rule would make the law of self-defense a snare and a delusion. It would become but a mockery of the sacred right of self-preservation. Reversed. Campbell v. P., 16 Ill. 17, 61 Am. Dec. 49-n. F. 223, 1 L. 282.

Apparent intent to infure justlfes defense: Pond v. P., \$ 70 ; Mead's Case, \$ 70.

(Fng. Assize, 1858.) Suspected Blow. Indictment for assault with intent to injure. It appeared that the prosecutor, Withy and two women, who had been drinking together, met the prisoner at midnight on the highway. Some words passed between them, when 
Witly struck the prisoner. The prisoner then made the blow, which was the subject of the charge. It was contended for him that, under the circumstances, he was justified in doing so. CROWDER, J. (to the jury): Unless the prisoner apprehended robbery or some similar offense, or danger to life or serious bodily danger (not simply being knocked down), he woula not be justified in using the knife in self-defense. Not guilty. R. v. Hewlett, 1 F. \& F. 91, B. 329, Ke. 150.

(Ohio Sup. Ct., 186\%) By Assailant in Self-Defense. RANNEY, J. * * * From the bill of exceptions it appears that, after the state had given evidence tending to prove that the plaintiff made an assault upon Webb in the street, with the intent to murder him with a knife, and that in the conflict which ensued, Webb was killed by him, the plaintiff in error gave evidence tending to prove that he desisted from the conflict, declined further combat, and retreated rapidly a distance of one hundred and fifty feet, and took refuge in the house of a stranger, where he shut and held the door; that Webb, his brother, and one Dingman immediately pursued, throwing stones at him, and erying "Kill him!" as he retreated, and, forcibly opening the door, they entered the house and assaulted him, and in the contlict, which immediately ensued, Webb was killed. Upon this state of the evidence, comusel for the plaintiff in error requested the court to instruct the jury that the killing of Webb would be excusable, although the accused should have made the assilult upon him with the malicious intent of killing him, if the jury should find that, before Webb had received any injury, the accused desisted from the conflict, and in good faith declined further combat, and retreated to "a place which he might reasonably regard as a place of security, and that Webb and those in concert with him, immediately pursued and forcibly entered such place, and there made an assault upon the accused, in such manner as to warrant him in believing that his life was in danger at the hands of Webb, and without deliberation or malice, and to save his own life, he took that of Webb. This instruction the court refused to give, but, in substance, charged the jury that, under such circumstances, the accuser would be guilty of manslaughter, provided they "should regard the conduct of Webb, from the commencement of the conflict in the street to the time of the conflict in the house, as continuous." The difference between the instruction asked and that given is easily appreciated. The one makes the conduct of the accused in declining, in good faith, further conflict, and retreating to a place of supposed security from the attacks of Webb, decisive of his right to defend himself there, when afterward assaulted by Webb and those in concert with him, and if necessary to save his own life, without malice or premeditation to take that of Webb; while the other makes the conduct of Webb the test whether the conflict had so far terminated as to restore the accused to his right of self-defense. $* * *$ If the 
question cannot be said to be settled upon authority, we think its solution upon principle very obvious, in the light of doctrines upon which all are agreed. It is very certain that while the party who first commences a malicious assault continues in the combat, and does not put into exercise the duty of withdrawing in good fuith from the place, although he may be so fiercely pressed that he cannot retreat, or is thrown upon the ground or driven to the wall, he cannot justify taking the life of his adversary, however necessary it may be to save his own; and must be deemed to have brought upon himself the necessity of killing his fellow-man. "For otherwise," as said by Ch. J. Hale, "we should have all eases of murder or manslaughter, by way of interpretation, turned into se defendendo." 1 Hale, P. C. 482. There is every reason for saying that the conduct of the accused, relied upon to sustain such a defense, must have been so marked, in the matter of time, place, and circumstance, as not only clearly to evince the withdrawal of the accused, in good faith, from the combat, but also such as fairly to advise his adversary that his danger had passed, and to make his conduct thereafter, the pursuit of vengeance, rather than measures taken to repel the original assault. But when this is made to appear, we know of no principle, however criminal the previous conduct of the accused may have been, which allows him to be hunted down and his life put in jeopardy, and denies him the right to act upon that instinct of selfpreservation which spontaneously arises alike in the bosoms of the just and the unjust. * * * Reversed. Stoffer v. S., 15 Ohio St. 47, 86 Am. Dec. 470, B. 334, 1 L. 213.

(Ind. Sup. Ct., 1865.) Reasonable Fear. Appellant was indicted for murder and convicted of manslaughter. Instructions requested by him and refused raise the question whether actual fear of great bodily harm from deceased would be sufficient to excuse the homicide. FRAZER, J. * * * It ought to be borne in mind that the criminal law holds sane men responsible for the ordinary exercise of their reason. It is a power common alike to cowards and those who know no fear. It is a guide to which both may apply, if they wish to do so. By the power of will, he who is naturally very timid can, and often does, meet danger with as much self-possession as the boldest man, and even his fears beget that caution which is a necessary safeguard against rashness. Of all men, he is probably least likely to commit needless homicide in selfdefense, for his unfortunate weakness usually tends to paralyze his arm, and makes him slow to strike, quite as much as it subjects him to the torture of groundless apprehension. Of course, we speak of persons not so unmanned by fear as to be incapable of exercising either judgment or will. A sane man is so constituted that he can be either the master or the slave of his fears, as well as his passions. The criminal law, indulging to a humane extent the mere infirmities of human nature, nevertheless requires the exercise of this mastery. 
Accordingly the great weight of authority is against the doctrine urged by the appellant's counsel. We believe it has met the approval of the supreme court of T'ennessee only. Shorter v. P., $2 N$. Y. 197 [above] ; Stewart v. S., 1 Ohio St. 71. *** Reversed. Creek v. S., 24 Ind. 151, F. 224, 1 Is. 253.

(Ohio Sup. Ct., 1876.) Duty to Retreat from Feloneous Assault. Appellant was convicted of manslaughter. Deceased was his son-in-law and lived in a house adjoining defendant's. Between the two houses, but not within the curtilege of either, was a corncrib, used as a storage house for tools, etc., and claimed by both appellant and deceased. Appellant's tools had been thrown out of it, he had returned them, and fastened the building shut with locks and chains. These had been broken. While appellant was engaged in securing his tools again, deceased approached with an ax in a threatening manner, and did not stop when warned not to enter; and when perhaps within striking distance was shot by appellant. Complaint is made of the charge to the jury, that if appellant had an opportunity to retreat in safety and did not do so, but stood his ground, he is guilty of manslaughter. MaILVAINE. .J. * * [after reviewing the authorities at considerable length]: It is true that all anthorities agree that the taking the life in defense of one's person cannot be either justified or excused, except on the ground of necessity; and that such necessity must be imminent at the time; and they also agree that no man can avail himself of such necessity if he brings it upon himself. The question, then, is simply this: Does the law hold a man who is violently and feloniously assaulted responsible for having brought such necessity upon himself, on the sole ground that he failed to fly from his assailant when he might have safely done so? The law, out of tenderness for human life and the frailties of human nature, will not permit the taking of it to repel a mere trespass, or even to save life, where the assault is provoleed; but a true man, who is without fault, is not obliged to fly from an assailant, who, by violence or surprise, maliciously seeks to take his life or do him enormous bodily harm. Now, under the charge, below, notwithstaluling the defendant may have been without fault, and so assaulted, with the necessity of taking life to save his own upon him, still the jury could not have acquitted, if they found he had failed to do all in his power otherwise to save his own life, or prevent the intended harm, as retreating as far as he could, etc. In this, we think, the law was not correctly stated. The suggestion, by the attorneygeneral, that that rule should be declared the law which is best calculated to protect and preserve human life, is of great weight, and we can safely say that the rule announced is at least the surest to prevent the occurrence of occasions for taking life; and this. by letting the would-be robber, murderer, ravisher, and such like, lnow that their lives are, in a measure, in the hands of their intended 
victims. * * * Reversed. Erwin v. S., 29 Ohin St. 186, $23 \mathrm{Am}$. Rep. 733, F. 219.

(Iowa Sup. Ct., 1883.) Attacked in His House. Indicted of murder and convicted of manslaughter. Hle appeals. DAY, C. J. * * Defendant complains of the following instructions: "The right to defend one's self against assault, and repelling force by force, is the first law of our nature, and this natural law is recogr. nized in the laws of this state. A party who is assitulted with rio. lence has a right to prevent harm to himself by overcoming or dis. abling his assailant; but, before a party assaulted has a right to resort to a deadly weapon, such as a knife, and use it in a manner dangerous to life, he must try to save himself by flight or retreating. if he may safely and reasonably do so." The evidence shows that on the day of the homicide, the defendant and his stepson, Charles Davis, had some trouble. The evidence also tends to show that MIrs. Middleham sent for the deceased, who was not a member of the de. fendant's family, and that the deceased eame into the diningrom of the defendant's hotel, where he was at dinner, and made motions with his fist, when the defendant picked up a chair, and the decensed picked up a chair, and they fought for a time, when they threw up the ehairs and passed into the bar-room, where the homicide was committed. No witness has been introduced who saw the closing of the affray in the bar-room. 'Ihis instruction, as applied to the facts of this casse, in so far as it makes it incumbent upon the defendant to retreat, is, we think, erroneous. The defendant at the time of the difficulty was in his own house. *** Reversed. S. v. Middle. ham, 62 Iowa 150, 17 N. W. $4+6$.

No duty to retreat from own house: Esten v. C., \$70; Wright $\nabla$. C., $\$ 70$.

(Iowa Sup. Ct., 1886.) When He Might Have Escaped Safely. Appellant was indicted for murder and convicted of manslanghtter. Hle excepted to the instruction to the jury that the killing was not excused if he could have escaped without manifest danger of denth or grievous injury. ADAMS, C. J. 'The defendant shot his father, Patrick Donnelly, with a shot-gun, causing a wound of which he died about two days afterwards. The deceased had become very angry with the defendant, and at time of the firing of the fatal shot was pursuing the defendant with a pitchfork, and the circumstances were such that we think that the jury might have believed that he intended to take the life of the defendant. On the other hand, the circumstances were such that we think that the jury might have believed that the defendant could have escaped, and fully protected himself by retreating, and that he had reasonable ground for so thinking. * * He contends that the court misstated the lar in holding the general rule to be, that the assaulted must retreat ind in holding, by implication, that he is excused from doing so only where it would manifestly be dingerous to attempt it. His position 
is, that the assailed is under obligation to retreat only where the assault is not felonious, and that where it is felonious, as the evidence tends to show in this case, he may stand his ground and kill his assailant, whatever his means of retreat and escape might be; provided only he had reasonable cause for-believing that it he stood his ground, and did not kill his assiliant, his assililant would kill him, or infliet a great bodily injury. Under this theory and the evidence, the jury might have found that the defendant was justified in killing his father, and that, too, even though there had been other evidence showing that his father was so old and decrepit that the defendant could have esenped him by simply walking away from him. It is, perhaps, not to be denied that the defendint's theory finds some support in text-books and decisions, but in our opinion it caunot be approved. * * * Affirmed. S. v. Donnelly, 69 Iowa 705. 2T N. W. 369-n, jS Am. St. Rep. 234, B. 338.

(Ky. Ct. of App., 1886.) To Prevent Illegal Arrest. PRIOR, J. * * Appellant was indieted, tried and convicted of mauslaughter for the killing of Ambrose Wilson. It is elaimed by the accused that Wilson attempted to arrest him for a misdemeanor, when he was not a peace officer, and had no authority to take charge of his person or make the arrest, and that in the unlawful conduct of Wilson originated the altercation resulting in his death. ${ }^{*}{ }^{*}{ }^{*}$ In resisting the arrest-and this the accused had the right to do-he could not take the life of Wilson unless his own life was in danger, or to save his person from great bodily injury. If either fact existed, or if he had reasonable grounds to believe, and did believe, that he was in imminent peril of losing his life, then, for his own protection, he had the right to take the life of the deceased. *** The law has merely said to the citizen that, although your liberty has been restrained, you camnot deprive the aggressor of his life in order to regain it, unless you are in danger of losing your own life. Such was the instruction given by the court below, and the aceused having been found guilty of manslaughter only, we pereciv" no reason for disturbing the judgment, and the same is now affirmed. Creighton v. C., 84 Ky. 103, 4 Am. St. Rep. 193, 13. 339.

Ace., avoiding illegal arrest by homiclue : R. v. Thompson, \$ 108; Cook's Case, \& 70.

(Tex. Ct. of App., 1888.) In Resisting Menacing Arrest. Defendant was couvicted of murder in the second degree of an officer attempting to arrest him at night out of the officer's county. When he refuised to gro, the officer and he fired ut each other about the same time; opinions differed as to which, if either, was first. 'The trial court refused to charge that if the arrest, though lawful, was made in such a menacing manner as to threaten death or bodily harm to defendant, the killing was justifiable, and that an attempted illegal 
arrest would be provocation to make the offense mansiaughter. 'This was held error. HUR'l, J. *** What, therefore, are the rules of law applicable to a homicide committed in the prevention of an illegal arrest? (1) Whether the arrest be legal or not, the power to arrest may be exercised in such a wanton and menacing mannel as to threaten the accused with loss of life, or some bodily harm. In such a case, though the attempted arrest was lawful, the killing would be justifiable. (2) "Though a man will not be justitiable, then, if he kill in defense against an illegal arrest of an ordinary character, (not such as is mentioned in the first rule) yet, the law sets such a high value upon the liberty of the eitizen, that an attempt to arrest him is esteemed a great provocation, such as will reduce a killing in the resisting of such an arrest to manslaughter. 'This principle is declared in Wales v. S., 26 Ala. 31, 6.2 Am. Dec. 711; and C. v. Drew, 4 Mliss. 391, and is well established, both in England and in this country." [Citing numerous other cases.] * * * Reversed. Jones v. S., 26 l'ex. App. 1, y S. W. 53, 8 Am. St. Rep. 454.

(Ark. Sup. Ct., 1889.) While Adversary Retreating for Advantage. The evidence tended to show that while deceased and defendant were together in a room, deceased attempted to draw his pistol to shoot defendant, but had difficulty in getting it from his pocket, and moved slowly towards the door, seeking constantly to get his pistol in position to shoot. Held that, notwithstanding such retreat, defendant was justified in shooting deceased while so engaged in the attempt to use his pistol, and the court erred in charg. ing the jury, without the proper qualification, that it was murder or manslaughter to pursue an adversary and kill him while in retreat. Per CURIANI. "'l'he evidence tended to show that he was not attempting to retire from the combat, but was merely seeking a situation more favorable for waging it. If such was true, it was not incumbent on the defendant to suspend his defense until the deceased had gained the situation he sought." Cockrill, C. J., and Battle, J., dissenting, on the ground that the instruction given fairly defined the law of self-defense. Luckenbill v. S., 5: Ark. 45, 11 S. W. 963.

(R. I. Sup. Ct., 1889.) Duty to Retreat from Mere Assault. 'This is a criminal complaint against John $P$. Sherman for assault and battery. Complainant had built a stone and sand causeway, which was across the mouth of a cove, and defendant wished to take out his sailboat, which he could do only by making an opening in this causeway. While he was doing so, complainant came down to protest and protect his causeway, and the conflict ensued. Each party claimed that the other attacked, and he only acted in self-defense. Defendant was convicted. DURFEE, C. J. * * * After the 
case had been argued to the jury, he asked the court to instruct the jury as follows, to wit: "That a man in a public place, if attacked, may resist with his natural weapons, using no more force than is necessary, without retreating." "The court refused, but did instruct them that in such a case a man must retreat, if he can safely, and that the defendant did not testify that there was anything to prevent his retreating. The defendant excepted to both the refusal and the instruction. The bill of exceptions sets forth that the complainant's counsel stated, in his argument to the jury, that he did not claim for the complainant the right to use any force to protect the causeway, or any force against the defendant, except such as he might lawfully use in any public place. We think the court below erred. Generally a person wrongfully assailed cannot justify the killing of his assailant in mere self-defense, if he can safely avoid it by retreating. Retreat is not always obligatory, even to avoid killing; for if attack be made with deadly weapons, or with murderous or felonious intent, the assailed may stand his ground, and if need be kill his assailant. But there is no question of killing here, and we know of no case which holds that retreat is obligatory simply to avoid a contlict. Where there is no homicide the rule generally laid down is, that the assaulted person may defend himself, opposing force to force, using so much force as is necessary for his prorection, and can be held to ansiver only for exceeding such degree. * * Exceptions sustained. S. v. Sherman, 16 R. I. 631, 18 Atl. 1040, B. 341 .

(U. S. Sup. Ct., 1895.) Duty to Retreat into House. Beard was indicted for murder and convicted of manslaughter. He brought error. "In our opinion the court below erred in holding that the accused, while on his premises outside of his dwelling-house, was under a legal duty to get out of the way, if he could, of his assailant, who, according to one view of the evidence, had threatened to kill the defendant, in execution of that purpose had armed himself with a deadly weapon, with that weapon concealed upon his person went to the defendant's premises, despite the warning of lide latter to keep away, and by word and act indicated his purpose to attack the accused. The defendant was where he had the right to be, when the deceased advanced upon him in a threatening manner, and with a deadly weapon; and if the accused did not provoke the assault, and had at the time reasonable grounds to believe, and in good faith. believed, that the deceased intended to take his life or do him great bodily harm, he was not obliged to retreat, nor to consider whether he could safely retreat, but was entitled to stand his ground, and meet any attack made upon him with a deadly weapon. in such way and with such force as, under all the circumstances, he, at the monient, honestly believed, and had reasonable grounds to believe, was necessary to save his own life, or to protect himself from great 
bodily injury." Per IIARLAN, J. Reversed. Beard v. U. S., 158 U. S. 550, 15 S. Ct. 962,39 L. Ed. 1086, Mi. 416.

Acc. Rowe v. U. S., 164 U. S. 546, 17 S. Ct. 172, 41 L. Ed. 547 ; Rungan v. S, 57 Ind. \&0, ti am Rep 52; Eversole v. C., 95 Ky. 623, 28 S. W. 816 ; Irwin v. S., 20 Ohio St. 186, 23 Am. Lep. i3i: S. Cushin 5,14 Wash. 527, 45 Pac. 145, $53 \mathrm{Am}$. St. Rep. 883. The duty to retreat was held to extend to defendunt's land beyond the curtilage. Lee v. S., 82 Ala. 15, 9 So. 407, 25 Am. St. Kep. 17. And even to the yard if a sially was made from the house to assault. "It is it shelter, but not a silly-port." Watkins v. S., 89 Ali. 82,8 So. 134.

\section{\$ 70. "In Defense of Castle."}

(Eng. King's Bench, 1506.) Right to Assemble Aid. FINEUX, C. J. If one is in his house, and hears that such a one will come to his house to beat him, he mily well assemble folk of his friends and neighbors to assist him, and aid in the safeguard of his person; but if one were threatened that if he should come to such a market, or into such a place, he should there be beaten, in that case he conld not assemble persons to help him go there sately, for it is umeces. sary to go there, and he may have a remedy by surety of the peace. But a man's house is his castle and his defense, and where he may well stop, etc. And all the justices agreed that a servant mily beat one in defense of his master. 'TREMAILE, J., said that a sirvant may kill one in defense of his master's life, if he cannot otherwise save it. Nota., Y. B. 21, II. 7, 39 pl. 50, Fit\%. Abr. t. 'Trespass ㄴ46. B. 346.

(Eng. Queen's Bench, 1561.) Shooting One Breaking into House. IIarcourt, being in possession of a house by title, as it seems, $A \mathrm{en}$ deavored to enter, and shot an arrow at them within the house. and Harcourt, from within shot an arrow at those that would have entered, and killed one of the company. This was ruled mansliughter, and not se defendendo, because there was no darger of his life from them without. Harcourt's Case, 1 Hale P. C. 48j-6, Crompt. $: \bar{i}$ a.

(Eng. King's Bench, 1639.) Same. An officer, with a cilyias ad satisfaciendum, went with other officers, for the purpose of executing the same, to the dwelling-house of the respondent, and, finding him within, demanded of him to open the door and suffer them to enter. He commanded them to depart, telling them they should not enter. Thereupon, they broke a window, and afterwards went to the door of the house and oftered to force it open, and broke one of the hinges; whereupon Cook dischariged his musket at the deceased and hit him, and he died of the wound. After argument at the bar, all the justices, seriatim, delivered their opinions, that it wiss not murder, but manslaughter; the bailift was slain in doing an unlawful act in seeking to break open the house to execute process for a sub. ject, and everyone is to defend his own house. Yet they all held it was mansiaughter, for he might have resisted him without killing 
him; and when he saw and shot voluntarily at hinı, it was manslaughter. Cook's Case, Cro. Car. 537.

This was one of the euriest cases. was fully considered, and hus been much cited in bouks on criminal law since-with some incurrectuess of statement, in I Hale 1'. C. 458, and in other books adupting Hale's text. 'This is in sume mensure rectilled by a remirk, 1 listst P. C. 321, 322. See ulso Rostoe, Cr. Ev. 758; also 1 Bishop, Ur. I. $858, n$. 2 (5th ed.). It is to be specially noticed that whut made it manslaughter was that in order to defend his castle, it wus not necessary to kill the builiff. Per Barret, J., in S. v. Patterson, $45 \mathrm{Vt}$. 308.

(Eng. Assize, 1823.) Same. Some exasperated sailors had ducked Meade, and were in the act of throwing him into the sea, when he was rescued by the police. As he was leaving, they threatened that they would come by night and pull his house down. In the middle of the night a great number came, making menacing demonstrations. Neade, under an apprehension, as he alleged, that his life and property were in danger, fired a pistol, by which one of the party was killed. Meade was indicted for murder. Gpon that state of facts and evidence, HOLROYD, J., said to the jury: A civil trespass will not excuse the firing of a pistol at a trespisser in sudden resentment or anger. * * $*$ A man is not anthorized to fire a pistol on every intrusion or invasion of his house. He ought, if he has reasonable opportunity, to endeavor to remove him without having recourse to the last extremity. But the making an attack upon a dwelling, and especially at night. the law regards as equivalent to an assault on a man's person; for a man's house is his castle; and, therefore, in the eye of the law, it is equivalent 10 an assiult; but no words or singing are equivalent to an assault; nor will they muthorize an assault in return. * * There are cases where i person in heat of blood kills another, that the law does not deem it murder, but lowers the oftense to minslaughter; as where a party coming up by way of making an attack, and without there being any previous apprehension of danger, the party attacked, instend of having recourse to a more reasonable and less violent mode of averting it, having an opportunity so to do, fires on the impulse of the moment. In the present ease. if you are of opinion that the prisoner was jeally attacked, and that Iaw [the deceased] and this party wore on the point of breaking in, or likely to do so. and exernto the threats of the day before, he perhaps. was justified in tiring as he clicl. * * Verdict, guilty. Sentcnce, two years in York castle. Meade's Case, 1 Lewin C. C. 184.

(Eng. Assize, 1837.) Kicked Out Trespasser. On indictment for manslaughter, it appeared that, the prisoner. coming home, found deceased there, and desired him to leave. which he refused to do, whereon words followed, the prisoner became excited, and gave deceased a kick, of which he died. ALDERSON. B. A kick is not a justifiable mode of turning a man out of your house, though he be a trespasser. If a person becomes excited, and being so excited gives another a kick, it is an unjustifiable act. If the deceased would not have died but for the injury he received. the prisoner having unlaw- 
fully caused that injury, he is guilty of manslaughter. Wild's Case, 2 Lewin 214, 13. 347, Ke. 116, 1 L. 111.

Compare s. v. Silddleham, \& 09 .

(Mich. Sup. Ct., 1860.) Danger Real or Apparent. Appellant was convicted of manslaughter, and assigns error in the instructions to the jury, concerning justification. Appellant was a fisherman by occupation, and Plant, Robilliard, and Blanchard combined with ex. press intention to do him personal violence. Numerous unprovoked assaults by them on him on the night of the homicide and before are recited in the report. On this night neither appellant nor his family went to bed for fear of violence. One assault on the house was made; and the arm of appellant's wife seized through a doorway slightly opened, and squeezed till she fainted. Being unable to get in, they went away for a while and appeliant went to a brother. in-law's house and grot a double-barrelled shot-gun loaded with pigeon shot. Shortly, the attackers were heard returning and saying they were going to find appellant and whip him or have the soul out of him. 'They asked admittance to search for him. His wife refused to let them in. They immediately went to the net-house, where Cull was asleep. Plant seized Cull, and pulled him out of bed on the floor, and began choking him. Cull demanded who it was, but received no answer. Blanchard and Robilliard had commenced tearing down the boards. Pond went to the door and hallooed, "Who is tearing down my net-house?" to which there was no answer. The voices of a woman and child were heard crying, and the woman's voice was heard twice to cry out "for God's sake!" Cull's voice was also heard from the net-house, not speaking, but hallooing as if he was in pain. Pond cried out loudly, "Leave, or I'll shoot." The noise continuing, he gave the same warning again, and in a few seconds shot off one barrel of the gun. Blanchard was found dead the next morning. Pond took immediate steps to surrender himself to justice. CAMPBELL, J. *** Human life is not to be lightly disregarded, and the law will not permit it to be destroyed unless upon urgent occasion. But the rules which make it excusable or justifiable to destroy it under some circum. stances, are really meant to insure its general protection. They are designed to prevent reckless and wicked men from assailing peaceable members of society, by exposing them to the danger of fatal resistance at the hands of those whom they wantonly attack, and put in peril or fear of great injury or death. And such rules, in order to be of any value, must be in some reasonable degree accommodated to human character and necessity. They should not be allowed to entrap or mislead those whose misfortunes compel a resort to them. Were a man charged with crime to be held to a knowledge of all facts precisely as they are, there could be few cases in which the most innocent intention or honest zeal could justify or excuse homicide. The jury, by a careful sifting of witnesses on both sides, 
in cool blood, and aided by the comments of court and counsel, may arrive at a tolerably just conclusion on the circumstances of an assault. But the prisoner, who is to justify himself, can hardly be expected to be entirely cool in a deadly affray, or in all cases to have great courage or large intellect; and cannot well see the true meaning of all that occurs at the time; while he can know nothing whatever concerning what has occurred elsewhere, or concerning the designs of his assailants, any more than can be inferred from appearances. And the law, while it will not generally excuse mistakes of law (because every man is bound to know that), does not hold men responsible for a knowledge of facts unless their ignorance arises from fault or negligence. * ** We feel constrained to say that there are very few of the precedents which have shown stronger grounds of justification than those which are found here. Instead of reckless ferocity, the facts display a very commendable moderation. Apart from its character as a dwelling, which was denied by the court below, the attack upon the net-house for the purpose of destroying it, was a violent and forcible felony. * * We think there was error in requiring the actual instead of apparent and reasonably founded causes of apprehension of injury; in holding that the protection of the net-house could not be made by using a dangerous weapon; and that the conduct of the assailing party was not felonious; and also in using language calculated to mislead the jury upon the means and extent of resistance justifiable in resisting a felony. $* *{ }^{*}$ Reversed. Pond v. P., 8 Mich. 150, Kn. 191, 1 L. 814.

Appmrent danger is sumcient to Justify striking in defense: Shorter v. P., \&69; Campbell v. P., \& 69 .

(Vt. Sup. Ct., 1873.) Same. Indictment for manslaughter. Plea, not guilty. The evidence showed that deceased and another came drunk, after the family were in bed, to the tenement where defendant and family lived, insisted on coming in to talk, became violent and threatened to break in. Defendant shot through the window and killed him. Verdict, guilty. BARRETT, J.

It was claimed in behalf of the prosecution, and the evidince given in that behalf showed that the gun was not fired at Flanders as a measure of force, to repel and prevent him from breaking into the house. Moreover, in the exceptions it is said: "The respondent testified that he fired to the ground, and the object in firing was not to hit them, but to scare them away." The respondent seems not to have regarded it a case, or a conjuncture, in which it was needful or expedient to use a deadly weagon as a means of forceful resistance to meet and repel an assault on his housewhatever such assault in fact was-or to protect himself from any threatened or feared assault on his person. The gun, loaded with powder alone, would have served all the needs of the occasion, and of the exigency which the respondent supposed then to exist and 
to press upon him. * * * If one min deliberately kills another to prevent a mele trespass on his property-whether that trespass conld or could not otherwise be prevented-he is guilty of murler. If, indeed, he had at first used moderate force, and this had heen returned with such violence that his own life was endangered. and then he killed from necessity, it would have been excusilble homicide. Not because he could take life to save his property, but he might take the life of the assailant to save his own. * * " The idea that is embodied in the expression that a man's house is his eastle, is not that it is his property, and, as such, he has the right to defend and protect it by other and more extreme means thin he might lawfully use to defend and protect his shop, his office, or his barn. The sense in which the house has a peculiar immunity is that it is sacred for the protection of his person and of his family. An as. sault on the house ean be regarded as an assault on the persom only in case the purpose of such assault be injury to the person of the occupant or members of his family, and, in order to accomplish this, the assailant attacks the castle in order to reach the inmates. In this view it is said and settled, that, in such case, the inmate need not flee from his house in order to escape from being injured by the assailant, but he may meet him at the threshold, and prevent him from breaking in by any means rendered necessary by the exigency; and upon the same ground and reason as one mily defend himself from peril of life, or great bodily harm, by means fatal to the assailant if rendered neressary by the exigency of the assault. * * * If it were to be assumed that the defense might legitimately claim that there was an assault on the house, with the intent either of taking the life of the respondent or doing to him great bodily harm, the respondent would be justified in using a deadly weapon, if it should be necessary in order to prevent the perpetration of such crime, or if, under the existing circumstances attending the emergeney, the respondent had reason to believe, and was warranted in believing, and, in fact, did believe, that it was necessary in order to prevent the commission of such crime. In case the purpose of the assailant was to take life, or inflict great bodily harm, and the object of his attack (if there was such attack) upon the house was to get access to the inmate occupying the same, for such purpose. the same means might lawfully be used to prevent him from breaking in as might be used to prevent him from making the harmful assiult upon the person, in case the parties were met face to face in any other place. In either case the point of justification is that such use of fatal means was necessary in order to the rightful effectual protection of the resnondent, or his family, from the threatened or impending peril. *** New trial granted. S. v. Patterson, 45 Vt. 308, 12 Am. Rep. 200-n, B. 348.

(Ky. Ct. of App., 1887.) Defending Wife in House. To defend his own wife and himself from a murderous assault, committed in 
defendant's house by deceased and his wife, defendant shot deceased with a pistol. On trial for murder, the court, in instructing on the law of sell-defense, made it a condition of the right to take the life of decensed that defendant had no other safe means of escape f'rom the danger. Held erroneous and misleading, as it implied a duty of defendant to leave his own dwelling-house. Defendant had it right to remain in his house, and defend himself and its immates. Estep v. C., 86 K!. 39, + S. IV. 820, 9 Am. St. Rep. 260.

(Ky. Ct. of App., 1887.) Right to Defend Guest. A party of armed men marched on the house of aceused in night-timi', and broke in for the purpose of arresting an inmate, whom they charged with the commission of a misclemeanor. but for whose arrest they had no warrant. IIeld, that the aceused and his gruest had the righit to resist the breaking in by every means in their power, even to the taking of life, and, the assanlt being made by a combined party, he might disable or kill one aiding and assisting, as well as those actually breaking in; and the party, after breaking in, clrawing ofl for a time, the owner of the house was not obliged to retreat from his dwelling, but had still the right to fire on any member of the party, if he believed. from all the circumstances, the attack was to be renewed. Wright v. C., $85 \mathrm{Ky} .1233,2$ S. W. 904.

\section{§71. "In Defense of Property."}

(Conn. Sup. Ct. of Errors, 1863.) Homicide to Defend ShopSpring Gun. Information for nuisance in maintaining spring guns in a blacksmith shop near the highway, as a protection against thieves, to the terror of the inhabitants, who might be injured while passing, by an accidental discharge. The guns were inside the shop, which was lathed, plastered, and double boarded on the outside; and some of them were aimed obliquely toward the highway. 'The court held that a man may not do indirectly what he may not do directly; and as a man may not kill a thief to prevent lareeny firom a shop at night, the maintenance of a spring crun for that purpose would not be justifiable at common law. The court said the right to take life to prevent crime did not extend to any case in which the crime could otherwise be prevented, and was confined to felonies committed by violence or surprise, such as murder, robbery, burglary, arson, or breaking into a house in the daytime to rape, rob, or the like. As to whether the changed conditions of modern life, when the greatest values are kept in banks and storehouses away from the residence, instead of in the castle, as of old, and the ease and rapidity of travel and conversion of goods now, may not call for a more liberal defense of property, the court left undecided; but in this case the prisoner was discharged because there was not 
sulficient proof of danger to the public. S. v. Moore, 31 Conn. 479 , l. 215,1 L. 891, 83 Am. Dec. 159-n.

(Mass. Sup. Judicial C't., 1889.) Recaption of Money. Defendant having bought goods, a dispute arose as to the price, and defendant placed \$20 and the goods side by side, and told the seller to choose, whereupon the latter took the money, and said, "You owe me $\$ 1.55 . "$ Defendant then, after demanding the money back, threw the seller down, and choked him till he gave up a pocketbook containing money. Defendant being indicted for robbery, his attorney claimed justification. The court stated that defendant was not justified in assaulting to get his own money, and that, if defendant choked and otherwise assaulted the se!ler, he was guilty, though the sole motive was to get by force money which he believed to be his own. IHOLMIES, J. *** * Since IIitchelman, of course, whatever the sum due him, had no right to that particular money except on the conditions on which it was offered (C. v. Stebbins, 8 Gray 49?, $[\$ 54]$ ), he took the money wrongfully from the possession of the defendant, or the jury might have found that he did, whether the true view be that the defendant did not give up possession, or that it was obtained from him by Mitchelman's fraud. **** It is settled by ancient and modern authority that, under such circumstances, a man may defend or regain his momentarily interrupted possession by the use of reasonable force, short of wounding or the emplinyment of a dangerous weapon. C. v. Lynn, 123 Mass. 218; C. v. Kennard, 8 Pick. 133; Anderson v. S., 6 Baxter 608; S. v. Filliot, 11 N. H. 540, 545; R. v. Milton, Moody \& Malk. 107; Y. B. 9 Edw. IV. 28, pl. 42; 19 Hen. VI. 31, pl. 59; 21 Hen. VI. 27, pl. 9. See Seaman v. Cuppledick, Owen, 150; Taylor v. MIarkham, Cro. Jac. 224, Yelv. 157, and 1 Brownl. 215; Shingleton v. Smith, Litw. 1481, 1483; 2 Inst. 316 ; Finch, Law, 203; 2 Hawk. P. C. c. .60, $\$ 23 ; 3$ 13l. Com. 121. 'To this extent the right to protect one's possession has been regarded as an extension of the right to protect one's person, with which it is generally mentioned. Baldwin v. Hayden, 6 Conn. 4i33; ·Y. B. 19 Hen. VI. 31, pl. 59; Rogers v. Spence, 13 M. \& W. 571, 581; 2 Hawk. P. C. c. $60, \S 23 ; 3$ Bl. Com. $120,131 .{ }^{*} *{ }^{*}$ If the force used by the defendant was excessive, the jury would have been warranted in finding him guilty. Whether it was excessive or not was a question for them; the judge could not rule that it was not, as matter of law. *** It will be seen that our decision is irrespective of the defendant's belief as to what he had a right to do.

* * Exceptions sustained. C. v. Donahue, 148 Mass. 529, 20 N. F. 171. 12 Am. St. Rep. 591, 2 L. R. A. 623, B. 353, C. 157.

No right to kill sneak thicf, even to recapture property: Storey $\nabla$. P., \& 68 .

(Ga. Sup. Ct., 1893.) Recaption of Meat. Defendant was convicted of murder; and on new trial being denied, brought error. Deceased drove up behind defendant's wagon on the way home 
from town, and after some talk, drove past, said: "G-d damn it, stop your mules, and take my things out," and seized the lines. Defendant did as requested; and deceased then stepped to the wagon, took out a piece of meat defendant had, and began cutting. it. Defendant remonstrated, asked what it meant, was told he owed deceased a quarter and he was going to take meat for it; said he needed the meat to live on, offered to pay when he got home where he had some money, and tinally another with defendant ofiered to pay the quarter; but deceased still insisted on having the meat, refused the money, and continued cutting off a piece. Several times defendant tried to take the meat, but each time deceased raked at him with the knife, and prevented him getting it. Finally defendant picked up a rail the size of a man's arm and ten feet long, a "deadly weapon," struck deceased on the head with it, put the meat in the wagon, and drove home. Deceased did not seem seriously injured at the time, but died next day. SIMINONS, J. **** The theory of the defense was that the killing was justifiable, because done to prevent a robbery; and that if the deceased was not attempting a robbery, his trespass upon the defendant was such that the homicide, if not justifiable, was not murder but merely mauslaughter. In defense of his property "against one who manifestly intends by violence or surprise to commit a felony" thereon, a person may kill the aggressor if he does so under a reasonable belief that the killing is necessary for that purpose. Code $\$+330,1$ East P. C. 271,1 Bishop Cr. L. (Ed. 8), $\$ \S 853$, 875. To constitute robbery there must be force or intimidation, asportation without the consent of the owner, and an intent to steal. **** It is true, such a taking, although wrongful and violent, would not be robhery if the claim of right was in good faith, and if the taking was for no other purpose than to satisfy the claim. *** But it would be otherwise if the claim of right was a mere pretext. ${ }^{*} *{ }^{*}$ The trial judge ought, therefore, to have submitted to the jury the question whether, under the circumstances in evidence, the defendant had reason to believe that the claim of right was made and acted upon in good faith, or was merely a pretext. *** Tiversed. Crawford v. S., 90 Ga. 701, 17 S. E. 628, 35 Am. St. Rep. 242.

(U. S. Sup. Ct., 1896.) Man at Wife's Bedroom Window. Defendant, a negro, was convicted of murder of Phil Duncan, and appealed. "Defendant, however, was working at Lipe's, where his wife was staying; and if, as he claims, he saw a man in the act of raising a window which led to his wife's room, it was perfectly natural that he should wish to investigate, and to ascertain for what purpose the man was there. It appears to have been so dark at the time that defendant did not recognize deceased except by his voice; that the deceased threatened, with an oath, to kill him, and, as he says, 'made for him' with a knife. Under such circumstances we think that a charge to the jury that he was bound to retreat as far as he 
could, or disable his adversary without killing him, was misleading. We think that a man who finds another trying to obtain aceess to his wife's room in the night-time, by opening a window, may not only remonstrate with him, but may employ such force as may be necessary to prevent his doing so; and if the other threatens to kill him, and makes a motion as if to do so, and puts him in fear of his iife or great bodily harm, he is not bound to retreat, but mar use such force as is necessary to repel the assault." Per BROVI: J. lieversed. Alberty v. U. S., $16:$ U. S. 499,16 S. Ct. $86 t, 40 \mathrm{~L}$. Ed. 1051 .

\section{$\S 72$. "Defense of Friend or Stranger."}

Persons in Relations of Duty. "A assaults the master, who llies as far as he can to avoid death; the servant kills $A$ in defense of his master; this is homicide defendendo of the master, and the servant shall have a pardon of eourse (21 Ilen. $7,39 \%$ ); but if the master had not been driven to that extremity, it had heen manslanghter at large in the servant, if he had no precedent malice in him. Plowd. Com. 100. The like law had been for a master killing in the neessalry defense of his servant, the husband in the defense of the wife, the wife of the hushand, the ehild of the parent, or the parrent of the ehild; for the act of the assistant shall have the same construction in such eases as the act of the party assisted should have had, if it had been done by himself: for they are in a mutual relation one to another." 1 Hale P. C. 484.

(Eng. King's Bench, 1639.) By a Prisoner to Prevent Burglary. Cooper being indicted in the comnty of Surrey of the murder of W. L. in Southwark with a spit, he pleaded not guilty; and upon his arraignment it appeared that the said Cooper, being a prisoner in the king's bench, and lying in the house of one Anne Carricke. who kept a tavern in the rules, the said W. L. at one of the elock in the night, assaulted the said house, and offered to break open the door, and brake a staple thereof, and swore he would enter the house and slit the nose of the said Anne Carricke, because she was a bawd, and kept a bawdy house. And the said Cooper dissuading him from those courses, and reprehending him, he swore, that if he could enter he would cut the said Cooper's throat; and he brike a window in the lower room of the house, and thrust his rapier in at the window against the said Cooper, who in defense of the house and himself thrust the siid W. L. in the eve, of which stroke he diel. The question was, whether this were within the statute of 24 Hen. 8 , c. 5. The court was of opinion, that if it were true he brake the house with an intent to commit burglary, or to kill any therein, and a party within the house (although he be not the master, but a lodger or sojourner therein) kill him who made the assiult and 
intended mischief to any in it, that it is not felony, but excusuble by the said statute of $2 \pm$ Hen. 8 , c. 5 ; which was made in affirmance of the common law; wherefore the jury were appointed to consider of the circumstances of the fact; and they, being a substantial jury of Surrey, found the said Cooper not guilly upon this indictment; whereupon he was discharged. Cooper's Case, Cro. Car. 54t, B. 347, Kie. 138.

(Ky. Ct. of App., 1887.) Extent of Right-Appearances. HOL'l, J. The appellants, Renzy and Harmon Stanley, seek to excuse the killing of Rufus Ebling upon the ground that it was done by them to save the life of William Stanley, who is the brother of the one, and the uncle of the other. It is a general rule that whatever a person may lawfully do in his own defense, another may do for him. MIr. Bishop ** * says: "The doctrine here is that whatever one may do for himself he may do for another; *** and, on the whole, though distinctions have been taken and cloubts expressed, the better view plainly is that one may do for another whatever the other may do for himself:" 1 Bish. Cr. L. \$87T. * * * This other person in such a case steps into the place of the assailed, and there attaches to him, not only the rights, but also the responsibilities of the one whose cause he espouses. $* *^{*}$ Thus, if A unlawfully assaults $B$, endangering the latter's life, $C$ has no right, becaluse he may come upon the scene of conflict at a time when, during its progress, $A$ is in danger, to kill $\mathrm{B}$. 'This would be murder in $\mathrm{C}$, just as it would in A. Any other rule could not be tolerated. The innocent cannot be sacrificed to save the guilty. This would be paradoxical. A volunteer must not kill in behalf of one in fault. 'This would be what some writers have termed a negligent killing. Ile may, however, do so far for one not in fault, if the impending danger thus brought about be either actual or apparent. In other words, as the person not in fiault may, if he believes and has reasonable grounds to believe that his life is in immediate danger, defend it to the extent of taking life, so another may act upon the like appearances as to such danger, and defend it for him to the same extent. ${ }^{*}{ }^{*} *$ It is evident that it [the instruction to the jury] confined the right of the appellants to act in defense of William Stanley's life to the existence of actual danger to it. It did not allow them to act in good faith upon appearances, however reasonable. * * * Reversed. Stanley v. C., 86 Ky. 440, 6 S. W. 155. 19 Am. St. Rep. 305.

Compare right to defend self from gnparent nssnult, etc.: Campbell v. P., $\$$ 60: pond v. P.. $\$ 70$; Mend's Case. $\$$ 70: Shorter v. I.. $\$$ G9.

(Eng. Assize, 1884.) To Save Mother from Murder. The prisoner, a slender man of 22 , was indicted for the wilful murder of his father, a man of great size and strength, who on the night of the homicide came home intoxicated, and accused his wife of infidelity, 
and threatened to kill her, as he had done before when intoxicated. The family retired to adjoining bedrooms about 9 p. $\mathrm{m}$., and shortly deceased's wife retreated to her daughters' room for safety, followed by deceased, who dragged her to the head of the stairs and threat. ened to push her down, then said he would eut her throat, and went (as they supposed) for a knife. Returning, he crowded his wife against the baluster's, and she and her daughters shouted "murder!" At this the prisoner came from his room and fired the shot of which deceased died 12 hours later. On his arrest defendant said: "Wather was murdering mother. I shot on one side to frighten him; he would not leave her, so I shot him." "The defense was excusable homicide. LOPES, J., to the jury: * * If you think, having rearard to the evidence and drawing fair and proper inferences from it. that the prisoner at the bar acted without vindictive feeling towards his father when he fired the shot, if you think that at the time he fired that shot he honestly believed and had reasonable grounds for the belief that his mother's life was in imminent peril, and thit the fatal shot which he fired was absolutely necessary for the preserviltion of her life, then he ought to be excused, and the law will excuse him from the consequences of the homicide. If, however. on the other hand, you cannot come to that conclusion, if you think, and think without any reasonable doubt, that it is not a fair inference to be drawn from the evidence, but are elearly of opinion that he acted vindictively and had not such a belief as I have described to you, or had not reasonable grounds for such a belief, then you must find him unilty of murder. Verdict, not guilty. R. v. Rose, 15 Cox C. C. 540 , B. 343 , C. 194 , Ke. 140.

(U. S. C. C. for Cal., 1889.) Protecting Supreme Court Justice. A deputy United States marshal was instructed by his superior officers to protect the life and person of a supreme court justice from a threatened assault by deceased. The latter was a desperate and powerful mani, and on the occasion of the homicide struck the justice two violent blows. The deputy called to decensed to stop, saying that he was an officer, when deceased put his hand to a pocket where he usually carried a bowie-knife, and was immediately shot by the deputy. Feld, that the homicide was justifiable. In re Neagle, 39 Fed. 833,5 L. R. A. 78 . See also on same fucts, Cunningham v. Neagle, 135 U. S. 1, 10 S. Ct. 658, 34 L. Ed. 55. 


\section{CHAPTER V.}

\section{THE PARTIES TO CRIME.}

873. Classifled, 249.

priscipals.

8 74. "In the First Degree," 249.

\$75. "In the Second Degree," 252. Accessontrs.

\$76. "Before the Fact," 253.

$\$ 77$. "After the Fact," 25js.

DEFENSES.

\$78. Generally, 250.

870. "The I'rinclpal Just be Convicted Before the Accessory Can be 'lued,"

\$8. "There Inust be I'roof of Complicity Between the rarties," 261.

881. "Withln the Scope of the Orlyinal Design," 201.

\$82. "A Natural Consequence of Its Execution," "263.

\$83. "Abandonment," 266.

\$73. Classified. Having considered the general nature of a crime and its two elements, intent and act, we come now to speak of the actors, viz: 1, Principals (a) in the first degree, and (b) in the second degree; and, 2, Accessories (a) before the fact, and (b) after the fact.

\section{PRINCIPALS.}

\section{§74. "In the First Degree."}

(Eng. Queen's Bench, 1592.) Absent Principal. William Vaux was indicted for the murder of Nicholas Ridley by poisnining, and pleaded former acquittal and not guilty. By the record in the former case, put in evidence, it appeared that the indictment was insufficient, and that the jury found by special verdict that Vaux was not present when Ridley took the poison, whereupon the justices had given judgment for defendant. Because of the defect in the indictment the former acquittal was held no defense. Further, it was agreed per curiam that Vaux was a principal murderer, although he was not present at the time of the receipt of the poison, for otherwise he would be guilty of such horrible offense, and yet should be unpunished, which would be inconvenient and mischievous, for every felon is either principal or accessory, and if there is no principal there can be no accessory, quia accessorium sequitur principalem; and if any had procured Vaux to do it, he had been 
accessory before; quod nota a special case, where the principal and accessory also shall both be absent at the time of the felony committed. * * * Vaux's Case, 4 Coke 44a, 13. 67.

Allsent principal. Obtaining money in another state by means of false pretenses and innovent agent is punishable where the money was obtained: P. v. Adams, $\S 8 \bar{i}$; Ii. y. Birisalc. $\$ 87$. See also Lindsey v. S., $\$ 87$. As to accessory out of state, sce $S$. v. Wyckom, $\$$ 8i. Sollelting burglary and arson and sending key: Grimn v. S., $\$ 60$.

(Eng. C. C. R., 166-.) Poison Administered Through Innocent Agent. A woman, after she had two daughters by her husband, eloped from him and lived with another man. And afterwards one of her daughters eame to her, and she asked her, "How doth your father," to which her claughter answered, "that he had a cold," to which his wife replied, "Here is a good powder for him, give it him in his posset;" and on this the daughter carried home the powder. and told all this that her mother had said to her, to her other sister. who in her absence gave the powder to her father in his posset, of which he died. Upon conference with all the judges, it was resolved. that the wife was principal in the murder, and also the man with whom she ran away, he being proved to be advising in the poison: but the two danghters were in no fault, they both being ignorant of the poison; and aceordingly, the man was hanged, and the mother burnt. Memo., Kely'ng 52, 53, B. 377.

(Mass. Sup. Judicial Ct., 1814.) Passing Counterfeit by Innocent Agent. Hill was convicted of passing a counterfeit bank-note to Bradbury, on proof that he gave it to a boy (who supposed it was good), offered him half he would get for changing it, and that the boy bought a waist of Bradbury, gave him the bill, and took the change to Hill. It was objected that Hill did not pass the bill to the boy as true, that giving another a bill to pass is not passing it, and that the conviction or aequittal on this charge would be no defense to a charge of passing it to the boy. The court took time in the vacation to consider the question, and, being agreed that the evidence was sufficient, the defendant was sentenced by Thatcher. J. C. v. Hill, 11 Mrass. 136. F. 121.

(Eng. C. C. R.. 1821.) A Part Separately by Each-Forgery. On trial of three for forging the notes of the bank of England, it appeared that one printed the notes in blank alone at one place, and put in the number and date line at another place in the presence of the other two, one of whom alone forged the signatures, and afterwards completed the notes with the other, who did not know that the first printed the blanks. They were all convicted under instruction to find guilty if they all co-operated in the joint design: and the point being reserved, the judges held the conviction of all was right. and that the printer was as guilty as the others, though he was not present when the notes were completed. R. v. Bingley, Russell \& R. 446, B. 381. 
(Engr. C. C. R., 18t0.) Poison Given by Boy. Catherine Nichael was indicted for murder of a child. The evidence indicated that the prisoner delivered an ounce of laudanum to the child's nurse, telling her to give the ehild a teaspoonful (a sufficient amount to liill) each night, saying that it was proper medicine, but intending to kill. The nurse took it home and put it on the shelf, thinking the child did not need it, and not intending to give it; but four day's later the nurse's little boy of tive years, during her absence, gave the child a dose of much more than a teaspoonful, of which it died. 'The court directed the jury that if defendant intended that the child should be killed by the laudanum, and her intent still continuing, it was administered later by an unconscious agent, and the child died of it, it was murder, and that the boy gave a much larger quantity would make no difference. 'The jury found the prisoner guilty. Judgment was respited to take the opinion of the judges. The calse was considered by all the judges (except (furney, B., and Maule, J.), and they were imamimously of opinion that the conviction was right. R. v. Michael, 1 Moody 120, 9 Car. \& P. 356, 38 E. C. L. 213, B. 37s, C. 133.

(Eng. C. C. R., 18tt.) Dies for Coin by Innocent Die-sinker. Defendant was convieted at the $\mathrm{Warwick}$ assize, 18t4, on an indictment of three counts: (1), for making, and (2), for beginning to make a die that wonld impress the resemblanee of the obverse side of a shilling, and (3), for making a die intended to make such resemblance. It was proved by the die-sinker, that defendant applied to him to make two dies for counters for two whist clubs, stating that it was their custom to play with counter's resembling coins on one side, all the dies to be of the same size and fit either collar. It oecurred to the die-sinker that there was something suspicious. and he corresponded with the agent of the mint at Birmingham, under whose directions he made two of the dies ordered: and ther when finished formed a die for coining a shilling, and an impression made hy them was produced in eourt. For the prisoner it was contended that he had done nothing. and was not answerable for the acts of the die-sinker done under instructions from the mint; who, having knowledge, was authorized or gruilty, and the prisoner absent: and that then he should have been indicted for inciting the die-sinker to commit a felony. The jury found the prisoner guilty. and the point was reserved. All the judges (except Cresswell, J.) thought the die-sinker innocent and held the conviction good. R. v. Bannen, 2 Mondy 309, 1 Car. \& Kir. 295, B. 379, C. 131.

(Ohio Sup. Ct.. 1875.) Forgery-Innocent Agent. Motion for writ of error. Plaintiff in error was convicted of uttering and puhlishing as true a false and forged note for $\$ 300$, intending to defratud. On the trial it was proved that he and Bevis had made an agreement that Bevis would act as sales agent for machinery: and Bevis, being 
unable to write, asked his daughter to sign the contract for him, and thus the daughter was induced to sign her father's name to the note in question. Plaintiff in error excepts to the charge of the court below that the act of the daughter was his act, and the signature a forgery. REX, J. * * * In this case the agency of the daughter for her father extended to the signing of his name to the contract in duplicate, and no farther. When, lierefore, these two papers were signed, her agency for her father ceased. 'The evidence in the case tends to show that this was the extent of her authority as such agent, and that she was induced to sign the promissory note by the representations of the plaintiff in error, and at his request, believing at the time that the representations were trile. In signing her father's name to the promissory note, Rebecea was, therefore, the innocent agent of the plaintiff in error, and hence her act was the act of the plaintiff in error, and was a forgery. $R$. v. Clifford, 2 Car. \& K. 202. * * * Denied. Gregory v. S., 26 Ohio St. 510, 20 Am. Rep. TT4, F. 122.

\section{$\S 75$. "In the Second Degree."}

(Eng. Corinsh Iter., 1302.) "If three thieves come to a mim's house, and one forces and enters the house, and the other two stand outside in the meantime, they shall all three be taken and convicted of this, whatever judgment you may think will be passed on the two." SPIGONEL, J., in Horwood's Y. B. 30 \& 31 Ed. I. p. 108, B. 385 .

(Eng. King's Bench, 1698.) Riot-Common Design-Suppression. HOLT, C. J. Two, three, or more are doing an unlawful act, as abusing the passers-by in a street or highway; if one of them kill a passer-by, it is murder in all; and whatever mischief one does. they are all guilty of it; and it is lawful for any person to attack and suppress them, and command the king's peace; and such attempt to suppress is not a sufficient provocation to make killing manslaughter, or son assault demesne a good plea in trespass against them. Ashton's Case, 12 Mod. 256, B. 392.

(Mass. Sup. Judicial Ct., 1830.) Near Enough to Assist. Knapp, Crowninshield, and another were indicted for murder of Joseph White at night at his house in Salem. The evidence indicated that Crowninshield only went into the house, the prisoner assisting in the street, 300 feet distant. PUTNAM, J. By the most ancient common law, as it was generally understood, those persons on: were considered as principals in murder who actually killed the man, and those who were present, aiding and abetting, were considered as accessories. So that if he who gave the mortal blow were not convicted, he who was present and aiding, being only an acces- 
sory, could not be put upon his trial. But the law was otherwise settled in the reign of Henry IV. It was then adjudged that he who was present, aiding and abetting him who actually killed, was to be considered as actually killing as much as if he himself had given the deadly blow. *** It must therefore be proved that the abettor was in a situation, in which he might render his assistance, in some manner, to the commission of the offense. It must be proved that he was in such a situation, by agreement with the perpetrator of the crime, or with his previous knowledge, consenting to the crime, and for the purpose of rendering aid and encouragement in the commission of it. It must also be proved that he was actually aiding and abetting the perpetrator at the time of the murder. But if the abettor were consenting to the murder, and in a situation in which he might render any aid, by arrangement with the perpetrator, for the purpose of aiding and assisting him in the murder, then it would follow as a necessary legal inference, that he was actually aiding and abetting at the commission of the crime. For the presence of the abettor under such circumstances must encouralge and embolden the perpetrator to do the deed, by giving him hopes of immediate assistance: and this would in law be considered as actually aiding and abetting him, although no further assistance should be given. For it is clear that if a person is present aiding and consenting to a murder or other felony, that alone is sufficient to charge him as a principal in the crime. And we have seen that the presence by construction or judgment of the law is in this respect equivalent to actual presence. We do not, however, assent to the position which has been taken by the counsel for the government, that if it should be proved that the prisoner conspired with others to procure the murder to be committed, it follows, as a legal presumption, that the prisoner aided in the actual perpetration of the crime unless he can show the contrary to the jury. The fact of the conspiracy being proved against the prisoner is to be weighed as evidence in the case, having a tendency to prove that the prisoner aided. but it is not in itself to be taken as a legal presumption of his having aided unless disproved by him. It is i question of evidence for the consideration of the jury. If, however, the jury should be of opinion that the prisoner was one of the conspirators, and in a situation in which he might have given some aid to the perpetrator at the time of the murder, then it would follow, as a legal presumption, that he was there to carry into effect the concerted crime; and it would be for the prisoner to rebut that presumption, by showing to the jury that he was there for another purpose unconnected with the conspiracy. We are all of opinion that these are the principles of the law applicable to the case upon trial. C. v. Knapp, 9 Pick. 496, 20 Am. Dec. 491, B. 383.

(Ohio Sup. Ct., 1861.) Constructive Presence-Decoying Owner Away. Appellant was convicted as princifal of breaking and enter- 
ing a store at night and stealing goods. IIe complains of an instruction to the jury, in substance that if defendant had agreed with the others to commit the burglary on the night it was done, and, to facilitate the act and lessen the chances of detection, agreed to decoy the owner, Whetstone, away from the store, where he usually slept, to a party a mile distant, and detain him there while his confederates were to break, enter, and remove the goods, and that both parties did their agreed part, then defendant was constructively present and might be convieted as principal. PECK, J. *** We are free to say that this charge, if there was evidence tending to prove it, is unexceptionable. *** The defenclant was by the agreement, not ouly to procure Whetstone to go to the party "to give his confederates greater" security from detection while in the act of breaking into the store," but the jury were reguired to find, as a part of the supposed case, that the defendant "kept him there while his confederates were engraged in breaking in said store, and in eoncealing the fruits of said erime in pursuance of said previous confedericy." * * * The part assigned by the agrement to the defendant-a constant supervision over Whetstone while the burglary was effected-formed an essential part of the plan of the burglary agreed upon, as much so as the rending of the shitter. or the forcing of the door. And the defendant, in the case supposed, was constructively present at the burglary. *** Affirmed. Breese v. S., 12 Ohio St. 146, 80 Am. Dec. 340, B. 386.

(N. Y. Ct. of Errors, 18t3.) To Misdemeanors. Appellant wis charged with petit larceny of butter of one Flagg, and gave evidence tending to prove that he did not himself steal the butter from Flagg, but sent another person to steal it; and that they afterwards divided the butter between them. And he requested the court to charge the jury that. if the butter was thus stoleu. he was merely an accessory. and could not be convicted as a principal for the petit larceny. This the court refused; but charged the jury that. if the other person stole the butter, in Ward's absence, by his advice and procurement, he might be convicted as a principal, as there were no accessories in petit lareeny. Exceptions were taken to these several decisions of the court, and upon argument of the exceptions before the supreme court, they were disallowed; and Ward was sentenced to imprisonment in the state prison. And on appeal this judgment was affirmed. Ward v. P., 6 Hill 144, Kn. 100, Mi. 66:3.

(Ohio Sup. Ct., 1861.) Assault-Accessory to MisdemeanorStatutes and Common Law. Appellant was convicted of assanlt on an indictment jointly with Henrietta Beardsley charging assiult with intent to kill. IIe excepts to the charge of the court that he could be convicted on pronf of aiding and abetting though not present at the time; to the subsequent entry of a nolle pros. as to the intent to murder, on motion of the prosecuting attorney withnut his 
consent; and to the denial of his motions to be dischanged at the closing of the state's evidence, in arrest of judgment, and for a new trial. SCO'I'l, C. J. * * * 'The assignments of erl'or ** * * present the question: Whether one who incites or procures another to commit an assault and battery, at the commission of which he himself is not present, and does not otherwise participate therein, can, in this state, be properly indicted and convicted as a principal in the offense. At common law it is elear that he would be liable as a principal. For the doctrine of the eommon law is that in misdemeanors, and in all crimes under the degree of felony, there are no accessories, but all persons concerned therein, if gilty at all, are principals. 4 131. Com. 36, Whart. Am. Cr. Law 118. So it is said: "One who incites others to eommit an assault and battery is guilty, and may be punished as a principal, if the oflense be actually committed, although he did not otherwise participate in it; as whatsoever will make a man an aceessory before the fact in felony will make him a principal in treason, petit lareeny, and misdemeanors." Id. 547. But it is chaimed that this rule can have no application in this state, because we have no common law crimes or offenses. But is this conclusion a logical sequence of the fact stated? An assault is an offense, not only at common law, but also by our statute; while neither the common law nor the statute makes it a distinct. substantive offense to aid or abet another in the commission thereof. The statute does not define an assanlt, nor specify the acts or degree of participation which will render a party guilty thereof. These are matters which the statute leaves to be determined $h y$ the definitions, rules, and principles of the common law. So far as these rules remain unchanged by the statute, they are applicable, and must govern. And while it is true that the statute makes it a substantive offense to aid or ahet another in the commission of certain specified misdemeanors, yet this is not the case in regalrd to an assault and battery. * * * Judement affirmed. Baker v. S., 12 Ohin St. 214. F. 126.

As to common law of erimes in Ohto, see also. Smith r. S.. $\$ 12$. and compare $\$$.

(Ind. Sup. Ct., 1866.) Indictment-Variance-Burglar's Guard. Appellant was convicted of burglary on proof that he stood ontside, watehing, and ready and near enough to assist, while his eonfederates entered and took the goods. RAY, T. **** It is objected that the appellant was not charged as an aider and abettor, but as a principal. This was correct. At common law it was not required, in order to constitute one a principal in an offense, that the party charged should have been an eye-witness of the transaction, or within hearing. It was suffieient that he had knowledge of the erime. and watched near enough $: 1 \mathrm{l}$ leady to assist those actually engaged. if required. That mad, a presence aiding and abetting. and constituted him a principal in the second degree, and he conld be charged and convicted as a pus oipal. * * * That presence renders him 
who would otherwise have been. but an accessory before the fact a principal in the second degree. "The law, however," says Archbold, "recognizes no difference between the offense of the principal in the first degree, and of the principal in the second. Both are equally guilty." *** [Reversed for an error in the charge to the jury.] Doan v. S., 26 Ind. $495, \mathrm{~F} .124, \mathrm{Kn} .89$.

(Ind. Sup. Ct., 1874.) Same. One present aiding and abetting an assitult and battery is a principal in the second degree, and not an accessory, though he takes no physical part in the matter; his conviction on an indictment as principal in the first degree was sus. tained by proof that he was principal in the second degree. Affirmed. Williams v. S., 47 Ind. 568, F. 125.

\section{ACCESSORIES.}

\section{§76. "Before the Fact."}

(Eng. Assize, 1878.) Accessory Present. F. Brown was indicted for murder and his wife as accessory before the fact. She stood within a few feet when the fatal blow was struck. COLERIDGE, C. J., directed an acquittal of the female, pointing out that she should have been indicted as principal if anything. An accessory before the fact must be absent, and the act must be done on his counsel or procurement. R. v. Brown, 14 Cox C. C. 144 , B. 389.

\section{§77. "After the Fact."}

(Eng. C. C. R., 1569.) Keeping Witnesses Away. Catlin and Browne, justices of assize in the county of Suffolk, put this case to all the judges: A man committed felony, for which he was committed to the jail; and $R$., an attorney, advised the friends of the felon to persuade the witnesses not to appear to give evidence against him, which was done accordingly. And it was resolved, that neither the friends nor the attorney were accessories to the fe'ony, but that it was a great contempt and misprison, for which they might be fined and imprisoned. Roberts's Case, 3 Cokr Inst. 138, $2 r_{i} 495$.

(Va. Ct. of App., 1875.) Generally. F was ivindicd of $\$ 570$ in a bogus lottery by Dull, and applied to Wren, a police detective of Richmond city, to get his money back. They went to Dull's house and found it closed. When $F$ and his lawyer were going into the office of a justice of the peace for a warrant to arrest Dull, Wren said he had brought Dull down. The three went to where Dull was and demanded the money. He denied liability, but finally a settlement in full was made by his paying $F \$ 285$; whereon Wren asked 
pay for his services, which $F$ refused. Dull was soon arrested, and Wren followed him to the station house, swore he would have him bailed and show up the others, and Dull attempted to hand him something as the police captain was about to search him. 'This is the substance of the evidence against Wren, on which he was convicted of being accessory after the fact to Dull's crime. Motion for a new trial being denied, he brought error. CHRIS'lIAN, J. * * The accused is charged with accessorial guilt. He is charged in the indictment with unlawfully receiving, harboring and maintaining John Dull, knowing him to have committed a felony. This charge constitutes what the law denominates "an accessory after the fact." 'The common law definitely and distinctly defines who is such an offender. He is a person who, knowing a felony to have been committed by another, receives, relieves, comforts or assists the felon. 1 Hale P. C. 618; 1 Arch. Crim. P. 78, and cases there cited. The reason on which the common law makes a party in such a case criminal, is that the course of public justice is hindered, and justice itself is evaded by facilitating the escape of the felon. To constitute one an accessory after the fact, three things are requisite: 1, the felony rinst be completed; 2 , he must know that the felon is guilty; $3, n$; must receive, relieve, comfort or assist him. It is necessary til.at the accessory have notice, direct or implied, at the time he assists or comforts the felon, that he has committed a felony. 2 Hawk. P. C., c. $29, \S 32$. And although it seemed at one time to be doubted, whether an implied notice of the felony will not in some cases suffice, as where a man receive a felon in the same county in which he has been attainted, which is supposed to have been a matter of notoriety, it seems to be the better opinion, that some more particular evidence is requisite to raise the presumption of knowledge. 1 Hale 323,622 , 3 P. Wms. 496, 4 Bl. Com. 37. But knowledge of the commission of the felony must be brought home to the accused, and whether he had such knowledge is always a question for the jury.

As to the Receiving, Relieving, and Assisting one known to be a felon, it may be said in general terms, that any assistance given to one known to be a felon in order to hinder his apprehension, trial or punishment, is sufficient to make a man accessory after the fact; as that he concealed him in the house, or shut the door against his pursuers, until he should have an opportunity to escape; or took money from him to allow him to escape; or supplied him with money, a horse or other necessaries, in order to enable him to escape; or that the principal was in prison, and the jailer was bribed to let him escape; or conveyed instruments to him to enable him to break prison and escape. This and such like assistance to one known to be a felon, would constitute a man accessory after the fact. 1 Hale $619,621,2$ Hawk. c. 29, \& 26 . But merely suffering the principal to escape, will not make the party accessory after the fact; for it amounts at most but to a mere omission. 1 Hale 619, 
9 H. iv. 1. Or if he agree for money not to prosecute the felon; or if knowing of a felony, fails to make it known to the proper author: ities; none of these acts would be sufficient to make the party an accessory after the fact. If the thing done amounts to no more than the compounding a felony, or the misprison of it, the doer will not be an accessory. 1 Bishop C. L., $\$ 633 ; 1$ Iale P. C. 371, 618

Now Applying These Well Recognized Principles to the case before us, we are of opinion that the commonwealth has failed to show that the plaintiff in error is an accessory after the fact to the felony committed by Dull. *** His failure to make the arrest himself, nor his effort, or expressed purpose to get him bailed after his arrest, nor his threat that as Dull is to be shown up others should be shown up also, none of thes acts constitute Wren an accessory after the firct to the felony committed by Dull. If, knowing that a felony had been committed, he concealed it, then he is guilty of misprison of felony. If, knowing a felony to be committed, he concealed it or forbore to arrest and prosecute the felon, for fee or reward, then he is guilty of compounding a felony. Both of these are grave oftenses, but they do not (if proved) constitute a party an accessory after the fact. *** Reversed. Wren v. C., 26 Gratt. (Va.) 952, Kn. 97.

('Tex. Ct. of App., 1888.) Suppressing and Perverting Evidence. Appellant was convicted of accessory to murder, on proof that after the murder was committed he induced witnesses to testify at the coroner's inquest that the murderer (May) shot in self-defense while being pursued by deceased with a knife. Appellant contends that under the statute "aid" means something which relates to the physical conduct of the offender. WHITT, P. J. *** MIr. Bishop says: "I'he true test whether one is an accessory after the fact'or not is whether what he did was by way of personal help to his principal to elude punishment; the kind of help being unimportant." 1 Bish. Cr. Law (Ed. 7 ), $\S 695$. *** We are of opinion that the facts we have stated, and upon which this case rests, brings it within the purview of the general law and our statute as to accessories. Appellant, if he did not in fact conceal May until the perjured testimony was given which justified him before the inquest, certainly aided him to the extent that he was not arrested and punished for his crime until the perjury was discovered, and but for the discovery the aid which defendant attempted to give him would have proven effectual in affording him perfect and complete immunity from apprehension, trial, and punishment for the murder he had committed. It is true that, under the facts disclosed, defendant might have been prosecuted and convicted. under our statute. for subornation of perjury (Pen. Code, art. 199); but this fact did not destroy nor affect his relation to the murder as an accessory. It was simply a question with the prosecution as to which of the 
offenses he should be tried for. [Judgment reversed for insufficiency of evidence to sustain conviction being the uncorroborated testimony of accomplices.] * * Blakeley v. S., 24 T'ex. $\Lambda$ pp. 616, is. W. 233, 5 Am. St. Rep. 912, 1. 128.

\section{DEFENSES.}

\$78. Generally. The principal must be convicted before the accessory can be tried (in the absence of statute changing the common law), there must be proof of complicity between the parties, and the crime committed must have been within the scope of the original design, or a natural consequence of its execution. Abandonment before the crime was committed is also a defense.

\section{\$79. "The Principal Must be Convicted Before the Accessory can be Tried."}

(Mass. Sup. Judicial Ct., 1820.) Trial of Accessory After Death of Principal. Indictment charging baniels as principal, and defendant as aceessory before the fact, of burglary, and alleging the death of Daniels. PARKER, C. J., stated that the justices had carefully examined the books upon the subject, and were uninimously of opinion that by the common law an accessory camnot be put on his trial, but by his own consent, until the conviction of the principal. 'The reason of this rule is very plain. If there is no principal there can be no accessory, and the law presumes no one guilty until convietion. Statutes have made a difference as to some lesser species of offenses, but do not touch the principle in capital casses. Our only doubt arose from the peculiar circumstance in this case, that the person charged as principal is dead, and can never be tried. If he were alive and on trial, it is possible he might establish his innocence, strong as the evidence has appeared in support of his guilt. In such case the prisoner could not be found guilty, for he could not lave been aceessory to the eommission of the erime as charged. The trial might have been stopped at the commencement of it had our minds been then free from all doubt. But as the prisoner has been put on his trial, he has a right to a verdict. Verdict of acquittal directed by the court. C. v. Phillips, 16 Mass. 423, B. 389.

(New York Ct. of $A_{p p}$., 1871.) Trial After Convicting One Principal. Plaintiff in error was indicted as accessory before the fact of a burglary committed by four principals named in the indictment. On the trial he objected to being tried till all the principals were convicted, which being overruled, he objected to being tried as accessory to the crime of any but the one who had been convicted. 
which was also overuled; and a jury was impaneled, and he was convicted. ClluRCH, C. J. * * * Formerly, if a man was indicted as accessory in the same erime to two or more persons, he could not have been alraigned till all the principals were convicted and attainted. Ilale's P. C. 6:3. And in order to try an accessory when only one of several principals had been convicted it was necessary to indict and arraign him as aceessory to that one only. Id. But the modern decisions have somewhat moditied this rule, and the weight of anthority now is that an accessory may be tried and convicted when one only of several principals named in the indictment has been eonvicted. 1. Russell on Cr. 38, Bishop Cr. I. \$ 611; C. v. Knapp, 10 Pick. 477. l3ut it is well settled that in such il ease the accessory must be tried and convicted as accessory to the convicted principal only, in the same mamner as thongh the convicted principal only was named in the indictment. 'The anthorities are uniform on this subject, and I have been umable to find any decision against this position. $* * *$ The decision of the court therefore, overruling the objection of the prisoner to being tried as accessory to any but the convicted principal, was clearly erroneous. * * * Reversed. Starin v. P., 4i) N. Y. 3333. 13. 390.

(Ind. Sup. Ct., 18i3.) Subsequent Acquittal of Principal. Indictment in two counts against H. and I. MeCarty, the first charging them with assault and battery on Gaines with intent to murder. and the second charering II. as principal and I. als accessory hefore the fact of said offense. They demanded separate trials. I. was first tried and convicter; then II. was tried and acquitted. 'I'hen I. moved to be discharged, and, the motion being denied, appealed. WORDEN, J. * * * We quote the following paragraph from 4 Cooley's 131. 323: "By the old common law the accessory conld not be arraigned till the principal was attainted. unless he chose it; for he might waive the benefit of the law; and therefore principal and accessory might. and may still, be arraigned, and plead. and also be tried together. But otherwise, if the principal had never been indieted at all, had stood mute, had challenged above 35 jurors peremptorily, had elaimed the benefit of elergy, had obtained a pardon, or had died before attainder, the acessory in any of these cases could not be arraigned; for non constitit whether any felony was committed or no, till the principal was attainted; and it might so happen that the accessory should be convicted one day, and the principal acquitted the next, which would be absurd."; *** Having thus adverted to the common law on this subject. we proceed to inquire how far it has been changed by our statnte. *** Section 51, Cr. Code 2 G. \& H. 453, is as follows: "Every person who shall be guilty of any crime punishable by the provisions of the last two preceding sections, may be indicted and convicted before or after the principal offender is indicted and convicted." *** Shall the statute be construed to authorize the conviction of the 
accessory after the acquittal of the principal? It does not, in terms, as we have seen, so provide. By its provisions, the accessory may be tried and convicted, either after the principal has been tried and convicted, or before the principal has been tried, his guilt remaining, in the meantime, undetermined. But if, at any time before the final conviction of the accessory, the principal has been tried and acquitted, there is no authority, either in the principles of the common law or under the statute quoted, for proceeding to the final conviction of the accessory. In this case, the appellant had been found guilty by the verdict of a jury, but before judgment thereon the principal had been tried and acquitted. This entitled the appellant to be discharged, and, in our opinion, the court below erred in overruling his motion for such discharge. The judgment below is reversed, and it is ordered that the appellant be discharged from imprisonment in the state prison. McCarty v. S., 44 Ind. 214, $15 \mathrm{Am}$. Rep. 232,'Kn. 102.

\section{\$80. "There Must be Proof of Complicity Between the Parties."}

(Fngr. Assize, 1883.) Proximate Cause-Complicity. Death by Chloroform, administered to deceased to operate on his jaw, which had been broken, and on his larynx, which had been injured, in a melee with defendants, was charged against them as manslaughter. On the trial the court instructed the jury that if defendants acted in concert, both were liable, and it was not material which did the injuries; and if one broke the jaw and the other injured the larynx both were liable; but if they could not ascertain which did either injury, and they did not act in concert, the jury might acquit both. As to the death from the operation, the court instructed them that the assailants were responsible in law. Verdict, not guilty. R. v. Davis, 15 Cox C. C. 174 , B. 171.

See other cases on proximate cause, $\$ \$ 14,82$. Rloters not linble for acts of oppon. ents: C. v. Campbell, \$ 14. But If deceased used as buffer, see Tnylor $* \$, \S 14$.

\section{\$ 81. "Within the Scope of the Original Design."}

(Vt. Sup. Ct., 1868.) Unauthorized Act-Driving on Sidewalk. Defendant was charged with driving a coal wagon on the sidewalk; and it was proved that he hired a man over 21 years old to deliver the conl, and that he, without the direction, consent, or knowledge of defenclant, drove on the walk, for his own eonvenience, in delivering the coal. The court held defendant not liable, as his orders did not require violation of the law, and he had no reason to suppose any such act would be done. S. v. Bacon, 40 Vt. 456, F. 138. 
(Mich. Sup. Ct., 1882.) Liability for Sale by Clerk. CAMPBEIL, J. Respondent was convieted under the statute of 1881, making it a misdemeanor to sell intoxicating liquor to persons who are in the habit of becoming intoxicated. 'The sale was not made by respondent, but by a clerk. The court below held that the respondent was responsible for the knowledge of his elerk, as well as if he had known the condition of the vendec himself. 'The statute in question prohibits sales by means of clerks as well as in person. Laws 1881, p. $355, \$ 12$. And a subsequent section (13) makes violations of the statute misdemeanor's, and punishable as such. But it would be an unjust and inadmissible interpretation to construe such a provision as covering anything but an act in which the will of the respondent concurred in the sale. It is contrary to every rule of law to hold a person criminally responsible for an act in which he has taken no part. * * * lieversed. P. v. Parks, 49 Mich. 333, 13 N. W. 618, 13. 376 .

But see P. v. lloby, \$ 42 .

(Eug. King's Bench, 1771.) Same-Libel-Knowledge of Publisher. Defendant was convicted of libel, in publishing one of Jumius's letters in a magazine bearing his imprint and sold at his shop. He moved for a new trial on the ground that the evidence was insufficient to prove intention or the least knowledge by defend. ant; and offered affidavits to prove that the magazine was published by one Miller; who (without his consent, but according to the custom of booksellers) had struck ofí 300 copies bearing defendant's imprint, and delivered them at his shop to be sold; and that a clerk in eharge of the shop sold a number of them without his knowledge; but that as soon as he discovered what they contained he stopped the sale and returned the rest of the copies to Miller. It was also urged that one of the jurors, after they had been out about two hours, proposed a doubt to the court whether "bare proof of sile in Mr. Almon's shop, without any proof of privity, knowledge, consent, approbation, or malus animus, in $\mathrm{Mr}$. Almon himself, was sufficient in law to convict him of criminally publishing a libel." The juror said that otherwise he would not convict. The court answered him that this evidence was sufficient to convict, and indeed conclusive unless disputed. And in denying the motion for a new trial the judges (Mansfield, Aston, Willes, and Ashurst) were agreed that none of the matters urged, nor all together, were sufficient reason for granting a new trial, whatever weight they might have to lessen the punishment. The evidence was held sufficient prima facie, though liable to be refuted or explained; but as no such excuse was shown the conviction should stand. R. v. Almon, 5 Burr. 2686. 20 St. Trials 803, 1 B. \& H. 241-n, F. 136, Ke. 38.

Acc. R. v. Clayton, I Car. \& Kïr. 128, B. 388. 


\section{\$82. "A Natural Consequence of its Execution."}

(Eng. Assize, 1838.) Probable Consequence-Act of Insane Leader. 'lhom, a religious fanatic, was told by defendunts, his followers, that men ealled him a fool and imposter and threatened to take him; to which he replied: "I can clap my left hand on my right arm and slay 10,000 men; if the constables come I shall cut them down like grass." 'The prisoners continued to follow him, and two days later he shot a constable who came to arrest him in the presence of defendants. The prisoners are charged with murder as principals in the first degree to the act of thom, he being considered insane. The defense was that there was no community of purpose in any unlawful act, and that defendants followed and assisted 'Thom only through fear of him. LORD DENMIAN, C. J. (to the jury). **** Where parties for such a reason are induced to join a mischievous man, it is not their fear of violence to themselves which can excuse their conduct to others. You probably, gentlemen, never saw two men tried at a criminal bar for an offense which they had jointly committed, where one of them had not been to a certain extent in fear of the other. **** If you think that they kept together with the knowledge of any general purpose of resistance to the law, then they are guilty. It cannot be too often repeated, that the apprehension of personal danger does not furnish any excuse for assisting in doing any act which is illegal. You will, therefore, discird that as an exeuse, and say whether you find that Thom was a dangerous and mischievous person; that these two prisoners knew he was so, and yet lept with him, aiding and abetting him by their presence, and concurring in his acts; and if you do so, you will find them guilty, for they are then liable as principals for what was done by his hand. Verdict, guilty. R. v. Tyler, 8 Car. \& P. (34 E. C. I.) 616. F. 116, Ke. 57.

Sce severnal cases on liability for unexpected consequences of wrongful act, $\$ \$ 14,38$, 39. 40 and 44 .

(New York Ct. of App., 1871.) Consequence of Illemal Act Intended. Appellant was convicted of murder. ALIstis. J. The jury have, by their verdict, found that the homicide was committed either by the accused in person or by some one acting in concert with him in the commission of a felony, and in the prosecution and furtherance of a common purpose and design. It must be assumed, from the finding of the jury, that the prisoner was one of the three persons who burglariously entered the store on the night of the homicide; that Merrick was killed by one of the burglars, in pursuance of the common intent of all; and that the aceused either fired the shot which caused the death, or was present. aiding and abetting. * * * There were but three persons, other than the deceased and his fellow clerk, present. One of these was disabled and lying upon the floor seriously wounded. and the other 
was in the grasp of Merrick, the deceased, and was also wounded and injured. The third came up the stairs and fired the pistol which caused the death, and he alone of the three was uninjured and unwounded. The accused, when arrested a day or two after the occurrence, bore no mark of injury. *** If there was a general resolution against all opposers, and to resist to the utmost all attempts to detain or hold in custody any of the parties, all the persons present when the homicide was committed were equally guilty with him who fired the fatal shot. 1 Russ. on Crimes, 29, 30. This general resolution of the confederates need not be proved by direct evidence. It may be inferred from circumstances; by the number, aims, and behavior of the parties at or before the scene of action. Id.; Fost. 353, 354; 2 IIawk. P. C., c. 29, \$ 8 ; 'Tyler's Case, 8 C. \& P. $616 . * * *$ The jury were authorized to infer that this act was within the general purpose of the confederates. They may have desisted from their larcenous attempts, and yet the full purpose of the combination not have been carried out so long as one of the party was detained and held a prisoner. ${ }^{*} *{ }^{*}$ Affirmed. Ruloff v. P., 45 N. Y. 213, B. 392.

(Iowa Sup. Ct., 1880.) Independent Crime not Agreed On. Defendant was indicted jointly with Wood and White for robbery of Edwards. It appeared that he rowed the other defendants across the river from La Crosse to Lansing about 9 o'clock at night, watched the boat while they went to the sawmill and robbed Edwards (the watchman) and the safe, and then rowed them back. The court instructed the jury that though they might believe that defendant did not leave the boat to commit either robbery, yet if they believed that he knew the intent to commit either or any other crime, and rowed them ashore for that purpose and waited for them, they might find him guilty. The supreme court held this was error. The court admitted that the accessory is "liable for all that ensues from the commission of the contemplated unlawful act; but if the accessory advise one crime and the principal commit an entirely different one, the court held the accessory would not be liable. "It follows that the defendant cannot be convicted of a robbery of Edwards from the mere fact that he abetted his associates in the robbery of Barclay \& Hemmingway's safe. If the intention of Lucas was to abet and share in the proceeds of any robbery that his associates might commit, a different rule would apply. But this is not the thought of the instruction under consideration." Per DAY, J. Reversed. S. v. Iucas, 55 Iowa 321, 7 N. W. 583, B. 396.

(Ill. Sup. Ct., 1880.) Common Object-Probable ConsequencesMurder. John Lamb was convicted in the criminal court of Cook county of murder of Race. a police officer. Lamb and others had burglarized a store on Fifth avenue, and taken the plunder in an express wagon to a pawn-shop on State street, Chicago; and while 
unloading there, Race approached the wagon and was iustantly shot by someone about the wagon. The evidence for the defense tended to show that Lamb was not present, and for him it was contended that if so he was not liable, since the act was not a natural or probable consequence of the burglary. 'The court refused to give such an instruction and instructed the jury that "if several persons conspire to do an unlawful act, and death happens in the prosecution of the common object, all are alike guilty of the homicide." MIULKEY, J. * * * The place of deposit-a pawn-shop-was least of all others calculated to attract notice or comment by reason of unloading goods in front of it. The night was very dark, and altogether favorable to the execution of an enterprise of that kind. Indeed, when all the circumstances are considered in connection, they would seem to exclude all probability of force and violence becoming necessary in carrying into execution the arrangement agreed upon. This being so, it would be manifestly unjust to hold the accused liable for an act done by another, which he had never in any sense, either expressly or impliedly, assented to. The principle which underlies and controls cases of this character is the elementary and very familiar doctrine, applicable alike to crimes and mere civil injuries, that every person must be presumed to intend, and is accordingly held respousible for the probable consequences of his own acts or conduct. When, therefore, one enters into an agreement with others to do an unlawful act, he impliedly assents to the use of such means by his co-conspirators as is necessary, ordinary, or usual in the accomplishment of an act of that character. But beyond this his implied liability cannot be extended. So, if the unlawful act agreed to be done is dangerous or homicidal in its character, or if its accomplishment will necessarily or probably require the use of force and violence, which may result in the taking of life unlawfully, every party to such agreement will be held criminally liable for whatever any of his co-conspirators may do in furtherance of the common design, whether he is present or not. But where the unlawful act agrced to be done is not of a dangerous or homicidal character, and its accomplishment does not necessarily or probably require the use of force or violence, which may resuit in the taking of life unlawfully, no such criminal liability will attach inerely from the fact of having been a party to such an agreement. The views here expressed are fully sustained by the following authorities: 1 Bish. Cr. Law (6th ed.), \& 641; Hawk. P. C. bk. 2 , e. $29, \S \S 19-21$; Fost. Crown Law 369,370 ; R. v. Franz, 2 Fost. \& F. 580 ; R. v. Horsey, 3 Fost. \& F. 287; R. v. Luck, Id. 483; Rose. Cr. Ev. 673,655 ; R. v. Tyler, 8 Car. \& P. 616 ; R. v. Lee, 4 Fost. \& F. 63 ; R. v. Turner, Id. 339 ; R. v. Hawkins, 3 Car. \& P. 392; Watts v. S., 5 W. Va. 532 ; R. v. Howell, 9 Car. \& P. $437 . * * *$ CRATG, J. (dissenting): I cannot concur with a majority of the court in reversing the judgment. * * * Had it appeared that the killing of Race was not done in furtherance of or in prosecution 
of the original design to rob the store, or secrete the stolen goods, or was not a necessary or probable consequence likely to result from the conspiracy to rob and seerete the stolen goods, there might be more force in the position of counsel for defendant. *** But the evidence, when fairly considered, seems to establish beyond a doubt that the killing was a consequence likely to flow from the conspiracy, which was anticipated by the conspirators, and for which they prepared themselves before they attempted to rob the store. Previous to the robbery a navy revolver was obtained at Friedberg's. 'This was loaded, and, on the night of the burglary, given to the defendant. Three of the other parties were armed, and Freeman, who was stationed on the outside, with Lamb, to watch, while the other's entered the store. in his evidence says that liaml sent him into the store, to see why those engaged in getting the goods were so slow, and when he ascended the stairs where they wre, as he was not recognized, two revolvers were pointed at him. If those parties engaged in the burglary did not intend to shoot if molested, why were they armed with revolvers? * * Judgment reversed; Craig, Walker, and Sheldon, JJ., dissenting. Lamb v. P., 96 I1l. 73, F. 130.

\section{\$ 83. "Abandonment."}

(Eng. Old Bailey 1785.) Taking Last Penny-Proof. Defendants were indicted for highway robbery; and it was proved that they stopped prosecutor in the street and demanded what money he had, on which he said he had but two-pence half-penny, and one of the prisoners then said to the other: "If he really has no more, do not take that." But the other tonk it. THE COURT. The point of law goes to the acquittal of both the prisoners; for if two men assault another with intent to rob him, and one of them, before any demand of money, or offer to take it be made, repent of what he is doing, and desist from the prosecution of such intent, he cannot be involved in the guilt of his companion who afterwards takes the money; for he changed his evil intention before the act which completes the offense was committed. * * * It is like the Ipswich case, where five men were indicted for murder; and it appeared, on a special verdict, that it was murder in one, but not in the other four; but it did not appear which of the five had given the blow which caused the death, and the court thereupon said that as the man could not be clearly and positively ascertained, all of them must be discharged. Both acquitted. R. v. Richardson, Leach C. C. (Ed. 3) No. 173, B. 166, Ke. 448.

(Conn. Sup. Ct. of Errors, 1879.) Giving Notice on Abandoninent. Defendant and one Hamlin were convicted of murder in the first degree, in killing a night-watchman, Shipman, in their effort to 
escape from the state prison. The evidence for the state indicated that they provided themselves with revolvers, gag, and handeuffis, and hid in the prison hall; and being discovered by Shipman, both fired at, wounded, pursied, caught, handeufted, and gagged him; and that Allen then went to his cell, 150 fent away, leaving llamlin with Shipman, where he was diseovered and fired at by the guard; and that shipman died of the wound next day. The defense was that Allen fired no shot, and that just before Hamlin shot Allen abandoned the effort and returned to his cell. The court instructed the jury that if Allen suddenly abandoned the enterprise and returned to his cell during the fatal encounter, without saying a word to Hamlin to the effect that he had abandoned it; and Hamlin, supposiug that he was still acting with him, and had gone to his cell for something to aid it, fired the fatal shot, his abandonment under such circumstances would be of no importance. BEARDSLEY, J. * * * A majority of the court think that the jury may have been misled by this part of the charge, and that, therefore, especially in view of the grave issues involved in the case, a new tidal snould be granted. If Allen did in fact before the. homicide withdraw from the conspiracy, abandon the attempt to escape, and with the knowledge of Hamlin leave and go to his cell, Hamlin's misconstruction of his purpose in leaving did not necessarily make his conduct of no importance. Until the fatal shot there was the "locus penitentiale." To avail himself of it Allen must indeed have informed Hamlin of his change of purpose, but such information might be by words or acts; and if with the intention of notifying Hamlin of his withdrawal from the conspiracy he did acts which should have been effectual for that purpose, but which did not produce upon the mind of Hamlin the effect which he intended and which they naturally should have produced, such acts were proper for the jury to consider in determining the relation of Allen to the crime which was afterwards committed. Allen's act of leaving and going to his cell, if he did so, had some significance in connection with the question of intention and notice, and was therefore proper for the consideration of the jury. How much weight was to be given to it woull depend upon circumstances, such as the situation of the parties and the opportunity for verbal or other notice. ${ }^{*} *^{*}$ New trial advised. S. v. Allen, 47 Conn. 121, 13. 394, Kn. 29, Mi. 483.

(Gi. Sup. Ct.. 1860.) Defendant, convicted of larceny, moved for a new trial because the court erred in not instructing the jury at his request that if he repented before the theft, and did not participate in it he was not guilty, though he had conspired with the thieves to commit the crime. Motion denied and he brings error. IsUMIPKIN, J. * * We think the fourth charge should have been given. The law as well as the gospel allows a place of repentance. And. notwithstanding the accused may at one time have agreed to engage in this crime, yet, if he afterwards changed his mind and abandoned 
that intention, he is not guilty. And there was proof in that case to warrant a charge to that effect. Reversed. Pinkard v. S., $30 \mathrm{Ga}$. 757, F. 135, Mi. 335.

See other cases of abandonment as a defense: Glover v. C., 8 62. Rape abandoner after attempt: Grifin $\nabla$. S., \$ 60 , dictum. 
CHAPTER VI.

\section{JURISDICTION AND PUNISHMENT.}

\$84. Outline, 269 .

"I,OCALITY OF THE ChISIE."

885. Classlfication, 260.

886. "What Courts Have Jurisdiction to Punish Crimes committed at the Particular Place," 268.

887. "If the Wrong-doer wis in One Place and Ilis Act Took Enect In Another." 279.

\$ 88. "If Guods Stolen in One Place are Taken to Another," 286.

89. "If a Fatal Injury is Inflicted in One Place and the Vletim Goes to Another Place and Dles," 294.

"Estradition aND Rendition."

\$90. In General, 299 .

"FORMDR JHOPAInY."

\$01. Old Maxim and Constitutional Provision, 306.

\$92. "Twlce Put in .Jeopardy," 307.

\$3. "For One nnd the Same Offense," 315.

§84. Outline. Having examined the nature of a crime in general, and as to the intent, act, and actors, a few topics concerning jurisdiction and punishment, aside from pleading and procedure, merit attention before closing our observations on crimes in general. of these we will consider: 1 , locality of the crime; 2 , extradition and rendition; and, 3, former jeopardy for the same offense.

\section{"1. LOCALITY OF THE CRIME."}

$\$ 85$. Classification. The most perplexing questions on this topic are as to: 1 , What courts have jurisdiction to punish crimes committed at the particular place; 2 , if the wrongdoer was in one jurisdiction and his act took effect in another, where was the crime committed; 3 , if goods stolen in one place are taken to another, is every removal or moving a new or continuing theft; and, finally, 4, if a fatal injury is inflicted in one place and the victim goes to another place and dies, where is the homicide committed.

\$86. "What Courts Have Jurisdiction to Punish Crimes Committed at the Particular Place."

(Eng. C. C. R., 1807.) Homicide on Merchant Ship. The defendant, an alien enemy and prisoner of war, serving as a marine on an English merchant ship, was prosecuted under St. 43 G. 3, c. 113, $\S 6$, and 33 Hen. VIII., c. 23 , which give jurisdiction to a special 
commission for offenses committed abroad, for a homicide perpetrated or the ship near Canton, China, upon an English subject; and it was held that inasmuch as the defendant owed no allegiance to the Euglish government, he could not be tried for the offense in England. R. v. Depardo, 1 I'aunt. 26.

(L. S. Sup. Ct., 1818.) Murder on U. S. Ship in Boston Harbor. On verdict of guilty on indictment in U. S. C. C. for Mass., for a murder committed aboard a U.S. ship of warr anchored quarter of a mile from shore in Boston harbor, and on motion for new trial, the judges of the circuit differed in opinion as to whether the court had jurisdiction, and so certified the question to this court. MARSIIALL, C. J. *** The indictment appears to be founded on the "Act for the punishment of certain crimes against the United States," §8. 'That section gives the courts of the union cognizance of eertain offenses committed on the high seas, or in any river. haven, basin, or bay, out of the jurisdiction of any particular state. Whatever may be the constitutional power of congress, it is clear that this power has not been so exercised, in this section of the act. as to confer on its courts jurisdiction over any otfense committed in a river, haven, basin, or bay, which river, basin, or bay is within the jurisdiction of any particular state. What, then, is the extent of jurisdiction which a state possesses? We answer without hesita. tion, the juriscliction of a state is coextensive with its territory, coextensive with its legislative power. The place described is $\mathrm{un}$. questionably within the original territory of Massachnsetts. It is then within the jurisdiction of Massachusetts. unless that jurisdiction has been ceded to the United States.

[U. S. Maritime Jurisdiction.] It is contended to have been ceded by that article in the constitution which declares that "the judicial power shall extend to all cases of admiralty and maritime jurisdic. tion." The argument is, that the power thus granted is exclusive; and that the murder committed by the prisoner is a case of aldmiralty jurisdiction. Let this be admitted. It proves the power of congress to legislate in the case. not that congress has exercised that power. *** T'o bring the offense within the juriscliction of the courts of the union it must have been committed in a river. etc.. nut of the jurisdiction of any state. It is not the offense comımitted, but the bay in which it is committed, which must be out of the jurisdiction of the state. If then it should he true that Massachusetts ean take no cognizance of the offense, yet unless the place itself be out of her jurisdiction. congress has not given cognizance of that offense to its courts. If there be a common jurisdiction. the crime cannot be punished by the courts of the union. Can the cassion of all cases of admiralty and maritime jurisdiction be construed into a cession of the waters on which those cases may arise? This is a question on which the court is incapable of feeling a doubt. The article which describes the judicial power of the Urited States is not intended 
for the cession of territory or of general jurisdiction. It is obviously designed for other purposes. ** * Although the bay on which this murder was committed might not be out of the jurisdiction of Massachusetts, the ship of war on the deck of which it was committed, is, it has been said, "a place within the sole and exclusive jurisdiction of the United States," whose courts may consequently take cognizance of the oftense. That a govermment which possesses the broad power of war, which "may provide and maintain a navy," which "may make rules for the govermment and l'egulation of the land "d naval forces," has power to pumish an offense committed by a marine, on board a ship of war, wherever that ship mily lie, is a proposition never to be questioned in this court. On this section, as on the 8th, the inquiry respects not the extent of the power of congress, but the extent to which that power has been exercised. The objects with which the word "place" is associated are all, in their nature, fixed and territorial. A fort, an arsenal, a dock-yard, a magazine, are all of this character. $* *{ }^{*}$ Upon these reasons the court is of opinion that a murder committed on board a ship of war, lying within the harbor of Boston, is not cognizable in the cireuit court for the district of Massachusetts. $*^{*} *^{*}$ U. S. v. Bevans, 16 U. S. (3 Wheaton) 336, C. 17.

(J. S. Sup. Ct., 1855.) Homicide on American Boat in Chinese River. The question was certified to this court for difference of opinion, after conviction in the circuit court of the United States for the district of Pennsylvaria, on indictment for manslaughter committed on board an American ship in fresh water in the l'igris river in China, where the tide ebbs and flows, but 35 miles from the sea. The question was whether the court had jurisdiction; and on mature consideration. this court advised the court below that it had no jurisdiction; because the place was not on the high seas within the meaning of "An act for the punishment of ecrtain crimes a arainst the United States," under which the indictment was laid, \$12 of which provided "that if any seaman or other person shall commit mauslaughter on the bigh seas, or confederate, *** such person or perions so offending and being thereof conviel, l, shall be imprisoned, not exceeding three years, and fined, not exceeding one thousand dollars." U. S. v. Wiltberger, 5 Wheaton 76.5 L. Fd. 37, C. 49,1 L. 34 .

(Eng. C. C. R., 1868.) Murder on British Ship in France. Anderson, an American citizen, was convicted of murder committed on board of a British ship in the river Garonne, 90 miles from the sea. while the ship was in motion. BOVILL, C. J. There is no doulbt that the place where the offense was committed was within the territory of France, and that the prisoner was therefore subject to the laws of France, which the local authorities of that realm might have enforced if so minded; but at the same time, in point of law, the 
offense was also committed within British territory, for the prisoner was a seaman on board a merchant vessel, which, as to her crew and master, must be taken to have been at the time under the protection of the British Hag and, therefore, also amenable to the provisions of the British law. It is true that the prisoner was an American citizen, but he had with his own consent embarked on board a British vessel as one of the crew. Although the prisoner was sub. ject to the American jurisprudence as an American citizen, and to the law of France as having committed an offense within the territory of France, yet he must also be considered as subject to the jurisdiction of British law, which extends to the protection of British vessels, though in ports belonging to another country. [Byles, Blackburn, and Lush, JJ., and Chaunell, B., gave similar cpinions.] Conviction affirmed. R. v. Anderson, 11 Cox C. C. 198, L. R. 1 C. C. R. 161, B. 895 .

(Eng. C. C. R., 1876.) Collision at Sea. Keyn was convicted of manslaughter in the central criminal court, under $4 \& 5$ Wm. 4 , c. $36, \S 22$, giving that court jurisdiction of offenses committed within the jurisdiction of the adiniralty. The oroof was that Keyn was in command of a foreign ship, sailing for a foreign port from a foreign port, and was a foreigner; and that while so sailing, by negligent steering, he collided with a British ship within three miles of the const of England. 'The British ship sank, and the deceased, on board, was drowned. On case reserved the questions were discussed at great length by several of the judges. Four held that the court had jurisdiction because the offense was committed within the three-mile zone, and two others for the same reason and the additional one that it was in fact committed on board the British ship. Seven judges held that the court was without jurisdiction, denying both of these contentions. R. v. Keyn, 2 Ex. D. 63, 13 Cox C. C. 403,46 L. J. m. c. 17, B. 897 .

(Eng. C. C. R., 1882.) Receiving Goods Stolen Aboard Domestic Ship in Foreign Port. LORD COLERIDGE, C. J. * * * Where she was lying in front of the "dolphin" there is always enough water to float ships of her class. There was no actual proof when, or by whom, the bonds were stolen. The case states, "I'here was no evidence upon which the jury could have found that the theft occurred after the voyage began; the evidence rather pointed to its having occurred before she sailed." Whether the bonds were carried off the ship on to the shore, and sent by some conveyance to the prisoners in England, or whether they were brought by the prisoners to England, does not appear. The prisoners were acquitted of stealing the bonds and found guilty of receiving them with guilty knowledge that they had been stolen. It is obvious that the prisoners could not be convicted of feloniously receiving the bonds unless they were stolen within the same jurisdiction where the receiving 
took place, and therefore it becomes material to inquire whether the jurisdiction of the admiralty attached so that the prisoners could be tried at the Old Bailey. It is admitted that the exact point raised in this case has never arisen for decision in our courts before. There appear but two points for us to decide. 1. Was the ship within the jurisdiction of the admiralty so as to make offenses committed upon it triable according to the English law? 2. If that point is answered in the affirmative, were the prisoners, according to the decisions, liable to be tried in the English courts? First, as to the place. The place appeurs to me to come within the old definition of the admiralty jurisdiction. The ship was at a part of the river which is never dry, and where it would not touch the ground at low water, and the tide ebbs and flows in the river, and great ships do lie and hover there. That is sufficient to bring this ship within the admiralty jurisdiction. Without saying that the reports of the case of $R$. v. Jemot and R. v. Allen, 7 C. \& P. 664, 1 Moody 494, are as full as could be desired, it seems very difficult to driw any tangible distinction between them and the present case. This case also falls within the decision of $R$. v. Anderson [above], where the ship was half-way up the river Garonne, in France, and at the time of the offense about 300 yards from the nearest shore, and this court held, the prisoner having been convicted of manslaughter, that the offense had been committed within the juriscliction of the admiralty, and that the central criminal court had jurisdiction to try the prisoner. I am unable to distinguish this case from that, but if anything $R$. v. Anderson seems an a fortiori case. Then, as to the second point, whether there is anything in the personality of the prisoners which would make them not liable by the law of England. It is true that some of the judges in R. v. Anderson (ubi sup.) place reliance upon the fact that the prisoners formed part of the crew of the vessel, but Bovill, C. J., in his judgment points out that England has always insisted on her right to legislate for persons on board her vessels in foreign ports. None of the judges suggested that their judgments would have been in any way altered if the prisoners had not, in those cases formed part of the crew. I think it makes no difference whether a person is a British subject or not who comes on board a British ship where the British law reigns, and places himself under the protection which that Hag confers; if he is entitled to the privileges and protection of the British ship he is liable to the disabilities which it creates for him. I am unable, therefore, to make a distinction between a passenger or stranger on board a ship and one of the crew, and it makes no difference in my mind whether the person is on board voluntarily or involuntarily; if while on board he is entitled to the protection of its flag, he is also bound by the obligations imposed by the law governing that ship. The utmost that can be said as regards the theft in this case is that the bonds may have been stolen by some one who came on board casually; it may be a 
foreigner who took them off the vessei at Rotterdam. Suppose the thief had not been able to gret off the ship, and had been captured and brought here, could he have been tried here? In my opinion he could, for if while he was on board the ship he was entitled to the protection of the British flag, he was at the same time equally liable to the disabilities of the criminal law of this country. It appears to me that the evidence shows that the bonds were stolen vithin the jurisdiction of the Finglish law, and I am of opinion that the prisoners therefore were triable at the central criminal court for receiv. ing them, well knowing them to have been stolen. I think that the conviction should be affirmed. Pollock, B., Lopes, Stephen, and Williams, JJ., concurred. Conviction affirmed. R. v. Carr, 10 (2. B. 1). 76, 15 Cox C. C. 129,37 Moak 379, C. 429.

(U. S. Sup. Ct., 1893.) On U. S. Boat in Canadian Waters. Dofendant and others were indieted in the U. S. D. C. for eastern district of Michigan for an assault with dangerous weapons on one Downs on board the Alaska while within the territorial limits of Canada in Detroit river. On plea to the jurisdiction, the circuit court, to which the case had been remitted, was divided; wherefore the case is certified for the opinion of this court. The question was whether the federal courts had jurisdiction of this offense by virtue of U. S. Rev. Stat., § 5346, making it an offense aurainst the U. S. to assatulc any person with a dangerous weapon, "upon the high seas, or in any arm of the sea, or in any river, haven, creek, basin, or bay, within the admiralty jurisdiction of the United States and ont of the jurisdiction of any particular state, on board any vessel belonging in whole or in part to the United States or any citizen therenf." FIELD, J. * * * The Great Lakes possess every essential characteristic of seas. They are of large extent in length and brendth; they are navigable the whole distance in either direction by the largest vessels known to commerce; objects are not distingruishable from the opposite shores; they separate, in many instances, stites. and in some instances constitute the boundary between independent nations; and their water's, after passing long distances, debonch into the ocean. The fact that their waters are fresh and not subject to the tides, does not affect their essential character as seas. Man! seas are tideless, and the waters of some are saline only in a very slight degree. *** The reason of the statute. in providing for protection against violent assaults on vessels in tidal waters. is no greater but identical with the reason for providing against similar assaults on vessels in navigable waters that are neither tidal nor saline. The statute was intended to extend protection to persons on vessels belonging to citizens of the United States, not only umon the high seas, but in all navigable waters of every kind out of the jurisdiction of any particular state, whether moved by the tides or free from their influence. * * * The general rule is that the eountry to which the vessel belongs will exercise jurisdiction over all mat- 
ters affecting the vessel or those belonging to her, without interference of the local government, unless they involve its peace, dignity, or tranquillity, in which case it may assert its authority. Wildenhus's case, 120 U. S. 1, 12, 7 S. Ct. 385; Halleck on International Law, e. vii, $\$ 26$, p. 172 . 'The admiralty jurisdiction of the country of the owners of the steamer upon which the oftense charged was committed is not denied. 'They being citizens of the United States, and the steamer being upon navigable water's, it is deemed to be within the admiralty jurisdiction of the United States. It was, therefore, perfectly competent for congress to enact that parties on board committing an assault with a clangerous weapon should be punished when bronght within the jurisdiction of the district court of the United States. * * * There were no bodies of water in the United States to any portion of which the term "high seas" was applicable if not to the open, unenclosed waters of the Great Lakes. It does not seem reasonable to suppose that congress intended to contine its legislation to the high seas of the ocenn, and to its navigable rivers, havens, creeks, basins, and bays, without the jurisdiction of any state, and to make no provision for olfenses on those vast bodies of inland waters of the United States. There are vessels of every description on those inland seas now carrying on a commerce greater than the commerce on any other inland seas of the world. And we eannot helieve that the congress of the United States purposely left for a century those who navigated and those who were conveyed in vessels upon those seas without any protection.

* We do not accept the doctrine that, because by the treaty between the United States and Great Britain the boundary line between the two comntries is rum through the center of the lakes. their character as seas is changed, or that the juriscliction of the United States to regulate vessels belonging to their eiti\%ens navigating those waters and to punish ofienses committed upon such vessels, is in any respect impaired. * * * In our judgment the district court of the castern district of Michigan had jurisdiction to try the defendant upon the indictment foumd, and it having been transferred to the circuit court, that eourt had jurisdietion. $* * *$ [Justices Gray and Brown filed separate dissenting opinions, arguing that the place was not within the high seas, ete., within the meaning of the statute, and was within the exclusive jurisdiction of Canada.] U. S. v. Rodgers, 150 U. S. 249,14 S. Ct. 109, KKn. 353.

(Marss. Sup. Judicial Ct., 1890.) Fishing Along Shore in SeaState Power to Regulate. Complaint for taking fish by use of a purse seine in Buziard's Bay a mile and a quarter in front of the shore of Falmouth, Barnstable county, contrary to St. 1886, c. 192 , which place the harbor and land commissioners had made a part of that port acting under St. 1881. c. 196, § 2. Defendant showed that he was a citizen of $R$. I.; was fishing in a boat cnrolled and licensed of Newport, R. I., under the U. S. laws for menhaden fishing; that 
he took only menhaden, valuable only for bait and fish oil, and did not touch or disturb the bottom of the sea; and that the distance across the mouth of Buzzard's bay is nearly two marine ieagues, and at the point where the alleged offense was committed it was more than two leagues across. He contended that the place was outside the jurisdiction of Massachusetts. 'The Pub. Sts., c. 1, $\$ \S 1,2$, are as follows: \$1. The territorial limits of this commonwealth extend one marine league from its seashore at low-water mark. When an inlet or arm of the sea does not exceed two marine leagues in width between its headlands, a straight line from one headland to the other is equivalent to the shore line. $\$ 2$. The sovereignty and jurisdiction of the commonwealth extend to all places within the boundaries thereof; subject to the rights of concurrent jurisdiction granted over places ceded to the United States. The Pub. Sts., c. 22, contains the following provision: $\$ 1$. "I'he boundaries of counties bordering on the sea shall extend to the line of the common. wealth, as defined in $\$ 1$ of c. 1 ." $§ 11$. "The juristiction of counties separated by waters within the jurisdiction of the common. wealth shall be concurrent upon and over such waters." 'The St. of 1881 , c. 196, is as follows: $\$ 1$. "The boundaries of cities and towns bordering upon the sea shall extend to the line of the commonwealth, as the same is defined in $\$ 1$ of c. 1 of the general statutes. \$2. The harbor and land commissioners shall locate and define the courses of the boundary lines between adjacent cities and towns bordering upon the sea, and upon arms of the sea, from highwater mark outward to the line of the commonwealth, as defined in said $\S 1$, so that the same shall conform as nearly as may be to the course of the boundary lines between said adjacent cities and towns on the land; and they shall file a report of their doings, with suitable plans and exhibits, showing the boundary lines of any town by them located and defined, in the registry of deeds in which deeds of real estate situated in such town are required to be recorded, and also in the office of the secretary of the commonwealth." FIELD, C. J. * * * By the definitive treaty of peace between the United States of America and Great Britain, "His Britannic MIajesty acknowledges the said United States, viz.: New Hampshire, Massa. chusetts bay, *** to be free, sovereign, and independent states; that he treats with them as such; and for himself, his hits and successors, relinquishes all claims to the government, propriuty, and territorial rights of the same, and every part thereof." $8 \mathrm{~J}$. S. Sts. at Large, 81. If Massachusetts had become an indepundent nation, there can be no doubt, we think, that her boundarje's on the sea, as she has defined them by the statutes, would be acknuwledged by all foreign nations, and that her right to control the fisheries within these boundaries would be conceded. It has riten been a matier of controversy how far a nation has a right to control the fisheries on its sea coast, and in the bays and arms of the sea within its territory; but the limits of this right have never been placed at 
less than a marine league from the coos's on the open sea; and bays wholly within the territory of a nation, the headlands of which are not more than six geographical mile's ajart, have always becn regarded as a part of the territory $r i f$ the nation in which they lie. Mlore extensive rights in these respects have been and are now claimed by some nations; but, so far as we are aware, all nations concede to each other the right to control the fisheries within a marine league of the coast, and in bays within the territory the headlands of which are not inore than two marine leagues apart.

* * We regard it as estrablished that, as between nations, the minimum limit of the territorial jurisdiction of a nation over tide waters is a marine leagur from its coast, and that bays wholly within its territory not exceeding two marine leagues in width at the mouth are within this limit, and that included in this territorial jurisdiction is the right of control over fisheries, whether the fish be migratory, free-swimming fish, or free-moving fish like lobsters, or fish attached to oj imbedded in the soil. 'The open sea within this limit is of course subject to the common right of navigation; and all governments, fus the purpose of self-protection in time of war, or for the prevention of frauds on the revenue, exercise an authority beyond this limit. * * We see no error in the rulings at the trial, and thicre must be judgment on the verdict. C. v. Manchester, 152 MIass. 430,25 N. F. 113, 23 Am. St. Rep. 820, 9 L. R. A. 236, B. 930 .

(U. s. Sup. Ct., 1891.) Same Case as the above on error to this court. BLATCHFORD, J. The principal contentions in this court on the part of the defendant are, that, although Massachusetts, if an intlependent nation, could have enacted a statute like the one in question, which her own courts would have enforced and which other nations would have recognized, yet when she became one of the United States, she surrendered to the general government her right $i \mathrm{i}$ control over the fisheries of the ocean, and transferred to it her ights over the waters adjacent to the coast and a part of the ocoun; that, as by the constitution, Art. $3, \S 2$, the judicial power of the United States is made to extend to all cases of admiralty and maritime jurisdiction, it is consistent only with that view that the rights in respect of fisheries should be regarded as national rights, and be enforced only in national courts; that the proprietary right of Massachusetts is confined to the body of the county; that the offense committed by the defendant was committed outside of that territory, in a locality where legislative control did not rest upon title in the soil and waters, but upon rights of sovereignty inseparably connected with national character, and which were intrusted exclusively to enforcement in admiralty courts; that the commonwealth has no jurisdiction upon the ocean within three miles of the shore; that it could not by the statute in question oust the United States of jurisdiction; that fishing upon the high seas is in its nature 
an integral part of national commeree, and its control and regralation are necessarily vested in eongress and not in the indiviclual states; that congress has manifested its purpose to take the reurulation of coast fisheries, in the particular's covered by the Milssichusetts statute in question, by the joint resolution of congress of feb. 9, 1811 (16 st. j93), establishing the fish commission, and by R. St. 51 , entitled, "Regulation of lisheries," and by the act of feb. 28,158 , c. 288 ( It S't. 434), relating to the mackerel fisheries, and by acts relating to bounties, privilegres, and agreements, and by granting the lieense under which the defendant's steamer was fisthing; and that in view of the act of congress authorizing such license, no statute of a state could defeat the right of the defendant to fish in the high seas under it. * * $*$ We think it must be regionded as established that. as between nations, the minimum limit of the territorial juriscliction of the nation over tide waters is a marine league from its coast; that bays wholly within its territory, not exceeding two marine leagues in width at the mouth are within this limit; and that included in this territorial jurisdiction is the right of control over fisheries, whether the tish be migratory, free-swimming fish, or free-moving fish, or fish attached to or embedded in the soil. The open sea within this limit is, of course, subject to the common right of navigation; and all governments, for the purpose of self-protection in time of war, or for the prevention of frauds on its revenue, exercise an authority beyond this limit. Gunld on Waters, part 1, c. 1, $\$ \$ 1-17$, and notes. * * * In Smith v. Mlaryland, 18 How. $71,7 t$, a vessel licensed to be employed in the coasting trade and fisheries, was seized by the sheriff of Amme Arundel count.y, Mld, while engaged in dredging for oysters in Chesapenke bay, in violation of a statute of Maryland enacted for the purpose of preventing the destruction of oysters in the waters of that state; and the questions presented were whether that statute. was repugnant to the provisions of the constitution of the United States which grant to congress the power to regulate commerce, or to those which dechare that the judicial power of the United States shall extend to all cases of admiralty and maritime jurisdiction, or to those which declare that the eiti\%ens of ench state shall be entitled to all privileges and immunities of eitizens in the several states. Curtis. .J.. in delivering the opinion of this eomrt, said: "Whatever soil helow Jow-water mark is the subject of exelusive property and ownership, belongs to the states on whose maritime border and within whose territory it lies, subject to any lawful grants of that soil by the state, or the sovereign power which governed its territory hefore the declaration of independence. $*{ }^{*}$ *As this law conflicts mither with the admiralty jurisdiction of any court of the linited states conferred by congress, nor with any law of congress whatevor. we are of opinion it is not repugnant to this elause of the enistitution." The court also held that the act was not repugnant to the clanse of the constitntion which conferred upon congress the power to regr- 
late commerce, and that the emrolment and license of the vessel gave to the plaintiff in error no right to violate the Maryland statute.

* The statute of Massachusetts, which the defendant is charged with violating, is in terms confined to waters "within the jurisdiction of this commonwealth," and it was evidently passed for the preservation of the fish; and makes no discrimination in favor of citizens of Massachusetts and against eitizons of other states. If there be a liberty of fishing for swimming fish in the navigable waters of the United States common to the inhabitants o! the citizens of the United States, upon which we express no opinion, the statute may well be considiered as an impartial and reasonable reguJation of this liberty, and the subject is one which a state may well be permitted to regulate within its territory in the absence of any regulation by the United States. The preservation of fish, even although they are not used as food for human beings, but as food for other fish which are so used. is for the common benefit; and we are of opinion that the statute is not repugnant to the constitution ind the laws of the United States. ${ }^{*} *^{*}$ Judgment affirmed. Manchester v. Massachusetts, 139 U. S. 240, 11 S. Ct. 559, 35 L. Ed. 159.

\section{\$87. "If the Wrong-doer Was in One Place and His Act Took Effect in Another."}

(N. Car. Superior Ct., 1799.) 'The defendant was indicted under a statute (N. Car. Acts of 1784 , c. $25, \$ 4$, making it criminal for any person to counterfeit or vend the state securities out of the state the same as if done in the state) for counterfeiting out of the state with intent to defraud the citizens of the state. IIe was found guilty, but upon full consideration the court refused to render judgment and discharged him. 'TAYLOR, J. *** The states are to be considered, with respect to each other, as independent sovereignties possessing powers completely allequate to their own government, in the exercise of which they are limited only by the nature and objects of government, by their respective constitutions at.al by thil of the United States. Crimes and misdemeanors committed within the limits of each are punishable only by the jurisdiction of that state where they arise; for the right of punishing being founded upon the consent of the citizens, express or implied, cannot be directed against those who never were citizens, and who likewise committed the offense beyond the territorial limits of the strite claiming jurisdietion. * * * Prisoner discharged. S. v. Knight, Tayl. (1 N. Car.) 65.

(Eng. King's Bench, 1803.) Fraudulent Vouchers Sent from Foreign Parts. Information against the captain and purser of a British man-of-war, for a conspiracy to cheat the crown by means of false 
vouchers. 'The trial was in the county of Middlesex, and it appeared that "all the acts in which either of the defendants immediately took a part were done by them either on the high seas at Brassa Sound, or at Lerwick in the Isle of Shetland. 'The only acts proved to be done in Middlesex were those which were doue by them mediately, through the intervention of innocent persons." $U_{p}$ on this it was objected that "all the acts of the defendants themselves which constituted the offense of conspiracy were committed out of the jurisdiction of the common law." GROSE, J., delivered the opinion of the court on this point, which was that the acts done by the agents of the defendants in Middlesex were their acts done in that county. "I say," said he, "it was their acts, done by them both; for the persons who innocently delivered the vouchers were mere instruments in their hands for that purpose; the crime of presenting these vonchers was exclusively their own, as the crime of administering poison through the medium of a person ignorint of its quality would be the crime of the person procuring it to be administered." R. v. Brisac, 4 Wast 164 .

(Eng. King's Bench, 1805.) Libel Written in Ireland and Puh. lished in England. The defendant was indicted in Middlesex in England, for procuring a libel to be published in that county, he being, when it was procured to be so published and at the time of its publication, as well as when he wrote it, in Ireland. But although the defendant had personally done nothing in Midalesex or in Lingland, he was held to be liable for the publication in that county, and was accordingly found guilty by the jury. R. v. Johnson, 6 East 583, 7 East 65.

(MIass. Sup. Judicial Ct., 1825.) One Who Publishes a Libel in Another State, in a newspaper which circulates in this commonwealth also, is liable to indictment here. C. v. Blanding, 3 Pick. (20 Mass.) 304,15 Am. Dec. 214.

(New York Sup. Ct., 1846.) False Forwarder's Receipt Made in Another State. Defendant was indicted for obtaining money of S. S. \& Co. by means of a false receipt made in Ohio by him and sent to innocent commission merchants in New York and by them presented to S. S. \& Co. in New York, and thereon obtaining from S. S. \& Co. acceptance of drafts for $\$ 28,160$, which were afterwards paid. The false receipt indicated that the signer had received of Adams several thousand barrels of pork and lard consigned to $\mathbf{S}$. S. \& Co. for sale, and by such false pretenses S. S. \& Co. were deceived to belief that the goods had been sent, and were thus induced to accept the drafts. Adams appeared in person, protested that he was not guilty, and pleaded that he was not in New York when the alleged offense was committed, nor at any time before, but was in 
Ohio, where he resided. Demurrer to the plea was overruled and the people brought error. BEARDSLEY, J. * * * 'The fraua may have originated and been concocted elsewhere, but it became mature and took effect in the city of New York, for there the false pretenses were used with success, the signatures and money of the persons defrauded being obtained at that place. The erime was, therefore, committed in the eity of New York and not elsewhere. (2 R. St. 677, § 53; 1 Chit. Cr. Law, 4th Am. Ed. 191; R. v. Buttery, mentioned by Abbott, C. J., in R. v. Burdett, 4 Barn. \& Ald. 95.) And of this crime, thus committed within the limits of this state, taking the facts charged and acimitted to ve true, the defendant, in my opinion, was plainly guilty, although at the time of its perpetration he was out of this state and within the limits of the state of Ohio. The intent to cheat was his; the fraudulent contrivance was his; and by agents, acting within this state, for him and under his anthority and guidauce, themselves innocent of all frand, were the false pretenses used and the crime fully consummated. He and he alone was, therefore, the guilty party. 'This conclusion is certainly sound in morals and reason, and it should be so in law. 'The immediate actors in effecting the frand were entirely guiltless; they were but instruments in the hands of the defendant, and wholly uncon. scious of the part they were made to perform in his guilty plot. A great fraud was thus perpetrated in this state, and maimed or impotent indeed must our law be, if the contriver of the mischief, by whose efforts alone the cheat was effected, can escape punishment on the ground that he was out of the state when his fraudulent machinations were concocted, and when they took effect within it. * * This in no sense affirms or implies an extension of our laws beyond the territorial limits of the state. The defendant may have violated the law of Ohio by what he did there, but with that we have no concern. What he did in Ohio was not, nor could it be, an infraction of our law or a crime against this state. He was indicted for what was done here, and done by himself. True, the defendant was not personally within this state, but he was here in purpose and design, and acted by his authorized agents. Qui facit por alium facit per se. The agents employed were innocent, and he alone was guilty. * * Reversed. P. v. Adams, 3 Denio 190, 45 Am. Dec. 468 , F. 327, Kn. 90.

(N. J. Sup. Ct., 1864.) Accessory Out of State. BEASLEY, C. $J$. The defendant was convicted before the court of oyer and terminer, wn an indictment containing two counts, the first of which charges him with the larceny of certain goods of a value exceeding twenty dollars, and the other with receiving goods knowing them to be stolen. It appeared that the defendant was in New York at the time of the theft, and while in that state he made an arrangement with one Kelly to come into this state and steal the articles in question and to bring and deliver them to him in New York. This 
arrangement was carried into effect, the articles being stolen by Kelly and delivered to the defendant in New York. 'The delendant was not in this state at any time, from the inception to the conclusion of the transaction. The court of oyer and terminer have asked the advisory opinion of this court upon two points: 1. Whether proof of the above stated facts will support the indictment. 2. IIas the defendant committed any offense indictable by the laws of this state? In regard to the first point, the circumstances proved on the trial established the fact that Kelly was guilty of the crime of grand lareeny in. this state. Kelly therefore committed a felony, and consequently, as the defendant was not present, either actually or constructively, at the commission of the offense, he could not be a principal therein, but was an accessory before the fact. Kelly did the act, and the defendant's will contributed to it. ** * * 'ine first count, therefore, charging the defendant as a principal in the larceny, is not sustained by the evidence. **** Neither will the second count of the indictment sustain the conviction. The evidence shows that the stolen goods were received by the defendant, with guilty knowledge, in the state of New York. But this was no offense against the laws of this state. *** The remaining question is, has the defendant committed any offense indictable by the laws of this state? *** As the defendant did no act within this state in his own person, the point to be decided is, did he do such act in this state by construction or in contemplation of law? It is undoubtediy true that personal presence within the jurisdiction in which the crime is committed, is not in all cases requisite to confer cognizance over the person of the offender, in the tribunals of the govermment whose laws are violated. In some cases the maxim applies, Crimen trahit personam. Thus, where a person being within one jurisdiction, maliciously fires a shot which kills a man in another juriscliction, it is murder in the latter jurisdiction, the illegal act being there consummated. *** The rule, therefore, appears to be firmly established, and upon very satisfactory grounds, that where the crime is committed by a person absent from the country in which the act is done, through the means of a merely material agency or by a sentient agent who is innocent, in such cases the offender is punishable where the act is done. The law implies a constructive presence from the necessity of the case; otherwise the anomaly would exist of a crime, but no responsible criminal. But the more difficult question remains to be considered, which isin case of a felony committed here by a responsible agent, who is therefore the principal felon, and punishable by our laws-can the procurer, who is an accessory before the fact, and whose acts of procurement have been done in a foreign jurisdiction, be indicted and punished for such procurement in this state. *** His ofiense consists in the enticement to commit the crime; and that enticcment, and all parts of it, took place in a foreign jurisdiction. 
Let the court of oyer and terminer be advised accordingly. S. v. Wyckoff, 31 N. J. L. (2 Vroom) 65, B. 399.

(Ohio Sup. Ct., 1882.) Deed Forged in Missouri Uttered in Ohio. lindsey was indicted jointly with one Morris and convicted on soparate trial of uttering a false and Horged deed for Missomri land as true and genuine. Lindsey was never in Ohio till brought there for trial. He procured the deed to be forged in St. Louis, No., and there given to his co-defendant, Morris, who mailed it to $\mathrm{T}$. $\$ D$. Iall, in Ohio, who gave it to 'Turnbull as true, and sent the money received from him to defendants. less commission. JOHNSON, J. * * * Is the crime charged an extra-territorial crime? Was it committed by the accused in Missouri, or in Ohio? If he were indieted for the forgery of this deed, he could not be punished in Ohio, as it is conceded that all his acts that constitute that crime were committed in Missouri. When he procured the notary in St. Louis to forge the signatures, and the acknowledgmerit of the grantors, with the criminal intent, the erime of forgery was consummated in the state of Missouri. But this is not the chinge in the case at bar. It is for knowingly uttering and publishing as true and genuine a false and forged deed. It is wholly immaterial where the forgery was eommitted. The question, therefore, is, was this deed nttered and published in Jefferson comtr; Ohio, and was lindsey guilty of this crime? That this forged deed was uttered and published in Ohio by 'T. \& D. Ilall, who supposed it was genuine, is cleat from the evidence. Now, it is assumed that the jury had evidence to warrant them in finding that 'T'. \& D. Ilall did so utter and publish this deed by the procurement of lindsey. The crime was, therefore, completed or consummated in Ohio, through the instrumentality of an innocent agent. It is wholly immaterial whether his eo-defendant. Mrorris, was his confederate or his dupe, as in either case the acts of MIorris. by colrespondence mailed in St. Iouis to T. \& D. IIall, were simply the means used to consummate a crime in Ohio. *** The inherent power of the state to punish the uttering and publication of forged instrumnits within its territorial limits, withont regard to the place where the forgery was committed, or purpose was formed, is essential to the protection of her people. It is now a generally accepted principle that one who in one county. or state employs an innocent agent in another to commit a crime, is liable in the latter county or state. * * Affirmed. Iindsey v. S., 38 Ohio St. 507, 13. 404.

(U. S. C. C., 183T.) Shot in Foreign Harbor from U. S. Ship. Indictment for numrder. A gun was fired from an American ship lying in the harbor of Ratiatea, colle of the Society Isles and a foreign government, by which a person on board a schooner, belonging to the natives and lying in the same harbor, was killed. STORY, J.

* What we found ourselves upon in this case is, that the offense, 
if any, was committed * * * on board of a ioreign schooner belonging to inhabitants of the Society Islands, and of course, under the territorial government $*^{*}{ }^{*}$ of the Society Islands, with which kingdom we have trade and friendly intercourse, and which our government may be presumed (since we have a consul there) to recognize as entitled to the rights and sovereignty of an independent nation, and of course entitled to try offenses committed within its territorial jurisdiction. I say the offense was committed on board of the schooner; for, although the gun was fired from the ship Rose, the shot took effect and the death happened on board of the schooner; and the act was, in contemplation of law, done where the shot took effect. *** We lay no stress on the fact that the deceased was a foreigner. Our judgment would be the sume if he had been an American citizen. ** * Defendant dis(aharged. U. S. v. Davis, 2 Sumner 482, Fed. Cas. No. 14,932, B. 398.

(Ga. Sup. Ct., 1893.) Attempt-Shooting and Missing. Defendant was convicted of shooting at the prosecutor. 'The evidence which the jury believed showed that defendant, standing on the South Carolina shore of the Savannah river, fired two shots at the prosecutor while the latter was in a boat within 30 yards of the Georgia shore where the river was 175 yards wide; and that the shots missed him, and struck water near the Georgia shore. Defendant brolight error, claiming that no offense was committed in Georgia. The court by LUMIPKIN, J. *** Of course the pres. ence of the accused within this state is essential to make his act one which is done in this state; but the presence need not be actual. It may be constructive. The well established theory of the law is that where one puts in force an agency for the commission of crime, he, in legal contemplation, accompanies the same to the point where it becomes effectual. *** So, if a man in the state of South Carolina criminally fires a ball into the state of Georgia the law regards him as accompanying the ball and as being represented by it up to the point where it strikes. If an unlawful shooting occurred while both parties were in this state the mere fact of missing would not render the person who shot any the less guilty. Consequently, if one shooting from another state goes, in a legal sense, where his bullet goes, the tact of his missing the object at which he aims cannot alter the legal principle. *** Judgment affirmed. Simpson v. S., 92 Ga. 41, 17 S. E. 984, 22 L. R. A. 248, 44 Am. St. Rep. 75-n.

(iN. Car. Sup. Ct., 1894.) Jurisdiction of State from which Shot was Fired. SHEPHERD, C. J. There was testimony tending to show that the deceased was wounded and died in the state of T'ennessee, and that the fatal wounds were inflicted by the prisoners by shooting at the deceased while they were standing within the bound- 
aries of the state of North Carolina. The prisoners have been convicted of murder, and the question presented is whether they committed that offense within the jurisdiction of this state. It is a general principle of universal acceptation that one state or sovereignty cannot enforce the penal or criminal laws of another, or puuish crimes or offenses committed iti and against another state or sovercignty. * * It cannot be doubted that the place of the assault or stroke in the present case was in Tennessee, and it is also clear that the offense of murder at common law was committed within the jurisdiction of that state. If this be so it must follow that unless we have some statute expressly conferring jurisdiction upon the courts of this state, or making the act of shooting under the circumstances a substantive murder, the offense with which the prisoners are charged can only be tried by the tribunals of 'Tennessee.

'There being; then, no concurrent jurisdiction at common law, we will now consider whether it has been conferred by statute; for it is well settled that "whenever a homicide is committed partly in and partly out of the jurisdiction where the charge is made, the power to punish it depends upon the question whether so much of the act as operates in the county or state in which the offender is indicted and tried has been declared to be punishable by the law of that jurisdiction." Kerr on Homicide, 226 ; C. v. Macloon [supra], * * Our statute*** provides: "In all cases of felonious homicide, when the assault shall have been made within this state and the person assaulted shall die without the limits thereof. the offender shall be indicted and punished for the crime in the county where the assault was made, in the same manner, to all intents and purposes as if the person assaulted had died within the limits of this state." This statute has received a judicial construction by this court in S. v. Dunkley, 3 Ired. 116, and it was held that it did not create any new offense, but merely removed a difficulty which existed as to the place of the trial. In view of the anthorities cited it can hardly be contended that the assault in the present case was committed in this state, and especially is this so when the assault mentioned in the statute evidently mins not a mere attempt, but such an injury inflicted in this state, which results in death in another state. This would seem manifest from the history of the legislation as well as the language of the act, which plainly contemplates that every part of the offense, except the death, must have occurred in this state. It was a subject of doubt, as we have seen, whether the accused could be tried in the place of the stroke, the death having occurred without the jurisdiction, and it was to remove this doubt alone that this and similar legislation was resorted to. It was, of course, never questioned that the place where both the stroke and the death occurred was the place where the crime was committed. *** The fact that the prisoners and the deceased were citizens of the state of North Carolina cannot affect the conclusion we have reached. If, as we 
have seen, the offense was committed in 'Tennessee, the personal jurisdietion generally claimed by nations over their subjects who have committed offenses abroal or on the high seas calmot be asserted by this srate. Such jurisdiction does not exist as between the states of the union under their peculiar relation to each other (Rorer's Interstate Law, 208 ), and even if it could be rightlully claimed it could not in a case like the present be enforced in the absence of a statute providing that the offense should be tried in North Carolina. Even in England, where it seems the brondest elaim to such jurisdietion is asserted, a stitute (33 Ilen. VIII.) appears to have been necessary in order that the courts of that country could try a mulder committed in Lisbon by one British subject upon another. R. v. Sawyer, Russell \& Ryan Cr. Cases 294. * * * We are of the opinion that it is competent for the legislature to determine what acts within the limits of the state shall be deemed eriminal. and to provide for their punishment. Certainly. there could be no complaint where all the parties coneerned in the homicide are citizens of North Carolina. * * New trial granted. S. v. Hall, 114 N. Car. 909, 19 S. E. 602, 41 Am. St. Rep. 82.2, 28 I. R. A. 5!. Kn. 377.

\section{§ 88. "If Goods Stolen in One Place are Taken to Another."}

(Fing. King's Bench, 1406.) Goods Carried to Another County. A man was appenled of lareeny in Middlesex, while the felony was done in London; and the court was informed that the appellee, after the felony done, took the groods into Middlesex county. 'Tho court said the appeal was well taken; for when a man robs anorher of his goods and carries them into other counties, he eommits the erime in each county, and the appeal mity be brought in whicherer county the plaintiff' wishes. ** * Anon., Y. B. 7 IIen. 4, 4.3 pl. 9, B. 595 .

(Eng. Exchequer Chamber, 1489.) Same. One was arraigned upon in indictment, for stealing certain goods, in the county of Surrey. And the defendant said that he was indicted for taking the same groods on the same day in Middlesex, and thereof acruitted. And prayed judgment. FISIISR. It is no plea. for it shall be taken most beneficially for the king, and they may have been taken twice. FROWIKE, to the contrary. For where goods arr stolen in one county, and earried into another county. he mar be indicted in each county, and shall have judgment of life; and. therefore, it is reason that if he should be acquitted in one eounty. he should be acquitted in the other comty. And if one should be beaten in one county, and after die in another county, and indict. ment in both counties, it is reason that if he should he acquitted in one county that should help him in the other county, ete 
HUSSEY [C. J.]. It seems no plea. And as I inderstand, trespass for battery done in one county camnot be found in another county on pain of attaint; and the same law of goods taken and calried out of the county where they were taken, it can be found only in the county where the taking oceurred, and that on pain of attaint. But che law is otherwise in appeal; for there he may bring an appeal m each county where the goods are carried. And this has been a diversity, for the appenl is to recover his groods, and affirms property continually in the party, ete., but it is otherwise of trespass; for it is not to recover the goods, but damages for the goods, ete. And, sir, I take it. if one steals my groods, and another steals the goods from him, I shall have an appeal against the second felon, but it is otherwise of trespass. And notwithstanding the appeal lies in each comnty where the groods are carried, still he camnot be indicted except where the taking was made, for the indictment is not to have the goods, etc.; and that has been the diversity between indictment and appeal. And, so here, notwithstanding he submits that it is the same felony, that camnot be tried; for if it should be tried, it ought to be tried by both counties, and here neither of them ean give evidence to the other, for the takings are so several that one cannot give evidence nor notice to the other; and therefore, notwithstanding mischief shall happen to the party, such mischief shall be borne; for in one county, etc., without cause; and yet he ought to answer. FAIRFAX, J., agreed to the diversity between appeal, indictment, and trespass, ete.. and said that the ailegation that it is the same felony could not be tried by both counties when he is aequitted in one comnty, and those of this county cannot give evidenee of any felony in that county. And then MIordent pleaded the plea, and prayed allowance of it; and as to the felony, not guilty. And the ehief' justice said that he should have the plea, becanse it is matter in law, and the other matter in fact. And all the court was arainst him. And it was held by all the justices and barons that in a writ of trespass in Middlesex it is no plea to say he has recovered for a trespass committed in the county of Surrey, because it could not be intended as the silnt trespalsi; but some at the bar held that it is different in felony, for it is felony in every county where the goods are, or come, ete. Anon., Y. B. 4 Hen. 7, 5, pl. 1, 13. 596 .

(Mass. Sup. Jud. Ct., 1306.) Receiving Goods Stolen in Another State. Goods having been stolen in New Hampshire and brought to and received by defendant at Boston. Nass., he was convicted of receiving stolen groods in Boston; and the conviction was affirmed on exception to this court, on the grround that if the principal could be tried and eonvicted in thit county, as had been decided in a previons case, the accessory could also be tried there. C. v. Andrews, 2 Mass. 14, 3 Am. Dec. 17-n, C. 436. 
(Eng. C. C. R., 1832.) Goods Brought into England. The prisoner was indicted for larceny in Dorset county and convicted on proof that he took the goods at St. Helier's in Jersey island, and was soon found with them in his possession in Weymouth, Dorset county. "A doubt occurred, whether the original taking was such whereof the common law could take cognizance; and, if not, whether the case fell within the statute 7 and 8 Geo. 4, c. 29 , $\$ 76$; or in other words, whether the island of Jersey could be considered as part of the united kingdom. * * * At a meeting of all the judges, (except Lyndhurst, C. B., and Taunton, J.) * * * they held unanimously that the conviction was wrong, and that the case was not within the statute." R. v. Prowess, 1 Moody C. C. 349, B. 597, 2 B. \& II. 224 n, C. 379.

(Vt. Sup. Ct., 1839.) Respondent Stole Oxen in Canada and brought them into this state, for which he was convicted of larceny here. He moved in arrest of judgment. The motion was overruled, and he excepted. REDFIELD, J. * * * The only remaining ground urged by the respondent's counsel is that an indictment for larceny cannot be sustained here where the original caption was in the province of Canada. If this question were entirely new and to be now decided upon the weight of authority at common law, I confess I should incline to the view taken by the respondent's counsel. For it is expressly laid down by all the English law writers upon this subject, that "if the original taking be such whereof the common law cannot take cognizance, or if the goods be taken at sea, the thief cannot be indicted of the larceny in any county into which he shall carry them." 2 Russell on Crimes, 175. The case of the Pirates, 3 Inst. 113; 1 Hawk. P. C. c. 33, § 32. The same exceptions obtained in regard to goods taken in any other part of the united kingdom and brought into any county in lingland. R. v. Anderson, 2 East's P. C. c. 16, § 156, p. 772 . These obstacles were removed by the statute of $45 \& 54$ Geo. III.. and $7 \& 8$ Geo. IV. But in this state the rule has been too long settled, and recognized by too long and uniform a course of practice and decision, to be now changed, unless it be by act of the legislature. We think, too, that the reasons are quite sufficient why the law, upon principles of mere policy, should not be changed. Larceny consists in the felonious taliing and carrying away of the goods of another. It implies a forcible violation of the right of the owner in regard to possession as well as property; and that this should be done secretly or feloniously. Now, precisely the same reason found in all the books, why the offender is guilty of larceny, in every county into which he conveys the goods; viz.- "that every moment's continuance of the trespass and felony amounts to a new caption and asportation,"-will apply to the present case with the same force of its original use. Hence it has been decided, that where goods are taken in one of the United States and brought into 
another, the offender may be indicted in the latter state, and there tried. S. v. Mockridge, decided by this court, some years since, in the county of Chittenden, and not reported. The same rule obtains in some of the other states. C. v. Cullins, 1 Mass. R. 116; C. v. Andrews, 2 Mass. 14 [above] ; S. v. Ellis, 3 Conn. 185. New York and North Carolina have decided otherwise. It is believed no good reason can be urged why the rule should apply as between the American states and not extend to all countries. These states, so far as punishment for crime is concerned, are as foreign to each other as distinct nations. There could be no pretence, that in the case of Mockridge, the stealing of money, in the state of New York, was any more punishable here than if he had taken it in Canada, or even in a country where there is no law on the subject. It could only be upon the ground that the bringing the money into this state "amounted to a new caption and asportation," like the carrying of goods feloniously through more than one county, which is indictable in either county. Such has been the long established practice in this state. A case is mentioned by one of my brethren as having occurred while the late Judge 'lichenor was chief justice of this court, where the original taking was in Canada, and the offender was convicted here. Other cases of a similar character are known to have occurred in the state at different periods. We are not disposed to relax the rule. The argument that it might operate severely upon offenders who took property in a remote section of the union and, after having carried it through many intervening states, should finally be arrested, having passed perhaps a jurisdiction where larceny was a capital offense, is one of those arguments ab inconvenienti which are always specious, but not always safe to be relied upon. It is sufficient to say that no country not absolutely barbarous would ever presume to punish any one a second time for the same offense. Again, it would never be in the power of a second jurisdiction to punish the same offense unless the first jurisdiction, after having inflicted the utmost punishment, should surrender the expiated offender to be still further punished, which is not a supposable case in any Christian country. Exceptions overruled. S. v. Bartlett, 11 Vt. 650 , C. 376.

Acc. S. v. Underwood, 49 Me. 181, 77 Am. Dec. 254: Contra: Lee v. S, 64 Ga. 203. 37 . Am. Rep. 67; C. v. Uprichnrd, 3 Gray (69 Mass.) 434, 63 A m. Dec. 602,5 L. 501 ; Stanley v. S., 24 Ohlo St. 168, 15 Am. Rep. 604, B. 605, 5 I. 508.

(Mass. Sup. Jud. Ct., 1857.) Gords Stolen in R. I. Brought to Mass. Defendant broke and entered a shop in Smithfield, R. I., and stole goods and brought them into Massachusetts. He was convicted on indictment for stealing in Massachusetts on proof of these facts. He excepted. SHAW, C. J. A majority of the court are of the opinion that this case must be considered as settled by the case of C. v. Uprichard, 3 Gray, 434, and the principles stated and the precedents cited. Though to some extent these colonies before the Revolution were distinct governments and might have different 
laws, it was not unreasonable, as they all derive their criminal jurisprudence from the English common law, to regard the rule applicable to a theft, in an English county, of goods carried by the thief into another, as analogous, aud adopt it. We are of opinion that Massachusetts did adopt it, and this is established by judicial precedent, before and since the Revolution, and is now settled by authority as the law of this state. THONLAS, J. The real question in this ease is, whether the defendant can be indicted, convicted. and punished in this commonwealth for a lareeny committed in the state of Rhode Island. If it were a new question, it would be enough to state it. The obvious, the conclusive answer to the indictment would be that the offense was committed within the jurisdiction of another and, so far as this matter is concerned, independent state, of whose law only it was a violation, and of which its courts have exclusive cognizance. By the law of that state the offense is defined and its punishment measured. By the law which the defendant has violated he is to be tried. Whether the acts done by him constitute lareeny and, if so, of what degree, must he determined by that law. Its penalties only he has incurred. Its means of protection and deliverance he may justly invoke, and especially a trial by a jury of his peers in the vicinage where the offense was committed. This obvious view of the question will he found upon reflection, I think, to be the only one consistent with the reasonable security of the subject or the well-defined relations of the states. It is well known that the laws of the states upon the subject of larceny materially differ. In most of them the common law of larceny has been greatly modified by statutes. The jurisprudence of all is not even based on the common law. In severil the civil law obtains. In cases where a difference of law exists, by which law is the defendant to be judged; the law where the offense (if any) was committed, or where it is tried? For example. the defendant is charged with taking with felonious intent that which is parcel of the realty; as the gearing of a mill or fruit from a tree. By the St. of 1851 , c. 151 , the act is larceny in this commonwealth. If it appears that in the state where the act was done it was, as under the common law, but a trespass, which law has the defendant violated and by which is he to be tried? Or suppose the defendant to be charged with the stealing of a slave-a felony in the state where the act is done, but an offense not known to our laws. The difficulty in both cases is the same. You have not only conflicting jurisdictions, but different rules of conduct and of judgment. But supposing the definitions of the offense to be the same in the two states, the punishments may be very different. Where such difference exists, which penalty has the defendant justly incurred, and which is he to suffer? For example, the offense is punishable by imprisonment in Rhode Island, say for a year; in this state the same offense is punishable by imprisonment from one to five years; is the defendant liable to the heavier punishment? $0 \mathrm{r}$ 
suppose he has been convicted in Rhode Island, and in consideration of his having indemnitied the owner for the full value of the goods taken, his punishment has been more mercifully measured to him, can he, after he has suifered the punishment and because the goods were, after the larceny, brought into this state, be made to suffer the penalty of our law for the same ofiense? Or suppose him to have been convicted in Rhode Island and a full pardon extended to him, can he be tried and convicted and punished here? Again; the power to indiet, convict, and punish the offense in this state proceeds upon the ground that the original caption was felonious. If the original taking was innocent or but a trespass, the bringing into this state would not constitute a lareeny. You must therefore look at the law of the state where the first caption was made. And how is the law of another state to be ascertained? What is the law of another state is a question of fact for the jury. The jury in this way are in a criminal case made not only to pass upon the law, but to pass upon it as a matter of evidence, subject, strictly speaking, neither to the direction nor the revision of the court. Again; the defendant is indicted here for the lalreeny committed in Rhode Island; while in custody here awaiting his trial, he is demanded of the executive of this state by the executive of Rhode Island as a fugitive from the justice of that state, under the provisions of the constitution of the United States, art. $4, \$ 2$, and the U. S. St. of 1793 , c. $4 \bar{j}$. Is he to he tried here, or surrendered up to the state where the ofrense was committed, and tried there? Or. if he has been already tried and convicted and punished in this state, is he to be sent back to Rhode Island to be tried and punished again for the same offense? And would his conviction and punishment here be any answer to the indictment there? Or, if he has been fully tried and acquitted here and then demanded by the executive of Rhode Island, is he. upon requisition, to be sent to that state to be again tried, to be twice put in jeopardy for the sume offense? It is quite plain no ground in law would exist for a refusal to surrender. The defendant was indicted for larceny, not for the offense of bringing stolen goods into the commonwealth. He was, under the instruction of the presiding judge, tried for the lareeny in Rhode Island, was convicted for the lareeny in Rhode Island, and must be punished, if at all, for the larceny in Rhode Island. And, under the pule given to the jury, is presented a case where, for one and the sime moral act, for one and the same violation of the rights of property, the subject may be twice convicted and punished. Nay more, if a man had stolen a watch in Rhode Island and traveled with it into every state of the union, he might, under the rule given to the jury, if his life endured so long, be indieted and punished in thirty-two states for one and the same offense. And it is well to observe that it is the retention of the property which is the cause of the new offense, and the carrying of it from the place of caption into another state. If the defendant had stolen property in Rhode 
lsland, and consumed or destroyed it, and then had removed to Massachusetts, but one offense would have been committed. and that in Rhode. Islind. Such are some of the more obvious difficulties attending the position that an offense committed in one state may be tried and punished in another. The doctrine violates the first and most elementary principles of govermment. No state or people can assume to punish a man for violating the laws of anc.ther state or people. 'I'he surrender of fugitives from justice. whether under the law of nations, treaties with foreign powers, or the provisions of the eonstitution of the United States, proceeds upon the ground that the fugitive cannot be tried and punished by any other jurisclietion than the one whose laws have heen violated. Even in cases of the invasion of one comntry by the subjects of inother, it is the violation of its own laws of neutrality that the latter country punishes, and not the violation of the laws of the country invaded. 'The exception of piracy is apparent rather than real. Piracy may be pumished by all nations, because it is an offense against the law of nations upon the seas, which are the highways of nations. 'The ruling of the learned chief justice of the common pleas was, I may presume. based upon the decisions of this cont in C. v. Cullins, 1 Mlass. 116. and C. v. Andrews, 2 Mass. 14 labove]. * * An examination will show, I think, not only that the cases were put upon erroncous views as to the relation of the states. but that they were also unsound at common law. In the ense of C. v. Cullins, a jury trial where three judges of the court were present, the evidence showing that the goods were taken in the state of Rhode 1sland, Sedgwick, J... who charged the jury, stid that "the court was clearly" of opinion that stealing goocis in one state and conveying stolen goods into another state was similar to stealing goods in one county and conveying the stolen goods into another, which was always holden to be felony in both counties." Whitever the points of similarity, there was this obvious and vital difference, to-wit: that conviction in one county was a bar to conviction in another, and that conviction in one state is no bar to conviction in another state. It was a doctrine of the commor law, that the asportation of stolen goods from one. county to another was a new caption and felony in the second county-a legal fiction, devised for greater facility in convicting the offender where it was uncertain where the first eaption took place. The foundation of the rule was that the possession of the owner continued, and that every moment's continuance of the trespass may constitute a cap. tion as well as the first taking. But in what respect was the taking in one state and conveying into another state similar to the taking in one county and conveying into another county? It could only be "similar" because the legal relation which one state bears to another is similar to that which one county bears to another; because, under another name, there was the same thing. If a man is to be convicted of crime by analogy, the analogy certainly should 
be a close one. Here it was but a shadow. In the different counties there was one law, one mode of trial, the same interpretation of the law, and the same punishment. The rule, mode of trial, and jurisdiction were not changed. The states of the union, it is quite plain, hold no such relation to each other. As to their internal police, their law of crimes and punishments, they are wholly independent of each other, having no common law and no common umpire. 'The provision, indeed, in the Constitution of the United States for surrendering up fugitives from justice by one state to another is a clear recognition of the independence of the states of each other in these regards. It excludes the idea of any jurisdiction in one state over crimes committed in another, and at the same time saves any necessity or reason for such jurisdiction. Nor is there any provision in the constitution of the United States which impairs such independence, so far as the internal police of the states is concerned. On the other hand, the widest diversity exists in the institutions, the internal police, and the criminal codes of the several states, some of them, as Louisiana and Texas, having, as the basis of their jurisprudence, the civil and not the common law. In the relation which Louisiana holds to this state can any substantial analogy be found to that which Surrey bears to Middlesex" An analogy closer and more direct could have been found in the books when C. v. Cullins was decided. It was that of Scotland to England, subject both to one crown and one legislature; yet it had been decided that when one stole goods in Scotland and carried them to England, he could not be convicted in the latter country. R. v. Anderson (1763), 2 East P. C. 772; 2 Russell on Crimes (7th Amer. Ed.), 119. Or an analogy might have been found in the cases of goods stolen on the high seas and brought into the counties of England, of which the courts of common law refused to take cognizance, because they were not felonies committed within their jurisdiction. 1 Hawk., c. 33, §52; 3 Inst. 113. In these cases a test would have been found, applicabl: :0 the alleged larceny of Cullins, to-wit: the offense was not committed in a place within the jurisdiction of the court, but in a place as foreign to their jurisdiction, so far as this subject matter was concerned, as England or the neighboring provinces. 'The case of $\mathrm{C}$. v. Cullins has no solid principle to rest upon. The "ase of C. v. Andrews, two yeirs later, may be held to recognize the rule laid down in C. v. Cullins, though it was an indictment against Andrews as the receiver of goods stolen by one Tuttle in New Hampshire; and though there is, at the least, plansible ground for saying that there was a new taking by l'uttle at Harvard in the county where the defendant was indicted and tried. $* * *$ Such was the condition of the law in this state when the case of C. v. Uprichard, 3 Cray 434, 63 Am. Dec. 762, came before the court. In that case the original felonious taking was in the province of Nova Scotia. The bringing of the stolen goods into this commonwealth was held 
not to be a lareeny here. I3ut if it be true that every act of removal or change of possession is a new caption and asportation, that every moment's continuance of the trespass is a new taking-if this legal fiction has any life-it is difficult to see why the bringing of the goods within another jurisdiction was not a new offense. No dislinction in principle exists between this case and a felonious taking in another state and bringing into this. So far as the law of crimes and punishments is concerned, the states are as independent of each other as are the states and the British provinces. 'The case of $\mathrm{C}$. $v$. Uprichard rests, I think immovably, upon the plain grounds that laws to punish crime are local and limited to the boundaries of the states which preseribe them; that the commission of a erime in another state or country is not a violation of our law, and does not subject the offender to any punishment prescribed by our law. 'These are principles of tunversal jurisprudence, and as soumd as they are universal. ** * Heceptions overruled. C. v. Holder, 9) Gray T, B. $\overline{5} 98$, C. 368, ј L. 507 in.

Contra, agreeing with Thomas J.: Heul v. S., 15 Ind. 378; S. v. Reonnals, 14 La. An. 278: P. v. Loughridke, 1 Neb. $11,93 \mathrm{Am}$. Dee. 325: P. v. Gardier. 2 .Jhns. (N. Y.) 4.7. 13. 598: S. V. Le Blunch. 2 Vrum (31 N. J. L.) \&e: S. v. Brown, 1 Hayw. i2 $v$ liar.) 100, 1 A m. Dec. 548; Simmono 7. C., 5 Bin. (Pa. J17. 1 B. \& H. 212; Simpson v. S., 4 Humph. (23 Tenn.) 456.

Acc. with inajority opinton: S. v. Ellis, 3 Coun. $185.9 \mathrm{Am}$. Uec. $175:$ stinson v. P.. 43 1!l. $345 ;$

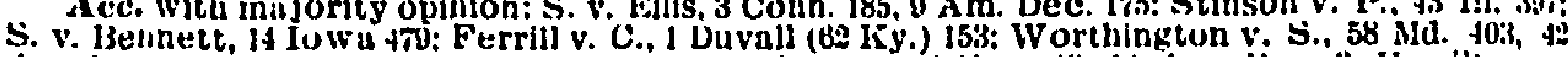
Am. Rep. 338: Watsun v. S., 33 Miss. 533: S. v. Newmin, 9 Nev. $48,16 \mathrm{Am}$. Kep. 3; liamilten v. S.. 11 Ohlu 435 ; s. v. Johnsun, 2 Ure. $115 ;$ S. v. Hill, 19 s. Car. 435.

\section{$\$ 89$. "If a Fatal Injury is Inflicted in one Place and the Victim Goes to Another Place and Dies."}

The statute of $2 \& 3 \mathrm{Edw}$. VI (1547), c. 24, begins with declining, "Forasmuch as the most necessary office and duty of the law is to preserve and save the life of man, and condignly to punish such persons that unlawfully and wilfully murder, slay or destroy men," and, after reciting the defects in the previous laws, enacts, "for redress and punishment of which ofienses and safeguard of man's life, that where any person or persons hereafter shali be feloniously stricken or poisoned in one county, and die of the silme strolic or poisoning in another county, that then an indietment thereof founden by jurors of the county where the death shall hilppen, whether it shall be founden before the coroner upon the sight of such dead body, or hefore the justices of peace or other justices or commissioners which shall have athority to inquire of such offenses, shall be as good and eftectual in the law, as if the stroke or poisoning had been committed and done in the same county where the party shall die, or where such indictment shall be so founden; any law or usage to the contrary notwithstanding."

(New Jersey Sup. Ct., 1859.) Death Here from Injury in Another State. Indictment for manslaughter. Plea to jurisdiction. 
Case reserved. VREDENBURGH, J. * * * The defendant, we must assume, was a citizen of the state of New York. Nothing was done by the defendant in this state. When the blow was given, hoth parties were out of its jurisdiction, and within the jurisdiction of the state of New York. The only fact connected with the offense, alleged to have taken place within our jurisdiction, is that after the injury, the deceased came into, and died in this state. This is not the case where a man stands on the New York side of the line, and shooting across the border, kills one in New Jersey. When that is so, the blow is in fuct struck in New Jersey. It is the defendant's act in this state. The passage of the ball, after it crosses the boundary, and its actual striking, is the continuous act of the defendant. In all cases the eriminal act is the impinging of the weapon, whatever it may be, on the person of the party injured, and that must necessarily be where the impingement happens. And whether the sword, the ball, or any other missile, passes over a boundary in the act of striking, is a matter of no consequence.

* If the defendant is liable here at all, it must be solely because the decensed came and died here after he was injured. Can that, in the nature of things, make the defendant guilty of murder or manslaughter here? If it can, then for a year after an injury is inflicted, murder, as to its juriscliction, is ambulatory at the option of the party injured, and becomes punishable, as such, whereever he may see fit to die. It may be manslaughter, in its various degrees, in one place, murder, in its various degrees, in another. Its punishment mily be fine in one conntry, imprisonment. whipping, beheading, strangling, quartering, hanging. or torture in another, and all for no act done by the defendant in any of these jurisdictions, but only because the party injured found it convenient to travel. This is not like the case of stolen goods, carried from one state to another, or of leaving the state for any purpose whatever. * * We may exercise acts of sovereignty over the wastes of ocean or of land, but we must necessirily stop at the boundary of another. The allegation of an act done in another sovereignty, to be a violation of our own, is simply alleging an impossibility, and all laws to punish such acts are necessinily void. It is said that if we do not take jurisdiction. Al defendint will go unpunished, inasmuch as the party injured, not dying in New York, he could not be guilty of murder there. But New York may provide by law for such eases, and if she does not, it is their fault, and not ours. * * Lower court advised that no crime is charged. S. v. Carter, 27 N. J. I. (3 Dutch.) 499, B. 407. Kn. 365, Mi. 585.

(Mich. Sup. Ct., 1860.) Constitutionality of Statute. Tyler injured Jones while both were aboard an American boat near the Canadian shore of the St. Clair river, of which boat Jones was master, and which Tyler, as deputy U. S. marshal, was attempting 
to attach on a writ from the U. S. D. C. for district of Mich.; and of the wounds so received Jones afterwards died in Michigan. Tyler being found within the state, was indicted for murder, and convicted. On error to the supreme court, he contended that no offense was committed in Michigan, and that the statute making such death from such act criminal was unconstitutional. MIANNING, J. * * * We think it clearly within the scope of the legislative power. *** The expediency or policy of the statute has nothing to 10 with its constitutionality, and if it was a legitimate subject of inquiry and consideration in determining the constitutional question, we should not hesitate in the present instance to declare in its favor; for the crime, though commenced in Canada, was consummated in Michigan. 'The shooting itself, and the wound which was its immediate consequence, did not constitute the offense of which the prisoner is convicted. Had death not ensued, he would have been guilty of an assault and battery, not murder; and would have been criminally accountable to the laws of Canada only. But the consequences of the shooting were not confined to Canada. They followed Jones into Michigan, where they continued to operate until the crime was consummated in his death. If such a killing did not by the common law constitute murder in Michigan, we think it the clear intent of the statute to make it such, to the same extent as if the wounding and the death had both occurred in the state. *** Martin. C. J., and Christiancy, J., concurred. Campbell, J., dissented on the ground that no part of the criminal act of the defendant was done at the place of the death. Affirmed. Tyler v. P., 8 Mich. 320.

(Mass. Sup. Judicial Ct., 1869.) Death on Land from Injuries at Sea. Indictment against C. H. Macloon, F. Macloon, and Nic. Kearney, for manslaughter. Kearney and C. HI. Macloon were convicted, and have excepted. GRAY, J. The defendants, the one a citizen of Maine, and the other a British subject, have.. been convicted in the superior court in Suffolk of manslaughter of a man who died within the county in consequence of injuries inflicted by them upon him in a British merchant ship on the high seas. The principal question in the case is that of jurisdiction, which touches the sovereign power of the commonwealth to bring to justice the murderers of those who die within its borders. 'This question has been ably and thoroughly argued, and has received the consideration which its importance demands. The statute on which the defendants were indicted, after prescribing the punishment for murder and minslaughter, provides that "if a mortal wound is given, or" other violence or injury inflicted, or poison is administered, on the high seas, or on land either within or without the limits of this state, hy means whereof death ensues in any county thereof, such offense may be prosecuted and punished in the county where the death happens." Gen. Sts., c. 171, $\$ 19$. This statute is founded upon the 
general power of the legislature, except so far as restrained by the constitutions of the commonwealth and of the United States, to declare any wilful or negligent act which causes an injury to person or property within its territory to be a crime, and to provide for the punishment of the oftender upon being apprehended withiu its jurisdiction. * * * The general principle, that a man who does a criminal act in one county or state may be held liable for its continuous operation in another, has been affirmed in various other cases. * * * 'The crime not being murder or manslaughter before the death, an indictment alleging the stroke at one day and place, and the death at another day and place, is good if it alleges the murder or manslaughter: to have been at the time and place of the death, but bad if it alleges that the defendant killed and murdered the deceased at the day and place at which the stroke was given, "for," in the words of Lord Coke, "though to some purpose the death hath relation to the blow, yet this relation, being a fiction in law, maketh not the felony to be then committed." 2 Inst. 318, 1 Hale P. C. 427, 2 Hale P. C. 188. *** 'The legislature of the commonwealth, from an earlier period, has asserted the right of punishing such crimes in the county where they take final effect by destroying life. At February term, 1795, of this court in Sutfolk, at conviction of manslaughter at common law was had upon an indictment charging that Joseph Hood on the high seas mortally injured John Antony, by assaulting and beating him with a rope and a stave and his hands and feet, and exposing him, without sufficient covering, to the cold, winds, and storms, and depriving him of necessary food, of all which injuries he languished on the high seas and at Boston in said county, and died at Boston. At August term, 1795, judgment was arrested, upon the ground that the indictment charged that the cause of death arose on the high seas and not within the jurisdiction of this court. Hood's Calse, Rec. 1795 , fol. 216 , and papers on filc. It was to cure the defect thus declared to exist in our law, that the legislature at its next session, or Feb. 15, 1796, passed the St. of 1795. c. 45, \$2. **** The most plausible form of the argument against the jurisdiction is, that the coming into the state is the act, not of the wrong-doer. but of the injured person, and therefore should not subject the former to the jurisdiction, merely because the latter happens to die there. But it is the nature and the right of every man to move about at his pleasure, except so far as restrained by law; and whoever gives him a mortal blow assumes the risk of this, and in view of the law, as in that of morals, takes his life wherever he happens to die of that wound; and may be there punished if the laws of the country have been so framed as to cover such a case. *** $*$ * Neither of the statutes of the commonwealth upon this subject has ever contained any words limiting the description of the persons by whom the offense might be committed, and the existing statute clearly manifests the intention of the legislature to punish all who 
without legal justification cause the death of any person within the commonwealth, wherever the first wrongful act is done, or of whatever country the wrong-doer is a citizen. The power of the commonwealth to punish the causing of death within its jurisdiction is wholly independent of the power of the United States, or of the nation to which the vessel belongs, to punish the inflicting of the injury on the high seas. And upon full consideration the court is numimously of opinion that there is nothing in the constitution or laws of the United States, the law of nations, or the constitution of the commonwealth to restrain the legislature from enacting such a statute. *** Exceptions overruled. C. v. Macloon, 101 Mass. 1, 100 Am. Dec. 89, B. 409, F. 336.

(Ald. Ct. of App., 1892.) Death in Another State from Wound Given Here. Indietment for nurder. Demurrer overruled and defendant brings error. ALVEY, C. J. ** * 'The death veculrring in Philadelphia as the result of the mortal wound intlieted in Maryland, the question presented on demurrer to the third and fourth counts of the indictment is one in regard to which some doubts, it would appear, were entertained in the early days of the English common law. These doubts seem to have had their foundation in certain maxims and practice that originally obtained in respect to the venue for the trial of facts, the reason for which has long since ceased to exist; it being supposed, in the early periods of the English law, that it was neeessary that the jury should come from the vicinage where the matters of fact occurred, and there. fore he better qualified to investigate and discover the truth of the transaction than persons living at a distance from the seene could be. Hence the venue wis always regarded as a matter of substance; and where, at the common law, the commission of an offense was eommenced in one county and consummated in another, the venue could be laid in neither, and the offender went altogrether unpunished. And even in the case of murder, if the mortal wound was intlicted or poison administered, in one county, and the party died in consequence of the wound or poison in another, it was doubted by snme whether the murderer could be punished in either county; for it was supposed that a jury of the first could not talie cognizance of the death in the second, and a jury of the second could not inquire of the wounding or poisoning in the first; and so the felon would escape punishment altogether. 1 Chit. Cr. Iaw 177. This doubt was founded in a mere technicality, and savored so much of a senseless nicety, that it was deemed a reproach to the law; and to remove all doubt, and to fix a certain venue for the trial of the crime, St. 2 \& 3 Edw. 6, was passed. * * * By $\$ 278$ of Art. 27 of the Code, codified from $\$ 17$ of the Act of 1809, c. 138, it is provided that "if any person be feloniously stricken or poisoned in one county, and die of the same stroke or poison in another county, within one year thereafter, the offender shall be tried 
in the court within whose jurisdiction such county lies where the stroke or poison was given; and in like manner, an accessory to murder or felony committed, shall be triel by the court within whose jurisdiction such person became accessory." This statute, as will be observed, conforms neither to St. 2 \& 3 Edw. 6, nor to that of 2 (a. 2; but it is, as we think is manifest, simply in confirmation or declaritory of the common law. This, we think, is made elear upon examination of text writers of high authority, and by judicial decisions of courts entitled to great weight in the determination of such a question. And if this provision of our code be simply declaratory of the common law, as we suppose it to be, the sime reason and principle equally apply to the case where the mortal blow or poison is given in any county in this state, and the party so stricken or poisoned shall. in eonsequence of the blow or poison, die ont of the state, within the year and a day after the blow given or poison administered, as to the case provided for by the terms of the statite. In such case it is the law of Maryland that is violated, and not the law of the state where death may happen to oceur. By the felonious act of the accused, not only is there a great personal wrong inflicted upon the party assaulted or mortally wounded. while under the protection of the law of the state, but the peace and dignity of the state where the act is perpetrated is outraged; and though death may not immediately follow, yet if it does follow as i consequence of the felonious act within the year, the crime of murder is complete. In inflicting the mort:a? wound then and there, the aceused expends his active agency in producing the crime, no matter where the injure party may languish, or where he may die. if death ensues within the time, and as a consequence of the stroke or poison given. The grade and characteristies of the crime are determined immediately that death ensues, and that result relates back to the original felonious wounding or poisoning. The giving the blow that caused the death constitutes the crime. ** * Affirmed. Stout v. S., 76 MId. 317, 25 Atl. 299 . Kn. 386.

Acc. S. v. Gessert (1875). 21 Minn. 389, B. 403.

\section{EXTRADITION AND RENDITION.}

\$90. Foreign extradition depends on the treaties with the several nations; interstate rendition depends on the United States constitution and the acts of Congress.

(U. S. Sup. Ct., 1860.) "A Person Charged"-Duty and Rights of State Applied To. Motion for mandamus in behalf of Kentucky to compel the governor of Ohio to surrender Lango as a fugitive from prosecution for seducing and enticing away a slave and aiding her in attempting to escape. The governor of Ohin had refused. 
on advice of the attorney general of the state that no crime was charged. TANEY, C. J. * * The clause of the constitution which has given rise to this controversy is in the following words: "A person charged in any state with treason, felony, or other crime, who shall flee from justice, and be found in another state, shall, on demand of the executive authority of the state from which he fled, be delivered up, to be removed to the state having jurisdiction of the crime." Looking to the language of the clanse, it is difficult to comprehend how any doubt could have arisen as to its meaning and construction. The words, "treason, felony, or other crime," in their plain and obvious import, as well as in their legal and technical sense, embrace every act forbidden and made punishable by a law of the state. "The word "crime" of itself includes every offense. from the highest to the lowest in the grade of offenses, and includes what are called "misdemeanors," as well as treason and felony. 4 13. Com. 5, 6, and note 3, Wendall's edition. *** And as the states of this union, although united as one nation for certain specified purposes, are yet, so far as concerns their internal grovern. ment, separate sovereignties, independent of each other, it was obviously deemed necessary to show, by the terms used, that this com. pact was not to be regarded or construed as an ordinary treaty for extradition between natious altogether independent of each other, but was intended to embrace political offenses against the sover(rignty" of the state, as well as all other crimes. And as treason was also a "felony" ( \pm Bl. Com. 94), it was necessary to insert those words, to show, in language that could not be mistaken, that politi. cal offenders were included in it. For this was not a compact of peace and comity between separate nations who had no claim on each other for mutual support, but a compact binding them to give aid and assistance to each other in executing their laws. and to support each other in preserving order and law within its confines. whenever such aid was needed and required; for it is manifest that the statesmen who framed the constitution were fully sensible, that from the complex character of the government, it must fail unless the states mutually supported each other and the general govern. ment; and that nothing would be more likely to disturb its pence. and end in discord, than permitting an offender against the latrs of a state, by passing over a mathematical line which divides it from another, to defy its process, and stand ready, under the pro. tection of the state, to repeat the offense as soon as another oppor. tunity offered. * * * Looking, therefore, to the words of the constitution-to the obvious policy and necessity of this provision to preserve harmony between states, and order and law within their respective borders, and to its early adoption by the colonies, and then by the confederated states, whose mutual interest it was to give each other aid and support whenever it was needed-the conclusion is irresistible, that this compact engrafted in the constitution included, and was intended to include, every offense made pun. 
ishable by the law of the state in which it was committed, and that it gives the right to the executive authority of the state to demand the fugitive from the executive authority of the state in which he is found; that the right given to "demand" implies that it is an absolute right; and it follows that there must be a correlative oblisation to deliver, without any reference to the character of the crime charged, or to the policy or laws of the state to which the fugitive has fled. *** It will be observed, that the judicial acts which are necessary to authorize the demand are plainly specified in the act of congress; and the certificate of the executive authority is made conclusive as to their verity when presented to the exccutive of the state where the fugitive is found. He has no right to look behind them, or to question them, or to look into the character of the crime specified in this judicial proceeding. 'The duty which he is to perform is, as we have already said, merely ministerial-that is, to cause the party to be arrested, and delivered to the agent or anthority of the state where the crime was committed. * * ' The objection made to the validity of the indictment is altogether untenable. Kentucky has an undoubted right to regulate the forms of pleading and process in her own courts, in criminal as well as civil cases, and is not bound to conform to those of any other state. And whether the charge against lango is legally and sufficiently laid in this indictment according to the laws of Kentucky, is a judicial question to be decided by the courts of the state, and not by the executive authority of the state of Ohio. The demand being thus made, the act of congress declares, that "it shall be the duty of the executive authority of the state" to cause the fugitive to be arrested and secured, and delivered to the agent of the demanding state. "The words, "it shall be the duty," in ordinary legislation, imply the assertion of the power to command and to coerce obedience. But looking to the subject-matter of this law, and the relations which the United States and the several states bear to each other, the court is of opinion, the words "it shall be the duty" were not used as mandatory and compulsory, but as declaratory of the moral duty which this compact created, when congress had provided the mode of carrying it into execution. The aet does not provide any means to compel the execution of this luty, nor inflict any punishment for neglect or refusal on the part of the executive of the state. **** And it would seem that when the constitution was framed, and when this law was passed, it was confidently believed that a sense of justice and of mutual interest would insure a faithful execution of this constitutional provision by the executive of every state, for every state had an equal interest in the execution of a compact absolutely essential to their peace and well-being in their internal concerns, as well as members of the union. Hence, the use of the words ordinarily employed when an undoubted obligation is required to be performed, "it shall be his duty." But if the governor of Ohio refuses to discharge 
this duty, there is no power delegated to the general government, either through the judicial departmeat or any other department, to use any coercive means to compel him. And upon this ground the motion for the mandamus must be overruled. Kentucky v. Dennison, 65 U. S. (24 How.) 66, 16 L. Ed. 717, B. 943.

(Iowa Sup. Ct., 1878.) "Who Shall Flee." Appeal from an order of the circuit court granting a writ of habeas corpus for release from arrest under an order of the governor on extradition from the governor of Massachusetts on a charge that the petitioner had fled from prosecution there for obtaining money there by means of a letter written and mailed in Iowa to persons in Boston, by means of. which they were defranded. It is not claimed that petitioner was ever in Massachusetts. SEEVERS, J. * * It is difficult to see how one can flee who stands still. 'That there must be an actual fleeing we think is clearly recognized by the constitution of the United States. The words "who shall tiee" do not include a person who never was in the country from which he is salid to have Hed. It is $11 \mathrm{rged}$, however, that the plaintiff's were constructively in Massachusetts at the time the crime is allegred to have been committed, and that they have constructively fled therefrom. *** Granting that a crime may be thus committed, the question before us is whether, then, the state of Iowa is bound to surrender a citizen to the state in which the crime was committed? 'This depends upon the obligation in this respect imposed by the constitution of the United States. Before it can be said there is such an oblination. two things must appear. 'There must be-First, a crime charged; and, second, that the person charged is a fugitive from justice; that is to say, "that he has fled from the state in which he is charged with the crime to escape punishment." Such must be the legal effect of his fleeing. In other words, he must have been in the state. committed the crime, and fled. ****Affirmed. Jones v. Leonard, 50 Iowa 106, 32 Am. Rep. 116, B. 950.

(U. S. Sup. Ct., 1886.) Kidnaped Abroad. Frror to the supreme court of Illinois, to reverse a judgment affirming a conviction of larceny on plea of not gruilty entered by the court on Ker's refusal to plead further on sustaining demurrer to his plea in abatement of the indictment. The matter in abatement was that Ker was kidnaped in Peru without process or authority and brought to Illinois to be apprehended and tried. MILLER, J *** The main proposition insisted on by counsel for plaintiff in error in this court is, that by virtue of the treaty of extradition with Peru the defendant acquired by his residence in that country a right of asvilum, in right to be free from molestation for the crime committed in Illinois. a positive right in him that he should only be forcibly removed from Peru to the state of Illinois in accordance with the provisions of the treaty, and that this right is one which he can assert in the courts of 
the United States in all cases, whether the removal took place under proceedings sanctioned by the treaty, or under proceedings which were in total disregard of that treaty, amounting to an unlawful and unauthorized kidnaping. * * * There is no language in this treaty, or in any other treaty made by this country on the subject of extradition, of which we are aware, which says in terms that a party fleeing from the United States to escape punishment for crime becomes thereby entitled to an asylum in the country to which he has fled; indeed, the absurdity of such a proposition would at once prevent the making of a treaty of that kind. It will not be for a moment contended that the government of Peru cond not have ordered Ker out of the country on his arrival, or at any period of his residence there. If this could be done what becomes of his right of asylum? Nor can it be doubted that the government of Peru could of its own accord, without any demand from the United States, have surrendered Ker to an agent of the state of Illinois, and that such surrender would have been valid vithin the dominions of Peru. It is idle, therefore, to claim that, either by express terms or by implication, there is given to a fugitive from justice in one of these comtries any right to remain and reside in the other; and if the right of asylum means any thing, it must mean this. The right of the government of Pel'u voluntarily to give a party in Ker's condition an asylum in that country, is quite a difterent thing from the right in him to demand and insist upon security in such an asylum. The treaty, so far as it regulates the right of asylum at all, is intended to limit this right in the case of one who is proved to be a uriminal fleeing from justice, so that, on proper demand and proceedings had therein, the government of the country of the asylum shall deliver lim up to the country where the crime was committed. And to this extent, and to this alone, the treaty does regulate or impose a restriction upon the right of the government of the colmtry of the asylum to protect the criminas from removill therefrom. In tile case before us, the plea shows, that, although sulian went to Puru with the necessary papers to procure the extradition of Ker under the treaty, those papers remained in his pocket and were never brought to light in Peru: that no steps wero t:ien undre them; and that Julian, in seizing upon the person of Ker and carrying him out of the teritory of Peru into the United States, did not act nor profess to aci under the treaty. In fact. that treaty was not called into operation, was not relied upon, was not made the pretext of arrest, and the facts show that it was a clear case of kidnaping within the dominions of Peru, without any pretense of anthority under the treaty or from the government of the United States.

[Conviction of Different Offenses.] In the case of U. S. v. Rauscher, just decided, 119 U. S. 40'7, 7 S. Ct. 234, and considered with this, the effect of extradition proceedings under a treaty was very fully considered, and it was there held, that, when a party was duly surrendered, by proper proceedings, under the treaty of 1842 
with Great Britain, he came to this country clothed with the pro. tection which the nature of such proceedings and the true construc. tion of the treaty gave him. One of the rights with which he was thus clothed, both in regard to himself and in good faith to the country which had sent him here, was, that he should be tried for no other offense than the one for which he was delivered under the extradition proceedings. If Ker had been brought to this country by proceedings under the treaty of 1870-74 with Peru, it seems probable, from the statement of the case in the record, that he might have successfully pleaded that he was extradited for larceny, and convicted by the verdict of a jury of embezzlement; for the statement in the plea is. that the demand made by the president of the United States, if it had been put in operation, was for an ex. tradition for larceny, although some forms of embezzlement are mentioned in the treaty as subjects of extradition. But it is quite a different case when the plaintiff in error comes to this country in the manner in which he was brought here, clothed with no rights which a proceeding under the treaty could have given him, and no duty which this country owes to Peru or to him.

Affirmed. Ker v. Illinois, 119 U. S. 436, 7 S. Ct. 225, 30 L. Ed. 421. B. 939 .

(U. S. Sup. Ct., 1888.) Kidnaped in Another State. 'Two petitions in the district court of the United States for the district of Kentucliy, one by the governor of West Virginia, the other by Mahon, both praying that a writ of habeas corpus issue to require Abner Justice, jailor of Pike county, to produce "s: body of Mahon, show the cause of his detention and abide the order of the court. 'The jailor made return that he held Mahon by virtue of process from the criminal court of the county to answer indictments for murder committed in the county where he was arrested; and it was further shown that one Phillips having requisition from the governor of Kentucky to the governor of West Virginia for the surrender of Mahon to answer the above charge of murder, and being unable to get the warrant from the governor of West Virginia. had forcibly seized Mahon in West Virginia and carried him to Kentucky, where he was arrested. On hearing and considering these facts, the court ordered Mahon returned to the jailor to hold to answer the charge against him. On appeal to the circuit court the judgment was affirmed, and petitioners appealed to this court. FIELD. J. * * The surrender of the fugitives in such cases to the state whose laws have been violated is the only aid provided by the laws of the United States for the punishment of depredations and violence committed in one state by intruders and lawless bands from another state. *** No mode is provided by which a person unlawfully abducted from one state to another can be restored to the state from which he was taken, if held upon any process of law for offenses against the state to which he has been carried. If not 
thus held, he can, like any other person wrongfully deprived of his liberty, obtain his release on habeas corpus. **** As to the removal from the state of the fugitive from justice in a way other than that which is provided by the second section of the fourth article of the constitution, which declares that "a person charged in any state with treason, felony, or other crime, who shall flee from justice, and be found in another state, shall, on demand of the executive authority of the state from which he fled, be delivered up to be removed to the state having jurisdiction of the crime," and the laws passed by congress to carry the same into effect,-it is not perceived how that fact can affect his detention upon a warrant for the commission of a crime within the state to which he is carried. The jurisdiction of the court in which the indictment is found is not impaired by the manner in which the accused is brought before it. There are many adjudications to this purport cited by counsel on the argument, to some of which we will refer. [Reviewing several.] *** There is, indeed, an entire concurrence of opinion as to the ground upon which a release of the appellant in the present case is asked, namely, that his forcible abduction from another state, and conveyance within the jurisdiction of the court holding him, is no objection to his detention and trial for the offense charged. They all proceed upon the obvious ground that the offender against the law of the state is not relieved from liability because of personal injuries received from private parties, or because of indignities committed against another state. It would indeed be a strange conclusion, if a party charged with a criminal offense could be excused from answering to the government whose laws he had violated, because oth.r parties had done violence to him, and also committed an offense against the laws of another state. *** Affirmed. Bradley and Harlan, JJ., dissenting. Mahon v. Justice, 127 U. S. 700, 8 S. Ct. 1204, 32 L. Ed. 283.

\section{(U. S. Sup. Ct., 1893.) Surrender on One Charge and Conviction} on Another. Error to the supreme court of Georgia to reverse a conviction on an indictment for forgery. He had been surrendered by the governor of New York and brought to Georgia on roquisition. to answer an indictment for being a common cheat and swindler. After his arrival he was indicted and convicted on the present charge. JACKSON, J. * * * The proposition advanced on behalf of the plaintiff in error in support of the federal right claimed to have been denied him, is, that, inasmuch as interstate rendition can only be effected when the person demanded as a fugitive from justice is duly charged with some particular offense, or offenses, his surrender upon such demand carries with it the implied condition that he is to be tried alone for the designated crime, and that in respect to all offenses other than those specified in the demand for his surrender, he has the same right of exemption as a fugitive from justice extradited from a foreign nation. This proposition as- 
sumes, as is broadly claimed, that the states of the union are independent governments, having the full prerogatives and powers of natious, except what have been conferred upon the general government, and not only have the right to grant, but do, in fact, aftord to all per'sons within their boundaries an asylum as broad and secure as that which independent nations extend over their citizens and inhabitants. * * If a fugitive may be kidnapped or unlawfully abducted from the state or country of refuge, and be, thereafter, tried in the state to which he is forcibly carried, without vio. lating any right or immunity secured to him by the constitution and laws of the United States, it is difficult to understand upon what sound principle can be rested the denial of a state's authority or juriscliction to try him for another or difterent offense than that for which he was surrendered. If the fugitive be regarded as not lawfully within the limits of the state in respect to any other crime than the one on which his surrencler was effected, still that fact does not defeat the jurisdiction of its courts to try him for other offenses, any more than if he had been brought within such jurisdiction forcibly and without any legal process whatever. *** 'lo apply the rule of international or foreign extraclition, as announced in United States v. Rauscher, 119 U. S. 407 , to interstate rendition involves the confusion of two essentially different things, which rest upon entirely different principles. In the former the exiriadition depends upon treaty contract or stipulation, which rests upon good faith, and in respect to which the sovereign upou whom the demand is made can exercise discretion, as well as investigate the charge on which the surrender is demanded, there being no rule of comity under and by virtue of which independent nations are required or expected to withhold from fugitives within their juris. diction the right of asylum. In the matter of interstate rendition, however, there is the binding $\mathrm{f}_{0}: \cdots \cdot \mathrm{n}$ and obligation, not of contract, but of the supreme law of the land, which imposes no conditions or limitations upon the jurisdiction and authority of the state to which the fugitive is returned. *** Affirmed. Lascelles v. Georgia, 148 U. S. 537, 13 S. Ct. 687, 37 L. Ed. 549, B. 952.

\section{FORMER JEOPARDY.}

§91. Old maxim. The life of a man shall not be twice put in jeopardy for one and the same offense.

U. S. Const., Amend. 5. * * * Nor shall any per'son be subject for the same offense to be twice put in jeopardy of life or limb.

Cal. Const., Art. 1, $\S 13 . * * *$ No person shall be twice put in jeopardy for the same offense.

Mich. Const., Art. 6, $\S 29$. No person, after acquittal upon the merits, shall be tried for the same offense. 


\section{§92. “Twice Put in Jeopardy."}

(Fing. (Queen's Bench, 1592.) On Insufficient Indictment. William Vaux was indicted at the session before the justices of the peace of Northumberland for voluntarily murdering Nicholas Ridley by poisoning, and in discharge pleaded former indictment, trial, and acquittal before the justices of assize of the same county on the same charge. But the indictment in the former ease, put in evidence here, appeared to be insufficient, prineipally becanse it did not allege that Ridley received and drank the poison. It was resolved by LORD WRAY, SIR 'IHONAS GAWDY, CLENCH, and FENNER, justices, that the reason of auterfoits acquit was because where the maxim of common law is that the life of a man shall not be twice put in jeopardy for one and the same offense, and that is the reason and cause that auterfoits acquitted or convicted of the same offense is a good plea; yet it is intendable of a lawful acquittal or conviction, for if the conviction or aequittal is not lawful. his life was never in jeopardy; and because the indictment in this case was insufficient, for this reason he was not legitimo modo acquietatus, and that is well proved, because upon such acquittal he shall not have an action of conspiracy, as it is agreed in $9 \mathrm{~F} .4,12 \mathrm{a}$. b. vide 20 J. 4, 6. And in such case in appeal, notwithstanding such insufficient indictment, the abettor shall be inquired of as it is there also held; and although the judgment is given that he shall be acjuitted of the felony, yet this acquittal shall not help him, because le was not legitimo modo aequietatus; and when the law saith that auterfoits acquitted is a good plea, it shall be intended when he is lawfully acquitted; and that agrees with the old book in $19 \mathrm{E} .3$, Corone 444, where it is agreed if the process upon indictment or appeal is not sufficient, yet if the party appears (by which all imperfections of the process are saved) and is acquitted, he shall be discharged; but if the appeal or indictment is insufficient (as our case is) there it is otherwise ; but if one, upon an insufficient indictment of felony, has judgment, quod suspend' per coll', and so ittainted. which is the judgment and the end which the law has appointed for the felony, there he cannot be again indicted and arraigned until this judgment is reversed by error; but when the offender is discharged upon an insufficient indictment. there the law has not had its end; nor is the life of the party, in the judgment of the law, ever in jeopardy; and the wisdom of the law abhors that great offenses should go umpunished, which was grounded without question upon these ancient maxims of law and state; maleficia non debent remanere impunita, et impunitas continuum affectum tribuit delinquendi, et minatur imnocentes qui parcit nocentibus; so if a man is convicted either by verdict or by confession upon an insufficient indictment, and no judgment thereupon given, he may be again indicted and arraigned, because his life was never in jeopardy, and the law wants its end; and afterwards, upon this new 
indictment, the said Vaux was tried and found guilty, and had his judgment and was hanged. Vaux's Case, 4 Coke $44 a$, B. 67 .

(Cal. Sup. Ct., 1885.) Former Information Charged no Offense. Defendant pleaded not guilty, previous conviction, and former jeopardy. The jury found guilty of burglary. "Inasmuch as the former information failed to charge the defendant with the commission of any erime, the court below was justified in instructing the jury that the pleas of former conviction and once in jeopardy eonld not be sustained." Affirmed. P. v. Clark, 67 Cal, 99, 7 Pic. 178.

(Mass. Sup. Judicial Ct., 1808.) Former Fine on Confession before Justice, Without Notice to Injured Person. Defendant being arraigned on an indictment for assault and battery, and being in. quired of by the elerk whether he was guilty or not guilty. said he was guilty, but added that he had informed a justice of the peace of the comnty of his offense, by whom he had been sentenced to pay a fine, ete. 'The COUR'l' directed the clerk to enter the plea of guilty alone, ohserving that it had heretofore been solemnly determined that a conviction of a breach of the pence before a matgistrate, on the confession or information of the offender himself was no bar to an indietment by the grand jury for the same offense. C. v. Alderman, 4 Mass. 477, B. 70.

(Mass. Sup. Judicial Ct., 18t1.) Prior Complaint Irregular. Defendant was indicted for stealing lumber, and testimony was introduced which the court charged the jury would warrant a conviction if believed. Then defendant proposed to prove a former conviction for the same offense; and the record produced showed that the complaining witness alleged that he had cause to believe and did believe that his lumber had been stolen by defendant, bat did not charge that he had stolen it. On this complaint the justice had found defendant guilty, and fined him $\$ 10$ and costs, which fie paid. It is admitted that the further conviction was for the same offense. 'The court below ruled that the former proceedings were no bar, and defendant excepted. PU'TNAN, J. ** It is contended for the commonwealth, that the supposed former conviction was not only erroneous, but was merely void. In the case of C. v. Phillips. 36 Pick. 211, it was held that a conviction on a complaint in similar form to that which was used in the case at bar was erroneous. * We cannot think that those proceedings before the milgistrate were merely void. On the contrary, it is reasonable to believe that the complainant intended to prosecute for a larceny. The defendant understood it so. and so did the magistrate. Now, the judgment that the defendant was guilty. although upon proceedings which were erroneous, is good until the same be reversed. 'l'his rule of eriminal law is well settled. It was the right and privilege of the defendant to bring a writ of error and reverse that judgment: 
which writ would have been sustained by the case before cited of C. v. Phillips; but he might well waive the error, and submit to and periorm the judgment and sentence, without danger of being subjected to another conviction and punishment for the same ofiense. Yaux's Case, 4 Coke $45 ; 2$ Hale 1'. C. $251 ; 2$ Hawk. c. $36, \$ 10$ et seq. * * \#* Exceptions sustained and defendant discharged. C. v. Loud, 3 Metc. $3: 8,37$ Am. Dec. 139, 13. 7\%.

(Eng. Assi\%e at Liverpool, 185.1.) By Mutual Consent. The irisoner was indicted for forging the acceptance to a bill of exehange for $\pm 15+16 \mathrm{~s}$. 3d. The jury had been sworn and charged to inquire into the guilt of the prisoner. Simon. for the prosecutor. had opened the calse, when Monk, for the prisoner, having come into court during the opening of the learned counsel for the prosecution, informed his lordship that the prisoner was not prepared with his defense; upon which LRLE, J., discharged the jury from griving a verdict, observing that, with the consent of both parties, there was power to do so; and such consent being then given the trial was accordingly postponed to the following da:y. IHis lordship added that Parke, 13., held the same opinion. R. v. Deane, 5 Cox C. C. 501, B. 69 .

(U. S. Sup. (t., 18:t.) Jury Discharged for Disagreement. Ciase certitied for opinion on division of opinion of the circuit judges. "'he jury having been unible to agree on a former trial on this indictment, were discharged by the court without the defendant's consent; and on this ground he contended that he could not be put on trial again. S'TORY, J. *** We are of opinion that the facts constitute no legall bar to a future trial. The prisoner has not been eonvieted or acruitted, and may again be put on his defense. We think, that, in all cases of this nature, the law has invested courts of justice with the authority to discharge a jury from giving any verdict, whenever in their opinion, taking all the circumstances into consideration, there is a manifest necessity for the act. or the ends of public justice would otherwise be defeited. They are to exereis: a sound discretion on the subject; and it is impossible to define all the circumstances which would render it proper to interfere. To be sure, the power ought to be used with the greatest caution, under ingent circumstances, and for very plain and obvious causes; and, in capital cases especially, courts should be extremely careful how they interfere with any of the chances of life in favor of the prisoner. But, after all, they have the right to order the discharge; and the security which the public have for the faithful, sound and conscientious exercise of this discretion rests, in this, as in other cases, upon the responsibility of the judges. under their oaths of office. U. S. v. Perez, 9 Wheat. (22 U. S.) 579, 2 B. \& II. 35T-n.

(Mich. Sup. Ct., 1886.) Same. Respondrnt was prosecuted be- 
fore a justice of the peace for stealing a horse blanket, the jury disagreed, and were discharged by the justice; whereupon the prosecuting attorney entered nol. iros., immediately swore out a new warrant before the sime justies, and had respondent arrested, on the sime charge. He pleaded the former proceedings in bar, to which a demurrer wals sustained, and on trial defendant convicted. Ile appealed to the cireuit, was again tried and convicted, and his plea in bar held bad. On error the conviction was aftirmed by Sherwood and Chaplin, JJ., Morse, J., not sitting. CANIP. 13ELL, C. J., dissented, saying: "In this case the jury, after being out only 15 minutes, annomeed they were ready to render their verdict, and then stated they disagreed. I do not think that so speedy a discharge, which was eviciently determined on by the jury for themselves, is within any admissible discretionary power of a justice, and it was, I think, illegal, and no further trial was proper." P. v. Pline, 61 Mich. 247,28 N. W. 83.

(Mass. Sup. Judicial (it., 1896.) Same. Defendant excepts to conviction on indictment for robbery. LA'IIIROP, J. *** * 'The first exception relates to a plea in balr to which the government filed a demurere, which was sustained by the court. The plea set forth, that, on a merious indietment for the same offense, the peti.tioner was tried, and the jury, not being able to agree, were discharged against his will and consent. *** We are of opinion that the ruling of the court below was right. It is well settled in this commonwealth that the court, in its discretion, may discharge il jury where it is unable to agree, and that the person accused mily be tried again by another jury. [Citing prior decisions.] * * * Exceptions overruled. C. v. Cody, 165 Mrass. 133, 42 N. 13. 57i).

(U. S. Sup. Ct., 1891.) Discharging Jury for Incompetence. On trial for embez/lement from a national bank in New York city, after evidence had been given for the prosecution, the court, on motion of the district attorney, ordered a juror withdrawn and the jury discharged; to which defendant excepted, and thereupon moved for acquittal, which motion was denied. later the case was brought on before another jury and defendant convieted. Ife brought er'or. GRAY, J. * * * Pending the first trial of the present ease, there was brought to the notice of the counsel on both sides, and of the court, evidence on oath tending to show that one of the jurors had sworn falsely on his voir dire that he had no acquaintance with the defendant; and it was undisputed that a letter, since written and published in the newspapers by the defendant's coumsel, commenting upon that evidence, had been read by that juror and by others of the jury. It needs no argument to prove that the judge. upon receiving such information, was fully justified in concluding that such a publication, under the peculiar circumstances attending it. made it impossible for that jurv. in considering the case. to act with the 
independence and freedom on the part of each juror requisite to a fair trial of the issue between the parties. The judge having come to that conclusion, it was clearly within his authority to order the jury to be discharged, and to put the defendant on trial by another jury; and the defendant was not thereby twice put in jeopardy, within the meaning of the fifth amendment to the constitution of the United States. * * There can be no condition of things in which the necessity for the exercise of this power [to discharge one jury and put defendant to trial before another] is more manifest, in order to prevent the defeat of the ends of public justice, than when it is made to appear to the court that, either by reason of facts existing when the juror's were sworn, but not then disclosed or known to the court, or by reason of outside influences brought to hear on the jury pending the trial. the jurors or any of them are subject to such bias or prejudice as not to stand impartial between the government and the accused. *** Judgment affirmed. Simmons v. U. S., 142 U. S. 148, 12 S. Ct. 1i1, B. 76.

(lowa Sup. C't., 1885.) Jury Dismissed Because Grand Jury Did not Hear Witnesses. P. was put on trial on indictment for murder, and one witness was examined, when it was discovered that none of the witnesses had been examined before the grand jury, which had returned the indictment on the minutes of the committing magistrate. An application was made by the district attorney to compel P. to elect either to allow the cause to be continued or the witnesses to testify, and P. moved the court to direct the jury to return a verdict of not guilty, which being overruled he elected to continue the cause, and the jury was discharged. When brought to trial at the next term $P$. pleaded the prior proceedings specially in bar. An instruction to the jury that these facts constituted no defense, was held correct, and the judgment on conviction affirmed. S. v. Parker, 66 Iowa 586, 24 N. W. 225.

(Pa. Sup. Ct., 1893.) A Verdict of Not Guilty was Given by Order of the Court on an indictment of two counts for larceny, and the commonwealth appealed. WILLIAMS, J. *** The defendunt having been tried and acquitted upon an indictment charging a felony, we do not see how we can reverse the judgment and award a venire facias de novo. Even when, as in this case, the acquittal is the result of error alleged to have been committed by the judge in stating the law to the jurv, the right to direct a new trial is involved in great doubt. *** The judgment must be affirmed, becanse it rests on a verdict of acquittal in a trial for felony. We do not, however, wish to be understood as assenting to the statement of the law applicable to the facts of this case, made by the learned judge to the jury. $*{ }^{*}$ * C. v. Steimling, $156 \mathrm{~Pa}$. St. 400, 27 Atl. 297, B. 588, Mi. 659. 
('Tenu. Sup. Ct., 1836.) Former Conviction on One of Three Counts. 'l'he prisoner was tried upon an indictment containing three counts. Ile was acquitted on the tirst and third counts, and convicted on the second. He entered a motion for a new trial, and the court, in sustaining it, set aside the entire finding of the jury. On the second trial, he objected to being tried on the counts upon which he had been acquitted; but the court ordered him to be tried on the whole indictment. On this trial, he was acquitted on the first and second counts, and convicted on the third. On error, it was held that he was entitled to judgment of acquittal upon the first and third counts, because as to them he was legally discharged on the first trial; and that he was entitled to the same judgment on the second count, because as to that he was acquitted upon the second trial. 'The COURT remarked: "It is not necessary to deter'mine how f'ar' a party could be held, to even an express waiver of the benefit of a verdict of acquittal. It is enough, that in this case he has not done so. He moved for a new trial. We are not to suppose his application was more extensive than his necessities. As he had been acquitted upon two counts, he could have no motive to ask for another trial, except upon the one on which he was found guilty; and we are not to understand his application as going further. But the record shows that the judge, in granting a new trial, set aside the verdict. This was error; it improperly revived the proceedings upon those counts upon which he was acquitted. ** * But, although they were improperly revived, it was error to try the defendant a second time upon them. *** Having been once tried upon all the counts and acquitted as to some of them, to try him again upon the same counts would be putting him in jeopardy a second time for the same charge." Reversed. Campbell v. S., 9 Yerger 333, 30 Am. Dec. 417, 2 B. \& H. 498-n.

(Ill. Sup. Ct., 1854.) Former Conviction of Manslaughter on Charge of Murder. Indictment for murder. On a former trial on this indictment the other defendants were convicted of murder and Ryan of manslaughter; all moved for a new trial, were given it, agrain put on trial for murder, convicted of murder, and death sentence passed on them. TREAT, C. J. * ** Was the prisoner, Ryan, properly put upon his trial a second time for the murder of Story? An indictment for murder embraces the charge of manslaughter. The lesser is included in the greater accusation. On such an indictment, the jury may find the prisoner guilty of manslaughter. And such a finding amounts to an acquittal of the charge of murder. The finding of the inferior is necessarily a discharge of the superior offense. Ryan was regularly put upon his trial on the indictment, and was found guilty of manslaughter. In contemplation of law, the jury rendered two verdicts as to him; one acquitting him of the murder of Story; the other convicting him of the manslaughter of Story. He was thus legally tried for the offense of murder and 
aequitted. It is perfectly clear that he could not again be put in jeopardy on the same charge, unless that acquittal was set aside at his instance. A verdict either of acquittal or conviction is a bar to a subsequent prosecution for the same ofiense, although no judgment has been entered upon it. Mount, v. S., 1t Ohio 295; S. v. Norvell, 2 Yerger 24 ; Hurt v. S., 25 Miss. 378. It does not appear from the record that Ryan has ever waived the benefit of the verdict of acquittal. It is true that he united with the other prisoners in asking for a new trial, but that application as to him must be regarded as extending only to the charge upon which he was convicted. He had no occasion for another trial, except as to the charge of minslanghter. Being legally alequitted of the charge of murder, he surely did not desire that to be again investigated. It is not to be presumed that he would voluntarily place himself in peril upon a charge on which he had already been tried and acquitted. Even if the court, upon his motion, could open the whole case, the record does not show that such a power was either invoked or exereised. The application for a new trial did not necessarily relate to the charge upon which he was acquitted. It naturally referred to a charge on which he was convicted. ** * Reversed as to Ryan, and affirmed as to the other defendants. Brennan v. P., 15 Ill. 511, B. 74.

(U. S. Sup. Ct., 1905.) Same. Wrono and others were proceeded against in the court of first instance in Bulacan, Philippine Islands, for causing the death of $B$ with cruelty and premeditation. They were acquitted of the charge of murder and convicted of assault, included in the crime charged in the complaint. They appealed to the supreme court of the Philippine Islands, which, on hearing, reversed the judgment of the court below and convicted them of murder in the second degree. They appealed to this court, claiming that they could not be convicted on appeal of the crime of which they had been acquitted in the court of first instance, because the act of congress (July 1, 1902. 32 St. at Large 691, c. 1369) regulating judicial proceedings in the Philippines provides that "no person for the same offense shall be twice put in jeopardy of punishment." PECKHAM, J. * * * This question has given rise to much diversity of opinion in the various state courts. *** In our opinion the better doctrine is that which does not limit the court or jury, upon a new trial, to a consideration of the question of guilt of the lower offense of which the accused was convicted on the first trial, but that the reversal of the judgment of conviction opens up the whole controversy, and acts upon the original judgment as if it had never been. The accused, by his own action, has obtained a reversal of the whole judgment, and we see no reason why he should not, upon a new trial, be proceeded against as if no trial had previously taken place. We do not agree to the view that the accused has the right to limit his waiver as to jeonardy, when he appeals from a judgment against him. As the judgment stands before he 
appeals, it is a complete bar to any further prosecution for the offense set forth in the indictment, or of any lesser degree thereof. No power can wrest from him the right to so use that judgment, but if he chooses to appeal from it, and to ask for its reversal, he thereby waives, if successful, his right to avail himself of the former acquittal of the greater offense, contained in the judgment which he himself procured to be reversed. *** Affirmed. Brown, Brewer, and Day, .JJ., concurred. Holmes, J., concurred in the result. IIarlan and McKenna, J.J., wrote dissenting opinions in which Fuller, C. J., and White, J., concurred. Trono v. U. S., 199 U. S. ji21. 26 s. Ct. 121.

In a note to his alssenting opinion in the above case, Mr. Justice Mckenna collects the decisions of 17 states opposed to this decislon. To the contrary, supporting the miljorliy opinion in this cinse, are $\mathbf{S}$. v. Gillis (1006, S. Car.), 53 S. $\mathbf{L}$. 487, and several calses lierein cited from other states.

(Mass. Sup. Judicial ('t., 18\%2.) Effect of Rule on Right to New Trial. The prisuner having been convicted of murder, moved for a new trial, and satisfied the court that one of the witnesses on whose testimony he was convicted was infamous and incompetent by reason of conviction of lareeny in New York. 'The attoruey and solicitor general argued that a new trial cannot be granted of a capital felony, and eited English texts and decisions to support his - position. PARKER, C. J. *** That a prisoner, who has been tried for a felony, and acquitted, should not be subjected to a second trial for the same oflense, seems consistent with the humane principles of the common law. in relation to those whose lives have been once put in jeopardy. But the simne humane principles would appen: to require that after a conviction, a prisoner should be inclulged with another opportunity to save his life, if anything had occurred upon the trial which rendered doubtful the justice or legality of his conviction. Nemo bis debet vexari pro una et eadem eausa is a maxim of justice, as well as of humanity ; and was established for the protection of the subject against the oppressions of government. But it does not seem a legitimate consequence of this maxim that one who has been illegally convicted should be prevented from having a second inquiry into his offense; that he may be acquitted. if the law and the evidence will justify an acquital. * ** Where the error appears of record, in either country, the court will arrest the judgment after a verdict of guilty; and the party may be again indicted and tried for the same offense. If the error does not appear of record, but arises from inadverteney of the judge, in rejecting or admitting evidence, or from misbeliavior of the jury, or other cause which would be good ground for a new trial in civil actions or misdemeanors. justice and eonsisteney of principle would seem to demand that the person convicted should, upon his own motion, have another trial; instead of being obliged to rely upon the disposition of the court to recommend a pardon, or of the executive power to grant it. $* *$ Nor is it for the public safety and interest that new 
trials should be refused in such cases. For it must be obvious that in most calses of irregularity which would be a good cause for another trial if in the power of the court to grant it, a pardon, upon the representation of the court, would be thought to follow of course; and thus, in many cases, public justice might be prevented on account of defect in form, or some irregularity not affecting the merits of the ease, which mischief might be avoided by another trial. * * * In the case before us, the only advantage the prisoner would have on another trial, which he had not before, would be to show that Stoddard, one of the witnesses who testified against him, was not deserving of eredit. becaluse he had bern convicted of lareeny in New York. If this witness had gone before the jury wholly mimpeached and his testimony had been material [ete.]. *** Motion overruled. C. v. Green, 17 Mass. 515, 13. 70, 2 B. \& H. 464-n.

\section{\$93. "For One and the Same Offense."}

(Ling. C. C. R., 1796.) Burglary to Steal after Burglary with Stealing. On demurrer to a special plea of autrefois acquit on indictment for burglary, the question was argued before all the justices of England; and in giving their opinion, BULLER, J., said: "Ihese two offenses are so distinct in their nature that evidence of one of them will not support an indictment for the other. ** * * If erimes are so distinct that eridence of the one will not support the other, it is as inconsistent with reason as it is repugnant to the rules of law to sily that they are so far the same that an acquittal of the one shall be a bar to a prosecution for the other. [Here his honor reviewed the anthorities to this effect. These cases establish the principle that unless the first indictment were such as the prisoner might have been convicted upon, by proof of the facts contained in the second indictment, an acquittal on the first indictment can be no bar to the second.] *** * Now, to apply the principle of these cases to the present case: 'The first indictment was for burglariously breaking and entering the house of Miss Neville and stealing the groods mentioned; it appeared that the prisoner broke and entered the house with intent to steal. but that no larceny was committed, and therefore they could not be convicted on that indictment; but they have not been tried for burglariously breaking and entering Miss Neville's house with intent to steal. and therefore their lives have never been in jeopardy for this offense. For this reason the judges are all of opinion that the plea is bad; that there must be judgment for the prosecutor upon the demurrer; and that the prisoners must take their trials on the present indictment.

* Vandercomb's Case, 2 Ieach. C. C. (Ed. 3) 816. East P. C. 519, B. 78,2 B. \& H. 542-n.

(N. Car. Superior Ct., 1797.) False Imprisonment after Assault 
and Battery. On indictment for riot, beating, and imprisonment, defendant pleaded that he had been convicted and fined for assault and battery based on the same facts; and the state demurred. Per CURIAM. The state cannot divide an offense consisting of several trespasses into as many indictments as there are acts of trespass that would separately support an indictment, and afterwards indict for the oftense compounded of them all; as, for instance, just to indict for an assault, then for a battery, then for imprisonment, then for a riot, then for a mayhem, ete. But upon an indictment for any of these offenses the court will inquire into the concomitant facts, and receive information thereof, by way of aggravating the fine or punishment, and will proportion the same to the nature of the offense as enhanced by all these circumstances; and no indictment will afterwards lie for any of these separate facts done at the same time. This plea is a good one, and must be allowed. S. v. Ingles, 2 Hayw. (3 N. Car.) 4, B. 88.

(Vt. Sup. Ct. of Judicature, 1803.) Two Struck by One Blow. On indictment for assault and battery, a plea of former conviction for the very same affray and stroke on an indictment for assault and battery on another, was held to be a complete defense. The court said: "This is not a question between either of the persons injured by the assault and battery and their assailant; redress has ibeen, or may be obtained by them by private actions; but it is a question between the government and its subject, and the court are clearly of opinion that the indictment cannot be sustained. The indictment charges the defendant with having disturbed the public peace by assaulting and wounding one of its citizens. For this crime he shows that he has been legally convicted by a court of competent jurisdiction. He cannot, therefore, be again held to answer in this court for the same offense." Prisoner discharged. S. v. Damon, 2 Tyler 387, B. 88.

(N. Car. Sip. Ct., 1822.) Robbery after Larceny. 'The grind jury found two indictments on the same facts. one for burglary and larceny, the other for robbery. Without asking the state to elect. defendant went to trial on the indictment for burglary and was found guilty of the larceny, but not of burglary. The state then moved a nol. pros. on this indictment, which the court lefused. The state then moved to arraign the prisoner for robbery, which the court refused, and quashed the indictment. The state appealed. HALL, J. It is admitted in this case that both indictments are for the same felonious taking of the same goods. The defendant is found guilty of a grand lareeny on that indictment which charges a burglary and stealing. The other indictment is for a robbery; a robbery is a larceny, but of a more aggravated kind. The first is a simple larceny. The other is a compound or mixed larceny, becanse it includes in it the aggravation of a felonious taking from the 
person. Now, suppose the defendant should be tried and found guilty on the second indictment. It must certainly follow that he had been tried twice for the feloniously taking of the same goods. It is true, if the first conviction is a bar to a trial on the second indictment, the prisoner would go untried as to that which constitutes the difference between simple larceny and mixed and compound larceny, viz.: a taking from the person. In such case he would be convicted of a felonious taking, but not of a felonious taking from the person. Whereas, should he be tried and convicted on both indictments, it might be said he had been convicted twice of a felonious taking, and once of a felonious taking from the person.

* * Affirmed. S. v. Lewis, 2 Hawks (9 N. Car.) 98, 11 Am. Dec. $7+1$, B. 89 .

(Eng. Assize at Chester, 1836.) Accessory after Principal. LORD DBNIIAN, C. J., put the prisoner to trial on indictment for being accessory before the fact to a murder by poisoning, though he had been acquitted (because absent) on a former indictment in which he was charged as joint principal with another to the same murder. But his lordship reserved the point for consideration by the judges. R. v. Plant, 7 C. \& P. $575,13.79$.

(N. Y. Sup. Ct. of Judicature, 1837.) Larceny after RobberyOwnership Different. Defendant was indicted for grand lareeny of six watches, and pleaded former acquittal of entering a shop, putting in fear one DeForrest, and violently taking the same six watches from him, and averred that the offenses were identical. The district attorney replied that the offenses were not identical, the court so instructed on proof of the facts, and the jury found the prisoner guilty. ITe excepted. COWEN, J. The first indictment. though for a robbery, involved the question of simple larceny, of which the prisoner, under that indictment, might have been convicter. So far, therefore, as the nature of the offense is concerned. the plea was valid; the prisoner had, within the issue, been tried and aequitted of the lareeny. The rule laid down by the court of sessions applies; for the same proof would sustain either indictment to the extent necessiry for the purposes of the plea. *** $*^{*}$ In the ease before us, it is said for the people that the two offenses differ in respect to the identity of property; the former indictment, speaking of six gold and silver watehes, three of which belonged to Dollorrest, and three to MI'Harg; whereas, now it is eharged that ill the six, vi\%: three watches, and three gold and silver watches, belonged to the latter; and that the prisoner admits by his plea that he stole these six which belong to M'Harg. We cannot but see, however, that the difference is mere matter of form; and that proof might have been received at the last trial of the same facts which would have been sufficient to sustain the indictment upon the first. * * New trial granted. P. v. McGowan, 17 Wend. 386. B. 90 . 
(Eng. Central Crim. Ct., 185i.) Charge of Murder after Charge of Assault to Kill. Indictment for murder. Plea of autrefois aequit. 'The erown demurred. POLLOCK, C. B. *** On the former occasion the prisoner was charged with wounding with intent to kill. 'The jury found that he did not intend to kill, and there the intention was of the essence of the crime; that is not so in the present indictment; it is not necessary here to prove an intention to kill, it is only necessury to prove an intention to inflict an injury that might be dangerous to life, and that it resulted in death; that is sufficient to sustain the present charge. 'lry this by the very test presented to us. It is said that it is no bar to the second indictment that a party has been acquitted on the first unless the facts proved on the second indictment might have produced a conviction on the first. But a party may be convicted upon an indictment for anurder by evidence that would have no tendency to prove that there was any intent to kill. *** The only suggestion that raised for a moment a doubt in my mind was to the effect that an acquittal of an assialt with intent to kill was an acquittal both of the isssault and of the intent; but I think that is not so. The acquittal of the whole offense is not an acquittal of every part of it, it is only an aequittal of the whole. * * * MAR'IIN, B. * * * The offense for which the prisoner has been tried was one of intent, and was therefore complete the moment the stab was given, whereas the offense for which he was now indicted could only be consummated by the death of the party. 'To the mind of a lawyer this must be deemed conclusive against the plea. WILLES, J. **** All that was then disposed of was that he did not wound with intent to kill. It could not be assumed that the jury negatived the wounding. * * [Defendant was tried and convicted of man. slaughter.] R. v. Salvi, 10 Cox C. C. 481n, B. 80.

(AIass. Sup. Judicial Ct., 1863.) Iarceny-Different Condition of Property. Indictment for embezzlement of 16 overcoats. Defendinnt pleaded prior aequittal, and it was admitted that he had been acquitted of stealing the cloth, wadding and material of which the coats were made. The proof was that he was employed to make the coats, made and returned them, and again received them to make alterations, and that the acts of embezzlement were subsequent. BIGELOW, C. J. The obvious and decisive answer to the defendant's plea in bar of autrefois acquit is, that the first indictment charges a different offense from that set out in the indictment on which the defendant is now held to answer. The principle of law is well settled that in order to support a plea of autrefois acquit the offenses charged in the two indictments must be identical. The test of this identity is to ascertain whether the defendant might lave been convicted on the first indictment by proof of the facts alleged in the second. The question is not whether the same facts are offered in proof to sustain the second indictment as were given 
in evidence on the trial of: the first; but whether the facts are so combined and charged in the two indictments as to constitute the same oflense. It is not sufficient to say, in support of a plea of antrefois acquit, that the transaction or facts on which the two judictments are based are the same. It is necessary to go further, and to ascertain and determine whether they are so alleged in the two indirtments as to constitute not only the same offense in degree or kind, but. also that proof of the same facts offered to sustain the second indictment would have well supported the first. King v. Vaudercomb, 2 Leach (4th Ed.) 708 Labove]; C. v. Roby, 12 Pick. 496, 500; C. v. Wade, 17 Pick. 400. 'The last case aftords an apt illustration of the practical application of the rule. The defendant was indicted for burning a dwelling-house by setting fire to the barn of $A$ and $B$. 'The evidence showed that it was the barn of $A$ and $\mathrm{C}$. This variance in the description of the offense was held to be fatal, and the defendant was acquitted. He was subsequently indicted for burning the same house by setting fire to the barn of $A$ and $C$. On a plea of autrefois acquit it was held that the previous acquittal on the first indictment was no bar. 'The facts ofiered in support of the two indictments were the sime, but different offenses were charged in them. The averment of property in the barn was material, and this fact being alleged difierently in the two indictments, they were not for the same ofiense either in form or substance. So in the case at bar. The defendant was first indicted for embezzling eloth, velvet, flannel, and other materials of which overcoats were made. 'This indictment would not have been supported if it appeared that, at the time when the alleged emberzlement was committed by the defendant, these articles no longer existed separately, but had been used and converted into garments properly called and known as overcoats. ** * Exceptions overruled. C. v. Clair, 7 Allen 525, B. 93.

(Eng. C. C. R., 1867.) Conviction of Assault as Defense to Manslaughter. KELLY, C. B. In this case I lave the misfortune to differ with my learned brethren, who are of opinion that the conviction ought to be affirmed. The prisoner was charged before the magistrates with an assault under the $24 \& 25$ Vict., c. 100 , at the instance of the party aggrieved, and now deceased, 'Timothy Lymer; le was convicted and sentenced to imprisonment with hard labor, and has undergone that sentence. The assault, the unlawful act, with which he was charged, is the same assault and one and the same act as that which caused the death of Lymer, and of which he has been eonvicted under the present indictment. I think, therefore. that the ease comes within the precise words of $\S 45$ of the 24 is 25 Vict., c. 100 , which provides that in such a case" he shall be released from all further or other proceedings, civil or criminal, for the same caluse." ** * * BYILS, J. I am of opinion that the prior conviction for the assault under the $24 \& 25$ Vict., c. 100 , 
$\S 45$, affords no defiense to the subsequent indictment for man. slaughter, the death of the deceased having occurred after the con. viction, but being a consequence of the assault. 'The form and inten. tion of the common law pleas of autrefois convict and autrefois acquit show that they apply only where there has been a former judicial decision on the same accusation in substance, and where the question in dispute has been already decided. 'There has, in the present case, been no judicial decision on the same accusation, and the whole question now in dispute could not have been decided, for at the time of the hearing before the magistrates whether the assanlt would amount to culpable homicide or not depended on the then future contingency whether it would cause death. 'I'he case of $R$. $v$. Salvi, if not precisely in point, is nevertheless a strong authority for this view of the law. *** An additional reason in this case for following the common law is the mischief which would result from a different construction. My brother Martin has already illustrated the mischief in civil cases by a reference to Lord Campbell's Act, and in criminal cases the mischiefs might be much greater. A murderer, for example, by suffering or obtaining a previous conviction for an assault. might escape the due punishment, of his crime. Keating and Shee, J.J.s and Martin, B., concurred. Conviction affirmed. R. v. Morris, 10 Cox C. C. 480,36 L. J. m. c. 81 , L. R. 1 C. C. 90,16 L. 'T. 636,15 W. R. 999 . B. 82 .

(Eng. Queen's Bench Div., 1875.) Assault under Two Statutes. Case stated. On this indictment appellant was convicted and fined i1. The question for the court was whether the appellant, having been convicted on the 26 th of June, 1872 , under $3 \& 4$ Wm. 4, c. 50 , upon the complaint of the superintendent of police, could again be convicted on the 7 th of August, 1872 , under $24 \& 25$ Vict., c. 100 , $\S 42$, upon the complaint of the respondent. BLACKBURN, J. I think the fact that the appellant had been convicted by justices under one act of parliament for what amounted to an assault is a bar to a conviction under another act of parliament for the same assault. The defense does not arise on a plea of autrefois convict, but on the well established rule at common law that where a person has been convicted and punished for an offense by a court of competent jurisdiction. transit in rem judicatam; that is, the conviction shall be a bar to all further proceedings for the same offense, and he shall not be punished again for the same matter; otherwise there might be two different punishments for the same offense. The only point raised is whether a defense in the nature of a plea of autrefois convict would extend to a conviction before two justices whose jurisdiction is created hy statute. I think the fact that the jurisdicdiction of the justices is crented bv statute makes no difference.

* Judgment for apnellant. Wemyss v. Hopkins, L. R. 10, Q. B. 378,44 L. J. m. c. 101,33 L. T. 9,23 W. R. 691, B. 86 . 


\section{PART II. \\ SPECIFIC CRIMES.}

\$94. Classification. While crimes are numberless and limitless, they may be grouped into certain fairly well defined classes. This grouping may be made from various points of view. Classified with reference to the severity of the punishment prescribed, because of the supposed enormity of the offense, they are either misdemeanors, felonies, or treason. But for the purposes of the student they can be considered to better advantage by classifying them with reference to the thing injured. This classified, crimes are: 1, against the person; 2, against the habitation; 3, against property rights; 4 , against the public peace; 5 , against the general welfare (public morals, health, safety, and comfort); 6, against the administration of public justice and authority; 7 , threatening the very existence of the government; 8, piracy, against all mankind. We will consider these in their order. 
CHAPTER VII.

\section{OFFENSES AGAINST THE PERSON.}

805. Classiffed, 323.

SIMITIE AsSAUIT.

\$06. Defined, etc., $\$ 323$.

AgGinavited assault.

\$กT. Generally, 328.

BatTEILY.

898. Defined, etc., 328.

Falst: IMPRISONMEAT.

8 9!. Defined, etc., 330.

KIDNAPING.

8100. Defined, ctc., 330.

MatN.

\$101. Defined, ctc., 331.

RaI'E.

\$102. Defined, etc., 332.

HOSICIDL.

\$103. Definition and Classiffeation, $\mathbf{3 4 1}$.

\$104. Murder. 341.

10\%. Manslaughter Defined. 350.

\$106. Voluntary Manslaughter, 350 .

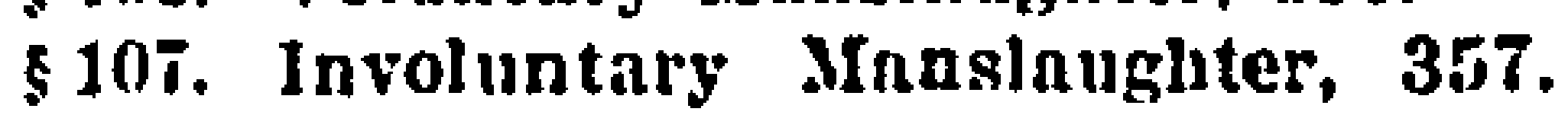

$\$ 108$. I'roof of Corpus Dellcti, 302.

$\$ 95$. Classified. The offenses against the person are: 1 , simple assault; 2, aggravated by intent to do greater injury than battery; 3 , coupled with battery, or by actual commission of; 4 , false imprisonment; 5, kidnaping; 6 , maim; 7, rape; 8 , homicide. We will consider these in their order, from the least to the greatest.

\section{SIMPLE ASSAULT.}

§96. Simple Assault Defined. "An assault is: (a) An attempt unlawfully to apply any the least actual force to the person of another, directly or indirectly; (b) the act of using a gesture toward another, giving him reasonable grounds to believe that the person using such gesture means to apply such actual force to his person as aforesaid; (c) the act of depriving another of his liberty, in either case without the consent of the person assaulted, or with such consent if it is obtained by fraud." Stephen's Dig. Cr. Law, Art. 241.

(Eng. King's Bench, 1669.) Explained by Words at Time. Action of assault, battery and wounding. The evidence to prove a provocation was, that the plaintiff put his hand upon his sword and said, "If it were not assize-time, I would not take such language from you." The question was, if that were an assault? The court agreed that it was not; for the declaration of the plaintiff was, that he would not assault him, the judges being in town; and the intention 
as well as the act makes an assault. Therefore, if one strike another upon the hand, or arm, or breast in discourse, it is no assault, there being no intention to assault; but if one, intending to assault, strike at another and miss him, this is an assault; so if he hold up his hand against another in a threatening manner and say nothing, it is an assiult. In the principal case the plaintift had judgment.

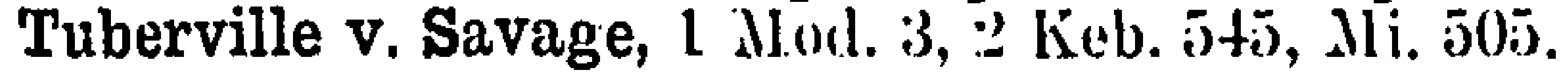

(Eng. Assize, 18ti.) Abandoning Child. Defendant was indicted for misdemeanor, with one count for assalult. She was delivered of a bastard ehild; and when it was ten day's old she left it, swathed in a large piece of Hamnel, in the bottom of a dry ditch, near a path and a lane seldom used; and went to a town 10 miles away. PARKE, B., to the jury: * $*$ * l'here were no marks of violence on the child, and it doess not appear, in the result, that the child actually experjenced an! injury or inconvenience, as it was providentially found soon after it was exposed; and therefore, although it is said in some of the books that an exposture to the inclemency of the weather may amount to an assault, yet if that he so at all, it can only be when the person exposed sulfer's a hurt or injury of some kind or other from the exposure. Verelict, not guilty. R. v. Renshaw, 2 Cox (:C. $285,11 \mathrm{Jur} .615,13.434$.

Conscht as defense to charge of assault: Smith v. S.. $\$ 12 ; 12$. v. Martiv, $\$ 20 ; 1$. ․ Clarence, $\$ 29: C$ v. Koosnell, $\$ 102 ; \mathrm{H}$. v. Case, $\$ 20$.

(S. Car. Ct. of Appeals, 1848.) Apparent Intent to Ride Down. Sims had threatened to shoot Holt if he should survey a line over Sims's land. After IIolt harl survered the line he and others met Sims in a foot-path, they being on foot and Sims on horseback. As Sims came alongside llolt said in a low tone, "You did not shoot mo." Answer, "No; but I'll horsewhip you." Sims turned his horse across the path before Holt, and then shook his hickory over his head in striking distance. He rode his horse twice very near to Holt; the third time he rode nearly upon him. Holt said, "Don't ride upon me," and thereupon struck the horse, with his jacob-staff. on the neck. The hor'se fell on his haunches; the defendunt jumped down and picked up a junk, but dropped it without attempting to throw. On this and other evidence of like import Sims was con. victed of assault. He appealed and moved for a new trial, claiming that the court erred in charging the jury that he might be found guilty of an assault if he rode his horse so near Holt as to endanger his person, although he intended to commit no assault; and because the verdict is contrary to law and evidence. Motion denied. S. v. Sims, 3 Strobh. 137, Mi. 509.

(Cal. Sup. Ct., 1865.) Retreat to Avoid Blow. Defendant called at prosecutrix's house and demanded liquor, which being finally given him he asked prosecutrix to drink, which she refused; then he threw a tumbler on the floor, threatened to kill her, seized a hatchet. 
and advanced toward her in a threatening attitude to within 7 or 8 feet, when she retreated to an adjoining room and locked the door behind her. Defendant struck the door with the hatehet, and prosecutrix went out of another door to an adjoining meat shop. Defendant followed her there and again threatened her life. Judgment on verdict of guilty was affirmed though defendant excepted to the court's refusal to charge the jury to acquit if prosecutrix had left the room before he raised the hatchet in striking posture or approached within striking distance. The court said: "In order to constitute an assault there must be something more than a mere menace. There must be violence begun to be executed. But where there is a clear intent to commit violence, accompanied by acts which, if not interrupted, will be followed by personal injury, the violence is commenced and the assault is complete." P. v. Yslas, 27 Cal. 631, F. 239.

Coming to assault: Yoes $\nabla$. S., $\$ 10$.

(Ala. Sup. Ct., 186T.) Without Threats or Violence. Defendant wats convicted of assault, and excepts to the charge of the court. The gist of the offense was in coercing prosecutor to give up his gun. The court instructed the jury that if prosecutor gave up the gun "through fear of bodily harm, reasonably excited in his mind by the conduct and manner of the defendant," an assault was committed. JUDGE, J. * * * It matters not that the gun was not delivered in consequence of threats by "word of month." * * * The defendant had as much the right to coerce the delivery to him of the prosecutor's hat, or his cont, or to compel him to strip, on the pretext that he was not dressed in the fashion, as he had to coerce the delivery of the prosecutor's gun; and it would be a reproach to the law if one could coerce the performance of acts like these. through fear of bodily harm, excited in the mind of his victim, though not by actually striking at him, or by the use in terms of threatening language, and still be guilty of no offense. But the law is not so unreasonable as to permit one who thus breaks down the barrier it has erected for the security of the citizen to go free of punishment. * * * Affirmed. Baikum v. S., 40 Ala. 671, F. 240.

(N. Car. Sup. Ct., 1868.) Striking Distance-Offer. Appellant wals convicted of assault and battery on proof that prosecutor and others called at his house, and a quarrel arising he ordered them to leave, at the same time, or soon after, taking down his gun, without aiming it at them or attempting to do so; and this being taken from him by members of his family, he picked up an ax and got near enough to throw it, which he did not attempt; and later, being dared to come out, advanced with it to within 25 or 30 yards. READE, J. His honor's charge, "that, in any view of the case, the defendant was guilty," is so broad as to entitle the defendant to a new trial, if there is any view consistent with his innocence. After 
a careful consideration of the testimony, we are obliged to say that in no view of the case is the defendant guilty. When the defendant ordered the prosecutor and his crowd to leave his house, as he had a right to do, it may have been rude behavior to seize his gun at the same time; but as he did not point his gun, or in any way offer or attempt to use it, there was certainly no assault, which is an offer or attempt, and not a mere threat, to commit violence. And so the picking up of the ax within some 25 yards of the prosecutor, without an offer or attempt to use it, was not an assault. There is error. New trial. S. v. Mooney, 61 N. Car. (Phill.) 434, F. 238.

(Mass. Sup. Judicial Ct., 1872.) Fear, Ability, and Intent, as Essentials-Gun not Loaded. Defendant excepts after conviction of assault. There was testimony that defendant drove in a wagon along a highway, which Harrington, Sullivan, and others were repairing; that they asked him to drive in the middle of the road; that he replied offensively; that they came towards him, asking what he meant; that he picked up a gun, aimed it at them, and threatened to shoot; that Harrington was put in fear; that Sullivan was not; and that the gun was not loaded. WELLS, J. **** The instructions required the jury to find that the acts of the defendant were done "menacingly;" that Harrington had reasonable cause to believe the gun pointed at him was loaded, and was actually put in fear of immediate bodily injury therefrom; and that the cireumstances were such as ordinarily to jadues such fear in the mind of a reasonable man. Instructions in accordance with the second ruling prayed for would have required the jury also to find that the defendant had an intention to do some bodily harm and the present ability to carry his intention into exceution. Taking both these conditions literally, it is difficult to see how an assault could be committed without a battery resulting. It is not the secret intent of the assaulting party nor the undisclosed fact of his ability or inability to commit a battery that is material; but what his conduct and the attending circumstances denote at the time to the party assaulted. If to him they indicate an attack, he is justified in resorting to defensive action. The same rule applies to the proof necessary to sustain a criminal complaint for an assault. It is the outward demonstration that constitutes the mischief which is punished as a breach of the peace. *** Exceptions overruled. C. v. White, 110 Mass. 407, B. 450, C. 153.

- (Mich. Sup. Ct., 1880.) Present Apparent Ability. Appellant was indicted for assault with intent to murder and was convicted of assault with intent to commit manslaughter. MARST'ON, C. J.

* The court instructed the jury: " $\mathrm{An}$ assault is an attempt or offer with violence to do a corporal hurt to another; an offer to inflict bodily injury, by one who is rushing upon another, is an assault. Although the assialant be not near enough to reach his 
adversary, if the distance be such as to induce a man of ordinary firmness to believe that he is in immediate danger of receiving such threatened injury, and any intent to commit violence, accompanied by acts which, if not interrupted, will be followed by bodily injury, is sufficient to constitute an assault, although the assailant may not be at any time within striking distance. And, in this case, if Lilley, being within 10, 15, or 20 feet of McKenzie, drew his knife from his pocket and commenced to open the same, and started towards McKenzie in a violent manner, threatening that he would do him bodily injury, and after advancing towards him a few steps, and while rushing towards MicKenzie, he was stopped by Dillman, Lilley would then be guilty of an assault." * * * The act done must have been sufficiently proximate to the thing intended. It may be so remote, although a distinct and essential act, coupled with the intent, us to fall far short of constituting an assault. 'The act done must not only be criminal, but it must have proceeded far enough towards a consummation thereof, and this must necessarily be a question for the jury under proper instructions. 1 Bish. Cr. Law [Ed. 1], c. 26, also §323. So, clearly, where the intent is formed and some act done in performance thereof, but the party voluntarily abandons his purpose, or is prevented from proceeding farther, and this while at a distance too great to make an actual assault, he could not be convicted of an assault. *** An assault is defined to be an inchoate violence to the person of another, with the present means of carrying the intent into efiect. Threats are not sufficient; there must be proof of violence actually offered, and this within such a distance as that harm might ensue if the party was not prevented. 2 Greenl. Ev. § 82, 3 Greenl. Ev. \$ 59, 1 Bish. Cr. Law, § 419; 3 Bl. Comm. 120, note 3 . We are of opinion, therefore, that the charge of the court as to what would constitute an assault was not sufficiently guarded, and had a tendency to mislead the jury.

Reversed. P. v. Iilley, 43 Mich. 521, 5 N. W. 982, F. 243.

(N. Car. Sup. Ct., 1890.) Officer Avoiding Blow. Prosecutor heard defendant was beating his wife, and on starting in search, soon heard defendant coming down the road scolding violently, heard a blow struck and a woman scream, and immediately met the wife crying and defendant following. with a sycamore limb large as his thumb and 5 feet long in his hand. Prosecutor, a justice of the peace, told defendant to consider himself under arrest and touched him on the shoulder, on which defendant raised the stick as if to strike, and prosecutor stepped aside to avoid the blow. It was quite dark, but the parties were well acquainted and recognized each other. AVERY, J. A justice of the peace, a constable, or a sheriff can unquestionably arrest without a warrant one who commits a felony or breach of the peace in his presence. S. v. Hunter, 106 N. Car. 798, 11 S. E. 366, 8 L. R. A. 529. *** If the defendant raised the stick described in striking posture over the pros. 
ecutor's head, and caused him to step aside to avoid an apprehended blow, it was an assault. S. v. Shipman, 81 N. Car. 513. There was evidence tending to show that the defendant committed an assault: 1 , upon his wife in the presence of the prosecutor; and, 2, that he committed an assault upon the prosecutor, who attempted to arrest him, and was known to the defendant to be a peace officer. The jiry passed upon the disputed facts. Judgment affirmed. S. v. McAfee, 107 N. Car. 81, 12 S. E. 435,10 L. R. A. 607.

\section{AGGRAVATED ASSAULT.}

\$97. Aggravated by Specific Intent. For example, assault with intent to do great bodily harm less than murder, to murder, to rape. etc.

Specife intent must be found: Carter v. S., $\$ 43 ; R$. v. Boyce, $\$ 43$. Intent to

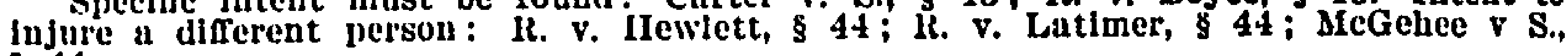
$\S 44$.

\section{BATTERY.}

\$98. Battery-Defined. Battery is the unlawful touching of the person or of anything connected with the person of another.

- (Eng. Nisi Prius, 170t.) The indictment was for a battery upon Doctor $R$. The evidence was that the defendant spit in his face. IIOL'I, C. J. It is a battery. T'hough one cannot justify a battery by son assault demesne, by pleading it to an indictment, yet he may give it in evidence upon a not guilty, and he may be thereupon acquitted. R. v. Cotesworth, 6 Mod. 172, Mi. 526.

Wilh consent or by agreement to fight. whethel criminal, several cases, \$ 28. Wffect of consent obtained by fear, or fraud, or of a chlld, $\$ 20$. Fraudulent sexual intercourse by physician, whether an assault: R. v. Case, 20 . Giving "love powders" on lgs, whether an assault: C. v. Stration, 8 29. Hisband glving wife venereal disease by intereourse, an assault: $\mathrm{R}$. v. Clarence, $\mathbf{8 0}$.

(N. Car. Sup. Ct., 1871.) Rude Jostling and Shoving. Defendant was convicted of assault and battery and appeals. READE, J. The defendant went up to the prosecutor and said: "I once thought we were friends, but I understand you have said thus and so about me, and you have got to take it back." The prosecutor refused to take it back, "whereupon the defendant put his hand, open and flat, on the prosecutor's breast and pushed him back some steps, when he fell over a flour barrel." At first sight this seems to be so indisputably an assault and battery that ${ }^{*}{ }^{*}$ it is necessary to state the ingenious shifts of his learned counsel in presenting his case. 1. "It was at a country store, where politeness is not a commodity." Suppose this to be so, and make full allowance for country manners, still there may be "rudeness" at a country store; and if this was not, then rudeness cannot be. 2. "The hand 
was open." so it would have been if he had slapped his face. 3. "Whether it was 'rudeness' was a question for the jury-putting the hand on being an equivocal act, and might have been friendly." Suppose the facts testified to had been embodied in a special verdict, would it not have been for the eourt to say whether they made a case of guilty? Doubtless. 'The facts were not disputed, and therefore they had the same force as a special verdict. It is true that a laying on of the hand may be friendly, but here the defendant said, at the time, that it was not in friendship. "I once thought we were iriends," sind he. And he preceded the act by a threat. And the act itself was so violent and insolent as to make it unequivocal. At any rate if it was intended as an innocent familiarity, in consonance with country manners and local custom, it ought to hive been proved to have been so, by the defendant. The burden of proof was on him. Affirmed. S. v. Baker, 65 N. Car. 332, F. $24 \%$.

Justifel: by tencher, Hutton v. S., \& 66; Boyd v. S., \$ 66 ; Heritage v. Dodge, 866. IBy hushind benting wife: $S$. v. Oliver, 866 . By father tying up girl of 12 : Hinkle $v$.

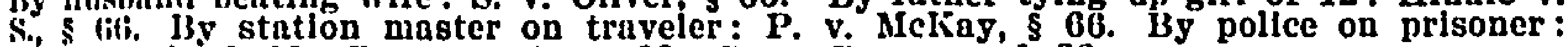
s. V. l'ugh, \$ 66 ; Burns v. S., \$66; S. v. IRoseman, \$ 66.

io dity on assaileal to retreat to avoid, but may stand and defend : $\mathbf{S}$. $\nabla$. Sherman, \$ (i!. No riglit to defend with deadly weapon: IR. v. Hewlett, \& 69 . All parties princtpals: Baker v. S., 875 .

(Ind. Sup. Ct., 1873.) Striking a Horse Being Driven. On trial 1or assault and battery it.was error to instruct the jury that if defendant struck the prosecutor or his horses while he was driving them in gathering corn, he was guilty. In giving the opinion of the court, BUSKIRK, J.. said: "The most accurate and complete definition of a battery that we have met with is that given by Saunders, and which has been adopted by most subsequent writers, and that is: 'A battery is an unlawful touching the person of another by the aggressor himself, or any other substance put in motion by him.' By this definition, it is an essential prerequisite that the person must either be touched by the aggressor himself or by the substance put in motion by him. There must be a touching of the person. One's wearing apparel is so intimately comnected with the person, as in law to be regarded, in case of a battery, as a part of the person. So is a came when in the hand of the person assaulted. But in the case under consideration, the court ignores all these things and instructs the jury to convict on proof alone of the striking of the horses of the prosecuting witness. It is not even necessary, according to this charge, that the prosecuting witness should have been in the wagon or holding the lines, or connected with or attached to the horses in any way. That Bein was driving his team and gathering his corn does not necessarily so connect him with the horses that the touching of the horses would be an assault and battery on him. He may have been, as is frequently done, driving his horses from one pile of corn to another, by words of command, without being in the wagon or having hold of the lines." Reversed, and new trial granted. Kirland v. S., 43 Ind. 146, 13 Am. Rep. 386, Kn. 207. 


\section{FALSE IMPRISONMENT.}

§99. "False Imprisonment is Any Unlawful Restraint of One's Liberty, whether in a place set apart for imprisonment generally or used only on the particular occasion, and whether between walls or not, effected either by physical force actually applied, or by words and an array of such forces." 1 Bish. Cr. L., \& 553.

liy captain transporting convicts: R. v. Leslle, \& 0 .

('Ienn. Sup. Ct., 1846.) Mere Arrogant Conduct. The defendant was indicted for an assault and false imprisonment. He was the kecper of a public ferry, and as such had carried over the Chucky river one Rodgers, with his horse and earryall. When over, the defendant demanded of Rodgers ferriage, which the latter said had been paid. The defendant told Rodgers he should not go on until he had paid the ferriage. Some other conversation ensued, when Rodgers paid the ferriage demanded. Rodgers testified on the trial that the defendant had not touched his bridle or his horse; that he made no efiort to strike or touch his person or his horse; and that he made no threats of personal violence; but that he was afraid of a difficulty with the defendant. The defendant was found guilty. and appealed. GREEN, J. * * * Although the defendant did not take hold of the prosecutor, or offer violence to his person, yet his manner may have operated as a moral force to detain the proseentor. And this appears the more probable as, after the affair was settled, the prosecutor inquired what defendant would have done if he had not paid the ferriage demanded, to which the defendant replied, "he would have put his carryall and horse back into the boat. and taken them across the river again." As this determination existed in his mind, it doubtless was exhibited in the manner of the defendant, and thus operated upon the fears of the prosecutor. Affirmed. Smith v. S., 7 Humph. 43, Mi. 534.

Robbery, though a lindred ofiense, is not treated under this head, because it involves lareeny also, which is yet to be considered. See post. $\S \S 146-149$.

\section{KIDNAPING.}

$\$ 100$. "Kidnaping is a false imprisonment aggravated by con. veying the imprisoned person to some other place." 1 Bish. Cr. L, $\S 558$.

That defendinnt was kidnneed ont of the state and brought here for trial: liar $\nabla$. Illinnis. \$ 90 ; Mahon v. Justice, \& 00 .

(Tex. Sup. Ct., 1848.) Indictment. After verdict of guilty on an indictment for kidnaping, motion in arrest of judgment was made, 
and overruling the motion was held erroneous; because the indictmeut did not charge an assault on prosecutor, nor that he was taken against his will. "The COURT said: "Kidnaping is defined to be, "the forcible abduction and conveying away of a man, woman or child, from their own country, and sending them to another.' 2 Tom. L. Dic. $335 ; 4$ Bl. Com. $219 ; 1$ East P. C. $430, \S 4$. This offense is treated as an aggravated species of false imprisonment. Roscoe on Ev. 465, 1 East P. C. 430 . And all the ingredients in the definition of the latter offense are necessarily comprehended in the former. These are: '1. The detention of the person. 2. The unlawfulness of such detention. Fvery confinement of the person is an imprisonment.' 'Unlawful, or' false imprisonment consists in such confinement or detention without sufficient authority.' 3 Bl. Com. 127, 1 T'om. L. Dic. 755. These essential elements in the definition of the offense must enter into the description of it in the indictment." Per WHEELER, J. Reversed. Click v. S., 3 T'ex. 282, Kn. 203.

\section{IMAIM.}

$\S 101$. Defined. "Such hurt of any part of a man's body whereby he is rendered less able, in fighting, either to defend himself or to annoy his adversary, is properly a maim. And therefore the cutting off or disabling or weakening a man's hand or finger, or striking out his eye or foretooth, or castrating him, are said to be maims; but the cutting off his ear or nose, etc., are not esteemed maims, because they do not weaken, but only disfigure him." 1 Hawkins P. C., c. $15, \S 1$.

(Muss. Sup. Judicial C Ct.. 1810.) Indictment for Burglary in Breaking and Entering to Cut Off the Ear of Fd. Dixon in his dwelling house at night. The prisoners demurred. PARSONS, C. J. The objection to the indietment is that the facts therein found do not amount to felony. The breaking and entering of a dwellinghouse in the night is not burglary unless it be done with an intent to commit a felony. 'This position the attorney general has not contested. The question for our decision then is. whether the cutting off the ear of Dixon, of set purpose and of malice aforethought, with the intention to maim and disfigure him, is by our laws a felony; for if it be not a felony, an intention to do it cannot be an intention to commit felony. That the cutting off an ear, maliciously and of set purpose, with the intention to maim and disfigure is not a mayhem by the common law, is not denied; but the attorney general has insisted that the statute of 1804 , c. 123, has made the cutting off the ear, with the disposition and intention aforesaid, a mayhem; that mayhem at eommon law is felony; and that, as a necessary conclu- 
sion, the cutting off the ear, maliciously and with the intention to maim and disfigure, is by foree of the statute a felony. By the ancient common law, mayher? was an injury of a particular nature, constituting a specific offense, the commission of which could be regularly averred by no circumlocution, without the aid of the barbarous verb mahemiare. It consisted in violently and unlawfully depriving another of the use of a member proper for his defense in fighting, and was punished by a forfeiture of member for member, in consequence of which forteiture it was deemed a felony. If the sufierer sought this satisfaction, or rather revenge, his remedy was by an appeal of mayhem; and the sovereign punished this injury done to his subject by an indictment for a mayhem; and in both the appeal and indictment the offense must be alleged to have been committed feloniously. A punishment of this description could have existed only in a rude state of civil society; and as eivilization advanced, the punishment was disused, and the offender made satisfaction by paying pecuniary damages and was punished by his sovereign by fine and imprisonment, in the same manner as in cases of trespass. So long ang was this punishment disused that Staundford, remarking on the statute of 5 H. IV. c. 5 , which made the putting out of an eye felony, observe that before that statute it was not felony. He however subjoins a quaere, and refers to Bracton. 'This was the state of the eommon law long before and at the time when our ancestors emigrated to this country, bringing with them but a very small part of the eommon law, defining crimes and their punishment. Miryem was therefore never deemed by them a felony, but only an argravated trespass at common law; and as such, the offender was answerable to the party injured in a civil action of trespass. and to the government upon an indictment for a misdemeanor; and no statute provision, during the existence of the colonial and provisional char. ters, recognizes mayhem as a distinct offense from trespass, or as constituting a specific felony. We are therefore obliged to consider mayhem as no felony by the common law adopted in this state.

* * Prisoners discharged. C. v. Newell, 7 Mass. 245, C. 482.

\section{RAPE.}

\$102. Defined Rape is a man's having unlawful carnal knowl. edge of a woman without her consent. Another woman or other person physically incompetent as principal in the first degree may be principal in the second degree, or a husband may be principal in the second degree to a rape on his wife by another man. $2 \mathrm{Bish} . \mathrm{Cr}$. L., $\S 1107-1136 ; 1$ Hale P. C. $628 ; 1$ Hawkins P. C., c. $16, \S 2 ; 4$ Bl. Com. 210.

Abandonment nfter attempt is no defense to prosecution for attempt: Glover $v(:$.

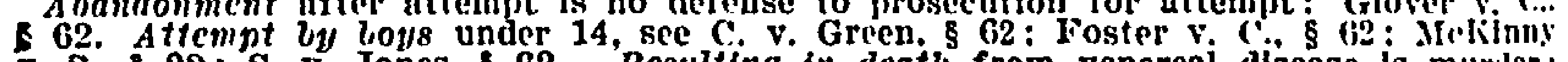
จ. S., \$ $82:$ S. v. Jones, \$62. Resulting in death from venereal disease is muriler: R. จ. Greenwood. \& 63 . 
(Eng. Central Crim. Ct., 1845.) While Insensible from Drink. Indictment for rape. It was proved, and the jury found, that the prisoner made prosecutrix (13 yean's old) quite drunk to excite her passion, not to render her insensible, but when she was insensible had intercourse with her. It was contended in behalf of the prisoner that the offense is not rape, because not aceomplished by force and against the will of the prosecutrix. After argument before Pollock, c. B., 'lindal, C. J., Denman, C. J., Patteson, Williams, Coltman, Coleridge, Wightman, Cresswell, and Earle. JJ.. and Alderson, Platt, and Rolfe, BBB., judgment was pronounced by PA'l'TESON, J.

* The prosecutrix showed by her words and conduct up to the last moment at which she had sense or power to express her will, that it was against her will that intercourse should take place. And it was by your illegal act alone, that of administering liquor to her to excite her to eonsent to your unlawful desires, that she was deprived of the power of eontinuing to express such want of consent. Whatever your origrimal intention was in giving her the liquor, you knew that it was calculated in its natural consequences to make her insensible, and you know also that it had produced that effect upon lecr at the time you took advantage of her insensibility. Your case, therefore, falls within the description of those eases in which force and violence constitute the crime. but in which frand is held to supply the want of hoth. ${ }^{*}{ }^{*} *$ Transported for life. R. v. Camplin, 1 Car. \& K. $7+6.1$ Den. C. C. 89. 1 Cox Cr. Cas. 220, 1 B. \& 11. 235 n, F. 228.

Iirunkenness of dofendant is no defense to a prosecution for rape (Burrow's Case. (5i) but on a prosecution for assnuit with intent to rnpe. It is competent proof to slicow inability to form any intent: Reagan v. S., \& 57 .

(Mass. Sup. Judicial Ct., 1870.) Same. GRAY, J. The defendint had been indicted and convicted for aiding and assisting Dennis Green in committing a rape upon Joanna Caton. The single exeeption taken at the trial was to the refusal of the presiding judge to rule that the evidence introduced was not sufficient to warrant a verdict of guilty. *** Green, with the aid and assistance of this defendant, had carnal intercourse with Mrs. Caton, without her previous assent, and while she was, as Green and the defendint hoth knew, so drunk as to be utterly senseless and incapable of consenting, and with such force as was necessary to effect the purpose. [After reviewing the decisions and legislation on the subject of rape, and referring to $R$. v. Camplin, above, as the leading case on this question, his honor continued.] We are, therefore, unanimously of opinion that the crime. which the evidence in this case tended to prove ** * was rape. If it were otherwise, any woman in a state of utter stupefaction. whether caused by drunkenness, sudden disease, the blow of a third person, or drugs which she had been persuaded to take even by the defendant himself, would be unprotected from personal dishonor. The law is not open to such 
a reproach. Exception overruled. Am. Rep. 531, B. 457, Kn. 199.

C. v. Burke, 105 Mass. 3i6, 7

(Ling. C. C. R., 182.2.) Consent Obtained by Impersonation. Jackson was convicted on an indictment of burglary with intent to rape, on proof that he went into the wornan's room and bed as if he was her husband, and was in the act of copulation when she discovered the fraud, and he immediately desisted. The jury found that he entered the house with intent to pass as her husband, not to use force, but to have connection if she did not discover the fraud. On case reserved eight of the judges thought having carnal knowledge of a woman under such circumstances was not rape, and four thought it was. DALLAS, C. J., pointed out forcibly the difference between compelling a woman against her will, when the abhorrence, which would naturally arise in her mind, was called into action, and beguiling her into consent. Severil of the eight judges intimated that if the case should occur again they wonld advise a special verdict. R. v. Jackson, Russell \& R. 487, 1 B. \& II. 234-n.

(Comn. Sup. (it. of Errors, 1828.) Same. Information for assiult with intent to rape. Defendant was convicted; and he moved in arrest of judgment, contending that the evidence proved rape, if any oftense, and the attempt was merged in the greater crime. and conviction on this charge would be no defense to a charge of rape. 'Jhe fincts were that the prosecutor was asleep, being much exhansted by broken rest, did not realize what defendant was doing till he had violated her person, at first thought it was her husband, and as soon as she became thoroughly awale and sensible to the situation sprang from the bed. The motion was denied because an acquittal on the present charge would be a defense to a charge of rape, and that the offense was worse than charged was no reason for not sustaining the conviction. S. v. Shepard, 7 Conn. 54.

('Temm. Sup. Ct., 1852.) Same. Appeal from conviction and sentence of death on indictment of three counts: 1, for burglary with intent to steal; 2, for burglary with intent to rape; and, 3, for assault with intent to rape. CARUTHERS, J. ** * It was proved that the prisoner forced the door of the dwelling honse of the prosecutor, in which he and his wife were sleeping, about 11 or 12 o'clock at night: that he approached the bed in which ther were sleeping and put his hand upon her, which aroused her from sleep, and she gave the alarm, when the prisoner fled, the prosecutor pursuing him with his dogs and gun, until he overtook, shot, and disabled him. The error alleged and relied upon for a new trial is in that part of the judge's charge to the jury, which is in these words: "If the jury believe that the defendant attempted, either by force, or by fraudulently inducing the prosecutor's wife to believe that it was her husband, and thereby to have earnal knowledge of her, that 
then they ought to find him guilty." * * * We agree with the attorney general that the moral turpitude of the crime would be as great when perpetrated by fraud and deception as by force. If we had the power to malie the law on that subject, we would not hesitate to have it as charged by his honor the circuit judge. *** The intent to commit a rape, or to make an assault with that intent, is a capital felony in a slave. But the intent is as essential as the act to constitute that felony; and to make out that felony, the intent must be to have the unlawful carnal knowledge of the woman, "forcibly, and against her will." ** * The current of authority is almost, if not entirely, unbroken on the subject. 'There is no respectable conflicting authority known to us. Fraud and stratagem, then, cannot be stibstituted for force, as an element of this offense, according to the existing law. *** Reversed. Wyatt v. S., 32 l'enn. (2 Swan) 394, C. 206.

(Eng. C. C. R., 1868.) Same. Defendant was convicted on indictment for rape. It was proved that prosecutrix was in bed with her husband, half asleep, and on realizing that someone was having connection with her, supposed it was her husband; whom she could not see, as a part of her dress was over her face; that she was completely aroused by his pushing away the baby she held on her arm and getting out of bed; whereon she pulled the dress from over her face, and first discovered that it was not her husband. No counsel appeared on either side in this court. BOVILL, C. J. We have carefully considered the facts as stated in this case. It does not appear that the woman, upon whom the offense was alleged to have been committed, was asleep or unconscious at the time when the act of councetion commenced. It must be taken, therefore, that the act was done with the consent of the prosecutrix, though that consent was obtained by frand. It falls, therefore, within the class of cases which decide that, where consent is obtained by fraud, the act done does not amount to rape. Channell, B., Byles, Blackburn, and Lush, JJ., concurred. Conviction quashed. R. v. Barrow, L. R. 1. C. C. R. 156, 38 L. J. m. c. 20,19 I. T. 293, 17 W. R. 102, 11 Cox. C. C. 191, B. 455 .

(Ir. C. C. R., 1884.) Same. MAY, C. J. The question which arises on the case is whether, in point of law, the prisoner should be considered as guilty of rape. There is not, I think, any doubt or dispute as to the facts and circumstances of the case. Upon the report of the judge, who was myself, and the findings of the jury, it is, I think, established that Judith Gorman, the wife of one J. Gorman, who was absent, having gone out to fish, lay down upon a bed in her sleeping room in the evening when it was dark; that the prisoner came into the room, personating her husband, lay down upon her, and had connection with her; that she did not at first resist, believing the man to be her husband, but that on discovering 
that he was not her husband, which was after the commencement but before the termination of the proceedings, her consent or acquies. cence terminated, and she ran downstairs. It appeared, I think manifestly, that the prisoner knew the woman was deceived, as she said to the prisoner in his presence and hearing when he came into the room, "You are soon home tonight," to which he made no reply. * * * There is no doubt that unlawful connection with a woman in a state of unconsciousness, produced by profound sleep, stupor, or otherwise, if the man knows that the woman is in such a state, amounts to a rape. The case which the court has to deal with is that of connection with a married woman obtained by personation of the husband while the woman is awake. On this point subtle distinctions have been drawn. The earliest reported case appears to be that of R. v. Jackson, Russ. \& R. 487 [above]. There the prisoner was convicted of burglary with intent to commit a rape on a married woman. It appeared in evidence that the prisoner got into the woman's bed as if he had been her husband and had partial connection with her. The case was considered by the twelve judges. Four of the judges thought having carnal knowledge of a woman while she was under the belief that the man is her husband would be a rape, but the other eight judges thought it would not. * * * The series of cases to which I have drawn attention appear to be an echo of the first case of $R$. v. Jackson. The others followed, no further argument being treated as necessary. Nevertheless, if the doctrine thus established had been adopted by the judges in England without objection, I do not think that this court should establish a different legal determination, unanimity on such points being of great importance. In its inception, however, that original case of $\mathbf{R}$. v. Jackson was dissented from by four of the twelve judges who heard it, while of the majority several apparently doubted the doctrine there contended for. In the case of $R$. v. Flattery all the judges desired that this doctrine should be reconsidered. In Ireland. until the present case, no similar question seems to have arisen; and it appears to me, under all the circumstances, that it is competent for us, and it is our duty, to consider the doctrine of those English decisions upon their merits. Now. rape being defined to be sexual connection with a woman without her consent. or without and therefore against her will, it is essential to consider what is meant and intended by consent. Does it mean an intelligent, positive concurrence of the will of the woman, or is the negative absence of dissent sufficient? In these surgical cases it is held that the submission to an act believed to be a surgical operation does not constitute consent to a sexual connection, being of a wholly different character; there is no consensus quoad hoc. In the case of personation there is no consensus quoad hanc personam. Can it be considered that there is a consent to the sexual connection, it being manifest that. had it not been for the deceit or fraud. the woman would not have sub. mitted to the act? In the cases of idiocy, of stupor, or of infancy, 
it is held that there is no legal consent from the want of an intelligent and discerning will. Can a woman, in the case of personation, be regarded as consenting to the act in the exercise of an intelligent will? Does she consent, not knowing the real nature of the act? As observed by Mr. Curtis, she intends to consent to a lawful and marital act, to which it is her duty to submit. But did she eonsent to an act of adultery? Are not the acts themselves wholly different in their moral nature? 'The act she permitted camnot properly be regarded as the real act which took place. 'Therefore the comnection was done, in my opinion, without her consent, and the crime of rape was constituted. I, therefore, am of opinion that the conviction should stand confirmed. ** * The other judges concurred. R. v. Dee, 15 Cox C. C. 579, 14 L. R. Ir. 468, C. 203.

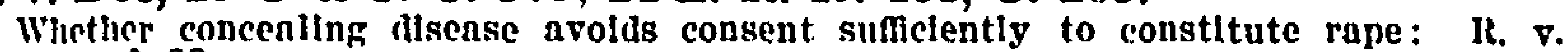
Clarence. \& 29.

(Mich. Sup. Ct., 1872.) Consent Obtained by Physician as Necessary Treatment. Defendant was convicted of rape on proof that he was employed by the father of a girl of 16 to treat her for consumption at defendant's house, that he made an examination, and told her it would be necessary to enlarge her parts to enable the "whites" to pass from her stomach, and to break ulcers; that this could be done by instruments, but would be painful and dangerous to life; that he could accomplish the same result without pain by having connection with her; that he did so with all women he treated; and that her father knew his purpose and assented to it, but if she did not consent he would have to use instruments which would probably prove fatal; all of which was false. 'The girl vielded to him because of these statements. Fxception was taken to the following instruction to the jury: "If you find that the defendant represented to the complaining witness that, as a part of his medical treatment, it was necessary for her to have carnal connection with him; that such representations were false and fraudulent; that she believed it and, relving upon it, consented to the solicitations of the defendant, and had connection with him; and that such representations were made for the purpose of inducing her to give such consent, and that without it she would not have yielded. the defendant is guilty of the crime charged against him." CHRISTIANCY, C. J. * * Section 5730, Comp. Laws 1857, declares. "If any person shall ravish and carnally know any female of the age of ten years or more, by force and against her will, ${ }^{*} * *$ he shall be punished," etc. In the interpretation of this statute it is clear. that the terms, "by force," must not be wholly rejected or ignored. but that some effect must be given to them; and the langliage of the provision certainly requires something more to be shown than if these words had been omitted; and it is equally clear that if that particular kind and amount of force only is required which is always essential to the act of sexual connection itself, when performed with the assent of the woman. then no effect whatever is given to 
the terms, "by force," but the interpretation and the effect of the statute will be precisely the same as if these words were not con. tained in it. 'This interpretation, therefore, is not permissible. Some effect must be given to the words; and such has been the almost, if not entirely, uniform course of decision, both in England and in this country, where the definition of the offense is substantially the same as that griven by our statute. *** I have not been able to find a single well authenticated case, where the question was directly raised, in which it has been directly decided the other way. * * When drugs are administered, or procured to be adminis. tered, by the criminal, for the purpose of taking away or lessening the power of resistance, and having that effect, there may be no ground for distinction between the force thus exerted by him through the ageney of the drugs, and that directly exerted by his hand and for the same purpose. *** * *nsidering the way, and the purpose for which, the girl had been placed by her father under the eare and treatment of the defendant, as her physician, the evidence had a tendency to show, and the jury might properly have found, that the girl was induced by the defendant to submit to the sexual intereourse with him, from the fear and under the appre. hension, falsely and fraudulently inspired by the defendant for the purpose of overcoming her opposition that, if she did not yield to such intercourse, he intended to, and would use instruments "for the purpose of enlarging the parts," and that such operation with instruments would be likely to kill her. And if the jury should so find-with or without the other facts submitted to them by the charge given-and that she would not otherwise have yielded. it would be their duty to find the defendant guilty of the erime charged. Campbell, J., concurred; Cooley, J.. concurred in the result; Graves, J., did not sit. Reversed. DonMoran v. P., 25 Mich. 356, 12 Am. Rep. 283-n, F. 230, Mi. 539.

Sinflar case: R. v. Case, \& 20.

(Mluss. Sup. Judicial Ct., 1886.) Consent of Child. Defendant was indicted under the statute for two separate assaults on girls under 10 years of age, with intent to abuse and carnally know them. Ile was eonvicted on both counts and excepts to the charge and refusal to charge. C. ALIISN. J. The chief argument for the defendant is that an indictment for an assiult upon a female child, under the age of 10 years, with intent to unlawfully and carnally know and abuse her, cannot be maintained without proof that the acts were done without her consent; that the carnal knowledge and abuse of a child is a special statutory offense, distinct from the crime of rape; and that the consent of the child is no defense to the sub. stantive crime, because the statute expressly so provides or implies, but is a defense to the assault with intent. because the terms of the statute do not extend to the assault. and because an assault con. sented to, is no assault in law; and there are many decisions. both 
English and American, some of which are cited, which sustain this defense. But it is not a valid defense in this commonwealth. The statutes upon which the case depends are as follows: Pub. St. c. 202, \$27: "Whoever ravishes and carnally knows a female of the age of ten years or more, by force and against her will, or unlawfully and curnally linows and abuses a female child under the age of ten years, shall be punished by imprisomment in the state prison for life, or for any term of years." $\$ 28$ : "Whoever assaults a female with intent to commit a rape shall be punished by imprisonment in the state prison for life, or for any term of years, or by fine," etc. *** It is contended, and there are many decisions elsewhere to support this ground of defense, that the assault is the gravamen of this offense, and that an assault must of necessity be against her will. 'This argument, however, involves a confusion in the use of the terms "against her will." Every rape involves an assault; and a rape, as well as an assault, must be against the will of the victim. But it has already been elearly established in this commonwealth that "against her will" means the same thing as "without her consent." C. v. Burke, 10j MLass. 376 [above].

* Exceptions overruled. C. v. Roosnell, 143 Mass. 32, 8 N. E. 747, C. $212,15.234$.

That chill's conscht is defense to indictment for assiult with intent to rape, though

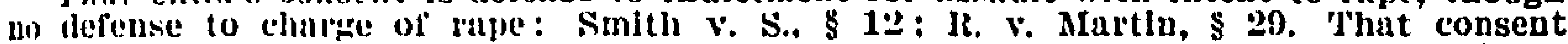
must be real and not from fear of father: $R$. V. Woodhurst, \& 2!). That consent is no defense though defentant supposed woman was of age. C. v. Murphy, 53.

(Aew York (ct. of Apl., 18Tt.) Resistance to Limit of Ability. Indictment for rape. The people appeal from the order of the gencral term reversing the judgment against defendant. FOLGER, J. * * 'The counsel for the prisoner asked the court to charge the jury that they must be sitisfied from the evidence, before finding the prisoner guilty; that the prosecutrix resisted him to the extent of her ability, on the occasion. The court declined to charge the jury in those words, but did charge that the act must have been done by force, and against the will and resistance of the prosecutrix, without saying how foreible and continued, or how feeble and yielding that resistance might be. T'he counsel excepted to the refusal to charge and to the charge as made. 'There is no error in the charge as made. *** Coupled with the refusal to charge as requested, it failed, however, to express all that it was necessiry for the jury to find. The resistance must be up to the point of being overpowered by actual force, or of inability from loss of strength longer to resist, or from the number of persons attacking, resistance must be dangerous or absolutely uscless, or there must he duress or fear of death. R. v. Hallett, 9 Car. \& P. 748; 1 Hawk. P. C., c. 41, \$2. In the case here, there is no evidence of inability from loss of strength longer to resist; there was but one for the prosecutrix to oppose. and he a man in years; there was no duress nor reason to fear death; there were no threats, instend thereof there were promises and words of 
palliation and persuasion; there was nothing to show that resistance was absolutely useless; she had possession of her faculties of mind and body, and retained her consciousness; she was then capable of resistance up to the point of being overpowered by actual force. * * * The request to charge is not beyond the limit of the rule. Certainly, if a female apprehending the purpose of a man to be that of having carnal knowledge of her person, and remaining conscious, does not use all her own powers of resistance and defense, and all her powers of calling others to her aid, and does yield before being overcome by greater force or by fear, or being surrounded by hostile numbers, a jury may infer that at some time in the course of the act, it was not against her will. *** Affirmed. P. v. Dohring, 59 N. Y. 374, 17 Am. Rep. 349, 1'. 226.

(Conn. Sup. Ct. of Lrrors, 18i7.) Same. PARK, C. J. ** * 'The defendant requested the court to charge the jury, that to constitute the crime of rape it was necessary that the prosecutrix should have manifested the utmost reluctance, and should have made the ut. most resistance. The court did not comply with this request, and the refusal to do so is made the ground for asking a new trial. While it may be expected in such cases from the nature of the crime that the utmost reluctance would be manifested, and the utmost resistance made which the cireumstances of a particular case would allow, still, to hold as matter of law that such manifestation and resistance are essential to the existance of the crime, so that the crime could not be committed if they were wanting, would be going farther than any well-considered case in eriminal law has hitherto gone. Such manifestation and resistance may have been prevented by terror callsed by threats of instant death, or by the exhibition of brital force which made resistance utterly useless; and other causes may have prevented such extreme opposition and resistance as the request mikes essential. The importance of resistance is simply to show two elements in the crime-carnal knowledge by force by one of the parties, and non-consent thereto by the other. These are essential elements, and the jury must be fully satisfied of their existence in every case by the resistance of the complainant, if she had the use of her faculties and physical powers at the time, and was not prevented by terror or the exhibition of brutal force. So far resistance by the complainant is important and necessary; but to make the crime hinge on the uttermost exertion the woman was physically capable of making, would be reproach to the law as well as to common sense. Such a test it would be exceedingly difficult, if not impossible, to apply in a given case. A complainant may have exerted herself to the uttermost limit of her strength, and may have continued to do so till the crime was consummated, still a jury, sitting coolly in.delib. eration upon the transaction, could not possibly determine whether or not the limit of her strength had been reached. They conld never ascertain to any great degree of certainty what effect the 
excitement and terror may have had upon her physical system. Such excitement takes away the strength of one, and multiplies the strength of another. * * The fallacy lies in the assumption that the deficiency in such cases necessarily shows consent. * * * * We do not advise a new trial. S. v. Shieids, t5 Comn. 256, Mi. 547.

\section{HONIICIDE.}

$\$ 103$. Definition and Classification. Homicide is the killing of a human being by a human being. Homicides are of two kinds: 1, justifiable or excusable (which we have considered, ante $\S \S 49-51$, 64.72); and, 2, felonious. Felonious homicide is homicide without justification or excuse, in which death results within a year and a day after the injury (3 Coke Inst. 47), and is either (1) murder or (2) manslaughter. Manslaughter is either (a) voluntary or (b) involuntary.

\section{$\$ 104$. Murder.}

Defined. Murder is homicide with malice aforethought: Malice aforethought is a technical term with a historic meaning in law entirely different from the popular meaning. In substance it is any state of mind and circumstances which in the history of the law has been held to render and, therefore, is now deemed to constitute, the homicide murder, spoken of as a mind depraved, devoid of a sense of social duty, and fatally bent on evil; but principally it is homicide: 1, premeditated and deliberate, as by lying in wait, poisoning, etc.; 2 , by any act intended to produce death and not done in the heat of extreme passion caused by sufficient provocation; 3 , by any act itself dangerous to life and showing a reckless disregard of human safety, as with a deadly weapon; 4, unintentionally resulting from an attempt to commit another felony; and 5, unintentionally in unlawfully opposing an officer or other person engaged in arresting or keeping custody of a prisoner. Degrees of murder are created by statute in most of the states, and 1 and 2, above, and some others, are made murder in the first degree. In some states there are three degrees of murder. Consult the statutes, also 2 Bishop C. L. $\$ 723$ et seq.

Intent to kill difforent verson: Saunders's (ase, \& 38 ; Gore's Case, \& 38. Staruation of child, if intentional, is murder: IR. $v$. Conde, $\$$ 33. Suicille intended: $c$. v. MIluk. \$38. Muress nnd necessity ns defense, \$\& 48-51. Rape resulting in death from venereal alsense is murder: $\mathrm{R}$. v. Greenwood, 803 . 
(ling. (Queen's Bench, 158T.) Homicide in Resisting an Officer. In this case it was held per totam curiam that if, upon an atfray, the constable and others in his assistance come to suppress the affray and preserve the peace, and in excenting their oftice the constable of any of his assistants is killed, it is murder in liw, although the murderer knew not the party that was killed. and althomgh the aftian was sudden; because the anstablo and his assistants came by authority of law to keep the pralee, and prevent the danger which might ensue by the breach of it: amb. therefore, the law will adjudge it mmeder. and that the murderere had malion prepronse. heanuse he set himself anainst the justion of the realm. So if the shorift ar ant of his bailifl's or other offieers is leillod in resenting the process of the law, or in doing their dinty. it is murder ; the same: law of a watehman, who is killied in the r.xuntion ul' his oftice. Yong's Case, 4 Coke ton, II. 4 (i).

(Jing. Old Bailuy. lifiti.) Punishment with Deadly Weapon. On trial of John (irey; at Ola Bailer, on 'indictment for murder, the jury foumd specially that the prisomel was a blacksmith, and commanded (iolding. his solvant. to mend some stralps, part of his trade; and, coming in. finding it not, dome. (imay asked why, and said if Golding wombl not serve him ho shomld serve in Bridewell : to which

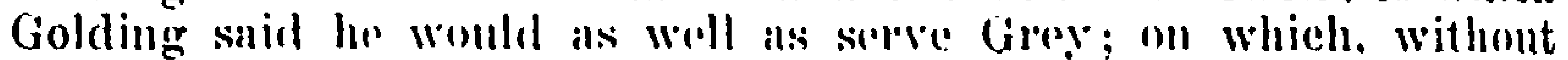
other provoration. (iley struck him with a bar of iron Grey had in his hand, on whioh ho ind folding were working at the anvil. 'Phis blow broke his skill and ho died: and if this was murder. Was the question. Ind lielyner, J.. who sat in the case, showed the special vereliet to all the judges of the king's hench. and to loord Bridrman. C. . . . of the rommon ploas; and they were all of opinion

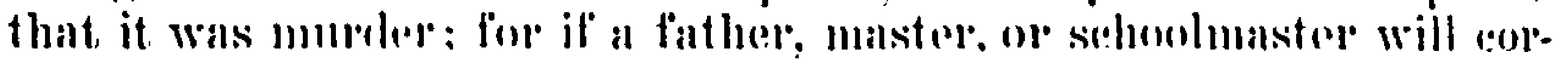
rect his child. servant. or seholar. they must do it with such things

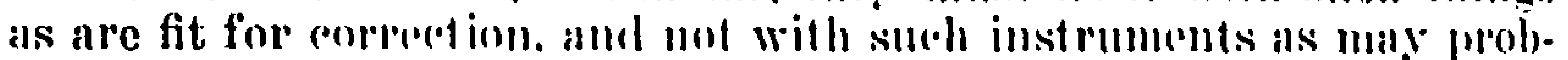

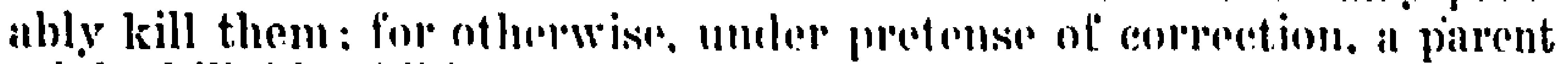
might kill his child. or a mastop his servant. or a schoolmaster his scholar: and a bar of iron is no instrument for eorrection. It is all one as if he had rum him through with a sword. 'The juderes remembered several cases at assizes in which like acts had been held mur. der. Therefore, when a master strikes his servant willingly with such things as these and death ansure the law will judere it of maliec prepense. But, for his gool repute, the prisoner in this case was given pardon by the king. on ropurest of thr eonut. Grey's Case, Kalyng 64, B. 463, Ko. 10i, Mli. 4(1).

(Eng. Old Bailer, 166-) Homicide of Peacemaker. On indictment for murder the jury found specially that Tomson and wife were fighting in Dawes's house, who. seeing them fighting. came in and endeavored to part them. whereon Tomson thrust him aside. and threw him on the iron ehimmey har, which kept the fire; and hy that 
a rib was broken, and he died. And Kelyng, J., who sat in the case, took the advice of Hyde, C. J., and Hales, B.; and they agreed in view of Yong's Case and Mackalley's Case, 9 Coke 65, "that if upon a sudden aftiray, a constable or watehman, or any that come in aid of them, who endeavor to part them, are killed, this is murder; and we hold likewise that if no constable or watchman be there, if any other person come to part them, and he be killed, this is murder; for every one in such case is bound to aid and preserve the king's peace. But in all those cases it is necessary that the party who was fighting and killed him that came to part them, did know or had notice given that they came for that purpose. As for the constable or other person who cometh to part them, to charge them in the ling's name to keep the kingr's peace, by which they have notice of their intents; for otherwise if two are fighting, and a stranger runs in with intent to part them, yet the party who is fighting may think he cometh in aid of the other with whom he is fighting, unless some such notice be griven as aforesaid, that he was a constable and came to part them; and that appeareth by Mackalley's case before cited, where in case of an arrest by a sergeant, it is necessary, to make it murder, that the sergeant tell him that he doth arrest, for else if he doth say nothing, but fall upon the man and be lilled by him, this is but manslaughter, unless it appear that the person arrested did know him to be a sergeant, and that he came to arrest him; for as the case is there put, if one seeing the sheriff or a sergeant whom he knoweth hath a warrant to arrest him, and to prevent it before the officer come so near as to let him know he doth arrest him, he shoots again at him, and kills him, this is murder; and in the principal case, though the jury find that Dawes came to part ine man and wife, ret it doth not appear whether it is found that Tomson knew his intent, nor that Dawes spake any words whereby he might understand his intention, as charging them to keep the king's peace, etc., and so we held it to be only manslaughter, which in law is properly chance-medley, that is, where one man upon a sudden occasion kills another without malice in fact, or malice implied by law." $\mathbf{R}$. v. Tomson, Kelyng 66, B. 462 .

(Fing. Assize at Newgute, 1674.) Homicide of Citizen in Pursuit of Felon. Five persons committed a robbery, the party robbed raised hue and ery, the country pursued, and at Hempstead, Jackson, one of the five turned upon his pursuers, the rest being in the same iield, and having often resisted the pursuers, and refusing to yield, killed one of the pursuers. By five judges *** it was ruled: 1. That this was murder; because the country, upon hue and cry levied, are authorized by law to pursue and apprehend the malefactors; and in this case here was a felony done, and a felony done by those persons that were thus pursued. 2. That, although there was no warrant of a justice of peace to raise hue and cry, and though there was no constable in the pursuit, yet the hue and cry was a 
good warrant in law for them to apprehend the offenders, and the killing of any of the pursuants by Jackson was murder. 3. Inasmuch as all of the robber's were of a company, and made a common resistance, and so one animated the other, all those of the company of the robbers that were in the same field, though at a distance from Jackson, were all principals, viz., present, aiding, and abetting. 4. That when one of the malefactors was apprehended a little before the party was hurt, that person being in custody when the stroke was given was not guilty, unless it could be proved that after he was apprehended he had animated Jackson to kill the party. 'They had all judgment of death for the robbery, and four of them for the murder. R. v. Jackson, 1 Hile P. C. 464.

(Engr. Maridstone Assize, 1838.) Wilfully Persisting in Dangerous Course-Following Fanatic. One 'lhom, a religious fanatic, of whom the defendants were adherents and followers, shot a constable in their presence; and on their trial for murder, as principals, this instruction was given to the jury by DENMAN, C. J. * * * It will be for you to say whether, from what was done by these men both before and after the killing of Nicholas Meares. they did not intend this general resistance to the law. In speaking of malice aforethought it is proper that you should know that that expression does not mean premeditated personal hatred or revenge against the person killed; but it means that kind of unlawful purpose which, if persevered in. must produce mischief, such as if accompanied with those circumstances that show the heart to be perversely wicked, is adjudged to be proof of malice prepense. ${ }^{*} *{ }^{*}$ Verdict, guilty. R. v. Tyler, 8 Car. \& P. (34 E. C. L.) 616, F. 116, Ke. 57.

Murder by poison given by innocent agent: Memo., 874 ; Vaux's Case, $\$ 74$.

(Mass. Sup. Judicial Ct., 1845.) Malice Defined-Burden of Proof of Provocation. Defendant was convicted of murder of $J$. Norton; and moved for a new trial on the ground that the court erred in directing the jury that if they found that he killed Norton by stabbing him to the heart with a knife, there is a presumption of malice in law to convict him of murder if nothing further is shown; and the burden of proof of matter of excuse (in this case, provocation) lies with the accused. In the opinion of the majority, written by SHA W, C. J., it was conceded that in cases of homicide by wanton and reckless negligence indicating a heart devoid of humanity and maliciously bent on mischief, the malice must be inferred from the circumstances, and the court might properly direct the jury to find manslaughter only, if there is a reasonable doubt on all the evidence whether malice is shown. But they held that when death is produced by an act intended to have that effect, or which would naturally and probably produce death or great bodily harm, as in this case. the act shows the malice, and the excuse must be shown by the defendant. Shaw, C. J., said: "But. however. suddenly any act 
is done, the intent to do it precedes the doing of it, and the act is done in pursuance of the intent and formed design. * * Otherwise, the suddenness of the mortal blow, on provocation, however slight, must exclude the implication of malice. But the law, in such cases, does impute malice to the act, because it does not consider the weight of the provocation such as naturally to arouse so violent a resentment; and as an act so violent and cruel camnot be attributed to a natural resentment, incident to the infirmity of human natureon which ground alone it can extenuate the homicide-it is necessinily attributed to malignity of heart. *** 'The natural and necessary conclusion and inference from such an act, wilfully done, without apparent excuse, are, that it was done malo animo, in pursuince of a wrongful injurious purpose, previously, though perhaps suddenly, formed, and is therefore "a homicide with malice aforethought,' which is the true definition of murder. And it appears to us, that this is not a forced, arbitrary, technical or artificial presumption of law, but a natural and necessary inference from the fact. * * Here the chief justice goes into an extended review of the anthorities and then concludes as follows]: [ have thus endeavored to establish the proposition, and it seems to be most abundantly proved, thist when the fact of voluntary homicide is shown, and this not accompanied with any fact of excuse or extenuation, malice is inferred firom the act; that this is a fact which may be controlled by proof; but the proof of it lies on the defendant; and if not so proved, it cannot be taken into judicial consideration.

* Now, whether it be regarded as a presumption, to be rebutted by proof, or a change of the burden of proof, or an inference of fact, to be controlled or disproved by evidence, as applied to this subject, it makes little difference. It is evidence of malicious homicide, which must have its effect, until the malice is disproved by satisfactory proof of circumstances of extemuation." *** WILD, J. (dissenting): * * In my opinion, the question depends entirely upon the rule of law as to the burden of proof. If the burden of proof, throughout the trial. was on the commonwealth, the instructions to the jury were clearly incorrect; if. on the contrary, it was on the prisoner. after the proof of the homicide. as charged, he has no ground of exception. * * * That the burden of proof was on the government. in the first instance, to prove all the essential facts alleged in the indictment, cannot be controverted. *** And how can the principle vary when a prima facie case is made out partly by presumption? If, on the whole evidence, the jury had a reasonable doubt of the prisoner's guilt as charged, they could not be justified in convicting him. ${ }^{*} * *$ Motion denied. C. v. York, 9 Metc. 93, 43 Am. Dec. 373, 7 Law Rep. 497, 2 B. \& H. 504-n. F. 179. $1 \mathrm{I} .676$.

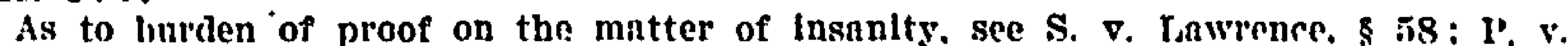
finibutt. $\$$ is: Hornish v. P., $\$ 58$.

(Conn. Sup. Ct. of Errors. 1873.) Deliberate Murder. Defendant 
was convicted of murder in the first degree, and excepted to the refusal of the trial court to submit the question of intoxication to the jury as bearing on deliberate killing. CARPEN'TER, J. ** * * 'The prisoner was indicted and on trial for murder in the first degree. * * A deliberate intent to take life is an essential clement of that offense. The existence of such an intent must be shown as a fact. Implied maliee is sufficient at common law to make the offense murder, and under our statute to make it murder in the second degree; but to constitute murder in the first degree, actual malice must be proved. Upon this question the state of the prisoner's mind is material. In behalf of the defense, insanity, intoxication, or any other fact which tends to prove that the prisoner was incapable of deliberation, was competent evidence for the jury to weigh. Intoxication is admissible in such cases, not as an excuse for crime, not in mitigation of punishment, but as tending to show that the less and not the grenter ofiense was in fact committed.

* New trial granted. Sermour, J., dissented. S. v. Johnson, 40) Conn. 136, B. 270, (.. 189.

That proof of drunkenness is competent to show lack of deliberntlon and as bearing on provocution, is held in several cases under $\$ 37$; also, s. v. Irecunts, $\$ 106$.

(New York (ct. of Apl.. 1858.) Same-Deadly Weapon-Sudden Impulse. HARRIS, J. 'That the defendant was guilty of some crime was conceded upon the trial. He had committed homicide. The act of killing was perpetrated with a deadly weapon. The only question to be determined hy the jury was whether the crime was murder or manslauginter. Upon the law applicable to this question the jury were properly instructed. They were told that if there was an intent to kill, even though that intent was concejved but the instant before the fital hlow was struck, the erime was murder. But if, on the other hand, the blow was struck in the heat of passion. without a design to effect death, the crime was manslaughter. 'This charge was unobjectionable. * * The defendant had struck a blow with a deadly weapon, which had resulted in immediate death. To this act the law, without further proof. imputed guilty design. If the perpetrator would escape the consequences of an act thus committed, it was incumbent on him to show either that he was incapable of entertaining such a purpose or that the act was committed under provocation. * * * Conviction affirmed. P. v. Rogers, 18 N. Y. 9. 72 Am. Dec. 484, 13. 264. F. 99, 2 T. 625.

(Mich. Sup. Ct., 1874.) Kick Regardless of Result. Appellant was convicted of murder on proof that he and deceased had lived tosether for several months; that on the evening of her death she had been on an errand in the neighborhood, and on her return. as she entered the front door of the barroom kept by appellant. she fell or was linocked to the floor; and while she lay there, he ordered her to get up, kicked her, and dragged her from there into a bedroom and left her; and there she died. He excepts to the instructions. CAMP. 
BLLL, .J. * * It will be found, by careful inspection of the charge, that the court specifically instructed the jury that, if Wellar committed the homicide at all, it would be murder, and not manslaughter, unless it was committed under such extreme provocation as is recognized in the authorities as sufficient to reduce intentional and voluntary homicide. eommitted with a deadly weapon, to that degree of crime. *** It is not necessaly in all cases that one held for murder must have intended to take the life of the person he sliy's by his wrongful act. It is not always necessary that he must have intended a personal injury to such person. But it is necessary that the intent with which he acted shall be equivalent in legral character to a criminal purpose aimed against life. Cienerally the intent must have been to commit either a specilic telony, or at least an act involving all the wickedness of a lelong. And, if the intent be direetly to procluee a bodily injury. it must be such an injur? as may be expected to involve serious conseguences, either periling life, or leading to gront hodily harm. There is no rule recognized as authority which will allow a convietion of murder where a fatal result was not intended. muless the injury intended was one of a very scrions chalacter which might naturally and commonly involve loss of life or grievons mischief. . Hoery assanlt involves bodily harm. But any doctrine which would hold avery assaliant as a murderer where death follows his act. would be barbandons and umreasonable. * * If respondent wilfully and violently kicked the decensed in such a way as he must have known would endanger her life, and her life was destroyed in that wa!: an ictual intention of killing would not be necessary, as in such ease the death would have been a result he might fairly be held to rearard as likely. **** Rerersed. Wellar v. P., 30 .1lich. 16, F. 173, Kn. 16:2, Mi. 306n.

(III. Sup. (1., 1883.) Malignant Temper-Throwing Beer-Glass. Appellant was convicted of murder of his wife. Ile came home at 9 p. m., intoxicated, covered with dirt. and carrying a pail of beer. His mother-in-law, wife, and daughter, sat at work about the table. IIis wife asked if he had fallen down. IIe said. "None of your busimess." She had the danghter get some water, and he washed. She then grot him some supper. He refused to eat. tried to throw a loaf of bread at her, a little later called for arsenic, and no reply being made, said he would kill her or she him. ITe asked for a fire; she said it was bed-time; he threw a tin quart measure at his daughter; the wife told the daughter to go to bed, took an oil lamp from tho table, and started for the door; he seized a heavy tumbler, threw it at the wife, hit and burst the lamp. covering her with burning oil; and seeing her on fire. made no effort to extinguish it; and of these injuries she died a few days later. The court instructed the jury that if appellant killed deceased he could not be convicted of murder unless he intended to kill or the circumstances show an abandoned and malignant heart in him. IIe excepts to the last 
clause of the instruction. SCHOLl'LlLD, J. * * We pereeive no objection to these rulings. Malice is an indispensable element to the erime of murder. But our statute, repeating the common-law rule, says, "Malice shall be implied when no considerable provocation appear's, or when all the circumstances of the killing show an abandoned and malignant heart." Rev. St. 18Tt, p. 3it, $\$ 140$. And hence it is said, "When an action unlawful in itself, is done with deliberation, and with intention of mischief or great bodily harm to particular's, or of mischief indiscriminately, fiall where it may, and death ensue, against or beside the original intention of the party, it will be murder." Whart. llom. tj. "* " It was utterly immaterial whether plaintiff, in error intended the glass should strike his wife, his mother-in-haw, or his child, or whether he had any specitic intent, but acted solely liom general malicious recklessness, disregarding any and all consequences. It is sufficient that he manifested a reckless, murderous dispositionin the language of the old books, "a heart void of social daty, and fatally bent on mischief:" $A$ strong man who will violently throw a tin quart measure at his daughter-a tender child-or a heavy beer glass in a direction that he must know will probably cause it to hit his wife, sufficiently manifests maliee in general to render his act murderous when death is the consequence of it. Ile may have intended some other result, but he is responsible for the actual re- sult. *** Aftirmed. IMayes v. P., 106 11l. 306. 46 Am. Rep. t;98, li. $17 \tilde{5}$.

(New York (t. of App., 188\%.) Deliberate. Appellant was convicted of murder in the first degree, and the judgment affirmed by the general term of the supreme court on error, and he again brings error, excepting to the trial court's charge as to the time required for deliberation to make murder in the first degree. DANFOR'III, J. * * * To bring the case within the statutory definition of murder in the first degree it was necessary that the crime should be "perpetrated from the deliberate and premeditated design to eff'ect the death of the person killed." Laws of 1873 , c. 644 , \$5. An act co-existent with and inseparable from a sudden impulse, although premeditated, conld not be deemed deliberate, as when under. sudden and ereat provocation one instantly, although intentionally, kills another. But the statute is not satisfied unless the intention was deliberated upon. If the impulse is followed by reffection, that is deliberation; hesitation even may imply deliberation; so may threats "gainst another and selection of means with which to perpetrate the deed. If, therefore, the killing is not the instant effect of impulse. if there is hesitation or doubt to be overcome. a choice milde as the result of thought. however short the struggle between the intention and the act, it is sufficient to eharacterize the crime as deliberate and premeditated murder. The charge upon this point was most favorable to the prisoner. After stating the statute 
(supra) the judge suid: "There must therefore be, in order to establish the crime of murder in the first degree, deliberation and premeditation; but there is no time prescribed within which these oper'ations of the mind must occur; it is sufficient if their exercise was accomplished when the deed was done resulting in the death." * " "For example," said the judge, "if I, having from any reason, it matters not what, an enmity toward another, should start from this point and walk to the corner of Chambers St., weigh in my mind, deliberate upon, and premeditate a deadly assault upon another, and at that corner, meeting there the person toward whom my thoughts were directed, I struck the deadly blow, that would be sufficient deliberation and sufficient premeditation to perfect the crime of murder in the first degree. ${ }^{*} *{ }^{*}$ In this there was no error. * * Judgment affirmed. Leighton v. P., 88 N. Y. 117, 13. 472 , C. 191. Mii. $610 \mathrm{n}$.

(Eng. Central Crim. Ct., 1887.) Phases of Malice Aforethought.Fire Set for Insurance. Serne and Goldfinch were indicted for the murder of two of Serne's sons. It was shown that one was an imbecile, on whom Serne had procured insurance; that he had insured his stock, furniture, and rent for much more than they were worth; that fires were discovered in several places in the house at the same time, in and near quantities of light combustibles; and that the body of one son was found in the basement, and the other near a window in the upper story, from which Serne, his wife, and daughters had eseaped to the roof of an adjoining building, from which they were rescued. STEPHEN, J.(to the jury) *** The definition of murder is unlawful homicide with malice aforethought; and the words malice aforethought are technical. You must not, therefore, construe them or suppose that they can be construed by ordinary rules of language. The words have to be construed accordingly to a long series of decided cases, which have given them mean. ings different from those which might be supposed. One of those meanings is. the killing of another person by an act done with an intent to commit a felony. Another meaning is. an act done with the knowledge that the act will probably cause the death of some person. Now it is such an act as the last which is alleged to have been done in this case: and if you think that either or both of these men in the dock killed this boy. either by an act done with intent to commit a felony, that is to say. the setting of the house on fire in order to cheat the insurance company, or by eonduct which. to their knowledge, was likely to cause death. and was therefore eminently dangerous in itself.--in either of these cases the prisoners are guilty of wilful murder in the plain meaning of the word.

* Therefore, gentlemen, if Serne and Goldfinch set fire to this house when the family were in it, and if the boys were by that act stifled or hurnt to death, then the prisoners are as much guilty of murder as if they had stahbed the children. I will also add, for my nwn 
part, that I think in so saying the law of England lays down a rule of broad, plain, common sense. *** Verdict, not guilty. R. Serné, 16 Cox. C. C. 311, B. 46.. C. 183, F. 177, Ke. 106, li. 600.

\section{$\S$ 105. Manslaughter Defined. Manslaughter is homicide without malice aforethought.}

31.6. Voluntary Manslaughter. It is intentional homicide com. mucted the heat of extreme passion induced by sufficient provocation.

(Cal. Sup. Ct., 18T4.) Voluntary. NILES. J. The Court instructed the jury as follows: "You will also observe that the difference between inurder and manslaughter is that in manslaughter there is no intention whatever either to kill or to do bodily harm. 'The killing is the unintentional result of a sudden heat of passion, or of an unlawf ul act committed without due caution or circumspection." This is elearly erroneous. Whether the homicide amounts to murder, or 'w manslaughter merely, does not depend upon the presence or absence of the intent to kill. In either case there may be a present intention to kill at the moment of the commission of the net. But - when the mortal how is struck in the heat of passion. excited by a quarrel, sudden, and of sufficient violence to amount to adequate provocation, the law, out of forbearance for thr weakness of human nature, will disregard the actuil intent. and will reduce the offense to manslaughter. * * * Reversed. P. v. Freel, 48 Cal. 436. F. ¡96, Kn. 176 .

(Engr. Resolution of the Judges. 1666.) Provocation-Words. All the judges of Fingland met at Serjeant's Inn to ennsider such points of law as might fall out on the trial of Jord Morly by his peers on the next Monday; and several things were resolved innmimously: "T. Agreed, that no words, be they what they will, are in law such provocation as, if a man kill another for words only, will diminish the offense of killing a man from murder to be manslaughter: as suppose one call another son of a whore, or give him the lie, and thercupon he to whom the words are given, kill the other, this is murder. But if upon ill words, both the parties suddenly fight, and one kill the other. this is but manslanghter. for it is a combat hetwixt two upon a sudden heat, which is the legal description of manslanghter: and we were all of opinion that the statute of 1 Jac. for stabbing a man not having first struck, nor having any weapon drawn. was only a declaration of the common law, and made to prevent the inconveniencies of juries, who were apt to believe that to be a provocation to extenuate a murder which in law was not. 8. Agreed. that if upon words two men arow to anger. and afterwards they suppress 
that anger, and then fall into other discourses, or have other diversions for such a space of time as, in reasonable intendment their heat might be cooled, and some time after they draw one upon another, and fight, and one is lkilled, this is murder, because being attended with such circumstances as it is reasonably supposed to be a deliberate act, and a premeditated revenge upon the first quarrel; but the circumstances of such an act being matter of fact, the jury are judges of those circumstances. Lord Morly's Case, Kelyng 53, B. 473.

(Eng. C. O. R.. 1666.) Same-To Rescue from Illegal Arrest. On indictment for murder at Newgate, the jury found specially, that John Berry and two others impressed a man to serve in his majesty's war's with the Duteh, but without warrant; that the impressed man wont quietly with them into Cloth-fair; where IIuggett and three other's pursued them, inquired to see their warrant, and on seeing it sild it was no warrant, and immediately drew their swords to rescue the man, and did thrust at Berry; and he and his company thereon drew their swords and fought; and IIuggett killed Berry. All the judges of England being together at Serjeant's Inn on other business, were desired to grive their opinions in this .case. whether it be murder or manslaughter. And having notes of the verdict three days before, Bridgman, C. J., Hales, C. B3., Atkens, 'I'yrell, Browne, Turner, Archer, and Rainsford, gave their opinion that it was no murder, but only manslaughter; and they said that if a man was unduly arrested by three men, although he be quiet himself, and do not endeavor any rescue. yet this is provocation to all othe" men of Fngland, not only his friends but stranger's also, for ..... ion humanity's sake, to endeavor his rescue; and if in such en ieavor they kill one, it is but manshuughter. But Kelyng, Morton, 'Twisden, and Windham, J.J.. Were of opinion that this was murder; for if no words are provocation. as ruled in M[orly's Case, it is not sufficient provocation to see a stranger go willingly under false arrest: and they thonght it dingerous to encourage private men to take on themselves to assert of nther men's liberties, where the courts are open to establish men's rights by peaceable means. Bnt if persons called spirits take a person to carry him away, and thereunon a tomult is raised, and several persons run in, and a man is lkilled in the fray, they held this would be but manslaughter. After this difference of opinion, the case was removed to the king's bench on certiorari; and although all the judges of the court were clearly of opinion that it was murder. yet it heing a case of life. did not think it prudent to give him judgment of death. but admitted him to his clergy; and after he had read. and was burnt in the hand, ordered him to lie in jail 11 montis withont bail. and then till he find sureties for good brhavior for life. Huggett's Case, Kelyng 59. B. 474.

(T. g. C. C. R.. 1825.) Same-Illegal Arrest. The prisoner was 
convicted of stabbing with intent to murder, on proof that he was a journeyman shoemaker, left a place without tinishing his work, taking his tools with him, against the protest of the man for whom he was working, who went after him with a constable to arrest him, and finding him at a public house, said to the constable: "I'hat is your man; 1 give you charge of him." And the constable said: "My good fellow, your master gives me charge of you; you must go with me." On which the prisoner, without saying anything, presented a knife, and stabbed the constable under the left breast and struck three other blows, which the constable parried off, and ained a blow at the prisoner's head, whereon he ran away. In Hilary term, 18:5, all the judges (except Best, L. C. J., and Alexander, L. C. B., who were absent) met and considered this case. 'The majority of the judgres, viz.: Abbott, L. C. J., Graham, B., Bayley, J., Park, J., Garrow, B., Hullock, B., Littledale, J., and Gaselee, $J$., held that as the actual arrest would have been illegal, the attempt to make it when the prisoner was in such a situation that he conld not get away, and when the waiting to give notice might have enabled the constable to complete the arrest, was such a provocation as, if death had ensued, would have made the case manslaughter only, and that therefore the conviction was wrong. But, Holroyd, J., and Burrough, J., thought otherwise. R. v. Thompson, 1 Moody C. C. 80, B. 477 , ᄂ. 174 .

Shooting a constable unlawfully breaking house to arrest was ruled manslaughter: cook's Case, \$ 70 ; creighton v. C., \$ 64 .

(Eng. King's Bench, 16i1.) Same-Caught in Adultery. A committed adultery with the wife of $\mathrm{C}$, who came up and took them in the very act, and with his staft $\mathrm{C}$ killed the adulterer on the place; and this was ruled manslaughter, and neither murder, nor under privilege of se defendendo; but if $A$ had been taken by $C$ in the very attempt of rape upon the wife, and she erying out, her husband had come and killed $A$ in the act of ravishment, it had been within the privilege of se defendendo, because, it was a felony. When he was to be burnt in the hand, the court directed it to be clone gently, because they said there could not be a greater provocation. Manning's Case, 1 ilale P. C. 486.

Kicking such visitor to death: Wild's Case, $\$$ io. No duty to retrent from attack of man seeking adultery : Alberty v. U. S., $\$ 71$. See also Maher v. ${ }^{2}$., below.

(Eng., Old Bailey, 1704.) Same-A Blow in Face Drawing Blood. There being an affray in the street, one Stedman, a footsoldier, ran hastily towards the combatants. A woman seeing him run in that manner cried out, "You will not murder the man, will you?" Stedman replied, "What is that to you, you bitch?" The woman thereupon gave him a box on the ear, and Stedman struck her on the breast with the pommel of his sword. 'The woman then fled, and Stedman pursuing her stabbed her in the back. Holt was at first of opinion that this was murder, a single box on the ear from a 
woman not being a sufficient provocation to kill in this manner, after he had given her a blow in return for the box on the ear; and it was proposed to have the matter found specially; but it afterwards appearing in the progress of the trial that the woman struck the soldier in the face with an iron patten, and drew a great deal of blood, it was holden clearly to be no more than manslaughter. The smart of the man's wound, and the effusion of blood might possibly keep his indignation boiling to the moment of the fact. $\mathbf{R}$ : v. Stedman, Foster C. L. 292, B. 477.

(Ga. Sup. Ct., 1889.) Same-Mere Words. The wife, merely to irritate, vex, and insult her husband, told him he was not the father of their children, and he, provolied by her words and the animus with which they were uttered, killed her. Though in a sudden heat of passion, it was held murder. An instruction that the fact that the wife was unchaste or otherwise a bad woman would not justify homicide, nor would it, in the absence of a sudden heat of passion resulting from adequate cause, tend to reduce the homicide below the grade of murder, was held correct. Conviction afirmed. Fry v. S., 81 Ga. $64 \overline{0}, 8$ S. E. 308.

In a similar case the point of provocation was left to the jury. who convicted of man sloughter. R. v Rothwell (1871, at assize) 12 Cox C. C. 145, B. 481.

(Ky. Ct. of App., 1889.) Same-Recent Injury to Daughter. It appenred that defendint, having heard that his daughter was being abused and driven from her home by her husband, which he knew was a frequent occurrence, and had happened the day before, took a pistol, and hurried to their home, where he met the husband, and, after some words between them, shot him. 'The court charged that if the killing was in sudden passion, produced by considerable provocation, such as a blow, etc., it was manslaughter. Held error, as failing to recognize the relation of the parties; and the court should have instructed that, if the daughter was beaten by deceased so as to endanger her life, on the day before and on the night of the killing, and defendant knew of it, he had a right to arm himself and go to her protection; and if he found the wife and children driven from home by deceased, and, suddenly meeting deceased, in sudden heat and passion, caused by the treatment of the wife, he shot deceased, when not necessary in self-defense. and without malice, he was guilty of manslaughter. Campbell v. C., $88 \mathrm{Ky} .402$. 11 S. W. 290, 21 Am. St. Rep. 348.

\section{(N. Car. Sup. Ct., 1839.) Induced Provocation-Loss of Reason.} Indictment for murder. The killing is not denied. Accused had been on bad terms with deceased for some time; some months before said that he would kill deceased if he did not quit troubling; bought a 12-inch knife a week before, saving that he might kill someone with it yet; went to Edwards's house intoxicated; and later the same day the deceased came there intoxicated. The quarrel was 
soon renewed. The accused followed deceased through one of the rooms of the house, both having knives drawn. Later accused caught deceased by the vest, saying: "Let us talk it over;" to which no reply being made, he struck deceased with his hand, not a very severe blow; whereupon deceased pulled out his knife, and strucls accused three times, once lightly on the arm, the other's across the abdomen and more severe. 'Then aceused jumped back, pulled out his linife, exclaimed, "Damn him ! he has killed me, and I will kill him if I can!" stepped forward and gave a thrust with great force, which proved fatal. Verdict, guilty. Defendant complains of the instructions to the jury. The court instructed: 1 . If the prisoner sought the provocation, by giving the first blow, in order to afford him a pretense for wreaking his vengreance, or with the design of using his linile, it is a case of: murder. 2 . If the prisoner gat re the first blow, and was then eut ly the deceased, although he may have breen agitated by resentment and anger, yet if the jury collect from what he said and did, when or just before he gave the mo:tal blow, that in fact he was possessed of deliberation and rellection, so ats to be sensible of what he was then abont to do. and intentionally did the act, it was a case of murder. * * * $*$ The supreme court appproved the first instruction, silving: "Such craft, indeed, would but the more strongly indicate a hoart fatally bent on mischief." But the second instruction was held erroncous, because provocation to reduce an intended homicide to manslatughter need not produce such violent anger as to destroy consciousness. GAS'TON, J., said: "When an assault is returned with a violence manifestly disproportionate to that of the assalult, the chalracter of the combat is essentially changed, and the assiulted becomes in his turn the assailant. Such, according to the case, was the state of this atfray when the mortal wound was given. To avenge a blow, the deceased attacked the prisoner with a knife-made three cuts at him, and gave him a severe wound in the abdomen. If instantly thereupon, in the transport of passion thus excited, and withont previous malice, the prisoner killed the deceased. it would have been a clear case of manslaughter; not because the law supposes that this passion made him unconscious of what he was about to do, and stripped the act of killing of an intent to commit it. but because it presumes that passion disturbed the sway of reason, and made him regardless of her admonitions." Reversed. S. v. Hill, 4 Dev. \& Bat. 491, $34 \mathrm{Am}$. Dee. 396, F. 193, 1 J. 199, Mi. 618.

(S. Car. Ct. of App. and Firrors, 18+2.) Actual Cooling or Time for It. Defendant was convicted of murder. Deceased and two others found him lving in the road at night, drunk, and aroused him; on which he was very angry, cursed, demanded a fight, would take no apology, had the fight till he begged, was released; after deceased had gone 225 yards, swore he would gut deceased, drew his knife, came up to deceased (who had hastily seized a rotten piece 
of rail for defense), and (when the stick broke) stabbed him to the heart. Exception is taken to the charge of the court to the jury on the question of cooling, that whether the interval between the first and second combats offered sulficient time for a reasonable man to cool was the test, not whether defendant had cooled. WARDLAW, J. * * "If, from any circumstance whatever, it appear that the party reflected, deliberated, or cooied any time before the fatal stroke given, or if, in legal presumption, there was time, or opportunity for cooling, the killing wiil amount to murder." 1 East P. (.. 25:, 1 Russ. Crimes 44\%. "Provocation will not avail, how grievous soever it may have been, if it appears that there was an interval of reflection, or a reasonable time for the blood to have cooled, before the deadly purpose was effected." 1 Russ. Crimes 423. Whether the lapse of time be taken as only evidence of cooling, or as a substitute for it, which takes away the peculiar indulgence of the law for sudden transport of passion, it was proper to submit the question in the double form-Did the prisoner cool, or was there reasonable time for his cooling? An affirmative answer to either of which would be fatal to his attempt at mitigation. * * - Was he cool: means not was there in fact a gentle flowing of the blood which had been hurred in its circulation, but means, was there, in law, malice in his act; and the reasonable time is then not mere evidence of actual cooling, or cooling in its popular sense, but is, in itself, a circumstance which, in law, stands in place of such ictual cooling. and is equally significant of malice. He who has received a sufficient legal provocation, such as might have mitigated to manslaughter a mortal blow proceeding from it and given instantly, would not be less than a murderer, if he should remain in apparently undiminished fury for a length of time unreasonable under the circumstances, and then kill. By lashing himself into greater fury by outward demonstrations of passion, no one should obtain upon trial any advantage over another. who, in like circum-stances, should in reasonable time master his passions, or at least: cover with a calm exterior the fires which inwardly consume him. * * * In all cases where the time of cooling may be considered, whether the time be regarded as evidence of the fact of cooling, or as constituting. of itself, when reasomable, legal deliberation, the whole eircumstances are to be faken into the estimate. in determining whether the time be reasonable. 'The nature of the provocation, the prisoner's physical and mental eonstitution, his condition in life and peculiar situation at the time of the atfair. his aducation and habits (not of themselves voluntary preparations for crime), his conduct, manner, and conversation throughout the transaction; in a word, all pertinent circumstances may be considered, and the time in which an ordinary man, in like circumstances, would have cooled. is the reasonable time. * * * But a majority of the court are of opinion that a proper view of this case exclucles all consideration of time. Here was neither a sudden combat, nor an unplemeditated 
attack upon sufficient provocation; but here was a combatant who, by" his own ery for perace, had obtained release from the grasp) of liis adversary, and the subse(puent taking of the deadly knife, with murderous threats, and pursuit of the unarmed foe, were acts of treachery and malignity, which rendered the execution of the threats malicions, and deprived heat and passion of their mitigating influence. * * Nifirmed. S. v. McCants, 1 Speill 384, F. 19T, Mi. 621.

That drunlichurss may he shown as bearing on provocation and dellberation, but not

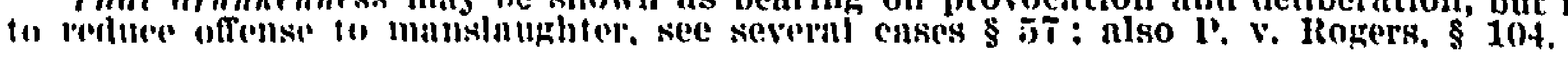

(Alich. Sup. ('t.. 186..) Adultery Suspected-Cooling Time. Ap)pellant was convieted of assault with intent to kill and murder, and excepts to the puling of the court below in excluding evidenee offered by him tending to show that his wife had eommitted adultery with the man assiulted. (MIRISTlANCY. o. *** If the homicide, in case death had ensiled. would have been but manslaughter, then defendant could not be groilty of the assiult with intent to murder. but only of a simple assinlt and battery. *** If the act of lilling, though intentional, he eommitted under the influence of passion, or in heat of hlond. produced hy an adequate or reasomable provocation, and before a reasomable time has elapsed for the blood to cool and reason to resume its habitual control. and is the result of the temporary excitement, by which the control of reason was disturbed, rather than of any wickedness of heart or eruelty or recklessness of disposition, then the law, ont of indulgenee to the frailty of human nature, or, rather. in recognition of the laws upon which human nature is constituted, very properly regaids the offense is of a less heinous character. than murder. and gives it the designation of manslaughter. 'lo what extent the passions must be alroused, and the dominion of reason disturbed. to reduce the offense from murder to manslaughter, the cases are by no means agreed. *** The principle involved in the question, and which I think clearly deducible from the majority of well-considered cases, would seem to sugrgest as the trite general rule that reason should, at the time of the act, be disturbed or obscured by passion to an extent which might render ordinary men, of fair averace disposition, liable to act rashly, or without due deliberation or reflection, and from passion, rather than judgment. *** In determining whether the provocation is sufficient or reasonable, ordinary human nature, or the average of men recognized as men of fair average mind and disposition, should be taken as the standard-unless. indeed, the person whose guilt is in question be shown to have some peculiar weakness of mind or infirmity of temper. not arising from wickedness of heart or cruelty of disposition. * * * The judge, it is true, must. to some extent, assume to decide; * * * but, if the alleged provocation be such as to admit of any reasonable doubt, whether it might not have had such tendency, it is much safer, I think, and more in accordance with principle, to let the evidence go to the jury 
under the proper instructions. *** It remains only to apply these principles to the present case. The proposed evidence, in connection with what had already been given, would have tended strongly to show the commission of adultery by Hunt with the prisoner's wife, within half an hour before the assault; that the prisoner suw them going to the woods together, under circumstances calculated strongly to impress upon his mind the belief of the adulterous purpose; that he followed after them to the woods; that Hunt and the prisoner's wife were, not long after, seen coming from the woods; and that the prisoner followed them, and went in hot pursuit after Ilunt to the saloon [where the assault was made], and was informed by a friend on the way that they had committed adultery the day before in the woods. I cannot resist the conviction that this would have been sufficient evidence of provocation to go to the jury, and from which, when taken in connection with the excitement and "great perspiration" exhibited on entering the saloon, the hasty manner in which he approached and fired the pistol at IIunt, it would have been competent for the jury to find that the act was committed in consequence of the passion excited by the provocation, and in a state of mind which, within the principle already explained, would have given to the homicide, had death ensued, the character of manslaughter only. * * * Martin, C. J., and Campbell, J., concurred. MIANNING, J. I differ from my brethren in this case. I think the evidence was properly excluded. 'To make that manslaughter which would otherwise be murder, the provocition-I am not speaking of its sufficiency, but of the provocation itself-must be given in the presence of the person committing the homicide. **** Any other rule, in an offense so grave as taking the life of a fellowbeing. in the heat of passion, I fear, would be more humane to the perpetrator than wise in its eftects on society. *** Reversed. Maher v. P., 10 Mich. 212, 81 Am. Dec. 781, B. 482, F. 202, Kn. 177.

$\$ 107$. Involuntary Manslaughter. It is homicide committed unintentionally in attempting to do an unlawful act not felonious, or resulting from criminal neglect of duty, misfeasant or nonfeasant.

I3y omission of legnl duty-several cases in \$11. By reckless blcycle rialng: Jnhn. son v. S., $\$$ 12. By lllegally keeping fireworks materinl in the elty: $R$. v. Ben.sett. 814 .

(Eng. Old Bailey, 166t.) A Man Found a Pistol in the street, which he had reason to believe was not loaded, having tried it with the rammer; he carried it home and showed it to his wife; and she standing before him he pulled up the cock, and touched the trigger. 'The pistol went oft' and killed the woman. This was ruled manslaughter. R. v. Rampton, Kelyng 41 .

(Eng. Assize, 17-) Didn't Know It was Loaded. I once upon the circuit tried a man for the death of his wife by the like accident. 
Upon a Sunday morning the man and his wife went a mile or two from home with some neighbors, to take a dinner at the house of their common friend. He carried his gun with him, hoping to meet with some diversion by the way; but before he went to dinner he discharged it and set it up in a private place in his friend's house. After dinner he went to church; and in the evening returned home with his wife and neighbors, bringing his gun with him, which was earried into the room where his wife was, she having brought it part of the way. He, taking it up, touched the trigger; and the gun went off and killed his wife, whom he dearly loved. It came out in evidence that, while the man was at church, a person belonging to the family privately took the gun, charged it and went after some game; but, before the service at church was ended, returned it, loaded, to the place whence he took it, and where the defendant, who was ignorant of all that had passed, found it, to all appearance, as he left it. I did not inquire whether the poor man had examined the gun before he carried it home; but being of opinion, upon the whole evidence, that he had reasonable grounds to believe that it was not loaded, I directed the jury that if they were of the same opinion they should acquit him. and he was acquitted. Foster, C. L. (1Dd. 2) 265 .

(Iowa Sup. Ct., 1878.) Didn't Know It Would Shoot. Defendant was indicted for murder in the second degree, and convicted of manslaughter. One day a neighbor woman called where he boarded, and as she came into the room he struck the door with a tackhammer. She said: "I thought it was a revolver." When she went out into the yard, he said he would frighten her with the revolver, which they had often tried to discharge and could not, and which the family generally considered harmless. He went out; the report of the revolver was heard; he returned, exclaiming: " $\mathrm{Ny}$ God, Hannah, come and see what I have done!" They went out and found the woman dying, with a shot wound in the head. Defendant insists that there was no such carelessness as to render the act criminal; that it was mere misadverture, and excusable; and he objects to the instructions to the jury, in substance that if he used a dangerous and deadly weapon in a careless and reckless mamner, and so killed deceased. it is manslaughter, though he intended no har'm. RO'THROCK, C. J. * * * That the revolver was in filat a deadly weapon is conclusively shown by the terrible tragedy consequent upon defendant's act in firing it off. If it had been in fact unloaded, no homicide would have resulted, but the defendant would have been justly censurable for a most reckless and imprudent act in frightening a woman by pretending that it was loaded. and that he was about to discharge it at her. No jury would be warranted in finding that men of ordinary prudence so conduct themselves. On the contrary, such conduct is grossly reckless and reprehensihle. and without palliation or excuse. Human life is not to be sported 
with by the use of firearms, even though the person using them may have good reason to believe that the weapon used is not loaded, or that being loaded it will do no injury. When persons engage in such reckless sport they should be held liable for the consequences of their acts. * * * Affirmed. S. v. Hardie, 47 Iowa 647, 29 Am. Rep. 496, F. 210, Ke. 123, Kn. 184.

"If a Physician or Surgeon gives a person a potion without any intent of doing him any bodily hurt, but with an intent to cure or prevent a disease. and, contrary to the expectation of the physician, it kills him, this is no homicide; and the like of a surgeon." 1 Hale P. C. 429 .

(ling., Old Bailey, 180T.) Midwife-Malpractice. The prisoner, a man midwife, tore away a part of the prolapsed uterus of a woman whom he had delivered of a child, supposing it to be a pait of the placenta; the woman died, and he was indicted for murder and manslaughter. LORD ELLENBOROUGH, C. J. (in summing up): There has not been a particle of evidence adduced which goes to convict the prisoner of the crime of murder; but still it is for you to consider whether the evidence goes so far as to make out a case of manslaughter. T'o substantiate that charge, the prisoner must have been guilty of criminal misconduct, arising either from the grossest ignorance or the most criminal inattention. One or other of these is necessary to make him guilty of that criminal negligence and misconduct which is essential to make out a case of manslaughter. * * Verdict, not guilty. R. v. Williamson, 3 Car. \& P. (14 E. C. L.) 635 .

(NIass. Sup. Judicial Ct., 1809.) Malpractice of Physician. Defendant, a physician, was indicted for murder because of the death of a patient. The court eharged the jury that, "if one, assuming the character of a physician. through ignorance, administer medicine to his patient, with an honest intention and expectation of a cure, but which causes the death of the patient. he is not guilty of "a felonious homicide." C. v. Thompson, 6 Mass. 134. (This case was followed in 1844 in Rice v. S.. 8 Mo. 561.)

(Eng. Assize, 1867.) Same. An Arsenical Ointment being furnished by a quack doctor for treatment of a tumor, without caution as to danger from excessive use of it, and death having resulted from that cause, he was indicted for manslanghter. BLACKBURN, J., to the jurv: If the prisoner by culpable negligence had caused the death of the deceased woman he was guilty of manslaughter : but the mere fact that death had occurred through mistake or misfortune would not be enough, or no medical man would be safe. There must, however, be competent knowledge and care in dealing with a dangerous drug. and if the man either was ignorant of the nature of the 
drug he used or was guilty of gross want of care in its use, there wouldi ie criminal eulpability. ** Not guilty. R. v. Cham. berlin, 10 Cod C. C. 486, B. 187 , C. 172.

(lowa Sup. Ct., 1876.) Same. Defendant, a physician, called to attend childbirth, was indicted and convicted of manslaughter in eausing the death of the child. 'The court instructed the jury that "if the ehild is fully delivered from the body of the mother, while the afterbirth is not, and the two are connected by the umbilical cord, and the child has independent life, no matter whether it has breathed or not, or an independent circulation has been established or not, it is a humal: being, on which the crime of murder may be perpetrated." * * 'The giving of this instruction was assigned as error. and was held erroneous, because if independent life without independent circulation and respiration is possible, there is no way 1. proving that such possibility existed, and the finding would be mere conjecture. Reversed. S. v. Winthrop, 43 Iowa 519, $22 \mathrm{Am}$. Rep. 257, F. 165, Ku. 117 .

(Ark. Sup. Ct., 1882.) Same. 'l'he state appeals from the judgment of the court below sustaining a demurrer to an indietment. ENGLISH, C. J. * * * The indictment charges, in substance. that appellees, holding themselves out as physicians, cte., were called to attend MIrs. Saunders, and that they feloniously. and withoul due eaution and circumspection, and by malpractice, in the use of the remedies and appliances described, and, finally, by abandonment, caused her death.." * " Sir William Blackstone said: "If a physician or surguon gives his patient a potion or plaster to cure him, which, contrary to expectation, kills him. this is neither murder nor manslanghter, but misadventure, and he shall not be punished criminally, however liable he might formerly have been to a civil action for neglect or ignorance. But it hath been holden that if he be not a regular physician or surgeon, who administers the medicine, or performs the operation, it is manslaughter at least. Yet Sir Matthew Hale very justly questions the law of this determination." 4 Bl. Com., p. 197. * * The court is of the opinion that the indictment in this casc is sufficient. Whether appellees are criminally responsible for the death of MIrs. Saunders must depend upon the evidence. A felonious want of "due care and circumspection" in her treatment must be proved as alleged, for a mer: unistake of judg'ment in the selection and application of the remedies and applinnces named in the indictment they would not be criminally liable. Were they grossly ignorant of the art which they assumed to practice? Did they manifest gross ignorance in the selectuon or application of the remedies? Were the remedies unusial. inapplicable, or rashly applied? Were appellees grossly negligent or inattentive? These are all questions of evidence. Reversed. $\$$ v. Hardister, 38 Ark. 605. 42 Am. Rep. 5, F. 207. 
(Eng. Old Bailey, 1664.) Throwing from Building. One John Hull was indieted for the murder of Henry Cambridge; and, upon the evidence, the case was, that there were several workmen building a house by the horse-ferry, whicli house stood about thirty feet from any highway or common passage; and Hull, being a masterworkman (about evening, when the master-workman had given over work, and when the laborers were putting up the tools), was sent, by his master, to bring from the house a piece of timber which lay two stories high; and he went up for that piece of timber, and before he threw it down he cried out aloud, stand clear, and was heard by the laborers, and all of them went from the danger but only Cambridge, and the piece of timber fell upon him and killed him. HYDF. C. J., held this to be manslaughter, for he should have let it down with a rope; but WILDE and KELYNG, JJ., held it to be misadventure, he doing no more than it is usual for workmen to do, and before he did it he gave notice. "But we did all hold that there was a great difference betwixt the case in question, the house from which the timber was thrown standing thirty feet from the highway or common footpath, and the doing the same act in the streets of London; for we all agreed, that in London that if one eleaning a gutter call out to stand aside, and then throw down rubbish, or a piece of timber, by which a man is killed, this is manslaughter; being in London there is a continual concourse of people passing up and down the streets; and a new passenger, who did not hear him call out [might be there], and therefore the casting down any such thing from a house into the streets is like the case where a man shoots an arrow or gun into a market-place full of people; if anyone be killed it is manslaughter." R. v. Full, Kelyng 40, 1 B. \& H. 42-n, Ke. 125, Mi. 215.

Ser several cases of negligent manslaughter under 811 .

(Eng. King's Bench. 1719.) The Defendant was Indicted for Throwing Down Skins into a man's yard, which was a public way, which put out another's eye. On the evidence it appeared that the wind took the skin and blew it out of the way, and so the damage happened. PRATT, C. J., remembered the case of the hoy, 1 Strange 128, and that in Hobart 134, where, in exercising, one soldier wounded another, and a case in the Year-Book of a man lopping a tree, where the bough was blown at a distance and killed a man. And in the principal case the defendants were acquitted. R. v. Gill, 1 Strange 190, Mi. 526.

(Eng. Old Bailey, 1785.) Picking Pocket-Accidental Killing. Where one, having had his pocket picked, seized the offender, and heing encouraged by a concourse of people, threw him into an ad. joining pond by way of avenging the theft by ducking him, but without any apparent intention of taking away his life, and the pickpocket was drowned, this was ruled to be manslaughter only. Fray's Case, 1 East P. C. 236, B. 477. 
(Ling. Assize, 187T.) Accidental in Unlawful Act-Fighting or Defense. Prisoner was inclieted for the manslaughter of Joseph 'l'jpper. It was proved that the prisoner, being challenged and attacked by the deceased, who had taken his coat oft to fight, also trok oft his coat, and blows of the fists were exchanged. Aftci four or five rounds the deceased received from the prisoner a blow which killed him. 'The jury were instructed by LINDLEY, J. *** If two men fight and one unfortunately kills another, then, they being engaged in an unlawful occupation or business, the kiling of either by the other is manslaughter even if it be by accident, and is a trime in point of law although the crime varies in degree of gravity. But on the other hand if a man attacks me, I am entitled to defend my. self, and the difficulty arises in drawing the line between mere self. defense and fighting. 'The test is this: A man defending himself does not want to fight and defends himself solely to avoid fighting. Then supposing a man attacks me and I defend myself, not intend. ing or desiring to fight, but still fighting-in one sense-to defend miself, and 1 knock him down and thereby unintentionally kill him. that killing is accidental. It is for you to draw the line. "* * Not guilty. R. v. Knock, 14 Cox C. C. 1, C. 192, F. 206.

$\$ 108$. Proof of Corpus Delicti. "I would never convict any person of murder or manslaughter unless the fact were proved to be done, or at least the body found dead, and this for the sake of two cases, one ment ioned in my Lord Coke's P. C., c. 10t, p. 232." " " * 2 Hale P. C. 290.

(Eng. Assize, 1612.) Ward Disappears. There were two hrothers, and one having hand and a daughter devised the care of the land and daughter till she should be 16 years old to his brother, and died. When the girl was about 9 years old she was heard to ery out, "Oh good uncle kill me not!" She could not be found afterwards, though diligrent inquiry was made; and the uncle was arrested on suspicion of murder, becanse he was next heir. The justices of assize admouished him to find her by the next assize and bailed him. At the next assize he brought a girl who was soon discovered not to be his niece; and by this fraud the suspicions were so confirmed that he was indicted for murder. convicted, and hanged. When the girl was 16 she returned to claim her land and was directly recognized. The facts were that her uncle punished her for some fault, whereon she ran away to another county. and being well received and entertained by a stranger, remained there. 3 Coke Inst., c. 104, p. 232.

(Fng. C. C. R., 1792.) Captain Put Overboard. This indictment, for murder of a ship captain, contained two counts, one for killing by beating, the other for drowning. The fact happened at sea; a witness proved that he was awakened at midnight by a violent noise; that on renching the deck he saw the prisoner take the captain up 
and throw him overboard into the ser, and that he was not seen or heard of afterwards. Another witness proved that the nrisoner proposed to one Atkyns to kill the cuptain; and another proved that on the deck, near where the captain was seen, a billet of wood was found, and that the deck and pait of the prisoner's dress was stained with blood. Garrow, of counsel for tire prisoner, contended, eiting 2 Hale P. C. 290 , that the prisoner was entitled to be acquitted for want of proof of the death. as he might have been picked up hy some other ship. He cited a case before Gould, .T., where the mother and reputed father of a bastard child took it to the margin of a dock in Jiverpool, stripped it and threw it in. The body of the child was not afterwards seen; and as the tide ebbed and flowed in the dock, the judge, observing to the jury that the tide might have carried out the living infant, directed them to acquit him. 'The court. at Old Bailey, which consisted of Marriott, judge of the admiralty, Ashurst, J., Fotham, B.. and others, admitted the general rule of law; and Ashurst. J., left it to the jury, on the evidence, to say whether the captain was not killed before his body was thrown into the sea. The jury found the fact to be so. Execution was respited, and the case came before all the judges at Ser.jeant's Inn, who unanimously held the conviction to be right, and the prisoner was expented. R. v. Hindmarsh, 2 Iseach C. I. (Fd. 3) Case 242.

(Fng. Assize, 1838.) Child Concealed. A woman was indicted for the murder of her illegitimate child. It was horn March 23, and sent to a nurse, where it remained till $\Lambda$ pril 7 , when the prisoner took it away, stating an intention to go to her father's. She was seen the next day at several times, the latest heing at 6 p. m.. with the child in her arms. on the way to her father's. Between 8 and 9 she arrived there withont it. IORD ABINGER. C. B., said: "She cannot by law be called upon either to account for it or say where it is. unless there he evidence to show that her child is actually dead," and directed an acquittal. R. v. Hopkins, 8 Car. \& P. 591.

(Mass. Sup. Judicial Ct.. 1850.) Teeth, etc., Found in Furnace. Defendaat was indicted for murder of Dr. George Parkman. The government introduced evidence that Dr. Parkman. quite peculiar in person and manners. and very well known to most persons in the city. left his home in Boston in the forenoon of Nov. 23. 1849. in good health and spirits; and that he was traced through varions streets of the eity until about $1: 45 \mathrm{p}$. $\mathrm{m}$. of that day, when he was seen going towards and abont to onter the medical college: that he did not return to his home ; that on the next day a very active, particllar, and extended search was commenced in Boston and the neighboring towns and cities, and continued until Nov. 30; that large rewards were offered for information ahout him: that on Nov. 30 and 31 certain parts of a human body were discovered in and about the defendant's lahoratory in the medical college; an! a 
great number of fragments of human bones and certain blocks of mineral teeth, imbedded in slag and cinders, together with small quantities of gold, which had been melted, were found in an assals furnace of the laboratory; that in consequence of some of these discoveries the defendant was arrested on the evening of Nov. 30 ; that the parts of a human body so found resembled in every respect the corresponding portions of the body of Dr. Parkman; that among them wil there were no duplicate parts; that they were not the remains of a body which had been dissected; that the artificial teeth found in the furnace were made for Dr. Parkman by a dentist in Boston in 1846, and refitted to his mouth by the same dentist a fort. night before his disilppearance; that the defendant was indebted to Dr. Parkman on certain notes, and was pressed by him for payment; that the defendaut had said that on Nov. 23, about 9 o'clock in the morning, he left word at Dr. Parkman's house, that if he would come to the medical college at $1: 30 \mathrm{p}$. m. on that day, ha would pay him: and that, as he said, he accordingly had an interview with Dr. Park. man at that time, at his laboratory in the medieal college; that the defendint then had no means of paying; and that the notes were afterwards found in his possession. After conference with the other judges, SHAW, C. J., who presided at the trial, submitted the ques. tion to the jury to find the death and homicide; and a verdict of guilty being found, defendant was sentenced to death, and the sentence carried out. Before execution he confessed. C. v. Webster, 5 Cush. 295, 52 Am. Dec. 711-n, Kn. 140.

Acc. S. v. Smith, 9 Wash. 341, 37 Pac. 401.

(N. Y. Ct. of $\Lambda$ pl., 1858.) Box of Clothes, etc., Found. 'Irial for murder. JOHNSON, C. J. At the opening of the trial the coun. sel for the prosecution, in answer to a question of the prisoner's counsel, stated that he did not propose to prove by any direct evidence that the infant daughter of the prisoner, with whose murder he was charged by the indictment, was dead or had heen murdered, or that, her dead body had ever been found or seen ly any one, but that from the lapse of time since the child and her mother were last seen, and from other facts and circumstanees, he should ask the jury to infer and presume and find that the infant daughter was dead and that she was murdered by the prisoner. "The prisoner's counsel, on this, moved the court to stop the trial. for want of proof of the corpus delicti ; that the rule laid down by Iord Hale, that no person should be convicted of murder or man. slaughter vonless the facts were proved to be done, or at least the body found dead," is the rule universally acted upon by our courts. and should never be departed from. The judge reserved the ques. tion till the eviadence should be closed. The prosecution gave proof tending to show that the prisoner did not live happily with his wife: , that his wife and infant daughter were seen alive and well on the . evening of June 24,1845 , by a woman who lived across the road 
from Ruloli's house. No per'son shows that either of them have been seen since. The next day Rulofi borrowed a wagon from a neighbor and took into it a box from his own house, which the neighbor helped him to place in the wagon; he drove off with it-where, is not shown; on the following day he returned with the wagon and hox. It was shown that he had in his possession a ring which his wife had worn on the twenty-fourth, and a shawl and some other articles of her apparel; that he to!d stories as to her being at sundry places where she was proved not to have been, and generally conducted himself in such a way as to lead strongly to the inference that he was the author of whatever had happened to his wife and child, if anything had, in fact, happened to them. In the house dothes were found lying about in disorder, dishes unwashed, a skirt lying in a circle at the foot of the bed, and shoes, stockings, and diapers. It was sworn that Ruloff had a cast-iron mortar of twentyfive or thirty pounds weight, and flat irons, which on searching the house were not found. Ile abseonded and was in Chicago early in August, under a false name; there said his wife and child had died six weeks before on the 1llinois river, in lllinois, and left a box containing books, paper's and articles of woman's appitrel, which had lelonged to MIrs. Rulloff, a paper on which were the words, "Oh, that dreadful hour!" and a loek of light brown hair in another paper. labeled "A lock of IInrriet's [or Miary's] hair ;" the witness thought the word was "Harriet's." At the close of the evidence the prisoner's counsel renewed his motion, made at the opening of the cause, and insisted that. as it now appeared that no direct evidence of the death or the murder of the infant daughter had been given, no conviction for murder could be properly had or allowed, and that the jury should be so advised and instructed, and should be directed to find a verdict of not guilty. The judge refused so to advise, direct, and instruct the jury, and to his refusal the prisoner's counsel excepted. The judge then charged the jury. After explaining the legal definition of murder, and the legal presumption of innocence in favor of the prisoner, and the duty of the prosecution, before they conld rightfully ask a convietion, not only to prove the alleged murder, but also to establish by evidence the guilt of the prisoner beyond any reasonable doubt, he proceeded as follows: "The first brunch of the case, the corpus delicti, as it is termed in the law, by which is meant the body of the crime, the fact that a murder has been committed. must be clearly and conclusively proved by the government. The corpus delicti is made up of two things: 1, of certain facts forming the basis of the corpus delicti, by which is neant the fact that a human being has been killed; and. 2. the existence of criminal and human agency as the cause of the death. Upon this first branch of the case the prisoner's counsel insists that it can only be proved by direct and positive evidence; that the government must prove the fact of death by witnesses who saw the killing, or at least the dead body must be found. It has been said 
by some judges, that a conviction for murder ought never to be permitted unless the killing was positively sworn to, or the dead body was found and identifice. 'This, as a general proposition, is undoubt. edly correct, but, like other general rules, has its exceptions. It may sometimes happen that the dead body cannot be produced, although the proof of death is clear and satisfactory. A strong case in illustration is that of a murder at sea, where the body is thrown overboard in a dark and stormy night, at a great distance from land or any vessel. *** I am of opinion that the rule, as understood in this country, does not lequire the fact of death to be proved by positive and direct evidence in cases where the discovery of the body, after the crime, is impossible. In such cases the fact may be established by circumstances, where the evidence is so strong and inteuse as to produce the full certainty of death." [Defendant excepted. $* * *$ The question presented to us, therefore, is whether there be a rule of law, in respect to the proof in casses of homicide, which does not permit a conviction without direct proot of the death, or of the violence or other act of the defendant which is alleged to have produced death. If it be objected that such a rule may compel the acquittal of one whon the jury are satisfir.: is guilty, the answer is, that the rule, if it exists, must be regardul as part of the humane policy of the common law, which affirms that it is better that many guilty should escape than that one imocent should suffer; and that it may have its probable foundation in the idea that where direct proof is absent as to both the fact of denth and of criminal violence calpable of producing death, no evidence can rise to the degree of moral certainty that the individual is dead by criminal intervention, or even lead by direct inference to those results; and that where the fact of death is not certainly ascertained, all mere inculpatory moral evidence wants the key necessary for its satisfactory interpretation, and cannot be depended on to furnish more than probable results. It may be, also, that such a rile has some reference to the dangerous possibility that a general preconception of guilt, or a general excitement of popular feeling, may creep in to supply the place of evidence, if, upon other than direct proof of death or a canse of death, a jury are to be permitted, upon whatever evidence may be presented to them, competent on any jort of the case, to pronounce a defendant guilty. *** A great deal of strong general language has been used by judges in respect to the power of circumstantial evidence to afford sufficient ground to warrant convictions, and many instances of this have been cited and are relied on by the prosecution. Most of those expres. sions have been used, in answer to the position that circumstantial evidence ought not to be relied on to prove any part of the case for the prosecution. But $I$ have not found any case in which a judge. speaking directly to the point here involved, has said that withont direct evidence on either branch of the corpus delicti a conviction for murder could be allowed. *** The rule is not founded in. 
a denial of the force of circumstantial evidence, but in the danger of allowing any but unequivocal and certain proof that some one is dead to be the ground on which, by the interpretation of circumstances of suspicion, an accused person is to be convicted of murder. We are of opinion that the judge, at the trial, erred, and that he should have directed an acojuittal. Roosevelt, J., dissented. Judgment reversed and new trial ordered. Ruloff v..P., 18 N. Y. 179, Kn. 124.

(N. Y. Ct. of App., 1888.) A Body Washed Ashore. FINCII, J. The prisoner was convicted of murder in the second degree, and that conviction reversed by the general term because there was no direct evidence which identified the hody found as that of the person alleged to have been murdered. From that decision the people appeal. 'The question is a very grave one, not merely for the prisouer, whose liberty mily depend upon the issue, but for the people and the administration of public justice; for, if the law be as the general ter'm have declared it, a murderer may always escape if only he shatl so mutilate the body of his victim as to make identification by direct evidence impossible, or shall so effectually conceal it that discovery is delayed until decomposition has taken away the possibility of personal recognition; and it will follow that the tenderness of the Penal Code has opened a door of escape to that brutal courage which ean mangle and burn the lifeless body, and has put a premium upon and offered a reward for that species of atrocity. This result is said to have been accomplished by $\$ 181$, which prohibits a conviction "unless the death of the person alleged to have been killed, and the fact of the killing by the defenclant as alleged, are each established as independent facts; the former by direct proof, and the latter beyond a reasonable doubt." In the first clause of this provision the endeavor to state and describe one fact has involved the statement of another, changing a simple into a compound fact. and making it possible to apply the requirement of direct proof to the two facts of death and identity, rather than to the one fact of death alone. 'That someone is dead is directly proved whenever a dead body is found. . Its identity as that of the person alleged to have been killed is a further fact, to be established in the process of investigation. * * * It has always been the rule, since the time of Lord Hale, that the corpus delicti should be proved by direct, or at least by certain and unequivocal evidence. But it never was the doctrine of the common law, that when the corpus delicti had been duly established, the further proof of the jdentity of the deceased persom should be of the same direct quality and character. And this becomes quite evident from a consideration of the history and philosophy of the rule. By the corpus delictithe body and substance of the offense-has always been meant the existence of a criminal fact. Unless such a fact exists there is nothing to investigate. Until it is proved, inquiry has no point upon 
which it can concentrate. Indeed, there is nothing to inquire about. *. * I am persuaded that a careful analysis of the section referred to will show that no such change, so racical and dangerous, was either made or intended, and that the sole scope and purpose of the section was to declare in explicit terms the existing rule of the common law. *** [Here his honor analyzed the statute.] 'I'he trial judge, therefor'e, was right, and the general term was in error. We have read the evidence given carefully. That the body found was that of Peter Bernard was established beyond a reasonable doubt. The prisoner was a witness in his own behalf. He shows that he and Bernard were in the locality where the body was found, at about the date of the latter's disappearance. His own declarations show that he had no doubt of the identity of the body found. He explains his possession of a $\$ 20$ bill, which in some manner he got from Bernard, but the explanation is not at all probable or satisfactory. The evidence of the persons who claim to have seen the deceased after the date of the murder was probably honest, but quite certainly mistaken. He was a total stranger to them, and their comparison was founded on a photograph. In the case of C. v. Webster [above] there were five persons who honestly believed that they saw Park. man alive after he had in fact been killed. Upon the whole case we see no reason to distrust the conclusion which the jury reached. The judgment of the general term should be reversed, and that of the oyer and terminer of Clinton county affirmed. All concur, except Gray, J., dissenting. P. v. Falmer, 109 N. Y. 110, 16 N. E. 529, 4 Am. St. Rep. 423 , reversing same case in 46 Hun. 479. 


\section{CHAPTER VIII.}

\section{OFFENSES AGAINST THE HABITATION.}

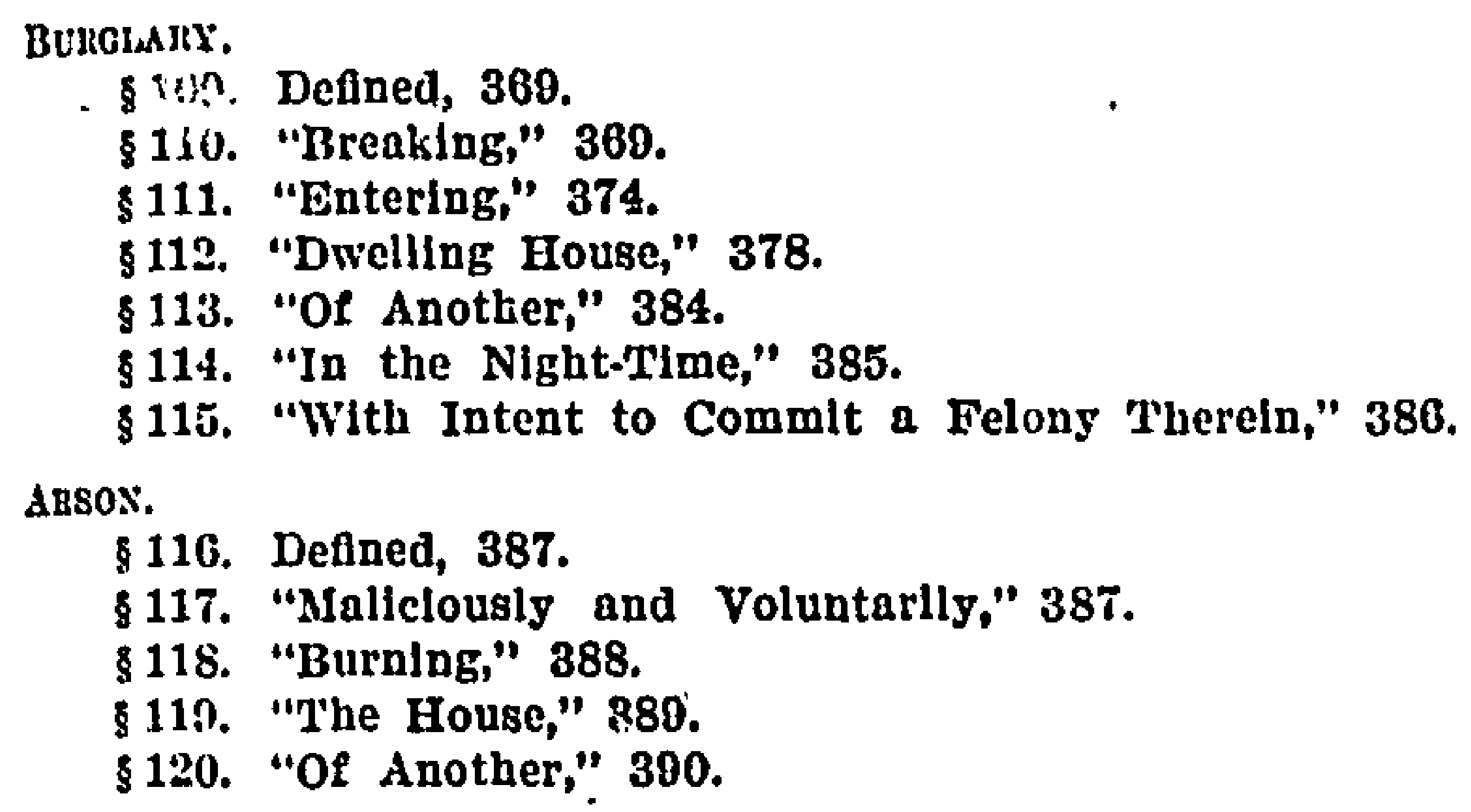

\section{BURGLARY.}

§109. Burglary Defined. Burglary at.common law is the breaking and entering of the dwelling house of another in the night-time, with intent to commit a felony therein.

\section{§110. "Breaking."}

(Eng. Assize, 166t.) 'This happened in 13lackfriars, 1664, where thieves, pretending that $\mathrm{A}$ harbored a traitor, called the constable to go with them to apprehend him, and the constable entering, they bound the constable and robbed A, and were executed for burglary, and y'et the owner opened the doors of his own accord to the constable. Anon, 1 Hale P. C. 553, Crompton 22a.

Ace. Farr's Case, 8133, p. 425.

Of Breaking Out. By 12 Anne, c. 7, § 3, it is enacted, "that if any person shall enter into the mansion or dwelling-house of another, by day or by night, without breaking the same, with an intent to commit felony, or, being in such house, shall commit any felony, and shall in the night-time break the said house to get ont of the same, such person is and shall be adjudged and taken to be guilty of burglary, and shall be ousted of the benefit of his and her clergy, in the same manner as if such person had broken and entered the said house in the night-time with an intent to commit felony there." 
(Eng. C. C. R., 1690.) Breaking Cupboard Fastened to Wall. At a meeting of the judges, upon a special verdict, they were divided upon the question, whether brealing open the door of a cupboard let into the wall of the house was burglary. Anon. Foster C. L. 108, 2 East P. C. 489, Mi. 919.

Mr. Justice foster, in hls comments on this case, sald, that with regard to cap. boards, presses, lockers and other fixtures of the like kind, in favor of life, a distinc. tion ought to be made between cases relatling to mere property, and such as afiect the law respecting capltal crlmes. In questlons between the belr or devisee, and the executor, those firtures may, with propriety enough, be considered as annexed to, and parts of the freehold; for the law wlll presume that It was the Intentlon of the owner, under whose bounty the executor clnims that they should be so considered, to the end that the house might remaln to those who, by operation of law or by bequest, should become entitled to $1 t$, in the same condition he put it, or should leave it entire and undefaced. But In capltal cases he was of opinion that such fixtures which mereiy supply the place of chests and other ordinary utenslls of household, should be con. sldered in no other light than as mere movables, partaking of the nature of those utenglls, and adapted to the same use. Foster C. L. 109. It would seem that Mr. Fast agreed with Mr. Justice Foster (2 East P. C. 489); and both of these writers took exception to Lord Hale's conclusion (1 Hale P. C. 527) from Simson's Case, Kelyng 31, that that case held such breaking to be sufficient under statutes, 5 and 6 Edw. 6 c. 9 , and 30 Eliz. c. 15. That case merely held that entering an open house In the day time and taking goode out of a chest and putting them on the floor was a complete fel. ony though the felon was surprised and taken before he left the house. Lord IIule tx. pressly declared that such breaking would not be burglary at common law. 1 Hale p. C. 527 .

(Eng. C. C. R., 1786.) Inner Doors. 'The prisoner entered at a back door of the house, which the family had left open; and afterwards broke open an inner door, and stole goods from a room, and then unbolted the street door on the inside and went out. And this was ruled by all the judges to be burglary. If a thief enter through an onter door, and when in lift the latch or turn the key of a cham. ber-donr with intent to commit felony, this is burglary. (And so it was adjudged at Newgate in 1672. '1 Hale P. C. 553.) Johnson's Case, 2 East P. C. 488, B. $78 \tilde{\text {. }}$.

(English, about 1650.) Robbers Knock at Door. Thieves came to rob a man, and finding the door locked. pretended that they cume to speak with him, and thereupon the maid opened the door, and they came in and robbed him; and this being in the night-time, it was burglary, and the persons were hanged. For their intention being to rob, and getting the door open by a false pretense, this was in fraud of the law, and they as guilty is if they did actually break the house. LeIMott's Case, Kelyng 42, B. 783, Ke. 169, Mi. 913.

Cases of consent to entrap burglur: Eggleston's Case, 820 : Love v. P., \$ 20: s. v. Albey, \$ 20.

(Ohio Sup. Ct., 1819.) Robbers Knock at Door. It was proved that on the night in question defendants knocked at the door of Mrs. Brown's house, whereupon her son John said, "Come in." They pulled the latch-string, but could not open the door. John got up and opened the door, and they came in, closed the door, and one of them stood by it, while the other said he had a warrant for John. John asked time to put on his clothes, which was given; then they 
said they wanted his money, and asked his mother for it. They told her to get the key to the chest where the money was, and ynder threats of violence she got it and took from the chest the money described in the indictment. 'This was held a constructive treaking sufficient to convict of burglary, though the statute provided only for forcible breaking. Ducher v. S., 18 Ohio 308.

Acc. Johnston v. C. 85 Pa. St. 54, 27 Am. Rep. 622, F. 261.

(Wis. Sup. Ct., 1887.) Fxpressed in a Box. On trial on indictment for burglary under $R$. S. $\$ 4410$, (providing that anyone who "shall enter in the night-time without breaking, or shall break and enter in the daytime, any *** ruilroad freight car, or passenger car, with intent" to commit any felony shall be punished, etc.) it appeared that defendant arranged with an express ugent at Black River Falls, Wis., to call at the hotel where defendant was stopping and get a box weighing 225 pounds and take it to the train for Chicago, just before the train would leave, 7:50 p. m., July 25, 1885 , which was done; that, suspicion being aroused, an officer was called a few stations further on, the ?:ox opened, and defendant found in it, with a bottle of chlorofor'n, rope, gimlet, billy, razor, knife, and revolver; and that he theis said if the train had passed Elroy, after which only one messenge: would be in the car, he hoped to get $\$ 50,000$ being sent on that car, and a human life in the way would not amount to a snip of the finger. The objection that there was no evidence of breasing to bring the case within the statute was not sustained, and defendant was convicted. On error, the supreme court cited several cases of constructive breaking. by knocking at the door or coming down the chimner, and sustained the conviction. Nicholls v. S., 68 Wis. $416,32 \mathrm{~N}$. W. $543,60-\mathrm{Am}$. Rep. 870.

(Mass. Sup. Judicial (jourt, 1829.) Cutting Window Screen. The prisoner cut or tore away a screen of twine nailed over the buttery window, and then entered th'sugh the winclow, which had been left up. He went out through a door which had been fastened by turning a button down over the latch. Defendant contended that the indietment could not be sustained, because the window was open and the netting was not put up as a protection against an entry by man but only to keep ont cats and the like. The conviction was sustained and the motion for a new trial denied. The court held that it makes no difference whether the door is bolted or the window secured; it is enough that the house is secured in the ordinary way, so that the owner did not tempt the accused by leaving the door or window open. C. v. Stephenson, 8 Pick. (25 Mass.) 354, B. 787.

(Enis. Central Criminal Court, 1836.) Unfastened Window. The prisciners were indicted and tried for burglary, and it appeared that they entered the house through a window shut down but not fas- 
tened, though there was a hasp by which it might have been secured. 'They contencied that this was not sufficient evidence of breaking, and that it was like further opening a window left partly closed. Coleridge and Park, JJ., were of opinion that there was enough breaking, and the prisoners were convicted. R. v. Hyams, 7 Car. \& P. (32 Eng. Com. 1. 万iTT) t41, Mi. 909.

(North Carolina Sup. Ct., 1952.) Opening Window. On trial for burglary Sarah $\Lambda$. Owen testified that on the night of the burglary she and her niece went to bed early in a room on the ground floor, and before retiring locked the door and saw that the windows were closed and nobody else in the room; that about ten o'clock she was awakened by someone grasping her ankle, whereupon she screamed. and immediately the intruder escaped through the window, and as he went through the window, she recognized him as the prisoner now on trial, he being well known to her. On getting up she found the window fastened up by a stick. She swore that the window was ordinarily held down by a nail in a hole over the sash in the casing. Defendant's counsel asked the court to charge the jury that there was no proof of felonious intent. and that if the window was not fastened on the night in question the entry was not burglarious. The court refused the request, and on appeal the conviction was affirmed. The cour't said, "There must be a breaking, removing. or putting aside of something material, which constitutes a part of the dwelling-house, and is relied on as a security against intrusion. Leaving a door or window open shows such a negligence and want of proper care as to forfeit all claim to the peculiar protection extended to dwelling-houses. But, if the door or window be shut, it is not necessary to resort to Jocks, bolts, or nails; because a latch to the door, and the weight of the window, may well be relied on as a sufficient security." S. v. Boon, 13 Ired. L. (35 N. Car.) 244, $57 \Lambda \mathrm{m}$. Nec. 555, F. 258, Kn. 241.

(Mass. Sup. Judicial Ct., 1870.) Window Partly Open. Prisoner was indicted and tried for burglary. It was proved that in the evening a domestic in the house heard a noise in the dining-room, and coming in from the kitchen, which adjoined, she noticed a window fully up, and that a silver piteher which had stood near it was gone. On cross-examination this domestic testified that the window might have been up from a quarter of an inch to an inch. Defendint's counsel asked the court to rule that if at the time defendant took the pitcher through the window it was not entirely closed. the further opening of the window would not constitute breaking. The court declined so to rule, and on appeal such refusal was held to be error. C. v. Strupney, 105 Mass. 588, 7 Am. Rep. 556, Fi. 260.

(Eng. Old Bailey, 1814.) Breaking - Yard Gate. Bennett and Turnwell were convicted of burglarionsly breaking and entering the 
dwelling-house of Frampton in the night, with intent to steal his groods and chattels in the said dwelling-house. It appeared in evidence that the place brokers was an external gate not cpening into any building, but only into the yard, through which access might be had without interruption to the dwelling part of the prosecutor's premises. But upon reficrence to the judges, on case reserved, they unanimously held this not to be burglary, the place broken being the outward fence of the curtilage only. R. v. Bennett, 1 Russell \& R. 289.

(Engr. Old Bailey, 181i.) Same. In the case of Davis and Lemon, who were convicted of burglary, a question arose, whether the opening an area gate by means of a skeleton key, and thereby effecting an entrance through the kitchen door, which was open, would constitute the crime of burglary. Graham, 13., stated, that nine judges, ansembled to consider this case, were unanimously of opinion that the area gate not being part of the dwelling-house. there was not a sufficient breaking to constitute the erime of burglary. R. v. Davis, 1 Russell \& R. 3:2.2. Ke. 160.

(North. Cilr. Sup. Ct., 1887.) Admitted by Apprentice. Defendant having committed larceny in a dwelling-house at night after having been admitted collusively by a girl apprenticed to the master of the house, the court was requested to instruct the jury that these facts did not constitute burglary, because a bound child is something more than a servant, and stands more nearly in the relation of parent and child. The request was refused, and the court instructed the jury that admission procured by such trick or frand is constructive breaking, and the relation of apprentice is that of servant not of child. Defendant being convicted, appealed, and the instruction was held to be correct. S. v. Rowe, 98 N. Car. 629, 4 S. E. 506.

(MIass. Sup. Judicial Ct., 1893.) Deceiving Night-Clerk. Johnson and Lowrey were convicted of breaking and entering a store on evidence showing that Johnson went to the night-clerk of the T. Metealf Co. at about midnight, pretending that he wished to buy something; and the clerk having admitted him to the shop, bolted the door, and gone to the cellar to get the desired article, Johnson let Lowrey in, who concealed himself; and after. Johnson and the clerk had left Lowrey stole money from the money drawer. Both defendants excepted to the conviction. Exceptions overruled. 'The court said it was not necessary that the jury should find Lowrey to:sched the door to get in if he procured an accomplice or an innoceni person to let him in. C. v. Lowrey, 158 Mass. 18, 32 N. E. 940.

(Neb. Sup. Ct., 1897.) Another Door Left Open. Defenilant was found guilty of statutory burglary from a barn. The barn door was double, being cut across the middie, and the upper half had been left 
open. The defendant lifted the hook that fastened the lower half, opened that half, and went in. Defendant contended that burglary was not shown, because he could have entered without any breaking; but the court held that the fact that he could have bounded over the lower door was no defense, and that the facts shown clearly (onstituted a breaking. Ferguson v. S., 52 Neb. 432, 72 N. W. 590, $66 \mathrm{Am}$. St. Rep. 512.

\section{\$111. "Entering."}

(Einglish Resolution of All the Judges, 1584.) Constructive Entry. All the justices assembled at Serjeant's Inn agreed that if one break the glass in a window in the dwelling-house of anyone, and there with hooks diaw carpets out, and feloniously steal them, it is burglary if it be done at uight, though the mau whe does it do not enter or break the house otherwise; and this case was put for a purpose, in order that the justices of assize in the county of Warwick might linow the law before the assizes, where this case was to come in question for an offense committed at Grdeburgh in said comnty. At this time the following ease was also put by the said justices, that thieves in the night eome to a dwelling. and someone within comes and opens the door, and when it is open, one of the thieves intending to kill the man shoots at him with a gun, the hullet from which misses the man and breaks the wall on the other side of the house. And it was agreed by all that this is no burglary; and this also was in order to know the law in this case, which happened in the county of Derby where they were also justiees. And as bearing upon these cases an actual ease was put, which was this, scil.: In the night one who intended to kill another in a house broke a hole in the wall of the dwelling. and perceiving where the person was, shot at him through the hole with a gun and missed the person, which was adjudged as burglary: so where one broke a hole in the wall and seeing a man with a purse of money hanging from his girdle coming by the hole, snatched at the purse and took it, this too was arreed to be burglary; which happened in Essex. And then it was remembered that one came to the window of Mr. Cave's study in the county of Leicester, and perceiving a easket with money in it, drew it to the window and took money out of it. and for this he was hanged in the county of Leicester. For in all these cases of burglary there is a breaking of the liouse to commit felony in the night; which makes the offense burglary. But in the preceding case of shooting with the gun into the droo and breaking the wall with the bullet. it is not a breaking of the house with intent to commit felony: wherefore it is not birglary. Anon., And. 114. B. 782.

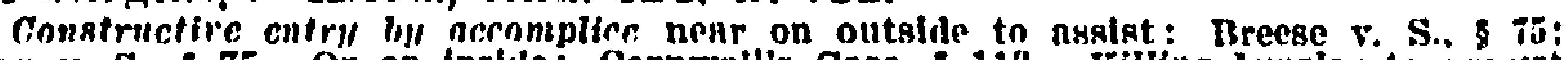
Doan จ. S. \$ 75. Or on inslile! Cornwall's Case, 8113 . Killing burglar to prerent entry justifiuble: Cooper's Case, 72.

(Eng. Old Bailey, 1752.) Reaching in for Goods. This was an 
indictment against Gibbons for burglary in the dwelling-house of Jolm Aller. It appeared that the prisoner in the night-time cut a hole in the window shutters of the prosccutor's shop, which was part of his dwelling-house, and putting his hand through the hole, took out watches and other things which hung within his reach; but no entry was proved otherwise than by putting his hand through the hole. And the judges held that to be burglary. Gibbons's Case, 2 Fast P. C. 490. Foster C. I. 107.

(Wing. Old Bailey, 1785.) By Instrument to Get In. On an indictment for burglary it appeared that the prisoners had bored a hole with an instrument, called a center bit, through the panel of a house door, near to one of the bolts by which it was fastened; and that some pieces of the broken panel were found within the threshold of the door; but it not appearing that any part of the bodies of the prisoners hat been within the house, or that the aperture was sufficienily large to admit a man's hand, the court held this not to be a sufficient entry, for the entry must be for the purpose of committing a felony; and the breaking must be such as will afford the hurglar an opportunity of entering so as to commit the intended felony. R. v. Hughes, 1 Leach No. 178, 2 Fast. P. C. 491, Ke. 173.

(Eng. C. C. R., 1828.) Bar Inserted to Make Opening. Indictment for breaking and entering the dwalling of $R$., to steal. He was convieted and case reserved. The glass sash window was left closed down, but was thrown up by the prisoner's; the inside shutters were fastened, and there was a space of about three inches between the sash and the shntters. and the shutter's themselves were about an inch thick. It appeared that after the sash was thrown up a crowbar had been introduced to force the shutters, and had been, not only within the sash, but had reached to the inside of the shutters, as the mark of it was found on the inside of the shutters. The judges were of opinion that this was not burglary, and the conviction was wrong; for it did not appear whether any part of the hand was within the window, although the aperture was large enough to admit it. R. v. Rust, 1 Moody C. C. 183, Ke. 174.

(King. Assize, 1818.) Hand Between Window and Inner Shutter. On indictment for burglary it appeared that the window sash belonging to a dwelling-house was fastened in the usual way, by a latch from the bottom of the upper sash to the top of the lower one, and that there were inside shutters, which were fastened. One of the prisoners broke a pane of glass in the upper sash of the window, and introdnced his hand within, with the intention to undo the lateh by which the window was fastened. While he was cutting a hole in the shutter with a centor bit, and before he had undone the latch of the window he was seized. All the judges were of opinion that the introduction of the hand between the window and the shutter, 
to undo the window latch, was a sufficient entry to constitute a burglary. R. v. Bailey, Russell \& R. 341.

(Ala. Sup. Ct., 18t3.) Hand Passing Within Outer Window Shutter. On indictment for burglary it appeared that after Mrs. Vincent had retired for the night, a noise was heard at the window; and a lodger went out to learn the cause, and found the defendant stand. ing in the yard and the window shutters or blind open. "The court then charged the jury that if they believed from the testimony that the defendant, by the application of force, wrested open the window shutters, and his hands protruded beyond the line made by the shutters wheu shut, that that, in law, was an entry, notwithstanding the sash remained down, and the glass was umbroken." The prisoner was found guilty, and sentenced to imprisonment in the penitentiary for the space of ten years. COLLIER, C. J. *** * Any, the least entry, is sufficient, by means of the hand or foot. or even by an instrument with which it is intended to commit a felony. 22 East P. C. 490; Foster C. L. 107; 1 Hawkins P. C. c. 38, $\$ \tau ; 1$ Hale, P. C. 555. But the entry, it is said, must appear to have been made with the immediate intent to commit a felony, as distinguished from the previous intent to procure admission to the dwelling-house. * * The citations from the crown cases, it must be admitted, lend their support to the charge of the circuit judge to the jury. The only difference being that there was a breach and entry of the sash, while here the breach and entry was of the blinds, which were the outer protection. 'This, it is conceived, cannot require the application of a different principle. It cannot be that the common security of the dwelling-house is violated by brealsing one of the shutters of a door or window which has several. True, it weakens the security which the mansion is supposed to afford, and renders the breach more easy; but, as additional force will be necessary before an entry can be effected, there can, under such circumstances, be no burglary committed. *** l'o constitute burglary, an entry must be made into the house with the hand, foot. or an instrument with which it is intended to commit a felony. In the present case there was nothing but a breach of the blinds, and no entry beyond the sash window. The threshold of the window had not jeen passed, so as to have enabled the defendant to consummate a felonious intention; and, according to the principle we have laid down, the charge to the jury was erroneous. *** Reversed. S. v. McCall, 4 Ala. 643, 39 Am. Dec. 314, F. 263, Kn. 243.

(Ala. Sup. Ct., 1879.) Boring into Granary. Appellant was convicted of breaking and entering a corn-crib, with intent to steal, in violation of Code (1876) : $\$ 4343$, declaring such acts to be burglary. BRICKELL, C. J. * * * In the crib was a quantity of shelled corn, piled on the floor; in April or May, 1878, the crib had been broken into, and corn taken therefrom, without the consent of the 
owners, who had the crib watehed, and thereafter the defendant was caught under it, and on coming out, voluntarily confessed that about three weeks before he had taken a large auger, and going under the crib, had bored a hole through the floor, from which the com, being shelled, ran into a sack he held under it; that he then got about three pecks of corn, and with a cob closed the hole. On these facts the city court was of opinion, and so instructed the jury, that there was such a breaking and entry of the crib, as would constitute the oftense, and refused instructions requested asserting the converse of the proposition. ** * The breaking may be complete, and yet an entry never effected. From whatever causi an entry is not effected, burglary has not been committed. When one instrument is employed to break, and is without capacity to aid otherwise than by opening a way of entry, and another instrument must be used, or the instrument used in the breaking must be used in some other way or mamner to consummate the eriminal intent, the intrusion of the instrument is not of itself an entry. But when, as in this ease, the instrument is employed not only to break, but to effect the only entry contemplated and necessing to the cousummation of the criminal intent; when it is intruded within- the house, breaking it, effecting an entry, enabling the person introducing it to consummate his intent, the oftense is complete. 'The instriument was employed not only for the purpose of breaking the house, but to efiect the larceny intended. When it was intruded into the erib the burglar acquired dominion over the corn intended to be stolen. Such dominion did not require any other act on his part. When the auger was withdrawn from the aperture made with it the corn ran. into the sack he used in its asportation. There was a breaking and entry, enabling him to effect his criminal intent without the use of any other means, and this satisfies the requirements of the law. Tudgment affirmed. Walker v. S., 63 Ala. 49. 35 Am. Rep. 1, B. 794.

Followed and conviction affirmed on facts nearlv identlcal in S. v. Craw ford. 8 N. Dak. 539 80 N. W. 183, 73 Am. St. Rep. 772, 46 L. R. A. 312, Mi. Bit.

(Ala. Sup. Ct., 1893.) Entering Chimney. On trial for burglary it appeared that prosecutor was awakened at night by cries for help. and on investigation found defendant stuck in the chimney flue and unable to get in or out, that prosecutor succeeded in drawing him to the top, and that defendant then confessed that he got into the chimney with the intention of going into the house where goods were kept and stealing a suit of clothes. The court instructed the jury that if he intended to steal from the house he was guilty as charged though he did not in fact get through the chimney. HARALSON, J. In Donohoo v. S., 36 Ala. 281, we held that getting into and descending the chimney of a house, with intent to steal, is a sufficient breaking and entering to constitute burgiary, although the party does not enter the room of the house below, and such was the ruling of this court in Walker v. S., 52 Ala. 376, though in the latter case the party entered into the house by going down the 
chimney. Such a breaking is an actual one, as much so as the forcible breaking by any other means. 3 Greenl. Ev. $\$ 76$. On the foregoing authorities, this case must be affirmed. Olds v. S., 97 Ala. 81, 12 So. 409.

A cc. R. v. Brice, Russell \& R. 450, Mi. 911.

\section{§112. "Dwelling-House."}

(ling. C. C. R., 1593.) Two Homes. It was agreed by all the justices and barons of the exchequer, upon an assembly made at Serjeant's Inn, after search made for the ancient precedents, and upon good deliberation taken, that, if a man have two houses, and in. habit sometimes in one, and sometimes in the other, if that house in which he doth not then inhabit be broken in the night, to the intent to steal the goods then being in the house. that this is burglary, though no person be then in the house. And the breaking of a church in the night to steal the goods there is burglary, although no person be in it. because this is the place to keep the goods of the parish. Resolution, Popham 52, Moore 660, B. 783, Mi. 919.

(Fing. Assize, 1619.) Rented Shop in House. One had a shop in the dwelling-house of another, where he worked in the day but did not lodge, and, vet he had a house out of the shop to the street. Breaking into this shop at night was held not burglary, because no person dwelt there, and the lease severed it from the house. Anon, Hutton 33, Mí. 920.

(Eng. Old Bailey, 1689.) After Death of Owner. $A$ died in his house. B, his executor, put servants into it, who lodged in it, and were on board wages; but $B$ never lodged there himself: and upon an indictment for burglary, the question was, whether this might be called the mansion-house of $B$. The court seemed to think it might, because the servants lived there. Jones and Longman's Case, 2 Wast. P. C. 499 .

(Eng. Old Bailey, 1697.) Away on Journey. John Nichols. being possessed of a house in Westminster, wherein he dwelt, tonk a journey into Cornwall, with intent to return, and sent his wife and family out of town, and left the key with a friend to look after the house; after he had been gone for a month, no person being in the house, it was broken open in the night. and robbed of divers goods. He returned a month after with his family. and resided there. The persons who had committed the robbery were adjudged burglars. Murray and Harris's Case, 2 East P. C. 496.

(Eng. C. C. R., 1768.) Room at Hotel-Whose Dwelling. This indictment for burglary stated that the prosecutor came to a pullic- 
house to stay all night, and fastened the door of his hedchamber; when the prisoner, pretending to the landlord that the prosecutor had stolen his goods, under this pretense, with the assistance of the landlord and others, forced open the chmmber door with intent to steal the goods mentioned in the indietment. and the prisoner accordingly stole them. Baron Adams, who tried the prisoner, doubting whether the chamber could be deemed the dwelling-house of the prosecutor, reserved the poinc for the opinion of the judges, who all thonght that though the prosecutor had for that night a special interest in the bedchamber, pet that it was merely for that particular purpose, namely, to sleep there that night as a traveling guest, and not as a regular lodger, and that he had no certain and permanent interest in the room itself, hut that hoth the property and the possession of the room remained in the landlord, and thepefore the indictment was insufficient, because the burglary should have been laid in the dwelling-honse of thr innkeeprer. and not of the guest. Prosser's Case, 2. Filst P'. C. j(1):

(Eng. (.. C. R., 17Ts.) Before Moving Into House. Smith purchased a house intending to reside in it. putt it moder the eare of a carpenter to repair it, and moved some of his effects in, to the value of about E.10. but neithey he nor any of his family had yet entered into possession of any part of it. 'The prisoner's broke and entered the house in the night, with intent to steal. The question reserved for the opinion of the juclues was whether this was Smith's dwellinghouse. 'The judges were all of opinion, that a house so situated could not be considered a dwelling-house, it being completely uninhabited. Judgment against the prisoners was aceordingly arrested. R. v. Iyons, Leach C. C. No. 9:3, 2 Fast P. C. 497, 13. 784.

(Eng. C. C. R.. 1785.) There was a Shop Built Close to a Dwelling-House in which the prosecutor resided. There was no internal communication between them. No person slept in the shop. The only door to it was in the courtyard before the house and shop, which yard was inclosed by a brick wall, including them within it. with a gate in the wall serving for ingress to them. The breaking and entering was into the shop. Objection wils taken that it conld not be cousidered the dwelling-house of the prosecutor, and the case was reserved for the consideration of the twelve judges. They were all of the opinion that the shop was to be eonsidered a part of the dwelling-house, being within the same building and the same roof, though there was only one door to the shop, that from the ontside; and that the prisoners had been duly convicted of burglary in a dwelling-house. R. v. Gibbon, Mutton, and Wiggs, Juench C. C. No. 165.

Furthre as to dwelling house: l'itcher v. $r ., \$ 7$, barn in curtilage.

(Eng. Old Bailev; 1795.) Goods Moved In. Dinsdale rented a 
dwolling-house in Cheapside, put in some of his merchandise and articies of trade, and hired two men to sleep in the house to take care of the goods. They were hair-dresser's and not his servants in any capacity. He had never slept in the house, but these men had slept there for six nights before defendant broke in and stole a watch worth $£ 10$, the property of Dinsdale. The colirt was of opinion that Dinsdale, the prosecutor, had not taken sufficient possession to make the house his dwelling, and that Harris was guilty of larceny only. Ile was sentenced and transported. R. v. Harris, 2 Leach C. C. No. 273, 2 Fast P. C. 498 , Ke. 163, Mi. 921.

(MIo. Sup. Ct., 1864.) Closed for the Season. Defendant appeals from a conviction of burglary and larceny and from an order deny. ing a motion for a new trial. On the trial IIntehmeyer testified for the state that he owned a dwelling-house in Osige county, and in the spritigr of $186^{\circ}$ moved ont of it and went about four miles ofl to live with a brother, leaving a part of his furniture in the house, which he left locked 11 . On his return three or four months later, he found that the house had been broken open and some things stolen. No une stayed in the house during this period. The indictment was for statutory burglary in the second degree, which required that the place should be a dwelling-house. Defendant argues that during the absence of the owner this was not a dwelling-house. The comrt held that this was burglary of a dwelling-house. citing 3 Coke Inst. 64: 1 Inale P. C. 556 ; 2 East P. C. 496 ; and affirmed the jud rment. 'The court said: "In this country it has been held, that if $A$ have a residence in the city and one in the country, residing with his family during the summer in one, and in the winter in the other, the breach of either, during the absence of $A$ and his family (though no one may he sleeping in it), for the purpose of committing a felony, is burglary. It is equally well settled, that if the owner locks up his house and leaves it, with a settled purpose not to return, it ceases to be his dwelling-house, in the sense necessary to make an unlawful breaking a burglary. To continue it his mansion-house, he must hare quitted it animo revertendi. In the ease at har. we think it apparent that the owner of the premises had no intention to remain away per. manently." S. v. Meerchouse, 34 Mn. 344. $86 \mathrm{Am}$. Dec. 109, F. 265. Kn. 247.

(N. Y. Ct. of App., 1863.) Flats and Apartments-Inner Door. Christopher 'lhomas and wife occupied three rooms in what is linown as a tenement house, for which they paid rent monthly. 'Three other families lived in other apartments in the same house. All the tenants used the same entrance from the street, which was provided with a door at the street. From the common hall each reached his apartments. The street door to the common hall being open defendant entered and broke the door of Mrs. Thomas's room. which she had left locked. Defendant's counsel requested the court to 
charge the jury that breaking the outer door would be breaking the house of the tenant whose goods he intended to steal, but that breaking the inner door was not burglary, because a double burglary could not be committed by first breaking the outer and then the inner door. The request was refused, and the defendant convicted of burglary in the third degree under the statute. He appealed to the supreme court, where the judgment was affirmed, and he again anpealed. Affirmed. The court said: "Any and every settled habitation of a man and his family is his house or his mansion, in respect to its burglarious entry. It was so held before Lord Hale's time as to the chambers in colleges and inns of court, and even as to a chamber hired by $A$ in the house of $B$ for lodging for a specified time. 1 Hale P. C. 556. *** Wherever a building is severed by lease into distinct habitations, each becomes the mansion or dwelling-house of the lessee thereof, and is entitled to all the privileges of an individual dwelling." Mason v. P., 26 N. Y. 200, B. 788.

(N. Y. Ct. of $\Lambda$ pp., 1878.) Stores Under Flats. Defendant was convicted of burglary in the first degree under the statute, which is the same as burglary at common law. It appears that he broke into a store-room used for purposes of trade by a partnership, and that one of the partners and other persons lived in rooms over the store. not connected with it by any internal communication, but within the same four walls and reached by a stairway on the outside of the building. It was claimed by the accused that this was not burglary because there was no internal communication. The court reviews a number of decisions, English and American, and holds that the breaking constituted burglary. The court said: "The dwelling-house in which burglary might be committed was held formerly to include outhouses-such as warehouses, barns, stables, cow-honses, dairy-houses-though not under the same roof or joining contignous to the house, provided they were a parcel thereof. 1 Russ. on Cr. * 799, and authorities eited. Any outhouse within the curtilage, or same common fence with the dwelling-house itself, was considered to be a parcel of it." Quinn v. P., 71 N. Y. 561,27 Am. Rep. 8T, B. 789. Nli. 9.2.2.

(Wis. Sup. Ct., 188T.) Unfinished House. Appellant was convicted of burglary under" a statete making it burglary to break "and enter in the night-time iny office, shop, or any other building not adjoining any dwelling-house, $* *$ with intent to commit the erime of lareeny or other felony." Wis. R. S. \$ 4409. 'The building broken into was a dwelling-house in process of construction, on a stone foundation, walls up, roof on, windows boarded up, temporary floors laid, a room in the basement partitioned off, and a door at the entrance of it hung and locked. The defendant appears to have torn off the boards from a window, gone into the basement, broken open the room there, and stolen some carpenter tools from that room and 
from a chest on the floor above. Counsel for appellant contended that a building in process of construction, as this was, is not within the meaning of the statute above quoted, because it was unfinished and unfit for occupation for the purpose for which it was intended. 'The court held that this was a building within the meaning of the statute, saying: "We think the provision was intended to include any building not within the curtilage, in which property might be stored, or men or animals sheltered." Judgment affirmed. Clark $\nabla$. S., 69 Wis. 203,33 N. W. 436, 2 Am. St. Rep. 732.

(N. Y. Ct. of App., 1888.) Burial Vault. Defendant was indieted and convicted of burglary in the third degree under a statute de. claring such burglary to consist of "breaking and entering in the day or in the night-time- * *2. Any shop, store, booth, tent, warehouse, or other building in which any goods, merchandise, or valuable thing shall be kept for use, sale, or deposit-with intent to steal therein, or to commit any felony." $2 \mathrm{R}$. S. $669, \S 17$. The proof showed that he broke into a granite vault used for burial of the dead. It was entirely above ground, $10 \mathrm{ft}$. wide, $16 \mathrm{ft}$. long, 10 f.t. high, with granite roof, and a granite and bronze door and gate at the entranee. Within were 12 burial compartments, seven of them occupied by dead bodies and sealed with marble slabs. The evidence tended to show that defendant's purpose in entering was to examine one of the bodies. Defendant's counsel asked the court to instruct the jury that this case was not within the statute, the vault not a building, and the chatre not proved. The motion was denied and tinc defendant convicted. Refusil of this request is held error. "We do not believe that the structure described in the indictment and the proof is within the statute describing burglary in the third or any degree. * * We think it plain that all the words in the revised statutes or in the statute of 1863 , in defining burglary in the third degree, referred to structures erected or built for the purpose of answering the necessities of living men in their intercourse with each other of a commercial or trading nature, where their property might be deposited and used, or while awaiting sale or transportation." Per PECKHAM. J. Reversed. P. v. Richards, 108 N. Y. 137, 15 N. E. 371, 2 Am. St. Rep. 373, C. 474.

('Tex. Ct. of Crim. App., 189S.) A Header Box. Appellant was convicted of burglary. It appears that he stole grain from a header box, such as is commonly used with header grain harvesters. The box was $16 \mathrm{ft}$. long, $6 \mathrm{ft}$. wide, $t \mathrm{ft}$. deep at one end, and 18 inches deep at the other, and covered with a wagon-sheet securely fastened down. It was made of boards securely joined together. was drawn around the field with the harvester, and would hold about 150 to 200 bushels of thrashed grain. The court said: "Was this a 'house' within the contemplation of the statute of burglary? We are of cpinion that it was not. It is true that it had four sides, and was 
covered over, but it was nevertheless a box and not a house. All boxes which contain goods-shoes, groceries, etc.-for shipment would be houses if this box were held to be one. The evidence excludes the idea of permanency of location. * * * It was portable and was not used, nor intended to be used, in any way or for any purpose connected with a habitation, or other purposes for which houses are ordinarily used." Reversed. Williamson v. S., 39 Tex. Crim. R. 60, 44 S. W. 1107, 73 Am. St. Rep. 901.

(Tex. Ct. of Crim. App., 1898.) Ranch Tent. Appellant was convicted of burglary. A witness described the place as follows: "I put two forked mesquite poles, about seven feet high, into the ground, and then put a pole from one to the other, and then stretched a wagon-sheet over the pole, and brought the ends down to the ground, and nailed them to planks on each side, which planks were nuiled to stakes driven in the ground. Then I boxed up the east end of this tent with boards, and, the evening I left, I picked up an old door and set it sideways in front of the west opening, leaving it up against the end pole. But as this did not fill up the west end entirely, I also put some boxes at one end of this old door, and then tied the wagon-sheet together about this old door. I did this to prevent a hog from getting in and to prevent anything from entering. I knew there was a hog in that neighborhood, and I fixed my place to prevent it getting in. When I came back from Pearsall to my place, on Monday, after I left on Saturday, I found that the door had been moved aside sufficient to allow one to pass into this house; and I missed a pair of blankets, a quilt, and a vest. * * I afterwards saw the blankets in the possession of the sheriff." This structure was in the exclusive possession of the witness, Ryman; he resided in it, but did not own the ground. It was contended that this was not a "house" within the meaning of the following statute: "Any building or structure. erected for public or private use, whether the property of the United States, of this state, or of any public or private corporation, or association, or of any individual, of whatever material it may be constructed." Pen. Code Tex. (1895) Art. 813. The court distinguished Williamson v. S., above, and held this to be a house. saving: "Such a structure as this is as much under the protection of the burglary statute as would be a structure entirely made of wood, brick, or granite. The law does not mention the character of the structure or the material of which it shall be made. It protects the humble tenant in his tent as well as his more fortunate neighbor in his palace." .Judgment affirmed. Favro v. S., 39 Tex. Crim. R. 452, 46 S. W. 932. 73 Am. St. Rep. 950.

(Ga. Sup. Ct.. 1898.) Poultry Coop. Defendant was charged with larceny from a house. under the statute providing that, "any person who shall, in any dwelling-house, store, shop, warehouse. or any other building, privately steal any money or other thing." (Pen. 
Cod. \$ 179) shall be punished, etc. Defendant pleaded not guilty, and at the close of the evidence moved to be discharged, on the ground that the place was a chicken coop, and not a house. 'The motion was denied, and the judgment against defendant was affirmed on appeal. "The court said: "The structure from which the pigeons were taken, as shown by the evidence in the case, was about eight feet high, stationary, inclosed with wire, and covered with shingles. The fact that it was inclosed with wire instead of other material, in our judgment, makes no difference." Williams v. S., 105 (Ga. 814, 32 S. E. 129, 70 Am. St. Rep. 82.

\section{$\S 113$. "Of Another."}

See also the cases on this point under arson, $\$ 120$.

(Eng. C. C. R., 1617.) Servant Opening Inner Door. On indictment for burglary the jury found specially at the Winchester assizes, 15 Jac., that Edmonds was a servant and apprentice of Heydon, and slept in the house; and at night Edmonds opened the door to the toot of the stairs by lifting the lateh, went upstairs, and entered the chamber where Heydon and wife were in bed, with intent to miurder Heydon, and then struck him 15 wounds with a hatchet, etc. This verdict being shown to the judges of Serjeant: 3 Inn in Chancery Isane, and later at a meeting in Serjeant's Inn in Fleet St., they all agreed that it was burglary. Edmonds's Case, Hutton 20, Mi. 917.

(Eng. Old Bailey, 1722.) By Servant. A servant in the house opened his lady's chamber door (which was fastened with a brass bolt) with design to commit a rape; and King, C. J., ruled it to be burglary, and the defendant was convicted and transported. R. v. Gray, 1 Strange 481, B. 784.

(Eng. King's Beuch, 1731.) Collusion with Servant. Cornwal and another were indicted for burglary; and on the trial it appeared that Cornwal was a servant in the house, and in the night-time opened the street-door, and let in the other prisoner, and showed him the sideboard, from which the other took plate; whereupon Cornwal opened the door again and let him out, yet did not go out with him, but went to bed. It was doubted whether it was burglary in the servant, he not going out with the other; and afterwards at a meeting of all the judges at Serjeant's Inn, they were all of opinion that it was burglary in both. And upon report of this opinion the next session, the defendant was executed. Joshua Cornwal's Case, 2 Strange 881.

(S. Car. Sup. Ct., 1902.) By Servant. Appellant was convicted of burglary on evidence tending to show that at night after the 
house was closed, he entered the house and room of the prosecutor (for whom he worked, and in whose room he was accustomed to sleep) opened a trunk therein, took $\$ 16$ in money therefrom, left the house, and was taken the next day with part of the money on his person. Exception being taken to refusal to grant, a new trial, the supreme court sustained the judgment of the court below, because there was no complaint of improper instruction to the jury, and there was evidence from which they might have found that defendant entered the house vith intent to steal; which being so, the conviction was proper. It was admitted that if the intent to steal was formed after the entry the entry was authorized, and there would then be no burglary. S. v. Howard, 64 S. C. $34 \&$, 42 S. E. 173, 58 L. R. A. 685.

\section{§114. "In the Night-time."}

(N. Ham. Superior Ct. of Judicature, 1839.) Evidence. Indictment for burglary. Verdict, guilty. Defendant contended that there was no proof of the time of the act. The only testimony on that point was by the housewife, that she saw the firlin of butter after dark and that it was gone when she got up in the morning. The court held the evidence sufticient to sustain the verdict, though it did not appear what the witness meant by "after dark" nor when she got up in the morning. As to what is night-time the court said: "There is no intervening time between the night and the day; and when the light of the latter is entirely gone, and the great characteristic which distinguishes it from night no longer exists, the day terminates with it. The next day commences with the earliest dawn, and the night of course ends at that time. That the matter does not depend unon the degree of light, and the ability to distinguish objects at the time, is evident, because the light of the moon, however bright it may be, makes no difference." Per PARKER. C. J. Judgment affirmed. S. v. Bancroft, 10 N. H. 105, F. 266, Kn. 249.

(Mich. Sup. Ct., 1893.) Window Unlocked in Daytime. GRANT, J. The respondent was convicted of burglary under $\S 9132$, How. St. The evidence on the part of the people tended to show that the owner of the dwelling-house occupied the front room for a shoe shop, and the rear and overhead part as a dwelling. The shop was upon the ground floor, and had two windows, each about four feet from the ground. These windows had double sash; were without pulleyweights, and were fastened when raised, and bolted when down, by stops operated by springs. When the windows were closed, the springs threw the bolts into the slots in the cases, so that the window could not be raised without drawing the bolt. One of the windows was opened during the night of October 8 , and three pairs of shoes were stolen. *** It was contended on behalf of the respondent that no breaking or entering in the night-time was es- 
tablished. * * When a merchant enters his store in a city at the usual hour in the morning, though it be after daylight, and finds that it has been broken open and entered from the front door or window, it is contrary to good sense to say that the crime might have been committed after daylight, and therefore, the court must direct an acquittal. Such crimes are not committed in broad day. light. * * The theory of the prosecution was that the respondent went in the shop, either on the 6th or 7th of October, and raised the window just enough to prevent the bolt entering the slot (and there was evidence to sustain it). It is insisted that even if this was so and the respondent raised the window on the following night, it did not establish the crime of burglary. We cannot agree to this contention. * * Affirmed. P. v. Dupree, 98 Mich. 26, 56 N. W. 1046, Mi. 909.

\section{§115. "With Intent to Commit a Felony.Therein."}

(Eng. Assize, 1770.) To Disable Horse. Dobbs was indicted for burglary in breaking and entering the stable of Bayley, part of his dwelling-house, in the night, with a felonious intent to kill and destroy a gelding of one A. B., there being. It appeared that the gelding was to have run for forty guineas, and that the prisoner cut the sinews of his foreleg to prevent his running, in consequence of which he died. PARKER, C. B., ordered him to be acquitted; for his intention was not to commit the felony, by killing and destroying the horse, but a trespass only to prevent his running; and therefore no burglary. But the prisoner was again indicted for killing the horse, and capitally convicted. Dobbs's Case, 2 East P. C. 513, B. 181, Ke. 176.

(Eng. C. C. R., 1782.) To Recapture Goods. Prisoners were indicted for breaking and entering a dwelling-house at night to steal the goods of Hawkins, an excise officer, who had seized 17 bags of tea at Smith's shop, as being an illegal shop. The witnesses said they supposed the tea belonged to Smith and that the taking was in his coinpany or by his procurement, and the jury found that the prisoners intended to take the tea on behalf of Smith. In Easter term, 1782, all the judges held that the indictment could not be supported, there being no intent to steal, however outrageous the behavior of the prisoners was in thus endeavoring to get back the goods of Smith. R. v. Knight, 2 East P. C. 510, B. 220, C. 111, Ke. 177.

Compare Fort $\nabla$. S., \& 143, taklng cotton from house to get credit for plcking it.

(Vt. Sup. Ct., 1844.) To Commit Adultery. WILLIAMS, Ch.J. The respondent was indicted for burglary, and was convicted on the second count-which charges him, in substance, with breaking and entering a dwelling-house in the night-time, with intent to commit 
adultery. * * * Adultery was not a felony at common law, nor a crime to be punished in the common law courts. Neither does our statute make it felony. Nor does it come within any definition of felony, which can be found. Until the legislature think proper to declare the transaction, of which the respondent was found guilty, an offense, we cannot determine it so to be. Judgment reversed and arrested. S. v. Cooper; 16 Vt. 551, Ke. 176, Kn. 251.

(Ill. Sup. Ct., 1888.) To Get Drink. Defendant had been in the saloon, which it was alleged he was attempting to enter, on Sunday morning, and obtained a drink. He went out, and, on returning the same morning, found the door closed, and was seen with his body leaning half over the top of a window, which had been left down, and, on being asked what he was doing, said he wanted whiskey. He was found guilty of attempting to enter the saloon to steal. The indgment was reversed on error, because it was evident that he only wanted another drink; and probably he thought, as he testified, that someone was in there, and was playing "shenanagen" on him. Fiester v. P., 125 Ill. 348, 17 N. E. 748.

Other Cases: Entering house to carry away goods before embezzled (R. v. Dingley, $\$ 130$ ); to cut off a man's ear (C. v. Newell, $\S 101$ ) ; to get intercourse with woman by impersonating her husband (R. v. Jackson, \& 102; Wyatt v. S., \& 102).

Guest stealing at night from hotel bar-room does not show eutry with intent: $S$. $\nabla$.

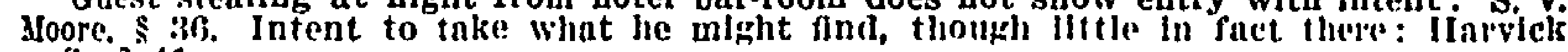
ร. S., $\$$. 41 .

\section{ARSON.}

§116. Defined. Arson is maliciously and voluntarily burning the house of another by night or by day. 3 Coke Inst. c. 15, p. 66; 1 Hale P. C. 566.

\section{§117. "Maliciously and Voluntarily."}

(Eng. Assize, 1799.) Burning Beyond Intention. On indictment for a misdemeanor in setting fire to 'T.'s house occupied by defendant, counsel for the prosecution said in opening, that defendant set fire to the house to defrand the Phoenix Ins. Co., but the fire spread to and burned down several adjoining houses of others. Upon which, BULLER, J., said that if other persons' houses were in fact burned, the prisoner was guilty of felony, if at all, though he only set fire to his own; and the misclemeanor being merged in the felony, he could not be convicted on this indictment; and therefore directed an acquittal. Isaac's Case, 2 East P. C. 1031, B. 799. 
(Ala. Sup. (t., 1873.) To Escape Jail. Appellant was convicted uf arson in burning a hole in the floor of the jail where he was contined on charrge of assinult with intent to murder. He controlled the fire with water furnished him to drink and wash with. When the hole was burned nearly through the Howr the sheriff discovered and extinguished the fire. The question was, whether burning to escape and without intent to consmme the building, would be arson. The court held, that, the burning being sufticient, the intent was no exeuse, at least in view of the fact that it was an act done in attempting to commit another felony, prison breach. "Was it done wilfully" This term menns less than maliciously, and more than intentionally or designedly. It means mulawfully, and to some extent wickedly. $* *$ All of the anthorities agree, that where the firing is done with the intention of committing any felony, it is arson. * * 'The guilt or innocenes of this defendant is not dependent upon whether he was in the eommission of a different felony or not. He intentionally and designedly set fire to the jail, in order to arecomplish an unlawful purpose. and comsequently the burning was wilfully done. It would not be safe to gradiate his offense hy the extent of the burning he intended to do. becanse, als far as intention constitutes the crime. the eriminality is the same whether the honse is burned slightly or consumed. The lives and property of other persons camnot be made dependent upon his supposition of how much burning he can do withont eonsuming the honse." Per S.AF. FOLD, J. Judgment affirmed. Luke v. S., 49 Ala. 30, 20 Am. Rẹp. 269 , Kn. 238.

\section{§118. "Burning."}

(Eng. C. C. R., 1759.) Paper in Attic Burned. A prisoner being indicted on 9 Geo. 1, c. 22, for setting fire to an onthouse commonly called, a paper-mill; it appeared that he had only set fire to a large quantity of paper, which was drying in a loft annexed to the mill. and that no part of the mill itself was burned. 'lhe judges thonglt the case not within the statute. R. v. Taylor, 1 Lench C. L. Xio. 2i. 2 East P. C. 1020.

(Eng. Assize, 1842.) Fire Set on Floor. In a case of arson, it appeared that a small fagot was set on fire on the board floor of a room, and the fagrot was entirely consumed; and that the boards of the floor were scorehed black, but not burnt. and no part of the wood of the floor was consumed. CRESWELI, J. R. v. ?'arker.? Car. \& P. 45, is the nearest case to the present, but I think it is distinguishable. * * I have conferred with my Brother Pattesom, and he concurs with me in thinking that as the wood of the floor was scorched, but no part of it consumed, the present indietment cannot be supported. We think that it is not essential to this offense 
that the wood should be in a blaze, because some species of wood will burn and entirely consume without blazing at all. 'The prisoner must be acquitted. R. v. Russell, Car. \& M. (+1 E. C. L.) 541, Mi. 931.

(Alass. Sup. Judicial Ct., 1872.) Shingles Burned. On indictment for burning C's house, it appeared that defendant set fire to C's barn, which was entirely consumed, and that shingles on the house burned in two places, and further damage was prevented only by persous on the roof constantly watehing and keeping it wet. The judge refused to instruct the jury that they must find that the house had been on fire and some portion consumed and actually destroyed; but he did instruct them that in order to eonvict they must find that the substance of the wood on fire wins actually burned. Verdict, guilty. Tucker excepted. WWLLS. J. The instructions given to the jury were eorrect, and in accordance with the authorities; as well those eited for the defendant as those for the commonwealth. They required the jury to find that some portion of the dwellingrhouse had been actually on fire and burned. 'To have repuired them to find something more, by use of the terms "consumed" and "destroyed," as prayed for", would have been to go beyond the provisions of the statutes, and to leave the jury with no precise definition of that which was necessary to constitute the offense. F.. ceptions overrulerl. C. v. Tucker, 110 Mass. 403. B. 800.

('lex. Ct. of App., 1891.) Smoked and Scorched Walls. On trial for arson three witnesses testified that the floor was burned or charred in one place, that the walls of the house were smoked and seorched, but could not suy that they caught fire. Two others testified that the house did not eatch fire or burn, that coal-oil had been poured on the bed and ignited, that they carried out the burning bed and bedding, and that nothing else was burned. It was held that the court erred in refusing to instruct the jury, as requested by the defendant, that "if they found that the house was simply scorched or smoked, then this would not be sufficient, and they should aequit the defendant." The court of appeals said: "If the fire had burnt a hole in the floor, as testified by some of the witnesses, then the offense was complete." Woolsey v. S., 30 'l'ex. App. 346. 17 S. W. 546, F. 246, Kn. 229 .

\section{§119. "The House."}

(Comn. Sup. Ct. of Errors, 1850.) House Nearly Built. On trial for arson, defendant was convicted. and excepts to the refusal of the court to direct a verdiet of aeruittal. CIIURCII, C. .J. 'The statute of this state prescribes the punishment of ar'son, but it does not define the crime. We look to the common law for its definition. 
Arson, by the common law, is the wilful and malicious burning of the house of another. The word "house," as here understood, includes not merely the dwelling-house, but all outhouses which are parcel thereof. 1 Hale P. C. 570, 4 Bl. Com. 221, 2 Russ. Crimes 551. * * The building is described to be one built and designed for a dwelling-house constructed in the usual manner. It was designed to be painted, but was not yet finished, in that respect, and not quite all the glass were set in one of the outer doors. The building had never been occupied, and it was not parcel nor an appurtenant of any other. We think this was not a dwelling-house, in such a sense as that, to burn it. constituted the crime of arson. In shape and purpose it was a dwelling-house, but not in fact, because it had never been dwelt in-it had never been used, and was not contemplated as then ready for the habitation of man. ** * We think it was the duty of the court to have instructed the jury as to the law of the matter, and leave it to them to say from the proof whether the building was a house, within the meaning of the law thus explained. * * * New trial granted. S. v. McGowan, 20 Conn. 245, 52 Am. Dec. 336, F. 247, Kn. 232.

Compare cuses on burglary, $\$ 112$.

\section{\$120. "Oî Another."}

(Eng. King's Bench, 1634.) Burning by Tenant in Possession. Wm. Holmes was indicted in London, for that, being possessed of a house there for 6 years yet enduring, remainder to $\mathrm{S}$. for 3 vears, remainder to $H$. in fee, he vi et armis the said house wilfully, maliciously, and feloniously burned, etc. On being arraigned at Newgate he was found guilty; but before judgment the indictment was removed by certiorari to this court. RICHARDSON, C. J., JONES, and BERKJIEY. J.J., held that it was not felony to burn a house whereof he is in possession by virtue of a lease for years; for they said, that burning of houses is rot felony unless that they are ades olienx; and therefore Britton, p. 16, Bracton, p. 146, and the book Assize, 27, Assize, pl. 44, mention that it is felony to burn the house of another; and $10 \mathrm{Edw} .4$, pl. 14; $3 \mathrm{Hen} .7$, pl. 10; $10 \mathrm{Hen} .7$, pl. 1, and Powlter's Case, 11 Coke 29, which say that burning of houses generally is felony, are to be intended de adibus alienis, et non propriis; and although the indictment be "ea intentione ad comburendum felonice, voluntarie, et malitiose," the houses of divers others "contigue adjacentes," yet intent only without fact is not felony. Also BERKLEY and JONES, J.J., held that it cannot be said to be vi et armis when it is in his own possession. CROKE, J., said: Every indictment is vi et armis et contra pacem, where an act is done against the commonwealth; so it is where a servant runs away with goods committed to his trust above forty shillings, although properly it cannot be said to be vi et armis, because they were in 
his custody. And in this case the ill consequence which might have fallen out by this act makes the offense the greater; and The Year Books in $10 \mathrm{Edw} .4$, pl. 14; 3 Hen. T, pl. 10; 11 Hen. 7, pl. 1; and Stanford P. C. 36 ; 11 Coke 29 ; 4 Coke 20 a, put the case of burning of houses generally, and not of the burning of other men's houses; and it is an equal mischief in a commonwealth to burn his own in a city or vill as to burn the houses of others, for the danger which may ensue. But the other three justices resolved ut supra, that it was not felony; wherefore he was discharged thereof. But because it was an exorbitant offense, and found, they ordered that he should be fined $£ 500$ to the king, and imprisoned during the king's pleasure, and should stand upon the pillory, with a paper upon his head signifying the offense, at Westminster and at Cheapside, upon the market-day, and in the place where he committed the offense, and should be bound with good sureties to his good behavior during life. Holmes's Case, Cro. Car. 376, W. Jones 351, B. 797.

Servant burning at order of master for insurance: S. v. Haynes, p. 115.

(Eng. C. C. R., 1708.) Burned by Widow Before Dower Assigned While Possessed by Tenant. On an indictment for arson; in a dwelling-house in the possession of $E$. S. it appeared that the prisoner Elizabeth was the daughter of the prisoner Anne by a former husband, John Harris. From the evidence at the trial it was disclosed that John Harris died seised of the equity of redemption of this house, and of another adjoining to it, subject to a mortgage term for $£ 20$ and that the equity descended to his eldest son, a child left with other children under the care of their mother, the prisoner Anne, who was entitled to dower out of these houses, but no dower was ever assigned; that Anne, having the care of her son and his estate, let these houses to $\mathrm{E}$. S. at the rent of $\$ 5$ a year, and received the rent for some time; but having a large family of chiriren, she was obliged to ask relief of the parish where she lived; that she was denied such relief on account of these houses, the parishioners insisting that the overseers of the poor should be let into the receipt of the rent before she could be entitled to any parochial relief; that thereupon she frequently declared that she would set the houses on fire, if the parish did not relieve her; that she had young children whom the parish could not punish, though they might punish her, and that she would order the least child she had to carry a coal of fire to burn the houses down. And many other declarations of the like kind she made which discovered an obstinate resolution in her to burn the houses rather than submit to the terms the parishioner insisted on. It appeared further that the prisoner Elizabeth set the house on fire by the direction of the prisoner Anne, who went from home on purpose to be absent at the time when the fact was committed. The jury found both the prisoners guilty; but a doubt arising by reason of the interest the prisoner Anne had in the house. the judge who tried the cáuse thought proper to respite judgment in order to take the opinion of the judges on the case, who, at a meet- 
ing of the judges at the chief justice's chambers, unauimously agreed that both the prisoners were guilty of felony. R. v. Harris, loster C. L. 113, Mi. 928. .

(Eng. C. C. R., 1780.) House of Tenant Burned by Him. In sup. port of an indictment for wilfully and maliciously setting fire to and burning a certain dwelling-house, it was proved that the defendant was the tenant in possession under an agreement for a lease for 3 years, from a person who held under a building lease. bjon the jury finding the prisoner guilty the judge who tried the case respited the judgment to have the opinien of the judges on the question whether the conviction under these circumstances was legal. 'The judges, on the authority of IIolmes's Case, Cro. Car. 376 Labove], determined in the negative. R. v. Breeme, 1 Ieach C. L. No. 109. 2 East P. C. 1026 .

Are. R. v. Pedley, 1 Leach 2 rit, 2 East P. C. 1020.

(Eng. King's Bench, 1786.) By Pauper in Possession. 'The prisoner, a poor man, maintained by the parish, had, some time before the commission of the crime with which he was charged, been put by the parish officers to live in the house which he was aceused of having set on fire, and was resident therein with his family at the time of the fact being committed, having the sole possession and occupation of it, but without paying any rent. All the judges held that it could not he considered as his house, and that he was properly convieted of the arson. Gowen's Case, 2 East P. C. 102T, 1 Leach C. L. (Ed. 4), p. 462 n, Mi. 930.

(Mich. Sup. Ct., 1872.) Wife's House. Information for arson in burning the dwelling of defendant's wife. He was convicted ind brings error. Though there was evidence that defendant had separated from his wife, the evidence on that point became unimportint. because the court instructed the jury that defendant eonld he convicted for burning his wife's house, though living with her. 'The correctness of this instruction is the only point. COOLEY, .T. * * The statute provides that "every person who shall wilfully and maliciously burn in the night-time, the dwelling-house of another," etc., shall be punished, etc. Comp. Laws, § 5745 .

There are Numerous Decisions as to what is meant by the dwellinghouse of another, as well at the common law as under like statutes to our own. Arson is an offense against the habitation, and regards the possession rather than the property. S. v. Toole, 29 Conn. 344. The house, therefore, must not be described as the house of the owner of the fee, if in fact at the time another has the actual occupancy, but it must be described as the dwelling-house of him whose dwelling it then is (2 East P. C. 1034; 4 Bl. Com. 220; Whart. Cr. Law, § 1638; 2 Bish. Cr. Law [2d Ed.], § 24; Holmes's Case, Cro. Car. 376; Spalding's Case, 1 Leach No. 108; C. v. Wade, 17 Pick. 395); even, it seems, 
though the occupation be wrongful (R. v. Wallis, 1 Mloody C. C. $34 t$; S. v. 'loole, 29 Conn. 344). It follows that a lessee could not be guilty of the felony in burning the premises occupied by him as such (2) Eist P. C. 1029 ; 2 Russ. Crimes 550 ; MicNeal v. Woods, 3 Blackf. 485 ; S. v. Lyon, 12 Conn. 487 ; S. v. Fish, 27 N. J. Law 323 ; S. v. Sandy, 3 Ired. 570; 3 Greenl. Ev. \$55), while the landlord, during such occupation, might be (2 East P. C. 1023, 1024; Sullivan v. S., a Stew. \& P. 175). A jail, it has been held, may be described as the dwelling-house of the jailor, living with his family in one part of it. P. v. Van Blarcum, 2 Johns. 105 ; Stevens v. C., 4 Leigh 683. And it seems that the wife, because of the legal identity with the husband, cammot be guilty of the offense in burning the husband's dwelling, even though at the time living separate from him. Narch's Case, 1 Moody C. C. 182 , C. 484 . This would doubtless be so held whenever the wife's domicil is regarded in law as identical with the lusband's, which for many purposes is no longer the case when they iive separate. It must be evident from this summary of the law on this subject that if the husband, living with his wife, has a rightful possession, jointly with her, of the dwelling-house, which she owns and they both occupy, he cannot, by common law rules, be guilty of arson in burning it. It remains to be seen

Whether the Statutes have Introduced any Changes which wonld affect the case. The statutes upon which the question arises are those for the protection of the rights of marred women.

[Here his honor reviewed the statutes to prove that their policy is to protect the wife's property, but not to weaken the family unity. Some of the legislation on the subject is exceedingly crude; some of it has injudiciously given powers to the wife in the disposition of property which it has prudently denied to the husband; but none of it makes the husband a stranger in law in the wife's domicil. The property is hers alone, but the residence is equally his; the estate is in her, but the dwelling-house-the domus-is that of both. If, therefore, the husband shall be guilty of the great wrong to his wife and family of setting fire to the house they inhabit, he is no more guilty of arson in so doing than the wife was at the common law for a like wrong to the dwelling-house of the husband. The case is a very proper one for a penal statute, but none has yet been enacted to meet it. The house. in legal contemplation. as regards the offiense. under consideration, is the dwelling-house of the husband himself. But in so holding we do not decide that

If the Family Relation is Broken Up in fact, and husband and wife are living apart from each other, whether under articles of separation or not, the same exemption from criminal liability can exist. There is much reason for holding that the wife's dwellinghouse can be eonsidered that of her husband only while he makes it such in fact. * * * New trial granted. Snyder v. P., 26 Mrich. 106, 12 Am. Rep. 302, F. 249, Kn. 234. 


\section{CHAPTER IX.}

\section{OFFENSES AGAINST PROPERTY.}

\$121. Classificution, :405.

\section{LARCENY.}

\$ 122. Defined, 395.

\$123. "Iarceny at Common Iaw," 395.

\$124. "Taking," 396.

\$125. "By 'Tresuass," 30y.

\$126. Classification, 400 .

\$127. "As Servant," 400.

$\$ 128$. "In Making an Exchange," 404.

$\$ 129$. "In Some Other Capacity," 408.

\$130. "Where the Accused Recelved the Property from Anotber," 410.

\$131. "Delivered by Mistake," 415.

8132 . "Finding Iost Property," 418.

8133. "Fraud," 424.

8134. "Without Consent," 438.

8 135. "Carrying Away," 444.

\$136. "Another"s," 447.

$\$ 137$. "Vnluable," 451.

8 138. "Personal," 452.

8139 . "Property," 459.

\$ 140. "Claim of Right," 466.

"With Intent."

$\$ 141$. General Rule, 468 .

\$142. Cases of Ballee's Breaking Bulk, 470.

8 143. "Io Deprive the Ownel of IIis Property," 476.

\$144. "Permunently," 481.

\$145. "Convert It to the 'laker's Own Use," 483.

ROBRERY.

\$ 146. Defined, 485 .

8147 . "Felonious Taking," 485.

8148. "In His Presence," 486.

$\$ 140$. "By Violence or Putting in Fear," $4 \$ 8$.

Larceny From the Person.

$\$ 150$. In General, 490.

Larceny Firou tif: Housh.

\$151. In General, 492.

BMBEZZLEMENT.

\$152. In General, 498.

Receiving Stores Goods.

\$153. The Statutes, 506.

\$154. "IRecelve," 506.

\$155. "That Shall be Felonlously Taken or Stolen," 511.

\$156. "Irnowing the Same to be Stolen," 514.

\$157. "Shall be Taken and Deemed an Accessory," 515.

Cheatixg at Comion Iaw.

\$158. Defined, 517.

Fonger.

\$159. Definltion, 518.

\$160. "It Includes as Well the Unsuccessful Attempt," 518.

8161. "It is the False Making," 518.

\$162. "Materially Alterlng," 523. 
FOnGER Y. - Continued.

sti:i. "With Intent to befraud." 524.

\$16. "Of Any Writing," 524,

\$16ir. "Mlinht Apparently be of Some Legal Eedney." 520 .

UTTEMNG FonGHD INSTHUMENTS.

\$166. In Genernl, 527.

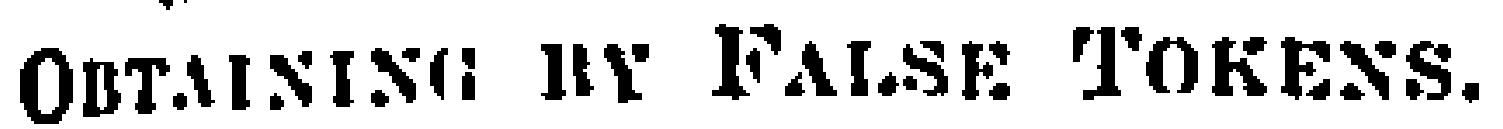

\$16i. In General. 529.

obtuising m Fatse Pnethasis.

ह16S. Stitute 30 Geo. 2. c. 24. 331 .

\$169. "By." 532.

\$170. "False," 534.

\$171. "l'retenses," 5335.

\$172. "Shnll Obtaln." ;43.

8173. "From Any Person." Bit6.

\$17t. "Iloney, Goods, Winces, or Merclunnllse." 546.

817.7. "Wilh Intent to ("heat or Inefraud," 54 ?. Mainctous MiscriseF.

$\$ 1$ iijil. In General.

$\$ 121$. Classification. Of the erimes arainst property we will consider the following: 1 , common law larceny; 2 , robbery; 3 , larceny from the person; 4, larceny from the house; 5 , receiving stolen goods ; 6, embezzlement; 7, cheating at common law; 8, forgery and uttering forged instruments; 9 , obtaining property by false tokens; 10 , obtaining property by false pretenses; 11 , malicious mischief.

\section{I.ARCENY.}

\$122. Larceny Defined. Common law larceny is the taking by trespass or fraud, without consent, and carrying away another's valuable personal property, without excuse or claim of right, intending to deprive the owner of it permanently, and convert it to the taker's own use.

\section{§123. "Common Law Larceny."}

Bracton and Fleta describe larceny" as "Contractatio rei alienæ fraudulenta, cum animo furandi, invito illo domino, cujus res illa fuerat." Bracton, lib. iii. c. 32, fol. 150; Fleta, lib. i. c. 36 ; Glanville (lib. vii. c. 17 ; lib. x. c. 1 j) follows Bracton.

Lord Coke defines larceny to be "the felonious and fraudulent taking and carrying away, by any man or woman, of the mere personal goods of another, neither from the person nor by night in the house of the owner." 3 Inst. 107.

East's Definition is, "The wrongful or fraudulent taking and carrying away by any person of the mere personal goods of another 
from any place, with a felonious intent to convert them to his (the taker's) own use and make them his own property, withonit the consent of the owner." 2 Last P. C. כj3.

\section{\$ 124. "Taking."}

(Eng., 1598.) A Had Keys Tied to the Strings of His Purse; B. a cut-purse, took the purse out of $A$ 's pocket, but the keys tied to the purse stuck in the pocket, and $A$ took $B$ with the purse in his hand, and the strings tied to the keys still in $A$ 's pocket. It was ruled that this was no felony, for $A$ still had possession of his purse in law; so that licet cepit non asportavit. Wilkinson's Case, 1 Hale

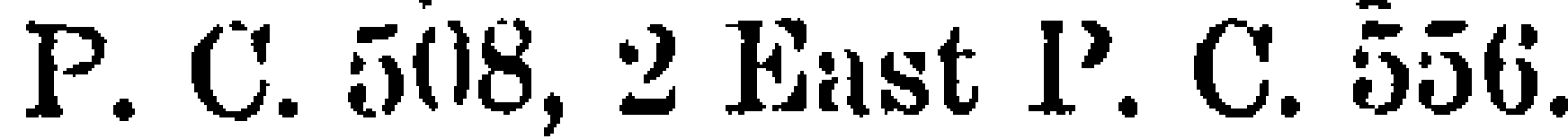

(Eng. (. C. R., 18:5.) Taking From Pocket. Indictment for stealing from the person. Prosecutor testified: "I was at a lair; I felt a pressure of two persons, one on each side of me; I had secured by book in the inside front pocket of my coat; I felt a hand between my coat and waistcoat; 1 could feel the motion of the knuckles; I was satisfied the prisoner was trying to get my book out; the other person had hold of my right arm, and 1 foreed it from him, and thrust it down to my book, in doing which I just brushed the prisoner's hand and arm; the book was just lifted out of my pocket; it returned into my pocket; it was out, how far I cannot tell; I saw a slight glance of a man's hand down from my breast; I secured the prisoner after a severe struggle, and a desperate attempt at escape, in which he was assisted by twenty or thirty persons; the coat was open; the pocket not over a quarter of an inch deeper than the book; I am satisfied the book was drawn from my pocket; it was an inch above the top of the pocket." The jury found the prisoner guilty, but the judge respited execution to take the opinion of the judges. After argument, Abbott, L. C. J., Park, Bailey, IIolroyd. Burrough, and Littledale, J.J., thought that the prisoner was not rightly convicted of stealing from the person, because from first to last the book remained about the person of the-prosecutor. Gaselee, J., and Graham, Garrow, and Hullock, BB., were of the contrary opinion. But the judges were unanimous that the simple !arceny was complete; and sentence of transportation for life having been passed, a pardon was recommended on condition of transportation for seven years. R. v. Thompson, 1 Moody 78, 5 L. 580, Ke. 221. Mi. 674 .

Such facts were held to show larceny from the person in Flynn v. S., 42 Tex. 301.

(Ala. Sup. Ct., 1881.) Enticing Hog Away. Defendant was in. dicted and convicted of larceny of a hog. The only evidence of caption was that defendant and his accomplice tollei the hog about 20 yards by dropping corn on the ground, then struck the hog with an ax, on which it squealed, and then ran away. SUMERVILIE. 
J. * * The court charged the jury that if they believed the evidence, it was sufficient to show such a taking and carrying away of the property, if done feloniously, as was necessary to make out the ofiense of larceny. We think the court erred in giving this charge, though the question presented is not free from some degree of doubt and difficulty. *** There must not only be such a caption as to constitute possession of, or dominion over the property, for an appreciable moment of time, but also an asportation, or calrying away, which may be accomplished by any removal of the property or goods from their original status, such as would constitute a complete severance from the possession of the owner. 3 Greenl. Hv., \$154; Roscoe's Cr. Ev., p. 625. It has been frequently held that to chase and shoot an animal, with felonious intent, without removing it after being shot, would not be such a caption and asportation as to consummate the offense of larceny. Wolf v. S., 41 Nla. 412; S. v. Seagler, 1 Rich. (S. C.) 30 ; 2 Bish. Cr. Law, \$ 797. - * It is clear, for example, if one should thus entice an animal from the possession, actual or constructive, of the owner, and toll it into his own inclosure, closing a gate behind him, the custody or dominion acquired over the animal might be regarded as so complete as to constitute lareeny. 2 Bish. Cr. Law, \$806. It is equally manifest that if one should, in like manner, entice an animal, even for a considerable distance, and it should, from indocility, or other reason, follow him so far off as not to come virtually into his custody, the crime would be incomplete. The controlling principle in such cases would seem to be that the possession of the owner must be so far changed as that the dominion of the trespasser shall be complete. His proximity to the intended booty must be such as to enable him to assert this dominion, by taking actual control or custndy by manncaption, if he so wills. If he abandon the enterprise. However, before being places in this attitude, he is not guilts of the offense of larceny, thou $\mathrm{t}$ h $\mathrm{z}$ may be convicted of an attemipt to commit it. Wolf's Case. 41 Alk. 412. It would seem there can be no asportation, within the legal acceptation of the word. without a previously acquired dominion. The facts of this case; taken alone. do not constitute larceny. It is not a reasonable inference from them that there was such a complete canion and asportation as to consummate the offense. Reversed. Edmonds v. S., 70 Ala. 8, 45 Am. Rep. 67, B. 511.

Acc. Molton v S., 105 Ala. 18, 16 So. 795, 53 Am. St. Rep. 97 hog, shot but not appronched afterwards.

(Tex. Ct. of App., 1886.) Selling a Cow Running at Large. On. appeal from conviction of larceny it was contended that all the cvidence taken as true did not support the conviction. It appeared that the day before the offense was committed appellant proposed to sell a cow and calf to one Hardy for \$20.50-\$7.00 down and the rest in the fall. Next morning Hardy and son and defendant went to see the cow. They found a red cow and calf in an open place, sort 
of prairie in the woods, which defendant pointed out as the one he wished to sell. They rode around the cow, and Hardy said he would take her, paid defendant $\$ 6$, and was promised a bill of sale when the rest was paid. 'Then defendant told Hardy and son to watch the cow, while he would look around for a better one, and swap for this if they wished. Then defendant loped off. and was not seen again by Hardy till just before the trial. After waiting some time, llardy and son drove the cow and calf home. 'ihere were several other cattle in the timber near by when the sale was made. 'Though the parties rode around the cow, they did not drive her; and, for aught that appears, she did not move in her tracks during the time defend. ant was present. It was not claimed that defendant had any interest in the cow. WHITE, P. J. *** It is contended most strenuously that such facts do not constitute "a taking" by defendant, under our statute defining theft; that, in so far as he was concerned, the range possession of the owner was never disturbed by him, and that he had not exercised the slightest control over silid animals of any lind whatsoever, much less having them in his manual possession, even though but for a single moment. "* * * [Here reviewing the cases and texts.] The defendant did not take the animal himself; but by selling it to Hardy, upon the pretense that it was his, he did procure Hardy, who was entirely iunocent, and who believed defendant was the owner, to buy and take possession of the animal. This was certainly causing another to be deprived of his property by indirect means, and under circumstances which, in contemplation of the statute, would malie him a principal in the theft. ** * Affirmed. Doss v. S., 21 Tex. App. 505, 2 S. W. 814, 57 Am. Rep. 618.

Followed in Lane v. S, 41 Tex. Cr. R. 558, 55 S. W. 831 . Contrn, P. v. Gillis, 6 Utah 84,21 Pac. 404.

(Cal. Sup. Ct., 1888.) Coat Chained to Dummy. Defendant was convicted of stealing an overcoat, and appealed. The only evidence of taking was as follows: "I was inside the store, and heard the chain of the dummy rattle, and on coming outside found defendant with said coat unbuttoned from the dummy, and under his arm, the same being entirely removed from the dummy, and about two feet therefrom and from the place where it had been originally placed on the dummy by me; and the accused was in the act of walking off with the said coat when grabbed by me, he being prevented from taking it away because said coat was chained to the dummy by a chain which ran through the coat-sleeve, and the dummy was tied to the building by a string." SHARPSTEIN, J. * * * Where goods were tied by a string, the other end of which was fastened to the counter, and the thief took the goods and carried them towards the door as far as the string would permit, and was then stopped, this was held not to be a severance from the owner's possession, and consequently no felony. 3 Greenl. Ev., \$15j. * * Tested by that rule, the evidence in this case was clearly 
insufficient to justify the verdict, and the defendant is entitled to a new trial on that ground. *** Reversed. P. v. Meyer, 75 Cal. 383, 17 Pac. 431.

(Ala. Sup. Ct., 1892.) Knocked Out of.Owner's Hand. 'Thompson was convicted of larceny and appeals. WALKER, J. The witness for the state testitied that he held out his open hand with two silver dollars therein, showing the money to the defendant; that the defendant struck witness's hand, and the money was either knocked out of his hand or was taken by the defendant, he could not tell positively which. It was after twelve o'elock at night, and the witness did not see the money, either in defendant's possession or on the ground. 'The court charged the jury: "If the jury find from the evidence that the defendant, with a felonious intent, grabbed for the money, but did not get it, but only knocked it from the owner's hand with a felonious intent, this would be a sufficient carrying away of the money, although defendant never got possession at any time of said money." This charge was erroneous. 'To constitute larceny there must be a felonious taking and carrying away of personal property. There must be such a caption that the accused acquires dominion over the property, followed by such an asportation or carrying away as to supersede the possession of the owner for an appreciable period of time. 'Though the owner's possession is disturbed, yet the offense is not complete if the accused fails to acquire such dominion over the property as to enable him to take actual custody or control. Frazier v. S., 85 Ala. 17; Croom v. S., 71 Ala. 14; Edmunds v. S., 70 Ala. 8; Wolf v. S., 41 Ala. 412 . It is not enough that the money was knocked out of the owner's hand, if it fell to the ground and the defendant never got possession of it.

- Reversed. Thompson v. S., 94 Ala. 535̄, 10 So. 520, 33 Am. St. Rep. 145, B. 513.

Compare several cases as what is taking in robvery, $\S 147$.

§125. "By Trespass." Of this Lord Coke says: "If he hath the possession of it once lawfully, though he hath animum furandi afterward, and carrieth it away, it is no larceny; but this receiveth some distinction, as hereafter shall appear." 3 Inst., c. 47, p. 107.

(Eng. Newgate Sessions, 1662.) Stealing Bedding from Lodgings hired for three months with furniture was held no felony (per Bridgman, Kelyng, and Wilde), because she had a special property in them by her contract; and so there could be no trespass, without which there could be no felony. R. v. Raven, Kelyng 24, B. 631.

(Tex. Ct. of. App., 1887.) Same. The owner of a horse gave defendant permission to ride it to a certain point, and then to turn it loose. On his way defendant exchanged the horse for an overcoat. 
Feld not lareeny, as the taking was not wrongful, nor was possession obtained by any false pretext, or with intent to deprive the owner of his property. Stokeley v. S., 24 'T'ex. App. 509, 6. S. W. 538.

\section{Classificntiọn.}

The difficulty as to whether there had been a trespass sufficient to convict of larceny has arisen in cases in which, for his own purposes, the owner has given the accused custody as servant, in making an exchange, or in some other capacity; or where the accused received the property from another, and the doubt was whether the prosecutor yet had sufficient possession to make the wrongful conversion a. trespass; or where the property had been delivered to the accused by mistake, or had been lost and was found by him. Let us examine these in the order named.

\section{\$ 1:7. As Servant.}

(Eing. King's Bench, 1470.) BILLING, C. J., said, that if I give my goods to my servant to sell or keep he cannot take them feloniously, for they are in his possession. Anon, $10 \mathrm{Ed}$. 4, $14 \mathrm{pl} .10$, at the end.

(Eng. C. C. R, 148T.) Possession and Custody of Servant Distinguished. HUSSEY [C. J.] put the question: If a shepherd steals the sheep which are in his charge, or a butler the pieces which are in his charge, or servants other things which are in their charge, whether this shall be called felony? And it seemed to him that it would; and he cited a case which was, that a butler had stolen certain stuff which was in his charge, and was hanged for it. HIAUGH [J.] cited the case Adam Goldsmith of $L_{1}:$ don, who had stolen cer. tain stuff which was in his charge and was hanged for it. BRIAN [C. J.] : It cannot be felony, because he could not take vi \& armis what he had charge of. And the justices were of the same opinion, and so no discussion, etc. R. see M. 13 Ed. 4, f. 3; P. 13 Ed. 4, f. 9; T. 22 Fd. 3 [Fitzh. Abr.] Corone 256, what shall be called felony of goods. Note by reporter, Y. 13. 3 Hen. 7, 12 pl. 9, B. 523.

(Eng. Common Pleas, 1533.) Same-Yorke Puts this Question Upon the Statute 21 H. VIII. [c. 7], which is "that if any master or mistress deliver any goods to his servant to keep, who withdraws himself, and goes away with the goods to the intent to steal them, or if he embezzle the goods of his master, or convert them to his own use, if the goods be worth forty shillings, it shall be felony." And a man delivers a bond to his servant to receive $£ 20$ of the obligor, 
and the servant receives them, and after that goes away, or converts them to his own use, whether this be within the meaning of the statute or not? And by the better opinion it is not, for he did not deliver to him any goods ; for a bond is not a thing in value, but a chose in action. And Englefielde [J.] said that if a man deliver to his apprentice wares or merchandises to sell at a market or fair, and he sell them, and receive money for them, and go away, that is not within the statute; for he had not it by the delivery of his master, nor goes off with the things delivered to him. Quaere. For the money was not delivered to the servant by the hands of his master, but of the obligor. But if one of my servants deliver to another of my servants my goods, and he go off with them, that is felony ; for it shall be said my delivery. And Fitzherbert [J.] said that in the case of a bond, by gift of omnia bona et catalla, bonds pass. Anon., Dyer 5a, B. 524.

(Eng. Old Bailey, 1664.) Silk Given to Work On. A silk throster had men come to work in his own house, and delivered silk to one of them to work, and the workmen stole away part of it. It was agreed by HYDE, chief justice, KELYNG and WYLDE, JJ., being there, that this was felony, notwithstanding the delivery of it to the party, for it was delivered to him only to work, and so the entire property remained then only in the owner, like the case of a butler who hath plate delivered to him; or a shepherd, who hath sheep delivered, and they steal any of them, that is felony at the common law. Vid. 13 Eliz. 4, 10; 3 H. VII. 12; 21 H. VII. 14; Accord Poulton de Pace, 126. Anon., Kelyng 35, B. 515.

(Eng. C. C. R., 1782.) A Messenger to Deliver Goods Received of Master, turned aside on the way to a public drinking house, at the invitation of two men he met, where ther persuaded him to open the package and sell the gonds, for which he received eight guineas. It was referred to the consideration of the twelve judges, whether he was guilty of a felonious taking on these facts; and Hotham, B., delivered the unanimous opinion of the judges that the conviction was proper; for the prisoner standing in the relation of a servant. the possession of the goods must be considered as remaining in the master until and at the time of the unlawful conversion of them by the prisoner; the master was to receive the money for them from the customer, and he could at anv time have countermancled the delivery of them. R. v. Bass, Leach C. C. No. 121, 2 Fist P. C. 566, 698 , B. 531.

(Eng. C. C. R., 1788.) Messenger with Money to Buy Goods for Master. William Watson was tried on an indictment containing three counts; the first stating that the prisoner, as a servant, received $£ 3$ 1Bs., the money of $\mathrm{F}$. Cowper, his late master, which was delivered to him safely to keep to the use of his said master: and 
that afterwards the said prisoner withdrew himself from his master with the money, with an intent to steal the same, and to defraud his said master thereof. The second count stated that the prisoner, having received the said money in the manner above stated, and being with his master, had converted the same to his own use; and both concluded against the form of the statute. The third count was for larceny generally. It appeared that Cowper, who was a surrogate, had sent the prisoner, who was his servant, to buy some blank licenses, and had delivered him the $£ 3$ 18s. for that purpose; but the prisoner ran away with the money, and being convicted, a question was reserved for the opinion of the judges, whether the evidence supported any of the counts. And in Easter term, 1788, ull the judges but the chief baron held that this case was not within the statute, for to keep means to keep for the use of the master, and to return to him. As to the count for larceny, all the judges held this could not be felony at common law; for to make it felony there must be some act done by the prisoner, a fraudulent obtaining of the possession, with intent to steal. R. v. Watson, 2 East P. C. 562, B. 532 .

(Eng. C. C. R., 1793.) Same. Lavender was indicted for larceny at common law of money belonging to John Edmonds. The prisoner was a servant to Edmonds, who had delivered him the money in question to carry to the house of one Flawn, and there to leave the same with him, * * for bills to be returned later. He did not carry the money to Flawn as directed, but went away with it, purchased a watch and other things with part, and part remained in his possession when he was apprehended. Being found guilty, sentence was respited for the opinion of the judges, whether this were a felony or a breach of trust; and in Easter term, 1793. all the judges held this was a felony, and that the last point in Watson's case above referred to was not law. In Trinity term following this case was again under the consideration of the judges, when they adhered to their former opinion. and some said that the distinction between this case and Watson's, if there were any, was that in Watson's case the money was not delivered to the prisoner to be paid specifically to any other person; but if the prisoner had laid out his own money to the same amount in buying licenses, it would have been a compliance with the order. He was commissioned to merchandise with the money. But they admitted that the distinc. tion, if any, was extremely nice. and Buller. J.. thought there was none, and recognized the case of R. v. Paradice, 2 East P. C. 56\%. Mi. 762, before Gould, J., as good law. R. v. Lavender, 2 East P. C. 566, B. 532 .

(Ala. Sup. Ct., 1889.) A Farm Hand Took a Mule. His employer had furnished and sent him with it to the field to plow crops. He plowed till sunset, and then drove the mule away and sold it. For 
this he was convicted of larceny. IIe excepts to the refusal of the court to charge that "if they believe the defendant had charge of the mule, and took it ont of the plow whilst in his custody, then he is not guilty of larceny." SOMERVILLE, J. Thie conviction of the defendant for larceny was proper under the circumstances. The prosecutor had parted only with the custody of the mule, as distinguished from the possession, which was still in him as owner, aithough the defendant had the custody of the animal as mere employee or servant. It has often been decided, and is now settled law, that goods in the bare charge or custody of a servant, are legally in the possession of the master, and the servant may be guilty of trespass and larceny by the fraudulent conversion of such goods to his own usc. * * Crocheron v. S., 86 Ala. 64, 5 So. 649, 11 Am. St. Rep. 18, F. 275.

(Ind. Sup. Ct., 1883.) Same. On trial for larceny the court instructed the jury: "If the jury find from the evidence that the defendant was in the employ of the prosecuting witness, Pugh, and was working for Pugh upon his farm, and that Pugh sent the defendant to 'Terre Haute with a load of corn in a wagon, with the mules charged to have been stolen, and that the defendant, while he still had possession of the mules, sold them, then he is not gruilty of larceny, and you should find him not guilty." Verdict, not guilty. On appeal by the state, the supreme court found no error in the charge, saying: "Pugh sent him to that city with the two mules and a wagon, loaded with corn, directing him to sell the corn and collect the money for it, and return the same day. The appellee did not have permission to sell the mules. * * * The prineiple is well settled that to constitute a larceny there must be a felonious taking of the property. When property which is lawfully in the custody of an employee or bailee is criminally appropriated to the use of such employee or bailee, the offense may be embezzlement, but it cannot be larceny." S. v. Wingo, 89 Ind. 204, 5 L. 499.

(Ala. Sup. Ct., 1895.) Same. On trial for larceny it appeared that defendant took prosecutor to the train for hire; and on arriving there the prosecutor left with him a quilt and requested him to return it to proseentor's house, which he consented to do, but instead took it to a store and sold it. He requested the court to charge the jury that if the quilt was received with intent to deliver it as requested and the intent to dispose of it was formed later they must acquit. The request was refused and defendant convicted, and the conviction affirmed on appeal, on the ground that defendant had mere eustody and not possession. Holbrook v. S., 107 Ala. 154, 18 So. 109, $54 \mathrm{Am}$. St. Rep. 65. 
8 128. "In Muking an Exchange."

(Eng. Exchequer, 1678.) Shopkeeper Gives Goods for Inspection. Adjudged, that where a person came to a seamstress's shop, and asked her to show him some linen, which she did, and delivered it into his hands, and then he lan away with it, that this is felony; for though the groods were delivered by the owner, yet they were never out of her possession, because though the contract might be begun by asking and telling the price, yet it was not perfecterl; and the subsequent act of his rumning away plainly shows his intention to talke the goods feloniously before the property was altered, for which he was indicted, convicted, and executed. R. v. Chissers, T'. Raym. 275, 3 Salk. 194 (sub) nom. R. v. Summers), B. 515, Ke. 217.

A co. C. v. Wilde, 71 Mass. (5 Gray) 83, 66 Am. Dec. 350; Devore v. Territory, 2 Okl. 562, $3 i$ Pac. 1092, taking team by permission while papers were being drawn.

(Eng. C. C. R., 1853.) Gas in Taker's Pipe. Defendant was convicted of stealing $5,000 \mathrm{ft}$. of carburetted hydrogen gas, on proof that the owners of the gas connected defendant's pipe with their inains, with a meter in his pipe; and that he made a private connection around the meter, thereby getting the gas without its passing through the meter. For the prisoner it was contended that he received the gas with full consent of the company, and without frand, and the evidence only showed fraud in tampering with the voucher of account, not in obtaining the possession; and that it was in de. fendant's pipe and possession with the consent of the company when taken. MAULE, J. The taking was by turning the gas into at new channel without the leave of the company and that was done with intent to defraud. LORD CAMIPBELL, C. J. I think that the conviction ought to be affirmed and that the direction of the learned recorder was most accurate. Gas is not less a subject of larceny than wine or oil; but is there here a felonious asportation? No one who looks at the facts can doubt it. The gas no doubt is supplied to a vessel which is the property of the prisoner, but the gas was still in the possession of the company. Then, being in the possession of the company and their property, it is taken away animo furandi by the prisoner. If the property remains in the company until it has passed the meter, which is found, to take it before it has passed the meter constitutes an asportation. If the asportation was with a fraudulent intent-and this the jury also have found-it was larceny. * * * Parke, B.. Maule, J., Talfourd, J., and Martin. B. concurred. Conviction affirmed. R. v. White, 6 Cox C. C. 213. Dears. 203, 3 Car. \& K. 363. 22 L. J. m. c. 123,17 Jur. 536. 1 W. R. 418, B. 506 , C. 381 . Mi. 679.

Ace. C. v. Shaw, $\$ 130$.

(Eng. C. C. R., 1873.) Delivery at House on Cash Sale. The prisoners met the prosecutor with a cart-load of onions and agreed to buy them for $£ 316$ s.. cash on delivery at a place they indicated. He 
unloaded the onions and asked for his money; they wanted a bill; he gave it; they made a cross on it, put on a penny stamp, said now they had a receipt, and refused to restore the onions or pay the price. Next morning they offered the onions for sale. The jury convieted both of lareeny. For them it was contended there was no larceny as the sale was on eredit. KlSLLY, C. B. I am of opinion that the conviction should be affirmed. If in this case it had been intended by the prosecutor to give eredit for the price of the onions, even for a singrle hour, it would not have been lareeny; but it is clear that no credit was given or ever intended to be given. Any idea of that is negatived by the statement in the case that the prisoners agreed to buy for ready money. In all such sales the delivery of the thing sold, or of the money, the price of the thing sold, must take place before the other; i. e., the seller delivers the thing with one hand while he receives the money with the other. No matter which takes place first, the transaction is not complete until both have taken place. If the seller deliver's first before the money is paid, and the buyer firudulently pruns off with the article, or if, on the other hand, the buyer pays first. and the seller fraudulently runs off' with the money without delivering the thing sold. it is equally lareeny. Mellor. J., Pigott. B.. Denman. J., and Pollock, B., concurred. Conviction affirmen. R. v. Slowly, 12 (Jox C. (. 269, 27 L. T. 803. B. §16.

(New York (t. of App., 18i4.) Money Given to Pay Bill and Have Change. Appellant was convicted of larceny. CHURCH, C. J. 'The prosecutor handed the prisoner, who was a bartender in a saloon, a fifty-dollar bill (greenback) to take ten cents out of it in payment for a glass of soda. The prisoner put down a few coppers upon the counter, and when asked for the change he took the prosecutor by the neck and shoved him out doors, and kept the money. 'The question is presented on behalf of the prisoner whether larceny cun be predicated upon these facts. There was no trick, device, or fraud in inducing the prosecutor to deliver the bill; but we must assume that the jury found, and the evidence was sufficient to justify it, that the prisoner intended, at the time he took the bill, feloniously to convert it to his own use. It is urged that this is not sufficient to convict, because the prosecutor voluntarily parted with the possession not only, but with the property, and did not expect a return of the same property. This presents the point of the case. When the possession and property are delivered voluntarily, without frand or artifice to induce it, the animus furandi will not make it larceny, because in such a case there can be no trespass, and there can be no larceny without trespass. [P. v. McDonald] 43 N. Y. 61 [Mi. 701]. But in this case I do not think the prosecutor should be deemed to have parted either with the possession of. or property in, the bill. It was an incomplete transaction. to be eonsummated in the presence and under the personal control 
of the prosecutor. There was no trust or confidence reposed in the prisoner, and none intended to be. * * Affirmed. Hildebrand v. P., 56 N. Y. 394,15 Am. Rep. 435,3 Thomp. \& C. 82, 13. j19; S. C. in the court below, 1 Hun. 19.

(Ling. C. C. R., 1873.) Same. On indietment against Elizabeth Bird for stealing 19s., property of Maria Lovell, it was shown that said Bird was the daughter of a man who traveled about to fairs with a merry-go-round; that on the day in question the said lovell got into the merry-go-round, which was then in charge of the said Bird, and handed to the said Bird a sovereign in payment for the ride, asking her to grive her the change; the said l3ird thereupon handed to the said Miaria Lovell 11d., and said she would give her the rest of the change when the ride was finished, as the "merry-goround" was then about to start; and that the said Lovell assented to this, and about ten minutes after when the ride was over, she found the said Bird, who was then attending to the shooting gallery, and asked her for her change, to which the said Bird replied that she had only received from her 1 s., for which she had given the proper ehange, and she declined to give any more. Upon these facts it was contended by the counsel for the prisoner: 1 , that the prisoner could not be convicted of stealing the $19 \mathrm{~s}$., because no specific 19s. had ever been appropriated as the change for the sovereign handed to the prisoner, nor had there been a taking, either actual or constructive, of the $19 \mathrm{~s}$. from the said Lovell; 2 , that under the above form of indictment the prisoner could not be con. victed of stealing the sovereign; and that even if the indictment was sufficient, there was no evidence of a felonious taking of the sovereign, as it was not taken from Lovell against her will; and further, that the prisoner could not be convicted of larceny of the sovereign as a bailce, because, assuming that there was any evidence of a bailment, which was denied, the bailment was not to redeliver the same money which was delivered to the prisoner. COCKBURN, C. J. The majority of the judges are of opinion that the prisoner was not properly convicted of stealing the $19 \mathrm{~s}$. charged in the indictment, for she had not taken them from the prosecutrix, and could not therefore be convicted on this indictment. The majority of the judges do not say that she might not have been convicted on an indictment charging her with stealing the sovereign if the issue had been properly left to the jury. Upon the present indictment, however, she must be discharged. Conviction quashed. R. v. Bird, 12 Cox C. C. 257,42 L. J. m. c. 44,27 L. T. 800,21 W. R. 448 , C. 361.

(Mass. Sup. Judicial Ct., 1878.) Bill Taken to Change. As A was passing a bar-room, the defendant, a girl, called him in, and he, at her request, gave her money to buy a bottle of brandy. They went upstairs together, and she said this bottle would not be enough for the night, and asked for more money with which to buy another 
bottle. A, thereupon, gave her a $\$ 20$ bill to get a quart of brandy, the price of which was $\$ 3$, not expecting to receive the bill back, but the change, after deducting the price of the brandy. The defendant went out and soon returned with another girl, saying she could not get it. The other girl said she knew where to get it, and the two girls went out and he saw no more of them or his money. Upon this evidence the defendant was held properly convicted of larceny. It was held that the jury was justified in finding that $\mathbf{A}$ intended merely to part with possession, retuining title. C. v. Barry, 124 Mass. 325.

(Minn. Sup. Ct., 1878.) Keeping the Change Without Paying the Bill. Appellant was convicted of larceny. He, being in a buggy, and in a hurry to cross the Minnesota river, applied to one Baldwin to cross him over as quickly as possible, in order to enable him to reach a train on the MI. \& St. L. R. R. While being ferried hurriedly over, but before reaching the opposite shore, he asked Baldwin the amount of the fee, and if he could change a five-dollar bill. The latter at once proceeded to count out the required amount in change, over and above the ferriage fee, placing it in the bottom of the bug. gy, in front of defendant, who was on the seat. About this time, the boat struck the shore, and the ferryman stepped back and seized the rope, in order to hold the boat, leaving the money in the buggy. Thereupon, the accused, without delivering over the five-dollar bill, immediately drove off. CORNELL. J. * * * It is immaterial at what precise moment of time, during the transaction, the felonious intention was first formed of taking and holding the money against the consent of the owner; whenever it was formed and executed, animo furandi, by carrying it off, that moment he became a trespasser, and was guilty of larceny. That he may have had no wrongful intent, in fact, at the precise point of time when he first received the money into his buggy from Baldwin, was not a controlling circumstance in determining the question of his guilt or innocence of the offense charged; for the delivery to him of the property, under the circumstances, was only a conditional one, out of which no legal possession nor right of possession, against the owner, could spring, except upon performance of the condition. His retention of the money without such performance, and against the consent of the owner, was wrongful, and made him a trespasser; and if this was also done with a felonious intent of stealing, he became criminally liable. ** Affirmed. S. v. Anderson, 25 Minn. 66, $33 \mathrm{Am}$. Rep. 455, F. 277.

(Kan. Sup. Ct., 1902.) To Make Change. Prosecutor gave defendant a $\$ 20$ gold piece to change into currency, put into a letter, and deposit in the mail at the postoffice where the parties then were. Defendant made the change, and put it into the letter, and then refused to deposit the letter or give it or the original piece to prose- 
cutor. Conviction of grand larceny on these facts was affirmed. Everything being intended to be done in the presence of the prosecutor, defendant had only custody. S. v. Walker, 65 Kan. 92, 68 Pac. 1095.

\section{\$129. "In Some Other Cnpadity."}

(Mlass. Sup. eJudicial Ct.. 1867.) Money Given to Count. IIOAR, j. We are of opinion that there was no evidence to sustain the indictment for emberzlement, and that the conviction was wrong. * * * The facts reported in the bill of exceptions do not show that the possession of the owner of the money was ever divested. She allowed the defendant to take it for the purpose of cominting it in her presence, and taking from it a dollar, which she consented to lend him. *** In all such cases the temporary custody, for the owner's purposes and in his presence, is only the charge or custody of an agent or servant, gives no right of control against the uwner, and the owner's possession is unchanged. Fxeeptions sustained. C. v. O'Malley, 97 Mlass. 584. 13. 518.

(Cal. Sup C't., 1891.) Money Given to Show Game. Defendant pretended to be agent for the Louisiana Lottery, wished to sell tickets, and finally, to explain the methods of drawing. He spread on a table a paper of squares and figures, and asked those present to put down money so he might illustrate with it, claiming he would return it in the end, but which he did not do. This proof was held insufficient to sustain embezzlement, being simple lareeny. "If the owner puts his property into the hands of another, to use, or do some act in relation to it, in his presence, he does not part with the possession, and the conversion of it, animo furandi, is larceny." Per DE HAVEN, J. Reversed. P. v. Johnson, 91 Cal. 265. 27 Pac. 663.

Ace. P. v. Shuughnesss, 110 Cal. 598, 43 Pac. 2.

(Mass. Sup. Judicial Ct.. 1891.) Giving Money to Pay Out in Owner's Presence. Defendant was convicted of larceny. Teeling employed him to learn the price of a piece of land. The land agent: Bent, told him the price was $\$ 125$. Defendant told Teeling the best price was $\$ 325$, of which $\$ 300$ was for the owner, $\$ 15$ for Bent, and $\$ 10$ for defendant. 'Teeling assented, the deed was made, the three met, defendant approved the deed, and Teeling counted out on the table \$325. Defendant took it up, counted it, called Bent into another room, gave him $\$ 125$, returned, gave Teeling a reccipt for $\$ 10$, and kept the rest of the money. Defendant excepted to the instruction to the jury, that they might convict if they found de. fendant obtained the money by premeditated trick, on the facts as above stated. HOLMES, J. *** When defendant took ilp the money from the table it had not yet passed under the dominion of Bent. who represented the opposite party. The defendant did 
not receive it as representing the opposite party; he purported to be acting in the interest of 'l'eeling. 'The jury would have been warranted in finding that Teeling impliedly authorized the defendant to take up the money from the table, but they only could have found that he allowed him to do so for the purpose of immediately transferring the identical bills, or all but ten dollars of them, to Bent under 'leeling's eyes. Subject to a single consider'ation, to be mentioned later, there is no doubt that in thus receiving the money for a moment the defendant purported at most to act as T'eeling's scrvant, or hand, under his immediate direction and control. 'l'herefore not only the title to the money, but the possession of it, remained in 'Teeling while the money was in the defendant's custody. (i. v. O'Malley, 97 Mrass. 584 lahove]. If the defendant had misappropriated the whole sum, or if he misappropriated all that was left af ter paying Bent, the offense would be larceny. C. v. Berry, 99 Mass. 428 [\$152]. *** The instructions made the defendant's liability conditional upon his having obtained the money from Teeling by a premeditated trick or device. If he did so, and appropriated all that was left after palying Bent, he was guilty of larcen!; irrespective of the question whether 'l'eeling retained possession, according to the dieta in C. v. Barry, 1.2t 1lass. 325, 327 [\$1.27], under the generally aceepted doctrine that if a party fraudulently obtains possession of goods from the owner with intent at the time to convert them to his own use, and the owner does not part with the title, the offense is larceny. Fven if the possession had passed to the defendant, there can be no question that the title remained in Teeling until the money should be handed to Bent. See note to R. v. Thompson, Leigh \& Cave, 225, 230. In this case, however, by the terms of his agreement with 'Teeling, the defendant had the right to retain ten dollars out of the moneys in his hands, and it may be argued that it is impossible to particularize the bills which were stolen. * * If the argument be sound, it might cause a failure of justice by the merest technicality. For it easily might happen that there was no false pretense in the case, and that a man who had appropriated a large fund, some small part of which he hald a right to take, would escape unless he conld be held guilty of larceny. We think the answer to the argument is this. All the bills belonged to 'Teeling until the defandant exercised his right to appropriate ten dollars of them to his claim. He could make an appropriation only by selecting specific bills to that amount.

Exceptions overruled. C. v. Lannan, 153 Mass. 287, 26 N. F. 858 , 25) Am. St. Rep: 629, 11 T. R. A. 450, B. 521.

(IIl. Sup. Ct., 1888.) Horse Taken to Feed. On indictment for the emberzlement and larceny of a horse, it was shown that defendant and another went to the house of $S$. (who had posted notice of the horse as an estray) and claimed him. S. refused to surrender the horse until they made proper proof. By arrangement. S. and wife took 
the horse to a town, to allow defendant to prove the horse by proper affidavits before a justice. They met, and defendant paid the cost of posting, and was allowed to take the horse to feed at a stable, but, without permission and without proving him, he left with the horse, and disposed of him. On proof of these facts the jury found de. fendant guilty under the count for common law larceny, which laid the property of the horse in S. On error the verdict was held justi. fied. Quinn v. P., 123 Ill. 333,15 N. E. 46.

\section{130. "Where the Accused IReceived the Property from Another."}

(Eng. King's Bench, 1688.) Selling Goods and Taking Pay for Master. It was found by special verdict, that the prisoner had been employed to sell goods and receive money for his master's use; that he sold a large parcel of goods; received 160 guineas for them from the purchaser; deposited ten of them in a private place in the chamber where he slept; and, on his being discharged from his scrvice, took away with him the remaining 150 guineas; but he had not put any of the money into his master's till, or in any way given it into his possession. Before this embezzlement was discovered he decamped from his master's service, leaving his trunk, containing some of his clothes and the 10 guineas so secreted, behind him; but he afterwards, in the night-time, broke open his master's house, and took away with him the 10 guineas which he had hid privately in his bed-chamber; and this was held to be no burglary, because the taking of the money. was no felony; for although it was the master's money in right, it was the servant's money in possession, and the first original act no felony. R. v. Dingley, (or Bingley) stated by counsel in Bazeley's Case, 2 Leach No. 294, B. 525, and in argument in R. v. Meeres, 1 Shower 53, Ke. 177, Mi. 684.

(Eng. C. C. R., 1799.) Money Received for Employer. The prisoner was chief teller of Esdaile \& Hammett, bankers, and was convicted of stealing a bank-note for $£ 100$ of them. The proof was that a customer of the bank sent $£ 137$ to the bank for deposit to his credit, including the $£ 100$ note in question; that the money was handed to the prisoner, who entered credit for the amount in the customer's book, and put the rest of the money in the money-drawer of the bank, but put the $£ 100$ note in his pocket. On case reserved it was argued by counsel for the prisoner that taking the note under the circumstances was not larceny from the prosecutors, for they never had possession of it. It was admitted that deposit in the till would give them sufficient possession to sustain the conviction, and that without it they might have maintained trespass against anyone who had taken it from him, yet, it was insisted that the servant's possession is not the possession of the master for the purpose of charging the servant with stealing the property. On con. 
sultation among the judges, some doubt was at first entertained; but at last all assembled agreed that it was not felony, inasmuch as the note was never in the possession of the bankers, distinct from the possession of the prisoner, though it would have been otherwise if the prisoner had deposited it in the drawer, and had afterwards taken it. And they thought that this was not to be differed from the cases of R. v. Waite, Leach No. 14, and R. v. Bull, Leach (in argument) No. 294, which turned on this consideration, that the thing was not taken by the prisoner out of the possession of the owner; and here it was delivered into the possession of the prisoner. That although to many purposes the note was in the actual possession of the masters, yet it was also in the actual possession of the servant, and that possession not to be impeached; for it was a lawful one. Fyre, C. J., also observed that the cases ran into one another very much, and were hardly to be distinguished; that in the case of R. v. Spears, Leach No. 291, the corn was in the possession of the master under the care of the servant; and Lord Kenyon said that he relied much on the act of parliament respecting the bank not going further than to protect the bank. Bazeley's Case, 2 Leach No. 294,2 East P. C. 571, B. 525, Ke. 305.

(Eng. C. C. R., 1854.) Receiving Coal in Master's Cart. The prosecutor sent his cart by defendant to the dock for $12 \mathrm{cwt}$. of coal, and discovered him taking out some in a basket at a house on the way back. On this he was convicted of larceny of 2 ewt. of coal. On case reserved it was contended for the prisoner that the coal had never been in the actual or constructive possession of the master. The case was first argued before Jervis, C. J., Parke, B., Alderson, B., Wightman, J., and Cresswell, J., who took time to consider, and then directed that it should be argued before all the judges, and so it was argued again. LORD CAMPBELL, C. J. * * * I am of the opinion that the prisoner has been properly convicted of larceny. There can be no doubt that, in such a case, the goods must have been in the actual or the constructive possession of the master, and that, if the master had no otherwise the possession of thern than by the bare receipt of his servant upon the delivery of another for the master's use, although as against third persons this is in law a receipt of the goods by the master, yet in respect of the servant himself this will not support a charge of larceny, because as to him there was no tortious taking in the first instance, and consequently no trespass. Therefore, if there had been a quantity of coals delivered to the prisoner for the prosecutor, and the prisoner, having remained in the personal possession of them, as by carrying them on his back in a bag, without anything having been done to determine his original exclusive possession, had converted them animo furandi, he would have been guilty of embezzlement, and not of larceny. But if the servant has done anything which determines his original exclusive possession of the goods, so that the master thereby comes 
constructively into possession, and the servant afterwards converts them anmo furandi, he is guilty of larceny, and not merely of a breach of trust at common law, or of embezzlement under the statute. On this supposition he subsequently takes the goods tortiously in converting them, and commits a trespass. We have therefore to consider whether the exclusive possession of the coals continued with the prisoner down to the time of the conversion. I am of opinion that this exclusive possession was determined when the coals were deposited in the prosecutor's cart, in the same manner as if they had been deposited in the prosecutor's cellar, of which the prisoner had the charge. *** JERVIS, C. J. *** It is admitted that the cart was in the possession of the servant for a special purpuse; if he had taken the cart, he would have been guilty of larceny; and if the cart for this purpose continued the cart of the master, the delivery of the coals into the eart was a delivery to the master, and makes the offense larceny. *** 'The other judges concurred. Conviction at'firmed. R. v. Reed, 6 Cox C. C. 284,23 L. J. m. c. 25 , Dears, 257,2 C. L. R. 607, 18 Jur. 67, 2 W. R. 190, B. 536, C. 232 , Mi. 692.

\section{(Mass. Sup. Judicial C't., 1892.) A Review of the Decisions-Cash} Dropped into Till for Servant's Purpose. HOLMES, J. This is a complaint for embezzlement of money. The case for the govermment is as tollows: The defendant was employed by one Sullivan to sell liquor for him in his store. Sullivan sent two detectives to the store, with marked money of Sullivan's, to make a feigned purchase lirom the defendant. One detective did so. 'The defendint dropped the money into the money drawer of a cash register, which happened to be open in connection with another sale made and registered by the defendant, but he did not regrister this sale, as was customary, and afterward-it would seem within a minute or two-he took the money from the drawer. The question presented is whether it appears, as matter of law, that the defendant was not guilty of embezzlement, but was guilty of lareeny, if of anything. 'The delendant asked rulings to that effect on two grounds: First. that after the money was put into the drawer it was in Sullivan's possession, and therefore the removal of it was a trespass and lareony; and secondly, that Sullivan's ownership of the money, in some way not fully explained, prevented the offense from being emberzlement. We will consider these positions successively. We must take it as settled that it is not larceny for a servant to convert property delivered to him by a third person for his master, provided he does so before the goods have reached their destination, or something more hats happened to reduce him to a mere custodian (C. v. King, 9 Cush. 284); while, on the other hand, if the property is delivered to the servant by his master. the conversion is larceny. C. v. Berry, 99 Mass. 428 [§ 152] ; C. v. Davis, 104 Mass. 548. This distinction is not very satisfactory, but it is due to historical accidents in the development of the 
criminal law, coupled, perhaps, with an unwillingness on the part of the judges to enlarge the limits of a capital offense. 2 Leach (4th ed.), 843,848 , note ; 1 Leach (4th ed.), 35, note; 2 East P. C. $568,571$. The history of it is this. 'There was no felony when a man received possession of goods from the owner without violence. Glanv., bk. 10, c. 13 ; Y. B. 13 Ldw. IV. 9, pl. 5 ; 3 Coke Inst. 107. The early judges did not always distinguish elearly in their language between the delivery of possession to a bailee and the giving of custody to a scrvant, which indeed later judges sometimes have failed to do. E. g. Littleton in Y. B. 2 Edw. IV. 15, pl. 7; 3 Hen. VII. 12, pl. 9; Ward v. Macauley, 4 'l'erm 489 , 490 . When the peculiar law of master and servant was applied either to the master's responsibility or to his possession, the test seems to have been whether or not the servant was under the master's eye, rather than based on the notion of status and identity of person, as it was at a later day. See Byington v. Simpson, 134 Mlass. 169, 170. Within his house a master might be answerable for the torts of his servant, and might have possession of goods in his servant's custody, although he himself had put the goods into the servant's hands; outside the house there was more doubt; as when a master intrusted his horse to his servant to go to market. Y. B. 21. Hen. VII. 14, pl. 21; 'T'. 24 Edw. III.; Bristol in Mrolloy, De Jure Mraritimo, bk. 2, c. $3, \S 16 ;$ Y. B. 2 Hen. IV. 18, pl. 6; 13 Edw. IV. 10, pl. 5; s. c. Bro. Abr. Corone, pl. 160 ; Staundforde, I., c. 15, f. 25 , c. 18, f. 26; 1 Ilale, P. C. 505, note. See Heydon \& Smith's case. 13 Coke 67, 69; Drope v. 'l'heyar', Popham, 178, 179; Combs v. Bradley, 2 Salk. 613; and, further, 42 Ass. pl. 17, f. $260 ; 42$ Edw. III. 11 , pl. 13; Ass. Jerus. (Ed. 1690), ce. 205̃, 217. It was settied by St. 21 IIen. VIII. c. 7 , that the conversion of goods delivered to a servant by his master was felony, and this statute has been thought to be only declaratory of the common law in later times, since the distinction between the possession of a bailee and the custody of a servant has been developed more fully, on the ground that the custody of the servant is the possession :f the master. 2 Fast P. C. 564, 565; King v. Wilkins, 2 Lench, No. 223. See Kelyng. 35; Fitzh. Nat. Brev. $91 \mathrm{E}$; Blosse's case, Moore 248, Owen 52, and Gouldsb. 72. But probably when the act was passed it confirmed the above mentioned doubt as to the master's possession where the servant was intrusted with property at a distance from his master's house in cases outside the statute. that is, when the chattels were delivered by a third person. In Dyer. 5a, 5b. it was said that it was not within the stiltute if an apprentice ran off with the moner received from a third person for his master's goods at a fair, because he had it not by the delivery of his master. 'This, very likely, was correct. becaluse the statute only dealt with delivery by the master; but the case was taken before loing as anthority for the broader proposition that the act is not a felony, and the reason was invented to account for it that the servant has possession. because the moner is delivered to him. 1 Hale P. C. 667, 668. This phrase abont delivery seems to have been 
used first in an attempt to distinguish between servants and brilees. Y. 13. 13 Ldw. IV. 10, pl. 5; Moore, 248; but as used here it is a perverted remnant of the old and now exploded notion that a servant away from his master's house always has possession. The old case of the servant converting a horse with which his master had in. trusted him to go to market was stated and explained in the same way, on the ground that the horse was delivered to the servant. Crompton, Just. 35b, pl. 7. See King v. Bass, Leach, No. 121. Yet the emptiness of the explanation was shown by the fact that it still was held felony when the master delivered property for service in his own house. Kelyng, 35. The last step was for the principle thus qualified and explained to be applied to a delivery by a third person to a servant in his master's shop, although it is possible at least that the case would have been decided differently in the time of the Year Books (Y. B. 2 Edw. IV. 15 pl. 7 ; Fitzh. Nat. Brev. 91 E.); and although it is questionable whether on sound theory the possession is not as much in the master as if he had delivered the prop. erty himself. R. v. Dingley [above]; Waite's case (1743), 2 East P. C. 570, Leach, No. 14; Bull's case, stated in R. v. Bazcley, 2 Leach, No. 294, 2 East P. C. 571, 572 ; R. v. Bazeley [above] ; R. v. Masters, 1 Den. C. C. 332 ; R. v. Reed, Dears. C. C. 257, 261, 262. The last mentioned decisions made it necessary to consider with care what more was necessary, and what was sufficient, to reduce the servant to the position of a mere custodian. An obvious case was when the property was finally deposited in the place of deposit provided by the master, and subject to his control, although there was some nice discussion as to what constituted such a place. R. v. Reed, Dears. 257 [above]. No doubt a final deposit of money in the till of a shop would have the effect. Waite's case, 2 East P. C. 570, 571; 1 licach, No. 14 ; Bull's case, 2 East P. C. 572, 2 Leach, No. 294 ; R. v. Batzeley, 2 East P. C. 571, 574, Leach, No. 294 [above]; R. v. Wright, Dears. \& Bell, 431, 441. But it is plain that the mere physical presence of the money there for a moment is not conclusive while the servant is on the spot and has not lost his power over it; as, for instance, if the servant drops it, and instantly picks it up again. Such cases are among the few in which the actual intent of the party is legally important; for, apart from other considerations, the character in which he exercises his control depends entirely upon himself. Sloan v. Merrill, 135 Mass. 17, 19; Jefferds v. Alvard, 151 Mass. 94, 95; C. v. Drew, 153 Mass. 588,594 . It follows from what we have said that the defendant's first position cannot be maintained, and that the judge was right in charging the jury that, if the defendant before he placed the money in the drawer intended to appropriate it, and with that intent simply put it in the drawer for his own convenience in keeping it for himself, that would not make his ap. propriation of it just afterwards lareeny. The distinction may be arbitrary, but, as it does not affect the defendant otherwise than by giving him an opportunity, whichever offense he was convicted of, 
to contend that he should have been convicted of the other, we have the less uneasiness in applying it. With regard to the defendant's second position, we see no ground for contending that the detective in his doings was a servant of Sullivan, or that he had not a true possession of the money, if that question were open, which it is not. The only question reserved by the exceptions is whether Sullivan's ownership of the money prevented the defendant's act from being embezzlement. * * Exceptions overruled. C. v. Ryan, 155 Mass. 523, 30 N. E. 364, 31 Am. St. Rep. 560, 15 L. R. A. 317, B. 543, F. 299 , Mi. 695n.

As to embezzlement in general, see $\$ 152$.

\$ 131. "Delivered by Mistake."

(Eng. C. C. R., 182T.) Letter Meant for One of Same Name. James Mucklow was convicted of larceny of a bill of exchange sent by mail, addressed to James Mucklow, St. Martin's Lane, Birmingham, near which defendant lived, delivered by the postman to defendant's father, and by him to defendant, who obtained the cash on it. It was intended by the sender for another James Mucklow, then of New Hall St., Birmingham, in payment for goods sold by him to the sender, and a letter was inclosed with the bill. The judges held this conviction wrong, on the ground that it did not appear that the prisoner had any animus furandi when he first received the letter; and a pardon was recommended. R. v. Mucklow, 1 Moody C. C. 160 , B. 547 .

(Ore. Sup. Ct., 1880.) Defendant Asked Change for $\$ 10^{\circ}$ GoldPiece. Prosecutor gave him for it what both supposed to be a roll of 10 silver dollars, but what both discovered later were $\$ 20$ goldpieces. Conviction of larceny, on instruction that conversion and refusal to make restitution on subsequent discovery of the mistake would be larceny, was approved and affirmed. S. v. Ducker, 8 Ore. 394, 34 Am. Rep. 590.

Acc. Wolfstein v. P., 8 Hun, (N. Y.) 121, 34 Am. Rep. 591n, B. 629.

Contrn: Cooper v. C., $110 \mathrm{Ky}$. $123,60 \mathrm{~S}$. W. 938, $22 \mathrm{KJ}$. Law R. 1627, 52 L. R. A. 136-n, 96 Am. St. Hep. 426; Fulcher v. S.. 32 Tex. Cr. R 621, 25 S. W. 625.

(Eng. C. C. R., 1885.) Mistake- $£ 1$ Loaned for 1s. The prisoner was convicted of larceny on proof that after dark he asked the prosecutor to loan him a shilling till next day, on which prosecutor took from his pocket and delivered to the prisoner a coin, which both supposed to be a shilling, but which was in fact a sovereign; and that when the prisoner afterwards discovered what it was he immediately determined to and did appropriate it, had it changed, and later denied receiving it. SMITH, J. * * * To constitute the crime of larceny at common law, in my judgment, there must be a taking and carrying away of a chattel against the will of the owner, and at the time of such taking there must exist a felonious 
intent in the mind of the taker. If one or both of the above elements be absent, there cannot be lareeny at common law. The taking must be under such eircumstances as would sustain an action of trespass. If there be a baiment or delivery of the ehattel by the owner, inasmuch as, among other reasons, trespass will not lie, it is not larceny at common law. * * * In the present ease it seems to me, in the first place, that the eoin was not taken against the will of the owner, and if this be so, in my judgment it is sufficient to show that there was no larceny at common law; and secondly, it being conceded that there was no felonious intent in the prisoner when he received the coin, this, in my judgment, is also fatal to the act being larceny at common law. * * The finder of a chattel may be guilty of larceny at common law; but how does that show that the finder out of a mistake may also be guilty of such a crime? $A$ mistake is not a chattel. The chattel (namely, the coin) in this case never was lost: then how could it be found? In my judirment the argument upon the point for the crown is wholly fallacious and fails. It was further urged for the crown that the present case was covered by authority, and the cases of Cartwright v. Green. 8 Ves. 405 I\$ 13.32 ], and Merry v. Green, $T$ M. \& V. 623 [\$ 132], were cited in this behalf. I fail to see that either case is an anthority for the point insisted upon by the crown. * * In my judgment a man who honestly receives a chattel by delivery thereof to him by its true owner cunnot be found guilty of larceny at common law, and in my opinion the prisoner in this case is not guilty of that offense. The second point has now to be considered, namely, was he guilty of lareeny as a bailee within the true intent of $\$ 3$ of $24 \& 25$ Vict. c. 96 ? To constitute a person bailee of a chattel there must be a bailment. * * R. v. Hassall, I. \& C. 58, is an express anthority to the effect that a person is not a bailee within the statute unless he is under obligation to return the identical chattel deposited with him. In my judgment the prisoner was not a bailee of the sovereign for the reasons above given. I am fully alive to the remark which has been made, that if the present case is not one of larceny, it should be. Whether this remark is well founded or not I do not pause to inquire; but it seems to me that the observations of Bramwell. B., in R. v. Middleton. I. R. 2 C. C. $38\lceil \$ 134\}$, on this head are well worthy of consideration. * * [Concurring opinions were de. livered by Mathew, Field, Manisty, and Stephen, JJ. Day and Wills. JJ., also concurred.] CAVF, .J. *** The thief must take the goods into his possession with the intention of depriving the owner of them. If he has got the goods lawfully into his possession before the intention of depriving the owner of them is formed. there is no larceny. Applying that principle to this case, if the prisoner ac. quired lawful possession of the sovereign when the coin was actually handed to him by the prosecutor. there is no larceny, for at that time the prisoner did not steal the coin; but if he only acquired possession when he discovered the coin to be a sovereign. then he is 
guilty of lareeny, for at that time he knew that he had not the consent of the owner to his taking possession of the sovereign as his own, and the taking under those cireumstances was a trespass. It is contended that, as the prosecutor gave and the prisoner received the coin under the impression that it wals a shilling and not a sovereign, the prosecutor never consented to part with the possession of the sovereign, and conseduently there was a taking by the prisoner without his consent; but to my mind, it is impossible to come to the conclusion that at the time when the sovereign was handed to him, the prisoner, who was then under a bona fide mistake as to the evin, can be held to have been guilty of a trespass in taking that which the prosecutor gave him. It seems to me that it would be equally logical to say that the prisoner would have been guilty of a trespass if the prosecutor, intending to slip a shilling into the prisoner's pocket withont his knowledge, had by mistake slipped a sovereign in instead of a shilling. The only point which ean be made in favor of the prosecution. so fin as I can see, is that the prisoner did not actually take possession until he knew what the eoin was of which he was taking possession, in which caste, as he then determined to deprive the prosecutor of his property. there was a taking possession simultaneously with the formalion of that intention. Had the coin been a shilling. it is obvions that the prisoner would have gatined the property in and the possission of the coin when it was handed to him by the prosecutor : as there wats a mistalke as to the identity of the eoin no property passied. and the question is whether the possession passed when the coin was handed to the prisonel or when the prisoner first linew that he harl grot a sovereign and not a shilling. There are four cusess which it is important to consider. * * * Ilere his honor reviewed Cartwright v. Green, $\$ 132$; Merry v. Green, $\$ 132$; R. v. Alucklow (abover. which he discredited); and $R$. v. Mliddleton, $\$ 134$. In this case. Ashwell did not hold himself out as being willing to assume the responsibilities of a possessor of the coin, whatever its value might be; nor ean I infer that at the time of the delivery he aneed to be responsible for the sufe custody and return of the sovereign. As therefore he did not at the time of the delivery subject himself to the liabilities of the borrower of a sovereign, so also, I think, that he is not entitled to the privileges attending the lawful possession of a borrowed sovereign. When hre discovered that the coin was a sovereign. he was. I thin.. homed to elect, as a finder would be, whether he would assmue the responsibilities of a possessor; but at the moment when he was in a position to elect, he also determined frumdulently to eonvert the sovereign to his own use; and I am therefore of opinion that he falls within the principle of $R$. v. Middleton. I. R. 2 C. C. tis $\mid \$ 134]$, and was guilty of larceny at common law. For these reasons. I am of opinion that the conviction was right. [Concurring opinions were delivered by Lord Coleridge. C. J., and Denman. J. Grove and Ilawkins. J.J.. Pollock and Huddleston, 13B., also concurred.| R. v. Ashwell, L. R. 
16 Q. B. D. 190,55 L. J. m. c. 65,53 L. T. 773,34 W. R. 297,16 Cox C. C. 1,50 J. P. 181, B. 566, Ke. 292, Mi. 751 n.

(Eng. C. C. R., 1886.) Overpaid by Mistake. Case reserved on verdict of guilty of lareeny directed by the recorder, on proof that defendant was a workman in a factory, and found the pay in his envelope short, whereon he made complaint, and in the adjustment he was accidentally given the envelope of another workman, who was also seeking adjustment, and on the jury finding specially that when the prisoner received the last envelope he did not know it did not belong to him, but having received it innocently, he afterwards discovered the error and fraudulently appropriated the money. HAWKINS, J. The old rule of law was not questioned by any of the judges in R. v. Ashwell [above]. This case is altogether different, for here the recorder told the jury that if the prisoner received the $7 \mathrm{~s} .111 / 2 \mathrm{~d}$. innocently, and afterwards appropriated it to his own use, he was guilty of larceny. It is perfectly clear to me that that direction could not be right, and that the learned recorder misanprehended the rule of law. [Coleridge, C. J., Manisty. Day. and Grantham, J.]., gave concurring opinions.] Conviction quashed. $R$, v. Flowers, 16 Q. B. D. 643.16 Cox C. C. 33.55 L. J. m. c. $179.54 \mathrm{l}$. T. 547,34 W. R. 367,50 J. P. 648, B. 574, C. 229.

\section{2. "Finding I,ost Property."}

LORD COKE says. "If one lose his groods and another find them. though he convert them 'animo furandi,' to his own use, it is not larceny, for the first taking is lawful. So if one find treasure trove, or waif, or stray, and convert them ut supra, it is no lareeny, both in respect of the finding, and also for that dominus rerum non ap. paret." "3d Inst. 108. The only authority given is Fitz. Abr. Corone 187. 265, 22 Ass. 99, 22 Ed. IJI.

LORD HALE says: "If $A$ find the purse of $B$ in the highway and takes it and carries it away, and hath all the circumstances that may prove it to be done animo furandi, as denying it or secreting it, yet it is not felony. The like in cuse of taking of a wreck or treasure trove, or a waif or stray." 1 Inale P. C. 506.

(Eng. Ct. of Chancery, 1802.) Money Found in Bureau Received to Mend. This was a bill for discovery in aid of a suit at law by plaintiff against defendants, and stated that Ann Cartwright died possessed of a bureau, in a secret part of which she had concealed 900 guineas in specie; that after her death Richard Cartwright, her personal representative, let the bureau to his brother, Henry, who took it to the East Indies and brought it back, the contents remaining still undiscovered; it was then sold to Dick for three 
guine:ts, who delivered it to the defendant Green, a carpenter, for the purpose of repairing it. Green employed a person named Hillingworth, who found out the money and received a guinea for his trouble, and the whole sum of 900 guineas was possessed by the three defendants, Green, his wife, and Elizabeth Sharps; who secreted and converted it to their own use. Defendants demurred, because the discovery might subject them to a climinal prosecution. LORD CHANCELLOR [LLDON]. This case involves a very delicate consideration in equity, for, whatever was the old doctrine as to larceny, distinctions have been taken in late cases, which make it frequently the subject of very nice consideration whether the taking is a trespass or only a breach of trust. I have looked into the bouks and have talked with some of the judges and others, and I have not found in any one person a doulht that this is a felony. 'To constitute felony there must of neeessity be a felonious taking. Breach of trust will not do. But from all the cases in Ilawkins there is no doubt, this bureau being delivered to the defendant for no other purpose than repair, if he broke open any part which it was not necessary to touch for the purpose of repair but with an intention to take and appropriate to his own use what he should find, that is a felonious taking within the principle of all the modern eases, as not being warranted by the purpose for which it was delivered. If a pocket-book containing bank notes was left in the pocket of a coat sent to be mended, and the tailor took the pocket-book out of the pocket and the notes out of the pocket-book, there is rot the least doubt that is a felony. So, if the pocket-book was left in a hackney coach, if ten people were in the coach in the course of the day, and the coachman did not know to which of them it belonged, he aequires it by finding it certainly, but not being intrusted with it for the purpose of opening it: and that is a felony according to the modern cases. * * Demurrer allowed. Cartwright v. Green, 8 Ves, 405, C. 214.

(Eng. Exchequer, 1841.) Money Found in a Bureau Bought. Trespass for assault and false imprisonment. Pleas : 1, not guilty; and, 2, that plaintiff had stolen a purse filled with coin, for which defendants caused him to be taken by a peace officer. On the trial it appeared that plaintiff bought an old secretary at anction sale for f1, 6s., that he afterwards found the purse and money in a secret drawer of the secretary, and he claimed that the sale was with contents if any. The trial judge told the jury that as the property was delivered to the plaintiff as purchaser, there was no felo. nious taking, left them to assess the damages, and they found for plaintiff, f50. Motion for new trial or nonsuit. PARKE, B.

- A fact was deposed to on the part of the plaintiff which ought to have been left to the jury, and which. if helieved by them, would have given a colorable right to him to the contents of the secretary as well as to the secretary itself; viz., the declaration of the 
auctioneer that he sold all that the piece of furniture contained with the article itself; and then the alsstraction of the contents could not have been felonions. There must therefore be a new trial, and not a nonsuit. but if Ire assimme, as the clefenclant's case was, that the plaintifi had axpress notice that he was not to have any title to the contents of the sereptary if these hapened to be anything in it, and indeed without such express motice, if he had no ground to believe that he hal bought the contents, we are all of opinion that there was cvidence to make ont a case of lareeny. It was contended that there was a delivery of the secretary and the money in it to the plaintiff as his own property, which wive him in lawful possession, and that his subserfunt misappropriation ald mot constitute a felony. But it seoms to us that. thomen there wits a delivery of the secretary, and a lawful property in it therply resteel in the plaintiff, there was no delivery so as in girre a law linl possisssion of the purse and money. The vendor had $n$ intontion to delivere it, nor vendee to receive it; both were inmorant of its existomes: and when the plaintiff discovered that there was a serepet drawere enntaining the purse and money, it was a simple casc of finding. and the law applicable to all caises of timling applies to this. The old role, that "if one lose his goods and another find them, thomgh he oonvent them animo furmoli to his own use, it is no lareeny, "has molererone in morere recent times some limitations; one is, that il llac finder knows who the own'y of the lost chattel is, or if, from any mark upon it or the eirenmstanees under which it is found, the owner conld be reasonably asiertained, then the fraudulent conversion animo fintudi constitutes a lareeny. * * Now trial granted. .lll concurred.

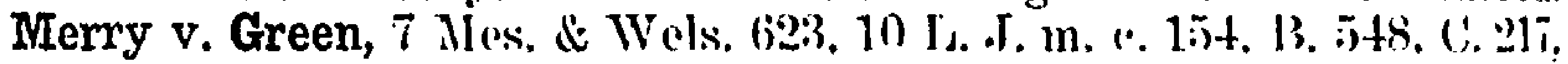
Mi. Ti:.

(... Y. Sup. (1., 1s17.) Same-Trunk Lost from Stage. Ont trial for lareeny of a trumk and contents, found on the highwa! he defendant. he was comvicted. The case arises here on habras arigus. SPENCER, J. * * * The court below instructed the jury that if the prisoner took the trunk with intention to steal it, they ought to find him guilty, and that in determining that question they hall in right. In take into consideration the prisoner's subsequent inmluet as woll as all the circumstances of the ease. We assume it is all indispinted fact that the prisoner found the trunk bona fide, imm $\mathrm{r} \cdot \mathrm{m}$. seruently that it had been lost by its proprietor; and we procind on the ground that if any subsequent embez:lement of the contents of the trunk would make the act a larceny of these articles, that then the eonviction is correct. But the conrt are of opinion that the hond fide finder of a lost article or of a lost trunk containing gonds. cinnot be guilty of larceny by any subsequent act of his in enucenling and apmerniating to his own use the article or the contents of the trunk thus found. In Butler's Case in 28 Flizabeth this doctrine is fully establisbed. In that ease it was deoided that the intent to stonl mist 
be when it comes to the hands or possession of the party ; for if he hath the possession of it once lawfully, though he hath animum furandi afterwards and carry it away, it is no larceny. 3 Inst. 107. * * There can be no trespass in taking a chattel found in the bighway, and the finder has a right to keep the possession against everyone but the true owner. How then can it be said that a thing found bona fide and of which the finder had a right to take possession, shall be deemed to be taken feloniously in consequence of a subsequent conversion by denying and secreting it, with an intention to appropriate it to the use of the finder? *** No frand is practiced on anyone in first acquiring the possession. It, therefore, never can be a question for the jury, how far forth a person who found a chattel intended to find it for the purpose of stealing' it. 'The very nature of the case excludes a premeditated or already formed intention to steal. 'That depends as matter of fact upon a variety of circimnstances, such as the value, the facility of concealment, etc., which are matters of after consideration. IIence, we do not find a single calse in the reports of criminal trials, or in the treatises on criminal !aw, in which it has ever been intimated that a person actually finding a chattel has been held to have stolen it, from the circumstance of denial. concealment, or appropriation. * * Thompson, C. J., dissented. P'risonel discharged. P. v. Anderson, 14 .Johns. 294, 7 Am. Dec. 462, $5 \mathrm{I}_{4} .45$.

(Fing. (.: C. R., 18t9) ' 'The Prisoner Found a Bank-note on the Highway and Picked it up Intending to Use it. As lo: meant to appropriate it when he first saw it, he was convieted of lanceny, though there was nothing on the note to indicate who thr owner was, and the prisoner knew of no means of finding him. PARKE, B. * " The rule of law on this subject seems to le, that if a man find goods that have heen actually lost, or are reasonably supposed by him to have been lost. and appropriates them with intent to take the entire dominion over them, really bolieving when he takes them that the owner camnot be found, it is not laneeny. But if he takes them with the like intent. though lost. or reasonably supposed to be lost, but reasonably believing that the owner can be found, it is lareeny. * * $*$ It would probahly be presumed that the taker would examine the chattel als an honest man ounht fo do. at the time of taking it, and if he did not restore it to the owner. the jury might conclude that he took it. when he took complete possession of it, animo furandi. The mere taking it up to look at it would not be a taking possession of the chattel. 'To apply these rules to the present case: the first taking did not amount to lareeny. because the note was really lost. and there was no mark on it or other circumstance to indiente then who was the owner, or that he might be found. nor any evidenee to rehut the presumption that would arise from the finding of the note as proved. that he believed the owner eould not be found. and therefore the original taliing was not felonions: ant 
if the prisoner had ehanged the note or otherwise disposend of it before notiee of the title of the real owner, he elearly would not have been punishable; but atter the prisoner was in possession of the rote, the owner became known to him, and he then apploplritted it animo furamdi, and the point to be decided is whether thit wats at felony. Linon this question we have felt considerable doulit. If he had taken the chattel innocently, and afterwards appropmiallinl it, withont knowledge of the owuership, it would not have been !alwny: nor would it, we think, if he had done so, knowing who wils the owner, for he had the lawful possession in both cases, and thr "(m). version would not have been a trespass in either. But here the original taking was not imnocent in one sense, and the question is does that make a difierence? We think not; it was dispunishable as we have already decided, and though the possession was accompranied by a dishonest intent, it was still a lawful possession and good against all but the real owner, and the subsequent conversion was not therefore a trespass in this case more than the others, and eonsequently no lareeny. We therefore think that the conviction was wrong. R. v. Thurborn, 1 Den. C. C. 387, T. \& N. 6T, 2 Car. \& K. 831, 13 Jur. 499, 18 I. J. m. c. 1.40. B. 551, 2 B. \& H. 18, C. 332 , Ke. 276, Mi. 720 ; s. c. sub. nom. R. v. Wood, 3 Cox C. C. 453.

(Eng. C. C. R., 18j1.) Same-Marked with Owner's Name. Mr. Collis lost a $\$ 50$ note of the bank of lingland marked "MIrs. Collis." There were few if any other's of that name in the city, and he was well known. The immediately notified the police, and circulated hand-bills, oftering' a reward for retur'n of the note. 'T'wo days later (Monday) the prisoner inquired of the police if there was not a reward oflered for the roturn of a lost note, suid he kept shop and might have it presented to him. asked if the number were known, and promised to give notice if: he learned of it; later the same day he incuired of another shopkeeper if the finder wonld be justified in keeping the note, and was told he would not; still later the sime day he passed the note for 50 sovereigns in gold, and when apprehended gave inconsistent explanations as to where he got the gold found with him, and finally sald he took the note in change from a tall stranger. The judge directed the juiry that if the prisoner knew the owner or reasonably believed he could be found at the time when he first resolved to appropriate the note to his own use-to exercise complete dominion over it-he was guilty of larceny, as there was no evidenee of any other person having the note after it was lost. Verdict, guilty. IJORD CANIPBFLL, C. J. I am of opinion that this conviction camnot be supported. Iarceny supposes a taking animo furandi. 'There must always be a taking; but in the present case it is quite consistent with the direction of the learned Recorder that the prisoner might he guilty of lareeny though, when he took possession of it, with a full knowledge of the nature of the chattel. he honestly intended to return it to the owner whensoever he should 
be found; because he puts it that the important question is, at what time the prisoner first resolved to appropriate it to his own use. But when was the taking? It is said that whenever he changed his mind, and formed the dishonest purpose of appropriating the note to his own use, that then he took it constructively from the possession of the owner; but that dishonest purpose may have first come into his mind when he was lying in bed at a distance of many miles from the place where the note was. It seems to me that that operation of the mind cannot be considered a taking, and that, as there was no taking except the original taking, which might have been lawfil, the conviction must be reversed. It is unnecessary to go into authorities upon this subject, after the elaborate judgment of my brother Parke in Thurborn's case. The other judges concurred. Conviction quashed. R. v. Preston, 5 Cox C. C. 390, 2 Den. C. C. 353 , T. \& M. 641, 21 L. J. m. c. 41, 11 Jur. 109, B. 557, 2 B. \& H. 25-n, 8 Eng. l. \& Eq. 589.

(Eng. C. C. R., 1854.) Purse on Shop Counter Taken by Keeper. JERVIS, C. J. 'The question is whetlier, under the circumstances stated in this case, the prisoner was properly convicted of lareeny, and we are all of opinion that she was properly convicted. The prisoner keeps a stall in the Iseicester market. 'The prosecutor went to that stall, left his purse there, and went alway. 'The purse was pointed out to the prisoner by another person, and she then put it in her pocket, and treated it as her own, and on the prosecutor returning to the stall and asking for the purse, she denied all knowledge of it. 'Two questions were left to the jury: First, did the prisoner take the purse knowing that it was not her own, and intending to appropriate it to her own use? 'This the jury said she did. Secondly, did the prisoner then know who was the owner of the purse? This the jury said she did not. If there had been any evidence that the purse and its eontents were lost property, properly so speaking, and the jury had so found, the jury ought further to have been asked whether the prisoner had reasonable means of finding the owner, or reasonably believed that the owner conld not be found; but there is in this case no reason for supposing that the property was lost at all. or that the prisoner thought it was lost. On the contrary, the owner. having left it at the stall, would naturally return there for it when he missed it. There is a clear distinction between property lost and property merely mislaid, put down, and left by mistake, as in this case, under circumstances which wonld enable the (Iwner to know the place where he had left it, and to which he would naturally return for it. The question as to possession by finding, therefore, does not arise. The other learned judges concurred. Conviction affirmed. .R. v. West, Dears. C. C. 402,3 C. L. R. 86, 24 L. J. m. c. 4.18 Jur. 1031,3 W. R. 21.6 Cox C. C. 415 . B. 561.

Ace. P. v. McGarren, 17 Wend. (N. Y.) 460. 
(Va. Sup. Ct. of App., 1855.) Irost Bank-note. Hunt was indicted for stealing a $\$ 20$ bank-note. The court instructed the jury that if they believed from the evidence that the owner lost the note and it was afterwards found in the possession of Hunt they ought to find him guilty unless his possession was explained. ALLEN, P.

* To constitute larceny of the kind set out in the indictment, there must be a taking animo furandi, and against the will of the owner. * * If the original possession of it was an innocent one, no subsequent change of his mind, or resolution to appropriate it to his own use, would amount to a lareeny. ** * 'The mere possession of goods which had been actually lost does not furnish any conclusive or prima facie proof of guilt; of itself, it does not raise the suspicion of guilt. The most honest man may be found in possession of a chattel proved to have been actually lost, but holding it with the intention of restoring it to the owner; and yet, according to the terms of this instruction, the mere possession under such dircumstances raises the presumption of guilt, unless he can explain by testimony how his possession was acquired. *** Reversed. Hunt v. C., 13: Gratt. 757,70 Am. Dec. 443, F. 284.

(Mass. Sup. Judicial (t.. 18Tt.) Defendant Found a Traveling Bag on the highway, shortly after it was dropped by the owner, took the contents, and hid the bag in the woods some distance from where it was found. On this he was convicted of lareeny. Ile excepted to the instruction of the comrt to the jury that he was guilty, if when he found it, he feloniously intended to appropriate it to his own use, and then knew or had reasonable means of ascertaining who the owner was. GRAY. C. J. The rulings and instructions at the trial were quite as favorable to the defendant as the great weight, if not the unanimous eoncurrence, of the eases eited on either side at the argument would warrant. The finder of lost goods may lawfully take them into his possession, and if he does so without any felonious intent at that time, a subsequent conversion of them to his own use. by whatever intent that conversion is acenpanied, will not constitute larceny. But if. at the time of first taking them into his possession. he has a felonious intent to appropriate them to his own use and to deprive the owner of them. and then knows or has the reasonable means of knowing or ascertaining, by marks on the goods or otherwise, who the owner is, he may be found guilty of larceny. *** Exceptions overruled. $\dot{C}$. $\nabla$. Titus, 116 Niass. 42.17 Am. Rep. 138, I3. 563.

Arc. Lainb v. S.. $40 \mathrm{Neb} .312 .58 \mathrm{~N}$. W. 963. a stra. sow found in pasture: Stenp v. S.. Tex. Cr. R. 349.20 S. W. 753 , a wateh of denarting bride tound at depro.

\section{§133. "Fraud."}

(Eng. C. C. R. 1573.) Replevined. A came to the sheriff and said $B$ had taken his horse. and he prayed replevin; and by replevin 
he obtained the horse which was not his, and sold it; for which he was indicted of felony, and on the evidence it appeared that he sued the replevin for that purpose; and on this he was found guilty and hung; for this was a fraudulent taking, so resolved by all the judges. Anon, stated R. v. Furr, 1 Sid. 254; also in 3 Coke Inst. 108.

(Eng. Old Bailey, 1665.) By Writ of Possession. Farr and Eleanor, his mistress, were indicted at the sessions at Old Bailey before the mayor, Hyde,. J. C., Kelyng, J., Wylde, J. etc., for feloniunsly taking certain goods. The facts were that Farr represented to an attorney of the common pleas that he owned a house in which the tenant was in arrear on rent and that he desired possession; and he so had suit brought in the common pleas in ejectment, and obtained juclgment according to the new rules, against a casual ejector, on false oath taken in the eommon pleas by said Eleanor that she has served a true copy on the tenant in possession. On this judgment Farr had a writ habere facias possessionem, under which the sherift's bailiffis with' him broke and entered the house; and at the sume time he had a latiat on a fialse claim for rent arrear, against the woman who was tenant of the house under lease by the true owner, on which he would accept no bail, but had her taken to Newgate; and then Fal' and Eleanor ransacked the house. and seized the plate and goods there. which were of great value. and took some away hy night and concealed them. It appeared that they prosecuted these proceedings without any color of title, merely to get possession. It was anreed by all these judges that though the defendants made use of the officers of the law to get possession, this course rather' agrgravated than excused the offense. hecanse in fraud of law; and both defendants were convicted of felony and executed. Though Farl was a solicitor and had heen envicted of forgery, he was not allowed to read. but was hanged. Farr's Case, Kelyng 43, 1. Sid. 254. also stated R. v. Chissers. 'T'. Raym. 27i. B. 515, and in R. v. Summer's. 3 Salk. 194.

(Eng. C. C. R., 1772.) Stockings Being Sold. Sharpless and Greatrix were convicted of lareeny of six pairs of silk stockings, property of Indson. Greatrix called on Hudson, a hosier, and said that his master. Sharpless, desired an assortment of sille stockings sent to his lodgings at the Red Lamp in Queen Square. Hudson called with the goods, and was ushered in by Greatrix, and Sharpless selected the six pairs of stockings mentioned in the indictment. and then desired some stockings of a color not contained in the assortment and some silk for breeches. No positive agreement had been made, but the price had been named. Hudson left the six pairs hanging on a chair and went for the other goods desired. When he returned defendants had decamped and the stockings wore gone. other similar transactions by defendants were shown. and they had afterwards pawned these stockings. The jury found that the 
evil intention preceded the leaving of the goods. 'The judges were of opinion that the conviction was right; for the whole of the pris. oner's' conduct manifested an original and preconcerted design to obtain a tortious possession of the property: R. v. Sharpless, Leach No. 52, 2 Last P. C. 675, 13. 611, Ke. 212.

(Eng. C. C. R., 1779.) Hiring Horse to Steal It. John Pear was indicted for stealing a mare of Finch. Ile hired the mare of Finch in London to gro to Sutton in surrey, and said he would return by $8 \mathrm{p} . \mathrm{m}$., the sime day. IIe had told linch on inquiry that he was a lodger at $25 \mathrm{King}$ St., whither prosecutor went to inquire for him next day, as he did not return, but no such person was found; and it was discovered that he sold the mare at Smithield the day he got her. ASHIIURS'T, J., told the jury that if the prisoner hired the mare to take the journey mentioned, and afterwards changed his mind and sold her while the privity of contract subsisted they should acquit; but if the jouruey was a mere pretense to get possession, and he hired her to steal her, they ought to convict. 'The jury found him guilty, and the question was reserved for the opinion of the judges. The case underwent great discussion; and finally the eleven judges who met for the purpose delivered their opinions at large. Seven of them held the offense to be elear felony ; two, that it was not; and two doubted to the last. The opinions and doubts of the four were ehiefly on statutes 333 I Ien. $S$ and 30 Geo. 2. against ob. taining goods by false tokens and pretenses. Two thought the mare was obtained by the false pretense that he wanted to go on a jour. ney, which, by the statutes, would be a misdemeanor only; and one thought it wis not felony at common law. because there was no actual taking. But ten held there was an actual taking to make it felony if no statute ever existed; and seven, that it was not within the statutes at all; for Coke defined larceny as a felonious and fraudulent taking; and by the old anthorities there need be no force; as where a carrier receiving gonds turned aside. opened the pack, and sold them; or a shopkeeper handed $A$ goods for inspection imd $A$ ran away with them; and so in Tumnard's case [\$141]. Whore the same directions were given the jury as here; and even in burglary the doorway may be broken open by frand as well as by foree; and in all these cases frand may supply the place of force, and intention is the principal thing; that so obtaining and disposing of the mare was such constructive taking in law that trespass would lie at the suit of the owner (quoting Lit. \$71); and therefore, ten of the eleven judges were of opinion that so obtaining the mare by frand and falsehood, intending then to steal her. was felony on principles of the common law. R. v. Pear, 1 Leach No. 105. 3 R. R. 703, 2 East P. C. 685.697 , B. 648 .

(Cal. Sup. Ct., 1863.) The Hirer of a Livery Horse was convicted of larceny of it, and excepts to the ruling of the court in admitting 
proof of his hiring the horse, to sustain the indictment. CROCKER, J. ** This objection is not well taken. If the defendant, at the time he hired the horse, intended to steal it, he was properly indictsd for grand lareeny; and the evidence was therefore admissible without averring the alleged bailment in the indictment. P. v. Jersey, 18 Cal. 337. If, however, the intent to steal did not exist at the time of taling the possession of the property by the bailee, but was conceived afterwards, then the indictment should have been haid under $\$ 71$, and should have averred the facts necessary to show that the defendant was the bailee of the property. P. v. Pogrgi, 19 Cal. 600. * * Affirmed. P. v. Smith, 23 Cal. 280, F. 276.

Auc. Johnson v. S., 119 Gil. 5e3. 46 S. H. 838: S. v. Woulrun. to lian. 151, 27 lace. 842. 9i Am. st Rep. 255 , suddle horse borrowed to get tooth pulled.

(Wing. C. C. R., 1784.) Fake Find of Diamond. Prosecutor fell in with a stranger on the street. and shortly the stranger noticed a purse on the sidewalk, which they found to contain a receipt for f't 10 for a diamond ring, and in another part of the purse found the ring. As they were talking about their good fortune, defendant joined them, pritised the ring, and oftered to help divide. The stranger said he had no moner'; prisoner asked prosecutor if he had; who said he had $t+0$ at home. IIe got it; prisoner said. "I will give you your share of the ring if yon will be eontent till to-morrow." Prosecutor latid down 20 gruineas and four andd doubloons, foreign coins; and prisoner picked the moner up and gave prosecutor the ring; and it was agreed that they three should meet at the same place on the morrow, when prosecutor's money should be returned and 100 guineas for his share in the find. 'The rogues did not appear as agreed; the ring was of no value; the jury found defendant and the stringer were confederates to obtain the money on pretense of sharing the value of the ring. and found him gruilty of stealing the money, subject to the opinion of the judges. All the judges anreed that in considering the mature of lareeny it was necessary to attend to the distinction between the parting with the possession only, and the parting with the property ; that in the first ease it is felony, and in the last ease it is not. Ujoon the circumstances of the present case two of the judges were of opinion that the doublons were to be considered as money. and that the whole was a loan on the security of the ring. which the prosecntor helieved to be of much greater value than the monoy he advanced on it. and therefore that he had voluntarily parted with the property as well as with the possession of the doubloons. But nine of the judges were clearly of opinion that it was felony, for they thought the twenty guineas and the four loubloons were deposited in the nature of a pledge till the half of the supposed value of the ring was paid to the prosecutor. and not as a loan; and therefore he had parted with the possession only, and not with the property (more especially as to the doubloons, which he elearly understood were to be returned the next day in specie) : and they could not distinguish this case from R. v. Patch 
and R. v. Pear [above]. The majority were therefore of opinion that he was properly convicted of felony. R. v. Moore, Leach No. 146,2 last P. C. 679, B. 658.

(Ling. C. C. R., 1799.) Forged Order for Ioan. Indictment for stealing bank notes. 'I'he prisoner sent one Dale (to whom he was unknown) with a letter directed to Dunn; bidding Dale to tell Dunn that he brought the letter from Mr. Broad, and to bring the answer to him (the prisoner) in the next street, where he would wait for him. Dale accordingly carried to Dumn the letter, which was written in the name of Broad, a friend of Dunn's, soliciting the loan of \pm 3 for a few days, and desiring that the money might be inclosed back in the letter immediately. Dumn thereupon sent the bank notes in question, inclosed in a letter directed to Broad, and delivered the same to Dale, who delivered them to the prisoner as he wals first ordered. 'The letter turned out to be an imposition. It was objected at the trial that this was no felony, because the absolute dominion of the property was parted with by the owner, though induced thereto by means of a fialse and firudulent pretense. And on reference to the judges after conviction all present held that it was no felony, on the ground that the property was intended to pass by the clelivery of the owner; and this case came within the Stat. 33 Hen. 8, c. 1, against false tokens. which particularly speaks of counterfeit letters. R. v. Atkinson, 2) Wist P. ('. 673, 13. 660 .

(Eng. C. C. R., 184t.) Fraud Inducing Owner to Part with Title and Possession. The prisoner was indicted for stealing a quantity of bacon and hams: and it appeared that he went to the shop of one Aston, and said that he came from Barker for some bacon and hams, and produced a note purporting to be signed by Barker, requesting that the meat be furnished and promising to pay for it when next in town. Believing the note to be gennine. Aston delivered the hams and bacon to the prisoner. The jury convicted him, but on case reserved, on the question whether the offense was larceny, the judges were all of opinion that the conviction was wrong. R. v. Adams, 1 Den. Cr. C. 38.

R. v. Coleman 2 Fast. P. C. tire. is to the snme effect. In that case the prisnner got some silver us change, falsely pretending to come from a nelghbor for it: and it wis held not to be larceny.

(Ga. Sup. Ct., 1888.) Same. The Harris excepted to denial of a motion for a new trial after conviction of larceny. contending that the verdict was contrary to the evidence. SIMMONS, J. ** Harris fraudulently represented to High and Ryan's sons that he was the agent of Moore \& Marsh. They did not sell him the goods. nor did they intend the title to go into Harris; but they simply delivered him the custody of the goods, to be delivered by him to Moore \& Marsh. He having converted the proceeds of the sale of the boxes to his own use. he was guilty of larceny. The title still re- 
mained in the vendor. Ilarris got the custody of the goods wrongfully and fraudulently. Judgment affirmed. Harris v. S., 81 Ga. 758, 7 S. E. 689, 12 Am. St. Rep. $35 \overline{5}$.

(Eng. C. C. R., 18jt.) Wheat Deposited with Prosecutor Swaine, was obtained by defendant from the servant in eharge of the storehouse by falsely stating that he had been sent for it hy another superior servant in eharge of another house; and on this proof he was couvicted of stealing five duarters of whent. Mliculfe, for the prisoner. In this case the prismer obtained the wheat by menns of a false pretense, and was not guilty of lareeny. The general rule is, that in larceny the property is not parted with, and in filse pretenses it is. IIere the prosecuntor parted with the property in the wheat. AlDERRSON, 13. It was clelivered to the prisoner for a special purpose. mamely, to be taken to the Brighton Railway. IERVIS, C. .J. He grets the key by a false pretense, and commits a larceny of the wheat. * * Mirlealfe. Swaine was the bailee of the consignor he had only a special property, and that special property he parted with to the prisoner. MLR'ILN, B. For the purposes of this case Swaine was the owner of the wheat. ALDERSON, B. If the prisoner had told the truth, and, having obtained the wheat without making any false pretense, had subseguently dealt with it as he has done, he would without doubt be guilty of lareeny; and can it be said that he is not guilty of lareeny simply because he told a falsehood? * * Conviction affirmed. $\dot{R}$. v. Robins, Dears. 418, 6 Cox C. C. 4201, 18 .Jur. 1058, B, 65\%, C. 321.

(Fing. C. C. R., 1368.) Obtaining on Forged Check-Ágent's Error. Indictment: 1, for lareeny of $₫ 100$ from Allen; 2 . receiving it knowing it to be stolen from him; 3 , stealing it from T. \& W. Bank; and, 4 , receiving it knowing it to have been so stolen. Allen lad $\$ 900$ on deposit at the bank: his wife presented a forged check for that amount at the bank. which the eashier paid her, supposing it to be genuine; she and dofendant were taken at Queenstown on a steamboat bound for New York; eight of the E100 motes griven her at the bank were found in her possession when taken: alıd it was shown that defendant had paid ont the other. and he said he had it from her. As to the first two eomnts it was objected. that Allen had no title to sustain them; and as to the other two. hant the evidence tended to show obtaining hy false pretenses rither than lareenv. But the case was submitted to the jury on thr fomm eomint. and the prisoner convicted. BrACKBURN, o. $* *$ " I must say I cannot but lament that the law now stands as it does. The distinction drawn between lareeny and false pretenses-onc heing made a felony and the other a misdemeanor, and rot tho same punishment attached to each-seems to me, I must confess. ummeaning and mischievous. The distinction arose in former timess. and I take it that it was then held in favor of life that in lare(en!' the taking must 
be against the will of the owner, larceny then being a capital offense. However, as the law now stands, if the owner intended the property to pass, though he would not so have intended had he known the real facts, that is sufficient to prevent the offense of obtaining another's property from amounting to lareeny; and where the servant has an authority coequal with his master's and parts with his master's property, such property canuot be said to be stolen inasmuch as the servant intends to part with the property in it. If, however, the servant's authority is limited, then he can only part with the possession, and not with the property; if he is triclied out of the possession the offense so committed will be larceny. In Regina v. Longstreeth, 1 lloody C. C. 137, the carrier's servant had no au. thority to part with the goods except to the right consignee. His authority was not generally to act in his master's business. * * * In the present case the eashier holds the money of the bank with a general authority from the bank to deal with it. He has anthority to part with it on receiving what he believes to be a genuine order. Of the genuineness he is the judge; and if under a mistake he parts with money he none the less intends to part with the property in it, and thus the offense is not, according to the cases, larceny, but an obtaining by false pretenses. The distinction is inscrutable to my mind, but it exists in the cases. 'There is no statute enabling a count for larceny to be joined with one for false pretenses; as the prisoner was indicted for the felony the conviction must be quished. [Bovill, C. J., Byles, J., Lush, J., and Channell, B., gave concurring opinions.] Conviction quashed. R. v. Prince, L. R. 1 C. C. R. 150, 11 Cox C. C. 193, 38 L. .J. m. c. 8,19 L. T. 364, 17 W. R. 179, B. 660, C. 270.

(New York Ct. of App., 1873.) Pretended Messenger for Money. Smith called at prosecutor's house, and said prosecutor had been arrested for striking a man on the head with a chair, and would be put in jail at once if he could not have $\$ 12$, which he had sent Smith to get. 'The wife had not the money, but, at Smith's suggestion, gave him \$2, a watch and some jewels to pawn, and directed him to take the money and ticket to prosecutor. The court charged the jury that if defendant had a felonious intent when he obtained the property to keep it, it was larceny. ALLEN, J. The accused ob. tained the custody of the chattels and money of the prosecutor from his wife by a fraudulent device and trick, and for a special purpose, connected with the falsely represented necessities of the owner, with the felonious intent to appropriate the same to his own use. Ile did not pawn or pledge the goods, as he proposed to do, but did appro. priate the same to his own use, in pursuance of the telonious intent with which he received them. This constitutes the crime of larceny. The owner did not part with the property in the chattels, or transfer the legal possession. The accused had merely the custody; the possession and ownership remaining in the original proprietor. The proposition is elementary that larceny may be committed of goods 
obtained from the owner by delivery, if it be done animo furandi. Per Cowen, J., Cary v. Hotailing, 1 Hill 311; Am. Crim. Law, by Wharton, $\$ 1847$, et seq.; R. v. Smith, 1 C. \& K. 423; R. v. Beaman; 1. C. \& M. 595 ; R. v. Evans, Id. 632. * * * The conviction was. right, and the judgment must be affirmed. Smith v. P., 53 N. Y. 111, 13 Am. Rep. 474, B. 653.

(New York Ct. of App., 1876.) Dice Thrown by ConfederatesSpurious Check for Loan. Lewis, one of the prisoners, made the acfuaintance of Olason, the prosecutor, and, under the pretense that he had a check for $\$ 500$ he desired to get cashed at a bank, invited Olason to go with him. Ile led him into a saloon, where was the prisoner, Loomis, whom the evidence showed to be a confederate of Lewis. Lewis proposed to Loom is to throw dice; they did so for $\$ 5$, and Loomis lost. 'They then proposed to throw for $\$ 100$. Lewis asked Olason to lend him $\$ 90$, saying, "I am sure to beat him again, and you can have your money back. If 1 do lose I have got the check for $\$ 500$, and we will go up to the bank and get the check cashed and you can have the money." Olason let him have the $\$ 90$. The dice were thrown and luewis lost. Olason insisted on the return of the money. 'The purported check was then put up against $\$ 100$, and Lewis again lost. Loomis and Lewis thereupon went away. The court charged the jury, in substance, that if satisfied beyond a reasonable doubt that the two prisoner's conspired fraudulently and feloniously to obtain the complainant's money and to convert it absolutely, without his consent and against his will, they could convict of larceny. Verdict. gruilty. Defendants took error to the general term supreme court, which affirmed the judgment, and they brought error in this court. MILLER, J. ** * It was a clear case of larceny, as marked and signifiennt in its general features as if the prisoners had wrongfully seized and appropriated it when tirst produced. The form of throwing the dice was only a cover, a device, and contrivance to conceal the original design, and, so long as there was no consent to part with the money, does not change the real character of the crime. While the element of trespass is wanting, and the offense is not larceny, where consent is given, and the owner intended to part with his property absolutely, and not merely with a temporary possession of the same, even although such consent was procured by fraud. and the person obtaining it had an animus furandi, yet, as is well said by a writer upon criminal law, "It is different where, with the animus furandi, a person obtains consent to his temporary possession of property and then converts it to his own use. The act goes further than the consent, and may be fairly said to .be against it. Consent to deliver the temporary possession is not consent to deliver the property in a thing, and if a person, animus furandi, avail himself of a temporary possession for a specific purpose, obtained by consent, to convert the property in the thing to himself and dofraind the owner thereof, he certainly 
has not the consent of the owner. Ile is therefore acting against the will of the owner, and is a trespasser, because a trespass upon the property of another is only cloing some act upon thit property against the will of the owner." In the case at bar there was no valid agreement to part with the money absolutely, and no eonsent to divest the owner of his title. It was passed over for a mere tem. porary use at most, and, the legal title remaining in the owner, the conversion of it by the prisoner's, within the rule cited, was lareceny. The reports are fiull of familiar illustrations of this rule, as a refer"nee to some of the leading cases will show. IAnd the court pro. ceceled to refer to many of them.] * * Altirmed. Loomis v. P., 6i N. Y. 3:2.2.

(Ohio Sup. C't., 18Tt.) Bunco-man with Bogus Coin. Appellant was convicted of larceny. 'The witness and the prisoner hald first met and formed a casslal acquaintance as passengers on a thain of cars passing from St. Louis to Cincinnati. "The defendant asked me if I was groing to take that train; I said yes. Ile silid he thought lie would go on that train, too. 'Then a man came up to us and said to the defendant. "If ron want to go on that train, you had better set your bagragere and pay your freight bill.' The defendant then said: 'Confound those fellows; they won't pay me any premium on my gold, and I have no other money to pay this fieight bill, and I don't want to give them two hundred and eighty dollars in gold and get ni) premium.' IIe then said to me. "Will rou let me have \$28 80 in currency, and I will give you this gold to hold as security until I ean gret to the bank." "Witness took the pieces offered. silpposing them to be sold, gave the $\$ 280$ in currency. and diseoverid the frand after defendant had gone, but was mable to catch him. M.cILVAINE, C. J. * * * The testimony of the witness was, that he voluntarily delivered the money to the defendant and never expected to get the same money acrain. It is true he was induesel to malie the loan through the fraud and false pretenses of the dofoml. ant. No doubt a crime was thus committed hy the defendint. but it was the crime of obtaining money under false pretenses. and not a lareeny. To constitute lareeny in a case where the owner voluntarily parts with the possession of his property, two other conditions are essential: 1. The owner, at the time of parting with the possession, must, expect and intend that the thing delivered will be returned to him or disposed of under his direction for his benefit. 2. The person taking the possession must, at the time, intend to deprive the owner of his property in the thing delivered. 13ut where the owner intends to transfer, not the possession merely, but also the title to the property, although induced thereto by the frind and fraudulent pretenses of the taker, the taking and carrying away do not constitute a larceny. * Reversed. Kellogg v. S., f Ohin St. 15, F. 278, 5 L. 411. 
(Cal. Sup. Ct., 1885.) Bogus U. S. Bond for Loan Till Money Obtained from Baggage Car. Defendant was convicted of grand larceny. He boarded an immigrant train, with his confederates; engaged witness in conversation, said he was a fur dealer, asked if witness knew 'I'urner of Boston whom he had telegraphed to meet him here; then the pretended Turner appeared, was introduced to witness, asked if he got the telegram, said he did, that he had the goods all fixed up and sent by express; defendant then produced two bills and what looked somewhat like a $\$ 1000 \mathrm{U}$. S. bond with coupons attached, offered the bond in payment of the bill for the goods, 'Turner said he could not change it, defendant said that was all he had with him, that he was in a great fix, asked witness to let him have $\$ 160$ to pay the bill and take the bond as security till defendant could get into the baggage car and get some money, and to hold his seat till he got back. Wituess did so, and defendant, with his confederate and the $\$ 160$ left the train at the next stop. ROSS, J. * * It is claimed for the appellant that the offense thus committed was not larceny, but the obtaining of money by means of false pretenses. The distinction between the two crimes is sometimes very narrow, but yet it is well defined. Where, by means of fraud, conspiracy, or artifice, possession of the property is obtained with felonious intent, and the title still remains in the owner, larceny is established. While the crime is false pretenses, if the title as well as the possession is absolutely parted with, no one, we presume, would seriously deny the sufficiency of the evidence to justify the finding of a felonions intent on the part of the defendant in taking the money in question; and, under the circumstances of the case, there can be as little doubt of the proposition that there was no intention on the part of the prosecuting witness to part with his ownership of the money. The eriminal and fraudulent conduct of the defendant and his confederate in no way operated a transfer of the title to them, or either of them, or at all changed the ownership of the money; it remained the money of the prosecuting witness.

* * Myrick, J., Thornton, J.. Morrison, C. J., concur. SHARP. STEIN, .T. I dissent. *** In the absence of. fraud, I think his intention to part with the property in the money would be too clear to admit of doubt. He, in effect. says that he lent the money to the defendant, understanding at the time that defendant was to pay it to a third person to whom he (defendant) was indebted. To say that the owner of the money intended to part with his property in the money if the representations made to him were truc, but to retain his property in it if they were not, is, in effect, saying that if his consent to part with it was obtained by fraud, he never consented, which is inconsistent with the doctrine that if the consent be obtained by gross fraud there is no larceny. And Bishop says this doctrine is too firmly established by the authorities to be overthrown by judicial power. $2 \mathrm{Cr}$. Law 808 . But the court below, in effect, instructed the jury that if the consent of the owner to part with his 
property was obtained by fraud, the fact of such consent being given was quite immaterial; that consent so obtained was not consent. * * * McKinstry, J., concurs. Affirmed. P. v. Rae, 66 Cal. 423, 6 Pac. 1, 56 Am. Rep. 102, F. 280.

(Mich. Sup. Ct., 1885.) Same-Cheater is Cheated with Cards, CAMPBELL, J. Respondents were convicted of larceny from James Brown of $\$ 80$ in money, which was accomplished by means of leger. demain with marked cards. 'The only substantial question before us, worth noticing, is whether the fraudulent transaction, whereby the victim was deprived of his money, came within the definition of that offense. Although he was taken in while trying to aid in per. forming a sharp trick himself, yet this may not destroy the public wrong if one existed. Shaw and Jones were confederates in the fraud. Shaw had introduced himself to Brown as a traveler for a tea-dealing firm in Cincinnati, and told him that one of the means used for getting custom in a new place was offering purchasers a chance, by drawing cards, to get 50 pounds free, in addition to the purchase, if they drew the winning card. In order to carry out the scheme, he wanted Brown to accompany him, and showed him how to draw the lucky card, by a little dot on the back. While they were practicing, and Brown succeeded each time in drawing the card, Jones came up, appearing to be a stranger, and inquired what they were doing; and Shaw told him he would show him, and gave him the same explanation as to the mode of selling tea, but did not tell him about the marked cards. Shaw, after some talk, said that Brown could draw the 50-pound eard. Jones offered to bet $\$ 100$ that he could not, and held out to Shaw what seemed to be a roll of bills. Shaw said he had not the money, but had a $\$ 300$ eheck. Jones said that he did not want the check; he wanteil monpy. Shaw asked Brown if he had it. Brown said that he had not $\$ 100$, but had $\$ 80$. Brown, at Shaw's request, handed to him the $\$ 80$, and Shaw whispered to him to draw the marked card. He drew it, and it was blank, and Shaw at once handed the money to Jones. There were some subsequent performances, which indicated the conspiracy between the respondents, but the larceny was charged on these facts and their purpose. The court below refused to charge the jury that they did not make out larceny. * * * There is some rather attenuated discrimination to be found in the books between such cheats as induce a person to give temporary custody of his property to another, who keeps or disposes of it, and those whereby he is induced to part with it out and out. We do not think it profitable to draw over-nice metaphysical distinctions to save thieves from punishment. If rogues conspire to get away a man's money by such tricks as those which were played here, it is not going beyond the settled rules of law to hold that the fraud will supply the place of trespass in the taking, and so make the conversion felonious. We have a statute which provides, that an indictment for larceny may 
include counts for false pretenses, embezzlement, and receiving or concealing stolen property, and allowing the jury to convict of either. How. St. \$9546. While this will not allow a conviction escept for an offense charged, it nevertheless recognizes the kindred nature of these offenses, and indicates a purpose to facilitate dealing with such offenders. *** Affirmed. P. v. Shaw, 57 Mich. 403, 24 N. W. 121, 58 Am. Rep. 372.

(Pa. Sup. Ct., 1888.) Renewing $\$ 1600$ Note with $\$ 16$ Note. PAXSON, J. * * * Defendant was indicted, under $\S 104$ of the crimes act of 31st March, 1860, for the larceny of a promissory note of the value of $\$ 1600$, the property of the Coopersburg Savings 13ank, and the jury have found that it was obtained animo furandi. The bank parted with the possession. If it also intended to part with its property represented by the note, we have no hesitation in saying the offense of the defendant was not larceny, whatever else it may have been. In considering this question regard must be had to the nature of the property alleged to have been stolen. It was a promissory note, as before stated, of the value of $\$ 1600$. What gave it that value? Certainly not the paper upon which it was written, for that was of so inconsiderable value as not to be the subject of larceny. It is clear that it was valuable only in so far as it was a representative of money; as the evidence of a debt which the bank held against the defendant.' The bank did not intend to part with its property in this note considered as an evidence of debt. 'The note was not the debt; it was the mere evidence of it. That it did not intend to part with any right of property is manifest from the fact that the cashier thought he was receiving in exchange for the note parted with a similar evidence of such debt, of equal amount and of equal value. It would be the baldest technicality, a mere sticking in the bark, to hold that the bank intended to part with any right of property by a mere delivery to the defendant of a piece of paper which qua paper, was of no value. It did not intend to deliver the evidence of its debt to the defendant, because it supposed it was getting another of equal value. and would have received it but for the trick and fraud of the defendant. In the absence of any decision of this court fully covering the facts of the ease, it was natural and proper for the learned judge below to give the defendant the benefit of the doubt which he evidently entertained. Were we in doubt, we would do likewise; but we are all of opinion that upon the facts found by the jury the offense is larceny. *** Proceed to sentence the defendint aecording to law. C. v. Eichelberger, 119 Pa. St. 254, 13. Atl. 422,4 Am. St. Rep. 642 .

(Eng. C. C. R.. 1887.) Bet on Race. Indictment for larceny. Defendant had a stand at the Ascot races taking bets. and took money of prosecutor on a bet by prosecutor 7 to 1 that "Bird of Freedom" 
would win. That horse won, and proseculor went for his money ; but defendant and stand were gonce. When found defendant denied all knowledge of the matter; but later confessed. For the prisoner it was submitted that there was no evidence of taking by trick or lalse pretense, and prosecutor had testified that he would have been satisfied had he not got back the same coins. The case was left to the jury. lerdict, guilty. SMIIII, J. I think that it is clear the prosecutor never intended to part with the property in the is. except on condition that a bona fide bet was made. I think also thit there is evidence that at the time the prosecutor handed the $5 \mathrm{~s}$. to the prisoner, the prisoner intended to keep possession of the muney, whether Bird of Freedom lost or won. He therefore obtained the possession of the prosecutor's money by means of a preconcerted and premeditated fratud; in other words, by a trick. T'here was, therefore, abundant evidence of larceny, and in my opinion the convietion should be affirmed. [Lord Coleridge, C. J., Pollock, B., Ministy, J., and IIawkins, J., grave similar opinions.] R. v. Buckmaster, $16 \mathrm{Cos}$ C. C. 339,57 L. J. m. c. 25,20 Q. B. D. 182, 57 L. 'T. 720,36 W. R. 701, 52 J. P. 358, B. 66:3, C. 316.

(Eng. C. C. R., 1890.) Selling Purse and 3s. for 1s. On indict. ment for lareeny, the substance of the prosecutor's testimony was: I was watehing a man sell purses on the strect when the prisoner came up and said he would show the trick, opened a purse he had in his hand, put 3s. in his other hand, appeared to drop them into the purse, asked me if 1 would give him 1s. for the purse and $3 \mathrm{~s}$., and I hesitated. hut ans him $1 \mathrm{~s}$. for it; he then pulled out another purse, showed 2 half-erowns in his hancl. seemed to drop them in, and offered me them and the purse for half-a-crown: as I walked away. T. found one purse had only three half-penee in it, and the other two pennies in it. I did not buy on speculation; he ofiered me 3s. for 1s.; and I was willing to take it if he was to give it. The jury found the money was obtained by a trick. and the prisoner was eom. victed. For him it was argued that there was no lareeny hy trick here, as prosecntor willingly parted with both title and possession. HAWKINS, J. I camnot myself imagine a clearer illustration of the difference between the oftense of false pretenses and that of lareeny than is afforded by this casc. It is perfectly clear that the prosecutor intended to part with the property in the coins. and that being so, the case is clearly not that of larceny. 'The conviction must therefore be quashed. [Coleridge, C. J., Jiathew. J.. Day, .T., and Grantham, J., gave concurring opinions.] Conviction quashed. R. $\nabla^{\prime}$ Solomons, 17 Cox C. C. 93,62 T. T. 672, B. 66 S.

(Fng. C. C. R.. 1892.) Taking Price and Running Off with Horse Sold. Defendant was eonvieted of larceny of $£ 8$ of $B$, on proof that he sold a horse at a fair to $\mathbb{B}$ for $£ 23$, received $\$ 8$ on the price, and agreed to wait while $B$ enuld find a friend abont the place to borrow 
the other $£ 15$ of the price, but instead of doing so left with the horse and $£ 8$. For the prisoner it was contended that $B$ intended to part with title to the money when he handed it over, and he had testified that he did not expect to get the money back, but to get the horse; wherefore there was no larceny. HA iVKLNS, J. * * * In my judgment the money was merely handed to the prisoner by way of deposit, to remain in his hands until completion of the transaction by delivery of the horse. He never intended, or could have intended, that the prisoner should talie the money and hold it. whether he delivered the horse or not. The idea is absurd; his intention was that it should be held temporarily by the prisoner until the contract was enpleted, whilc the prisoner linew well that the contract never wonld be completerl. hy delivery; the latter therefore intended to keep and steal the money. Nitogrether, apart from the eases and from the principle which has been so frequently enmeiated. I shonld not have a shadow of doubt that the conviction wis right. [Iord Coleridge, C. J., Pollock. B.. A. I. Smith, J.. and Wills, J., gave similar opinions. Affirmed.] R. v. Russett [1892]. 2 Q. B. 312. 67 L. T. 124, 40 W. R. 592, 17 Cox C. C. 534, 56 J. P. T43, 33. 671. Ke. 349.

(IIl. Sup. Ct.. 1895.) Betting on Foot-Race. Doss was convicted of larceny of $\$ 5.30$ from Divine. Doss obtained the money of Divine, who went with him. to bet on one Langdon as winner in a proposed foot-race, Doss assuring Divine that Langdon wis a very swift runner and sure to win. At the race they met Kiplinger, who acted as stakeholder, the runners (Langdon and Simpson), and another. All proceeded together to the race track. some envelopes were placed in Kiplinger's hands, which he said he did not open, but the evidence does not show that any money was put up against Divine's, and Doss nut only $\$ 20$ in the hands of the stakeholder. The race came off, Simpson won. Kiplinger gave him the envelopes. Doss seemed very angry at Langdon for failing, the parties separated, the whole affair was a fraud, the consnirators met near town to divide, and they then ran away. CARTER, J. ** * The jury were warranted in finding that possession of the money was frandulently obtained by plaintiff in error, with the felonious intent on his part, when he received it. to convert it to his own use, and that Divine. when he gave him the monev, intended to part with his possession merely, and not with his title. relving on plaintiff in error to dispose of it as agreed unon for his (Divine's) benefit. It is the settled law of this state that this nffense is larenny. Murnhy v. P.. 104 Ill. 528. * * Affirmed. Doss v. P., 158 Tll. 660. 41 N. E. 1093, 49 Am. St. Rep. 180.

Arr. R. v. Robson, Russ, \& R. 413. Mi. 788.

(Ind. Sup. Ct.. 1897.) Green Goods. One of defendants was a bank president. the other an insurance agent, and they represented to prosecutor, a credulous farmer, that they could get any quantity 
of "good money," "that would pass anywhere," five dollars for one, and would let him into the scheme. 'They induced him to give them $\$ 1,000$ in money and his note for $\$ 4,000$. Then the bank president started for New York to get the money $(\$ \overline{\$} 0,000)$, sent a box by express to prosecutor, notifying him to keep it safe till the three conld meet and divide. Prosecutor got the box, took it home, and hid it in the oat bin. A few days later defendants called, and asked if he had the box. He produced it, and the three went to the woods to divide. While opening it, the bank president noticed that the mails on the box were not the same as he used, and suspected that it might have been tampered with. When opened it was found to contain brown paper only. Fach defendant accused the other, the bank president stid the others had robbed him, drew a revolver and pointed it at prosecutor, and the other defendant grabbed the re. volver; then a great seuftle ensued hetween defendants, and prosecutor in great fright turned and fled. Later the insurance agent ealled to the farmere, and said come back, he had the grum. would investigate and they must keep the matter quiet or all would go to the penitentiary. After waiting some time without results, prosecutor made complaint, resulting in this proceeding. Both defendants were convieted on an indictment for lareeny, and on error the convietion was affirmed. It was contended that the offense was ohtaining money by false pretenses, if anything, and not larceny. J3ut the comrt held that prosecutor parted with possession only, not with his title to the money; that it was to he returned to him. or five to onr for it. in 30 days at most; that there was a taking hy trick and deception with intention to appropriate at once to the taker's own use. which reonstitute plain larceny. Crum v. S, 148 Tnd. 401. 4 T N. N. S:333.

\section{$\$ 134$. "Without Consent."}

(king. Issiz. 1s+1.) A Wife Having Agreed to Elope with the Prisoner, wis disirul by him to. bring all the money she condl; aceordingly she packind money, etc., into boxes, had the prisoner eall for them, and was about to depart with him when the hushand awoke. On trial for larceny, COLWRIDGE, J., instructed the jury that the cunity hetween husband and wife prevented her being comvieted of larceny from him, and a stranger receiving the hushinds goods from her hands could not ordinarily be convicted: but if the per'son to whom she delivered the goods was an adulterer with her or they then intended adultery, he can be convicted though he received the goods from the wife. Verdict, guilty. R. v. Tollett, Car. \& M. 112, B. 533.

Tikewige, though the jewelry was community property. P. v. Swalm. \&) Cal. 16, 42 ('ac. 6r. $13 \mathrm{Am}$. St. Rep. 83 .

(Ala. Sup. Ct., 1871.) Matches Set Out for Free Use. Defendant 
was convicted of larceny of a box of matches. It was proved that he took the matches put up in a store by the proprietor to accommodate customers in lighting their pipes and cigars. His counsel requested the court to charge the jury that if the matches were placed on the counter for the accommodation of the public, the owner consented that they should be taken, and so there was no larceny. SAFFOLD, J. * * * Tuarceny may be committed of property under the circumstances attached to the box of matches. T'he owner had not abandoned his right to them. They could only be appropriated in a particular manner and in a very limited quantity with his consent. 'Taking them by the boxful without felonious intent would have been a trespass, and with it, a larceny. The ownership. was sufficiently proved. Affirmed. Mitchum v. S., 45 Ala. 29, 13. 616, Ji. 711.

\section{(N. Car. Sup. Ct., 1892.) A Cotton Sampler was Permitted to Pull} Cotton from the Bales, to test its quality, and he used this privilege to take more cotton than was necessary for the purpose, intending fraudulently to appropriate it. A conviction of larceny on an instruction that this was sufficient to eonvict, though the owner consented to the taking of the samples, was approved and affirmed. S. v. MacRae, 111 N. Car. 665. 16 S. E. 173.

\section{(king. C. C. R., 1873.) Overpayment by Mistake, Knowingly}

Taken. The prisoner was convicted of larceny on proof that he presented an order at a postoffice for 10s. on deposit to his credit, that the elerk in the office took the prisoner's book, by mistake read another letter of advice, charged him with ts 16 s. $10 \mathrm{~d}$., and counted that sim ont onto the comnter; and that the prisoner took up the money and went away. BOVIlis, C. .J.. read the judgment of Cockhurn, (c. J., Blackburn, Mrellor. Isush, Grove. Denman, and Archibald, J.J. * * The finding of the jury, that the prisoner, at the moment of taking the money, had the animus furandi and was aware of the mistake, puts an end to all objeetion arising from the fact that the clerk meant to part with the possession of the money. On the second question, numely. whether, assuming that the clerk was to be eonsidered as having all the allthority of the owner, the intention of the clerk (such as it was) to part with the property prevents this from being larceny, there is mole difficultr, and there is, in fact. a serious difference of opinion, thomerh the majority, as alrendy stated, think the conviction right. 'The reasons which lead us to this conclusion are as follows: At common law the property in personal goods passes by a bargain and sale for consideration. or a gift of them accompanied by delivery; and it is clear from the very nature of the thing that an intention to pass the property is essential both to a sale and to a gift. But it is not at all true that an intention to pass the property, even though accompanied by a delivery. is of itself equivalent to either a sale or a gift. *** The property 
still remains that of the postmaster-general, and never did vest in the prisoner at all. 'There was no contract to render it his which recpuired to be rescinded; there was no gift of it to him, for there was no intention to give it to him or to anyone. It was simply a handing over by a pure mistake, and no property passed. ** * We admit that the ease is undistinguishable from the one supposed in the argument, of a person handing to a cabman a sovereign by mistake for a shilling; but after carefully weighing the opinions to the contrary, we are decidedly of opinion that the property in the sovereign would not vest in the cabman, and that the question whether the cabmin was guilty of larceny or not, would dejend upon this, whether he, at the time he took the sovereign, was aware of the mistake and had then the guilty intent, the animus furandi. But it is further urged that if the owner, having power to dispose of the property, intended to part with it, that prevents the crime from being that of larceny, though the intention was inoperative, and no property passed. In almost all the cases on the subject, the property had actually passed, or at least the court thought it had passed; but two cases, R. v. Adams, 2 Russ. C. (Ed. 4) 200 [\$133], and R. v. Atkinson, 2 East P. C. $673\lfloor \$ 133\rfloor$, appear to have been decided on the ground that an intention to pass the property, though inoperative, and known by the prisoner to be inoperative, was enough to prevent the crime from being that of lareeny. But we are unible to perceive or understand on what principles the cases can be sup. ported if R. v. Davenport. 2) Russ. C. (Fd. 4) 201, and the others involving the same principle are law. *** [Bovill, C. J., also read an opinion for himself and Keating, J., in part as follows:] * * We are of opinion that neither the clerk to the postmistress, nor the postmistress personally, had any power or authority to part with the $\$ 5$ note, three sovereigns, the half-sovereign, silver and eopper, : mounting to $\mathrm{fS} 1 \mathrm{16 \textrm {s }}$. 10d.. which the clerk placed upon the counter, and which was taken $11 \mathrm{p}$ by the prisoner. In this view the present case appears to be undistinguishable from other cases where, obtaining articles animo furandi from the master of a postoffice, though he had intentionally delivered them over to the prisoner, has been held to be larceny, on the principle that the postmaster had not the property in the articles, or the power to part with the property in them. For instance, the obtaining the mail bags by pretending to be the mail guard, as in R. v. Pearce, 2 East P. C. 603, the obtaining a wateh from the postmaster by pretending to be the person for whom it was intended, as in R. v. Kay. Dears. \& B. Cr. C. $231: 26 \mathrm{r}$. J. m. c. 119 (where R. v. Pearce, 2 Fast P. C. 603, was relied upon in the judgment of the court) ; and the obtaining letters from the postmaster under pretense of being the servant of the party to whom they were addressed, as in $R$. v. Jones. 1 Den. Cr. C. 188, and in R. v. Gillings. 1 F. \& F. 36, were all held to be larceny. The same principle has been acted upon in other cases, where the person having merely the possession of goods. without any power to part with 
the property in them, has delivered them to the prisoner, who has obtamed them animo furandi; for instance, such obtaining of a parcel from a carrier's servant by pretending to be the person to whom it was directed, as in R. v. Longstreeth, 1 Mlood. Cr. C. 137; or obtaining goods through the misdelivery of them by a carman's serrant, through mistake, to a wroug person, who appropriated them anino furandi, as in $R$. v. Little, $10 \mathrm{Cox} \mathrm{Cr}$. C. 559 , were, in like manner, held to amount to larceny. In all these and other similar cases, many of which are collected in 2 Russ. C. 211 to $21 \tilde{J}$, the prop(rty wats considered to be taken without the consent and against the will of the owner, though the possession was parted with by the roluntary act of the servant, to whom the property had been intrusted for a special jurpose. And where property is so taken by the prisoner knowingly, with intent to deprive the owner of it and feloniously to appropriate it to himself, he may, in our opinion, be properly convicted of lar'ceny. 'The case is very different where the goods are parted with by the owner himself, or by a person having authority to act for him, and where he or such agent intends to part with the property in the goods; for then, although the goods be obtained by fraud, or forgery, or false pretenses, it is not a taking against the will of the owner, which is necessiary in order to constitute larceny. *** In the present case, not only had the postmistress or her clerk no powere or anthority to part with the property in this money to the prisoner, but the clerk, in one sense, never intended to part with the $18 \mathrm{~s}$. $10 \mathrm{~d}$. to the person who presented an order for only 10s., and he placed the money on the counter by mistake, though at the time he (by mistake) intended that the prisoner should take it up, and by mistake entered the amount in the prisoner's book. When the money was lying upon the counter the prisoner was aware that he wass not entitled to it, and that it conld not be, and was not, really intended for him; yet, with a full knowledge on his part of the mistake, he took the money up and carried it away, intending at the time he took it to deprive the owner of all property in it, and feloniously to appropriate it to his own use. There was. therefore. as it seems to us, a wrongful and fraudulent taking and carrying away of the whole of this money by the prisoner, without any color of right. animo furandi. and against the will of the real owner; and for these reasons, ind upon the authorities before stated. we think the prisoner was properly convicted of larceny. [Kelly, C. B.. read a concurring opinion.]

[No Possession Given.] PIGOT'T. B. I algree in the judgment of the majority of the court. except that I do not adopt the reasons which are there assigned. *** The case states that the clerls. placed the money on the counter. **** This, no doubt, gave the prisoner the opportunity of taking up the money. *** ${ }^{*}$ If complete possession had been given by the clerk to the prisoner, so that no act of the latter was required to complete it after his discovery of the mistake and his own formed intention to steal it. I 
should not feel myself at liberty to affirm this conviction. ${ }^{*} *^{*}$ CLEASBY, B. *** The cases establish that, where there is a complete dealing or transaction between the parties for the purpose of passing the property, and so the possession parted with, there is no taking, and the case is out of the catagory of larceny. *** the cases show, no doubt, beyond question that where the transinction is of such a nature that the property in the chattel actually passes (though subject to be resumed by reason of fraud or trick), there is no taking, and therefore no lareeny. But they do not show the converse: viz., that when the property does not pass there is larceny. On the contrary, they appear to me to show that where there is an intention to part with the property along with the possession, though the fraud is of such a nature as to prevent that intention from operating there is still no larceny.

[Effect of Mistake on Intent.] BRAMIWELL, 13.*** But it is argued that here there was no intent to part with the property, becatuse the postoftice elerk never intended to give to Middleton what did not belong to him. A fallacy is involved in this way of stating the matter. No doubt the clerk did not intend to do an act of the sort described and give to Mliddleton what did not belong to lim, yet he intended to do the act he did. What he did he did not do involuntarily nor accidentally, but on purpose. See what would follow from such reasoning. $\Lambda$ intends to kill $B$; mistaking $C$ for $B$, he shoots at $C$ and kills him. According to the aryument, he is not guilty of intentional murder; not of 13 , for he has not killed him; not of $\mathrm{C}$, for he did not intend to kill him. There is anthority of a very cogent kind against this argument. A man in the dark urets into bed to a woman, who, erroneously believing him to he her hushand, lets him have connection with her. This is no lape, hesulse it is not without her consent, yet she did not intend that a man not her husband should have eomnection with her. I have noticed this above as another illustration of how the common law pefisses to punish an act committed with the eonsent of the eomplainain. * * * It is said that here the dominus was invitus: that the domimus was not the postoffice clerk, but the postmaster-grencral or the yneen; and that therefore it was an unauthorized act in the postofice cherlk. and so a trespass in Mliddleton invito domino. I think one answere to this is, that the postoffice clerk had authority to decide muder what circumstances he would part with the money with which he wals intrusted. But I also think that. for the purposes of this yulestion, the lawful possessor of the chattel, having authority to transfer the property, must be considered as the dominus within this rule, at least when acting bona fide. It is unreasonable that a man should be a thief or not, not according to his act and intention. but aceording to a matter which has nothing to do with them. and of which he has no knowledge. According to this, if $I$ give a cabman a sovereign for a shilling by mistake. he taking it animo furandi, it is no lar. ceny : but if I tell my servant to take a shilling out of my purse, and 
he by mistake takes a sovereign, and gives it to the cabman, who takes it animo furandi, the cabman is a thief. It is ludicrous to say that if a man, instead of himself paying, tells his wife to do so, and she gives the sovereign for a shilling, the eabinan is gnilty of larceny, but not if the husband gives it. It is said that there is no grent hirm in this; that a thief in mind and act has blundered into a crime. I cannot agree. I think the criminal law onght to be reasonable and intelligible. Certainly a man who had to be hung owing to this distinction might well eomplain, and it is to be remembered that we must hold that to be law now which would have been law when such a felony was capital. Besidles, juries are not infallible, and mily make a mistalke as to the animus furandi, and so find it man guilty of lareeny when there was no theft and no animus furandi. IIoreover, R. v. Prince, T. R. 1 C. C. 130 [\$ 133], is contrary to this argument, for there the banker's clerks had no authority to pay a forged check if they knew it; they had anthority to make a mistake. and so had the postoffice clerk. *** [Dissenting opinions were also given by liartin, 13., and Brett, .J.] Conviction affirmed. R. v. Middleton, I. R. 2 C. C. R. 38, 42 I. .J. m. c. 73, 28 L. T. 777, 12 Cox C. C. 260,417 , B. 617 , Ke. $266, \mathrm{MI}$. 794 .

Compare similar facts on charge of embeyslement: $\quad C$ v. Hays, $\$ 1$ in.

(Eng. C. C. R., 188T.) Stealing from Slot Machine. On inclictment for lareeny, it was shown that defendants obtained cigarettes from a penny-jn-the slot machine by putting into it metal disks about the size of a pemy, while a spy employed by the owner watehed to see them do it. J.ORD COIJRIDGE, C. J. In this ease a person wiss indicted for committing a lareeny from what is known as an "intomatic box," which was so constructed that if you put a penny into it and pushed a knob in aceordance with the directions on the box a cigarette wis ajected onto a bracket and presented to the giver of the penny. Finder these circumstances there is no doubt that the prisoners put in the box a piece of metal which was of no value. but which produced the same offocot as the placing a penny in the box produced. A cigarette was ejected, which the prisoners appropriated; and in a case of that celass it appean's to me there elearly was larceny. The means by which the cignarette was made to come out of the box were frandulent and the eisurette so made to come out was appropriated. * * * Pollocek. B.. Stephen, Mathew, and Wills, .J., concurred. Conviction affirmed. R. v. Hands, 16 Cox C. C. 188,56 I. T. 370,52 .J. P. 24. 13. 614. ('. 3883.

(Cal. Sup. C't., 1888.) Feigned Drunk to Catch Thief. Defendunt was convicted of grand lareeny from the person of F. O. Slanker. and appealed. IICFARIAND, J. ** "lhe appellant entunds that Slanker's testimony. taken as true, does not make out a case of larceny, because it shows that the money was taken with his (Slanker's) consent. The statement of Slanker was substantially 
this: He was a constable in the town of Pomona, and, some crimes having been committed in the town, he, for the purpose of detecting the thieves, on the night of the alleged lareeny, disguised himself, and feigned drunkenmess. Aftrer staggering around the strects awhile. he lay down in an alley, and. pretended to be in a drunken sto. w. Shortly afterwards the appellant and another person came to .ivin, sind took from his person three dollars, which he had put in tus pocket of his overalis. IIe was perfectly conscious at the time, and made no resistance, and intended that any thief who tried it should be allowed to take the three dollars, in order that a case of lareeny might be made out against him. He had no previrus suspicion, however. of the appellant. and was surprised at his participation in the act. And under these cireumstances, counsel for ap. pellant contends that the thing done was not larceny, because the money was not taken agninst the consent of the prosecuting witness. Tt is no doubt true. as a general proposition. that larceny is not committed when the property is taken with the consent of its owner: but it is difficult in some instances to determine whether eertain acts constitute. in law, such "consent," and. under the anthorities we do not think that there is such consent where there is mere passive sulbmission on the part of the owner of the goods taken. and no indication that he wishes them taken. and no knowledge by the taker that the owner wishes them taken, and no mutual understanding between the two. and no active measures of inducement employed for the purpose of leading into temptation. *** From the anthorities. and upon principle. we are of oninion that the conduct of the witness Slanker, as detailed by him in his testimony, did not amount to consent in law, and affords no reason why the act of appellant in taking the money (if he did take it in the manner as sworn to by Slanker) was not larceny. ** * [.Julgment reversed hecanse the indictment did not allege title to the monev taken was in another than defendant. 1 P. v. Hanselman, 76 Cal. 460, 18 Pac. 425. 9 Am. St. Rep. 238.

Sn. if the owner heing drunk. sunnosed defendant's purpose was to keep it. (a watch) for him till soher. Schafer v. S. (Ala.) \& Sn. 670 .

(Tex. Ct. of App.. 1887.) Property Exposed to Thief. A defendant charged with the larceny of a horse. which the owner loaned to another. who placed the horse out for the purpose of catching defendant in the theft. cannot set up the consent of the owner in defense. where he did not. directly or throngh another. snggest the theft to him. or induce him to commit, it. Connor v. S., 24 Tex. $A$ pp. 245. 6 S. W. 138.

Acc. Loive v. S., 44 Fia. 449.32 Sn. 950. See also several caces in \$ 99.

§135. "Carrying Away."

(Eng. C. C. R.. 1782.) The Prisoner Moved a Parcel of Goods 
from the Fore Part to Near the Tail of a Wagon, when he was detected; and it was held that, as the prisoner had removed the property from the spot where it was placed, with an intent to steal, the asportation was sufficient to constitute the offense. Cozlett's Case, 2 East P. C. 556.

(Eng. C. C. R., 1824.) Moving Mail Bag. The defendant, with a felonious intent, lifted a bag from the bottom of the front boot of a coach, but, before getting it completely out of the space it had oecupied, he was detected; yet as each part of it had been removed from the space which that specific part occupied, the asportation was held to be complete. Conviction affirmed. R. v. Walsh, 1 Moody C. C. 14, B. 505, C. $380, \mathrm{Ke} .220$.

(Lng. C. C. R., 1862.) A Letter Carrier was indicted for stealing a letter; and it was proved that it should have been delivered in due course in the morning, and when he was asked in the afternoon why he had not delivered it, he falsely said no one was at the house, and then took the letter from his pocket unopened. He was found guilty on instruction that if he put it into his pocket to secrete and steal it he might be convicted. On case reserved, the conviction was affirmed. R. v. Poynton, 9 Cox C. C. 249 , L. \& C. 247,32 L. J. m. c. 29, 7 L. 'T. 434, 11 W. R. 73, S Jur. n. s. 1218, C. 281.

(Ohio Sup. Ct., 1870.) Lifting Money and Turning It in D. w'er. Appellant was convicted of larceny. It was shown that he wel $\%$ into a store and asked the price of a pair of boots in the window. While the merchant went to get the boots he went behind the counter, opened the money drawer, took the money in his hands and disarranged the piles of bills; but being discovered by the merchant, left the drawer without taking any of the money out. DAY, J. It is elaimed on behalf of the plaintiff in error that the charge given to the jury was erroneous, and that the court erred in refusing to charge as requested. and in refusing to grant a new trial. These are the allecred error's chiefly relied on for a reversal of the judgment. * * The felony lies in the very first act of removing the prop. erty. Therefore, the least removing of the entire thing taken, with in intent to steal it. if the thief thereby, for the instant, obtain the entire and absolute possession of it, is a sufficient asportation. though the property be not removed from the premises of the owner, nor retained in the possession of the thief. *** The court charged the jury thai." "if he had actually taken the money into his hand, and lifted if ".s.s.m the place where the owner had placed it. so as to ent rely sever it from the spot where it was so placed, with the intentio. stealing it. he would be guilty of larceny, though he may have di'opped it into the place it was lying upon being discovered, and never had it out of the drawer." The charge recognizes the necessity of a felonious taking of the property, that it must be sev- 
ered, and lifted or carried from the place where it was left by the owner, and be, for the instant at least, in the entire and absolute possession of the party accused. 'This, according to the authorities, constitutes larceny, though the money may have been dropped where it was found, and never taken out of the drawer. *** Eckels v. S., 20 Ohio St. 508, F. 286, Kn. 258.

Acc. Harris v, S. 99 Tex. A pp. 101, 14 S. W. 300,25 Am. St. Rep. 717, opening drawer, lifting 86, dropping and on discovery - convicted of larceny of entire contents, $\$ 51$.

(Mass. Sup. Judicial Ct., 1878.) By Innocent Agent-Transposing Baggage Checks. Defendant was indicted and convicted of larceny of a trunk and contents. The evidence showed that one Briggs, in collusion with defendant, had a valise checked at the Worcester union station for New York, and called the attention of the baggage master, while defendant took that check off, put it on a trunk checked for Ilartford, and put the trunk check onto the valise. Briggs afterwards received the trunk from the railway station in New York, and riffed it of. its contents. LORD, J. * ** 'This, as we understand, has been the law from the earliest period: "There is no occasion that the carrying away be by the hand of the party accused, for if he procured in innocent agent to take the property," by means of which he became possessed of it, "he will himself be a principal offender." 3 Chit. Crim. Law 925. It is held to be a larceny "if a person, intending to steal my horse, take out a replevin, and thereby lave the horse delivered to him by the sheriff; or if one intending to rifle. my groods get possession from the sherift, by virtue of a judgment obtained without any the least color or title, upon false uffidavits, ete.; in which cases, the making use of legal process is so far form extenuating that it highly aggravates the offense, by the abuse put on the law in making it serve the purposes of oppression and injustice." 1 IIawlk. c. 33, \$ 12; 1 . Irale P. C. 507; R. v. Chissers. 'T'. Raym. 275 $\{\$ 1333\}$; Wilkins's Case, eited in 1 IIawk. c. 33, \& $22 ; 1$ leach (4th Ed.) 520 . It will thus be seen that an asportation may be effeceted by meins of innocent human ageney, as well as by mechanical agency. or by the offender's own hand. The case has been argued as if it was intended by the presiding justice to rule that the jur'y must find that, at the instant of the exchange of the checks. there was such an actual manual change in the possession as of itself to be an asportation. We do not so understand the instruction. An asportation at that time was unimportant. The real question was, whether the defendant it that time feloniously and with intent to steal, set in motion an innocent arency, by which the trunk and contents were to be removed from the possession of the true owner, and put into the defendant's possession, and whether such purpose was actually accomplished. If, before the trunk had been started, the scheme had been detected, the offense of the defendant would have been an attempt to commit larceny, and doing an act towards the commission of it, but failing in the perpetration; but, as sonn as the asportation was complete. for however short a distance. the 
ofiense of larceny was committed, such asportation having been caused by him, by fraudulent means, and through an innocent agent, unconscious of what, in fact, he was doing. As soon as the trunk was placed on board the cars, checked, with the corresponding check in the possession of the defendant or his confederate, the trunk and its contents were in the possession and control of the defendant or his confederate, and it is immaterial of which. Nor is the time when the actual manual possession came into the hands of the parties important, they having all the time constructive possession and the real control of it. * * * Exceptions overruled. C. v. Barry, 125 Mass. 390, B. 508.

(Ala. Sup. Ct., 1888.) Hog Shot, and Removed on Permission. On trial for larceny it appeared that defendant shot prosecutor's hog, covered it, told prosecutor he found it dead and too badly spoiled for use, and was allowed to take it home for soapgrease, where prosceutor found it eleaned and sound. The court rerfused to instruct that if defendint did not move the hog after he shot it they must acquit, and he was convicted. CLOP'ION, J. **** If the defendant shot and killed the hog, with the larceny of which he is charged, in a pine thicket in the field, with felonious intent, and covered it with pine tops, in order to conceal it until he conld return and secretly remove it, and if he subsequently removed it in pursuance of the previolis felonious intent, there was, in the legal acceptance of the terms, a taking and carrying away sufficient to complete the offense, though the removal may have been with the consent of the owner, if such consent was procured by intentional misrepresentation and deception. S. v. Wilkinson, T2 N. C. 376; Fulton v. S., 13 Ark. 168. The chirge requested by the defendant ignored these material facts, which there was evidence tending to prove, and was mislealing. 'There is no error in its refusal. Affirmed. Frazier v. S., 85 Ala. 17, 4 So. 691,7 Am. St. Rep. 21.

\section{§136. "Another's."}

(Eng. Assize, 1429.) Own Goods. Demurrer to indictment for lareeny from a bailee. It was said that if I deliver you certain goods to guard and then retake them feloniously I shall be hanged, and yet the ownership was in me. And Norton [.J.] said this was the law. Anon, Y. B. 7 Hen. 6. 43 pl. 18, Ke. 253.

Ace. Carriers' Case (1473), Post 472, per Nedham, J.

(Eng. C. C. R., 1821.) Lightermen Having Given Bond to Export 6696 pounds of nux vomica (which was export free, but subject to duty of $2 \mathrm{~s}$. 6d. per pound for home consumption). NIarsden, the owner, and Wilkinson, assisting him, obtained possession on pretense to take it to the ship for export. but on the way removed the nux vomica, filled the bales with rubbish, and delivered them aboard, 
intending to defraud the government of the duty; and on proof of these facts they were convicted of larceny on indictment alleging title in the lightermen, who were innocent. On case reserved, four of the judges doubted whether this was larceny, because there was no intent to defraud the prosecutor's, the lightermen, who admitted that they had not been charged on their bond nor required to pay the duty. Seven of the judges held it was lareeny; because the bailees had the right to possession till the goods were aboard ship, and had an interest in that possession, and the intent to deprive them of it against their will was larceny, without regard to intent to injure them, because it exposed them to suit on the bond. $R . v$. Wilkinson, Russell \& R. 470, 13. 674. C. 273, Ke. 253.

(New York Sup. C't., 1833.) A Constable Having Levied on five bunches of shingles on exceution agininst Palmer; he sold them and sued the constable for taking them. On this he was convicted of lareeny, and brought certiorari. SAVAGE, C. J. There is no doubt a man may be guilty of lareeny in stealing his own property, when done with intent to charge another person with the value of it. 2 East's C. P. 558, $\$ 7 ; 1$ IJawkins, c. 33, $\S 30$. The constable, by levying on the shingles, had acquired a special property in them, 7 Cowen 297, 6 Johns. 196; and the charge was well laid by stating the property to be in the constable. 8 Cowen 137, 14 Miass. 217. The evidence fully warranted the conviction, and the judginent of the court of special sessions must be affirmed. Palmer v. P., 10 Wend. 165. 25 Am. Dec. 5i51, C. 273.

(Eng. C. C. R., 1833.) By Wife of Member of Society Owning. On indictment for stealing money the property of forty persons named, including prisoner's husband, it appeared that an unineorporated society was held at her husband's public house. and the money stolen was kept in a chest there. under three locks. of which different members held separate keys; that her husband hnd no key, though he was a member of the society; and that she broke open the chest. and used a great deal of the society's money kept therein. 'The jury convicted her ; and, on case reserved, as to whether she conld be convicted of stenling money in which her husband had a joint interest, the judges were of opinion that the convietion was wrong, and the prisoner was discharged. R. v. Willis, 1 Moody C. C. 375. C. 360. Mi. 672.

Compar S. v. Kusinlck, E 152, sustaininy ambe\%lemont agninst. stockholipr of soclety acting as agent of it.

(N. Y. Sup. Ct.. 1842.) Stealing from Thief. Defendant wis convicted of larceny of butter, property of Flagg: and excepted to exclusion of evidence to show that Flagg had stolen it. NFISON, C. .T. * * * The question put to Flagg was properly overruled. * * If the question had been answered in the affirmative. the fact would have been immaterial. because possession of property in 
the thief is sufficient to make it the subject of larceny; and the title may be laid either in the owner or the thief. *** Ward v. P., 3 Hill 395, B. 595. Affirmed, (Foster, Sen., dissenting), 6 Hill 144.

(Eng. C. C. R., 1859.) Right of Landlord to Lost Goods. POLLOCK, C. B. The judges who have considered this case are unanimously of opinion that the conviction should be affirmed. The case finds that some iron had been stolen by the prisoner from the canal while the canal was in process of eleaning, and while the water was out. The prisoner was not in the employ of the canal company, but a stranger; and the property of the company in the iron before it was taken away by the prisoner was of the same nature as that which a landlord has in goods left behind by a guest. Property so left is in the possession of the landlord for the purpose of delivering it up to the true owner; and he has sufficient possession to maintain an indictment for larceny. Conviction affirmed. $R$. v. Rowe, Bell 93,8 Cox C. C. 139,7 W. R. 236, 28 L. J. m. c. 128, 5 Jur. n. s. 274, B. 562.

(Eng. C. C. R., 1877.) By Wife of Owner. Indictment for receiving stolen goods knowing them to have been stolen. Case reserved on conviction. KELLY, C. B. I am of the opinion that the conviction must be quashed. This is not a case of stealing, but the prisoner has been convicted of receiving the property, well knowing it to have been stolen. It may well be that when a wife has taken away the goods of her husband with a view to an ulterior adulterous intercourse, and her adulterer has participated in the act of taking them away, he may be indicted for larceny. This view seems to have passed through the mind of Lord Campbell, C. J., in R. v. Featherstone, but there is nothing in that case to show that a wife can be indicted for stealing the property of her husband. In the present case the prisoner is not convicted for stealing the property of the husband, and it is possible if he had been, the question might have arisen whether he could have been convicted upon the evidence. I am far from saying that he could not. That is not the case here: but the prisoner has been convicted of receiving, and the case fails in showing that the property could have been stolen by any other person than the prosecutor's wife. By the law of England a wife cannot steal her husband's property. If the wife has not stolen the property, there was no evidence of the property having been stolen at all, and therefore the conviction of the prisoner for receiving the property, well knowing it to be stolen, cannot be sustained. The other judges concurred. Conviction quashed. R. v. Kenny, 13 Cox C. C. 397.2 Q. B. D. 307,46 L. J. m. c. 156,36 L. T. 36,25 W. R. 679 , C. 359, Mi. 669 .

(N. J. Sup. Ct.. 1883.) Goods Left by Officer with Owner. Plaintiff in error was indicted of grand larceny, and convicted on proof 
that she sold goods levied on by Sloan as constable on an execution against her and left in her possession by him awaiting the execution sale. KNAPP, J. *** The defendant asked the court to charge the jury that there was a variance in the allegation of property in Sloan, and the proof upon the trial; that, therefore, the de. fendant should not be convicted. This the court refused to charge, and the evidence is brought here for examination as to the correctness of the court's action in so refusing; but upon the evidence it appears that Sloan, as already stated, had a special property in the goods, and they were therefore properly laid as his goods in the indictment. 'There was no error in refusing so to charge. The next exception is as to what the court did charge on the subject of ownership. By the bill of exceptions it appeil's that the court said that by virtue of the execution and levy "the constable became the owner of the goods levied upon until sold by him, and that if she took the groods, or assisted any one else in the taling, she is guilty." * * * It is not every sort of taking of these goods that would make her criminally liable. It might have amounted to no more thall it tres. pass or a conversion of the property as against the officer. The goods were left in her custody by the officer. As between them she may have been considered as a mere receiptor for the goods, with the right in the officer to deprive her of her possession and assume it himself. But she not only had their actual custody, but wis as well the general owner. and conld at any time before sale, by paying the judgment, remove the officer's hands entirely from her property. Now, unless her taking the goods was under such circumstances as in some way to fraudulently charge him with their value, it is diffeult to find any recognized rule of criminal law that would hold her answerable for larceny. This case fails in resemblance to that of Palmer v. P., 10 Wend. 166 [above], in this important feature.

* * It would not be every taking by a mere stranger of these goods from the possession of the constable that would amount to larceny. A felonious intent would be a requisite ingredient in such crime. A conversion of the goods by a stranger who had been appointed their keeper by a constable, would not have been in erime but a civil wrong merely. 'To hold the general owner in possession to a severer rule seems to me to savor of illegal severity. I am unable, in the researches $I$ have made, to find any case which warrants the ascription of criminality to such facts. The case of R. v. Wilkinson, Russ. \& Ry. 470 [above], which goes as far as any other that I have found, presented the features of flagrant fraud on the part of the defendants, who were the real owners of the property, upon either the prosecutors or upon the crown. **** Reversed. Adams v. S., 45 N. J. L. 448 , B. 679.

Acc. C. v. Greene. 111 Mass. 392.5 L. 418 ; Whiteside v. Lowney. 171 Mass. 131,50 N. E. 931: Clarke v S., 91 Neb. 370,59 N. W. 785 .

(IIl. Sup. Ct., 1888.) Stealing from Finder. On indictment for larceny of a horse, it was shown that he was stolen from one who 
had taken him up as an estray. Held, that the latter had a property in the horse to his full value, as against defendant, and not merely to the extent of his charges for posting. Quinn v. P., 123 Ill. 333, 15 N. E. 46.

(Ga. Sup. Ct., 1900.) Pledged Goods. On charge of stealing a bicycle and suit of clothes of the property and from the house of T. Mack, it appeared that defendant went to prosecutrix to get board, and she demanded pay in advance, saying she had lost considerable by giving credit; on this defendant deposited with her the things he was charged with stealing, which he said she might keep as security for the board. She put them in a room in the house where her son and defendant slept. He stayed about three weeks, and during that time rode on the wheel and wore the suit several times without objection. When the board bill amounted to $\$ 7$, he was asked to pay, but left without doing so, leaving the suit and bicycle in the house. Later he came secretly and got them, sold the bicycle, and was wearing the clothes when arrested. He claimed that he took the clothes to wear on the job where he was at work to get money to pay the bill. Being convicted on this proof, motion for new trial, for want of evidence to support the verdict, was denied. and on error the judgment was affirmed. "Property in the hands of a bailee may be stolen by the general owner." Henry v. S., 110 Ga. 750, 36 S. F. 55, 78 Am. St. Rep. 137, Mi. 665.

\section{\$137. "Valuable."}

(Eng. C. C. R., 1795.) Coercing to Sign Note. The prisoner was charged with robbing the prosecutor of a promissory note. It appeared that the prosecutor had been decoyed by the prisoner into a room for the purpose of extorting money from him. Upon a table covered with black silk were two candlesticks covered also with black; a pair of large horse pistols ready cocked; a tumbler glass filled with gunpowder; a saucer with leaden balls; two knives, on , of them a prodigiously large carving linife, their handles wrapped in black crape; pens and inkstand; several sheets of paper and two ropes. The prisoner, Mrs. Phipoe, seized the carving knife, and threatening to take away the prosecutor's life, the latter was compelled to sign a promissory note for $\$ 2,000$ upon a piece of stamped paper which had been provided by the prisoner. It was objected that there was no property in the prosecutor, and the point being reserved for the opinion of the judges, they held accordingly. They said that it was essential to larceny that the property stolen should be of some value; that the note in this case did not on the face of it import either a general or special property in the prosecutor, and that it was so far from being of any the least value to him, that he 
had not even the property of the paper on which it was written; for it alppeaied that both the paper and ink were the property of Mrs. Phipoe, and the delivery of it by her to him could not, under the circumstances of the case, be considered as vesting it in him; but if it had, as it was a property of which he was never, even for an instant, in the peaceable possession, it could not be considered as property taken from his person, and it was well settled that, to constitute the crime of robbery, the property must not only be valuable, but it must also be taken from the person and peacenble possession of the owner. R. v. Phipoe, 2 Leach No. 268, 2 East P. C. 599, Roscoe Crim. Ev. 884, C. 267.

(Eng. King's Bench, 1845.) A Void Check. 'IINDAL, C. J. There are two charges here-the one a charge of stealing a valuable security, the other a charge of stealing a piece of paper. You may get rid of the first by its being a bad check, but how can you get rid of the other? Rowe [for the prisoner]. It appeared to me that the effect of converting the paper into a check was to make it valuable, if at all, as a security for money, and that, the moment the paper had a check written upon it, it beeame a chose in action, which is jot the subject of larceny. ALDERSON, B. 'T'he nature of the paper is not so wholly absorbed in the chose in action as you put it. Rowe. If the paper is not wholly absorbed in the chose of action, I should submit that it was of so infinitesimal value as to fall within the rule de mininius non curat lex. I,ORD DENMAN, C. J. Your client got $1139 \mathrm{~s}$. 7 d. for it. Rowe. This check never could fultill any good purpose, for want of a stamp. I submit, therefore, that it was valueless, and not the subject of larceny. ${ }^{*} *{ }^{*}$ [The julges considered the conviction right, at least for stenling a piece of paper.] R. v. Perry, 1 Car. \& K. 725, 1 Den. C. C. 69, 1 Cox C. C. 222, F. 272 , Ke. $24 \bar{s}$.

\section{§ 138. "Personal."}

(Eng. Assizes, 1338.) Trees. A forester was indicted "that he feloniously ent down and earried away trees." The justices would not arraign him; for the felling of trees which are so annexed to the soil eannot be called a felony, even if a stranger hat done it. Besides, here perhaps he himself had the keeping of them. But because it was possible that the trees were first of all felled by the lord and then carried away by the forester, they questioned the inquest, who said that he was the forester when he felled and carried them away. SCHARSHULLE [J.], to the inquest: Did the forester conceal the trees from the lord? The Inquest: We do not know. ALDEBURGH [J.]. Certainly we do not think it important whether he concealed them or not; but we adjudge that it is no 
felony, because he was the keeper; and a tree is part of the freehold. Anon., Horwood's Year Book, 11 \& 12 Ed. III., 640, B. 488.

(Eng. C. C. R., 1470.) Boxes of Deeds. On indictment for felonious taking and carrying away of six boxes of charters and muniments of title concerning the inheritance of $\mathrm{C}$, the defense was that it was no felony, as it concerned the realty; and all of the justices of the several benches being assembled in the exchequer chamber, it was held that though damages might be had in detinue for the loss of the charters, and they were of greater value than many things, taking of which is felony, and so great an offense ought not to go unpunished; yet they pass to the heir with the inheritance, and are things real, and a franchise to have the chattels of a felon would not include the charters, and the felony caunot be on any goods but personal chattels. So it was advised by them all that this was no felony; wherefore, in the king's bench the defendant was discharged. R. v. Wody, Y. B. 10 Ed. 4,14 , pl. 9 \& 10, 13. 489.

(kingr. King's Bench, 1634.) Two Acts. "If a man comes to steal trees, or the lead off a church or house, and sever it, and after about an hour's time or so come and fetch it away, it is felony, because the act is not continuated, but interpolated, and in that interval the property lodgeth in the right owner as a chattel, and so it was agreed by the court of king's bench, 9 Car. 1, upon an indictment for stealing the lead off Westminster Abbey." 1 Hale's P. C. 510.

(Eng. King's Bench, 1739.) Court Records. Westbeer was indicted for lareeny of a parchment purporting to be a commission, ete. The court expressed a doubt on the evidence whether it was felony, and the jury found specially that the prisoner privately took a parehment writing, value one penny, from the records of the court of chancery, ete. The case was removed to the king's bench by certiorari. It was admitted by the counsel for the prisoner that the parchment writings were neither chattels real nor choses in action; but it was contended that as they related to the boundaries of manors and the right of water, they were charters which concerned the realty; for what can affeet the inheritance more than the right of water and the boundaries of a manor? It is true, perhaps, that the heir conld not maintain an action to recover them, because they are of that nature which are called nullius in bonis, and every man hats an equal right to resort to them. They are in the possession of the erown, as being public records, but it does not follow from thence that they are the property of the king. The court gave no opinion whether these were properly laid to be the goods of the king, nor whether the law as to this case was altered by 8 Hen. VI. c. 12; but they were unanimously of opinion that these parchment writings concerned the realty, and that therefore the prisoner was not gruilty of the felony charged in the indictment. $R$. v. Westbeer, 
1 Leach C. C. No. 6, 2 Strange (Ed. 2) 1133, 2 13. \& H. 45t, (. 242, Mi. 640.

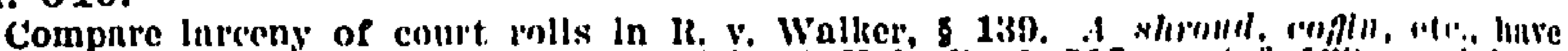

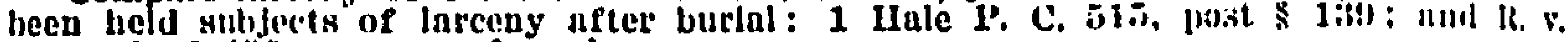
Fdwards, s 1is9, calleass of u plb.

(Eng. C. C. R., 1802.) Lead Images of Temple. Indictment 'or stealing 500 pounds of lead, fixed to an outlet to a dwelling-house of the Eill of Clarenden, contrary to 4 Geo. 2, c. 32, making it felony to remove, with intent to steal, any metal from any dwelling-house, cte. The lead taken was in the form of images fixed at the front of a building occasionally used as a tea drinking place by the callt. and separated from his dwelling by a public road and a distance of half a mile. The prisoners were convicted; but at a meeting of all the judges at Lord Ellenborough's chambers, May, 1802, the conviction was held wrong, this being no outlet or garden to any house within the meauing of the statute. R. v. Richards, Russell \& R. 28, C. 237.

(Ind. Sup. Ct., 1840.) House Keys. DEWEY, J. This was an action of slander. The words laid in the declaration to have been spoken by the defendant of the plaintiff, among others, are, "IIe broke into my room and stole the ikey." Plen, not guilty. Verdict and judgment for pluintift. 'There was evidence that the defendant said of the plaintiff," "He broke into a room of my house and stole the key out of the door." The defendant moved the court to instruct the jury. "That the key in the lock of the door of a house, and belonging thereto. is part of the realty, and not the subject of larceny, unless the same is first severed from the realty by one act and then stolen by another and distinct act." 'I'he court refused the charge. 'This refusal gives rise to a question not free from tech. nical difficulties. It was anciently decided in England that charters and other assurances of real estate, and the chest in which they were liept. savored so much of the realty that they could not be the subjects of theft. But it was held in a later case that a winoiow-sash not hung or beaded into the frame but fastened there by laths nailed across so as to prevent it from fallin ont. was the subject of larceny, R. v. Hedges, 1 Teach C. C. No. 100. It is not ensy, on principle, to reconcile these decisions. The latter case turned on the point that the temporary fastening of the window-sash did not make it a fixture. Certainly title papers and the trunk which contuins them are not fixtures. ** * It is true that che keys of a house follow the inheritance; and the writers who lay down this doctrine ma'se no distinetion bretween keys in the lock and those in the pockets of their owners. They are nevertheless not fixtures, but personal property. which from a rule of law founded on public convenience like title papers go with the land. And as no decision, so far as we know. has as yet ranked them among the articles upon which larceny cannnt he committed, and as we see no good reasnn 
for carrying the doctrine of exception farther than it has already gone, we feel at liberty, upon the authority of $R$. v. Hedges, supra, as well as on principle, to decide that as "personal goods" they are within the purview of our statute relative to crime and punishment, and are the subjects of theft. *** No error. Hoskins v. Tarrence, 5 Blackf. 417, 35 Am. Dec. 129, C. 240, Ke. 239, Mi. 642.

(C'al. Sup. Ct., 1861.) Gold Quartz. Defendant was convicted of lareeny of 52 pounds of gold-bearing quartz from ithe mining claim of the Bush Creek G. \& S. M. Co., and judgment was arrested on motion, on the ground that the indictment charged no felcny, because it did not indicate whether the rock had been severed from the ledge before it was taken. 'The state appealed. CROCKETT, J. * * * We find in the books much subtle reasoning in respect to the difference between trespass and larceny in this class of cases. From an early period in English jurisprudence it has been held that in consequence of the stable and permanent nature of real estate, an injury to it is not indictable at common law; and it is therefore not larceny to steal anything adhering to the soil. * * * At first it was held that at least one day must intervene, on the theory that the luw would not take notice of the fractions of a day. But this rule has been relaxed, and it is now held that no particular space of time is necessary, only the severance and taking must be so separated by time as not to constitute one transaction. The authorities maintaining these nice distinetions are fully collated in 2 Bishop on Criminal Law, $\$ \S 667,668,669$. We confess we do not comprehend the force of these distinctions nor appreciate the reasoning by which they are supported. We do not perceive why a person who takes apples from a tree with a felonious intent should only be a trespasser, whereas if he had taken them from the ground after they had fallen he would have been a thief; nor why the breaking from a ledge of a quantity of rich gold-bearing rock with felonious intent should only be a trespass if the rock be immediately carried off; but if left on the ground and taken off by the thief a few hours later it becomes lareeny. The more sensible rule, it appears to us, would have been that by the act of severance the thief had converted the property into a chattel; and if he then removed it with a felonious intent he would be guilty of a lareeny, whatever dispatch may have been employed in the removal. But we do not feel at liberty to depart from a rule so long and so firmly established by numerous decisions, and we have adverted to the question mainly for the purpose of directing the attention of the legislature to a subject which appears to demand a remedial statute. Judgrnent affirmed. P. v. Williams, 35 Cal. 671, C. $2 \dot{5} 3$.

(Eng. C. C. R., 1871.) Poachers Killed 126 Rabbits in the queen's forest, and concealed them in sacks and bundles in a ditch, where they were soon discovered by keepers for Mr. Fnllis, who had 
license from the queen's commissioners to take game there. The leeper's lay in wait, and three hours later defendant, and another, who escaped, came and began removing the rabbits, knowing that they had been so killed. On these facts being found by the jury a verdict of guilty was directed by the judge. BOVILL, C. J. 'The first question that arises is as to the nature of the property. Live rabbits are animals ferw natura, and are not the subject of absolute property; though at the same time they are a particular species of property ratione soli-or rather the owner of the soil has the right of taking and killing them, and as soon as he has exercised that right they become the absolute property of the owner of the soil. That point was decided in Blades v. Higgs, supra, as to rabbits, and in Lonsdale v. Rigg, 26 L. J. 196, Ex., as to grouse. In this calse the rabbits having been killed on land the property of the crown, and left dead on the sume ground, would therefore in the ordinary course of things have become the property of the crown. But before a person can be convicted of larceny of a thing not the subject of lar. ceny in its original state, as, e. g., of a thing attached to the soil, there must not only be a severance of the thing from the soil, but a felonious taking of it also after such severance. Such is the doc. trine as applied to stealing trees and fruit therefrom, lead from buildings, fixtures, and minerais. But if the act of taking is continuous with the act of severance, it is not larceny. The cilse of larceny of animals fere natura stands on the same principle. Where game is killed and falls on another's land, it becomes the property of the owner of the land; but the mere fact that it has fallen on the land of another does not render a person taking it up guilty of larceny, for there must be a severance between the act of killing and the act of taking the game away. In the present case we must take it that the prisoner was one of the poachers or connected with them. Under these circumstances we might come to the conclusion that it was a continuous act, and that the poachers netted, killed, packed up, and attempted to carry away the rabbits in one continuous act. and therefore that the prisoner ought not to have been convicted of larceny. [Martin, B., Bramwell, B., Byles, J., and Blackburn, J., gave concurring opinions.] Conviction quashed. R. v. Townley, 12 Cox C. C. 59, I. R. 1 C. C. R. 315,40 L. J. m. c. 144 , 24 I. T. 517,19 W. R. 725, B. 577 , C. 256 , Ke. 255,5 L. 458, Mi. 654.

(Ala. Sup. Ct., 1875.) Growing Corn. By the act of Feb. 20, 1875, stealing of. "any part of an ontstanding crop of corn or cotton" was made grand lareeny. BRICKELL, C. .J. * * * Under this amended statute, an indictment was preferred against the appellant, eharging that he "feloniously took and carried away fifteen ears of corn, a portion of an outstanding crop, the property of William Russell," etc. It is now urged, the indictment is insufficient to support a convictiou. because it does not aver the corn taken was not previously severed from the freehold-hecause there is no 
averment that it was the personal property of William Russellinecause it is not averred the corn was part of an outstanding crop. " * "Portion," as here employed, is the equivalent of the statutory word "part," and, equally with it, describes the act in which the offense consists. A distinct averment that the corn was not, at the time of the felonious taking, severed from the freehold, was not necessary. 'The statute makes it larceny to steal a thing not the subject of larceny at connmon law. The general rule is that in an indictment under such a statute the statutory term must be used, and is sufficient. 2 Bish. Cr. Proc. $\S 731$. The purpose of the statute was to convert the severance and asportation of a standing crop-i crop not severed from the freehold-into a criminal offense. Before the statute, under the common law, it was a mere trespass. The felonious taking and carrying away corn, or other produce of the soil, which the owner had severed from the freehold, was larceny at common law. *** Affirmed. Holly v. S., 54 Ala. 238, F. $273, \mathrm{Kn} .256$.

(Ir. C. C. R., 1889.) Grass Cut, Cured, and Removed. Defendant was convicted of larceny on proof that he cut 12 cwt. of hay on linoceupied land, left it three days on the land to cure and then drew it away. GIBSON, J. * * The continuity of transaction contemplated by the common law as excluding larceny may be considered from the point of view of time, act. and possession. The principal element being possession, if the thief is in continuous possession, the nccurrence of an interval of time between the taking and the carrying away can of itself make no difference. Townley's case, L. K. 1 C. C. R. 315 [ahove], only decides: (1) That where there is evidence of actual possession continuing, the fact that there is an interval of time between the taking and carrying away does not constitute larceny where the wrong-doer's intention is not ahandoned and the transaction is in substance continuous; (2) that chattels may be in the thief's possession. thongh left on the owner's land (the chattels there being rabbits which were not subject of property until killed). The expressions "abandon" and "intention to abandon." found in the report of Townley's case, L. R. 1 C. C. R. 315 [above], though not inappropriate when read with reference to the special facts of that case, are liable to misconstruction if emploved in reference to such a case as that before us. Where chattels after severance are left on the property of the true owner, no matter what the wrong-doer's intention may be, he sannot escape the common-law doctrine. if his possession is not in fact continuous. Continuity of intention is not the equivalent of continuity of possession. The transaction here was not continuous, and the eonvietion is right. [Andrews, Harrison. Holmes. Johnson. and $\sigma^{\prime}$ Brien. JJ., and Morris. C. J.. concurred. Palles. C. B.. dissented on the ground that whether time indicated abandonment was a question for the jurv.1 R. v. Foley, L. R. 26 Ir. 299, 17 Cox C. C. 142. B. 581. Ke. 241, Mi. $658 \mathrm{n}$ 
(Ala. Sup. Ct., 1892.) Fixtures. Defendant was convicted of larceny on proof that he took valves attached to pipes fixed in a chem. ical factory and other valves fixed to pipes attached to a pump and boiler standing on skids, drawn from place to place on the planta. tion as occasion required, and used to pump water from the river to water stock and for irrigation purposes. On appeal, the supreme court held that the valves attached to the pump were personal prep. erty, and subject to lareeny; but that the valves attached to tie factory were real fixtures, and therefore not subjects of larceny. New trial granted. Langston v. S., 96 Mla. 44, 11 So. 334.

(Pa. Sup. Ct., 1893.) Coal Gathered into Boat. Defendant was indicted for larceny of 1: tons of coal, gathered by him from the bed of Mahoney creek, within Bower's farm, where it had been car. ried and deposited by the water from the waste thrown on the banks of the stream at mines above. The trial court directed an acquittal, and the commonwealth appealed. WILLIAMS, J. * * * The judgment must be affirmed because it rests on a verdict of acquittal in a trial for felony. We do not, however, wish to be understood as assenting to the statement of the law applicable to the facts of this case, made by the learned judge to the jury. * * This material, having been abandoned by the original owners, belonged to him on whose land the water left it. * * the distinction in the mind of the lenrned judge was that between real and personal estate. The coal lying apon the surface he held to be real estate. The liftiris it up in the shovel was, on this theory, a severanec, which folcibly changed its character, and made it persomal. The loading into the flatboat, the transportation to the bins, and unloading of the boat, all of which acts were done within the lines of the prosecutor's land, and occupied hours of time lor each l:oat.load, were so connected with the severance as to make but a single act. For this reason he held that the defendant was guilty of a trespass only. * * * The real question presented is whether this case, upon its facts, is one for the application of the commonlaw rule. Have we here a severance and an asportation that con. stitute "one and the sime continuous act?" If the picking of the coal from the surface be treated as an act of severance. we have next the act of cleaning and sifting; then the deposit of the elcaned coal upon the flatboat, little by little; then the transportation of the boat-load to the bins; then the process of shoveling the coal from the boat into the bins. The acts, occupying considerable time for each boat-load, were all done within the inclosures of the prosccutor. * * He [defendant] makes no bona fide claim of title; no ofter to purchase; sets up no license; but rests on the proposition that, like the man who plucks an apple from a tree, and goes his way, he is liable only as a trespasser. If this be true. he could gather the coal from Bower's land as often as the stream made a sufficient deposit to justify the expenditure of time necessary to gather, clean, 
trausport, and put it in bins. Upon the same principle, he might gather all the crops growing on Bower's farm, as they matured, and, by hauling each load away when it was made up, defend against the charge of larceny on the ground that the gathering from the tree, the stalk, . " the hill, the loading into wagons, and the carrying of the loads away, though occupying hours for each load, and many days for the crop, was "one and the sume continuous act" of trespass. We cannot agree to such an extension of the common-law rule, but are of the opinion that this case should have gono to the jury, on the existence of the animo furandi. C. v. Steimling, $156 \mathrm{~Pa}$. St. 400, 27 Atl. 297, B. 588, Mi. 659.

\section{$\S 139$. "Property."}

(Eng. Chancellor's Question, 1528.) Peacock. 'The Chancellor put a question to all the judges: If a man felonionsly steals peacocks which are tame and domesticated, whether it is felony? Fitzherbert and Ingleficld [.J.J.] said it is not felony, because they are fere natura, like doves in a dove-cote, and if the young of doves are stolen it is no felony; * * * and a peacock is a bird more for pleasure than profit, for many intentionally kill all the young but one. Fitzjames [C. J.] and the other judges said that peacocks are commonly of the same nature as hens or capons, geese or ducks, and the owner has property in them, and they have animum revertendi, unlike fowls of warren, partridge, etc., taking of which, with felonious intent, is not felony; and at last, it was agreed by all the judges that this taking of peacocks was felony, for the cause aforesaid. Anon., Y. B. 19 Hen. 8, 2 pl. 11, B. 490, Ke. 250.

dec. C. v. Beumnn (1857), 8 Gray (Mass.) $49 \pi$.

(Mass. Sup. Judicial Ct. 1839.) Doves at Liberty. Defiendant was convicted of stealing 14 doves, on evidence tending to show that he shot them for food, animo furandi; that the owner reared doves, used them for food, and fed them regularly; and that they lived in houses kept by him, and would come when called; but where they were when shot was not shown. The court admitted that while they were resting on the grounds or buildings of the owner, such taking night be larceny; but that a new trial must be granted in this case, because they might have been shot while in flight a mile from home, or while mingled with the doves of other persons. PARKFR, C. J., said: "It is held in all the authorities, that doves are ferre naturx, and as such are not subjects of larceny, except when in the care and custody of the owner: as when in a dove-cote or pigeonhouse, or when in the nest before they are able to fly." C. v. Chace, 9 Piek. 15, 19 Am. Dec. 348, 1 H. \& B. 66.

(Eng. C. C. R., 1851.) Same. On indictment for stealing four 
tame pigeons, by taking them from their cote over the owner's stable it midnight, it was contended for the prisoner that, being at liberty to go in and out at any time, they were not reclaimed nor confined, and so not subjects of larceny. 'The chairman indicated to the jury that he arreed with prisoner's counsel. 'The jury found the prisoner enuilty; but judgment was postponed to take the opinjon of this eomit. I,ORD CAMPBELL, C. J., delivered the opinion of the eomet that the chairman was elearly wrong; that pigeons must from their nature have open air and free euress; that whether they were tame was a question for the jury; and that. if so, they are un(puestionably subjects of lareeny, though allowed libert... Conviction affirmed. R. v. Cheafor, 5 Cox C. C. 367,2 Den. C. C. 361, 8 Eng. I. \& Wq. 598, 'T. \& M. 621, 21 I. J. m. c. 43, 15 Jill. 106\%, 13. 492,1 13. \& H. 64.

(Ark. Sup. Ct., 188:3.) Song Bird. Ilaywood was indicted on three connts: 1, for stealing a reclaimed mocking-bird worth $\$ 25$ and its cage; 2, for receiving them knowing them to have been stolen; and 3 , for stealing the eage. Ilis demurrer was overruled, he pleaded not guilty, was convicted, senteneed, and denied a new trial. Ile excepts to the refusal of the court to charge that a mocking-bird is not a subject of lareeny, and that the bird gave its nature to the cage. ENGLISII, C. J. *** By the common law there can be no larceny of animals fere natura, or wild animals, unreclaimed. When reclaimed they become the subject of this ofiense, provided they are fit for food, not otherwise. But the linglish courts made exceptions to the rule that reclaimed animals, to be the subject of lareeny, must be fit for food. 'Thus the tamed hawk was held to be the subject of lareeny, though unfit for food, becmise it served to amuse the English gentlemen in their fowling sports. So reclaimed honey bees were made an exception, because, though not fit for food themselves, their honey is. Under decisions of Fug. lish and American courts, made upon the common law definition of larceny, Mr. Bishop classes the following animals, when reclaimed, as the subjects of the offense: Pigeons, doves, hares, conies, deer, siwans, wild boars, cranes, pheasants, partridges and fish suitable for food, including oysters. To which might be safely added wild turkeys, geese, ducks, etc., when reclaimed. Of those animals of which there can be no lareeny, though reclaimed, he put down the follow. ing: Dogs, cats, bears, foxes, apes, monkeys, polecats, ferrets, squirrels, parrots, singing hirds, martins and coons. In the south squirrels are in common use as food animals, and the hunters of all climates regard bears as good food. Iowa is credited with the decision (Warren v. S., 1 Greene 106) that coons are unfit for fond, and therefore, by the common law, not the subject of larceny, when reclaimed. Among the colored people of the south the coon, when fat, in the fall and winter, is regarded as a luxury, and the Iora decision would not be regarded by them as sound law or good tiste. 
- * The reclaimed mocking-bird in question was no doubt personal property. The owner could have brought trespass aguinst the thief who invaded her portico at night, and deprived her of the possession of her songster, which she prized above price; and she could have maintained replevin against the person to whom he sold it, had he refused to surrender it to her. 'The market value of the bird was, perhaps, more than ten times greater than that of the cage, which was the subject of petty larceny. 'To hold that lareeny might be committed of the cage, but not of the bird, wonld be neither good litw nor common serise. Affirmed. Haywood v. S., 41 Ark. 479, F. 270 , Kn. 252, Mi. 644.

(Ohio Sup. Ct., 1902.) Where Fish are Inclosed in a Pond-Net, from which they may be taken at any time at the pleasure of the owner of the net, the taking of them therefrom with felonious intent is lareeny. S. v. Shaw, 67 Oh io St. 157, 65 N. E. 875.

(Eny. C. C. R., 1818.) Ferrets. On trial for larceny in stealing five live tame ferrets confined in a hutch, it was shown that the prisoner took them and sold them for 9s., and he was found guilty; but on the point being made that they were of too base a nature to be subjects of larceny, the question was reserved; and all the judges were of opinion that judgment ought to be arrested for this reason, though the ferrets were confined, tame, and salable. R. v. Searing, Russel \& R. 350, B. 491, C. 248 , Ke. 244 , NLi. 639.

(New York Ct. of App., 1881.) Dog. EARL, J. The prisoner was convicted of stealing a dog of less value than $\$ 25$. His counsel contended at the trial and has argued before us that stealing a dog is not larceny, and whether it is or not is the sole question for our present determination. ** * At common law the crime of larceny could not be committed by feloniously taking and carrying away a dog. Wharton's Cr. Law (4th Fd.), \$ 1755; 4 Bl. Com. 235; 1 Hale P. C. $510 ; 3$ Coke Inst. 109 . And yet dogs were so far regarded as property that an action of trover could be brought for their conversion, and they would pass as assets to the executor or administrator of a deceased owner. Bacon's Abr., Trover, D.; 1 Wms. on Ex'rs (6th Am. Ed.) 775. The reason generally assigned, by common law writers for this rule as to stealing dogs is the baseness of their nature, and the fact that they were kept for the mere whim and pleasure of their owners. When we call to mind the small spaniel that saved the life of William of Orange, and thus probably changed the current of modern history (2 Motley's Dutch Republic 398), and the faithful St. Bernards, which after a storm has swept over the crests and sides of the Alps, start out in search of lost travelers, the claim that the nature of a dog is essentially base and that he should be left a prev to every vagabond who chooses to steal him, will not now receive ready assent. In nearly every 
household in the land can be found chattels kept for the mere whim and pleasure of the owner, a source of solace after serious labor, exercising a refining and elevating influence, and yet they are as much under the protection of the law as chattels purely useful and absolutely essential. 'This common law rule was extremely technical, and can scarcely be said to have had a sound basis to rest on. While it was not larceny to steal a dog, it was larceny to steal the skin of a dead dog, and to steal many animals of less account than dogs. * * One reason hinted at by Lord Coke for holding that it was not larceny to steal dogs was that it was not fit that "a person should die for them;" and yet those ancient lawgivers thought it not unit that a person should die for stealing a tame hawk or falcon. The artificial reasoning upon which these rules were based is wholly inapplicable to modern soaicty. 'lempora mutantur et leges mutan. tur in illis. Large amounts of money are now invested in dogs, and they are largely the subjects of trade and tratic. In many wiass they are put to useful service, and so far as pertains to their owner. ship as personal property, they possess all the attributes of other personal property. If the common law rule referred to ever pre. vailed in this state, we have no doubt it has been changed by legis. lation. ** It can scareely be supposed that the legislature meant to regrard dougs as property for the purpose of taxation and yet leave them without protection against thieves. *** Our attention has been called by counsel for the prisoner to certain deci. sions in other states which tend to sustain his contention. Findlay v. Bear, 8 S. \& R. (Pa.) 571 ; S. v. Lymus, 26 Ohio St. $400,20 \mathrm{Am}$. Rep. 772,5 I. 456 ; S. v. IIolder, 81 N. C. 527,31 Am. Rep. 517 ; Ward v. S., 48 Ala. 161, 17 Am. Rep. 31. But so far as those cases announce views in conflict with those above expressed, we are not disposed to follow them. *** Affirmed. Folger, C. J., dissenting. Mul. laly v. P., 86 N. Y. 365. B. 502 , C. 248.

Acc. Humby v. Samson, 105 I) wa 112.74 N. W. 918.67 Am. St. Rep. 285. 40 L. R. A. 506-E: Harrington v. Milles, il Kan. $480,15 \mathrm{Am}$. Rep. 355: C. v. Harelwood (1884).84 Ky. $681.2 \mathrm{~S}$. W. 180:

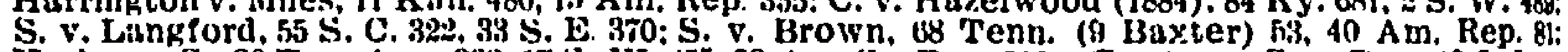
Hurley v. S., 30 Tex. A pp. $33 \%$, if S. W. 455,28 Am. St. Rep. 016 . Contra: S. v. Doe, 70 Ind. 0 , $41 \mathrm{Am}$. Rep. 590 . See ulso R. v. Robinson, 174.

(Eng. C. C. R., 182T.) Court Rolls. The prisoner was convicted of larceny of a roll of parchment from the Inner Temple, being records of the court of common pleas. of the value of 10s. In Hilary term, 1827, the judgres met and considered this case. and held, that is the records did not concern the realty, as was the case in $R$. $v$. Westbeer [\$138], stealing the parchment was larceny, and the conviction was therefore right. R. v. Walker, 1 Noody C. C. 15j, C. 246.

(Eng. C. C. R., 1851.) Unstamped Contract. Watts was indicted and convicted for stealing a piece of paper, an unstamped performed contract to build two cottages according to plans and specifications. LORD CAMPBELI, C. J. I am of opinion that this conviction is wrong. I think that the prisoner could not, under the circumstances 
stated, be indicted for stealing a piece of paper. If the agreement had been stamped, it seems to be allowed, notwithstanding the ingenious argument of Mr. Price, that an indictment for stealing a piece of paper could not be supported; because then it would be what is commonly called a chose in action, and by the common law larceny cinnot be committed of a chose in action. Strictly speaking, the instrument of course is not a chose in action, but evidence of it, and the reason of the common-law rule seems to be that stealing the evidence of the right does not interfere with the right itself; jus non in tabulis; the evidence may be taken but the right still remains. At all events, whatever be the reason of the rule, the common law is clear that for a chose in action larceny cannot be supported. *** As to this not being a chose in action, because all thit wis due had been paid upon it, it appears that the agreement is still executory, and might be used by either side to prove their rights. 'Then comes the ohjection as to its not being stamped; but though it is not stamped, I am of opinion that it is an agreement. There is a very cleal distinction between instruments which without a stamp are wholly roid, and those which may be rendered available at any moment by having a stamp impressed upon them. * * I agree that we must look at the state of the instrument at the time of the larceny committed ; but it then had a potentiality of being rendered available. and it was evidenee of an agreement; it was therefore evidence of a chose in action, and not the subject of larceny. [Coleridge. Cresswell. Crompton, Maule, and Wightman, JJ., and Alderson, Martin. and Platt. BB., concurred.]

PARKE. B. I am of opinion that the conviction is right. There is no doubt that at common law larceny cannot be committed of any instrument which is the evidence of a chose in action; but I think that when this instrument was stolen it was not evidence of a chose in action. Being unstamped, it was not available either in law or in equity, and by the operation of the stamp act could not be used for the purpose of showing a right. It was a piece of paper.

Reversed. R. v. Watts, 6 Cox C. C. 304, Dears. C. C. 326, 2 C. I. R. 604, 23 I., J. m. c. 56, 2 W. R. 2333,18 .Jur. 192. B. 493, Mi. 647.

(Eng. C. C. R., 1852.) Mortgage-Deeds. Defendant was convicted of burglary. JERVIS. C. J. 'The case assumes that the prisoner bioke and entered the honse, with intent to steal the mortgage-deeds, they being securities for money. It is therefore quite unnecessary to deal with the question whether mortgage-deeds, containing covenants to pay, are distinguishable from deeds savoring of the realty, because securities for money are not goods and chattels. Calye's case, 8 Rep. 33a: Chanell v. Robotham, Yelv. 68. The case of R. v. Vyse, 1 Moody C. C. 218, was different; the notes had been paid; they had become meie paper and stamps, the property of the prosecutor, and were thersfore his goods and chattels. In this case, the mortgage securities were not satisfied. We therefore 
think that the conviction was wrong. Conviction reversed. R. $\mathbf{v}$. Powell, 5 Cox C. C. 396,2 Den. C. C. 430,21 L. J. m. c. 78,16 Jur. 177, C. 244 .

(U. S. Sup. Ct., 1898.) Postage Stamps. Defendant was indicted and convicted of stealing postage stamps worth $\$ 163$ from the post. office at Hardinsburg, Ky., and brought error. PECKHAM, J. * The objection- that the postage stamps are not the subject of larceny while in the possession and being the property of the United States, we think is also untenable. The language used in the stat. ute is much broader, and covers more ground, than the common-law definition of larceny; and it is also more comprehensive than the statute of 1790. 1 Stat. 112, 116. "Any kind or description of per. sonal property," is an exceedingly broad designation. It is difficult to imagine language which would be plainer in its meaning, or which would more certainly embrace property such as is the sub. ject of this indictment. $* * *$ There is, while the stamps are in the possession of the government, some intrinsic value in the stamps themselves as representatives of a certain amount of cost of material and labor, both of which have entered into the article in the proc. ess of manufacture, entirely aside from any prospective value as stamps. * * Once out of the possession of the government they may be used for their full value to obtain carriage by mail of the article to which they are affixed. There is every reason, there. fore, why such stamps should be regarded as personal property, even while in the possession of the government. * * * Affirmed. Jolly v. U. S., 170 U. S. 402, 18 S. Ct. 624, 42 L. Ed. 1085.

(N. J. Sup. Ct., 1858.) Planted Oysters. GREEN, C. J. The indictment charges the defendant with stealing "eighteen bushels of oysters, of the value of eighteen dollars, of the goods and chattels of one George Hildreth." It is objected that oysters being animals feræe nature, there can be no property in them, unless they be dead or reclaimed, or tamed, or in the actual power or possession. of the claimant; and that the want of such averment is a fatal dit. fect in the indictment. 2 Bla. Com. 390, 392; Arch. C. P. 116:3 Chitty's Cr. L. 947; Wharton's C. L. $\$ \S 1754-55$. The principls; as applied to animals fera nature, is not questioned. But orsters, though usually included in that description of animals, do n'st come within the reason or operation of the rule. The owner has the same absolute property in them that he has in inanimate things or in domestic animals. Like domestic animals, they continue perpetually in his occupation, and will not stray from his house or person. IJn. like animals ferme naturx, they do not require to be reclaimed and made tame by art, industry, or education; nor to be confined, in order to be within the immediate power of the owner. If at liberty, they have neither the inclination nor the power to escape.

The jury were instructed that if the same oysters which were 
planted by Hildreth were unlawfully taken by the defendant, with the intent to steal them; if the oysters so planted could be easily distinguished from other oysters that grew in the sound; if they were planted in a place where oysters did not naturally grow; if the place where they were planted was marked and identified, so that the defendant and others soing into the sound for clams and oyster's naturally growing there could readily know that these oysters were planted and hiolu as private property, and were not natural oysters, or in or upon a natural oyster bed, then the oysters were the subject of larceny, and the defendant might be convicted. But if the jury believed that the oysters were planted in or upon a natural bed, they should be considered as abandoned to the public, and not the property of Hildreth; or, if the jury believed that the planted oyster's were not marked and identified, as before stated, the defendant shoul! be acquitted. *** The ovsters in question had once been the property of Hildreth. 'The only question is, whether the planting of these oysters in a public sound, where all the inhabitants have a common right of fishery, was necessarily an abandonment, ur a return of the property to the common stock. There was clearly no intention on the part of the owner to abandon his property. * * The authorities clearly sustain the instruction given ts the jury. ** * Affirmed. S. v. Tayjor, 3 Dutch. (27 N. J. J.) 117, 72 Am. Dec. 347 , B. 498.

(Mrass. Sup. Judicial Ct., 1862.) Gas-Possession. On indictment for lareeny of illuminating gas, the court instructed the jury that if they were satisfied defendant took the gas with felonious intent sle was guilty. After the gas had been shut off, and the meter removed for: nompayment of her bill, defendant made a secret conrection through a lead pipe and turned the cock in the service pipe. BIGELSW W, C. J. We cannot doubt that the instructions given to the ju:y in this case were right. There is nothing in the nature of gas used for illuminating purposes which renders it incapable of heing feloniously taken and carried away. It is a valuable article of inerchandise, bought and sold like other personal property, susceptible of being severed from a mass or larger quantity, and of being transported from place to place. In the present case it appears that it was the property of the Boston Gas Light Co.; that it was in their possession by being confined in conduits and tubes, which belonged to them, and that the defendant severed a portion of that which was in a pipe of the company by taking it into her house and there consuming it. All this, being proved to have been done by her secretly, and with an intent to deprive the company of their property, and to appropriate it to her own use, clearly constituted the crime of larceny. It was suggested by the counsel for the defendant that if she was guilty of any offense, it was not larceny, but embezzlement, inasmuch as it appeared that the gas was intrusted to her possession by the company, and that at the time of the alleged felonious taking 
she was the bailee thereof. But the facts proved entirely negative the existence of any such relation between her and the company. The gas was not in her possession. On the contrary, the pipe had been severed from the meter by closing a stopcock in the service pipe, which belonged to the company, for the very purpose of pre. venting her obtaining possession of it. The fact that the end of the pipe was on the premises occupied by her is wholly immaterial. * Exceptions overruled. C. v. Shaw, 4 Allen 308, 81 Am. Dec. 706, B. 501 .

Acc. S. v. Wellman, 34 Minn. 221, 25 N. W. 395; R. v. White, \$128.

Stealing a Shroud. "A digged up a dead body out of the grave, and stole the shroud, and buried him again; this is reported by Mr. Dalton, c. 103, p. 266 , to be no felony, but a misdemeanor, for which the party was whipped. And accordingly I have seen it reported to be held 16 Jac. in Nottingham's Case, quia nullius in bonis; but see Coke P. C. p. 110, in Haine's Case, ruled by the advice of all the judges to be felony, and in the indietment the goods shall be sup. posed the goods of the executor, administrator or ordinary. But it is held that if $A$ put a winding sheet upon the dead body of $B$; and after his burial the thief digs up the carcass and steals the sheet, he may be indicted for felony de bonis \& catallis $A$, because it trans. ferred no property to a dead man. 12 Coke 113." 1 Hale P. C. 515.

So of a cofin containing the corpse, S. v. Doepke. 68 Mo. 208, 30 Am. Rep. 785, i L. 474.

(Eng. C. C. R., 187T.). Buried Pigs. On indictment for larceny of three dead pigs, it was shown that the pigs were bitten by a mad dog, whereon the owner directed his steward to shoot them; and the steward, having done so, ordered defendants to bury them; which they did, but that night dug them up and sent them to London meat market, where they were sold for $\mathfrak{t} 93 \mathrm{~s}$. 9d., which was paid to the prisoners. Counsel for the prisoner's submitted that there was no evidence for the jury; because: 1 , property was not proved as laid, the owner having abandoned it; 2 , that the buried pigs were of no value; and, 3, that they had been attached to the soil, so as not to be the subjects of larceny. The chairman thought the case was one for the jury, and directed them that in his opinion the points were not well taken, but to acquit if they thought there was an abandonment. The jury found the prisoners guilty, and the judges affirmed the conviction. R. v. Edwards, 13 Cox C. C. 384, 36 L. T. 30 , B. 612 , C. 239 , Ke. 247 , Mi. 652.

\section{\$140. "Glaim of Right."}

(Mich. Sup. Ct., 1888.) Title in Doubt. On a trial for larceny of a sewing machine it apneared that defendant once owned it, and claimed it as exempt property; that a judgment creditor seized and sold it on execution; and afterwards, having obtained it from the 
purchaser at the sale, placed it with a person desiring to purchase, on trial, when defendant peaceably took it away under advice of his aitorney, telling the person under what right he claimed it, and giving a receipt for it, stating his name and residence. Conviction on this evidence was reversed, and the case dismissed. P. v. Schultz, 71 Mich. ?15, 38 N. W. 868.

Ace. Blair v. S. (Ark.), 71 S. W. 482; P. v. Eustman, 77 Cal. 171, 19 Pac. 206; S. v. Main, 75 Conn. 55, 52 Atl. 257 ; Causey v. $\$$. 79 Ga. 504, 5 S. W. 121, 11 Aw. St. Rep. 447; Dean v. S., 41 Fla, 291, 23 So. 638: P. v. Slayton, 123 Mich. 397, 82 N. W. 205, 81 Am. St. Rep. 2i1; Buchanan v. S. (Miss.), 5 So. 817 ; MeGowan v. S., 27 '1'ex. App. 183, 11 S. W. 112.

(Ind. Sup. Ct., 1901.) To Compel Performance of Contract. Prosecutors had agreed to install 1000 feet of pipe in defendant's greenhouse for $\$ 450$, to be secured by indorsed notes before the work commenced. He drew the pipe to the place, and they came for the notes before beginning work. He refused, suggesting that they retain title till payment. They proposed to take back the pipe. He hid it. 'They found a little, obtained a search-warrant and fourd some more, but not all. He proposed to take $\$ 50$ to settle and return the pipe, and made other propositions which were not accepted. $\mathrm{He}$ was indicted for stealing the pipe, and convicted. DOWLING, J. * * The claim is made on behalf of the appellant that he took the property honestly, under a claim of a right to its possession. It is impossible to adopt this view. Neither the title to the pipe nor the right of possession was vested in the appellant. True, the pipe was deposited on his land, but it was there as the property of Maloney \& Collins. It was there just as a box of their tools might have been. * * According to the appellant's own confession, he intended to compel the owner's of the property to settle with him on his own terms, to pay a claim they did not owe, or to perform work they were under no obligation to perform, or lose their property. 'The case readily falls within the well recognized rules relating to the crime of larceny: "'The mere delivery of property to another for a special purpose, vests in the person receiving it only the temporary charge or custody ; the possession of the property remains in the owner, and a conversion of it is larecny." * * $72 \mathrm{Am}$. \& Eng. Enc. L. 768. * * Affirmed. Currier v. S., 157 Ind. 114, 60 N. E. 1023.

Compare c. v. Stebbins, $\$$ i4. taking mones as payment.

(Mich. Sup. Ct., 1902.) Same. $\Lambda$ felonious intent, necessary to constitute larceny, is not shown where there was a dispute between defendant and one to whom an oryan had been sold as to the amount due on it, and defendant, hecause of the refusal to pay what he claimed. took the organ, telling the purchaser's wife where he was taking it, and that the purchaser could come there and settle. P. v. Walburn, 132 Mich. 24, 92 N. W. 494. 
"With Intent."

\section{General Rule.}

(Engr. Old Bailey, 1729.) Borrowed Horse Taken Aside and Sold. Tumnard was tried before Lord Raymond, C. J. (present Hale, B., and Denton, J.) for stealing a mare the property of Sinith. It appeared that prosecutor lived in Ely Isle; that he lent the prisoner the mare to ride to a place three miles distant; but the prisoner rode her to London and sold her. IJORD RAYMOND, C. J., left with the jury quo animo he rode the mare to London, and they foumd him guilty. Per CUR. The finding of the jury will make this case felony, because he rode the mare further than he agreed to do for if there had been no special arreement the privity would have remained, and it could not have been felony. Tunnard's Case, Leach (th Eil.) $21+n, .2$ liest P. C. 68T. B. 640.

(Win. C. C. R., 1821.) On Indictment for Horse-stealing. It ap. peared that the prisoner borrowed the horse to take a child to a surgeon (whether he took the ehild did not appear), and the following day went with the horse in another direction. was askind to sell it. and dici so; and the jury found he had no felonious intent till asked to sell. The question being reserved for the opinion of the judges, they held that if the prisoner had no felonious intent when he took the horse, his subseguent withhoiding and disposing of it did not constitute a new felonions taking, nor make him guilty of felony ; conseduentiy the conviction sould not be supported. R. $v$. Banks, Russell \& R. 441, B. 632. C. 364 .

Ace. A urums v. S., 121 Ga, 170. 48 S. E. $965 ;$ Hul v. S., 57 Wis. $37 \pi .15$ N. W. 445, 5 I. 450.

(Me. Sup. Julicial Ct.. 1868.) Horse Hired to Go to One Place and Taken to Another. DICKERSON, J. Exceptions. The prisoner was indicted for the larceny of a horse, sleigh, and bufialo robes. The jury were instructed that. if the prisoner obtained possession of the team by falsely and framdulently pretending that he wanted it to drive to a certain place. and to be gone a specified time, when in finct he did not intend to go to such place, but to a more distant one, and to be alssent a longer time, without intending at the time to steal the property, the team was not lawfully in his possession, and that a subsequent conversion of it to his own use. with a felonious intent while thus using it, would be lareeny. It is well settled that where one comes lawfully into possession of the goods of another, with his consent. a subsequent felonious con. version of them to his own use, without the owner's consint. does not constitute larceny, because the felonious intent is wanting at the time of the taking. But how is it when the taking is frandulent or tortious, and the property is subsequently converted to the use of the taker with a folonious intent? * * When propurty is 
thus obtained, the taking or trespass is continuous. The wrong-doer holds it all the while without right, and against the right and without the consent of the owner. If at this point no otler element is added. there is no larceny. But if to such taking there be subsequently superadded a felonious intent, that is, an intent to deprive the owner of his property permanently without color of right, or excuse, and to make it the property of the taker without the owner's consent, the crime of larceny is complete. **** Hxceptions overruled. S. v. Coombs, 55 Me. 477, 92 Am. Dec. 610, B. 593.

On this doctrine of continuing trespass compare $\$ 88$, on locality nf crime, goods brought into state.

(Ilaho Sup. Ct., 1902.) Taking Wrongfully and Subsequently Intending to Convert. On trial for larceny, it is error to instruct that if clefendant wrongfully, and withont the knowledge of the owner or any person, but as a trespasser, took or drove away the property described, not intending to steal it, and that while still in such wrongful possession, he feloniously appropriated the same to his use, such taking constituted larceny. S. v. Riggs, 8 Idaho 630, 70 P. 947.

Acc. cited in above: P. v. Morino, 85 Cal. 515, 24 Pac. 892; Beckham v. S 100 Ala, 15, 14 So. 859. bog found at high water in swamp; S. v. Rechnitz, 20 Mont. 488 , 52 Pac. 264.

(Engr. (. C. R., 1800.) Goods Taken from Burning House to Save. Fliz. lueigh was indicted for stealing various articles, property of A. Dyer. It appeared that Dyer's house and shop were on fire, and defendant with other neighbors assisted in removing the goods to a place of safety; that she removed muslin in his presenee. though not at his desire; that he asked her for it the next morning, and she denied having it, and that by search-warrant the property was found artfully concealed in her house in various ways. It was claimed that her first purpose was honest, since she took the property in Dyer's presence; but the court instrueted the jury that such purpose did not follow from that fact, and that if she took them with honest purpose, her subsequent denial and hiding would support the indictment. The jury found her guilty, but said that when she took them she had no evil design. On reference to the judges, all (absent, Lawrence, J.) held the conviction wrong; for if the original taking were not with intent to steal, the subsequent conversion was no felony, but a breach of trust. Leigh's Case, 2 East P. C. 694, 1 Iseach (Ed. 4) 411n, B. 632, Mi. 731.

That the intent must exist nt the time of the act is the prule. see $s 36$. Hut seo R. v. Woodward, \$154, ratification of wlfe's act in rocelving stolen goods.

(Eng. C. C. R., 1849.) A Traveling Watch Tinker was Indicted for stealing a watch delivered to him by the owner to regulate, and for stealing another watch given him to repair. A verdict of guilty was held not supported by the evidence, as there was no proof of animus furandi at the time of delivery, though defendant left town, taking the watches with him a few davs later. Conviction reversed. 
Before Pollock, C. B. Patteson, J., Wightman, J., Platt, B., Talfourd, J. R. v. Thristle, 3 Cox C. C. 573,3 N. Ses. Cas. 702, 2 Car. $\&$ K. 842, T. \& H. 204,1 Hen. C. C. 502,19 L. J. m. c. 66,13 Jur. 1035, B. 633, C. 291.

(Fing. C. C. R., 1853.) Accidentally Taken. In indictment for stcaling a whitefaced lamb, it appeared that defendant was driving 29 lambs to market, and was allowed to put them into a pasture with other sheep for the night, and in the morning when he drove them away took the lamb in question with him. The jury found him guilty on instruetion that if he discovered the lamb in the flock at any time before he sold it it was larceny to sell this with the other lambs. The jury found that he first discovered the lamb in the flock when it was pointed out to him when he was selling his flock. PARKE, B. The original taking was not lawful, but a trespass, upon which an action in that form might have been founded; but it was not felony, because there was no intention to appropriate. 'There was, however, a continuing trespass up to the time of appropriation, and at that time, therefore, the felony was committed. Where groods are carried from one county to another they may be laid as taken in the second county, and the difference between this and Leigh's case, as well as the others eited, is that the original taking was no trespass. It was by the implied license of the owner, and the same thing as if he had been intrusted by the prosecutor with the possession of the goods. Pollock, C. B., WilJiams, Talfotird, and Crompton, J.J., concurred. Conviction affirmed. R. v. Riley, Dears. C. C. 149.6 Cox. C. C. 88,22 I. J. m. c. 48,17 Jur. 189, B. 591. C. 279. Ke. 289 .

(Minn. Sup. Ct.. 1888.) Proof of Intent. Where dofendint, to whom rugs are intrusted to sell for cash, or on installments, or to return them within seven dars, is to have a commission on the sales, but sells two rugs, and uses the money to leave the state, having sent the balance of thr groods to the place to which he went. to a fictitious address, the jury are warranted in convicting him of larceny. S. v. Fisher, 38 Minn. 378, 37 N. W. 948.

\section{f 142. Cases of lkallees IBrenking IBulk, etc.}

(Eng. Star Chamber and Exchequer Chamber, 1473.) Carrier Breaking Bulk. Where one has bargained with another to carry certain bales with, etc., and other things to Southampton, he took them and carried them to another place and broke up the bales and took the goods contained therein feloniously, and converted them to his proper use and disposed of them suspiciously; if that may be called felony or not, that was the case. BRIAN, C. J. I think not, for where he has the possession from the party by a bailing and delivery lawfully, it cannot after be called felony nor 
trespass, for no felony can be but with violence and vi et armis, and what he himself has he cannot take with vi et armis nor against the peace; therefore it cannot be felony nor trespass, for he may not have any other action of these goods but action of detinue. HUSSEY, the king's attoriey. Felony is to claim feloniously the property without cause to the intent to defraud him in whom the property is, animo furandi, and here notwithstanding the bailment ut supra the property remained in him who bailed them, then this property can be feloniously elaimed by him to whom they were bailed as well as by a stranger; therefore it may be feiony well enough. THE CHANCELLOR. Felony is according to the intent, and his intent may be felonious as well here as if he had not the possession. MOLINEUX ad idem. A matter lawfully done may be called felony or trespass, according to the intent; sc. if he who did the act do not pursue the cause for which he took the goods, as if a man distrain for damage feasant or rent in arrear and then he sell the goods and kill the beasts, this is tort now where at the beginning it was good. So if a man come into a tavern to drink it is lawful; but if he carry away the piece or do other trespass, then all is bad. So although the taking was lawful in the carrier ut supra, etc., yet when he took the goods to another place ut supra he did not pursue his cause, and so by his act after it may be called felony or trespass, according to the intent. BRIAN, C. J. Where a man does an act ont of his own head, it may be a lawful act in one case and in another not, according to his act afterwards-as in the cases which you have put-for there his intent shall be judged according to his act; but where I have goods by your bailment; this taking camnot be made bad after by anything. VAVISOUR. Sir, our case is better than a bailment, for here the things were not delivered to him, but a bargain that he should earry the goods to Southampton ut supra, and then if he took them to carry them thither he took them warrantably; and the case put now upon the matter shows, that is. his demeanor after shows, that he took them as felon and to another intent than to carry them, ut supra, in which case he took them without warrant or eause, for that he did not pursue the cause, and so it is felony. CHOKE, I. I think that where a man has goods in his possession by reason of a bailment he cannot take them feloniously, being in possession; but still it scems here that it is felony, for here the things which were within the bales were not bailed to him, only the bales as an entire thing were bailed ut supra to carry, in which case if he had given the bales or sold them, etc., it is not felony ; but when he broke them and took out of them what was within he did that without warrant, as if one bailed a tun of wine to carry; if the bailee sell the tun it is not felony r.nor trespass; but if he took some out it is felony; and here the twenty pounds were not bailed to him, and peradventure he knew not of them at the time of the bailment. So is it if I bail the key of my chamber to one to guard my chamber, and he take my 
goods within this chamber, it is felony; for they were not bailed to him.

It was then moved that the case ought to be determined at com. mon law; but the chancellor seems to have thought otherwise, for the complainant was a merchant stranger, whose case ought to be judged by the law of nature in chancery and without the delay of trial by jury. *** The matter was afterwards argued before the judges in the exchequer chamber. And there it was holden by all but NEDHAM, J., that where goods are bailed to a man he cannot take them feloniously; but Nedham held the contrary, for he might take them feloniously as well as another; and he said it had been held that a man can take his own goods feloniously, as if I bail goods to a man to keep and I come privily, intending to recover damages against him in detinue, and I take the goods privily, it is felony. And it was holden that where a man has possession and that determines, he can then be felon of the things, as if I bail goods to one to carry to my house and he bring them to my house and then take them thereout, it is felony, for his possession is determined when they were in my house; but if a taverner serve a man with a piece, and he take it away, it is felony, for he had not pos. session of this piece, for it was put on the table but to serve him to drink. And so is it of my butler or cook in my house; they are but ministers to serve me, and if they carry it away it is felony; for they had not possession, but the possession was all the while in me; but otherwise peradventure if it were bailed to the servants so that they are in possession of it. LAICON. J. I think there is a diversity between bailment of goods and a bargain to take and carry, for by the bailment he has delivery of possession; but by the bargain he has no possession till he take them, and this taking is lawful if he takes them to carry, but if he take them to another intent than to carry them, so that he do not pursue his cause, I think that shall be called felony well enough. BRIAN, C. J. I think that it is all one, a bargain to carry them and a bailment; for in both eases he has authority of the same person in whom the property was, so that it cannot be called felony. M. 2 E. IIT. in an indictment "felonice abduxit unum equum" is bad, but it should be cepit; so in eyre at Nott.. $8 \mathrm{E}$. III.; and in this case the taking can. not be feloniously, for that he had the lawful possession: so then the breaking the bales is not felony, vide $4 \mathrm{E}$. II. in trespass. for that plaintiff had bought a tun of wine of defendant, and while it was in defendant's guard defendant came with force and arms and broke the tun and carried away parcel of the wine and filled up the tun with water. And for that it apneared he had possession hefore. the writ, being vi et armis, was challenged; and yet it was held well; and he pleaded not guilty, and then the justices renorted to the chancellor in souncil that the opinion of the most of them was that it was felony. *** [This is generally known as the Carrier's Case; may be found in blackletter in Y. B., Easter, 13 Fdw. 
4, f. 9, pl. 5; and this translation is from Pollock \& Wright, Possession 134; also given in B. 638, C. 297, Ke. 223, Mi. 734.]

"This has always appeured an extraordinary decision, as, to all common upprehension. thef t of the whole thing bulled must determine the builment quite as much as at thet of purt of it. I think it obvious from the report that the decision was a compromise intended to propitiale the chaucellor and perhaps the king. This required u deviation from the common p. which wis accordingly minde, but was as slight as the judpes could make it They would have liked to hold thut where the original cuking was luw ful, no subsequent deuling with the property could be felontous. 'I'he chuncellor, who seems to bive had regard rathtr to the position of the owner of the goods than to the criminality of the carifer. seens to have wished to make the mutter turn upon the morul charueter of the act of misuppropriation. The juages resorted to the expedient of treasing the breaking bulk as a new taking. They thus preserved the common-law detunition of theft but qualitled it by un obscure distinction resting on nu definite principle." 3 Stephen's Hist. Cirim. Law of Eng. 139.

This and the other cases under this section are reviewed by llolme:, $J$., in $C$. $v$. Ryan, \$ 130.

(Eng. King's Bench, 1633.) If a Man Says to a Miller, who keeps a mill, thou hast stolen three pecks of meal, an action lies; for, although, the corn was delivered to him to grind, yet, if he steal the meal it is felony, being taken from the rest. Conviction affirmed. Langley v. Bradshaw, 1 Roll. Abr. 73, pl. 16, Mi. 737.

(Eng. C. C. R., 1805.) Captain Stealing from Cargo. On indictment under 24 Geo. 2, c. 45 , for stealing at W. Cowes 6 casks and 1,000 pounds of butter, value \pm 20 , from a sloop at that port of entry, contrary to the statute, and on a second count for grand larceny; it appeared that the butter was part of a cargo of 280 firkins shipped on board the sloop of which defendant was captain, billed from Waterford in Ireland to Shoreham and elsewhere in lingland; that defendant met foul weather, was beaten from his path, and touched at Cowes in course for new sails; that the butter was delivered by the mate to the sail-maker's men at night on the captain's written order, being taken hap-hazard from the firkins standing on the halfdecks; and that the captain explained the shortage to the consignees, by saying he had been compelled by foul weather to throw it overboard. On the argument it was contended: 1. That no larceny had been committed; 2. That the case was not within the statute, because the ship was his own. As to the first the judge thought that taking the firkins from the half-decks where they were originally stowed was breaking bulk; and as the prisoner went into Cowes without necessity, the case was compared to those wherein it had been held that it was felony in a carrier to take goods aside from their course and embezzle them. As to the second objection he thought the vessel belonged to the freighter for the voyage, and the offense was aggravated by the owner being in charge and stealing the goods in his care. The whole case was left to the jury, who found the prisoner guilty. On case reserved, the judges were of opinion that it was not larceny ; and, if it were, it was not a capital offense within the statute, 24 G. 2, c. 45 . R. v. Madox, Russell \& R. 92, B. 641, C. 301, Mi. 738 .

(Mass. Sup. Judicial Ct., 1823.) Miller Adulterating Grist. On indictment for larceny of three tons of barilla, defendant was con- 
victed on proof that prosecutor's servant sook barilla to the mill of defendant to grind, brought back a mixture of three parts barilla and one part plaster of I'ar's, a cheaper substance; that defendant demanded and received the pay for the grinding; and by other circumstances. The court instructed the jury that if the defendant took firom the parcel of barilla any quantity with intent to convert it to his own use, introducing an inferior article to conceal the fraud, he was guilty of larceny. PU'TNAM, J. * * The jury have found that the defendant took the goods with an intent in steal them; and the verdict is well warranted, if at the time the defendant took them, they were not lawfully in his possession with the consent of the owner, according to a subsisting special contract, in consequence of an original delivery obtained without fiand. If that was the case, the inference which the counsel for the defendant drew would follow, that such a taking would not be felouy but a mere breach of trust, for which a civil attion would lic, but concerning which the public have no right to inquire by indictment. 'l'he counsel for the defendant have referred us to 13 lid. IV., fol. 9, as the anthority upon this point. * * It is referred to as the foundation upon which miny subsequent decisions rest. It will be perceived that here may be found the distinctions which are recognized in the text broks upon this subject. Thus, if the party obtain the delivery of the goods originally without an intent to steal, a subsequent conversion of them to his own use while the eintract subsisted would not be felony; but if the original intent was to steal, and the means used to obtain the delivery wore meioly eolorable, at taking under such cireumstanees would be felony. So if the goods were delivered origrinally upon a special eontract. which is determined by the fraudulent act of him to whom they were de! ivered. or by the completion of the contract, a taking animo furandi atterwards should be adjudged to be felony. * * In the ense at bar, the goods came lawfilly into the hands of the defendant by the delivery of the owner. If he is to be convicted, it must be: onl the ground that he took the groods as a felon after the special eontract was determined. * * Inawkins observes (bk. i. c. 333. \$4) that such possession of a part distinct from the whole was gatined by wrong and not delivered by the owner; and also, that it was obtained basely, fratudulently. and elandestinely. This remark is peculiarly applieable to the ease at bar; for there is no avidence that the owner intended to divest himself of his property he the delivering of it to the defendant. The defendant did not juirsue the purpose for which it was delivered to him. but separated a part from the rest, for his own use. without pretense of title; and by that act the contract was determined. From thenceforward the legal possession was in the owner, and a taking of the part so fraudulently separated from the rest, animo furandi. must he considered as larceny. Exceptions overruled. C. v. James, 1 Pick. 375, B. 645,2 B. \& H. $139-$ n, C. 304 . 
(N. Y. Ct. of App., 1858.) Pig Iron was Sent by Canal-Boat from Aibany to Buffalo. On the way the captain of the boat stopped at W. at night and unlouded 100 bars worth $\$ 175$. Ile delivered the balance at Buffalo. Ile was indieted for larceny, tried, and acquitted on the ground that his oftense was emberzlement. He was inmediately indieted for emberalement, tried and convicted. On error to the court of appeals the judgment was leversed, on the ground that the oftense was lareeny, unloading part, of the cargo being considered breaking bulk. "It is insisted on the part of the people, that the bailec can commit lanceny only where he actually breaks a bale or package; that it is this breaking alome which can determine the privity of contract and render the asportation by carrier a trespass. But this, I think, is too narrow il constrinction of the rule, and one not sustained by the commentalors and adjudications. Any separation of a part firem the whole would stem to be as much a trespass as the breaking of. a parekatge. $* *$ t'his seemed to be conceded upon the argrment in regard to grains and things of that kind." Per Pratt, o. Concurringr : Seldon, Roosevelt, Harris, and Strong, JJ. Denio and Comstock, J.J., dissented. Nichols v. P., 17 N. Y. 114, Mi. $7+2$ n.

(Eng. C. C. R., 18t9.) One Who Had Made an Assignment for Benefit of Creditors, was allowed to remain in possession of his factory the same as before the assignment, to finish work on hand, the wages being paid by the trustees; and he removed various machines from the factory nightly, and concealed them in the house of an employee; then the assignees took possession and sold the finctory, and the debtor became manager for the purchaser, and little by little returned the machinery to the mill. On indictment for lareeny the jury found that he removed the machinery fraudulently, after the assignment, and was not then in eustody as agent under the deed. $A$ verdict of gruilty was directed on these findings. T,ORD CANIPBELJ, C. o. It is found that he had mot the eare and custody of the goods as their agent; and that elenrly nogatives a bailment; and that is the only ground upon which this ealse conld be put. 'The prisoner, therefore, was in lawful possession of the groods and cannot be convicted of lareeny. Convietion quasilued. R. v. Pratt, 6 Cox

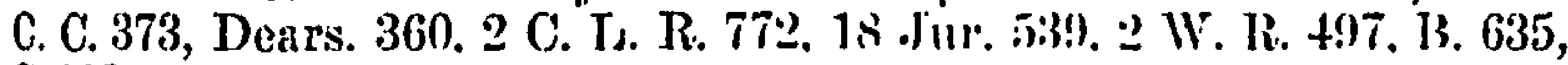
C. 293.

(Eng. C. C. R., 1851.) Clothes Peddler. On indistment for Jarceny it appeared that the prisoner was employed to sell elothes about the country, receive 3s. to the pound for his services. and return any clothes not sold; and that on Fehruary 12 he took away is parcel of clothes to sell, and later framilulently pawned a part of them and converted the rest to his own use; on which the trial judge directed the jury that the original bailment was determined by unlawfully pawning a part of them, and the subsequent appro- 
priation of the residue was lareeny. Was this direction right? U'Bricn, for the prisoner: 'I he contract with the prisoner was distinct and separate with regard to each article entrusted to him. 'The fact of his receiving all the articles at one time was a mere accident, which makes no legal difference in the case; each article had a separate price aflixed to it. After he had pawned some of the articles, when was the original bailment of the others determined? LORD CAMPBELL. The case states, that on the 12th of February, he took away a parcel of clothes; we must, therefore, reurard the delivery of that parcel as one bailment of all the articles contained in the parcel. O'Brien. 'The prisoner had authority to break the bulk; the contract imposed on him the necessity of opening it in order to take out ench article and deal with it separately. COLE. RIDGE, J. Why may not there be a single contract embracing several particulars, as for instance, where a carrier is entrusted with various articles to leave at different places, all of which articles are placed in one bag; if he wrongfully deals with any one. is it not a breaking bulk of the whole? o'Brien. The doctrine of break. ing bulk turns on there being no authority to open the parcel and deal with any of the articles separately from the rest. AlADER. SON, B. If you can make out this to be like the case of a carrier entrusted with several parcels under several distinct contracts, then certainly it is no lareeny. LORD CAMIPBELL, C. J. I think the convietion was right. The ease must be considered as thongh it was a single bailment. If there had been several bailments, then the wrongful dealing with one of the articles so bailed would not affect the case as to any other article. But it makes no difference that in one parcel there were several articles. The law has resorted to some astuteness to get rid of the difficulties that might arise in the case of a wrongful dealing with one or more of several articles, all of which, when entrusted, had been contained in one bulk. Alderson, B., and Platt. B., concurred. COLERIDGE, J. The fact of different prices being affixed to each article makes no difference in the case. R. v. Poyser, 2 Den. C. C. 233, T. \& MI. 559, 20 L. J. m. c. 191, 15 Jur. 386. 5 Cox C. C. 241, B. 643 , C. 308.

\section{$\S 143$. "To Deprive the Owner of His Property."}

(Fng. C. C. R., 1816.) Taking to Feed to Prosecutor's Horses, On indictment for stealing two bushels of beans from defendant's employer, the jury found that they were taken from the prosecutor's granary, by means of a false key, to feed to his teams in care of defendants. A verdict of guilty was directed, but the question was reserved for the opinion of the judges, because several different decisions on similar facts had been rendered in assizes. Fleven judges met to consider this case. Fight of the judges held that this was felony; that the purpose to which the prisoners intended to 
apply the beans did not vary the case. It was, however, alleged by some of the judges that the additional quantity of beans would diminish the work of the men who had to look after the hor'ses, so that the master not only lost his beans, or had them applied to the injury of the horses, but the men's labor was lessened, so that the lucri causa, to give themselves ease, was an ingredient in the case. Graham, B., Wood, 13., and Dallas, .J., thought this not a felony, and that the conviction was wrong. R. v. Morfit, Russell \& R. $307, B$. 683,1 B. \& H. $438-n$, C. 345 .

(Eng. C. C. R., 1846.) Same. On indictment and trial for lareeny it appeared that the prisoners took 5 sacks of oats from the barn floor in the presence of the thrasher and secreted them in the loft, intending to give them to their master's horses, they being employed as carter and earter's boy, but not being answerable at all for the eondition or appearance of the horses. The jury foumd that they took the oats with intent to give them to their master's horses, and without any intent of applying them for their private henefit. The learned judge reserved the case for the opinion of the judges on the point whether the prisoners were gruilty of larceny. R. $v$. Morfit and another, Russ. \& R.y. 307 /abovel; R. v. Cabbage, Russ. \& Ry. 292 [\$ 145]. Lord Denman, C. J.. 'T'indal, C. .J., Parke, B., Patteson, J., Williams, J., Coltman, J.. Rolfe, B., Wightman, J., Cresswell, J., Erle, J., and Platt. J3., met to consider this case. The greater part of the judges presont appeared to think that this was lareeny, because the prisoners took the oats knowingly anainst the will of the owner, and without color of title or of anthority. with intent, not to take temporary possession merely and then abmalon it (which would not be larceny). but to take the entire dominion over them, and that it madre no difference that the taking was not lueri causa, or that the olject of the prisoners was to apply the things stolen in a way which was acrainst the wish of the owner but might be beneficial to him. 13it all agreed that they were bound by the previous decisions to hold this to be lareeny, though several of them expressed a doubt if they should have so decided if the matter were res integra. Erle. .J., and Platt, B., were of a different opinion; they thought that the former decision proceeded in the upinion of some of the judges on the supposition that the prisoners would gain by the taking, which was negatived in this case. $\mathbf{R}$. v. Privett, 1 Den. C. C. 193,2 C. \& K. 114,2 Cox C. C. 40,1 B. \& II. 440n, C. 349. Mi. 814.

(Eng. Central Crim. Ct., 1846.) For Reward. Property was temporarily deposited by the owner in a public room. and was taken away by the prisoner for the purpose of exacting a reward for its restoration, the jury being of the opinion that he would not have restored it without such reward. It was held to be larceny. R. v. Spurgeon, 2 Cox Cr. Cas. 102, B. 685. 
(Eng. C. C. R., 1862.) Same. POLLOCK, C. B. In this case the prisoner was convicted of stealing a check. He took the check away from a boy who found it, and did not immediately give in. formation to the owner, but withheld it in the expectation of getting a reward. 'The taking of the check from the finder was not a felonious taking, and the merely withholding it in the expectation of a reward was not a larceny. The rest of the court concurring. Conviction quashed. R. v. Gardner, 9 Cox C. C. 253, L. \& C. 243,32 L. J. m. c. 35,11 W. R. 96,7 L. T. 471,8 Jur. n. s. 1217 , B. 686, C. 365.

Followell: S. v. Arkle, 116 N. Car. 1017, 21 S. E. 408.

(Mass. Sup. Judicial Ct., 1870.) Taking a Horse while Trespass. ing upon the Taker's Premises, with intent to conceal it until the owner should offer a reward for its return, and then to return it and claim the reward, or with intent to induce the owner to sell it astray for less than its value, was held to be lareeny. MOR'OON, J., said: We think that when a person takes property of another, with intent to deprive the owner of a portion of the property takel, or of its value, such intent is felonious and the taking is larceny. * * The jury must have found, under the instructions given them, that the defendant took the horse with intent to conceal and retain it until he could obtain a reward from the owner, or until he could effect a purchase from him at a price less than its real value. The intent, in either contingency, was to deprive the owner of, and appropriate to his own use, a portion of the value of the property. We are of opinion that, upon principle and the weight of the anthorities, the taking with such intent was lareeny. ** * Exceptions overruled. C. v. Mason, 105 Mass. 163, 7 Am. Rep. 507.

(Ohio Sup. Ct., 1877.) Taking Horses to Hoid for Reward. Molosh, Richie, and Berry were convicted of grand larcony, Berry appeals. BOYNION, J. *** That the two geldings were wrongfully taken from the owner without his consent. concealed and secreted in the woods some three miles distant, for the purpose of securing a reward which the parties to the transaction expected would be offered for their return, and that the result contemplated was accomplished by their return and a receipt of the reward, in the meantime offered, are facts clearly proved. They are almost a necessary result of the verdict. The claim of the plaintiff in error was, and his position now is, not that such talking with such intent was not shown, but that such taking with such intent was not larceny or horse stealing under the statute. ** The court held. in effect, and so advised the jury, that if the geldings were wrongfully taken without the consent of the owner, with intent to conceal and secrete them, until a reward was offered for their return, and for the purpose of obtaining such reward, such taking was larceny. The request refused embodied the converse of this 
proposition. We think the instruction was right. * * * "There must be an intention to deprive the owner wholly of his property." R. v. Holloway, 1 Den. C. C. 370 [below]. The contention of the plaintiff is, that the facts established at the trial did not bring the casa within the rule thus stated, inasmuch as there wis no intention to deprive the owner wholly or permanently of his property. In an exact sense, it is not true that all intent to appropriate permanently the property taken is a necessary ingredient in the crime of larceny, if by permanent appropriation is meant keeping the specific property from the possession of the owner. ${ }^{*} *{ }^{*}$ If the geldings taken in the case at bar, had been disguised, returned, and sold to the owner in pursuance of a purpose formed when they were taken, that the transaction would have constituted larceny cannot be doubted. Yet, in respect to the fraudulent character of the transaction, or in point of moral obliquity, it would be difficult to distinguish it from the case here made. The only possible difference in the two cases is, that in the one there would be an intent to convert the whole value of the property, and in the other only a part. But in this case there was an utter absence of intention to restore the property unless money was paid for its restoration. There was no evidence tending to show a purpose to return the property unless a reward was offered therefor. A return, at all events, was not designed. * * * Affirmed. Berry v. S., 31 Ohio St. 219, 27 Am. Rep. 506, F. 291.

Acc. Dunn v. S., 34 Tex. Cr. IR. $55 \%$. 30 S. W. 22 r. 53 Am. St. Rep. 714.

(Eng. C. C. R., 1849.) To Get False Credit for Work. On indictment for stealing 120 dressed skins, it wus shown and found by the jury, that the defendant was a skin-dresser in a tannery, was paid for his work by the piece, secretly entered the house where dressed skins were kept, and removed the skins mentioned in the indictment, intending to put them with the skins dressed by him and get credit as if he had dressed them. On this the jury were directed to find the prisoner guilty, and the question was reserved for the judges to consider whether the conviction was right. All the five judges called to hear the case held that the conviction must be reversed, because the defendant had no intention to deprive the owner of the skins permanently nor take them entirely from the owner's possession. R. v. Holloway, 3 Cox 241, 1 Den. C. C. 370, T. \& M. 40. 2 Car. \& K. 942, 13 Jur. 86, 18 I. J. m. c. 60, 3 New Sess. Cas. 410, B. 692 , C. 263 , Ke. 285 .

(Ala. Sup. Ct., 1887.) Same. On indictment for burglary it appeured that defendants were hired to pick cotton at so much per 100 pounds, and brokc into the cotton-house where the seed cotton was stored, and carried a quantity of cotton to the field, intending, not to deprive the owner of it, but to get paid for picking it. They were convicted, and on appeal the conviction was affirmed. "We 
think deprivation of the ownership of property is one of the essentials of larceny. But is it necessary that the intent shall be to deprive the owner of the whole property taken? Is not the animus furandi as manifestly shown when the intent is simply to deprive him of a partial though unsevered interest in the property?

* The taking and asportation were with the intent of depriving the owner of property which was absolutely his and in his possession, and fraudulently placing it where the taker could assert a lien, or claim to hold it until certain charges were paid him by the owner." Per S'TONE, C. J. Affirmed. Fort v. S., 82 Ala. 50, 2 So. 477.

(Eng. C. C. R., 1849.) To Sell to Owner. On indictment for stealing tallow, it appeared that Hall worked for Atkin, a tallowchandler, and during the noon-hour took some of Atkin's tallow, put it on the scales where tallow bought was weighed, and with another (who worked for a butcher of the town) came to Atkin and said the other had brought the tallow from the butcher and came to be paid for it. Verdict, guilty. For the defendant it was contended by Dearsley, that the ease was puled by R. v. IIolloway, above. ALDERSON, B. If a man takes my bank note from me, and then brings it to me to change, does he not commit larceny? Dearsley. A bank note is a thing unknown to the common law, and therefore the case put could not be lareeny at common law. IJORD DENMAN, C. J. The taking is aclmitted. The question is whether there was an intention to deprive the owner entirely of his property ; how eould he deprive the owner of it more effectually than by selling it? 'lo whom he sells it cannot matter. The case put of the bank note would be an ingenious larceny, but no case can be more extreme than this. PARKE, 13. In this case there is the intent to deprive the owner of the dominion over his property, for it is put into the hands of an intended vendor, who is to offer it for sale to the owner, and if the owner will not buy it, to take it away again. The case is distinguishable from that of R. v. Holloway by the existence of this intent, and further by the additional impudence of the frand. ALDERSON, B. I think that he who takes property from another intends wholly' to deprive him of it, if he intend that he shall get it back again under it contract by which he pays the full value for it. Coleridge, J., and Coltman, i., concurred. Conviction affirmed. R. v. Hall, 3 Cox C. C. 245, 2 Car. \& K. 947 , T. \& M. 47,1 Den. C. C. 381,18 L. J. m. c. 62,13 Jur. 87, B. 696, C. 282. 3 New Sess. Cas. 407.

(Eng. C. C. R., 1852.) Same. Prosecutor was a potato dealer and regularly bought bags of $\mathrm{S}$. The keeper of his warehonse was M. On proof that M. laid bags out of the warehouse and $S$. then claimed pay for them, both were convicted of larceny, and the conviction anproved on R. v. Hall [above]. Before Jervis, C. J., Alderson, B., Coleridge, J., Creswell, J., and Platt, B. R. v. Manning, 6 
Cox C. C. 86 , Dears. 21,22 L. J. m. c. 21,17 Jur. 28,1 W. R. 40, C. 268.

(Ark. Sup. Ct., 1894.) To Return to True Owner. On trial on indictment for stealing a mare, it appeared that defendant hired the mare of $\mathrm{H}$. to ride to visit an uncle in an adjoining county, there traded it to prosecutor for a horse, and shortly afterward sold the horse; that prosecutor became suspicious that all was not right, and required defendant to stay at prosecutor's house over night till an investigation could be made; that in the morning he discovered that defendant and the mare were gone; and that defendant was captured with the mare on the way toward the place where he hired her. On the trial the aefendant testified that he took the mare to return her to $H$., from whom he had hired her; and that he was 19 years old, was drunk when the trade was made, and did not realize what he was doing. The court refused to instruct the jury that if defendant took the mare from prosecutor to return her to her true owner, in an endeavor to correct the wrong he had done, he was not guilty of larceny. Refusal of this instruction was held orror; because there was no intent to deprive the owner of his property, if this was defendant's purpose. Reversed. Gooch v. S., 60 Ariz. 5, 28 S. W. 510.

\section{§144. "Permanently."}

(Eng. C. C. R., 1820.) To Induce Owner to Call. The prisoner was tried and convicted of stealing a girl's bonnet and other articles of her apparel. He entered the house where they were at night, through an open window, and took the things to a haymow of his own, where he and the girl, whom he had seduced, had twice been before; and the jury found that his object was not to deprive the girl of the things, but to induce her to go again to the haymow. The judges held that the taking was not felonious. R. v. Dickinson, 1 Rus. \& R. 420 , B. 684 , C. 358, F. 289.

(Del. Ct. of Err. \& App., 1854.) Horse Taken to Escape. Defendant, an indentured servant, was running away from his master; and, to make good his escape, mounted a horse he found hitched on the road, rode it to Wilmington, put it in a livery stable, and abandoned it. The court told the jury that felonious intent is where a man knowingly takes and carries away the goods of another, without any claim of right, with intent to deprive the owner of them, and convert them to his own use. But if he took the horse when he was running away, merely to facilitate his escape, and left him at the livery stable, without intent to deprive the owner of it, he ought to be acquitted. S. v. York, 5 Har. 493, F. 290.

Acc. Rex v. Crump, 1 Cur. \& P. 658, B. 685. Ke. 284; Lucas v. S., 33 Tex. Cr. R. 290, 20 S. W 218, taking horse from range to side to train and turning lt loose. 
(Tex. Ct. of Crim. App., 1894.) To Escape. Defendant being confined at the county farm for gambling, approached the guard to borrow his pocketknife, then seized him and called out: "Come, on boys, now is the time to get your liberty ;" and assisted by others, took the guard's gun and pistol and left him gagged and bucked. The gun and pistol were later given to friends, to be returned, or so defendant testified; but the person receiving them sold them. On trial for larceny, the jury asked for instruction as to what length of possession would constitute larceny; and the court answered: "The law fixes no length of time. A moment's possession is sufficient." On appeal the court held that while this answer was correct, it was insufficient, in view of the testimony as to fruudulent intent to appropriate to his own use at the time of taking. Reversed. Mahoney v. S., 33 'I'ex. Cr. R. 388, 26 S. W. 622.

(Eng. Assize, 1840.) To Pledge and Ultimately Restore. 'The prisoner was indicted for stealing silver plate of his master of \pm 18 value. It appeared that he was under butler for Lord Hay, took the plate from such as zame to his hands in his service, and pledged it. The jury found him guilty but recommended mercy, on the ground that they believed he intended to replace it. Jones, for the prisoner submitted that the verdict amounted to an aequittal. Gurney, B., expressed no opinion on the point, but put the prisoner on trial on another indictment for a similar offense, and Jones argued to the jury the prisoner's good intentions. GURNEY, B. (in his summing up observed): You will say whether the prisoner siole this property or not. I confess I think that if this doctrine of an intention to redeem property is to prevail, courts of justice will be of very little use. A more giorious doctrine for thieves it would be difficult to discover, but a more injurious doctrine for honest men cannot well be imagined. R. v. Phetheon, 9 Car. \& P. 552 (38 Fng. C. L. 324$)$, C. 337 , Mi. 811 .

(Eng. C. C. R., 1858.) Same. Defendant was convicted of larceny of a box of plate worth $£ 600$, which prosecutrix had left with him, in a locked chest, for safe keeping, during her absence of a few days. He had opened the box and pawned the plate for 1200 . LORD CAMPBELL, C. J. The general proposition contended for by Mr. Cox is yerfectly correct. 'I'o constitute larceny, there must be an intention on the part of the thief completely to appropriate the property to kis own use; and if at the time of the asportation his intention is to make a mere temporary use of the chattels tiken, so that the dominus should again have the use of them afterwards, that is a trespass, but not a felony; but that law does not apply to this case. Here there was abundant evidence of a larceny at common law; abundant evidence from which the jury might find that the prisoner feloniously stole the plate; and the jury have found a verdict of guilty. But they have recommended him to mercy, and 
accompanied that recommendation with a statement as to the prisoner's intention to return the stolen property. Now, I doubt whether what the jury say in giving their reason for recommending the prisoner to mercy, is to be considered as part of their finding; but even assuming it to be so, all that they say is, that he intended ultimately to return the property; not that at the time of the wrongful taking he originally intended to make a merely temporary use of it. [Coleridge, J., Crowder, J., Martin, B., and Watson, B., gave similar opinions.] Affirmed. R. v. Trebilcock, 7 Cox C. C. 408, Dears. \& B. 453, 27 L. J. m. c. 103, 4 Jur. n. s. 123, 6 W. R. 281, B. 688, C. $339, \mathrm{Mi} .811 \mathrm{n}$.

Ace. Truslow v. S., 85 Tenn. 189, 31 S. W. 887 ; R. v. Mediand, 5 Cox C. C. 292, C. 338 , Ke 236.

\section{\$145. "Convert it to the Taker's Own Use."}

(Eng. C. C. R., 1815.) Taking to Destroy. On indictment for stealing a grelding, it was proved that defendant took it from prosecutor's stable and backed it into the shaft of an abandoned coal mine, and that one Ilowarth was about to be tried for having stolen it. It was objected that the taking appeared not to have been done with intention to convert it to the use of the taker, animo furandi et lucri cantsal. On case reserved after convietion, six of the judges held that taking lucri causi was not essential to constitute larceny, and that taking to deprive the owner wholly of his property was sufficient. But some of these six judges thought that in this case intent to protect llowarth by destroying the animal might be deemed a sufficient benefit or lueri callsis. Five other judges thonght the conviction wrong. R. v. Cabbage, Russell \& R. 2920, 13. 682, 1 B. \& II. 436, C. $344, \mathrm{MI}$ i. 809 .

(N. Y. Sup. Ct. 1883.) Same. Appeal from conviction of grand larceny on proof that defendant took a horse from Jewell's stable and killed and buried it in a pit. Defendant and Jewell had been on bad terms. had had several lawsuits. and one was still pending when the horse was killed. BOARDMAN, J. The court below did not properly state the legal questions before the jury: Upon the evidence it is eertainly a grave question whether the act charged and proved was lareeny or malicious mischief. To constitute larceny there must have been a felonious intent, animo furandi or lucri causa. The malicious lilling of a horse is a misdemeanor.

The offenses are quite distinct. In either case there is a trespass. In larceny the taking must be for the purpose of enverting to the use of the taker. In malicious mischief no such intent is necessary. In the present calse the evidence tends to show a taking of the horse to kill him. with a sole desire to injure the owner. It was incumbent on the eourt then to point out to the jury the legal elements in the crime of larceny. so als to distinguish it from malicious mischief: 
'lhis, we think, was not done. *** Bockes, J., concurred. [Learned, P. J., filed a dissenting opinion.] Reversed. P. v. Woodward, 31 Hun. 57,5 L. 478.

"In Woodward s case there was un able and exhuustive dissenting opinlon by one of the three justices, und no authurities ure ciced in support ur the majority opinion except Whart. Cr. Law, \$ 1784, und certain cuses therein referred to, which do not sustain the text." Per LEONAKD, J., 11 s. v. Sllageriand velow.

(Eng. C. C. R., 1846.) To Avoid Report of Character. On indictment for stealing a letter, it appeared that the prisoner had applied for a position as cook for $D$, was told that $D$ had written to the prisoner's former employer for a statement as to her character, and knew that an unfavorable answer would be sent; where. fore she applied at the postoffice for D's mail, received the letter in question, and burned it. 'The question reserved for the opinion of the judgres was whether taking and destroying the letter under these circumstances was larceny. All the judges were present except Coleridge, Wightman, and Maule, JJ.; and all except Platt, B., were finally of opinion that it was larceny ; for, supposing that lucri causa (which was not admitted) to be an essential ingredient of larceny, there was sufficient advantage to the prisoner in making way with the letter. R. v. Jones, 1 Den. C. C. 188, 2 C. \& K. 236 , 1 Cox C. C. 6,2 B. \& H. 440 n, C. 346, Mi. 818.

(Eng. C. C. R., 1849.) To Avoid Penalty. On indictment for stealing two letters, containing money and stamps, it appeared that the prisoner was a clerk in the postoffice, and was subject to penalty for errors in sorting and failing to deliver properly the registered letters coming to his hands in due course; that the letters in question were so received by him; and that he made error in sorting them, to conceal which, and to avoid the penalty, he deposited them in the bowl of the watereloset in the office. LORD DENMIAN, C. J. * the bowl of the watereloset in the office. I lareeny, I am clearly of opinion that it is made out. We can only argue on the evidence of the caseupon the facts and circumstances before us. We find the prisoner, who had received the letter in the course of his duty, retiring to a private place and dropping the letter under circumstances that it would be probably destroyed, and this for the purpose of avoiding the penalty of previous misconduct. That is a sufficient lucri causa. It deprives the owner of the property. The letter was meant to be entirely withdrawn from him, for it cannot be gravely argued that it was intended he should find it. As to the asportavit, no doubt it occurred the moment the letter dropped from his hand. It appears to me, therefore, that the count for secreting is sustained by the evidence. The rest of the judges concurred. R. v. Wynn, 3 Cox C. C. 271,2 C. \& K. 859,1 Den. C. C. 365 , T. \& M. 32,3 N. S. C. 414 , 18 L. J. m. c. 51,13 Jur. 107, C. 352.

(Nev. Sup. Ct., 1885.) Horses Taken to Harass Owner. Appel. lant was convicted of grand larceny for taking two horses, two 
saddles, and a pair of spurs. He admitted he took them and removed them some five miles away; but said he did it to put the owner to all the expense and trouble possible to find them, and with no idea of benefiting himself in any way, his sole object being revenge. The court instructed the jury that taking with intent to deprive the owner of his property, and without intent to return it, was felonious; and if found, the defendant was guilty. This instruction was complained of ; but the supreme court, after reviewing the cases, concluded that there was no authority for the claim that the property must be taken for the benefit the thief expects to derive from it. Judgment affirmed. S. v. Slingerland, 19 Nev. 135, 7 Pac. 280, F. 295, Kn. 264.

('Tex. Ct. of Crim. App., 1893.) Destroying to Conceal Crime. On trial for cattle stealing, it appeared that the defendant had stolen a yearling and sold it to prosecutor's vendor who branded it with his mark and put it into his herd; and defendant learning that the identity of the animal had been discovered, shot it and threw it into a well to avoid detection and being required to pay for it. Admitting that personal advantage is essential to larceny, these facts were held sufficient to show it. Conviction affirmed. Stegall v. S., 32 Tex. Cr. R. 100, 22 S. W. 146, 40 Am. St. Rep. 761.

That Iucri Causa is not an eskential element of larceny: Williams v. S., 52 Ala. 411: P. v. Jaurez, 28 Cal. 380; Best v. S., 155 Ind. 46, 57 N. E. 534; Delk v. S., 64 Miss. 77, 1 So. 0, 60 Ảm. Rep. 46: Dignowitty v. S., 17 'lex. 521, 67 Am. Dec. 670; S. v. Caddle, 35 W. Va. 73, 12 S. L. 1098.

\section{ROBBERY.}

§146. Defined. "Robbery is a felonious taking of money or goods, to any value, from the person of another, or in his presence, against his will, by violence or putting him in fear." 2 East P. C. 707.

\section{$\S 147$. “Felonious Taking."}

(Eng. C. C. R., 1781.) Returned Purse. On indictment for highway robbery it appeared that Peat put Doane in fear of his life and so obtained Doane's purse containing 23 s., whereon Peat handed it back, saying: "If you value your purse take it back and give me the contents." While Doane was taking out the money, as ordered, his servant sprang upon Peat from behind and secured him. On case reserved after conviction, all judges held that the offense was complete when the property wis once obtained by the prisoner. $\mathbf{R}$. v. Peat, 1 Leach (Ed. 3) No. 112, 2 East P. C. 557.

Money glven by woman to avold rape: $R$. v. Blackham. \$ 44. (iolng into hluhway to be robhed and catch thief: MeDaniel's Case, $\mathbf{\$} \mathbf{2 0}$. Filling lobiler in alct justifitible: Crawford v. S., \$ 71 . 
(Eug. C. C. R., 178t.) Earring Caught in Hair. Lapier was indicted and convicted of robbery on proof that as Mrs. II. was passing from the opera house to her carriage, she felt someone (proved to be the prisoner) snatch her diamond earring. She found her ear torn through and bleeding, and the jewel gone; but on arriving home the earring was found hanging in her hair. Inasmuch as it was, for an instant, in the possession of the prisoner, separate from hel person, it was held by all the judges that the taking was sufficient and that the asportation was complete, wherefore the convic. tion of robbery was sustained. R. v. Irapier, 2 East P. C. 557, 1 Leach (ed. 3) No. 149, Ke. 222.

(Eng. C. C. R., 1787.) Compelling Owner to Drop Bed. On indictment for robbery, Farrel was found to have stopped one carrying a bed on his shoulders, telling him to lay it down or he would shoot him. The owner dropped the bed, but before Farrel could take it up he was apprehended. The judges were of opinion that the offense was not complete and the prisoner was discharged. Farrel's Case, 2 East P. C. 557,1 Leach (Wd. 3) 362n.

See severul cuses as to whut is taking in lurceny. $\$ 1: \bar{b}$.

\section{§148. "In His Presence."}

(Eng. King's Bench, 1735.) On Ground in Presence. Indictment for felonious assault on $C$ on the king's highway, putting him in fear. and stealing from his person $£ 9$. On plea of not guilty, the jury found specially that while $\mathrm{C}$ was riding on horseback past the prisoners on the highway, one of them asked him to change a half crown; and on putting his hand into his pocket, he pulled out several pieces of coin to make change; whereon one of the prisoners gently struck his hand and the money fell to the ground; whereon C. dismounted, saying he would not lose his money so, and attempted to pick it up; but the prisoners put him in bodily fear, by threatening to knock his brains out if he touched the money; on which he desisted, and they took it up, got on their horses, and rode away. This special verdict being argued in the king's bench, the judges were unamimously of opinion that taking from the presence was taking from the person in point of law. R. v. Francis, 2 Strange 1015, 2 East P. C. 708, B. 699.

(Eng. Central Crim. Ct.. 1859.) From Same Room. Indictment for robbery and stealing from the person, under $24 \& 25$ Vict. c. 96 , $\$ 40$, enacting that "whosoever" shall rob any person. ol" shall steal any chattel, money, or valuable sccurity from the nerson of another, shall be guilty of felony." The prosecutor was sitting on al sofa in a back room of his shop. when he received a violent blow on the head from one of prisoners while the other went to a cuphoild in 
the same room, and stole a cash box therefrom. The sergeant, having consulted with Crowder, J., and Channell, B., held that, although the box was not taken from the person, yet being virtually under the protection of the person, he should leave the question to the jury: Was the cash box under the protection of the prosecutor's persou when taken? The jury found that it was. Guilty. R. v. Selway, 8 Cox C. C. 235 , B. 700 , C. 386.

(Iowa Sup. Ct., 1887.) Adjoining Room. Defendant was convicted of robbery and appealed. BECK, J. *** In the case before us, defendant, by violence, bound the prosecuting witness, and thereby put her in fear. By this violence he extorted from her information of the place where she kept her money and watch in another room of the house. Leaving her bound he went into that room and took the property. We are clearly of the opinion that it was taken from her person in the sense of the words as used in the statute. In support of this conclusion, see the following authorities cited thereon: 2 Bish. Crim. Law, \$975; Wharton Crim. Law, $\S 1696$. ** * Affirmed. S. v. Calhoun, ra Iowa 432, 34 N. W. 194, 2 Am. St. Rep. 252.

(Ga. Sup. Ct., 1890.) Confining Owner in Outhouse and Taking from House. W. \& C. Clements were convicted on indictment for robbery, on proof that they found the prosecutor, Bird, in a smokehouse 45 feet back of his house, at 7 p. m., Jan. 19, 1888, where he had gone to weigh out rations for his help; and one of them stepped up and said the first man who put his head out would get it shot off, and meanwhile the other defendant went to the house and took a chest and contents (several hundred dollars) from under the bed, a few feet from the front door; that no one said anything about Bird's money or touched his person while he was in the smoke-house; but, by pecping through the cracks he saw a rather stout man standing with face towards him, with gun ready to shoot; and that when he came out he met his wife, and learned that the chest was gone. There was evidence to show that the accused were the guilty parties. Complaint was made of an instruction to the jurv that in order to convict it must be found that the defendants took the property from the person of the prosecutor; but in contemplation of law, goods in the dwelling-house are on the person of the owner while he is in the house or in any house so near to it that the whole is under his immediate dominion and control. SIMMIONS, J.

- We do not think that the court erred in giving the charges complained of, under the facts of this case. It is not necessary, in a case of robbery, to prove that the property was actually taken from the person of the owner. but it is sufficient if it is taken in his presence. Crews v. S.. 3 Cold. (43 Tenn.) 350 ; S. v. Jenkins, 36 Mo. 372; 2 Russ. Cr. 106. 107; 2 Rosc. Cr. Ev. 935. 936. * * * Bishop, in his work on Criminal Jaw (Vol. 2, $\$ 1177$ ) says: "The meaning 
of this legal phrase is not that the taking must necessarily be from the actual contact of the body, but if it is from under the personal protection that will suffice. Within this doctrine the person may be deemed to protect all things belonging to the individual, within a distance not easily defined, over which the influence of the personal presence extends." * * * Affirmed. Clements v. S., 84 Ga. 660, 11 S. E. 505,20 Am. St. Rep. 385.

\section{$\S 149$. "By Violence or Putting in Fear."}

(Eng. Old Bailey, 1712.) The Prisoner Took Hold of a Gentleman's Sword, who perceiving it, laid hold of it at the same time, and struggled for it. This was adjudged to be robbery. Davies's Case, 2 East P. C. 709, Mi. 832.

(Eng. C. C. R., 1820.) Breaking Watch Chain. The prisoner took a watch out of a gentleman's pocket, but it was fastened to a steel chain which was around his neck. The prisoner made two or thiee jerks, until he succeeded in breaking the chain. Park, B., instructed the jury that this was robbery; but, doubts being expressed, he referred it to all the judges, who were unanimous in the opinion that the conviction was right, because of the actual force used to break the chain. R. v. Mason, Russ. \& R. 419.

(Eng. Assize, 1824.) Struggle for Possession. Indictment for robbery, as the prosecutor was going along the street, the prisoner laid hold of his watch chain, and, with considerable force, jerked it from his pocket. A scuffle then ensued, and the prisoner was secured. GARROW, B. The mere act of taking, being forcible, will not make this offense a highway robbery. To constitute the crime of highway robbery, the force used must be either before or at the time of the taking, and must be of such a nature as to show that it was intended to overpower the party robbed, or prevent his resisting, and not merely is get possession of the property stolen. Thus, if a man, walking after a woman in the street, were, by vio. lence, to pull her shawl from her shoulders, though he might use considerable violence, it would not, in my opinion, be highway robbery, because the violence was not for the purpose of overpowering the party robbed, but only to get possession of the property. Verdict, guilty of larceny only. R. v. Gnosil, 1 Car. \& P. (12 F. (.. L.) 304.

(N. Car. Sup. Ct., 1857.) Struggle to Escape with Property. Indictment against John, a negro slave, for highway robbery. Brooks had been to Milton and sold a load of tobacco, and was driving home with the proceeds. along a country road, about dark, when he overtook .John going the same way. John said he found a bill 
in town and wanted Brooks to see it and say what it was. Finally Brooks consented, lighted a torch, and was examining it when he felt John's hand in his pocket. He seized John's arm, a struggle followed, and finally he was thrown out of the wagon, and when he got up John was running off with all the money, $\$ 227$. John was convicted and appeals. PEARSON, J. Robbery is committed by force; larceny, by stealth. The original cause for making highway robbery a capital felony, without benefit of clergy, was an evil practice (in former days, very common) of meeting travelers, and by a display of weapons, or other force, putting them in fear ("stand and deliver"), and in this way taking their goods by force. Hence the indictment (the form is still retained) contains this allegation: "And him [the person robbed], in bodily fear and danger of his life, in the highway, then and there, did feloniously put"; and it was for a long time held that the allegation must be proved. *** In Foster's day it would not have occurred to any lawyer that the facts set out in the record now under consideration made a case of highway robbery. There was no violence-no circumstance of terror resorted to for the purpose of inducing the prosecutor to part with his property for the sake of his person. Violence may be used for four purposes: (1) To prevent resistance. (2) To overpower the party. (3) To obtain possession of the property. (4) To effect an escape. Either of the first two makes the offense robbery. The last, I presurne it will be conceded does not. The third is a middle ground. In general it does not make the offense robbery, but sometimes, according to some of the cases, it does. It is necessary, therefore, to see how the authorities stand in respect to it. ** * * After much consideration, I am convinced that the facts set out in this record do not constitute highway robbery. I am therefore of opinion that the judgment ought to be reversed, and a venire de novo awarded. BAT'TLE, J. Mv associate. Judge Pearson, thinks that the facts in the prisoner's bill of exceptions do not constitute a case of robhery, but of larceny only. After an examination of all the authorities upon the subject which I have been able to find, and much reflection upon the principles they seem to establish, I am constrained to say that I do not entirely agree with him. * * * [Reviewing the principal texts on criminal law.] All these able and eminent writer's upon the criminal law agree in this: that if there he a struggle for the possession of the property, or a personal outrage, it is robbery. *** Now, it seems to me that in the case before us the testimony of the prosecutor, Brooks, shows something very much like a struggle for the pocketbook. **** The distinction between a struggle to escape and one to carry off the property, when the prisoner did both, is, in my estimation, almost too refined for prictical use. *** [On another ground, his honor concurred in granting a new trial.] S. v. John, 5 .Jones (50 N. Car.) 163, 69 Am. Dec. 777-n, F. 306, Kn. 285, MIi. 832n. 
(Mo. Sup. Ct., 1900.) Train Robbery. Defendant was convicted of train robbery and appealed. GAN'I'l, P. J. * * * 'The contention is that these facts do not establish that this robbery was committed "in the presence and against the will, and by violence, or putting in fear of immediate injury to his person." [Mo. Acts Apr. 2, 1895. It has long been decided that it is unnecessary to charge a putting in fear in the indictment, or to prove actual fear; for if the fact be laid to be done violently, and against the will, the law, in odium spoilatoris, will presume fear. S. v. Stinson, 124 Mo. 447, 27 S. W. 1098 ; S. v. Lawler, 130 MIo. 366, 371, 32 S. W. 979. That the robbers, with arms and threats of immediate violence, forced the agent and his assistant out of the express car to the platform, and by like force cut the train into two parts, and drove the engineer and fireman off of the engine, and then ran the front part of the train forward about one-fourth of a mile, is conceded; but it is urged that the robbers applied the drnamite after they had pulled the train away from the stition and after they had put the agent out of the express car, it was not in his presence. Clearly, this is not good law. *** Affirmed. Sherwood and Burgess, J.J., concurred. S. v. Kennedy, $15 \pm$ Mo. 268, 55 S. W. 293.

\section{LARCENY FROM THE PERSON.}

\section{§150. In General.}

Statute 8 Eliz. (1565), c. 4. \$1. Where a certain kind of evildisposed persons, commonly called cut-purses or pick-purses, but indeed by the laws of this land, verv felons and thieves, do consider together, making among themselves as it were a brotherhond or fraternity of an art or mystery, to live idly by the secret spoils of the good and true subjects of this realm; *** \$2. Be.it therefore enacted by the authority of this present parliament, that no person or persons which hereafter shall happen to be indieted or appealed for felonious taking of any monev, goods or chattels from the person of any other privily without his knowledge, in any place whatsoever, and thereupon found guilty by virtue of twelve men. * * * shall from henceforth be admitted to have the benefit of his or their clergy, but utterly be excluded thereof, and shall suffer death in such manner and form as they should if they were no clerks.

(Eng. Old Bailey. 1782.) While Asleep. Indictment for stealing a watch privately from the person of Thos. Sheridan without his knowledge. The defendant and Sheridan had been drinking at a public house together, both became much intoxicated, and went to: gether to defendant's lodging, where Sheridan fell asleep: and while he slept the defendant stole his watch. The court held that this 
was not such stealing privately as would oust the defendant of benefit of elergy within the meaning of the statute; and mention was made of a case in which a person intoxicated fell asleep in one of the watch-houses or niches on Westminster bridge on the way home, and one passing stole the buckles ont of his shoes without awaking him; which the judges held not within the statute, which was intended to protect the property which persons should not be cuabled to secure by proper vigilanee and caution, and did not extend to those who so exposed themselves to depredation. R. v. Gribble, 1 Leach C. C. (Wd. 3) No. 117, 5 L. 581.

(Cal. Sup. Ct., 1897.) Same. VAN FLEE'T, J. Defendant was charged with grand lareeny, in stealing $\$ 17$ from the person of James Shaw, and convicted. IIe complains that the evidence did not warrant the verdiet. Shaw and the defendant had their beds near together, in the open air. Shaw, in going to bed, removed his trousers. in the pocket of which was the money, and placed them mader his head, as a pillow. While he slept they were abstracted by the defendint and the money taken. The question is whether these facts show a "taking from the person," under our statute, which makes the offense grand larceny without regard to the amount stolen, "when the property is taken from the person of another." If it was not such taking, the amount was insufficient to constitute any greater offense than that of petit larceny. Pen. Code, $\$ \S 487$, 488. The stealing of property from the person has been from, an early period. under the English statutes, treatiod as a much graver and more heinous offense than ordinary o; eisnmon theft-partly by reason of the ease with which it could he perpetrated, and the difficulty of g zarding against it, and part? $\mathrm{y}^{\mathrm{r}}$ because of the greater liability of endangering the person or lite of the victim. The same general purpose animated the modern statutes. including our own; and, as in England, the offerise is macte punishable as a felony. The difficulty has been in defining with precision in all cases what eonstitutes a taking from the person, and this has given rise to some confusion in the authorities on the question as to whether the property must be actually on, or attached to the person, or merely under the eye, or within the immediate reach, and so constructively within the control of the owner. According to Mr. Bishop. "The thing taken must be under the protection of the person, but need not he attached thereto." 2 Bish. Cr. Tsaw 898. But he only cites R. v. Selway, 8 Cox C. C. $235\lceil\S 148]$. where the indictment was for robbery, and the facts show clearly that offense, and not larceny. - * Te think its obvious purpose was to protect persons and property against the approach of the pick-pocket, the purse snateher, the jewel abstracter, and other thieves of like character, who obtain property by similar means. and that it was in contemnlation that the property shall at the time be in some way actually upon or attached to the person, or carried or held in actual physical posses- 
sion. * * Had the garment alone been taken under like circumstances, the theft could not be held to have been from the person. A man does not wear his bed as he does his clothes. The money was therefore no more on his person, in any proper sense, than if it had been concealed under his bed, or elsewhere about it, or left in his elothes upon a chair, or hung on the wall. * * * Reversed. P. v. McElroy, 116 Cal. 583, 48 Pac. 718.

(Ala. Sup. Ct., 1897.) Secrecy or Force. On trial for lareeny from the person, the defendant requested the court to charge the jury that there could be no such larceny without taking forcibly or secretly from the person. Refusal of this instruction was held proper, as the force or secrecy are no part of the offense. Higgs v. S., 113 Ala. 36, 21 So. 353.

See several cases on attempt to plek pockets. \& 62 .

(Tex. Ct. of App., 1890.) Without Knowledge. Appeal from conviction of larceny from the person. Prosecutor testified that he felt someone touch his pocket containing his purse, and that on looking around quickly he saw defendant's hand holding the purse pass from his. to defendant's pocket. On this proof defendant was convicted of theft from the person, under Pon. Code Tex., Art. 745, which provides that "the theft must be committed without the knowledge of the person from whom the property is taken, or so suddenly as not to allow time to make resistance before the property is carried away." On error the judgment was aftirmed, because the theft had been committed before it was discovered. Green v. S., 28 Tex. App. 493,13 S. W. 784.

\section{LARCENY FROM THE HOUSE.}

\section{\$151. In General.}

Statute'12 Anne (1713), c. 7, entitled "An Act for the more effectual preventing and punishing robberies tinat shall be committed in dwelling-houses," recites "that divers wicked and ill-disposed servants, and other persons, are encouraged to commit robberies in houses by the privilege, as the law now is, of demanding the benefit of their clergy ;" and enacts "that all and every person or persons that shall *** feloniously steal any money, goods or chattels, wares or merchandises, of the value of forty shillings or more, being in any dwelling-house, or outhouse thereunto belong. ing, although such house or outhouse be not actually broken by such offender, and although the owner of such goods, or any other person or persons be or be not in such house or outhouse, or shall assist or aid any person or persons to commit any such offense, * * shall be ahsolutely debarred of the benefit of clergy." 
(Eng. Old Bailey, 1780.) By Wife of Tenant. Anne, wife of John Gould, was indicted for stealing a purse and 6 guineas, property of W., in the dwelling-house of said John Gould, contrary to St. 12 Anne, c. 7 ; and she was tried before Nares, J., present Skinner, C. B., Ashurst, J., and Adair, recorder. 'The judges present were clearly of opinion (in which Gould, J., afterwards concurred) that the prisoner could not be convicted of the capital part of the indictment, inasmuch as the felony was committed in the dwelling-house of her husband, which must be construed to be her house also, and it is apparent that the legislature intended that the stealing must be in the house of another person, to oust the offender of clergy. R. v. Gould, Leach C. C. (Ed. 3) Case 107, 2 East P. C. 644, C. 390.

(Eng. C. C. R., 1820.) At Prisoner's Lodgings. Taylor was indicted and convicted of stealing prosecutor's watch, value $40 \mathrm{~s}$., in the dwelling-house of W., contrary to St. 12 Anne, c. 7. The proof was that prosecutor and defendant were old acquaintances, and meeting at a public house. defendant invited him to share his bed at W.'s house, which he did, without the knowledge of W. or any of his family, so that he was the prisoner's guest; and while he was asleep the prisoner stole the watch from the bed-head. On case reserved for the opinion of the judges, the majority (Burroiugh, Holroyd, and Bailey, JJ., Abbott, C. J., Richards, C. B., Wood and Graham, BB.) held the conviction right. Richardson, J., Best, J., and Garrow, B., contra. R. v. Taylor, Russell \& R. 418, C. 389, Mii. 830 .

(Eng. C. C. R., 1843.) In Prisoner's House. Bowden was indicted for stealing in his own house, chattels property of S., value over $£ 5$, contrary to St. $7 \& 8$ Geo. 4, c. $29, \S 12$; and convicted before Alderson, B.; but for doubt whether the offense could amount to stealing from a dwelling house or simple larceny only, he reserved the question for the opinion of the judges; and the case being considered, at a meeting of the judges, they all thought the conviction right for the whole offense. R. v. Bowden, 2 Moody 285, 1 Car. \& K. 14i, C. 390 .

(Mrass. Sup. Judicial Ct., 1855.) From Husband's House. MIETCALF, J. The defendant is convicted of larceny in a building owned by her husband; and as the indictment does not aver that it was committed in the night-time, it must be taken to have been committed in the daytime. St. 1843 , c. $1, \S 2$. The question is whether the defendant is liable to the punishment prescribed by St. 18n1, c. 156, §4, for larceny "in any building," or only to the punishment elsewhere prescribed for simple larceny. *** By St. 1851, c. $156, \S 4$, "every person who shall commit the offense of larceny, by stealing in any building, shall be punished by imprisonment in the state prison not more than five years, or by fine not exceeding 
five hundred dollars, or imprisonment in the house of correction or county jail, not exceeding three years." For simple larceny, that is, for theft not aggravated by being from the person, nor by being committed in a dwelling-house or other huilding. ship, or vessel, a lighter punishment is prescribed by the Rev. Sts. c. 1:6. $\$ 17$, and e. $143, \$ 5$. And we are of opinion that the defendant is liable only to that lighter pmishment. $* * *$ It is a common learning. that the adjudged construction of the terms of a statute is enacted, as well as the terms themselves, when an act, which has been passed by the legislature of one state or country, is afterwards passed by the legislature of another. So when the same legislature, in a later statute, use the terms of an earlier one which has received a judicial construction, that construction is to be given to the later statute. And this is manifestly right. For if it were intended to exclute any known construction of a previous statute, the legal presumption is, that its terms would be so changed as to effect that intention. 6 Dame Ab. 613; Kirkpatrick v. Gibson, 2 Brock. 383. Fed. Cas. No. 7,848; Pennock v. Dinlogue, 2 Pet. 18; Adams v. Field. 21 Vt. 266; Whitcomb v. Rood. 20 Vt. 52; Rutland v. Mendon. 1 Pick. 153; Myrick v. Hasey, 27 Me. 9. There are many instances in which our legislature have made punishable, as offenses, acts which were first made so by Fnglish statutes. Among others are our statutes concerning the fraudulent obtaining of money or goods by false pretenses. In all such cases, the construction given by the Finglish courts is deemed to be the true one, when the statutes are alike. And we have already stated, that the act of stealing in certain buildings was first made an aggravated larceny, and subject to a greater punishment than before, by St. 1804, c. 143. Yet hr the English St. 12 Anne. c. 7 (passed in 1713, and now repealed), it was enacted that [quoting the statnte]; and hy 24 Geo. 2. c. 45 . a like provision was made [stating that statute in substance]. But it was early decided th: the first of these statutes did not extend to a stealing by one in his own house, nor to a stealing by a wife in hro husband's house. which is the same as her own. The intention of the statute was declared to be, to protect the owner's property in his own house from the depredation of others. or the property of others lodged in his house; thereby giving protection against all but the owner himself. It has also been decided that the property stolen must be such as is usually under the protection of the house, deposited there for safe custody, and not things immediately under the eye or personal care of some one who happens to be in the house. 2 East P. C. 644-646 : R. v. Gould, 1. Lueach (3d Ed.) 257 ; R. v. Thompson, 1 Leach 379 ; R. v. Camphell, 2 Leach 642 [below R. v. Taylor, Russ. \& Ry. 418 ; R. v. Hamilton, 8 C. \& P. $49:$ R. v. Carroll, 1 Mood. C. C. 89. And it has also been held that the St. 24 G. II. c. 45. does not extend to stealing bv the owner and master of a vessel. R. v. Hadox. Russ. \& Rv. 92. We are of oninion that the purpose and intent of St. 1804, c. 143, $\S 6$, and of the Rev. Sts. c. 126, 
$\$ 14$, were the same as the purpose and intent of St. 12 Anne, c. 7 , and that they must have the same construction which was given to that before these were enacted. Indeed, the attorney general frankly admits this, and that he cannot ask for sentence against the defendant, as for an aggravated larceny, unless it is required or warranted by St. 1851 , e. $156, \S 4$. We think that statute has not altered the law in this matter; that it has only made larceny "in any building." an aggravated offense, as former statutes made it when committed in certain enumerated buildings; and that it has not subjected to the pumishment therein prescribed any larceny which, if committed in either of those buildings, would not have been liable to such punishment. The statute was passed in consequence of the decision in C. v. White, 6 Cush. 181, that the passenger room of a railroad station was not an "office" within the meaning of Rev. St. c. 126, §14. Sentence for simple larceny. C. v. Hartnett, 3 Gray 450 . B. 701.

(Mrass. Sup. Judicial Ct., 1873.) Where Prisoner and Prosecutor Slept. On indictment and trial for stealing money from the dwelling-house of M., it appeared that Smith and G. slept in the same room: and that Smith got up at night when G. was asleep, took a key from G's breeches pocket, opened G's trunk, took the money charged in the indictment, and returned the key to the pocket. The defendant asked the court to rule that there was no evidence to convict of larceny from the building. The request was refused, the case left to the jury, and defendant found guilty. He excepted. GRAY. J. The indictment duly charges larceny in a building. The allegation that the defendant stole property in the dwelling-house described necessarily includes a statement that the act of stealing nas done in the building. And the whole charge was supported by the proof. In order to constitute larceny in a dwelling-house or other huilding, the property stolen must indeed be under the protection of the house, and not under the eve or personal care of some one who happens to be in the house. R. v. Owen, 2 Tseach (Ed. 3) 652, case 243: C. v. Hartnett. 3 Gray 450. 452. But money of a lodger in his trunk, as well as the key of the trunk in a pocket of his clothes, is clearly, while he is in hed. undressed, and asleep, not under his own protection, but under the protection of the house. R. v. Taylor, Russ. \& Rv. $418 ;$ R. v. Hamilton, 8 C. \& P. 49 . The defendant was therefore rightly convicted of larceny in a building. Exceptions ov'ermuled. C. v. Smith, 111 Mass. 429, B. 703.

(Eng. C. C. R., 1792.) Received to Change. On trial on indiet. ment for stealing a $£ 25$ bank-note from the dwelling-house of prosecutor, contrary to St. 12 Anne. c. 7, it appeared that prisoner had recently obtained lodgings at the house of prosecutor, representing that he was a major or colonel and well acquainted with her family, particularly her brother in the army at Gibralter; that when the overseer of the parish called for certain taxes, she handed him the 
bank-note in question, which he was not able to change; and so prosecutor sent it by the servant to defendant for change; who looked into his purse, and said he had not the change, but would get it; whereon he left the house with the note in his hand and did not return. The jury found the prisoner guilty, and the calse was reserved for the opinion of the judges, who held that it was not a capital offense within 12 Anne, c. 7 . The prisoner was transported for seven years. R. v. Campbell, 2 Leach C. C. No. 240 , C. 387.

(Mass. Sup. Judicial Ct., 1880.) Watch Handed to Customer. AMIS, J. In an indietment founded upon the Gen. Sts. c. $161, \S 15$, for larceny in a building, it is not enough to prove that the property stolen was in a building at the time of the theft. and that the defend. and was the thief. It is necessary to show also that the property was under the protection of the building, placed there for safe keen. ing, and not under the eye or personal care of some one in the build. ing. The watches in this ease were a part of the owner's stock in trade, usually kept by him in the building. But his testimony, which was the only evidence to the point. is to the effect that he was in charge of the property, when the defendant came in and asked to look at some watches, and that he handed the watches to the defendant; that he was not sure whether the defendant held the watches in his hand, or whether they were lying on the show-case; and that they were stolen while he turned partially round to place something upon the shelf behind him. If they were upon the show. case when stolen, it would be at least doubtful whether they must not, under the circumstances. be considered as rather in the possession of the owner than under the protection of the building. If by the act of the owner they were in the hands of the defendant. they certainly derived no protection from the building. is the evidence left it wholly uncertain whether they were on the showease or in the defendant's own hands. it did not warrant a convietion of larceny in a building; and the jury should have been so instructed. R. v. Camphell. 2 Leach No. 240 [above] ; R. v. Castledine, 2 East P. C. 645 ; R. v. Watson, 2 East P. C. 680,2 I Jeach 730 (Ed. 3) Case 262; R. v. Hamilton, 8 Car. \& P. 49, 50, note; C. v. Smith. 111 Mass. 429 [above]. Fxceptions sustained. C. v. Lester, 129 Mass. 101, B. 705 .

(Ga. Sup. Ct., 1874.) A Bail of Cotton was Stolen from an Alley by a Warehouse, and on indictment for "larceny from the house" the eourt instrueted the jury that "if they found from the evidence that the bail of cotton was in front of the warehouse and under its control and protection, it would be the same criminally as if within its walls." This was held error. Reversed. Middleton v. S., 53 Ga. 248, 5. L. 519.

(Tex. Sup. Ct., 1874.) Goods on Front of Store. REEVES, A.J. 
The only question in this case is presented in the brief for the state: "Is a" indictment for theft from the house, sustained by proof that the stulen property was taken while hanging at the outside of the store door on a piece of wood nailed to the door, facing and projecting towards the street?" * * "The idea of regarding the house at a place of security for the occupants, and a place of deposit for his goods, underlies all these statutes. * * 'The article under which the defendant was indicted is as follows: "If any person shall steal property from a house in such manner as that the offense does not come within the definition of burglary, he shall be punished by confinement in the penitentiary not less than two nor more than seven year's." Pas. Dig. Art. 2408. " * * We are of opinion that the groods were not under the protection of the house, so as to make the taking theft from a house in the meaning of the statute, and that the defendant was only liable to the punishment prescribed for simple theft. 'The goods were not deposited in the house for safe custody, but the witness says they were hanging out to attract customers or purchasers. 'The statutes of the states cited in the brief of counsel, in general, punish theft in a house, while other statutes referred to punish theft from a house, as does our code, and they seem to use these terms as meaning the same thing. A different rule would not admit of any definite application.

- Reversed. Martinez v. S., 41 'Tex. 126, 5 L. 517.

(Mlich. Sup. Ct., 1888.) Lodgings. CAMPBELL, J. Respondent was convicted of stealing from a dwelling-house in the daytime. ?'he only question raised is whether the building from which the theft took place was a dwelling. Mr. 'Tape, whose money was stolen, had a furnished room in the basement of a building, the upper part of which was in the daytime used by him and others as medical and other offices. At night he was the only occupant. He slept in the basement room. and had no other abiding place. Unless it is impossible for a single man to have a dwelling, we see no reason for holding that this room was not $\mathrm{Mr}$. Tape's dwelling. It was to all intents and purposes his home. It was precisely in its circumstances, like chambers in the inns of court, which have always been so treated. * * Affirmed. P. v. Horrigan, 68 Mich. 491, 36 N. W. 236.

(Mro. Sup. Ct., 1886.) Cellar. Under Mo. R. S. 1879, \$ 1309, which prescribes a penalty for larceny committed in a dwelling-house, an under ground cellar, lised for storing ice and beer, having no internal door of communication with the living-rooms in the upper stories of the same building. and not under the control and dominion of any occupant of the building, is not a "dwelling-house." $\mathbf{S}$. จ. Clark, 89 Mo. 423, 1 S. W. 332.

(MIo. Sup. Ct., 1888.) Hotel Office. It appeared that defendant stole certain goods from the office of an hotel kept by one 0. ; that 
the hotel was owned by, and the license to keep the same issued to, one D. Held, larceny from the dwelling-house of 0 . whether he paid rent or held by sufferance. S. v. Leedy, 95 Mo. 76,8 S. W. 245.

(Ala. Sup. Ct., 1890.) A Trunk Near the Door of a baggage-room on a platform, covered by the same roof, but not inclosed, which is used as a common passage-way by all going about the depot, is not in a warehouse within Code Ala. 1886, \$3789, punishing larceny therefrom. Lynch v. S., 88 Ala. 18, 7 So. 829.

\section{EMBEZZLEMENT.}

\section{$\$ 152$. In General.}

Statute, 39 Geo. III. (1799), c. 85. Whereas, bankers, merchants, and others, are, in the course of their dealings and transactions, frequently obliged to entrust their servants, clerks, and persons em. ployed by them in the like capacity, with receiving, paying, negociating, enchanging or transferring, money, goods, bonds, bills, notes, bankers' drafts, and other valuable effects, and securities; and, whereas, doubts have been entertained whether the embezzling of the sarne by such servants, clerks, and others, so employed by their master's, amounts to felony by the law of England, and it is expedient that such offenses should be punished in the same manner in both parts of the united kingdom; be it enacted and declared by the lking's most excellent majesty, by and with the advice and con. sent of the lords spiritual and temporal, and commons, in this pres. ent parliament assembled, and by the authority of the same, That if any servant or clerk, or any person employed for the purpose in the capacity of a servant or clerk, to any person or persons whomsoever, or to any body corporate or politic, shall, by. virtue of such employment, receive or take into his possession any moner, goods, bond, bill, note, banker's draft. or other valuable security, or effects, for or in the name or on the account of his master or masters, or employer or employers. and shall fraudulently embezzle, secrete, or make away with the same, or any part thereof, every such offender shall be deemed to have feloniously stolen the same trom his master or masters, employer or employers, for whose use or in whose name or names, or on whose account the same was or were delivered to, or taken into the possession of such servant, clerk. or other person so employed, although such monev, goods, hond, bill, note, banker's draft. or other valuable security was or were no otherwise received into the possession of his or their servant, c]erk or person so employed; and every such offender, his adviser. procurer, aider, or abettor, being thereof lawfully convicted or at. tainted, shall be liable to he trinsported to such parts beyond the seas of his majesty, by and with the advice of his privy coumcil, 
shall appoint, for any term not exceeding fourteen years, in the discretion of the court before whom such offender shall be convicted or adjudgred.

for the dlclsions whlch induced enuctment of thls and similar stututes, sies 130.

(Eng. C. C. R., 1809.) Money Supplied to Detect Thief. 'The prisoner was indicted and convicted of embezaling 3s., received on accomnt of his masters. It appeared in evidence that they supplied the money marked, to a neighbor, who bought articles at the shop with it, and defendant embezzled it. For the prisoner it was urged that the money was constructively in the possession of the masters, who parted with eustody only; wherefore the prisoner might have been convicted at common law for larceny. The judge, thinking the point worth considering, reserved it for the opinion of the judges. They held the conviction right, on the authority of Bull's Case, in which the judges had held a common law indictment not supported by similar facts. It seemed to be the opinion of the judges that the statute did not apply to cases which are larceny at common law. R. v. Headge, Russell \& R. 160, 2 Leach C. C. (Ed. 4) 1033, 13. 706, C. 401 .

(Eng. C. C. R., 1826.) Taking Bill to Change. On indictment of two counts for common law larceny: 1 , of a $£ 5$ note; 2 , of silver coins; property of 'T. \& G. Nevill: it appeared that the defendant being in the employ of T. \& G. Nevill, said T. gave him a $\$ 5$ note to get change; that he got the change, saying to the person who gave it that it was for said T. \& G.; and that he did not return with it. The jury found him guilty on the second count and not guilty on the first. On ease reserved, as to whether the indictment should not have been for embezzlement under 39 Geo. 3, c. 85; the judges held the eonviction wrong, becaluse the masters never had possession of the change. except by the hands of the prisoner. R. v. Sullens, 1 Moody 129, Carr. C. L. 319, C. 395, Ke. 320, Mi. 688.

(Eng. C. C. R.. 18:30.) Money Received from Another Servant to Pay Out. On indictment for emberylement from $A$, under St. 7 Geo. IV., c. $29, \S 47$, it appeared that the prisoner was in the employ of $A$, and received from another servant of $A \mathfrak{E} 3$ of $A$ 's money to pay (among other things) for inserting an advertisement in the Garette; and that he paid 10s. for the insertion, charged A 20 s. for it, and fraudulently kept the difference for his own use. After conviction on this proof, the court requested the opinion of the judges, as to whether the facts sustained the indictment. All the judges met and considered the case; and they thought the conviction wrong, becanse $A$ had possession by the hand of his other elerk, and so the case was not within the statute. R. v. Murray, 1 Moody 276,5 Car. $\&$ P. 145, C. 310 , Ke. 318.

(Fng. C. C. R., 1848.) Money Received from Another Servant to 
Pay In. On indictment for emberzlement, it appeared that the only duty of the defendant was to receive moneys from superintendent, make entry of account of the money so received, and pass it on to the cashier, thus acting as a check between them; and that the money in question came to his hands in due course and was fraudulently retained by him. For the prisoner it was objected, on anthor. ity of $R$. v. Murray, that the moneys had been in the master's pos. session before they were received by the prisoner, and so the charge of emberalement could not be sustained. The recorder left the cise to the jury, reserving the point. Verdict, guilty. POLLOCK, C. B. The court are unanimously of opinion that no further argment is necessiry. This case is quite different from that of R. v. Murray, 1 Mondy C. C. 276 [above]. 'T'here the case wils not within the Stat. $7 \& 8$ Geo. IV. c. $29, \S 47$, hecause the master had had possession of the money by the hands of another servant; and when it was given to the prisoner by that servant to be paid away on aceount of the master, it must be deemed in law to have been so given to the prisoner by his master; the fraudulent appropriation of it, being thus a tortious taking in the first instance, was not embezalement but lareeny, liut here the moner nerer reached the master at all; it was stopped by the prisoner on its way to him. 'l'he original taking was lawful, and therefore the frandulent alumo. priation was embeziement. Cresswell, Earle. BIaule, and Pattrison. Je., concurred. Conviction affirmed. R. v. Masters, 1 Den. C. C. 332. 3 Cox C. C. 178 , T. \& M. 1, 2 C. \& K. 930, 18 I. .J. m. c. 2, 12 Jur. 942. 3 New Sess. Cas. 326, C. 310, 395, Ke. 319, Mi. 689.

(Eng. Assi\%e, 1858.) By Debtor After Assignment. On indict-

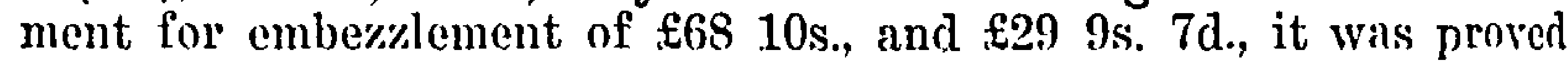
that the prisoner. a coal merchant, had made an assignment to proseeutors. of all his goods and accounts, as trustees for his creditors; and after making the assigmment, was employed by the trustees on a salary and conducted the business, and received the moneys men. tioned in the indictment in payment of book accounts existing before the assignment. and did not account for them. BYIAS, .J.. held that he was not in point of law a servant, agent, nor elerk; that the money was his own in law, a chose in action being assignable only in equity ; and that the trustees conld sue for the accounts only in the name of the assignor. Therefore the indictment could not he sustained and the prisoner was discharged. $R$. v. Barnes, 8 Cox C. C. 129, B. 710 , C. 394 .

(Mass. Sup. Judicial Ct., 1859.) Taking Over-payment, Given by Mistake. Indictment of two counts; one for simple lareeny. the other under St. 1857 , c. 233 ; which provides. that "if any person to whom any money, goods, or other property which may be the subject of lareeny. shall have been delivered. shall embe\%le. or fraudulently convert to his own use." etc.. such money, he shall be 
deemed to have committed lareeny. Defendant had a deposit in a savings bank, and took his pass-book to draw the aceount. The banker halaneed it and handed it out to him, showing a balance of $\$ 130$ due him. 'The banker testified, and the jury found, that he paid over $\$ 230$, by mistake giving $\$ 100$ more than was clue, that defendant comnted it and then left the bank; that, after he had gone the banker discovered the mistake, found him, and demanded return of the excess; and that he denied receiving more than $\$ 130$, and refused to refund any. On the direction of the court that this would make him liable under the indictment, the jury found him guilty; and he excepts. BIGELOW, J. The statute under which this indictment is found is certainly expressed in very general terms, which leave room for doubt as to its true construction. But interpreting its language according to the subject matter to which it relates, and in the light of the existing state of the law, which the statute was intended to alter and enlarge, we think its true meaning can be readily ascertained. 'The statutes relating to emberzlement, both in this country and in England, had their origin in a design to supply a defect which was found to exist in the criminal law. By reason of nice and subtle distinctions. which the courts of law had recognized and sanctioned, it was difficult to reach and punish the fraudulent taking and appropriation of money and chattels by persons exercising certain trades and necupations. by virtue of which they held a relation of confidence or trust towards their employers or principals. and thereby became possessed of their property. In such eases the moral guilt was the same as if the offender hatd been guilty of an actual felonious talking: but in many cases he eould not be eonvicted of lareeny. because the property which had been fraudulently converted was lawfully in his possession by virtue of his employment, and there was not that technical taking or asportation which is essential to the proof of the crime of larceny. R. v. Bazeley, 2 Leach (4 ed.) 835. 2 East P. C. 568 [\$130]. * * * Where money paid or property delivered through mistake has been misappropriated or converted by the party receiving it, there is no breach of a trust or violation of a confidence intentionally reposed by one party and voluntarily assumed by the other. The moral turpitude is therefore not so great as in those cases usually comprehended within the offense of embezzlement, and we cannot think that the legislature intended to place them on the same footing. We are therefore of opinion that the facts proved in this case did not bring it within the statute, and that the defendant was wrongly convicted. Fxceptions sustained. C. v. Hays, 14 Gray 62, $74 \mathrm{Am}$. Dec. 662. B. 711, C. 407, F. 297, Kn. 270.

Compare charge of larceny on similar facts: IR. w. Mifldleton. \& 134.

(Mass. Sup. Judicial Ct., 1868.) Messenger with Money. Defendant was convicted of embezaling $\$ 950$ from his employers. He was a teamster. and received the money from his employers at their warehouse in Boston to take to their factory in Sonth Boston. He 
did not deliver the package, but left the state, and did not return for several weeks. He excepted to the refusal of the court to instruct the jury that if any crime was shown it was lar'eny not embezzlement. IIOAR, J. * * "If the goods are not in the actual or constructive possession of the master, at the time they are taken, the offense of the servant will be embezzlement, and not larceny." We see no reason why the converse of the proposition is not true, that, if the property is in the actual or constructive possession of the master at the time it is taken, the offense will be lareeny, and not embez\%lement. And it has been so held in England. * * * In the present case, the defendant, who was employed as a servant, was directed by one member of the firm who employed him to take a sum of money from him to another member of the firm. He had the eustody of the money, but not any legal or separate possession of it. The possession remained in his master. His fraudulent and felonious appropriation of it wats therefore lareeny, and not embezzlement. C. v. O'Malley, 97 Mass. $58 \pm\lfloor \$ 129\rfloor$; C. v. Hays, 14 Gray 62 [above]; P. v. Call, 1 Denio 120; U. S. v. Clew, 4 Wash. C. C. 702. * Exceptions sustained. C. v. Berry, 99 Mass. 428, $96 \mathrm{Am}$. Dec. 767, B. $714, \mathrm{Kn} .273$.

(Mlich. Sup. Ct., 1886.) Failure to Pay. Rewpondent, a lawyer, and loan and land agent, was convicted of embiraling $\$ 275$ of Mrrs. Smith. She went to him to have him loan money fur her. He made two loans for her and showed her a letter from a man who had 40 acres to sell, and told her he knew who would pay more for it than the man asked, and desired to buy it himself to make the difterence. She let him have $\$ 400$, saying he could have the profits. Later she saw him at his house intoxicated, clemanded the money, obtuined $\$ 100$ and a chattel mortgage for $\$ 25$. Later she dumned him frequently and obtained other' security for the balance. 'The ember/ement is charged as of the clay she gave him the money. 'The supreme court held there was no proof of embezzlement, whatever wrong had been done; because a debt was admitted and recognized on both sides, he acted candidly, and there was no indication of intent to chent or deceive. Conviction quashed. P. v. Hurst, 62 Mich. 276, 28 N. W. 838, B. 716.

(Eng. C. C. R., 1854.) Wrongful Use of Master's Property to Farn the Money Appropriated. Harris was the miller in the county jail, and it was his duty to grind grain given with written orders or tickets from the governor of the jail, receive the money for the grinding, and account; but he had no right to orrind without such orders. On indictment for embezzlement it was shown that he ground grain received without such orders, took pay for it, and appropriated the money. On case reserved the judges were all of opinion that the conviction could not he supported; because it ap. peared that the prisoner had no right to grind for his master with. 
out written orders, and the conclusion is that as to all the corn ground without a ticket, he intended to and did make improper use of the machinery for his own benefit, and so received the money on his own account and not on account of his master. Conviction quashed. R. v. Harris, 6 Cox C. C. 363 , Dears. C. C. 344,2 C. L. R. 464,23 L. J. m. c. $1.10,18$ Jur. 408, 2 W. R. 413 , C. 397.

(Eng. C. C. R., 1873.) Same. 'The prisoner was indicted and convicted of embezzling \pm 2 , the property of his employer; and the proof was that he operated a barge for half the net earnings of it, under the orders of the owner; and having gone to London with a load of bricks, met the owner there and proposed taking back a load of manure for Mr. Pye; but the owner expressly forbade it, and ordered him to return empty. Nevertheless, he took the manure, received $\& 4$ for doing so, and kept all of it. BOVILL, C. J. In the former act relating to this offense were the words " by virtue of his employment." 'I'he phrase led to some difficulty ; for example, such as arose in R. v. Snowley and R. v. Harris [above]. Therefore in the present statute those words are left out, and $\$ 68$ requires instead that in order to constitute the crime of embezzlement by a clerk or servant the "chattel, money, or' valuable security * * * shall be delivered to or received or taken into possession by him, for or in the name or on account of his master or employer." Those words are essential to the definition of the crime of embezzlement under that section. The prisoner here, contrary to his master's order, used the barge for his, the servant's own purposes and so earned money which was paid to him, not for his master but for himself; and it is expressly stated that there was no proof that he professed to carry for the master. and that the hirer at the time of paying the money did not know for whom he paid it. The facts before us would seem more consistent with the notion that the prisoner was misusing his master's property and so earning money for himself and not for his master. Under those circumstances the money would not be received "for" or "in the name of" or "on account of" his master but for himself, in his own name, and for his own account. His act therefore does not come within the terms of the statute, and the conviction must be quashed. * * * The other judges (Blackburn, Honyman, and Archibald, JJ., and Bramwell, B.) concurred. R. v. Cullum, L. R. 2 C. C. R. 28,42 L. J. m. c. 64.28 L. T. 571,21 W. R. 687,12 Cox. C. C. 469 , B. 707 , C. 398 , Ke. 311 , Mi. 839.

(Ala. Sup. Ct, 1888.) Mail Carrier as Agent. SOMERviLIE. J. The record shows that the defendant was convicted of embezzling money which was alleged to have come into his possession by virtue of his employment as agent or servant of one Rainer. which is made punishable by the statute as if he had stolen it. Code (1886) $\$ 3795$. * * The evidence showed that in Sept., 1886, Rainer had sent 
the sum of $\$ 395$ in a registered letter, from a postoffice in Choctaw county, to Cuba station, another postoffice in Sumter county, through the mail service of the United States government. 'The defendant was then mail-rider between these two points, and the evi. dence tends to prove that, while thus engaged, he appropriated the money, by falsely converting it to his own use. In our opinion, the defendant, under these circumstances, was not the agent or servant of Rainer, who could in no sense be said to be his principal or em. ployer. He was not in the service of Rainer, but of the United States government, from which he received his appointment, and by whose official authorities only he was liable to be removed or de. posed. The term "agent or servant," as used in the statute, imports the correlative idea of a principal, or master, and "implies employ. ment-service, delegated authority to do something in the uame or stead of the principal-an employment by virtue of which the money or property came into his possession." Pullam v. S., 78 Ala. 31; Code (1886) § 3795; 2 Bish. Crim. L. (7 Ed.) \$§ 352-354. *** Reversed. Brewer v. S., 83 Ala. 113, 3 So. 816, 3 Am. St. Rep. 693.

(Ohio Sup. Ct., 1888.) By Manager and Shareholder in Unin. corporated Society. On indictment for embezzlement the stite ex. cepted to an order of the trial court directing the jury to return a verdict of not unuilty. The proof was that defendant was a share. holder, and had been elected agent and cashier, of an unincorpo. rated society, engaged in a general banking business, having a paid up capital of $\$ 23,000$; that by virtue of his employment he reccived $\$ 28,000$ in money, notes, checks, etc., the assets of the society; which he fraudulently converted to his own use. OWEN, C. J.

It is not necessary to a solution of the question before us that we define or discuss the relation which this association or its memhers sustain to creditors, or whether that relation is that of partners. No rights of creditors intervene here to complicate the question. The only proposition calling for a solution is whether Kusnick's re. lation to the assets of this association was such that they were sub. ject to embezzlement at his hands. It is true that at the common law, to constitute larceny, the thing alleged to have been stolen must be shown to be the "property of another" person than the offender. It is also true that the statutes of nearly all the states which undertake to define embezzlement require that the subject of the offense shall be shown to be the "property of another;" and this has almost universally been construed to mean that it must be wholly the prop. erty of another. It has resulted that. as a rule. a member of an ordinary partnership conld not be convicted of embezzlement of part. nership property. The same rule has been applied in this respect as in the case of larceny. An act passed March 15, 1867 (66 Ohio L. 29), seems to have been framed upon this theory. It provided that if any clerk, agent, or servant of any private person, or of any corporation or co-partnership, shall embezzle or convert to his own 
use uny money, goods, rights in action, or valuable security or effects belonging to any other person or persons, etc., which shall come to his possession or care by virtue of such employment, etc., shall be punished as for larceny, etc. This peculiar element of this offense seems, however, to have been eliminated from our law by the enactment under which the present indictment was framed. It simply provides that an agent, etc., who embezzles or converts to his own use "anything of value which shall come into his possession by virtue of his employment" shall be punished as for larceny of the thing embezzled. 'The words "property of another" are omitted. The element of exclusive ownership by another person is wholly eliminated, and the test of the crime is that the property converted shall come to the hands of the offender by virtue of his employment as agent, etc. If we are to have regard to the plain provision of this statute, the fact that an agent who converts the assets of an association to his own use may be interested in them is not by that fact to be permitted to say that he is the owner of them, and cannot be held to answer for converting the "property of another." The general ownership was undoubtedly in the association. It was clearly established in the trial below that by the articles of association, to which the defendant became a party, and under which he was chosen its agent and cashier, he had no right by reason of his relation as a shareholder to the possession of a dollar of its assets. If it had been within the intent of the members of the general assembly to declare that the very act with which the defendant was charged should constitute the crime of embezzlement, they could not easily have chosen more appropriate language. If this language be accepted at its palpable import, it may, without violence or any strained construction, be held as intended to prevent a mere shareholder in a private business association, who is made its sole manager and the sole custodian of its property, converting to his own use its entire capital and assets, by declaring such conversion to be a crime. The law of embezzlement is statutory. The offense was unknown to the common law. The statutes on the subject differ in the different states. It has been well observed by Bishop ( 2 Cr. L. \$ 326): "Seeing that the statutes are numerous, and in some respects diverse in their provisions, the practitioner should be catttious about coming to conclusions upon a question under the law of embezzlement, unless, when he examines a decision relied upon, he first sees whether the statute on which it was rendered is, in its terms, the same with the one of his own state." Griffin v. S., 4 Tex. App. 390, 409. The cases cited in support of the action of the court below, when subjected to this test, fail to meet the question involved. The case of S. v. Kent, 22 Minn. 41, upon which most reliance is placed, arose upon a statute declaring the conversion by an agent, etc., of "any money or property of another" which had come to his possession by virtue of his emplcyment, to be a crime. The case turns upon the words above quoted. The facts which the 
indictment charges, and which the evidence below tended to establish, considered in the light of the statute under which the prosecution was had, leave no place for the application of the familiar fiction that the interest of a partner in and his dominion over the firm property is such that he cannot be guilty of lareeny or embezzlement by converting it to his own use. *** Exceptions sus. tained. S. v. Kusnick, 45 Ohio St. 535, 15 N. E. 481, 4 Am. St. Rep. 564.

As to larceny of property in whlch the thlef has an interest, see $\$ 136$.

\section{RECEIVING STOLEN GOODS.}

\section{$\S 153 . \quad$ The Statutes.}

Statute 3 William \& Mary (1691), c. 9, §4. And for as much as thieves and robbers are much encouraged to commit such offenses, because a great number of persons make it their trade and business to deal in the buying of stolen goods; be it therefore enacted by the anthority aforesaid, That if any person or persons shall buy or receive any goods or chattel that shall be feloniously taken or stolen from any other person, knowing the same to be stolen, he or they shall be taken and deemed an accessary or accessaries to such felony after the fact, and shall incur the same punishment as an accessary or accessaries to the felony after the felony committed.

Statute 7 \& 8 Geo. IV. (1827), c. 29, § 54. With regard to receivers of stolen property, be it enacted, That if any person shall receive any chattel, money, valuable security, or other property whatsoever, the stealing or taking whereof shall amount to a felony, either at common law, or by virtue of this act, such person knowing the same to have been feloniously stolen or taken, every such re. ceiver shall be guilty of felony, and may be indicted and convicted either as an accessary after the fact, or for a substantive felony.

\section{§ 154. "Receive."}

(Eng. Old Bailey, 1834.) Without Bargain or Profit. Four were indicted for stealing from St. Philip's chapel, and one for receiving the goods. As to the last, TAUNTON, J., said to the jury: Whether he made any bargain or not is a matter of no consequence. If he received the property for the mere purpose of concealment without deriving any profit at all he is just as much a receiver as if he had purchased it. It is a receiving within the meaning of the statute. R. v. Richardson, 6 Car. \& P. 335, B. 758, C. 465.

(Mass. Sup. Judicial Ct., 1875.) Same. Complaint under Gen. St. c. $161, \S 43$, for receiving a pair of eye-glasses, knowing them to 
have been stolen. The evidence tended to show, and defendant asked the court to charge that if defendant received them from the thief as a mere friendly act, to aid him in concealing them, and without any benefit or intent to receive benefit on his part, he could not be convicted. The court instructed that the motive was immaterial if he received them knowing them to have been stolen and to aid in concealing them. Verdict, guilty. Defendant excepted. ENDICOT', J. The statute provides that whoever receives or aids in the concealment of stolen goods, knowing the sume to have been stolen, shall be punished. Gen. Sts. c. 161, \& 43 . The ruling at the trial was correct. There was evidence that the defendant received the eye-glasses from Daniels, knowing them to have been stolen, and aided Diniels in their concealment. That he did this as a friendly act to Daniels without any benefit or intent to receive benefit himself is immaterial. Exerptions overruled. C. v. Bean, 117 Mass. 141, C. 465.

(Eug. Assize, 1844.) Taking from Thief's Deposit. Leigh was indicted for receiving stolen goods, knowing them to be such. Wade and Kenyon stole the goods, buried them in a cellar near Leigh's house, told him where to find them, and he had his wife get and take them to a pawnshop. POLLOCK, C. B. I doubt whether, when the possession has been transferred by an act of larceny, the possession can be considered to remain in the owner. Were it so, then every receiver of stolen goods, knowing them to be stolen, would be a thief; and so on, in series from one to another, all would be thieves. If this was an act done by the prisoner (Leigh) in opposition to Wade, or against his will, then it might be a question whether it were a receiving. But if Leigh took the articles in consequence of information given by Wade. Wade telling Leigh in order that the latter might use the information by taking the goods, then it is a receiving. Verdict, guilty. R. v. Wade, 1 Car. \& K. 739, B. 758 , C. 441, F. 314 .

(Eng. C. C. R., 1850.) Taking Thief with Goods into House to Bargain for Them. Strangham, Williamson, and Wiley were jointly' indicted for stealing and receiving 9 ducks; contrary to $8 \mathrm{G}$. 4, c. $20, \S 5 t$, and the first two were convicted of stealing, and Wiley of receiving them. On case reserved. it was twice argned as to whether the evidence showed a receiving by Wiley, and after consultation and deliberation the judges delivered their opinions seriatim. MARTIN, B. *** Now, the question is, What is the meaning of the word "receive" as applied to the facts of this case? I' understand the facts to be these: Two men stole some fowls, which they put into a sack, and carried to the house of Wiley's father, for the purpose of selling them to Wiley. All three went together from the house to an outhouse; the bag was carried on the back of one of the thieves; and when the policeman went in, the 
sack was found lying on the floor unopened, and the three men around it as if they were bargaining, but no words were heard. Now, I am of the opinion that Wiley, under those circumstances, never did receive those fowls. * * 'IALFOURD, J. I am also of opinion that this conviction is wrong. 'I he rfuestion turns on the word "receive" as applied to the facts of this case; and it seems to me that the magistrate gave an improper alrection to the jury on that subject, because he told them that the taking by Wiley of the two thieves with the stolen goods in the manner stated, to a stable over which he had control, for the purpose of traticicing as to the purchase of the stolen property, was a receiving within the statute; and I think it was not. 'The persons asserting the right of possession at that time were the two thieves; and the position of Wiley, as a person negotiating for the purchase, excludes the idea of his having any possession. There was still for him a locus penitentia; he might still have determined not to take the fowls; and the whole matter was, I think, inchoate and incomplete. PARKE, B. * * * The only question is, whether by letting the thieves with the goods into the stable, he received the goods. I think that there must be a receiving of the groods into possession as distinet in some way from the receiving of the thief; and that the receiving of the thief with the goods into a house is not a receiving of the goods within the statute, in a ease like this, any more than it would be in the case of a thief received into a house with a stolen watch in his pocket. [Alderson, B., Patteson, J., Coleridge, J., Manle, J., and Platt, B., read similar opinions.]

ERLE, J. I am of opinion that the conviction was right on two grounds: 1, Upon the facts found and left to the jury, I think that Wiley co-operated with the thieves in removing the stolen property from the house to the stable, which was under his control, for the purpose of more securely bargaining and evading the officers of the law. If Wiley had actually taken part in carrying the goods, I believe in the minds of many of the judges there would be no doubt that he had had a joint posses. sion with the thieves, which would be sufficient to convict him of the present charge; and as he accompanied them, and lighted them to the stable, I think he did co-operate with them in transporting the goods as much as if he had helped to carry them. I found my opinion on the law, which has often been laid down, that where goods are stolen, and the removal from the owner's premises is complete, and the thief afterwards procures somebody to assist him in removing them again to a place of greater security, the person who so removes them is not liable to be convicted of larceny, because by the first removal the larceny was complete. A person who so co. operates is certainly a criminal within the intention of the law, and I think that the law is strong enough to reach him as a receiver of stolen goods. That is one ground of my opinion; but $I$ also attach a wider meaning to the word "receive" than some of my learned 
brother's are disposed to give to it. It appears to me that, with reference. to acts of felonious receiving or taking, the rules of the civil law relating to possession have no application. Originally the person who received and assisted a thief, after he had committed a larceny, was held to be an accessary after the fact; but then several statutes were passed, in conseguence of the imperfect state of the law, which only rendered a person punishable who harbored the thief. By those statutes the gruilty reeeipt of the stolen property was nude punishable; and I think that the word "receive," as applied to the goods, ought to be construed with reference to the other offense of harboring the thief. If a man harbors a thief with a view in any way to assist his escape, he is guilty; and so, I think, if he harbor's the groods for the purpose of assisting the thief, he is guilty of a felonions receiving within the meaning of the statute. If the owner of a stable anthorizes thieves to deposit in that stable stolen goods, he is guilty of receiving them. That proposition by itself would probably not be contested; and I think that, if he authorizes the thieves to go into the stable with the stolen groods, he is not the less a receiver because the thieves stay with the property. The earlier statutes clearly did not contemplate a bargain or consent to the trinsfer of the stolen property as essential to the offense of receiving; for both in the 29 Geo. II. (. 30, and 2 Geo. III. c. 28 , the crime of receiving is expressed thus: "Every person who shall privately buy or receive any stolen laal, etc.. by suffering any door, window, or shutter to be left open or unfastened between sun-setting and sum-rising, for that purpose:" so that the offense there enntemplated involved no communication with the thief at all after he had possession of the stolen groods, but applied to the practice of leaving open a place of deposit previonsly known to the thieves. Such a case is certainly within the mischief of the statute; and in 2 East P. C. 765 it is expressly laid down "that in order to constitute a receiver, generally so called. it is not necessary that the goods should be actually purchased by him; neither doess it seem necessiry that the receiver should have any interest whatever in the goods; it is sufficient if they be in fact received into his possession in any manner malo animo, as to favor the thief. **** * [Lord Camphell, C. J., and Williams and Cresswell. J.J.. also read dissenting opinions.] Conviction reversed. R. v. Wiley, 4 Cox C. C. 412. 20 I. J. m. c. 4, 15 Jur. 134, 2 Den. C. C. 37, T. \& M. 367, 1 Eng. L. \& Eq. 567, 1 B. \& H. 582. C. 445 , Ke. 361,5 L. 643 , Mi. 895.

(Ir. C. C. R., 1854.) By Servant. On conviction of receiving stolen goods, it appeared on case reserved, that Ellen Connors stole goods and brought them to defendant's shop, who ordered her servant to take them to a pawn shop, return with the monev, and give it to Connors, which was done. LEFROY, C. J. * * * It appears to us that it was virtually a receiving by Mary Miller, inasmuch as her servant, by her order and direction, received the goods 
from the thief, took them to the pawn office, and brought back the money to the thief. This, in our opinion, was virtually as much a receiving of stolen goods as if her own hand, and not that of her servant, had received them. No question can be raised in this ease involving the neeessity of those subtle distinctions taken on former occasions, with respect to the continuance of the possession of the goods in the thief, for the goods here were elearly transferred to hands which were virtually those of Mary Miller herself. No question has heen reserved relative to the sufficiency of the evidence of guilty linowledge. * * Affirmed. R. v. Miller, 6 Cox C. C: 353, 13. 759.

(Eng. C. C. R., 18\%5.) By One Under Control of Accused. Simith was convicted of receiving a watch knowing it to have been stolen. The evidence was that prosecutor and a woman went to a public drinking house where Smith and five or six others were; that prosecutor heard the ring of his watch click. immediately missed the Watch. and aceused smith of taking it; that a policeman wals called, and partial seareh made withont success; that an hour later Smith came to the room where prosecutor and the woman were, and asked how much he would give for return of the witeh. was told $€ 1$. and took the woman with him to his room to gret it: where she foumd II, who was at the drinking house, shortly saw the watch on the table, thought it must have been put there by II.. and that it was not there when she entered. It was eontended that there was no prof of possession by Smith. The recorder told the jury that if Smith knew the watch was stolon, that II. had it, that Smith conld malie him deliver it, and had absolute eontrol over him. they would he justified in finding him gruilty. IJORD CAIIPBBSLL, C. .J. I think that conviction was right. In the first place the direction of the learned recorder was unexceptionable. According to the drecided cases as well as to the dicta of learned judges, manual possession is unnecessary. If we were to hold a contrary doctrine. many re. ceivers must escape with impunity. Then it has been held in de. cirled cases, including R. v. Wiley, 2 Den. Cr. Ca. 37 [above], that there may be a joint possession in the receiver and the thief: that is the ratio decidendi on which the judgment in that case proceeds. Then, was not there ample evidence to justify the jury in eoming to the conclusion at which they arrived? I think there was.

[Alderson. B.. Crowder, .J.. Fr]e. J.. and Platt. B.. expressed similar opinions.] Conviction affirmed. R. v. Smith, Dears. 494. 6 Cox C. C. 554,24 Ts. T. m. c. 135,1 Jur. n. s. 575,3 W. R. 484,33 Fing. L. \& Fq. 531. B. 760. 1 B. \& II. 576. C. 442.

(Eng. C. C. R., 1862.) Ratification of wife's Act. Conviction of receiving stolen goods on proof that the wife paid the thief $6 \mathrm{~d}$. on receint of the goods in absence of the husband, who afterwards met the thief and agreed on and paid the balance. BI ACKBURN, J. 
The principal felon left the stolen property with the wife as the husband's servant, but the court below, as I understand the case, doubted whether the husband could be found guilty of feloniously receiving, as he was absent at the time when the goods were delivered to the wife, and could not then know that they were stolen. It is found that, as soon as the husband heard of it, he adopted and ratified what had been done, and that as soon as he adopted it he had a guilty knowledge; he therefore at that time received the goods knowing them to have been stolen. KEATING, J. I am of the same opinion. 'The case finds that the agreement as to the price was not complete till the thief and the husband agreed. I think therefore that the receipt was not complete till then, and that the convietion was right. If we were to hold that the conviction was not right, the consequences would be very serious. WILDE, B. I read the case as showing that the wife received the goods on the part of the prisoner, her husband, and that act of liers was capable of being ratified on the part of the prisoner. If so, that makes the first act of receiving by the wife his act. * * * [Mellor, J., concurred, and Erle, C. J., gave a concurring opinion.] Conviction affirmed. R. v. Woodward, 9 Cox C. C. 95 . L. \& C. 122.31 L. J. m c. 91.8 Jur. n. s. 104,5 L. T. 686,10 W. R. 298 , B. 763 , C. 457 , Ke. 364 , Mi. 898.

That the Intent must exist at the time of the net to muke it irfminal, $\$$ s 141.2 (as to larceny), $\mathbf{3 6}$.

(Ark. Sup. Ct., 1894.) To Hold for Reward. Baker was convicted of receiving stolen gonds and appealed. He contended that conviction of receiving stolen goods could not be sustained without proof. that he intended to deprive the owner of the specific stolen property received by him: and the fact that he sought to get money as a condition to the return of the property is not sufficient. But the court held that if the jury believed from the evidence, as they well might, that he concealed from the owner the fact that he had the property, intending to defraud him into paying a reward for it, the offense under the statute was made ont. citing $R$. v. O'Donnell, 7 Cox 337. Mi. 815; C. v. Mason, 105 Mass. 163 [\$ 143] ; Berry v. S.. 37 Ohio St. $227[\$ 1+3]$. Affirmed. Baker v. S., 58 Ark. 513, 25 S. W. 603.

Arc. P. v. Wileg, 3 nill (N. Y.) 194. C. 438, Mi. 804.

\section{\$155. "That Shall Be Feloniously Taken or Stolen."}

(Eng. C. C. R.. 1855.) Owner Has Thief Sell. Rogers was indicted for stealing and Dolan for receiving a brass casting. the goods of Turner. Rogers pleaded guilty and Dolan was convicted. Turner found the goods in the pockets of Rogers, the thief: and when they were given up. the policeman and Turner thought they might catch the receiver of such goods hy returning them to the thief to be sold, which was accordingly done. Rogers took them by Turner's direc- 
tion to Dolan's shop, and grave the money to Turner. On these facts it was contended by counsel for Dolan and held by the court, that the conviction of Dolan could not be sustained; because the goods ceased to be stolen goods within the meaning of the statute when the owner resumed possession, and because the thief acted as his agent in making the subserpuent sale. Before Lord Camplell, C. J., Coleridge, Cresswell, and Williams, J.J, and Platt, B. Conviction quished. R. v. Dolan, 6 Cox Cr. Cas. 449, Dears. 436 , B. 765, F. 316, 5) L. 658.

(U. S. D. C. for E. Dist. of Wis., 1875.) Ordered by Owner to Forward. The postoffice at Unionville, Mo., was broken into and stamps to amount of $\$ 150$ taken and enclosed in parcel addressed to DeBare at Milwaukee, but the robber being detected and arrested at Quincy, Ill., gave an order to the postmaster there on the express office at Milwankee, by which that postmaster obtained possession of the parcel; after which the U. S. authorities ordered him to enclose them in the same wrapper and send them forward as first directed. This was done. and the parcel was received by defendimt. On these facts Crawford was convicted of receiving stolen goods. He moved for a new trial. DYER, J. * * * The ownership of these stamps was in the United States. 'The Quiney postmaster was an agent of the owner. When Crawford surrendered them to this agent they were reclaimed property that had been stolen. but their character as stolen property ceased in the hands of the postmaster, so far as the subserpuent receiver was concerned. The moral turpitude of a receiver under such cireumstances may be as grent as in case the property comes directly from the hands of the thicf, because the criminal intent on his part exists equally in both cases. But to ereate the offense which the law punishes, the property when received must, in fact, and in a legal sense, be stolen property. If these stamps were received by the defendant, they did not, when received, upon the proof made. hear this character. They hat heen captured from the thief by the owner, and the act of forwarding them to the alleged receiver was the act of the owner.

Notion for new trial granted. U. S. v. DeBare, 6 Biss. 358, Fed. Cas. No. $14,935 \overline{0}$, C. 426,5 L. 662 .

(Ning. C. C. R. 1866.) Same. Passengers left luggage at the Arundel station on the Brighton Ry., which was soon stolen; and the next day a parcel deposited at another station on the same line. for delivery to F. Schmidt. Brighton, was discovered to contain part of the goods stolen. The porter in charge of the Brighton station was ordered not to deliver it till further notice; and, knowing :t was there. told one who called for it that it had not arrived. Next morning he took it to the place addressed, asked defendant if her name was Schmidt; and being told it was. left the parcel with her. in the absence of her husband. Then a policeman went to the house. found the bundle unopened, and arrested the prisoner. On con- 
viction, the question was reserved as to whether the goods received by her had lost their stolen character. MELLOR, J. I agree entrrely with my brother, Erle, C. J., and think the conviction was right. The indietment rightly alleges the property to have been in the railway company at the time it was stolen; they had the bailment of it from the true owner. 'Then it is stolen while in their custody, and the next step is, the thieves afterwards send a portion of it by the same railway company to be forwarded to the receiver at Brighton; so that the railway company get possession of this part from the thieves under a new baiment. 'Then the policeman examines the property and directs it not to be forwarded until further orders; but this was not done with the view of taking possession of it or altering its transit, but merely to see whether it was the stolen property. I agree with Dolan's case labove], but in the present case I think the stolen property had not grot back to the true owner. KELTING, J. * * It screms conceded, on the authority of Dolan's case, that if the property had got back again for any time into the hands of the true owner, the conviction would be wrong. It is said that, in this case, the owners mentioned in the indictment, the rililway company, were not the real owners, whereas in Dolan's case [above] the real owner intervened. But I think there is no distinction in principle between this case and that. The railway company are alleged in the indictment to be the owners of the property, and we sitting here can recognime no other. $* * *$ LUSH, J. I agree with my brothers, Martin, B., and Keating, J., and think that the eonviction was wrong. I think that the goods had got back to the owner from whom they had been stolen. Had the railway company innocently carried the goods to their destination and delivered them to the prisoner, the felonious receipt would have been complete; but while the goods are in their possession, having been previously stolen from them, the goods are inspected, and as soon as it was discovered that they were the goods that had been stolen. the railway eompany did not intend to carry them on as the agents of the bailor; the forwarding them was a mere pretense for the purpose of finding out who the receiver was. It was not competent. to the railway company to say, as between them and the original bailor, that they had not got back the goods. They were bound to hold them for him. In afterwards forwarding the groods to the prisoner, the company was using the transit merely as the means of detecting the receiver. The similar opinions of Frle, C. J., and Martin, B., are omitted.] Conviction quashed. R. v. Schmidt, 10 Cox C. C. 172 , L. R. 1 C. C. R. 15,35 I. J. m. c. 94.12 .Jur. n. s. 149 , 13 L. T. 679,14 W. R. 286 , B. 769 , C. 421,5 I. 653 , Mi. 885. 


\section{§ 156. "Knowing the Same to be Stolen."}

(Eng. Assize, 1859.) What Knowledge. Indictment for receiving the queen's lead, knowing it to be stolen. BRAMWELL, B. (to the jury). The knowledge charged in this indictment need not be such knowledge as would be acquired if the prisoner had actually seen the lead stolen; it is sutficient if you think the circumstances were such, accompanying the transaction, as to make the prisoner believe that it had been stolen. Guilty. R. v. White, 1 F. \& F. 665, B. 778, C. 469 .

(Mass. Sup. Judicial Ct., 1886.) Same-Embezzled or Stolen. Defendant was convicted of receiving old iron, knowing it to have been stolen from the Boston \& I. Ry. Co.; and excepted. FIEID, J. * * * The offense of receiving stolen property, knowing it to have been stolen, must be considered as distinct from the offense of receiving embezzled property knowing it to have been embez/led, Pub. Sts. c. 203, $\S \S 48,51$, although embezzlement under our statutes has been held to be a species of larceny. C. v. Pratt, 132 Mass. 246. The punishments of the two offenses may be different, as the offense of receiving embezzled goods may be punished by a fine without imprisonment. If the property had actually been stolen, a belief on the part of the defendant that it had been stolen is tantamount to knowledge. If the defendant knew all the facts and the facts constituted larceny as distinguished from emberzlement, it would be no defense that the defendant thought that the facts constituted embezzlement. If the defendant did not know the facts, but be. lieved from the circumstances that the property had been either cmbezzled or stolen, and it had been actually stolen. it was competent for the jury to find the defendant guilty of the offense charged. The second request for instructions was therefore rightly refused. * * Exceptions sustained. C. v. Leonard, 140 Mass. 473. 4 N. E. $96.54 \mathrm{Am}$. Rep. 485 , B. 778 , C. 466.

(Ill. Sup. Ct.. 1890.) Proof of Knowledge. Conriction of knor. ingly receiving a stolen ring was held supported and warranted br evidence that defendant knew the value of such property. purchased it for one-fourth of its value. from an ex-convict, denied having received it, lied as to how he had disposed of it when it was shown that he had had it, and finally offered to produce it for a reward and produced it when arrested. Judgment affirmed. Huggins v. S., 135 Ill. 243. 25 N. E. 1002.25 Am. St. Rep. 357.

(Miss. Sup. Ct., 1889.) Same. A conviction for receiving car brasses, knowing them to be stolen. was upheld where it appearel that defendant, a junk dealer, after the theft, in an interview with some of the railroad company's emplovees and the chief of police. denied all knowledge of the brasses, which were marked with the 
company's initials; that afterwards these brasses were discovered jabeled with defendant's shipping mark, who then acknowledged that he had shipped them; and that the foreman of the railroad company's shops nad warned defendant not to buy any car brasses, as some had been missing from time to time. Affirmed. Frank v. S., 67 Mliss. 125, 6 So. 842, Mi. 901.

('Tex. Ct. of Crim. App., 1892.) Samè. Murio was convicted of receiving stolen goods worth $\$ 20$. Three witnesses testified that one Nestoro was indebted to defendant and told him he had some coffee talien on in debt, that defendant could sell on commission to pay himself; and that Nestoro delivered it for that purpose. It was not denied that the coffee was stolen from the I. \& G. N. Ry. depot, but J'estoro denied delivering it. 'The only question was sulficiency of the testimony to sustain the conviction. 'The court held that guilty knowledge at the time of receiving was essential to a conviction; but that if the defendant received the goods under circumstances sufficient to satisfy a man of ordinary prudence and caution that they were stolen, guilty knowledge might be inferred; and in this case the facts that defendant asked Nestoro where he got the coffee, received it at night unboxed, arranged the packages in the form of a bed, and covered them, were circumstances ample to justify the rerdict. Affirmed. Murio v. S., 31 ''ex. App. 210 , 20 S. W. 356, F. $315, \mathrm{Kn} .292$.

(Iowia Sup. Ct., 189;.) Suspicion. There was held to be no error in trial for receiving stolen groods, in instructing the jury, as follows: "If you find that all the facts and cireumstances surrounding the receiving of the goods by defendant were such as would reasomably satisfy a man of defendant's age and intelligence that the goods were stolen, or if he failed to follow up such inquiry so suggested, for fear he would learn the truth and know that the goods were stolen, then the defendant should he as rigridly held responsible as if he had actual knowledgre." Affirmed. S. v. Feuerhaken, 96 Iowa 299,65 N. W. 299.

\section{$\S 157$. "Shall be Taken and Deemed an Accessory."}

(N. Car. Sup. Ct., 185i2.) Naming Principal-Receiving from Receiver. Ives was convicted of receiving a barrel of tar and a bale of cotton, knowing them to have been stolen. IIe appealed. PEARSON. J. * * * A receiver of stolen goods is made an accessary by the statute of Anne; and it is provided, by another section of that statute, that. if the principal felon escapes and is not amenable to the process of the law, then such accessory may be indicted, as for a misdemeanor. This statute was so construed as to require, in the indictment for a misdemeanor, an averment that the prin- 
cipal felon was not amenable to the process of the law. Foster, 373 . Our statute, Rev. Stat. e. 34. \$\$\$ 53 and 54 , is taken from the statute of Anne, and hals received a similar eonstruction. firofles catse, 1

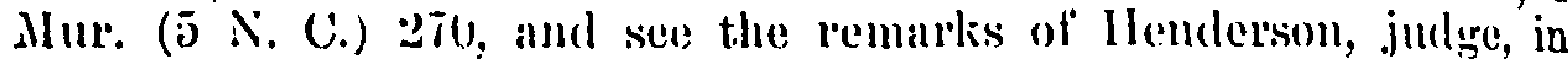
Good's cisse. 1 llawks ( 8 N. (J.) 4633. 'The objection taken to the indietment, is the absence of an averment, that the principal felon is not amenible to the process of the law; and it is insisted that, as the principal felon is alleged to be some persom to the juroms unknown, it eonld not be averred that he hat "seaped and eluded the process of the law," in the words used by our statute, and it vals ureed that the statnte did not apply to a case of the kind. 'The attorney general in reply took the position, that the averment that the principal felon was some person to the jurors unknown, necessarly included and amounted to an arerment, that he had escipend and eluded the prosess of the law, so as not to be amenable fo justice. This would seem to be so: hut we give no definito apinion, becmuse there is another lefeet in the eomnt. which is clearly fiatal. After averring that the eotton and tall had been stolen by some person to the jurors monown. the indietment proceeds: "Altepwards, ete. the said Josiah lres, the satid bale of eotton and the salil hatrel of tar felonionsly did have and receeive, well knowing the silid balle of eoton and harrel of tar to have heen theretofore felonimsly: stolen." "ete. "There is no averment from whom the defondint received the anton and tar. We cammot imply that he perecived them from the preson who stole them. It may he that he reroiving them firom some third person: and this fluestion is presentonl: 1 steals

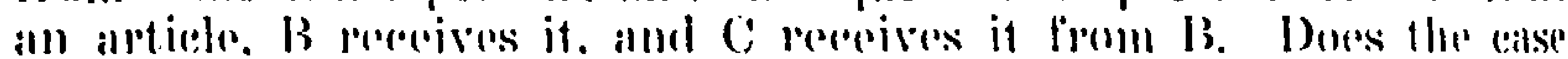
fall within the statute? Wre think not. The statute obvionsly ant-

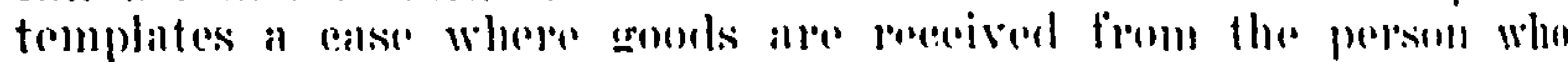
stole them: he is termed the principal folon. In the alse put above.

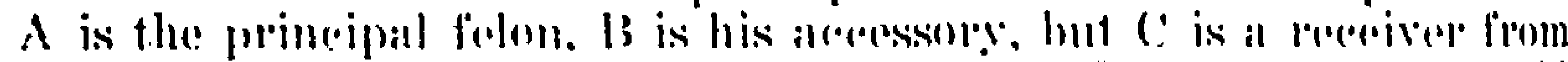

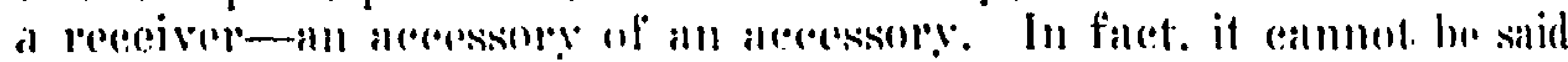
whether $A \mathrm{or}$ B is the princigal felon in regard to him. 'The statute does not provide for sitch it anse. It makes the receiver an areess. sory; and in case the principal is not amenable to the process of law; such acecssory may be prosecuted as for a misclemeanor. ('onsequently it is inecessary to point out the principal. and the malter is involved in the doetrine of "principal and accessory." 'J'his and many other omissions are. in England, remedied by the statutes. W. III. and G. II., by which "the act of receiving" is madr " sull. stantive felony without reference to the person who stole. * * Judgment reversed and arrested. S. v. Ives, 13 Ired. (35 N. (.) 338 , B. 775 . C. 460 .

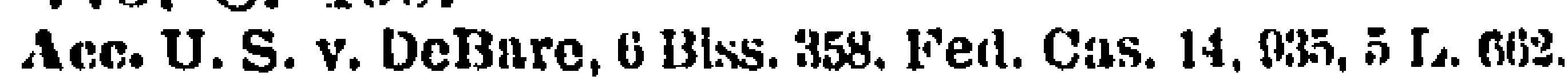

(Neb. Sup. Ct.. 1883.) Same. IAKE. C. J. The plaintiff in crror stands eonvicted of receiving stolen goods, and he seeks to reverse the judgment. ** * In this state, the receiving or buy- 
ing of stolen goods is not an accessory, but a substantive offense, as will be seen by reference to the statute by which it is governed. Crim. Code, \$116, provides that "if any person shall receive or buy any goods or chattels, of the value of $\$ 35$ or upwards, that shall be stolen or taken by robbers with intent to defrand the owner, * * * every per'son so offending shall be imprisoned in the penitentiary not more than seven years, nor less than one year." (C. S. 681.) 'The jury found the value of the stolen property, which consisted of a lot of eopper and brasses, to be $\$ \overline{0} 0$; and this finding is fully justified by the evidence. *** The prisoner bought and received it from one Bierbaum, but from whom the latter obtained it was not shown. 'Therefore, the point is made that inasmuch as it was not shown afirmatively that Bierbaum stole the property the receiving of it from him was not within the statute. In other words, that to make the crime of receiving stolen property, it must be shown that it was received from the person grilty of the larceny, and not from another receiver; and in support of this view wi are referred to 1 Whart. Cr. L. (8 Ed.) $\$ 990$; 2 Bish. C. L. $\$ 1140$; and Desty Am. r.. L. $\$ 147$. The first of these citations does not sustain the position taken; and even the other two, although seeming to do so, if we look to the text of the works alone. in view of our statute, really do not, as will appear from an examination of the cases referred to by the anthor's in support of that doctrine. One of these casses, S. v. Ives fahovel. 13 Ired. 3338. was decided under a statute which, as the court said, contemplated a receiving of the goods from the person who stole them. who was the prineipal felon. *** Clearly these eases have no application here. ** * Affirmed. Levi v. S., 14 Neb. 1, 14 N. W. 543.

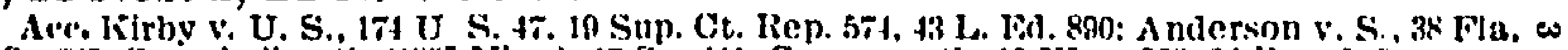

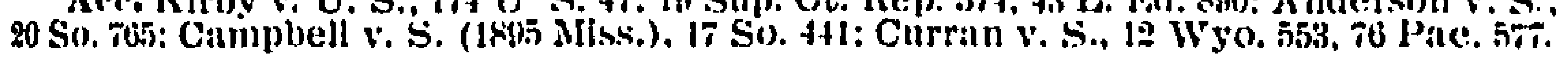

\section{CHEATING AT COMIMON LAW.}

\$158. Defined, etc. "The common law chealt is importinnt to bo understood, though practically it is nearly superseded by the statutes against fialse pretenses. It is a fraud wrought by some false symbol or token of a nature against which common prudence cannot guard, to the injury of one in any pecuniary interest." 1 lish. Cr. L. 571. See also, to same effect, $C$. v. Warren, $\$ t$, getting credit by lies; R. v. Wilders and R. v. Whentley, $\$ 16$, short delivery; R. v. Bower. \$16, selling inferior grold chain for sterling. Cheating by false weights and measures (R. v. Burgaine, 1 Sid. 409), or with false diee (R. v. Maddocke, 2 Rolle 107; Leeser's Case, Cro. Jac. 497 ), were held to be indictable common law cheats. 


\section{FORGERY.}

$\$ 159$. Definition. "Forgery is a species of common-law cheat, which early was separated from the rest under this distinctive name; and it includes as well the unsuccessful attempt as the accomplished fraud. It is the false making or materially altering, with intent to defraud, of any writing which, if genuine, might apparently be of some legal efficacy, or the foundation of a legal liability." 2 Bish. New Crim. L. § 572.

\section{$\S 160$. "It Includes as Well the Unsuccessful Attempt."}

(Eng. King's Bench, 17:6.) What Instrument-PublicationActual Fraud Shown. Ward, being chargeable to deliver $315^{1 / 4}$ tons of alum to Duke Edmund, fabricated a schedule, and indorsed upon it a direction to himself in the name of the duke, to charge $6601 / 4$ tons of alum to the duke's account, part of the quantity mentioned in the schedule; and out of the proceeds of sales of alum in I'ard's hands, to pay himself 10 for every ton according to acreement, and for so doing the indorsement should be his (Ward's) discharge. This was held forgery at common law. In answer to an objection taken in arrest, that no publication of the instrument, or actual fraud upon the duke, was averred in the information, the court said that the crime was complete by the act of forgery; publication or actual fraud were not necessary ; but it was sufficient that the duke might have been defrauded. An objection in arrest was also taken, that the information did not allege that at the time of making the writing he was bound to deliver, and so, perhaps, nobody prejudiced. This time was held sufficiently certain, and the information was sustained against every objection. R. v. Ward, 2 I. Raym. 1461, 1466, 1469, 2 Strange 747, 2 East P. C. 861, Mi. 932.

'This is a leading case. It underwent great examination and. in the course of the discus. sion. almost every authority upon common-law forgeries, then extunt, appears to hive been considered.

\section{$\S 161$. "It is the False Making."}

By innocent agent: Gregory v. S., Tt. Separately by several: R. v. Bingley. \& it.

(Eng. C. C. R., 1772.) Fictitious Name. Charles Loekett was convicted of knowingly uttering a forged order for the parment of money in these words: "Nlessrs. Neal. Fordyce \& Down, pay to William IIopwood or bearer $\& 16$ 1s. 6d. Rt. Vennest," with intent to defrand John Scoles. The case was that the prisoner applied to Scoles, a colorman, and a grreed to purchase gronds to the amomint of $£ 106 \mathrm{~d}$., which he was to sent for. IIe came ag!in. pritending to 
be in a hurry, and presented this note, which he said was a good one, and Scoles gave him $\mathfrak{t} 6$ 10s., being the difference. No such persou as Rt. Vennest kept cash with Neal \& Co., nor did it appear that there was any such man existing. The question submitted to the judges was, whether this were an order within the statute 7 Geo. 2, c. 22, being in the name of a fictitious person? the doubt arising on what is said in Mitchell's Case, Foster C. L. 119. The judges, after very long consideration, at last agreed, in Trin. term, 1774, that this was forgery. They thought it quite immaterial whether such a man as Vemest existed or not; or if he did, whether he had kept cash at the banking house of Neal \& Co., it was sufficient that the order assumed those facts, and imparted a right on the part of the drawer to direct such a transfer of his property. R. v. Lockett, 2 East P. C. 940, 1 Leach C. C. (Ed. 3) Case 53, C. 498, Mi. 939.

A.c. P. v. Warner, 104 Mich. 337,62 N. W. 405. Compare C. v. Drew, $\$ 171$, banking in false name. Having dies to stsmp colns: R. v. Sutton, $\$ 10$. R. v. Heath. $\$ 10$.

(Eng. C. C. R., 1777.) Same. On indictment for forgery, the jury found that 'luft picked a bill of exchange and other property out of the pocket of the owner, and took the bill to a banker to be changed; and the clerk, knowing the bill to be good, said he could not pay it till indorsed by the person presenting it for payment; whereon defendant indorsed it "John Williams," and obtained the cash for it. The judges were unanimously of opinion that this was forgery, though the fictitious signature was not necessary to obtain the money, and his intent in writing a false name was probably to conceal himself, yet the owner thereby lost the chance of tracing his property and the discounter his indorser. R. v. Tuft, 1 Leach C. C. (Ed. 3) Case 88, C. 500.

Approved IR v. Marshall (1804), Kussell \& R 75. C. 487.

(Ore. Sup. Ct., 1890.) Same. Ed. Wheeler drove a team of horses up in front of Milner's office, applied for a loan of $\$ 85.50$, and offered to give a mortgage on the team to secure it. Milner did not know him, but looked at the team and then drew up the note for the amount desired, which Wheeler signed "John Williams," and thereon obtained the $\$ 85.50$. Conviction of forgery on allegation and proof of these facts was affirmed on appeal aiter reviewing the decisions at some length. S. v. Wheeler, 20 Ore. 192, 25 Pac. 394, 23 Am. St. Rep. 119, 10 L. R. A. 779.

(Tex. Ct. of Cr. App., 1893.) Name of Dead Man. Appellant was convicted of forgery. DAVIDSON, J. ${ }^{*}{ }^{*}{ }^{*}$ It is contended, inasmuch as Iathaway was dead at the time his name was signed to the cheok, that therefore the making of the false instrument cannot constitute the crime of forgery. The authorities do not sustain this position. On the other hand, so far as we have been able to ascertain, the contrary doctrine has been held to be the cor- 
rect one, and adhered to wherever the question has been adjudicated. Hender'son v. S., 14 I'ex. 503; Billings v. S., 107 Ind. 7T, 6 N. L. 914; 2. Bish. Cr. L. $\$ \bar{j} \pm 3$, and notes. It has also been held that he who signs the name of a person who had or has no legal capacity to make the instrument is guilty of forgery. L. v. Krummer, 4 Parker Cr. R. (N. Y.) 217. * * Aflimed. Brewer v. S., 3: 'Tex. Cr. R. 7t, 2.2 S. W. 41,40 Am. st. Rep. T6u.

(Eng. C. C. R., 18ti.) Assumed Authority to Sign. 'The prisoner indorsed a bill of exchange, "per procuration, 'Thomas 'l'omliuson, Emanuel White." He had no authority to make the indorsement, but the twelve judges held unamimously that the act was no forgery. R. v. White, 2 Cox C. C. 210,1 Den. C! C. 208, 2 Car. \& K. 404, ('4!5. A cec. S. v. 'Taylor, 40 Lil. Ann. 1332, 16 So, 100, 40 Am. St. R. 351, 25 L. R. A. 591.

(Mass. Sup. Juclicial Ct., 1858.) Pretended Authority to Sign. Indictment for forming a note, signed "Schouler, Baldwin di Co." by defendant. It wais proved, that the note was given in payment of an overclue note of defendant; that in reply to inquiry at the time of signing it, he said the firm consisted of himself and Willian Schonler; and that in fact if such partnership ever existed it had been dissolved before the note was given. Defendant was eonvieted and excepts. The question was whether so executingr the note with intent to definud was forgery. 'THOMAS, J. **** it would be difficult perhaps by a single definition of the crime of forgery to include all possible cases. Forerer, speaking in greneral terms, is the false malsing or material alteration of or addition to a written instrument for the purpose of deceit and frand. It mas be the making of a filse writing purporting to be that of another. It may be the alteration in some material particular of a genuine instrilment by a change of its words or figures. It may be the addition of some material provision to an instrument otherwise gremuinr. It may be the appending of a genume signature of another to ain instrument for which it wiss not intended. The false writing, alleged to have been made, may purport to be the instrmment of a person or firm existing or of i fictitious person or firm. It may be even in the name of the prisoner, if it purports to be. and is desired to be received as the instrument of a thire? person having the same name. * * * The writing alleged to be forger in the case at bar was the handwriting of the defendant. known to be such and intended to be received as such. It hinds the defendant. Its falsity eonsists in the implication that he was a partner of Schouler and authorized to bind him by his act. 'l'his, though a frand, is not, we think, a forgery. *** Fxceptions sustained. C. v. Baldwin, 11 Gray 197, $71 \mathrm{Am}$. Dee. 703, C. 495. T. 319, Kn. 294. Mi. 940.

(Pa. Sup. Ct.. 1853.) Signature Induced by Fraud. Indictment for forgery. BI ACK, C. .T. The defendant wrote a note pilyalle 
to himself, for $\$ 141$, and got in illiterate man to sign it, by falscly and fradulently pretending that it was for $\$+1$ only. On a special verdict finding these facts, the court gave judgrment in favor of the accused. The act was a forrery aceording to all the text writers on criminal law, from coke to Wharton. But their doctrine is not sustained by the ancient linglish eases, and is opposed by the moder'n ones. Only three American decisions were eited on the argument; and we take it for granted that there are no others on the point. 'Two of these. P'utnam v. Sullivan. + Mlass. $45,3 \mathrm{Am}$. Dec. 206 , and Ilill v. S.. 1 Yerger (9 T'enn.) $76,24 \mathrm{~A}$ m. Dee. $4+1$, are wholly with the defendant; and the other. $\$$. v. Shurtliff, 18 Me. 3i1, supports the argument of the eommonwealth's counsel. 'The weight of the judicial anthorities is in favor of the opinion that this is no forgery. We think that the arguments drawn from principle, and the reason of the thing. preponderate on the sime side. It must be admitted that, in morals, such an imposture as this stands no better than the making of a fialse paper. But even a knave must not be punished for one offense becaltse he has heen gnilty of another. Forgery is the framdulent making or altering of at writing to the prejudice of another's right. 'The defendant was gruilty of the fratul. but not of the making. 'The palper was male hy the other person himself: in prejullice of his own right. '?o eomplete the offense. necording to the definition is requires a froudulent intent and a making both. The lattor is innocent withont the former. and the former, if earried into sffeed without the latter, is merely a cheat. If every trick, or false pretense, or frandulent act by which a person is induced to put his mame to a paper which he would not otherwise have simned. is to be ealled a forgery. where shall we stop. and what shall be the rule? Is it forgery to take a note for a deht known not to be due? Or to procure a deed for valuable land by frandulently representing to the immolant owner that it is worthless; or to get a legricy inserted in a will hy imposing on a weak min in his illness? All these would be framds-frands perpetrated for the purpose of getting papers signed-as much as that which was committed in this case. But no ono thinks they are forgeries. $* *{ }^{*}$ Affirmerl. C. v. Sankey, 2.2 Pil. St. 390 . 60 Am. Dee. 91, Mi. 943.

(Eng. C. C. R.. 1865.) False Entry by Bookkeeper. IInheas corpus on application for axtradition. Windsor was clerk in a New York bank, and was eharged with emberaling large sums of that bank's money and making false entries in the books to conceal his erime. BLACKBLRN. J. * * the only power that the extradition treaty gives to surrender a prisoner is that derived from the statute: and that statute. as far as I see. dnes not enact that all fugitives from justiee shall he griven 11 . but only those who have committed eertain enumerated erimes-it provides for the delivery of any person charged with the erime of murder. assault with intent 
to commit murder, the crime of piracy, arson, robbery, and forgery; these, both in the treaty and the statute passed to give effect to it, are the defined cases given by those high contracting parties to the treaty on which to deliver over prisoners to each other. Now the charge that is made out agninst this person is that he, being a clerk in a bank, did steal a large sum of money, and in order to conceal it did make an entry in a book, which entry, as I make it out, was an entry stating on his behalf that a certain quantity of specie had been deposited in the vaults, whereas, in point of fact, the statement was wilfully and fraudulently false, with the intention to con. ceal and embez\%le. But though he was guilty of that erime, it did not amount to forgery. Forgery is the false making of an instrument purporting to be that which it is not; it is not the making of an instrument which purports to be what it really it, but which contains false statements. Telling a lie does not become a forgery because it is reduced into writing. The guilt of the thing which he has done is by no means more than that. He has not made any statement that is purported to be made by the authority of any person on behalf of that person. Now this man has made a false statement, falsely stating a fact which purports to be what it is. It is quite true that the state of New York by statute has enacted that those guilty of this offense shall, on conviction. be deemed guilty of forgery in the third degree. I pass by, without entering into them, the various observations that have been made to show that this did amount to this crime within the New York state; I am inclined to think it would be certainly a crime in the New York state. But then if this is not forgery. how does the fact that the local state of New York in the United States has declared in effect that he shall be deemed guilty of forgery. make it forgery within the meaning of the extradition statute? That. I think. we cannot do.

Cockburn and Shee, J.J. concurred. Petitioner released. Ex Parte Windsor, 10 Cox C. C. 118. 6 B. \& S. 522, 34 L. J. m. c. 163, 11 Jur. n. s. 807,12 ᄂ. T. 307. C. 493.

(Mass. Sup. Judicial Ct.. 1873.) True Name With Intent to Cheat. Foster was indicter for uttering a forged note signed "Little \& Co." He was indebted on notes for a large amount to one Chaddock. There was a Little \& Co. in Boston, of known financial standinu, doing a large manufacturing business. There was also a George P. Little, who had done a brokerage business in a small way and had sometimes done business under the name of Little \& Co. Foster gave him $\$ 10$ to sign a large note, by the name of Ijittle \& Co.: an!l Little testified that he knew of no fraudulent purpose. When Chaddock called to adjust his accounts, Foster gave his this note. and for it obtained return of other notes of his and some stock, at the same time representing that the note was executed by the Little \& $\mathrm{C}_{0}$. doing a large manufacturing business in Boston. The court refused to instruct that if the note was signed by Geo. P. Little, and he had 
done business as Little \& Co., Foster could not be convicted of uttering a forged paper, however false his statements concerning it may have been. 'The jury found him guilty, and on exceptions the judgment was atfirmed. The court said: "Forgery is not necessarily counterfeiting. * * * It matters not by whom the signature is attached, if it be not attached as his own. If the note is prepared for the purpose of being fraudulently used as the note of another person, it is falsely made. 'T he question of forgery' does not depend upon the presence upon the note itself of the indieia of falsity. If extrinsic circumstances are such as to facilitate the accomplishment of the cheat without the aid of any device in the note itself, the preparation of a note with intent to take advantage of those circumstances and use it falsely is 'making a false instrument.'" C. v. Foster, $11 \pm$ Mass. 311, 19 Am. Rep. 353, C. 503.

(Cal. Sup. Ct., 1900.) Same. Edwin Geddes had a deposit by the name of "E. Gediles" in the Fresno Loan \& Sav. Bank when it suspended, and he assigned the account to the First Nat. Bank for collection. Later Rushing obtained from one Elmer Geddes a power of attorney signed and acknowledged by the name of "E. Geddes" by virtue of which Rushing assigned the deposit to one Levy for 65 cents on the dollar, much less than its value, received from him a check for the amount, $\$ 1,103.70$, payable to the order of " $\Psi$. Geddes," and on the check obtained the money, indorsing it " $\mathrm{E}$. Geddes, by his attorney in fact, W. W. Rushing." Being convicted of uttering a forgery and being denied a new trial, Rushing appealed; and the judgment was affirmed. The court said that the jury having found that he knew Elmer Geddes who gave the power of attorney had no interresit in the account, he was guilty of the offense charged. P. v. Rushing, 130 Cal. 449, 62 Pac. 742, $80 \mathrm{Am}$. St. Rep. 141.

\section{§162. "Materially Altering."}

(Minn. Sup. Ct., 1895.) Middle Initial. An indictment for forgery alleged that Marion $F$. Higgins agreed by contract signed " $M$. $F$. Higgins" to build a church, and thereafter, with intent to make it appear that the contract was made by his wife, Martha Jane, changed the " $F$ " to a "J." A demurrer on the ground that no material change-was alleged, was overruled; and on case certified the order was affirmed. Buck, J., dissenting. The court said that if the first name had been signed in full the alteration might have been immaterial; but that when initials only are used, the middle letter is commonly relied on to fix the identity. Demurrer overruled. S. v. Higgins, 60 Minn. 1, 61 N. W. 816, 51 Am. St. Rep. 490, 27 L. R. A. 74. 


\section{\$163. "With Intent to Defraud."}

(Eng. C. C. R., 1856.) College Diploma. On indictment for forning and uttering a diploma of the college of surgeons, it appeared that Ilodgson procured a diploma that had been issued to another, substituted his own name, changed the date, etc.. hung it up in his room, stated that he was a member of the college, produced the paper to prove his statement. became a candidate for vaccinator at the poorhouse. and offered to produce his diploma to plove his qualification for the office. By statutes. members of the college were entitled to numerous privileges concerning vaceination, jails. asylums, serving on juries. etc. After conviction under these circum. stances it was objected that no particular intent to defrand any individual was shown. and he had no intent to utter and publish to defrand or wrong any individual. This objection was held to be fatal, and the conviction was quashed. R. v. Hodgson, Dears. \& B. 3, 25 L. J. m. e. 78,2 Jur. n. s. 453.7 Cox C. C. 122, 4 W. R. 3019. 36 Eng. L. \& Nq. 626, Ke. 202, Mi. 946.

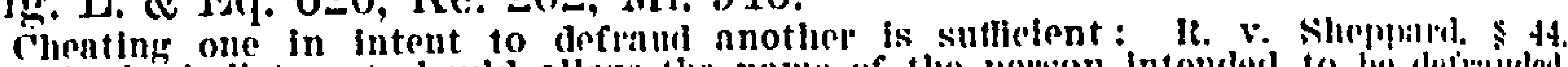

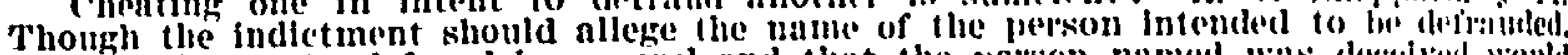
proof of intent to definud in genelol and that the porsen named was deceiverl woulis

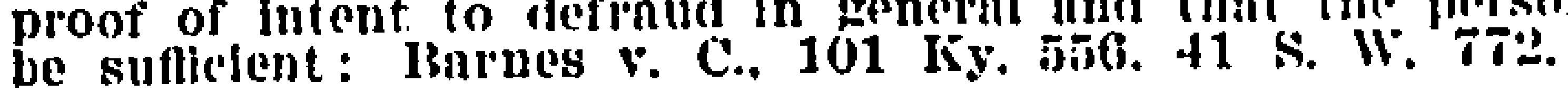

\section{$\$ 164$. "Of Any Writing."}

(Mass. Sup. Judicial Ct.. 1855.) Counterfeit Ry. Ticket. For'gery. Defendint was indicted for fraudulently and withont authority pro. curing innocent engravers and printers. in his absence. to angrave and print faesimiles of the tickets used on the N. Y. Central Ry. for passage from Boston to Albany, and selling them to be used for passage between these points. Verdict. guilty. IIe excepts. DEWEY. J. The instrument here set forth as the subject of the alleged forgery is not one included in the enumeration in Rov. St. e. $127, \S 1$. It is not. therefore, a statute oftense. But many writings not enumerated in the statute are vet the subjects of forgery at the common law. The definition of forgery at common law is quite sufficient to embrace the present case. 'Take that in +131 . Com. 247 , "the fraudulent making or alteration of a writing to the prejudice of another man's rightit." * * * It is said that this instrument does not import a contract or promise of any kind. $W_{0}$ think otherwise. * * * It is then objected that the crime of forgery cannot be committed by counterfeitingr an instrument wholly printed or engraved. and on which there is no written signature personally made by those to be bound. *** In the opinion of the court. such an instrument may be the subject of forgery, when the entire contract. including the signature of the party, has been printed or engraved. * * * It has never been considered any objection to contracts required by the statute of frands to be in writing, that 
they were printed. $* *$ It may be more difficult to establish the fiact of their signatures; but, if shown, the eftect is the same. Such being the effect of snch form of executing like contracts, it would seem to follow that any comnterfeit of it, in the similitude of it, would be making a fialse writing, purporting to be that of another, with the intent to defiand. It is further insisted that this indictment camot be sustained arainst the present defendint because he did not personally aid in the actual, manual operation of engravinger, printing or lithographing the alleged spmorous railroal ticket. It is conceded that it was donce hy his procuration; that he procured the stereotype phate from which the ticket was printed. and that he carried the plate to a minter, who, at his recfuest and on his behalf, printed the tiekets, and delivered them to him. These fincts are quite sufficient to charge the defendant. * * * Verdict set aside. C. v. Ray, 3 (Gra! +41, F. 3:21.

(Eng. C. C. R., 185T.) Name on Picture. COCKBURN, C. J. If you once go beyond a writing where are you to stop? Could there be a forgery of a seulpture? * * The prisoner was indieted on a charge of having sold to one Fitypatrick a picture as and for an original picture painted by limnell, when in truth it was only a copy, and that he had passed it off by means of having the name "J. Linnell" painted in the corner of the picture in imitation of the original. which bore such signature. 'There were three counts in the indietment. The first was for obtaining money by filse pretenses. on which the prisonel was aeguitted. 'The second was for a eheat at common law; and the third for a chent by means of forgery at common law. As to the third eount, we are all of opinion that that was no forgery. A forgery must be of some docmment or writing: but the name of Tinnell in this case can only be regarded as an arbitrary mark put upon the picture by the painter to enable him to recognize his own work. * Convietion quashed. R. v. Closs, 7 Cox C. C. 494 . Dears. \& 13. 460.27 T. J. m. c. 54. 3 .Jul. n. s. 1309. 6 W. R. 109. C. 486. Ke. 184.

(Bng. C. C. R.. 1858.) Imitating Trade Label. Smith wits indicted and convicted of forgery. It was proved that he went to a printer and obtained 10.000 labels as nearly leppresenting those used on Borwick's baking and egg powders as possible. put them on packages of powder put II) to resemble Borwiek's, and sold a great many of them. The judge instructed the jury to convict if the labels were similar enough to deceive persons of eommon understanding, and were uttered to deceive. WIILIES. . I. I a crree in the definition of forgery at common law, that it is the forging of a false document to renresent a genuine document. That does not anply here, for it is quite absurd to suppose that the prisoner was guilty of ten thonsand forgeries as soon as he got these wrappers from the printer: and if he had distributed them over the whole earth and done no 
more, he would have committed no offense. The frand consists in putting inside the wrappers powder which is not genuine, and selling that. It the prisoner had had one hundred genuine wrappers and one hundred not genuine, and had put genuine powder in the spmrious wrapper's and spurious powder into the genuine wrappers, he wonld not have been gnilty of forgery. 'I his is not one of the difterent kinds of instruments which may be the subject of forgery. It is not made the subject of forgery simply by reason of the assertion of that which is false. In cases like the present, the remedy is well known: the prosecutor may, if he pleases, file a bill in equity to restrain the defendant from using the wrapper, and he may also bring an action at law for damages; or he may indict him for obtaining money under false pretenses. But to convert this into the offense of forgery would be to strain the rule of law. BYLES, J. Every forgery is a comnterfeit. ILere there was no counterfeit. The offense lies in the use of it. [Pollock, C. B., and Bramwell, B., gave similar opinions. Channell, 13.. concurred.] Conviction quashed. R. v. Smith, 8 Cox C. C. 32. Dear's. \& 13. 566, 27 L. J. m. c. 225, 4 Jur. n. s. 1003, 6 W. R. 495. C. 488, Ke. 186, Mi. 934.

\section{\$165. "Might Apparently be of Some Legal Efficacy."}

(Engr. C. C. R., 1800.) Will Void on Its Face. The conviction was on an indictment for forging a will of all the premises belonging to J. S., which he bought of I. W. \& S. H. The will was attested by only two witnesses and was, therefore, void as a devise of a freehold; but would have been good as a bequest, if the pretended testator's interest had been but a term for years. It was suggested to be the latter; but no such fact appears to have been averred in the indietment; and it was not in proof at the trial. The judges, on conference, held the conviction wrong; for as it was not shown to be a chattel interest. it was presumed to be freehold. Wall's Case, 2 Fast 1'. C. 9i3, Mi. 93i.

(Eng. C. C. R., 1802.) Raising Void Bill. On indictment for forging and counterfeiting a bill of exchange and for uttering it knowing it to be forged, it was shown that defendant erased the ten and wrote fifty in the words and figures of a bill of exchange for $₫ 10$. The bill was written on a $16 \mathrm{~d}$. stamp and had been reissued twice after payment. The jury found guilty of uttering knowing it to be forged. After which it was objected that it was not forgery because there was no warrant in law for reissuing a bill of exchange after it had been paid, without a new stamp. At a meeting of the judges they all held that it was the same thing as forging or uttering a forged bill with a wrong stamp, which had been heid to be felony; and therefore the conviction was right. R. v. Teague, Russell \& R. 33, 2 East P. C. 979, Mi. 937. 
(Eng. C. C. R., 1787.) Moffatt was convicted of forging and uttering as true a forged acceptance on a bill of exchange, which bill was void on its face by St. 17 Geo. III. c. $30, \S 1$, for want of a stamp; and, on case reserved, all the judges held the conviction wrong; for if it had been a genuine instrument, it would have been absolutely void; and nothing could have made it good. Moffatt's Case, 2 East P. C. 95 1 Leach C. L. (Ed. 3) Case 190.

(New York Ct. of Oyer and Terminer, 1829.) Promise to Work, Showing No Consideration. Indictment for forging the following: "Three months after date, I promise to pay Sebastian I. Shall, or bearer, the sum of three dollars, in shoemaling, at cash price; the work to be done at his dwelling-house, near Simon Vrooman, in Minden. Minden, August 24th 1826. David W. Houghtaling." Defendant moved in arrest of judgment on the ground that the writing was void on its face, no consideration being mentioned, and the indictment averred no extrinsic matter to make it good. After reviewing the decisions at some length, COWEN, J. **** I have shown that the paper forged, if genuine, would be a mere nullity for any purpose; nor, to my mind, conld it be made good by any possible averment. It could not be made the foundation of liability, like the letter of eredit. It does not come within any of the cases sustaining indictments; but to me it appears to be directly within the cases cited holding that an instrument purporting to be void on its face, and not shown to be operative by averment, if genuine, is not the subject of forgery. How is it possible, in the nature of things, that it should be otherwise? Void things are as no things. Was it ever heard of, that the forgery of a nudum pactum, a thing which could not be declared on or enforced in any way, is yet indictable? It is the forgery of a shadow. I grant that on coupling a genuine note, like the one in question, with a consideration, a cause of action would be made. But you must aver the consideration in your declaration, and show it in proof on the trial. **** Had this paper been used as a token, and thus made the medium of actual frand by the defendant, he would be punishable as for a cheat. The instrument might, in that relative sense, become the subject of an indictment. It here stands alone. * * * Judgment arrested. P. v. Shall, 9 Cowen 778, F. 324.

\section{UTTERING FORGED INSTRUMENT.}

§166. In General. To utter a forged instrument is a distinct common-law misdemeanor.

(Eng. C. C. R., 1844.) Exhibiting a Receipt. Radford was a stonemason and purchased stone to the amount of over $\mathfrak{f 5}$, for which invoices were sent him and payment frequently demanded and prom- 
ised. Finally he claimed that the bill had been paid, and produced a receipt purporting to be signed by the former manager of the quarry. Le refused to part with the receipt, but it was taken from him and he was arrested. On conviction of uttering a forged instru. ment, a question was reserved as to whether the proof showed an uttering. On argument before eleven judges they were of opinion that the conviction was right, though he had not parted with the receipt out of his hand. $R$. v. Radford, 1 Den. C. C. $\overline{5} 9,1$ Car. N $\mathbb{K}$. 707, 1 Cox C. C. 168, 1 13. \& 11. 397. C. 508.

(Mich. Sup. Ct., 1872.) Uttering Forged Mortgage. Defundint was convicted on information of uttering as true a false ann forged writing for the payment of money, in the likeness of a mortugare; and brings error. COOLNY, J. there was no evidence of the uttering and publishing to gon to the jury. We think that, on the testimony of Hr. Howod, the juy would have been waranted in finding that a negotiation for the sale of the mortgage was entered upon with him, and that the forged paper was put into his hands as a genuine instrument, ready for his acceptance as such, had he been prepared then. on behalf of the bank, to close the transaction. And these facts, if found. we think, would have constituted an uttering. T'o constitute an uttering, it is not necessary that the forered instrument should havo been actually received as uenuine by the party upon whom the altempt to defind is made. To ntter a thing, is to offer it, whether it be taken or not; Jervis, Ch. .J., R. v. Welch. 2 Den. C. C 78, 15) .Jur. 1:36. 1t is to de. clare or assert, directly or indirectly, by words or anctions. that it is grood: Tilghman, Ch. .J., C. v. Searle, ¿2 Binn. 333!). A rereeipt may be uttered by the mere exhibition of it to one with whom the party is claiming credit for it. though he refuses to part with the posies. sion: R. v. Radford. 1 C. \& $\mathrm{K}, 70 \%$. In P. v. Rathhun, 21 Wenit. 520. Cowen, J., says, "not, only a sale or paying away a counterfoit note or indorsement, but obtaining credit on it in any form, as by laiving it in pledere: R. v. Birkett. Russ. \& R. C. C. $86-0 \mathrm{r}$ indeed offiring it in dealing. though it be refused: R. v. Arscott, 6 C. \& P. 408: R. v. Shukard. Russ. \& R. 200 ; R. v. Palmer. 2 Tseach (Jid. 4) 978-amount to an nttering and publishing." There are no decisions detracting from the force of these. We do not think it an important cimeminstance that it may have been contemplated that the board would he consulted by Elwood before closimg the negotiation. **** .Judg. ment ordered. P. v. Caton, 25 Mich. 388. Kn. 297.

Forglug in ono state nnd uttering in another: I.Indsey v. S.. s 87 . Minving forged Innk notes intending to utter: (:. v. Morse, \$ 10. Giving counterfeit coin for illicit intercourse is uttering it: $12 . v,-\$ 24$. 


\section{OBTAINING BY FALSE TOKENS.}

\section{§167. "In General.}

Statute 33 Hen. VIII. (1541), c. 1. A bill against them that counterfeit letters or privy tokens to receive money or goods in other men's names. Forasmuch as many light and evil-disposed persons, not minding to get their livings by truth, according to the laws of this realm, but compassing and devising daily how they may unlawfully obtain and get into their hands and possession goods, chattels and jewels of other persons, for the maintenance of their unthrifty living, and also knowing that if they come to any of the same goods, chattels, and jewels, by stealth, that then they, being thereof lawfully convicted according to the laws of this realm, shall die therefore; have now of late falsely and deceitfully contrived, devised, and imagined, privy tokens, and counterfeit letters in other men's names, unto divers persons their special friends and acquaintances, for the obtaining of money, goods, chattels and jewels of the same persons, their friends and acquaintances, by color whereof the said light and evil-disposed persons have deceitfully and unlawfully obtained and gotten great substance of money, goods and jewels into their hands and possession, contrary to right and conscience. \$2. For reformation whereof, be it ordained and enacted by authority of this present parliament, That if any person or persons, of what estate or degree soever he or they be, at any time after the the first day of April next coming, falsely and deceitfully obtain or get into his or their hands or possession, any money, goods, chattels, jewels, or other things of any other person or persons, by color and means of any such false token or counterfeit letter made in any other man's name as is aforesaid, that then every person and persons so offending, and being thereof lawfully convict, shall have and suffer such correction and punishment, by imprisonment of his body, setting upon the pillory, or otherwise by any corporal pain (except pains of death) as shall be unto him or them limited, adjudged.or. appointed by the person or persons before whom he shall be so convicted of the snid offenses, or of any of them.

(Eng. King's Bench, 1704.) What is Token-Pretended to Be Sent. Indictment for cheating: Defendant obtained $£ 20$ of $\mathbf{A}$ by pretending that $B$ sent him for it, which was false. Per CURIAM: It is not indictable unless he came with false tokens; we are not to indict one man for making a fool of another. Let him bring his action. R. v. Jones, 1 Salk. 379, 2 L. Raym. 1013. Mi. 845.

(Pa. Sup. Ct., 1780.) Same-Marked Weight. Certiorari. This was an indictment against the defendant, a. baker, employed by the army of the United States, for a cheat, in baking 219 barrels of 
bread, and marking them as weighing eighty-eight pounds each, whereas they only severally weighed sixty-eight pounds.

And now Lewis, for the defendant, contended, that false tokens are enly indietable by the St. of 33 Hen. 8, c. 1, which has no operation in Pennsylvania, and he cited 3 Burr. 1697, 1 Burn. 291, 2 Sess. Ca. 2. The Atty. (ien. (Sergeant) insisted that the defendant's office was a public trust; and cited 2 Burr. 1125, 1 Hawkins P. C. 187. The COUR'l said, that this was clearly an injury to the public; and the fraud the more easily to be perpetrated, since it was the custom to take the barrels of bread at the marked weight, withont weighing them again. The public, indeed, could not by common prudence prevent the fraud, as the defendant was himself the officer of the public pro hac vice. Ther were therefore of opinion, that the offense was indictable. Respublica v. Powell, 1 Dallas 47, Mi. 56.

vessels falscly marked as to cnpacity : $K$. v. Wheatly, 16.

(Eng. King's Bench, 1796.) Same-Buyer's Check. The defendant rot possession of certuin lottery tickets, the property of $A$, pretending that he wanted to purchase them, and he delivered to $\mathrm{A}$ a fictitious order on a banker. knowing that he had no authority to draw it, by means of which he crot possession of the lottery tickets. On the argument in arrest of judgment. it was admitted, that as this was a fraud upon a private individual, the prosecutor must show that the frand was effected hy means of a false token, as well as a false pretense, and one of such a nature as that ordinary prudence could not guard against it. The counsel for the crown contended, that the false pretense was the alleged wish to purchase, and the false token was the order. But the court said that there was no false token: that it wonld he ridiculous to call the check a false token. and that all depended upon the credit due to the defendant's assertion, and the judgment was arrested. R. v. Lara, 6 Term 565 .

(New York Sup. Ct.. 1810.) Same-Obtaining Discharge by Prom. ise to Pay. Defendant obtained a letter from the judgment creditor to the justice who rendered the judgment against defendant, to discharge it on receipt of costs; and this letter was obtained by defend. ant saying he had come to settle. and would pay $\$ 10$ down and give his note for the rest: but on getting the letter went away without giving the note or $\$ 10$. For this he was indicted and convicted of a cheat at common law. Te appealed. In arresting judgment the court said: "We search in vain for the false token. There was not even the production of either note or money; and eommon prildence wonld have dictated the withholding of the receipt until the money was paid and the note drawn. To support this indictment would be to overset established principles." P. v. Babcock, 7 .Johns. 201, 5 Am. Dec. 256. F. 301.

\section{(S. Car. Ct. of App.. 1838.) Same-Assertion of Value.}


0 NENLL, J. The indictment charges the defendiant in three counts: 1 , 'T hat she did overreach; 2 , that she did cheat; 3 , that she did defraud one Alexander L. Gregg of sundry articles of property, by passing to him a promissory note on one L. G. Smith and John Foxworth for $\$ 10$, pretending that it was of that value, and that the maker's were in law liable to pay, and would pay the same, when she in fact knew that they were not liable to pay, and would not pay the same. 'This is the substance of the charge. 'The first inquiry arises, is any offense at common law charged? I think it is very clear there is not. It is a mere eivil injury, for which the party injured might have his remedy by action of deceit. It is a mere false representation of $a$ thing to be of value, which the defendant knew to be valueless. There is in this no offense against the public. It is in its consequences and effects confined to the parties to the transaction, and thus at once shows that no prosecution at common law em be sustained. * * * Under this statute [33 llen. 8, c. 1.], as well as at common law, the obtaining money or goods by false token is punished. It is, therefore, now necessiry, in this comnection, to inquire What is a False Token. . It is somewhat difficult to define with precision, or rather to describe, a false token in all cases. 'Taking the preamble of the statute as our guide, we would say it must be something false and purporting to come from one not the bearer, and having in itself some private mark or sign, ealculated to induce the belief that it is real, and thus to cause the person to whom it is delivered to part with his money or goods to the bearer or person delivering it. On looking into 2 Russell, 1384, I find the definition which I have given, is substantially that which he approves. This would be enough for this part of the case, for it is manifest that the note set out in the indietment could not be a privy false token, according to the definition or description which has been given. But it may be well here to notice what is meant by a false token at common law; for it will, perhaps, aid us in the view which we may have to take of this case under the Act of '91. It seems to me that it is anything which has the semblance of public anthority, as false weights. measures, seals and marks of produce and mannfactures, false dice, marked cards, and things of a similar kind, false and deceptive, used in unlawful games; 2 Russ. on Crimes, 1368. * * * Motion in arrest of judgment granted. Middleton v. S., Dudley 275, Mi. 57.

\section{OBTAINING BY FALSE PRETENSES.}

\$168. Statute 30 Geo. II. (1757), c. 24, §1. Whereas divers evildisposed persons, to support their protligate way of life, have by various subtle stratagems, threats, and devices, fraudulently obtained divers sums of money, goods, wares, and merchandises, to the great injury of industrious families, and to the manifest preju- 
dice of trade and credit; therefore for the punishing all such offend. ers, be it enacted by the king's most excellent majesty, by and with the advice and consent of the lords spiritual and temporal and com. mons in this present parliament assembled, and by the authority of the same, That from and after the twenty-ninth day of September, one thousand seven hundred and fifty-seven, all persons who knowingly and designedly, by false pretense or pretenses, shall obtain from any person or persons, money, goods, wares, or merchandise, with intent to cheat or defraud any person or persons of the same; or shall knowingly send or deliver any letter or writing, with or without name or names subscribed thereto, or signed with a fictitious name or names, letter or letters, threatening to accuse any person of any crime punishable by law with death, transportation, pillory, or any other infamous punishment, with a view to extort or gain money, goods, wares, or merchandises from the person or persons so threatened to be accused, shall be deemed offenders against law and the public peace; and the court before whom such offender or offenders shall be tried, shall in case he, she, or they shall be con. victed of any of the said offenses, order such offender or offenders to be fined or imprisoned, or to be put in the pillory, or publicly whipped, or to be transported, as soon as conveniently may be (according to the laws made for the transportation of felons) to some of his majesty's colonies or plantations in America, for the term of seven years, as the court in which any such offender or offenders shall be convicted shall think fit and order.

(Eng. C. C. R., 1812.) Typical Case. On indictment for grand larceny, it appeared that the prisoner had learned that one Paul was to call on his hatter (Beer) for a new hat soon, and so told a boy, who did not know him, to go to Beer and say Paul had sent him for that new hat, and to bring the hat to him (Adams), which the boy did; and the fraud being soon discovered, the prisoner was apprehended with the hat in his possession. The fraudulent purpose and the falsity of the prisoner's statements were sufficiently shown; but it was contended on his part that the offense was not larceny, and the indictment should have been for obtaining goods by false pretenses. He was convicted, and the point reserved for the opinion of the judges; and, all being present except Lord Ellenborough, Mansfield, C. J., and Lawrence, J., they all held that the conviction was wrong, and that it was not larceny, but obtaining goods by false pretenses. R. v. Adams, Russell \& R., 225, B. 720, C. 410 .

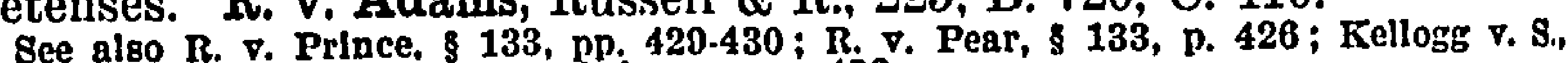
p. 432 ; P. $\nabla$. Rae, p. 433 ; R. จ. Solomons, p. 436 .

\$ 169. "By."

(New York Ct. for Correction of Frrors, 1835.) After Shipment. Error from conviction on indictment for obtaining goods by false pretenses. Merchandise was purchased, and placed by the seller 
in a box, marked with the buyer's name and address, and delivered to the carrier named by the purchaser, to be delivered at his residence; but the seller, before delivering the shipper's receipt and invoice, having learned that the purchaser was embarrassed, asked him in regard thereto, whereupon the buyer made false and fraudulent representations as to his condition, and, in consequence thereof, the seller delivered to the buyer the shipper's receipt and invoice, and did not stop the goods in transitu; and it was held that the buyer was not criminally liable for obtaining the goods by false pretenses, since the goods were in law obtained when they were delivered to the carrier, which was before the false pretenses were made. Reversed. P. v. Haynes, 14 Wend. 546, 28 Am. Dec. 530, 5 L. 258.

(Eng. C. C. R., 1856.) Remote Consequence. JERVIS, C. J. *** The prisoner represented himself to be the paymaster of the Duke of Wellington, of the name of DeLancy, upon which he made with the prosecutrix a contract for board and lodging, at the rate of one guinea a week, and he was lodged and fed as the result of the contract, in consequence of the engagement so entered into; upon that which was found to be a false pretense; and the question which was submitted to us was, whether it was a false pretense within the statute; or rather whether the conviction was right? That we have considered, and on consideration we are of opinion that the conviction was not right, because we think that the supply of articles, as it was said upon the contract made by reason of the false pretense was too remotely the result of the false pretense in this particular instance to become the subject of an indietment for obtaining those specified goods by false pretenses. * * * Conviction quashed. Coleridge, Cresswell, and Erle, JJ., and Martin, B., concurred. R. v. Gardner, Dears. \& B. 40, 7 Cox 136, 25 L. J. m. c. 100,2 Jur. n. s. 598,4 W. R. 526,5 L. 287 , Mi. 870.

(Eng. C. C. R., 1857.) Known to be False. On indictment for obtaining $3 \mathrm{~s}$. by falsely pretending that prisoner had cut 63 fans of chaff, when he well knew he had cut only 45 , on which prosecutor was to pay him $2 \mathrm{~d}$. each. It appeared that prosecutor had seen prisoner carry 18 fans of chaff from an adjoining house and add to the heap he had pretended to cut, and paid the 10s. $6 \mathrm{~d}$. demanded by the prisoner well knowing that he was entitled to oniy $7 \mathrm{~s}$. 6d. For the prisoner it was objected, that he simply made an over charge, and, further, that the money was not obtained by the false pretense. On verdict of guilty, the case was reserved for the opinion of the judges. COCKBURN, C. J. The question in these cases is, whether the false representation is the immediate motive operating on the mind of the prosecutor, and inducing him to part with his money. It cannot be said that that was the case here, because he paid the money although he knew the representation to be false. Unless the money be obtained by the false pretense, it is an attempt only. The 
other judges concurred. Conviction quashed. R. v. Mills, 7 Cox C. C. 263 , Dears. \& B. 205,26 L. J. m. c. 79,3 Jur. n. s. $447, \bar{j}$ W. R. 528, B. 727, Ke. 340 .

(Mass. Sup. Judicial Ct., 1865.) Equally within Knowledge of Prosecutor. Indictment for obtaining $\$ 4.80$ of $\mathrm{C}$ by falsely pre-

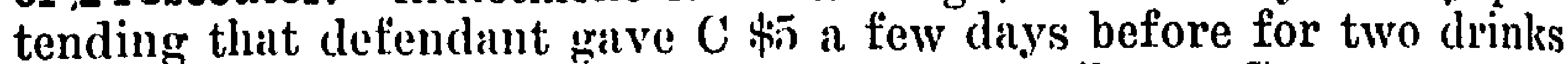
and received no change back. Plea, guilty. Case reserved. DEWEY, J. It seems to us that the present case is one which the court may properly consider as not embraced within the intention of the framers of the statute punishing the obtaining of goods by wilfully false pretenses. The case as presented by the indictment is a naked case of a wilfully false affirmation, made to a party who had like means of knowledge whether the affirmation was true or false as the party who made it. ${ }^{*} *{ }^{*}$ We are aware that some of the Finglish judges have given a more extended construction of their statute in eases that have there arisen. Judgment arrested. C. v. Norton, 11 Allen 266, B. 750 .

(Ind. Sup. Ct., 1889.) Witches. Representations that defendant was a witch doctor, and could kill and destroy witches; that the person to whom the representations were made was the victim of witches; and that unless he employed defendant to exorcise them they would kill him and his family-constitute no offense, being mere expressions of opinion, and not calculated to deceive a man of common understanding. S. v. Burnett, 119. Ind. 392, 21 N. F. 972.

(New Jersey Sup. Ct., 1896.) Too Evident to Deceive. Certiorari to review a refusal to quash an indictment alleging thit defendant obtained $\$ 200$ by falsely pretending to sell and deliver $\$ 2,000$ in a box for $\$ 200$, well knowing that the box contained only $\$ 1$. VAN SYCKEL, .J. *** The third alleged infirmity in the indictment is that the false pretense charged is such that a person of ordinary caution and prudence would not be deceived by it. To this it is a sufficient answer that it is of common knowledge that many persons have been deluded by a like artifice. Laws are made to protect weakminded and credulous, as well as sagacious, persons. The wise and wary can protect themselves. Writ dismissed. Oxs v. S., 59 N. J. L. 99,35 Atl. 646.

Ace. Lefler v. S., 153 Ind. 82,54 N. E. 439, 74 Am. St. Rep. 300, 45 I. R. A. 424, citing mang cases; S. v. Southall, 77 Minn. 200, 79 N. W., 1007; Watson v. F., 87 N. Y. 564, 41 Am. Rep. 397; Bowen v. S., 9 Baxter (68 Tenn.) 45, 40 Am. Rep. 71; S. v. Kuowlton, 11 Wash. 512, 39 Pac. 968 .

\section{\$170. "False."}

(N: Car. Sup. Ct., 1887.) On indictment for obtaining goods under false representations that a certain crop to be raised was not subject to a mortgage, it appeared that a mortgage, which it was 
alleged covered the crop in question, did not specify the land on which it was to be raised. The court held, that no property passed by such mortgage, that the court below erred in receiving parol evidence to correct the description, and that there was therefore no false representation. Conviction reversed. S. v. Garris, 98 N. C. 733,4 S. E. 633 .

compare S. v. Asher, $\& 10$.

\section{§171. "Pretense."}

(Eng. C. C. R., 1821.) By Promise to Pay C. O. D. Indictment for obtaining goods by false pretenses contrary to the statute. It appeared in evidence, that the prosecutor, Thomas Perks, was a butcher at Wolverhampton; and that, on the 17th of August, 1821, the prisoner came to his shop to purchase three sheep and two legs of veal; on being told by the prosecutor that he would not trust him, he promised the prosecutor, if he would send the sheep and veal in good time on the following morning, he would remit the money back by the bearer. The meat was accordingly sent on the 18th of August, by the prosecuter, and delivered to the prisoner by the prosecutor's servant, who asked him for the money; and said, if he did not give it him, he must take the meat back again. The prisoner replied, "Aye, sure!" and wrote a note; and told the prosecutor's servant to take it to his master, and it would satisfy him. This note (of which the following is a copy) was delivered to the prosecutor by his servant: "MIr. Perks, Sir, I have a bill of Walsall bank, which is a very good one, if you will send me the change, or I'll see you on Wednesday certain. Yours, M. G." The jury found the prisoner guilty; and said they were of opinion, that at the time the prisoner applied to Perks, he knew Perks would not part with the meat without the money; and that he promised to send back the money to obtain the goods. The jury also found, that at the time he applied for the meat, and promised to send back the money, he did not intend to return the money; but by that means to obtain the meat, and cheat the prosecutor. On case reserved the judges held the conviction wrong; being of opinion, that was not a pretense within the meaning of the statute. It was merely a promise for future conduct, and common prudence and caution would have prevented any injury arising from the breach of it. $\boldsymbol{R}$. v. Goodhall, Russell \& R. 461, B. 725.

(New York Ct. of App., 1860.) False Promise of Job. COMSTOCK, C. J. The offense charged consisted in a false representa-. tion made by the prisoner to Hock that he could give to him a certain employment, and in a false and fraudulent promise. that he would employ him and pay him $\$ 50$ a month for his services. Hock, believing the representation and relying on the promise, deposited 
$\$ 100$ as a security on his part for the faithful performance of the contract. * * * The transaction was simply a private cheat, without a conspiracy, and having, certainly, no extraordinary circumstances of art or contrivance. *** [After discussing the common law and old English statutes his honor came to N. Y. Laws, 1853, p. 219 , "to punish gross frauds and to suppress mock auctions." "] In the enacting part $(\S 2)$ it is made a criminal offense to obtain money or property, not only by that particular instrumentality, but by "any other gross fraud or cheat at common law." * * * There is some reason for saying that these words include only such frauds and cheats as were indictable at common law; and this construction is preferable to one which would indiscriminately convert into crime every fraudulent dealing or practice which might be a cause of action for damages in the civil courts. If we were to adopt that construction, then a fraudulent warranty in a horse trade would be a felony, and the offender might be punished in the state prison. The cheat, it is true, must be a "gross" one; but that term suggests no legal standard or test. One court and jury might think the fraudulent representation to be slight and venial, and another might consider it gross or criminal. There would be no certainty or rule in the administration of the law. Even a mere suppression of the truth may be, in many circumstances, a very gross fraud, according to a popular acceptation of those terms. * * $*$ In morals, the imposition was gross and detestable. But, in logic and law, the offense consisted in making a false and delusive promise, with no in. tention of performing it. This is not indictable. *** Reversed. Ranney v. P., 22 N. Y. 413, F. 303.

(Pa. Sup. Ct., 1882.) Promise to Take up Note. PAXSON, J. The only question presented by this record is whether the indictment sets forth an indictable offense. It contains two counts, in each of which the defendant below is charged with cheating by false pretenses. The particular act alleged was the procuring of the prosecutor's indorsement of the defendant's promissory note, and the false pretense charged consisted in representing to the prosecutor that he would use the note so indorsed to take up and cancel another note of the same amount then about maturing, and upon which the prosecutor was liable as indorser. In other words, the note was given in renewal of another note of like amount, and the indictment charges that the defendant, instead of using it for this purpose, as he promised to do, procured it to be discounted, and used a portion of the proceeds for other purposes. A false pretense, to be within the statute, must be the assertion of an existing fact, not a promise to perform some act in the future. * * * But it is said, the jury, having convicted the defendants of the offense of cheating by false pretenses, we must assume that the facts proved amounted to larceny. This does not follow. A general verdict of guilty upon the indictment is a finding only of the facts sufficiently 
pleaded. Neither of the counts would sustain a charge of larceny. * * The order arresting the judgment is affirmed. C. v. Moore, 99 Pa. St. 570, 5 L. 283.

(Eng. C. C. R., 1862.) Statement of Fact and Promise TogetherSingle and Will Marry. ERLE, C. J. We are of opinion that the conviction in this case was proper. The indictment was for obtaining $f 8$ from Ann Hayes by false pretenses, and it was found by the jury that the woman parted with the money on the false representation by the prisoner that he was a single man, and the promise that he would lay out the money in furnishing a house for them to live in, and that he would then marry her. It is perfectly clear that obtaining money by a false promise is not the subject of an indictment; but here there was the false pretense that the prisoner was an unmarried man, which was an essential fact in this case, and without which pretense the prisoner never would have obtained the money from the woman. Now, one false fact, by means of which the money is obtained, sufficiently sustains the indictment, although it may be united with false promises which would not of themselves do so. The conviction therefore was right. The other judges concurred. Conviction affirmed. R. v. Jennison, 9 Cox C. C. 158 , L. \& C. 157, 31 L. J. m. c. 146,8 Jur. n. s. 442,6 L. T. 256,10 W. R. 488, B. 742 , Ke. 324 .

Acc. Jules v. S., 85 Md. 305, 30 A tl. 102\%, physicinn and will cure; P. v. Winslow, 39 Mich. 507 can and will get job; S. v. Thuden, 43 Minn. 325,45 N. W. t14, own und will sell; $c$. v. Walluce, 114 Pa. St. 405, 6 Atl. 685,60 Am. Kep. 353, solvent and will pay; Boscow v. S., 33 Tex. Cr. K. 380, $28 \mathrm{~S}$. W. 625 , physician and will cure.

(Eing. C. C. R., 1857.) Statement of Opinion as to Quality. Defendant was convicted of obtaining money by falsely representing to a pawnbroker that spoons offered in pawn for a loan were plated equal to Elkington's A, and on the best foundation material. LORD CAMPBELL, C. J. I am of opinion that this conviction cannot be supported, as it seems to me to proceed upon a mere representation, during the bargaining for the purchase of a commodity, of the quality of that commodity. In the last case which we disposed of (R. v. Sherwood), after the purchase had been completed there was a distinct averment which was known to be false, respecting the quantity of the goods delivered, and in respect of that misrepresentation a larger sum of money was received than ought to have been received, the amount of which could be easily calculated; and therefore I thought, and I think now, that that was clearly a case within the act of parliament. But here, if you look at what is stated upon the face of the case, it resolves itself into a mere misrepresentation of the quality of the article that was sold, bearing in mind that the article was of the species that it was represented to be to the purchaser, namely, plated spoons, and that the purchaser received them. Now, it seems to me, it never . nald have been the intention of the legislature to make it an inuic $\urcorner$ ble offense for the 
seller to exaggerate the quality of that which he was selling, any more than it would be an indictable oftense for the purchaser, dur. ing the bargain, to depreciate the quality of the goods, and to say that they were not equal to that which they really were. It seems to me that this is an extension of the criminal law which is most alarming, for not only would sellers be liable to be indicted for an extravagant representation of the value of goods, but purchasers would be liable to be indicted if they improperly depreciated the quality of the goods, and induced the sellers by that depreciation to sell the goods at an under price, and below the real value of the goods, which would have been paid for them had it not been for that representation. Now, as yet, I find no case in which it has been held that this misrepresentation, at the time of sale, of the quality of the goods, has been held to be an indictable offense. In R. v. Roebuck the article delivered was not of the species bargained for, for there it was for a silver chain, and the chain that was sold was not of silver, but was of some base metal, and was of no value. But here the spoons were spoons of the species that was bargained for, although the quality was inferior. It seems to me, therefore, that this is not a case within the act of parliament, and that the conviction cannot be supported. [Concurring opinions were given by Pollock, C. B., Cockburn, C. J., Coleridge, Cresswell, Erle, Crompton, and Crowder, JJ., and by Watson and Channell, BB.] WILLES, J. I am of opinion at variance with those which have been generally expressed. *** I think the words of the act should be implicitly followed, and the legislature should be obeyed according to the terms in which it has expressed its will in $\$ 53$ of $7 \& 8$ G. 4 , c. 29 . I am looking to the words of that section, and I am unable to bring myself to think that its framers were dealing with anything in the nature of a distinction between the case of goods fraudulently obtained by contract and goods so obtained without any contract. 'The section commences with the l'ecital, "That whereas a failure of justice frequently arises from the subtle distinction between larceny and fraud;" now this recital ought not on a proper constraction, and according to those authorities by which we are bound, to have the effect of restraining the operation of the enacting clause. The enacting part of the section is, "if any person shall by any false pretense obtain from any other person any chattel, money, or valuable security, with intent to chent or defraud any person of the same, every such offender shall be guiltr of a misdemeanor." And it appears to me that the only proper ter' to apply to any case is this, whether it was a false pretense by whic: the property was obtained, and whether it was obtained with the intention to cheat and defraud the person from whom it was obtained. Now in this case it appears that there was a false pretense; there was a pretense that the goods had as much silver upon them as Elkington's A; there was also the pretense that the foundations were of the best material. If I could bring myself to take the view 
which my brother Erle has taken of the statement of the case, that these were matters of opinion, and not matters of fact, which could be ascertained by inspection or calculation, possibly I might arrive at the same conclusion as he has done; but it appears to me on the face of the case that Elkington's A must have been a fixed quantity, and that the proper material, the best material for the foundation of such plated articles, must have been a well known quality in the trade, because it appears that the prisoner made a statement with respect to the quantity of silver and the quality of the foundation with the intent to defraud. It appears that the person who made the advance was thereby defrauded-thereby induced to make the advance; the jury have found that the statements were known by the prisoner to be untrue, and that in consequence of these statements he obtained the money mentioned in the indictment. It appears to me that, for all practical purposes, that ought to be taken to be a sufficient fact coming within the region of assertion and calculation, and not a mere speculative opinion, and that it should be considered a false pretense. If the misrepresentation was a simple commendation of the goods; if it was a mere puffing of the articles which were offered in pledge; if it was entirely a case of one person dealing with another in the way of business, who might expect to pay the price of the articles which were offered for 11 . purpose of pledge or sale, I. apprehend it would have been eni,. y disposed of by the jury who had to pass an opinion upon the pliestion, acting as persons of common sense and knowledge of the world. It would be a question for them in such case. *** * Bramwell, B., also dissented. R. v. Bryan, 7 Cox C. C. 312, Dears. \& B. 265, 26 L. J. m. c. 84,3 Jur. n. s. 620,5 W. R. 598, B. 729, Ke. 328, 5 L. 134, Mi. 855 .

Contru: P. v. Perkins, 153 N. Y. 576, 47 N. E 883 , that statements as to quality and value known to be taise and inducing sale ire criminal.

(IIl. Sup. Ct., 1888.) Nice Horse. Evidence that defendant had carried on the business of a horse-dealer. for years, in the city, generally at stables in the rear of houses, making his business known by advertisements in the papers, as in this instance; that, led by steh advertisement, representing the horse in question to be "a real nice driving-horse," very fast, the property of a lady, with other ste -rments afterwards proving untrue, the purchaser went to the 1) [:ar. where defendant made substantially the same representations, and a w:io that the horse was a good one, and had always worked for i. $i n$, aune of the statements heing made as on information, and all herrg untrue, and the horse almost worthless-sufficiently shows detendant's knowledge of their falsity, and, added to the fact that defendant knew the purchaser was ignoranti of the diseases of horses, and trusted to his statements, justify a verdict of guilty. Conviction affirmed. Jackson v. P., 126 ㄲl. 139, 18 N. E. 286.

(N. Car. Sup. Ct., 1889.) Same. On indictment for false pre- 
tense, by which defendant sold an unsound horse, it appeared that defendant knew the horse had a disease ("swinney") of long stand. ing, and that lameness would only occur after about three days' driving; also that the purchaser, discovering that the horse limped, was assured by defendant that it had never been lame, and that the limping was the result of recent shoeing, and was temporary. An instruction that, if the purchaser could perceive the lameness, the principle of caveat emptor applied and defendant was not guilty, was held properly refused. Conviction affirmed. S. v. Wilkerson, 103 N. C. 337,9 S. E. 415.

(Eng. C. C. R., 1860.) Quantity and Identity. 'Two cases were considered together. One against Goss, for selling 8 cheeses by taking a sample out for the buyer to taste, and fraudulently in each in. stance substituting other cheese for him to taste; the other against Ragg for knowingly selling 8 cwt. of Rutland coal for $15 \mathrm{cwt}$. of Forest coal. ERLE, C. J. We are all of opinion that the conviction in each case was right. With reference to the case of Joseph Ragg, there was a false representation that the quantity of coals in the cart was $15 \mathrm{cwt}$., whereas only about $8 \mathrm{cwt}$. were delivered, and there was a pretense of a delivery of $T$ cwt., no part of which had been delivered. And although the falsehood was only as to part of the entire quantity to be delivered, yet this falls within the class of cases of false representations as to the quantity of goods delivered, the principle of which is a false pretense of a matter of fact cognizable by the senses, which is an indictable offense within the statute. With regard to the case of Thomas Goss, there was also a false pretense of a matter of fact within the cognizance of the senses; for by a sample which he falsely represented as a part of the very cheese to be sold, but which was part of a cheese altogether different both in substance and value, he procured the purchaser to buy the inferior cheese, and part with his money. That was a false pretense as to the substance of the article for sale, whereby the prisoner was enabled to pass off a counterfeit article as and for the genuine sub. stance. In R. v. Roebuck, 7 Cox C. C. 126, it was held that falsely representing to a pawnbroker that a chain is silver, the prisoner knowing it to be a base metal, is indictable. So here the drawing from the prisoner's pocket, samples from another cheese, and not the cheese intended for sale, which was a totally different substance, and falsely pretending to the purchaser that those samples were part of the substance which he was to buy, that is equally an indictable offense within the statute, and falls within the class of cases to which belong $R$. v. Abbott, where the substance of the purchase was a cheese of the identical character with the taster: and R. v. Dnndas, 6 Cox C. C. 380 , where the article sold was falsely pretended to be Everctt's blacking, which was a known article in the neighborhood, whereas in fact the article passed off was a counterfeit. In the case of $R$. v. Bryan, the case of the plated spoons represented as equal 
to Elkington's $A$, the judges who constituted the majority decided that cuse on the principle, that indefinite praise on a matter of opinion, is not within the limit of indictable offenses. A great deal of dissatisfaction has been expressed with that decision, as if it must operate as an encouragement to falsehood and fraud, and so lead to a great deal of mischief; but it should be recollected what an extreme calamity it is to a respectable man, to have to stand his trial at a criminal bar as a cheat, upon an indictment at the instance of a dissatisfied purchaser. It is easy for an imaginative person to fall into an exaggeration of praise upon the sale of his goods. And if such statements are indictable, a person who wishes to get out of a bad bargain made by his own negligence, might have recourse to an indictment, on the trial of which the vendor's statement on oath would be excluded, instead of 'being obliged to bring an action, where each party would be heard on equal terms. * * * The other judges concurred. Convictions aftirmed. R. v. Goss and R. v. Ragg, 8 Cox C. C. 262 , Bell C. C. 208 , 29 L. J. m. c. 86,6 Jur.n. s. 178,1 L. T. 337,8 W. R. 193, B. 737 .

(Mich. Sup. Ct., 1876.) Puffing-Opinion-Omnibus Instruction. Jacobs was convicted of obtaining money by false pretenses. $\mathrm{He}$ obtained a loan secured by mortgage on his wife's land. He told the lender that the lots were near the city limits, on a street leading directly to the business district, nicely located, and would sell any day for $\$ 1,200$ to $\$ 1,500$ cash. Iic excepts. GRAVES, J. * * No instruction was given that any representation laid as a false pretense could not legally be so laid, nor any instruction that any representation laid as a pretense was unproved, or any instruction to preclude the jury from resorting to the whole evidence, and finding from it that all the representations laid as pretenses were in fact made. Hence, if any representation laid as a false pretense could not be lawfully impressed with that character, the jury were in effect permitted to convist upon it. Now the alleged pretense that the lots were "nicely located," was a distinct pretense in the information. But it was not such a representation as could be made the subject of criminal prosecution as a false pretense. It could not convey or be understond as conveying any definite idea at all. There is no standard for trying the accuracy of such a statement. What is a nice location to one may be far otherwise to another, and even to the mind of one using it the expression is vague and indeterminate. No one can be supposed to accept such a representation as an assertion of the existence of some fact or circumstance sufficient to cause him to change his situation in reliance on it, and the law cannot measure or weigh people's fancies. The alleged representation concerning the value of the lots to be mortgaged cannot be construed as anything beyond matter of opinion, and it is not to be supposed the expression was understood in a sense more absolute. There is no reason for implying that Barts relied 
upon it or was in any way or to any extent duped by it. Bishop v. Snlall, 633 Me. 12; Mooney v. Miller, 102 Mass. 217; Long v. Woodman, 58 Nle. 49, and cases cited. *** Conviction set aside. P. v. Jacobs, 33) Mich. 36, F. 305, 5 L. 115.

(Mass. Sup. Judicial Ct., 1837.) Overdraft. Defendant was convicted of obtaining money of the llancock bank of Boston by finlsely pretending that his name was Charles Adams; that he wished to open an honest account at the bank, to deposit and draw in the usual manner; and that two checks signed by him, presented by himself, and drawn on his accomnt at that bank were grood. It was proved that he overdrew his accounts at other banks about the same time. The eourt held that four things must be averred and proved to make out the statutory offense: 1 , intent to defraud; 2 , fraud committed; 3 , a false pretense for that purpose; and, 4 , the fraud accomplished by that means. MIOR'TON, J. * * * The bank officers did not confound the defendant with Charles Adams, and it does not appear that the defendant knew that there was any other person by that name. He never claimed any eredit on account of his name. and the coincidence might have been accidental. At any rate it had no influence upon the eredit of either, nor any effect upon their ac. counts or the payment of their checks. 2. 'The opening and kreping an account with the IIancoek bank might have been, and doubtless was, a part of a cumning stratigem, by which the defendant intended to practice a firaud upon that bank. But the business was done and the account kept in the usual mamner. 'The defendant mide his deposits and drew his ehecks like other customers of the bank. He made no representation of the eourse he intended to pursuc and gave no assurance of integrity and fair doaling. And we can see nothing in the course of this business. constituting it a false pretense, which would not involve the account of any depositor who might overdraw, in the same categrory. 3. 'The pretense, if any such there were. that the eheck was good, or that the defendant had funds in the bank for which he had a right to draw, was false. ITe had no such funds. Did the defendant make any such pretense? He made no statement or declaration to the officers of the bank. IIe merely drew and presented his checks and they were paid. 'This was done in the ustal manner. If then he made any pretense, it must result from the acts themselves. What is a false pretense, withia the meaning of the statute? It may be defined to be a representation of some falet or circumstance, calculated to mislead, which is not true. 'To grive it a criminal character there must be a scienter and a fraudulent intent. Although the language of the statute is very broad, and in a Inose and general sense, would extend to every misrepresentation, how. ever absurd or irrational. or however easily detected; yet we think the true principles of construction render some restriction indispensable to its proper application to the principles of criminal latr and to the advantagenus execution of the statute. We do not mein 
to say that it is limited to cases against which ordinary skill and diligence cannot guard; for one of its principal objects is to protect the weak and credulous from the wiles and statagems of the artful and eumning; but there must be some limit, and it would seem to be unreasonable to extend it to those who, having the means in their own hands, neglect to protect themselves. $* * *$ 'The representation is inferred from the act, and the pretense may be made by implication as well as by verbal declaration. In the case at bar the defendant presented his own checks on a bank with which he had an account. What did this imply? Not necessarily that he had funds there. Overdrafts are too frequent to be classed with false pretenses. A check, like an order on an individual, is a mere request to pay. * * * New trial granted. C. v. Drew, 19 Pick. 179, B. 744, Kn. 277.

Compare cases of forging fictitious names, $\$ 161$, ani c. v. Warren, $\$ 4$.

(Eng. Assize, 18:37.) By Conduct-Distinctive Dress. On indictment for obtaining a pair of boot-straps of $\mathrm{V}$., by falsely pretending to be a student at Oxford University and a commoner of Magdalen College, it appeared that the defendant wore a commoner's cap and gown and falsely said he belonged to Magdalen College at the time he asked for and obtained the goods mentioned. BOLLAND, $B$. (in summing up to the jury): If nothing had passed in words, I should have laid down that the fact of the prisoner's appearing in the cap and gown would have been pregnant evidence from which a jury should infer that he pretended he was a member of the university, and if so, would have been a sufficient false pretense to satisfy the statute. It clearly is so by analogy to the cases in which offering in payment the notes of a bank which has failed, knowing them to be so. has been held to be a false pretense without any words being used. Verdiet, guilty. R. v. Barnard, 7 Car. \& P. 784, B. 727, Ke. 333.

\section{\$172. "Shall Obtain."}

(New York Sup. Ct.. 1842.) Inducing Payment of Debt. Defendant was convicted of ohtaining money hy false pretenses on proof that he had received prosecutor's note, then payable, on which the amomnt paid was due, and induced prosecutor to pay it by stating that it had been lost or destroyed, which defendant well knew to be false; and that after it was paid he sold it for value to an innocent purchaser. On certiorari from this court, the judgment was reversed; because a false pretense which cheats a man into performing his duty is not punishable by the statute, which was the only consequence to the prosecutor: and whether he is compelled to pay again depends only on whether he armed himself properly with proof at the time of payment, and was yet wholly speculative. New trial ordered. P. v. Thomas, 3 Hill 169, 33. 722. 
(Ling. C. C. R., 1870.) Inducing Owner to Let. Indictment under $24 \& 25$ Vict. c. $96, \$ 88$, for obtaining goods by false pretenses. On trial it was shown that the prisoner went to the prosecutor's livery stables, said he was sent by $\mathrm{H}$. to order a horse to be ready next morning, and at the appointed time called for the horse, rode it dur. ing the day, and returned it at night, but had never paid for the use of it, and that he had no authority from $H$. to hire the horse. He was convicted, and the question was reserved as to whether he was properly found guilty of obtaining chattels by false pretenses within the meaning of the statute. BOVILL, C. J. We are of opinion that the conviction in this case cannot be supported. The Stat. 24 \& 25 Vict. c. $96, \$ 88$, enacts that, "whosoever shall, by any false pretense, obtain from any other person any chattel, money, or valuable security, with intent to defraud, shall be guilty of misdemeanor." The word "obtain" in this section does not mean obtain the loan of, but obtain the property in, any chattel, etc. This is, to some extent, indicated by the proviso, that if it be proved that the person indicted obtained the property in such manner as to amount in law to larceny, he shall not, by reason thereof, be entitled to be acquitted; but it is made more clear by referring to the earlier statute from which the language of $\$ 88$ is adopted. $7 \& 8$ G. IV. c. $29, \$ 53$, recites that "a failure of justice frequently arises from the subtle distinction between 'larceny and fraud," and for lemedy thereof enacts that "if any person shall, by any false pretense, obtain," etc. The subtle distinction which the statute was intended to remedy was this: That if a person by fraud induced another to part with the possession only of goods and converted them to his own use, this was larceny; while if he induced another by fraud to part with the property in the goods as well as the possession, this was not larceny. But to constitute an ob. taining by false pretenses it is equally essential, as in larecny, that there shall be an intention to deprive the owner wholly of his prop. erty, and this intention did not exist in the case before us. In sup. port of the conviction the case of $R$. v. Boulton was referred to. There the prisoner was indicted for obtaining by false pretenses a railway ticket with intent to defraud the company. It was held that the prisoner was rightly convicted. though the ticket had to be given up at the end of the journey. The reasons for this decision do not very clearly appear, but it may be distinguished from the present case in this respect; that the prisoner, by using the ticket for the purpose of traveling on the railway, entirely converted it to his own use for the only purpose for which it was capable of being applied. In this case the prisoner never intended to deprive the prosecutor of the horse or the property in it. or to appropriate it to himself, but only intended to obtain the use of the horse for a limited time. The conviction must therefore be quashed. $\boldsymbol{R}$. v. Kilham, L. R. 1 C. C. R. 261,39 I. J. m. c. 109,22 I. T. 625.18 W. R. 957,11 Cox C. C. 561, B. 718 , C. 411 , Ke. 347. 
(Iowa Sup. Ct., 1877.) Obtaining Contract to Sell Under Lease. On indictment for obtaining a harvesting machine worth $\$ 190$ by false pretenses, the pretenses relied on were the false statement anade in the contract of sale, that the proposed purchaser owned in his own name 40 acres of land, 25 improved, worth $\$ 1,000$, and personalty worth $\$ 800$ above indebtedness, but as the same contract provided that title to the machine, and right to take possession at any time, should remain in the seller till the price was fully paid, the suprome court held that the trial court did not err in directing the jury to acquit on motion of defendant at the close of the state's evidence. Affirmed. S. v. Anderson, 47 Iowa 142, 5 L. 254.

(New York Sup. Ct., 1837.) Obtaining Charity. Indictment for obtaining charitable donations by falsely pretending to be deaf and dumb. Demurrer overruled, and judgment suspended for the opinion of this court. COWEN, J. The decision of this case depends upon the question whether the statute to punish the obtaining of money or goods by false pretenses was intended to protect the citizens from frauds beyond his commercial dealings. * * * I have looked into the books farther, and failed to find a single case which holds a false pretense of any kind to the end that another should do $a$ charitable act to be indictable. The absence of any such authority, especially in England, where beggars greatly abound, drilled and practiced too in all the fraudulont devices of their trade, is itself enough to raise a doubt. *** Looking to our statute, the man who merely gives to a beggar without ordering him instantly to be taken into custody and carried before a justice of the peace, as he may do [ 1 R. S. (2 ed.) 640 § 2] would seem to be a moral participant in the crime of vagrancy. It would sound somewhat extravagant were we to apply a law severely penal to the protection of such an act. *** Reversed. P. v. Clough, 17 Wend. 351, 31 Am. Dec. 303, 5 T. 276.

(Wis. Sup. Ct., 1903.) Same. Baker was convicted of obtaining 25c. by falsely pretending that he was agent for the "Baker Orphauage" of Duluth, Minn. DODGE, J. The first assignment of error involves the contention that the statute, R. S. (1898) §4423, punishing the obtaining of money under false pretenses applies only to commercial transactions, and is not applicable to the mere inducing of one to donate money as a charity. This contention has support from $P$. v. Clough, 17 Wend. 351, which seems not to have been questioned or expressly reaffirmed on this point in New York. The conclusion was reached in that case on the strength of the recitation which preceded the English statute (30 G. 2, c. 24), which was the prototype of most of the statutes in this country; the latter, however, not retaining the preamble. That preamble recited as to the wrong to be reached by the statute the obtaining by evil-disposed persons of divers sums of money or merchandise, "to the great in- 
jury of industrious families and to the manifest prejudice of trade and credit." From this the New York court argued that such trifling sums as people were ever induced to give to mendicants or for charity were not likely to cause great injury to industrious families, or to prejudice trade and credit. The English courts, in construing their own statute have never so limited it. $R$. v. Hensler, 11 Cox C. C. $570 ;$ R. v. Jones, T. \& M. 270. Nor has any other court, so far as we, or apparently the counsel, have ascertained, adopted the view of the New York court, which has been repudiated by many of them. C. v. Whitcomb, 107 Mass. 486, B. 751; S. v. Matthews, 91 N. Car. 635; Strong v. S., 86 Ind. 208, 44 Am. Rep. 292 ; S. v. Styner, 154 Ind. 131, 56 N. E. 98 ; 2 Wharton's C. L. $\$ 1153 ; 2$ Bishop's C. L. $\S 467$. * * The magnitude of the money or property so obtained is of no consequence to the existence of the crime. 'The turpitude of one who defrauds in the name of charity is at least as great as that of one who meets another at arm's length in the open field of commercial transactions. Criminal statutes are not so much to protect the individual from injury, as to purge, as far as possible, from the community, the act deemed wrongful and prejudicial. Nor can we concur with the suggestion of the New York court that parsimony and resistance to calls of charity are so strong and effective generally with our people as to make fraud in solicitation for such purposes of but trifling efficacy or danger. We are persuaded not only that the great weight of authority, but the true principle underlying this enactment, requires the holding that it prohibits and pun. ishes as well the fraudulent obtaining of money or goods, for an ostensibly charitable purpose, as for any other. *** [Reversed on another ground.] Baker v. S., 120 Wis. 135, 97 N. W. 566.

\section{§173. "From Any Person."}

If defrauded person equally guilty ? See ante, $\S 24$.

\section{§ 174. "Money, Goods, Wares, or Merchandise."}

(Pa. Sup. Ct., 1848.) Obtaining a Receipt. Indictment under Pa. act of July 12, 1842, $\S 21$ ("money, personal property, or other valuable thing"), for obtaining a receipt in full of his account from $P$. Harman by passing to him a worthless $\$ 5$ note of the Com. Bank of Millington and representing it to be good. Error on denial of motion in arrest of judgment, because no offense is charged. BURN. SIDE, J. * * * What did the defendant obtain? A receipt for an old debt, which on the allegations in the indictment is not worth a farthing. A receipt is always open to explanation, and when ob. tained by fraud, or given either under a mistake of facts or an ignorance of the law, it may be inquired into and corrected in a 
court of law as well as in equity. *** The payment alleged on the face of the indictment was no payment, and the receipt was no bar to Harman's recovering his debt. If Moore had obtained any money or merchandise, or anything of value from Harman, his case would be within the provisions of the act; but as the receipt was for a preceding debt, and if that receipt was obtained by fraudulent misrepresentations, and without value, it was neither a cheat at common law, or within the statute. ${ }^{* * *}$ [Rogers and Coulter, JJ., dissented.] Reversed. Moore v. C., 8 Pa. St. 260, Mi. 846.

(Eng. C. C. R., 1859.) Dogs. Defendant was indicted under 7 \& 8 Geo. 4 , c. 29 , convicted and sentenced to 7 years servitude. The proof was that prosecutor advertised dogs for sale; that defendant saw the advertisement, and wrote prosecutor a letter falsely intimating that defendant lept a manservant, and requested shipment of two pointers on trial; which were sent on the strength of the representation, received by the defendant, and sold by him for $\mathfrak{f}^{5}$ each. The question reserved was whether dogs were chattels which one might be convicted of obtaining by false pretenses under the statute. LORD CAMPBELL, C. J. It is - admitted that dogstealing is not larceny at common law, and a specific punishment of a milder character has been enacted by the later statute, which makes the offense a misdemeanor. That being so, it would be monstrous to say that obtaining a dog by false pretenses eomes within the stutute $7 \& 8$ G. IV. c. 29 , s. 53, by which the offender is liable to seven years penal srrvitude. My brother Coleridge used to say that no indictment would lie under that section unless, if the facts justified it. the prisoner could be indicted for larceny, and that is now my opinion. Conviction quashed. R. v.' Robinson, Bell C. C. 34, 28 L. J. m. c. 58, 5 Jur. n. s. 203, 7 W. R. 203, 8 Cox C. C. 115, B. 721 , Ke. 357 .

Compare Mfullanly v. P., \& 139.

(Wis. Sup. Ct., 1890.) Obtaining Board, etc. Defendant went to prosecutor's hotel, October 25 , and engaged room and board for himself and wife at an agreed price for an indefinite time, but paid nothing. November 18 prosecutor presented a bill for the amount then due, and defendant said he had no money, but had some on deposit at a bank at M., which he expected every day; on the strength of which representation, which wis false, prosecutor furnished defendant and wife accommoditions till March 1, following. when defendant left without paying. These facts were the basis of a prosecution and conviction of obtaining property by false pretenses. Case stated for the opinion of this court. CASSODAY, J. * * * From the very wording of the statute it is manifest that no complete offense can be committed under it until the "money, goods, wares. merchandise, or other property," is actually obtained by the offender. This being so, it is equally obvious that if the statute applies to the ob- 
taining of board and lodging, then each meal of board obtained constitutes a separats offiense; and the same would be true of each night's lodging. If the section applies to board and lodging, then, for the same reason, it would apply to almost any service or use. Another serious difficulty with such application in the case at bar is the absence from the record of any certain and definite description of the property actually obtained. Misny of the authorities hold that in the information or indictment in such cases, "the property should be descriled with as much accuracy and particularity as in indict. ments for larceny." S. v. Kube, 20 Wis. *225, 91 Am. Dec. 395. Where the description of the property is uncertain, the defect is fatal. Ibid. We are to remember that it is a criminal statute we are construing. It should not be so construed as to multiply crimes, un. less required by the context. The word "property" is, in many cases, construed to include "things in action and evidences of debt." Subd. 3, 4, sec. 4972 , R. S. But the words "other property," in the statute quoted must. under the familiar rule, noscitur a sociis, be limited to such tangible elasses of property as are therein previously enumerated. * * The construction of the statute indicated has additional foree from the fact that the same section punishes the obtaining by false pretenses of a signature to a written instrument the false making whereof would be punishable as forgery. Sec. 4423, R. S. This clearly covers some "things in action and evidences of debt," and hy necessury implication excludes others, as, for instance, a mere credit, as here. We must hold that the words "ur other propert.." do not include the mere obtaining of board and lodging under the cireumstances stated. * * S. v. Black, 75 Wis. 490,14 X. W. (6i3i). R. T2:3.

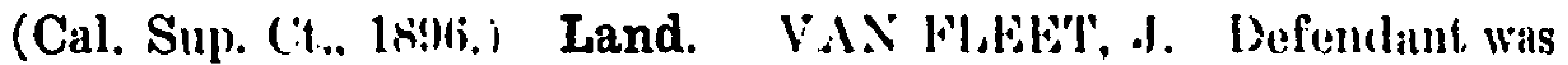
accused by information of the arime of obtaining property hy false pretenses, under len. Conl. \$ 3 i3:, the property charged to have been obtained being desieribed as two certain pareels of land. He demurred to the information as not stating an offense. The demurrer was sustained. and the people appeal, the sole question being whether land is such property as to be the subject of the oftense sought to be eharged. We think the demurrer was properly sustained. Jooking it the history of the offense, and the evil which it has niways been designed to correct, and regarding as we must the contcinporary construction given to stututes of like purpose and effect buth in England and the United States. we are satisfied that the provision of the code was not designed to include an instance of defrauding another of real estate. * * In their nrigin, both the common law and statutory offenses were undoubtedly designed and aimed solely at protecting personal property. $*$ Indeed they appear to have sprung into being largely hy reason of certain defects in the application of the laws against lareeny. * [His honor here proceeded to review the statutes and decisions on 
the subject.] Garroutte and Harrison, JJ., concur. Affirmed. P. v. Cummings, 114 Cal. 437, 46 Pac. 284, Mi. 847.

Acc. S. v. Burrows, 11 Ired. (33 N. C.) 477; C. v. Wuodrun, 4 Pa. Law J. 362 . But see P. v. Pickens, 153 N. Y. 576,17 N. E. 888.

\section{\$175. "With Intent to Cheat or Defraud."}

(Eng. C. C. R., 1823.) To Avoid Going to Work on the order of the overseer of the poor of the parish from which the prisolser had obtained help, he said he could not work, for he had no shoes, whereas the fact was that he then had two new pairs of shoes recently furnished by the parish. On the strength of this statement, the overseer sent him another new pair, but afterwards aiscovering the fraud, caused him to be prosecuted and convicted for obtaining goods by false pretenses. On case reserved, the judges held that the conviction could not be supported, for the statement was not made to obtain goods, but was rather a false excuse for not going to work. R. v. Wakeling, Russell \& R. 504, B. 726.

(Va. Ct. of App., 1879.) Intent to Make Good. On trial for obtaining money by false rretenses, it appeared that defendant intended to buy a lot, told $R$. that he owned it, sold it to $R$. for $\$ 200$, then made a contract with the true owner for the title, and paid part of the price, but never paid the full price nor acquired the title. Though defendant had been discharged from liability on his land contract by virtue of bankruptcy proceedings, he had been of good repute in the neighborhnod for 20 years, and had revived his liability by promise to pay after he was discharged. Conviction on this evidence was held unwarranted by the proof; since it is apparent that defendant had no desire to defraud when he made the statement, gave the deed, and obtained the money. Judgment reversed. Fay v. C., 28 Gratt. (69 Va.) 912, 5 L. 248.

(New York Ct. of App., 1902.) Dividends at 10 Per Cent Per Week. On trial on indictment in two counts; 1 , for embezzlement; and 2, for common law larceny; it appeared that defendant took a prominent part in a leading Brooklyn church, became president of the Christian Endeavor Society of the church, thus made acquaintance of the young men of the church, then established what he called the Franklin Syndicate, with himself as manager, told the young raen its business was dealing on the stock exchange where he had inside information. and offered them 10 per cent a week on their money to be used in the business. A few of the credulous invested, the promised dividends were promptly paid, each investor became a proselite, the few becume many, larger quarters were rented, depositors lined up and stood in line for hours to put in their money, others stood in line likewise to draw dividends, and as much as $\$ 60$,000 in a day was received in deposits. The money received was used 
to pay office expenses, dividends, advertising, etc., and the balance put in the banks, or other deposits. No trading on the exchange was done. The crisis was inevitable, as the dividends increased and deposits did not grow in much greater proportion. Defendant made an assignment, took $\$ 100,000$ in cash and as much more in U. S. bonds and went to Canada. The prosecutrix was one of his victims. She testified that she put in $\$ 100$ of her own accord, and arew $\$ 10 \mathrm{a}$ week on it for several weeks, then conceived the idea that it would be a good thing to put in $\$ 1,000$ and get $\$ 100$ a week; that she took it to defendant herself, asked him if he would insure the money against loss, and was told that the coupon was insurance enough, but was not asked to put the money in, nor was any representation made as to how it would be used, but she understood that the money of the Goalds and Vanderbiits was made in Wall St., and thought this money would be used in this way for her benefit. Was this larceny? Was it obtaining money by false pretenses? Was it embezzlement? Was it any crime? P. v. Miller, 169 N. Y. 339, 62 N. E. $418,88 \mathrm{Am}$. St. Rep. 546 ; same case, 64 N. Y. App. Div. 450, 72 N. Y. Supp. 253.

Compare R. v. Ilodlsson, \$ 163 , as to intent to defraud.

\section{MALICIOUS MISCHIEF.}

\section{§ 175a. In General.}

Definition and criminality: See several cases under $\S 16 ;$ R. $\nabla$. Kelly, 843 ; R. v. Pembliton, \& 44 : Dobbs's Case, 8 115. Dlstinguished from larceny: $P$. V. Woodward, \$ 145. Mere noises'as: C. v. Taylor, \& 180 . 


\section{CHAPTER X.}

\section{OFFENSES AGAINST PUBLIC PEACE.}

8170. General Statement, 851.

Common Barratry, maintenanch, and Champerty.

8177. Common Barratry, 551.

\$178. Maintenance, 55i.

8179. Champerty, 552.

simire Breaches of the Pract.

\$ 180 . Nolsen, etc., 552.

Forcible ENTRY AND Forcible DetaINer.

8181. Defined, etc., 653.

AFERAX.

8182. Defined, etc., 554.

UNLAWEUL ASSEMBLY, ROUT, AND RIOT.

\$183. Defined and Dlstingulshed, 555.

LIBEL.

\$184. Defined, etc., 556.

\$176. General Statement. Since the prime purpose of government is to maintain peace and tranquility to enable the people to live in comfort and security, any disturbance of sufficient magnitude for the law's notice is criminal. Chief among crimes of this class are: stirring up strife by common barratry, maintenance, and champerty (prosecutions for which are very rare and their criminality now doubtful); various simple breaches of the peace, as eavesdropping, common scolding, and making noises to the disturbance of the community; forcible entry and forcible detainer; affray; unlawful assembly, rout, and riot; and libel. Let us examine these separately.

\section{COMMON BARRATRY; MAINTENANCE, AND CHGMPERTY.}

$\S 177$. "Common Barratry is the offense of frequently exciting and stirring up suits and quarrels between his majesty's subjects, either at law or otherwise." 4 Bl. Com. 134.

\$178. "Maintenance is an offense that bears a near relation to the former, being an officious intermeddling in a suit that no way belongs to one, by maintaining or assisting either party with money or otherwise, to prosecute or defend it. * * 4 man may, how. ever, maintain the suit of his near kinsman, servant, or poor neighbor, out of charity and compassion, with impunity." 4 Bl. Com. 134. 
\$179. "Champerty, campi-partitio, is a species of maintenance and punished in the same manner; boing a bargain with a plaintiff or defendant campum partiro, to divide the land or other matter sued for between them if they prevail at law; whereupon the champerter is to carry on the party's suit at his own expense."

Common law not adopted on thls oftense in Pennsylvanla: James v. C., \& 5 .

\section{SIMPLE BREACHES OF THE PEACE.}

\section{§180. Noises, Etc.}

(Pa. Sup. Ct., 1812.) Making Disturbance at Night. Taylor was indicted and convicted of entering the house of J. Strain at 10 p. m., and making 'a great noise. The court arrested judgment on the ground that no erime was charged. 'The record comes here on writ of error. TILGHMAN, C. J. It is contended on the part of James Taylor, that the matter charged in the indictment is no more than a private trespass, and not an offense subject to a criminal prosecution. On the other hand it has been urged for the commonwealth that the offense is indictable; 1st, as a forcible entry; 2nd, as a malicious mischief. I incline to the opinion that the matter charged in the indictment does not constitute a forcible entry, although no doubt a forcible entry is indictable at common law. There must be actual force to make an indictable offense. The bare allegation of its being done with force and arms does not seem to be sufficient, for every trespass is said to be with force and arms. * * There is another principle, however, upon which it appears to me that the indictment may be supported. It is not necessary that there should be actual force or violence to constitute an indictable offense. Acts injurious to private persons, which tend to excite violent resentment, and thus produce fighting and disturbance of the peace of society, are themselves indictable. To send a challenge to fight a duel is indictable, because it tends directly towards a breach of the peace. Libels fall within the same reason. A libel even of a deceased person, is an offense against the public, because it may stir up the passions of the living and produce acts of revenge. Now, what could be more likely to produce violent passion and $n$ disturbance of the peace of societr. than the conduct of the defendant? He enters secretly after night into a private dwelling-house with an intent to disturb the family, and after entering makes such a noise as to terrify the mistress of the house to such a degree as to cause a miscarriage. Was not this enough to produce some act of desperate violence on the part of the master or servants of the fumily? It is objected that the kind of noise is not descrilird. No matter; it is said to have been made vehemently and turbulently, and its effects on the pregnant woman are described. In the case 
of R. y. Hood, Sayer 161, the court refused to quash an indictment for disturbing a family by violently knocking at the front door of the house for the space of two hours. It is impossible to find precedents for all offenses. The malicious ingenuity of mankind is constantly producing new inventions in the art of disturbing their neighbors. To this invention must be opposed general prinoiples calculated to meet and punish them. I am of opinion thit the conduct of the defendant falls within the range of establisied principles, and that the judgment of the court below should be reversed. [Yeates, and Brackenridge, JJ., filed concurring opiniots.] C. v. Taylor, 5 Binney 277 , Mi. 44.

shooting dog on porch of owner to terror of members of family is: Henierson $v$. C. 8 18. Shooting a wild goose near a house, so that a woman bad a at: C. v. Wing,

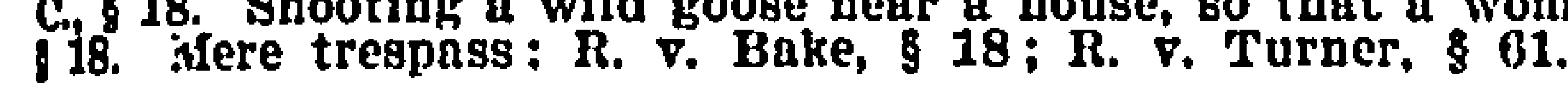

\section{FORCIBLE SNTRY AND FORCIBLE DETAINER.}

§181. Defined. "Forcible entry or detainer, which is committed by violently taking or keeping possession of lands and tenements with menaces, force, and arms, and without the authority of law." $4 \mathrm{Bl} . \mathrm{Com} .148$.

(Mass. Sup. Judicial Ct., 1849.) What Constitutes at Common Law. Indictment for forcible entry and detainer. Defendant demurred. Demurrer overruled. Verdict, guilty. He excepts, among other things, to the sufficiency of the indictment. DEWEY, J. * - We apprehend that both before and since the enacting of the various statute provisions in England, the remedies for a forcible entry unlawfully made have been twofold, one by indictment at common law, and the other by proceedings under the statutes. In R. v. Bathurst, Sayer 225, it was held, that an indictment lies at common law for a forcible entry into a dwelling-house and expelling the occupants. In R. v. Bake, 3 Burr. 1731 [\$ 18], Justice Wilmot says, "Undoubtedly ai indictment will lie at common law, for a forcible entry, though the proceedings are generally under the acts of parliament." In R. v. Wilson, 8 T. R. 357, 362, Lord Kenyon says, "There is no doubt that the offense of forcible entry is indictable at the common law, though the statute gives other remedies to the parties aggrieved." 3 Chit. Crim. Law 1131; Rosc. Cr. Ev. 374, are also authorities to the same effect. *** This must be so upon sound principles, as the preservation of the public peace requires that the offense should be punished criminally. Individuals are not to assert their claims to real estate, and especially to a dwelling-house, in the actual possession of another, by force and violence, and with a strong hand. The peace of the commonwealth forbids it. This principle does not in any degree interfere with 
the making of a formal entry upon land, preparatory to the bring. ing of an action at law, and which may be necessary to give. a legal seizin to the party, but which leaves those in possession un. disturbed as to the actual occupation. Nor does it embrace the case of a mere trespass upon land, as to which the civil remedy is alone to be resorted to. To sustain an indictment for a forcible entry, the entry must be accompanied with circumstances tending to excite terror in the owner, and to prevent him from maintaining his right. 'There must at least be some apparent violence; or some unusual weapons; or the parties attended with an unusual number of people; some menaces, or other acts giving reasonable cause to fear, that the party making the forcible entry will do some bodily hurt to those in possession, if they do not give up the same. It is the existence of such facts and circumstances, connected with the entry, that removes it from the class of cases of civil injury, to be redressed in actions of trespass or other civil proceedings, and holds the party thus making an unlawful entry amenable to the public as for a public wrong. Does the present indictment charge such an offense, as we have above described as that of a forcible entry? Charging the entry to have been unlawfully made with force and arms, and with a strong hand, is a sufficient allegation to constitute the offense a forcible entry. The words "with a strong hand" mean something more than a common trespass. By Lawrence, J., in R. v. Wilson, 8 'T. R. 362, these words are said to imply that the entry was accompanied with that terror and violence which constitute the offense. See Rastall's Entries, 354; Bande's Case, Cro. Jac. 41 . It seems to us, therefore, that this indictment does well charge the offense of a forcible entry, and that such forcible entry is an oftense at common law. *** Exceptions overruled. C. v. Shattuck, 4 Cush: 141, Kn. 324 .

"Force and arms" does not Imply breach of peace sufficient to sustnin indletment: IR. จ. Bake, $\$ 18$; Kllpatrlck จ. P., \$ $16 ;$ C. v. Taylor, $\$ 180$. A common law offense: R. จ. Bake, \& 18 .

\section{AFFRAY.}

$\$ 182$. Defined, Etc. "Affrays (from affraier, to terrify) are the fighting of two or more persons in some public place, to the terror of his majesty's subjects: for, if the fighting be in private, it is no affray but an assault." $4 \mathrm{Bl}$. Com. 145.

(Ga. Sup. Ct., 1853.) Proof of Joining in Affray-Mere Words. WARNER, J. The defendants were indicted for an affray, which is defined by our code, to be "the fighting of two or more persons in some public place, to the terror of the citizens, and disturbance of the public tranquility." Prince, 643. * * Where two are indicted for an affray, the successful defense of one will operate as an acquittal of both; as where the evidence shows that one of 
the parties acted entirely in self-defense, while the other assaulted and beat him, the aggressor may be guilty of an assault and battery, but neither of them guilty of an affray; and neither can be convicted on an indictment therefor; so that on the trial of an indictment for an affray, the aggressor is as much interested to show that both parties did not fight, as the innocent party is to show that fact; the defense of one enures to the benefit of the other. But it is said, there is no evidence that Hawkins, one of the defendants, fought at all, and that an affiray cannot be committed by words alone. The evidence is, that an altercation took place between the parties in a public street in Milledgeville, at the instance of IIawkins, who first accosted Bonner. Bonner then drew his linife, cut at Hawkins. Hawkins then drew his knife from his pocket, but did not use it, being prevented by the bystander's. 'l'he drawing his knife and attempting to use it on that occasion, was an act quite significant of his intention, had he not been prevented from using it. The words alone of the parties, independent of their acts, would not have constitnted an affray; but their words, accompanied by their acts respectively, in drawing their knives and attempting to use them, was calculated to terrify the good eitizens of Milledgeville, and disturb the public tranquility. 1 Russell on Crimes 271.

* Affirmed. Hawkins v. S., 13 Ga. 322, 58 Am. Dec. 517, Kn. 313. Prize fight: C. v. Colberg, $\$ 28$; S. v. Burnhnn. \& 28 .

\section{UNLAWFUL ASSEMBLY, ROUT, AND RIOT.}

$\S$ 183. Defined and Distinguished. "Ricts, routs, and unlawful essemblies, must have three persons at least to constitute them. An unlawful assembly is when three or more do assemble themselves together to do an unlawful act, as to pull down inclosures, to destroy a warren or the game therein, and part without doing it, or making any motion towards it. A rout is where three or more meet to do an unlawful act upon a common quarrel, as forcibly breaking down fences upon a right claimed of common or of way, and make some advances towards it. A riot is where three or more actually do an unlawful act of violence, either with or without a common cause or quarrel: as if they beat a man; or hunt and kill game in another's park, chase, warren, or liberty; or do any other unlawful act with force and violence; or even do a lawful act, as removing a nuisance, in a violent and tumultuous manner." 4 Bl. Com. 146.

(Ind. Sup. Ct., 1853.) Charivari. Indictment for riot under $2 \mathbf{R}$. S., (1852), p. 425, providing: "If three or more persons shall do an act in a violent and tumultuous manner, they shall be deemed guilty. of a riot." Verdict, guilty ; motion for new trial overruled; and on 
exceptions the question was whether there was evidence to sustain the verdict. It was shown that defendants marched back and forth in the highway before the public house of J. Wise blowing horns, singing songs, and shouting, at night till two o'clock in the morning; but that they carried no weapons, and offered no violence. PERKINS, J. * * * A great noise in the night-time, made by the human voice or by blowing a trumpet, is a nuisance to those near whom it is ruade. The making of such a noise, therefore, in the vicinity of inhabitants, is an unlawful act; and, if made by three or more persons in concert, is, by the statute of 1843 , a riot. All these facts exist in the present case. Here was a great noise, heard a mile, in the night-time, made with human voices and a trumpet, in the vicinity of inhabitants. The requirements of the statute for the making out of the offense are filled. The noise was also made tumultuously. The act itself involves tumultuousness of manner in its performance. But it is said, here was no alarm or fear. The statute defining the offense says nothing about alarm or fear. In this case, however, it was only the witnesses who were not alarmed. Others within the distance of the mile in which the noise was heard, and who were not present to observe the actual condition of things, may have been, and doubtless were, alarmed; and the pedler was afraid his horses would be stolen. It is said the rioters were in good humor. Very likely, as they were permitted to carry on their operations without interruption. But with what motive were they performing these good-humored acto? Not, certainly, for the grati. fication of Wise and his family. T'hey were giving them what is called a charivari. which Webster defines and explains as follows: "A mock serenade of discordant music, kettles, tin-pans, etc., de. signed to annoy and insult. It was at first directed against widows who married a second time, at an advanced age." * * Judg. inent affirmed. Bankus v. S., 4 Ind. 114, Kn. 315.

Labillty of rloters for acts of opponents: C. v. Campbell, \& 14. Number necesary to create: Respublica v. Telscher, 815.

\section{IIBEL.}

\section{§184. Defined, Etc.}

(Conn. Sup. Ct. of Errors. 1828.) Letier Addressed to Person Libeled. Information for writing and sending a letter to a married woman insinuating libidinous conduct and soliciting adultery. Defendant moved in arrest of judgment after conviction, and asks the opinion of this court. PE'iERS, J. ***A libel is a malicions defamation of any person, made public by printing, writing, signs, or pictures, tending to blacken the memory of the dead, with intent to provoke the living, or injure the reputation of the living, provoke him to wrath, and expose him to hatred, contempt or ridicule. 1 Hawk. P. C. c. $73, \S 1 ; 4$ Bl. Com. 150; Holt, Libel, 73 ; Hillhonse v. 
Dunning, 6 Conn. 391. Is the writing in question a libel? It is a letter, addressed, by the defendant, to the wife of another man, stating she had "played peep-abo" with him long enough; by which the jury have found, that he meant, that she had acted libidinously towards him, and invited him to an adulterous intercourse and connection with her, and sought opportunities to effect it. It appears by the information, which the jury have found to be true, that the defendant composed and wrote the letter, and sent it to her, with intent to insult and abuse her, and to seduce and debauch her affections from her husband, entice her to commit adultery, and bring her into hatred and contempt. Adultery is a detestable crime, especially in a female; the most disgraceful a woman can commit; and is punished with great severity, by our law. St. 1821, tit. 22, §62. T'o say of a woman, falsely and maliciously, that she has committed this crime, is a gross slander. To say that she is running about the country seeking opportunities to commit adultery, renders her more contemptible and ridiculous than the crime itself; and to publish such a story, by printing or writing, is a libel. But a libel is a high misdemeanor; and it may be laid down as law, in all cases, that the allegation of an act, which the law recognizes and punishes as a crime, is libelous. Holt, Libel, 188, 189; R. v. Wilkes, 2 Wils. 151. It is said, that the letter in question is not a libel, because it was not published, by the defendant. But it is well settled, that the sending of a letter to the party, filled with abusive language, is an indictable offense, because it tends to a breach of the peace. It las, indeed, been a matter of doubt whether the sending of such a letter to another would support an action for a libel, because there. was no publication. But the sending of such a letter, without other publication, is clearly an offense of a public nature, and punishable as such, as it tends to create ill-blood, and cause a disturbance of the public peace. Holt. Tibel, 239; 2 Swift, Dig. 341; 1 Hawk. P. C. lib. 1, c. 73. \$11; Bac. Abr. tit. "Libel," B; Wooton v. Edwards, Poph. 140: Hicks's Case. Hob. 215. * Motion in arrest overruled. S. v. Avery, 7 Conn. 266, 18 Am. Dec. 105. F. 149.

A common law crime in America: C. v. Chapmun. $\$$ i: $\$$. Pulle. $\$$. Not an

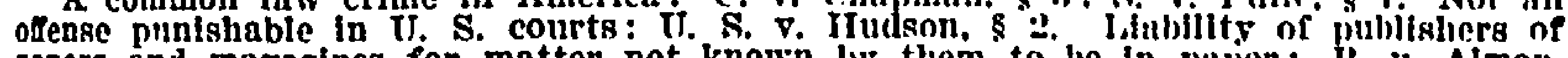
papers and magazines for matter not known ly them to bo in pujer: $R$. V. Almon, 81. Written ont of furlsdiction punishable where pullished: IR. v. Jolinson, 87 ;

C. v. Rlanding, \& 87. Obhscene publication as criminnl lihil: $i$. v. C'url. \$ 19 . 
CHAPTER XI.

OFFENSES AGAINST GENERAL WELFARE-PUBLIC MORALS, SAFETY, HFALTH AND COMFORT.

\$185. Genoral Statement, 558 .

Arontron.

\$186.' In General, 559.

Bilialy on Polygamy.

\$187. Defined, etc., 559 .

ADUt,TERY.

\$188. In General, 560.

Mischignation.

$\$ 189$. Defned, 561.

I.cesst.

$\$ 100$. Defined, etc., 501.

Sonomy on BugGenY.

$\S 101$. Defined, 562.

AnDuction.

8 102. In General, 562 .

SEDuCrion.

\$193. General Statement, etc., 565.

Folnication.

\$194. Deflned, 568.

ljtraing and Pumhining Orscene or Profane lasguage.

$\$ 19 \%$. In General, $\mathbf{5 6 8}$.

NuISANCE.

\$196. Definition, 5ĩo.

$\$ 197$. "By Act or Neglect Creates a Condition of Things Prejudicial," 570.

$\$$ 198. "Safety," 572.

\$109. "Business," 572 .

§ 200. "Health," 574.

$\$ 201$. "Comfort," 575.

8202. "Morals or Outraging the Sense of Decency," 579.

$\$ 203$. "Of the Citizens at Large," 581.

§185. General Statement. As immorality tends to undermine the foundations of society its worst forms are criminal as endangering the puiblic. Immoral conduct in public is criminal for the further reason that it outrages the public sense of decency. On both of these grounds the maintenance of any condition of things destructive of public safety or comfort is criminal. The principal crimes of this kind are: Abortion, bigamy or polygamy, adultery, miscegenation, incest, sodomy or buggery, abduction, seduction, illicit cohabitstion, fornication, indecent-exposure of person, uttering and publishing obscene and profane language, and nuisance. Let us observe some of these more particularly. 


\section{ABORTION.}

\section{§186. In General.}

(Pa. Sup. Ct., 1850.) Before Quickening. An indictment for causing miscarriage of a woman was sustained against objection that it should have charged the miscarriage if the child, because the act is rightfully predicated of the woman; and against objection that it did not charge that the woman had become quick, because that is not essential to the crime. "It is not the muxder of a living child, which constitutes the offense, but the destruction of gestation, by wicked means and against nature. The momient the womb is instinct with embryo life, and gestation has begun, the crime may be perpetrated. The allegation in this indictment was therefore sufficient, to-wit: "that she was then and there pregnant and big with child." Per COUITER, J. Affirmed. Mills v. C., 13 Pa. St. 631, Kn. 335, Mi. 536.

\section{BIGAMY OR POLYGAMY.}

\$187. Defined, Etc. Bigamy is entry into marriage by one having another spouse living; and this is felony by St. 1 Jac. 1, c. 11; and by some American statutes it is felony, by others a misdemeanor.

(Mich. Sup. Ct., 1876.) Second Marriage Otherwise Void. COOLEY, C. J. 'i'he defendant seeks to avoid the penalties of a bigamous marringe by showing that he is a negro, and that the other party to the marriage was a white woman, with whom, under the siatute, it was impossible for him to contract marriage at all. Comij. L., $\S 4724$. The argument is, that if the ceremony of marriage hos takel place between parties who, if single, would be incapable of contracting marriage, the marriage ceremony is merely idle and roid, and the respondent cannot be said to have been married the second time at all. The logic of the argument is not very obvious. It certainly cannot be based upon any idea that there must be something of binding and obligatory force in the second marriage; for tvery bigamous marriage is void, and it is the entering into the void marriage while a valid marriage exists that the statute punishes. Nor can we understand of what importance it can be that there are two elements of illegality in the case instead of one, or why the party should be relieved from the consequences of violating one statute because the act of doing so was a violation of another also. The authorities sanction no such doctrine. * * Judgment 
ordered on the verdict. P. v. Brown, 34 Mich. 339, 22 Am. Rep. 531, Kn. 334.

Spouse supposed to be dead: R, v. Jolson, 8 35; C. v. Mash. $83:$ C. v. Thompson, 53. Spouse supposed to be divorced: Squlre v. State, 53. Marriage supposed in be rold: S. v. Goodenow, 54 ; S. v. Zicheld, 84. BIgamy as religtous duty: Heynolds vs. TI. S., 837 .

\section{ADULTERY.}

\section{\$188. In General.}

(Mass. Sup. Judicial Ct., 1839.) With Single Woman. On indictment and trial for adultery the jury found specially: "The jury find the defendant guilty of having had sexual intercourse with Eliza Foster, the person named in the indictment, she at the same time being an unmarried woman, and the defendunt being a married man and having a lawful wife at the time then living." "The de. fendant moved in arrest of judgment, the motion was overruled, and he excepted. DEWEY, J. * * * By the civil law, adultery could only be committed by the unlawful sexual intercourse of a man with a married woman. Thus, as is stated in Wood's Institute, 272, adultery is a carnal knowledge of another man's wife, and the connection of a married man with a single woman does not make him guilty of the crime of adultery. On the other hand, in the Ing. lish ecclesiastical courts it is held that the offense of adultery is established by showing that the husband has had illicit intercourse with any person, and no distinction is taken whether the alleged offense was committed with a married or unmarried female. Such is the general rule in cases of divorce granted for the canse of adultery, not only in England, but also, as I suppose, throughout the United States. [Here his honor reviewed the statutes of the state, using the same words in speaking of adultery as a crime and as ground for divorce.] Whatever, therefore, may have been the original meaning of the term adultery, it is very obvious that we have in this commonwealth adopted the definition given to it by the ecclesiastical courts, and this not merely in relation to divorces, but also as descriptive of a public crime. We hold the infidelity of the hushand as well as that of the wife, the highly aggravated offense. con. stituting the crime of adultery. * * The court are satisfied that by the proper construction of the term adultery as used in our statutes, the offense is committed by a married man who shall have sexual intercourse with an unmarried woman. Applying this rule of law to the facts specially found by the jury, they establish the crime of adultery to have been committed by the prisoner. [New trial ordered on another ground.] C. v. Call, 21 Pick. 509, 32 Am. Dec. 284-n, Kn. 329.

As provocation for manslaughter: Manning's Cake, 8106 ; Muluer v. I., \& 10k, At common iaw. Bingle man with married womnn: Respublicn 5 . Tolierts, \& $G$. Married man with gingle woman: Anderson $v, C$., \& . Sollciting, whether criminal: $S$. $\nabla$. Avery, 80 : S. v. Butler, 860 . Mlsdemeanor or felony by statites varying in ilter. ent states: S. . Butler, 60 : \$. v. Cooper, 115, on charge of burglary. 


\section{MISCEGENATION.}

§189. Defined. Miscegenation is inter-marriages of races in violation of statute. See P. v. Brown, $\$ 187$.

\section{INCEST.}

$\S 190$. Defined, Etc. Incest is sexual intercourse between persons 30 nearly related that marriage between them would be illegal.

Attempt to contract incestuous marriage is not shown by proof of eloping with nlece und sending for magistrate to perform cel'emony: P. v. Murray, 82.

(Wash. Sup. Ct., 1899.) By Force. GORDON, C. J. The defendant was convicted of the crime of incest. For a reversal of the judgment he relies upon a single assignment of error. The question presented is, can the crime of incest be committed without the concurrent consent of both parties to the sexual act? That it cannot has been held in numerous cases: DeGroat v. P., 39 Mich. 124; Baumer v. S., 49 Ind. 544 ; S. v. Thomas, 53 Iowa 214,4 N. W. 908; S. v. Jarvis, 20 Ore. 437, 26 Pac. 302 ; Yeoman v. S., 21 Neb. 171, 31 N. W. 669. The dcctrine upon which these cases rest is that it is a joint offense, and can be committed only by consenting parties; that, to constitute the crime, both parties must be guilty; that there must be a union of minds as well as of actions; that force and want of consent exclude incest, and what is rape cannot be incest. But we are disposed to agree with Mr. Bishop, that, in principle, the doctrine has no just foundation. Bish. St. Cr. $\$ 660 . *{ }^{*} *$ The holding in S. v. Thomas, above, was by a divided court-three to two; Beck, J., dissenting in an opinion of remarkable clearuess, in which Day, J., concurred. The decision in that case seems to us to have been substantially overruled in the later cases of S. v. Chambers, 87 Iowa 1, 53 N. W. 1090, 43 Am. St. Rep. 349 ; S. v. Hurd, 101 Iowa 391,70 N. W. 613 ; S. v. Kouhns, 103 Iowa 720,73 N. W. 353. * * In our view the consent or non-consent of the female is of no importance except as it bears on the question of the weight or credit to be given her testimony, as being or not being that of an accomplice. * * This view is supported by the following anthorities: S. v. Hurd, above; P. v. Barnes, 2 Jda. 148, 9 Pac. 532; P. v. Kaiser, 119 Cal. 456, 51 Pac. 702; Mercer v. S., 17 Tex. App. 452 ; S. v. Kouhns, above; C. v. Goodhue, 2 Metc. (Mass.) 193 ; C. v. Bakeman, 131 Mass. 577; 10 Am. \& Eng. Fnc. I. 341. Judgment affirmed. S. v. Nugent, 20 Wash. 522, 56 Pac. 25. 72 Am. St. Rep. 133.

(Tex. Ct. Crim. App., 1898.) Proof-Iegitimacy. Appellant was convicted of incest on an indictment in three counts: 1 , for statu- 
tory rape; 2 , for rape by force; and 3 , for incest. HENDLRSON, J. * * * 'The jury aequitted appellant of rape, and therefore of the force necessary to constitute rape. They found that she had copulated with appellant and that he was her father. They evidently found that such act of carnal intercourse was with her consent. Lnder this state of case, the court should have given a chargn? on accomplice testimony. ${ }^{*} *^{*}$ Appellant also insists, that the testimony of the prosecutrix is not corroborated, and that consequently, the verdict camnot be sustained. We believe he is correct in this contention. * * Appellant also insists, that the proof is not sufficient to show that the prosecutrix was his daughter. There is testimony in the record tending to show that she wis his illegitimate danghter. 'The anthorities hold that the crime of incest can be committed between illegitimate relations within the prohibited degree. See $2 \mathrm{M}$ ICChin Cr. L. \$1120, and authorities cited in note. The proof here made, however, is by no means satisfactory. And we hold in such case, that the evidence should be clear and unequivocal as to the fact of relationship. * * * Reversed. Clark v. S., 39 Tex. Cr. Rep. 179, 45 S. W. 576, 73 Am. St. Rep. 918.

\section{SODOMY OR BUGGERY.}

$\S 191$. Defined. It is carnal copulation by human being with beast, or any unnatural copulation with another person. See Estes v. Carter, § 7.

\section{ABDUCTION.}

\section{\$ 192. In General.}

Statute 3 Hen. 7 (1488), c. 2. 'This act, after reciting that "whereas women, as well maidens as widows and wives, having substances, some in goods movable, and some in lands and tenements. and some being heirs apparent unto their ancestors, for the lucre of such substances have been oftentimes taken by misdoers, contrary to their will, and after married to such misdoers. or to others, by their assent, or defiled, to the erreat displeasure of God. and eontrary to the king's laws. and disparatrement of the said women, and ntter heaviness and discomfort of their firiends, and to the evil example of all others," proceeds to ennct. "That what person or persons from heneeforth that taketh any woman so against her will unlawfully, that is to say, maid. widow, or wife, that such taking, proculying, and abetting to the same. and also receiving willingly the same woman so taken against her will, and knowing the same, be felony, and that such misdoers, takers. and procurators to the same. and receivers, knowing the said offense in form aforesaid, be henefforth 
reputed and adjudged as felons, provided always that this act extend not to auy person taking any woman, only claiming her as his ward or bondwoman."

(Engr. King's Bench, 1672.) The prisoner was indicted on the Stut. 3 II. 7, c. 2, for forcibly taking away and marrying the daughter of $S$. ' $T$., a city orphan in the custody of the chamberlain. 'I'he facts established in evidence were, that the prosecutrix was possessed of $\$ 5000$; that she was menaced by the defendant, who was disguised in a mask, and carried away in a coach to Westminster; and the next day, by her own consent, but caused by the precedent menaces, she allowed herself to be married, but was not actually defiled, the defendant being interrupted in his designs; and, by direction of the court, the defendant was found guilty, received sentence of death, and was executed. R. v. Brown, 3 Keb. 193, 1 Vent. 243.

(Eng. King's Bench, 1682.) This was an information at common law against loord Grey and several others, for conspiring and intending the ruin of the dudy Ilenrietta Berkley, then a virgin ummaried, within the age of eighteen years, one of the daughters of the Earl of Berkiley (she being under the custody, ete., of her father), and soliciting her to desert her father, and to commit whoredom and indultery with Lord Grey, who was the husband of another daughter of the Warl of Berkley, sister of the Lady Henrietta, and to live and colnahit with him; and further, the defendants were charged, that, in prosecution of such conspiracy, they took away the said Lady Henrietta at night from her father's house and custody, and against his will, and cansed her to live and cohabit in divers secret places with Iord Grey, to the ruin of the lady, and the evil example, ete. The defendants were found gruilty, though there was no proof of any force; but on the contrary it appeared that the lady, who was herself examined as a witness, was desirous of leaving her father's house, and coneurred in all the means taken for her departure and subsequent concealment. It was not siown that any artifice was made use of to induee her to leave her father's house; but the calse was put upon the gromed that there was a solicitation and enticement of her to unlawful lust by Lord Grey, who was the principal person concerned, the others being his servants, or persons acting by his command, and under his control. R. v. Lord Grey, 3 Iowell's State Trials 519, 1 East P. C. c. 11, p. 460.

(Eng. Queen's Bench, 1701.) The defendants were indicted upon the Stat. 3 IIen. 7 , c. 2. The facts disclosed in evidence were, that the fomale was resident with her aunt, and that on the day stated in the indictment they were waylaid, and arrested in a fictitious suit, and convered from Westminster, where they lodged. to the Garter Tavern, Drury-lane, and that the defendants there separated the annt and niece from each other, and carried the latter to Hol- 
born, where Swanson, the principal defendant, became her bail, and there married her while in custody. Baynton, one of the defend. ants, told her that if she did not marry Swanson she must go to New. gate. The court, in directing the jury, told them, that though the female might have had a regard for Swanson, yet, as she was not privy to the contrivance of coming out to him, and knew nothing of the scheme adopted by the defendants, and being married whilst she continued under that restraint and violence, though perhilps she consented to the marriage, the act itself was a crime within the statute; for here was a forcible taking away; and her subsequent consent, while under the restraint, could not be looked upon but as the effect of a continuing coercion; and that though Swanson had known nothing of the first force, yet he knowing her to be under restraint, and marrying while he knew her to be under it, made him an approver of the first act of violence, and hence a participator in the general guilt. R. v. Swanson, 7 Mod. 101, Holt 319, 5 How. St. Trials 453.

(Mich. Sup. Ct., 1885.) Purpose of Accused. CAMPBELL, J. Respondent was convicted under the statute for enticing away a girl under 16 years of age for the purpose of prostitution. Various exceptions were taken, but the only point argued was whether there was any case made that the intent was for the purpose named. The testimony showed that respondent began his contrivances as early as May, 1883, by inviting the girl to visit his photographic rooms, showing her obscene pictures, and giving her small sums of money, and finally had illicit intercourse with her at several times up to December, when her mother found her there, though he denied her presence, and she was removed. The girl testified to the various acts and circumstances, and to his promises to pay her. The statute which names the illegal purposes of such enticement of females under the age of consent, includes marriage, concubinage and prostitution. The last two were evidently intended to cover all cases of lewd inter. - course. Neither of these words has any common law meaning, but both are popular phrases. either of which might be made to cover the crime here shown without any change in general usage. We see no reason whatever for attempting to narrow them. The statitory purpose is clear. and there is no difficulty in carrying it out. The conviction was right. and it must be certified to the court below that sentence should pass upon it. P. v. Cummons, 56 Mich. 544, 23 N. W. 215. 


\section{SEDUCTION.}

\section{$\S 193$. General Statement. It is doubtful whether seduction was} an offense before Stat. $4 \& 5 \mathrm{Ph}$. \&. M. (1557), c. $8, \S \S 1 \& 2$. It is defined by statute in most states. These differ considerably. Many confine the offense to seduction by promise of marriage.

Not punishable at common law: c. v. Anderson. \& 6. Taking life to prevent sedoction is not fustifiable: F. v. Cook, $\$$ 68. Cunspiracy to secluce crininal at common law: Smith v. L., \& 61 ; R. v. Deluval, \$19.

(Cal. Sup. Ct., 1898.) Capacity-Indefinite Promise-Proof of Chastity. HENSHAW, J. 'The defendant was convieted of the crime of seduction under promise of marriage, and appeals from the judgment, and from the order denying him a new trial. The sections of the Penal Code bearing on the offense are the following: $\S 268$. "Every person who, under a promise of marriage, seduces and has sexual intercourse with an unmarried female of previous chaste character, is punishable by imprisonment in the state prison for not more than five years, or by a fine of not more than $\$ \overline{5}, 000$, or by both such fine and imprisonment." $\$ 269$. "Intermarriage of the parties subsequent to the commission of the offense is a bar to a prosecution for a violation of the last section, provided such marriage take place prior to the finding of an incictetment, or the filing of an information charging such offense." Defendant and the girl with whose seduction he is charged were both sehool children, and about the same age. At the time of the seduetion, and of the first act of sexual intercourse, each was about 16 years old. The girl testified that she submitted to his embraces under his promise to marry her "when he was old enough," and "when they were old enough." She says: "Thero was no time ever set when we were to be married, only after he became of age, and became old enough to be married, we would be. I did not know whether we would be married in one year or two years or three years or five years. I knew when he would become of age." The girl's cvidence, if believed by the jury, was sufficient to support the conviction. * * * It is argued that a boy of 16 is incapable, under our law, of consenting to and consummating marriage; that only an unmarried male of 18 years or upwards can do so. * * * Still further it is pointed out that a boy of 14 or 15 years of age may be thus convicted of the seduction of a mature woman of 30 or 40 ; and, finally, it is insisted that the statute has in contemplation only male offenders that have passed their non-age. This argument is not without much force, yet, after having given to it the full weight to which we deem it entitled, we are zevertheless of opinion that it cannot prevail. The law is designed to protect female chastity; for, as said by Judge Cooley, "Whenever it shall be true of any country that the women as a general fact are not chaste, the foundations of civil society will 
be broken up." P. v. Brewer, $2 T$ Mich. 134. If a previously chaste woman submits herself to the embraces of a man, under promise of marriage from him, upon which she in fact relies, the conviction, generally speaking, may not be aroided by proof that the promise was not learal and binding. The exceptions to the rule are found in those cases in which the promise itself is base and meretriogous, and known to be such by the consenting woman. I'hus if a married man seduces a woman under promise of marriage, she not knowing that he has a wife, his promise is illegal and invalid, but this fact does not excuse him. * * * There was sulficient evidence to justify the finding of the jury that the complaining witness, was of previous chaste character. In the first place, the law piesumes a woman to be ehaste mintil the eontrary is shown. P. v. Brewer, 27 Mich. 134. In the next place, there was affirmative testimony of the girl herself to this effeet. 'The rejected evidence by the defendant that she had had sexual intercourse with other men after the date of the alleged seduction was properly exchuded, and the admitted evidence that she had permitted certain liberties to be taken with herself by her young male companions was not sulficient to show that, at the time of the seduction, she was of "unchaste character," within the meaning of the law. Chastity, as here emploved, means, in the case of an unmarried female, simply that she is virgo intacta, and thongh one woman may permit familiarities, liberties, or even indecmeies, at the thought of which another woman would blush, so long as that woman has not surrendered her virtue she is not put withont the pale of the law. Crozier v. P., 1 Parker (N. Y.) 455. It is conceivable that a woman may permit or suffer many things which would be regarded as improprieties. and yet hold firmly to hor vir. tue. As is happily silu in S. v. Brinkhaus, 34 Minn. 285,25 X. W. 642 , "Although a female may from ignorance or other calssess hase so low a standard of propriety as to commit or permit indelicate acts of familiarities, yet if she have enough sense of virtue that she would not surrender her person unless seduced to do so under promise of marriage she could not be said to be an unchaste woman. within the meaning of the statute." * * * Affirmed. Temple and IICFarland, JJ., concur. P. v. Kehoe, 123 Cal. 224, 55 Pac: 911, 69 Am. St. Rep. 5̃2.

(N. Y. Ct. of App., 1897.) Conditional Promise-Age of Consent. Nelson appealed from an order of the general term affirming a judr. ment on conviction of seduction, on proof that when he was 20 and prosecutrix was 15 he obtained sexual intercourse with her on promise to marry her "if anything happened," the day she was 16 made an absolute promise to marry her, and subsequently had interenurse with her on several occasions, each time promising marriage if she became pregnant. VANN, J. *** The defendant insisted upon the trial, and insists upon this appeal, that his conviction was barred by Pen. Code, $\$ 285$. He further claims, and the point was 
distinctly made at the trial, that, if any subsequent act is relied upon to convict, it. does not satisfy ihe statute, because at the time the prosecutrix had ceased to be chaste. 'The position of the people upon the suoject is that all intercourse with the prosecutrix before she became 16 is conclusively presumed to have been without her consent, because by the statute then in force the age of consent was 16 , and accordingly they seek to avoid the bar of the statute by busing the conviction upon the first act of intercourse that occurred after she became of that age. **** [Here reviewing the statutes as to rape and seduction.] None of these limitations upon the power to consent have been expressly applied by statute to the crime of seduction, and we have no power to extend them by implication to an offense that is purely statutory. Penal statutes must be strictly construed, and cannot be extended to cases that are not clearly covered thereby. An essential element in the crime of seduction is the consent of the female, founded upon a contract to marry, and plain language would be necessary to permit us to hold that the prosecutrix, although old enough to make that contract, was not old enough to consent to the defendant's advances. ** * It is true that subsequently, and within the period of two years, there were further acts of intercourse, based on concurrent as well as prior promises to mary. We think, however, that a woman can be seduced but once, at least under the statute in question, and that the first voluntary act on her part, after she is able to understand its nature and comprehend its enormity, is the only one in which she can participate as a victim. *** In a case that arose in the state of Michigan, under a similar statute, it appeared that illicit intercourse was had between the parties at short intervals, and as opportunity offered ; and it was held that, to warrant a conviction of seduction for the second or third or later acts, there should be clear and satisfactory proof of reformation. P. v. Clark, 33 Mich. 112. Our statute does not punish seduction generally, but only when it is committed under a promise of marriage, uponi a woman of "previous chaste character." "Chaste character," as thus used in the statute, does not mean reputation for chastity, but actual personal virtue. Kenyon v. P., 26 N. Y. 203, 207.

* For these reasons we think that the defendant was unlawfully convicted. *** O'BRIEN. J. I dissent on the ground that unchastity, within the meaning of the statute, cannot be imputed to a female in consequence of intercourse involving the crime of rape. ** * Judgment reversed. P. v. Nelson, 153 N. Y. 90, 46 N.. E. 1040. 60 Am. St. Rep. 592.

(Mich. Sup. Ct., 1902.) Previous Chaste Character-Conditional Promise. Smith was convicted of seduction: and he excepted to the lefusal of the court to charge that. as complaining witness testified to intercourse with responilent prior to the act charged, she was not a person who could be seduced, and that the alleged promise 
to marry if complaining witness should become pregnant was not a sufficient prornise to support the charge. CARPEN'TER, J. * * * In the case of P. v. Clark, 33 Mich. 112, the lower court permitted the jury to find defendant guilty of seduction because of illicit intercourse in August, 1873, though the complaining witness testified that she had such intercourse with defendant not only in August, but on the preceding 28th of July. In deciding this case the court said: "We do not wish to be understood as saying that, even as between the same parties, there could not be a second, or even a third, act of seduction; but, where the subsequent alleged acts follow the first so closely, they destroy the presumption of chastity which would otherwise prevail, and there must ie elear and satisfactory proof that the complainant had in truth and fact reformed; otherwise there could be no seduction. * * * And, although the female may have previously left the path of virtue on account of the seductive arts and persuasions of the accused or some other person, yet, if she has repented of that act and reformed, she may again be seduced." * * " "This decision is decisive of the case at $:: a r$. The people introduced no evidence whatever tending to show is reformation on the part of the complaining witness. * * There is, in our judgment, however, a more serious error in the case. All that the defendant did, according to the testimony of the complaining witness, to induce her to have illicit intercours? with him, was to promise to marry her if she became pregnant. Does s:.xual intercourse induced by such a promise constitute seduction? * * Where the woman is a young inexperienced girl the courts very properly hold that promises and means are sufficient which would not move a woman of mature years. P. v. Gibbs, 70 Mich.; at page 427,38 N. W. 257. The complaining witness in this case, however, was not a young and inexperienced girl.

She was willing to lose her virtue if some provision was made to. conceal its loss. * * ${ }^{*}$ New trial granted. P. v. Smith, 132 Mich. 58, 92 N. W. 776.

\section{FORNICATION.}

\section{\$ 194. Defined. Fornication is illicit sexual intercourse.}

Not criminal at common inw: R. v. Nelaval, 8 19: Respublica v. Roherts, 8 : Anderson $\nabla$. C., \& 6 . That solicitation to, is not crimlnal : $\mathbf{S}$. v. Butler, 8 60. Bot see S. v. Avery, \$ 60 . Consplracy to procure it is indictable: $R$. v. Delnval, \& 11 .

UTTERING AND PUBLISHING OBSCENE OR PROFANE IANGUAGE.

\section{§ 105. In General.}

(Tenn. Sup. Ct., 1851.) Obscene Talk. Appellant was convicted of saying in substance that he had contracted a venereal disease 
from the wife of $\mathrm{H}$. and of discoursing obscenely in public of illicit intercourse with others. McKINNEY, J. *** The books of reports, both of England and this country, abound with cases where, upon these principles of the common law, convictions have been enforced for various offenses agrainst public morality and decency, without the aid of any statutory enactment. And surely it can be no reason for the relaxition of these salutary principles, but rather the eontrary, that in this country we have no "spiritual court," to lend its aid in the suppression of the numerous offenses falling within the class now under consideration; and that such of them as cannot be reached in the mode pursued in the case before us, must "go unwhipt of justice." It would be tedious to enumerate the cases in which offenses have been held indictable as contra bonos mores-in few will suffice for the present purpose. Public drunkenness, 4 13l. Com. 41. All indecent exposure of one's person to the public view, Id. 65 , n. 25 . In the case of $R$. v. Crunden, 2 Camb. 89, 1 Russ. on Crimes 302 , it was held an indictable offense to bathe in the sea near inhabited houses, from which the person might be seen; although the houses lat been recently ereeted, and previously thereto it had been used for persons in great numbers, to bathe at such place. And it was so held, for the reason, "that whatever place becomes the habitation of eivilized men. there the laws of decency must be enforced." So it has been held by this court, that if the master of a slave in his employ, permit such slave to pass about, in view of the public, so meanly clad as not to protect the person of such slave from indecent exposure, the master is indictable for lewdness, or scandalous public indecency: $3 \mathrm{Humph}$. 203. And it may be laid down. in general terms. that all such acts and conduct as are of a nature to corrupt the public morals, or to outrage the sense of public decency, are indictable. whether committed by words or acts. These adjudications, without citing others, we think furnish analogies sufficiently strong to sustain the present prosecution. Are the outrageously vulgar and obscene words found in this record, if uttered in the ear of the public. less likely to shock any one's sense of decency. and to corrupt the morals of society-not to speak of their inevitable tendency to provoke violence and bloodshedthan the offenses charged in the several adjudicated cases above cited? It dnes not so appear to us. $* *{ }^{*}$ Affirmed. Bell v. S., 1 Swan (31 Tenn.) 42. Mi. 59.

Sending obscene matter throwgh the mall to improve mullle molals: V. S. v. Harmon, \& 37. Obscene hooks: IR. v. Rend. \& 19 : Dughlale v. R.. \& 10: R. v. (curl. \$ 11). obscene pictures: C. $\nabla$. Sharplese, of 19." Indrecut Exposure' of l'reson, discussed in C. v. Sharpless, \& $10:$ it. v. rurl, $\$$ in.

(Pa. Sup. Ct., 1893.) Cursing. Indictment for unlawful assembly and for profane cursing. The state appeals from an order quashing the count for profane cursing and swearing. GREEN, J. With un earnest desire to sustain this indictment, if possible, we find ourselves unable to do so. It cannot be sustained under the crimes 
act of $1860, \S 30$, prohibiting blasphemy, because it does not charge that offense; nor under the act of 1794 , because it is not framed upon that act, nor is any attempt made to bring it within the special proceedings under which the act is executed. It only remains to consider whether it can be sustained as charging a common law offense. It camnot be doubted that profane swearing and cursing in a loud and boysterous tone of voice, and in the presence and hearing of citizens of the commonwealth passing and repassing on the public streets and highways of the commonwealth, to such an extent as to be a common nuisance to all citizens being present and hearing the same, is an indictable offense at common law. But this indictment omits to charge all or any of these facts and circumstances which are essential to constitute the offense as a common nuisance. * * * It is the publicity of the offense, and the place in which it is committed, that make it punishable as a common muisance. Of course, there can be no publicity unless the profane lan. guage is uttered in the presence and within the hearing of the citizons present, and this is an essential and an indispensible fact. which must necessarily be charged in the indictment in order to make out a successful allegation of any offense. There is no such language in the third count of this indictment, and we must therefore pro. nounce it insufficient as a pleading. Judgment affirmed. Com. v. Linn, 158 Pa. St. 22, 27 Atl. 843, 22 L. R. A. 353-n.

\section{NUISANCE.}

§196. Definition. One is guilty of a public, common, or criminal nuisance, who by act or neglect creates a condition of things prejudical to the safety, business, health, comfort, or morals, or outraging the sense of decency and propriety, of the citizens at large.

Single malicious act not nuistince though a mistlemennor: ( $v$. Wing. 18 . lieep). Ing unanthorized lottery is: $P$. v. Jackson, $\$ 10$. Corporation liable for maintaining: C. v. Proprletors, $\$ 46$.

\section{§197. "By Act or Neglect Creates a Condition of Things Prejudicial."}

(Eng. Assize, 1826.) License. On indictment for keeping a slaughter house to the annoyance of those who lived near it and persons passing on the highway, defendant pleaded license and pro. duced his certificate. $\triangle \mathrm{BBO}^{\prime} \mathrm{T} T, \mathrm{C}$. J., said the certificate was no defense, and if signed by all the magistrates in the county, would not entitle the defendant to continue the business for an hour after it became a public nuisance. Verdict, guilty. R. v. Cross, 2 C. \& P. 483, B. 844 . 
(Eng. Queen's Bench, 1866.) Obstructing Navigation.-Defense, Instructions to Servants. On indictment for obstructing the navigation of the river 'livy, defendant, who was over 80 years old and unable to give personal attention to his business, offered to prove that he had given instructions to his workmen not to throw waste from the quarry onto the river bank. The judge intimated that the evidence was immaterial; and instructed the jury that as the defendant was proprietor of the quarry and it was operated for his benefit, he was bound to take all proper precautions to prevent rubbish from falling into the river, and if the river was obstructed by it he was guilty though the workmen put it there without his knowledre and against his orders. Verdict, guilty. Rule for new trial. JIELLOR, J. *** It is quite trio that this in point of form is a proceeding of a criminal nature, but in substance I think it is in the nature of a civil proceeding, and I can see no reason why a different rule should prevail with regard to such an act as is charged in this indictment between proceedings which are civil and proceedings which are criminal. I think there may be nuisances of such a character that the rule I am applying here, would not be applicable to them, but hele it is perfectly elear that the only reason for proceeding criminally is that the nuisance, instead of being merely a nuisance affecting an individual, or one or two individuals, atfects the public at large, and no private individual, without receiving some special injury, could have maintained an action. Then if the contention of those who say the direction is wrong is to prevail, the public would have great difficulty in getting redress. The object of this indictment is to prevent the recurrence of the nuisince. The prosecutor cannot proceed by action, but must proceed by indictment, and if this were strictly a criminal proceeding the prosecution would be met with the objection that there was no mens rea; that the indictment charged the defendant with a criminal offense, when in reality there was no proof that the defenclant knew of the act, or that he himself gave orders to his servants to do the particular act he is charged with; still at the same time it is perfectly elo:il' that the defendant finds the eapital, and carries on the business which causes the nuisance, and it is carried on for his benefit; although from age or infirmity the defendant is mable to go to the premises, the business is carried on for him by his sons, or at all events by his agents. Under these circumstanees the defendant must necessarily give to his servants or agents all the anthority that is ineident to the carrying on of the business. It is not because he had at some time or other given directions that it should be carried on so as not to allow the refuse from the works to fall into the river, and desired his servants to provide some other place for depositing it; that when it has fallen into the river and has become prejudicial to the public, he can say he is not liable on an indictment for a nuisance caused by the acts of his servants. It appears to me that all it was necessary to prove is, that the nuisance was caused in the 
carrying on of the works of the quarry. That being so my brother Blackburn's direction to the jury was quite right. ****. Shee and Blackburn, JJ., concurred. Rule discharged. R. v. Stephens, L. R. 1 Q. B. 702,7 B. \& S. 710,35 L. J. Q. B. 251,12 Jur. n. s. 961, 14 L. 'T. ร993, 14 W. R. 859, B. 845.

\section{§198. "Safety."}

(Eng. Nisi Prius, 1699.) Prescription-Beneficial-PriorityGunpowder. One was indicted for a nuisance for keeping several barrels of gunpowder in a house in Brentford town, sometimes two days, sometimes a week, till he could conveniently send them to London. HOLI, C. J., resolved: 1, 'That to support this indictment there must be apparent danger, or mischief already done; 2 , though if had been done for fifty or sixty years, yet if it be a nuisance time will not make it lawful; 3 , if:, at the time of setting up this house in which the gumpowder was kept there had been no houses near enough to be prejudiced by it, but some were built since, it should be at the peril of the builder; 4 , though gunpowder be a necessary thing, and for defense of the kingdom, yet if it be kept in such a place as it is dangerous to the inhabitants or passengers it will be a nuisance. Anon. 12 Mod. 342, B. 843.

\section{§ 199. “Business."}

(Philadelphia Oyer' and 'Terminer, 1785.) Evidence of Benefit to the Public was offered by defendant under indictment for nuisance in maintaining a wharf on public property; but M'KEAN, C. J., delivered the opinion of the court, that the evidence was inadmissible, for two reasons: First, because it would only amount to matter of opinion, whereas it is on facts the court must proceed; and the necessary facts are already in proof; secondly, because it would be no justification; for, on the same principle that the defendant might carry his wharf twelve feet, he could justify extending it farther; or any other man might excuse a similar intrusion. Suppose, for instance, a street were sixty feet wide, twelve feet might be taken off it, withont doing any material injury to the public property, or creating any great obstruction to passengers; yet, surely this will not justify any man's actually building upon, and assuming the property of the twelve feet that could be thus spared. Respublica v. Caldwell, 1 Dallas 150, B. 177.

(Mich. Sup. Ct.. 1880.) Indictment for Obstructing an Alley. Defendant was convicted and brings certiorari. MARSTON, J. An alley can in no proper or legal sense be considered as a public highway, or be governed by rules relating thereto. * * $*$ It is de- 
signed more especially for the use and accommodation of the owners of property abutting thereon. *** Any obstruction to the right of passage through, or to the proper use of any alley, by those entitled thereto, cannot, therefore, be considered as a public wrong. The grievance, if any, is an individual one, for which there may, for \& wilful or unnecessary obstruction, be a private remedy. * * Proceedings quashed. Bagley v. P., 43 Mich. 355, 5 N. W. 415, 38 Am. Rep. 192.

Other cases of private nuisance: C. v. Webb, $\$ 17$, stagnant pond near hlghway; R. จ. Lloyd, 8 17, tin-shop near inns of court.

(Pa. Sup. Ct., 1892.) Traction Engine on Highway. PER CURIAM. The defendants were convicted in the court below of maintaining a nuisance. *** It appear's that the defendants had been operating a stone quarry for several years. This quarry is situated on a public road about three miles from Rummerfield station. It is a narrow road, with four bridges between the stone quarry and the station. For several year's the defendants hauled the stone from the quarry in the ordinary manner by horses. Some time during the year 1891, Charles A. Allen, one of the defendants, procured a traction engine and put it on the road, for the purpose of drawing heavier loads of stone. Behind the engine they hitched two wagons, one behind the other, making a train from 50 to 55 feet long, and when loacled weighing from 13 to $1 \pm$ tons. They made two trips a day from the guarry to the station. It took from an hour to an hour and a half to go over the road one way. There was evidence that the train would sumetimes stop for half an hour to get up steam; the steam would blow off trequently, and make a good deal of noise; that it hindered and obstructed travel over the road; that people took other roads several miles out of their way to avoid it; that women and children accustomed to drive to the station for different purposes wele afraid to do so; that farmers who had contracted to deliver produce to Rummerfield refused to do so because of the obstruction, and cars partly loaded had to be unloaded on that account; that parties at the station and on the roar had been hindered and delayed sometimes for half an hour or more, waiting for this train to get out of the way; that persons who had met it in the road had been obliged to unhitch their horses, and go off behind schoolhonses, into the woods and lanes, and wait until it had gone by. We are not prepared to say that the indictment does not set forth a public nuisance, and that the jury were not justified in finding in the evidence the existence of such nuisance. The running of a traction engine over a public highway upon a single occasion would not constitute a public nuisance. That may be necessary to remove it from one location to another, as in the case of a steam threshing machine. which is at certain seasons of the year removed from one farm to another, for the purpose of threshing out the farmers' erops. * * At common law, any obstruction which unnecessarily incommodes or impedes the public 
use of a highway by the public is a nuisance. Angell, Highw. $\$ 223$, 4. 33l. Com. 167. * * Affirmed. C. v. Allen, 148 Pa. St. 358, .23 Atl. 1115, 33 Am. St. Rep. 830, 16 L. R. A. 148.

\section{$\S 200$. "Health."}

(Alich. Sup. Ct., 1890.) City Built About Offensive Factory. Certiorari. GRANT, J. *** Defendants were convicted of unlawfully and wilfully creating and maintaining a nuisance, consisting of the creation and emission of unwholesome, offensive, and uauseating odors, smells, vapors, and smoke, to the great damage and common nuisance of all people living in the neighborhood thereof, and of all people passing and repassing on the streets and alleys adjacent thereto, contrary to an ordinance of the city in such calse made and provided, being \& 5, c. 55, Rev. Ord. 1884. *** The facts found and returned by the recorder's court elearly estab. lish a nuisance, aceording to all the authorities. These facts so found are eonclusive in this court, and we can only apply the law to the fiacts. * * Defendants are not aided by the fact found by the court that, during the time covered by the complaint, the business, in all respects, had been carried on in a careful and pritdent manner, and nothing had been done by those managing it that was not a reasonable and necessary incident of the business; nor by the further fact that, when the defendant company commenced its business, the lands in the vicinity of its works were open common. It is undoubtedly trine that the defendants, or their predecessor's, established their works at a point remote from habitation, possibly in recognition of the fact that such a business was at least not pleasant, if not injurious, to the health and enjoyment of those living near it. 'The city of Detroit has extended to the defendants' works, and the owners of adjoining lands have erected dwollings thereon. This they, of course, had the legal right to do. The defendants cannot be protected in the enjoyment of their property, and the carrying on of their business. if it becomes a nuisance to people living upon the adjoining properties, and to those foing legitimate business with them. Whenever such a business beemes a nuisinee, it must give way to the rights of the public, and the owners thereof must either devise some means to avoid the nuisine, or must remove or cease the business. It may not be continued to the injury of the health of those living in its vicinity. This rule is founded both upon reason and authority. Nor is it of any consequence that the business is useful or necessary, or that it contributes to the wealth and prosperity of the community. Wond, Nuis., § 19 ; Queen v. Train, 2 Best \& S. 640: Works v. Railrond Co,, 5 Meluean 425; Respublica v. Caldwell, 1 Dall. 150 $\lceil \$ 199]$; Ross v. Butler, 19 N. J. Eg. 296; Robinson v. Baugh, 31 Mich. 290. It is true that. in places of population and business, not everything that 
causes discomfort, inconvenience, and annoyance, or which, perhaps, may lessen the value of surrounding property, will be condemned and abated as a muisance. It is often difficult to determine the boundary line in many such cases. The carrying on of many legitimate businesses is often productive of more or less annoyance, discomfort, and inconvenience, and may injure surrounding property for certain purposes, and still constitute no invasion of the rights of the people living in the vieinity. Such a case was Gilbert v. Showerman, 23 Mich. 448. *** No case has been cited, and we think none can be found, sustaining the continuance of a business in the midst of a populous community, which constantly produces odors, smoke, and soot of such a noxious character, and to such an extent, that they produce headache, nausea, vomiting, and other pains and aches injurious to health, and taint the food of the inhabitants. All the defendants were properly convicted. The officers of the company are jointly responsible for the business. It is not necessary to conviction that they should have been actually engaged in work upon the premises. * * * Affirmed. P. v. Detroit White Lead Works, 82 Mich. 471,46 N. W. 735,9 L. R. A. 722 , B. 851 .

\section{$\S 201$. "Comfort."}

(Eng. King's Bench, 1726.) Making Great Noises at Night with a speaking trumpet was held on indictment to be a nuisance, and defendant was convicted and fined $£ 5$. R. v. Smith, 1 Strange 704 , B. 844 .

(Iowa Sup. Ct., 1872.) Proof of Benefit-Stock Pens as Nuisance. Indictment charges that Kaster kept and fed cattle and hogs in a pen near divers public streets, left the refuse and excrement to rot on the ground, and that the air was contaminated, rendered unwholesome, etc., to the common nuisance, etc. Verdict guilty. Defendant, appcals. MILLER, J. *** The defendant called as a witness one IIugh MicClure, and proposed to prove by him that the inclosure charged as a nuisance "was a great and essential accomodation to the public; that, owing to the lay of the ground and locality of the premises, they were less offensive to the community than any other premises could be that would accommodate the shipping public; and that they were as well kept as they could be." This evidence was objected to by the state and excluded by the court, and this ruling is assigned as error. In R. v. Russell, 6 Barn. \& Cress. (13 E. C. L. 258) 566. it was held by Bayley, J., at nisi prius, that where a great public benefit accrues from which arises the abridgment of the right of passage, that abridgment is not a muisance, but proper and beneficial. But in R. v. Ward, 4 Adolph. \& E. 384 (31 E. C. L. 92), Russell's case was expressly overruled by the court of king's 
bench, and it is there held that a defendant indicted for muisance "will not be permitted to show that the public benefit resulting from his act is equal to the public inconvenience which arises from it." In support of this doctrine, see, also, Respublica v. Caldwell, 1 Dall. 150; Angell on 'lide-waters, c. 8 ; Roscoe's Cr. Lv. pp. 568, 790; Hart v. Mlayor, etc., of Albuny, 9 Wend. 571, 582; Wharton's Am. Cr. Iaw ( $3 \mathrm{~d}$ ed.), 799 , and cases cited; 3 Greenl. on Lv., §187. 'Lhere was, therefore, no error in the exclusion of the proposed evidence. * * We need not determine whether each of the nuisances de. fined in $\$ 4409$ are not to be considered public nuisances, and as such indictable, for it is clear that the acts charged in the indict. ment in this case constitute a public indictable nuisance, both under this section and at common law. 'The indictment charges that the acts specified oceasioned noxious exhalations, offensive and unwholesome suells, so that the air was then and there greatly corrupted and in. fected thereby, becoming and being dangerous to the health, comfort, cte., of all the good people of the state there passing, repassing, being, or residing. It also alleges that the inclosure from whence issued these noxious exhalations and offensive and unwholesome smells is situated near to divers public streets and highways. 'The evidence shows that the pens are within a few rods of a public street, and that persons passing thereon have been greatly annoyed by offensive smells issuing therefrom. It also appenr's that the pens are situated in a populous neighborhood. These facts establish the public character of the nuisance. * * Affirmed. S. v. Kaster, 35 Iowa 221 , C. 549 .

(Mlass. Sup. Judicial Ct., 185ð.) Disagreeable Smells-CustomNeighborhood. Indictment charged that Perry lept 500 hogs near several public strects and the dwellings of many citions, whereby noisome and noxious smells corrupted the air, to the common nuisance, ete. Defendant moved to quash the indietment, "because: 1 , no crime is stated; 2 , the crime is not fully set forth; and, 3 , the place is not stated to be populous. Motion overruled. The govern. ment proved that Perry kept 500 hogs on his place of about $2:$ i acres of farm land in the town of Needham in lots and buildings divided into 75 pens, where all of the animals were housed; that T'rec road, a public highway, bounded the premises on one side and passed within a few feet of the boiler house, where the food was cooked; that Great Plain Ave. bounded the place on the east; that the nearest dwelling-houses were about 500 to 800 feet distant from the pens; that there were several houses within a quarter of a mile, and many more within half a mile; and that the odors from the swine were noticeable and disgusting to the inhabitants of these houses, and sometimes obliged them to close their doors and windows. It was conceded that no swill, slops, or unclean foods were fed, but only grain, beets, etc. Defendant showed that others in the town raised hogs, and he claimed that the odors did not come from his place. 
He offered to prove that throughout the state such pens were built as near the highway as his, had been tolerated for years, and were customary. This evidence was excluded. He asked the judge to instruct that evidence of natural odors from the bodies of domestic animals would not sustain the indictment, and that keeping j00 hogs near the dwelling-houses of a town is not per se a nuisance. These requests were refused, and the jury instructed that if the odors from one unimal were not a nuisance such odors from 500 might be; that proof of actual injury to health was not necessary; that the people were entitled to pure air; and it was sufficient if the residences of the vicinity were made uncomfortable. Verdict, guilty. Defendant excepted. HOLNIES, J. A piggery in which swine are kept in such numbers that their natural odors fill the air thereabouts, and make the occupation of the neighboring houses and passage over the adjacent highways disagreeable, or worse, is a nuisance. C. v. Kidder, 107 Mass. 188, 192: R. v. Wigg, 2 Salk. 460, 2 Ld. Raym. 1163. See C. v. Oaks, 113 IIass. 8; C. v. Upton. 6 Gray 473. The indictment was sufficient and the instructions asked were erroneous. See, further, C. v. Rumford Chamical Works, 16 Gray 231; C. v. Sweeney, 131 Mass. 579 ; C. v. Brown, 13 Met. 365. No defect has been pointed out in the instructions given. It would have been well if they had impressed more fully on the jury that the question was one of degree; but that was implied by what was said, and the defendant asked for nothing more specific. Bvidence of the practice throughout the commonwealth was inadmissible. See Cutter v. Howe, 122 Mass. 541, 549. Exceptions overruled. C. v. Perry, 139 Mass. 198, 29 N. E. 656. C. 552 .

(Pa. Sup. Ct., 1890.) Effect of Usefulness, Investment, Surroundings, etc., on Character-Refinery. WILIIAMS, J. The defendants own and operate a refinery where crude petroleum and its products are prepared for market. 'There are four acres within the inclosure fronting on the Ohio river. The Pittsburg \& W. R. R. passes in front of it. along the river's edge. The Cleveland \& P. R. R. runs upon the street directly in the rear. The city of Allegheng, like its sister eity Pittsburg, owes its growth and prosperity to the extent of its manufacturing interests, and the river front is almost wholly given over to these great industries. The indictment charges that the defendants' refinery is a public and common nuisance, because of the emission therefrom of ccrtain noxions and offensive smells and vapors, and because the oils and gases stored and used therein are inflammable, explosive, and dangerous. 'The jury, under the instructions of the court. found the defendants guilty, and the sentence which has been pronounced requires the abatement or destruction of a plant in which some three hundred thousand dollars are said to be invested, and which gives employment to seventy-five men. * * The learned judge had his attention directed by the written points to the definition of a public nuisance. and to the cir- 
cumstanoes under which the defendants' refinery had been estab. lished and maintained for many years; and he instructed the jury that the character of the location where the refinery was established, the nature and importance of the business, the length of time it had been in operation, the capital invested, and the influence of the business upon the growth and prosperity of the community, were no defense to an indictment for nuisance. Among other expressions used by him are the following: "It is no defense to an indictment for a common nuisance that the business complained of has been in operation many years." "I do not think the size of an establishment makes any difference." And again: "Neither is it a defense in any measure that the business is a useful one," etc. If it had been an admitted or an established fact that the business of the defendants was a common nuisance, and they have attempted to justify its maintenance, these instructions would have been appropriate; but the question before the jury was whether the business was a nuisunce. The decision of that question depended upon a knowledge of all the circumstances peculiar to the business, the place, its surroundings, and the employments of the persons in the vicinity. While no one of these, nor all together, would justify the maintenauce of a unisance, they might be sufficient, and they certainly were competent evidence from which the jury might determine whether the defendants' refinery was a common nuisance at the place where it was located, and this was the question to be determined by the trial. They might make, therefore, or contribute to make, a defense to the indictment trying. This distinction between an effort to justify an admitted or established nuisance, and a denial that the business complained of amounts to a nuisance, was evidently in the mind of the learned judge, but in the haste that attends jury trials, he failed to place it clearly before the jury. He did say that the facts referred to had "weight, and are to be considered in determining the degree of the injury produced, and whether the effects are so annoying, so productive of inconvenience and discomfort, that it can be said to be really so prejudicial to the public as to be a nuisance," but, following an explicit statement that these same facts were "no defense to an indictment for erecting and maintaining a nuisance," such as they were then trying, the jury was left without an adequate presentation of the defense. That such facts are proper for consideration and may make a defense, has been long and well settled. Wood on Nuis. $\S 430$. *** The instructions complained of in the first, second, and third specifications were inadequate. They gave the general rule without the qualification which the situation of the defendants' refinery entitled him to. The right to pure air is, in one sense, an absolute one, for all persons have the right to life and health, and such a contamination of the air as is injurious to health cannot be justified, but in another sense, it is relative, and depends upon one's surroundings. People who live in great cities that are sustained by manufacturing 
enterprises must necessarily be subject to many annoyances and positive discomforts, by reason of noise, dust, smoke, and odors more ur less disagreeable, produced by and resulting from the business that supports the city. They can only be relieved from them by going into the open country. The defendants had a right to have the character of their business determined in the light of all the surrounding circumstances, including the character of Allegheny as a manufacturing city, and the manner of the use of the river front for manufacturing purposes. If, looked at in this way, it is a common nuisance, it should be removed; if not, it may be conducted without subjecting the proprietors to the pecuniary loss which its removal would involve. * * * Judgment reversed. C. v. Miller, 139 Pa. St. 77,21 Atl. 138, 23 Am. St. Rep. 170, B. 849, C. 555.

\section{$\S 202$. "Morals, or Outraging the Sense of Decency."}

(New York Ct. of App., 1881.) What is Disorderly, Bawdy, or Gambling House. ANDREWS, J. The indictment charges the plaintiff in error with keeping a disorderly and common bawdy and gambling house, concluding ad commune nocumentum. The evidence abundantly sustained the charge, and justfied the jury in finding that the defendant kept a house to which gamblers and prostitutes resorted for the purpose of gambling and prostitution. The court, in the course of the charge, stated to the jury that it was not necessary, to constitute the offense of lieeping a disorderly house, that the public should be disturbed by noise, and refused to charge that, in order to convict the defendant of keeping a disorderly house, the jury must find that the house was so kept as to disturb, annoy, and disquiet the neighbors and the people passing and repassing the house. An exception was taken to the charge in this respect and to the refusal to charge as requested. 'The exception was not well taken. The keeping of a common bawdy or gambling house constitutes the house so kept a disorderly house and an indictalle nuisance at common law. R. v. Dixon, 10 Mod. 335; 1 Hawk. P. C. 693. It is a public offense, for the reason its direct tendency is to debauch and corrupt the public morals, to encourage idle and dissolute habits and to disturb the public peace. It is not an essential element that it should be so kept that the neighborhood is disturbed by the noise, or that the immoral practices should be open to public observation. The law, it is true, gives a remedy by indictment against those who unduly disturb the quict of a community by roises which tend to impair the enjoyment of life, but it does not refuse cognizance of those far greater public injuries. which arise from practices which destroy the peace of families and disturb and undermine the foundations of social order and virtue. The court also charged. that if prostitutes came to the defendant's saloon for the purpose of prostitution, and there consummated their intent, 
to the knowledge and with the consent of the defendant, the jury should tind him guilty. 'The defendant's counsel excepted, and requested the court to charge that, in order to tind the defendant guilty of keeping a bawdy house, the jury must tind that he kept his house for the resort and unlawful commerce of lewd people of both sexes. 'The court said: "I have charged the jury on that subject, and decline to change my charge; I have substantially so charged;" and exception was taken to the refusal of the court to charge as requested. In this there was no error. If the defendant's house was the resort of prostitutes plying their vocation there, to the knowledge of the defendant, the house was a bawdy house; and this was what in substance the court charged, and the court, in stating that it had charged substuntially as requested by the defendant's counsel, gave the defendant the benefit of the definition contained in his request. * * * Judgment aftirmed. King v. P." 83 N. Y. 587, B. 847 .

(Md. Sup. Ct., 1899.) Same. AlNEY, C. J. The traverser * * * was indicted for keeping a disorderly house, and upon trial by jury, was convicted. * * * The offense is that of a common nuisance, and it is necessary that the indictment should contain facts to show that a common nuisauce has been created or permitted. This is done by allegation of such facts as show that the traverser maintains, pro. motes, or continues what is noisome and offensive, or annoying and vexatious, or plainly hurtful to the public, or is a public outrage against common decency or common murality, or which tends plainly and directly to the corruption of the morals, honesty, and good habits of the people, the same being without anthority or justitica. tion of law. 3 Greenl. Liv. \$184. * * The court, notwithstanding the protest of comnsel, reduced to writing and read to the jury the following instruction: "If you find from the evidence that the traverser kept a harroom and dance hall, with music, for the purpose and with the intent of bringing together and entertaining prostitutes and men desirous of their company, and that such persous habitually assembled there to drink and dance together, then you may find such establishment a disorderly house, within the meaningr of the indietment, even though you may also believe that the house was quietly kept, and no conspicuous improprieties were permitted inside. The jury being the judges of the law as well as fact, this charge is to be understood as advisory only of what the law is." In the first place, it is argued that the judge had no right to give the instruction, against the protest of the traverser; and, in the second place, that the instruction was erroneous in principle. * * It does not require, in a case like the present, that there should be acts violative of the peace of the neighborhood, or boisterous disturbances, or open acts of lewdness shown, in order to constitute the place a disorderly house. The habitual assembling there of lewd women, and men desirous of their company, to drink 
and dance together, must necessarily be hurtful to the public, and tend to scandalize the neighborhood. It is an outrage against common decency and common morality, and could have no other effect than the corruption of the morals, honesty, and good habit's of the people, and that constitutes the place a nuisance. * * Lffirmed. Beard v. S., 71 Md. 275, 17 Atl. 1044, 4 L. R. A. 675, 17 Am. St. Rep. 536.

Harried Women are llable for keeplng gaming and disorderly houseg, 48 . 4 Oorporation is liable for such offenses: C. v. Polaski C. A. M. Assn. \& 46 ; S. v. Passaic agr. Soc., \& 46. It is a common law offense to keep such a place. P. $\mathbf{\nabla}$. Jackson, 8 18.

\section{§203. "Of the Ciiizens at Large."}

See several cases, ante, $\S 17$. 


\section{CHAPTER XII.}

OFFENSES AGAINST PUBLIC JUSTICE AND AUTHORITY.

\$204. General Statement, 582.

Caimas relating to Poblic Orbice.

\$ 205. General Statement, 582.

OpatuUctino an OHEICER.

\$206. General Statement, 582.

Bribegy.

8207. Defined, etc., 583.

Compodnding Caime.

8208. Defined, etc., 584.

Migpaison of Felony.

8209 . Defined, 585.

Egcape, limison Breach, and Rescug.

810. General Statement, etc., 585.

Embracery.

8211. Defined, etc., 886.

Parjurt.

8 212. Defined, etc., 587.

Contesiat.

\$13. Nature and Kinds, 591.

§204. General Statement. Crimes against the administration of public affairs which are not designed to overthrow the govern. ment, and which nevertheless prevent or impair its effective opera. tion, are principally: offenses relating to office, obstructing an officer, compounding crime, misprison of felony, escape, prison breach, and rescue, bribery, perjury, embracery, and contempt. Let us consider these in the order named.

\section{CRIMES RELATING TO PUBLIC OFFICE.}

§ 205. General Statement. As government cannot exist without officers, it is criminal to refuse office, an offense happily rare. Any act or omission in breach of official duty by one exercising a public office is criminal, especially if the duty is ministerial and does not involve discretion. On this subject see generally $1 \mathrm{Bish}$. Cr. L. $\S \S$ $458-471 ; 2$ Id. $\$ \$ 971-982$.

Illegal voting: C. จ. Silsbce, $\S 20$; C. v. Callaghan, $\$ 20$; C. จ. Randolph, $\$ 6$.

\section{OBSTRUCTING AN OFFICER.}

§206. General Statement. "Since the public good requires the due performance of official functions, a person who obstructs an officer therein, in any matter of public concern and of sufficient magnitude, is punishable." 1 Bish. Cr. L., § 465. 
(Mich. Sup. Ct., 1888.) Unauthorized Acts. The sheriff with a writ of attachment against the property of Clements and wife, went to the farm and attempted to levy on a team of horses, wagon, harness, etc., belonging to the wife, and exempt from process; and when Clements discovered the sheriff's purpose he made such resistance that the sheriff left for fear of his personal safety. For these acts Clements and wife were prosecuted for resisting an officer. She was acquitted and he was convicted and sentenced to nine months' imprisonment. He excepted to the refusal of the court to instruct that the property was exempt and defendant entitled to use such force as was necessary to prevent the sheriff taking it; and also to the instruction given, that the law afiords tribunals where men may have their rights judicially determined and secured, and does not sanction a man acting as judge in his own cases, and enforcing his own judgment in opposition to an officer. In reversing the judgment, the court said: "No writ in this state authorizes the sheriff to levy on such property, and, when he does it, it is at his own peril. The law will not protect him in doing that which it has expressly commanded him not to do. Neither is the debtor compelled to submit to such trespass without reasonable resistance. If the dectrine contended for by the prosecution, and laid down in the charge, were to obtain, every poor debtor would be at the mercy of. the sheriff and constabulary of the county, and the statutory benefits intended by the exemption would be of little avail." Per SHERWOOD, C. J. P. v. Clements, 68 Mich. 655, 36 N. W. 792, 13 Am. St. Rep. 373.

Unnecessarlly killing the oflicer in such case was held manslaugbter: Cook's Case. \$ 70 : Crelghton v. C., \$ 69 . See also, IR. V. Thompson, \$ 106 .

\section{BRIBERY.}

\$207. Defined, Etc. Bribery is "the voluntary giving or receiving of anything of value in corrupt payment of an official act, done or to be done." 1 Bish. Cr. L. $\S 468$.

(N. J. Sup. Ct., 1868.) Offering Bribe to Councilman. Indictment for offering $\$ 50$ to a councilman of Hudson City for his vote on an application for a franchise to lay a railway track in a street of the city. On certiorari and motion to quash, defendant claimed that no crime was charged. DALRIMPLE, J. **** It is said that the common law offense of bribery can only be predicated of a reward given to a judge or other official concerned in the administration of justice. ** * The later commentators, supported, as I think, by the adjudged cases, however, maintain the broader doctrine, that any attempt to influence an officer in his official conduct, whether in the executive, legislative, or judicial department of the government, by the offer of a reward or pecuniary consideration, 
is an indictable common law misdemeanor. 3 Greenleaf's Ev. $§ 71 ; 1$ Bish. Cr. L. § 95, and notes; 1 Russell C. 156.* ** Indeed, the authorities seem to be all one way. Neither upon principle nor authority can the crime of bribery be confined to acts done to corrupt officers concerned in the administration of justice. If in the case now before us, it was no crime for the defendant to offer, it would have been no erime for the councilman to accept the bribe. The result would, therefore, be that votes of members of council on all questions coming before them, could be bought and sold like merchandise in the market. The law is otherwise. 'The common law offense of bribery is indictable and punishable in this state. Our statutes against bribery merely define and fix the punishment for the offense, in cases of bribery of judicial officers and members of the legislature; they do not repeal or abrogate, or otherwise alter the common law. It is contended, in the next place, that the facts set forth in the indictment constitute no offense, inasmuch as the common council had not jurisdiction to grant the application for which the vote was sought to be bought. In my opinion, it is entirely imma. terial whether council had or had not jurisdiction over the subject. * * Whether the common council had authority to make the grant, or the railroad company the power to avail itself of its benefits, if made, or whether the offer of a bribe was before or after the application in due course of proceeding, had been embodied in an ordinance or resolution is immaterial. The offer of anything of value in corrupt payment or reward for any official act, legislative, executive, or judicial, to be done, is an indictable offense at the common law. * * * Motion denied. S. v. Ellis, 33 N. J. L. (4 Vroom) 102, 97 Am. Dec. 707-n, Kn. 305, Mi. 23. 60 .

Ofier by an alderman to take a bribe and soliciting it is criminal. Walsh $\nabla$. P.,

\section{COMPOUNDING CRIME.}

§ 208. Defined, Etc. "Compounding crime is agreeing with one who has committed it not to prosecute him." 1 Bish. Cr. I., §710.

(N. Ham. Sup. Ct., 1897.) At Common Law-Violation of Liquor Law. Defendant was convicted of compounding a violation of the statute as to selling spirituous liquors. He claimed that no offense by him was shown. It appeared from the evidence that he went to Fernald and informed him that he had a case against him for the illegal sale of liquor; that he read the law to Fernald and told him if he would settle it would save him a good many dollars; that for $\$ 30$ he would destroy the evidence, which was a bottle of liquor; that he would prosecute unless $\$ 30$ was paid, and the fine would be $\$ 50$ and the costs $\$ 25$; that subsequently Fernald paid him $\$ 30$ as demanded, and that thereupon the defendant turned the liquor into 
the sink, gave Fernald the bottle, and wrote and delivered to him a paper as follows: "Milton, N. H., Sept. 2, 1897. This is to certify that I promise to withdraw all further action against Frank $\mathbf{E}$. Fernald for illegal sale of liquor March 29, 1897. F. E. Carver." There being no statute of the state prohibiting compounding misdemeanors, the court resorted to the common law of England; found it applicable to our institutions; that such an offense would be indictable at common law, though no decision exactly in point was discovered; that the absence of any statute sufficiently indicated the general understanding that such acts are criminal, since it could not be supposed that such an offense should be permitted to go unpunished; and especially as the act defrauded the government of a portion of its revenue, and this 'ff itself would be ground for indictment at common law. "The motion to quash the indictment because it describes the offense for which composition was made as a 'supposed offense,' was properly denied. "The bargain and acceptance of the reward makes the crime' (S. v. Duhammel, 2 Harr. 532, 533); and in such a case, 'the party may be convicted though no offense liable to a penalty has been committed by the person from whom the reward is taken.' R. v. Best, 9 C. \& P. 368,38 Eng. C. L. 159 ; R. v. Gotley, Russ. \& Ry. 84; P. v. Buckland. 13 Wend. 592; 1 Russ. Cr. *133, 134; 3 Arch. Crim. Pr. \& Pl. 623-11." Per BLODGETT, J. Exceptions overruled. S. v. Carver, 69 N. H. 216, 39 Atl. 973, Kn. 308.

See also Wren v. C. 577 .

\section{MISPRISON OF FELONY.}

§209. Defined. "Misprison, whether of felony or of treason, is a criminal neglect, eivher to prevent it from bting committed or to bring to justice the oriender after its commission." 1 Bish. Cr. I. §717. See also Wren v. C. $\$ 77$.

\section{ESCAPE, PRISON BREACH, AND RESCUE.}

\$210. General Statement. Escape, prison breach, and rescue are different methods of liberating a prisoner before he is discharged out of custody. Escape is without violence, prison breach by violence, and rescue by aid of third persons. Actual escape is gaining entire liberty; constructive escape is allowing the prisoner more freedom than the law permits. Voluntary escape is the intentional liberation by the officer, or departure by the prisoner. Negligent escape is the mere neglect of the officer. See generally 2 Bish. Cr. L. $\S \S 1064-1106$; 2 Hawkins P. C. p. 18. 


\section{(Kan. Sup. Ct., 1877.) Law, Paw-Guilt, Wilt.}

This defendant, whlle at large, Was arrested on a charge of burglnitous intent, And direct to jall be went. But he somehow felt misused, And through prison walls he oozed, And in some unbeard-of shape He effected his escape.

Mark you, now : Again the law On defendant placed its paw, Like a hand of tron mall,

Then the court met, and they tried Lxwis up and down each side, On the good old-fashloned plan : But the jury cleared the man.

Now, you think that this strange case Ends at just about this place. Nay, not 80. Again the law On defendant placed its pawThis time takes him round the cape For effecting an escape.

LEWIS, tried for this last act, Mikes a special plea of fact: "Vrongly did they me arrest. "As my trial did attest, "And while rightfully at large, "Taken on a wrongful charge. "I took back from them what they "From me wrongly took away."

When thls speclal plea was heard, Thereupon THE STATE demurred. The defendant then was palned

When the court was heard to say

In a cold Impassive way-

"The demurrer is sustained."
Back to jall did Lowis go,

But as liberty was dear,

He appeals, and now is here

To reverse the judge below.

The oplaion will contain

All the statements that remaln.

Argument, and brief of Appellant: As a inatter, slr, of fact,

Who was Injured by our act,

Any property, or man?-

Point it out, sir, if you can.

Cau you selze us when at large

On a baseless, tri:mped-up charge:

And if we escape, then say

It is crime to get away?

Please-the-court-gir, what is crime?

What is right, and what is wrong?

Is our freedom but a song-

Or the subject of a rhyme? Argument, and brief of Attorney for Tho
State:

Plense-the-court-sir, how can we

Janage people who get Iree?

Reply of Appellant:

Please-the-court-sir, if It's sin,

Where does turpitude begln?

Opinton of the Court-PER Cunias:

We-don't-make-law. We are bound To interpret it as found.

The defendant broke away:

When arrested, he should stay.

'l'his appeal can't be malntalned,

For the record does not show

Frror in the court below, And we nothing can Infer

Iet the fudgment be sustninedAll the justices concur.

S. v. Lewis, 19 Kan. 260,27 Am. Rep. 113, printed as abridged by Eugene E. Ware, and printed in 19 Kan. 266, note.

Liabllity of offler killing to prevent escape: 1. v. Doulson, \& 66; Reneau v. S., \& 66 ; Head $\mathrm{V}$. Martln, \& 66 .

\section{EMBRACERY.}

§ 211. Defined. "Embracery is an aficempt to influence a jury corruptly to one side by promises, persuasions, entreaties, money, entertainments, and the like." 4 B1. Com. 140.

(New York Sup. Ct., 1826.) Definition-By Witness. Case for saying of plaintiff, "I should have got clear of the charge without the jury going out of the box, if old Gibbs (who was a witness) had not handed papers to Wilson (a juror) to influence the jury; and he ran away or the judge would have shut him up in prison." After verdict for plaintiff defendant moved in arrest of judgment that the words alleged were not actionable, as they impute no offense. SUTHERLAND, J. Embracery is defined to be an attempt by either 
party, or a stranger, to corrupt or influence a jury, or to incline them to favor one side, by gifts or promises, thrcats or persuasions, or by instructing them in the cause, or any other way, except by opening and enforcing the evidence by counsel at the trial, whether the jurors give a verdict or not, and whether the verdict be true or false (3 Bacon Abr. 785; 1 Hawkins P. C. c. 85; Coke Lit. 369); and it is an offense at common law as well as by statute (Id., 1 R. L. 174, 4 Bl. Com. 140); and punishable by fine and imprisonment. *** Any attempt by a witness to influence a jury, in any other way than by the open delivery of his testimony, is improper; and, in judgment of law, corrupt. A witness has no right to deliver any paper to the jury without the direction of the court. The act is as criminal in a witness as it would be in a bystander. There can be no doubt of the intention of the defendant to charge the plaintiff with the commission of a criminal act; and the terms used by him necessarily import a charge of that character. *** Motion denied. Gibbs v. Dewey, 5 Cowen 503.

(Nev. Sup. Ct., 1866.) By Juror-Attempt. Indictment charging "the crime of attempt to sommit the crime of embracery," and stating in substance that defendant, as juror in a civil action in Lander district court, approached one of the attorneys and offered for $\$ 100$ to secure a verdict for defendant therein. Demurrer sustained, and the state appealed. LEWIS, C. J. ****The only question presented to this court for determination is whether the facts detailed in the indictment constitute an indictable offense. While we are inclined to believe that the defendant might be held under a proper indietment, we do not think the bill presented to us in this record charges the defendant with any crime known to the law. [Here his honor quotes the definition of embracery from Gibbs v. Dewey, above.] ***As the crime itself consists of a mere attempt to do an act or to accomplish a result, it is difficult to comprehend how there can be an attempt to commit such crime. Any attempt or effort corruptly to influence a juror, whether it be successful or not, is itself embracery. *** Affirmed. S. V. Sales, 2 Nev. 269.

\section{PERJURY.}

\$212. Defined, Etc. "Perjury is a crime committed when a lawfal oath is ministered, by any that hath authority, to any person; in an'y judicial proceeding, who sweareth absolutely and falsely, in a matter material to the issue or cause in question, by their own act or by the subornation of others." 3 Coke Inst. 164.

(Eng. Star Chamber, 1611.) Recklessly. Damages were awarded 
to the plaintiff in the star chamber according to the value of his goods riotously taken away by the defendant. The plaintiff caused two men to swear the value of his goods that never saw nor knew them. And though that which they sware was true, yet because they knew it not, it was a false oath in them, for the which both the pro. curer and the witnesses were sentenced in the star chamber. Gurneis's Case, 3 Coke Inst. 166, Mi. 960.

(Eng. King's Bench, 1652.) Extra-judicial and Immaterial. Gwinn was indicted for perjury in taking a false oath in an affidavit made before the master of the chancery, and found guilty. He moved in arrest of judgment that it does not appear that the master had power to take this oath. ROLLE, C. J. ** * Perjury at the common law is intended to be in some court and legal proceedings. For a false oath made before us not touching the niatter in question between the parties, an indictment of perjury lies not; and it appears not here that the chancery took notice of the affidavit, for nothing was done upon it. *** If one make a false oath, the party is punishable for it by an action upon the case, in case it be not perjury for which he may be indicted for it. A false oath is one thing, and perjury is another thing, for one is judicial, and the other is extra-judicial. And the law inflicts greater punishment for a false oath made in a court of justice than if it be made elsewhere, because of the preservation of justice. Jerman. J., said, that perjury takes its name from perverting of justice. and therefore it is intended to be in a court of justice. The court held the indictment ill. and gave judgment against the Custodes. Custodes $\nabla$. Gwinn, Style 336, Mi. 959.

(Conn. Sup. Ct. of Errors, 1836.) Judicial and Material. Information for perjury. Plea, not guilty; verdict, gnilty. Motion in arrest of judgment denied. Defendant brings error. WIILLIAMS, C. J. The only question in this case is. whether the falsely taking of the poor debtor's oath, before a magistrate authorized to admin. ister it, constitutes the crime of perjury. * * * Perjury, as defined by Lord Coke, is when a lawful oath is administered, by any that hath authority, to any person, in a judicial proceeding, who swear. eth absolutely and falsely, in a matter material to the issue or cause in question, by their own act, or the subornation of others. 3 Inst. 163. Hawkins says, it seemeth to be a wilful, false oath, by one who, being lawfully required to depose the truth. in any proceeding in a course of justice. swears absolutely to a matter of some consequence to the point in issue. whether he be believed or not. 1 Hawk. P. C. c. 69. $\$ 1$. Chitty adopts Lord Coke's definition: and Russell speaks. of a proceeding in a court of justice. 2 Russ. 1751. His American editor concurs with Judge Johnson, in the case before cited [S. v. Stevenson, 4 McCord 1681, that the word court is substituted for the word course. of justice. And it is believed. that 
those who speak of a judicial proceeding, and of a proceeding in a court of justice, mean the same thing. It is apparent it cannot be intended that the outh must be administered before a court. It need not be before a court of record. 2 Rol. $\Lambda$ br. 257 . It may be before a court baron: 1 Mod. 55 , Winch 3 ; or a court of requests : Hut. 34; or an ecclesiastical court: (Uro. Wiliz. 609, 1 Sid. 454; or before commissioners: 1 Show. 397, Cro. Car. 97; or in an answer in chancery : Cro. Car. 321, 327, 353; Cro. Eliz. 907; 2 Burr. 1189; ol upon a complaint to the chancellor, on account of the arrest of one of the officers of his court: 1 Term 63 . So, too, it may be upon some collateral matter, not directly connected with the issue of a cause on trial, as an affidavit to hold to bail : Peake's Cas. 112; or when one, who offers himself as bail, swears his property to be greater than it is: Cro. Car. 146. And the crime may be committed, in some court of justice having power to administer oaths, or before some magistrate or proper officer invested with similar authority, in some proceeding relative to a civil suit, or criminal prosecution. 4 Bl. Com. 137. In the case before the court, it is not denied, that the oath was false, the intention wilful, the oath lawfully administered, and the assertion absolute. But it is denied, that it is in the course of judicial proceeding. and that it is material. *** Here the magistrate had a general power to administer oaths, and the particular power to administer this oath. $\mathrm{He}$ was intrusted with a portion of the administratioin of public justice; for he was to decide, in some capacity. whether the oath should be administered. The question is not so much in what character the magistrate acted, is what was to be the effect of his act: would it affect the course of public justice? For that purpose we must look at the situation of these parties. After the usual course of litigation, the creditor had obtained a judgment and execntion against his debtor, and had confined. him in prison. The debtor wished to be relieved from the incorvenience of this judgment, and to deprive the creditor of one of those means of satisfying it. which the law had given him; and for this purpose, took the oath which has given rise to this inquiry; and the effect of it is to relieve him from the operation of the judicial sentence, and to deprive the ereditor of the benefit of it. Is not, then, the immediate effect to interfere with the course of public justice? * * It was further said that here was no point in issue, or in the language of the law, nothing in debate between these parties. So far as regards a formal issine, this is true: and that will apply to every oath collateral to the question at issue. But here the real question between the parties was, shall, or shall not, this debtor be liberated from his imprisonment. unless the cleditor will support him? A question of deep interest to one party, and of some importance to the other: a question which the forms of proceeding cannot conceal. ** * Affirmed. Arden v. S., 11 Conn. 408, Mi. 962. 
(Ark. Sup. Ct., 1877.) Against Another Sovereign. Defendant was indicted for perjury, and all the evidence of the state being exeluded on the trial, it appealed. ENGLISH, C. J. *** Per. jury is an offense against the sovereign whose law is violated by the making of the false oath. 'The courts of no country or sover. eign, execute the penal laws of another. Story, on Confl. T. $\S 621$; The Antelope, 10 Wheaton 66, 123. * * ' the oath in this case was not taken under or by virtue of any law of the state, nor by an officer acting, in administering the oath, under authority conferred upon him by any law of the state, nor was the affidavit to be used in any court. tribunal, or before any officer of the state. On the contrary, the oath was taken under the homestead act of congress, it was administered by an officer acting under authority of that act, and the affidavit was taken to be used before a United States land officer to, procure a homestead entry. If the oath was wilfully false, it was an offense not in violation of a state law, nor against the sovereignty of the state. U. S. v. Bailey, 9 Peters 238. * * Affirmed. S. v. Kirkpatrick, 32 Ark. 11i, Kn. 300.

(Me. Sup. Judiciul Ct.. 18S4.) Extra-judicial. Indictment in the form prescribed by R. S. (1871), c. 122, $\$ \overline{5}$, for perjury. Verdiet. guilty. Motion in arrest of judgment for insufficient indictment. WAI'TON, J. 'The defendant is charged with having committed the cime of perjury "by falsely swearing to material matter in a writing signed by him." 'T'le indictment makes no mention of the character or purpose of the writing. Nor does it state what the matter falsely sworn to was. Nor does it contain any averments which will enable the court to determine that the oath was one anthorized by law. The question is whether such an indictment can be sustained. We think it cannot. It does not contain sufficient matter to enable the court to render an intelligent judgment. The recital of facts is not sufficient to show that a crime has been committed. All that is stated may be truce and yet no crime have been committed. The character of the writing is not stated. nor its purpose; nor the use made, or intended to be made. of it. For anght that appears. it may have been a voluntary affidavit to the wonderful cures of a quack medicine. Such an affidavit. as every lawyer knows, conld not be made the basis of a conviction for perjury. In the language of our statute defining perjury, it is only when one who is required to tell the truth on oath or affirmation lawfully administered, wilfully and corruptly swears or affirms falsely to material matter, in a proceeding before a court, tribunal, or officer created by law, that he is guilty of perjury. R. S. c. $122 . \S 1$. The oath must be one authorized or required by law, to constitute perjury. Swearing to an extra-julicial affidavit is not perjury. * * Arrested. S. v. Mace, 76 Me. 64. B. 32. 


\section{CONTEHTPT.}

$\S 213$. Nature and Kinds. Contempt is " $a$ wilful disregard or disobedience of public anthority." Bouvier L. Dic. "The contempts that are thus punished are either direct, which openly insult or resist the powers of the courts or the persons of the judges who preside there, or else are consequential, which (without such gross insolence or direct opposition) plainly tend to create a universal disregard of their authority." 4 Bl. Com. 283.

(Eng. King's Bench, 1721.) Jurisdiction of Other Courts. IIabeas corpus to the keeper of Newgate, to bring the body of $A$. Murray. WRIGII', J. It appears upon the return of this habeas corpus that Ur. Murray is committed to Newgate by the house of commons "for an high and dangerous contempt of privileges of that house;" and it is now insisted upon at the bar that this is a bailable case within the meaning of the habeas corpus act. 'To this I answer that it has been determined by all the judges to the contrary, that it could never be the intent of that statute to give a judge at his chamber, or this court, power to judge of the privileges of the house of commons. The house of commons is undoubtedly an high court, and it is agreed on all hands that they have power to judge of their own privileges. It need not appear to us what the contempt was, for if it did appear we conld not judge thereof. Lord Shaftesbury was committed for a contempt of the house, and being brought here by an habeas corpus, the court remanded him. And no ease has been eited wherever this court interposed. The house of commons is superior to this court in this particular, this court cannot admit to bail a person committed for a contempt in any other court in Westminster hall. DENISON. I. This court has no jurisdiction in the present ease. We granted the habeas corpus not knowing what the commitment was. * * FOSTER, J. The law of parliament is part of the law of the land, and there would be an end of all law if the house of commons could not commit for a contempt; all courts of record (even the lowest) may commit for a contempt. * * * Murray's Case, 1 Wils. 299, B. 854.

(Eng. King's Bench. 1821.) Indictment for saying of a justice of peace, in the execution of his office. "You are a rogue and a liar." Wearg moved after verdict pro rege, in arrest of judgment, that though the justice might have committed him for the contempt, yet the words are not indictable, sinee it is not to be presumed they wonld provoke a justice of peace to a breach of the pence, which is the reason why indictments have been held to lie for words. Sed PER CURIAM. The allowing he might be committed shows they were indictable. It is true the justice may mike himself judge, and 
punish him immediately; but still if he thinks proper to proceed less summarily by way of indictment, he may; the true distinction is, that where the words are spoken in the presence of the justice, there he may commit; but where it is behind his back the party can be only indicted for a breach of the peace. Cases cited, Sulk. 698; 3 Mod. 139; 2 Show. 207; 1 Roll. Rep. 79; R. v. Langley, Soley, Nuns, and Legasseck. Judgment pro rege. R. v. Revel, 1 Strange $4: 20$, B. 854 .

(U. S. Sup. Ct., 1885.) Right of Appeal and Review. Petition for writ of habeas corpus. In a suit against petitioner in the supreme court of New York he was ordered to appear and submit to examination before a judge of the court before trial pursuant to Cod. Civ. Proc. $\$ \S 870-3$, appeared accordingly and gave testimony, the hearing was continued, he removed the case to the U. S. C. C., the hearing was ordered continued before a master of the court, and he refused to testify further, claiming that the court had no jurisdiction to proceed in that way. For this refusal the court declared him in contempt, ordered him to pay a fine of $\$ 500$, and committed him to custody till he paid it. MILLER, J. *** 'There can be no doubt of the proposition that the exercise of the power of punishment for contempt of their orders by courts of general jurisdiction is not subject to review by writ of error, or appeal to this court. Nor is there in the system of federal jurisprudence, any relief against such orders, when the court has authority to make them, cxcept through the court making the order, or possibly by the excrcise of the pardoning power. This principle has been uniformly held to be necessary to the protection of the court from insults and oppressions while in the ordinary exercise of its duties. and to enable it to enforce its judgments, and orders necessary to the due administration of law, and the protection of the rights of suitors. When, however, a court of the United States undertakes. by its process of contempt, to punish a man for refusing to comply with an order which that court had no authority to make, the order itself. heing without jurisdiction, is void, and the order punishing for the entempt is equally void. It is well settled now, in the jurisprudence of this court, that when the proceeding for contempt in such a case results in imprisonment, this court will, by its writ of habeas corpus, discharge the prisoner. It follows necessarily that on a suggestion by the prisoner that, for the reason mentioned, the order under which he is held is void, this court will, in the language of the statute, make "inquiry into the cause of the restraint of liberty." Rev. St. \& 752. TThe court then proceeded to show that the court below had no jurisdiction to continue the examination because the New York Code Civ. Proc. is in conflict with U. S. R. S. \$ 861.1 * * Prisoner released. Ex parte Fisk, 113 U. S. 713, 5 S. Ct. 724.

(N. Ham. Superior Ct. of Judicature, 1844.) Summary Jurisdic. 
tion of Inferior Courts. Indictment for resisting a deputy sheriff in discharge of his duty. It appeared that defendant as a spectator at a trial before a justice of the peace took a seat very near the justice, who asked him to move off; and this request being disregarded, ordered the deputy acting as officer of the court to remove him, which he did with the assistance of three others. Defendant kicked and struck as he was able in resistance of execution of this order, and this is the offense here charged. He was found guilty, and this is a motion in arrest of judgment. GILCHRIS'T, J.

It is also contended that the justice had no authority to make the order in question. The power of keeping order, and of requiring a decorous and proper demeanor in a court room during the progress of a trial, lies at the very foundation of the administration of justice. Without it there can be no law and no justice, for if the law will not authorize the means necessary to insure its observance and proper administration, it must remain a dead letter. But the law never intended that the prisoner should have the power of stationing himself in any position he might desire during the trial. If it rested with him to select the location he might find most convenient, he might see fit to place himself upon the bench or in the jury box. He was present at this trial, neither as a party nor as a witness. He went there to gratify his curiosity, and it behooved him so to conduct as not to disturb the proceedings of those who had duties to perform. These duties cinnot be discharged unless the justice possesses the power upon an emergeney to direct the removal of any individual whose presence he may think prejudicial to the interests of justice. The law does not, indeed, authorize any court to act arbitrarily, and unreasonably exclude persons, but the right to have the courts open is the right of the public and not of the individual. If every person for whom there is sufficient space, has a right to be in court, he has a right to be in any part of it where there is sufficient space, and the inconvenience resulting from the cxercise of such a right is a strong argument against its existence. It will be in many cases impossible that a proceeding should be? conducted with due order and solemnity, and with the effect that justice demands, if the presiding magistrate, by whatever name he may be called, has not the control of the proceeding, and the power of admission or exclusion, according to his own discretion. It is better that this discretion should he exercised by a person acting under the responsibility of an official oath, than that it should be left to a crowd of lounging bystanders to enter and depart as their humors might dictate; and far better than that a court of justice should be desecrated by such lawless eonduct as was exhibited by the prisoner. Garnett v. Ferrand, 6 B. \& C. 611. We think this objection should be overruled. ${ }^{*} * *_{*}$ S. v. Copp, 15 N. II. 212, B. 865 .

(U. S. Sup. Ct. 1888.) Contempts in Open Court. Application for 38 
a writ of habeas corpus, alleging that petitioner had heen unlawfully imprisoned by an order of the circuit court of the United States for the northern district of California. The order, which was made a part of the application, showed that petitioner was com. mitted for contempt of court in the court room by resisting the marshal of the court in executing the order of the court to remove the petitioner's wife from the room, and also for contempt by petitioner in assuulting the marshal with a deadly weapon in the face of the court. HARLAN, J. *** What, then, are the grounds upon which the petitioner claims that the circuit court was without jurisdiction to make the order committing him to jail? They are: 1. That the order was made in his absence; 2 . That it was made without his having had any previous notice of the intention of the court to take any steps whatever in relation to the matters referred to in the order; 3 . That it was made without griving him any opportunity of being first heard in defense of the charges therein made against him. The second and third of these grounds may be dismissed as immaterial in any inquiry this court is at liberty, upon this original application, to make. For, upon the facts recited in the order of September 3, showing a clear case of contempt committed in the face of the circuit court, which tended to destroy its authority, and, by violent methods, to embarrass and obstruct its business, the petitioner was not entitled, of absolute right, either to a regular trial of the question of contempt. or to notice by rule of the court's intention to proceed against him. or to opportunity to make formal answer to the charges contained in the order of commitment. It is undoubtedly a general rule in all actions. whether prosecuted by private parties, or by the government, that is, in civil and criminal cases, that "a sentence of a court pronounced against a party without hearing him, or giving him an opportunity to be heard, is not a judicial determination of his rights, and is not entitled to respect in any other tribunal." Windsor v. McVeigh, 93 U. S. 274, 277. But there is another rule, of almost immemorial antiquity, and universally acknowledged, which is equally vital to personal liberty and to the preservation of organized society, because upon its recognition and enforcement depend the existence and authority of the tribunals established to protect the rights of the citizen, whether of life, liberty, or property, and whether assailed by the illegal acts of the government or by the lawlessness or violence of individuals. It has relation to the class of contempts which, being committed in the face of a court, imply a purpose to destroy or impair its authority, to obstruct the transaction of its business, or to insult or intimidate those charged with the duty of administering the law. Blackstone thus states the rule: "If the contempt be committed in the face of the court, the offender may be instantly apprehended and imprisoned at the discretion of the judges, without any further proof or examination. But in 
matters that arise at a distance, and of which the court cannot have so perfect a knowledge, unless by the confession of the party or the testimony of others, if the judges upon affidavit see sufficient ground to suspect that a contempt has been committed, they either make a rule on the suspected party to show cause why an attachment should not issue against him; or, in very flagrant instances of contempt, the attachment issues in the first instance, as it also does if no sufficient cause be shown to discharge, and thereupon the court confirms and makes absolute the original rule." 4 Bl. Com. 286.

* It was within the discretion of that court, whose dignity he had insulted, and whose authority he had openly defied, to determine whether it should, upon its own view of what occurred, proceed at once to punish him, or postpone action until he was arrested upon process, brought back into its presence, and permitted to make defense. Any abuse of that discretion would be at most an irregularity or error, not affecting the jurisdiction of the circuit court. We have not overlooked the earnest contention of petitioner's coumsel that the circuit court, in disregard of the fundamental principles of Magna Charta. in the absence of the accused, and without giving him any notice of the accusation against him, or any opportunity to $b \in$ heard, proceeded "to accuse, to try and to pronounce judgment, and to order him to be imprisoned; this. for an alleged offense committed at a time preceding, and separated from, the commencement of his prosecution." We have seen that it is a settled doctrine in the jurisprudence both of England and of this country, never supposed to be in conflict with the liberty of the citizen. that for direct contempts committed in the face of the court. at least one of superior jurisdiction, the offender may, in its discretion. be instantly apprehended and immediately imprisoned, without trial or issue. and without other proof than its actual knowledge of what occurred; and that. according to an unbroken chain of authorities. reaching back to the earliest times, such power, although arbitrary in its nature and liable to abuse, is absolutely essential to the protection of the courts in the discharge of their functions. Without it. judicial tribunals would be at the mercy of the disorderly and violent, who respect neither the laws enacted for the vindicating of public and private rights, nor the officers charged with the duty of administering them. 'T'o say, in case of a contempt such as is recited in the order below, that the offender was accused, tried. adjudged to be guilty and imprisoned, without previous notice of the aceusation against him and without an opportunity to be heard. is nothing more than an argument or protest against investing any court, however cxalted, or however extensive its general jurisdiction, with the power of proceeding summarily, without further proof or trinl, for direct contempts committed in its presence. Nor. in our judgrment, is it an accurate characterization of the present case to say that the petitioner's offense was committed "at a time preeeding. and sepa- 
rated from, the commencement of his prosecution." His mishehavior in the presence of the court, his voluntary departure from the court-room without apology for the indignity he put upon the court, his going a few steps, and under the circumstances detailed by him, into the marshal's room in the same building where the eomrt was held, and the making of the order of the commitment, took place, substantially on the same occasion, and constituted, in legal effect, one, continuous complete transaction, occurring on the same day, and at the same session of the court. 'The jurisdiction, therefore, of the circuit court to enter an order for the offender's arrest and imprisomment was as full and complete as when he was in the court-room in the immediate presence of the judges. $* * *$ Writ denied. Ex Parte Terry, 128 U. S. 289, 9 S. Ct. 77, 32 L. Ed. 405, B. 869.

(U. S. Sup. Ct., 1873.) Disbarment Without Hearing. Petition for writ of mandamus to compel the judge of the U. S. D. C. for W. Ark. to vacate an order disbarring petitioner for contempt of court, and to compel him to restore petitioner to the roll of attorneys. Petitioner, the U. S. marshal, and another, having been charged with contempt, the petitioner filed a response for the marshal; and being reminded that there was a rule against himself also, stid: "I am here to respond; I don't know what there is for me to answer; it (the report of the grand jury) says I saw Silas Steplenson." The judge: "You must answer in writine, Mr. Robinson." R.: "The rule itself does not require me to respond in writiug." of: "It should have done so; rou will amend the order if it does noi, Mr. Clerk." R. declined to inswer till the rule was amended. .J.: "Well, I will make the order for you to respond in writing now. Mr. Clerk, you will make an order requiring Mr. Robinson to answer the rule in writing." R.: "I shall answer nothing"-and without time for another word, the judge ordered the elerk to strike R.'s name from the roll of attorneys and the marshal to remove him from the bar. 'The petition says that the interview with Stephenson had no reference to any matter in court. FIELD. J. * * * No act of his is mentioned which could constitute within the statute a contempt either of the court or of its judge. The allegation that the witness Stephenson, after seeing Robinson, had suddenly absented himself, amounted to nothing more than an insinuation that possibly he may have been advised to that course by Robinson. There was no averment of any fact which the court could notice or the attorney was bound to explain. Whatever eontempt was committed by the petitioner consisted in the tone and manner in which his language to the court was uttered. On this hearing we are bound to take the statements in that respect of the judge embodied in his order as true, for the question before us is not whether the court erred, but whether it had any jurisdiction to disbar the petitioner for the alleged contempt. The law happily preseribes the punishment which the court can impose for contempts. The seventeenth section of the 
Judiciary Act of 1789 declares that the court shall have power to punish contempts of their authority in any cause or hearing before them, by fine or imprisonment, at their discretion. The enactment is a limitation upon the manner in which the power shall be exercised, and must be held to be a negation of all other modes of punishment. 'The judgment of the court disbarring the petitioner, treated as a punishment for a contempt, was, therefore, unauthorized and void. 'The power to disbar' an attoruey proceeds upon very different grounds. 'I'his power is possessed by all courts which have anthority to admit attorneys to practice. But the power can only be exercised where there has been such conduct on the part of the parties complained of as shows them to be unfit to be members of the profession. Parties are admitted to the profession only upon satisfactory evidence that they possess fair private character and sulficienit legal learning to conduct causes in court for suitors. The order of admission is the judgment of the court that they possess the requisite qualifications both in character and learning. They become by such admission officers of the court, and as said in Ex parte Garland, 4 Wallace 378, "they hold their office during grood behavior', and can only be deprived of it for misconduct asecrtained and declared by the judgment of the court after opportumity to be heard has been afforded." Before a judgment disbarring an attorney is rendered he should have notice of the gromnds of complaint against him and ample opportunity of explanation and lefense. This is a rule of natural justice, and should be equally followed when proceedings are taken to deprive him of his right to practice his profession, as when they are taken to reach his real or personal property. And such has been the general, if not the miform, practice of the courts of this country and of England. There may be cases undoubtedly of such gross and outrageous conduct in open court on the part of the attorney, as to justify very summary proceedings for his suspension or removal from office; but even then he should be heard before he is condenned. The principlo that there must be citation before hearing, and hearing or opportunity of being heard before judgment, is essential to the security of all private rights. Without its observance no one would be safe from oppression wherever power may be lodged. That mandamus is the appropriate remedy in a case like this to restore an attorney disbarred, where the court below has exceeded its jurisdiction in the matter, was decided in Ex parte Bradley. * * * Mandamus awarded. Ex Parte Robirson, 86 U. S. (19 Wall.) 505, 22 L. Ed. 205, B. 882. 


\section{CHAP'IER XIII. TREASON AND PIRACY.}

Treason and Piracy.

Treason.

8 214. Defined, 598 .

likACY.

\section{TREASON.}

§ 214. Definition. Treason against the United States shall consist only in levying war against them, or in adhering to their enemies, giving them aid and comfort. No person shall be convicted of treason unless on the testimony of two witnesses to the same overt act, or on confession in open court. U. S. Const. Art. 3, § 3, sub. 1.

Intended in jolning own army supposed to be enemy: Respublica $v$. Malin. \$10.

\section{PIRACY.}

See U. S. v. Smith, § 2. 


\section{TABLE OF CASES DIGESTED.}

The Figurgs Rgerer to paghs.

Page.

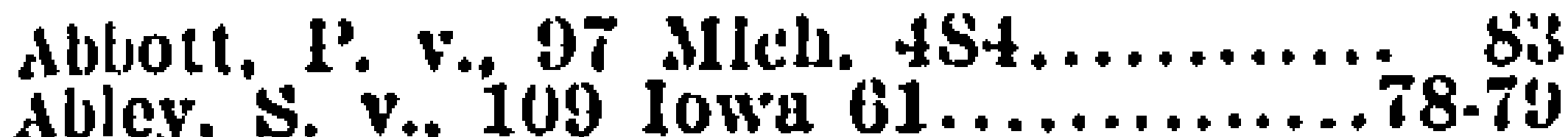

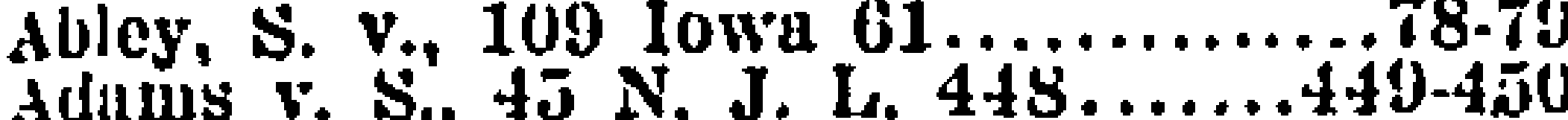
c. v. 114 Mass. 323............... I.. v., 3 Jonio (N. I.) 190........280-281 li. V., 1 Den. Cr. C. $38 \ldots \ldots \ldots \ldots \ldots \ldots$......

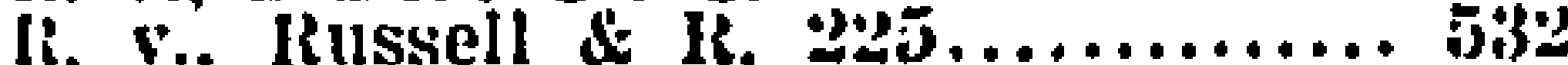
Alberty v. U. S., 162 U. S. 490....245.240 Alderman, $c$. v., 4 Jiass. $47 \% \ldots \ldots \ldots . . .308$ Alled, c v., 148 ra. St. 358......tis3-iott s. $v .47$ Conn. 121.............266.26 Almon, IR. v., 5 Burr. 2686 .......... 269 Auderson v. C.. 5 Randolph (Va.)

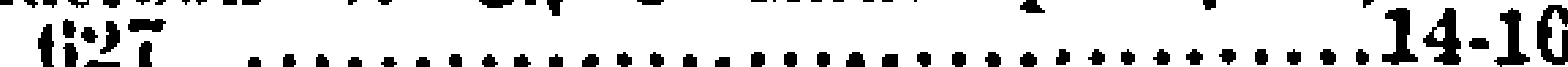

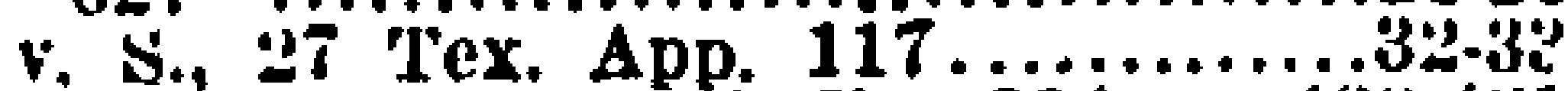

i. $i ., 14$ Joling (N. Y.) $294 \ldots \ldots 420.421$

k. P., 11 Cox C. C. 198.........271-27.

s. $\nabla .$, it Minn. $66 \ldots \ldots \ldots \ldots \ldots \ldots \ldots .407$

S. v., 47 lowa $142 \ldots \ldots \ldots \ldots \ldots \ldots \ldots .54 \bar{j}$ Andrevs, (" v. 2 Inss. 14........... 285 Anrelo v. $b, 96$ Ill, $209 . \ldots \ldots \ldots \ldots 139-140$ Anonymotss, And, $114 \ldots \ldots \ldots \ldots \ldots$. 374 :3 Coke Inst. c. 104, p. $232 \ldots \ldots \ldots .36$ 1 cox Cr. Cas. 250................ b1

1) ver 5a ..................400.401

Fitz. Abr. t. corone, pi. $284 . . . \ldots \ldots . . .28$

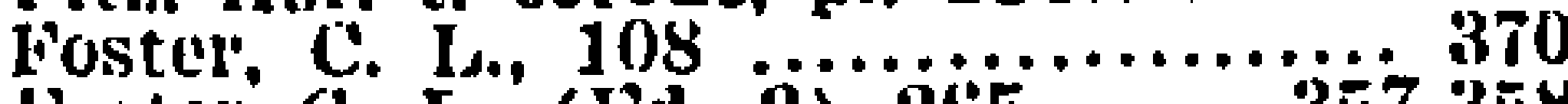

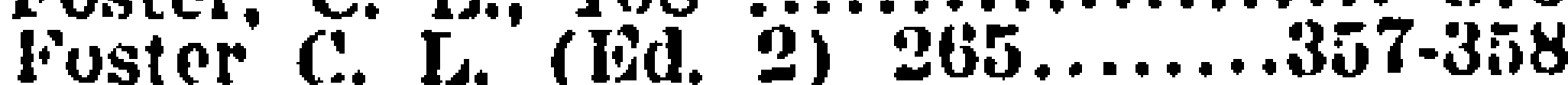

lioster ( . I. (3 Wd.) 430.......... 127

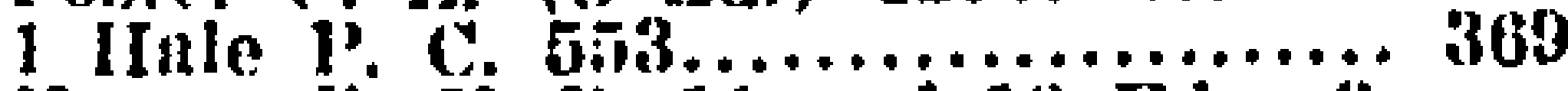

IIorwood's $Y$. B. 11 and 12 Edw. 3,

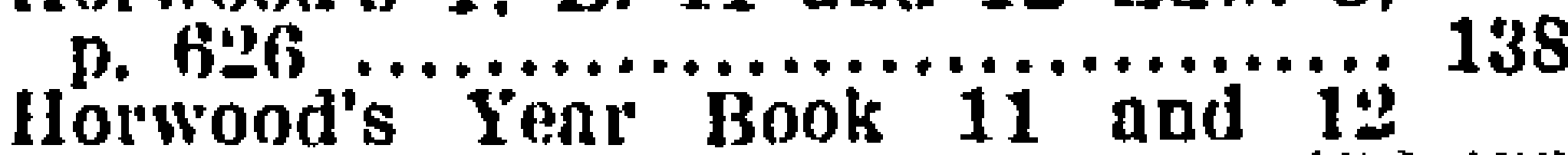

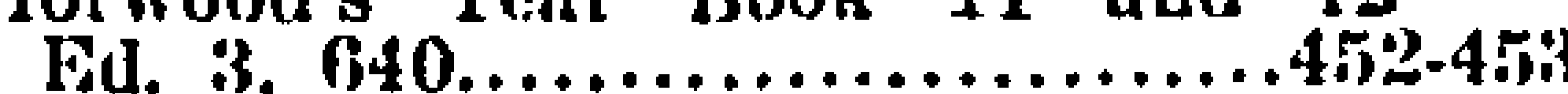

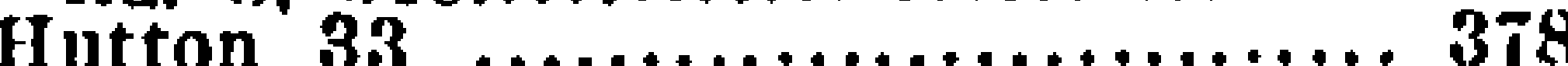

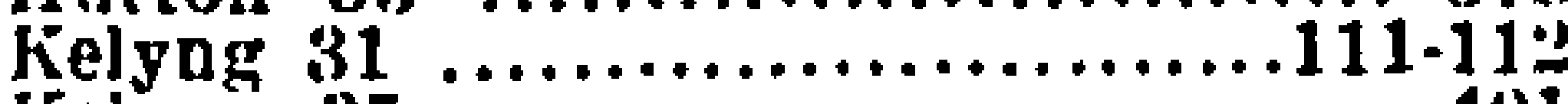

Kelyner $35, \ldots \ldots \ldots \ldots \ldots \ldots \ldots \ldots \ldots, 401$

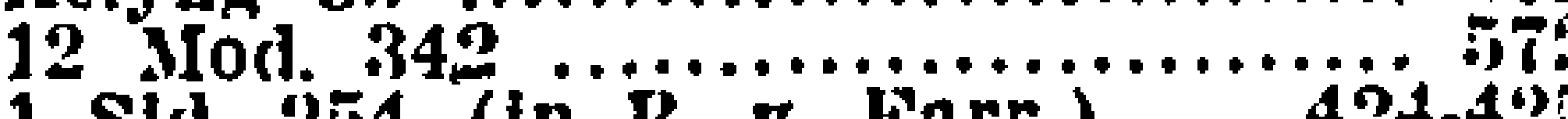

1 Sld. 254 (in IR. $\%$. Farr. $) \ldots \ldots . .424-42$,

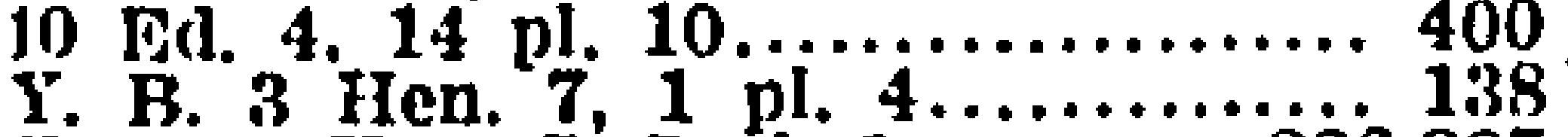

Y. 13. 4 IIen. 7 , 5 pl. $1 \ldots \ldots \ldots \ldots .286-287$

Y. B. 7 Hen. 4, 43, pl. 9.......... 286

Y. B. 7 IIpn. $6.43 \mathrm{p} .18 \ldots \ldots \ldots \ldots, 447$

i. B. 10 Hen. 8, 2 pl. $11 \ldots \ldots \ldots \ldots 45$ Anthony, $\pi$. S. v. 11 Biatche. 200.... 135 Arden v. S. 11 Conn. $408 . \ldots \ldots \ldots . .588 .58 \%$ Arp v. S. 97 Ala. 5..............119-120 dsher, S. v., 50 Ark. $427 \ldots \ldots \ldots \ldots .24,2$ Ashton's Case, 12 Mod. $256 . . . . . . .2$ 2613 Ashwell, IR. v., I. IR. 16 Q. B. I).

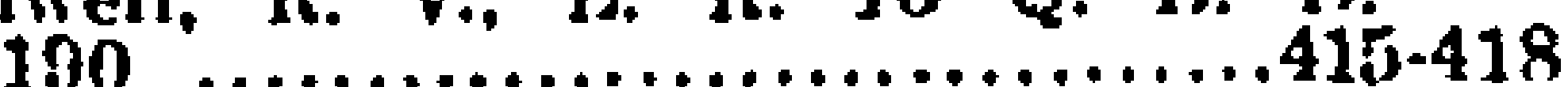
Atkinson. R. v., 2 East P. C. $673 . . .42 \%$ ivery. S. v., 7 Conn. $266 \ldots . .179 .656-567$

I3abcock. I'. v., 7 Johns. (N. Y.) 201, 530 Bacon, S. v., 40 vt. $456 \ldots \ldots \ldots \ldots . .261$ Bagley v. P., 43 MIch. 355........572.3 Bavley, $i$. $v$., Rugs. and $R y, 1 \ldots . .134-135$ Ii. V., Russ, and $R, 341 . . \ldots \ldots \ldots 375-376$ Rain $\nabla$. S.. 67 Miss. $557 . \ldots \ldots \ldots \ldots . .110$ Buke, $\dot{\mathrm{R}}$. llaker $\nabla$. S. 58 Ark. $513 \ldots \ldots \ldots \ldots \ldots$. 511 v. S.. 12 Ohto St. $214 \ldots \ldots \ldots \ldots .254-25 \pi$ v. S.. 120 Wts. $135 \ldots \ldots \ldots \ldots \ldots \ldots . . . \ldots \ldots 45446$ S. v., 65 N. Car. 332............328-320
Page.

Inlalwin, c. v., 11 Gray (Mass.) 197. 520

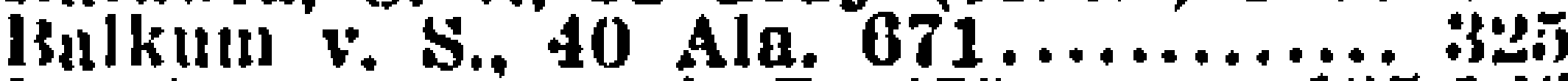

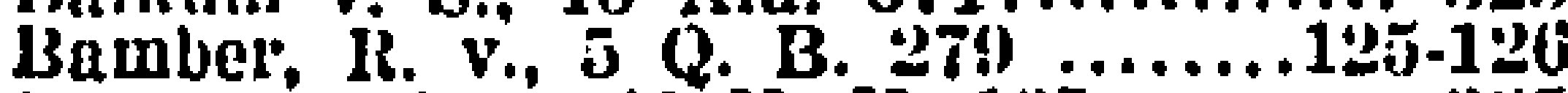
liancelolt. $s$. v. 10 N. II. 105......... 38. lanks, R. v., Kussell and $R .441 \ldots . .468$ liunkils $v$. S.. 4 Ind. 114......... Bntnen, ik. v., 2 Moody $30 ! \ldots \ldots \ldots \ldots$.... Inntley. s. v., 44 Conn. Eist........ 40 Isarnard, $i$. v., 7 Car. and $I^{\prime}, 784 \ldots . .543$ Harnes, li. v., $8 \mathrm{Cox}$ c. C. 129...... 500 Harrow, K. v. I. R. I C. C. IR. 156. 335 Ihaty, $\therefore$ v., 124 Mass. $325 \ldots \ldots .406 .407$ C. vin Mass 300.............446.44

Initloit. s. v. 11 vt $650 \ldots \ldots \ldots . .288 .280$

Barton. ll. v., 3 cox C. C. 275...154-155

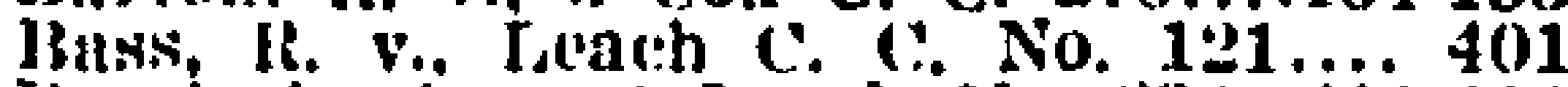

Jinzeluy's Casp.2 Lench No. 204..410-411

lleun. C. v. 117 Mass. $141, \ldots \ldots \ldots$ J06-507

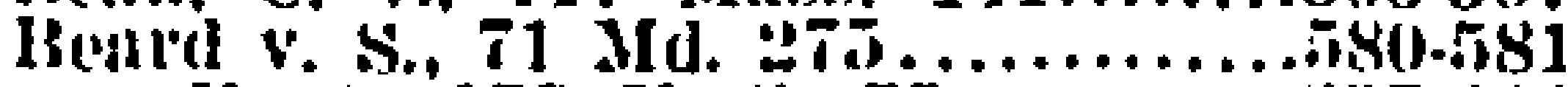
v. U. S.. 1.58 U. S. กinu........237.238 Beatty v. Gillbanks, 15 Cox. C. C.

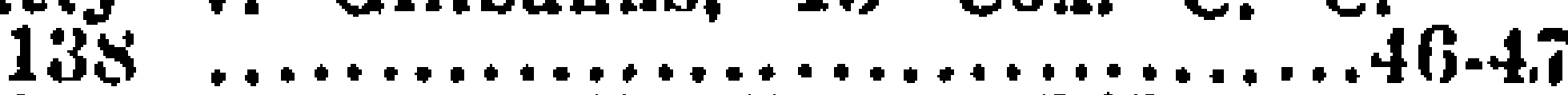

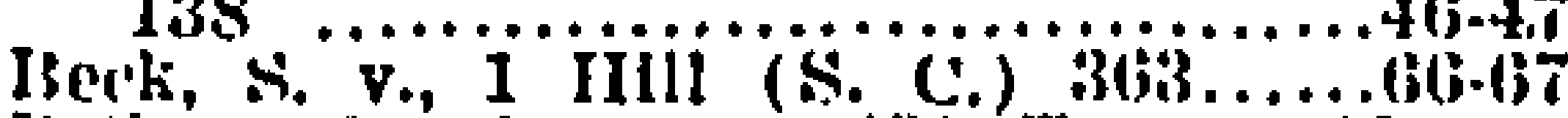
Lell v. S., 1 Swan (31 Tenn.) 42

keunett, $R, v$. Bell 1.2. 16, 56\$.56!)

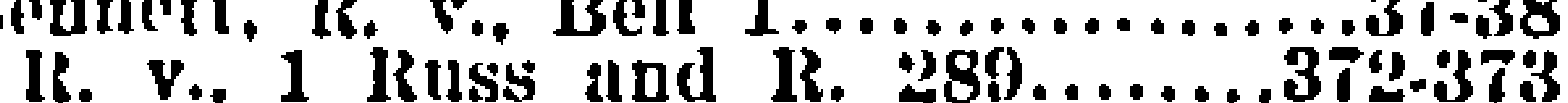
Iserly v. S.. i31 Olifo st. $210 . \ldots . .478 .479$ (.. F.. 99 Mass. 42S............501-502 Best, ir. v., 2 Ld. Raym. 1167...... $18 t^{\circ}$ Hevans, I. S. v. 16 U. S. 336....270.271 I3jbb v.. .04 Ala. 31............113-114

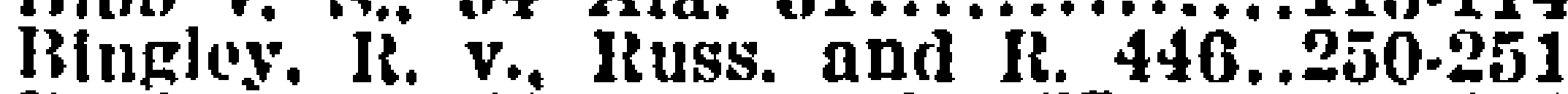
IBird, li. v. is cox C. C. 257......... 406 Hirnoy v. $s ., 8$ oblo $230 \ldots \ldots \ldots \ldots \ldots$ 12s Black. s. $V_{0}$ ti llis. $\left.490 \ldots \ldots \ldots \ldots 47-i\right) 48$

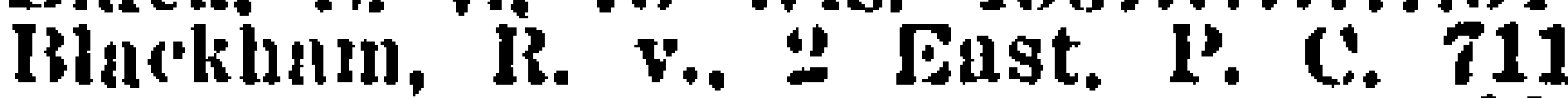

100.107

IBlakeley v. S., 24 Tex. App. 616.258.25!) Blanding, $(*$ v., 3 l'ick. (20 Mass.)

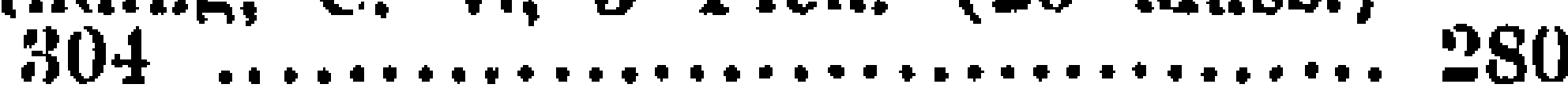

Boon. S. V. 13 Ired. I. (3J N. Car.) 244 ............................ Roston if i\%, Ry. Co. v. Iana, 1 Gray

(Mnss.) 83 . . ..................

Bowden. I. v.. "2 Moody 285.........49:3

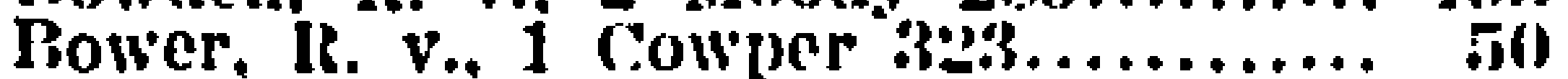

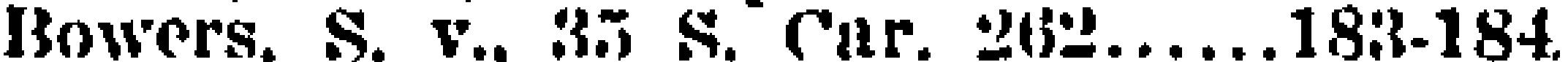

I3oyce, 1R, v.. 1 Moody 29.......... 10.5

Boyd v. s.. 88 Ala. $16 n . \ldots \ldots \ldots \ldots \ldots$.

Boynton. (: v.. " All(2n (IInss.) 16(0.. 132 Breemc. 1R. v.. 1 I, men (.. J. No. 100. 392

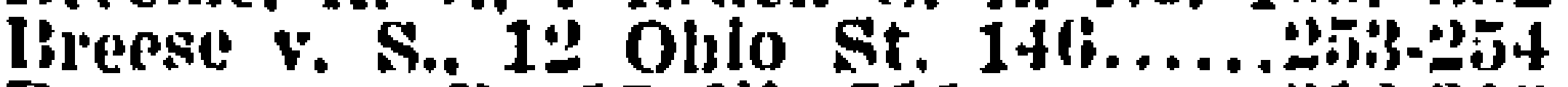

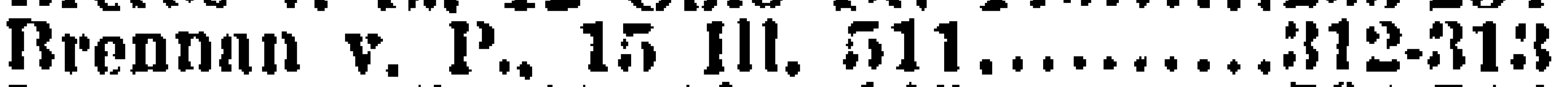

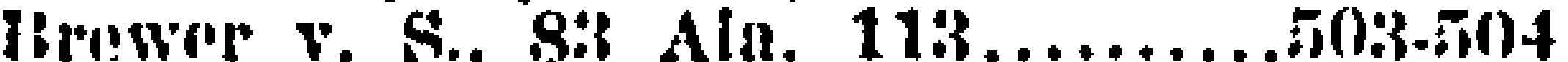

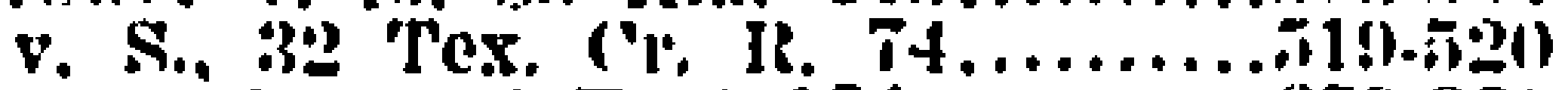

Brisac, R. v., 4 Fast if4..........270.280

Blooks, (.. v., of Mnss, 4i34........ 126

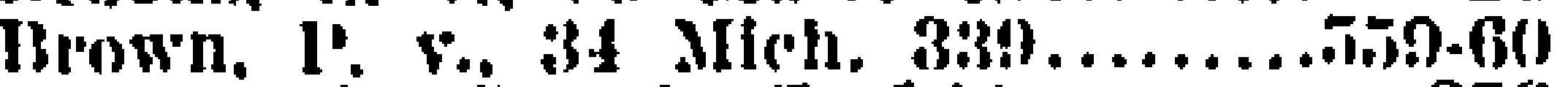
IR. V., it $\operatorname{Cox}$ C. (.. $144 \ldots \ldots \ldots \ldots$ 2nt6 If. $v .3$ Keb, $193 \ldots \ldots \ldots \ldots \ldots \ldots ., 5(33$

Bruce, 1R. v., 2 Cox $C$ ( $262 \ldots \ldots \ldots 101$

Bryan. K. v.: 7 Cox C. C. $312 \ldots \ldots . .737-530$ Buchanan, S. צ., 5 IIar. und J. (Ma.) 317 ..........................184-186 
I3uckmaster, R, Page.

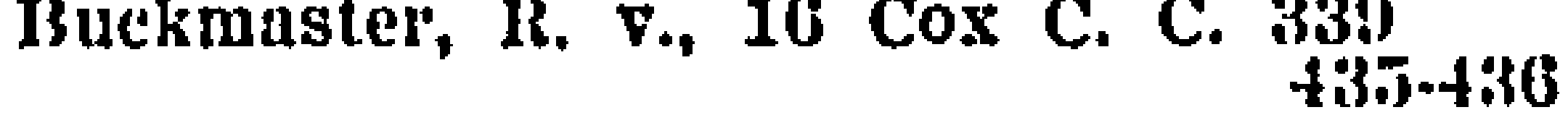

Burke, C. v., 105 Mass. 376......3333-334

Burnett, IR. v., 4 Maule and Sel. 272

S. v., 119 Ind. $392 \ldots \ldots \ldots \ldots \ldots \ldots .534$

Burnlium, s. v., 56 vt. $445 \ldots \ldots \ldots \ldots . .68$

S. v. 15 N. II. $396 \ldots \ldots \ldots \ldots \ldots \ldots$ 18t-18!)

Burns $v, S ., 80 \mathrm{Gn}, 544 \ldots \ldots \ldots \ldots \ldots . . .22$

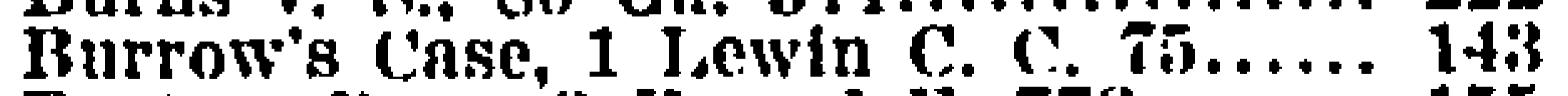

Burton, 12. v. 3 IF. and F. $752 \ldots \ldots \ldots$ 155

liush v. C., is liv. $268 \ldots \ldots \ldots \ldots \ldots \ldots$, 41

Butler, s. v., 8 wash. 194..........179-180

\section{Commonwenlth}

Cabbuge, It. v., liussell and IR. 292.. 483 calhoun, s. v., 72 Iowa $4.12 \ldots \ldots \ldots .487$ Call, (. v., 21 Plck. (Minss.) $509 . . .500$ Cullaghnn, c. v., 2 va. Cas. 460....5T-5s Camplell v. C.. 88 Ky. $402 \ldots . . . \ldots .35$. v. $1 . .16$ Ill, 17................229.231 v. S., Yerger (Tenn.) $333 . . . . . .312$ C: v., 7 Allen (Mass.) $541 \ldots . . . . .44-4.5$ ii. v. 2 Lench C. C. No. $240 \ldots .495-49 n$ Camplin. IR. v.. 1 Car and $\mathrm{K} .746 \ldots . .323$ Carl, 12. v. 10 Q. B. D. $76 \ldots \ldots \ldots . . .272 .274$. Carrier"s Case, 1 . B. Laster ij Law.

$4, f, g, p l, 5 \ldots \ldots \ldots \ldots \ldots \ldots \ldots .470 .473$ Carter, s. v. 27 N. J. I. $409 . \ldots . .204 .20$ v. S.. is Hex. App. $355 \ldots . . . \ldots \ldots \ldots$...... 100 Cartwright v. (ireen, \& Ves, 405.418-419) Cawer, S. v., t99 N. II. $216, . .137,584-58.5$ (ase, il. v. 4 Cox C. C. $220 \ldots . . \ldots .60-70$ ('astell v. IBnmbrldye, 2 Strange 854. 215 Caton, I. v., an Mich. 3S8.......... 5.28

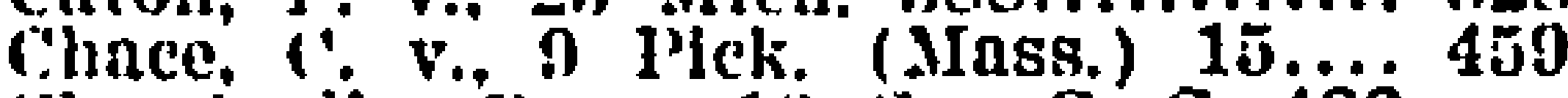
Chamberlin. h. v. io $\operatorname{cox}$ C. C. 486

- 350 -360

Champer v. S., 14 Ohio St. $437 \ldots \ldots 67$ ('bapman, $(: ., 13$ Metc. (Mass.) os

Chastian. $\$$. v. 10 Ore. 176......... 10. Cheafor, ll. v., 5 Cox C. C. 367....459-400 Chissers, IR. v.. 'T. Invm. 275.......404 Cholec . C.. 31 Ga. $424 \ldots \ldots \ldots \ldots \ldots .144$ Churchili, C. v., a Met (Mass.) 118. 30 Clair, C. v. 7 Allen (Ilass.) 525..318.310 CInrence, iR, v. 16 Cox C. C. $511 \ldots 71-74$ Clark v. S.. 39 Tex. Cr. Rep. 179..501-562 v . S., 60 Wis. $203 \ldots \ldots \ldots \ldots \ldots \ldots . . . .381-382$

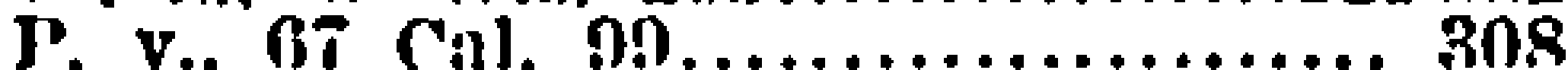
s. v. 89 Mo. $423 \ldots \ldots \ldots \ldots \ldots \ldots \ldots ., 497$ ij. S. v., 31 Fed. $710 \ldots . . . . . .8$, ii6.117 Clements, I', v. 68 Mich, 655....... 583

V. S., 84 Ga. $660 \ldots \ldots \ldots \ldots \ldots \ldots 487-488$ Cllck v. S., 3 Tex. $282 \ldots \ldots \ldots \ldots \ldots 330.331$ closs. ir. v. 7 cox C. C. $494 \ldots \ldots \ldots$ 52.

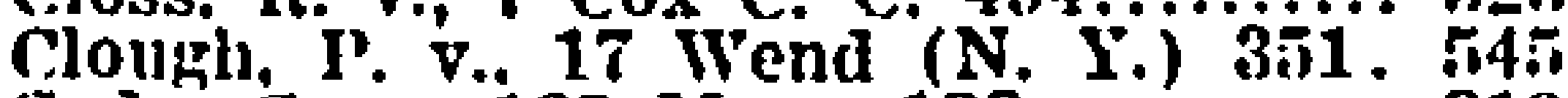
Cods, C. v., 16n Mass, $133 \ldots \ldots \ldots \ldots . .310$ Collbers. C. v.. 119 Mnss. $370 \ldots \ldots \ldots$ (7)-68 Collins, R. v., 9 Cox C. C. 497....211-212 Commonweaith $v$., sce name of party dofendint.

Compton, I. v., Iit. Ass. 97, pl, wit

Conde. IR. v.. 10 Cox C. C. 547....214.21\% Connolly's cuse 2 Inwin C. C. 200.112 connor v. P.. 18 rolo. $373 \ldots . . . \ldots .77 .78$ v. S.. 24 Tex. Anp. $245 . \ldots \ldots \ldots \ldots \ldots .44$ Cook. P. v. 39 Mich. $236.40-41$, 225-220 Cook's Case, Cro. Car. 537.........38.23n Coombs, S. v., 5it Me. 477......488-480 Cooper. S. v.. 16 Vt. $551 \ldots \ldots \ldots \ldots . .386-387$ Cooper's Case. Cro. Car. $344 \ldots . . .248 .247$ Copn. S. จ.. 15 N. н. $212 \ldots \ldots \ldots \ldots 502.503$ Cornwal's Case. 2 Strnnge $881 . . . . .384$ Cotesworth. R. ₹. ( I Mnd. 172........ 228 Cozlett's Case, 2 East P. C. 556..444-445
Page. Cirnwford v. S., 90 Ga. 701.......244.245 Creek v. S., 24 Ind. 151.........232-233 Creighton v. C., 84 KJ. 103......... 235 Crocheron v. S., 86 Ala. 64.......402-403 (ross, $R$. v., 2 C. and $I .483 \ldots \ldots \ldots .570$ (routhel's Case, Cro. Eliz. 654....... 33 Crum v. S., 148 Ind. 401.........437-438 ('vump v. C., 84 Va. 927.........199.201) Crutehley, IR. v., 5 C. and $P .133 \ldots 118$ cullum. 1R. v., I. K. 2 C. C. IR. 28... 503 ('unmings, P. v., 114 Cal. 437 ...548-549 ('ulmmins, In re, 16 Colo, 451....... 64 Cummons. 1'. v., 56 Mich. 544....... 564 (vill, R. V., a Strange $788 \ldots \ldots \ldots \ldots . .64 .55$ ('urver v. S. 157 Ind. 114......... 46i ('ustodes v. Gwinn, Style 336....... 585

Indison, R. v., 4 Cox C. C. 358...... 222 Inley, C. v., 148 Mass. $11 \ldots \ldots \ldots \ldots . .113$ Jamon, $S$. v., 2 Tyler (vt.) $387 . . . .316$ lavies's (ase, 2 Hast $I$. C. $709 \ldots \ldots$. 488 1)avis v. T\}. S., 160 U. S. $469 \ldots \ldots \ldots 176$

R. v., 15 Cox C. C. $174 \ldots \ldots \ldots \ldots . .261$

Il. v., 1 russ. and $R .322 \ldots \ldots \ldots \ldots$. 373

IJ. S. v. 2 Sumner $482 \ldots \ldots \ldots \ldots \ldots . .283 .284$

Deanr. R. v., 5 Cox C. C. $501 . . . \ldots . .30 !$

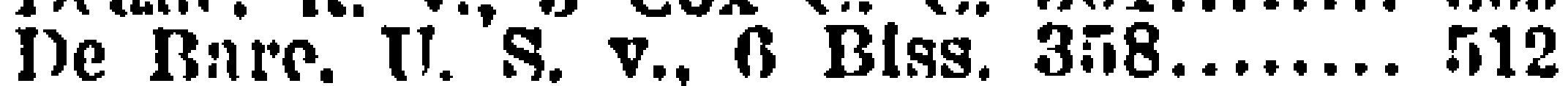
Dee, $R$ v. 15 Cox C. C. $579 \ldots \ldots .335-337$

Delavil. I. v., 3 Burr. 1434........5!-56 Jinnton's Case, Foster C. I. 108...... 370 Ienardo, $R$. v.. 1 Taunt. $26 \ldots . . . .269 .270$ Detroit white Lead Works, $P$. V., 82 Mleh. 471 ..................574.575 Dellitt, U. S. v., 9 Wall. (76 U. S.)

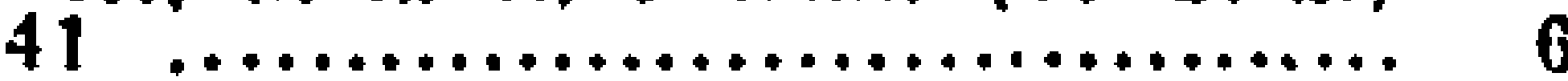
Dickinson, $R$. v., 1 Inssell and $R$.

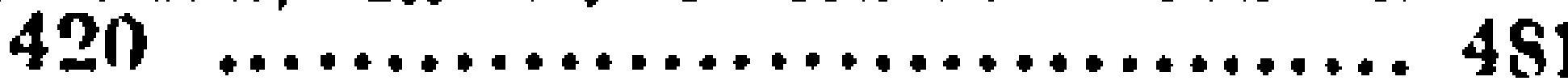

Dinglev, R. $\nabla ., 2$ Leach, No. 294 (Bazcley's Cane) ................. 410

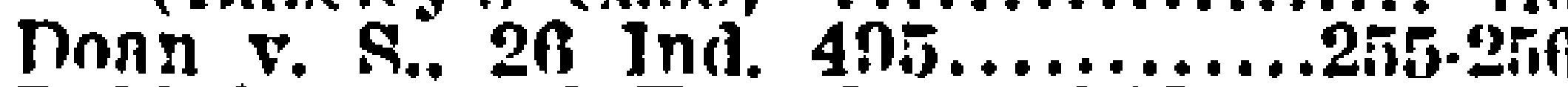
Tohbs's Case, 2 Enst $P$. C. 513 .........38t

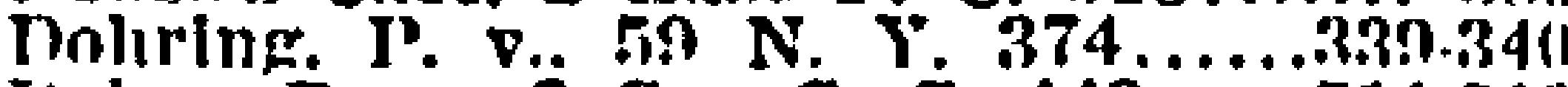
Inlnn. $\dot{R}$.. i Cox c. c. $449 \ldots \ldots 511-512$ Tonalue, C. v., 148 Mass. 529....... 244 Donaldson, S. v.. 32 N. J. L. 151..194-198 non Moran v. P.. 25 Mich. 356.....327.31s nonnellv. S. v. A9 Iown $705 . . . .234-23$. Thoorly, If. v. $6 \operatorname{Cox} C$. C. $463 \ldots \ldots . .148$ nownes. $\mathrm{R}$. 13 rox $\mathrm{C}$. c. $111 \ldots . .20-30$ noss v. P. iss Ill. Gin............ 437 v. S. 21 Tex Anp. 505.........397-39s Drew. (c. v.. 19 Plek. (Mass.) 179 $542-543$ IT. S. v.. 5 Minson (t. S.) 28...143-144 Muchnr v. S., 18 Ohlo 308........370.371 Duckrr. S. v., 8 Oreg. 394 ......... 415 Dudlev. R. v.. 15 Cox C. C. Bit....i23-12. Dugdile $r$. R., J Filts nnd $B .435 . .$. 2. Ditpren, P. v., 98 Mich. 20.......385.-396

Felkels v. S., 20 Ohto St. 508......445.44f Wrmonds v. S.. 70 Aln. 8..........396-3!? Vilmonis's Case. IIutton 20.......... 3. v(jwinls. R. v. 13 Cox C. C. $384 \ldots . . .46 n$ Viggington's Case. 2 Fast $P$. C. 494 .7n-7f

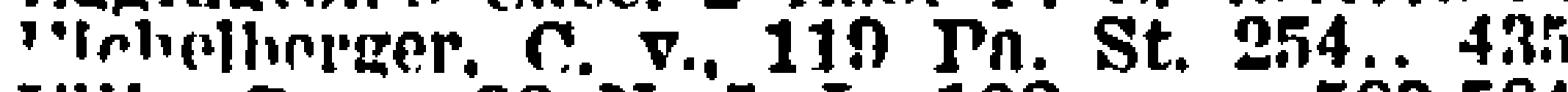
IAlls. S. v., 33 N. J. T. 102.......583.584 Drwin $r$. S.. on onto st. 186......233-234 Fstnll v. S.. it N. J. T. 182......... n! Tisten v. C.. 86 Kr. 39...........242.243 Fetes v. Crirter. in Iown $400 . . . . . . .$. to Ex parte. spe name of party.

Fnrr's Case. Kelyng 43............. 425 Parrol's Case, 2 Fust P. C. 557...... 480 Farren. C. v., 9 Allen $489 . \ldots \ldots \ldots 128.129$ Fuulkner. R." v. 13 Cox C. c. Favin v. S.. 39 Tex. Cr. IR. 452..... 389 Way v. C., 28 Gratt. (Va.) 012...... b49 
Page.

Ferguson v. S., 52 Neb, 432......373-37t Fouerhaken. \$. v., g( Iowa $209 . \ldots . .515$ Flester จ. P., 125 Ill. 348.......... 387 Fisher, $s$, v. 38 Minn, $378 \ldots \ldots \ldots .471$ Fiske, Ex purte, 113 U. S. $713 \ldots \ldots . . .592$

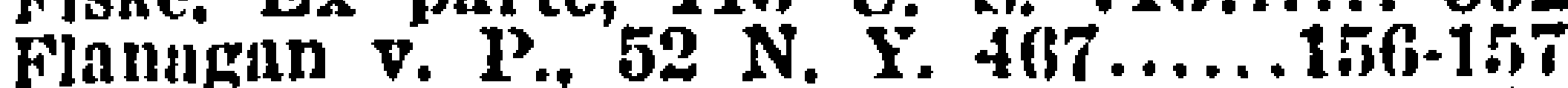
Nleener v. S., 58 Ark. !s..........t.ti. Flowers, $R$. v., 16 Q. B. D. 643..... 418 Foley, k. v. i. k. 20 Ir. 209........ 45T Fort v. S., \$2 Ala. 50.............479-480 Foster v. C., 06 Va. 306............. 209

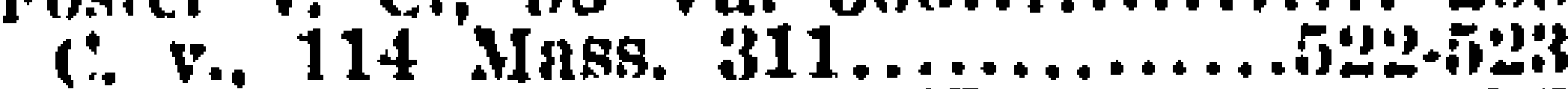
Fox, U. S. v. gi ti. S. 670.......... (i.s Frnacis, $i$. v.. 2 Strange iois......486

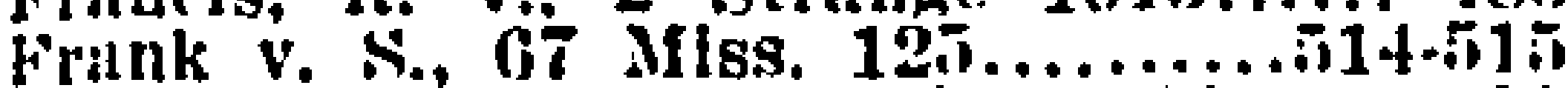
Franklin. R. v. 15 Cox C. C. 163... 99 Fray's Case. 1 East 1. C. $236 . . . \ldots . .3631$ Frvoler v. S., 85, Ala. 17............44 Freel. P. v., 48 Cal. 436............ 3in Friencl, $R$. Russel and $R$. $20 \ldots \ldots$. Fiy v. S., 81 Gn. $645 \ldots \ldots \ldots \ldots \ldots \ldots .653$

(iamlen. IR. v.. 1 IS. nnd F. 90....... 148 qalbutt, I. v. 17 Mich. $9 . \ldots \ldots \ldots 174.176$

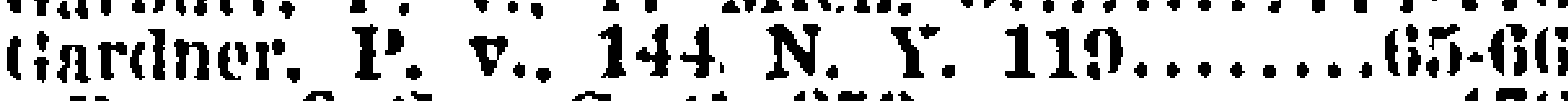

1. $v$ Cox $C$ C $253 \ldots \ldots \ldots \ldots \ldots+4$

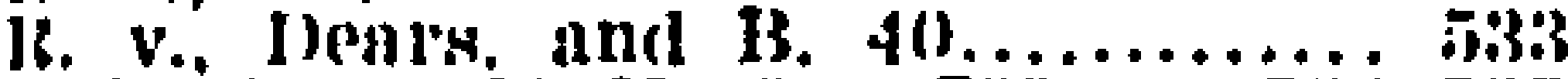

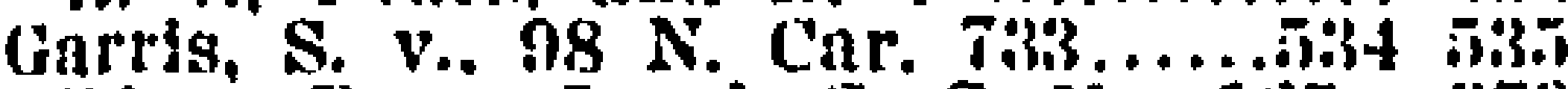
Gibbon. IR. v.. Lench C. C. No. 1ti... 3t!) Giblons's Case ..................374-37.

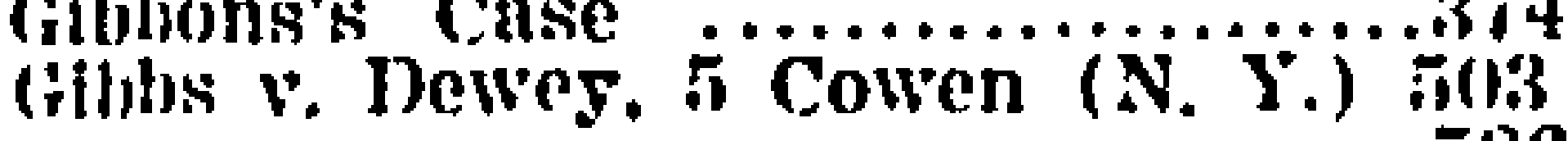

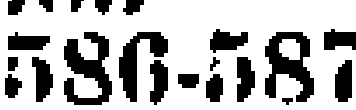
(ilil. I. v. 1 Strange 100............. 361

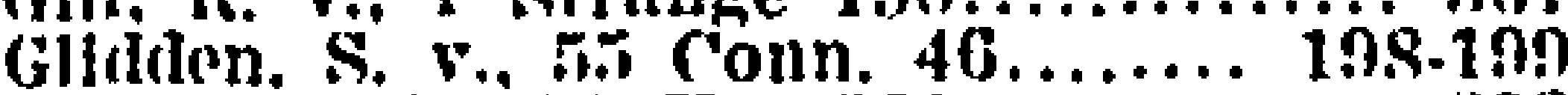
(ilover v. (.., 86 Va. 382............208 Ginosll, R. v., 1 Car. and $\mathrm{P} .304 . . .$. 4.84 Gooch v. S.. fo Ark. 5............481 Goothall, R. V.. Russell and $\mathrm{R}$. 461.. 53.5 finodenow. S. v.. 6.T Me. 30........t3.130 Gorrlon v. S.. 52 Ala. 308.........13n.131 Gore's Cnse. 9 Coke 81a..............? (inss. IR. v.. 8 Cox C. C. $262 \ldots \ldots .40-641$ Gould, R. v.. Jench C. C. (Ed. B)

No. 107 ......................... 49

R. v. 1 Snlk. $381 \ldots \ldots \ldots \ldots \ldots \ldots$ 25

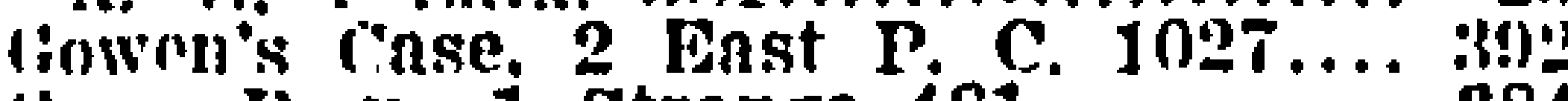
liny. R. v. 1 Strnnge $481 . . . . \ldots \ldots . . .384$ limgory v. S.. 26 Ohio St. $510 . . . \ldots$. ati. irnon v. S.. 28 Tex. App. 403...... t!n \&. v. 17 Mass.

$\because$ v. 2 Plek. (Mnss.) 380........20s.?ng

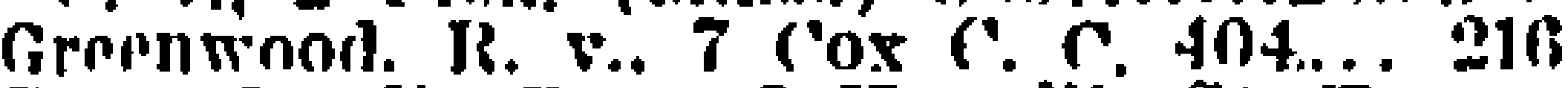
frey (lord). R. v., 3 Howell's St. 'T.

510 Grev's Conse. Kolyng $64 \ldots \ldots \ldots \ldots \ldots$.... Gribhle, R. v., 1 Tench C. C. (Bri. 3i) No. 117 . $17 . \ldots \ldots \ldots \ldots . . .490 .491$ Grifin $v$. S. $2 f$ (in. $493 \ldots \ldots \ldots \ldots 182.182$

IR. v.. 11 Cox r. r. $402 \ldots \ldots \ldots \ldots \ldots 210$ (ilitenu's Case io lied. Ren. 161.157-ifis

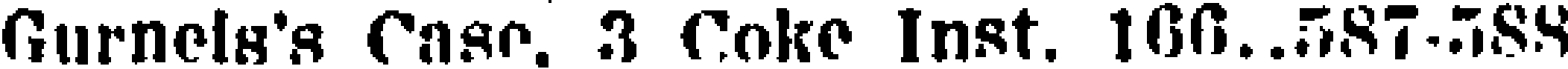

Inckutt, C. v., 2 Allon (Mass.) 131..38.3n Indley, C. v., 11 Metc.............. 11t Inines. Ir. v., 2 car. nnd Kir. $308 . .2$

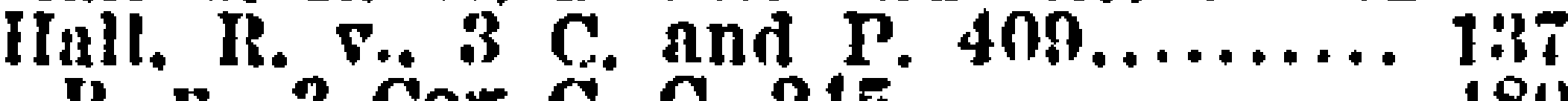
IR. v., 3 Cox C. C. $245 \ldots \ldots \ldots \ldots \ldots .+1811$ s. v. $114 \mathrm{~N}$. Car. Ong......... est.:Nil IInilldny. IR. v. 61 T. T. IR. T01..21T-21s JInnds. B. v.. 16 Cox C. C. 189..... 4t:

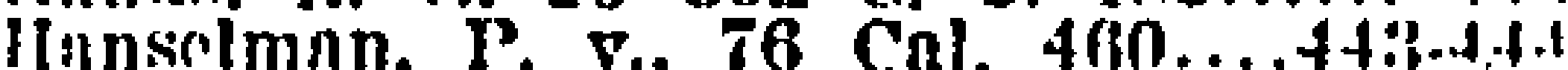

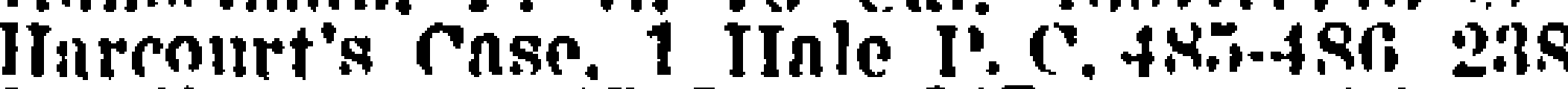

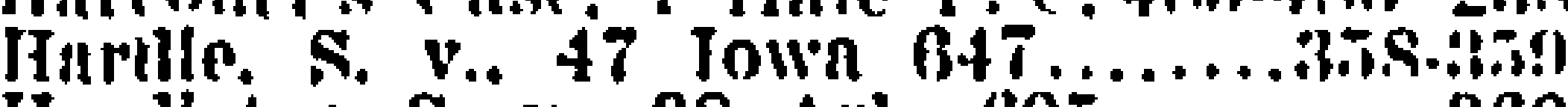
Inrdilster. S. v.. 39 Ark. (jo5......... an

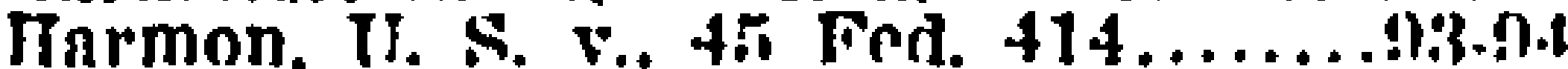
IIarrls $v$. S.. 81 Gn. $758 \ldots \ldots \ldots \ldots .498 .4 ? !$

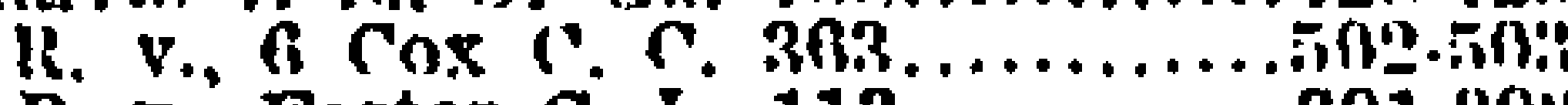

R. v. Foster C. I 113...........391-89: R. V., 2 J.ench C(. C. No. $283 . .379 .380$

Ifirtnett, C. v., 3 Gray (Mass.) 450

Page.

$493-495$

Irarvick v. S., 49 Ark. 514.......102.103 linwkins v. S., $13 \mathrm{Ga}$. $322 . \ldots \ldots \ldots .554-555$ (.) v., (Mass.) 3 Gray $4.63 . \ldots .146 .147$ IInynes, I. v., 14 Wend. (N. Y:) Kt6

5i3)-5.533

1R. v., 1 Fos. und Fin. 666.......15i).156

S. v. Go 1Ie $307 \ldots \ldots \ldots \ldots \ldots \ldots$ 115

Irays, C. v., 14 Gray (IIass.) 62..700.501 IInywond $v$. S. 41 Ark. $479 \ldots \ldots \ldots .460 \cdot 461$ IInarl v. Martin, 85 Ko. 480......2:3-22.

IIendge, R. v., I Russell and $I$. 160... 49 ? Ileath. R. v., Russ. nnd $R$. 184..... 23 IIenclerson v. C.. 8 Grat. (Va.) 708.. 53 IIendidickson v. C.. 85 Kv. 281....... 217

IIenry v. S., 110 Ga. $750 \ldots \ldots \ldots \ldots \ldots 451$ IIensisler, $t$. v. 48 Milch. $50 . . . \ldots \ldots .63-64$ IIeritage v. Dollge. 64 N. IT. $297 . . .220$ IIelsey $C$ v 2 dilen (IInss.) 173.101-102 IInwirtt. R. V., 1 F. and F. 91. 10T, 230-231 lliggins, R. v., 2 East 5..........178-170 5,60 Jifnn, $1 \ldots \ldots \ldots \ldots \ldots \ldots \ldots, \ldots$

IIjegs v. S., 113 Aln, $36 \ldots \ldots \ldots \ldots .492$ Jildehrand v. J.. 56 N. Y. 394...405-406 IIII, (.. v., 11 Jinss. $136 \ldots \ldots \ldots \ldots$ 250 S. v.. 4 Dev. and Bat. (N. Car.) $4 n 1$................................354 IIIndmarsli. R. v., 2 Isench C. I. (FA.

3) Casp $242 \ldots \ldots \ldots \ldots \ldots \ldots \ldots$. $2 . .363$ IIter quong Cliow, it. s. v.,

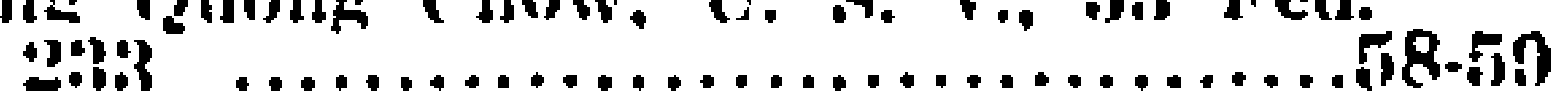
IInkle $\because . . .127$ ind. $490 . \ldots \ldots \ldots \ldots .219$ IIolleson. K. v., Dears, and B. 3..... 524 IIollirook v. S., 10T Ala. 1it ........ 408 IIolder. (C. v.. a Tray (Mass.) $T$..289-294

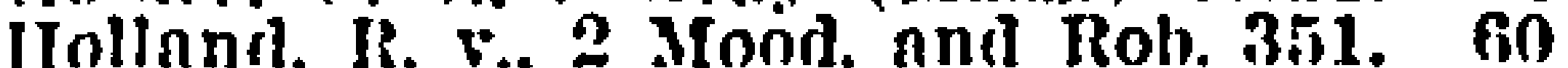
IInl!nway. R. F., 3 Cox C. C. $241 \ldots 479$ ITolls v..S.. 54 Ala. 239..........460.457 Iolmess if. $s$ v. 1 Prll. Jr. 1...120)123 Iolmos's ruse, Fin. car. 376.....390-391 IInnkins. R. v. \& Car, and $P$. 591... 363 IIOnt $v . r . .104$ T. S. G?1.........148.149 IIolnish $v .1 .142$ Iil. $620 . . . . . .176-177$ Holvignn. P. v. कs Mlch. $401 \ldots \ldots \ldots .497$ IInskins $r$. Tarrence. 5 Binclif. 4 it

4.14.45:

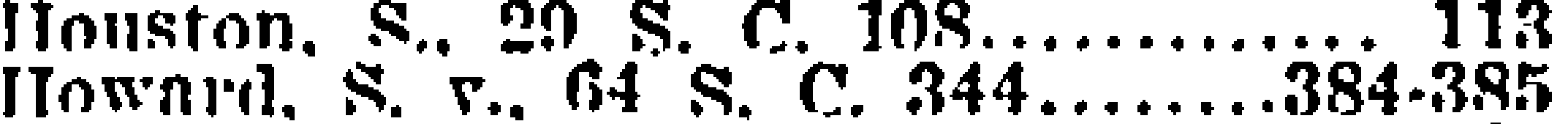

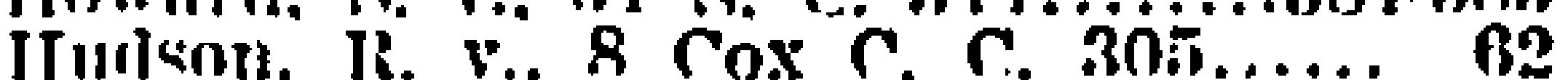
T. S. *. T ranch (1i Ii. S.) $32 . . .3-4$

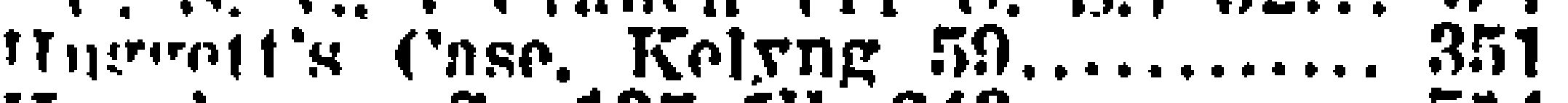
Huerins v. S., 185 IIl. $243 . \ldots \ldots \ldots \ldots$ 514 IIIthes. R. v.. 7 Cox $c$ (.. 301.....26-27 R. v. 1 r.Mgrh. No. $178 \ldots \ldots \ldots \ldots \ldots$.

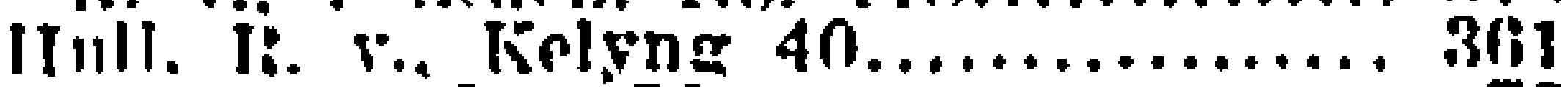

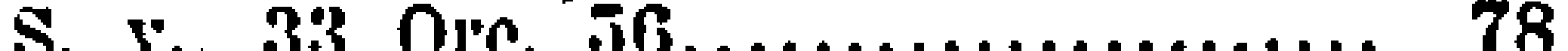
liunt $v$ r 13 Gratt (Va) T5i.... 424 (.. firtr. (Mass.) 111....... ino.194

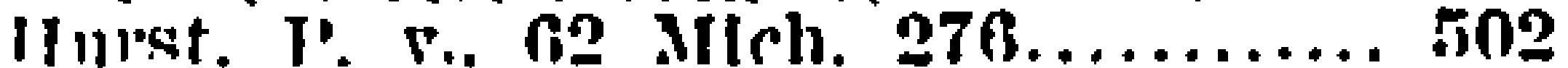

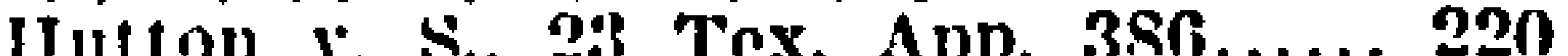

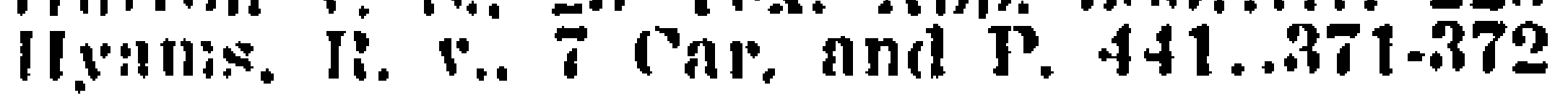

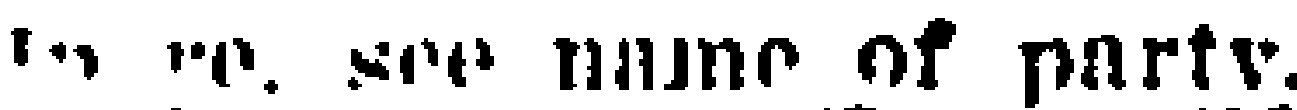

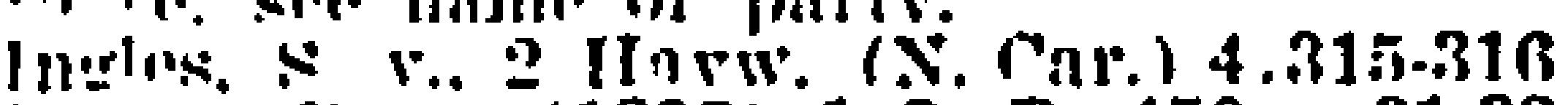

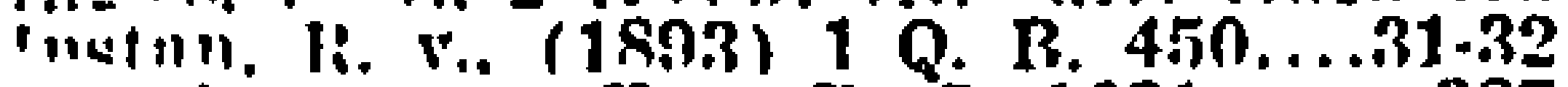
lande's rise. 2 Fast P. C. 1031..... 38T Ives. S. v.. 18 Irea. (X. Car.) 338.516-516

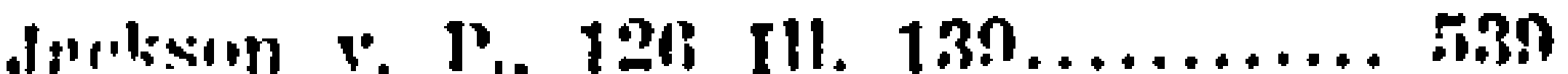

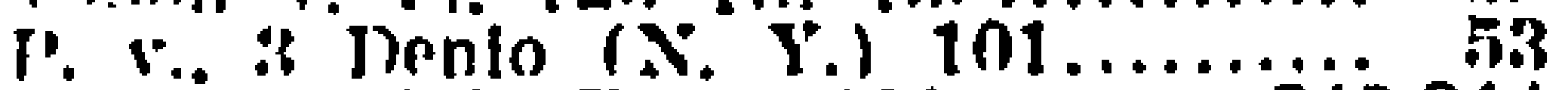

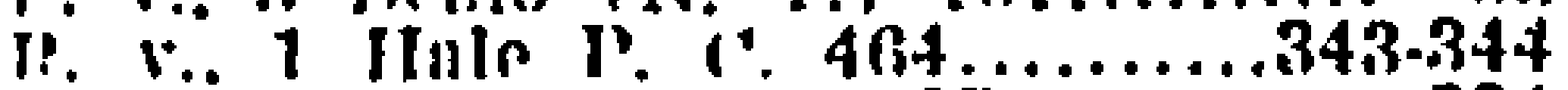

It. v. Missell and $R .487 \ldots \ldots \ldots \ldots .334$

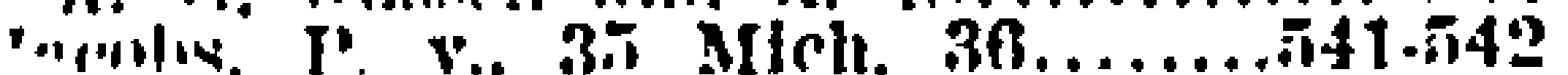
lmmes. r. is s. nna it. (Pn.j $220.11-12$ (. v.. 1 jif'k. (Mnss.) 375.....473.474 ionison, R. v. " Cox C. c. 15s.... 537 
Page.

John, s. v., 5 Jones (N. Car.) 163

$488-48 ! 1$

Johnson v. S., 66 Ohlo St. 59........34.3.;

b. v., 01 Cal. 2(3.,................ 408

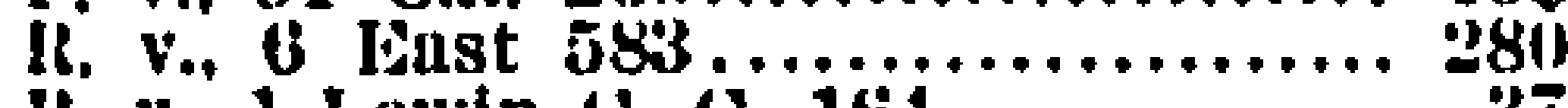

18. v., 1 lewin C. C. 164............. 37

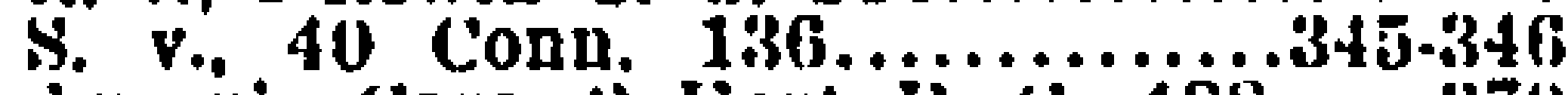
Julinson's Case, IFast $i$ c. $488 \ldots$ aro Jolly v. U. S., 170 U. S. $402 \ldots \ldots \ldots . .444$ Iones $v$ ideonara, bo lowa $106 . . . .30 .3$

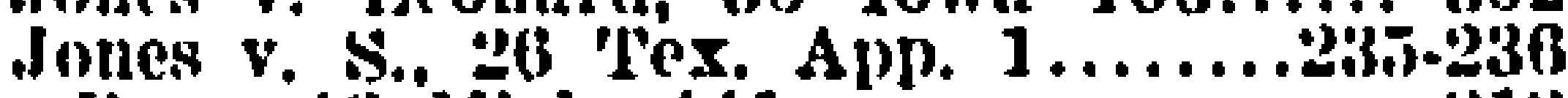
1. v., 46 Mlch, $441 \ldots \ldots \ldots \ldots \ldots \ldots$. 112

IR. v., 1 Den. C. (. $188 \ldots \ldots \ldots \ldots \ldots, 484$

1R. v., 1 Salk, $379 . \ldots \ldots \ldots \ldots \ldots \ldots .5$

s. v., 39 La. Ann. 935..........200.210

u. S. v. 3 Wash. c. c. $209 \ldots \ldots \ldots$..... 115

Jones \& Longman's Case, It Last i'. $c$ 49!)

linnuwats Case, 1 Gr. (1 Me.) 2:26.

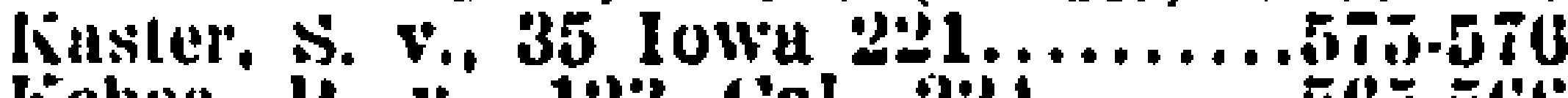

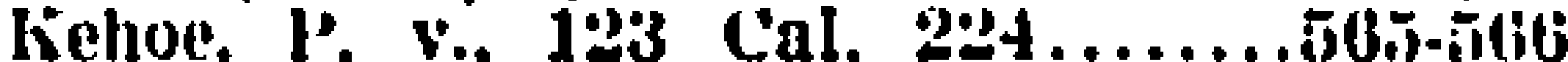
Kellogg v. S., 26 ohlo st. $15 . \ldots \ldots .43:$ kelly, il. v., 1 Craw. and Dix. 186... 116 Keninly, s. v., 154 Mo. $268 . . . \ldots \ldots .4 !)$ lienny, is. v., 13 Cox c. c. $397 \ldots \ldots$ t4) lieutucky v. Wennison, 65 U. S. 66

$290-302$

lier v. Illinois, 110 li. s. $436 . . . . .3(10.304$

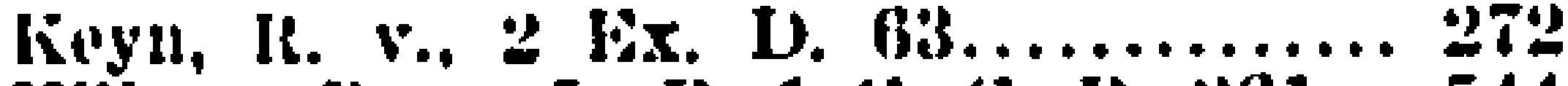
Kliham, R. v., L. IR. 1 C. C. IR. 201 544 Ki!lputrick v. H., j Denio (N. Y.) 2it

$48 \cdot 49$

ling v. l'.. 83 N. Y. $587 \ldots \ldots \ldots .579-58()$ Kirputick, s. v. 32 Ark. $117 . . . \ldots$. Kliluad $v$. s., 43 Ind. $146 \ldots \ldots \ldots \ldots 320$ Kluseman, s. v. si Minn. $541 \ldots . .140-141$

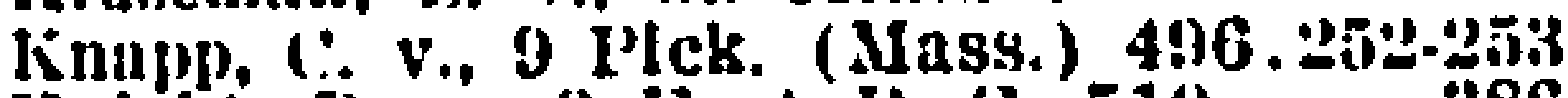
Knight, iR. v., \& East I'. C. $510 \ldots \ldots$ \$86 S. v." 'Payl." (N. Car.) (b.).........270 knoek, It. v., 14 cox c. C. $1 \ldots \ldots \ldots, 362$ linowiton, ( v. 2 Mass. $\$ 30 \ldots \ldots \ldots 10-11$

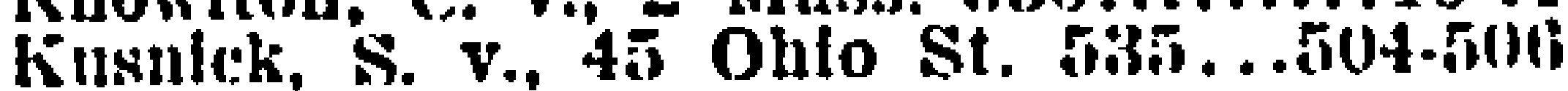

Lamil $v, P .96$ Ill, $73 \ldots \ldots \ldots \ldots \ldots$. l.nugley v. B̈rndshaw, 1 Koll. Aïr. 73 , pl. 16 ...................... 473

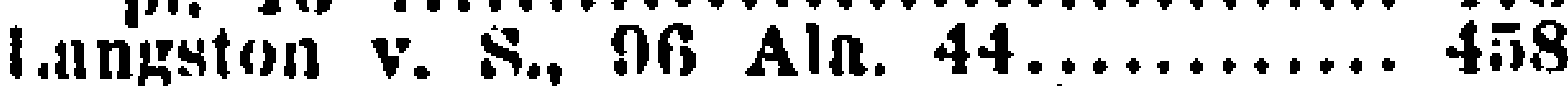
Lannan. $($. v., 15.3 Mass. $287 . \ldots .408-409$

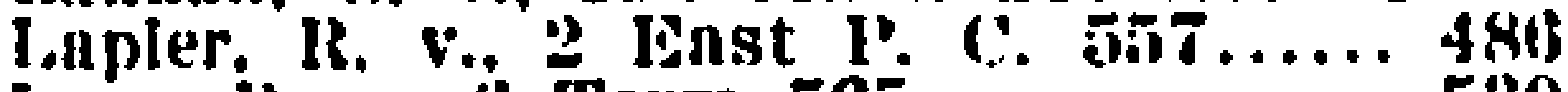

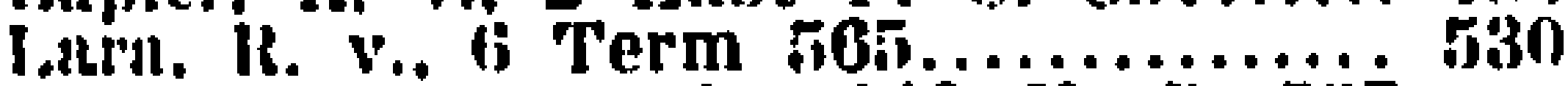
i.ascolles v. Georgia. 148 i: s.

30 ii-30ti

latlmer, It v. 16 (ox C. (c. 70..... 108 lavender, ik. v., 2 East $l^{\prime}$. C. $506, \ldots .402$

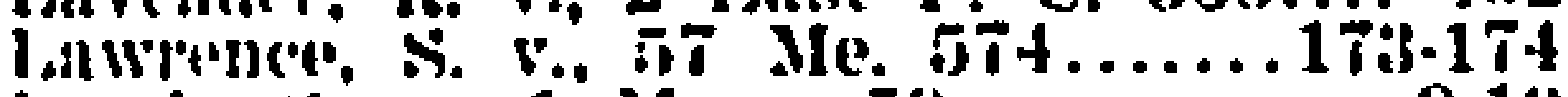

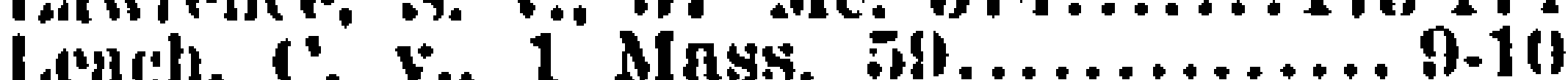

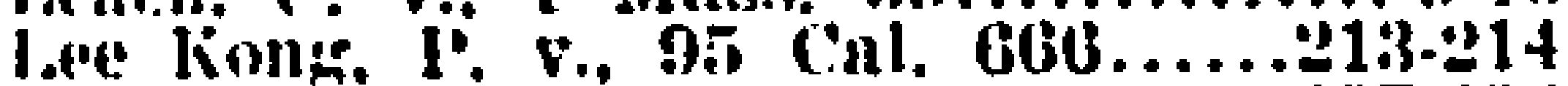
l.Medy. s. v.. 95 Mo. $76 . \ldots \ldots \ldots .497-4 !)$

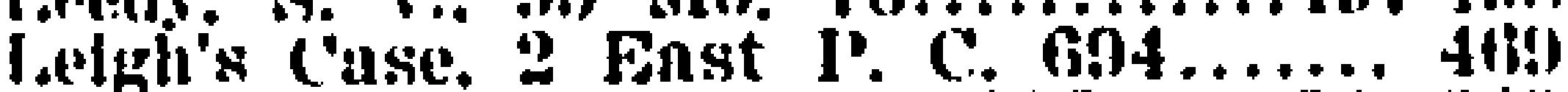
leiphton v. 1 ... 88 N. Y. $117 \ldots \ldots .34$ s..34! I.e Intt's (ase, Kolyng 42.......... औitl l.eomard. (. v. 140 Mass. 473...... 514

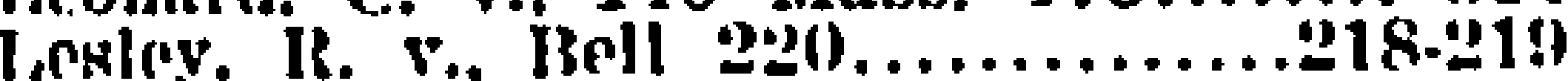
i.pster. (.. v. 120 Mass. 101......... 49H

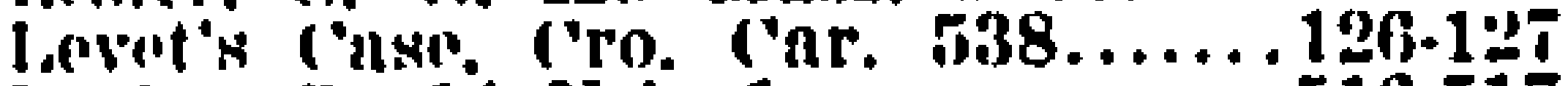
I.ev v. S.. 14 Neb. 1.............516-îti l.ewls, ]. v.. 124. Cal. 551.........42.4t l, Wis. s. v., 2 Hawks (N. Car.) 98 316.817 l,illey, 1'. v.. 43 Mich. $521 . . . \ldots \ldots . .326 .327$ I.jndsey v. S., 38 ohio St. $507 \ldots \ldots \ldots$......

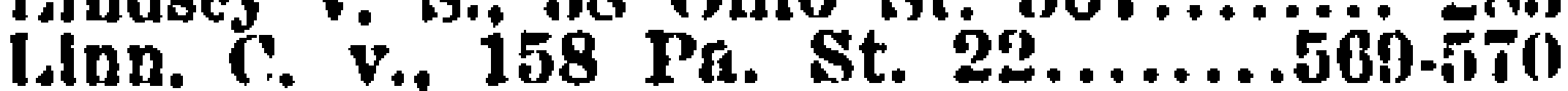
I.lovd. R. v.. 4 Fsplnasse $200 \ldots . . \ldots \ldots$.1 fockett, R. v., 2 East P. C. 940..5i8-519 longbuttom, li. v., i Cox cr. Cas. 430

60.61

loumls v. I". 67 N. Y. 3.2........431.43" lond, C. v. 3 Metc. (Mass.) 328.308.iul lovve v. I., 160 III. ju1............ is l.owe, 1t. v., 3 Car. and Klr. 128...... 20

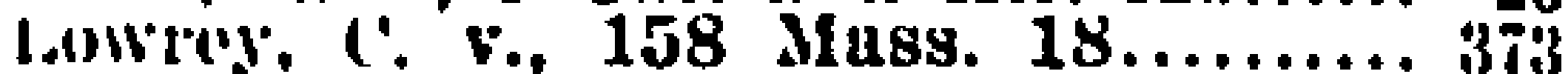
l.lleus. s. $\nabla ., 55$ lowa $321 \ldots \ldots \ldots \ldots . . .2$.tit

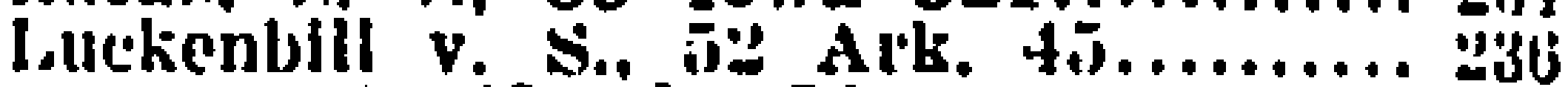
t.llni" v. S., 49 Ala. $30 \ldots \ldots \ldots \ldots \ldots \ldots$.......

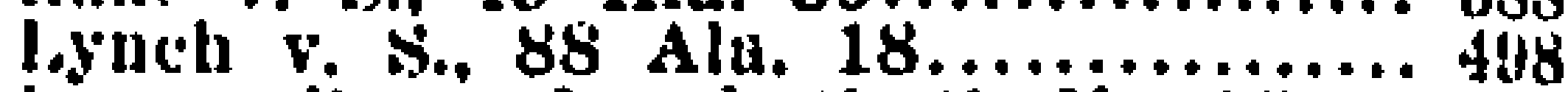

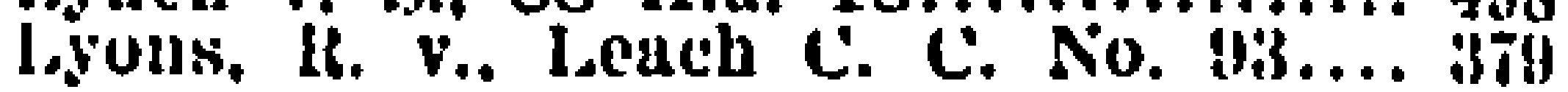

Mcatee, s. v., 10t $\mathbf{N}$. Car, 812....32tijas

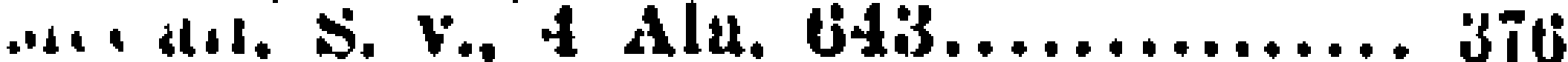
Ilecuuts, s. v., 1 speur (s. C'ar.) 354

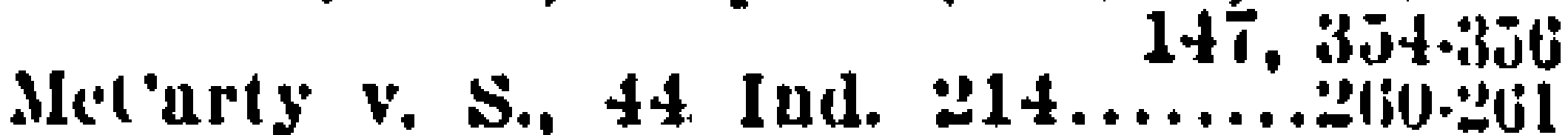

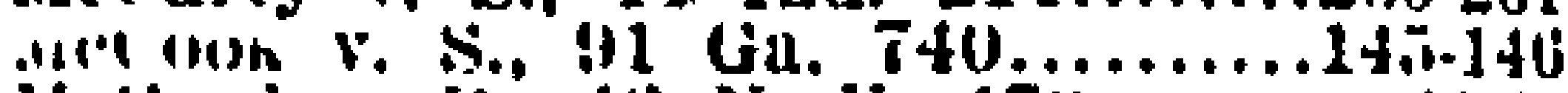

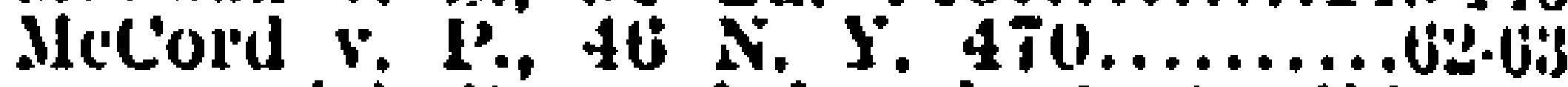

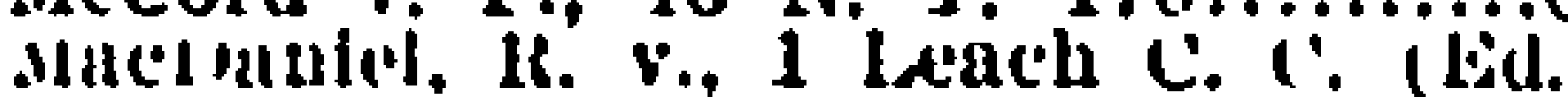

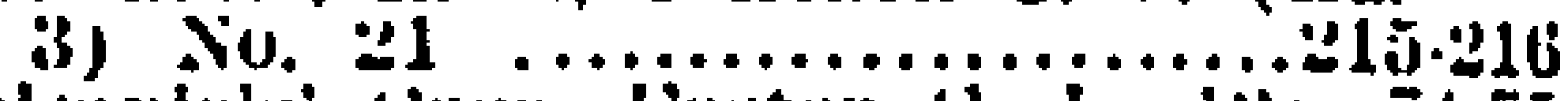

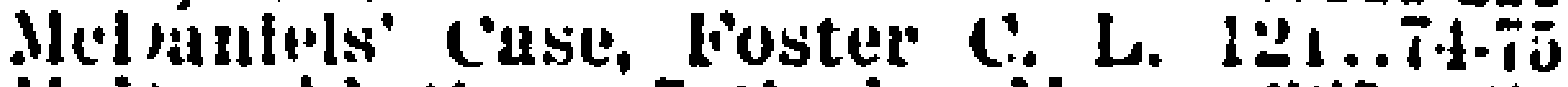

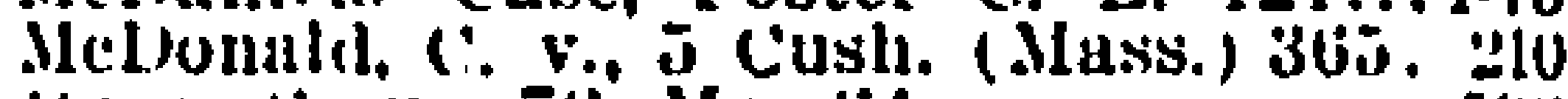

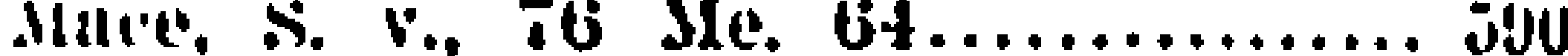

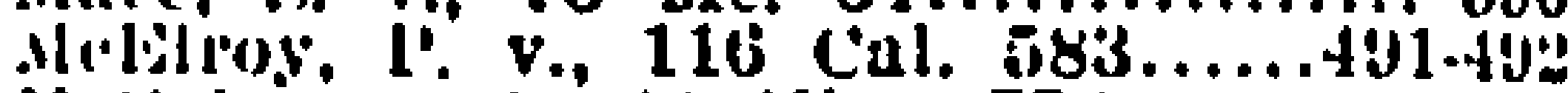

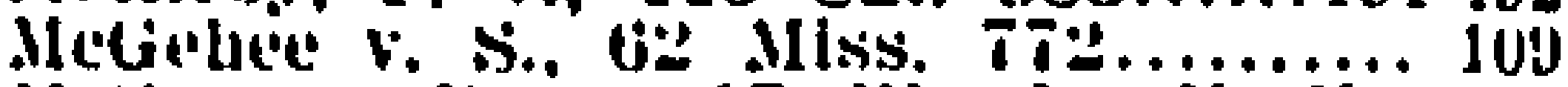

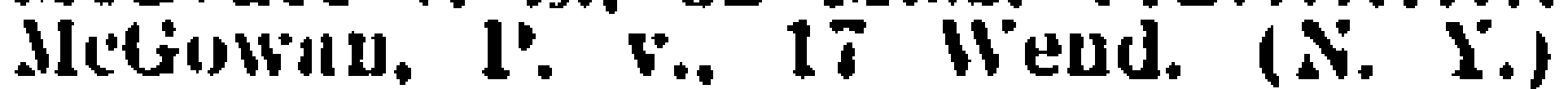

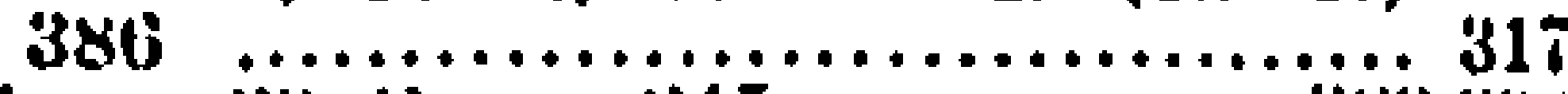

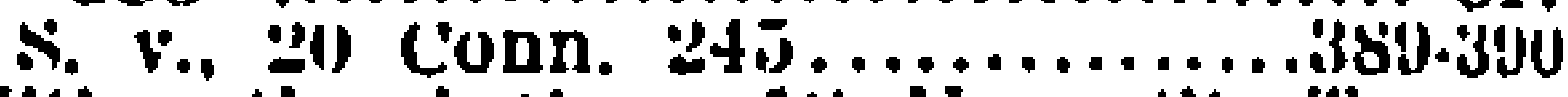
II'Growtbers' Cust, 18 How, st. 'T'.

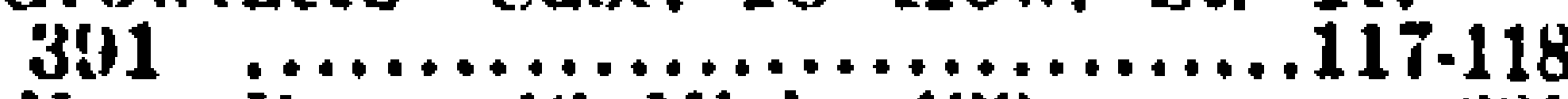
Mckay, 1'. v., 46 dich. 434)......... 201

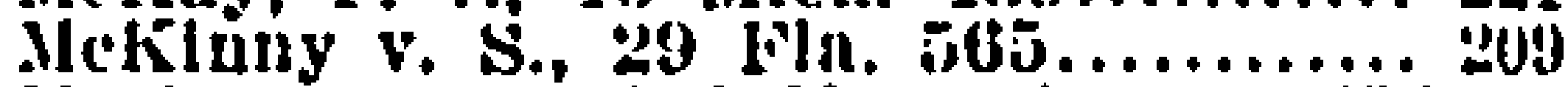
Macioun. (.. v., 101 Mass. 1........29t.:2ys IINaghten's Case. 111 (1. and F. 200

$150 \cdot 1 i^{2}$

Nurelue, s. v., 111 \&. Car. $605 . . . . .439$

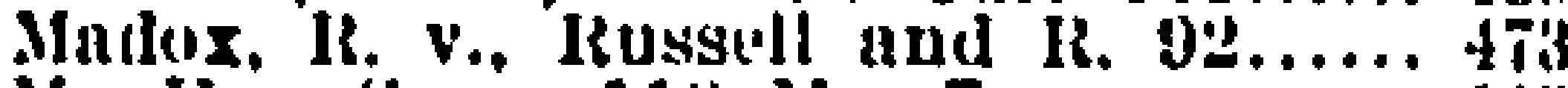
Ifu Foo, s. v. 110 No. $7 \ldots \ldots \ldots \ldots \ldots$ 113

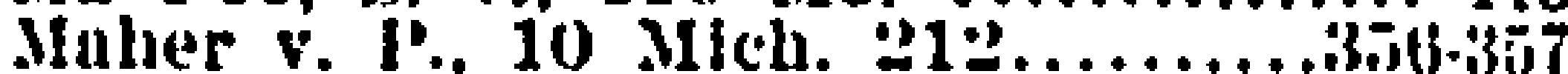
Mahon v. Justles. 12t L. S. $700 . .304-3105$ Mahoney v. s., 33 'Fex. Cr. IR. $388 . . .4+5$

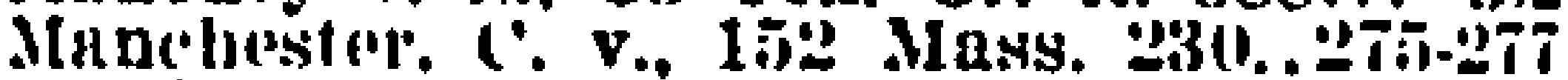
v. Massuchuset ts, $139 \mathrm{U}$. S. 240.277.27) Ianniug. li. v., 6 cox c. C. 86...480.481

ilannins: case. 1 Hale $I$. C. $486 \ldots$... $35 \%$ Ilarshall, (? v., 11 lick. (Mass.) 3.j)

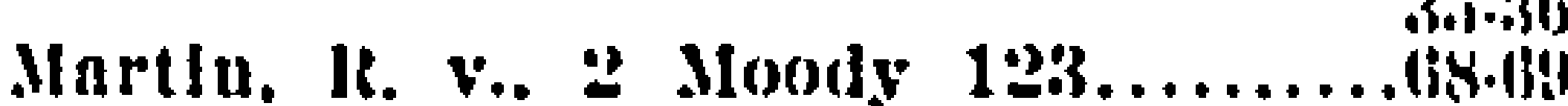
R. v. Lussell and IR. $196 . \ldots \ldots \ldots$ it

Martlne\% v. S., 41 Tex. 1213.......4tik.4t)

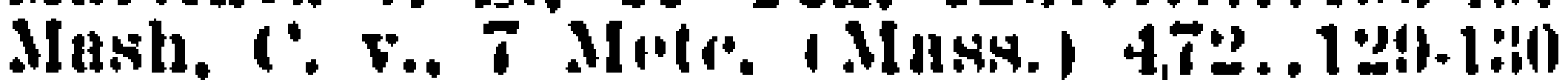
Inson \&. P.. 26 N. Y. 200.......380)-381

(. v., 11is Mass. 163............. 478

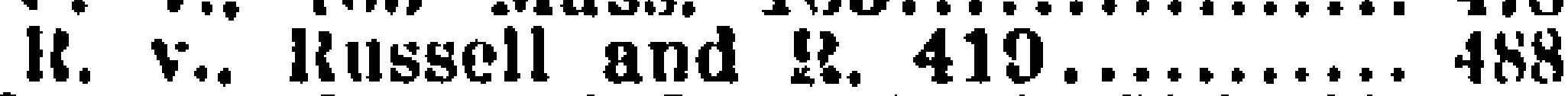
Ilisters. IR. V.. 1 len. C. C. 332.4941 .500 Natter of, see name of party.

Mnyes v. I.. 1018 111. 306.........347-348

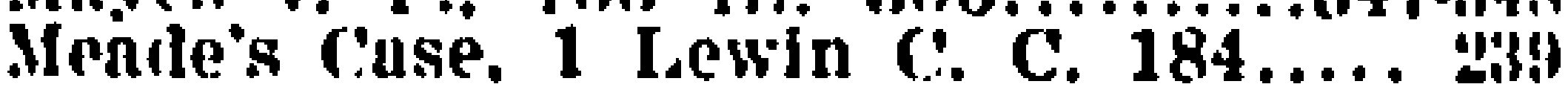

Meaklu. It. Y., 7 (al. and I'. afi..... 147

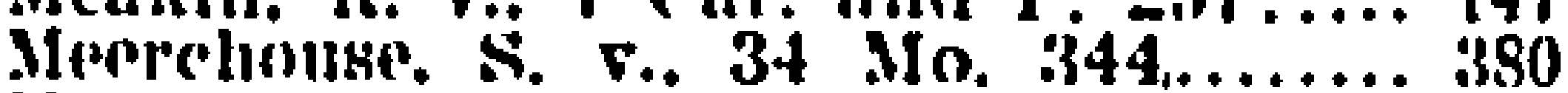

Menoumdum, Keiyng $13 ., \ldots \ldots \ldots \ldots \ldots$ is

Kelgug 52 ...................... 250

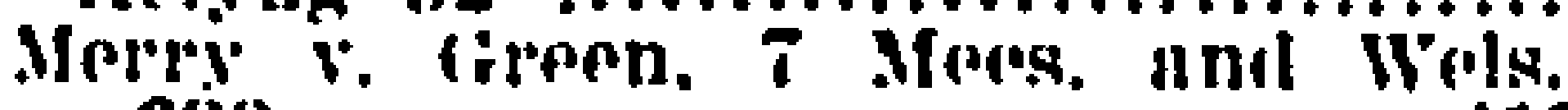

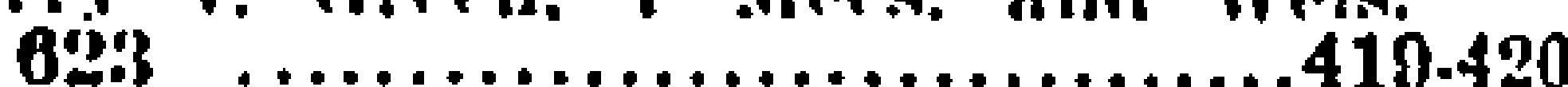

Meyer, [․ v. 75 ('al. $383 . \ldots \ldots \ldots 398.399$

Mlchnel, ir. v., 1 Mooty $120 \ldots \ldots \ldots \ldots . .51$

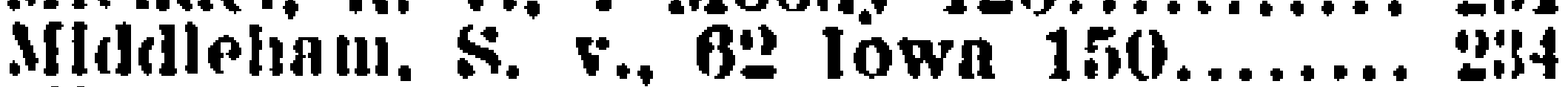

Niddleton $\vee$. S.. 53 Ga. 248.........496

¿. S.. Inudiey (S. Car.) 275......530-531 il. $\nabla$. I. R. 2 C. C. R. 38.......439-443

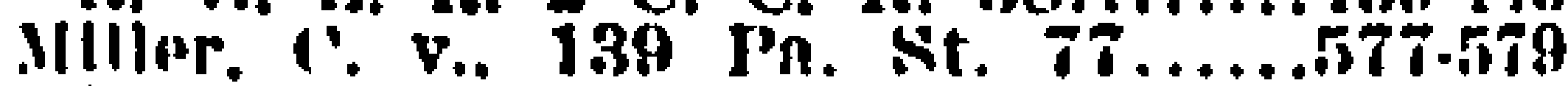
I. $\therefore 169$ N. Y. 33!)............ Ii. v. $6 \operatorname{Cox}$ r. c. $35 . . . . \ldots \ldots \ldots . .500 .510$

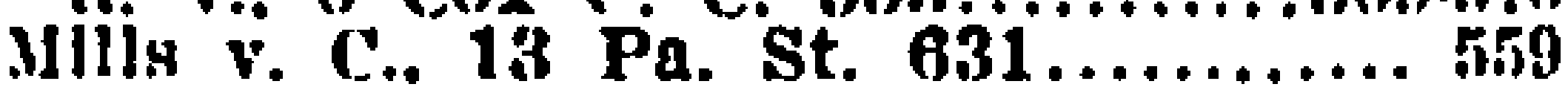

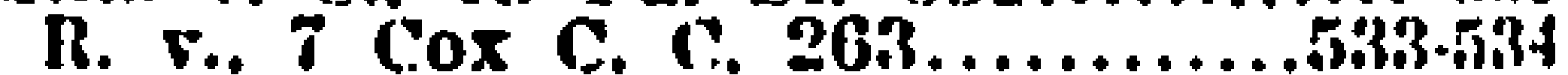
Mink, $($. v. 123 Mass. $42 i \ldots \ldots \ldots \ldots \ldots ., \ldots 7.98$ 
Pabe.

Sitchum v. S., $4 \overline{5}$ Ala. $3 y . . . \ldots \ldots+38-430$ Mollutt's Case, ¿- Eust 1'. C. jot.... j:T jlooney, s. v., 61 N. Car. (1'ulll.) 434

$3: 5 \cdot 326$

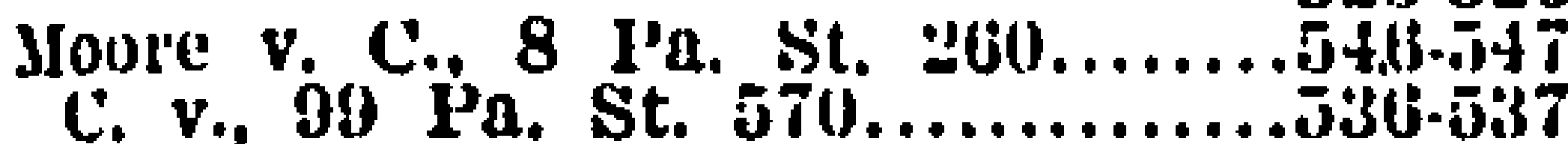

li. F., Leach, No. $146 . \ldots \ldots \ldots \ldots \ldots+\ldots 27.428$

s. v.. 31 Conn. $47 \% \ldots \ldots \ldots \ldots \ldots \ldots 243.244$

s. v." 12 N. $11,42 \ldots \ldots \ldots \ldots \ldots \ldots, 89.90$

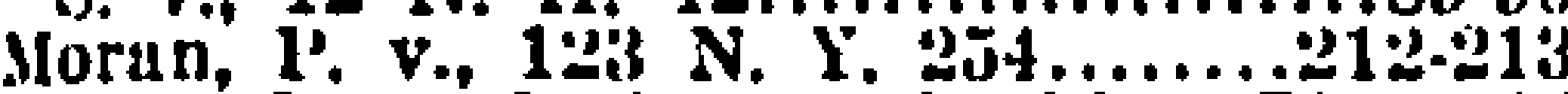
liurby, R. v., l. R. \& $Q$. l3. Ulv. 571.. 38 Mortit, IR. v., liussell and $\mathrm{l}$. 307..476.477

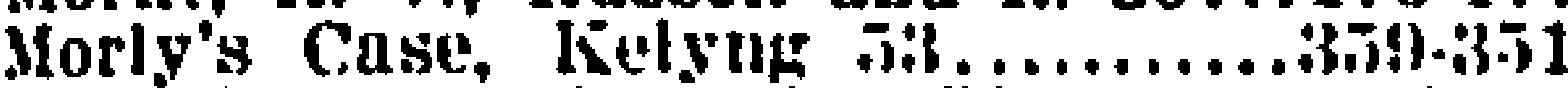

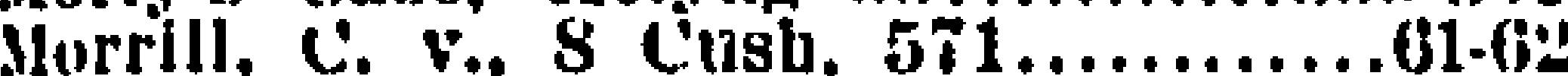
iloris, K. v., 10 Cox C. C. 480 ...311)-330 Jlorse v. \$., 6 Conn. $8 \ldots \ldots \ldots \ldots \ldots \ldots$, 89 c. v., "2 Mass. 138................. Muiklow. R. v., 1 Mooty (: c. 160. . 415 Jifuler v. Kansas, 123 U. \$. (i23.....19.20

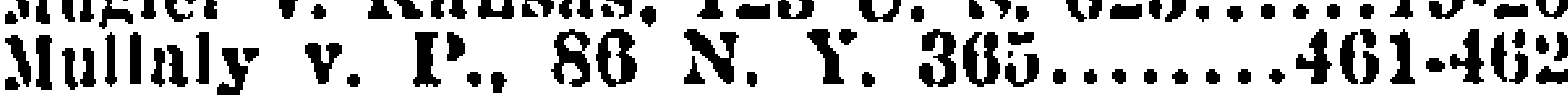
Jurio v. S., 31 Tex. App. 210....... i1.

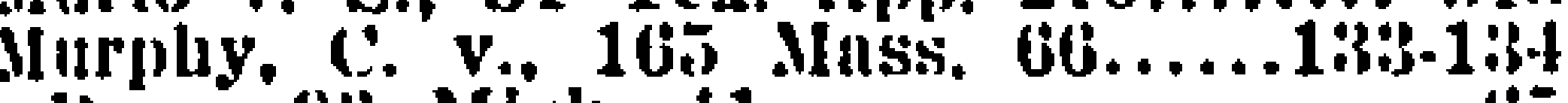
I. v., gi Mitch. $41 \ldots \ldots \ldots \ldots \ldots \ldots \ldots$ ti.j

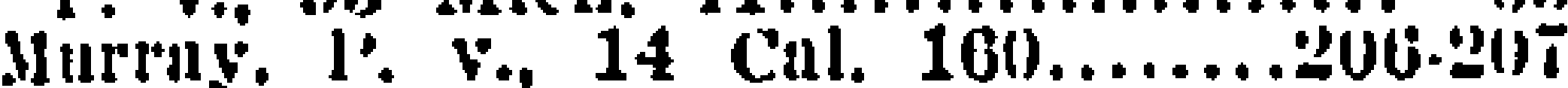
IR. v., 1 Moody $270 . . \ldots \ldots \ldots \ldots \ldots .490$ Murray \& In

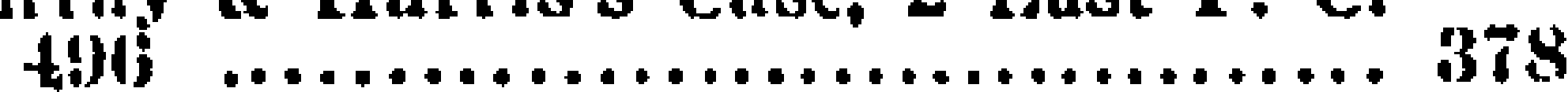

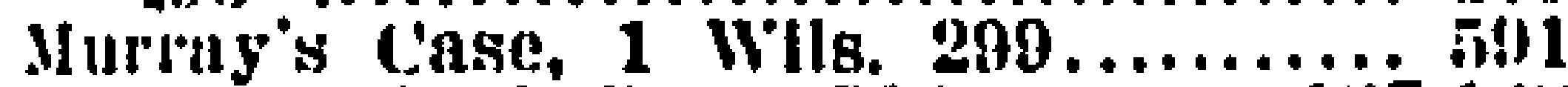
IIyes's v. s., 1 Conn. 502..........127-1.3

Ningle, In re, 39 Fid. $\$ 333 . . . . . . . . .248$ Fetul, C. v., 10 Mass. $152 \ldots \ldots \ldots \ldots \ldots$ 11:

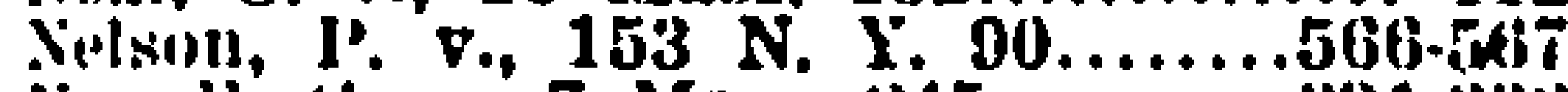
Niwell, (.. v.. 7 MInss. $245 \ldots \ldots \ldots . . .331$-33i32 Ficholls $v$. S., 68 Wis. $416 \ldots \ldots \ldots \ldots$...... 371

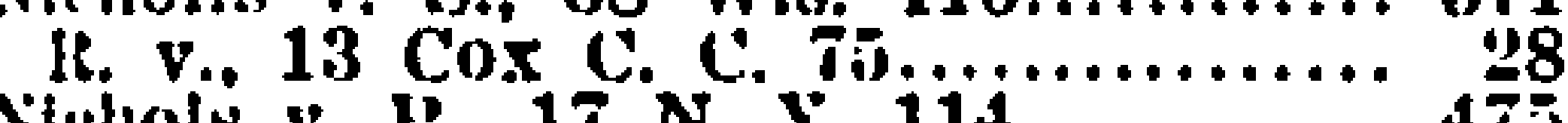
viehols v. $1 ., 17$ N. Y. $114 \ldots \ldots \ldots \ldots .47 \%$ Sorton, (. v., 11 Alten (Mass.) 266.. 5i34 Sista.

1. 13., 21 llen. T. 39 $\mathrm{pl}$. .11......... 238

Nugent, s. v., in Wash. $52,2 \ldots \ldots \ldots, 561$

d'lirlun, s. v., 81 lown $88 \ldots \ldots \ldots \ldots+1 \cdot 4$. s. v.. 3: N. J. L. 16n.............. 2i (ogden, IR. V., $6 \mathrm{C}$ and 1 . 631........ (0) olis $v$. S., G A Ala. $81 \ldots \ldots \ldots \ldots \ldots 377-378$ ollver. S. v.,70 N. C. $(00 \ldots \ldots \ldots \ldots .219-2.20$ o'suliey.

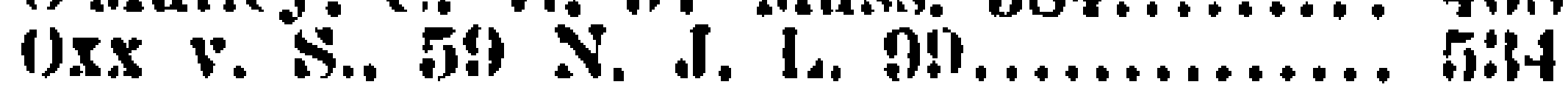

l'. I'eople.

Pilmer v. I'. 10 Wend. (X. Y.) 1tis.. 4t8

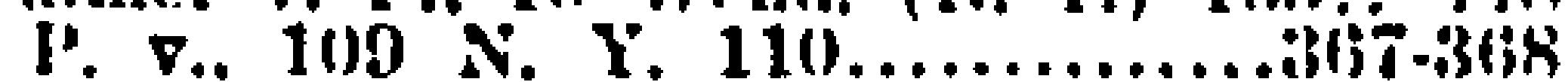

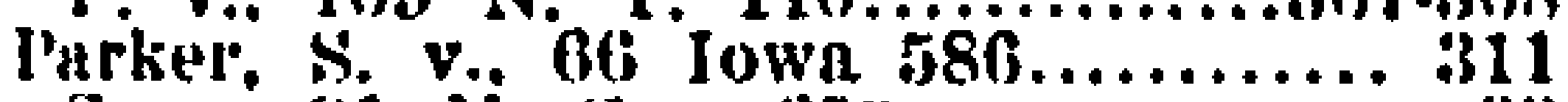
S. v., 91 N. Car. (3in)............. $3: 3$ Parks, 1\%. จ., 4! Mleh. 333........... 20.2

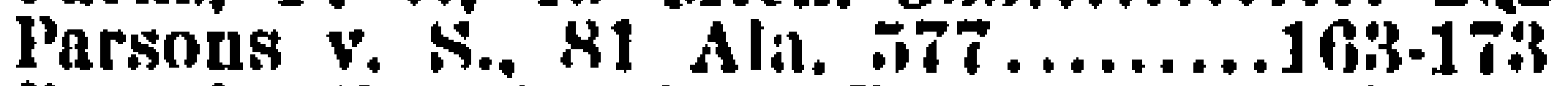
Passule county Agr. Soc., S. V., itt

N. J. L. $260 \ldots \ldots \ldots \ldots \ldots \ldots \ldots, 111$

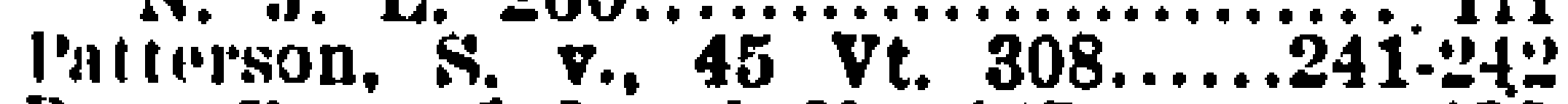

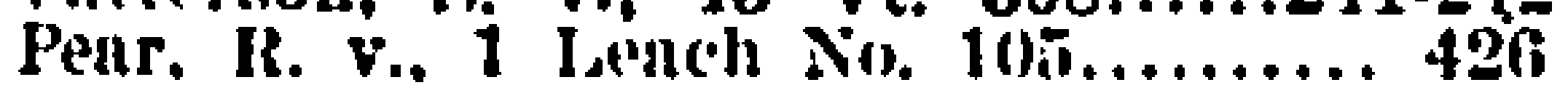
Pearson's Case. 2 Lewin $14.4 \ldots . . . . .14$ 14 leat. IR. v., 1 loweh (lid. 3) No. 112. 45.

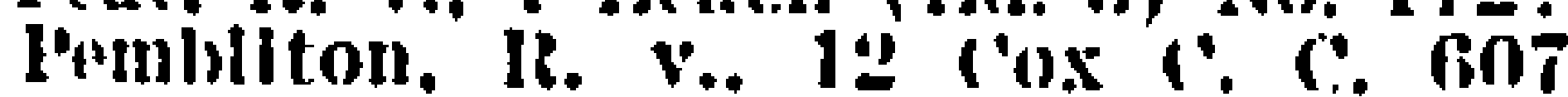

$10 \pi-10 \mathrm{~s}$

I'pople y., see name of party defendunt. Pere\%. U. S. จ.. 20 U. S. 579........ 300 lerry. C. จ.. 139 Mass. 198....... R. $\nabla ., 1$ Car. and $K .725 \ldots \ldots \ldots \ldots .4$ Phetheon. 1R. v. ! Car. and P. 5i2... 482 Phillips, C. จ., 16 Mnss. 423......... 250

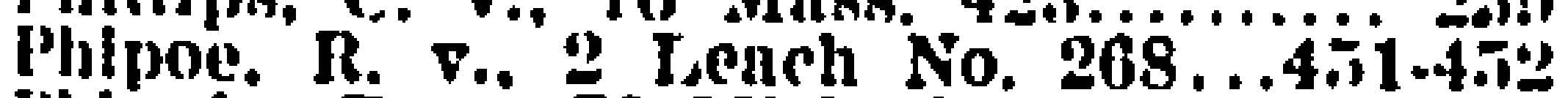
Phipuln, P. v., 70 Mich. 6............ on Plgman v. S.. 14 Ohto 5iso.........147-148 Pine. I. v., IBnrl. (N. Y.) B(ik..153-154 Pinkard v. S., 30 Ga. 757.........287-268 Pltcher v. P.. 16 Mich. $142 \ldots \ldots \ldots \ldots \ldots$ is 19 Plant, R. v., 7 C. and P. 575............ 317
Page.

lline, l'. $r ., 61$ Mich. 247.........30!)-310

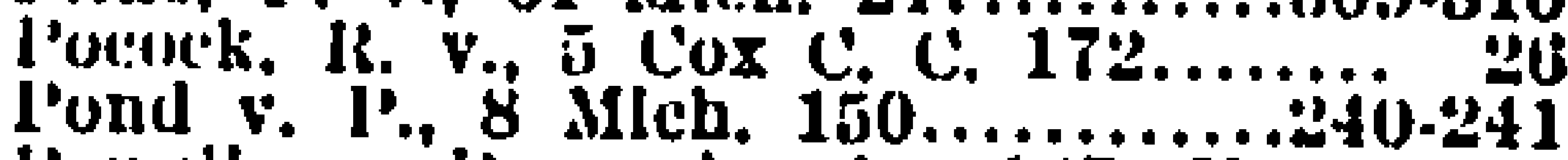
'owell v. Lenusylvaula, 127 U. S

k78

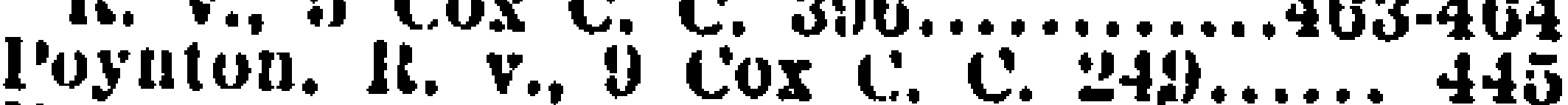
l'oyser, IR. v. 2 Den. C.

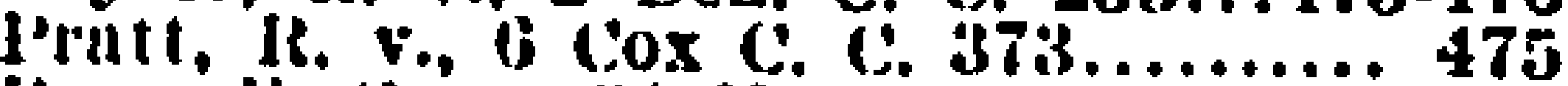
I'resnell, s. v., 34 N. Cur. 103........ 103

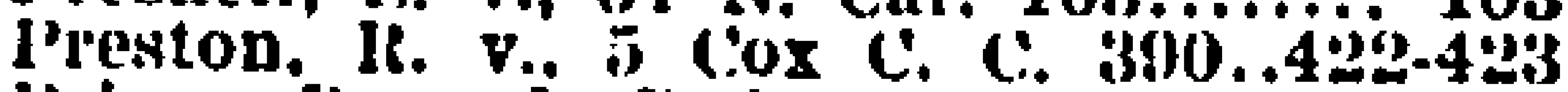
lrince, IR. v., L. IR. 1 c. c. it. $150.420-430$ l'rlus, (.. v., o Grag (Muss.) 127.... 190 l'ivilt, $R . v ., 1$ Wen. C. C. 193...... 477

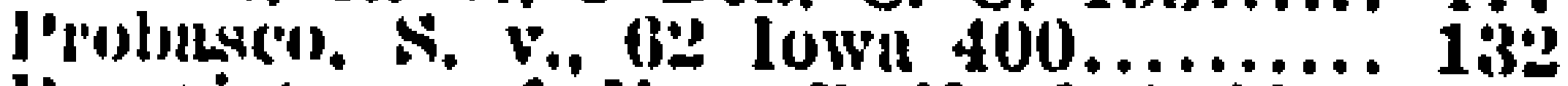
l'omrietors of New IBelford iBridge,

C. v. : Gray (Muss.) 333!....... 110

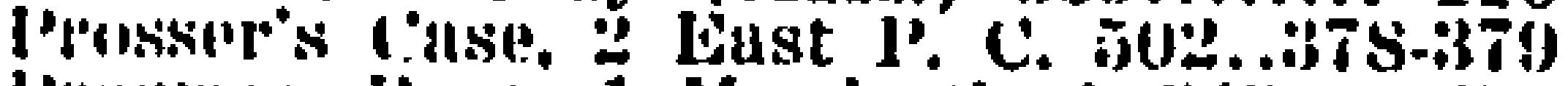
low's. IR. v. 1 Moody C. C. 341... 288 logh, s. v., 101 N. Car. $737 . . . . .2 i 21-2.21$ l'ulaski C. A. Ml. Assn., C. จ., G2 Ky.

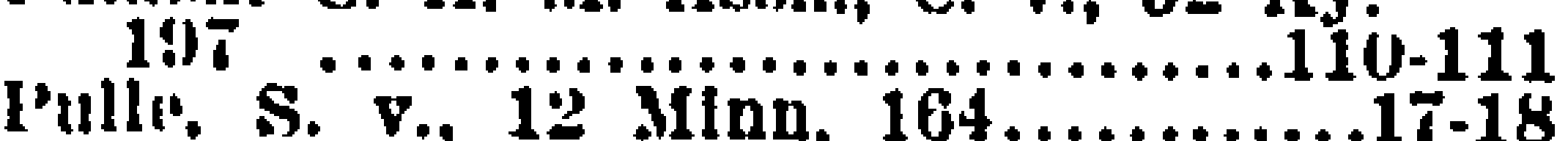
lywell. IR. v., 1 starkle 402.......... 187

(guinn v. ['.. 1:33 I11. 333..409.411), 450.4.1 v. I.. 71 N. Y. 561............... 381

li. Iiex or IRerina.

lRadiord. R. v., 1 Den. C. C. $59 . . .527-i \pm 28$ Rae, I'. v., tit c.al, 423.............4333-434

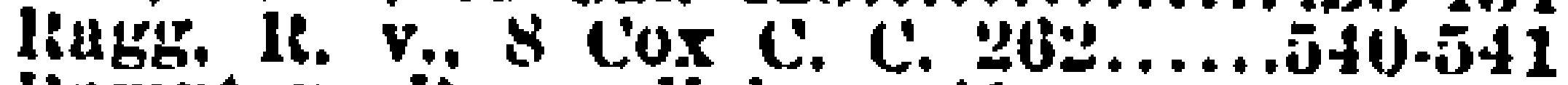
limpton. if. v., Kelyng $41 \ldots \ldots \ldots \ldots ., 357$ Rilndolph, ( $\therefore$ v., 146 l'a. St. 83...... 16

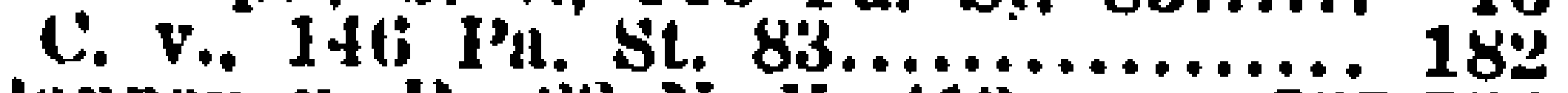
lunney v. 1., .2. N. Y. $413 \ldots \ldots \ldots \ldots$. kaluen, IR. v., kilyn $2.24 \ldots \ldots \ldots \ldots .339$

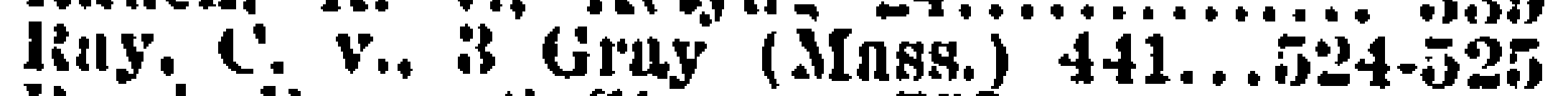
liead, 1R. v., "2 Strange 789.......... 54 Reugnn v. S.. 28 Tex. Apl. 2:....... 150 lieed, 12. v.. f cox c. (. 284........4i1-413 Regina $v$.. see name of party defendant.

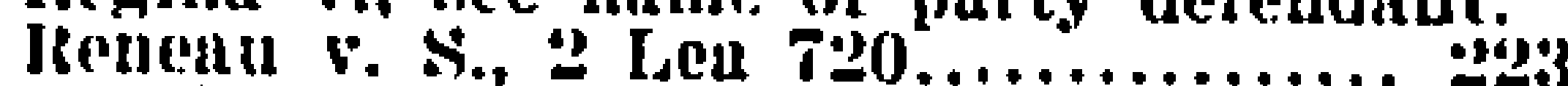

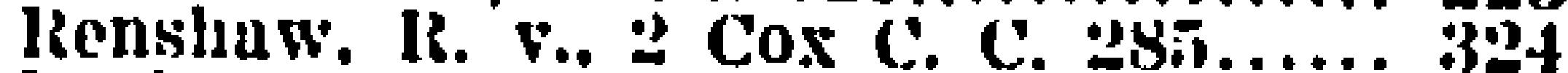
IReple, 1 . v.103 Mich. $45 ! 1 . . . . . .11$ is.119 iliporter's iote, Y. B. 3 IIen. 7,12 bl. () ........................... 400

Resolution. Poph. 52................. 378 Hespublica $v$. Caldwell. 1 Dallas I'n.) 150 ............................ v. IIcinrty. 2 mallas (2 if. s.) $86 . .118$

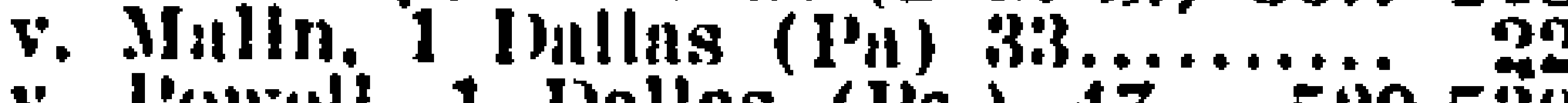
v. Iowell, 1 Dallas (1'a.) $47 \ldots . .5 i 29-530$ v. IRolnopts, 1 leates (Pa.) (G......... 14

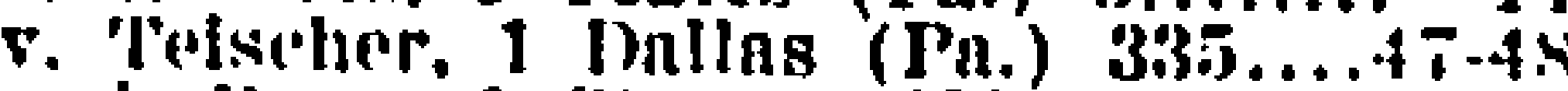

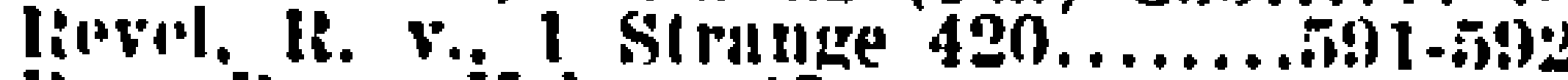

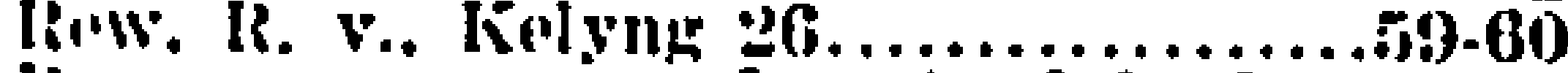

liex $v$ see nume of prity defondunt.

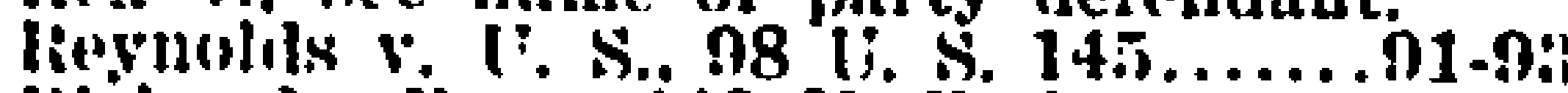

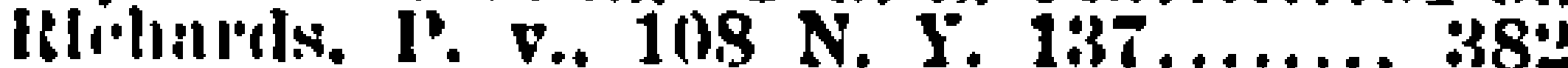

li. v.. llusseli and $k$. $28 . \ldots \ldots \ldots \ldots$ 4.54

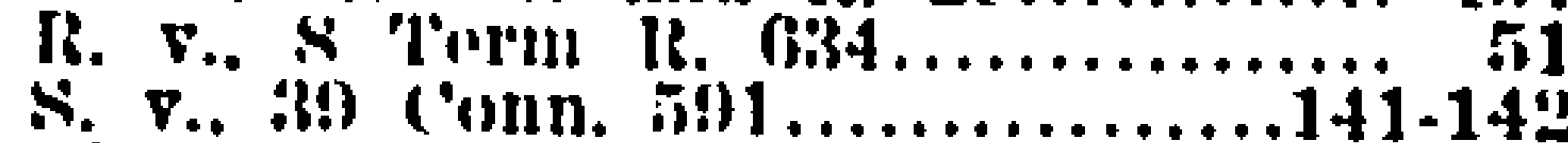

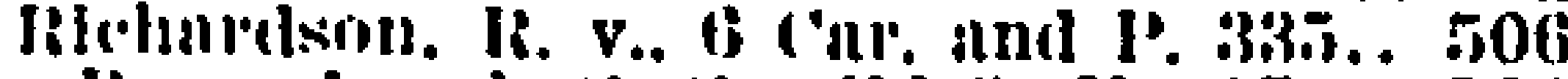

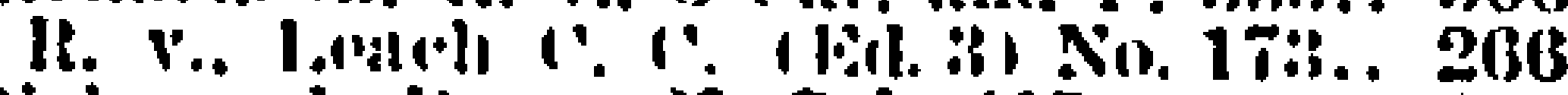
IRleliminnl. I'. v. en Cal. 415........ 11.

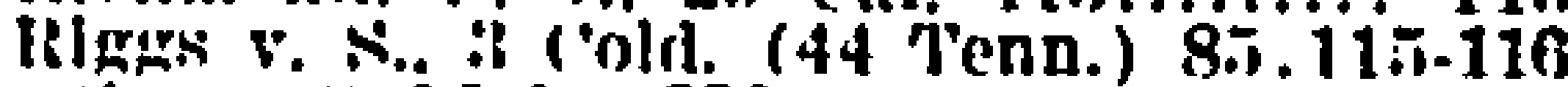

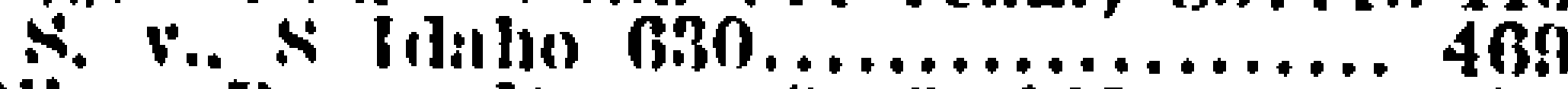

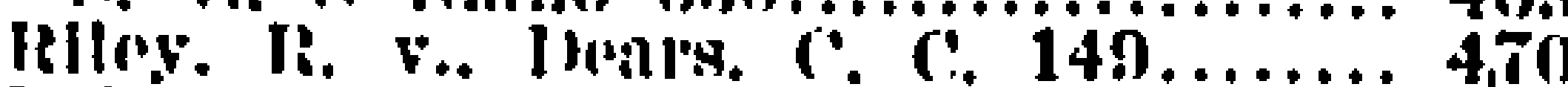
loblielts"s l'sist. 3 coke Inst, 138..... 256 liohins. IR. v.. Inors. 418............ 409

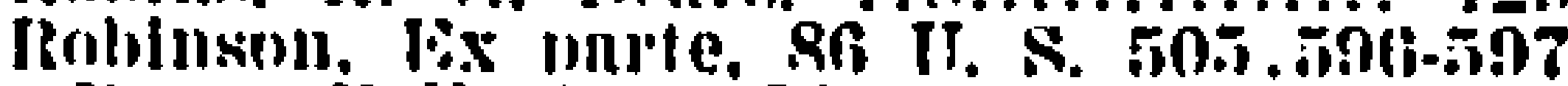

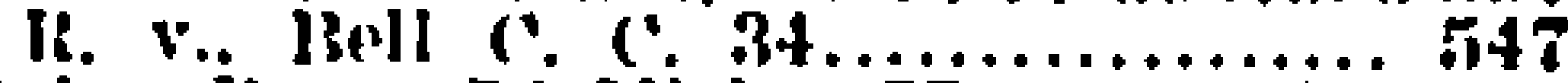
Rolis. ip. v. is virch.

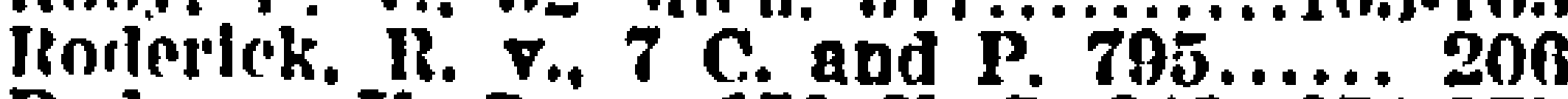
Rodgers. T. S. v. 150 U. S. 240..274-275

Rogers. (. v. 7 Metc. no0.........152-153 P. v. is $\mathrm{S}$. Y. o..........144.145. 346 
Roosnell, $C$ Hose, IR. $v$. 15 Cox $c$ c. 540.......347.248 Roscman, s. v., 108 N. Car. $760 . . . .220$ IRowe, IR. v., Bell $03 \ldots \ldots \ldots \ldots \ldots \ldots \ldots$ 449 s. v. os N. car. (329.............373 liviof $v$. I'. is N. $Y$. 179.........304.367 v. 1.. 4.5 N. Y. 213............263-264

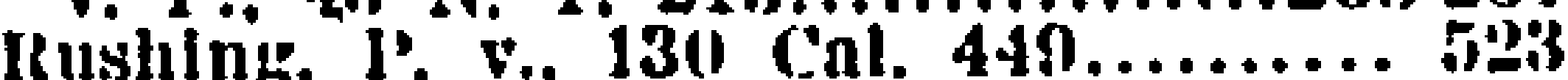
IRussell, IR. v., Car. and M. 541 ...388-399 lussett, is. v., (1892) 2 Q. 13. 312.436-4.37

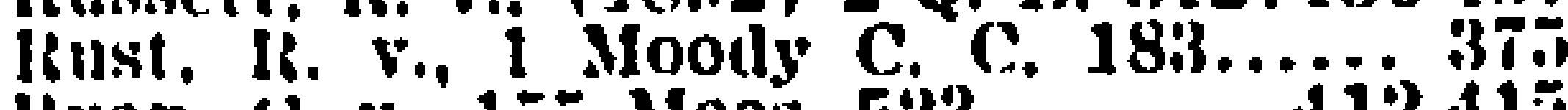
livnn, (.. v. 15ij Mass. 523.........412-41\%

s. v., to N. II. 100,............. 134

\section{S. State.}

Sulus, s. v., 2 Nev. $260 . \ldots \ldots \ldots \ldots \ldots$. ist

Sillmon. li. v. 14 cox c. C. $404 . . . .111$ snlvi, i. v. io cox c. C. 481 ....... 31s

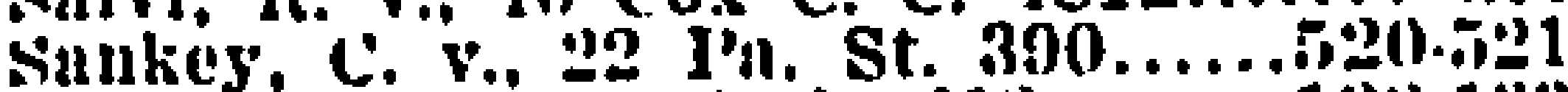
Susse $s$. 6 s. Dak. 212.......132-13i3 Saunders's Casc, : Plowd. Com. 473 . (14-4) Schmidt, 1R. v., 10 Cox C. C. 172.51:-ili Schult\%, 1'. v." 71 Mlch. $315 . . . . . .466-467$ Senring, il. $\because$, lisussell and ik. $350 . . .4$ ti1 Selwny. IR. v., s cox C. C. 235....486.18t Serne. it. v. lif 1 ax i. $19311 \ldots . .340-350$ Setter, S. v. 57 Conn. $461 \ldots \ldots \ldots \ldots 81-80$ Shall. I. v." o Cowen (N. Y.) 778....5\%7 Sharpe, ir. v. 7 (ox c. c. $214 \ldots \ldots . . .00-91$ Slunrpless, C. v., 2 Serg. and R. (Pa.)

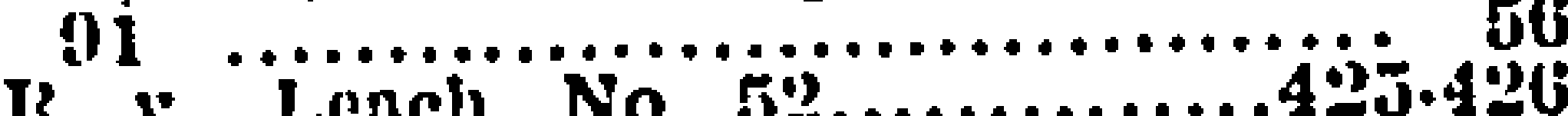
Shattuck, C. v., $t$ Cush. (Muss.) 141

$\mathbf{5 5 3 \cdot 5 5 4}$

Shaw, (. v. 4 Allen (Mass.) 308..46\%.466

I. V., if Mlph. $403 \ldots \ldots \ldots \ldots \ldots .434-435$

S. v. 6i Ohlo st. $157 \ldots \ldots \ldots \ldots \ldots$. 461 Shepard. S. v. $t$ inm. it.......... 334 Slueppnrd, R. v.. Russell nnd IR. 169.. 107 Sherman. S. v., 16 IR. I. B31 ........236.237 Shielis, s. v. 4 i Conn. 250......340.341 Shorter v. 1., 2 N. Y. 193.........228.2y

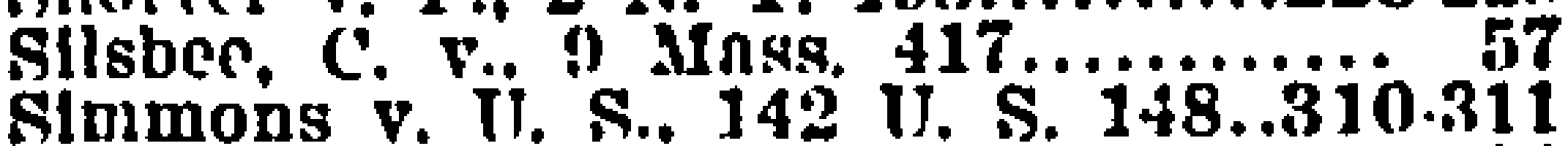
Simpson v. S., 02 Ga. $41 \ldots \ldots \ldots \ldots$..... Sims, S. v., 3 Strolbh. (S. Cnr.) 137.. 324 Sinttery. $\odot$.. 147 Mass. $423 \ldots . . .665$ Silngritind. S. v. 10 Nev, $13 \pi \ldots . . .484 .485$ Slowly, IR. v. 12 Cox C. C. 269...404-4n.T Smith v. $P .25$ III. 17.........17. 189.180 v. P.. 5.3 N. Y. 111.............430.431

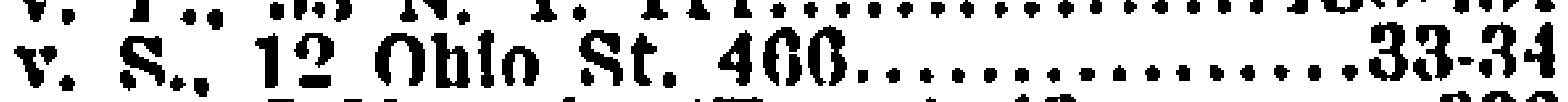
v. S.. 7 IIImph. (Tenn.) 43........ 3R0 c. v. 111 Masa $420 \ldots \ldots \ldots \ldots \ldots \ldots$ tn.

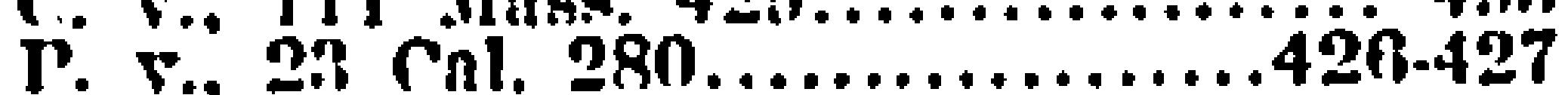

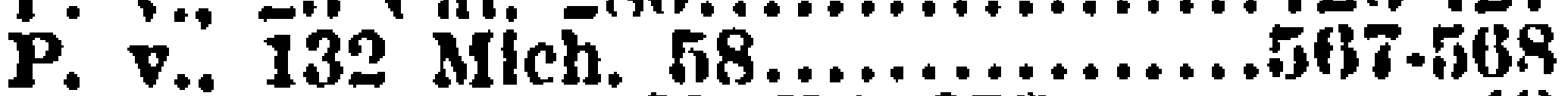
1. v., F Cowen (X. Y.) $258 \ldots \ldots \ldots$ ts

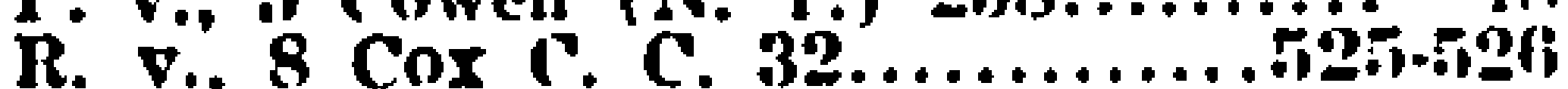
R. v.. 11 Cox C. C. $75 \ldots \ldots \ldots \ldots \ldots .27-28$ R. v.. Denrs. $494 . \ldots \ldots \ldots \ldots \ldots \ldots \ldots \ldots, 510$

IR V. 1 Stringe 704.............. 57. s. v., (3) Me. $25 . \ldots \ldots \ldots \ldots \ldots \ldots$. s. v.." strobl. (s. (j)............ st

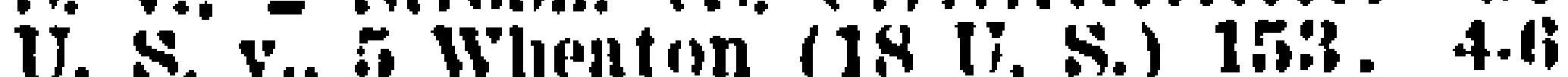
Snyder v. l.. 26 Mich. 106........390-393 Solomons, IR. v. 17 cox 9. C. 93..... 4316 Squire v. S., 46 Indl. $459 . \ldots \ldots \ldots \ldots . .130$ Spurzeon. ik. v.. 2 rox (. C. 102.... 47t

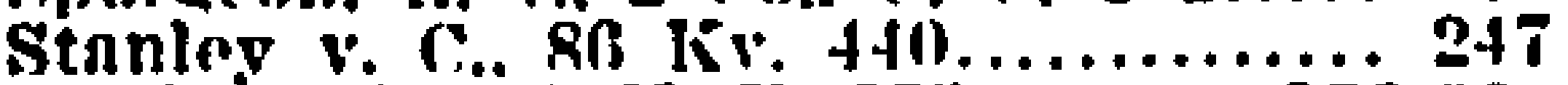
Starin v. P.. 45 N. Y. 3.33.........25n-200 Stsito r.. see nnme of party defendant. Stebhins. C. v.. 8 Fruy (Mnss.) 490

Stedmnn. R. v.. Foster C. T. 202.,352.3r:: Stegnil v. S.. 32 Tex. Cr. IR. 100..... 48.1 Strimilnz. $($ v.. 1.jo Pa. St. 40n

311, 458.459
Stephens, R. v., 1. R. 1 Q. R. 702

l'age. \#71.57:2

U. S. v., 8 Sawy. (U. S.) 116...207.208 Stephenson, C. จ., 8 Plek. (25 Maiss.)

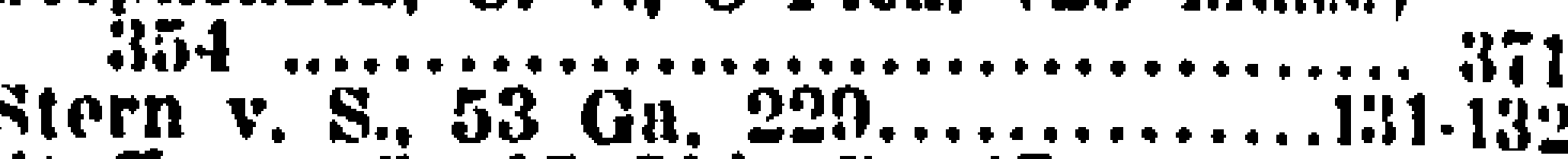

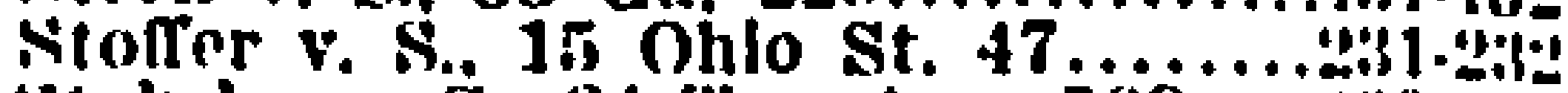
Stokeley v. S., 24 Tex. A pp. $500 . .$. is!n. f(iu Storey v. S., T1 Ala. 329............2(b. ous

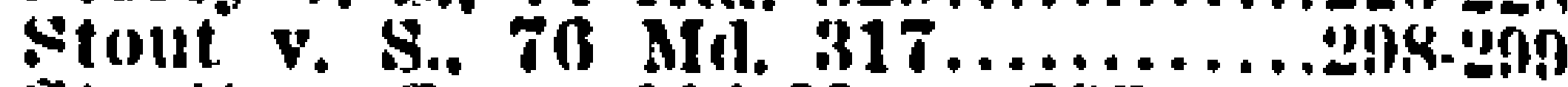
Strutton, C. v., 114 Mnss. 303........to.ti

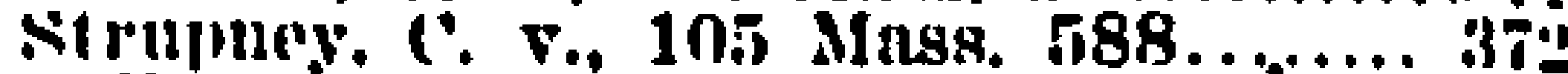
Sullens, iR. v., 1 Mondy 12n........... 4n Sutton, IR. v., Cos. t. Inrdw. 370....21.2.

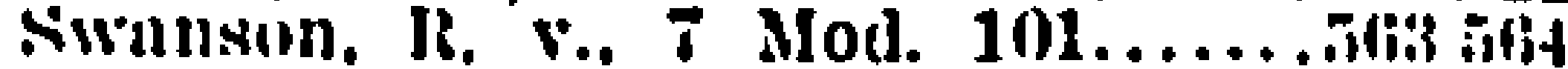
Fwinlall. IR. v.. a Car. ana K. 230.... fin

I'aylur v. Stale, 41 Tex. Cr. Amp.

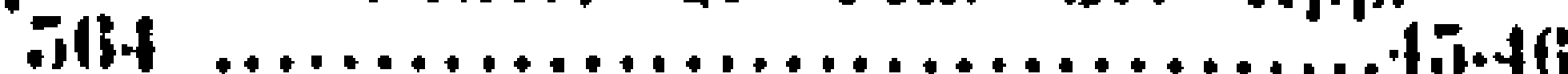

(‥

li. v. I I,ench C. I. No. 25.......... . 8.

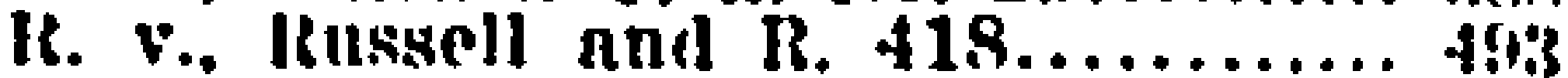

s. v.. is lutt(h. (N. J.) $117 \ldots \ldots$.

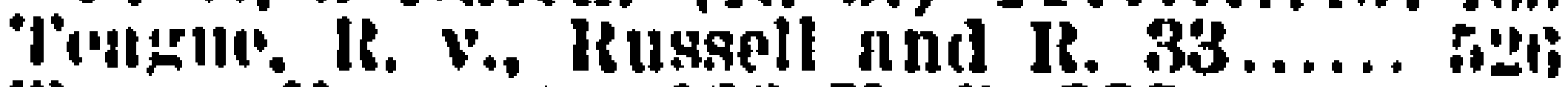

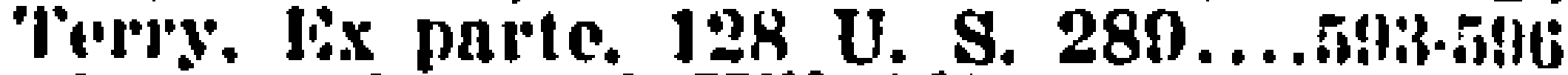

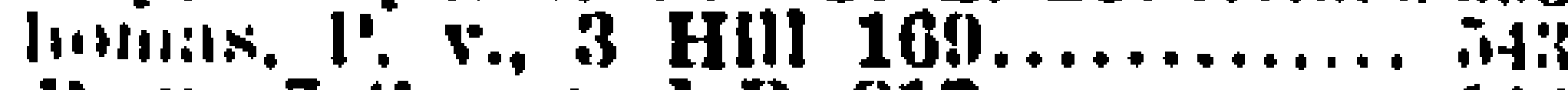

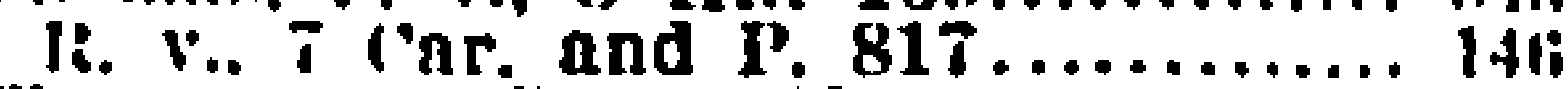
'Thompson v. S., (14 Aln. 535.......... 39!

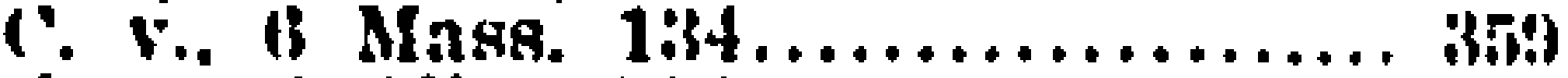

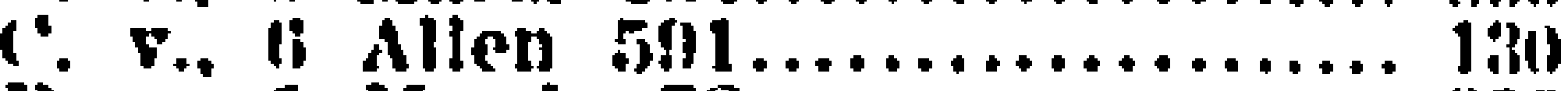

IR. v., 1 Moody 78.................. 396

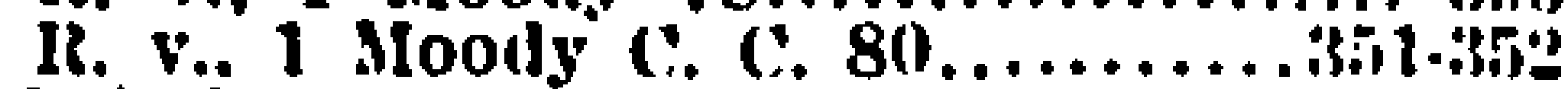

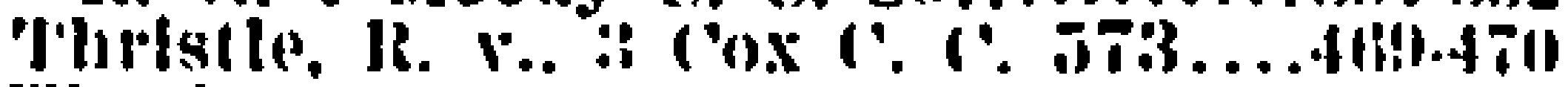
Thurborn. is. v. 1 nen. C. C. $387 . .421 .42 \pm$ Tice. S. v., gn Mo. 112.............. 140

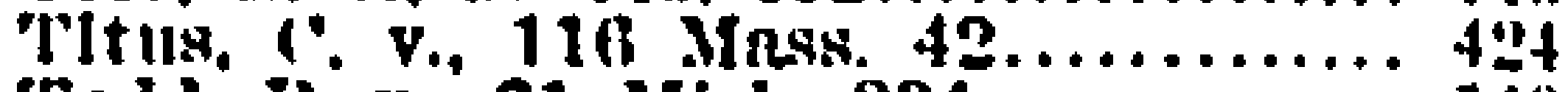

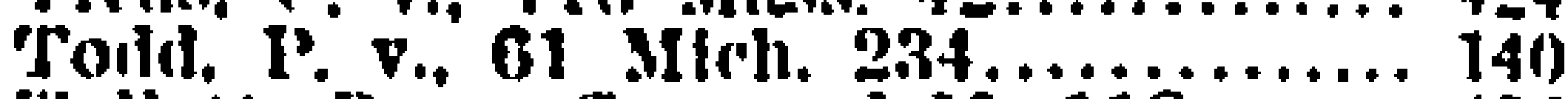

'ollett. Ir. v., Car. nud M. 112....... 438

Tolson. R. v.. Is. IR. 23 Q. IB. Niv. 168 .............................81.89

Tomson, R. v.. Kelvng $86 . \ldots \ldots \ldots . .342 .343$

Towers, R. v., 12 Cox C. C. 530...21k.21\% Townley, R. V., 12 Cox C. C. 59 ...45.5.45 Treblleock, R. v., 7 Cox C. C. 408..482.483 Trono v. it. S.. 20 s. .t. 121.......13.314

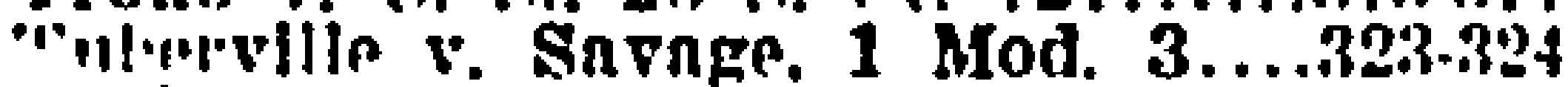
Tucker. C. จ.. J10 Minss. 403......... 388 Tuft, R. P., 1 I,pach C. C. (Fa. 3)

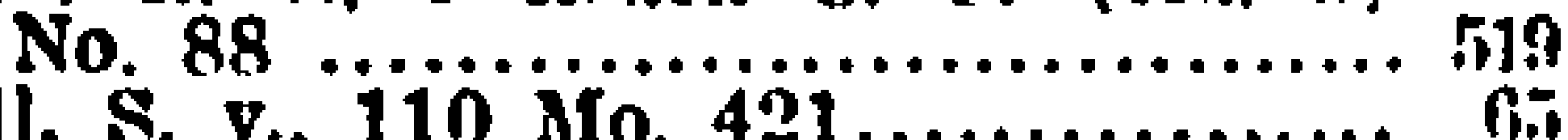
Tull. S. v.. 110 MIn. $421 \ldots \ldots \ldots \ldots \ldots$ n.

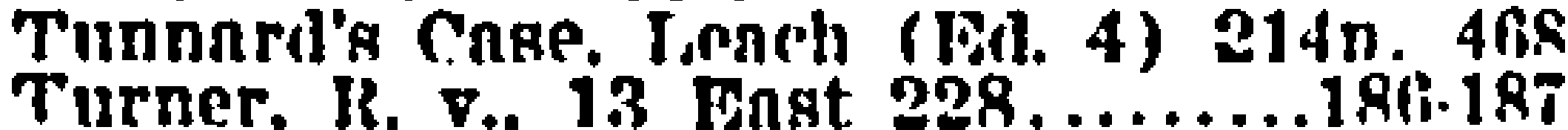

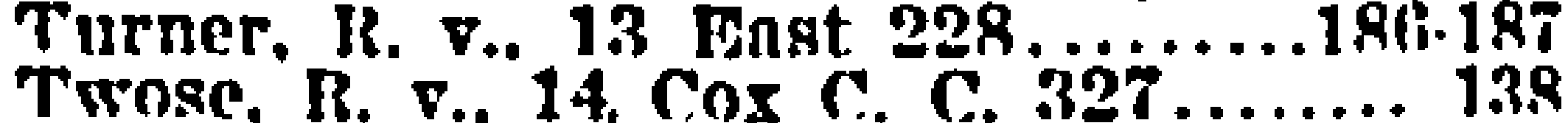
Trler v $p$ s Nich 320 . Tyler. $\dot{R}$.. \& Car. and P. Bif.....263. 344

II. S. Inited States.

Initeyl States $\nabla$. , see name or party dofendinnt.

Vandercomb's Case, 2 Lench $C$. $C$.

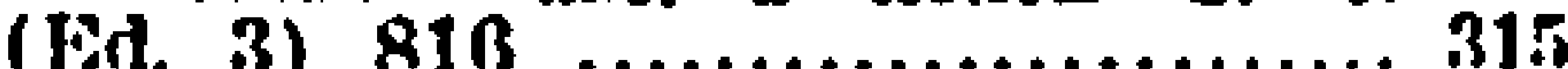

Vnn leit. S, v., 13\% N. Car Bis... gon.2nk viux's Cuse. 4 Coke 44 a..240-250. $307-308$

Winde. IR. จ. 1 ('ar. and K. T39..... הill Wngstaffe. R. v. 10 (ox C. C. 5.30..28.29 Wokeling, IR. จ., Ituse li and $R$. 504...549

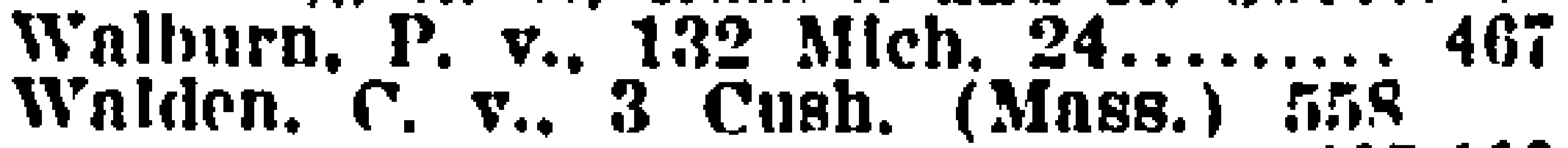

$105 \cdot 106$

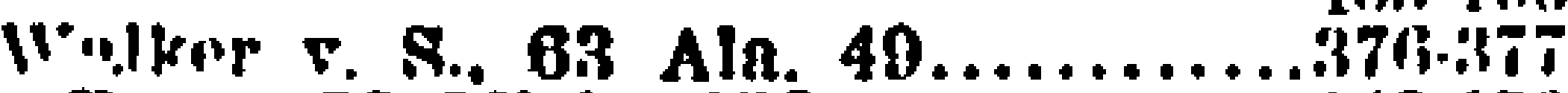
P. v.. 38 Mleh. $156 \ldots \ldots \ldots \ldots \ldots$ 149.150 i. v., 1 Mondy c. c. 155........... 48: S. v. Bis Kinn. 02..............407.408 Vnil's rake. 2 Fnat P. C. 953...... Walgh r. P. B5 I11, t8...........181.18 IR. V., 1 Moody C. C. $14 \ldots \ldots \ldots \ldots \ldots$ 44i 
rage.

Ward v. P.. 3 Illll (N. Y.) $305 \ldots . .448 \cdot 449$

v. P.. B IIIII (N. Y.) $144 \ldots \ldots \ldots \ldots . .264$

R. จ., 2 L. Raym. 1401............ 518

Warren, C. v., of Mass. $72 . . . \ldots . . . . . \ldots 7$ o

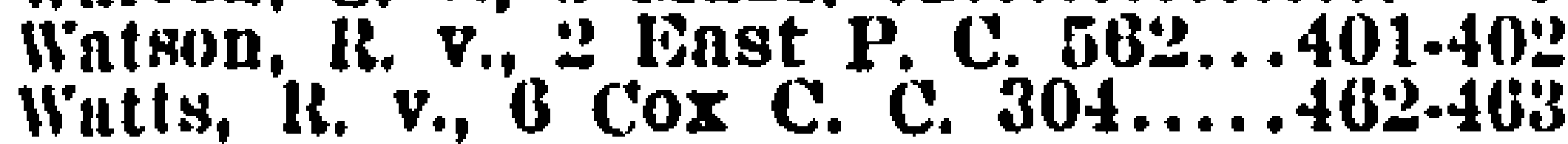

Witts, R. v., (3 cox C. C. 304.....462-463

Nelster, C. v., i Cush. (Mass.) 205

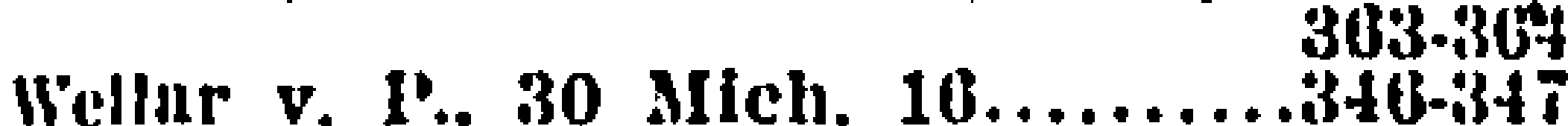

Netnyss v. IIopklus, L. R. 10 Q. 13 .

it 8 . ........................... 320

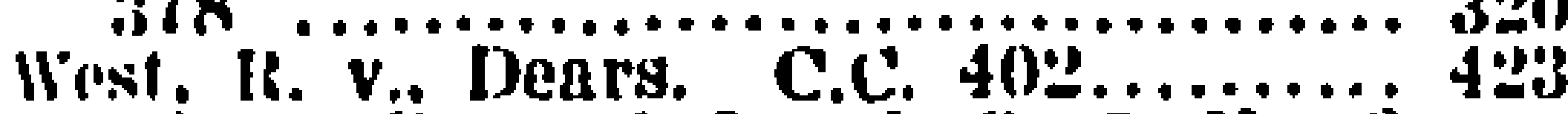

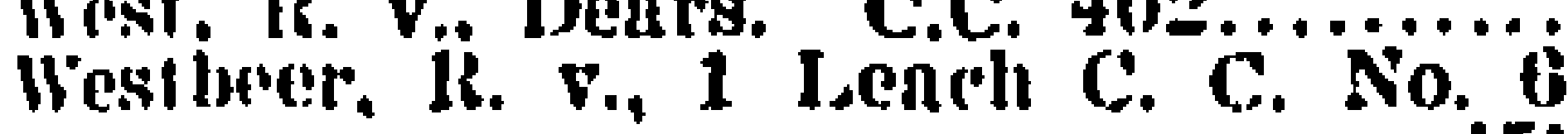

We 453-4:4

Whentley, R. v. .2 Isurr, 1125 .......490-50

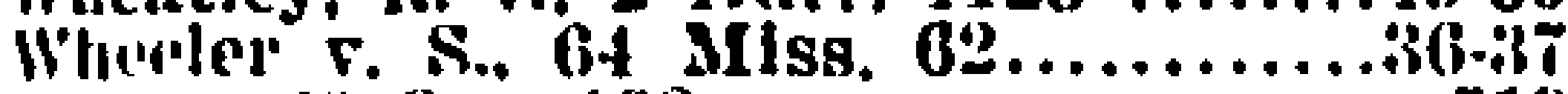

s. v. 20 Ore 192.................. 519

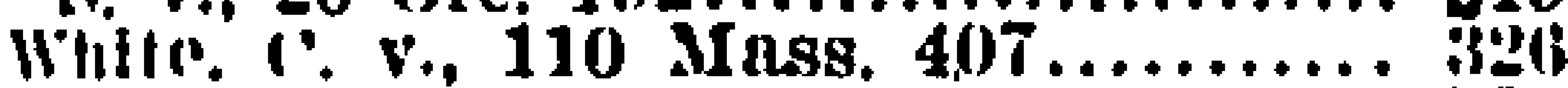

IR. v., $\operatorname{Cox} C$. C. $210 \ldots \ldots \ldots \ldots \ldots \ldots, 520$

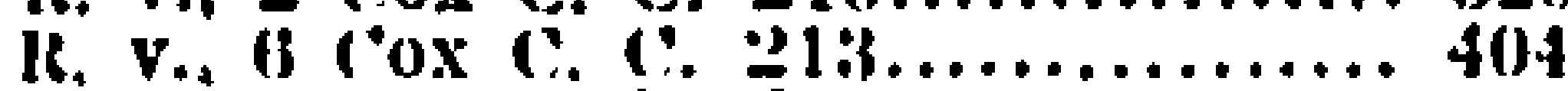

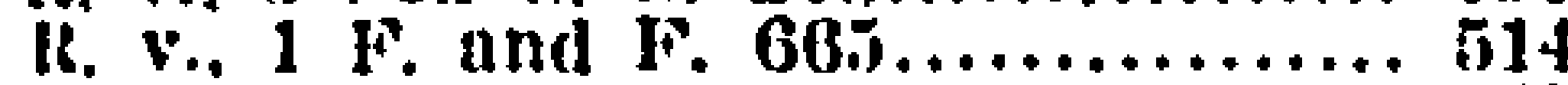

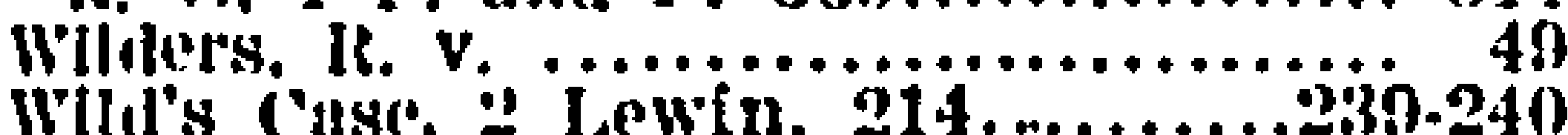

Whil's cusce : Tewin. $214 . \ldots \ldots . . . .2339 .240$

Whicy. Re v. 4 cox C. C. $412 \ldots . . .507 .509$

wilkersm. s. v.. 10:3 N. (ar. 337...539-j40

whkinson. is. v., Russell and R. 470

IVilkinson's case 1 IIte $P$ C 508 -

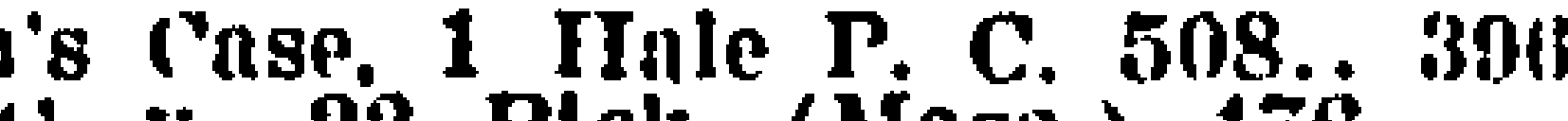
llilintr. ('. v., 22 Plek. (Miass.) 4 io

Williams $y$ Dickenson, 28 Fla 00 180-18

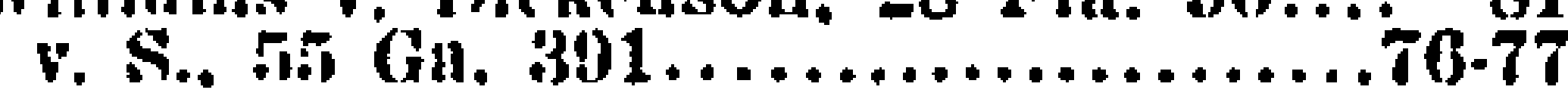

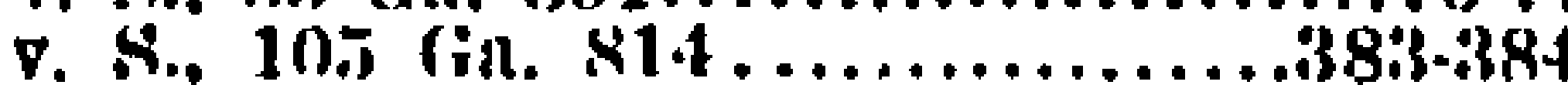

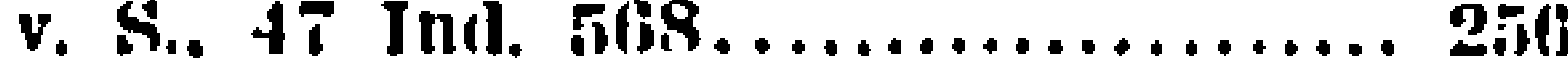

P. v., 3i Cai $671 \ldots \ldots \ldots \ldots \ldots \ldots \ldots \ldots$ 45.

s. v.. ot N. Car. $455 \ldots \ldots \ldots \ldots \ldots \ldots$...........

s. v.. :- Overton (¿ 'Teun.) 108..... 11
Williamson v. S., 30 Tex. Cr. R. 80

Page.

R. v., 3 Car. and P. $035 . . . \ldots \ldots . . .3839$

Willis, IR. v., i Moody C. C. $375 . . . . .448$

Wilson, s. v., 30 Conn. 500..2i3-24, 210-211

Whitberger, U. S. v., 5 Wheaton (U.

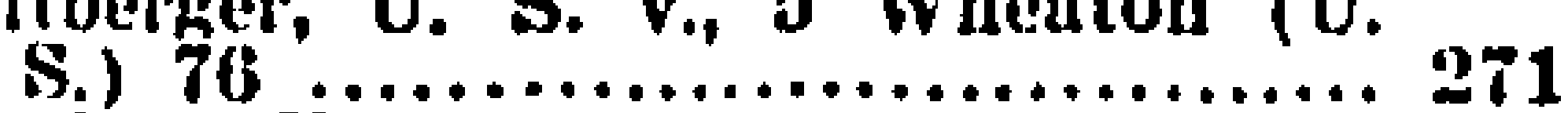

Winisor, bæ parte, 10 cox c....

Wing, (. .., 9 Plek. (Mnss.) 1.......

Wingo, s.

Winthrop, S. 8., 43 Iown $510 . \ldots \ldots . .360$

Woily, R. \$i, Y. B. 10 Fd. 4, $14 \mathrm{pl}$. (i) andi 1ii ......................... 453

Wonllhurst, 12. V., 12 Cox. Cr. Cuis.

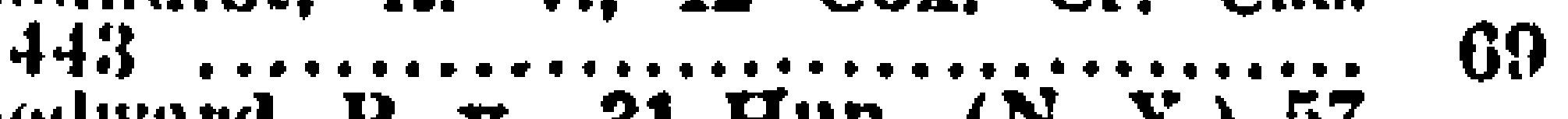

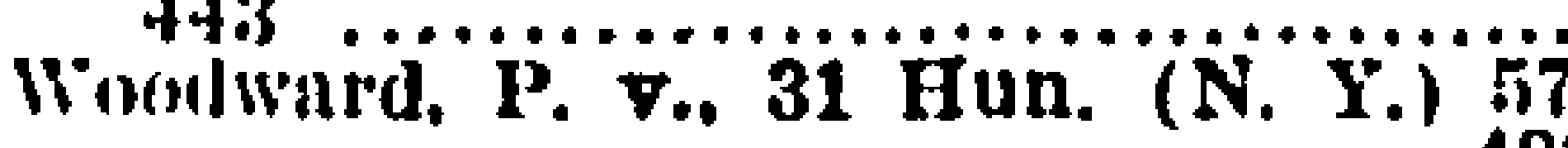

\$83.484

Woolsey v. S. 30 Trex. App. $346 . . . . .389$

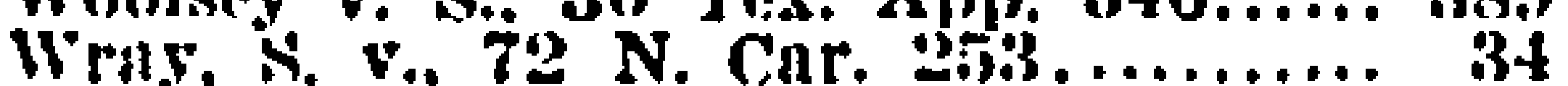

Wren v. C.. 20 Grntt. (Vn.) 9i)...256-258

Wright v. (.. 85 Ky. 123..............243

P. 38 Niteh $744 \ldots \ldots \ldots \ldots . . . . .112-113$

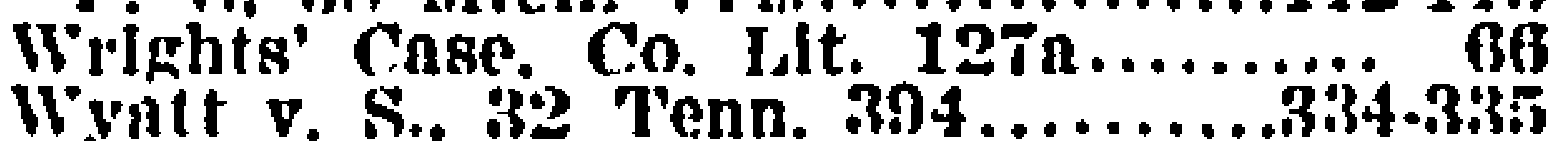

Wyckof. S. v.. 31 N. J. I...6......281-283

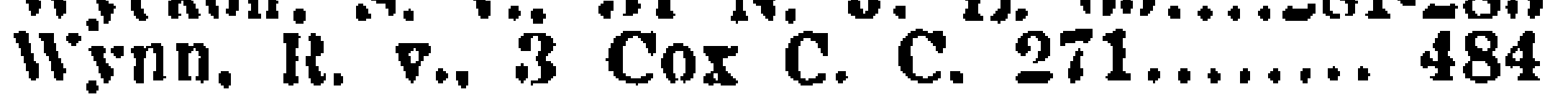

Yeargan. s. v. 117 N. Car, 706..... 141

Fops v. S.. 8 A re. 42.................

Yon's cuse, 4 Coke 40 a.................. 34.

Fork. (. v. o Metc. (Mass.) 03....344-345

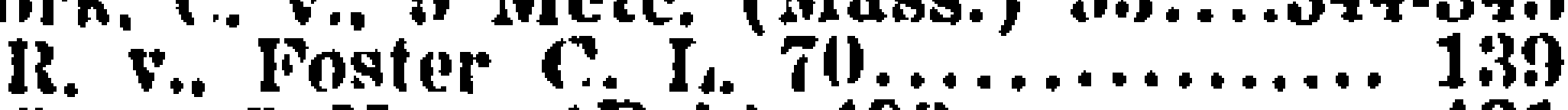

s. v. $\Rightarrow$ Har. (Del.) $493 \ldots \ldots \ldots \ldots . . .481$

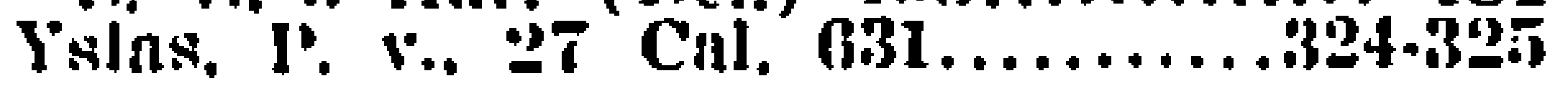

\%irlutild. \&. v. :23 Nev. 304...... 136-137 


\section{TOPICAL INDEX.}

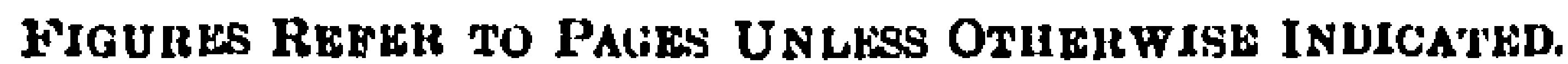

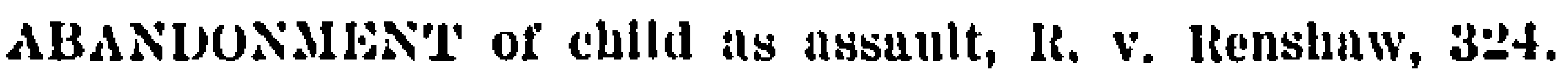

of designed crime, as defense to party, 206, \$8:3; Glover v. C., 208.

ABWLC'ILI, in general, 562-564, \$ 192.

ABOll'lUN, in general, 55), \$ 186.

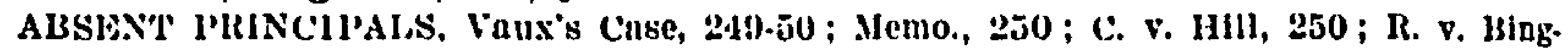
ley, :00-1; 11. v. Michinel, 251 .

ACCLSSORISS, after the lact, $205-209,877$.

before the fact, $256, \S 76$.

conviction before principal, c. v. l'blllips, 250; Starin v. 1'., 259.60.

subseguent acejultal of princlpal, Mccarty v. S., 260-1.

trinl as after acquittal, $2 . v$. Plant, 317.

liablity for atet done out of state, s. v. Wyckof, 281-3.

ACcissiolk, whether receiving stolen goods is, S. v. Ives, 515.6; Levl v. S., 516.17. ACCIIISN"I, dentl resulting from, IR. v. 131uce, 101 ; compare cases under \& 11.

AC', ciliMINAl, in general, ch. IV.

essentlal to crime, 33, $\$ 10$.

may lo exercise of woral force, $\$ 63$.

may be exerclse of Indirect force, $C$. v. Strniton, 70.1, \$ 63.

conspiracy is without further overt act, IR. v. Best, 186.

AC'I OF GOI). See GOb.

ADMIRAL'YY, jurisdiction for crimes within jurisiletion of, 269.272, 86.

ADULTElis, in generul, it(i). \& 188.

entry to commit, not felony, s. v. Cooper, 387.

lareeny by tukinr property by wife's cousent, R. v. 'lollett, 43s. But see $R$. v. lienny, 449.

by marriage after mleven years absence of hushand supposed dend, C. v. Masb, 120).30: C. v. 'T'hompson, 130.

by maried man and single woman, not crlminal, Anderson v. C., 14-16.

as provocation for manslaughter, Mannings Case, 352 : Fry v. S., 353.

right to kill to provent. Alberty v. li. S., 24in-6.

slngle man and murried womnn, not criminal, Resp. v. Roberts. 14.

solleitation to, whether criminal, s. v. Avery, 17!); s. v. Butler, 179-80.

whether conspilacy to commit crminal. s. v. Butler, 179-80.

ADViCE, rendering advisor criminally lable when absent, Vaux's Case, 249-50; Ward v. I'., 254 ; IBaker v. S., 254-5.

AFIDAVI'T, when making is perjury, s. v. Mace, 590.

AFFIRA, in general, 5i4, \$ 182.

AGliNe'. agent liable though lie thought principal bad anthority. s. v. Chastian, 105. asportation through, is larceny, C. v. Barry, 446-i.

defense of command by master, C. $\nabla$. Iladley, 114.

enbezilement by, 498-506, \& 152.

forgery in exceeding instructions, Gregory v. S., 252.

liability of hartender if employer had no license, C. V. Hadley, 114.

liabllity of principal for unauthorjzed act, S. v. Bacon, 26: I'. v. Parks, 262; 1. v. Almon, 262.

mall carrier not agent of nddressee, Brewer v. S.. 503-4.

slenature on assumed, not forgery. K. v. White, $520:$ ( v. Baldwin, 520. when principal liable for crime of agent. Morse v. S.. 89.

AGLN', crime committed through Innocent, Vaux's Case, 249-50: Memo., 250; C. $\mathrm{r}$ IIII, 250; R. v. Michnel. 251 : IR. v. Bnnnen, 251-2: Gregory v. S., 252.

AI.ISN, linbility for crimis out of jurisdletion. R. v. Depardo, 260-70: C. v. Macloon, :96-8. 


\section{Figures Refer to Pages Untess Otheirwise Indicated.}

ALLEY, obstruction to, is private nuisance only, Bagley v. 1', 572.3.

Alilila'iloN, when forgery, $523, \$ 162$.

AlPbilla NCLS, self defense in relinnce upon justliable. Showter v. L'., 228.9; Campbell v. 1'., 2:29-30; Creek v. S., 232-3.

APPRENTICE, admission by, not suficient consent in burglaly, s. v. lRowe, 373.

linbility for neglect to support, $\$ 11$.

ARREST, illegal, as provocation to munslaughter, linggett's ('asce, 351 ; I. v. Thompson, 351.2.

killing one attempting to take felon is murder, R. v. Jackson, 334.

kllling to prevent illegal, Creighton v. C., 235; R. v. 'l'hompson, 351-2; Cuok's Case, 238.9.

menucing, kiuing to prevent, Jones v. S., $235 \cdot 6$.

shooting to accomplish, R. v. Iadson, 22u; Reno v. S.. 22u3 : IIend v. Martin, 223-4; 11. v. Compton, 2:24:5.

ARSON, in generml, 387-393, \$\$116.1:0.

attempt proved by offer of matches and money for burning, $s$. v. Bowers, 183-4.

burning ship in attempt to steal a drink, 1R. v. Faulkner, 99-100.

by servant at command of owner, s. v. Haynes, 11:.

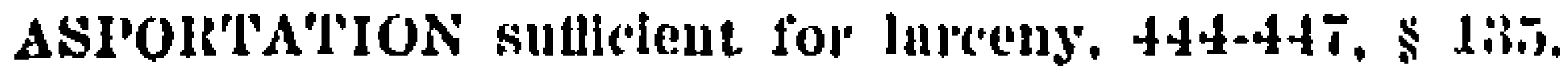

ASSAULA, simple, detined, etc., 323-328, § 96.

by marted woman, C. v. Neal, 11:.

consent as defunse to assault and battery, S. v. Beck, 66.

C. v. Collberg, 67-8; s. v. Burnham, 68.

incomplete, loes v. S., 23.

intercourse by busband having concealed disense is nssault. R. v. Clarence, 71-4. love nowders on figs, C. v. Stratton, 70.1 .

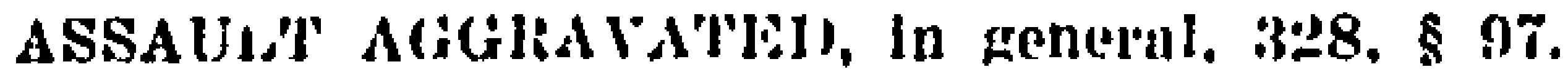

consent as defense to, assanlt with intent, ete.. Smiin v. S., 33-4; R. v. Martin, 68-9): R. v. Woodhurst, (A) : R. v. Case, 60-7(1).

with intent, specific intent must be shown, R. v. Boyce, 105; R. v. Kelly, 105;

C. v. Waldron. 106 ; carter v. S., 106.

with intent to murder if burglar merely sought to disnble, $n$. v. Boyce, $10 \pi$.

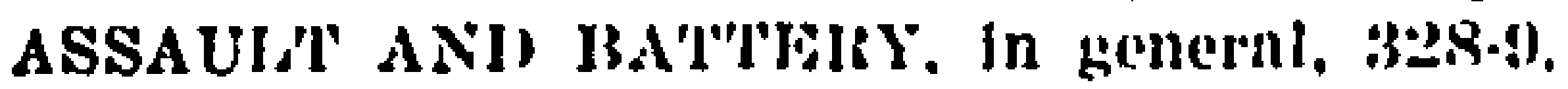

as provocation for manshuphter. R. v. Stedman, 352-3.

by police and jaller, when justifable, $\mathrm{S}$. v. Pugh, 221-2: Imurns v. S., 222 ; S. v. lRoseman, 2:22.

by school tencher as punishment. Ifutton v. S., 220: IIeritage v. Nonge, 220; Royd v. S., 221.

by station ugent In expelling passenger, I'. v. MeKay, 221.

double Ilability for two injurles from one stroke, s. v. Tramon. 316.

homicile to prevent not justifinble. Ir. r. IIewlett, 230.1.

parental authority as defense, Irinkle v. S.. 219.

recaption of property as defense to, r. r. Ionnhuc. 244.

wife benting, $210-220$.

ASSEMIBI,Y, unlawful, 5ist. \$ 183.

AT'TEiII'l'. nlanilonment after overt net. Glover v. ('. 208.

impossibllity because agent will not act, $S$, v. Bowers, 183-4.

impossibillty from mistake of fact as defense. C. v. MeDonald, $210 ; \mathrm{s}$. v. Wilson, 210-1; I. v. c ollins. 211-2; r. v. Jones, 212; I. v. Moran, 212-3; P. v. I,ee Kont, 213-4.

Indictment for attempt to commit attempt is bad. S. v. Sales, 687 .

furisdletion if shot fired from one state into nnother. Simpson v. S., 284.

preparntion distingulshed from, P. v. Murray, 206-7: IT. S. v. Stephens, 207-8;

Glover v. C., 208.

to assault, effect of consent, R. v. Martin, 69; R. v. Woodhurst, 69: Smith v. S., 33-4.

to chent by forgery criminal. 518, $\$ 160 ;$ P. v. Caton, 528. 


\section{Figures Refer to Pages Unless Othkrwise Indicated.}

\section{ATTEMP'T-Contiuued.}

to commit arson hy offer of reward not accepted, s. v. Bowers; 183.4 .

to commit statutoly ofrense is common law offense, S. v. Butler, 179.80; R. v.

Roderlck. 206 .

to extort, criminal though recoyed into, 1. v. Gardner, Gis.6.

to pick empty pocket, C. v. McDonald, 210 ; (. v. Wilson, 210-11; R. v. Collins,

211-12: I'. v. Jones, 212: 1'. v. Jloran, 212-213.

A'TTORNEYS, disharment of, ex parte Robinson, 596-7.

dU'lioni'l'y. from superior officibl, as defense, $\$$ to.

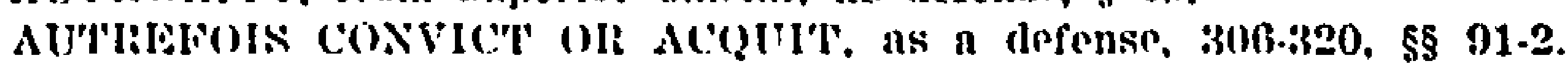

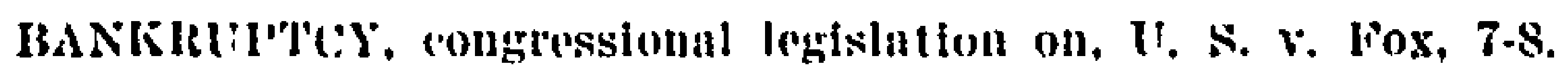

BARBAROUs punishments, James v. C., 11-12.

BARRATliY. common, delinet. Bist.

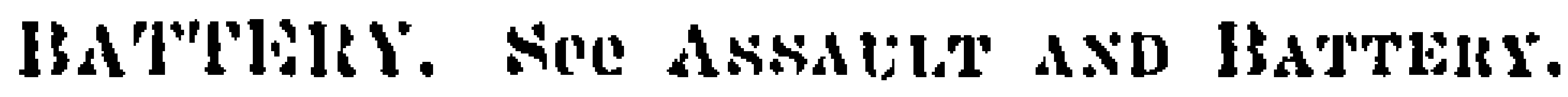

BAWLY HOLNES, 57!-\$1, \$ 20.

BIBLIOGRAIIY, 1.

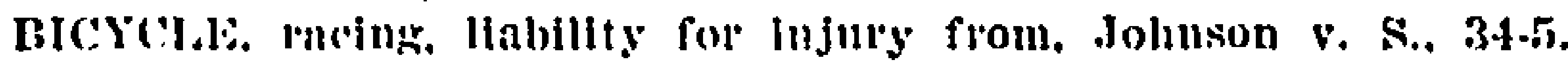

BIGAMT, in general, 559), \$18T.

as religions duty, Reynolds v, c. S., 91-3.

husband supposed dend from long absence, c. v. Mash, 129.30; R. v. Tolson, 85.9. marriatre supposid vold, as defense, s. v. Goodnow, 136; s. v. Zitchfeld, 136-7.

supposed that wife had divorce. squire $v$. s.. 130.

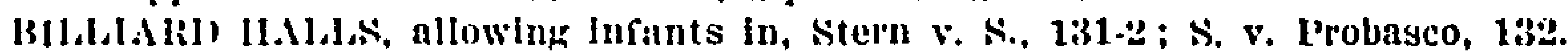

BJRLs, whether subject of larceny, Anon., 459); C. v. Chace, 459; R. v. Cheafor, 45i)-460: Haywood v. S., $480-1$.

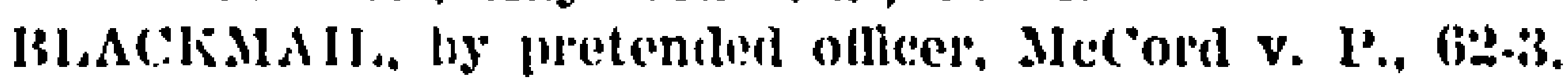

BOOKkERIINi, false ontry not forgery, ex parte windsor, 521-2,

BoXIN(x, if meich of peace, is criminal, $($. v. Collherg, 68 ; s. v. Burnham, 68.

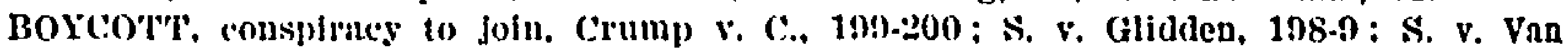
1'olt, :-200-206.

BRDACH of plidck, in hoxiug mateh, consent no defense, c. v. Collberg, 67-s; s. v. Burnham, 68. See also. P'Eace.

IBRF.ACII OF IPISON, in general, 585-6. \$ 210.

BRPAKIN(i, to constitute burglary, 369.374, $\$ 110$. bulk by ballee as larceny. $472-476, \$ 142$.

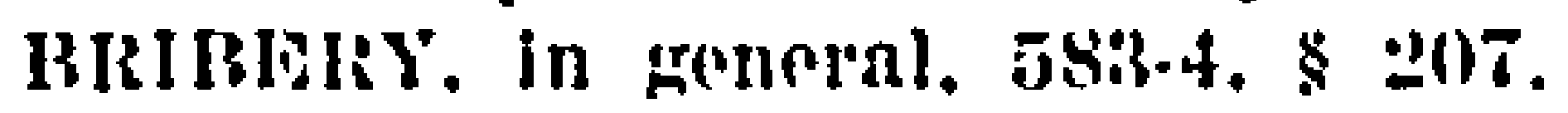

offer by furor, to obtain verdict for pay, s. v. Sales, 587.

what is at common law. Walsi v. P., 181-3.

BugGishy, Bo:2.

BIILTING, larceny from, 402-8. 5151.

BULK. breaking by hallee. when larceny. 470-6, \$ 142.

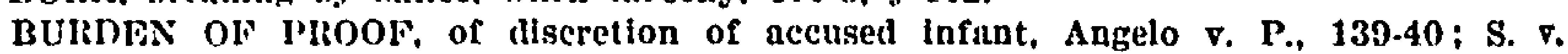
'Tice, 140.

of insanity, s. v. Lanvence. 173-4: P. v. Garbutt, $74:$ Uavis v. U. S., 176: Itora. ish v. I'., 170-i.

of provocation. C. v. York. 344-5.

where an act in itself indifferent becomes criminal with intent, s. v. Coodenow, $135 \cdot 6$.

BURtilatir, in general, 36!)-376, ş 10!-115.

consent as defense, Eygington's Case, $75-6$ : S. v. Abley, $78-9 ;$ P. v. Love, 78.

entry by servant to remove money already embezzled. Is not, $R$. v. Dingley, 410 .

from barroom, by ghest at hotel, S. v. Moore, 80.90.

intent to eut off ear, whether felony, C. v. Newell, 331.2.

intent to take goods if none were there, Harvick v. S., 102-3.

liabllity of party for unexpected murder in, Lamb จ. P., 264-6 ; Ruloff จ. P., 263-4.

right to kill to prevent, Cooper's Case, 246-T. 
Figdrfs Rheir to Pages UNiess Otherwise Indicated.

BURNING, sufficlent to constitute arson, 388-9, $\$ 118$.

CASTLE, defense of justifiable, 238-243, \&70.

CAUSE, remote consequence of false pretense, liablity, R. v. Gardner, 533.

to be criminal act of accused must be, $\$ 14$.

liabillty for unexpected result, $\$ \$ 38.40 ; 81 ; 82$; s. v. O'Brlen, 41-2; C. v. Stratton, 70-1.

severul causes contributing, liablity, \& 14.

CHAMPERTY, defined, 552.

CIIANGE, liability for larceny in making, Hlldebrand v. P., 405.6; R. v. BIrd, 306:

C. v. Barry, 306-7 ; S. จ. Anderson, 407; S. v. Walker, 407-8.

CHARITY, obtained by false pretenses, 1'. v. Clough, J45; Barker v. S., 545.6.

CHEATING, at common law, in general, 517, \& 158.

getting credlt by lies not, $C$. v. Warren, 0.

by false pretenses, 531-550, \$§ 168-175.

by false tokens, 520-531, 8167 .

by forgery, 518-528, \& 150-165.

by prosecutor as defense, C. v. Morrill, 61.2; R. v. Hudson, 62; In re Cummlns, 64.

conspiracy to cheat is common law offense, S. v. Buchanan, 184-6; R. v. Pywell, 187.

jurisdiction to punish act done beyond borders, R. v. Brlsac, 279.80; P. จ. Adams, 280.1 ; S. จ. Wyckof, 281-3; Iindsley v. S., 283.

CHECK, of buyer, not a false token, R. v. Lara, 530.

CHINESE, exclusion statutes, not criminal, U. S. v. Hing Quang Chow, 58-8.

CIRCUMSTANTIAl, EVIDIENCE, to prove corpus delictl, 362-8, \&108.

COERCION, as defense, 117-125, \& 50-1.

COLLISION, at sea, jurlsdiction to punish for, $R$. v. Keyn, 272.

COMFOIT, disturbing public is nutsance, 574-9, $\$ 201$.

COhiMANL, by superior oflicer as defense, $\$ 40$.

COMMON IsAW, growth of. In this country, Resp. v. Roberts, 14: Anderson v. C., 16 ; sell v. S., 16 ; C. v. Rimdolph, 16.

implied abrogration by code, $\$ 11$; Smith v. P., 17.

of crimes includes statutes before settlement, c. v. Warren, 0.

of England how far adopted in this country, S. v. Whilinms, 11 ; James v. C., 11-12;

C. $\mathbf{7}$. Chapman, $12-14$.

COMMON SCOLD, James v. C., 11-12.

COMPOUNDING CHIME. 584.5. \$ 20 (I.

by reward for not prosecuting, Wren $\nabla$. C., 250.8.

COMPULSION, as defense, 117-125, § 50.1 .

CONDONATION, no defense to rape or folgery, C. v. Slattery, 65; S. v. Tull, 65.

CONGress, contempt, by members of, Murray's Case, 591.

power of, on crimes in general, U. S. v. Fox, 6.8.

power of, to regulate commerce in state, U. S. v. De Witt, 6.

CONSENT, obtained by fraud, (pretended treatment by physicina) as defense to assault, R. v. Case, 69-70.

obtained by fiaudulent concealment by husband of disease, R. v. Clarence, 71-4. obtained by impersountion in rape, $\mathrm{R}$. v. Jackson, :344; $\mathrm{S}$. v. Shepard, 334 ; Wgatt

v. S., 334-5; R. v. Barrow, 335 ; R. v. Dee, 335-8.

of chlld as defense to assault with intent to rape, C. v. Roosnell, 338-9.

to admission of burglar obtained by fraud, Johnson's Case, 370; LaMfott's Case, 370; Ducher v. S., 370-1.

to assault and battery as defense, S. F. Beck, 67 ; Champer v. S., 67 ; C. v. Collberg, 67-8; S. v. Bunham. 68: R. v. Case, 60-70; C. v. Stratton, 70-1: R. จ. Clarence, $71-4$.

to burglary as defense, Eggington's Case, 75-6; Love จ. P., 78; S. v. Abley, 78-9. defense, to charge assanlt with intent. Smith v. S., 33.4: R. จ. Martln, 68-9; R. v. Woodhurst, 69. 
Figures Rereh to pages Unlegs Otraikwise INdicated.

CONSENT-Contlnued.

defense, to charge of recelving stolen goods, U. S. v. DeBarc, 512; R. v. Lolan, 511.2; 12. v. Schmidt, 512.3.

to escape of prisoner of war, R. v. Martin, 76.

as defense to larceny, 390.444 , $\$ 8122-134$.

to robberg to get reward offered for conviction of robber, McDanlel's Cuse, 74.75.

to taking, as defense to larceny, S. v. Wllliams, 76.7; S. จ. Hull, 78.

CONSHIRACY, in general, 184-206, \& 01.

unlon of two or more essential to, S. v. Setter, 82 .

not merged in completed larceny, S. $\nabla$. Setter, 82 .

of employees to strike, C. v. Hunt, 100.4; S. v. Donaldson, 194.8.

to assault, S. v. Pulle, 17-18.

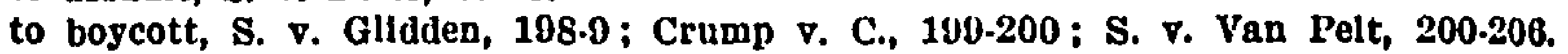

to commlt adultery, whether criminal, S. v. Butler, 170-80.

to convlct of robbery, R. จ. McDantel, 215.6.

to procure crime for reward of conviction, MrcDanlel's Case, 74-5.

to seduce, criminal at common law, R. จ. Delaval, 55.6 ; Smith v. P., 189-190.

CONBTITUTIONAL LAW, act not an offense at time committed, U. S. v. For, 6-8.

blgamy statutes restralning religlous freedon, Reynolds v. U. S., 91-3.

constitution paramount, 1.

crime without intent may be by statute, C. v. Waite, 19.

denging women right to vote not violation of 14th amendment, U. S. $\nabla$. Anthouy, 135.

federal jurisdiction of local matters, U. S. v. Dewitt, p. 6.

former jeopardy, 306-320, \& 01-2.

oleomargarine law valid, lowell v. Pennsglvania, 20.

law requiring license of physician valld, P. จ. Phippin, 20 .

valldity of state statutes as to shore fisherles, C. v. Manchester, 275-7; Manchester

v. Srassachusetts, 277-9.

validity of statute punlshing death from injury elsewhere, Tyler v. P., 295.6.

constructions. See Statutony Constrdotion.

CONSTIRUC'IVE IN'TEN'T. See INTENT.

CONSTRLC'IVE PRESENCL, by principal, Ibreese v. S., 253-4.

CONTHAI'T, in general, 591-37, $\$ 213$.

CONTRIBUTORY NGGLIGLSCE, no defense to crime, 59.61, § 23.

Cokpordtions, conspiracy to control offces of, by firadulent means, S. v. Burnham, $187-9$.

criminal liability of, c. v. l'roprletors, ctc.. 110; C. จ. Pulaski, etc., 110-11; S. v.

Passale $\Lambda \mathrm{gr}$. Soc., 111.

liability of stockholdars and officer's for embezzlement. S. v. Kusnlck, 504-6.

CORPSF. STe Dridv BODIES.

CORPUS DELIC'I, proof of. 362-36S, \& 108.

CoUn'wirel'l, colns, mere intent to pass, R. v. Sutton, 21.2 ; R. v. Heath, 23. obtaining dies through innocent ngent, $R$. v. Brnnen, 251.2. passing through innocent agent, C. v. UIll, $2 \pi 0$.

COURTS, clvil and martlal, Jurlediction of, U. s. v. Clark, 8.

state and federal, comparative jurlsdiction, 3.20.

contempt of, in general, 501.07, \& 213.

statutory crimes, Jurisdlction of, C. v. I.each, 9-10 ; C. v. Knowlton, 10-11.

CRIME, definition of, 21, 21-83.

CRIMINAI, ACT, must be criminal at the time and untll punlshment, s 13. no crime without, $\$ 10$.

In genernl, Chap. IV.

CRIMinat, CONVERSATION with marled woman, Regp. v. Roberts, 14. See also, ADULTERY.

Criminat, intint, 85-17t. Chap, IIt. See also, Intent.

CRIMINalitTY, test of, C. F. Randolph, 16. 
Floures Repera to Pages Unlergs Otherwise Indicated.

ChOPS, whlle growing, not subject of larceny, Holly v. S., 450-7; R. v. Foles, 457. COHSING, in general, 568-70, \& 195 .

CUSTODY dlstingulshed from possession for purpose of larceny, 400.403, 110-416, $\$ 8127,130$.

DEAD BOVIES, exposing without burial, Kanavan's Case, 54. stealing shroud from after burlal, 466 .

unlawful disinterment of, C. v. Marshall, 35.6.

or motive, as defense, $h_{\text {. }} \mathrm{v}$. Sharpe, 00-1.

DEADLY WEAPON, accident from negligent use of, as manslaughter, R. v. Rampton, 357 ; Anon., 357-8; S. จ. Hardle, 358-9.

death from punishment with, is murder, Grey's Case, 342.

kllling with, Is murder, C. v. Rogers, 346.

DEATH, direct proof of, required in murder, 362.8, \& 108.

DEBTS, llability for embezzlement, falling to pay, $\mathcal{1}$. จ. Hurst, 502.

DECOY, Induclng crime, as defense, $\$ 27$; Egglngton's Case, 75.6; R. v. Martin, 76;

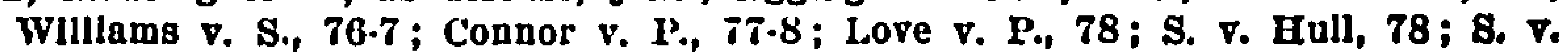
Abley, 78-9.

DEEDS, whether subject of larceny, K. v. Wody, 453 ; R. v. West, 453 ; R. จ. Walker, 462.

DEFENSE, of castle, as justlfinble, 238-243, $\$ 70$.

of others as justifiable, 246.248, 82 .

of property as justiflable, 243.246, \& 71 .

of self as justlacation, 228-238, \&69.

DELIBERATION by murderer while Intoxicated, R. v. Thomas, 146 ; S. v. MrCants, 147 ; Hopt v. P., 148-8.

DELIRIUM TIREMENS, as defense to crime, U. S. v. Drew, 143-4.

DEMENTED PDRSONS, llabillty for crlme, S. v. Richards, 141-2.

DeTainer. See Forcible Detainer.

DISBALMIEN'T, of attorney for mlsconduct, ex parte Robinson, 596-7.

DISEASE, contributing to death, S. v. O'Brien, 41-2; R. จ. Rew, 59.60.

Infecting with as assault, R. $\nabla$. Clarence, 71-4.

DISORDFRLY HOUSE, in general, 570.81, \& 202.

llabllity of corporation for keeping, C. v. Pulaskl, etc., 110-111 ; S. v. Pagsalc Agr.

- Soc., 111.

marrled woman, liability for keeplng, 112.

disturbance. See Peace.

DOGS, obtalning by false pretense, whether crimlnal, R. v. Roblnson, 547.

whether subject of larceny, Mullaly v. P., 461.2.

DRUGS used to overcome will in rape, R. v. Camplin, 333; C. v. Burke, 333-4; Don Moran จ. P., 337.8.

DRUNKEN INSANITY, U. S. v. Drew, 143.4.

DRUNKFNNESS, as defense to crime, 143.150, $\$ 57$.

deceased, debllitated by, as defense, R. v. Johnson, 37.

dipsomanla, as defense to crime when drunk, Choice v. S., 144.

intercourse whlle woman Insenslble from, is rape, R. v. Camplln, 332-3; C. r. Burke, 333-4.

punished in splritual courts, R. v. Curl, 54-5.

preventing deliberation, in murder, S. จ. Johnson, 344-5.

DUCKING.STOOL, James v. C., 11-12.

DURESS, as defense to crlme, 117-125, \$\$ 50-1.

DUTY, done as defendant saw It, sufficlent, $R$. v. Wagstaffe, 28-9.

fallure to volunteer beyond line of, Anderson v. S., 32.3.

non-performance when criminal, R. v. Conde, 214-5, 11.

positively Imposed by statute, R. v. Downes, 29.30.

DWhLLING HOUSE, defined for burglary, Pitcher v. P., 18.19, 112. 


\section{Figdres ReEzR to Pages Unless Othebwise Indicathd.}

EAVESDIROPPING, S. v. WHllams, 11.

ECCLESIAS'IICAI COUIR'S, jurisdiction of In England, Res. v. Roberts, 14 ; Anderson จ. C, 14-16; Bell จ. S., 16 .

ELECTION, conspiracy to defraud in, S. v. Burnham, 187.0. voting twice whlle drunk, McCook v. S., $14 \overline{\mathbf{v}} \mathbf{6}$.

woman voting in violation of law, U. S. v. Anthony, 135.

corrupt voting at, criminal at common law, C. v. Silsbee, 57 ; C. v, Callaghan, 57-8.

EMBEZZLEMENT, in general, 498-500, \&152.

conspiracy to embezzle is a common law offense, S. $\nabla$. Buchanan, 184-6.

distingushed from larceny, 410-15, 830.

Indictment for recelving stolen goods, whether supported by, C. v. Leonard, 514. EMBRACERY, in general, 586-7, \& 211.

ENGINE, on hlghway, nulsance, C. v. Allen, 573.4.

ENGLISH STA'IU'ILS, cnacted before settlement are common law here, C. v. Warren,

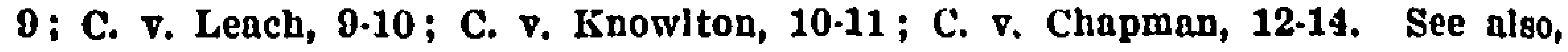
Staturag.

ENTERING, in burglary, 374.378.

ENTRY. See Foncible ENTRY.

ESCAPE, in general, 585.6, \& 210.

burning jall, to effect is arson, Luke $v$. S., 388.

consent of officers to detect person alding him, R. v. Martin, 76.

shooting to prevent, when Justifiable, R. v. Dadson, 222 ; Reneau v. S., 223 ; Head

จ. Martin, 223-4.

EVIDENCL, sufficient to prove death in murder trials, 362.8.

sufficlent to prove knowledge that goods were stolen, 514-15, \$ 156.

when sufficlent to prove intent in burglary, Niester v. R., 387 .

EXCUSABIL AC'TS, 218-248, $\$$ 64-72.

EXPLOSIVES, when keeping of nulsance, Anon., 572.

EXPosure, Indecent, IR. v. Curl, 54; C. v. Sharples, 56.7 ; Anderson v. C., $14-5$.

to Injury, llability for, 214-8; R. จ. Burnett, 52, 803.

EXTORTION, attempt, though no fear, $P$. V. Gardner, 65.6.

EXTHADITION, in general, 209-306, \& 00 .

"forgery" under treaty with Fngland menns common Inw, ex parte WIndsor, 521-2. $i !$

FALSE IMPIRISONMEN'1, in general, 330, \$ 09.

liability of offcer transporting criminnl, IR. v. I.eslej, 218-0.

FALSE PRETENSES, cheating by, in general, 531-550, \$\$ j'68.175. getting property by, not a common law offense, C. v. Warren, 0 . true but helleved to be false, S. v. Asher, 24-5.

FALSE TOKENS, defendant's note not, C. $\nabla$. Warren, 0.

obtaining property by, when criminal in general, 520.531, \& 167.

what Is, R. v. Jones, 529; Kesp. v. Powell, 530 ; R. v. Lara, 530 ; P. v. Babcock, 530 ; Middleton v. S., 531 .

FEAR, as an element of robbery, 488-490, \& 149.

supplying the place of force is rape, Don Mornn v. P., 337.8. avolding consent in assault with intent, $R$. v. Woodhearst, 69.

EELONY, what 1s, S. v. Setter, 82.

FICTICTIOUS NAML, forgery of, criminal, 518-510, 8161.

FINDFR, larceny from, Quinn v. P., 450-1.

finding and converting lost property, whether larceny, 418-424, \$ 132.

FISH, whether subject of Inrceny, S. v. Taylor, 464.5; S. V. Shaw, 461.

FISHERIES, at sea liability for violnting statutes on, C. v. Manchester, 275-7; Man. chester $\nabla$. Massachusetts, 277-0.

FIXTUKES, not subject of larceny, Langston v. S., 458.

BORCIBLE DFTAINER, in general, $553,8181$. 


\section{fiaures Rheil to Pages Unless Otherw lse Indicated.}

FORCIBLE ENIRK, In general, 55:, \$180.

breach of peace essential to, R. v. Bake, j1.2.

not implled by "force and arms," R. v. Bake, 51-2.

Forkin'luke of property ior felony was common law rule, but not so here, Boston \& W. Lty. Co. v. Dana, 70-81 ; s. v. Setter, $8:$.

FORGEIRY, in general, 518-527, \$\$ $159 \cdot 16 \overline{\text {. }}$

by several separately, 1R. v. Bingley, 250.1.

defrauding one intending to defraud another, R. v. Sheppard, 107.

liabllity for larceny fol money obtalned by, $k$. v. Prlnce, 420-30.

made in one state and uttered in another, jurisdiction, Lindsey v. State, 283.

through innocent agent, Gregory v. S., $2 \overline{5} \%$.

uttering forgery, 5:7-j:28, \$ 166 .

FORGIVING, forgery, s. v. 'lull, Gj.

rape, C. $\nabla$. Slattery, $6 \mathbf{5}$.

FORHER JEOP'ARUY, in general, 306.320, §§ 91-2.

conviction in another state, C. v. Holder, at 201.

conviction or acquittal in unother county, Anon., 286.

court martlal is not, U. S. v. Clark, 116-7.

when charge or offenses are different, 315-32, \& 93.

FORNICA'IIONS, In general, 508, \& 104.

not common law offense, Res. v. Roberts, $14 ;$ Anderson v. C., 14-16; Smlth v. P., 180.90.

solicitation to, whether criminal, S. v. Butler, 179-80.

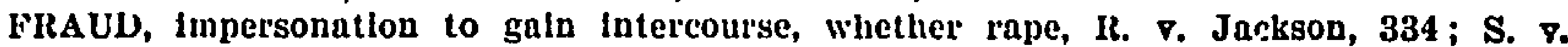
Shepard, 334 ; Wyatt v. S., 334-5; K. v. 13arrow, 335; R. v. ¿'ee, 335-8.

inducing slgnature by, not folgery, C. v. Sankey, 520-521. But see Gregory v. S., 252.

of complalning witness, as defense, C. v. Morrill, 61.2 ; R. v. Hudson, 62; McCord

จ. P., 62-3; In re Cummins, 64 .

to obtain admission supplies place of breaking In burglary, Johnson's Case, 370 :

Le.Mott's Case, 370 ; Ducher v. S., 370-1 ; Nlcholls v. S., 371 ; C. v. Lowrey, 373. obtaining by, is larceny, 424-438, \& 133.

supplying place of force for assault, R. v. Case, 69-70; C. v. Stratton, 70-1; R. v. Clarence, 71-4.

avolding the effect of consent in assault, IR. v. Clarence, 71-4; 1. v. Case, 69-70;

C. $\nabla$. Stratton, 70-1.

FRIGHT, liability for Injury resulting from, 214-8, 863.

FUGI'IIVE, from Justice who Is, Jones v. I.eonard, 302.

GAME, whether subject of lalceny, R. v. Townley, $455-6$; Anon., 459 ; C. v. Chace, 450 ;

ll. v. Cheafor, 460 ; Haywood v. S., 461 ; S. v. Shaw, 461.

GAMING IIOUSES, in general, 570.81, \& 202.

corporation llable for keeping, C. v. Pulaski, etc., 110-111; S. v. Passalc Agr.

Soc., 111.

GAS may be subject of larceny, ll. v. White, 404; C. จ. Shaw, 365.6.

GOD, act of, as defense for omission of duty, $R$. v. Ramber, 125.6.

GoVbikNMLiN'T, offenses against administration of, in general, 582.9i, Ch. 12.

HABEAS Co'RPUS, when it lies to have relense from prison for contempt, Murray's Сase, 501 ; ex parte Terry, 593-6; ex parte Fish, 592.

HEAL'II, odors prefudicing constitute nuisance, P. จ. Detrolt White I.ead Works, 574-5. HIGHWAYS, blockaded liabllity for stopplng In, C. v. Brooks, 126.

Injuiy from fallure to repair, llability of officer, R. v. Pocock, 26; R. V. Richarde, 51.

obstruction In, Is nulsance, R. v. Stephens, 571-2; C. v. Allen, 573-4.

swept away by the sea, llability for not repalring, R. v. Bamber, 125-6. 


\section{Pigukgs Reghe to Paghs Unlass Othehwise Indicated.}

HIRING, to steal, a larceny, R. จ. Year, $426 ;$ P. v. Smith, 427.

HOMICIDE, in general, 341-308, \$\$ 103.108.

furladiction to punish injury at one place taking place at another, $270-86,587$.

See algo, Munder, Manslaughter., Justifiable action.

HOUSE, larceny from $40 \%$, \& 151 .

sufficlent for arson, $380, \& 110$.

BUSBAND AND WIFE, death of wife from neglect, S. v. Smith, 30-1.

husband glving disease to wlfe, liablity for rape, assault, etc., $R$. V. Clarence, $71-4$. husband ratlfying recelpt of stolen goods, $R$. v. Woodward, b10-11.

liability for burning house of the other, Snyder v. P., 392-3.

llability for wife beating, S. v. Ollver, 210-220.

married women liable for certain crimes, nurriage as defense, 848.

wife cannot steal from husband, R. v. lienney, 449.

IDIO'IC, linbllity for crimes, S. v. Ilichards, 141.2.

IGNOIRANCZ. See Mistake.

IMPLISONA'ION, Intercourse obtained by, whether rape, R. v. Jackson, 334; S. 7. Shepard, 334; Wyatt v. S., 334-5; IR. v. Burlow, 335 ; 1R. จ. Dee, 335-8.

IAIPOSSIBILI'Y of perfornunce of crime as defense, C. v. Green 208-9; Foster $\nabla$.

C., 209 ; Mckinny v. S., 209 ; S. v. Jones, 209-10; C. จ. McDonald, 210 ; S. จ.

Wilson, 210.11 ; 1l. v. Collins, 211.2 ; P. v. Jones, 212 ; 1. v. Lee Kong, 213.4.

of performunce of duty as defense, IR. v. Bamber, 125-6; C. v. Brooks, 126.

IMPIISONMIEN'T. See FALSE IJIPKISONMENT.

INCEST, in general, $561, \S 130$.

INCESTUOUS MARIRIAGL, attempt to commit not shown by sending for preacher, P. v. Murray, 200-7.

INDICIMEN'l, allegation of ownership In burglary, Jone \& Longman's Case, 378. for attempt to commit attempt, is bad, $s$. v. Sales, 587.

for recelving stolen goods, necessary to name thlef, S. v. Ives, 515.6; I,evi v. S., 516-7.

for recelving stolen goods and proof thit they were embezzled, C. v. Leonard, 514 . necessity of alleging Intent, C. v. Hersey, 102.

varlance as to nature of property stolen, C. v. Clalr, 318-9.

variance as to ownership in larceny, $P$. v. McGowan, 317 .

varlance in proof of principal in first or second degree, Wllliams $\nabla$. S., $260 ;$ Doan P. S., 255-6.

INEANT, age as defense to crime, 138-141, $\$ 55$.

allowing In billiard hall, mistake as to age, etc., Stern v. S., 131-2; S. v. Probusco, 132.

command by mother, as defense, C. v. Rlchmond, 115.

Bale of liquor to, by bartender, llabllity of keeper, Morse v. S., 89.

voting in ignorance of age, Gordon . S., 130.1.

INFOKMER'S REWARD, conspiring for, MrDanlels Case, 74-5.

INJURY, as proximate and remote result, llabllity for, $R$. $\nabla$. Johnson, 37 ; R. $\nabla$. Bennett,

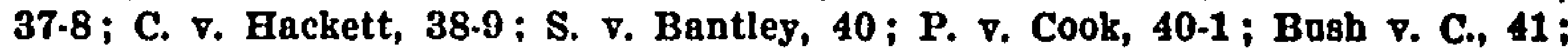
S. จ. O'Brien, 41.2 ; P. v. I.wis, 42.4 ; C. v. Campbell, 44.5 ; Taylor v. S., 46.8; Beatty v. Gillbanks, 46.7.

INSANITY, as defense to crime, 150-177, \$ 58 .

burden of proof In, S. v. Lawrence, 173-4; P. v. Garbutt, 174-6; Davls v. U. S., 176 ; Hornish, 167.

Irresistlble Impulse, danger of test, R. จ. IIaynes, 155-6 ; Flanagan $\nabla$. P., 156-7. is a questlon of fact, not of law, Parsons v. S., at pp. 160-70.

kinds of, P. P. Plne, 153.4.

moral obliquity is not, Guiteau's Case, 162 ; Parsons v. B., 171.

McNaghten's Case criticised In Parsons v. S., p. 164, 171.

nature of a delusion, Guitenu's Case, 160-1.

partlal Insanity no defense, Guitenu's Case, at p. 167. 
Figdies Reger to Pages Unless Otherwise Indicatra.

INSANITY-Continued.

proof of, by absence of motive, R. v. Haynes, 155.6.

proofs of, Gulteau's Case, 158.

right and wrong test, McNaghten's Case, 150.2; C. v. Rogers, 152-3.

INsTruUC'IION, right of defendant to special, as to insanity, Hornlsh จ. P., 176-7.

INSURANCE, burning to get, whether arson, Isaacs Case, 387.

consplracy to obtain undue amount, C. v. Prius, 190.

INTENT, criminal intent in general, Chap. III.

to cheat, in general, sufficlent in forgery, R. v. Hodgson, 524; R. v. Sheppard, 107. must exist at the time of taking to be larceny, 468.76, $88141-2$; U. S. v. E0工 7-8 shown by act, P. $\nabla$. Jones, 212.

specific to cheat essential to false pretenses, 540, \& 175.

without nct not criminal, R. v. Sutton, 21.22 ; Resp. จ. Malln, 22 ; C. v. Morse

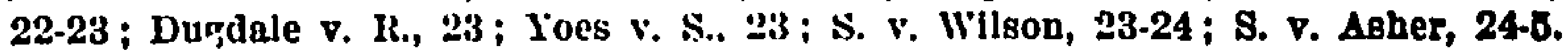
criminal, 85-177, Chap. III.

criminal nature of, in general, R. v. 'Tolson, 85-9.

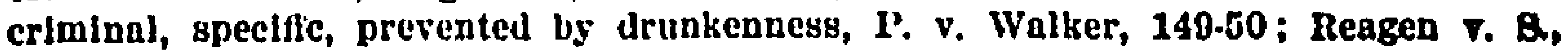
150.

INTERNA'liONAL LAW, Jurisdiction for crimes at gea, p. 270.9, \&86; ర. \$. จ. \$mith,

4.6. See Exthaditios.

right to try for one offense on extradition for an other, Ker v. Illinols, 302-4.

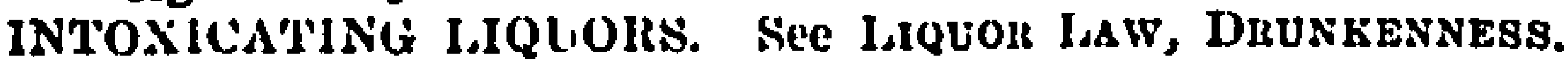

INVITA'rion, of prosecutor, as defense, 829.

JAILER, llabillty for assault by, S. v. lroseman, 222.

JEOPARDY, former as defense, 300.332, \&\$ 01.3.

JOINING counts for different offenses, P. v. Abbott, 83.

JURISDIC'IUN, depending on locality of crime, 269-209, 88 85.9.

of state and federal courts, respectively, 3.20.

to review contempt proceclings, Murray's Case, 501; ex parte Flsk, 60\%; ex parte

Terry, 503-7; ex parte Roblnson, 507-8. See also, Counts.

JURX, right of court to discharge, without verdlet, U. S. จ. Perez, 309 ; P. V. Plina

310 ; C. v. Cody, 310 ; Simmons v. U. S., 310-11 ; S. V. Parker, 311.

JUSTICE AND AU'THOMITY, oftenses against publlc in general, 682.87, Chap. 12.

JUSTIFIABLE AND EXCUSABIE ACTS, 21s.248, \$\$ 64-72.

KIDNAPING, in general, 330-331, 8100 .

to bring to trial, as defense, Ker v. Illinois, 302.4; Mahan v. Justice, 304-6.

KNOWLEDGE, of falsity of pretense by prosecutor, 532-4, \$160.

Iand. See Reai Property, Landlond and Tenant, Deeds, Iarceny, Tregapag.

IANDLORD, title to goods found on land, R. V. Rowe, 440.

IANDLORD AND TENANT, when liable respectively in arson, R. V. Harrls, 391.2;

Holmes Case, 390.1; R. จ. Breeme, 302 ; Gowen's Case, 392.

LARCENY, in general, 394-484, \$8 122.45.

caption whether shown by bringing stolen goods from another state, 286-294, 88 consent as defense, Williams $\nabla$. S., 76-7; S. v. Hnll, 78.

taklng overpayment made by mistake is, C. v. Hays, 500-501.

IARCENY FROM THE HOUSE, in general, 492-498, 151.

IARCENY FROM THE PERSON, in general, 490-2, 140.

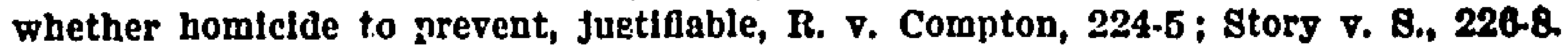

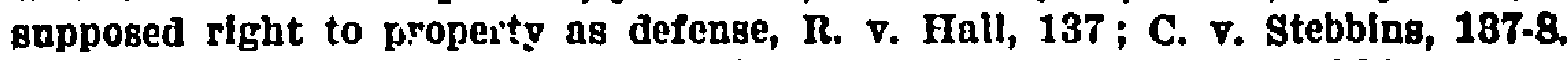

LEGI8LATURE, punlshing members uf, for contempt, Mrarray's Case, 501. 
LIBHI, in general, inis, s 184.

a common law erime, c. v. Chupmun, 12.14.

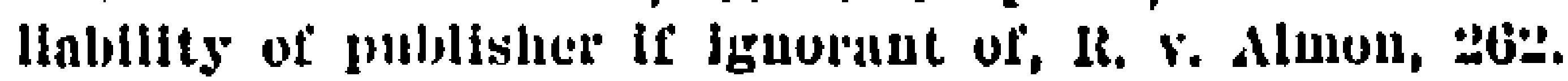

obscene, Jugdale v. K., 23 ; li. v. Read, 54; R. v. Curl, 5.5.5; c. v. Sharpless, 50.7.

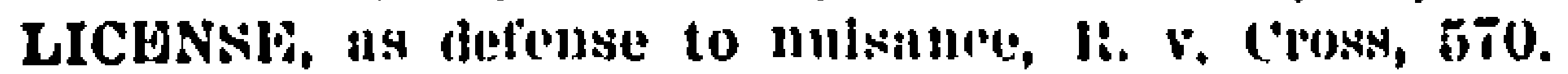

LIQUOR lall, lastender linble if no license, c. v. Ladley, 114.

falling to keep saloon closed, l'. v. lkody, 103-5.

llalility of principal for unauthorized sule by bartender, F. จ. Parks, 262.

llabllity of marrled woman for selling liquors, C. $\nabla$. Daley, 113.

liquor supposed not to be intoxicating, C. ק. Boynton, 132.

local option election before trial, Wheeler $\nabla$. S., 36-7.

LIQUOR, person busing is not llable for Inducing sale of, C. v. Willard, 180-1. prohibition statuie constitutional, Munger $\nabla$. Kansas, 19-20.

ratification of bartender's sale to minor, Morse v. S., 89.

repeal of second law by amendment, S. v. Yarker, 33; S. v. Wlllams, 37 ; S. v. Wheeler, 36-7.

selling by agent supposing principal has license, S. v. Chastain, 105.

selling llquor to minor supposed to be of age, S. v. Sasse, 132-3.

selling liquor to slave supposed to have authority, S. v. Presnell, 103.

selling liquor without llcense, S. v. Wray, 34.

violation of letter of law only not criminil, S. v. Wray, 34. See also, Drowkenswss,

LOCAL OI'TION election before trlal, Wheeler v. S., 36-7.

LOCALI'TY ON CRIME, affecting jurlsdiction, 260.286, 88 85.9.

LOST PROPWRTY, larceny of, 418-424, \& 132.

LOTTERY, place to sell tickets, not gamlng house, P. v. Jackson, 53.

selling tickets In, not keeplng guming house, P. v. Jackson, 53.

unauthorlzed, a public nuisance, $P$. v. Jackson, 53.

LUCRI CAUSA, not essential to recelving stolen goods, R. v. Richardson, 506; C. . Beun, 506.7.

whether essential to lareeny, 483-5, \& 145.

YAIM, 331-2, \& 101.

MaIMIING ShLF, to beg, criminal, Wright's Case, 06.

MAINTENANCl, detined. init.

MALICE AFOHE'HOVGH'l, defined, $k$. v. Sterne, 349-50.

MALICE, in inurder, defined. $C$ v. York, 344.5; $R$. v. Sterne, 349.50.

Implied from intent to kill a different person, S. v. Smith, 07 ; C. v. Mlink, 97-8. Implied striking one with intent to strike another, R. . Latimer, 108; McGeheo จ. S., 109.

whether a conclusion of law or facr, R. v. Faulkner, at p. 100 ; C. v. Walden, 105-6.

MALICIOUS, distinguished from willful, C. v. Walden, 105.6.

whether knowingly gtving wife gonorrhoea ts, R. v. Clarence, 71-4.

burning to constitute arson, Isaac's Case, 387 ; Luke $\nabla$. S., 388.

MALICIOUS MISCIIIEF, in general, 550, \&175a.

breaking window with intent to injure man, R. v. Pembliton, 107-8.

lluréss as defense, 1 . v. Crutchley, 118.

entry to disable horse not felony and so not burglarg, Dobb's Case, 386.

horse kllled in attempt to shoot rider, ls not, R. v. Kelly, 105.

meanlng of "willfully and mallclously," C. Y. Waldon, 105.6.

not shown by wanton destructlon of bullalng, Kilpatrlck $\nabla$. P., 48-9.

setting fire with supposed right to do so, R. v. Twose, 138.

sliown by wanton and cruel killing of cow or horse, Res. $\nabla$. Telscher, 47-8; P. $v$.

Smith, 48.

spectfic intent must be proved, R. จ. Pembliton, 107-8; R. จ. Kelly, 105.

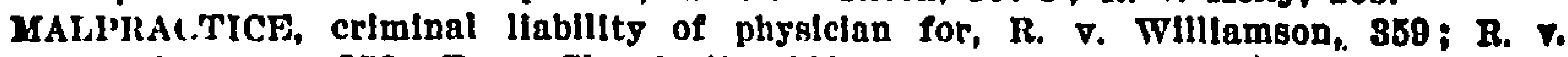

Thompson, 359 ; R. v. Chamberlln, 360 ; S. จ. Hardlster, 360 . 


\section{Figtaes Reyer to Pages Unless Otrer wisk Indicated.}

MaLTredTMEN'Y, contributing to death, as defense, C. v. Hackett, 38.9; P. v. Coot, $40-1$; Bush จ. C., 41 ; R. v. Rew, 59.60 ; R. v. Holland, 60.

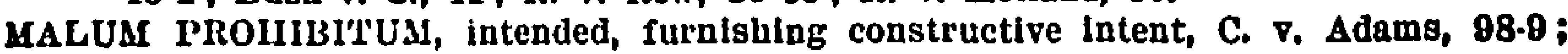
Estell v. S., 99.

MaNDAMIUS, to reinstate attorney disbarred lor contempt, ex parte Robinson, 590-7.

MANSLAUGH'LER, in general, p. 350-362, $\$ 8$ 105-7.

death caused by negligent switchman, S. v. O'Brien, 27 ; R. v. Smith, 27-8.

death from defect in highway, R. V. Pocock, 26.

open mine shaft causing death, I. v. Hughes, 26.7.

death of wife from exposule, $S$. v. Smith, 30-1.

explosion of gas in mine, R. v. Haines, $25 \cdot 6$.

explosion of fleworks material, R, v. Bennett, 37-8.

in bicking out adulterer, Wild's Case, 239-40.

neglectlng medical treatment, "Peculiar People," R. v. Wagstaffe, 28-9; R. v. Downs, 20-30; R. v. Morby, 38.

neglecting grandchild, R. v. Nicholls, 28.

neglecting helpless aunt, $R$. $\nabla$. Instan, 31-2.

In preventing lllegal arrest, Creighton v. C., 235 ; Jones v. S., 235.6; Cook's Case, 238-9 : R. v. 'Thompson, 351-2.

Married WOMAN. See Adultery, Husband aNd Wift.

MASTER AND SERVAN'T. See AGENCY.

MAYHEM, 331-2, \& 101 ; malming self, Wright's Case, 66.

MEDICAL AT'THNDANCE, statute on, R. จ. Downes, 20-30.

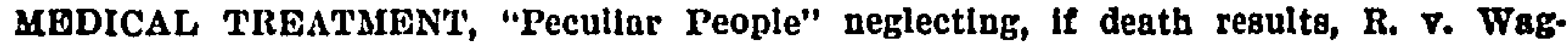
staffe, 28-29; R. v. Downes, 20-30; R. จ. Lorby, 38.

MERGER, \$\$ 30.32.

of greater and lesser crimes, Boston \& W. R. R. Co. V. Dana, 70.81; P. P. Abbott, 83.

of tort and crime, Boston \& W. R. R. Co. v. Dana, 79-81; Wlllams v. Dicken: son, 81.

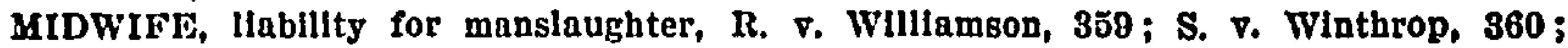
S. v. Hardlster, 360.

MrLiTARY AND NAVAL SERVICE, criminal llablity for obedlence to commands in;

U. S. v. Jones, 115 ; Memo. 115, Riggs v. S., 115-6 ; U. S. v. Clark, 116-7.

MINORS. See Infants.

MISCEGENATION, 561, \$180.

MISDESIEANOR, all partles liable as principal, Ward v. P., 254 ; Baker v. S., 254-65; Williams จ. S., 257.

distinguished from felonics, S. v. Setter, 82.

MISFEASANCE, of duty, when criminal, \$8 11, 63.

MISPRISON OF FELONY, 585. \& 209 ; Wren v. C., 258.

MISTAKF, as to right to property, as defense, to larceny, 466-7, \& 140.

taking overpayment made by, whether embezzlement, C. v. Hays, 501.

taking overpayment made by, whether larceny, R. v. Mflddleton, 439-443; 415-8; \$131.

taking property by, whether larceny, R. v. Rlley, 470.

MISTAKE OF FACT, as defense to crime, 126.134, \& 53.

defense to rape, R. v. Tolson, 85-89.

rendering attempted crime Impossible, whether defense, C. v. McDonald, 210 ; S. จ.

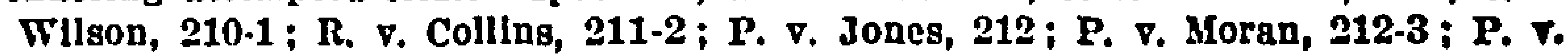
Lee Kong, 213-4.

MISTAKE OF IAAW, as defense, 134-138, 54.

MISTREATING WOUND, resulting in death, liabllity of assallant, S. . Bantley, 40 ; C. v. Hackett, $38-9$; P. จ. Cook, 40-1; R. v. Holland, 60.

MORALS, consplracy to debauch public, criminal, S. v. Buchanan, 184.6.

offenses agalnst in general, 558-570, Chap. 11. 
MORALS-Contlnued.

pablle courts are guardlans of publlc, and corruption of, crlminal, R. v. Carl, 54-5 ; R. จ. Delaval, 55.6 ; R. v. Sharpless, 06.7; Bell จ. S., 16.

XOTIVE, absence of, as proof of insanlty, R. v. Hayne日, 155.6.

distingulshed from crimlnal Intent, 00.94; R. v. Ogden, 90 ; R. v. Sharpe, 90.1; Reynolds v. U. S., 01-3; U. S. v, Harmon, 03-4.

UURDER in general. $341.350,8104$.

assanlt, with intent to, R. v. Bosd, 105 ; Carter v. S.. 108.

by marrled woman, llabllity, Blbb 7 . S., 113.4.

by wllfully exposing to danger from disease, Castell จ. Bambridge, 216 ; R. v. Greenwood, 216.

solicitation to commit, C. v. Randolph, 16.

through innocent agent, Vaux Case, 240.50 ; memo. 250 ; R. v. Michael, 251.

with deadly weapon while intoxleated, P. v. Rogers, 144-5; Pearson's Case, 146. see MANSLAUGHTER.

NECESSITY, as defense to crime, 117 et seq., 51.

NEGLIGENCE, accldental killing of woman by boy shoved into street, $\mathbf{R}$. v. Brace, 101. contributory, of stranger, no defense, R. v. Bennett, 37-8.

death from careless rifle practice, R. v. Salmon, 101.

manslaughter from, 357-362, \& 107.

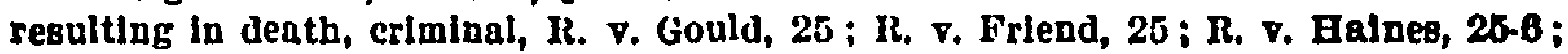

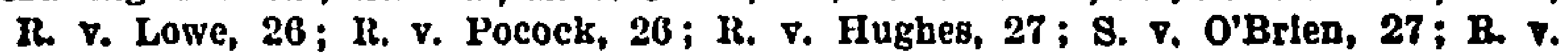

Smith, 27.8; R. v. Nicholls, 28; R. v. Wagstaffe, 28.9; R. v. Downes, 29.30;

S. v. Smith, 30-1; Anderson v. S., 32-3; R. v. Instan, 31.

resulting in death in driving faster than ordinance permits, C. P. Adamo, 98.9;

Estell v. S., 99.

NIGHT-TIME, what is in burglary, S. $\nabla$. Bancroft, 385.

proof of entry In, S. จ. Bancroft, 385 ; P. จ. Dupree, 385.6.

NOISES, as breach of peace, C. v. Taylor, 552-3.

constituting nulsance, R. จ. Smith, $575 ;$ R. จ. Lloyd, 51.

NOTICE of falsity, sufficlent to convict of false pretenses, 532.4, $\$ 109$.

that goods recelved were stolen, 514-5, \$156.

NUISANCE, In general, 570-581, ş 106-203.

corporation llable for keeplng, C. จ. Proprletors, 110.

one act causing fit is not, C. v. Wing, 52.

stagnant pond defiling the alr, when public, C. $\nabla$. Webb, 50.

tin-shop near inn, a nulsance, R. จ. Lloyd, 51.

whether publle cursing Is, C. จ. LInn, 560-70.

OBSCENE exposure of person criminal, Kanavan's Case, 54; B. จ. Carl, 64-6; C. 7. Sharpless, 56-57.

language, in general, 508-70, 105.

In public, criminal, Bell v. S., 16.

prints, intent to publish, not criminal, Dugdale v. R., 23.

published, criminal, C. v. Sharpless, 56.57.

sent through mall, U. S. V. Harmon, 93-4.

OBTAINING, by false pretense and tokens, 529.550, 167.75 .

ODORS, constituting publlc nulsance, S. v. Kaster, 575-6; C. จ. Perry, 576-7; C.. Miller, 577-9; P. จ. Detrolt Whlte Lead Works, 574.6.

OFFICE, crimes relating to, 582, \& 205.

OFFICER, homicide in reslating is murder, Yong's Case, 342.

obstructing in general, 582-3, \& 206.

crimes by, in general, 582, 805.

llabllity for neglect of duty (constable), Cronther's Case, 33.

not liable for acts in discharge of duty, 65 . 


\section{Figuris Reter to Pages Unless Otherwish indicated.}

OFFICER-Continued.

misconduct in office, crimlnal, C. v. Silsbee, 5i; C. v. Callaghan, 67-8.

when fustlfied in taking llfe to avold escupe, R. v. Dadson, 222 ; Reneau v. S., 223 ; Head v. Murtín, 223.4.

OFFICIAL ORDER, and duty as defense, \& 49.

oleomargarine law, valid, Powell v. Pennsylvanla, 20.

supposed to be butter, as defense, $S$. $\nabla$. Ryan, 134.

OPINION, matters of, not false pretense, IR. v. Bryan, 537.8; Jackson จ. P., 639 ; \$. จ. Wilkerson, $540 ; P$. จ. Jacobs, 541-2.

ORDER, by superior as defense to arime, 849.

ORDINANCE, liability for stopping in street in violation of, C. v. Brooks, 126.

limiting speed, liabllity for violation, if injury results, C. v. Adams, 88.9; Estell v. S., 00.

OWNERSHIY us defense to larceny, $447-451,8136$.

PARENTAL AU'THORITY, as excuse for crime, 86.

Parties to Cirine, in general, 249-268, Chap. 5, 88 73-83.

absent principal, to forgery, C. v. Ray, 524.5.

felon arrested is not liable for later murder by comrade, R. v. Jackson, 343-4.

liable only for acts within scope of design, 201-6, \& 81 .

llability for unexpected consequences, 263.6, \& 82.

of servant letting in burglar, Cornwal's Case, 384 .

whether receiver of stolen goods is princlpal or accessory, S. V. Ives, 516.6; Levl

v. S., 516-7.

all engaging in rifle practice llable for death from shot of one, though no proof of which, IR. จ. Salmon, 101.

each liable for acts of those in concert, $R$. v. Swindall, 60 .

llablity of one furnishing polson, for death of person not Intended, Saunders Casp, 04.6 : Gore's Case, 06-7.

only liable for acts of those in concert, C. v. Campbell, 44-5.

abandonment as defense, 260.8, \&83.

PARTNERS, liability for embezzlement from firm, s. v. Kusnick, 504-6.

PEACE, breach of, 5ina. \$ 180.

scaring family by shooting dog on porch, IIenderson v. C., 53.

by shooting wild goose, giving woman ft, C. v. Wing, 52.

assault justifled in restoring, 224, \&67.

disturbance of by Salvation Army, Beatty v. Gllbanks, 46.7.

klling one attempting to restore is murder, R. v. Tomson, 342-343.

offenses agalnst, 551-7, Chap. 10.

"PeCuliar PEOPIf," medical treatment, R. จ. Nagstaffe, 28-29; R. จ. Downes, $20-30$; R. v. Morby, 38.

PERJURY, in general, 587.80, \& 212.

PERSON, offenses against, 323-368, Chap. $i$.

larceny from, in general, 400-2, \& 140 .

PHYSICIAN, death from fallure to employ, criminal, R. v. Wagstaffe, $2 \theta ;$ R. . Downes, 28-30.

fanlt of contributing to death, $n$ defense, C. v. Hackett, 38.0 ; S. v. Bantley, 40 ;

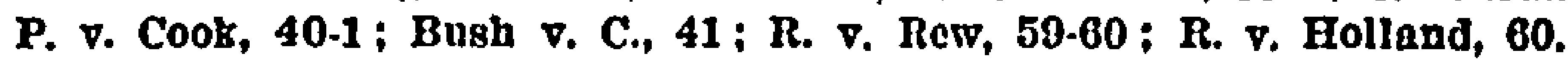

liability for negligent manslanghter, R. v. Willamson, 350 ;. C. จ. Thompson, 350 ;

R. v. Chamberlin, 350.60 ; S. v. Winthrop, 360 ; S. v. Hardister, 360.

liabllity for inoculating small-pox and exposing publlc to, R. v. Burnett, 62. requiring license of, constitntional, P. จ. Phippln, 20.

PICK-POCKFT, liablity for attempt, if pocket empty, C. v. MCDonald, 210 ; s. จ. Wilson, 210-1; R. v. Collins, 211-2 ; P. จ. Jones, 212 ; P. v. Moran, 212-3.

liabillty for drowning, Fray's Case, 361. 
Figurgs Reger to pages Unluss OTherwise INdicated.

PICTUREs, not subject of forgery, R. v. Closs, 525 . obscene, published, criminul, C. v. Sharpless, 68-7.

PIRACl, In general, 508. defined and discussed, U. S. P. Smith, 4.6. command of superior as defense, U. S. v. Jones, 115.

PLEALING. See INUICTALNT.

PLEDGED GOOUS, larceny by owner, Anon. 447; R. v. Wilkinsou, 447-8; Adams 7 . S., 449-50 ; Henry v. S., $4 \overline{1} 1$.

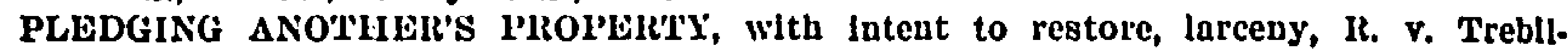
cock, 482.3 ; K. v. Phetheon, 48:

YOLICE, Justitiable killing hy, to protect superlor, in re Neagle, 248.

liability for assault in coutse of duty, S. v. 1'ugh, 2:21.2; Burus v. S., $222 ; \mathrm{S}$. v. Roseman, 222'.

poligany. See bigany.

POSTOFlice, mall carrier not liable for embezzlement from addressee, Brewer $\nabla$. S., $503-4$.

obscene matter in mulls, U. S. v. Harmon, 03-4.

PREPARA'TiON, distingulshed from attempt, P. v. Mlurray, 208.7; U. S. v. Stephens, $207-8$.

PRESENCE suficient taking from, for robbery, 486.88, § 148.

PRESUAl'IION, of criminal Intent from act, c. v. Hersey, 102 ; Harvick v. S., 102-3; 1. $\nabla$. Jones, $21 \%$.

PRETENSE, cheating by false, in general, 531-550, 88 168-175.

if true, no criminality, 534,8170 .

what is a ralse, $535 \cdot 543, \S 171$.

when falsits evident to all, liabllity for malsing, C. v. Norton, 534; S. จ. Burnett, 534 ; Oxx v. S, 534 .

princilals. See agency, Palities.

PRIN'T, may be subject of folgery, C, v. lay, 524.5.

PRISON, breach of, in general, 585.6, \& 210.

PRIVILLGE, against self incrimination, C. v. Willard, 180-1.

PROCESS, obtnining entry by, is burglary, Anon., 360.

obtainlng property by fraudulent use or, is larceny, Anon., 424-5; Farr's Case, 425.

PROFANITY, in general, 568-70, $\$ 195$.

PROHIBITION IAAWS, valld, Mugler v. Kansas, 19-20.

PROMISE, false not a false pretense, 535-7, \& 171.

not a false token, P. v. Babcock, 530 .

PROPERTY, what obtained by false pretense, is criminal, 546.8, \& 174. which may be subject of larceny, 452.466, s\& 138.0.

PRovocation, adultery as, IInnning's Case, 352; Fry จ. S., 353; Maher จ. P., 956-7. affected by drunkenness, R. v. Thomas, 146 ; C. v. Hawklns, 146-7. burden of proof of, C. $\nabla$. York, 344-5.

cooling and coollng time, S. v. McCants, 354-6; Maher v. P., 356-7.

Illegal arrest as, IIugget's Case, 351; R. จ. Thomson, 351-2.

menacing arrest as, Jones $\nabla$. S., 235.6.

mere words, Morly's Case, 350.1; Fry マ. S., 353.

PUBLIC JUSTICE AND AUTHORITY, offenses agninst, in general, 582-87, Chap. 12.

PUNISHMENT, barbarous common law not adopted, C. จ. James, 11-12.

by fallers and other officers, S. v. Pugh, 221.2 ; Burns v. S., 222; S. จ. Roseman, 222.

by mnster with dendly weapon, Gray's Case, 342.

by parent, when justifinble, R. v. Grinn, 219; Hinkle v. S., 219.

by teacher, when Justifable, 220 : Heritage $\nabla$. Dodge, 220 ; Boyd จ. S., 221.

of wife not Justiflable, S. v. Ollver, 210-220.

for crlmes, purpose of, Anon., 138. 


\section{Figores Refer to Pages Unless Othehwise Indicatkid.}

PURE FOOD IJAW, oleomargarlne, S. จ. Ryan, 134.

valld, C. $\nabla$. Waite, 10 ; Powell v. Pennsylvania, 20.

RABBITS, subject of larceny, R. v. Townley, 455.6.

RAPE, in general, 332-341, \& 102.

abandoned after attempt, Glover $\mathbf{}$. C., 208.

assault with intent, consent of child a defense, Smith $\nabla$. S., 33.4; R. v. Martin,

60 ; R. จ. Woodhurst, 69.

attempt by boy, presumption and proof of capacity, C. v. Green, 208-8; Foster

จ. C., 200 ; Mckinny v. S., 200 ; S. v. Jones, 200-10.

attempt of statutory, is common law offense, 1R. v. Roderick, 208. But see Smlth

v. S., 33.4.

Intoxication as defense, Burrows's Case, 143 ; Reagan v. S., 150.

killing to prevent, Justifable, P. v. Cook, 225.6.

whether husband may commit, upon wife, R. v. Clarence, 71-4.

woman supposed to be of age, as defense, C. v. Mirphy, 133-4.

RATIFICATION, of act of servant does not make principal liable, Mforse v. S., 80.

by husband of wife's receipt of stolen goods, IR. v. Woodward, 510.1.

REAI PROPERTY, not subject to larceny, 452.9.

obtaining title by false pretense, not criminal, P. v. Cummings, 548.0.

RECEIP'T, obtained by false pretense. Moore v. C., 540- $\tau$.

RECEIVING STOLEN GOODS, 506-517, \$\$ 153-157.

from another state, C. v. Andrews, 287.

what is receiving, 500.511, \& 154 .

RELIGION, freedom of effected by bigamy statute, Reynolds v. U. S., 91-3.

RENDITION, between states, in general, 299-306, \& 90.

REPEALS, of repealing lnw, C. v. Churchill, 36.

after sentence, S. v. Williams, 37; Wheeler v. s., 37.

RESCUE, In general, 585, \& 210.

from Hllegal arrest, llablilty for killing to effect, Huggett's Case, 351.

RETREAT, duty to, before taking life, Shorter v. P., 228.9; Stoffer $\nabla$. S., 231-2; Erwin

จ. S., 233.4 ; S. v. Mlddleham, 234 ; R. v. Donnelly, 234-5 ; Beard v. U. S., 237.8.

REWARD, conspiring for Informer's, McDanlel's Case, 74.

bolding property for, whether larceny, R. จ. Spurgeon, 477 ; R. จ. Gardner, 478 ;

C. จ. Mnson, 478 ; Berry v. S., 478.9.

RING DROPPING, larceny by R. v. Moore, 427.8.

RIOT, in feneral, 555,8183 .

llabllity of rioters for act of offlals, opposing, C. v. Campbell, 44-5; Taylor v.

S., 45.6 ; Beatty v. Gllbanks, 46-7.

ROADS. See HIGHWAY.

ROBBERY, in general, 485-90, $\$$ 148-149.

consent and conspiracy to be robbed as defense, McDanlel's Case, 74.5.

consplracy to convict of, R. v. McDnnlel, 215.6.

death resulting from train robbery is murder, Taylor $\nabla$. S., 45.6.

homicide to prevent, justifiable, Crawford $\nabla$. S., 244-5.

marrled woman liable for, P. v. Wright, 112-113.

supposed ownership of property as defense, R. v. Hall, 137.

ROUT, defined, 555, \& 183.

SAFETY, Imperiling public, is criminal nuisance, Anon., 572.

SAILORS, command of superior, as defense to crime by, U. S. v. Jones, 115 ; $\mathbf{~}$. \$. v. Holmes, 120-3.

SALE, not larceny in salesman to convert recelpts for, 410.415, \& 130.

to owner, larceny, R. v. Mall, 480 : R. v. Manning, 480.

when purchaser liable for larcens in taking goods, R. จ. Chlssers, $404 ;$ R. จ.

Slowly, 404.5; R. v. Sharpless, 425.6. 


\section{Figures Reter to Pages Unless Otherwise Indrcated.}

SALVATION ARIY MAlRCH, cauglng disturbance, Beatty v. Gllbanks, 46. SCARING, liabllity for injui'y resulting from, 214-8, \& 63 .

SCOLD, common, James v. C., 11-12.

SEAS, Jurisdiction to punish crimes committed on, 260-270, \& 86 .

SEDUCTION, in general, j65-568, \& 103.

conspiracy to seduce, Smith v. P., 17; R. v. Delaval, 55.56.

not common law crime, lRes. v. Roberts, 14 ; C. v. Anderson, 14-16.

homlclde to prevent, $\mathbf{P}$. v. Cook, $225 \cdot 6$.

SELF DEFENSE, in gennral, 228.238, \& 69.

death of wife driven from house in, Hendrickson v. C., 217.

duty to retreat, Erwin v. S., 233-4; S. v. Mlddleham, 233 ; S. v. Donnelly, 234-6.

Selfi-incrimination. See Privilege.

SERVANTS, when llable for larceny of master's goods, 407, 127.

SODOMY, in general, 562 ; Estes v. Carter, 17.

SOLDIER, criminal liability for acts in service, U. S. จ. Jones, 115.6; Riggs v. 8., 116 ; U. S. v. Clark, 116-7.

SOLICITA'IION, to commit murder, C. v. Randolph, 16.

to crime, criminal, 860 .

whether an attempt, S. v. Butler, 179-80; S. v. Bowers, 183-4.

STATE, what are crimes ngainst, 88 3-8.

STATUTES-AMERICAN, U. S. Const. Art. $1 \& 8,3$.

$\$ 10,10$.

smend. $5,306$.

$10,3$.

$14,81,18$.

Callfornia Const. Art. $1,813,306$.

Michigan Const. Art. 6, \$29, 306.

STATUTES-English, 3 Hen. 7, c. 2, 562.

21 Hen. 8, c. 7, 400.

33 Hen. 8, c. $1,520$.

2 and 3 Edw. 6, c. 24, 204.

8 Ellz. c. $4,81,490$.

3 W. \& M. c. $9,84,506$.

12 Anne c. $7,402$.

12 Anne c. $7, \$ 3,369$.

30 Geo. 2, c. $24,81,531$.

39 Geo. 3, c. $85,498$.

7 and 8 Geo. 4, c. $29,854,506$.

24 and 25 Vlet. c. $100, \& 57,85$.

STATUTORY CONSTRUCTION, act prohlbited without penalty, criminal, Crouther's

Case, 33 ; S. v. Parker, 33 ; C. v. Chapman, $12-14$.

effect of general codes, as repealing common law crimes, C. v. Chapman, 12-4; Smith v. P., 17 ; Estes v. Carter, 17 ; S. v. Pulle, 17-18.

malum prohibltum intended, furnlshing constructive Intent, C. $\nabla$. Adams, 98-9;

Estell v. S., 00.

repeals and amendments effect of, 813 .

statutory privilege abused, criminal, C. จ. Sllsbee, 57 ; C. v. Callaghan, 57-8.

technical terms, technical meaning, "dwelling house," Pitcher $\nabla$. P., 18-9.

STATUTORY CRIMES, attempt to commit, is a common law offense, 8. $\nabla$. Butler, $179-80$; R. v. Roderlck, 206.

due caution in relying on decisions under different statutes, S. v. Kusnick, 504.6. when proof of intent Immaterial, C. v. Walte, $10 ;$ P. v. Roby, 103-5; S. V. Chas-

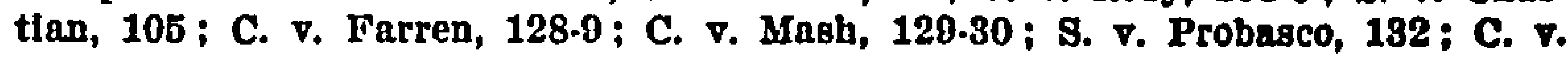

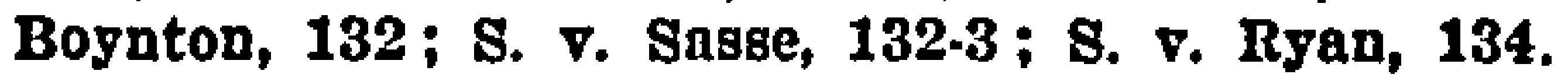

STOLEN GOODS, RECEIVING, 506-517, 83 153-157.

STOPPAGE IN TRANSITU, avolding by false pretense, is not obtalning, P. $\mathbf{\text { . Hayaes, }}$ 632-3. 


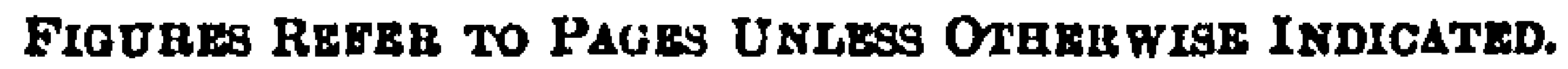

STREETS. SeO HIGHWAYS.

STRIKES, consplracy to joln in whether criminal, C. v. Hunt, 100.4; S. v. Donald80n, 194.8.

SUBORNATION, of perjury, Blakeley $\nabla$. S., 258.9.

SUICIDE, caused by wound, as defense, I'. v. Lewis, 42-4.

manslnughter resulting from Intended, C. v. Mink, 07-8.

offense and punishment at common law, C. v. Mlnk, 97-8.

SUNDAY, not closing saloon on, r. v. Roby, 103-5.

SUNDAY LAWS, renting coach on Sunday for charity, Mgers v. S., 127.8.

SUPPOKT, of wife, llablity of infant neglecting, P. V. Todd, 140.

SUPPRESSION of proof as making one criminal accessory, Blakeley $\nabla$. 8., 258-9.

SWEARING punished in spiritual courts, R. v. Curl, 54-5.

TAKING, sufficlent for larceng, 306-0.

when sufficlent in robbery, $485-6, \& 147$.

TEACHER, liablity for assault and battery, as punishment, Hutton 7. 8., 220: Heritage v. Dodge, 220 ; Boyd v. S., 221.

THREATS, assault by, Balkum v. S., 325.

TORT, Intended resulting in crime, liability, R. v. Franklin, 89. distlngulshed from crimes, \$8 22-28.

TRADE MARKS, not subjects of forgery, R. v. Smith, 525-6.

TREASON, in general, 598.

defense of command by superior officer, Memo., 115.

duress as defense, Resp. v. McCarty, 118.

TRESPASS, consplracy to not criminal, R. v. Turner, 186-7.

sufficlent to sustain larceny, 399-424, 88 125-132.

TRICK, obtalning property by, is larceny, 434.438, \& 133.

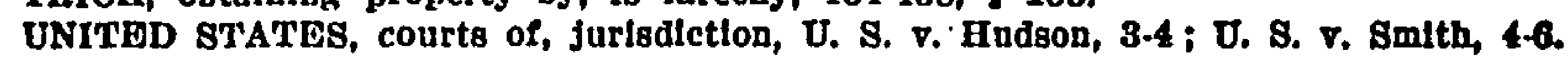

UNWRITTEN LAW. See Common law.

OSAGE, matters settled by anclent, Andereon $\nabla$. C., 14-16.

UTILITY, as defense to charge of nulsance, 572.8, 88 198.201.

UTTgring. See Forgert, Counterfeit.

VALUE, sufficlent for larceny, 451, 8137 .

VARIANCE. See INDICTMBNT.

VIOLENCE as an element of robbery, 488-90, \& 140.

VOID INSTRUMENTS, not subject of forgery, 526-7, 165.

VOLUNTARY MANSLAUGHTER, 350.357, \& 106.

Voting. See Et.bction.

WILLFur, dlstingulahed from "mallclous," C. v. Walden, 105-6.

WITNESSES, when Interference with crimlnal, Blakeley $\nabla$. 8., 258-9.

WORDS, as provocation, Lord Morly's Case, 350-351; Fry 7. 8., 853.

WRITING which may be lorged, 524.6, 8164.

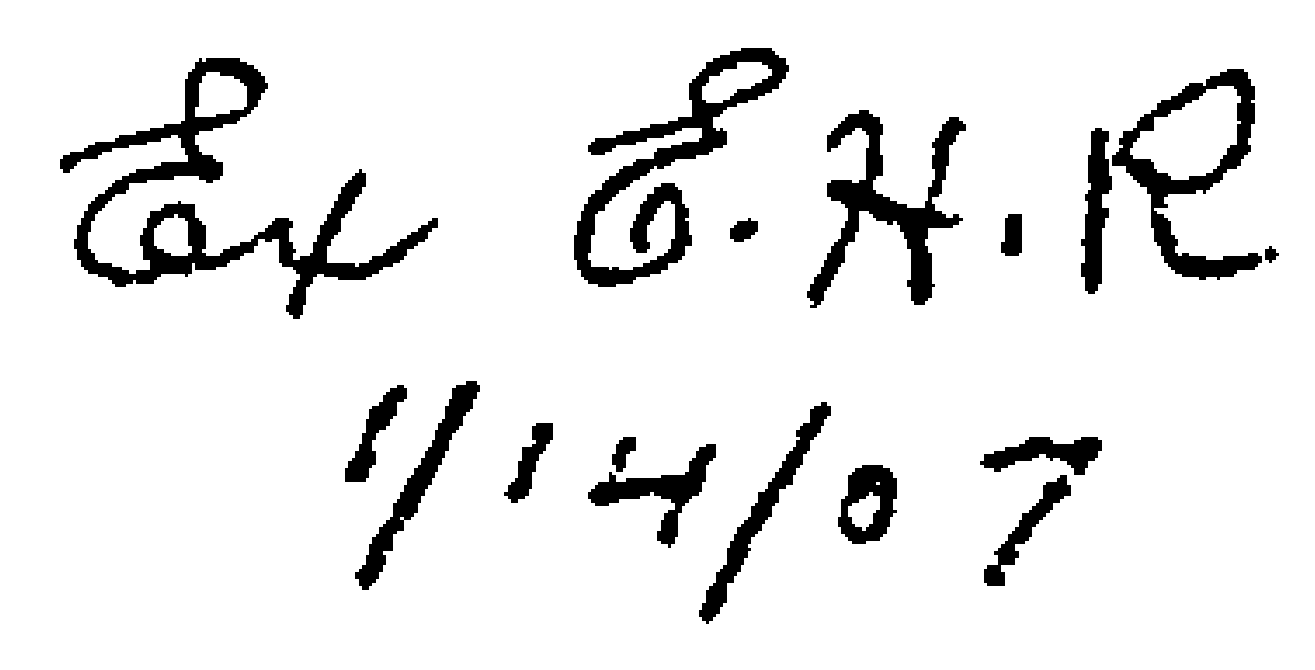

